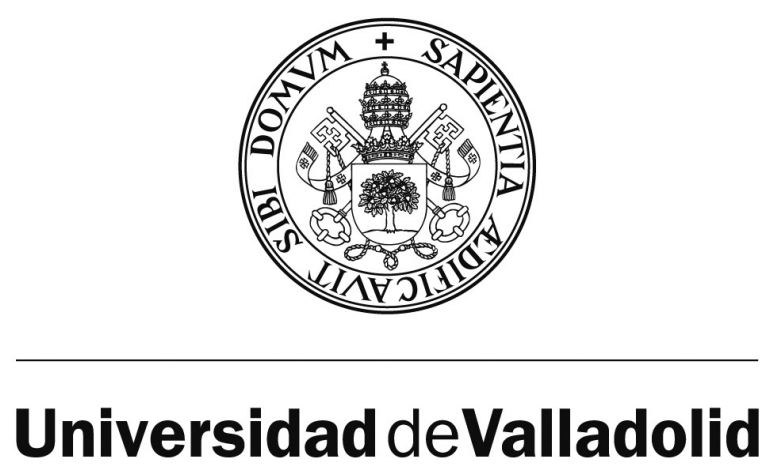

ESCUELA TÉCNICA SUPERIOR DE INGENIERÍAS AGRARIAS DE PALENCIA Departamento de Ingeniería Agrícola y Forestal

\author{
TESIS DOCTORAL:
}

\title{
RECUPERACIÓN AMBIENTAL DEL PAISAJE DE TIERRA DE CAMPOS
}

Presentada por Raúl Blanco Esteban para optar al grado de doctor por la Universidad de Valladolid

\author{
Dirigida por: \\ Joaquín Navarro Hevia \\ Doctor Ingeniero de Montes
}

Mayo de 2015 



A todas las personas que trabajan por el bien común 



\section{Agradecimientos}

A mis compañeros del Servicio Territorial de Medio Ambiente de Palencia, quienes me permiten diariamente desarrollar mi vocación en un clima de gran cordialidad.

A Aureliano González, Eleuterio Alonso, Carlos Estébanez y Marta de la Rosa, labradores de ayer y de hoy, cuyas experiencias me han permitido interpretar la agricultura tradicional y la contemporánea.

A todos aquellos profesionales del paisaje cuyos libros y documentos he tenido el placer de leer y referir en este estudio, que me han transmitido su gran sensibilidad hacia el entorno en el que vivimos.

A Asier Saiz, que me ha ayudado a maquetar este trabajo, justo en el momento en que más lo necesitaba.

A Joaquín Navarro, director de la tesis, compañero y amigo. Es él quien me dio fuerzas en momentos de gran zozobra personal y profesional. Quien ha sido espejo para contemplar a un ingeniero de montes humilde y ejemplar. Quien ha enderezado la marea de ideas divagantes que me han surgido a lo largo de los varios años de esta travesía. Quien ha tratado de encaminar mis emociones y experiencias hacia el rigor científico.

A mis padres, que me dieron la vida y me permitieron estudiar esta carrera que tanto estimo.

A Anna. Con ella vivo feliz en Villalón de Campos, junto con nuestros tres hijos Nuria, Sonia y Martín. Ella me hace valorar cada día las ventajas de vivir en un pueblo: la casa con sus maderas y su febril actividad, el patio con sus geranios, los amaneceres con el canto de los gorriones, los inmensos cielos, el transcurrir de las estaciones, la tranquilidad, la amistad con nuestros convecinos... Ella siempre me ha apoyado en los momentos difíciles y críticos de la vida, y me ha proporcionado la positividad y las fuerzas necesarias para afrontar el gran reto de esta tesis, que se ha convertido también en terapia. 



\section{ÍNDICE}

0.- RESUMEN 59

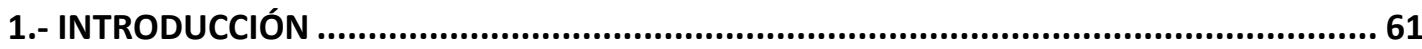

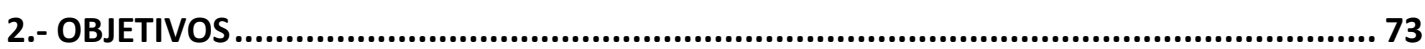

3. ANTECEDENTES

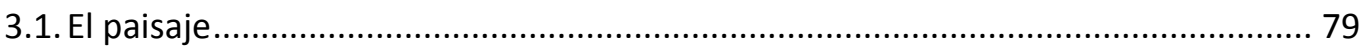

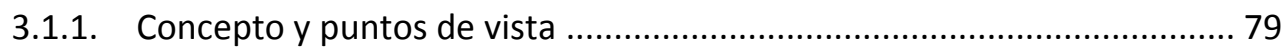

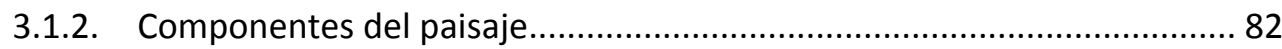

3.1.3. Una nueva perspectiva: el Convenio Europeo del Paisaje........................ 83

3.1.4. Arquitectura del paisaje y paisajismo ........................................................ 86

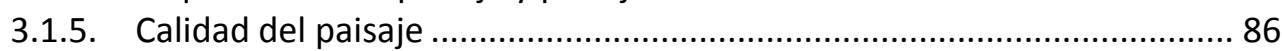

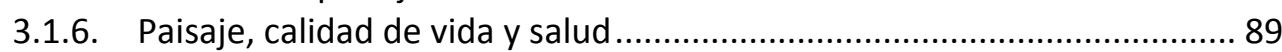

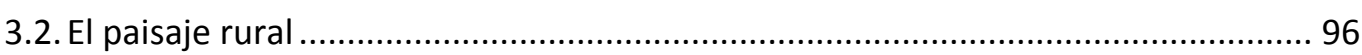

3.2.1. Concepto e importancia .................................................................... 96

3.2.2. Historia y evolución del paisaje rural agrícola ......................................... 98

3.2.3. Tipos de cultivos (paisajes) agrícolas. El cultivo (paisaje) cerealista ........ 100

3.2.4. Elementos singulares del paisaje rural ................................................ 104

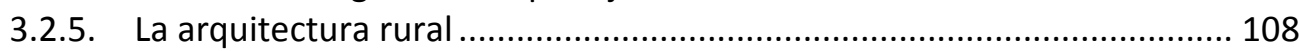

3.2.6. Los paisajes rurales de campiñas españoles.......................................... 109

3.2.7. El paisaje de campiñas de la Meseta Norte: la llanura cerealista de

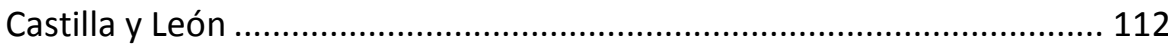

3.2.8. El paisaje de campiñas de Tierra de Campos........................................ 117

3.3. Paisaje y Medio Ambiente: dos conceptos asociados........................................... 118

3.3.1. El paisaje como manifestación externa del medio y como

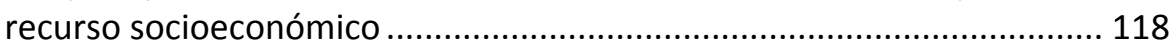

3.3.2. Problemática ambiental y paisajística en las campiñas cerealistas de Tierra de Campos ............................................................................. 120

3.3.3. Instrumentos de gestión ambiental aplicables en Tierra de Campos ...... 127

3.4. Instrumentos preventivos de gestión ambiental: herramientas para la protección del paisaje de Tierra de Campos

3.5. La recuperación de espacios degradados como técnica para corregir impactos y mejorar la calidad del paisaje de Tierra de Campos. ........................................... 140

3.5.1. Concepto de recuperación de espacios degradados y justificación .......... 140

3.5.2. Contenido y alcance de la recuperación de espacios degradados ............ 144

3.5.3. Bases ecológicas y paisajísticas de la recuperación de espacios

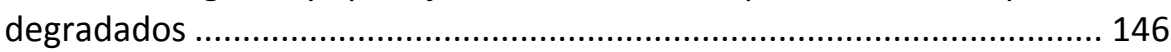

3.5.4. Diseño de la recuperación y definición de usos futuros........................... 148

3.5.5. Actuaciones básicas en la recuperación ................................................. 152

3.5.6. Técnicas específicas de recuperación ..................................................... 179

3.5.6.1. Elementos de estabilización de taludes .......................... 179 
3.5.6.2. Elementos de estabilización de cauces y cuencas degradadas .............................................................. 191

3.5.6.3. Pantallas sónicas...................................................... 193

3.5.6.4. Pasos de fauna...................................................... 194

3.6. Diversificación del paisaje agrario de Tierra de Campos: setos vivos, sotos y bosques-isla

3.6.1. Historia de una profunda transformación ........................................ 201

3.6.2. Funciones de los setos vivos .......................................................... 205

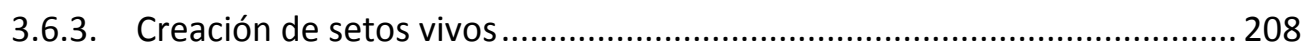

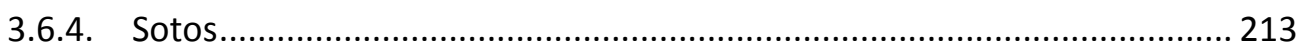

3.6.5. Bosques-isla ................................................................................. 215

3.6.6. Medidas de condicionalidad de la Política Agraria Común..................... 217

3.6.7. La forestación de tierras agrícolas ............................................... 220

3.7. Valorización del paisaje de Tierra de Campos ................................................... 226

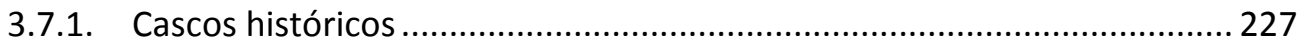

3.7.2. Parques y jardines urbanos ........................................................ 229

3.7.3. Parques periurbanos y anillos verdes ............................................... 229

3.7.4. Áreas recreativas. Las ermitas ...................................................... 230

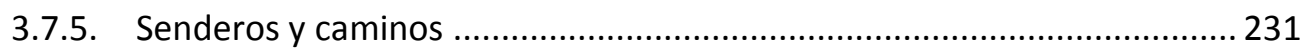

3.7.6. Miradores.................................................................................. 234

3.7.7. Centros de interpretación de la naturaleza ..................................... 236

3.7.8. Observatorios de avifauna ..................................................... 236

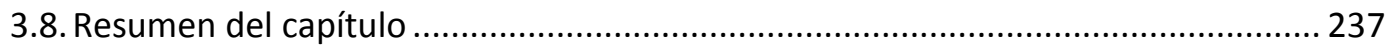

4.- ZONA DE ESTUDIO: TIERRA DE CAMPOS ..............................................................239

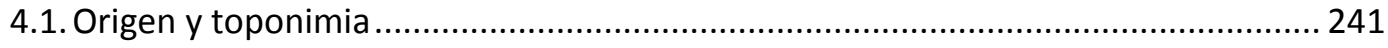

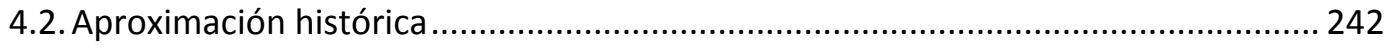

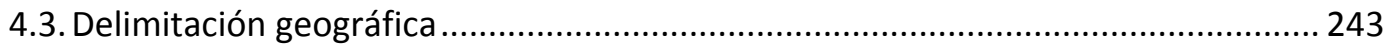

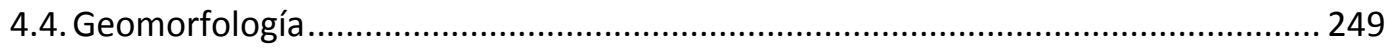

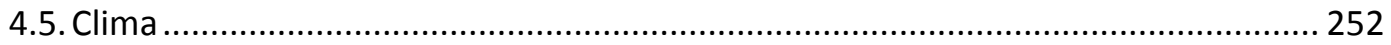

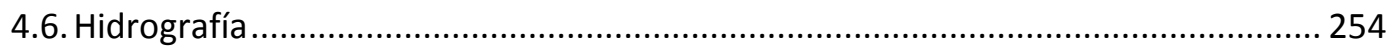

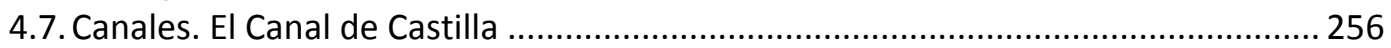

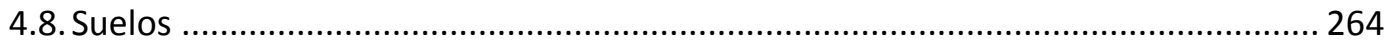

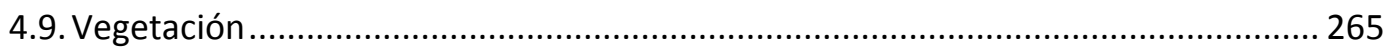

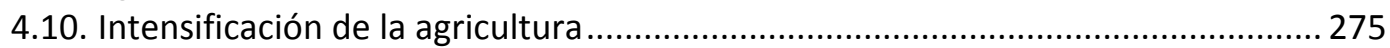

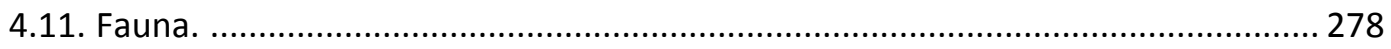

4.12. Espacios naturales protegidos y Red Natura 2000 ......................................... 283

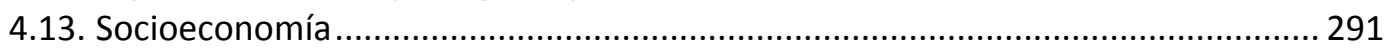

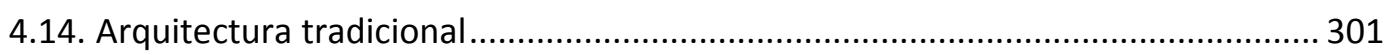

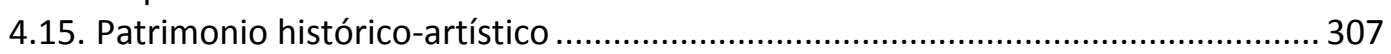

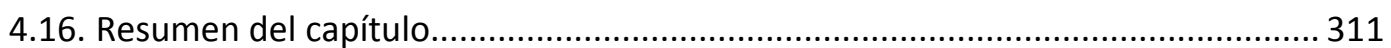


6.1. Caracterización del paisaje de Tierra de Campos.

6.1.1. Paisaje de campiñas cerealistas vs Paisaje de Tierra de Campos ............ 333

6.1.2. Organización del paisaje ........................................................ 333

6.1.3. Dinámica del paisaje ................................................................ 335

6.1.4. Percepción visual del paisaje ......................................................... 336

6.1.4.1. Características visuales básicas....................................... 337

6.1.4.2. Calidad visual .............................................................. 345

6.1.4.3. Fragilidad visual ...................................................... 349

6.1.4.4. Impacto visual ...................................................... 357

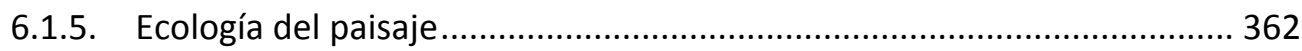

6.1.5.1. Elementos del mosaico territorial ................................... 362

6.1.5.2. Conectividad del paisaje ............................................... 364

6.1.5.3. Fragmentación del hábitat................................................ 366

6.1.5.4. La percepción del paisaje ecológico ...................................... 366

6.2. Deterioros del paisaje de Tierra de Campos. ...................................................... 367

6.2.1. Impactos paisajísticos de grandes obras a escala comarcal ................... 368

6.2.1.1. Concentraciones parcelarias........................................ 368

6.2.1.2. Transformaciones en regadío ......................................... 371

6.2.1.3. Explotaciones de ganadería intensiva ............................. 373

6.2.1.4. Infraestructuras lineales de transporte: carreteras, autovías y líneas de ferrocarril .................................................. 374

6.2.1.5. Explotaciones mineras, préstamos y vertederos................... 376

6.2.1.6. Líneas eléctricas de alta tensión ....................................... 377

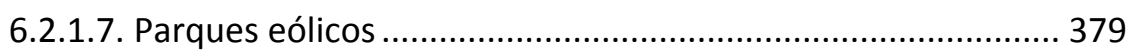

6.2.1.8. Urbanizaciones residenciales y polígonos industriales.......... 381

6.2.2. Degradaciones paisajísticas a escala municipal ................................. 383

6.2.3. Síntesis de degradaciones características del paisaje de Tierra de Campos .................................................................................... 396

6.3. Recuperación ambiental de los espacios degradados de Tierra de Campos ................ 404

6.3.1. Tratamientos generales de recuperación del paisaje de Tierra de Campos ........................................................................................ 404

6.3.2. Actuaciones de recuperación ambiental ....................................... 412

6.3.2.1. Espacios con agricultura intensiva afectados por concentraciones parcelarias ......................................... 414

6.3.2.2. Espacios afectados por transformaciones en regadío........... 424

6.3.2.3. Espacios afectados por infraestructuras lineales de transporte.

6.3.2.4. Espacios afectados por explotaciones mineras, préstamos y vertederos ................................................ 435

6.3.2.5. Espacios afectados por infraestructuras energéticas ............ 436

6.3.2.6. Ríos y arroyos desnaturalizados ........................................ 439

6.3.2.7. Zonas húmedas degradadas ............................................. 444

6.3.2.8. Vías pecuarias y del ferrocarril sin uso ................................ 448

6.3.2.9. Fuentes y pequeñas parcelas públicas degradadas............... 453

6.3.2.10. Espacios deforestados y/o erosionados........................... 457

6.3.2.11. Escombreras y vertederos de residuos ............................ 464

6.3.2.12. Entorno de construcciones en suelo rústico ...................... 468

6.3.2.13. Periferias de los pueblos .............................................. 470

6.3.2.14. Pueblos en descuido y abandono................................... 478

6.4. Árboles y arbustos utilizables en la recuperación del paisaje de Tierra de Campos...... 486 


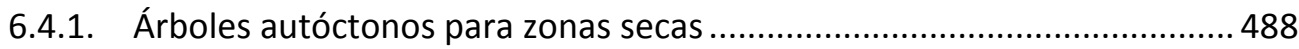

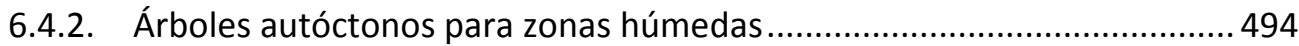

6.4.3. Árboles exóticos ornamentales rústicos ................................................. 498

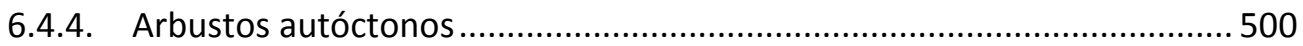

6.5. Imagen-objetivo del paisaje de calidad de Tierra de Campos ...................................... 507

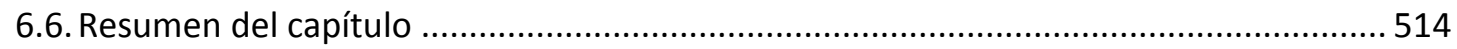

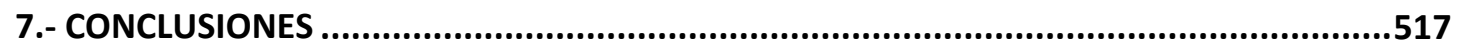

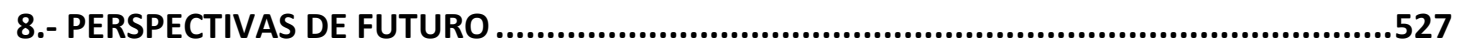

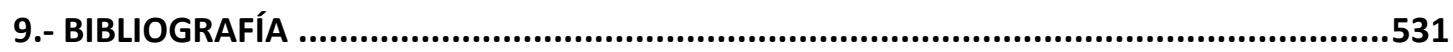

\section{ANEJOS}

\section{ANEJO 1: PROYECTOS REPRESENTATIVOS DE OBRAS QUE AFECTAN AL PAISAJE DE} TIERRA DE CAMPOS.

A1.1. Concentración parcelaria de los términos municipales de Herrín de Campos, Villafrades de Campos, Villalón de Campos y Boadilla de Rioseco.

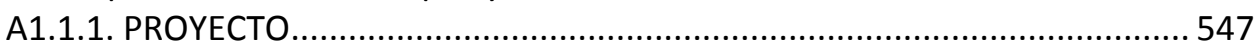

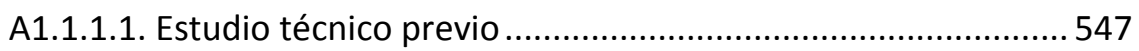

A1.1.1.2. Proyecto modificado de concentración parcelaria ................ 551

A1.1.1.3. Acuerdo de concentración parcelaria ..................................552

A1.1.1.4. Proyecto de infraestructura rural ........................................553

A1.1.1.5. Proyecto modificado de infraestructura rural........................ 555

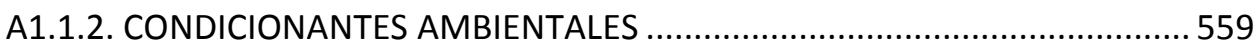

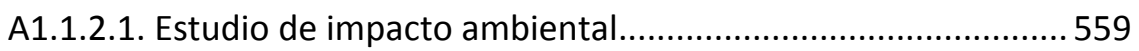

A1.1.2.2. Declaración de impacto ambiental........................................561

A1.1.2.3. Proyecto de restauración del medio natural y

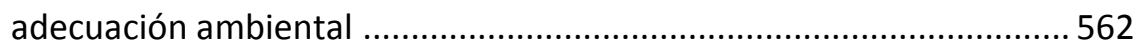

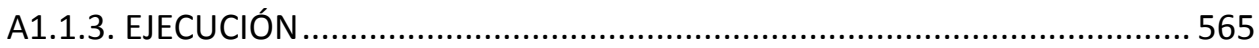

A1.1.3.1. Seguimiento de la obra e Informes de vigilancia ambiental . 565

A1.1.3.2. Conclusiones del seguimiento ambiental...... 570

A1.2. Transformación en regadío del sector IV de la zona regable del canal del

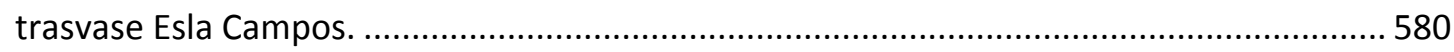

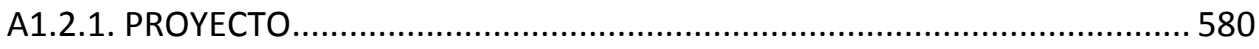

A1.2.1.1. Anteproyecto de zona regable ........................................... 580

A1.2.1.2. Proyecto básico de transformación en regadío ...................... 581

A1.2.1.3. Proyecto de transformación en regadío, obras de interés

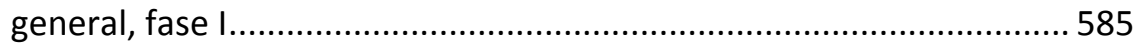

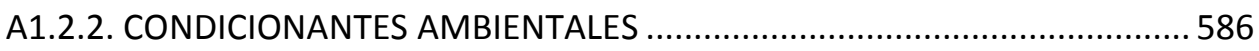

A1.2.2.1. Estudio de Impacto Ambiental ........................................... 586

A1.2.2.2. Declaración de impacto ambiental....................................... 586

A1.2.2.3. Separata ambiental del proyecto de transformación en

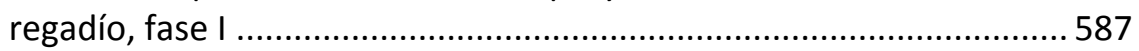

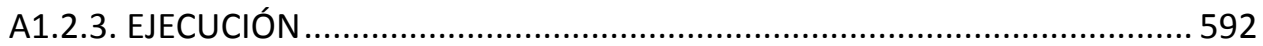


A1.2.3.1. Seguimiento de la obra e informes de vigilancia Ambiental ............................................................................ 592

A1.2.3.2. Conclusiones del seguimiento ambiental ....................... 597

A1.3. Explotación de ganado ovino en Ampudia. ....................................................... 601

A1.3.1. PROYECTO ............................................................................. 601

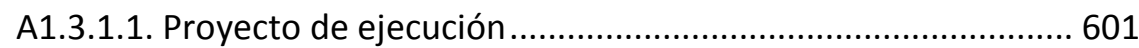

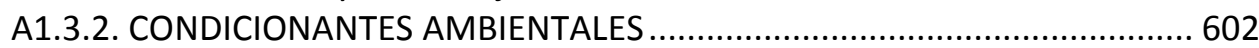

A1.3.2.1. Memoria ambiental.................................................. 602

A1.3.2.2. Informe de la Comisión Territorial de Prevención Ambiental ............................................................................ 603

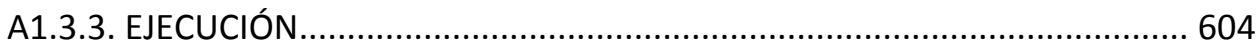

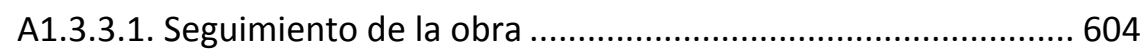

A1.3.3.2. Conclusiones del seguimiento ambiental ...........................6 606

A1.4. Explotación de ganado ovino en Cisneros. ....................................................... 607

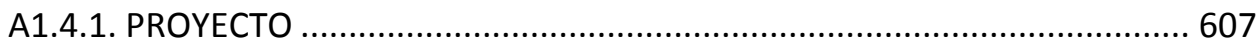

A1.4.1.1. Proyecto básico ............................................................. 607

A1.4.2. CONDICIONANTES AMBIENTALES ............................................. 611

A1.4.2.1. Memoria de actividad ................................................. 611

A1.4.2.2. Informe de la Comisión Territorial de Prevención Ambiental .............................................................................. 612

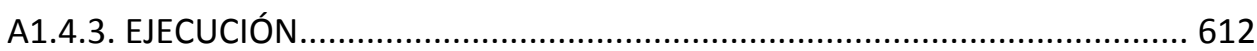

A1.4.3.1. Seguimiento de la obra ................................................. 612

A1.4.3.2. Conclusiones del seguimiento ambiental ...........................615 615

A1.5. Variante de carretera de Villada................................................................. 617

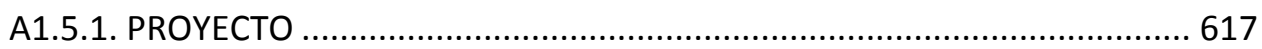

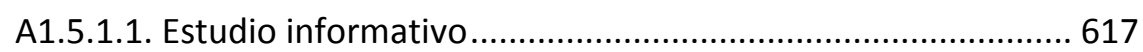

A1.5.1.2. Proyecto de construcción.............................................. 619

A1.5.2. CONDICIONANTES AMBIENTALES .............................................. 621

A1.5.2.1. Estudio de impacto ambiental .......................................6 621

A1.5.2.2. Declaración de impacto ambiental ................................... 625

A1.5.2.3. Anejo de medidas correctoras del proyecto de Construcción.......................................................................... 626

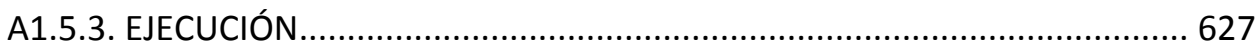

A1.5.3.1. Seguimiento de la obra ............................................. 627

A1.5.3.2. Conclusiones del seguimiento ambiental ........................6 629

A1.6. Explotación de la zona de préstamos PR-1 asociada al proyecto de construcción de la plataforma corredor norte-noroeste de alta velocidad tramo Palencia-León, subtramo Becerril de Campos-Valle del Retortillo. Términos municipales de Becerril de Campos y Paredes de Nava (Palencia). ..........................636

A1.6.1. PROYECTO ............................................................................ 636

A1.6.1.1. Proyecto de construcción de plataforma de LAV ................. 636

A1.6.2. CONDICIONANTES AMBIENTALES ........................................... 638

A1.6.2.1. Plan de restauración ambiental ....................................6 638

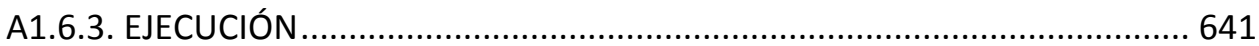


A1.6.3.1. Seguimiento de la obra e informe final de restauración........641

A1.6.3.2. Conclusiones del seguimiento ambiental 646

A1.7. Línea eléctrica aérea de alta tensión entre las subestaciones de transformación de Ampudia y Grijota.

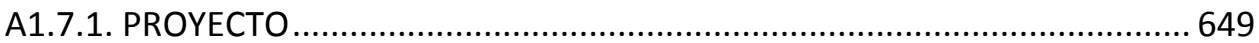

A1.7.1.1. Proyecto de línea de alta tensión ......................................... 649

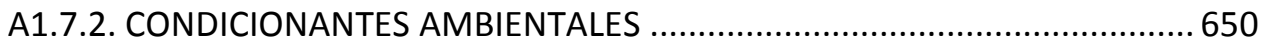

A1.7.2.1. Estudio de impacto ambiental y Plan de restauración ........... 650

A1.7.2.2. Declaración de impacto ambiental....................................... 651

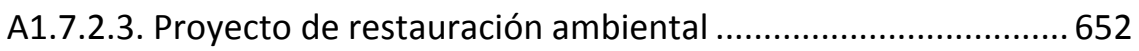

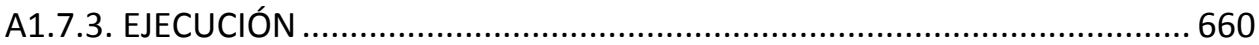

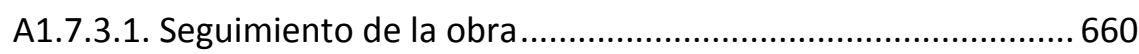

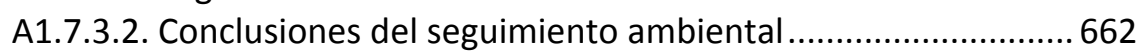

A1.8. Parque eólico El Castre, en los términos municipales de Torremormojón y

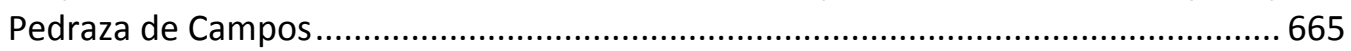

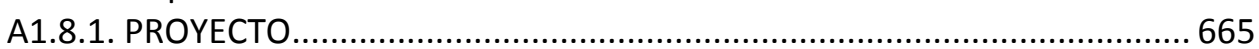

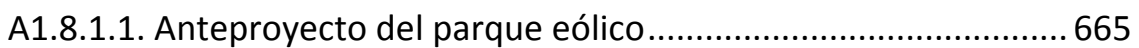

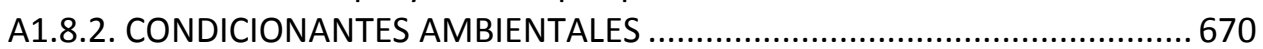

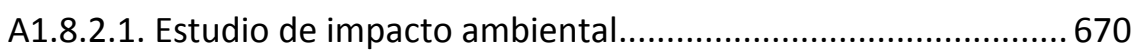

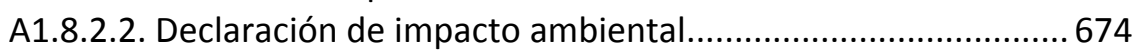

A1.8.2.3. Proyecto de restauración ambiental .......................................675 67

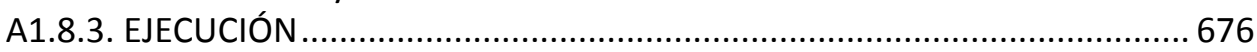

A1.8.3.1. Informes de vigilancia ambiental del parque eólico ..............676 676

A1.8.3.2. Informes de seguimiento del proyecto de restauración

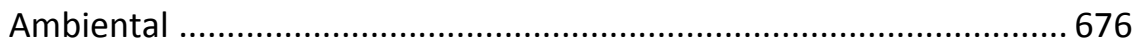

A1.8.3.3. Conclusiones del seguimiento ambiental........................... 677

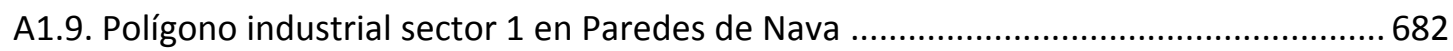

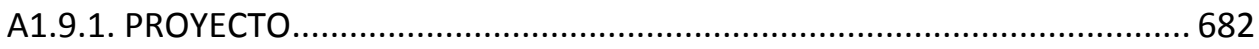

A1.9.1.1. Plan Parcial de ordenación sector polígono industrial...........682

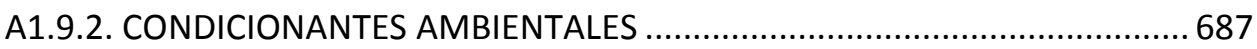

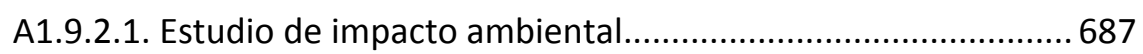

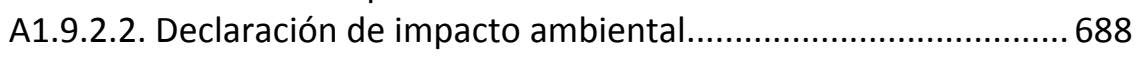

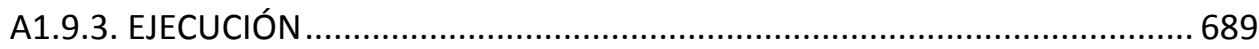

A1.9.3.1. Seguimiento de la obra e informe de vigilancia ambiental... 689

A1.9.3.2. Conclusiones del seguimiento ambiental.. 689

\section{ANEJO 2: PROYECTOS DE RECUPERACIÓN AMBIENTAL SINGULARES EN TIERRA DE}

A2.1. Realización de plantaciones, construcción de área de descanso y tramo accesible en el Camino de Santiago en la provincia de Palencia ...............................................695

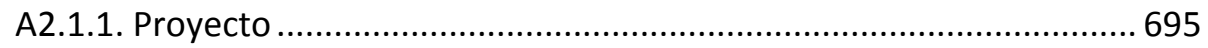

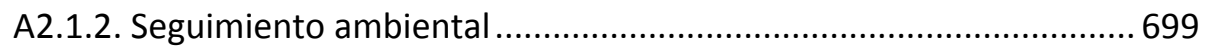


A2.2. Repoblación forestal en una parcela sobrante de vía pecuaria, en el término municipal de Herrín de Campos

A2.2.1. Proyecto......................................................................... 705

A2.2.2. Seguimiento ambiental............................................... 706

A2.3. Repoblación forestal de laderas en el término municipal de Ampudia .................... 709

A2.3.1. Proyecto.......................................................................... 709

A2.3.2. Seguimiento ambiental..................................................... 711

A2.4. Repoblación forestal de una parcela de masa común en el término municipal de Frechilla................................................................................................. 715

A2.4.1. Proyecto ........................................................................ 715

A2.4.2. Seguimiento ambiental.................................................. 716

A2.5. Restauración hidrológico-forestal y posterior tratamiento selvícola y plantación de diversificación en la cuesta de Coruñeses, término municipal de Medina de Rioseco ......................................................................................... 719

A2.5.1. Proyecto........................................................................... 719

A2.5.2. Seguimiento ambiental................................................. 722

A2.6. Recuperación ambiental y adecuación de la "Ruta de los parques" en Villalón de

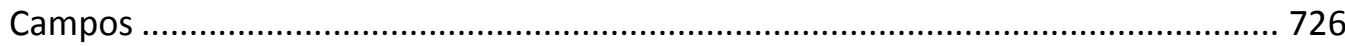

A2.6.1. Proyecto........................................................................... 726

A2.6.2. Seguimiento ambiental.................................................... 731

A2.7. Adecuación de camino turístico en el término municipal de Tamariz de Campos...... 734

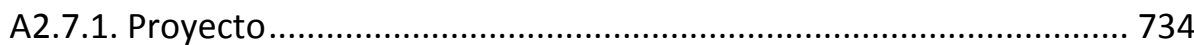

A2.7.2. Seguimiento ambiental................................................. 737

A2.8. Rehabilitación de antigua vía del ferrocarril como Vía Verde "Tierra de Campos", tramo Cuenca de Campos - Villalón de Campos .............................................. 739

A2.8.1. Proyecto........................................................................... 739

A2.8.2. Seguimiento ambiental................................................... 741

A2.9. Restauración del arroyo Berruez en el término municipal de Villalón de Campos ..... 746

A2.9.1. Proyecto......................................................................... 746

A2.9.2. Seguimiento ambiental................................................... 748

ANEJO 3: RECORRIDOS PAISAJÍSTICOS EN VILLALÓN DE CAMPOS............................... 751

A3.1. Fichas de los Recorridos paisajísticos ........................................................ 753

1) Ruta exterior, fuente la Florida y antigua vía ......................................... 753

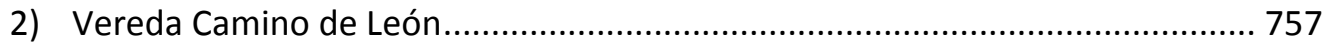

3) Carretera de Fuentes ........................................................................ 761

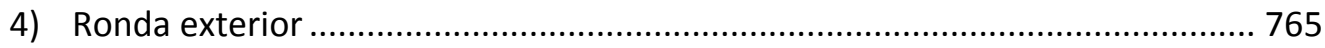




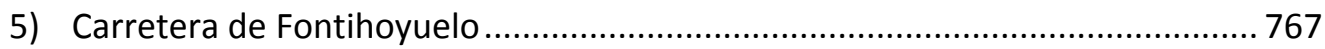

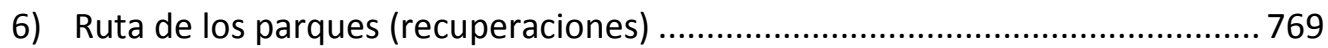

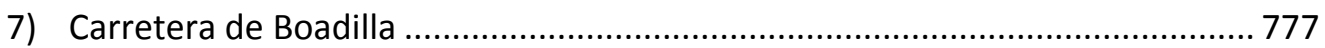

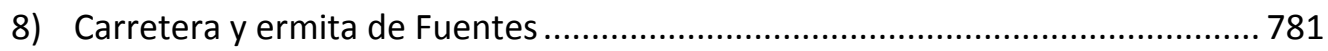

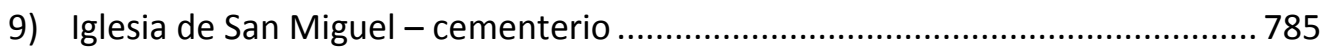

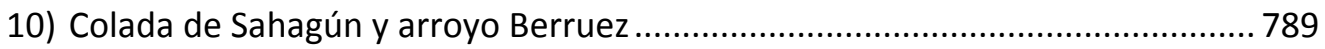

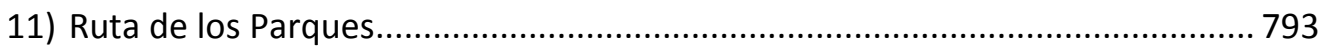

12) Colada de Villalón a Villada, San Salva y ruta larga por el Rosario .................... 797

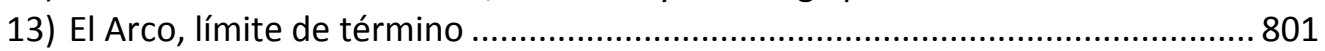

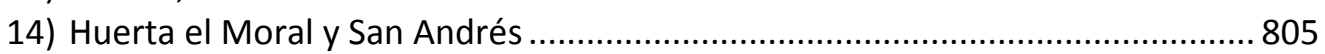

15) Villarrobejo, camino de circunvalación y San Juan .......................................... 809

16) Ruta de los Parques (actuaciones/degradaciones) .......................................... 815

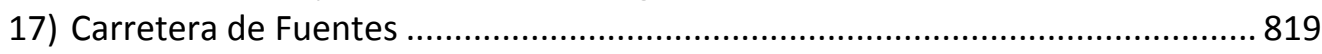

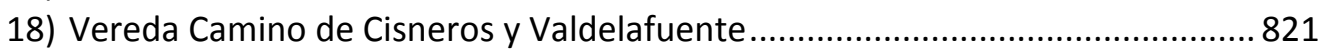

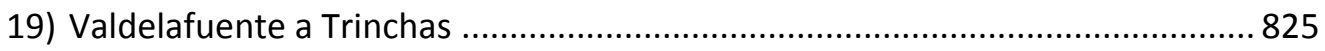

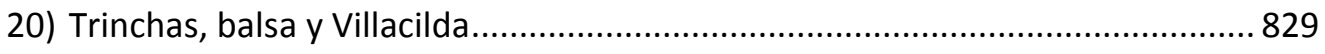

21) Colada de Villalón a Guaza y carretera de Herrín .............................................. 833

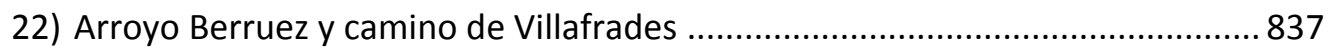

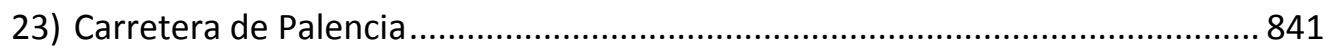

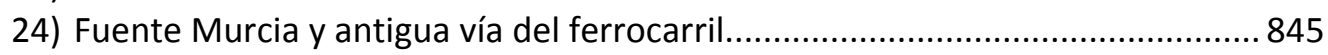

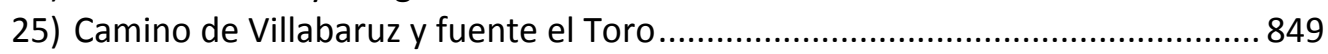

26) Ruta de los Parques (recuperaciones potenciales) ...........................................85 85

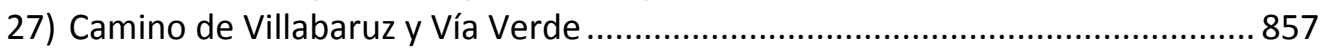

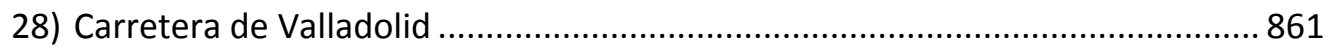

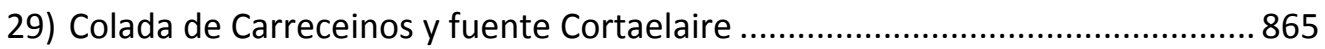

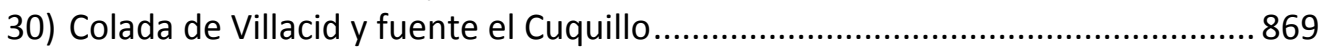

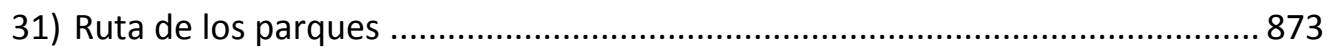

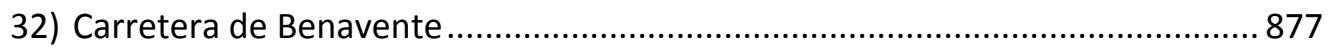

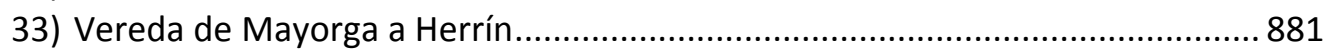

34) Carretera de Bustillo y Colada de Cabezón-Villalón............................................. 885

A3.2. Seguimiento de las recuperaciones ambientales incluidas en el Anejo 3 ................... 889

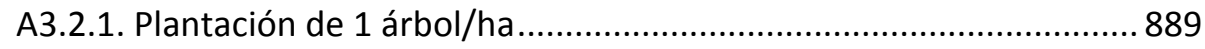

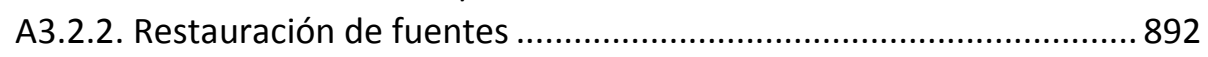

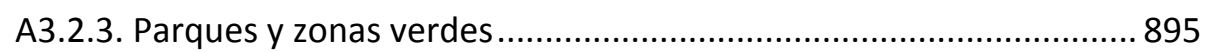




\section{ÍNDICE DE FIGURAS}

Figura 1.1. Fuente y pago de la Alameda. Dos chopos secos son testigos de un pasado donde los árboles tenían un mayor protagonismo en el paisaje.

63

Figura 1.2. A la izquierda, imagen de uno de los escasísimos majuelos de Villalón de Campos en la actualidad; a la derecha, el árido paisaje circundante. 65

Figura 1.3. Graciosa fotografía de un majuelo de Villalón de Campos en 1943, que ahora no existe. En ella se aprecian los árboles que solían acompañar este cultivo.

Figura 1.4. Ilustración realizada en un muro de Melgar de Abajo, reivindicativa ante el éxodo rural que sufre Tierra de Campos.

Figura 1.5. Fotografía tomada de la prensa británica. Esta imagen podría haber sido tomada desde cualquier punto en la línea de cumbres de los Torozos, mostrando un hipotético paisaje de Tierra de Campos mejorado, con más verde y más diversidad, pero agrícola al fin y al cabo. 70

Figura 1.6. Ilustración contenida en un paquete de galletas, donde se intenta relacionar el origen natural de las mismas. Los cultivos cerealistas de las que proceden se han "mejorado" con varias alineaciones arboladas. 70

Figura 3.1. Paseo peatonal en Abarca de Campos, donde se emplean los árboles como valor fundamental de mejora de un paisaje agrario ordenado.

Figura 3.2. Propiedades del modelo de Kaplan y Kaplan, que son los predictores más potentes de preferencia ambiental (CORRALIZA, 1993).

Figura 3.3. Senderismo por la vía verde Tierra de Campos. 93

Figura 3.4. Carteles señalizadores de itinerarios saludables en Santa Coloma de Farners (Girona). En estas dos fotografías se percibe que estos itinerarios conectan el centro urbano con los parques periurbanos, haciéndolos más accesibles 95

Figura 3.5. Paisaje rural paradigmático de La Toscana (Italia), que aporta a esta región un innegable carácter. En NAVÉS et al. (2005).

Figura 3.6. Imágenes actuales que pueden servir de modelo de la transformación del paisaje agrícola. A la izquierda, paisaje en mosaico -prácticamente relicto- con viñedo, frutales y cereal. A la derecha, monocultivo cerealista. Ambas fotografías están tomadas en Villalón de Campos, aunque la segunda es abrumadoramente mayoritaria en el territorio. 99

Figura 3.7. Tipos de cultivos españoles desde el punto de vista paisajístico (NAVÉS et al., 2005). 
Figura 3.8. Fases fundamentales del cultivo cerealista: barbecho (arriba izquierda), cereal nacido (arriba derecha), cereal en maduración (abajo izquierda) y rastrojo (abajo derecha). 102

Figura 3.9. Ficha de variación cromática (NAVÉS et al., 2005). 103

Figura 3.10. Bancales construidos para el cultivo de cerezos, en el valle del Jerte. En la época de floración, se trata de uno de los paisajes agrícolas de mayor belleza de nuestro país. 105

Figura 3.11. Alineación de plátanos en torno a un camino en una zona de huertas de Palencia, una de las escasas alineaciones arboladas en vías de Tierra de Campos. 106

Figura 3.12. Ejemplos de alineaciones arboladas en Luxemburgo y Polonia (Consejo de Europa, 2009), donde se aprecia la belleza que generan en el paisaje interno de la carretera. 107

Figura 3.13. Izquierda, fuente El Rosario (Villalón de Campos). 108

Figura 3.14. Derecha, chopo de gran envergadura en la fuente Cortaelaire (Villalón de Campos). 108

Figura 3.15. Mapa de Asociaciones de tipos de paisajes de España (MATA y SANZ, 2004). En la leyenda aparecen diferenciadas las Campiñas en un tono anaranjado. 110

Figura 3.16. Izquierda, campiña de Gereña (Sevilla). Derecha, campiña de olivares en Villamanrique (Ciudad Real). En MATA y SANZ (2004). 111

Figura 3.17. En amarillo, aparecen reflejadas parte de las Campiñas de la Meseta Norte. En esta hoja del Atlas se encuentra representada la mayoría de Tierra de Campos -salvo el extremo suroccidental zamorano- solo interrumpida por las Vegas de la cuenca del Duero (MATA y SANZ, 2004). 113

Figura 3.18. Plano topográfico de Tierra de Campos, donde se observa la gran coincidencia de la comarca (perímetro en rojo) con el tipo de paisaje de Campiñas (en fondo blanco, con intercalaciones verdes de las Vegas). Páramos detríticos y calcáreos son sus límites naturales al norte y al sur respectivamente. 117

Figura 3.19. Quemas de regueras con arbustos en Becerril de Campos en febrero de 2012, para el control del topillo campesino, que fueron generalizadas en la comarca..... 121

Figura 3.20. Préstamo para el AVE en Villada (izquierda) y vertedero para la misma obra en Paredes de Nava (derecha).

Figura 3.21. Parque eólico y diversas líneas eléctricas en Ampudia (izquierda). Huerto solar en Terradillos de los Templarios (derecha). 124

Figura 3.22. Escombrera a escasos $200 \mathrm{~m}$ de la iglesia mudéjar de Aguilar de Campos (izquierda). Depósito incontrolado de escombros en una zona periurbana de Cisneros (derecha). 127 
Figura 3.23. Esquema del procedimiento de Evaluación de Impacto Ambiental (GÓMEZ OREA, 2003).

Figura 3.24. Posibles evoluciones de un ecosistema alterado (UDPP, 2002). 143

Figura 3.25. Fases por las que pasa el tratamiento de un espacio degradado y contenido de cada una de ellas (GÓMEZ OREA, 2004). 144

Figura 3.26. Impactos visuales irrecuperables: izquierda, antenas contiguas a la iglesia de Quintanilla de la Cueza; derecha, aerogeneradores alrededor del conjunto histórico-artístico de Ampudia. 148

Figura 3.27. Vista del vertedero de inertes de Cisneros, para las obras del ferrocarril de alta velocidad Palencia-León, una vez restaurado como uso agrícola. 149

Figura 3.28. Uso forestal (plantación de frondosas ripícolas, aunque todavía no se aprecien) en el préstamo P1 para el ferrocarril de alta velocidad Palencia-León, en Grijota. 150

Figura 3.29. Antiguo préstamo para la autovía Camino de Santiago en Calzada de los Molinos, que actualmente se ha convertido en una laguna perfectamente naturalizada. 151

Figura 3.30. Vista de la cantera de arcilla El Pilar, en las proximidades de una zona industrial en Palencia. 151

Figura 3.31. Erosión en regueros producida en los taludes de desmonte del canal Esla-Carrión, en Villacarralón. Sus pendientes son pronunciadas y no tienen tierra vegetal. 154

Figura 3.32. Adecuada remodelación del terreno en el préstamo PR1 para la línea de alta velocidad Palencia-León, en Becerril de Campos. 156

Figura 3.33. Escombros en margen de camino en Villalón de Campos (izquierda) y en margen de carretera (Tamariz de Campos). 157

Figura 3.34. Corrección hidrológica (bajante) en la autovía del Camino de Santiago. 159

Figura 3.35. Fases de la elección de especies (OTERO et al., 1999). 167

Figura 3.36. Sección típica de plantación de arbusto (izquierda) y de planta perennifolia (derecha). El tamaño del hoyo dependerá del volumen del cepellón (UDPP, 2002).

Figura 3.37. Izquierda, estaquillas de chopo lombardo; derecha, estaquilla brotada de chopo en reguera de Villalón de Campos.

Figura 3.38. Plantación de frondosas en el Camino de Santiago: retroexcavadora que realiza los hoyos y operarios colocando la planta. 173

Figura 3.39. Pinos con tutores en la autovía del Camino de Santiago, en Osorno. 173 
Figura 3.40. Muro de gaviones inclinado (UDPP, 2002). 180

Figura 3.41. Hormigón proyectado en talud de desmonte en la carretera VA-905, en Moral de la Reina. Tal como se puede apreciar, se trata de una solución muy artificial.... 181

Figura 3.42. Encachado en paso superior de la autovía Camino de Santiago, en este caso rejuntado con cemento. 182

Figura 3.43. Manta orgánica en el canal Esla-Carrión. 183

Figura 3.44. Técnica de estaquillado (LÓPEZ GIMENO, 1999) 184

Figura 3.45. Esquema de fajinas (LÓPEZ GIMENO, 1999). 185

Figura 3.46. Fotografía de la técnica de escalones de matorral (LÓPEZ GIMENO, 1999)..... 185

Figura 3.47. Técnica de reparación de cárcavas con material vivo (LÓPEZ GIMENO, 1999). 186

Figura 3.48. Esquema y fotografía de la estructura de tierra reforzada (LÓPEZ GIMENO, 1999).

Figura 3.49. Esquema de la técnica de muros verde (LÓPEZ GIMENO, 1999). 187

Figura 3.50. Esquema del enrejado viviente (LÓPEZ GIMENO, 1999)...... 188

Figura 3.51. Esquema del estaquillado de escolleras (LÓPEZ GIMENO, 1999). 189

Figura 3.52. Muro de gaviones con vegetación (LÓPEZ GIMENO, 1999). 189

Figura 3.53. Esquema del muro de roca y vegetación (LÓPEZ GIMENO, 1999). 190

Figura 3.54. Izquierda, diques de piedra suelta caliza en restauración hidrológico-forestal en laderas con cárcavas en Torremormojón (realizada por la Confederación Hidrográfica del Duero, hacia 1960). Derecha, dique con madera instalado recientemente en las mismas laderas, dentro de las medidas compensatorias por la construcción del parque eólico El Castre. 192

Figura 3.55. Izquierda, dibujo esquemático de un paso superior específico para la fauna. Derecha, paso superior en Ledigos (MMA, 2006) . 195

Figura 3.56. Dibujo de un paso superior multifuncional (MMA, 2006). 196

Figura 3.57. Arriba, distribución de distintos usos bajo un viaducto: curso fluvial, sectores revegetados que se mantienen secos y una carretera en las proximidades de uno de los estribos (MMA, 2006). Abajo, adaptación de viaducto como paso de fauna en Tierra de Campos, en el tramo de AVE Valle del Retortillo-Pozo de Urama.

Figura 3.58. Esquema de un paso inferior específico (MMA, 2006). 198

Figura 3.59. Esquema de un paso inferior multifuncional. En el dibujo de la derecha se dispone una acequia en uno de los márgenes de la estructura (MMA, 2006). 198 
Figura 3.60. Esquema de un paso inferior específico para pequeños vertebrados (MMA, 2006).

Figura 3.61. Izquierda, esquema de un drenaje adaptado para animales terrestres; derecha, distribución de las plantaciones en los accesos a los pasos de fauna (MMA, 2006).

Figura 3.62. Dibujo de un drenaje adaptado para peces (MMA, 2006)..... 200

Figura 3.63. Esquema de un paso para anfibios (MMA, 2006) 200

Figura 3.64. Fotografías ilustrativas de setos: GAMBIER (2009) y JUNTA DE CYL (1992)..... 201

Figura 3.65. Arriba, mosaico de setos arbolados de encinas y otras especies acompañantes, como almendros, en Villalpando. Abajo, ortofotografía de 2011 de la zona, en el límite de los términos municipales de Cañizo y Villalpando. Parece un espejismo en Tierra de Campos. 203

Figura 3.66. Setos situados en regueras de Villalón de Campos (izquierda) y Fontihoyuelo (derecha). Abajo, ortofotografía de uno de los escasos setos de este último municipio. 204

Figura 3.67. Esquema gráfico de la mejora del paisaje cerealista que entrañaría la creación de setos vivos (JUNTA DE CYL, 1992). 205

Figura 3.68. Seto arbóreo y arbustivo en márgenes de camino rural en Castromocho....... 206

Figura 3.69. Espino majoleto con varios nidos en Villalón de Campos 206

Figura 3.70. La plantación de este seto de Cupressus arizonica en Villalón de Campos, mitiga el impacto visual de la valla metálica y de las naves agrícolas del interior de la parcela. 208

Figura 3.71. Modelo de creación de seto en un lindero de parcelas agrícolas (JUNTA DE CYL, 1992) 209

Figura 3.72. Ejemplos de módulo de plantación de setos (GAMBIER, 2009). 210

Figura 3.73. Distancias mínimas de plantación según el Código Civil (GAMBIER, 2009)...... 211

Figura 3.74. Soto en los márgenes del río Valdeginate, en Castromocho. 213

Figura 3.75. Esquema de plantación de un soto (DE ANDRÉS et al., 2003). 215

Figura 3.76. Arriba izquierda, encina de gran porte en Paredes de Nava; arriba derecha, dos chopos que parecen uno en Villalón de Campos; abajo izquierda, pinarcillo en Herrín de Campos; abajo derecha, grupo de álamos que antaño rodearon un majuelo.

Figura 3.77. Esquema de plantación de bosques isla (DE ANDRÉS et al., 2003). 217 
Figura 3.78. Plantación de árboles en Tamariz de Campos (izquierda) y Gatón de Campos (derecha), como medida de condicionalidad de la PAC..... 220

Figura 3.79. Distribución de Castilla y León en Zonas. Las que corresponden a Tierra de Campos son la 11 (básicamente), la 10 y la 12.

Figura 3.80. Iglesia de San Pedro, cuyo interior alberga un museo parroquial de arte sacro. 228

Figura 3.81: Dos pueblos pequeños ejemplares en cuidado de las zonas verdes urbanas: Cuenca de Campos (izquierda) y Abarca de Campos (derecha). 229

Figura 3.82. Parque de la laguna del Tinte en Villalón de Campos, ejemplo de espacio periurbano anteriormente degradado (fue una laguna rellena de escombros). 230

Figura 3.83. Ermita de Carejas, en Paredes de Nava (izquierda) y ermita de San Bernardino, en Cuenca de Campos (derecha), dos de los mejores ejemplos de adecuación recreativa en Tierra de Campos. 231

Figura 3.84. Cartel interpretativo en la Vía Verde de Tierra de Campos, tramo Villalón de CamposCuenca de Campos, sobre el antiguo "tren burra". 233

Figura 3.85. Cuatro miradores de tipologías diferentes: arriba izquierda, castillo de Montealegre; arriba derecha, páramo de Autilla del Pino; abajo izquierda, depósito en Cuenca de Campos; abajo derecha, mirador en la muralla de Urueña.. 235

Figura 3.86. Casa de la Reserva de las lagunas de Villafáfila. 236

Figura 4.1. Mapa de la comarca natural de Tierra de Campos (LANCIA, 2004). 244

Figura 4.2. Mapa de Tierra de Campos realizado a partir de la delimitación de GONZÁLEZ GARRIDO (1941). 245

Figura 4.3. Mapa de La Tierra de Campos (GONZÁLEZ GARRIDO, 1941). La imagen superior es el plano original del autor y, la inferior, una aproximación de la comarca en el mapa topográfico actual. 248

Figura 4.4. Dos vistas de Tierra de Campos desde el mirador de Autilla del Pino: a la izquierda, laderas de transición al páramo calcáreo; a la derecha, campiña en su inmensidad.

Figura 4.5. Mapa esquemático del relieve de Tierra de Campos (VACA, 1992). 251

Figura 4.6. Panorámica de cerro testigo en Tordehumos, desde otro contiguo donde se ubicaba su castillo. 252

Figura 4.7. Río Cea en Melgar de Abajo. 255

Figura 4.8. Río Valderaduey en Cañizo. 255

Figura 4.9. Dos pequeños arroyos o regueras rectificadas en Villalón de Campos. 255 
Figura 4.10. Vistas del impresionante grupo de esclusas de Calahorra de Ribas. 257

Figura 4.11. Izquierda, vista del Canal de Castilla en Abarca de Campos; derecha, esclusa 7 y antigua fábrica de harinas en las cercanías de Tamariz de Campos. 258

Figura 4.12. Esquema del trazado del Canal de Castilla a través de Tierra de Campos (LANCIA, 2004), comarca que ocupa buena parte de su recorrido. 259

Figura 4.13. Arriba, museo temático del Canal de Castilla y embarcación turística Juan de Homar, en Villaumbrales. Abajo, embarcación Antonio de Ulloa en la ruta desde Medina de Rioseco hasta Tamariz de Campos (7a esclusa). 261

Figura 4.14. Canal de Castilla a su paso por Castromocho, con sus márgenes floridos en mayo. 262

Figura 4.15. Confluencia del Canal de Castilla con el río Carrión en Calahorra de Ribas. .... 263

Figura 4.16. Vista del Monte El Viejo (Palencia), en el borde del páramo calcáreo. 266

Figura 4.17. Izquierda, ortofotografía del Monte Becerril, en Becerril de Campos: un enclave forestal de 166 ha en pleno medio agrícola. Derecha, encinar en el Monte Becerril. 269

Figura 4.18. Panorámica de Tierra de Campos desde el castillo de Tordehumos, sin prácticamente atisbo alguno de vegetación arbolada. 271

Figura 4.19. Ribera del río Carrión, en Villoldo, con abundante vegetación arbórea. 272

Figura 4.20. Izquierda, laderas aún deforestadas en Autilla del Pino; derecha, ladera repoblada en Tordehumos. 273

Figura 4.21. Encinar roturado en Perales, en el que aún se conservan buenos ejemplares de esta especie. 273

Figura 4.22. Izquierda, pino piñonero en Villaumbrales; derecha, encina en Paredes de Nava. 274

Figura 4.23. Grupo de machos de avutarda (SANZ ZUASTI y GARCÍA, 2006). 279

Figura 4.24. Arriba, bandada de gansos en las lagunas de Villafáfila. Abajo, imagen de un atardecer de invierno en la laguna de la Nava, con miles de gansos regresando a las aguas para pasar la noche. 281

Figura 4.25. Plano topográfico de Tierra de Campos donde se refleja, en verde, la importante superficie ocupada por espacios naturales con algún tipo de protección. A esta superficie habría que añadirle las riberas de los ríos principales. 284

Figura 4.26. Izquierda, palomares y laguna de Salina Grande en Otero de Sariegos. Derecha, acuáticas en laguna de Villardón, en Villarrín. 285

Figura 4.27. Atardecer en la laguna de la Nava. 288 
Figura 4.28. Una de las lagunas del Canal de Castilla, en Castromocho. ................................289

Figura 4.29. Ribera del río Cea en Melgar de Abajo............................................................... 291

Figura 4.30. Gráfica de la evolución de la población en la Tierra de Campos rural............... 293

Figura 4.31. La imagen lo dice todo. Pintada contra la despoblación en una nave semiderruida de un entorno degradado en Berrueces. 295

Figura 4.32. Tres ejemplos de viviendas tradicionales: en Abarca de Campos (las dos superiores) y en Melgar de Abajo (abajo derecha). Abajo a la izquierda, paredes interiores descubiertas con adobes y estructura "en poste y carrera" en Villalón de Campos. 303

Figura 4.33. Dramática secuencia del derrumbe por abandono en 2014 de un ejemplo de arquitectura tradicional en Villalón de Campos, datada del siglo XVI. 304

Figura 4.34. Corral y portalón restaurados de una casa en Villalón de Campos. 304

Figura 4.35. Palomar en Monasterio de Vega. 306

Figura 4.36. Grupo de palomares de planta circular en Guaza de Campos. 306

Figura 4.37. A la izquierda, iglesia de San Martín de Frómista; derecha, iglesia de Santa Eulalia de Paredes de Nava. 308

Figura 4.38. Castillo de Ampudia. 309

Figura 4.39. Iglesia de San Andrés de Aguilar de Campos. 310

Figura 4.40. Torre de la iglesia de Santa María, en Medina de Rioseco. 311

Figura 5.1. Medición de la pendiente de un talud de arroyo, a través de su componente vertical y horizontal. 329

Figura 6.1. Palomares en Guaza de Campos (izquierda) y Villárdiga (derecha). 335

Figura 6.2. Izquierda, vista característica de paisaje cerealista en Villalón de Campos. Derecha, en la misma localidad, espectacular cielo nublado.

Figura 6.3. Diversas vistas de parcelas agrícolas de Villalón de Campos: barbecho (arriba izda.), cereal nacido (arriba dcha.), cebada en crecimiento (abajo izda.) y cebada madura (abajo dcha.). 339

Figura 6.4. Naves agroganaderas de diversos colores: blanco en Villalón de Campos (arriba izda.), ocre en Montealegre de Campos (arriba dcha.), aluminio brillante en San Martín de Valderaduey (abajo dcha.) y azul en Fontihoyuelo (abajo dcha.). 340

Figura 6.5. Vista de Tierra de Campos desde el castillo de Montealegre de Campos, donde se puede apreciar el predominio absoluto de la componente horizontal en la escena. 
Figura 6.6. Existen múltiples ejemplos de presencia de la componente línea en el paisaje: izda. Camino rural en Boadilla de Rioseco; dcha. canal en Villafolfo (Paredes de Nava).

Figura 6.7. La escasez general de arbolado provoca la ausencia de texturas marcadas en el paisaje de Tierra de Campos: arriba izquierda, panorámica del paisaje cerealista desde Urueña; arriba derecha, grupo de pinos piñoneros en Herrín de Campos. A escalas más reducidas, la textura adquiere mayor importancia: abajo izquierda, barbecho en Villalón de Campos; abajo derecha, balas de alfalfa en Boadilla de Rioseco. 343

Figura 6.8. Ejemplos de elementos dominantes por escala: izquierda, nave agrícola en Cisneros; derecha, aerogeneradores y líneas eléctricas en Ampudia. 344

Figura 6.9. Las escenas panorámicas son características de Tierra de Campos. Vista desde la muralla de Urueña. 345

Figura 6.10. Inventario/evaluación de la calidad escénica. Criterios de ordenación y puntuación (BLM, 1980; tomado de AGUILÓ et al., 1993). 347

Figura 6.11. Dos vistas realizadas desde la muralla de Urueña. En la fotografía de la derecha, se percibe un paisaje de una mayor calidad visual, con una presencia mayor de vegetación y de actuaciones humanas integradas. 348

Figura 6.12. Mapa de calidad del paisaje de España (OTERO et al., 2007). La flecha indica la posición de Tierra de Campos. 349

Figura 6.13. Modelo general de fragilidad visual (ESCRIBANO et al., 1987). 351

Figura 6.14. La presencia de chopos en Villoldo hace aumentar la capacidad de absorción visual ante instalaciones como antenas de telefonía móvil o construcciones descontextualizadas. 352

Figura 6.15. Parque eólico próximo al castillo de Ampudia. Toda la localidad está catalogada como conjunto histórico-artístico. 354

Figura 6.16. Nave agrícola en Cisneros, que provoca un fuerte impacto visual por contraste de color y dominancia en escala. 359

Figura 6.17. Izquierda, antena de telefonía móvil y cable de teléfono en Herrín de Campos; derecha, estación de servicio en Fuentes de Nava. 360

Figura 6.18. Parque eólico en Ampudia. 361

Figura 6.19. Movimientos de tierra ocasionados en autovía en Grijota y en línea de ferrocarril de alta velocidad en Cisneros. 362

Figura 6.20. Ortofotografía superior izquierda, mancha de encinas en Becerril de Campos. Superior derecha, mancha como laguna en Boada de Campos. Inferior izquierda, 
matriz agrícola en Castromocho. Inferior derecha, corredores riparios en Villoldo. 363

Figura 6.21. Ejemplos de conectores del paisaje: izquierda, curso fluvial; derecha, márgenes de cultivos con vegetación arbustiva (MMA, 2006). El caso de la izquierda podría darse en las riberas de los grandes ríos de Tierra de Campos, no así en ningún modo el de la derecha. 365

Figura 6.22. Ribera del río Templarios en Moratinos (izquierda) y ribera del río Cueza en Cervatos de la Cueza (derecha). 366

Figura 6.23. Obras de reconcentración parcelaria en Boadilla de Rioseco; a la izquierda, construcción de caminos; a la derecha, limpieza de arroyos. 368

Figura 6.24. Intensísimas transformaciones producidas por dos concentraciones parcelarias en Villalón de Campos. La primera ortofotografía procede del vuelo americano de 1956, con el parcelaria típico de la agricultura tradicional. En la segunda (del entorno de 1980) se perciben los efectos de la primera concentración. En la última ortofotografía de 2011 se aprecian los cambios producidos por la reciente segunda concentración parcelaria. 370

Figura 6.25. Izquierda, canal Cea-Carrión en Villacarralón; derecha, interior de la gran balsa de regadío en construcción en el sector IV. 371

Figura 6.26. Arriba, en primer plano, alfalfa en una zona regable del Canal de Castilla en Villarramiel. Abajo, maizal en Carrión de los Condes en pleno agosto.

Figura 6.27. Granja de ovino en Cisneros. 373

Figura 6.28. Vista de un tramo de la variante de Villada, que en este caso discurre en terraplén 375

Figura 6.29. Préstamo en el tramo del AVE Palencia-León "Becerril-Valle del Retortillo" . .. 376

Figura 6.30. Imagen de un apoyo de la línea de alta tensión Ampudia-Grijota. 378

Figura 6.31. Parque eólico El Castre, en Torremormojón. 380

Figura 6.32. Arriba, urbanización residencial en Grijota, donde se puede apreciar un vial principal y las viviendas. Abajo, polígono industrial en Paredes de Nava; en primer plano, los espacios ajardinados y al fondo una de las primeras naves edificadas. 382

Figura 6.33. Montón de escombros en el margen de la carretera nacional N-610. 385

Figura 6.34. Vista de un arroyo/reguera típico de Tierra de Campos, totalmente rectilíneo y sin vegetación en los márgenes. Recorrido paisajístico 20 "Trinchas, balsa, Villacilda". 
Figura 6.35. Los caminos rectos como este -de Villalón de Campos a Herrín de Campos- son una constante en Tierra de Campos; ni una brizna de vegetación en sus márgenes.

Figura 6.36. Proliferación de líneas eléctricas en la colada de Villacid de Campos (Recorrido 30).

Figura 6.37. La componente lineal no puede ser más evidente en la carretera de Herrín de Campos a Villalón de Campos. En los márgenes no se atisba ni la más mínima zarza.

Figura 6.38 (izquierda). Corta de chopos en margen de carretera Herrín de Campos-Villalón de Campos. 388

Figura 6.39 (derecha). Desmoronamientos en desmonte de carretera Villalón de CamposFontihoyuelo. 388

Figura 6.40. Nave agrícola en Recorrido paisajístico 8 (derecha). 389

Figura 6.41. Antenas de telefonía móvil en Recorrido 34 (derecha). 389

Figura 6.42. Dos imágenes de la escombrera municipal de Villalón de Campos (Recorrido 13). 390

Figura 6.43. Ortofotografía que muestra el desorden de una zona periurbana de Villalón de Campos, en el entorno de la carretera nacional 610, con construcciones de todo tipo asentadas sin una urbanización previa. 391

Figura 6.44. Silo de trigo de Villalón de Campos. 392

Figura 6.45 (izquierda). Carteles variados, entre los que destaca uno de una obra terminada hace más de 10 años. 393

Figura 6.46 (derecha). Micro polígono industrial en el acceso por la carretera de Palencia (Recorrido 23). 393

Figura 6.47. Impacto crítico provocado por el derrumbe de una casa del siglo XVI en Villalón de Campos, que conservaba restos de origen judío. 394

Figura 6.48. Acabados exteriores inadecuados en una calle urbana del Recorrido paisajístico 16. 394

Figura 6.49. Imagen de una zona urbana del Recorrido 15, en la que se pueden apreciar varias de las degradaciones mencionadas: presencia de un aprisco de ovejas, suciedad de las calles, acabados inadecuados, puertas traseras, cableado desordenado, deficiente pavimento 396

Figura 6.50. Fuertes terraplenes (izquierda) y desmontes (derecha) en el AVE tramo Valle del Retortillo - Pozo de Urama. 397 
Figura 6.51. En general, el paisaje de Tierra de Campos conserva su morfología natural, aunque una de sus mayores degradaciones es la eliminación prácticamente total de la vegetación arbórea y arbustiva (Villalón de Campos).

Figura 6.52. Izquierda, camino rectilíneo en Boadilla de Rioseco; derecha, río Sequillo rectificado y dragado en Tamariz de Campos. En ambos casos se constata la ausencia de vegetación. 399

Figura 6.53. Nave agrícola en Moral de la Reina..... 399

Figura 6.54. Huerto solar en Frechilla. 400

Figura 6.55. Intrusión visual de una nave agrícola sobre el castillo medieval de Torrelobatón (izda.) o de una explotación de vacuno intensivo en un monasterio cisterciense de Ribas de Campos (dcha.). 401

Figura 6.56. Detalles de un aerogenerador y un apoyo de línea eléctrica en Ampudia, donde se puede apreciar su envergadura. 402

Figura 6.57. Izquierda, palomares en estado de degradación en Guaza de Campos; derecha, palomar derruido en Otero de Sariegos. 403

Figura 6.58. A la izquierda, ruinas de viviendas de adobe en Baquerín de Campos, pueblo fustigado por la emigración (ahora ya demolidas). A la derecha, la imagen del estado actual de la iglesia de San Juan Bautista de Tamariz de Campos, del siglo XVI, es un lamento hecho fotografía. 403

Figura 6.59. Ejemplo de naturalización de un gran talud de terraplén de la balsa de riego del sector V Esla-Carrión. A pesar de su altura, la pendiente es relativamente reducida, lo que favorece su cobertura con herbáceas. 405

Figura 6.60. Restauraciones vegetales en el río Templarios, en Villelga (izquierda), y repoblación forestal en Herrín de Campos. 406

Figura 6.61. Dos zonas de depósito incontrolado de residuos y escombros en Herrín de Campos (izquierda) y Boadilla de Rioseco (derecha), afortunadamente ya restauradas. 406

Figura 6.62. En la imagen se perciben dos alteraciones a un antiguo depósito de agua catalogado urbanísticamente -transformador y apoyo de línea eléctrica-, cuya retirada es relativamente sencilla.

Figura 6.63. Magnífico ejemplo de valorización de atributos de calidad: palomar en Otero de Sariegos que mejora el paisaje y sirve como mirador de las lagunas de Villafáfila. 408

Figura 6.64. Fotografía de las naves ganaderas contiguas al monasterio de Ribas de Campos, tomada en enero de 2014, una vez pintados en tonos ocres sus paramentos frontales. Tal como se puede apreciar, el impacto visual del blanco inicial se reduce sensiblemente. 409 
Figura 6.65. Paso superior en el AVE Palencia-León, que embellece el paisaje por su integración, armonía y gracilidad de sus formas.

Figura 6.66. Dos parcelas similares de almacén de materiales detectadas en los Recorridos paisajísticos en Villalón de Campos; la de la izquierda sin ocultación, la de la derecha, con malla de plástico verde.

Figura 6.67. Izquierda, pantalla vegetal formada por pinos piñoneros, cipreses, olmos y romeros en una explotación porcina de Cuenca de Campos. Derecha, silo de almacenamiento de cereal integrado cromáticamente y con pantalla vegetal.

Figura 6.68. Construcciones en suelo rústico disimuladas con motivos artísticos en Boadilla de Rioseco. A la izquierda, cientos de fotografías componen la imagen de niños en silos de grano; a la derecha, un mural pintado en los paramentos de una nave agraria.

Figura 6.69. Depósito de agua en Becerril de Campos, en el que anidan numerosas cigüeñas.

Figura 6.70. Imagen ideal de márgenes restaurados de camino rural, con mezcla de vegetación arbustiva y arbórea (Recorrido paisajístico 30).

Figura 6.71. Reguera con vegetación arbustiva de escaramujos.

Figura 6.72. Ilustración del resultado de varios tipos de restauraciones vegetales en espacios degradados por concentraciones parcelarias (JUNTA DE CYL, 1992). 423

Figura 6.73. Ramal de Campos del Canal de Castilla, paradigma de uso funcional (regadío) compatible con el ecológico y el recreativo. 425

Figura 6.74. El contraste entre el canal Cea-Carrión (Villacarralón) y el canal de Castilla (Tamariz de Campos) no precisa comentarios. Aunque parezca mentira, ambos son grandes infraestructuras hidráulicas dedicadas al regadío y ambos están en Tierra de Campos; la diferencia estriba en su naturalización. Da la impresión de que, en los 200 años que distan de su construcción, no hayamos aprendido nada.

Figura 6.75. Paso de fauna superior en Ledigos, en la autovía Camino de Santiago que, en sí misma, es una estructura que mejora el paisaje. Se pueden observar también remodelaciones de taludes de desmontes, hidrosiembras y correcciones hidrológicas.

Figura 6.76. Vista de un talud de terraplén en el tramo Palencia-León de la línea de alta velocidad, donde comienza a nacer la vegetación herbácea tras la hidrosiembra. También se observa el vallado perimetral, un camino de servicio y zonas colindantes (el dominio público está delimitado por los mojones) donde se podrían realizar plantaciones de árboles y arbustos. 430 
Figura 6.77. Dos imágenes objetivo a alcanzar de márgenes con vegetación en las carreteras de Tierra de Campos. A la izquierda, carretera de Carrión de los Condes a Villoldo. A la derecha, entrada a Herrín de Campos.

Figura 6.78. Puente sobre el río Valdeginate en Autillo de Campos, recientemente restaurado. Merecería la pena acondicionar y anunciar el entorno para que pudiese ser adecuadamente contemplado, ya que desde la carretera no se llega a apreciar.

Figura 6.79. Dos tramos totalmente diferentes ubicados en la misma carretera provincial VP4011; en la fotografía inferior se observa la mejora paisajística generada por la presencia de arbustos y árboles en los márgenes. 434

Figura 6.80. Restauración de gravera (préstamo P1) en Grijota, en las obras del AVE PalenciaLeón. El uso dado a los terrenos es el natural, constituyendo una zona húmeda con vegetación pratense en los taludes y arbolado de ribera en las zonas no inundadas.

Figura 6.81. Subestación eléctrica de un parque eólico en Ampudia con una adecuada integración paisajística: edificio de control con paredes ocres y cubierta rojiza; y pantalla vegetal perimetral que comienza a realizar su función (Fotografía Jesús Roldán). 437

Figura 6.82. El impacto paisajístico de este parque eólico de Ampudia es sin duda menor por la presencia de estos rodales de vegetación arbórea y arbustiva. 438

Figura 6.83. Vista desde el mirador del parque eólico el Castre, construido además en la zona adyacente al castillo de Torremormojón: energía renovable, patrimonio y paisaje unidos.

Figura 6.84. Tremenda imagen del grado de desnaturalización que alcanza la confluencia del arroyo Berruez con el río Sequillo en Villafrades de Campos. Tal como se aprecia, ambos cauces presentan una abundancia de especies helófitas que, ante la ausencia de arbolado que proporcione sombra, invaden el lecho y provocan el efecto contrario al perseguido originalmente: el taponado de los cursos ante las riadas. 440

Figura 6.85. La ribera del río Cea, a su paso por Melgar de Abajo, presenta un alto grado de naturalidad, con abundante presencia de vegetación riparia variada y en todos sus estratos. 441

Figura 6.86. Dos imágenes de un mismo río en las que se aprecia lo que supone para el paisaje la restauración. En la superior se observa el cauce absolutamente desnaturalizado del río Sequillo en Tamariz de Campos. En la inferior se aprecia el importante papel de los chopos en la naturalización del mismo río en Villacidaler. 443

Figura 6.87. Ejemplo ideal representando una zona húmeda artificial (UDPP, 2002). 445 
Figura 6.88. En la imagen superior se distinguen unas praderas colindantes al río Sequillo, en Tamariz de Campos, que constituían zonas húmedas antes de que este curso hídrico se encauzase; recientemente se ha restaurado precisamente una parte con aguas del Canal de Castilla. En la imagen inferior se observa la restauración de una laguna en el entorno de la Casa de la Reserva de las Lagunas de Villafáfila; magnífica actuación en la que se conjuga la recuperación de hábitats naturales, la valorización del patrimonio popular constituido por los palomares y el desarrollo turístico de la comarca.

Figura 6.89. Vista de la Cañada Real Leonesa Occidental en Ceinos de Campos, donde discurre contigua a la carretera nacional $\mathrm{N}-610$. En general se trata de un pastizal con un camino rural en su interior. Como otras vías pecuarias, está sometida a numerosas presiones: intrusiones de colindantes, ocupaciones ilegales, depósitos de escombros, etc. 448

Figura 6.90. Dos imágenes de vías pecuarias en Villalón de Campos. A la izquierda, vereda de Mayorga a Herrín; cuenta con un sobreancho de unos $10 \mathrm{~m}$ sobre el camino y con dos de los típicos problemas asociados a estas vías: intrusiones de colindantes y depósitos de escombros. A la derecha, colada de Cabezón-Villalón, cuya traza coincide con un camino rural en su integridad. 450

Figura 6.91. Imagen superior, antiguo trazado del ferrocarril de vía estrecha Villalón de CamposVillada. Imagen inferior, tramo rehabilitado de la Vía Verde "Tierra de Campos" pocos metros más adelante; se observa la adecuación de la plataforma con gravilla fina, la recreación de la antigua vía del ferrocarril con los raíles de hierro y la plantación lineal de almendros, que tienen un buen desarrollo vegetativo. .. 452

Figura 6.92. Fuente el Rosario en Villalón de Campos. Se observa el depósito del que fluye agua a un abrevadero. Su parcela es muy pequeña y posee algunos árboles y arbustos.

Figura 6.93. Ejemplo de una parcela de Restauración del Medio Natural; suelen ser "picones" donde no es rentable el uso agrícola. En caso de no realizar plantaciones, pueden ser ocupadas por los colindantes o ser foco de depósitos de escombros.

Figura 6.94. En estas dos imágenes se aprecia la diferencia que aporta el arbolado a la fuente Juan Palacios (inferior), en contraposición a la árida Valdelafuente (superior).

Figura 6.95. Arriba izquierda, laderas de Autilla del Pino parcialmente deforestadas e incluso cultivadas. Arriba derecha, cerro testigo en Tordehumos donde solamente se repobló con pino carrasco la zona alta de la ladera; además, el pinar presenta escasa diversidad. Abajo izquierda, teso en Villalón de Campos. Abajo derecha, parcela cultivada en el mismo término municipal, cuya pendiente hace predecir la existencia de fenómenos de erosión laminar.

Figura 6.96. Repoblación forestal realizada en laderas de Ampudia, donde se observa que van despuntando los pinos piñoneros. 
Figura 6.97. Repoblaciones recientes de pino piñonero como especie principal en Villoldo (izquierda) y Frechilla (derecha). En ambas también se introdujeron en pequeña proporción encina y quejigo, que también han arraigado aunque con un crecimiento menor. 460

Figura 6.98. El contraste es patente en las imágenes de estas dos laderas. En la superior, se observan las cuestas de Autilla del Pino sin repoblar; en la inferior, las de Medina de Rioseco constituyen ya bosques casi maduros. 463

Figura 6.99. A la izquierda, escombrera municipal de Villalón de Campos, que se encuentra clausurada y pendiente de restaurar. A la derecha, depósitos puntuales de residuos en una antigua vía del ferrocarril en Boadilla de Rioseco. 464

Figura 6.100. Restauración de antiguo basurero en Villalón de Campos. Sobre el pastizal creado se realizó una plantación perimetral de arbustos. El hueco no se impermeabilizó artificialmente, ni se instaló una valla perimetral. Ha habido vertidos posteriores, aunque afortunadamente no muy abundantes. 465

Figura 6.101. Antes y después de la restauración de una escombrera en Villalón de Campos, en el camino del Rosario. Posteriormente, además, se han plantado almendros y arbustos en el talud. 467

Figura 6.102. Contraste entre dos construcciones en suelo rústico. En la imagen superior, la nave agrícola de Cisneros genera un fuerte impacto visual por sus acabados llamativos. La depuradora de Villalón de Campos (imagen inferior) tiene sus paramentos de colores terrosos y una pantalla vegetal perimetral, por lo que resulta muy integrada en el paisaje. 469

Figura 6.103. En la imagen del Recorrido paisajístico 14 se pueden apreciar dos de las actuaciones mencionadas: en primer plano, pequeña zona antes degradada y que ha sido mínimamente restaurada creando una pradera y plantando árboles; en segundo plano, seto de thuyas en valla metálica que delimita una explotación de ganado ovino. 471

Figura 6.104. Arriba, buen ejemplo de recuperación de bodega en Aguilar de Campos; abajo, conjunto de varios palomares en Villárdiga, varios de ellos restaurados. 473

Figura 6.105. Imagen del Proyecto de recuperación ambiental y adecuación de la Ruta de los Parques en Villalón de Campos, que crea un anillo verde por la periferia de su casco urbano. 476

Figura 6.106. Dos imágenes de la periferia de Villalón de Campos. En la superior se observa una calle con un buen número de elementos disonantes en las fachadas de sus casas. En la inferior, la simple plantación de chopos en un arroyo antaño degradado ha generado un paseo peatonal ribereño de gran belleza.

Figura 6.107. Restauración de la ermita de Fuentes (Recorrido 8) realizada hace 13 años, en la que, entre otras actuaciones, se ha colocado una teja mixta envejecida muy 
similar a la árabe (izquierda) y se han rematado paños exteriores en mortero bastardo y rejuntado otros de ladrillo de tejar (derecha). 479

Figura 6.108. Albergue de peregrinos de Villalón de Campos (Recorrido 15) restaurado recientemente. Es un buen ejemplo de tipología arquitectónica tradicional: mezcla de pilares de ladrillo y paños en color tierra, recercados blancos de los huecos, carpintería de madera, canes del mismo material y teja árabe. 480

Figura 6.109. Ilustraciones-modelo con pautas arquitectónicas a seguir en los cascos históricos de los pueblos de Tierra de Campos (dibujos de Luis Frechilla, en BLANCO y FRECHILLA, 2009). 481

Figura 6.110. Antes y después de un muro gris pintado en el Recorrido paisajístico 15.

Figura 6.111. Buen ejemplo de muro de un solar en Villalón de Campos, con mortero terroso.

Figura 6.112. Pavimentaciones ornamentales en Ampudia (izquierda) y Grajal de Campos (derecha), que mejoran la calidad urbanística del conjunto. 484

Figura 6.113. Son fotografías extremas, pero reflejan la realidad de muchos pueblos. En la superior se aprecia Baquerín de Campos prácticamente abandonado (estos edificios han sido recientemente derribados). En la inferior se observa una plazuela de Abarca de Campos; esta población tiene muy pocos habitantes pero ha demostrado una gran sensibilidad por su paisaje urbano. 485

Figura 6.114. A la izquierda, bello ejemplar aislado de pino piñonero en Villaumbrales. A la derecha, bosquete en el entorno de la Casa del Parque de las Lagunas de Villafáfila. 488

Figura 6.115. Grandes encinas en Cañizo (izquierda) y Perales (derecha). 489

Figura 6.116. Quejigo en el monte Becerril, Becerril de Campos. 490

Figura 6.117. Brotes de olmo en margen de carretera en Villalón de Campos. A mediados del siglo pasado, las carreteras de la comarca estaban frecuentemente flanqueadas por robustos ejemplares de olmo. 491

Figura 6.118. Higuera en el borde de una parcela agrícola en Cañizo. 491

Figura 6.119. Moral aislado en el campo de Villada. 492

Figura 6.120. Piruétano en arroyo de Villalón de Campos. 493

Figura 6.121. Almendro florido en Villalón de Campos. 494

Figura 6.122. Guindal y guindaleras en un majuelo de Villalón de Campos. 494

Figura 6.123. Alisos en la ribera del río Carrión, en Villoldo. 495

Figura 6.124. Alameda en la ribera del río Templarios, Villelga. 495 
Figura 6.125. Izquierda, alameda en Santervás de Campos; derecha, álamos en el camino de Santiago. 496

Figura 6.126. Chopos lombardos en las riberas de los ríos Sequillo (izquierda, Villacidaler) y Templarios (derecha, Moratinos). 496

Figura 6.127. Diversos ejemplares de Salix en la ribera del río Carrión, en Villoldo. 497

Figura 6.128. Cipreses en el cementerio de Castroverde de Campos. 498

Figura 6.129. Izquierda, seto de arizónicas en Becerril de Campos. Derecha, plantación en margen de la autovía Variante Norte de Palencia. 498

Figura 6.130. Plátanos en alineación en una zona de huertas de Palencia. 499

Figura 6.131. Ejemplares aislados de falsas acacias en el paisaje agrario de Villalón de Campos. 500

Figura 6.132. Espino majoleto en Villalón de Campos. Se encuentra situado junto a varios ejemplares más de esta especie en la fuente La Florida, que debe su nombre a la vistosidad de la flor de este arbusto. 500

Figura 6.133. Endrino en flor (izquierda) en Fontihoyuelo y con fruto (derecha) en Becerril de Campos. 501

Figura 6.134. Escaramujo en flor (izquierda) en Villalón de Campos y en fruto (derecha) en Villaumbrales. 502

Figura 6.135. Tamarindo en flor en un parque periurbano de Villalón de Campos. 503

Figura 6.136. Torvisco en el monte del Raso de Villalpando...... 504

Figura 6.137. Sebe en flor en Cuenca de Campos (derecha); conjunto en márgenes de la carretera $\mathrm{N}-610$ en Castromocho. 505

Figura 6.138. Retama común aislada en margen de camino rural asfaltado en Herrín de Campos. 506

Figura 6.139. Ilustración de una imagen objetivo del paisaje agrario de Tierra de Campos (dibujo de Luis Frechilla, en BLANCO y FRECHILLA, 2009)...... 509

Figura 6.140. El Canal de Castilla es el paradigma de integración paisajística de una infraestructura.

Figura 6.141. En el paisaje de calidad recuperado, todos los ríos y arroyos de Tierra de Campos tendrán riberas como esta, perteneciente al río Templarios en Moratinos.. 511

Figura 6.142. La Reserva Natural de Villafáfila es un magnífico ejemplo del valor ecológico, paisajístico y turístico que tienen los humedales, especialmente en un medio árido como el de Tierra de Campos. 512 
Figura 6.143. Parque del Paseo en Villalón de Campos, uno de los que constituyen la Ruta de los Parques trazada por la periferia del pueblo. 513

Figura 6.144. Bella estampa de un conjunto de edificios bien conservados en la plaza mayor de Paredes de Nava, que es uno de los pueblos que mejor mantiene su patrimonio en Tierra de Campos. 514

Figura A1.1. Imagen de la parcelación del polígono 101 de Boadilla de Rioseco, recogida en el Acuerdo de concentración parcelaria. 552

Figura A1.2. Situación de la zona de concentración parcelaria y transformación en regadío en el interior de la ZEPA La Nava-Campos. 559

Figura A1.3. Modelo para la restauración de arroyos y desagües en la concentración parcelaria, extraído del Estudio de Impacto Ambiental. 560

Figura A1.4. Dos fotografías de delimitación inicial de parcelas, con los mojones en primer plano. En muchas ocasiones, como en la vista de la derecha, se observa cómo estos hitos de hormigón son movidos e incluso eliminados. 566

Figura A1.5. Dos imágenes de linderas imperceptibles. A la izquierda, lindera de dos parcelas recién sembradas de cereal; en este caso el mojón se mantiene en correcto estado, habiéndose pintado incluso para ser más visto. A la derecha, lindera entre dos parcelas recientemente labradas; tan solo el diferente tono marrón permiten distinguirlas. 567

Figura A1.6. Dos ejemplos de limpieza de pequeños arroyos. En el de la izquierda se observa el mantenimiento de varias zarzas presentes en los taludes. 567

Figura A1.7. Varias imágenes de la fase de construcción o mejora de los caminos. Arriba izquierda, traíllas generando la traza de un nuevo camino. Arriba derecha, motoniveladora perfilando una cuneta. Abajo izquierda, descarga y extensión de zahorra en un camino ya explanado. Abajo derecha, camino en el que se ha extendido parcialmente zahorra. 568

Figura A1.8. A la izquierda, marco de hormigón y escollera de protección de los taludes. En la imagen de la derecha se observa un caño y embocadura en el cruce de un desagüe con un camino. 569

Figura A1.9. Camino en el que se ha extendido recientemente la capa de sellado arena-arcilla. También se puede apreciar cómo, después de tres años desde su perfilado, las cunetas se han ido cegando por arrastres de los cultivos colindantes. 569

Figura A1.10. Bionda metálica de protección en el cruce de un camino con el arroyo Pajarillas. A la derecha se observa un detalle del acabado tipo madera. 570

Figura A1.11. Arroyo principal con agua fluyendo en invierno. Se puede observar la ausencia de vegetación riparia y cómo los cultivos colindantes llegan hasta el cauce..... 571 
Figura A1.12. En el pequeño arroyo de la imagen, afortunadamente se ha respetado el chopo existente, que es el único árbol presente en el entorno. 572

Figura A1.13. Cauce en el que se ha recuperado totalmente la vegetación higrófila y en el que se observa que se respetaron los escaramujos. 573

Figura A1.14. Imagen de taludes de desmonte de caminos en la primera fase después de las obras (izquierda). Actualmente una parte de ellos se han revegetado naturalmente (sobre todo los orientados al Norte), aunque son numerosos los taludes altos con una protección herbácea deficiente (la fotografía de la derecha es en la misma ubicación transcurridos tres años). 574

Figura A1.15. Cuando se apura en exceso el laboreo de las parcelas, la tierra se va depositando en la cuneta, que poco a poco pierde su función drenante o incluso desaparece. Si este talud tuviese arbustos, es probable que ejerciesen un papel de protección de la cuneta. 575

Figura A1.16. Talud de camino en el que se han depositado restos de antiguas obras de fábrica. 576

Figura A1.17. Zanja realizada para delimitar la franja pública situada en el margen de un camino de circunvalación que, tal como se aprecia, había sido intrusada. Estas franjas tienen una gran importancia para la posible futura creación de corredores vegetales.

Figura A1.18. Imágenes del acondicionamiento de puentes de madera para la rehabilitación de la antigua vía del ferrocarril, en las que se comprueba su integración e incluso el realce de las estructuras primitivas. 578

Figura A1.19. Simulación gráfica de la balsa de regadío. 584

Figura A1.20. En color verde se reflejan las zonas susceptibles de plantaciones arbóreas y arbustivas. 588

Figura A1.21. En color amarillo se observa la superficie de talud exterior de terraplén de la balsa, que será restaurada con la extensión de tierra vegetal, siembra de herbáceas y posterior plantación de matas arbustivas....... 589

Figura A1.22. Plano con el diseño de la adecuación paisajística del entorno del observatorio de aves, que además incluye una senda peatonal y diversas plantaciones vegetales. 591

Figura A1.23. Imagen inicial de las obras en la balsa. El material extraído en el vaso se utiliza fundamentalmente para la creación del dique. A la par, se dispone la escollera de protección del talud interior. 593

Figura A1.24. Distintas fases de la restauración vegetal del talud exterior de la balsa de regadío. Arriba izquierda, extensión de la tierra vegetal con buldócer. Arriba derecha, primera fase de la nascencia de herbáceas. Abajo izquierda, detalle del talud con 
una aceptable cobertura herbácea. Abajo derecha, vista al fondo del dique en primavera muy bien integrado en el paisaje. 594

Figura A1.25. Antes y después de la restauración de una parcela en Villalón de Campos, realizada con sobrantes del desmonte de la balsa de riego. 595

Figura A1.26. Imagen de una fase de la obra en la que se observa su magnitud. 595

Figura A1.27. Imagen del interior de la balsa una vez alcanzada la coronación del dique. Se observa la integración de la piedra de escollera del talud interior, así como las irregularidades topográficas en el lecho. 596

Figura A1.28. Imágenes de las plantaciones en abril de 2015: en el talud exterior (izquierda) y en la franja exterior a la balsa (derecha). 597

Figura A1.29. La irrupción de una importante superficie de agua en Tierra de Campos supondrá una notable mejora de su paisaje, tanto en su vertiente visual como ecológica. 598

Figura A1.30. Vista de la caseta de bombeo perfectamente integrada en el paisaje, construida con paneles de hormigón con acabado de adobe y cubierta metálica en tonos teja. 599

Figura A1.31. Ortofotografía con la ubicación de la nave ganadera al norte del casco urbano de Ampudia. 601

Figura A1.32. Imágenes de la nave ganadera y de su interior. 604

Figura A1.33. Imágenes del entorno vallado de la nave de ovino. 604

Figura A1.34. Sendas vistas de la construcción ganadera. 605

Figura A1.35. Imagen del estercolero, que también se encuentra vallado. 605

Figura A1.36. Plano de localización y situación del Proyecto básico. 608

Figura A1.37. Plano de parcela y condiciones urbanísticas del Proyecto básico. 609

Figura A1.38. Plano de alzados de la nave ampliación del Proyecto básico. 610

Figura A1.39. A la izquierda, vista de la explotación antigua. A la derecha, corderos en el interior de la nueva nave. 613

Figura A1.40. Ortofotografía de 2011 con la ubicación de la explotación ganadera. 613

Figura A1.41. Vista de los paramentos exteriores y las cubiertas. 614

Figura A1.42. Fotografías del estercolero (arriba) y de los montones de escombros (abajo, izquierda y derecha). 615

Figura A1.43. Planos de localización geográfica con las dos alternativas de variante planteadas en el Estudio Informativo. 618 
Figura A1.44. Plano de localización de medidas correctoras del Estudio de Impacto

Ambiental 623

Figura A1.45. Plano de detalle del tratamiento de isletas incluido en el Estudio de Impacto Ambiental.

Figura A1.46. Ortofotografía de 2009, donde se puede apreciar la presencia y funcionalidad de la variante Este de Villada. 627

Figura A1.47. Diversas imágenes de los tramos principales: enlace Sur (arriba izquierda), vista de la carretera (arriba derecha), enlace con la carretera de Villelga y con Villada (abajo izquierda) y enlace Norte (abajo derecha)..

Figura A1.48. Varios ejemplos de estructuras: marco para el paso inferior de camino rural (arriba izquierda), paso inferior bajo el ferrocarril (arriba derecha), puente sobre el río Sequillo (abajo derecha) y obra de drenaje sobre arroyo (abajo derecha) ... 629

Figura A1.49. Imágenes de los dos puentes sobre el río Sequillo, donde se observa la franja de terreno de continuidad protegida mediante escollera, que permite su naturalización. 630

Figura A1.50. Vistas de bajantes a través de taludes de terraplén. 630

Figura A1.51. Vista de un talud de desmonte (izquierda) y de terraplén (derecha) protegido mediante escollera. 631

Figura A1.52. La diferencia entre la revegetación de los taludes de terraplén (arriba) y desmonte (abajo) es patente, tal como se observa en las fotografías. 632

Figura A1.53. Chopos (Populus nigra) a la izquierda y acacias (Robinia pseudoacacia) a la derecha. 633

Figura A1.54. Vista de dos zonas de plantación de pinos, en las que se observa el alto porcentaje de marras y el deficiente estado vegetativo.

Figura A1.55. Imágenes del buen estado de las plantaciones de Spartium junceum. .634

Figura A1.56. Márgenes regenerados naturalmente con sauces y chopos. 634

Figura A1.57. Vistas de las isletas del enlace Sur (izquierda) y de la glorieta (derecha), donde se observa una excesiva invasión de herbáceas en la zona de canto rodado.... 635

Figura A1.58. A la izquierda, vista de la fachada principal de la ermita de la Virgen de la Cruz; a la derecha, imagen del acceso desde Villada y de un depósito de escombros de antiguas obras de la carretera. 635

Figura A1.59. Plano de planta del proyecto de construcción, en el que se puede observar en la parte central la ubicación del préstamo PR-1 y, a la izquierda, la traza de la línea de alta velocidad. 637 
Figura A1.60. Plano de planta del proyecto de construcción, con un detalle del perfil tipo del préstamo PR-1.

Figura A1.61. Plano de planta del proyecto de construcción en el que se grafía, por una parte, la restauración ambiental del préstamo PR-1 y, por otra, las zonas excluidas, restringidas y admisibles. 638

Figura A1.62. Plano de localización del préstamo PR-1, incluido en el plan de restauración. 639

Figura A1.63. Ortofotografía de la zona afectada por el préstamo, realizada en 2009 , en la que se observa la naturaleza agrícola de toda su superficie. 640

Figura A1.64. Ortofotografía de 2011 del préstamo PR-1, en la que se aprecia que el proyecto se encuentra en la fase de extracción; en algunas zonas se observan cordones lineales de los acopios previos de tierra vegetal. 642

Figura A1.65. Vista de dos zonas de la extracción de áridos llevada a cabo en el préstamo PR-1, en julio de 2011. 642

Figura A1.66. Diferentes imágenes de zonas en remodelación topográfica. En la fotografía de abajo a la derecha se observa el cauce de drenaje recreado en la parte oriental del préstamo.

Figura A1.67. Plano de detalle con los distintos rodales de la restauración realizada en el préstamo PR-1, en la que se diseñan siete tipos diferentes de agrupación de especies. 644

Figura A1.68. Detalle del subsolado lineal realizado para la plantación de árboles y arbustos. En estos surcos se aprecia algún pino piñonero. 644

Figura A1.69. Vista general de la plataforma sembrada (izquierda) y detalle del entorno de una encina plantada, en el que crece la vegetación herbácea. 645

Figura A1.70. Imágenes del préstamo PR-1 en mayo de 2013. A la izquierda se puede apreciar la densidad y desarrollo de la vegetación herbácea; a la derecha, la funcionalidad del cauce hídrico recreado. 645

Figura A1.71. Detalle de la densidad y envergadura de la vegetación herbácea implantada. A la derecha se observa un pino que ha sobrevivido a pesar de la fuerte competencia de la cubierta adyacente.

Figura A1.72. Zonas húmedas en el interior del préstamo restaurado, donde se aprecia la aparición espontánea de especies frondosas de ribera. 648

Figura A1.73. Trazado de la línea eléctrica (en rojo). 650

Figuras A1.74. Vista de dos apoyos de la línea eléctrica. 651

Figura A1.75. Ejemplo de plano de actuaciones, en este caso en arroyos y caminos 653 
Figura A1.76. Pequeño rosal silvestre (centro de la imagen) en la base de un apoyo........... 654

Figura A1.77. Actuaciones en la intersección con el río Valdeginate. 655

Figura A1.78. Plantación de árboles en margen del arroyo del Salón, que discurre paralelo a la línea en buena parte de su trazado 656

Figura A1.79. Pequeños montículos cercanos a la traza repoblados. 658

Figura A1.80. Plantaciones realizadas en margen (izquierda) y talud (derecha) de camino. 659

Figura A1.81. Ejemplo de un plano del informe final de las obras, que incluye actuaciones de restauración. 661

Figura A1.82. A la izquierda, vista de la retroaraña realizando hoyos. A la derecha, pinos piñoneros en envase forestal (Fotografías de Jesús Roldán). 662

Figura A1.83. Plano de situación del anteproyecto. 665

Figura A1.84. Plano del edificio de control incluido en el anteproyecto. 667

Figura A1.85. Plano de alzado de la subestación eléctrica. 667

Figura A1.86. Ortofotografía con la ubicación definitiva de los 16 aerogeneradores. 670

Figura A1.87. Plano de ubicación de los aerogeneradores en la alternativa seleccionada, incluido en el estudio de impacto ambiental. 671

Figura A1.88. Cuenca visual del parque eólico, en la que se puede comprobar que la zona visible es mayoritaria..

Figura A1.89. Vista del parque eólico El Castre desde el castillo de Torremormojón. Al fondo se divisan más aerogeneradores correspondientes a otros parques ubicados en Ampudia.

Figura A1.90. Imagen de dos aerogeneradores. En días nublados el contraste de las máquinas con el fondo escénico es muy reducido. Hay que tener en cuenta que, a lo largo del año, son escasos los días en que el cielo está totalmente despejado..... 678

Figura A1.91. Imagen del edificio de control y la subestación eléctrica; en primer plano, plantaciones ya consolidadas de lavandas y escaramujos.... 679

Figura A1.92. Izquierda, obras de plataformas, zanjas y caminos recientemente remodelados. Derecha, camino y zanjas revegetadas 5 años después.

Figura A1.93. Arriba izquierda, adecuación del camino de acceso, con revegetación de sus márgenes. Arriba derecha, panel interpretativo del paisaje y el patrimonio cultural. Abajo izquierda, castillo de Torremormojón. Abajo derecha, vista del paisaje de Tierra de Campos en primavera. 680 
Figura A1.94. Ortofotografía con la ubicación del sector 1 de suelo industrial de Paredes de Nava. 682

Figura A1.95. Plano de zonificación del Plan Parcial del polígono industrial de Paredes de Nava. 685

Figura A1.96. Imagen de una vista aérea del polígono industrial, contenida en el informe de vigilancia ambiental de enero de 2010 . 689

Figura A1.97. Izquierda, ortofotografía de 2011 del polígono industrial; derecha, una de las dos naves instaladas. 690

Figura A1.98. Izquierda, encinas en una parcela de ELP cercana al arroyo. Derecha, parcela de ELP paralela a la carretera CL-613. 690

Figura A1.99. Viales que podrían contar con alineaciones de árboles en sus aceras. 691

Figura A1.100. Izquierda, marras de encinas; derecha, vegetación herbácea sin segar. 692

Figura A1.101. Uno de los carteles anunciadores del polígono industrial, situado en una parcela de espacios libres públicos. 692

Figura A2.1. Imagen de un peregrino en un tramo de Camino recientemente plantado de árboles.

Figura A2.2. Nave para boxes de caballos cerrada. Al menos, se consiguió la integración paisajística de la construcción, de acuerdo a las prescripciones de la Comisión Territorial de Patrimonio. 699

Figura A2.3. Dos imágenes del área de descanso poco después de su ejecución. Dentro de una concepción contemporánea del diseño, se han integrado en la construcción materiales típicos de la arquitectura tradicional de Tierra de Campo: bolos de grava para el zócalo, adobe en los paramentos, madera y teja árabe en la cubierta. 700

Figura A2.4. Por desgracia, la ausencia de mantenimiento provoca situaciones desagradables como la de la imagen, donde se aprecia la acumulación de residuos sin recoger de los contenedores. 700

Figura A2.5. Dos imágenes del tramo accesible. A la izquierda, un detalle del acceso con un pequeño área estancial. A la derecha, tramo del Camino limitado con rollizos de madera. 700

Figura A2.6. Vista de un tramo del Camino que discurre paralelo a una carretera autonómica. La sensación para el caminante es desoladora: sin un árbol en kilómetros y con la compañía del ruido de los coches. 701

Figura A2.7. En la imagen superior se observa la máquina y operarios realizando la implantación. En la inferior se visualiza una fila de pinos piñoneros con el alcorque realizado. 
Figura A2.8. Rodal de olmos y chopos donde se han eliminado los pies defectuosos y se han podado los mejores ejemplares. En este tramo, el Camino discurre paralelo al Canal de Castilla, lo que proporciona un atractivo adicional. 703

Figura A2.9. La diferencia entre las imágenes superior e inferior solo se encuentra en los árboles del Camino. El paisaje agrícola adyacente es el mismo, pero el valor añadido que aporta la vegetación a su calidad es indudable. 704

Figura A2.10. Ortofotografía de 2011 en la que se aprecia la parcela repoblada inmersa en terrenos agrícolas. 705

Figura A2.11. Vista general de la parcela desde el camino de acceso. 706

Figura A2.12. Imagen de la zona más elevada de la parcela, con arbolado de menor porte.

Figura A2.13. Vista de una parte de la zona baja. Al fondo se pueden apreciar ejemplares de chopos y álamos de los que se conservaron previamente. 708

Figura A2.14. Ortofotografía de 2011 de las dos laderas; a la izquierda la ubicada al Este de Ampudia y, a la derecha, la situada entre esta localidad y Valoria del Alcor. Se distinguen por su contorno irregular y sus tonos grisáceo-blanquecinos, debido a los intensos procesos erosivos sufridos. 710

Figura A2.15. En primer término se observa la microcuenca generada por el ahoyado mecanizado, que aún se conserva. Tal como se aprecia, la alteración del perfil natural de la ladera es mínimo. 712

Figura A2.16. Arriba izquierda, imagen general de los pinos piñoneros. Arriba derecha, encina excepcional. Abajo izquierda, rodal de sebes. Abajo derecha, rodal de romeros.

Figura A2.17. En la fotografía de la izquierda se observan pinos piñoneros en buen estado vegetativo. En la de la derecha su estado es más deficiente, debido a que las condiciones edáficas son peores. 713

Figura A2.18. Vista general de las laderas, con una buena cobertura vegetal y donde los pinos comienzan a despuntar. 714

Figura A2.19. Parcela forestada, que linda con el río Valdeginate y parcelas agrícolas (ortofotografía de 2011). 715

Figura A2.20. En la zona sur -tal como ya se indicó en la memoria previa a la repoblación- los suelos eran pobres, por lo que en ellos el arraigo de la vegetación fue considerablemente menor. 
Figura A2.21. En esta imagen se constata el buen desarrollo vegetativo del pinar en los terrenos llanos, aunque la densidad sea excesiva. También se aprecia que las encinas tienen un crecimiento más discreto. 717

Figura A2.22. Vista del pinar desde el teso, donde se observa el éxito de la repoblación forestal. 718

Figura A2.23. En la primera ortofotografía, procedente del vuelo americano de la década de los 50 del siglo pasado, se observa la deforestación e intensos procesos de erosión de las laderas de Coruñeses; como curiosidad, por el contrario, también se constata la existencia de arbolado en los márgenes de la carretera, así como de linderas de vegetación en las parcelas. En la segunda ortofotografía de 2011, se distingue la gran diferencia ocasionada por la repoblación forestal de las cuestas, cuya trama vegetal contrasta con los terrenos agrícolas. 720

Figura A2.24. Imágenes de varios diques de piedra de mampostería que, tal como se observa, se encuentran totalmente aterrados y han conseguido la práctica eliminación de los fenómenos erosivos generados en las cárcavas. 721

Figura A2.25. La imagen muestra la naturalización del entorno del pequeño dique, que además se encuentra perfectamente integrado paisajísticamente. 722

Figura A2.26. En las imágenes superiores se observa el buen porte que actualmente poseen los pinos carrascos de la repoblación primitiva. En la imagen inferior se constata el aceptable crecimiento (tal vez algo mayor en términos relativos) de los pinos piñoneros. 723

Figura A2.27. Imágenes de una encina (izquierda) y un quejigo (derecha). Aunque el crecimiento de estas especies es muy lento en sus inicios, una vez afianzadas sus raíces pivotantes este aumenta notablemente. 724

Figura A2.28. Imagen de las dos laderas cubiertas de pinar de la cuesta de Coruñeses, en la que se aprecia un pequeño tramo de la carretera nacional N-601 que discurre por el espacio central. 725

Figura A2.29. Imágenes de cuatro espacios verdes del municipio. Arriba izquierda, ribera del arroyo Pajarillas; arriba derecha, parque del Hospital de San Roque; abajo izquierda, parque del Paseo; abajo derecha, paseo de la Residencia. 727

Figura A2.30. Ortofotografía con las zonas verdes y la Ruta de los Parques (en rojo) 729

Figura A2.31. Plano de las zonas verdes y las actuaciones. 730

Figura A2.32. Arriba, recuperación del paseo de Barrios o Pajarillas (izquierda, antes; y derecha, después). Abajo, adecuación del paseo del Polideportivo. 731

Figura A2.33. Imagen de uno de los dos grandes carteles interpretativos de la Ruta, ubicado en el parque de la reguera del Tinte. 733 
Figura A2.34. Imágenes del conjunto de zonas húmedas situadas entre el río Sequillo y el Canal de Castilla, que son visualizadas en todo momento desde el Camino turístico. En la fotografía superior se aprecia la presencia de una laguna junto al río, con tamarindos y aves acuáticas. En la inferior se observa una pradera húmeda con un nutrido grupo de cigüeñas.

Figura A2.35. A la izquierda, observatorio de avifauna cercano a la laguna y colindante con el Camino turístico. En la imagen de la derecha se observa un grupo de álamos que ahora acompañan el tránsito por varios tramos de esta vía. 735

Figura A2.36. En la imagen de la izquierda se observa un panel informativo del Camino de Santiago Real de Madrid, colocado en Tamariz de Campos. En la de la derecha se distingue un hito de granito de este ramal, así como una de las tradicionales flechas amarillas que sirven como guía a los caminantes. 735

Figura A2.37. Séptima esclusa del Canal de Castilla, punto final del recorrido. Se trata de una zona realmente bella, en la que se conjuga la existencia de la propia esclusa (que realmente funciona para el barco turístico), una antigua fábrica de harinas, la chopera que acompaña los caminos de sirga y una gran lámina de agua en el quiebro que realiza la traza del Canal. 736

Figura A2.38. Los carteles de Camino turístico (izquierda) y sendero PR de Pequeño Recorrido (derecha) conviven a lo largo del trazado. 736

Figura A2.39. A la izquierda, ortofotografía en la que se enmarca el camino turístico desde Tamariz de Campos (al norte) y la séptima esclusa del Canal de Castilla (al sur). En la ortofoto de la derecha se observa con más detalle la laguna de Tamariz y el Canal de Castilla. 737

Figura A2.40. Se observan las notables diferencias que provoca la presencia o no de vegetación en los márgenes del camino. En los tramos que aparecen árboles o arbustos, el trayecto tiene mayor belleza y se hace más diverso. 738

Figura A2.41. A la izquierda, vista de la ermita de San Bernardino y la zona arbolada en el inicio de la Vía Verde en Cuenca de Campos. A la derecha, final del tramo en el cruce con una carretera en Villalón de Campos; se puede apreciar la talanquera y un cartel con prohibición para vehículos a motor. 740

Figura A2.42. Imagen de la Vía Verde justo después de su construcción. La plataforma está totalmente afirmada, se han colocado las infraestructuras y se han realizado las plantaciones. En este tramo se observa además que, además de los árboles en línea, se han plantado arbustos en el talud de terraplén, todos con protectores.

Figura A2.43. Grupo de personas caminando y en bicicleta en el Día nacional de las Vías Verdes, que se celebra anualmente. 741 
Figura A2.44. Arriba izquierda, almendros en flor. Arriba derecha, rodal de encinas. Abajo izquierda, grupo de álamos y abajo derecha, chopos castellanos ya con una altura considerable. 743

Figura A2.45. Diferencias en el crecimiento de los pinos piñoneros. Paradójicamente, los pinos de la imagen izquierda tenían un porte pequeño en su plantación, por lo que su crecimiento ha sido más proporcionado. Lo contrario sucedió en los ejemplares de la imagen derecha, que han crecido muy poco y no han logrado mejorar su porte y calidad vegetativa. 744

Figura A2.46. A la izquierda se refleja el nuevo puente de madera sobre los antiguos sillares de piedra; incluso se observa la tubería de abastecimiento de agua que, indirectamente, propició la restauración de la Vía Verde. A la derecha, detalle de otro puente construido con rollizos de madera tratada. 744

Figura A2.47. En la imagen de la derecha se muestra un área estancial diseñada junto a un antiguo almendro de gran belleza, que se encuentra florido en su totalidad. A la derecha se observa un panel informativo sobre el "tren burra", con una tipología homologada de acuerdo con el programa de Caminos Naturales. 745

Figura A2.48. Imagen inicial del arroyo Berruez, característica de la mayor parte de cursos hídricos de Tierra de Campos. Se aprecia el cauce dragado, con invasión de especies helófitas y ausencia de vegetación de ribera; los cultivos llegan hasta el borde mismo del cauce. 746

Figura A2.49. Varias imágenes en los primeros años tras la plantación. Arriba izquierda, planta pequeña con protectores. Arriba derecha, estaquillas de chopo brotadas. Abajo izquierda, tamariz en primer plano. Abajo derecha, alineación de chopos en otoño. 748

Figura A2.50. Imágenes en las que se aprecia el buen crecimiento de los chopos a los cuatro años tras su plantación. En la fotografía de la izquierda se observa cómo las labores agrícolas llegan hasta el borde del cauce, por lo que las plantas se han de colocar en su talud. En la de la derecha aparece una franja de $10 \mathrm{~m}$ sin cultivar a un lado del mismo, que se dejó posteriormente en la concentración parcelaria para restaurar; de extenderse este hecho abriría notablemente las posibilidades de restauración integral de los arroyos desnaturalizados. 750

Figura A2.51. La restauración vegetal del arroyo Berruez está cambiado en gran medida el paisaje del entorno, creando un corredor ecológico natural y diverso. 750

Figura A3.1. Vista general de camino. 755

Figura A3.2. Paisaje de cereal madurando 755

Figura A3.3. Detalle de espigas de cebada 755

Figura A3.4. Reguera con arbustos. 755 
Figura A3.5. Chopos lombardos en antigua vía del ferrocarril.......................................... 755

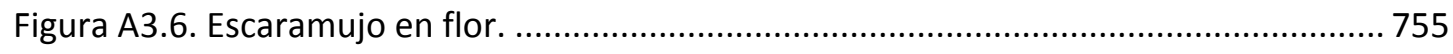

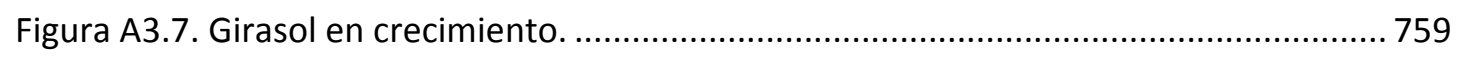

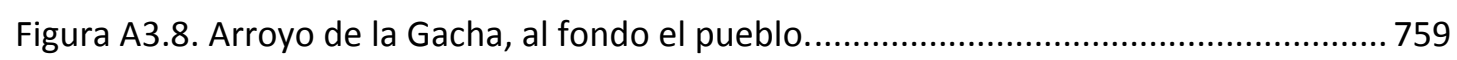

Figura A3.9. Vista de la arboleda de la ermita de Fuentes y abundantes amapolas. ............ 759

Figura A3.10. Detalle de espigas de cebada, ya muy maduras. .......................................... 759

Figura A3.11. El ocre del cereal se hace dominante en el paisaje. ....................................759

Figura A3.12. Vista del camino; a ambos lados, cereal y girasol.........................................759

Figura A3.13. Panorámica de rastrojos con la ermita de Fuentes al fondo.......................... 763

Figura A3.14. Rastrojos y girasol se dividen con una reguera poblada con escaramujos, que aumentan la diversidad paisajística. ............................................................ 763

Figura A3.15. El color ocre del rastrojo es el dominante en esta época estival.................... 763

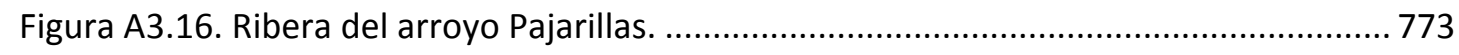

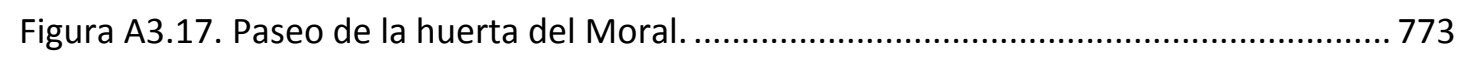

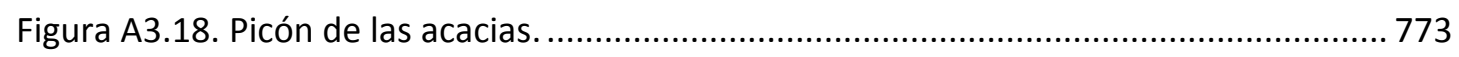

Figura A3.19. Parque de la reguera del Tinte (primer tramo)........................................... 773

Figura A3.20. Parque de la reguera del Tinte (segundo tramo)....................................... 773

Figura A3.21. Parque de la laguna del Tinte o laguna de San Juan..................................... 773

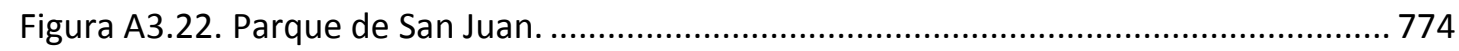

Figura A3.23. Parque de la laguna de la Pedrera. ........................................................... 774

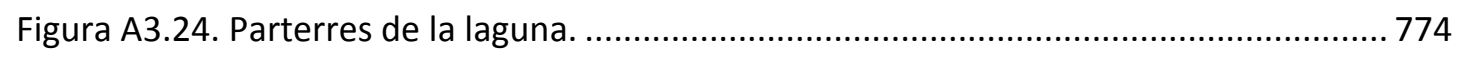

Figura A3.25. Parterres de los Cuartos de San Miguel................................................... 774

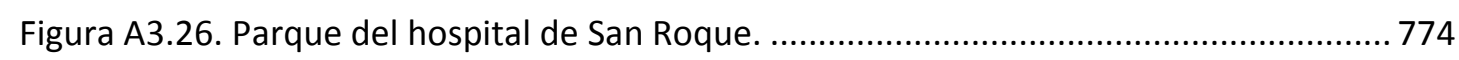

Figura A3.27. Avenida del Parque y jardines del Colegio.................................................. 774

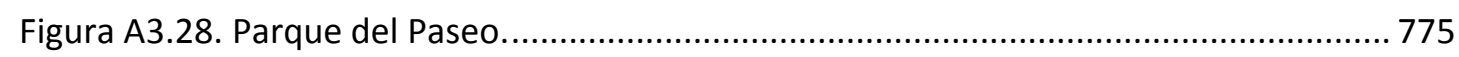

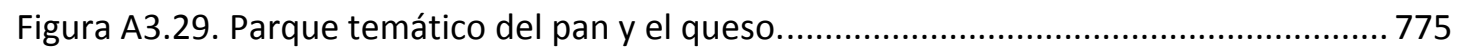

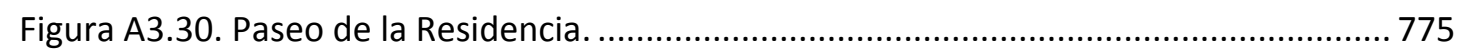

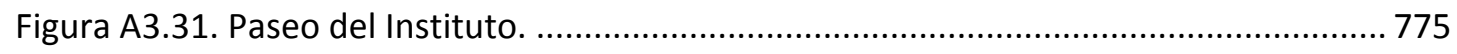




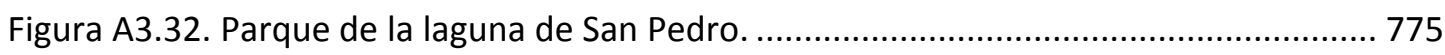

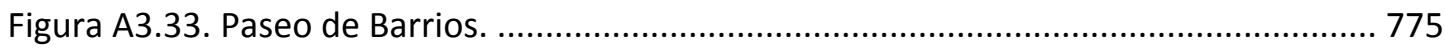

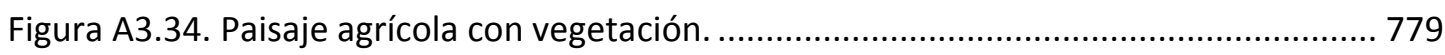

Figura A3.35. Chopos en los márgenes de la carretera. .................................................... 779

Figura A3.36. Detalle de apoyo de una línea eléctrica...................................................... 779

Figura A3.37. Nave agrícola, que tiene plantación del árbol/ha........................................ 779

Figura A3.38. Palomar y granja avícola conviven en un mismo espacio.............................. 779

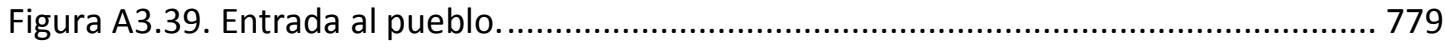

Figura A3.40. Varias construcciones agrícolas a la salida del pueblo. ..................................783

Figura A3.41. Línea eléctrica y transformador al lado de depósito. ...................................... 783

Figura A3.42. Seto de leylandi en parcela de invernaderos............................................. 783

Figura A3.43. Antigua caseta de barro degradada por construcción metálica...................... 783

Figura A3.44. Parcela - almacén del Ayuntamiento, bastante integrada. ........................... 783

Figura A3.45. Taludes de desmonte de la carretera, erosionados. ................................... 783

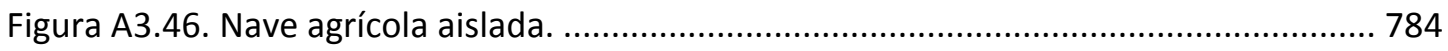

Figura A3.47. Fachada principal de la ermita de Fuentes.................................................... 784

Figura A3.48. Valla de madera y acacias en perímetro de la pradera.................................. 784

Figura A3.49. Zona de bancos, con pozo, pila y fuente. .................................................... 784

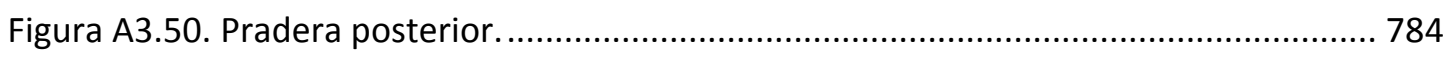

Figura A3.51. Fachada lateral de la ermita a la carretera................................................. 784

Figura A3.52. Plaza mayor e iglesia de San Miguel.......................................................... 787

Figura A3.53. Soportales en C) Ángel Ma Llamas / plaza Mayor.......................................... 787

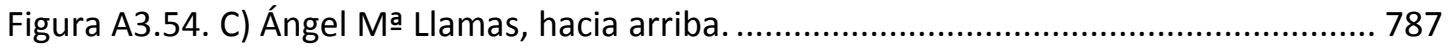

Figura A3.55. Cruce por la carretera nacional. ................................................................... 787

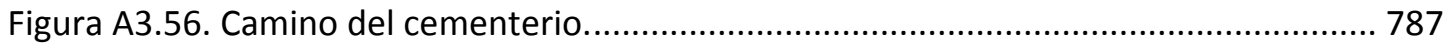

Figura A3.57. Interior del cementerio........................................................................ 787

Figura A3.58. Camino de salida del pueblo.................................................................... 791 
Figura A3.59. Arbolado en industria de tratamiento de lana. ............................................ 791

Figura A3.60. Restauración de antigua escombrera. ............................................................ 791

Figura A3.61. Chopos en fuente el Rosario. ……......................................................... 791

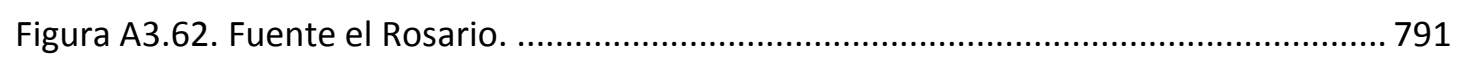

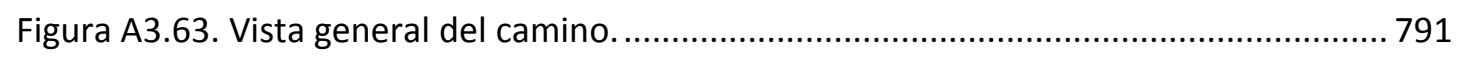

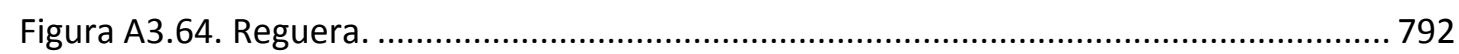

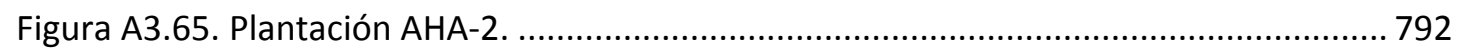

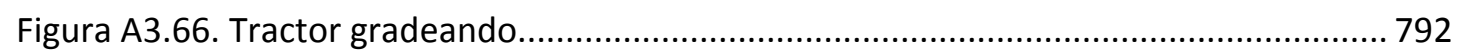

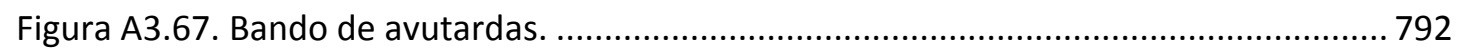

Figura A3.68. Restauración del arroyo Berruez.............................................................. 792

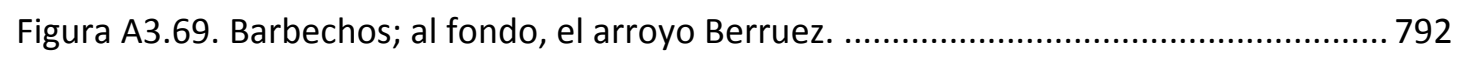

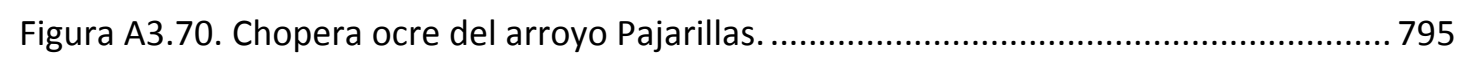

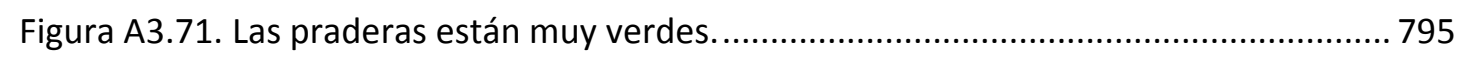

Figura A3.72. Contraste de colores en el parque del Paseo................................................ 795

Figura A3.73. El otoño es intenso en los jardines. ............................................................ 795

Figura A3.74. Los castaños de indias muestran el ocre de sus hojas marchitándose............ 795

Figura A3.75. Muchos árboles ya han perdido sus hojas.................................................. 795

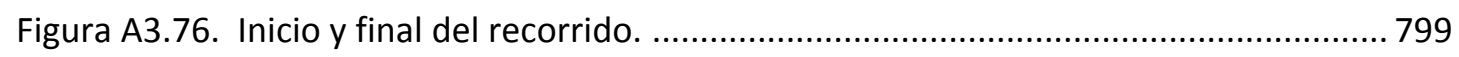

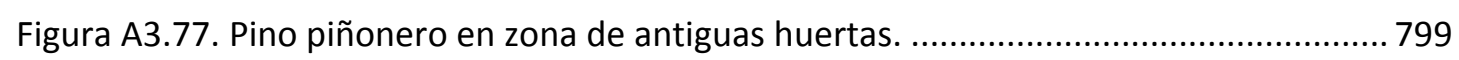

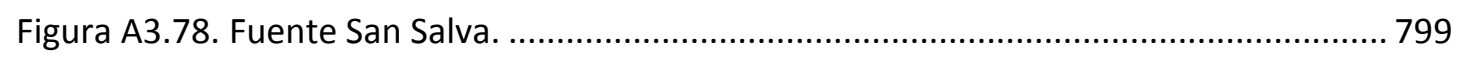

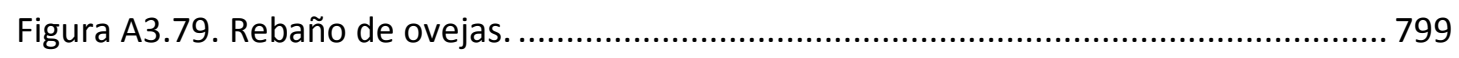

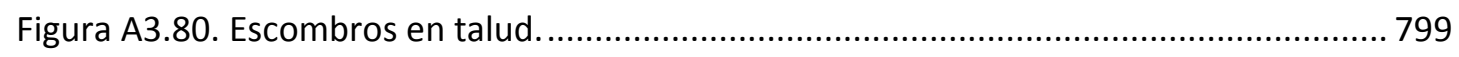

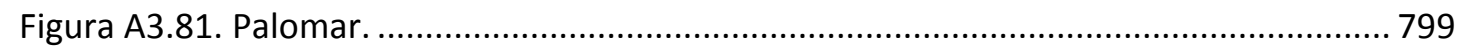

Figura A3.82. Vista del camino y el paisaje adyacente...................................................... 803

Figura A3.83. Tractor gradeando el rastrojo. ……....................................................... 803

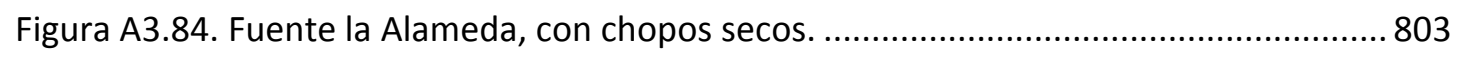

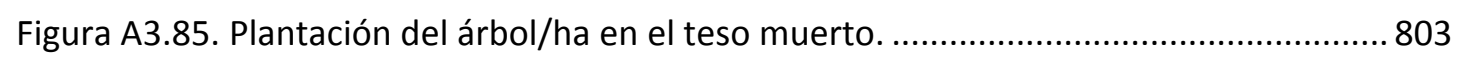




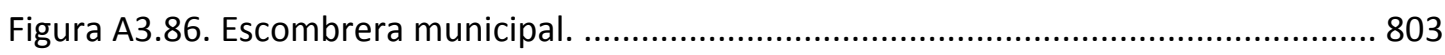

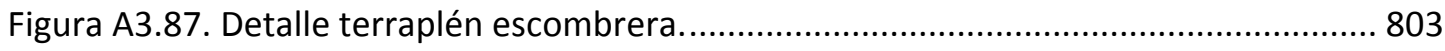

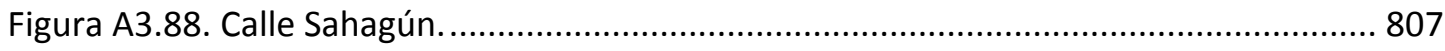

Figura A3.89. Arroyo Pajarillas y granja de porcino. ......................................................... 807

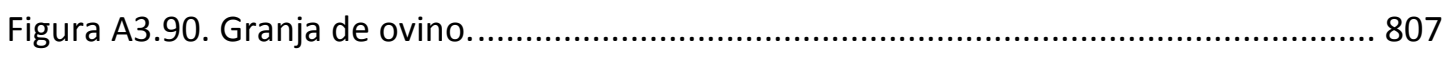

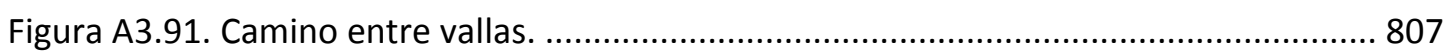

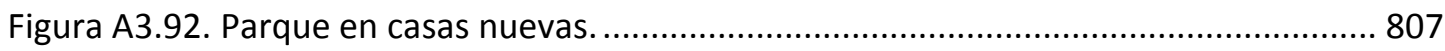

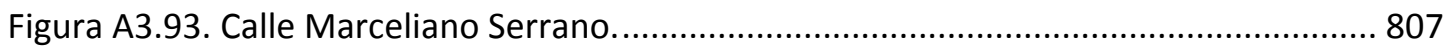

Figura A3.94. Buen ejemplo de integración en el paisaje urbano. ...................................... 812

Figura A3.95. Solar urbano con vallado metálico. ……..................................................... 812

Figura A3.96. Imagen urbana de la calle Villarrobejo. ................................................... 812

Figura A3.97. Apriscos de ovejas en el casco urbano. ................................................... 812

Figura A3.98. Camino de circunvalación, con varias explotaciones ganaderas.................... 812

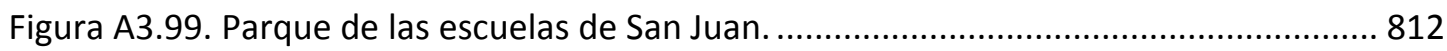

Figura A3.100. Naves agrícolas en el casco urbano. ......................................................... 813

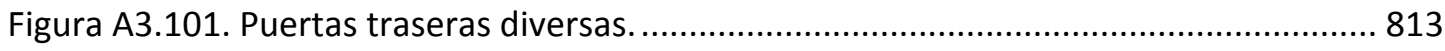

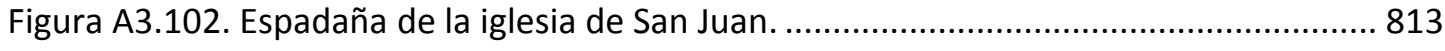

Figura A3.103. Antiguo hospital de la Vera Cruz................................................................ 813

Figura A3.104. Las puertas traseras son un factor de degradación del paisaje urbano....... 813

Figura A3.105. Un elemento singular en extinción: las casas de barro. .............................. 813

Figura A3.106. Aprisco de ovino en casco urbano, ladrillo visto. ........................................ 818

Figura A3.107. Conjunto de traseras grandes, ladrillo visto, cemento, etc......................... 818

Figura A3.108. Las puertas metálicas brillan mucho al comienzo de su colocación............. 818

Figura A3.109. Plaza de San Miguel en clara degradación...................................................... 818

Figura A3.110. El parque del Paseo está ya sin hojas. ......................................................... 818

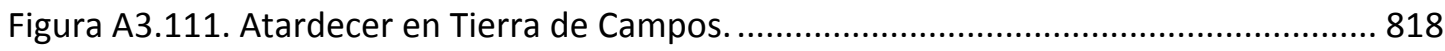

Figura A3.112. Rebaño de ovejas pastando las eras cercanas al pueblo.............................. 820 
Figura A3.113. Los barbechos aportan textura al paisaje. ............................................... 820

Figura A3.114. Terrenos recién sembrados. Monotonía cromática. ..................................... 820

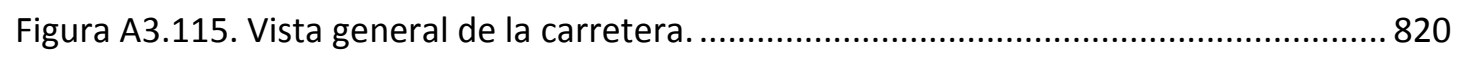

Figura A3.116. Fachada principal de la ermita de Fuentes. ................................................. 820

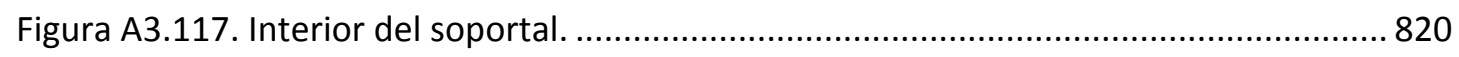

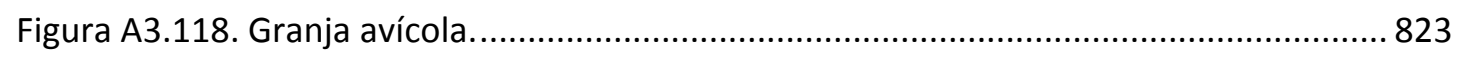

Figura A3.119. Camino-vereda, barbecho (izquierda) y leguminosas (derecha).................. 823

Figura A3.120 Reguera, barbecho (izquierda) y cereal nacido (derecha)............................ 823

Figura A3.121.Valdelafuente, con los únicos árboles del recorrido.................................... 823

Figura A3.122. Detalle de la fuente de Valdelafuente. .................................................... 823

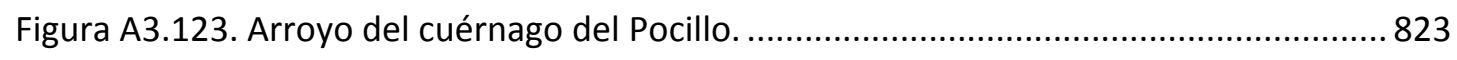

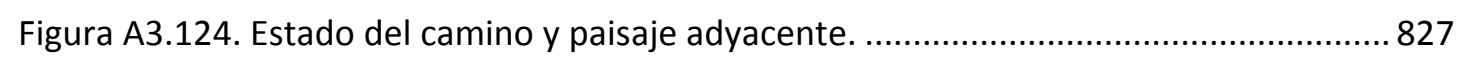

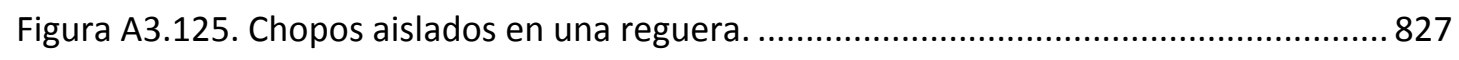

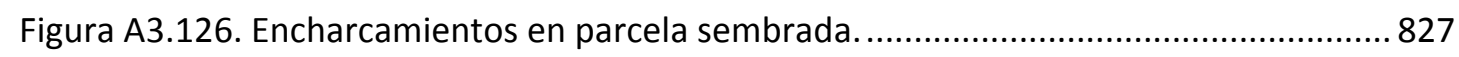

Figura A3.127. Camino, árbol por ha AHA 2 y reguera con agua......................................... 827

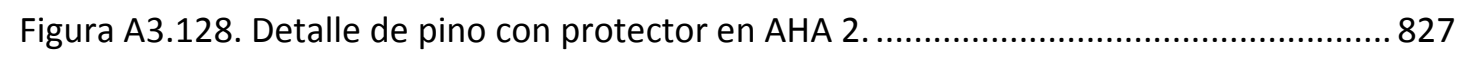

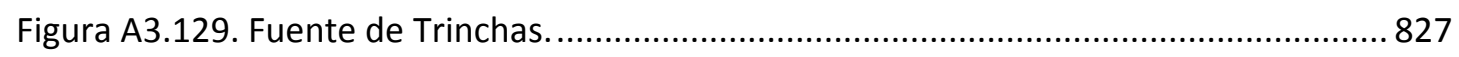

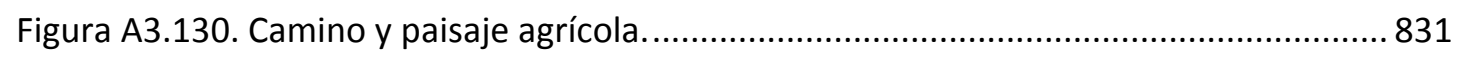

Figura A3.131. Plantación de árbol por hectárea ejemplar. ............................................. 831

Figura A3.132. Talud de terraplén de la balsa, con regueros de erosión.............................. 831

Figura A3.133. Plataforma de la balsa con agua abundante............................................. 831

Figura A3.134. Reguera con agua en circulación. ........................................................... 831

Figura A3.135. Fuente Villacilda, con cuatro chopos singulares........................................ 831

Figura A3.136. Restauración con escollera en caminos y arroyo.......................................... 835

Figura A3.137. Vista general del camino y del paisaje agrícola. ......................................... 835

Figura A3.138. Restauración de pinos en arroyo del cuérnago del Pocillo............................ 835

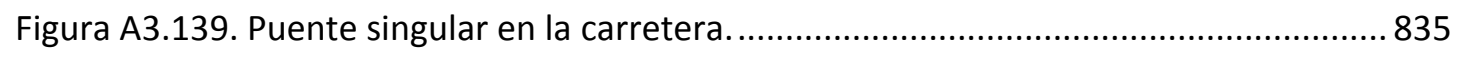




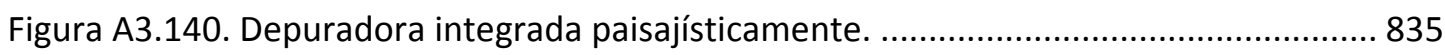

Figura A3.141. Entrada del pueblo con varias naves agropecuarias. ................................... 835

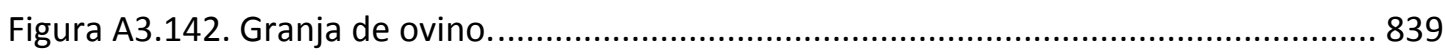

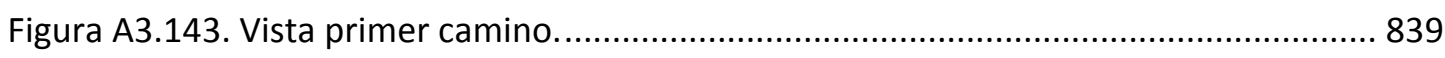

Figura A3.144. Parcela de RMN en el arroyo Berruez........................................................ 839

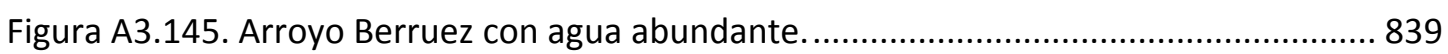

Figura A3.146. Reguera, sembrados y cielo espectacular................................................ 839

Figura A3.147. Rastrojo, camino de Villafrades y cielo................................................... 839

Figura A3.148. Gasolinera a la entrada del pueblo............................................................ 843

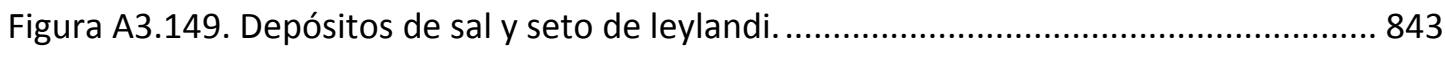

Figura A3.150. Fachada del antiguo asilo modernista. .................................................... 843

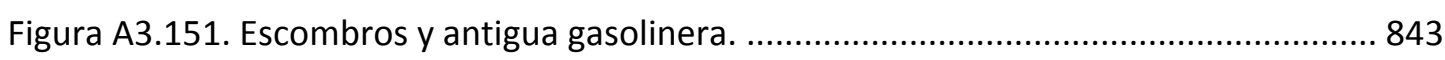

Figura A3.152. Vista general de la entrada del pueblo.................................................. 843

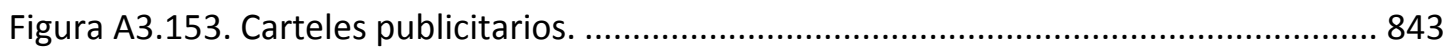

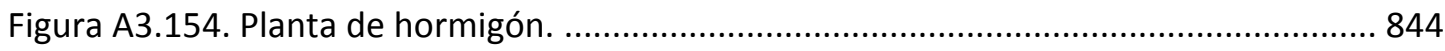

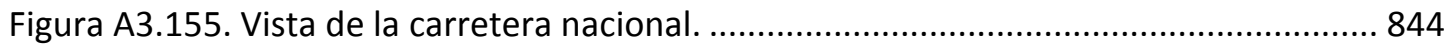

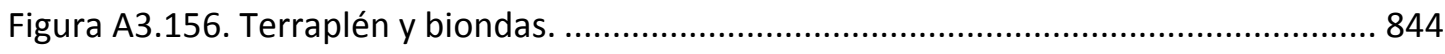

Figura A3.157. Chopos aislados en antigua vía del ferrocarril............................................ 844

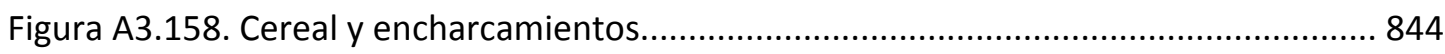

Figura A3.159. Planta clasificadora al final del término municipal..................................... 844

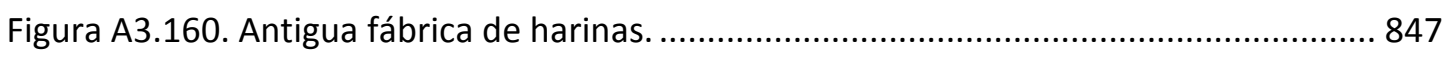

Figura A3.161. Construcciones ganaderas cerca del pueblo. ........................................... 847

Figura A3.162. Tolvas de la planta de hormigón.................................................................... 847

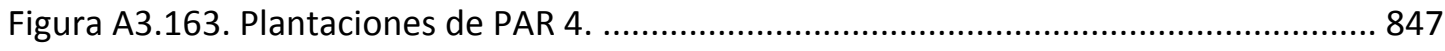

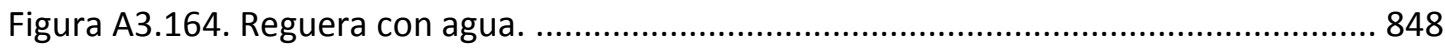

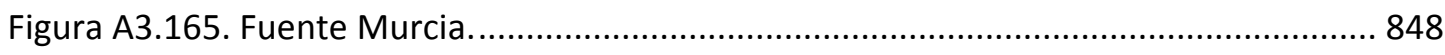

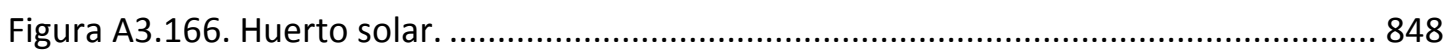


Figura A3.167. Nave con cubierta metálica y plantación AHA 3........................................ 848

Figura A3.168. Reguera y parcela de restauración del medio natural...................................851

Figura A3.169. Paisaje general con nubes espectaculares............................................. 851

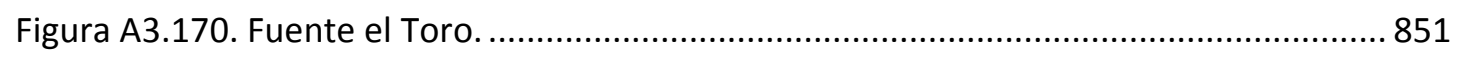

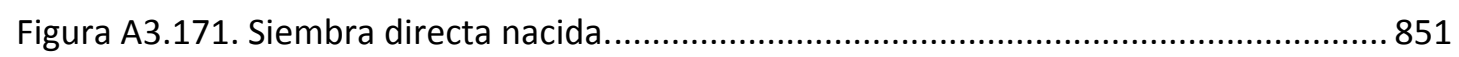

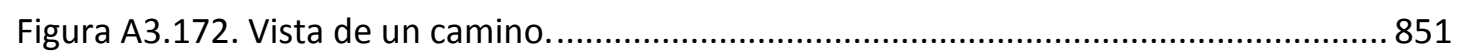

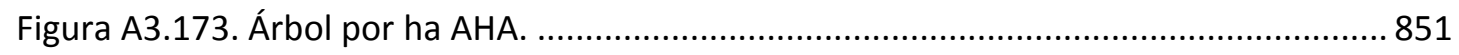

Figura A3.174. Parque reguera del Tinte, tramo a restaurar. ........................................... 856

Figura A3.175. Parterres de la plaza de San Juan............................................................ 856

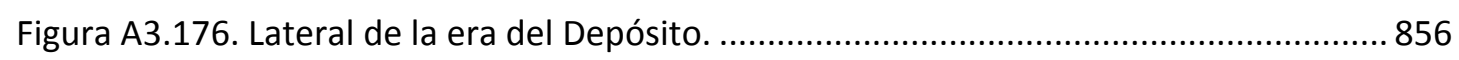

Figura A3.177. Valla metálica en Parque temático. ............................................................ 856

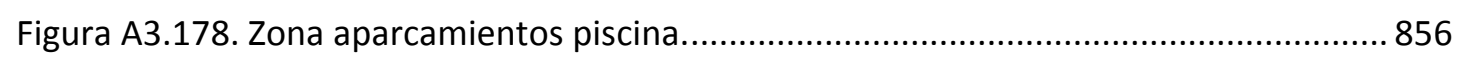

Figura A3.179. Valla metálica en Paseo del campo de fútbol. ........................................... 856

Figura A3.180. Tapia del cementerio y planta de hormigón al fondo................................... 860

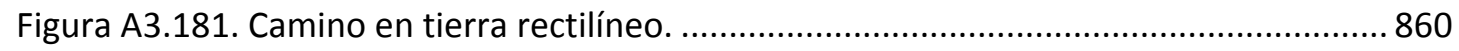

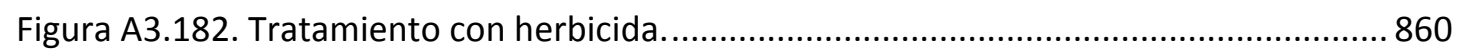

Figura A3.183. Vía verde con pinos algo torcidos. ............................................................ 860

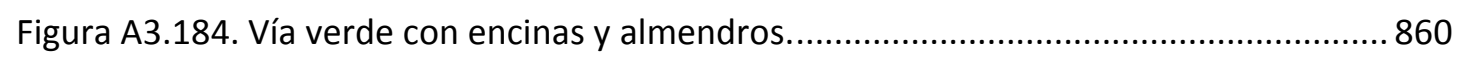

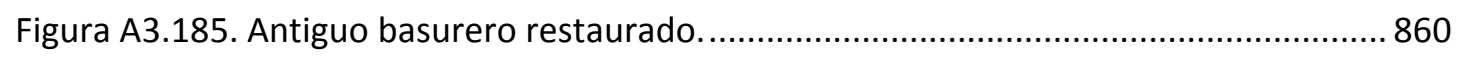

Figura A3.186. Detalle de basuras en la cuneta; al fondo, chalets. .................................... 863

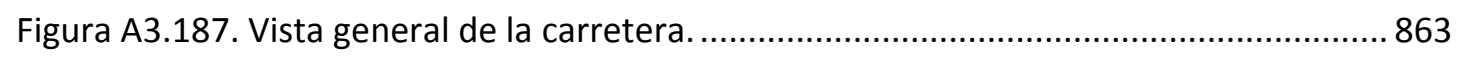

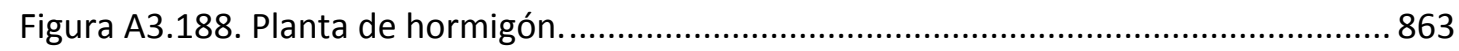

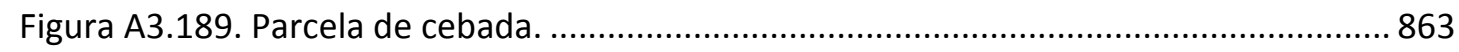

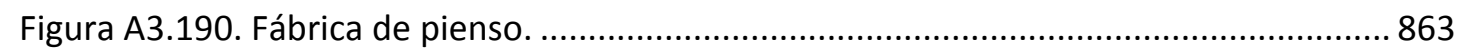

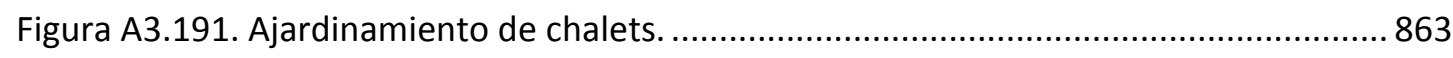

Figura A3.192. Camino excesivamente rectilíneo. ............................................................ 867

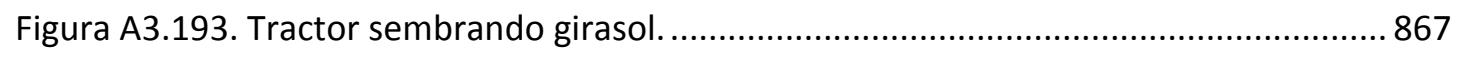


Figura A3.194. Lindera vegetal en reguera interior de una parcela. 867

Figura A3.195. Restos de caños antiguos. 867

Figura A3.196. Arroyo Gorreras con sauces y chopos al fondo. 867

Figura A3.197. Restauración vegetal de la fuente Cortaelaire. 867

Figura A3.198. Subestación eléctrica y naves agrícolas. 871

Figura A3.199. Colada de Villacid de Campos. 871

Figura A3.200. Chopos y matorral variado aguas abajo de la fuente el Cuquillo. 871

Figura A3.201. Chopera particular al fondo. 871

Figura A3.202. Plantación AHA 3. 871

Figura A3.203. Plantación AHA 4. 871

Figura A3.204. Chopera frondosa del arroyo Pajarillas. 875

Figura A3.205. Acacias en flor 875

Figura A3.206. La hoja de los prunos aporta gran colorido. 875

Figura A3.207. Grandes flores de los castaños de indias. 875

Figura A3.208. Parterre de flores anuales en el parque del Paseo. 875

Figura A3.209. Rosas y lilas en un parterre del paseo de Barrios. 875

Figura A3.210. Varias construcciones a la salida del pueblo. 879

Figura A3.211. Vista de la carretera nacional. 879

Figura A3.212. Chopos aislados en el margen de la carretera / línea eléctrica. 879

Figura A3.213. Vezas recién segadas. 879

Figura A3.214. Cebada espigada / Poste telefónico paralelo a la carretera. 879

Figura A3.215. Entrada a Villalón de Campos. 879

Figura A3.216. Tramos iniciales de la vereda con escombros. 883

Figura A3.217. Vista general de una zona de la vereda conservada...... 883

Figura A3.218. RES 2, con chopos en reguera paralela al camino. 883

Figura A3.219. Mojón tirado (cinta métrica) e intrusión de toda la franja. 883

Figura A3.220. Fuente Juan Palacios. 883 


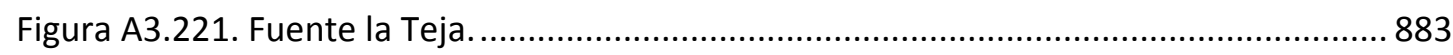

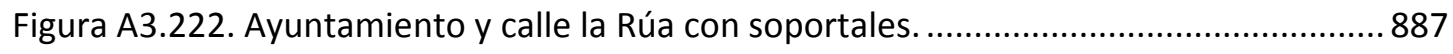

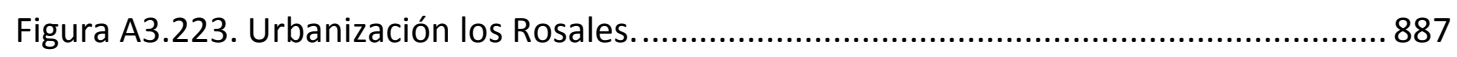

Figura A3.224. Granja de vacuno, con buena integración paisajística................................. 887

Figura A3.225. Antenas de telefonía móvil. ................................................................. 887

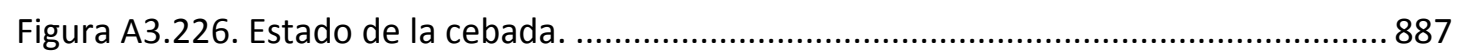

Figura A3.227. Vista de la colada de Cabezón-Villalón. .................................................... 887 


\section{ÍNDICE DE TABLAS}

Tabla 3.1. Criterios de la calidad paisajística. 88

Tabla 3.2. Subtipos y unidades del paisaje incluidos en el tipo 51 114

Tabla 3.3. Relación de especies que pueden emplearse en la Zona 11. 224

Tabla 3.4. Procedencias de las especies, tamaño y tipo de planta en la Zona 11. 225

Tabla 3.5. Densidades y marco de plantación en la Zona 11 "Campos Centro". 225

Tabla 3.6. Características de la estación 3, que es la más representativa de Tierra de Campos.

Tabla 4.1. Datos generales de Tierra de Campos (GEOSISTEMA, 1994; INE). 292

Tabla 4.2. Evolución de la población en Tierra de Campos 292

Tabla 5.1. Expedientes de Evaluación de Impacto Ambiental (excepto los del Anejo 1). .... 319

Tabla 5.2. Expedientes de Restauración de Minería. 320

Tabla 5.3. Recorridos paisajísticos en Villalón de Campos 325

Tabla 6.1. Variación mensual de los colores por dominancia en las parcelas agrícolas. 338

Tabla 6.2. Valores de la capacidad de absorción visual (C.A.V.), tomado de YEOMANS (1986). 356

Tabla 6.3. Degradaciones paisajísticas de los Recorridos en Villalón de Campos. 383

Tabla 6.4. Actuaciones de recuperación ambiental planteadas en los espacios degradados de Tierra de Campos

Tabla 6.5. Porcentaje de los distintos rangos de altura (longitud de pendiente) en los taludes de los caminos de Villalón de Campos. 415

Tabla 6.6. Porcentaje de los distintos rangos de anchura en los arroyos y regueras de Villalón de Campos.

Tabla 6.7. Porcentaje de los distintos rangos de altura (longitud de pendiente) en los arroyos y regueras de Villalón de Campos.

Tabla 6.8. Árboles y arbustos utilizables en la recuperación del paisaje de Tierra de Campos

Tabla A1.1. Superficies de los términos municipales de la zona de concentración parcelaria. 548

Tabla A1.2. Titulares de explotación. 548

Tabla A1.3. Evolución de la propiedad en cada término municipal 549 
Tabla A1.4. Datos de la concentración parcelaria............................................................ 551

Tabla A1.5. Resumen de la concentración parcelaria. .......................................................... 553

Tabla A1.6. Presupuesto del proyecto de restauración. .................................................... 565

Tabla A1.7. Características geométricas más destacables de la balsa................................. 582

Tabla A1.8. Características geométricas más destacables de la balsa (actualizadas)............585

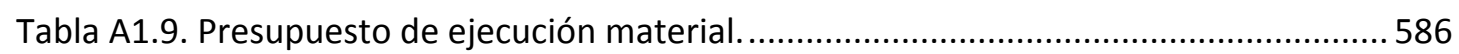

Tabla A1.10. Presupuesto de restauración del medio natural............................................592

Tabla A1.11. Presupuesto de ejecución material del proyecto de construcción de la Variante de Villada. 621

Tabla A1.12. Presupuesto de ejecución material de medidas correctoras. 624

Tabla A1.13. Unidades y precio de medidas correctoras. .626

Tabla A1.14. Presupuesto ejecución material proyecto restauración. ..................................660

Tabla A1.15. Porcentaje de marras en las plantaciones vegetales. ......................................661

Tabla A1.16. Presupuesto del anteproyecto de parque eólico El Castre..............................669

Tabla A1.17. Intensidades y usos del sector 1 polígono industrial. ....................................683

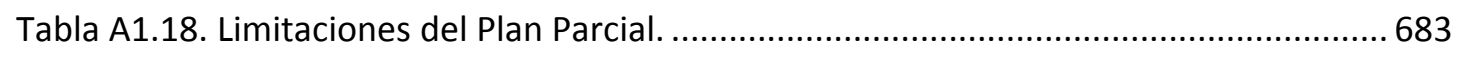

Tabla A1.19. Resumen de la evaluación económica del Plan Parcial industrial.....................687

Tabla A2.1. Resumen del presupuesto de ejecución material del proyecto..........................698

Tabla A2.2. Parcelas a forestar en Ampudia. .................................................................. 709

Tabla A2.3. Especies seleccionadas en la forestación de Ampudia. .................................... 710

Tabla A2.4. Especies seleccionadas en la forestación de Frechilla. .................................... 716

Tabla A2.5. Resumen del presupuesto de ejecución material del proyecto......................... 730

Tabla A2.6. Especies plantadas y número de marras...................................................... 742

Tabla A2.7. Especies seleccionadas, presentación y ejemplares plantados. ........................ 747

Tabla A3.1. Muestra de plantaciones de 1 árbol/ha en los Recorridos paisajísticos............ 889

Tabla A3.2. Fuentes de Villalón de Campos, con los datos del Acuerdo de la reciente

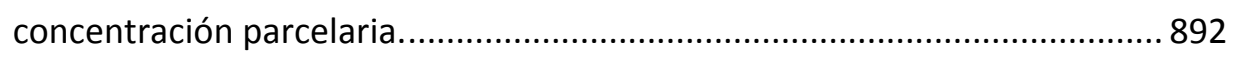

Tabla A3.3. Parques y zonas verdes de Villalón de Campos. .............................................. 895 

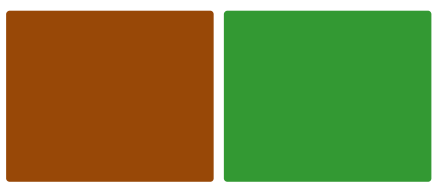

\section{RESUMEN}




\section{RESUMEN}

Tierra de Campos es una comarca natural de considerable superficie (en torno a $4400 \mathrm{~km}^{2}$ ), con una identidad muy definida geográfica, histórica y culturalmente. El rasgo que mejor la caracteriza es que la práctica totalidad de su superficie está ocupada por el cultivo agrícola herbáceo, cuya presión ha provocado la casi total desaparición de la vegetación arbórea y arbustiva. La especialización del cultivo cerealista ha sido una de las causas del tremendo declive demográfico que sufre, que le ha hecho perder un $70 \%$ de su población desde el comienzo del éxodo rural.

El paisaje de Tierra de Campos es uno de los más representativos de las campiñas cerealistas de Castilla y León así como de otras españolas que, en su conjunto, ocupan una superficie de considerable extensión. Su configuración actual y degradaciones son en general comunes, por lo que el modelo de recuperación ambiental que se propone para esta comarca es sin duda extensible a otros territorios cerealistas del país.

Los principales objetivos de este estudio son caracterizar el paisaje de Tierra de Campos, diagnosticar sus deterioros, describir las actuaciones de recuperación ambiental en cada uno de los espacios degradados, proponer los árboles y arbustos utilizables en la recuperación y definir una imagen-objetivo de su paisaje de calidad.

El material y los métodos empleados son: el análisis de fuentes documentales; la utilización de sistemas de información geográfica; la creación de una amplia base de datos con más de 3900 fotografías de Tierra de Campos; el análisis documental y trabajo de campo de 9 proyectos representativos de grandes obras que afectan al paisaje de la comarca, sometidos a algún trámite de prevención ambiental; el análisis documental y trabajo de campo de 9 proyectos de recuperación ambiental singulares; $y$, finalmente, el trabajo de campo en 34 recorridos paisajísticos, durante un año, en Villalón de Campos para diagnosticar actuaciones de menor entidad pero más frecuentes.

Las principales características del paisaje de Tierra de Campos son: geomorfología de llanuras suavemente onduladas, climatología continental extrema, abertales de cultivos con dominio claro del cereal, grandes parcelas con infraestructuras rurales regularizadas, ríos y arroyos en su mayoría rectificados y encauzados, núcleos urbanos compactos y ausencia prácticamente total de arbolado. Se trata de un paisaje simplificado y muy frágil. Las tres alteraciones más significativas al paisaje de la comarca son la pérdida de vegetación ( $y$, por tanto, de diversidad); el cambio de las características visuales, por la irrupción de formas y colores ajenos; y la pérdida del patrimonio cultural edificado.

Se constata que la recuperación de espacios degradados o recuperación ambiental es una magnífica técnica para corregir impactos y mejorar la calidad del paisaje de Tierra de Campos. Esta técnica es relativamente poco costosa; sin embargo es compleja y requiere una minuciosa ejecución. La diversificación del paisaje y su valorización son actuaciones paralelas que también se proponen en el modelo.

De los tratamientos generales que se pueden plantear para la recuperación de los espacios degradados de Tierra de Campos, se considera que tres son los fundamentales: la restauración 
vegetal con árboles y arbustos, la integración paisajística de las edificaciones e infraestructuras y la restauración de los atributos de calidad (en especial el patrimonio).

La recuperación ambiental integral de Tierra de Campos supondrá una transformación radical del territorio hacia un paisaje de gran calidad. En este modelo se han diagnosticado 14 espacios degradados diferenciados: espacios con agricultura intensiva afectados por concentraciones parcelarias; espacios afectados por transformaciones en regadío; espacios afectados por infraestructuras lineales de transporte; espacios afectados por explotaciones mineras, préstamos y vertederos; espacios afectados por infraestructuras energéticas; ríos y arroyos desnaturalizados; zonas húmedas degradadas; vías pecuarias y del ferrocarril sin uso; fuentes y pequeñas parcelas públicas degradadas; espacios deforestados y/o erosionados; escombreras y vertederos de residuos; entorno de construcciones en suelo rústico; periferias de los pueblos; $y$ pueblos en descuido y abandono. En ellos se han definido un total de 56 actuaciones de muy diversa naturaleza. La recuperación se plantea -a modo de cirugía- sobre una superficie relativamente reducida (no se afectan los cultivos), pero homogéneamente repartida por todo el territorio.

La recuperación de un paisaje de calidad ligado a la naturaleza conllevará unos innegables beneficios para los habitantes de Tierra de Campos. De entre ellos cabe destacar los relativos al bienestar, la calidad de vida y la salud, tanto física como mental. El paisaje de calidad constituirá además un recurso socioeconómico de especial valía para esta comarca tan deprimida.

El listado de especies vegetales utilizables en Tierra de Campos es muy extenso. Se han seleccionado un total de 62 especies: 32 árboles y 27 arbustos, que es un amplio abanico a tener en cuenta en cualquier restauración del paisaje de la comarca.

La imagen objetivo del paisaje de calidad de Tierra de Campos es la de un paisaje que seguirá siendo agrícola, pero más diverso. Las infraestructuras estarán integradas y crearán nuevos paisajes. Los ríos, arroyos y vías pecuarias constituirán grandes corredores ecológicos. El agua será un elemento de valía del paisaje de calidad. Tierra de Campos será un paisaje limpio sin contaminación. Los pueblos de la comarca estarán integrados y poseerán abundantes zonas verdes. Y sus cascos urbanos estarán cuidados, con un patrimonio rehabilitado y más valorado. 

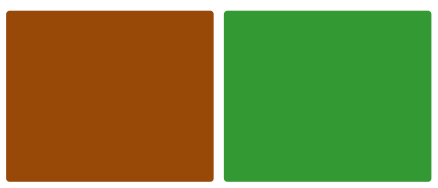

\section{INTRODUCCIÓN}




\section{INTRODUCCIÓN}

En los documentos técnicos es usual que se utilice el tiempo impersonal en la redacción del texto; así se realizará en este caso en su inmensa mayoría. Sin embargo, permítaseme la licencia de que en este apartado utilice la primera persona. Solo así podré expresar unas vivencias y unos sentimientos que han constituido el germen sobre el que se ha conformado el estudio que aquí se presenta.

Un grupo de música tradicional del que formo parte, Juglares del Alón, eligió como título de su último disco el tema "Árboles de la Alameda". Se trata de una canción muy popular en Villalón de Campos que, entre otras cosas, dice:

\section{"Árboles de la Alameda, los de arriba y los de abajo (...)" \\ "A la sombra de un árbol frondoso mi morena se puso a coser (...)"}

Lo paradójico del asunto es que, actualmente, en el pago de la Alameda, donde además se encuentra la fuente del mismo nombre, no existe ningún árbol; tan solo había hace unos años dos grandes chopos que se han secado (Figura 1.1). Cómo resultará de evidente esta contradicción que, después de la presentación del disco, bastantes personas me comentaron la necesidad de plantar unos árboles en la zona. Este es solo un ejemplo del tremendo cambio en el paisaje que ha vivido Tierra de Campos en las últimas décadas.

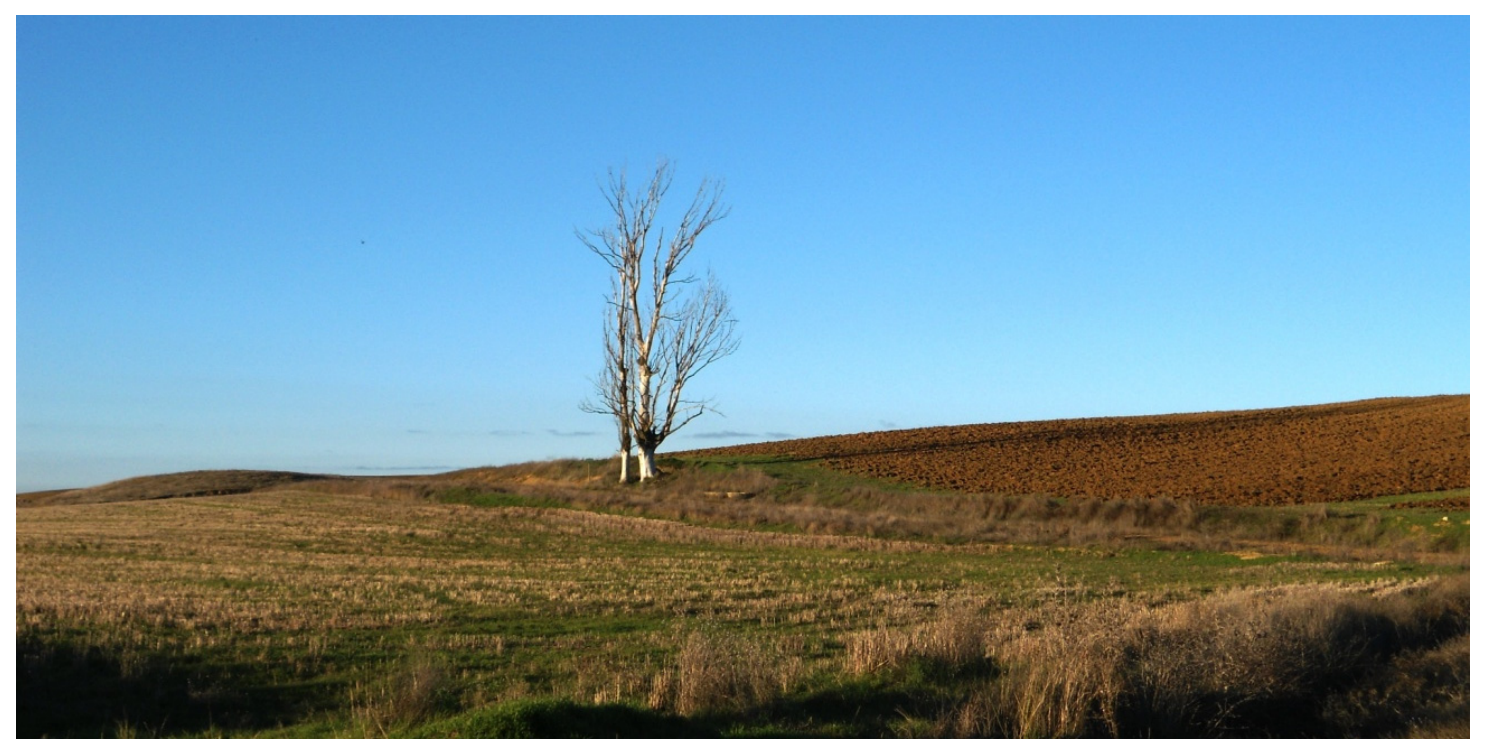

Figura 1.1. Fuente y pago de la Alameda. Dos chopos secos son testigos de un pasado donde los árboles tenían un mayor protagonismo en el paisaje.

$Y$ es que abordar un estudio de estas características tiene un problema importante: se junta lo estrictamente técnico con lo personal. Soy ingeniero de Montes, paisajista ante todo, defensor de la naturaleza y del medio ambiente dentro del rigor científico y técnico. Pero también soy de 
Tierra de Campos - de Villalón de Campos-, vivo allí, defiendo el medio rural y por tanto siento lo que ocurre y lo que ha ocurrido en el pasado con especial intensidad.

También soy hijo de ingeniero de Montes, de familia labradora, del que heredé la afición por el paisaje y el campo. Mi padre nunca me comentaba nada personalmente sobre el tema, pero desde muy niño escuchaba con atención todas sus conversaciones relacionadas con ese campo de antes que me fascinaba. Viví todos sus afanes por rescatar del olvido las fuentes que tanto uso habían tenido y por tratar de plantar árboles en un pueblo prácticamente desértico. De este modo, cuando me fui a estudiar a Madrid esta carrera y, ante la pregunta de cómo la había elegido siendo de una comarca tan deforestada, siempre decía lo mismo: "por eso, precisamente, para intentar recuperarla".

Desde pequeño tengo grabado que el campo de antaño no tenía nada que ver con el de ahora. Desde luego, con lo que suponía de trabajo: horas y horas, días y días de duras labores bajo los rigores climatológicos: labrar, sembrar, arrastrar, escardar, sembrar, arrancar, agavillar, acarrear, respigar, vendimiar... ¡Qué palabras tan bonitas! El campo tenía que ser un hervidero de gente, yendo y viniendo, con sus carros, sus mulas y sus aperos. Mis tías incluso me enseñaban lo que cantaban con todo este trajín, a pesar de la dureza de las labores. En especial me marcó la palabra iguada, que equivale a $3988 \mathrm{~m}^{2}$ (HERNÁNDEZ et al., 2001); salía en múltiples conversaciones y yo no me enteraba de nada de lo que significaba.

A la vez, esto me suponía un choque con lo que he ido viendo a lo largo de los años; no en vano nací en 1967, en plena concentración parcelaria y tecnificación agrícola. Las parcelas eran grandes y se medían en hectáreas; no había majuelos por ningún lado, y los pocos que había se iban arrancando; las eras perdieron su función y sus casetas de barro se han ido transformando en naves y construcciones de todo tipo; ya no había huertas en las que pasar el verano ni frutales a los que subirnos...

Produce estremecimiento escuchar a Aureliano González Moro y a Eleuterio Alonso Palazuelo a sus 80 años, labradores de toda la vida, que con una memoria prodigiosa me relatan cómo era el campo de Villalón de Campos -y por tanto, de toda la comarca- en el entorno de 1950, con anterioridad a la concentración parcelaria. Todo ello con el detalle de los pagos y los nombres de las personas, de forma que los relatos adquieren plena verosimilitud. Cuando las parcelas se medían en iguadas y no en hectáreas, de modo que cada labrador tenía múltiples de ellas, pequeñas y muy repartidas. Cuando estas se delimitaban por linderas, por donde se podía caminar o donde se asentaban las sebes. Cuando una parte sustancial del término eran majuelos (Figuras 1.2 y 1.3), con sus árboles frutales asociados: almendros, cerezos, guindales, manzanos, ciruelos, nogales.... Cuando incluso había plantaciones de almendros y frutales regularmente dispuestos con calles. Cuando existían numerosas huertas en el entorno del pueblo, donde incluso vivían familias todo el año. Cuando el campo estaba lleno de arroyos y regatos, plagados de zarzas, endrinos, espinos y grupos de chopos y álamos. Cuando las veredas se conservaban en su histórica y verdadera dimensión. Cuando las muchas fuentes que había manaban agua de forma casi permanente, estaban llenas de árboles y se usaban con asiduidad. Cuando en todas las carreteras había chopos y negrillos en sus dos márgenes, "que se tocaban unos con otros", lo mismo que en la vía del ferrocarril. Cuando en los ojeos se llegaban a ver hasta 60 u 80 
perdices, cuando había auténticas bandadas de terreras y calandrias que se comían las tierras sembradas de lentejas...
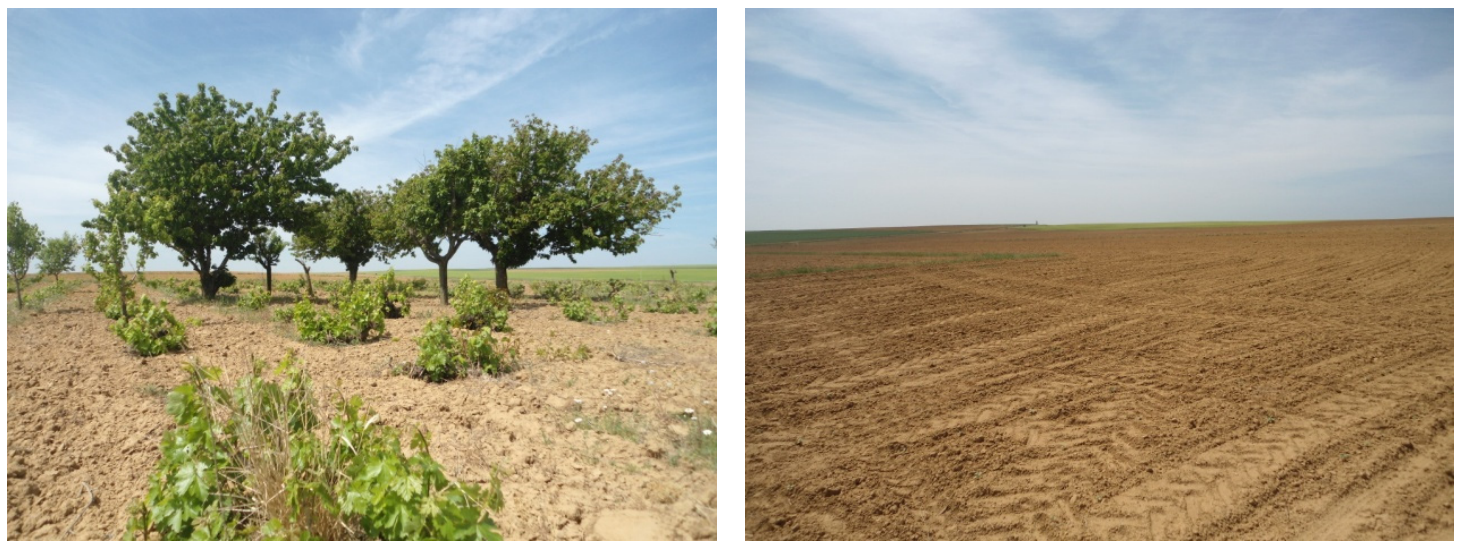

Figura 1.2. A la izquierda, imagen de uno de los escasísimos majuelos de Villalón de Campos en la actualidad; a la derecha, el árido paisaje circundante.

Este relato de Aureliano y a Eleuterio también se lo he escuchado a mi padre, a mis tíos, a mis abuelos, así como a numerosos vecinos mayores con los que alguna vez he conversado. Está también en la teoría, en algunos libros o escritos, pero nada como vivirlo y sentirlo. El paisaje que ahora se contempla en Tierra de Campos es radicalmente diferente al de hace no muchas décadas. No tiene nada que ver. Es agrario, sí, pero es extraordinariamente más simple. Es como si por el campo hubiese pasado un tsunami devastador, llevándose todo lo que le hacía diverso.

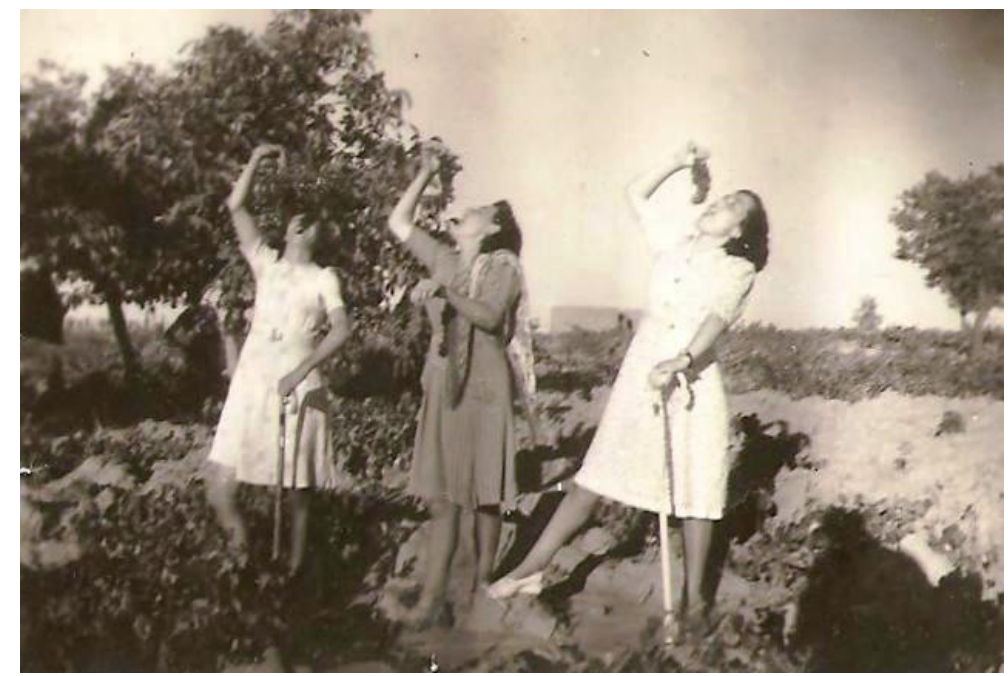

Figura 1.3. Graciosa fotografía de un majuelo de Villalón de Campos en 1943, que ahora no existe. En ella se aprecian los árboles que solían acompañar este cultivo.

El problema es que, paralelamente a esta devastación del paisaje, se ha producido otra mucho más importante: una devastación sin freno de la población. Si se quería conseguir una 
reestructuración de la comarca se ha logrado, pero con la fuga masiva a las zonas urbanas. Del éxodo rural se lleva hablando desde 1950, pero lo lamentable es que aún continúa. Jesús Torbado, en su Viaje por Tierra de Campos de 1966, ya se indigna por la postración de la comarca, "aplastada por el peso de la historia, ayer floreciente y hoy marginada" y carga contra el tan publicitado Plan de Tierra de Campos del Ministerio de Agricultura. Apoyado en una caminata por los pueblos de la comarca, relata una situación poblacional trágica, donde ya han emigrado un $20 \%$ de los vecinos, acabando con una frase lapidaria: "Es tierra para morir. Solo para eso". A través de una magnífica prosa, muestra un paisaje árido, duro, desarbolado, con notable pobreza y un patrimonio histórico-artístico en buena parte en ruinas, donde lo normal es que la gente se marche. Así lo cuenta con dramatismo cuando, ante la duda de dos francesas de si alcanzar Galicia o llegar a Burgos a través de Tierra de Campos, un paisano responde:

"Vayan ustedes a Galicia-les digo-. No atraviesen esa tierra.

Tengo el brazo extendido hacia el este, el país sin ríos y sin árboles.

Pues, ¿qué es esa tierra?

El infierno".

Como a continuación veremos en este estudio, el porcentaje de caída de población apuntado por Torbado se ha visto netamente superado y parece que no tiene fin. Incluso las escasas descripciones de arbolado en linderos, huertos y márgenes de carreteras ya no tienen reflejo en la actualidad; ni existen majuelos con frutales. El paisaje es aún más árido y desolado. La mayoría de las tabernas y tiendas en las que paraba el autor se han cerrado. En las eras ya no hay trabajadores. No hay chiguitos haciendo laboradas por las calles ni llenando las escuelas. Los coches de línea -entonces atestados de gente- ahora cuentan sus pasajeros con los dedos de una mano, y el tren burra cerró al año siguiente de ser escrito el libro citado. En muchas de las localidades que el escritor atravesó ya no podría ni conversar. En nuestros días el sonido de las campanas de las iglesias tañendo a muerto es una constante en los pueblos de Campos y en ocasiones se hace insoportable. La situación actual es tan fuerte que ya casi ni se habla de ella; debe ser porque el tejido social rural es tan escaso que no tiene fuerzas para levantar la voz. Cuando ya en la infancia vas escuchando la cantinela de que "es que antes había...", pero a la vez compruebas que a lo largo de tu vida también cuentas a las generaciones posteriores "lo que antes había...", no puedes constatar otra cosa que la situación de Tierra de Campos es gravísima.

Ante esta situación agónica muy pocas voces se alzan, tal vez por ser tan voraz el poder succionador de las ciudades, puede que por ser tan débil la sociedad civil rural o tal vez por ser tan alto el poder amortiguador de la clase política, mediática e incluso cultural. Parece mentira que tengan casi plena vigencia las palabras de Julio Senador, notario de Frómista y escritor regeneracionista, que en su libro Castilla en escombros de 1915 ya clamaba justicia con esta tierra e incluso alertaba de la destrucción de su paisaje: "Venid vosotros, politicastros de un régimen podrido que, sin saber siquiera cómo se hace una estadística, discutís sobre riegos y aranceles... y vosotros, los patriarcas de la vaciedad periodiquil que, tan pronto sin respeto a la miseria ajena perpetráis alguna revistilla de salones... y vosotros, los poetas de flor natural y veinte duros que, sin haber pisado un surco, representáis la pantomima de embriagaros con la fragancia de estas mieses... iVenid a ver lo que es este país por dentro! 
Ante vuestros ojos van a desfilar estos bosques asolados por el hacha, estos viñedos asesinados por la filoxera, estos pueblos en ruinas, estos cultivos semibárbaros, esta incomunicación, este abandono, este analfabetismo, esta ferocidad, este hambre, que son vergüenza de España y afrenta a la civilización de nuestro siglo.

Cuando hayáis visto todo esto, seguid si os parece bien. Sólo correríais peligros de consideración si el pueblo despertara; pero no despertará".

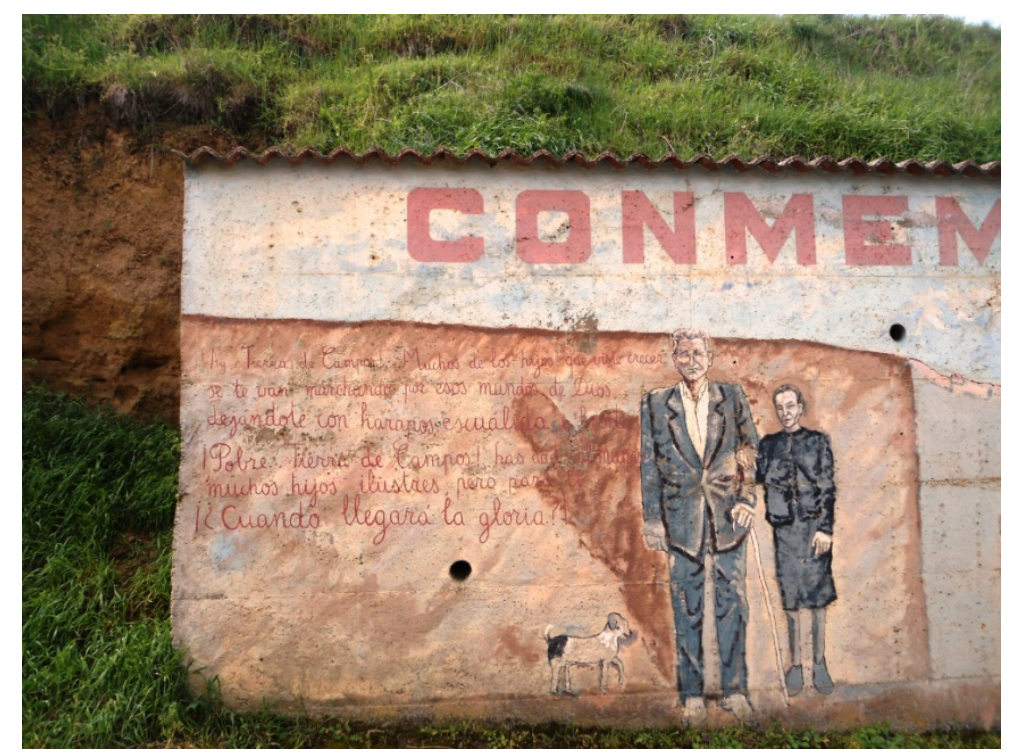

Figura 1.4. Ilustración realizada en un muro de Melgar de Abajo, reivindicativa ante el éxodo rural que sufre Tierra de Campos.

Se le pone a uno la piel de gallina leyendo el grito de auxilio de Julio Senador, así como el verso escrito en una pared de Melgar de Abajo (Figura 1.4.):

\section{iTierra de Campos!}

Muchos de los hijos que viste crecer

Se te van marchando por esos mundos de Dios

Dejándote con harapos escuálidos.

¡Pobre Tierra de Campos!

Has dado al mundo muchos hijos ilustres

pero para ti, ¿cuándo llegará la gloria?

Tanto Jesús Torbado como la mayoría de literatos que han escrito sobre Tierra de Campos coinciden en relacionar la decadencia socioeconómica de la comarca con la aridez y desolación de su paisaje. Tal como señala este autor "solamente algún viajero imaginativo como Víctor de la Serna ha visto en Tierra de Campos jardines que no existen, maravillas geográficas irreales y glorias no pasadas. Solamente los poetas optimistas han descubierto un paisaje literario tan cruelmente falso que acongoja a cuantos han visto el verdadero paisaje. La Tierra de Campos es en verano un gran desierto caldeado y amarillo. El invierno es todavía más trágico". 
Macías Picavea, a finales del siglo XIX, es igualmente ilustrativo en su libro El problema nacional: "Toda la naturaleza viva se reduce allí al trigo y a la cebada (...) Ni un monte, ni un bosque, ni una dehesa (...) iParece que la naturaleza, dejando allí de ser Proteo, se ha hecho infinitamente homogénea, monótona, uniforme!". Palabras increíblemente actuales, que justifican la necesidad reflejada en este trabajo de recuperar el paisaje como base para recuperar la comarca.

En esta línea, también resulta asombroso que el citado intelectual Julio Senador, hace exactamente cien años, fuese tan crítico con el sistema agrario de la época ("Toda la tierra de Castilla está empeñada, porque sobre toda ella pesa un error fundamental, el de creer que toda ha de servir para dar trigo"), que al menos en Tierra de Campos poco ha cambiado. Este autor atestiguó la tragedia que supuso la pérdida de los viñedos ("No fue una fuga, fue una desbandada") y profetizó con la imperiosa necesidad de que se plantasen árboles en la meseta castellana -iaspecto este al que dedicó cuatro de los diez capítulos del libro referido!- para combatir su extrema aridez y contribuir a su progreso.

Con el patrimonio edificado de los pueblos me ha pasado algo parecido a la situación del campo. Todavía tengo en la retina la cantidad de casas de barro que había en mi pueblo, los soportales, los corros, los pasadizos, las iglesias con vida... He sentido como un pinchazo cada uno de los revocos o enladrillados de una pared de barro, cada soportal tirado, cada casa derrumbada, cada iglesia cerrada. El patrimonio es la seña de identidad de un pueblo, es aquello que heredamos y estamos obligados a transmitir a nuestras generaciones. Estoy convencido además, que este es uno de los elementos diferenciadores con las ciudades y tiene un gran potencial de futuro, sobre todo si la conservación del patrimonio no solo se hace a nivel de elementos aislados, sino también como entornos de los mismos, como paisaje urbano en definitiva.

El paisaje de Tierra de Campos ha sido asociado a tristeza, rudeza, aridez... desde variados ámbitos culturales: la pintura, la fotografía, la poesía o la literatura. Estos paisajes desarbolados albergan el alma de Castilla y le proporcionan su esencia. Ello le ha dado una impronta característica y una especie de perdurabilidad; da la impresión de que siempre ha sido así y así ha de seguir siendo. Pero, realmente, ¿̇ha sido siempre así?

Jesús González Garrido, en su relato de Tierra de Campos de 1941, expresa esta situación derrotista con estas palabras:

Se planta un árbol, y se seca;

Abrís una fuente, y se agota;

Cuidáis un pájaro y se muere.

Pero, vuelvo a plantearme, ¿es esto verdad? Incluso los recientes postulados en materia de conservación de la naturaleza, acuñando el término de estepa cerealista, contribuyen a afianzar esta imagen de prácticamente un desierto comarcal.

Pues bien, en este desalentador panorama creo que no todo es negativo. Por ejemplo, doy fé del considerable crecimiento de las zonas verdes y jardines de mi pueblo, que también es extrapolable a otros muchos de Tierra de Campos. En 1980 había solo uno y mal cuidado; en la actualidad hay más de veinte, están adecuadamente repartidos y, en general, bien arreglados. 
También pienso que esta es una cuestión importante; si un pueblo se abandona no hay remedio alguno, cuando se cuida aún se mantiene la esperanza de vivir. Y esperanza es lo que más necesitamos en esta tierra.

Por mi actividad laboral conozco que desde hace décadas se está desarrollando una política de repoblación forestal en zonas degradadas de gran envergadura, que está cambiando el paisaje de muchas zonas del país, ya que ahora gran parte de estas plantaciones son bosques casi maduros. El peso que tiene la agricultura en Tierra de Campos hace que estas reforestaciones le toquen un poco de refilón -las cuestas y alguna que otra parcela-, pero está claro que son ejemplarizantes. También lo son las actuaciones de revegetación desarrolladas en las riberas de los principales ríos, que han mejorado notablemente el paisaje de las vegas, así como las recuperaciones puntuales realizadas en otros tipos de espacios degradados: lagunas, antiguas vías del ferrocarril, vías pecuarias, etc.

A la vez, también constato que el desarrollo del país está provocando la generación de muchas infraestructuras (carreteras, autovías, líneas de ferrocarril de alta velocidad), proyectos energéticos (parques eólicos, huertos solares, líneas eléctricas), polígonos industriales, proyectos de regadío..., que también se han ido ejecutando en Tierra de Campos. Estas obras generan impactos sobre el paisaje, aunque también una oportunidad de cara a la recuperación del mismo. El caso del Canal de Castilla, gestado en el siglo XVIII, es paradigmático; actualmente constituye uno de los principales valores patrimoniales de la comarca, desde variados puntos de vista: de ingeniería civil, hidrológico, ecológico y paisajístico.

Cuando se trabaja en la protección y recuperación ambiental del paisaje se es consciente que estamos en un constante tira y afloja. El ser humano puede crear las cosas más maravillosas pero también puede generar las mayores degradaciones. A la vez, también tiene capacidad para recuperar estos espacios degradados. Es capaz de crear y mantener durante siglos un paisaje sostenible y diverso y, en una década, devastarlo hasta lograr una simplificación máxima. Tal vez una de las ideas que más me impulsaron a llevar a cabo este proyecto fue la extraída de Domingo Gómez Orea, cuando señala que una de las ventajas de la recuperación de espacios degradados es el posible asentamiento de actividades tecnológicas de vanguardia. ¿No merece la pena imaginarse, tan solo, la implantación de alguna empresa informática relevante en una Tierra de Campos recuperada paisajísticamente?

Yo voy a tratar de extraer la parte positiva de esta dualidad, destacando aquellas actuaciones que se han realizado adecuadamente y que, por ello, pueden ser aplicadas al conjunto del espacio físico. Ante las preguntas que he planteado anteriormente, trataré de demostrar que no es cierto que el paisaje de Tierra de Campos haya sido siempre árido y que, además, es posible su recuperación. Desde luego que no propugno una transformación radical del mismo; creo que la comarca ha de seguir siendo eminentemente agraria. Pero opino que es necesario realizar una especie de cirugía en el territorio para que, recuperando un pequeño -pero bien repartidoporcentaje del mismo, la mejora del paisaje de Tierra de Campos pueda ser sustancial. Será a partir de ahí desde donde pueda, a su vez, plantearse una verdadera recuperación social de la comarca.

Una prueba de esta idea se halla en la siguiente curiosidad. Frente a la imagen de paisaje árido, monótono y desolado de Tierra de Campos, resulta paradójica la noticia recogida recientemente 
en un conocido periódico del Reino Unido, que señala que de lo que se sienten más orgullosos los británicos es de su paisaje de campiñas: the likeable landscape (Figura 1.5).

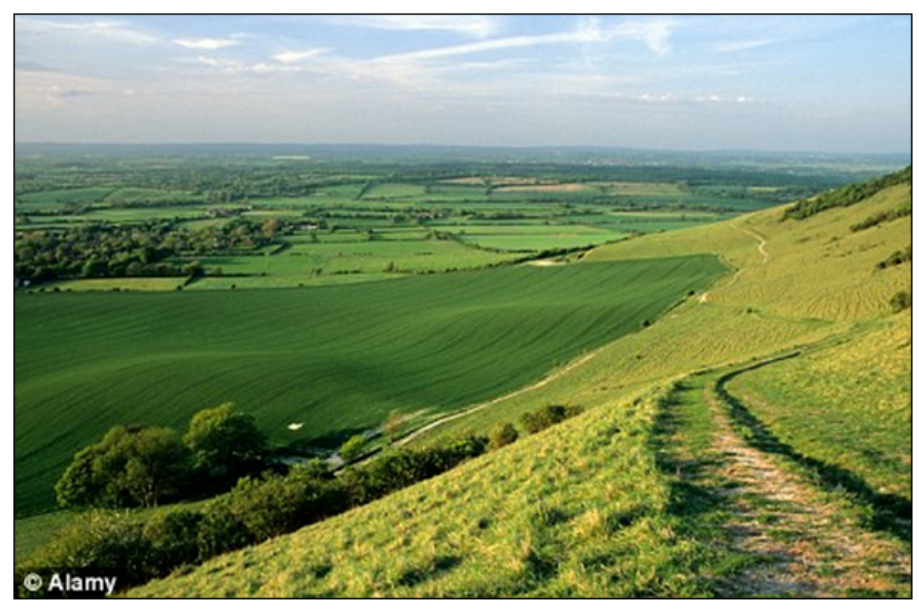

Likeable landscape: The rolling countryside came out top in a poll of what makes us proud to be British

Figura1.5. Fotografía extraída de la prensa británica. Esta imagen podría haber sido tomada desde cualquier punto en la línea de cumbres de los Torozos, mostrando un hipotético paisaje de Tierra de Campos mejorado, con más verde y más diversidad, pero agrícola al fin y al cabo.

Otra imagen anecdótica, pero muy sintomática, se encuentra en el diseño de los envases de una conocida marca de galletas española, en el que se trata de reflejar el origen del producto en unas campiñas cerealistas... con árboles (Figura 1.6).

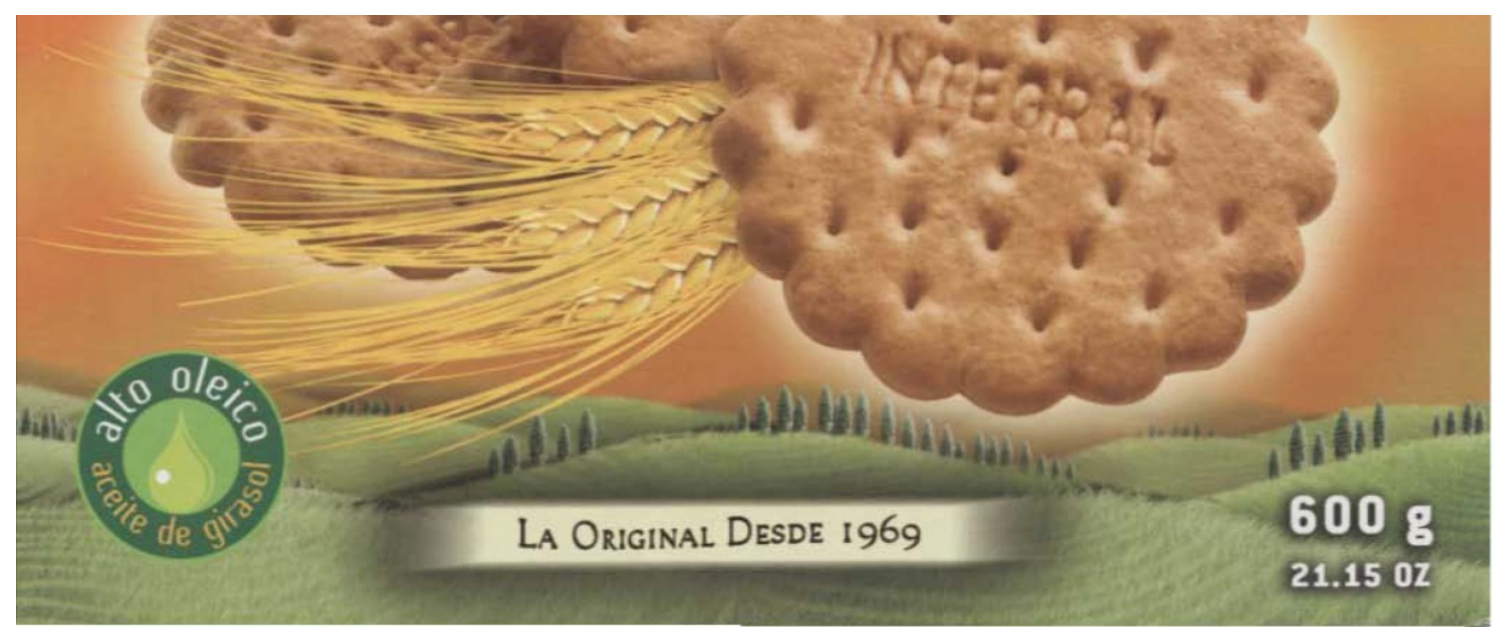

Figura 1.6. Ilustración contenida en un paquete de galletas, donde se intenta relacionar el origen natural de las mismas. Los cultivos cerealistas de las que proceden se han "mejorado" con varias alineaciones arboladas 
Por todo ello siento la obligación moral de llevar a cabo este estudio. Porque necesito aportar algo y así contribuir de cierta manera al desarrollo rural de la comarca. Porque la conozco, la he vivido y la vivo. Porque pienso que es imprescindible incorporar dosis de esperanza en Tierra de Campos y me parece que la mejora de su paisaje puede ayudar a conseguirlo. Y porque, sincera y humildemente, creo que mi aportación profesional en el ámbito de la recuperación ambiental del paisaje puede ser provechosa para esta tierra. 

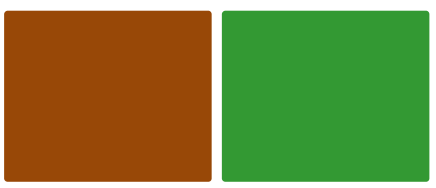

\section{OBJETIVOS}




\section{OBJETIVOS}

El objetivo general del presente estudio es definir un modelo de recuperación ambiental del paisaje de Tierra de Campos. Asumiendo que este paisaje cerealista en la actualidad es muy poco diverso y está sometido a un buen número de alteraciones, se pretende demostrar que existen actuaciones técnicas cuya aplicación puede mejorar sustancialmente su calidad, lo que a su vez redundará en el desarrollo socioeconómico de la comarca. De igual modo, aunque pueda percibirse que el territorio está tan intensamente transformado -especialmente mediante la agricultura- como para no admitir su recuperación, se tratará de probar que la realización de actuaciones adecuadamente diseñadas en espacios de superficie reducida, son suficientes para provocar una mejora significativa de la diversidad y calidad del paisaje de Tierra de Campos.

Este planteamiento general se puede diferenciar en los siguientes objetivos particulares, que han sido trazados en los apartados del estudio:

- Revisar el concepto de paisaje a la luz de las últimas interpretaciones, especialmente en lo que respecta al Convenio Europeo del Paisaje. Examinar la relación entre el paisaje de calidad y el bienestar y la salud de la población.

- Analizar la importancia de los paisajes rurales agrícolas y, en particular, de los paisajes de campiñas cerealistas de Castilla y León, entre los que se halla el de Tierra de Campos.

- Identificar la problemática ambiental del paisaje de Tierra de Campos.

- Considerar los principales instrumentos de gestión ambiental aplicables a la protección y recuperación del paisaje de Tierra de Campos, poniendo especial énfasis en el procedimiento preventivo de evaluación de impacto ambiental de proyectos.

- Revisar la técnica de recuperación de espacios degradados para corregir impactos y mejorar la calidad del paisaje de Tierra de Campos.

- Considerar las fórmulas para diversificar el paisaje agrario de Tierra de Campos.

- Diagnosticar las posibilidades de valorización del paisaje de Tierra de Campos, a partir de las experiencias ya existentes.

- Analizar Tierra de Campos como zona de estudio, comarca natural paradigmática del paisaje de campiñas cerealistas.

- Caracterizar el paisaje de Tierra de Campos, en especial desde dos ámbitos paralelos y complementarios: la percepción visual y la ecología. 
- Identificar los deterioros del paisaje más significativos de Tierra de Campos, tanto los impactos producidos por obras de gran envergadura, como las alteraciones producidas por las actuaciones menores pero más numerosas.

- Realizar una valoración de recuperaciones ambientales representativas realizadas en la comarca, a través de su seguimiento, al objeto de extraer conclusiones para su aplicación generalizada.

- Determinar, con carácter general, los posibles tratamientos de recuperación ambiental del paisaje de Tierra de Campos. Asimismo, de un modo concreto, definir las actuaciones de recuperación ambiental aplicables a cada uno de los tipos de espacios degradados de la comarca.

- Seleccionar un listado de árboles y arbustos utilizables en la recuperación del paisaje de Tierra de Campos, clasificándolos en función de las principales estaciones ecológicas y zonas de actuación. Describir los principales rasgos de las especies seleccionadas a efectos del paisaje y la recuperación ambiental.

- Aportar una imagen-objetivo del paisaje de calidad de Tierra de Campos. 

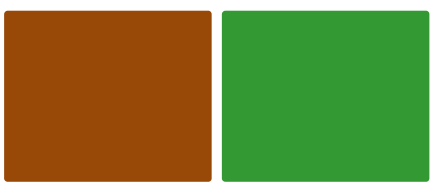

\section{ANTECEDENTES}




\section{ANTECEDENTES}

\subsection{El paisaje}

\subsubsection{Concepto y puntos de vista}

Tradicionalmente el concepto de paisaje ha tenido tantas definiciones como campos desde los que es utilizado: pintura, poesía, geografía, arquitectura, ingeniería, etc. Así mismo, este término ha sido empleado a lo largo de la historia con muy diversos significados: naturaleza, territorio, medio ambiente, recurso natural, etc.; no obstante, en todos ellos el paisaje es manifestación externa e indicador de los procesos que tienen lugar en el territorio (MOPT, 1993).

Esta amplitud de visiones es constatada por NAVÉS et al. (2005), quien señala que existen cuatro perspectivas para el análisis del paisaje:

- La científica -propia de las ciencias ambientales, la geografía, la ecología, la biología, etc.-, que se dedica al estudio y regulación de las interacciones y procesos que tienen lugar en la naturaleza.

- La del planeamiento -correspondiente a paisajistas y urbanistas, quienes intervienen a escala territorial-, que se dedica a la ordenación del territorio y la planificación de sus grandes infraestructuras.

- La artística -propia de paisajistas, arquitectos, escultores, pintores, etc.-, que aborda las actuaciones en el paisaje realizadas desde una visión estética de las formas de la arquitectura del paisaje.

- La tecnológica -propia de los ingenieros del paisaje, agrónomos, de montes, etc.-, que se ocupa de la identificación y corrección de impactos.

ESCRIBANO et al. (1987) centra el término desde tres vertientes principales: el paisaje estético, que hace alusión a la armoniosa combinación de las formas y colores del territorio, e incluso a la representación artística de él; el paisaje ecológico o geográfico, cuando se alude al estudio de los sistemas naturales que lo configuran; y el paisaje cultural como escenario de la actividad humana.

En cualquier caso, el paisaje siempre está ligado a la percepción, entendida como proceso por el cual el organismo humano se informa de los objetos y cambios que se manifiestan a su alrededor. La percepción del paisaje se lleva a cabo en la mente del hombre, allí forma la imagen del paisaje a través de todos sus sentidos, lo que lleva a otra definición integradora: "percepción plurisensorial de un sistema de relaciones ecológicas" (DÍAZ PINEDA et al., 1973). En la misma línea cabe citar el concepto acuñado por GONZÁLEZ BERNÁLDEZ (1981), al definir los componentes perceptibles de un sistema natural como fenosistema (paisaje), que se complementa con el criptosistema o componentes del sistema no perceptibles de difícil observación.

ESPAÑOL (1995) señala que los contenidos convencionales del paisaje en términos de nuestra cultura y momento histórico hacen referencia fundamentalmente a los siguientes aspectos:

- a la sensibilidad artística y la apreciación positiva del entorno, 
- al entorno natural o solo relativamente humanizado (paisajes naturales y rurales),

- a los espacios abiertos de grandes dimensiones o a las vistas profundas,

- al conjunto de la escena, nunca a elementos aislados,

- a la imagen de la escena, más que a la escena en sí misma.

No obstante, teniendo en cuenta estas consideraciones, y siempre bajo la necesidad de poder analizar, diagnosticar e intervenir en el paisaje, señala que la definición que GONZÁLEZ BERNÁLDEZ (1981) aporta del paisaje se presenta como la más adecuada. Se define el paisaje, entonces, como el fenosistema, es decir, en una primera aproximación como el "medio ambiente percibido".

En la Guía para la elaboración de estudios del medio físico (MOPT, 1993) -referencia básica en este capítulo- se indica que existen dos enfoques para el estudio del paisaje: el paisaje total o ecológico, que identificaría el paisaje con el medio, y el paisaje visual o percibido, que se corresponde más con la estética o la percepción. Mientras que en el primero el interés se centra en la importancia del paisaje como indicador o fuente de información sintética del territorio, en el segundo se concreta en lo que el observador es capaz de percibir de ese territorio.

El paisaje ecológico surge de la consideración conjunta de los componentes y procesos que tienen lugar en el paisaje: la geomorfología, los suelos, el agua, la vegetación, la fauna, el hombre; además de sus múltiples relaciones. En el ámbito de la ecología, el estudio del paisaje supone un aumento en la escala: de ecosistemas a unidades de paisaje, dando lugar al ámbito científico de la ecología del paisaje. En este marco teórico se entiende el paisaje como "una superficie de terreno heterogénea compuesta por un conjunto de ecosistemas en interacción que se repite de forma similar en ella" (FORMAN Y GODRON, 1986). Se presta más atención a la funcionalidad que a un simple listado de componentes; no es solo la existencia de componentes distintos lo que caracteriza a los paisajes sino su relación y estructura espacial. La aplicación práctica de este enfoque se encuentra en aspectos tan importantes como la conservación de espacios naturales, el aprovechamiento racional de los recursos naturales o la restauración de espacios degradados.

El paisaje visual o percibido es el territorio definido por la percepción del observador y, aunque intervienen todos los sentidos, es el definido fundamentalmente por su visión. En esta línea se puede considerar el paisaje como el entorno visual que rodea al observador (MOPT, 1993). Este paisaje está ligado a su cuenca visual, como territorio percibido por el observador, pudiendo tener componentes muy diversos. En este enfoque existen aplicaciones prácticas también reseñables, como el uso público y recreativo en zonas verdes o espacios naturales, su contemplación o experimentación, la protección y rehabilitación de espacios desde un punto de vista estético, etc.

Otro de los principales acercamientos al paisaje se produce desde el punto de vista geográfico, entendiéndolo como parte de una estructura territorial, tanto en su aspecto físico como humano. El paisaje es la forma y, en consecuencia, la faz que toma una estructura territorial. Como tales estructuras y formas, son cambiantes en el tiempo. En definitiva, es la formalización espacial del estado de un sistema geográfico y la forma que toman los hechos territoriales (MARTÍNEZ DE PISÓN, 1993). Según este autor, el estudio del paisaje se compone de múltiples aspectos: 
- Estructura, forma y faz.

- Elementos, que son mixtos, antrópicos y naturales.

- Dinámica y evolución, ya que el paisaje no es pasivo.

- Fuerzas o energías, dado que el paisaje está vivo.

- Relaciones geográficas y ecológicas, horizontales en el espacio y verticales entre sus componentes.

- Unidades que forman una estructura jerárquica.

- Funciones territoriales, naturales y sociales específicas.

- Contenidos culturales, históricos y estéticos que lo cualifican.

- Significados directos o indirectos, a través de los cuales puede ser percibido y valorado de forma subjetiva o cultural.

SANTOS (2002) reconoce la polisemia existente en el concepto paisaje, que ha conducido a una imprecisión terminológica, y realiza un detallado acercamiento -que a continuación se resumede las distintas perspectivas del mismo de cara a la conveniente ordenación del paisaje en el marco de la planificación espacial.

La palabra paisaje proviene etimológicamente del latín pagensis, campestre, que habita en el campo, y después del francés pays, que venía a significar espacio rural peculiar, territorio concreto. En castellano no aparece este término hasta el siglo XVIII, adoptando como primer significado pintura o dibujo que representa una cierta extensión de terreno; es decir, el sentido estético antecede al científico-espacial. No obstante, sea cual sea la acepción, siempre hay un elemento común: el territorio; y el gran elemento diferenciador reside en la percepción de esta realidad espacial, puesto que el paisaje siempre precisa de la contemplación humana.

En cuanto a los paisajes adjetivados, cabe decir que el paisaje natural es equivalente a medio natural. El paisaje agrario se entiende como una combinación concreta en la que intervienen un gran número de hechos naturales y rurales (una determinada ocupación del suelo, una morfología parcelaria, los caminos, la ordenación hidráulica, etc.). El paisaje rural es otro término más reciente, que incorpora al anterior los fenómenos en relación con la urbanización de las sociedades. El paisaje urbano es una aplicación al conjunto de espacio público y privado, y espacio construido y no construido, de la ciudad. Finalmente, el paisaje cultural es el resultado de la actuación humana sobre el medio natural.

En una línea similar a la apuntada por MOPT (1993), SANTOS (2002) señala que en los últimos decenios se han desarrollado dos grandes corrientes en relación con la denominada "ciencia del paisaje". Por un lado, el enfoque "fisiológico" o ecológico, que estudia los procesos que sustentan la morfología del territorio: el paisaje desde la ecología del paisaje. Por otro lado, el enfoque "fisionómico" o perceptual, del paisaje como manifestación formal, como imagen, que plantea el análisis de la percepción, los aspectos visuales y la consideración estética.

En este estudio se va a tratar el paisaje desde una perspectiva integradora de las dos principales tendencias, ecológica o geográfica y visual. Consideraremos el territorio en su conjunto -en este caso, el paisaje de Tierra de Campos-, con todos sus componentes y relaciones, pero dando a la vez importancia a su percepción (que fundamentalmente es visual). Hay que tener en cuenta que estos enfoques son coincidentes en muchos aspectos: la calidad visual suele ser un indicador 
de una adecuada salud ecológica (por ejemplo, por presencia de vegetación variada), a la vez que una degradación de determinados procesos ecológicos (por la irrupción de infraestructuras de transporte, por citar una causa) suele ir aparejada a un mayor impacto visual. La presencia de un estercolero en condiciones inadecuadas próximo a un pueblo provoca alteraciones ecológicas (contaminación de las aguas) a la vez que impactos en los valores perceptivos (visual y olfativo). En otros casos la relación no es tan directa, como puede ser la presencia de avifauna esteparia, aunque se puede abordar desde uno u otro enfoque sin entrar en contradicción con la otra perspectiva (en este ejemplo se trata de un valor ecológico objetivo, aunque estéticamente tenga un carácter muy puntual).

\subsubsection{Componentes del paisaje}

Los componentes del paisaje visual son los factores físicos que lo configuran y que son diferenciables a simple vista. Pueden agruparse en tres grandes bloques:

- Físicos: formas del terreno, superficie del suelo, rocas, cursos o láminas de agua, nieve, etc.

- Bióticos: vegetación, tanto espontánea como cultivada, y bien sean formaciones como individuos aislados; fauna, especies silvestres y domésticas en tanto en cuanto sean apreciables visualmente.

- Actuaciones humanas: distintos usos del suelo, estructuras y construcciones diversas. Pueden tener carácter puntual (aerogeneradores, naves agrícolas), lineal (carreteras, ferrocarriles, tendidos eléctricos) o superficial (polígonos industriales, balsas de regadío, urbanizaciones).

A estos tres grandes bloques podrían añadirse las condiciones atmosféricas y el estado del cielo, que son importantes factores que condicionan los procesos ecológicos de un territorio y ocupan una parte fundamental del fondo escénico.

A veces, los componentes del paisaje poseen valor en símismos, sobre todo cuando intervienen condiciones de escasez, o de especiales características, valor estético, interés histórico, etc. En general, su importancia para la evaluación radica más en las interacciones con otros elementos, generando composiciones que provocan emociones estéticas. Tanto los componentes como sus composiciones 0 , incluso, la totalidad del paisaje poseen más características visuales 0 elementos básicos organizados que de modo particular.

De una forma más detallada, GÓMEZ OREA y VILLARINO (2004) señalan que los componentes territoriales más utilizados en la caracterización y en la valoración del paisaje son los siguientes:

- Caracteres permanentes

o Posición relativa.

o Geomorfología.

o Rasgos físicos sobresalientes, hitos y puntos culminantes.

o Presencia de agua en sus múltiples formas: cursos superficiales, láminas, surgencias, etc. 
o Exposición.

o Pendiente.

o Singularidades biofísicas.

- Caracteres temporales

- Singularidades asociadas a elementos climáticos.

- Aspectos visuales de la vegetación: color, textura, densidad, etc.

o Aspectos visuales de la fauna.

o Sonidos y ruidos.

- Caracteres extra

o Manifestaciones percibidas por todos los sentidos.

o Intrusiones.

o Contraste natural-artificial con el entorno.

- Elementos antrópicos

o Accesibilidad.

o Presencia de vías de comunicación.

o Elementos singulares del paisaje.

o Elementos culturales, históricos, arqueológicos, etc.

- Intervisibilidad

o Potencial de vistas.

o Extensión de la cuenca visual.

En el paisaje ecológico, se considera que los componentes del paisaje pueden articularse en el espacio de tres formas diferentes (FORMAN Y GODRON, 1986):

- Manchas: Superficies no lineales que se distinguen por su aspecto de lo que las rodea.

- Corredores: Superficies de terreno estrechas y alargadas que se diferencian de su entorno por su aspecto.

- Matriz: Elemento del paisaje que ocupa una mayor superficie y se encuentra más conectado, jugando el papel dominante en el funcionamiento del paisaje. Es el elemento que, por lo general, rodea las manchas.

Las características de estas tres configuraciones espaciales definen la estructura general del paisaje -tanto desde el punto de vista ecológico como visual- y su funcionalidad. También el carácter del paisaje viene dado en general por la composición de todos sus componentes, aunque alguno de ellos pueda tener una mayor importancia por su singularidad.

\subsubsection{Una nueva perspectiva: el Convenio Europeo del Paisaje}

El Convenio Europeo del Paisaje, firmado en Florencia el 20 de octubre de 2000 y ratificado por España el 1 de marzo de 2008, es un instrumento normativo fundamental de cara a la protección, gestión y ordenación de todos los paisajes de Europa. Supone una transformación de la visión de este concepto-que se hace más integrador-y un impulso de las políticas europeas en materia de paisaje, a la vez que clarifica diferentes denominaciones relacionadas sobre este asunto. 
El Convenio parte de los importantes valores que posee el paisaje en nuestra sociedad, en particular:

- Desempeña un papel importante de interés general en los campos cultural, ecológico, medioambiental y social.

- Constituye un recurso favorable para la actividad económica; pudiendo su protección, gestión y ordenación, contribuir a la creación de empleo.

- Contribuye a la formación de las culturas locales y es un componente fundamental del patrimonio natural y cultural.

- Contribuye al bienestar de los seres humanos.

- Es un elemento importante de la calidad de vida de las poblaciones en todas partes: en los medios urbanos y rurales, en las zonas degradadas y de gran calidad, en los espacios de reconocida belleza excepcional y en los más cotidianos.

- La calidad y la diversidad de los paisajes es un recurso común, siendo importante cooperar para su protección, gestión y ordenación. En otras palabras, el paisaje es un bien común de toda la sociedad.

En el artículo 10 del Convenio se define el paisaje como "cualquier parte del territorio tal como la percibe la población, cuyo carácter sea el resultado de la acción y la interacción de factores naturales y/o humanos". Esta definición representa un cambio cualitativo en cuanto a las muy diversas acepciones que hasta esta fecha venía teniendo el paisaje, que a partir de ahora se extiende al conjunto del territorio y cubre los espacios naturales, rurales, urbanos y periurbanos. Concierne tanto a los espacios terrestres como a las aguas interiores y marítimas. Afecta a paisajes que pueden ser considerados excepcionales, así como a paisajes cotidianos y a paisajes degradados (CONSEJO DE EUROPA, 2008). Es decir, el paisaje forma un todo, cuyos componentes son considerados simultáneamente en sus interrelaciones.

De acuerdo a esta definición, se puede interpretar que el paisaje nace sobre el patrimonio natural y crece como patrimonio cultural, es decir, el paisaje sufre una evolución como resultado de las actividades humanas de las que es objeto y que pueden mejorarlo o empeorarlo, tanto si nos referimos a paisajes naturales, rurales o urbanos (MAGRAMA [en línea]).

Por política en materia de paisajes se entiende la formulación, por parte de las autoridades públicas competentes, de los principios generales, estrategias y directrices que permitan la adopción de medidas específicas con vistas a la protección, gestión y ordenación del paisaje.

Por objetivo de calidad paisajística se entiende, para un paisaje específico, la formulación, por parte de las autoridades públicas competentes, de las aspiraciones de las poblaciones en lo que concierne a las características paisajísticas de su entorno.

Por protección de los paisajes se entienden las acciones encaminadas a conservar y mantener los aspectos significativos o característicos de un paisaje, justificados por su valor patrimonial derivado de su configuración natural y/o la acción del hombre.

Por gestión de los paisajes se entienden las acciones encaminadas, desde una perspectiva de desarrollo sostenible, a garantizar el mantenimiento regular de un paisaje, con el fin de guiar y 
armonizar las transformaciones inducidas por los procesos sociales, económicos y medioambientales.

Por ordenación paisajística se entienden las acciones que presenten un carácter prospectivo particularmente acentuado con vistas a mejorar, restaurar o crear paisajes.

Gracias a este Convenio, los países y las regiones se comprometen a reconocer jurídicamente los paisajes, a definir y a aplicar políticas destinadas a la protección, gestión y ordenación de los mismos, a establecer procedimientos para la participación pública, así como a integrar el paisaje en las políticas sectoriales y, especialmente, en la ordenación territorial y urbanística. Para ello, se deben adoptar medidas específicas para la identificación y valoración de los paisajes, la sensibilización sobre la conveniencia de su conservación, la formación y la educación en relación con los mismos, y la definición de objetivos de calidad paisajística para los paisajes identificados y valorados.

En España el desarrollo del Convenio Europeo del Paisaje se está realizando de un modo bastante heterogéneo. Así, Cataluña es una de las comunidades que más ha avanzado en este sentido: ha aprobado la Ley 8/2005, de 8 de junio, de Protección, Gestión y Ordenación del Paisaje de Cataluña, ha creado un Observatorio del Paisaje y está aprobando catálogos de paisaje de sus comarcas. Estos son documentos de carácter descriptivo y prospectivo que determinan la tipología de los paisajes, identifican sus valores y su estado de conservación y proponen los objetivos de calidad que deben cumplir (GENERALITAT DE CATALUNYA, 2006). Asimismo, las cartas del paisaje son instrumentos voluntarios de concertación y mediación entre los agentes públicos y privados del territorio, dirigidos a promover la mejora de los paisajes y la calidad de vida de las personas.

El citado Observatorio del Paisaje de Cataluña detalla de forma didáctica, pero muy aclaratoria, las razones por las que es importante el paisaje:

- Porque del paisaje depende la calidad de vida de las personas: en el entorno urbano o en el rural, en áreas degradadas o en otras de gran calidad, en espacios singulares o en espacios cotidianos.

- Porque refleja la buena o mala salud de las relaciones entre la sociedad y el territorio. Es un excelente indicador de la calidad del medio.

- Porque es un elemento fundamental del bienestar individual y colectivo. El Convenio Europeo del Paisaje convierte la calidad del paisaje en un derecho (derecho a gozar de paisajes agradables, armónicos, no degradados, que transmitan identidades, culturales y territoriales diversas).

- Porque ofrece sensaciones placenteras (estéticas, sensoriales, emotivas).

- Porque nos identifica con la tierra, con el país (de hecho, las palabras paisaje y país tienen la misma raíz). El paisaje es un reflejo de estilos de vida pasados y, en definitiva, de nuestra historia: de ahí su valor patrimonial.

No en vano, resulta clarificador el análisis de los contenidos de un reciente suplemento especial dedicado al paisaje en un diario catalán (ARA, 2015), que versa sobre aspectos tan variados como "paisaje como bien común", "paisaje y salud", "paisaje y turismo", "cocina y paisaje mediterráneo", "democracia y paisaje: una relación cada vez más relevante", "literatura y 
paisaje: el mundo a través de la cultura", "educar en el paisaje para promover una ciudadanía activa", "arte y paisaje humano" o incluso "paisaje y empresa". Tal como se puede apreciar, el paisaje afecta a buena parte de nuestras vivencias.

\subsubsection{Arquitectura del paisaje y paisajismo}

Frente al estudio de los paisajes, frecuentemente en una escala regional, la arquitectura del paisaje se plantea en lugares concretos y tiene un sentido de intervención y de bellas artes: la creación y preservación de belleza, la conformación del espacio que se diseña con fines estéticos. Está muy vinculada con los parques, jardines y huertos, la naturaleza en la ciudad, la domesticación de la naturaleza en las villas de recreo y los palacios en el campo, etc.

Suele entenderse por paisajismo a la disciplina (arte y técnica) cuyo fin es conformar o modelar el paisaje humanizado, con unos límites imprecisos en su campo de acción, desde la jardinería, el diseño urbano y el land art hasta la ordenación rural y la restauración ambiental en los paisajes alterados por las obras públicas.

La arquitectura del paisaje se confunde con el paisajismo en tanto se consideran bellas artes: el arte del paisaje auxiliado por la naturaleza, cuyo fin es crear y preservar belleza en torno a los asentamientos y en los paisajes naturales, fomentando la proximidad y el bienestar de la población mediante la relajación y la tranquilidad que proporcionan las vistas con valor estético. Se trata de aquella parte del paisaje que se diseña como un espacio para que viva el hombre, aparte de las infraestructuras y servicios y aparte también de la auténtica naturaleza (SANTOS, 2002).

En este mismo sentido, se puede decir que la arquitectura del paisaje está ligada a las técnicas de la jardinería, de manera que ambos conceptos son equivalentes en sus objetivos aunque diferentes en su concepción. Esta ligazón deriva de la utilización de elementos vivos (vegetales para el diseño de espacios abiertos, aunque estos no sean ni imprescindibles, ni los únicos elementos que se utilicen). La utilización del concepto de arquitectura parece referirse más a una visión espacial gráfica, mientras que la expresión jardinería se centra, quizás, en la selección y mantenimiento del paisaje (ESPAÑOL, 1995).

\subsubsection{Calidad del paisaje}

Popularmente se asume como paisaje una escena con calidad, es decir una escena que el observador disfruta. Se puede establecer, por tanto, una primera aproximación al concepto de calidad paisajística definiéndola como "el potencial de disfrute de una escena dada". Según esta idea, se podría considerar que la apreciación del paisaje es esencialmente subjetiva y ligada a la propia identidad evolutiva de cada observador; no obstante, para superar esta dificultad, se han desarrollado distintos planteamientos para el tratamiento de la calidad paisajística, que se pueden resumir en los siguientes (ESPAÑOL, op.cit.): 
Calidad de contenido, referido al interés propio de la escena observada y perfectamente objetivable mediante el tratamiento que proporcionan las ciencias ambientales (geomorfología, ecología, botánica, etc.) y sus criterios de valoración.

La justificación de esta concepción de la calidad paisajística descansa sobre el innegable potencial informativo del paisaje. El paisaje muestra el entorno al observador ilustrando claramente los procesos y mecanismos ambientales de los que es parte y en los que el individuo se desarrolla. Medios con un elevado grado de conservación (espacios naturales) ilustran los elementos y procesos de los ecosistemas, con mayor calidad cuanto mayor es la calidad ecológica del sistema. Tomando como referencia la historia, por ejemplo, conjuntos patrimoniales del pasado (conjuntos histórico-artísticos) explican en su paisaje formas de vida y culturas que se encuentran en el origen de nuestra civilización actual. Entre estos dos ejemplos de contenidos extremos, podemos encontrar numerosos ejemplos intermedios de escenas 0 territorios en los que sobreviven sistemas de aprovechamientos tradicionales de gran calidad.

Calidad visual, de mano del reduccionismo que conduce a sobrevalorar el sentido óptico frente a los demás sentidos humanos. La calidad visual es también objetivable mediante el análisis físico (geometría y leyes ópticas), centrándose en los puntos de vista panorámicos y en las cuencas de visibilidad e intervisibilidad.

La apreciación de la calidad visual emana del análisis geométrico de las relaciones que entre distintos espacios establece la propia visibilidad. La escena se entiende aquí como una superficie opaca y continua sobre la que se puede situar el observador, es decir, el punto de vista. Las visuales, líneas rectas y sin interrupción, enlazan unos puntos con otros (observador con objeto observado). Desde un determinado punto de vista se contempla un conjunto de puntos en una disposición determinada. La calidad visual, entonces, queda asociada a aquellas localizaciones desde las que el observador domina el panorama. El análisis geométrico permite por lo tanto identificar en un determinado territorio los puntos de vista de mejor calidad, que proporcionan vistas de mayor calidad. Dentro del estudio de visibilidad se suele considerar también la frecuencia de la observación, es decir, la frecuencia con la que una vista determinada es observada, como un criterio más de calidad visual.

Calidad estética, que hace referencia al interés que despierta la percepción de la escena en el observador. Los estudios enfocados a este concepto de la calidad paisajística se centran en la sistematización de la inherente subjetividad del observador, mediante la justificación socioestadística de preferencias paisajísticas.

El planteamiento de la calidad estética se focaliza en la apreciación subjetiva del observador frente a una escena dada. Por eso está estrechamente relacionado con los esquemas perceptuales de la psicología humana. Sin embargo, aunque es inevitable aceptar la individualidad de cada observador, existen pautas básicas de valoración paisajística que son generalizables a colectivos. Estas pautas son las que identifican los estudios de preferencias paisajísticas. Aunque la calidad estética es esencialmente subjetiva, esta subjetividad está enmarcada dentro del campo de las experiencias perceptuales de cada individuo y por ello se ve grandemente afectada por condicionantes sociales tales como cultura, origen geográfico, actividad, etc. 
Estos tres criterios de calidad paisajística se pueden resumir del modo siguiente:

Tabla 3.1. Criterios de la calidad paisajística.

\begin{tabular}{cccc}
$\begin{array}{c}\text { Calidad } \\
\text { paisajística }\end{array}$ & Carácter & Referencia & Valor \\
\hline De contenido & Ambiental & $\begin{array}{c}\text { Geomorfología, Ecología, } \\
\text { Historia, etc. }\end{array}$ & $\begin{array}{c}\text { Representatividad o } \\
\text { exclusividad }\end{array}$ \\
\hline Visual & Topográfico & $\begin{array}{c}\text { Panoramas, vistas y } \\
\text { perspectivas. Series de } \\
\text { secuencias }\end{array}$ & $\begin{array}{c}\text { Composición y/o } \\
\text { frecuencia } \\
\text { observación }\end{array}$ \\
\hline Estética & Perceptual & Paisaje de contacto & $\begin{array}{c}\text { Subjetividad experto } \\
\text { o subjetividad } \\
\text { colectivo }\end{array}$ \\
\cline { 3 - 4 } & & Componentes agregados & \\
\hline
\end{tabular}

Hay que entender que esta clasificación en tres concepciones de la calidad paisajística es meramente explicativa, pues rara vez se adopta uno solo de estos tres enfoques, sino que generalmente se recurre a enfoques combinados de los tres.

De acuerdo a los distintos planteamientos sobre la calidad del paisaje, el citado autor clasifica los métodos de valoración de acuerdo a su tratamiento de la subjetividad, en los siguientes grupos:

- Referencias objetivas, utilizan el análisis de contenido como referencia básica, valorando la calidad informativa del medio en términos de elementos ambientales (geomorfológicos, ecológicos, vegetales, culturales, etc.); generalmente completan estas referencias con apreciaciones sobre la calidad estética.

- Subjetividad de expertos, se acepta la subjetividad como inevitable, utilizando la opinión de uno o varios expertos como referencia objetiva.

- Subjetividad representativa, se intenta concluir una referencia común de calidad determinada mediante métodos sintéticos (encuestas de opinión, entrevistas, reunión de representantes) o mediante la interpretación del gusto popular.

Otra clasificación establece las diferencias entre el tratamiento directo de la escena (paisaje de contacto) o el tratamiento desagregado en sus componentes (ambientales o estéticos):

- Métodos directos. Se acepta la subjetividad del experto sobre el paisaje de contacto como un aspecto primordial de la evaluación. Como variante se dan los métodos que matizan la subjetividad del experto recurriendo a un grupo de profesionales, a la media aritmética de los valores obtenidos (subjetividad controlada) o mediante el consenso entre los miembros del grupo (panel de expertos, subjetividad compartida). Existen técnicas para la sistematización de las apreciaciones; generalmente se recurre a una 
escala cualitativa común de calidad del paisaje (por ejemplo: espectacular, soberbio, distinguido, agradable, vulgar, feo) o a escalas numéricas.

- Métodos desagregados de valoración. Son los métodos más clásicos basados en valoraciones cuantitativas y cualitativas en función de componentes del paisaje de carácter ambiental (relieve, vegetación, fauna, etc.), estéticos (variedad, intensidad y contraste) o una combinación de ambos. El procedimiento se inicia a partir de la desagregación de las características físicas del paisaje (topografía, usos del suelo, agua, etc.); cada unidad paisajística se valora agregando los valores parciales.

Finalmente, cabe citar a un grupo de autores -CAÑAS (1995), GARCÍA y CAÑAS (2001), CAÑAS y RUIZ (2001), CAÑAS et al. (2009)- que profundizan en la realización de metodologías para la valoración del paisaje y del impacto paisajístico fundamentalmente desde el ámbito rural, en el ámbito de líneas de investigación relacionadas con el patrimonio, las construcciones agrarias o las infraestructuras.

\subsubsection{Paisaje, calidad de vida y salud}

LÓPEZ LILLO y RAMOS (1969) son precursores en España en manifestar la creciente valoración de la sociedad por el paisaje natural o naturalizado. El fenómeno de emigración a gran escala a las ciudades que se inició a partir de la segunda mitad del siglo XX y la consiguiente mayor concentración de la población en ellas, conllevó a una mayor valoración de la naturaleza así como de los jardines y espacios verdes. Dicho de una forma coloquial, antes se estaba en el campo y ahora se va al campo; antes la caminata servía para ir de un sitio a otro y ahora se camina por disfrute. El contacto del hombre con la naturaleza es un nexo profundo, es una relación existencial, viva, más allá todavía de lo estético, según estos autores. Pero esta relación vital no puede suplirse con sucedáneos: el jardín o los parques solo pueden ser subsidiarios de la naturaleza primitiva. Y en ellos, como en todos los espacios naturales, el árbol ha de ser el elemento principal; el árbol es el otro ser vivo que está en nuestro espacio experimentado, su espacio y el nuestro coinciden y se confunden.

Un paisaje de calidad ligado a la naturaleza puede mejorar el estado anímico de las personas. GONZÁLEZ BERNÁLDEZ (1990) estudia los elementos del paisaje que tienen efectos beneficiosos para nuestro ánimo (paisajeterapia), como el agua (hidrofilia) y la vegetación (fitofilia). En lo que respecta a las distintas apreciaciones del paisaje desde el mundo rural y urbano, entiende que para quien vive en el mundo rural el paisaje ideal es un paisaje ordenado (Figura 3.1) en el que hay pocos elementos de distorsión, como ocurre en el paisaje agrario. Así pues, los campesinos muestran más aprecio por paisajes cultivados y con signos de control del hombre, es decir, paisajes productivos. Por el contrario, quien vive en la ciudad, acostumbrado a cambios, prefiere un paisaje dinámico y variado, pues de lo contrario sería un paisaje aburrido. El ciudadano tiene una valoración más lúdica o aventurera de la naturaleza. 


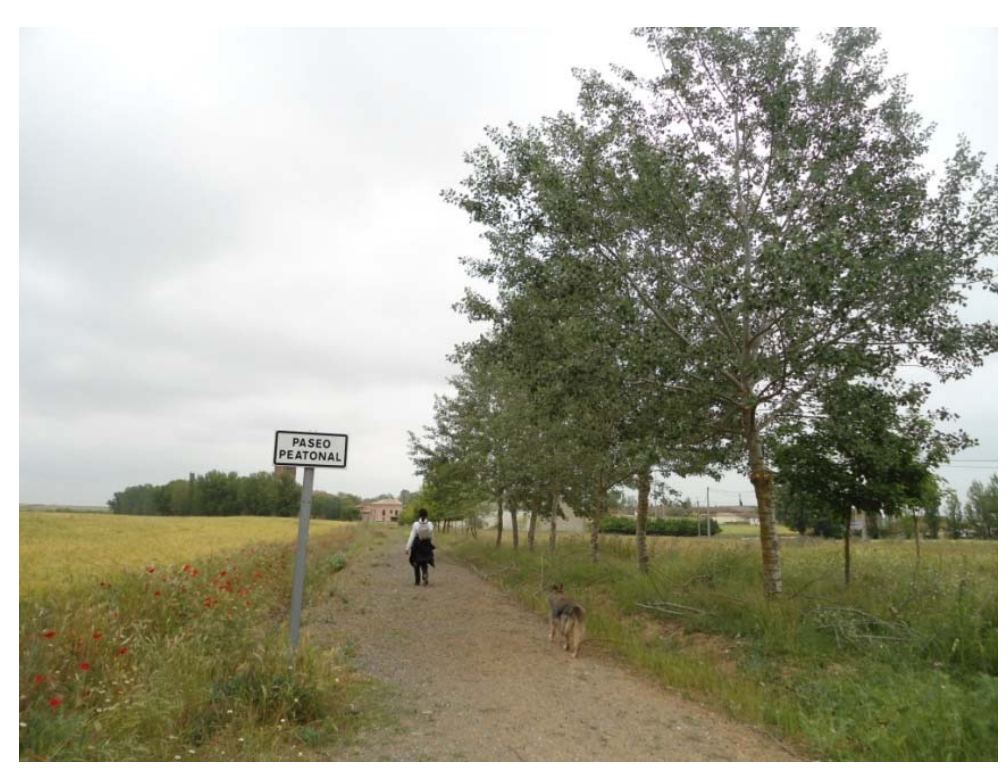

Figura 3.1. Paseo peatonal en Abarca de Campos, donde se emplean los árboles como valor fundamental de mejora de un paisaje agrario ordenado.

CORRALIZA (1993) realiza un interesante análisis en el que justifica que el paisaje no es un recurso complementario, sino fundamental para el funcionamiento psicológico. Desde distintas perspectivas se ha aludido al potencial efecto restaurador del funcionamiento psicológico que tiene la exposición del sujeto a paisajes naturales. Los paisajes preferidos, particularmente aquellos en los que predominan elementos de la naturaleza, cumplen la función de restaurar el equilibrio psicológico roto por el exceso de demandas ambientales de los entornos urbanos, complejos, altamente tecnificados y fuera del control del sujeto. Uno de los aspectos más relevantes del estudio de las reacciones psicológicas ante el paisaje deriva de la importancia que para el bienestar humano tiene el contacto con la naturaleza. ULRICH (1992) muestra de forma contundente que la exposición a imágenes de naturaleza disminuye el tiempo de recuperación tras el estrés, aumenta los sentimientos positivos y disminuye los sentimientos negativos.

En cuanto a la comprensión y exploración de los paisajes, CORRALIZA (1993) indica que el sujeto ante un paisaje pone en marcha dos tipos de actividades mentales: la actividad descriptiva de propiedades y la actividad predictiva de experiencias. Sobre la primera, señalar la importancia que, para el juicio de preferencia del paisaje, tienen propiedades como la presencia de árboles, agua y otros contenidos objetivos del paisaje. En el modelo de KAPLAN y KAPLAN (1989) de la figura 3.2 se alude a dos variables en particular: la coherencia y la legibilidad. La propiedad de la coherencia se refiere a que los elementos del paisaje tengan una colocación lógica y un orden en la organización que pueda ser aprehendido con relativa inmediatez. La legibilidad se refiere a que la escena del paisaje tenga una cierta permeabilidad visual para el sujeto; que el sujeto pueda acceder, penetrar y desenvolverse en el paisaje. 


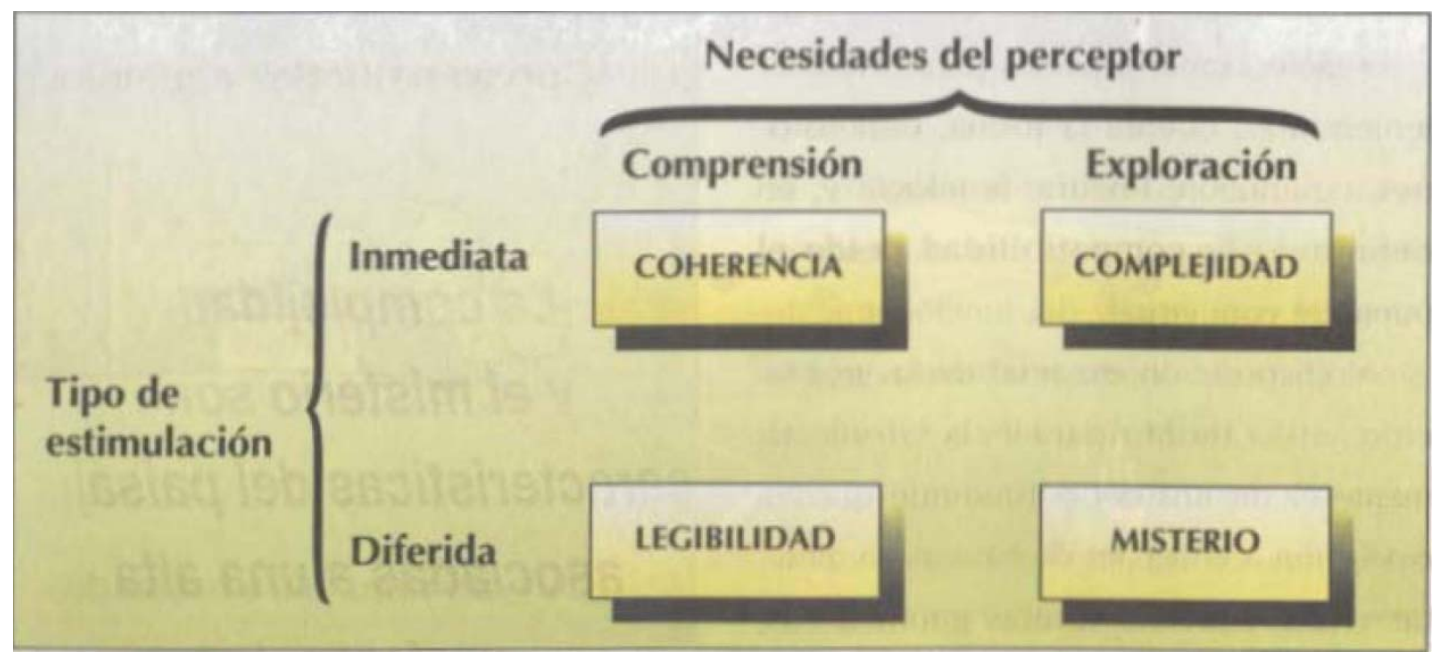

Figura 3.2. Propiedades del modelo de Kaplan y Kaplan, que son los predictores más potentes de preferencia ambiental (CORRALIZA, 1993)

El segundo tipo de actividad mental, la actividad predictiva o de exploración, se refiere al grado en el que el sujeto no solo da sentido al paisaje, sino que puede evaluar el grado en el que el paisaje satisface sus necesidades $y$, por tanto, planear su comportamiento en él. Destaca la importancia de dos propiedades: la complejidad de la escena (el grado en el que un paisaje posee una gran riqueza visual y de elementos diferentes) $y$, sobre todo, la propiedad del misterio (característica de un paisaje que induce al sujeto a la exploración; las curvas o los árboles, por ejemplo, son cualidades ligadas al misterio).

La investigación realizada sobre los procesos psicológicos de preferencia de paisajes muestra que la protección de la riqueza paisajística de un entorno, la atención y cuidado de los impactos visuales de las intervenciones humanas, no es solo relevante desde un punto de vista ecológico. Es decisiva desde el punto de vista del bienestar psicológico y social del ser humano. La destrucción de paisajes no solo entorpece la identificación del ser humano con su hábitat, sino que dificulta e incapacita al sujeto para establecer un diálogo efectivo con su propio entorno.

En cuanto a la relación entre paisaje y bienestar individual y social, LUGINBÜHL (2008) manifiesta que esta ha sido estrecha desde antiguo. A pesar de que el paisaje, como tal, es un término relativamente moderno, la preocupación por un paisaje bello y ordenado se pone de manifiesto desde tiempos antiguos en diferentes intervenciones por parte del poder o del pueblo. Un paisaje considerado bello es necesariamente armónico, y no solo desde el punto de vista estético, sino también desde la perspectiva de la relación entre el ser humano y la naturaleza (dimensión ecológica), y en el seno de la misma sociedad (dimensión social). A través de estos vínculos el paisaje se traduce en bienestar.

El bienestar se puede concebir como la satisfacción de la que goza un individuo a través de los sentidos y, en lo referente al paisaje, la vista es su perceptor evidente, que discierne lo que es bello y que, a su vez, está fuertemente influida por un sustrato cultural. Pero hay otros sentidos que también pueden tener su implicación en la percepción del paisaje. Se puede citar la influencia del tacto en la apreciación de un lugar a partir del propio caminar sobre determinadas 
superficies, por ejemplo. El olfato también puede convertirse en esencial en la valoración de un paisaje y puede despertar sensaciones agradables o desagradables que determinen el bienestar individual. En la misma línea, el oído es un sentido que también participa de la apreciación que se tiene de un paisaje a través, por ejemplo, de los sonidos naturales o entrañables, en oposición a los ruidos molestos o ensordecedores. En el caso del gusto, esta relación no es tan clara, aunque pueden asociarse determinados alimentos a un territorio.

El ser humano siempre ha aspirado a modelar el paisaje para crear un entorno agradable que satisfaga sus necesidades materiales pero también sea fuente de bienestar. No obstante, la situación actual del paisaje queda lejos de ser la más deseable, en gran medida por las rápidas y numerosas transformaciones que ha sufrido el territorio en los últimos sesenta años. La búsqueda de la máxima productividad de la agricultura, con la ayuda de nuevos medios técnicos dentro del marco de un capitalismo fuertemente competitivo, ha destruido no solo la complejidad y belleza de los antiguos paisajes rurales, sino que se ha mostrado incompatible con una gestión esmerada de la naturaleza. El resultado es una cierta connotación negativa del campo, motivo por el cual la sociedad, en una proporción creciente, tiende a vincular más el paisaje con los espacios naturales que con el medio agrícola. En lo referente a la ciudad, la situación no es más positiva. La preponderancia de los beneficios inmobiliarios ha provocado la banalización del paisaje urbano, lo que, junto a otros motivos, ha conducido a la percepción de la ciudad moderna como un espacio de inseguridad y fealdad, de malestar, en definitiva. Esta degradación de los paisajes rurales y urbanos afecta directamente al bienestar de la población, lo que está generando cada vez mayores preocupaciones e incidencias en la ciudadanía.

PERAY y PLASENCIA (2008) ahondan en esta línea, destacando las oportunidades y retos que el paisaje y el medio ambiente ofrecen a la salud pública. Aunque hasta ahora han tenido una escasa consideración, sus efectos sobre la salud física, psíquica y social están ampliamente documentados. Se conoce que si el medio proporciona a los seres humanos la satisfacción de las necesidades materiales, el paisaje proporciona la satisfacción de las necesidades psicológicas, emocionales y espirituales y que, del mismo modo que puede tener un papel positivo para la salud (paisajes de calidad), también presenta riesgos (paisajes degradados).

Estos autores sostienen que está demostrado el efecto positivo que algunos paisajes tienen sobre la salud de la población. Hay abundante literatura y documentación referidas a experiencias que utilizan el paisaje para mejorar la salud y el bienestar y se está trabajando en el uso preventivo, terapéutico y restaurador del mismo. De hecho, son numerosas las consultas médicas que acaban recomendando -evidentemente, de forma complementaria a otros tratamientos farmacológicos- el paseo u otras formas de ejercicio físico moderado en la naturaleza (Figura 3.3).

Recientemente se ha constatado científicamente que la relación entre naturaleza y salud es muy acusada. Así, en el Proyecto de investigación Phenotype (NIEUWENHUIJSEN, 2014) se ha demostrado que existe una correlación entre el número de árboles que hay en el lugar donde se vive y la tasa de mortalidad por enfermedades cardiovasculares. De este modo, a mayor número de árboles menor es la tasa de mortalidad por esta causa. Estas correlaciones también se dan en otros indicadores de salud, como el peso al nacer, el asma, la obesidad infantil, el cáncer de piel o el estrés. 


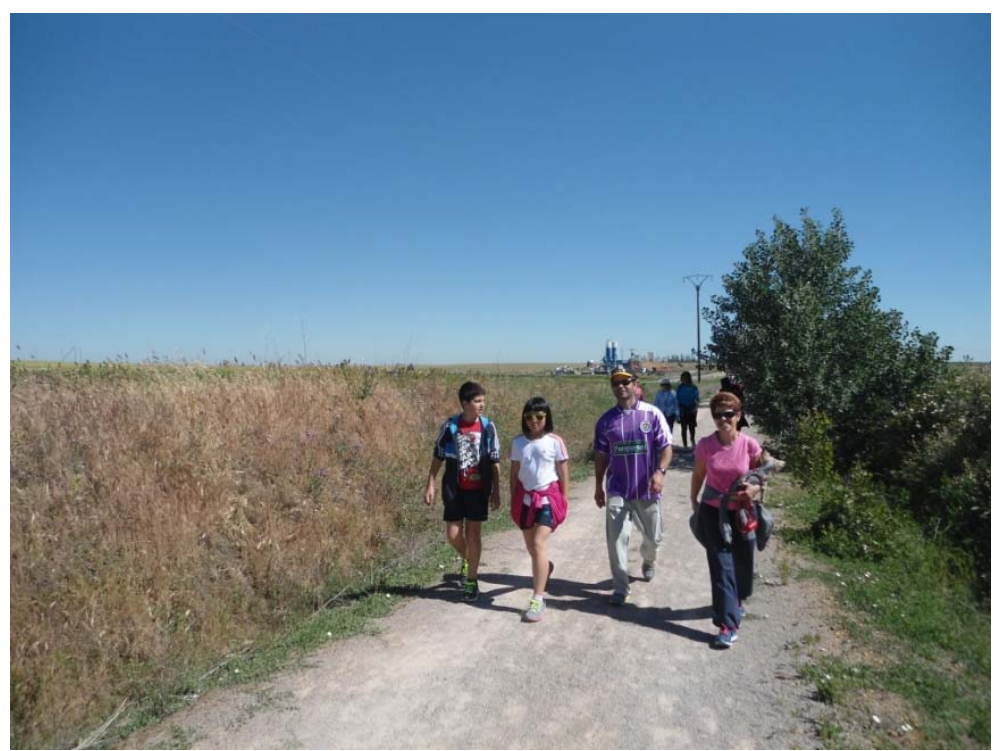

Figura 3.3. Senderismo por la vía verde Tierra de Campos.

En esta línea ahondan COLLADO y CORRALIZA (2014), que constatan los beneficios que el contacto con el medio natural tiene para la población infantil. Estos pueden ser físicos (por ejemplo, disminución de la obesidad en los niños), psicológicos (los espacios naturales pueden restaurar su atención) y los derivados de la conexión emocional de los niños con la naturaleza (se ha demostrado que pasar una o dos semanas en contacto con la naturaleza aumenta las actitudes ambientales infantiles y su intención de llevar a cabo comportamientos ecológicos).

POL et al. (2008) precisan que la relación entre paisaje, bienestar y salud es muy compleja, ya que la capacidad restauradora de un paisaje se asocia a su capacidad de facilitar la relajación, la desconexión de la vida cotidiana, el olvido de las preocupaciones y la capacidad de estimular la reflexión tranquila sobre uno mismo y sus cuestiones personales. Pero estas cualidades que se le suponen a un paisaje restaurador no siempre son objetivas. Dependen, entre otros, de aspectos y matices de tipo subjetivo, de atribución de causas, de valores simbólicos variables y cambiantes; en definitiva, de procesos de construcción social de la realidad. No obstante, conviene precisar que, a pesar de esta complejidad, algunos trabajos -como los citados anteriormente en este apartado- establecen una cierta jerarquía de paisajes en relación con el bienestar.

Estos autores consideran que los valores dominantes en nuestra sociedad nos han convertido no solo en usuarios del paisaje, sino también en consumidores de paisaje, con unos efectos depredadores terribles. En una sociedad acelerada como la nuestra, se da la paradoja que cada vez queremos preservar más paisajes a los que atribuimos cualidades restauradoras, pero al mismo tiempo demandamos la posibilidad de tener un acceso rápido a unos servicios de estándares elevados que, inevitablemente, generan un fuerte impacto sobre el paisaje. Por ello, las intervenciones para la mejora del paisaje y de la salud y el hecho de profundizar en las sinergias entre ambos, tienen como objetivo último incrementar la calidad de vida de los ciudadanos. 
La conexión entre naturaleza y bienestar está demostrada por CORRALIZA (2014), que incluso muestra la existencia en algunos casos de un "síndrome de déficit de naturaleza", con diferentes síntomas y problemas vinculados a la ausencia de un entorno natural. Todo ello surge como consecuencia del esfuerzo prolongado del cerebro humano por hacer frente a la selva de estímulos estridentes de la vida urbana: menor uso de los sentidos, dificultades de atención y mayores tasas de enfermedades físicas y emocionales.

Las consecuencias que puede tener la degradación del paisaje sobre la salud mental es un tema tratado por VALLERANI (2008), quien afirma que puede influir fuertemente en la serenidad existencial de la población. De hecho, hay una estrecha relación entre la degradación ambiental y paisajística y el creciente aumento del desasosiego y la angustia entre los habitantes de territorios amenazados por la urbanización intensiva de zonas suburbanas o la construcción de grandes infraestructuras de transporte. Dicho pesimismo crece con el aumento de la sensibilidad ambiental y paisajística de la población, hecho que genera preocupación y miedo respecto a la calidad de vida actual, así como la de las generaciones futuras. Esta situación nos conduce a hablar de las "geografías del miedo", es decir, de una angustia social que puede causar estados depresivos y pérdida de los vínculos de identidad con respecto a los propios paisajes, que son los que aportan seguridad a las personas.

ORTIZ et al. (2008) reflexionan sobre la relación de los paisajes cotidianos -que son los que mayoritariamente nos rodean- con la salud y el bienestar. Consideran que la calidad ambiental es muy importante por diversas razones, y el bienestar que proporciona a las personas se asocia significativamente a la presencia de vegetación, agua, equipamientos cómodos y de calidad, a una buena accesibilidad, a una luz y vistas buenas, a una distribución correcta de los espacios de sol y de sombra, así como a la ausencia de ruidos, humos y tráfico.

Una línea muy interesante de investigación es la relatada por FULLER et al. (2008), que analizan paisaje, tranquilidad y salud. Las ventajas de los paisajes verdes van más allá del placer estético, ya que abarcan el bienestar emocional, la reducción del estrés y, en algunos casos, la mejora de la salud de diferentes modos, que van desde la potenciación de las aptitudes de comunicación personal y social y la mejora de la salud física, mental y espiritual hasta el aumento de la percepción psíquica, sensorial y estética. Asimismo, los estudios han evidenciado que existen aspectos concretos de los paisajes naturales que pueden propiciar la aparición de diferentes procesos terapéuticos. En esta línea, se ha demostrado que la vegetación y la naturaleza refuerzan nuestra capacidad de atención espontánea, ayudan a relajar el aparato sensorial y nos inyectan energía fresca.

La tranquilidad de un paisaje no solo contribuye a sus efectos terapéuticos, sino que representa un valor enormemente apreciado por las personas en busca de dichos efectos. A menudo se habla de la tranquilidad como uno de los muchos beneficios o activos sociales derivados del contacto con el mundo rural, como un motivo decisivo para visitar los espacios rurales y como un elemento que debe protegerse y fomentarse.

En otro orden de cosas, la realización de actividad física en entornos naturales y rurales puede contribuir de una manera muy eficaz tanto a mejorar el bienestar general de la población como a minimizar la degradación de estos espacios naturales y rurales, al darles un uso (MOSCOSO et al., 2008). En este sentido, las entidades locales adquieren un papel dinamizador muy 
importante y a menudo promueven actividades puntuales relacionadas con el medio natural, como huertos urbanos, vías verdes, museos tradicionales o itinerarios terapéuticos (Figura 3.4). Estas actividades facilitan el contacto con el paisaje natural y mejoran la calidad de vida de la población en general, pero especialmente de la gente mayor, de los niños y de las personas con determinadas carencias, dificultades o riesgo de exclusión social.
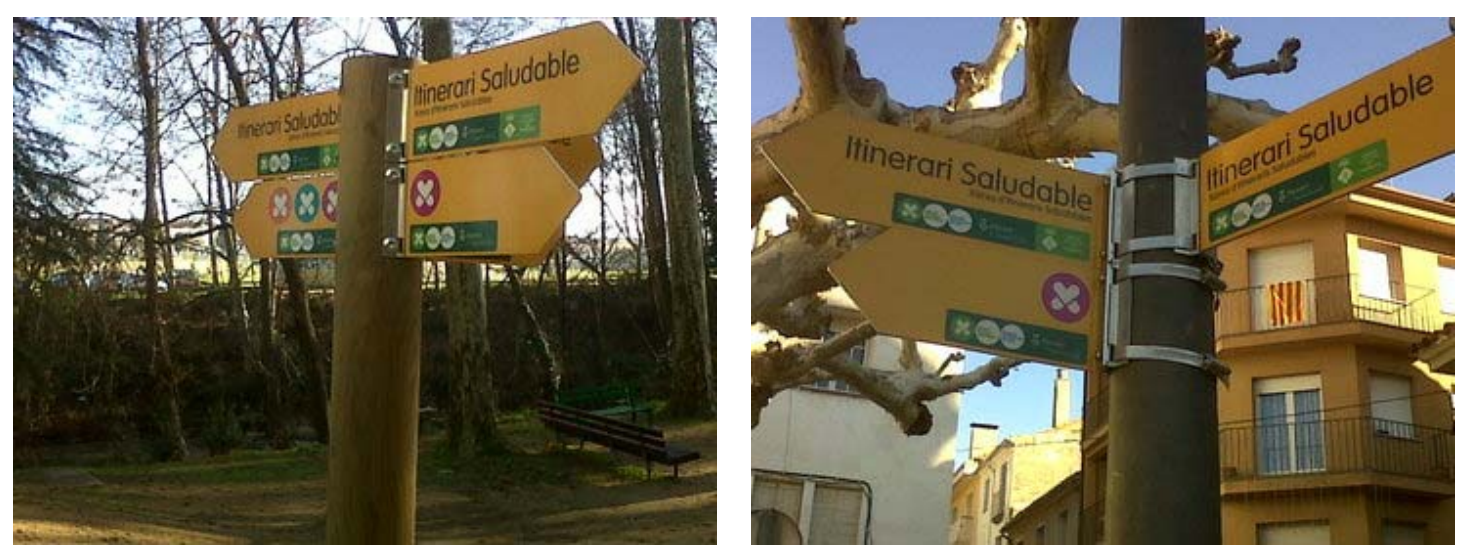

Figura 3.4. Carteles señalizadores de itinerarios saludables en Santa Coloma de Farners (Girona). En estas dos fotografías se percibe que estos itinerarios conectan el centro urbano con los parques periurbanos, haciéndolos más accesibles.

En lo referente a las iniciativas empresariales privadas, estos autores señalan que la potenciación de los paisajes naturales y rurales como generadores de salud y bienestar es una fuente prometedora de desarrollo rural. Este nuevo filón de ocupación puede contribuir a contrarrestar el abandono del mundo rural. Aunque todavía son pocas las iniciativas en este sentido, destacan los parques agroecológicos y las empresas de deportes en la naturaleza. La buena aceptación del conjunto de iniciativas puestas en marcha demuestra en cierta manera la influencia positiva en la salud y el bienestar humano de la realización de actividades en el paisaje natural y rural. Y, al mismo tiempo, evidencia su poder para revalorizar paisajes naturales y rurales que, en muchos casos, están en proceso de degradación por falta de gestión.

La relación entre actividad física y la contemplación del paisaje es analizada por SALLENT (2008), quien señala que ambas materias se han estudiado ampliamente como generadoras de bienestar para el individuo, entendiendo la vertiente más amplia del término bienestar (vertiente física, mental y social). Sin embargo, el estudio de los beneficios de su relación solo ha sido objetivo de los investigadores en la última década. De esta relación ha surgido el concepto de green excercise (ejercicio verde), que se refiere a la sinergia beneficiosa que se obtiene al realizar una actividad física en contacto con la naturaleza. Esta incidencia entre el paisaje natural y la actividad física se ha estudiado en tres niveles: presenciar la naturaleza (aunque sea desde una ventana), estar rodeado de naturaleza de manera accidental mientras se realizan diferentes actividades (caminar o ir en bicicleta) o participar e implicarse con la naturaleza cuando se realiza una actividad física (labrar una huerta o recoger castañas). Según algunos autores los resultados obtenidos son cambiantes e incluyen el incremento de la autoestima, la mejora del estado de ánimo y de la depresión, la motivación para realizar más 
actividad física y el alivio del estrés. Sin embargo, los beneficios de la actividad física en un paisaje natural agradable, en un paisaje bonito y ordenado, inciden, probablemente, de manera más profunda. Y aquí puede valer tanto la belleza natural con presencia de árboles, ríos o grandes panorámicas, como sencillamente calles y parques bien diseñados y cuidados.

Este autor señala que el deporte nos puede hacer vivir experiencias agradables de flujo armónico y gratificante, y el paisaje -fuente de experiencias estéticas- intensifica y perfecciona nuestras sensaciones. La convergencia de ambas experiencias permite hacernos llegar a estados de gozo y bienestar sin necesidad de estructuras complejas. Así pues, aceptar que la vivencia gratificante de combinar la actividad física con la contemplación del paisaje es fuente de beneficios para el bienestar del individuo representa el primer paso para exigir medidas que garanticen esta experiencia. Y por ello son tan necesarias la protección de los paisajes de calidad y la restauración de los paisajes degradados.

\subsection{El paisaje rural}

\subsubsection{Concepto e importancia}

BOLÓS (2005) realiza un interesante análisis conceptual de los diferentes tipos de paisaje, que resulta útil para centrar el que aquí nos ocupa: el paisaje rural. De este modo, considera como paisaje natural aquel en el que sus elementos abióticos y bióticos, así como las energías que lo hacen funcionar, no tienen nada que ver con el hombre. En el extremo opuesto, el paisaje urbano es el antrópico, creado y diseñado totalmente por el hombre, que lo construye y le aporta -mediante transporte- la energía necesaria para su funcionamiento. El paisaje rural es el espacio restante, aquel que no es ni natural ni urbano, y que se puede definir como un paisaje natural antropizado, constituido por campos de cultivo, prados para pasto y bosques productores de frutos, leña, madera, etc. Se trata de un tipo de paisaje que alcanza sobre la Tierra una extensión extraordinaria, pero al que se ha considerado normalmente como vulgar y de poco valor. No obstante, por su riqueza, complejidad y representación territorial debería ser contemplado desde una perspectiva más positiva. De hecho, en la actualidad el paisaje rural está experimentando una importante revalorización, siendo el espacio donde se conservan valores tradicionales tales como los económicos y estéticos de la agricultura o el gran valor arquitectónico de muchas construcciones antiguas en peligro de desaparición. Además, el paisaje rural es el gran productor de bienes renovables e incluso de otros recursos no renovables, como los productos mineros.

Desde una perspectiva urbanística, el paisaje rural suele coincidir con el suelo rústico común, que en general es aquel que no es suelo urbano ni urbanizable (paisaje urbano) ni suelo rústico con protección natural (paisaje natural). En este territorio los usos permitidos suelen ser los vinculados a las actividades agrarias y ganaderas, aunque son autorizables muchos otros: viviendas unifamiliares aisladas, actividades extractivas, plantas de tratamiento de materiales, parques eólicos, instalaciones fotovoltaicas, etc. lo que provoca fuertes tensiones al configurarse como una especie de cajón de sastre en el que todo cabe. Además, las infraestructuras lineales suelen trazarse por el paisaje rural (carreteras, autovías, líneas de 
ferrocarril de alta velocidad, líneas eléctricas, etc.), con los impactos ambientales añadidos que ello comporta.

NAVÉS et al. (2005) señala distintos ámbitos de intervención en el paisaje rural:

- La correcta planificación y gestión del paisaje rural, como elemento consustancial que forma el mosaico de nuestro territorio y sirve de conexión entre el paisaje urbano y el paisaje natural, haciendo muchas veces de corredor biológico de los espacios naturales.

- Su potenciación como elemento de valor económico de sostenibilidad y de autosuficiencia alimentaria.

- Su potenciación y protección por la belleza paisajística que genera, los jardines agrícolas y silvícolas con sus pueblos y casas rurales aisladas y sus cultivos, especialmente en las zonas de montaña.

- Su tratamiento como elemento que históricamente forma parte de nuestros parques y jardines públicos, ya que partimos de la hipótesis de que el estilo de un jardín es siempre una abstracción basada en el paisaje agrario (su trama de cultivos, la forma de solucionar los desniveles, el riego, etc.). Es decir, el jardín geométrico es al paisaje agrario lo que el jardín paisajístico es al paisaje natural.

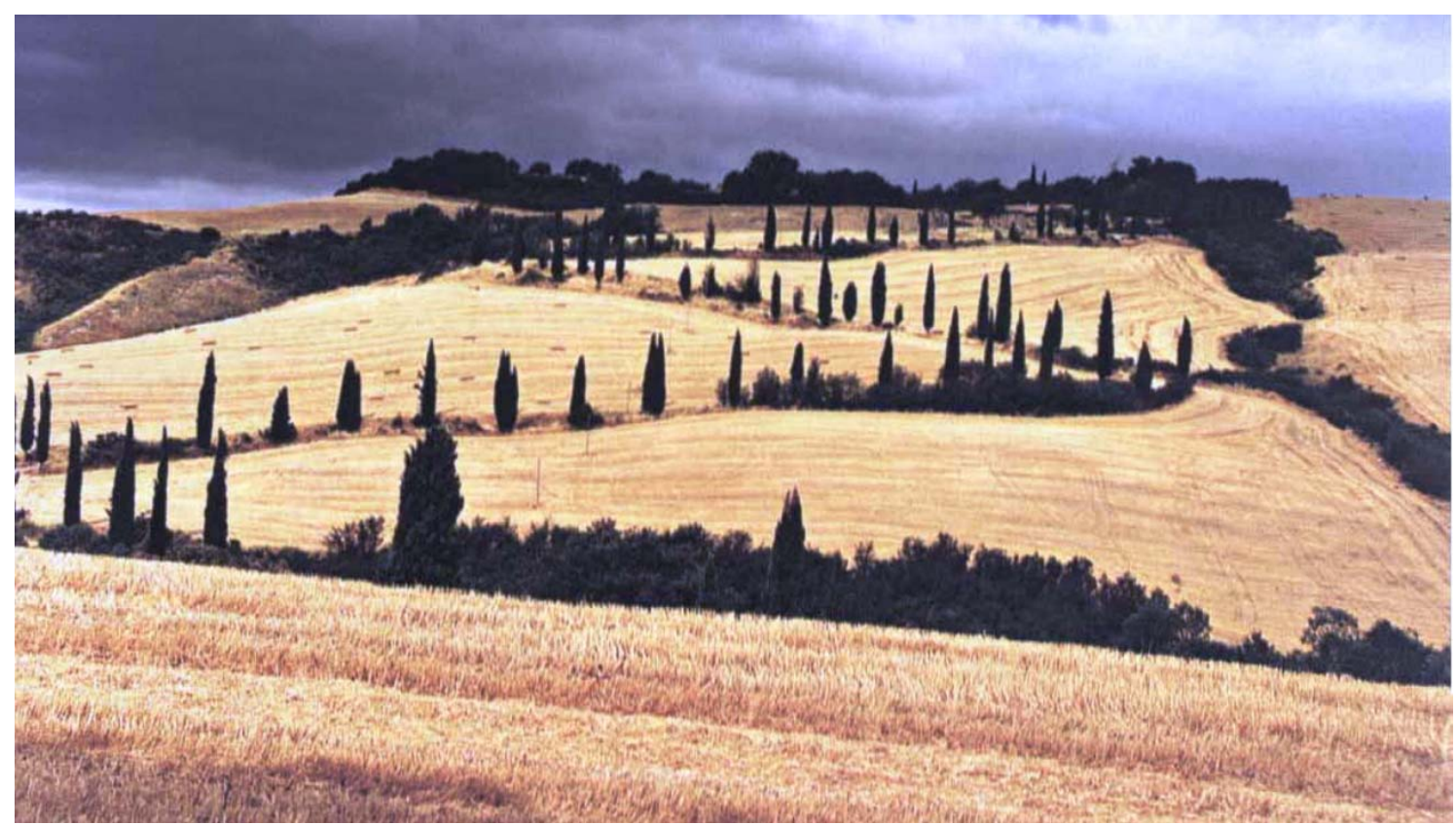

Figura 3.5. Paisaje rural paradigmático de La Toscana (Italia), que aporta a esta región un innegable carácter. En NAVÉS et al. (2005)

Este autor indica que el paisaje rural, además de tener un interés económico de sostenibilidad alimentaria, permite un equilibrio ecológico territorial, dando como resultado en algunos casos paisajes bellísimos -jardines agrícolas- que deben ser protegidos (Figura 3.5). La arquitectura popular, siempre respetuosa e integrada en el medio, ha favorecido esta belleza, pero las actuaciones de las últimas décadas en las que ha primado exclusivamente el aspecto económico, han afectado gravemente a estos paisajes. Ejemplos de ello son la construcción de grandes 
naves, la intensificación de la agricultura en forma de monocultivos y la transformación de tierras fértiles en zonas urbanizadas.

Tal como se ha venido exponiendo en este apartado, el paisaje rural posee en general un gran valor, aunque no está exento de alteraciones humanas. A pesar de que el hombre que habita el medio rural no demanda tanto la existencia de espacios naturales como el que lo hace en medios urbanos, lo cierto es que sus gustos y necesidades son similares. También precisa sus espacios de ocio (para realizar actividades de paseo, caza, pesca, etc.). Además, el interés por el paisaje rural sobre todo comienza a manifestarse cuando el "urbanita" se hace hombre de fines de semana y vacaciones en el campo. Por ello, en las previsiones de zonas de recreo ha de contarse también con el mundo rural; la presencia del árbol es tan necesaria en el campo como en la ciudad (LÓPEZ LILLO Y RAMOS, 1969).

El hombre es agente activo en la modelación del paisaje y algunas de sus actividades crean o destruyen paisaje de calidad, según cómo se mire y cómo se practique. Ocurre así con la agricultura, que puede crear e integrar muy bien paisajes de calidad o solo crearlos, pero reduciendo en gran medida el valor de sus atributos. En sentido positivo, la integración de actividades diversas puede dar lugar a paisajes de calidad que fomenten el turismo rural (PUERTO, 1993).

\subsubsection{Historia y evolución del paisaje rural agrícola}

El paisaje agrícola es la manifestación de la historia del hombre en un lugar determinado, siendo su evolución el reflejo del progreso de la tecnología hidráulica y de cultivo con que se cuenta en cada momento histórico (NAVÉS et al., 2005). Así, el hombre transforma el paisaje desde los primitivos tiempos del Neolítico, periodo en el que deja de ser recolector y cazador para convertirse en agricultor y ganadero, y cuya aparición fluctúa en las diferentes regiones de Europa entre los años 3500 y 6000 a.C. Para establecer cultivos abre claros en el bosque, destruyendo la vegetación arbórea primitiva. También traslada plantas de un lugar a otro, selecciona semillas y busca nuevas especies vegetales a través del intercambio cultural. Las plantas cultivadas dan fruto abundante en el momento de la recolección, lo que le permite consumirlas poco a poco o intercambiarlas, obligándolo a almacenarlas para protegerlas de agentes que puedan dañarlas. Paralelamente, el hombre domestica animales que le proporcionan leche, carne y pieles y que también necesitan cuidados y protección.

El ser humano que cultiva la tierra y cuida de algunos animales domesticados convierte el campamento móvil de la fase nómada en poblado fijo, que consta de viviendas, almacenes, establos y lugares de relación social; todo ello protegido por vallas, murallas y otros elementos asociados. Se trata del inicio de la organización social, donde se definen los distintos trabajos que se deben realizar en cada núcleo de población.

Es imaginable que la transformación del paisaje natural en paisaje agrícola discurriese pareja a los movimientos de población entre territorios, dependiendo de la mayor o menor calidad de los terrenos y de los aconteceres históricos. No obstante, la evolución de los métodos de cultivo a lo largo de la Historia ha sido muy paulatina, teniendo en cuenta que la fuerza de trabajo era 
manual humana o de origen animal, por lo que también ha sido lenta la transformación del paisaje agrícola. Es decir, después de la primera gran modificación que supuso la destrucción de los bosques primitivos para su cultivo, el paisaje agrícola no sufrió cambios sustanciales en cuanto a su configuración a lo largo de siglos.

Pero este paisaje sufre una gran modificación en España y otros países de nuestro entorno a partir de la segunda década del siglo XX, con motivo de la revolución tecnológica. A partir de este momento se impone una intensificación de los cultivos, en busca del máximo beneficio económico, lo que conlleva diversas alteraciones del equilibrio ecológico (aparición de nuevas plagas, aumento de la erosión, pérdida de diversidad biológica, contaminación de las aguas subterráneas, etc.) y una reducción de la calidad del paisaje. Según los autores citados, las principales causas de esta transformación son las siguientes:

- Tecnificación. Aplicación de la mecánica y toda clase de energías al cultivo, cosecha y almacenaje de los productos.

- Selección de semillas, control genético y aceleración del crecimiento de las plantas mediante la aplicación de fertilizantes y herbicidas.

- Automatización de operaciones, especialmente de riego y recolección en algunos casos, con la influencia de carácter cultural que ello conlleva.

Todo ello ha dado lugar a una selección de cultivos dirigida al monocultivo con el objetivo de la venta del producto en gran cantidad, lo que necesita del consumo de gran cantidad de energía externa. A este propósito ha contribuido la Administración, realizando las concentraciones parcelarias a las que se han sometido buena parte de nuestros espacios agrarios. A medida que se realizan las transformaciones de la estructura agraria se modifica su paisaje; van desapareciendo del territorio las pequeñas parcelas, dedicadas a cultivos diferentes, donde se podían contemplar simultáneamente el verde prado, el florido campo de forrajeras, el cereal en crecimiento, los viñedos y los árboles y arbustos dibujando límites de las propiedades y dando vida a los taludes y las zonas residuales (Figura 3.6). A su vez, aparece una nueva arquitectura en las zonas rurales alejada de la tradicional; las nuevas edificaciones agrícolas tienen nuevas formas y materiales ajenos al lugar, que rompen completamente la estética y el equilibrio del paisaje rural (NAVÉS et al., op.cit.).
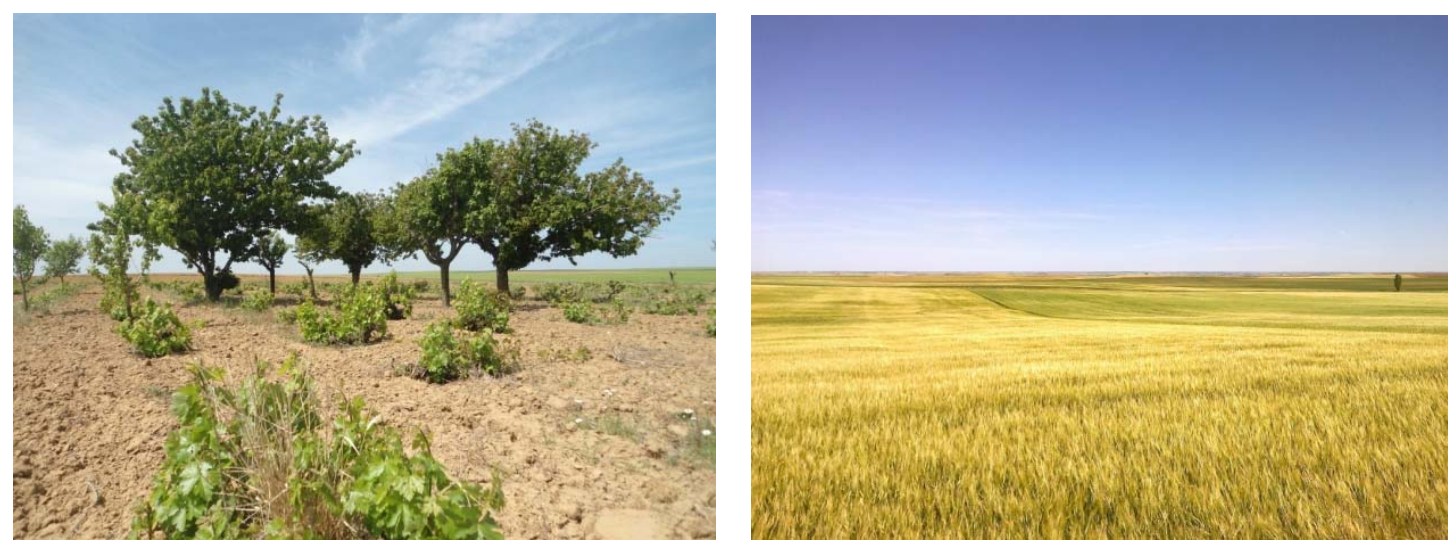

Figura 3.6. Imágenes actuales que pueden servir de modelo de la transformación del paisaje agrícola. A la izquierda, paisaje en mosaico -prácticamente relicto- con viñedo, frutales y cereal. A la derecha, monocultivo cerealista. Ambas fotografías están tomadas en Villalón de Campos, aunque la segunda es abrumadoramente mayoritaria en el territorio. 
De hecho, la Unión Europea es consciente en los últimos años de los deterioros paisajísticos y medioambientales causados por la agricultura productiva y está favoreciendo la adopción de prácticas más sostenibles, como la ecocondicionalidad. La revisión de la Política Agraria Común (PAC) para el periodo 2014-2020 es aún más ambiciosa. En su debate previo, el comisario europeo responsable de Agricultura y Desarrollo Rural Dacian Ciolos (2013) planteaba una "ecologización" (greening) de los pagos directos agrícolas, con tres medidas básicas. En primer lugar, diversificación de los cultivos -dirigida a evitar el empobrecimiento de los suelos y la pérdida de biodiversidad. En segundo, mantenimiento de pastizales permanentes, terreno importante para la captación de carbono, la lucha contra la erosión del suelo y el mantenimiento de una amplia variedad de fauna y flora. En tercer lugar, mantenimiento del $7 \%$ de superficies de interés ecológico en las explotaciones agrícolas, ya que estas no consisten solo en campos, sino que también comprenden setos, caminos agrícolas, pequeños muros, bosquetes, etc. Todos estos elementos son muy importantes para mantener un buen equilibrio dentro de los ecosistemas agrícolas y desempeñan un papel clave en la gestión correcta de los recursos hídricos, los fertilizantes y pesticidas, la lucha contra la erosión, el aumento de la diversidad y la mejora del paisaje. Estos aspectos se están reflejando con mayor o menor intensidad en la transposición a la normativa estatal y autonómica (MAGRAMA, 2014), donde se articulan las buenas condiciones agrarias y medioambientales de la tierra.

\subsubsection{Tipos de cultivos (paisajes) agrícolas. El cultivo (paisaje) cerealista.}

En general, el paisaje agrícola es diverso porque en él confluyen muchas variedades: tipos de cultivos, desarrollo del ciclo de cada especie, evolución del suelo en función de dicho desarrollo, tamaño y forma de cada planta, cambios de color a lo largo de la temporada, etc. NAVÉS et al. (2005) realizan una primera diferenciación de los cultivos en relación con el paisaje que generan:

El cultivo diferenciado ocupa extensiones menores de parcelas y da lugar a un tipo de paisaje mucho más variado (mosaico de cultivos). Posee una mayor calidad visual y desde el punto de vista ecológico es más sostenible y resistente a las plagas, no haciéndose tan patente la contaminación provocada por fertilizantes, herbicidas y plaguicidas químicos. En general, se trata de un cultivo más tradicional. Un caso particular es el cultivo ecológico, que solo utiliza abonos naturales y plaguicidas biológicos, y emplea especies vegetales de la zona.

El monocultivo emplea grandes extensiones de parcelas -como, en el extremo, ocurre con los cultivos industriales de Estados Unidos- y es más rentable desde el punto de vista económico inmediato. Este tipo de paisaje es visualmente muy monótono $y$, a la larga, provoca desequilibrios ecológicos importantes debido a la contaminación agraria difusa y a las plagas. Este cultivo tiene un grado de mecanización muy elevado, en cuanto a desarrollo tecnológico y superficie de trabajo.

Aunque el Ministerio de Agricultura suele distinguir en España 23 tipos de aprovechamiento de suelo cultivable, de los cuales 19 son productivos y 4 improductivos, los autores citados realizan 
una clasificación de acuerdo a criterios paisajísticos en 16 tipos de cultivos (Figura 3.7), diferenciando vegetación baja y alta.

\begin{tabular}{|l|c|c|}
\hline VEGETACIÓN BAJA & REGADIO (R) o SECANO (S) & CALIDAD DEL SUELO \\
\hline $\begin{array}{l}\text { 1. CULTIVO HERBÁCEO DE SECANO } \\
\text { Cereales (trigo, cebada, centeno, avena) }\end{array}$ & $\mathrm{S}$ & Media \\
\hline $\begin{array}{l}\text { 2. PRADOS } \\
\text { Leguminosas o gramíneas (alfalfa, trébol) } \\
\text { Prados alpinos atlánticos }\end{array}$ & $\begin{array}{c}\text { S (zona húmeda) } \\
\text { R (zona seca) }\end{array}$ & Rica \\
\hline $\begin{array}{l}\text { 3. PASTIZALESY PÁRAMOS MEDITERRÁNEOS } \\
\text { Herbáceo } \\
\text { Matorral } \\
\text { Arborado }\end{array}$ & $\mathrm{S}$ & Media-pobre \\
\hline $\begin{array}{l}\text { 4. VINEDO } \\
\text { 5. HUERTA }\end{array}$ & $\mathrm{S}$ & Pobre \\
\hline $\begin{array}{l}\text { 6. ARROZALES } \\
\text { 7. PLANTACIONES INDUSTRIALES } \\
\text { Algodón, girasol, lúpulo }\end{array}$ & $\mathrm{R}$ & Media \\
\hline $\begin{array}{l}\text { 8. VIVEROS EN INVERNADERO } \\
\text { Hortícola forzado } \\
\text { Ornamental de jardinería }\end{array}$ & $\mathrm{R}$ & Media \\
\hline $\begin{array}{l}\text { ESPARTALES } \\
\text { (Se tratan en el capítulo 2.2 del libro Arquitectura } \\
\text { del paisaje natural) }\end{array}$ & $\mathrm{R}$ & Media \\
\hline
\end{tabular}

\begin{tabular}{|l|c|c|}
\hline VEGETACIÓN ALTA & REGADÍO (R) o SECANO (S) & CALIDAD DEL SUELO \\
\hline $\begin{array}{l}\text { 9. FRUTALES DE SECANO } \\
\text { Almendro, algarrobo }\end{array}$ & $\mathrm{S}$ & Media \\
\hline 10. OLIVARES & $\mathrm{S}$ & Media \\
\hline $\begin{array}{l}\text { 11. DEHESA } \\
\text { Agricola forestal }\end{array}$ & $\mathrm{R}$ & Media \\
\hline $\begin{array}{l}\text { 12. FRUTALES DE REGADIO } \\
\text { Manzanos, perales, melocotoneros, cerezos, ciruelos }\end{array}$ & $\mathrm{R} / \mathrm{S}$ & Media \\
\hline $\begin{array}{l}\text { 13. AVELLANOS } \\
\text { 14. CITRICOS } \\
\text { Naranjales }\end{array}$ & $\mathrm{R}$ & Media \\
\hline $\begin{array}{l}\text { 15. PALMERALES } \\
\text { 16. FORESTAL - SILVICULTURA (bosques y arboledas) } \\
\text { Pinos, plátanos, choperas, eucaliptos }\end{array}$ & $\mathrm{S}$ & Media \\
\hline
\end{tabular}

Figura 3.7. Tipos de cultivos españoles desde el punto de vista paisajístico (NAVÉS et al., 2005)

El cultivo herbáceo de secano es el primero de los tipos de paisajes agrícolas caracterizados por estos autores; será el único que se describa, dado que el ámbito del presente estudio se encuentra en esta tipología. Comprende básicamente las superficies dedicadas a cultivos extensivos cerealistas como el trigo (Triticum sp.), la cebada (Hordeum vulgare), el centeno 
(Secale cereale), la avena (Avena sativa), etc. En proporciones muy inferiores, se encuentran intercalaciones de guisantes (Pisum sativum), garbanzos (Cicer ariethinum), alfalfa (Medicago sativa), etc. Tiene un aspecto cambiante en cuanto a volumen y color, en función del crecimiento y maduración de la planta. Cuando el ciclo es bianual (año y vez), el esquema típico de cultivo es el siguiente:

- Primer año: en otoño se realiza la siembra; en invierno arraiga; en primavera se da el máximo crecimiento y engrosado del grano; y a comienzos del verano se siega, permaneciendo posteriormente como rastrojo.

- Segundo año: en otoño e invierno se utiliza el rastrojo como pasto; y en primavera se levanta el rastrojo. De este modo el terreno queda como barbecho, que puede ocupar incluso buena parte del año si no hay aprovechamiento de pastos.

El carácter anual o bianual es función de varios factores: la calidad del suelo, las ayudas de la política agraria común al barbecho, el precio del cereal, etc. La realidad es que, en general, en las zonas cerealistas se ha abandonado este sistema tradicional para realizarse todas las fases de cultivo en un año. De este modo, si el cultivo es anual, el esquema anterior se simplifica (Figura 3.8): siembra al final del otoño, arraigo en invierno, crecimiento en primavera, siega al comienzo del verano, rastrojo durante el resto de esta estación y, finalmente, laboreo tras las primeras lluvias del otoño.
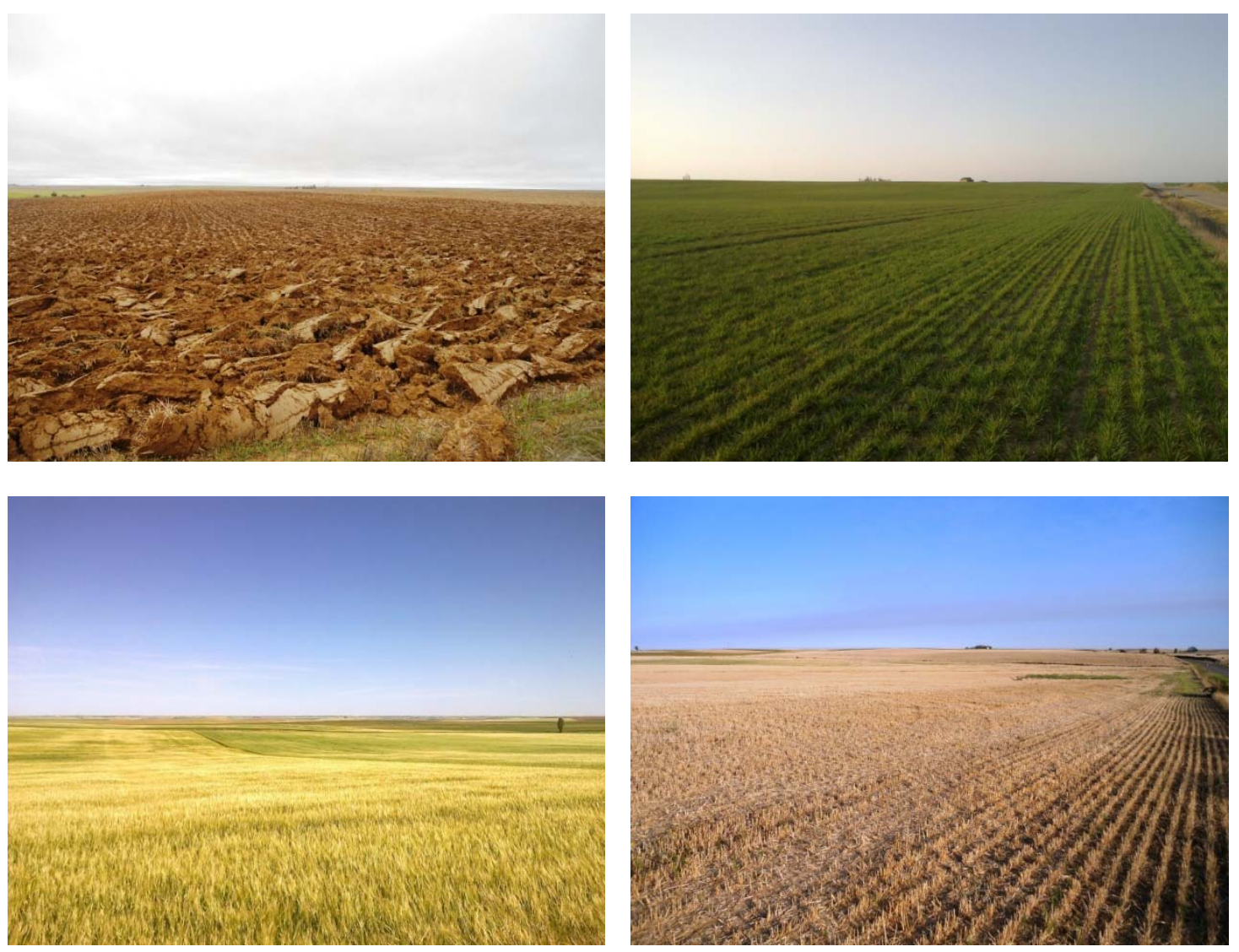

Figura 3.8. Fases fundamentales del cultivo cerealista: barbecho (arriba izquierda), cereal nacido (arriba derecha), cereal en maduración (abajo izquierda) y rastrojo (abajo derecha). 
En el cultivo extensivo la horizontal es la principal componente del paisaje. El paisaje está formado por llanos uniformes que dibujan una línea recta con el horizonte, existiendo un contraste entre el verde del cereal nacido, el amarillo una vez este va madurando y el marrón de la tierra (Figura 3.9). Por el contrario, este mismo cultivo tiene un aspecto muy distinto en terrenos más montañosos o con parcelas más pequeñas, donde paisajísticamente se crea el efecto mosaico. Aquí las tramas del cereal contrastan con los barbechos, pero también con los prados y otros cultivos. A su vez, hay más linderos de separación de parcelas, muretes de contención de tierras y otros elementos estructurales.

\begin{tabular}{|c|c|c|c|c|c|c|c|c|c|c|c|c|}
\hline & \multirow{2}{*}{\multicolumn{3}{|c|}{ PRIMAVERA }} & \multirow{2}{*}{\multicolumn{3}{|c|}{ VERANO }} & \multirow{2}{*}{\multicolumn{3}{|c|}{ OTONOO }} \\
\hline \multicolumn{4}{|c|}{ 1. CULTIVO HERBÁCEO DE SECANO } & & & & & & & & & \\
\hline \multirow{2}{*}{\multicolumn{13}{|c|}{ NOVIEMBRE DICIEMBRE }} \\
\hline & & & & & & & & & & & & \\
\hline \multirow{2}{*}{\multicolumn{13}{|c|}{ Flor }} \\
\hline & & & & & & & & & & & & \\
\hline \multicolumn{13}{|l|}{ Futo } \\
\hline & & & & & & & & & & & & \\
\hline Sulo & & & & & & & & & & & & \\
\hline
\end{tabular}

Figura 3.9. Ficha de variación cromática (NAVÉS et al., 2005)

En este esquema general del paisaje cerealista existen algunas singularidades. Así, cuando se siegan los campos de cereales, se separa la semilla de los tallos y estos se acumulan en balas de paja, dejándose secar al sol, lo que crea una sucesión en el paisaje. Esta paja se utiliza como alimento para el ganado. Existen dos modos de embalar, en cubos y en cilindros, formas que han incrementado notablemente su volumen en los últimos años.

Desde el punto de vista del paisaje ecológico, los cultivos cerealistas extensivos son sistemas muy simplificados por la intervención humana $y$, por consiguiente, poseen una diversidad paisajística baja. En ellos no existe un equilibrio propio, sino que se caracterizan por una fuerte extracción de biomasa que debe ser compensada con un gasto energético externo que restituye el continuo expolio de nutrientes y materia orgánica (PUERTO, 1993).

En estos ecosistemas, el aumento de la diversidad paisajística puede venir estructurando los monocultivos mediante setos. Estas soluciones permiten un mejor equilibrio entre la diversidad de especies y la adquirida. BERDOULAY y PHIPPS (1985) apuntan que el rejuvenecimiento provocado en ciertos espacios ha permitido la entrada de especies antes ausentes, como la alondra, en principio circunscrita a determinadas praderas y llanos herbosos.

Recientemente, el Ministerio de Agricultura, Alimentación y Medio Ambiente (2014) ha elaborado un Atlas de los paisajes agrarios de España. En la España mediterránea se definen las siguientes unidades:

- Huertas y cultivos intensivos mediterráneos

- Paisajes de la colonización, vegas y otros regadíos 
- Paisajes de los secanos mediterráneos interiores (donde se encontrarían los cultivos cerealistas)

- Paisajes de los cultivos leñosos mediterráneos

- Paisajes forestales y de alta montaña

- Paisajes de policultivos en comarcas serranas, de altiplanos y piedemontes

- Paisajes de comarcas ganaderas

\subsubsection{Elementos singulares del paisaje rural.}

Además del tipo y forma de cultivo, el paisaje rural de la península Ibérica posee elementos muy singulares ligados a la casa y a la parcela, que determinan en gran manera el paisaje. Todos estos elementos deben ser preservados ya que, junto a los propios cultivos y a la arquitectura agrícola, conforman un paisaje de gran belleza, superior incluso a los espacios naturales y a los jardines, constituyendo verdaderos jardines agrícolas. A partir del listado aportado por NAVÉS et al. (2005), se consideran los siguientes elementos singulares:

Muro, muretes y puertas de separación. Su finalidad es variada: separar parcelas, cercar el ganado, delimitar propiedades, etc. Generalmente están construidos con la piedra del lugar (caliza, granito, esquistos, areniscas, etc.). Son típicos de zonas de premontaña o montaña; cabe citar como ejemplos de singular belleza las "paredes" o "cortinas" de los Arribes del Duero en el occidente de Castilla y León.

Setos vegetales de separación. Pueden estar formados por restos de la vegetación arbórea y arbustiva original, o por ejemplares implantados ya adaptados a la zona. Son los también denominados setos verdes. Ayudan a dar continuidad visual y ecológica entre las zonas agrícolas y el bosque, constituyendo verdaderos corredores para la fauna. A ellos nos referiremos con mayor detalle en posteriores apartados, debido a su valor potencial en la recuperación ambiental del paisaje agrario.

Caminos rurales. Estas vías crean tramas de gran interés, sobre todo cuando tienen trazados no excesivamente geométricos y están flanqueadas por arbustos o árboles de sombra. Además de tratarse de infraestructuras de comunicación rural, pueden ser muy interesantes como vías verdes para caminantes y ciclistas.

Bancales. Son aterrazamientos de cultivos hechos con pequeños muros de contención de gravedad, construidos con piedra o aprovechando la compacidad del terreno (Figura 3.10). 


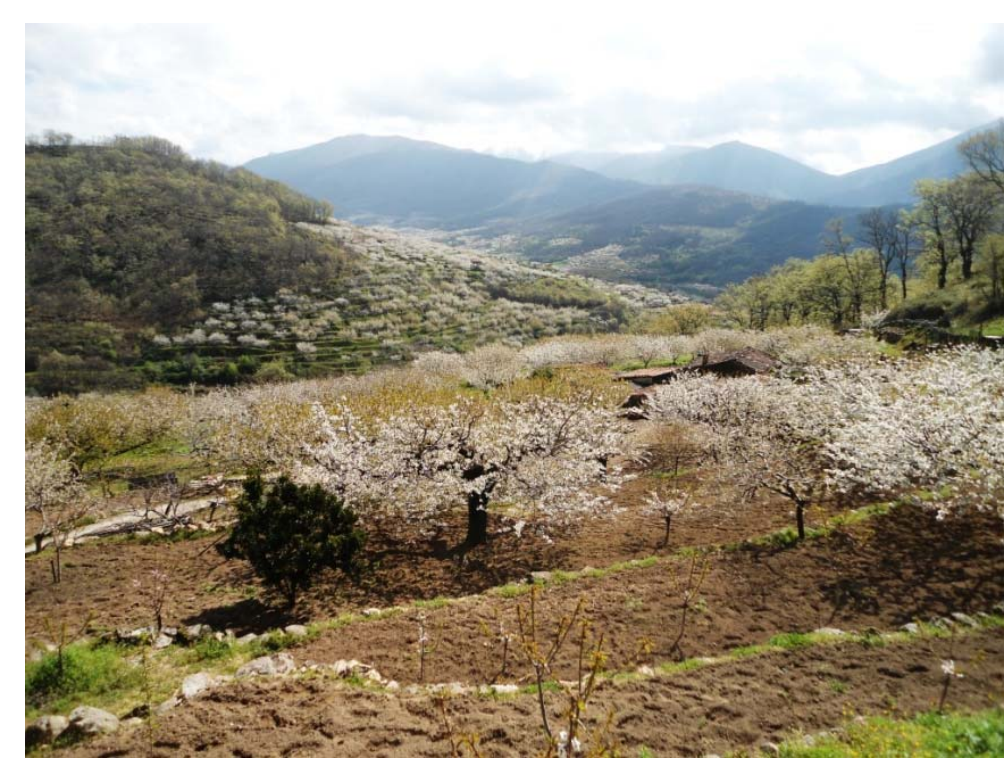

Figura 3.10. Bancales construidos para el cultivo de cerezos, en el valle del Jerte. En la época de floración, se trata de uno de los paisajes agrícolas de mayor belleza de nuestro país.

Pantallas de árboles cortavientos. Características de zonas donde soplan vientos de gran intensidad, como los existentes en las comarcas de Monegros (Aragón) o Ampurdán (Cataluña). Generalmente están formadas por cipreses o chopos piramidales.

El mosaico. Depende fundamentalmente de la parcelación, del cultivo y de la orografía. Aparece más en cultivos medios o de minifundio. El paisaje diferenciado o de "bocage" posee una mayor calidad estética y ecológica que el monocultivo intensivo.

Vegetación herbácea de los márgenes. Las erróneamente llamadas "malas hierbas", que crecen en los márgenes de los caminos y campos en primavera, constituyen un elemento importante del paisaje que se debe proteger. Los herbicidas son su peor enemigo.

Los canales de riego. Generalmente se dan en zonas secas próximas a las riberas de los ríos. Los canales más antiguos suelen ir acompañados de vegetación de ribera, como consecuencia de las filtraciones de agua y de la existencia de franjas longitudinales sin labrar. También tienen un gran potencial como vías verdes.

Balsas de riego. De tamaños y tipologías muy variadas, son características de la agricultura mediterránea que introdujeron los árabes. Tienen gran valor paisajístico por la generación del elemento agua en zonas secas.

Alineaciones arboladas. Pueden situarse en el acceso a ciertas edificaciones, márgenes de antiguas carreteras, márgenes de caminos (Figura 3.11), etc. Se utilizan diversas especies: cipreses, olmos, plátanos, etc. Las sombras que dibujan en el camino también refuerzan la alineación, a la vez que mejoran el confort ambiental y el valor estético del paisaje. Un ejemplo paradigmático es el de los cipreses de la Toscana italiana (Figura 3.5). 


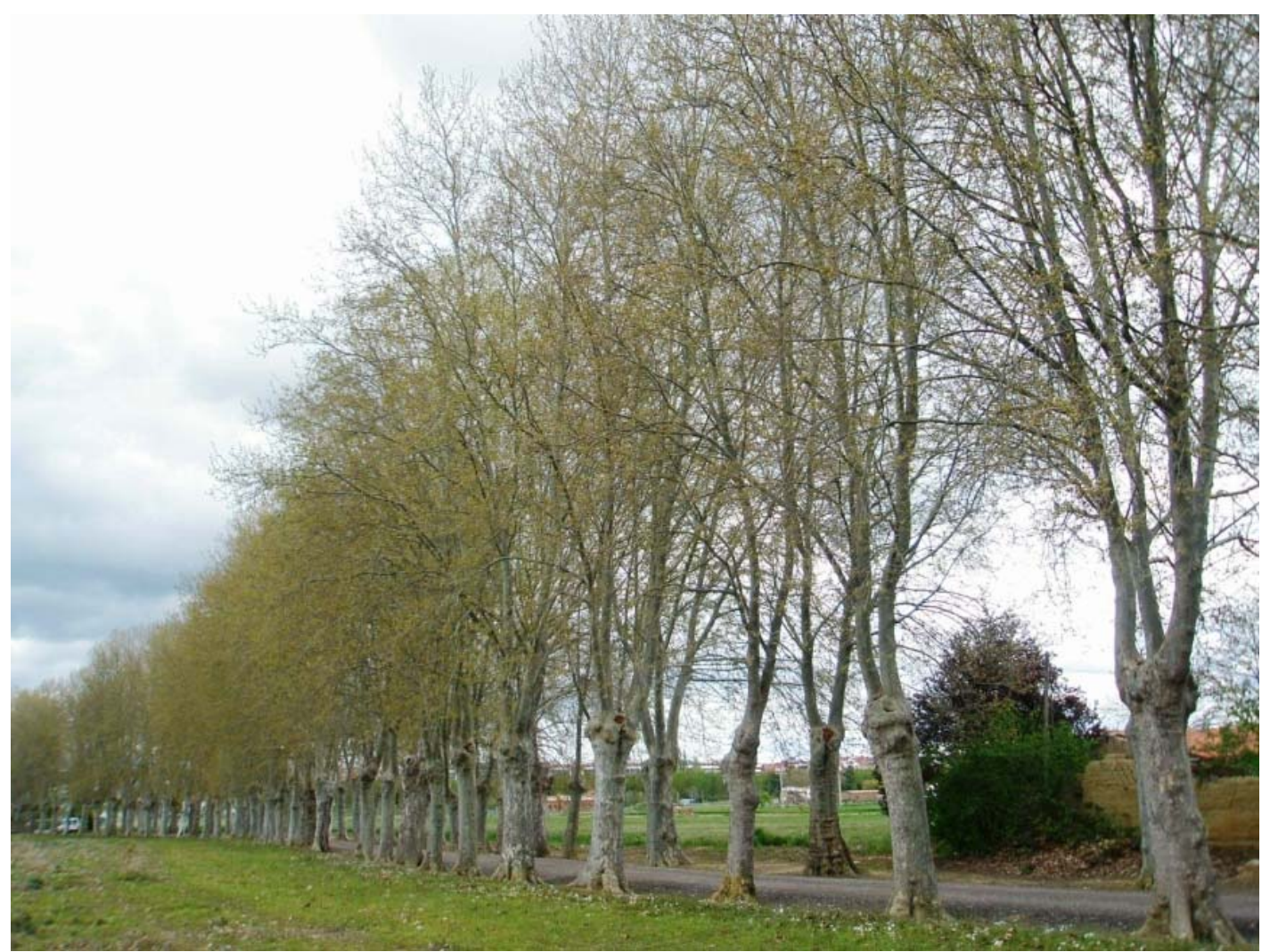

Figura 3.11. Alineación de plátanos en torno a un camino en una zona de huertas de Palencia, una de las escasas alineaciones arboladas en vías de Tierra de Campos.

El Consejo de Europa (2009) señala el gran valor de las alineaciones arboladas de las carreteras en el paisaje rural (Figura 3.12), que se manifiesta desde diferentes puntos de vista: patrimonio que proporciona identidad a un territorio, elemento caracterizador de la arquitectura de un paisaje, expresión del paisaje cultural, aumento de la belleza del paisaje, generación de calma y bienestar, mitigación del cambio climático, creación de microclimas, aumento de la biodiversidad, inducción de turismo y desarrollo rural. No obstante, tal vez el beneficio más sorprendente es el que se deriva de un mayor confort y seguridad en la conducción, que choca con los postulados que imperan desde la segunda mitad del siglo pasado, por los que se talaron un gran número de alineaciones arboladas en Europa debido a la alta accidentalidad. 

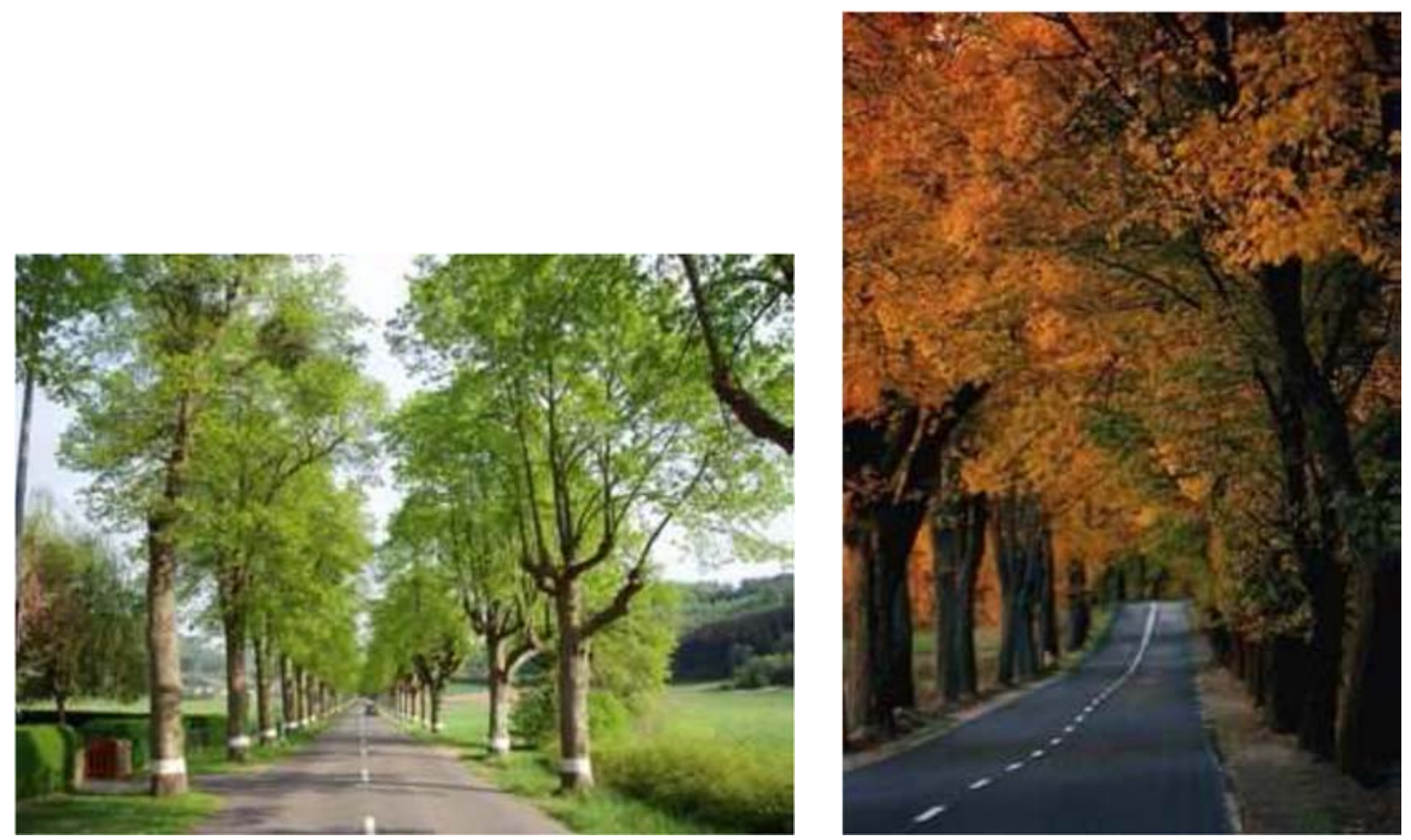

Figura 3.12. Ejemplos de alineaciones arboladas en Luxemburgo y Polonia (Consejo de Europa, 2009), donde se aprecia la belleza que generan en el paisaje interno de la carretera.

Árboles heráldicos. Algunos árboles, por su forma o especial simbología, se han usado en el entorno de las casas: palmeras, robles, cipreses, plátanos, etc.; se convierten en un hito y las identifican.

Fuentes. Se trata de captaciones de agua, que suelen constar de un pequeño depósito construido y un abrevadero (Figura 3.13). Los objetivos tradicionales de estos elementos han sido dar de beber al ganado y, si la calidad del agua es buena, servir de abastecimiento a la población. Su valor es importante, tanto como elemento del patrimonio etnográfico, como motivo de diversificación del paisaje.

Árboles aislados. En los paisajes cerealistas una constante es la práctica ausencia de vegetación arbolada. Por ello, la presencia de árboles aislados de cierta envergadura (Figura 3.14) dota de carácter al paisaje, modificando la textura, aumentando la diversidad cromática y ecológica, etc. 

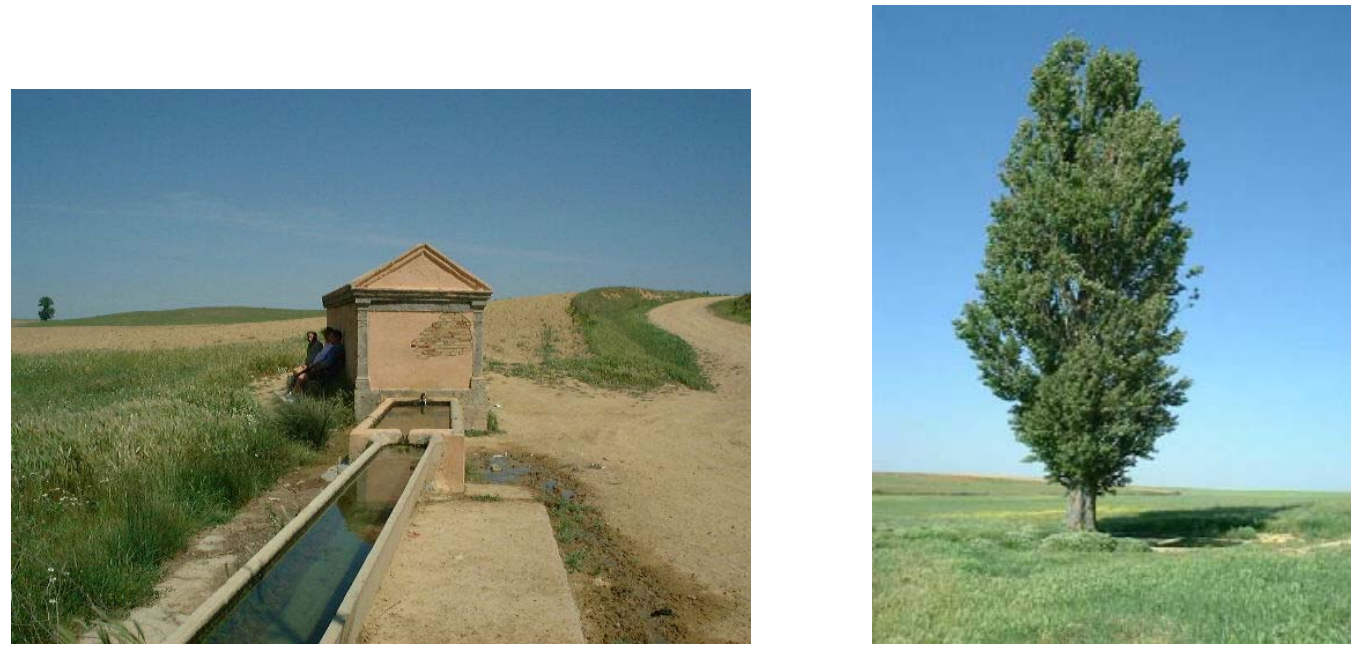

Figura 3.13. Izquierda, fuente El Rosario (Villalón de Campos). Figura 3.14. Derecha, chopo de gran envergadura en la fuente Cortaelaire (Villalón de Campos).

Referencias topográficas. En los paisajes de llanura, los elementos orográficos singulares (cerros, tesos, hondonadas, etc.) contribuyen a caracterizar un determinado territorio, a la vez que le aportan diversidad estructural.

\subsubsection{La arquitectura rural.}

La arquitectura rural forma la parte más amplia de la denominada arquitectura popular o vernácula. Sus componentes, junto con sus cultivos, conforman la imagen de su paisaje y dependen fundamentalmente de los siguientes factores que la diferencian (NAVÉS et al., op.cit.):

- El uso, que responde a las necesidades de sus moradores en el medio rural. Este uso personalizado hace que sea una arquitectura variada y que huye de la masificación propia de muchas de las viviendas de las ciudades.

- Los materiales utilizados son predominantemente los de la zona; es una arquitectura sin pretensiones que asegura una adecuada integración en el paisaje.

- La tecnología constructiva siempre es la tradicional, que ha demostrado su eficacia a lo largo de los siglos, lo cual supone equilibrio y sostenibilidad.

- El tamaño, que es distinto en la producción doméstica que en la industrial o intensiva.

Dentro de la arquitectura rural, estos autores consideran los siguientes grupos de edificaciones:

La casa rural aislada, los pequeños caseríos y los pueblos rurales. Cada una de estas agrupaciones de viviendas responde a una forma histórica de poblamiento. FLORES (1990) divide la arquitectura popular de los pueblos en función del material principal: de piedra, de adobe, de madera y de estucos. Es importante que los edificios de nueva construcción se adapten a las construcciones ya existentes, y si se utiliza una arquitectura actual, que los materiales y la tecnología respeten la arquitectura tradicional de la zona. 
Iglesias, ermitas y cementerios; cuya situación puede ser en el interior de los núcleos o diseminados por el campo. Configuran una de las partes más relevantes del patrimonio histórico-artístico rural.

Las construcciones anexas a las casas (cabañas, barracas, edificios hortícolas, hórreos, palomares, molinos, etc.), que suelen tener un carácter tradicional y pueden ubicarse contiguas a las viviendas o aisladas. Estas edificaciones poseen un tamaño relativamente reducido, un alto valor patrimonial y están muy integradas en el paisaje.

Las construcciones ligadas a la industria rural. Las edificaciones más abundantes de este grupo son las de carácter agropecuario (silos, almacenes, granjas, etc.). Estos elementos han cambiado sustancialmente para adecuarse a las mayores dimensiones, nuevos materiales y tecnología actual, como utilización de estructuras metálicas o de hormigón pretensado, elementos de muros prefabricados, etc. por lo que, en muchas ocasiones, producen considerables distorsiones en el paisaje.

Por otro lado, aunque en el medio rural la actividad industrial propiamente dicha es considerablemente inferior que en el medio urbano, la realidad es que se pueden implantar edificaciones de carácter variado en las zonas periurbanas de los pueblos y en el suelo rústico: industrias de transformación de productos agrarios y ganaderos, plantas de tratamiento de materiales mineros, plantas de tratamiento de residuos, etc. En este caso se cumplen los mismos parámetros señalados anteriormente, produciéndose incluso mayores impactos visuales sobre el paisaje. Estas alteraciones han generado la aparición de distintos grupos de investigación, que pretenden diagnosticar los impactos en el paisaje y proponer medidas preventivas y correctoras; de entre ellos destaca el denominado PADOC (Patrimonio, paisaje, documentación gráfica y construcción agroforestal), liderado por Ignacio Cañas Guerrero.

\subsubsection{Los paisajes rurales de campiñas españoles.}

Dentro del paisaje rural, los paisajes rurales de campiñas ocupan en España una considerable extensión. En el Atlas de los Paisajes de España (MATA y SANZ, 2004) -que es la primera gran caracterización de los diferentes tipos de paisaje de nuestro país, realizada en aplicación del Convenio Europeo del Paisaje, y por ello obra de referencia en este estudio- se diferencian las Campiñas como una de las 34 asociaciones de tipos de paisajes presentes en España (Figura 3.15), tal vez, de las de mayor superficie y representación territorial. No en vano, en esta asociación se distinguen cuatro tipos de paisajes: Campiñas de la Meseta Norte (del norte del Duero, del sur del Duero, segovianas, del sur de Burgos y sorianas), Campiñas de la Depresión del Ebro, Campiñas de la Meseta Sur (extremeñas, de la fosa del Tajo y manchegas) y Campiñas Andaluzas (olivareras, cerealistas y de viñedo y olivar). 


\section{- Cartografía de los paisajes de España}

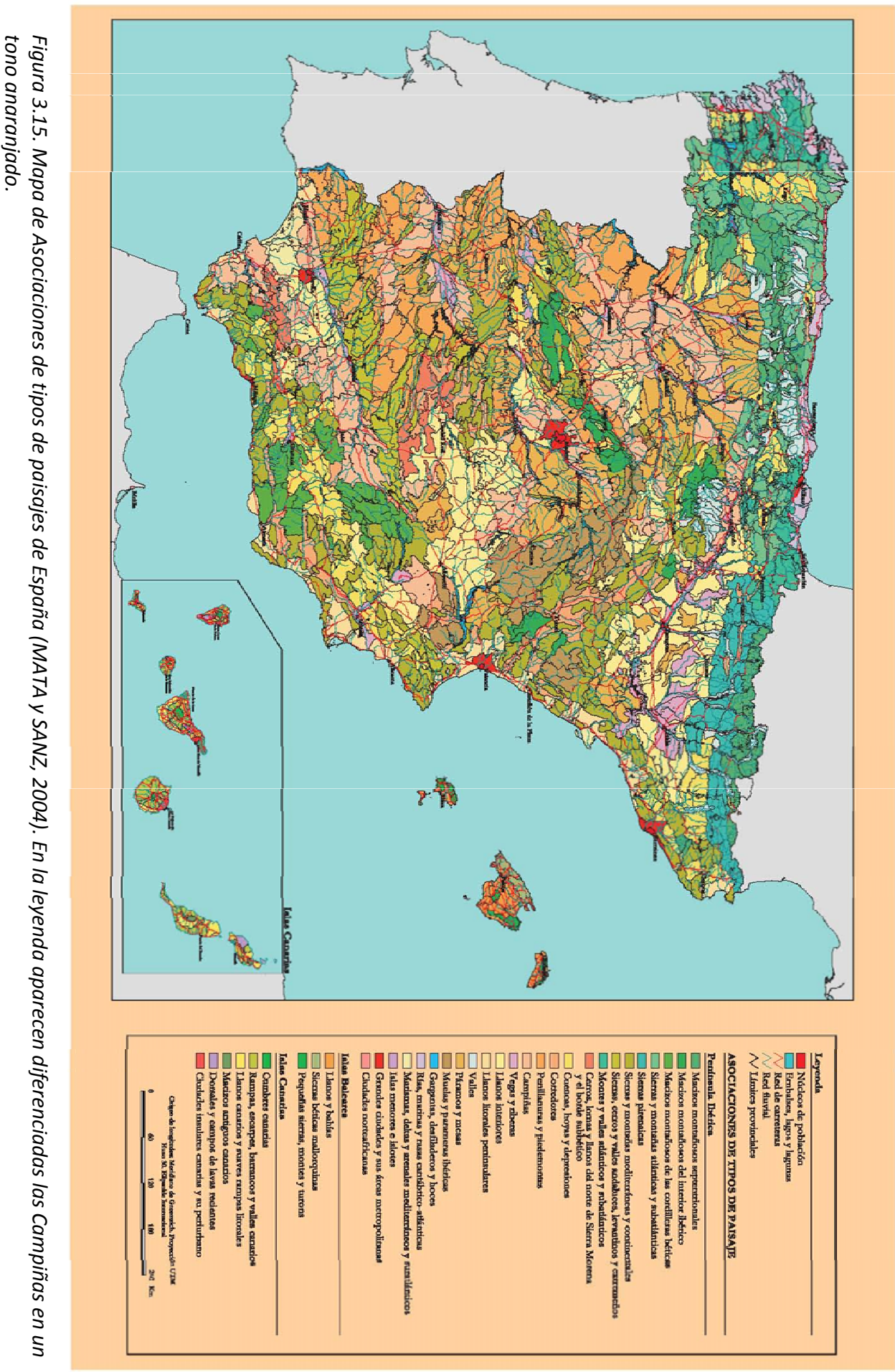


El paisaje de las campiñas ibéricas se caracteriza, por encima de variantes regionales, por dos rasgos principales. En primer lugar, por el predominio de formas suavemente alomadas, modeladas sobre materiales sedimentarios (arcillas, margas arcillosas, arcosas, etc.). En segundo lugar, por el uso agrícola casi exclusivo, con apenas presencia de vegetación natural, debido precisamente a las reducidas pendientes del terreno y la bondad de los suelos.

No obstante, condiciones edáficas y, sobre todo, agroclimáticas explican distintas peculiaridades de cultivo. Bajo los duros inviernos de la Meseta septentrional, las campiñas castellano-leonesas $y$, en parte, las de la Depresión del Ebro, se han especializado en cultivos herbáceos, fundamentalmente cerealistas. Esto ocurre también en las campiñas bajas de Andalucía, aunque aquí, por el alto contenido en arcillas de los suelos y las más favorables condiciones térmicas que hacen los inviernos menos severos, las campiñas se pueblan también de olivares y viñedos. Del mismo modo, en algunas campiñas extremeño-toledanas, estos cultivos leñosos se asocian a los cereales, formando un mosaico agrícola típicamente mediterráneo; en otras, forman extensos monocultivos de ámbito comarcal o regional, como sucede con los viñedos riojanos o con el olivar en varias unidades de campiña andaluzas (Figura 3.16).
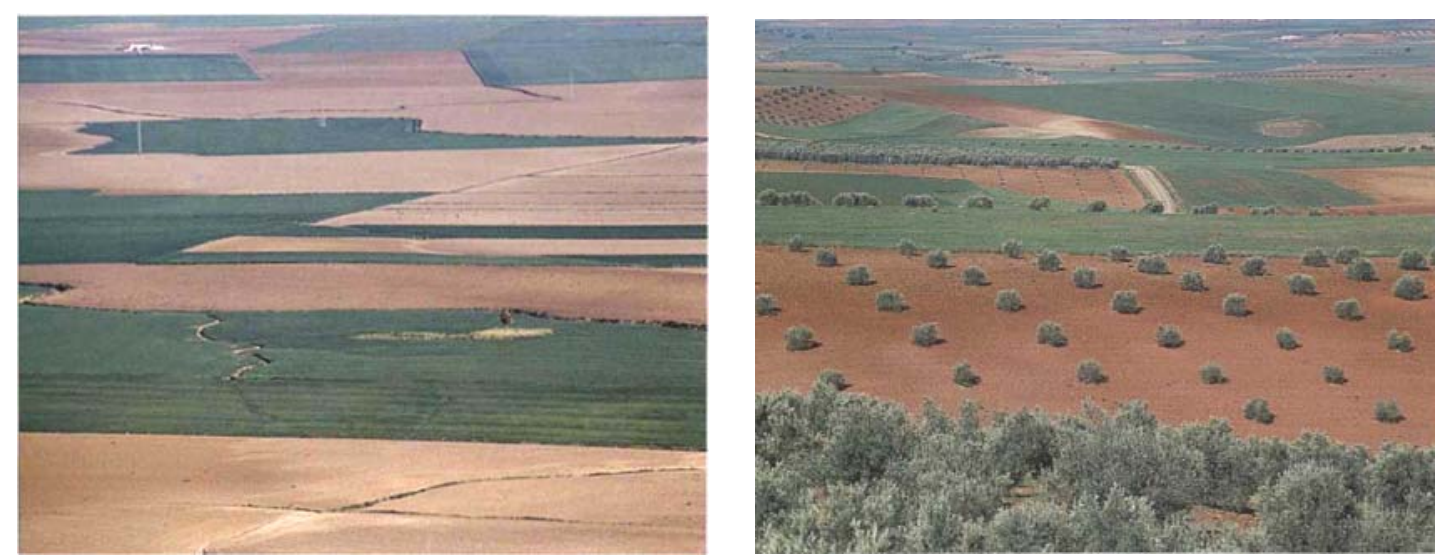

Figura 3.16. Izquierda, campiña de Gereña (Sevilla). Derecha, campiña de olivares en Villamanrique (Ciudad Real). En MATA y SANZ (2004).

En las campiñas, dominadas por la agricultura de secano, el poblamiento concentrado constituye otro elemento fundamental y reiterado de caracterización del paisaje. Pueblos de mayor o menor tamaño organizan los terrazgos, ocupando con frecuencia una posición central y culminante de las campiñas, que en muchas ocasiones fueron frontera cristiano-musulmana durante la Edad Media. Los pueblos se convierten en hitos y atalayas de unos paisajes en los que su larga historia agraria se refleja en la trama de los asentamientos, en un parcelario de fuertes contrastes entre el atomizado rompecabezas de las campiñas de la cuenca del Duero y los latifundios béticos.

La pérdida notable de población de las campiñas no ha supuesto reducción de la superficie labrada, gracias a la sustitución fácil de trabajo humano y animal por maquinaria y al aumento consiguiente de los niveles de rentabilidad, de modo que los paisajes agrarios campiñeses se caracterizan, desde ese punto de vista, por su estabilidad. Se han producido, no obstante, 
cambios que han afectado en detalle al paisaje, como la concentración parcelaria en la cuenca del Duero, o la expansión reciente del regadío por aspersión y la de los cultivos leñosos sobre terrazgos tradicionalmente herbáceos. La política agroambiental y de precios de la Unión Europea ha favorecido en los últimos años la ampliación de los barbechos blancos u "holgones", muy reducidos en los años setenta y ochenta del siglo pasado, con lo que el contraste tradicional entre siembras y barbechos, y su correlato de cambios cromáticos a los largo del año, se refuerza en los paisajes campiñeses. Sin embargo, las recientes modificaciones de la PAC promueven el uso agrícola continuado de las parcelas siempre y cuando se establezcan rotaciones de cultivos, lo que favorece la conservación de la calidad de los suelos y los contrastes paisajísticos.

\subsubsection{El paisaje de campiñas de la Meseta Norte: la llanura cerealista de Castilla y León.}

Siguiendo con la caracterización efectuada en el Atlas de los Paisajes de España (2004), las campiñas de la Meseta Norte es uno de los cuatro tipos de paisajes de campiñas españolas (Figuras 3.17). Este espacio, que tiene una superficie de centenares de miles de hectáreas al norte y al sur del río Duero, ocupado secularmente por abertales cerealistas, posee en las formas suavemente alomadas del relieve una de sus mayores señas de identidad. Los terrenos se modelan sobre arcillas y arcillas arenosas, interrumpidos puntualmente por bancos areniscosos, y cubiertos en áreas del sector suroriental por un depósito arenoso característico. La planitud y la debilidad de la red hidrográfica explica la existencia de áreas endorreicas, con láminas de agua habitualmente estacionales, salpicando las zonas más arcillosas y de menores pendientes, como ocurre en el entorno de la laguna de La Nava o en el de las lagunas de Villafáfila.

Los terrazgos han estado siempre organizados en torno a pequeños pueblos, integrantes de una densa red de núcleos hacia los que convergen caminos y carreteras, y que destacan en el horizonte por sus torres-campanarios y espadañas y -en el caso de los pueblos de mayor tamaño- por los silos construidos en los años cincuenta del siglo pasado por el Servicio Nacional del Trigo. 


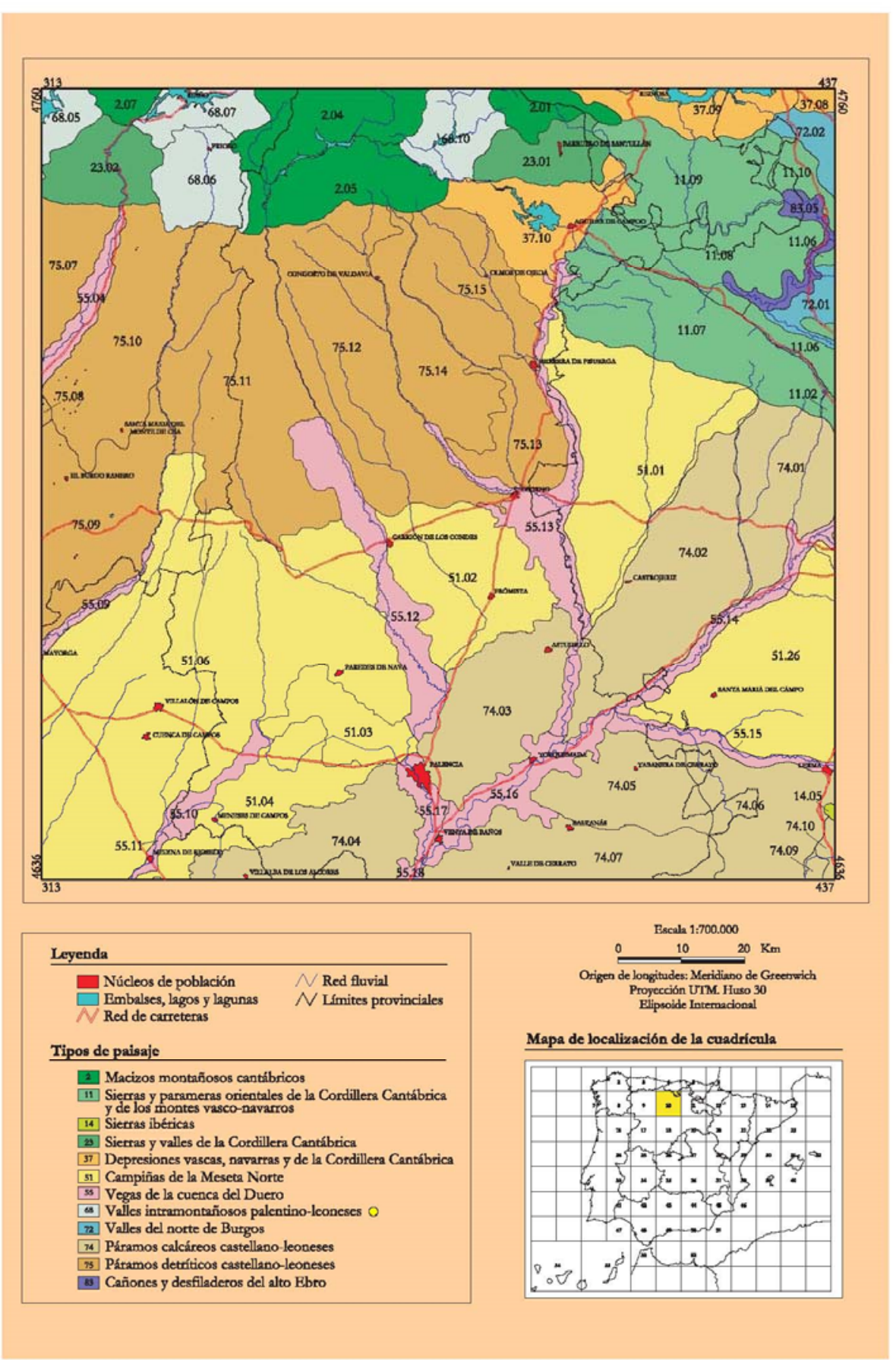

Figura 3.17. En amarillo, aparecen reflejadas parte de las Campiñas de la Meseta Norte. En esta hoja del Atlas se encuentra representada la mayoría de Tierra de Campos -salvo el extremo suroccidental zamorano- solo interrumpida por las Vegas de la cuenca del Duero (MATA y SANZ, 2004). 
El paisaje de las campiñas castellano-leonesas se encuentra en la actualidad notablemente transformado, como consecuencia de la reducción de barbechos, el arranque de viñedos, el aumento del tamaño de las parcelas motivado por la concentración parcelaria y el progresivo dominio de la cebada de siembra temprana. La eliminación de la vegetación natural presente en bosquetes, riberas, ribazos y linderos ha ocasionado una paulatina disminución de la diversidad biológica y paisajística. ORIA DE RUEDA (2011) apunta a que en Castilla y León la concentración parcelaria ha sido la culpable de la erradicación de gran parte del arbolado y los setos que imprimían un carácter ameno a las campiñas, vegas y páramos. A su vez, la reducción del periodo de rastrojo y la progresiva estabulación del ganado ovino está propiciando que ya no sean tan visibles los característicos rebaños de ovejas y sus pastores. En el entorno de los pueblos se construyen grandes naves de ganadería extensiva o de almacenamiento de productos agrícolas, que modifican sustancialmente las vistas características. Todo esto conlleva la imagen de un paisaje más productivo, pero a la vez más banal.

Dentro del tipo de paisaje Campiñas de la Meseta Norte, se diferencian una serie de subtipos, en los que a su vez se definen las distintas unidades de paisaje, como se puede apreciar en la Tabla 3.1.

Tabla 3.2. Subtipos y unidades de paisaje incluidas en el tipo 51. Campiñas de la Meseta Norte (MATA y SANZ, 2004)

CAMPIÑAS DEL NORTE DEL DUERO

\begin{tabular}{cl}
\hline & \multicolumn{1}{c}{ CAMPIÑAS DEL NORTE DEL DUERO } \\
\hline $\mathbf{5 1 . 0 1}$ & CAMPIÑAS ENTRE EL PISUERGA Y VILLADIEGO \\
\hline $\mathbf{5 1 . 0 2}$ & CAMPIÑAS ENTRE EL CARRIÓN Y EL PISUERGA \\
\hline $\mathbf{5 1 . 0 3}$ & CAMPIÑNAS DE LA NAVA \\
\hline $\mathbf{5 1 . 0 4}$ & CAMPIÑAS DE TIERRA DE CAMPOS AL NORESTE DE LOS TOROZOS \\
\hline $\mathbf{5 1 . 0 5}$ & $\begin{array}{l}\text { CAMPIÑAS CEREO-VITÍCOLA ENTRE LOS TOROZOS Y LA VEGA DEL } \\
\end{array}$ \\
\hline $\mathbf{5 1 . 0 6}$ & CISUERGA \\
\hline $\mathbf{5 1 . 0 7}$ & CAMPIÑAS DE TIERRA DE CAMPOS \\
\hline $\mathbf{5 1 . 0 8}$ & CAMPIÑNAS DE TÁBARA \\
\hline $\mathbf{5 1 . 0 9}$ & CAMPIÑAS DEL NORTE DE ZAMORA EN MONTAMARTA \\
\hline $\mathbf{5 1 . 1 0}$ & CAMPIÑAS DE TORO Y TORDESILLAS \\
\hline
\end{tabular}


Tabla 3.2. (Cont.) Subtipos y unidades de paisaje incluidas en el tipo 51. Campiñas de la Meseta Norte (MATA y SANZ, 2004)

\section{CAMPIÑAS DEL SUR DEL DUERO}

51.11 CAMPIÑAS PINARIEGAS DEL SUR DE VALLADOLID

51.12 CAMPIÑAS VITÍCOLAS DE MEDINA Y RUEDA

$\mathbf{5 1 . 1 3}$ CAMPIÑAS DE LA ARMUÑA

$\mathbf{5 1 . 1 4}$ CAMPIÑAS DE LA GUAREÑA

51.15 CAMPIÑAS DE LA TIERRA DEL VINO

51.16 CAMPIÑAS ADEHESADAS DE VALDELOSA

51.17 CAMPIÑAS DE PEÑARANDA DE BRACAMONTE Y DEL OCCIDENTE DE LA TIERRA DE ARÉVALO

51.18 CAMPIÑAS DE LA MORAÑA

51.19 CAMPIÑAS AL OESTE DE ALBA DE TORMES

$\mathbf{5 1 . 2 0}$ CAMPIÑA DEL SUR DE SALAMANCA

51.21 CAMPIÑAS ENTRE SALAMANCA Y CIUDAD RODRIGO

$\mathbf{5 1 . 2 2}$ CAMPIÑAS DEL SUROESTE DE CIUDAD RODRIGO

CAMPIÑAS SEGOVIANAS

51.23 CAMPIÑAS DEL ERESMA AL OESTE DE SEGOVIA

$\mathbf{5 1 . 2 4}$ CAMPIÑAS DE TURÉGANO-AGUILAFUENTE

51.25 CAMPIÑAS DE LA TIERRA DE AYLLÓN

CAMPIÑAS DEL SUR DE BURGOS

51.26 CAMPIÑAS Y PÁRAMOS ENTRE EL ARLANZÓN Y EL ARLANZA

CAMPIÑAS Y ALTOS CAMPOS SORIANOS

\begin{tabular}{cl}
\hline $\mathbf{5 1 . 2 7}$ & CAMPIÑAS DE LA TIERRA DE ALMAZÁN \\
\hline $\mathbf{5 1 . 2 8}$ & ALTOS DE MAJÁN \\
\hline $\mathbf{5 1 . 2 9}$ & ALTOS DEL CAMPO DE GÓMARA \\
\hline $\mathbf{5 1 . 3 0}$ & VALLES DEL UCERO Y EL AVIÓN Y ALTOS DE BURGO DE OSMA \\
\hline
\end{tabular}


SANZ-ZUASTI et al. (1995) analizan la riqueza ecológica -en especial, faunística- de este territorio, que denominan como la "Llanura cerealista de Castilla y León", y que consideran que abarca a 2 millones de las 9,4 millones de hectáreas que ocupa la comunidad autónoma (un 21 $\%$ de su superficie). En este documento se analiza la profunda transformación habida en este territorio que, a pesar de lo cual, posee importantes valores naturales merecedores de conservación.

Algunos autores como Mauricio Willkomm, Eduardo Reyes Prosper o Dantín Cereceda han utilizado el apelativo estepa cerealista para caracterizar desde una óptica naturalística gran parte de las llanuras de Castilla y León, pues presentan evidentes afinidades esteparias por el carácter semiárido del clima, la dureza y duración del invierno, los condicionantes edáficos y la escasa presencia de vegetación espontánea. A ello se le añade la presencia en estos hábitats de una avifauna definida como esteparia, principalmente la avutarda (Otis tarda) y el aguilucho cenizo (Circus pygargus). No obstante, publicaciones más rigurosas como el Avance geobotánico sobre la pretendida estepa central de España, realizadas en 1942 por el geógrafo Emilio Huguet del Villar, niegan el carácter natural de estas formaciones, explicándolas como el resultado de la secular intervención humana sobre el verdadero clímax, constituido por un bosque natural de quercíneas. El único elemento en común que posee la avifauna esteparia de las estepas reales y de la llanura cerealista es ser propia de medios abiertos. Por otra parte, tampoco se debe hacer corresponder el carácter salino de las lagunas de Villafáfila o la Nava con la existencia de un espacio de exiguas precipitaciones $-y$, en consecuencia, de naturaleza esteparia-, pues estas superan ampliamente los $300 \mathrm{~mm}$ al año; la génesis de estas zonas húmedas se encuentra en el endorreísmo y el carácter salino se relaciona con fenómenos geoquímicos del acuífero (GUERRA, 2010). También MARTíNEZ DE PISÓN (2002) citando a Pío Font Quer matiza el abuso del término estepa para designar las zonas desarboladas, pues "fuera de algún que otro rincón de tales o parecidas condiciones (de variedades de xeroestepa) y de las aréolas salinas adendras, todo cuanto se acostumbra a calificar de estepario son tierras desertizadas por el hombre, en su mayoría pertenecientes al territorio de la encina".

GIL (2010) realiza un análisis detallado de la paulatina destrucción del bosque en nuestro país, asumiendo que discurre en paralelo a la historia del ser humano. Su encendida defensa de la bondad del incremento de la superficie arbolada le lleva a poner en cuestión las tendencias actuales en materia de Espacios naturales y conservación, que prestan especial importancia a los matorrales o a la estabilización del paisaje humanizado. En el caso de la llanura cerealista castellana, la ausencia de arbolado ha hecho a numerosos autores asemejar este territorio a un ecosistema seminatural de "estepa o pseudoestepa cerealista", aunque ello no justifica de ningún modo que el bosque no cubriese originalmente prácticamente todo el territorio (salvo probablemente las zonas salinas endorreicas ligadas a lagunas). Aunque actualmente existan valores naturales ligados a la llanura cerealista -especialmente faunísticos-, no deben ser argumento para objetar la recuperación del arbolado en la llanura. Es decir, una cosa es que sea lógico mantener la esencia de la comarca como paisaje agrícola dominante y, otra bien distinta, es que no se hayan de realizar esfuerzos por recuperar -al menos en una pequeña parte- la superficie arbolada que pobló el territorio con anterioridad a la acción del hombre. 


\subsubsection{El paisaje de campiñas de Tierra de Campos.}

La comarca natural de Tierra de Campos, tal como la definiremos en el capítulo correspondiente, se caracteriza por pertenecer casi en su totalidad al tipo de paisaje de Campiñas de la Meseta Norte (Figura 3.18).

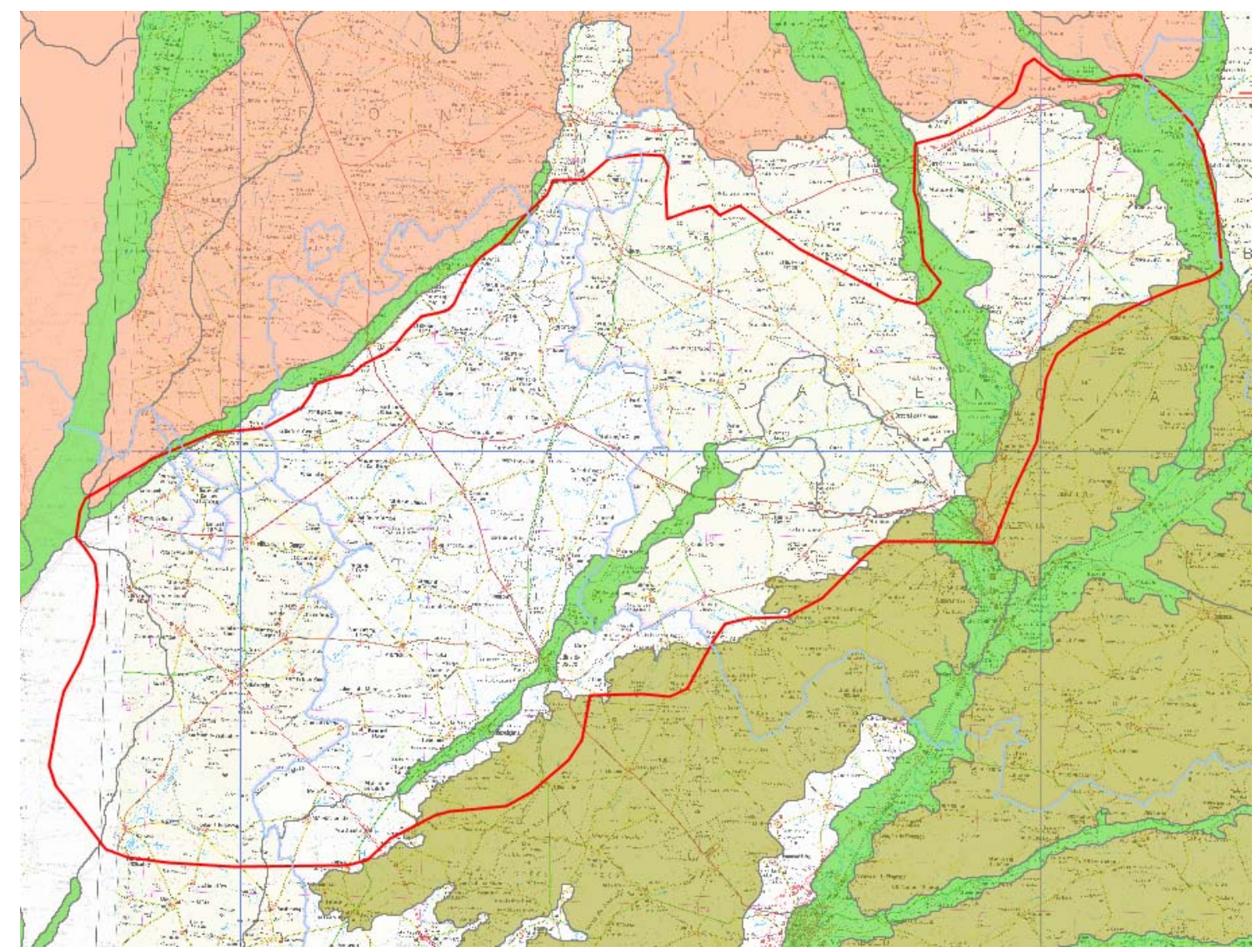

Figura 3.18. Plano topográfico de Tierra de Campos, donde se observa la gran coincidencia de la comarca (perímetro en rojo) con el tipo de paisaje de Campiñas (en fondo blanco, con intercalaciones verdes de las Vegas). Páramos detríticos y calcáreos son sus límites naturales al norte y al sur respectivamente.

Pero incluso el paralelismo existente entre esta comarca y su paisaje va aún más allá. En el Atlas referido, el paisaje de campiñas de Tierra de Campos es una de las unidades del subtipo Campiñas del Norte del Duero, la más representativa y la que tiene mayor extensión. Teniendo en cuenta que será descrita con mucho mayor detalle en el apartado de caracterización del paisaje de Tierra de Campos, aquí solo daremos unas pequeñas pinceladas de sus rasgos generales.

Desde el punto de vista geomorfológico, se trata de una campiña de extensas llanuras suavemente onduladas, apenas modificadas por la incisión de una débil red fluvial. El uso del suelo es su principal característica: estamos ante un extenso abertal de cultivos cerealistas, con grandes parcelas e infraestructuras regularizadas. El caserío es compacto, con pequeños pueblos en los que destacan las torres de las iglesias, y una arquitectura tradicional basada en el empleo de la tierra. Los palomares son su elemento más singular. En la actualidad uno de los aspectos 
de transformación más perceptibles son las diversas construcciones -naves agrarias, sobre todoque se han ido edificando en los espacios periurbanos, que han cambiado notablemente la imagen de los pueblos.

\subsection{Paisaje y medio ambiente: dos conceptos asociados.}

\subsubsection{El paisaje como manifestación externa del medio y como recurso socioeconómico}

De forma genérica se entiende por medio ambiente el entorno vital que constituye nuestro soporte físico y nos provee a los hombres de bienes y servicios, y cuyo conocimiento, estudio y manejo supone el de los sistemas naturales (ecosistemas) y los sistemas culturales (sistemas humanizados). Aunque hay muchas otras definiciones, todas coinciden en lo que se refiere al entorno vital, es decir, todo aquello que en suma rodea al hombre y le condiciona. El concepto de medio ambiente es, por consiguiente, mucho más amplio que los tradicionales de naturaleza o de medio natural, que se encuentran ya muy asimilados en nuestro lenguaje. Lo cierto es que irrumpe con tal fuerza, que trasciende el ámbito de la conservación de la naturaleza, abriéndose a campos tan diferentes como la arquitectura, la psicología o la salud.

Ahora bien, un concepto tan amplio necesita para su estudio de la descomposición en elementos: son los que se denominan factores ambientales. Se trata de una serie de variables susceptibles de ser inventariadas, cartografiadas, medidas, valoradas y tratadas. La Ley $21 / 2013$, de 9 de diciembre, de evaluación ambiental, define los siguientes: la población, la salud humana, la flora, la fauna, la biodiversidad, la geodiversidad, el suelo, el subsuelo, el aire, el agua, los factores climáticos, el cambio climático, el paisaje, los bienes naturales incluido el patrimonio cultural, y la interacción de todos ellos.

Así, de acuerdo con esta interpretación, el paisaje es uno más dentro de los factores ambientales. Bien es cierto que, desde la óptica medioambiental, el paisaje se suele tratar desde la perspectiva de la percepción visual, encontrándose la ecología del paisaje en el compendio de otros factores: vegetación, fauna, ecosistemas, etc. Realmente, tanto paisaje como medio ambiente son conceptos transversales, asociados a un determinado territorio, pero que integran múltiples variables del medio.

En esta línea, GÓMEZ OREA (2003) considera que el paisaje es la expresión externa polisensorialmente perceptible del medio: el medio se hace paisaje cuando alguien lo percibe. Dicho de una forma más sencilla: el paisaje es el medio ambiente percibido. Esta percepción se produce de una vez sobre el conjunto del sistema ambiental; es subjetiva, variable en razón del tipo de perceptor y se adquiere a través de todos los órganos de percepción que operan en el observador: vista, oído, olfato, tacto,... El paisaje se concibe como un factor ambiental ligado a una experiencia subjetiva, aunque esta subjetividad no invalida la posibilidad de aproximarse a su análisis con unas mínimas garantías de objetividad, por cuanto existen elementos positivos y negativos en la percepción ampliamente compartidos desde diversas disciplinas. 
El paisaje, en cuanto manifestación externa del medio, es un indicador del estado de los ecosistemas, de la salud de la vegetación, de las comunidades animales, del uso y aprovechamiento del suelo y, por tanto, del estilo de desarrollo de la sociedad y de la calidad de su gestión.

Este autor considera que el paisaje es un recurso en el sentido socioeconómico del término, porque cumple la doble condición de utilidad y escasez; utilidad para la población y escasez para que resulte realmente un bien económico. En este sentido, que el paisaje de calidad es útil al hombre es evidente, siendo apreciado de forma variable aunque con ciertas constantes:

- Positiva para un gran número de componentes: relieve variado, presencia de agua limpia y en movimiento, de vegetación frondosa, de elementos topográficos sobresalientes, de sonidos y olores gratos, de orden, de posibilidad de observar animales silvestres, etc.

- Negativa para otras: presencia de escombros y basuras, de agua sucia y/o estancada, de olores pestilentes, de sonidos discordantes como el ruido del tráfico, de edificaciones construidas con materiales, colores y diseños estridentes, de monotonía excesiva, etc.

De igual modo, que el paisaje de calidad es escaso también resulta obvio, teniendo en cuenta la degradación paisajística de buena parte del territorio provocada por actividades de diversa naturaleza: instalaciones industriales, urbanizaciones, infraestructuras de todo tipo, agricultura intensiva, minería, depósitos de residuos, etc.

Existe una demanda generalizada, creciente y cualificada por el paisaje de calidad. Paralelamente, la oferta de paisaje resulta cualitativamente decreciente $y$, en consecuencia, el paisaje de calidad adquiere el carácter de recurso crecientemente escaso. En este sentido, cabe afirmar que, si la demanda de paisaje se concentra en el medio urbano, la oferta se encuentra en el medio rural. Y dentro de los paisajes rurales, además de las escasas zonas naturales sin práctica intervención humana, destacan aquellos donde la actuación del hombre se ha realizado de una forma sostenible: estructuras agrarias tradicionales con presencia de muros secos o setos vivos, aterrazamientos en pendientes elevadas, paisajes en mosaico con espacios forestales, etc. Es decir, un paisaje de calidad no tiene por qué ser exclusivamente un espacio natural protegido; también lo son muchos paisajes rurales que mantienen una alta diversidad ecológica y contienen valores estéticos dignos de significación.

Si se atribuye al paisaje la condición de recurso económico debería ser inventariable, valorable y explotable mediante actividades de tipo social o económico. El recurso paisaje es valorable no solo en términos de su grado de excelencia intrínseco, sino también a través de las actividades económicas que genera o que encuentran su justificación en la presencia de un paisaje de calidad. Se trataría de una especie de valor potencial de uso, de un recurso renovable susceptible de ser inventariado, valorado y utilizado.

Esta línea de asociar el paisaje como recurso natural es también asumida por otros autores como ESCRIBANO (2008), que profundiza en cómo abordar su análisis y valoración.

Desde esta perspectiva, podemos afirmar que el paisaje es una oportunidad para el desarrollo de muchos espacios rurales y, en particular, de la comarca cerealista de Tierra de Campos. 
Teniendo en cuenta la regresión demográfica y económica de la zona, se debe considerar la posibilidad de mejorar la calidad de su paisaje porque su valor potencial es evidente. Cuando desde la disciplina del Desarrollo Rural se habla de la potenciación de los recursos endógenos, no se debe olvidar que el primer recurso endógeno de un territorio es su paisaje.

\subsubsection{Problemática ambiental y paisajística en las campiñas cerealistas de Tierra de Campos}

Lamentablemente, la incidencia que las actividades realizadas por el ser humano tienen en su propio entorno suele ser desfavorable. Por ello el concepto de medio ambiente se utiliza casi siempre a la defensiva, con una connotación más negativa que positiva. Ello es así porque el propio modelo de desarrollo que se ha escogido desde hace décadas así lo exige: fuertemente consumista, devorador de recursos, necesitado de grandes superficies de territorio para sus actividades, etc. El resultado no puede ser otro al de la existencia de una serie de problemas de muy diversa índole que afectan al medio que rodea al hombre.

En las campiñas cerealistas de Tierra de Campos la actividad humana no es muy intensa, por la baja densidad demográfica de su territorio, aunque no están exentas de incidencias sobre su medio ambiente. A continuación se detallan de forma esquemática los principales problemas ambientales, con especial atención a los de naturaleza paisajística, diferenciándolos por sectores productivos:

\section{AGRICULTURA}

- Pérdida de biodiversidad aparejada a la adopción de una agricultura productivista. La concentración parcelaria llevada a cabo en todo el territorio en las décadas de los sesenta y setenta del siglo pasado, e incluso la reconcentración reciente de algunas zonas, ha ocasionado una profunda simplificación del mosaico de parcelas tradicional. Además se han eliminado la mayoría de linderos arbustivos, pequeñas zonas húmedas, sotos y arbolado disperso, en aras de un aprovechamiento intensivo agrícola. Es el impacto que tiene una mayor connotación paisajística.

- Erosión de las capas fértiles del suelo por el laboreo de terrenos en pendientes inadecuadas. Aunque la comarca es eminentemente llana, a pequeña escala existen ondulaciones topográficas donde, para determinados episodios de lluvia de intensidad elevada, se pueden ocasionar significativas tasas de erosión hídrica. Este proceso se acrecienta en los tesos cultivados y en las cuestas de transición del páramo a las campiñas, muchos de cuyos terrenos han vuelto a ser cultivados como consecuencia de las subvenciones de la política agraria común y el buen precio actual de los cereales.

- Incendios agrícolas y forestales. En Tierra de Campos la superficie forestal es muy escasa: se restringe a pequeñas masas de quercíneas y a los pinares de repoblación ubicados en las cuestas. No por ello se debe obviar este riesgo, que tiene una importancia cualitativa muy alta. Por otra parte, la quema de rastrojos -que 
afortunadamente actualmente se restringe a circunstancias muy puntuales- es muy perjudicial, al degradar la estructura de los suelos como consecuencia de la eliminación de la materia orgánica vegetal, generar la emisión de gases contaminantes a la atmósfera, aportar cenizas a ríos y arroyos y provocar un fuerte impacto paisajístico. Mayor gravedad tiene la quema de linderos y arroyos por motivos específicos, como la lucha para el control del topillo campesino (Figura 3.19), que aniquila los únicos retazos de vegetación arbustiva de toda la matriz agrícola y elimina los refugios de la fauna silvestre.
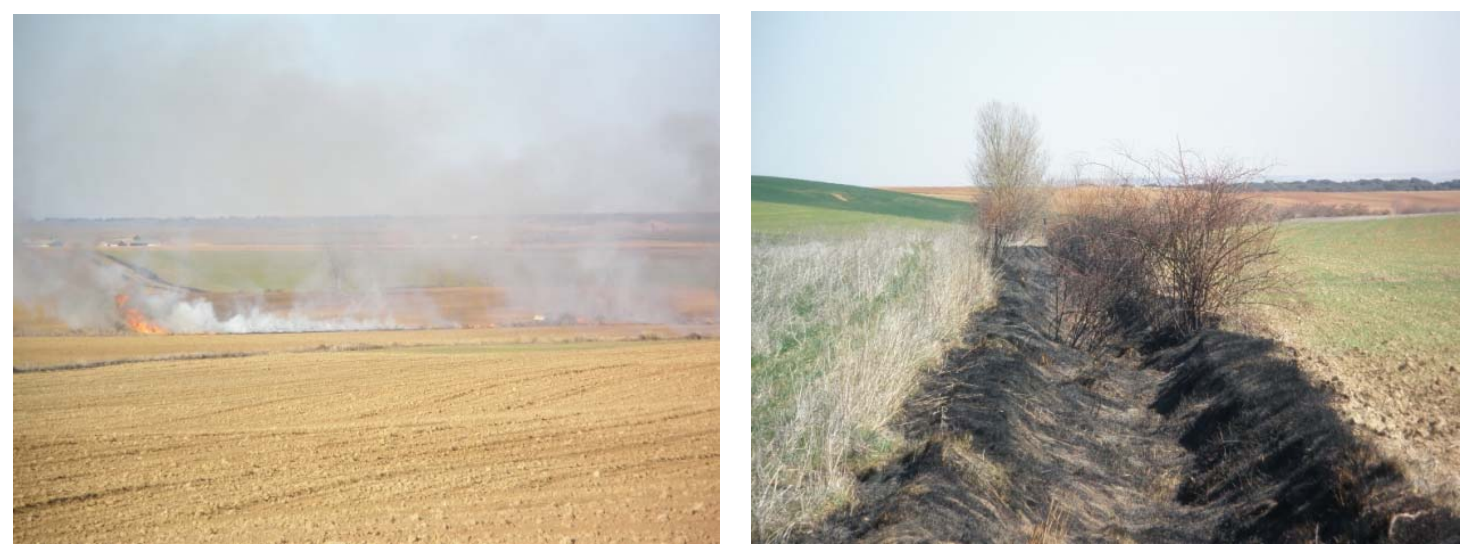

Figura 3.19. Quemas de regueras con arbustos en Becerril de Campos en febrero de 2012, para el control del topillo campesino, que fueron generalizadas en la comarca.

- Contaminación agraria difusa, provocada por la incorporación en los horizontes edáficos de sustancias contaminantes derivadas de la aplicación de fertilizantes, herbicidas y plaguicidas. De entre ellas, destaca por su importancia la correspondiente a los fertilizantes de tipo nitrogenado. De acuerdo con el Código de Buenas Prácticas Agrarias (JUNTA DE CYL, 1998), la contaminación difusa por nitratos es el vertido indiscriminado del ión $\mathrm{NO}_{3}$ en el suelo y consecuentemente en el agua, hasta alcanzar los $50 \mathrm{mg} / \mathrm{l} \mathrm{de}$ concentración máxima admisible y/o $25 \mathrm{mg} / \mathrm{l}$ como nivel guía o recomendado. Su mayor efecto es la contaminación de las aguas del nivel freático, que dejan de ser viables como agua potable. También entraña una enorme gravedad el uso a gran escala del glifosato (de nombre comercial Roundup), herbicida no selectivo o total de amplio espectro; en la actualidad se emplea en la preparación de la siembra directa del cereal y en la del girasol, aunque también afecta en muchas ocasiones a cunetas, regueras y arroyos.

- Pérdida general de cualidades del suelo (materia orgánica, estructura), teniendo en cuenta que las extracciones de biomasa vegetal realizadas a lo largo de miles de años han sido excesivas, no siendo compensadas con abonados orgánicos. Ello se acrecienta con el cambio de modelo tradicional (cultivos de "año y vez", que dejan descansar las tierras) a productivista (que siembra el cereal cada año, ayudado con los abonos minerales). El porcentaje medio de materia orgánica en los suelos de Tierra de Campos se halla muy por debajo del $2 \%$ recomendable.

- Despoblación rural, como consecuencia entre otras cosas de la adopción de unas prácticas agrarias que necesitan unos bajos índices de mano de obra. La superficie 
media por explotación ha ido aumentando con el paso de los años, sobre todo por la aparición de una maquinaria potente capaz de realizar las labores agrícolas de un modo muy eficiente. No hay que olvidar que la población es la principal variable del factor socioeconómico y, tal como se ha señalado anteriormente, uno de los factores ambientales a tener en cuenta en cualquier análisis territorial. En Tierra de Campos, la despoblación es sin lugar a dudas uno de sus mayores problemas medioambientales.

\section{GANADERÍA}

- Compactación de los suelos, cuando el pastoreo es excesivo. Ello provoca una disminución de la tasa de infiltración en el terreno y, como consecuencias, menor humedad edáfica y aumento de la escorrentía superficial y del riesgo de erosión hídrica. En la actualidad se aprecia, no obstante, una continua reducción de la ganadería extensiva por la intensiva, por lo que este problema alcanza una menor intensidad.

- Contaminación de las aguas por nitratos, provocada por la incorrecta gestión de los residuos ganaderos de las explotaciones ganaderas intensivas. El Código de Buenas Prácticas Agrarias antes citado diferencia entre estiércol bovino, lisier bovino, lisier porcino, estiércol de ovino o sirle y gallinaza. Un primer problema de gestión es el estercolero o la balsa de purines, que deben asegurar la impermeabilidad sobre el terreno y la ausencia de escurrimientos. En cuanto al aporte a las tierras, los abonos sólidos (mezclados con paja) son de lenta descomposición pero mejoran mucho la estructura. Los abonos líquidos, por el contrario, presentan mayores riesgos medioambientales pues, aunque su mineralización es rápida, poseen fuertes pérdidas por volatilización y pueden contaminar las aguas superficiales por escorrentía.

- Generación de olores desagradables procedentes de los residuos ganaderos. La principal causa de olor es su acumulación y manipulación en las propias granjas, sobre todo cuando se sitúan próximos a los núcleos rurales y los vientos dominantes soplan hacia ellos. Su reparto a tierra también es una fuente de malos olores principalmente en el caso de los abonos líquidos, si es que no se mezclan inmediatamente en el terreno. Aunque algunos autores hablan de contaminación olfativa, desde nuestro punto de vista es realmente una alteración paisajística, en cuanto que percepción por dicho sentido. De hecho, en determinados núcleos con una alta cabaña ganadera, se trata de uno de los principales impactos ambientales o paisajísticos.

- Afección a la calidad visual del paisaje por la construcción de naves agro-ganaderas. En las últimas décadas están proliferando en los espacios periurbanos naves agrícolas y ganaderas de gran tamaño, que contrastan con las formas tradicionales de construcción en la comarca, mucho más sencillas. Si, además, los colores de las cubiertas y los paramentos son llamativos, se generan fuertes impactos visuales por contraste con los que dominan el entorno (ocres o tierras). 
- Disgregación de hábitats faunísticos, por el efecto barrera que ocasionan. Este impacto sobre todo es significativo en las autovías (Madrid-La Coruña y Camino de Santiago) y las líneas de ferrocarril de alta velocidad (tramo Palencia-León). El efecto barrera se considera el impacto ecológico más negativo de las infraestructuras de transporte; se basa en la dificultad que tienen los animales para cruzar la superficie de la vía. La dificultad para superar estas barreras y desplazarse entre los distintos fragmentos de hábitat, puede conllevar la extinción de determinadas poblaciones de fauna silvestre (MMA, 2006). La fragmentación de hábitats es un impacto asociado al paisaje ecológico, que constituye una de las principales amenazas para la conservación de la diversidad biológica.

- Impacto visual, como consecuencia de la irrupción en el entorno de obras civiles de gran envergadura. Nuevas carreteras, autovías o ferrocarriles de alta velocidad generan terraplenes de considerable altura y morfologías regulares que alteran las visuales características de la llanura. Además, estas obras necesitan de instalaciones auxiliares necesarias en su funcionalidad: biondas de protección, carteles, vallas, infraestructura eléctrica, que generan mayores impactos sobre la calidad visual del territorio.

- Ocupación irreversible de elevadas superficies, con la consiguiente pérdida de suelo fértil para uso agrícola. No olvidemos que todas las nuevas infraestructuras se desarrollan sobre suelos productivos y que su superficie afectada es elevada. En este apartado se puede contemplar el efecto debido a la pérdida de hábitat para muchas especies de fauna, que será severo en el caso de la avifauna esteparia. También la posible afección al patrimonio arqueológico.

- Generación de elevadas superficies de préstamos y vertederos (Figura 3.20). Los préstamos son zonas de extracción de materiales -sobre todo áridos- necesarios para la construcción del firme y de las distintas bases hasta su capa final. Su superficie puede ser mayor incluso a la ocupada por la traza de la propia infraestructura. En el fondo, se trata de proyectos de explotaciones mineras que generan impactos ambientales asociados: ocupación de suelos agrícolas, posible afección a vegetación, alteración de hábitats faunísticos, probable afección al nivel freático y al sistema hidrológico superficial, impacto visual por la irrupción de taludes, afección a yacimientos arqueológicos, etc. En el caso de los vertederos, se trata de materiales sobrantes procedentes de la traza que han de ser depositados en alguna ubicación próxima a la misma, si es que no han podido verterse sobre algún hueco de extracción, que debería ser lo prioritario. Sus efectos principales son los relativos a ocupación de terrenos, impacto visual y posible riesgo de erosión. 

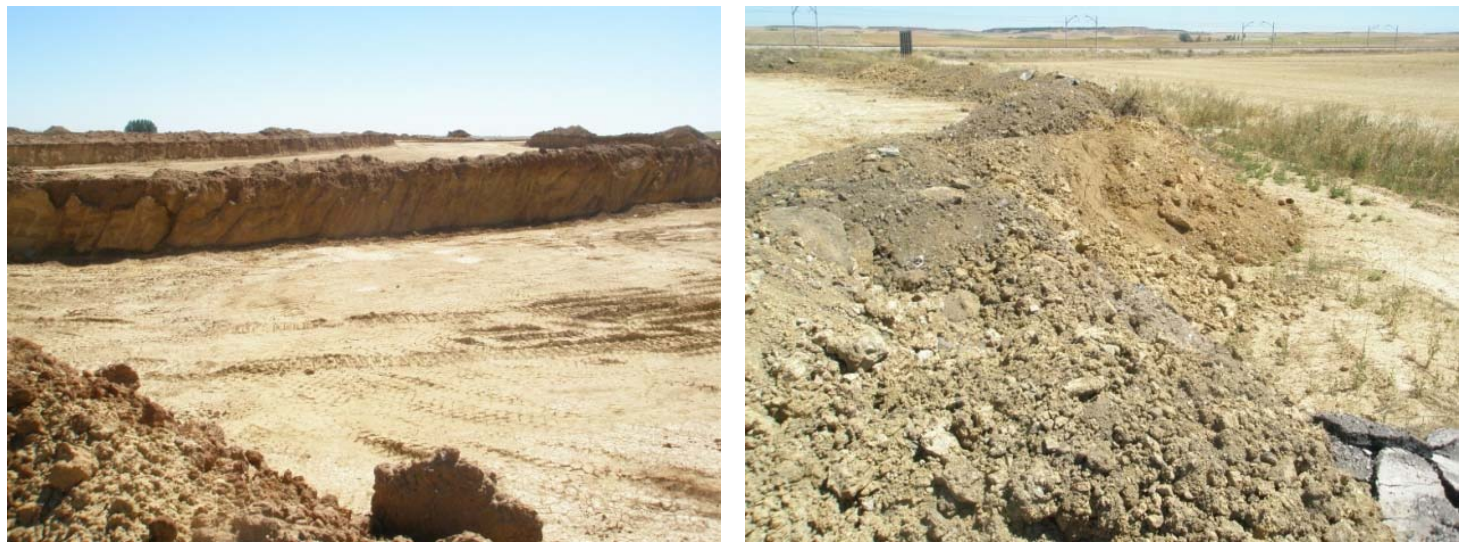

Figura 3.20. Préstamo para el AVE en Villada (izquierda) y vertedero para la misma obra en Paredes de Nava (derecha).

\section{ENERGÍA}

- Impacto visual provocado por las grandes infraestructuras energéticas (Figura 3.21). Los aerogeneradores de los parques eólicos poseen una altura total superior a los $120 \mathrm{~m}$ y se sitúan en las ubicaciones de mayor altitud con objeto de ser más eficientes; en Tierra de Campos, las crestas de los páramos y alguna cadena de cerros en el interior de la llanura. Su impacto visual por dominancia es evidente y sus cuencas visuales son enormes. La asociación a una energía renovable y limpia mitiga este efecto para ciertos sectores de la sociedad. Las subestaciones de transformación eléctrica también ocasionan puntuales impactos. En el caso de los huertos solares, su altura es generalmente reducida, pero necesitan grandes superficies para su implantación que, por su artificialidad, contrastan en gran medida con el medio agrícola circundante. Su localización es dispar por todo el territorio. Las líneas eléctricas de evacuación de las fuentes generadoras de energía, así como las de transporte y distribución de la misma producen importantes impactos visuales, proporcionales a su voltaje $y$, en consecuencia, a la altura de los apoyos (pueden llegar a alcanzar más de $30 \mathrm{~m}$ ). En el entorno de los pueblos también es visible una cierta proliferación de líneas aéreas de pequeño voltaje que abastecen a los núcleos, donde en muchas ocasiones se observa una acusada falta de planificación.
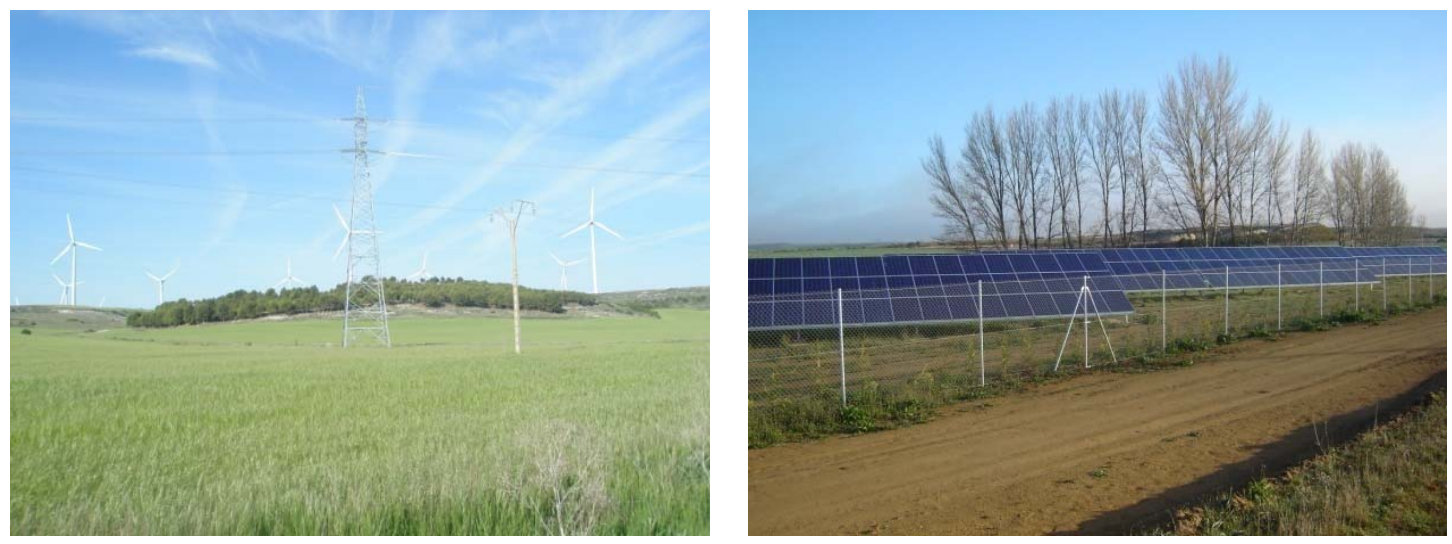

Figura 3.21. Parque eólico y diversas líneas eléctricas en Ampudia (izquierda). Huerto solar en Terradillos de los Templarios (derecha). 
- Impacto sobre la avifauna. En el caso de los parques eólicos es el otro impacto más significativo, afectando sobre todo a las grandes planeadoras que no se acostumbran al movimiento de las aspas de los aerogeneradores (buitres, rapaces, etc.). El efecto es mayor si no se dejan espacios libres que puedan servir de corredores para la avifauna. En los últimos años se han conseguido avances tecnológicos que aumentan la potencia unitaria de los aerogeneradores, lo que aumenta su envergadura pero, a la vez, eleva la distancia entre ellos, por lo que se disminuye el riesgo de colisiones. Para las líneas eléctricas el impacto es mucho más elevado, ya que su densidad por todo el territorio es realmente elevada. El impacto puede deberse a la electrocución en los apoyos o a la colisión, sobre todo en los cables de tierra debido a su menor diámetro. En Tierra de Campos es un riesgo particularmente grave la colisión de aves esteparias, sobre todo de avutardas.

INDUSTRIA (de forma puntual, sobre todo en los mayores núcleos de población)

- Generación de residuos industriales, con especial afección en el caso de ser tóxicos. En Tierra de Campos el desarrollo industrial está ligado exclusivamente a los medianos y mayores núcleos de población: Villada, Villarramiel, Carrión de los Condes, Villalón de Campos, Medina de Rioseco, Mayorga, Villalpando, etc. Es allí donde se concentran las instalaciones fabriles, que en general tienen escasa envergadura. Dominan las de transformación agraria: queserías, mataderos, de despiece y envasado, de curtidos... Tienen importancia también los talleres, que suelen ser familiares: mecánicos, de hierro, carpinterías, etc. En todos ellos resulta fundamental que el acopio de los residuos se realice en las condiciones más adecuadas y que se gestionen mediante entidades autorizadas.

- Contaminación de las aguas por vertidos. Las industrias que incluyen dentro de sus procesos de producción actuaciones de lavado son las que más pueden generar contaminación por vertidos. Las autorizaciones ambientales exigen un proceso de depuración autónomo, que transforme las aguas en asimilables a las residuales urbanas para, si es posible, ser finalmente depuradas en la EDAR municipal.

- Impacto visual de las instalaciones. Aunque en la comarca el desarrollo industrial es escaso, hay que reconocer que, allí donde se produce, se repiten las mismas degradaciones paisajísticas que en cualquier otra zona urbana. En este sentido, destaca el contraste con el entorno debido a la presencia de grandes volúmenes edificados con colores llamativos. A ello se unen otras instalaciones auxiliares, depósitos de materiales, vallados o cartelería de todo tipo, que alteran las vistas desde las principales vías de entrada a los núcleos.

URBANISMO

- Falta de planeamiento urbanístico adaptado a los pequeños núcleos y de un adecuado cumplimiento. La inmensa mayoría de los municipios de la comarca poseen menos de 500 habitantes; en muchos, no hay Normas Urbanísticas (se rigen por las provinciales) 
$y$, en cualquier caso, los Ayuntamientos no tienen capacidad técnica para realizar una adecuada gestión en materia de urbanismo. Además, el planeamiento urbanístico está realmente pensado para el crecimiento de población; en los pueblos los problemas son muy distintos: inmuebles en ruina, abundancia de solares sin muros perimetrales, presencia de explotaciones ganaderas en suelo urbano, deficiencia de infraestructuras de saneamiento y abastecimiento...

- Degradación paisajística por la adopción de tipologías arquitectónicas diferentes a las del entorno. La arquitectura tradicional basada en el uso de la tierra como material de construcción es una de las señas de identidad de la comarca. La debilidad física de este material frente a la lluvia, los avances sociales y las influencias externas han provocado una gran transformación en la fisonomía de los núcleos urbanos, que en muchos casos ha imitado tipologías ajenas. La teja cerámica curva árabe se sustituye por la de hormigón (cuando no por chapa metálica), las paredes de barro se derriban o se revisten con ladrillos de modelos variados, los colores ocres o tierras dominantes tornan en un puzle de tonos, las carpinterías de madera se cambian por otras metálicas o en PVC, etc. La arquitectura popular se asocia a endeblez y a pobreza, y por ello no se conserva.

- Escasez de zonas verdes y corredores bien conservados. En las comarcas agrarias hay una cierta mentalidad de que no hacen falta muchas zonas ajardinadas, porque ya existe mucho campo. Si bien es cierto que no es del todo falso este aserto, la verdad es que en las zonas urbanas y periurbanas de los pueblos de Tierra de Campos existe un déficit de espacios con árboles y arbustos. En parte es debido a la falta de capacidad técnica y recursos humanos para implantarlos y conservarlos, pero también hay que reconocer que la población o sus representantes municipales no son capaces de percibir los innegables valores positivos que la presencia de zonas verdes cotidianas puede tener sobre su calidad de vida.

\section{ACTIVIDAD URBANA}

- Generación de residuos domésticos. Su tratamiento es costoso debido a la baja población y elevada dispersión de los núcleos de población. Para ello, la gestión se realiza a través de Mancomunidades de municipios, en colaboración con las Diputaciones provinciales. Las basuras convencionales de los contenedores verdes se trasladan a una planta de transferencia desde donde, una vez prensados, se conducen los residuos al centro de tratamiento de residuos provincial. En la mayoría de los pueblos se realiza recogida selectiva de residuos, existiendo -además de los contenedores de basura- otros de papel y cartón, de envases y de vidrio. Las Diputaciones realizan convenios con sistemas integrados de gestión, que son empresas especializadas en su recogida y tratamiento. En los núcleos de mayor población (los menos) existen puntos limpios que recogen residuos voluminosos, electrónicos, colchones, enseres, pilas, etc. En algunos casos, las Diputaciones trasladan puntos limpios móviles a las poblaciones con este fin.

- Generación de residuos de construcción y demolición. Hasta hace pocos años, generalmente existía en cada municipio una zona de depósito de escombros 
(escombrera), que solía ser coincidente con antiguos huecos de extracción. Como consecuencia de la reciente legislación en materia de Residuos, se obliga a cerrar todas las escombreras, de forma que estos residuos deban ser tratados en plantas de reciclaje de residuos de construcción y demolición. El problema es que estas se sitúan en las proximidades de las ciudades, allí donde son más rentables. Así, en Tierra de Campos, en 2014 la única planta existente se sitúa en Calzada de los Molinos, muy alejada de muchas poblaciones. En teoría, para las obras mayores el promotor debe llevar los residuos a la planta; para obras menores, en cambio, el Ayuntamiento debiera habilitar un espacio de recogida temporal para su posterior traslado a la planta. El alto coste del traslado de escombros a las plantas, por una parte, y la deficiente gestión municipal por otra, provoca la aparición de numerosos depósitos incontrolados de escombros en cunetas, arroyos, vías pecuarias, eriales, etc. (Figura 3.22).
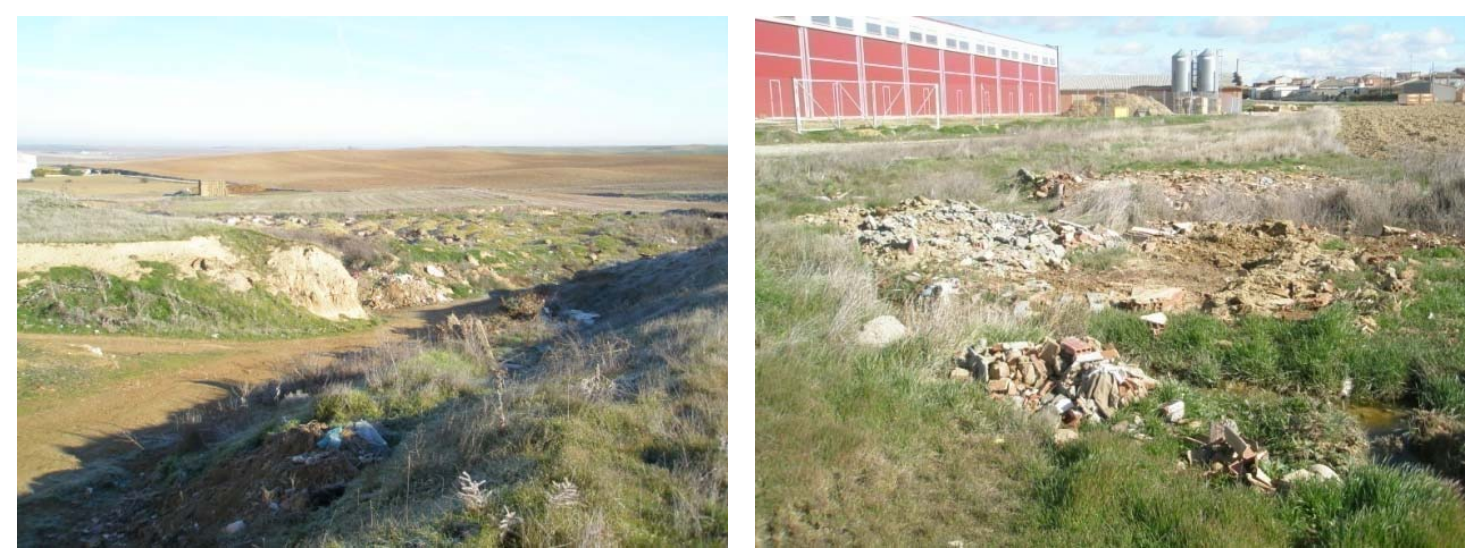

Figura 3.22. Escombrera a escasos $200 \mathrm{~m}$ de la iglesia mudéjar de Aguilar de Campos (izquierda). Depósito incontrolado de escombros en una zona periurbana de Cisneros (derecha).

- Vertidos contaminantes a las aguas. En la mayor parte de las poblaciones de Tierra de Campos, las aguas fecales procedentes de la red de saneamiento municipal no son depuradas; se vierten directamente a cauce público. Solo se han construido estaciones de depuración de aguas residuales en las poblaciones de mayor población, o en aquellas con problemas industriales específicos: Medina de Rioseco, Villalón de Campos, Villarramiel, etc., sin que en algunos casos estén en adecuado funcionamiento.

Tal como se puede apreciar, buena parte de estos impactos ambientales también pueden ser considerados como impactos sobre el paisaje, entendido este de forma global, tanto desde el punto de vista ecológico (procesos y perturbaciones) como perceptivo (manifestación externa del territorio).

\subsubsection{Instrumentos de gestión ambiental aplicables en Tierra de Campos.}

Una vez analizados los conceptos de medio ambiente y paisaje, distinguidos sus elementos, y diagnosticados los impactos originados por las actividades humanas en Tierra de Campos, se trata ahora de concretar las soluciones que se plantean para su protección. En este sentido, se 
entiende por gestión ambiental la realización de las oportunas diligencias con objeto de que la sociedad disponga de una elevada calidad ambiental.

El objetivo último de la gestión ambiental es el desarrollo sostenible, término acuñado en la Conferencia de las Naciones Unidas sobre Medio Ambiente y Desarrollo (Cumbre de Río de Janeiro, 1992). Ello supone adoptar las medidas necesarias para que exista un equilibrio entre las actividades humanas y el entorno donde se desarrollan, de forma que se garantice a los futuros pobladores unos niveles adecuados de bienestar.

Este objetivo general señalado sugiere una inmediata partición en cinco objetivos más concretos o líneas de acción, que se complementan y refuerzan de forma sinérgica:

- Prevenir degradaciones ambientales.

- Corregir actividades que generen o puedan generar degradaciones.

- Curar degradaciones: recuperar, restaurar, reformar, rehabilitar espacios y factores ambientales degradados.

- Potenciar la fortaleza del medio ambiente y de los factores que lo forman.

- Valorizar recursos ambientales ociosos.

Siguiendo a GÓMEZ OREA (2003), los instrumentos de gestión ambiental se pueden clasificar en preventivos, correctores y curativos. Los instrumentos preventivos se articulan en la fase previa a la generación de impactos ambientales; se clasifican en primarios, secundarios y de gestión propiamente dicha. Los instrumentos correctores se dirigen a modificar las acciones que originan impactos para reducirlos o evitarlos; los más importantes son las auditorías ambientales, las autorizaciones ambientales integradas y el etiquetado ecológico. Finalmente, los instrumentos curativos se dirigen a los factores ambientales una vez alterados, con el fin de restaurarlos, reformarlos, rehabilitarlos o valorizar recursos ociosos.

En los dos apartados siguientes se desarrollarán los instrumentos preventivos y los curativos, ya que son estos los que mayor aplicación tienen para la protección y recuperación del paisaje de campiñas de Tierra de Campos.

\subsection{Instrumentos preventivos de gestión ambiental: herramientas para la protección del paisaje de Tierra de Campos.}

Los instrumentos preventivos tienden a evitar que se produzcan impactos y se pueden clasificar en primarios, secundarios y de gestión propiamente dicha (GÓMEZ OREA, 2003). A continuación realizaremos una descripción de todos ellos siguiendo a este autor, con las consideraciones normativas que existen en el ámbito de Castilla y León:

PRIMARIOS.

- La formación, sensibilización y educación ambiental, de la población en general, de los planificadores, de los proyectistas, de los gestores, de los agentes sociales y de todos los 
estamentos implicados en la producción y el consumo. En este sentido, son muy interesantes los documentos de fácil interpretación sobre distintos aspectos medioambientales; por ejemplo, las guías para la integración paisajística de distintos proyectos de la Generalitat de Catalunya (GENERALITAT DE CATALUNYA [en línea]) o el Código de Buenas Prácticas Agrarias aprobado por Real Decreto 261/1996, de 16 de febrero, sobre protección de las aguas contra la contaminación producida por nitratos procedentes de fuentes agrarias. Para asegurar su eficacia resulta fundamental que se difundan intensamente y de manera adecuada entre los sectores implicados (urbanistas y técnicos municipales, para el primer caso; agricultores y técnicos de Agricultura, para el segundo).

\section{SECUNDARIOS.}

- La normativa en materia de calidad ambiental: conjunto de disposiciones legales y administrativas que fijan los límites aceptables de los parámetros ambientales y que no son otra cosa que la traducción al lenguaje jurídico de una racionalidad técnica. La Unión Europea dispone de un amplio elenco de Reglamentos, Directivas y Decisiones, traspuestos al ordenamiento jurídico español, que a su vez se completa con legislación nacional y autonómica. Ejemplos de normas con gran incidencia en materia de protección y recuperación del paisaje son las siguientes:

o Ley 42/2007, de 13 de diciembre, del Patrimonio Natural y de la Biodiversidad que regula, entre otras cuestiones, los planes de ordenación de los recursos naturales (PORN), los espacios naturales protegidos y la Red Natura 2000, la conservación de la biodiversidad y el uso sostenible del patrimonio natural en España.

o Ley 4/2015, de 24 de marzo, del Patrimonio Natural de Castilla y León. Esta ley incluye un título dedicado al paisaje para dar cumplimiento al Convenio Europeo del Paisaje, que incluye principios generales para su preservación, la integración de la conservación del paisaje en planes y programas, la elaboración de un catálogo de paisajes sobresalientes de Castilla y León y el establecimiento de criterios para la conservación del paisaje.

o Real Decreto 975/2009, de 12 de junio, sobre gestión de los residuos de las actividades extractivas y de protección y rehabilitación del espacio afectado por actividades mineras. Esta norma regula el contenido del plan de restauración que, de forma obligatoria, deben disponer todas las explotaciones mineras. Hay que reseñar que este sector fue pionero desde 1982 en la formulación de este instrumento.

- La investigación básica, la investigación aplicada (tecnologías apropiadas, tecnologías limpias, mejor tecnología disponible y económicamente viable), la experimentación, la difusión/extensión de la tecnología de prevención y corrección. Desgraciadamente, nuestro país no cuenta con centros de investigación o experimentación ligados a la ciencia del Paisaje; la que se realiza se desarrolla en determinados departamentos de las Universidades que imparten esta materia (Ciencias Biológicas, Ciencias Ambientales, Ingeniería Forestal y del Medio Natural, Ingeniería Agrícola y del Medio Rural, Arquitectura, etc.) y en algún foro asociativo (Asociación Española de Paisajistas, Asociación Española de Ingeniería del Paisaje, Asociación Española de Ecología Terrestre, Asociación Española de Evaluación de Impacto Ambiental, etc.). La difusión y extensión de los conocimientos tal vez sea el aspecto que más 
se haya desarrollado en los últimos años, sobre todo a partir de la firma del Convenio Europeo del Paisaje; en este sentido merece la pena destacar el papel desarrollado por el Observatorio del Paisaje de Cataluña.

- Los bancos de datos ambientales en cualquiera de sus formas, como información básica del entorno donde tendrán objeto los proyectos de actuación. Su disposición en bases de datos informatizadas facilita en gran medida el acceso al público. Como caso particular, los indicadores de calidad ambiental, que son índices o elementos que permiten expresar de forma sintética el estado del medio ambiente, a la vez que facilitan una cierta normalización de las mediciones realizadas sobre factores ambientales. Destaca el Banco de Datos de la Naturaleza (http://www.magrama.gob.es/es/biodiversidad) del Ministerio de Agricultura, Alimentación y Medio Ambiente. En Castilla y León, es muy utilizado el Sistema de Información Geográfica del Medio Natural (SIGMENA).

En materia de paisaje, resulta de considerable aplicación el desarrollo cartográfico realizado en el Atlas de los Paisajes de España (MATA y SANZ, 2004), que divide el país en tipos, subtipos y unidades de paisaje, e interpreta documentalmente cada una de estas clasificaciones.

\section{TERCIARIOS O DE GESTIÓN PROPIAMENTE DICHA.}

- La planificación: "proceso racional de toma de decisiones" en todas y cada una de sus múltiples formas: nacional, regional, local y particular; integral y sectorial; física, económica y social; espacial; urbana y rural; a corto, medio o largo plazo; a condición de que incorpore un diagnóstico correcto y completo del medio físico: del territorio y sus recursos. Por ello el tipo de planificación que mejor cumple este papel preventivo es la que utiliza el enfoque y la metodología de la ordenación territorial o su equivalente la planificación integral. Una correcta localización y un riguroso control del uso del suelo, son el punto de partida para la integración ambiental de las actividades. Tanto la planificación urbanística como la ordenación territorial tienen una gran importancia en la conservación de los espacios y recursos forestales de Castilla y León (FERNÁNDEZ MANSO, 2003 y 2005).

La Ley 10/1998, de 5 de diciembre, de Ordenación del Territorio de la Comunidad de Castilla y León contempla varios instrumentos en relación con esta materia. Las Directrices Esenciales de Ordenación del Territorio de Castilla y León (Ley 3/2008, de 17 de junio) incluyen determinaciones de carácter muy general, al tratarse realmente de una agenda para el gobierno del territorio. Las Directrices de Ordenación de Ámbito Subregional ya poseen mayores vinculaciones; por ejemplo, las Directrices de la provincia de Palencia (Decreto 6/2009, de 23 de enero) clasifican Áreas de Singular Valor Ecológico (ASVE) y Corredores Ecológicos de mayor amplitud a los espacios naturales protegidos, así como directrices paisajísticas para las diversas unidades definidas en la provincia (entre las que está Tierra de Campos). Existen Planes Regionales que también pueden tener importantes implicaciones paisajísticas, como el Plan Regional de Ámbito Territorial del Canal de Castilla, aprobado por Decreto 205/2001, de 2 de agosto.

El segundo pilar básico de la planificación es el planeamiento urbanístico, que es el conjunto de instrumentos para la ordenación del uso del suelo y el establecimiento de las condiciones 
para su transformación o conservación. La Ley 5/1999, de 8 de abril, de Urbanismo de Castilla y León distingue el planeamiento general de términos municipales completos (Planes Generales de Ordenación Urbana y Normas Urbanísticas Municipales) y el planeamiento de desarrollo de sectores (Estudios de Detalle, Planes Parciales y Planes Especiales). En Tierra de Campos, por su escaso desarrollo en esta materia, predominan las Normas Urbanísticas Municipales o bien la aplicación a las Normas provinciales por inexistencia de locales. En el planeamiento general existen importantes determinaciones que afectan al paisaje:

- Clasificación del suelo en urbano, urbanizable y rústico, diferenciando este último en varios tipos: común, de entorno urbano, con asentamiento tradicional, con protección agropecuaria, con protección de infraestructuras, con protección cultural, con protección natural y con protección especial.

- Previsión de los sistemas generales de espacios libres públicos (parques y jardines, corredores verdes, etc.).

- Catálogo de elementos naturales o culturales a proteger.

- En suelo urbano o urbanizable, determinación de los usos posibles, densidad máxima, altura máxima u otros parámetros urbanísticos.

- Normas de protección en cada categoría de suelo rústico (usos prohibidos, permitidos y autorizables de forma excepcional).

Los planes de desarrollo establecen la ordenación detallada de sectores, incluyendo cuestiones a esta escala: determinaciones urbanísticas para el suelo edificable, sistema local de espacios libres públicos, condiciones estéticas, etc. En particular los Planes Especiales de Protección tienen por objeto preservar el medio ambiente, el patrimonio cultural, el paisaje $\mathrm{u}$ otros valores socialmente reconocidos; entre ellos son especialmente valiosos los Planes Especiales de Conjuntos Históricos. En Tierra de Campos este documento lo tienen las localidades que están declaradas conjuntos histórico-artísticos, como Medina de Rioseco o Ampudia.

Una de las cuestiones más importantes del planeamiento urbanístico en materia de paisaje es la integración en el entorno. Así, el artículo 9 "Deberes de adaptación al ambiente" de la citada Ley de Castilla y León, establece con carácter general que las construcciones deberán ser coherentes con las características naturales de su entorno inmediato y del paisaje circundante.

NAVÉS et al. (2005) considera que el planeamiento urbanístico se debería complementar con un planeamiento paisajístico verde, que incida en los espacios verdes urbanos y en su conexión con la trama rural, así como en la protección de los espacios de mayor valor ambiental. El Plan Verde debería considerar actuaciones globales a diversas escalas, que abarcan desde el jardín privado y el parque urbano hasta el paisaje rural y natural. Habría de concebir dichas zonas verdes urbanas y periurbanas, con sus múltiples funciones (ecológica, recreativa, social, educativa, agrícola productiva, etc.) como un sistema que formara parte del equipamiento urbano, al que se le otorgara la misma importancia que, por ejemplo, la red viaria y otras infraestructuras. 
En el paisaje de campiñas cerealistas juega un papel importante el control de los usos en el suelo rústico; las construcciones agropecuarias suelen ser usos permitidos; hay determinados usos prohibidos en ciertas clases de suelo rústico (por ejemplo, vivienda unifamiliar aislada o actividades extractivas en suelo rústico con protección natural); mientras que, finalmente, buena parte del resto de usos son autorizables en determinadas condiciones. En todos estos casos, las licencias municipales no tienen mucho margen de decisión para modificar los proyectos, se trata de cumplir la normativa, lo que en materia de paisaje únicamente puede hacer mención a materiales, colores, etc.

- El diseño de los proyectos con sensibilidad ambiental es muchas veces el punto de partida básico. Se puede dar muchas veces el caso de proyectos que, sin haber tenido que pasar un filtro preventivo ambiental, se ejecutan con un respeto hacia los temas ambientales envidiable; ello, como siempre, depende de la profesionalidad y de la sensibilidad de los proyectistas. Metodológicamente esto implica que el paisaje es anterior al proyecto, de modo que debe ser analizado y valorado como base para la concepción del proyecto, buscar muchas soluciones alternativas al problema que se desea resolver, evaluarlas incluyendo los factores ambientales y desarrollar el proyecto después. Es la base de lo que se denomina integración ambiental.

- La calificación ambiental, asociada al antiguo Reglamento de Actividades Clasificadas como Molestas, Insalubres, Nocivas o Peligrosas, que vincula la autorización de dichas actividades a una evaluación de sus efectos y opera, fundamentalmente a nivel municipal, a través de la concesión de licencias.

En Castilla y León la normativa aplicable es la Ley 11/2003, de 8 de abril, de Prevención Ambiental de Castilla y León, que ha sufrido varias modificaciones. Esta ley dispone la necesidad de que los ayuntamientos emitan licencias ambientales de las actividades así calificadas. Los objetivos de esta licencia son regular y controlar las actividades e instalaciones con el fin de prevenir y reducir en origen las emisiones a la atmósfera, al agua y al suelo que produzcan las actividades correspondientes, incorporar a las mismas las mejores técnicas disponibles validadas por la Unión Europea y, al mismo tiempo, determinar las condiciones para una gestión correcta de dichas emisiones. Para ello se establece un procedimiento que tiene las siguientes fases:

o Elaboración de un proyecto básico que contenga información sobre las incidencias de la actividad en el medio, medidas de gestión de residuos, sistemas de control de emisiones y otras medidas correctoras.

o Información pública mediante anuncio en el Boletín Oficial de la Provincia, exposición en el tablón de anuncios del Ayuntamiento y notificación a los vecinos colindantes.

o Informes sectoriales, con especial importancia para el urbanístico.

- En los casos de mayor incidencia ambiental, emisión de un informe preceptivo y vinculante por la Comisión Territorial de Medio Ambiente y Urbanismo de la Junta de Castilla y León.

o Resolución de la licencia ambiental por el alcalde del municipio, con inclusión en su caso, de las medidas correctoras dispuestas por la citada Comisión. 
En los casos de menor incidencia en el medio ambiente, el procedimiento se simplifica considerablemente con el trámite de comunicación ambiental del promotor de la actividad al ayuntamiento, que podrá reglamentar una tramitación específica.

Cuantitativamente, es sin lugar a dudas el procedimiento ambiental de mayor aplicación para obras o actividades a implantar en el paisaje de Tierra de Campos. Si excluimos el suelo urbano de los núcleos de población, nos encontramos con muy diversas tipologías: explotaciones de ganadería intensiva de vacuno, porcino, ovino o aves de mediano y pequeño tamaño; mataderos; naves de almacenamiento de fitosanitarios, semillas, abonos minerales, etc.; naves de almacenamiento de forrajes; plantas de fabricación de hormigón, de hormigón asfáltico u otros derivados minerales; plantas de tratamiento de residuos de construcción y demolición, de gestión de residuos de otro tipo, puntos limpios, vertederos, etc.; huertos solares u otras instalaciones energéticas de baja potencia; antenas de telefonía móvil; estaciones de servicio; talleres mecánicos u otras instalaciones industriales en suelo rústico, etc.

Tal como se puede apreciar, se trata de obras y actividades de localización puntual pero dispersa por el suelo rústico, aunque normalmente se ocupan parcelas relativamente próximas al suelo urbano. El impacto paisajístico que ocasionan estas construcciones está fundamentalmente asociado al efecto visual, que resulta considerable en las abiertas campiñas cerealistas de Tierra de Campos.

Precisamente por los antecedentes históricos de las licencias ambientales -radicados en las antiguas licencias para actividades molestas, insalubres, nocivas y peligrosas- las medidas correctoras suelen ir dirigidas a controlar los efectos por ruidos excesivos, contaminación atmosférica, vertidos, contaminación de suelos, riesgo o peligro para la salud, etc. El impacto paisajístico suele tener un papel más secundario, que en muchos casos se limita a recomendaciones sobre el color de las construcciones y la implantación de posibles pantallas vegetales perimetrales.

- La Evaluación de Impacto Ambiental (EIA) es el procedimiento administrativo formado por un conjunto de estudios y análisis técnicos que permiten estimar los efectos que la ejecución de un determinado proyecto puede causar sobre el medio ambiente.

El procedimiento de EIA regulado en la legislación aplicable en los últimos años, es decir, el texto refundido de la Ley de Evaluación de Impacto Ambiental de proyectos, aprobado por Real Decreto Legislativo 1/2008, de 11 de enero, el Reglamento aprobado por Real Decreto 1131/1988, de 30 de septiembre, y la Ley 11/2003, de 8 de abril, de Prevención Ambiental de Castilla y León, consta de las siguientes fases (Figura 3.23):

- Elaboración por el promotor de un documento inicial del proyecto, que es sometido a consultas a las administraciones afectadas por parte del órgano ambiental.

- Elaboración por el promotor de un estudio de impacto ambiental, con la amplitud y nivel de detalle descritos en los informes emitidos en la fase anterior. En teoría, es en esta fase en la que se debería redactar el proyecto, que se habría de ir retroalimentando a lo largo del proceso. 
o Información pública del estudio de impacto ambiental por el órgano sustantivo, mediante anuncio en el Boletín Oficial de Castilla y León, exposición en el tablón de anuncios del Ayuntamiento y comunicación a las administraciones previamente consultadas.

- Remisión del expediente al órgano ambiental que, tras su análisis por la Comisión Territorial de Prevención Ambiental, dictará la correspondiente declaración de impacto ambiental, que será vinculante. En Castilla y León, este acto se emite por la Consejería de Fomento y Medio Ambiente o por la Delegación Territorial en cada provincia, en función de la regulación normativa.

o Remisión de la declaración de impacto ambiental (DIA) al órgano sustantivo y al ayuntamiento, para que las medidas correctoras sean incorporadas en la autorización del proyecto y en la licencia ambiental municipal.

o Seguimiento del cumplimiento de las medidas correctoras propuestas, que corresponderá en primera instancia al órgano sustantivo, sin perjuicio de la alta inspección que realizada por el órgano ambiental.

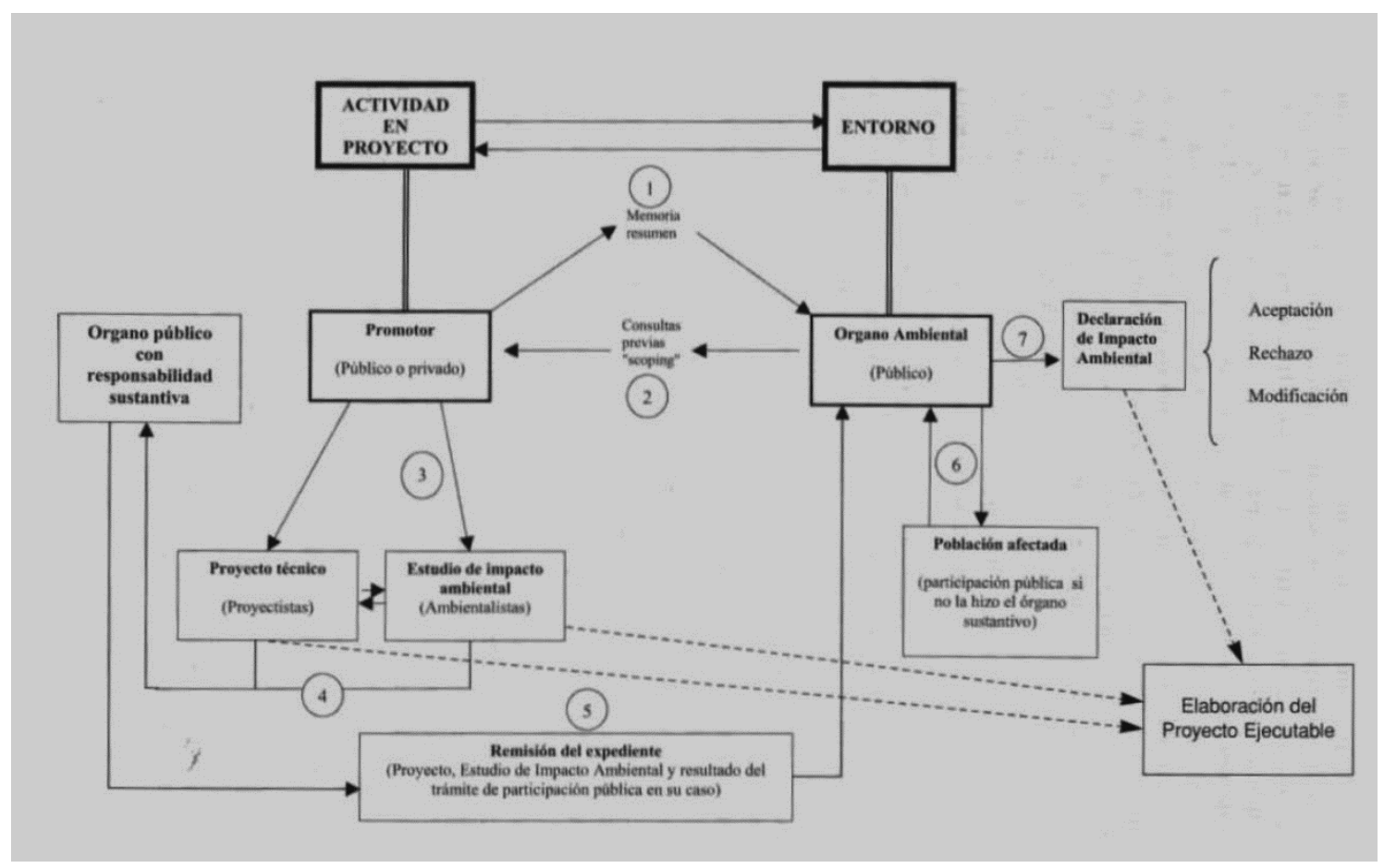

Figura 3.23. Esquema del procedimiento de Evaluación de Impacto Ambiental (GÓMEZ OREA, 2003)

En Tierra de Campos, los principales tipos de proyecto que se han sometido a evaluación de impacto ambiental en los últimos años han sido las concentraciones parcelarias, las transformaciones en regadío, las grandes explotaciones ganaderas intensivas, las explotaciones de áridos, los polígonos industriales, los parques eólicos, las líneas eléctricas de alta tensión, las nuevas carreteras, las autovías y las líneas de ferrocarril de alta velocidad. Como se puede apreciar, se trata de proyectos de gran envergadura que generan un considerable impacto sobre el paisaje. 
Este procedimiento se ha modificado ligeramente con la nueva Ley 21/2013, de 9 de diciembre, de evaluación ambiental. Propone dos tipos de EIA, la ordinaria y la simplificada, en función de su situación en dos anexos diferentes, lo que generará a su vez dos tipos de dictámenes finales: la declaración de impacto ambiental y el informe de impacto ambiental. A su vez, la fase inicial de consultas previas se convierte en opcional para el promotor.

El estudio de impacto ambiental es el documento técnico fundamental para realizar una adecuada evaluación del proyecto y dictar la DIA. Este estudio debe identificar, describir y valorar de manera apropiada, y en función de las particularidades de cada caso concreto, los efectos notables previsibles que la realización del proyecto produciría sobre los distintos aspectos ambientales (efectos directos e indirectos; simples, acumulativos o sinérgicos; a corto, a medio o a largo plazo; positivos o negativos; permanentes o temporales; reversibles o irreversibles; recuperables o irrecuperables; periódicos o de aparición irregular; continuos o discontinuos). El documento contiene, al menos, los siguientes apartados:

- Descripción general del proyecto y exigencias previsibles en el tiempo, en relación con la utilización del suelo y de otros recursos naturales. Estimación de los tipos y cantidades de residuos vertidos y emisiones de materia o energía resultantes.

- Principales alternativas estudiadas y justificación de las principales razones de la solución adoptada, teniendo en cuenta los efectos ambientales.

- Evaluación de los efectos previsibles directos o indirectos del proyecto sobre la población, la flora, la fauna, el suelo, el aire, el agua, los factores climáticos, el paisaje y los bienes materiales, incluido el patrimonio histórico artístico y el arqueológico. Asimismo, se atenderá a la interacción entre todos estos factores.

- Medidas previstas para reducir, eliminar o compensar los efectos ambientales significativos.

- Programa de vigilancia ambiental.

- Resumen del estudio y conclusiones en términos fácilmente comprensibles.

La declaración de impacto ambiental es el pronunciamiento de la autoridad competente de medio ambiente (el órgano ambiental), en el que se determina, respecto a los efectos ambientales previsibles, la conveniencia o no de realizar la actividad proyectada y, en caso afirmativo, las condiciones que deben establecerse en orden a la adecuada protección del medio ambiente y los recursos naturales. En todo caso, las condiciones formarán un todo coherente con las exigidas por el órgano que autorizará el proyecto.

La DIA será dictada por el órgano ambiental donde resida la competencia sustantiva; es decir, si el proyecto es aprobado por la Administración del Estado (por ejemplo un tramo de ferrocarril de alta velocidad), el órgano ambiental residirá en el Ministerio respectivo; si el proyecto se aprueba por la administración local o por la autonómica, el órgano ambiental se encontrará en la Consejería competente en materia de medio ambiente.

El contenido de las Declaraciones es muy variado, dependiendo fundamentalmente de la complejidad del proyecto y de los criterios del órgano que la realice. De todos modos suele tener un patrón común que, por ejemplo en el ámbito de la comunidad de Castilla y León contempla los siguientes apartados: 
- Resolución. Es una primera parte previa de carácter formal, que aprueba la Declaración real que se presenta a continuación como Anexo.

- Antecedentes. Se contemplan los siguientes aspectos:

o Órgano ambiental competente.

- Justificación de por qué el proyecto se somete a EIA (supuestos de los anexos de la legislación).

o Descripción del proyecto.

o Descripción del estudio de impacto ambiental.

o Posibles afecciones a espacios naturales protegidos $u$ otras figuras de protección ambiental.

- Tramitación de la fase de consultas previas.

- Tramitación de la fase de información pública del estudio, informes emitidos y alegaciones.

- Declaración de Impacto Ambiental propiamente dicha.

o Puede ser favorable o desfavorable.

o Si es desfavorable, ha de ser motivada.

- Si es favorable, en la práctica totalidad de las ocasiones contiene CONDICIONES:

Medidas protectoras específicas. Es la parte fundamental de la DIA; se engloban medidas preventivas, correctoras y compensatorias, que normalmente aluden a cada uno de los factores ambientales (agua, suelo, vegetación, fauna, paisaje, patrimonio, etc.), o bien a la fase del proyecto (replanteo, ejecución, finalización, restauración, etc.).

$>$ Integración ambiental del proyecto, mediante la inclusión de las medidas en el proyecto definitivo o incluso la redacción de un proyecto de recuperación ambiental complementario.

$>$ Coordinación con el órgano ambiental para el adecuado cumplimiento de las condiciones.

Tramitación de posibles modificaciones.

Programa de vigilancia ambiental e informes periódicos (suelen ser anuales).

$>$ Dirección ambiental de obra, en aquellas de mayor envergadura.

Seguimiento y vigilancia. 
El seguimiento de las evaluaciones de impacto ambiental es la última fase de este procedimiento preventivo y, tal vez, la más importante. En teoría, el proceso está claro: el órgano ambiental prescribe una serie de condiciones, que se han de incorporar al proyecto definitivo y a sus respectivas autorizaciones. Por consiguiente, son de obligado cumplimiento por el promotor, que además lo deberá justificar en los informes periódicos del programa de vigilancia ambiental. Además, la legislación en EIA contempla un riguroso régimen de infracciones y sanciones por, entre otras cuestiones, el incumplimiento de las medidas protectoras prescritas.

La realidad no es tan sencilla. El promotor lógicamente da prioridad a la ejecución de su proyecto, considerando las medidas ambientales como accesorias o incluso prescindibles por su sobrecoste o las limitaciones que conllevan. En este sentido, cabe reseñar que en gran parte de las ocasiones, el posible cumplimiento de las condiciones es directamente proporcional a la sensibilidad ambiental del promotor o la empresa promotora. Por otro lado, el órgano sustantivo también da preferencia a que el proyecto se lleve a cabo conforme al cumplimiento de su legislación sectorial; además, la usual escasez de medios personales en la Administración provoca que la teórica vigilancia por el órgano sustantivo no suela realizarse con la adecuada diligencia. Por último, el papel asignado al órgano ambiental es secundario: "podrá recabar información del órgano sustantivo al respecto, así como efectuar las comprobaciones necesarias para verificar el cumplimiento del condicionado" (artículo 18 Texto refundido de la Ley de EIA); tampoco los medios materiales y personales asignados ayudan a realizar este seguimiento supletorio.

En los proyectos de mayor envergadura -sobre todo en el campo de la obra pública civil-, aunque los impactos ambientales son también mayores, la realidad del seguimiento es bien diferente. En un determinado proyecto, la empresa promotora generalmente dispone de un técnico de medio ambiente (suele compaginar también con calidad) de apoyo al jefe de obra. Paralelamente, el órgano sustantivo dispone de un director ambiental de obra (o coordinador ambiental de obra) que apoya en esta materia al director de obra. Este organigrama es plenamente eficaz si ambas figuras competentes en materia ambiental son debidamente consideradas en la toma de decisiones de la ejecución de la obra.

En cuanto a la relación entre EIA y paisaje, se debe reconocer que la evaluación de impacto ambiental es uno de los procedimientos más eficaces para proteger y recuperar el paisaje. No obstante, en los estudios de impacto ambiental el paisaje no se analiza desde una perspectiva global; su estudio se realiza a través de sus componentes (suelo, agua, vegetación...), tanto en el inventario ambiental, como en la detección de impactos y la implementación de medidas correctoras. Por su parte, el análisis específico del paisaje suele cubrir únicamente su faceta de percepción, fundamentalmente visual, quedando fuera la perspectiva ecológica.

- La Evaluación Ambiental Estratégica de planes y programas es una herramienta fundamental en el proceso de integración ambiental, que ahonda en la idea de que la evaluación de la incidencia humana sobre el entorno debe ser lo más previa posible. Este procedimiento preventivo emana de la Directiva 2001/42/CE de 27 de junio de 2001, relativa 
a la evaluación de los efectos de determinados planes y programas en el medio ambiente, que tiene por objeto "conseguir un elevado nivel de protección del medio ambiente y contribuir a la integración de aspectos medioambientales en la preparación y adopción de planes y programas con el fin de promover un desarrollo sostenible, garantizando la realización, de conformidad con las disposiciones de la presente Directiva, de una evaluación medioambiental de determinados planes y programas que puedan tener efectos significativos en el medio ambiente".

Esta Directiva se traspone a nuestro ordenamiento jurídico a través de la Ley 9/2006, de 28 de abril, sobre evaluación de los efectos de determinados planes y programas en el medio ambiente, que ha estado vigente en los últimos años. Define Evaluación ambiental como el proceso que permite la integración de los aspectos ambientales en los planes y programas mediante la preparación del informe de sostenibilidad ambiental (ISA), de la celebración de consultas, de la consideración del ISA, de los resultados de las consultas y de la memoria ambiental, y del suministro de información sobre la aprobación de los mismos. Asimismo, los planes y programas son el conjunto de estrategias, directrices y propuestas que prevé una Administración pública para satisfacer necesidades sociales, no ejecutables directamente, sino a través de su desarrollo por medio de un conjunto de proyectos.

En cuanto al ámbito de aplicación, serán objeto de evaluación ambiental, de acuerdo con esta ley, los planes y programas, así como sus modificaciones, que puedan tener efectos significativos sobre el medio ambiente y que cumplan los dos requisitos siguientes:

a) Que se elaboren o aprueben por una Administración pública.

b) Que su elaboración y aprobación venga exigida por una disposición legal o reglamentaria o por acuerdo del Consejo de Ministros o del Consejo de Gobierno de una comunidad autónoma.

2. Se entenderá que tienen efectos significativos sobre el medio ambiente aquellos planes y programas que tengan cabida en alguna de las siguientes categorías:

a) Los que establezcan el marco para la futura autorización de proyectos legalmente sometidos a evaluación de impacto ambiental en las siguientes materias: agricultura, ganadería, silvicultura, acuicultura, pesca, energía, minería, industria, transporte, gestión de residuos, gestión de recursos hídricos, ocupación del dominio público marítimo terrestre, telecomunicaciones, turismo, ordenación del territorio urbano y rural, o del uso del suelo.

b) Los que requieran una evaluación conforme a la normativa reguladora de la Red Ecológica Europea Natura 2000, regulada en la Ley 42/2007, de 13 de diciembre, del Patrimonio Natural y de la Biodiversidad.

Dentro de los planes sometidos a evaluación ambiental destacan los instrumentos de ordenación del territorio y, sobre todo, los instrumentos de planeamiento urbanístico. En Castilla y León la inmensa mayoría de evaluaciones ambientales realizadas corresponde al planeamiento general: planes generales y normas urbanísticas municipales. 
De una forma sucinta, las fases del procedimiento de evaluación ambiental estratégica son las siguientes:

- El órgano promotor presenta un documento de iniciación, que será sometido a consultas de las administraciones afectadas por el órgano ambiental.

- El órgano ambiental elabora un documento de referencia, con los criterios ambientales estratégicos e indicadores de los objetivos ambientales y principios de sostenibilidad aplicables en cada caso. En él se determinará el contenido de la información que se debe tener en cuenta en el informe de sostenibilidad ambiental y definirá las modalidades de información y consultas.

- Elaboración del ISA por el órgano promotor, que será sometido a consultas.

- Elaboración de la memoria ambiental, de forma conjunta entre el órgano promotor y el órgano ambiental, que contendrá las determinaciones finales que deban incorporarse al plan o programa.

- Redacción definitiva del plan o programa por el órgano promotor, tomando en consideración el ISA, las alegaciones y la memoria ambiental.

- Seguimiento por parte del órgano promotor, sin perjuicio de la participación por el órgano ambiental.

En el ISA el órgano promotor debe identificar, describir y evaluar los probables efectos significativos sobre el medio ambiente que puedan derivarse de la aplicación del plan o programa, así como unas alternativas razonables, técnica y ambientalmente viables, incluida entre otras la alternativa cero, que tengan en cuenta los objetivos y el ámbito territorial de aplicación del plan o programa. Su contenido será el siguiente:

a) Un esbozo del contenido, objetivos principales del plan o programa y relaciones con otros planes y programas conexos.

b) Los aspectos relevantes de la situación actual del medio ambiente y su probable evolución en caso de no aplicar el plan o programa.

c) Las características ambientales de las zonas que puedan verse afectadas de manera significativa.

d) Cualquier problema ambiental existente que sea relevante para el plan o programa, incluyendo en concreto los relacionados con cualquier zona de particular importancia ambiental designada de conformidad con la legislación aplicable sobre espacios naturales y especies protegidas.

e) Los objetivos de protección ambiental fijados en los ámbitos internacional, comunitario o nacional que guarden relación con el plan o programa y la manera en que tales objetivos y cualquier aspecto ambiental se han tenido en cuenta durante su elaboración.

f) Los probables efectos significativos en el medio ambiente, incluidos aspectos como la biodiversidad, la población, la salud humana, la fauna, la flora, la tierra, el agua, el aire, los factores climáticos, los bienes materiales, el patrimonio cultural, incluido el patrimonio histórico, el paisaje y la interrelación entre estos factores.

g) Las medidas previstas para prevenir, reducir y, en la medida de lo posible, contrarrestar cualquier efecto significativo negativo en el medio ambiente por la aplicación del plan o programa. 
h) Un resumen de las razones de la selección de las alternativas previstas y una descripción de la manera en que se realizó la evaluación, incluidas las dificultades que pudieran haberse encontrado a la hora de recabar la información requerida.

i) Una descripción de las medidas previstas para el seguimiento.

j) Un resumen no técnico de la información facilitada en virtud de los párrafos precedentes.

k) Un informe sobre la viabilidad económica de las alternativas y de las medidas dirigidas a prevenir, reducir o paliar los efectos negativos del plan o programa.

La mayoría de los planes sometidos a evaluación ambiental estratégica en Tierra de Campos han sido urbanísticos, con gran incidencia paisajística.

El procedimiento de evaluación ambiental también se ha modificado recientemente con la Ley $21 / 2013$, de 9 de diciembre, de evaluación ambiental. La evaluación ambiental estratégica constará, a partir de este momento, de los siguientes trámites, que no difieren mucho de los anteriores:

a) Solicitud de inicio.

b) Consultas previas y determinación del alcance del estudio ambiental estratégico.

c) Elaboración del estudio ambiental estratégico (antes informe de sostenibilidad ambiental, de similar contenido).

d) Información pública y consultas a las Administraciones afectadas y personas interesadas.

e) Análisis técnico del expediente.

f) Declaración ambiental estratégica (antes Memoria Ambiental).

La relación entre la evaluación ambiental estratégica y el paisaje suele reproducir los mismos planteamientos que en el caso de la evaluación de impacto ambiental. El paisaje se convierte en un factor ambiental más, en plano de igualdad con cualquiera de sus componentes (fauna, flora, tierra, agua, etc.), limitándose a su vertiente visual. No suele estudiarse el territorio afectado por el plan desde una perspectiva integradora, como paisaje ecológico y visual. Este hecho se traduce tanto en el contenido de los documentos evaluados y en los dictámenes finales emitidos.

\subsection{La recuperación de espacios degradados como técnica para corregir impactos y mejorar la calidad del paisaje de Tierra de Campos.}

\subsubsection{Concepto de recuperación de espacios degradados y justificación.}

De acuerdo con GÓMEZ OREA (2004) -autor que va a ser referencia en este capítulo- la recuperación de espacios degradados es la técnica mediante la cual se pueden reconvertir espacios cuyo estado es insatisfactorio por otros que nos satisfagan. Es la herramienta que opera sobre la tercera línea de acción de la gestión ambiental: la curativa. Se trata de uno de los grandes desafíos de la gestión ambiental hacia el futuro, que requiere valentía para afrontarla y 
recursos humanos, tecnológicos y económicos para ejecutarla. Pero además de tratarse de una necesidad ética, dado que la degradación ambiental está asociada a la historia del hombre, la actividad curativa y su repercusión en la calidad ambiental se convierte en motivo de prestigio para las zonas donde se produce, y por ello en factor que alentará la localización de actividades económicas de vanguardia: aquellas que a partir de poca materia prima generan mucho valor añadido utilizando alta tecnología y mano de obra muy cualificada. Este es uno de los aspectos que deseamos resaltar en este estudio: la oportunidad que representa la recuperación ambiental en Tierra de Campos para afrontar la terrible despoblación que le aqueja y promover su desarrollo socioeconómico.

El concepto de degradación es relativo, como relativa es la valoración -más o menos satisfactoria o ideal- de un estado o situación determinado a la que tal concepto se asocia. Se refiere a una situación que se considera total o parcialmente indeseable con respecto a otra que se considera satisfactoria, y ello en las circunstancias económicas, sociales y ambientales en que se inscribe.

En este sentido, calificar a un espacio como degradado exigirá una doble condición:

- En relación con el valor:

o Valor negativo del espacio para todas las dimensiones que conforman tal concepto: ecológica, paisajística, científico-cultural, funcional o productiva.

- Valor inferior y alejado del que podría tener en una situación más o menos ideal.

- En relación con la función que cumple para la sociedad:

o Carencia de una función que justifique el estado parcialmente degradado.

o Práctica negligente o insatisfactoria de dicha función, cuando existe, o localización inadecuada de la actividad gestionada en el entorno en que se ubica.

La escasez de valor podrá venir indicada, por ejemplo, por la ausencia de vegetación donde podría haberla o el mal estado de ésta, por la evidencia de procesos erosivos activos, por la presencia de residuos, por la incoherencia paisajística e intrusión visual, etc.

La ausencia de función o práctica insatisfactoria de esta también puede ser muy variable: ecológica (denunciada por la presencia de indicadores como biodiversidad, integridad, evolución, rareza, representación, etc.), productiva (capacidad de fijación de energía solar o de bienes con precio de mercado), científico-cultural (determinada por el papel que puede cumplir un espacio para la ciencia, la cultura o el aprendizaje), paisajística (excelencia plástica, olfativa, sonora, táctil, etc.; complejidad de la estructura o textura), territorial (pieza coherente, junto a otras, de un sistema territorial en el que se inscribe estructural y funcionalmente), conservadora (estabilidad del terreno, protección contra riesgo de erosión, recarga de acuíferos, control de inundaciones, etc.) o combinación de las anteriores.

Que el estado de un espacio que cumple una función sea insatisfactorio desde alguno de los puntos de vista citados (ecológico, paisajístico, etc.), indica exclusivamente degradación sectorial y solo puede justificar un tratamiento para la mejora de tal punto de vista. Es el caso de una zona de agricultura intensiva que puede aconsejar medidas de diversificación o que rompan su monotonía ecológica y paisajística, pero no son espacios degradados en sí mismos, 
aunque siempre admitan mejoras parciales respecto de alguno de los elementos que lo forman. Por ello, en este estudio no se considerará espacio degradado al propio cultivo cerealista; sí lo será, por el contrario, el paisaje agrícola simplificado basado exclusivamente en el productivismo, así como las afecciones en el mismo provocadas por las concentraciones parcelarias.

Las razones que justifican el tratamiento de recuperación son las siguientes:

- Con carácter general, necesidad de la curación de las degradaciones ambientales, en el marco de la gestión ambiental.

- Imagen; un espacio degradado ofrece una imagen deplorable de los tres tipos de agentes implicados en la degradación: los causantes directos, las autoridades responsables y la población afectada, que propicia la desconfianza.

- Calidad de la gestión; un espacio degradado denuncia desidia o insensibilidad por la calidad en general y la ambiental en particular, desanimando a posibles inversores.

- Factor de localización de actividades económicas de vanguardia; un espacio ambientalmente valioso atrae la localización de aquellas actividades que con poca cantidad de materia prima y utilizando mano de obra muy cualificada obtienen un elevado valor añadido.

- Yacimiento de empleo, directo e indirecto; por las razones señaladas en los puntos anteriores.

- Componente de la calidad de vida para la población; la calidad ambiental es un componente importante de la calidad de vida.

- Compensación de impactos imposibles de evitar o mitigar en ciertos proyectos.

En cuanto a los diferentes enfoques que pueden darse al tratamiento de un espacio degradado, la bibliografía suele utilizar los términos incluidos en los puntos siguientes (GÓMEZ OREA, 2004):

\section{RESTAURACIÓN}

Este término surge como reacción a la degradación de los ecosistemas. Se utiliza con mucha frecuencia para identificar estilos de tratamiento muy diferentes a través de los cuales se pretende emular, con mayor o menor fidelidad, la estructura, funcionamiento y dinámica del ecosistema inicial anterior a toda perturbación humana, es decir, en su estado natural. Este enfoque, que puede denominarse restauración sensu stricto, resulta poco menos que imposible por obvias limitaciones de conocimiento de la realidad preexistente, de coste o simplemente de viabilidad técnica. No obstante, a nivel español sí que existen casos de restauraciones estrictas, como la restauración del paraje Tudela-Culip, en el parque natural del Cap de Creus (Girona) que ha recibido el Premio Europeo del Paisaje Rosa Barba-, donde se devolvió íntegramente a su estado primitivo el espacio ocupado por las 430 edificaciones que integraban las instalaciones del Club Med.

\section{REHABILITACIÓN}

Este enfoque pretende llevar el espacio degradado a una situación que se considera aceptable y útil desde el punto de vista del entorno, sin pretender ninguna aproximación al estado inicial, antes de la degradación. Es un concepto muy utilizado en arquitectura (por ejemplo, en los 
planes de rehabilitación de los conjuntos históricos) o en minería (sirva como muestra el Real Decreto 975/2009, de 12 de junio, sobre gestión de los residuos de las industrias extractivas y de protección y rehabilitación del espacio afectado por actividades mineras).

\section{RECUPERACIÓN}

Más accesible y utilizada que la restauración sensu stricto, es la restauración sensu lato, a la que frecuentemente se denomina recuperación, que simplemente persigue detener la degradación y redirigir la trayectoria del lugar dañado hacia una formación solo parecida a la existente antes de la degradación (Figura 3.24). Este término se utilizará en este estudio para describir un proceso por el que un espacio que se considera degradado pasa a otra situación, imagen objetivo, en que el espacio ha dejado de estar degradado porque se le ha acondicionado para cumplir una función adecuadamente gestionada, o simplemente se le ha dotado de unas características que se consideran aceptables en las circunstancias específicas del lugar.

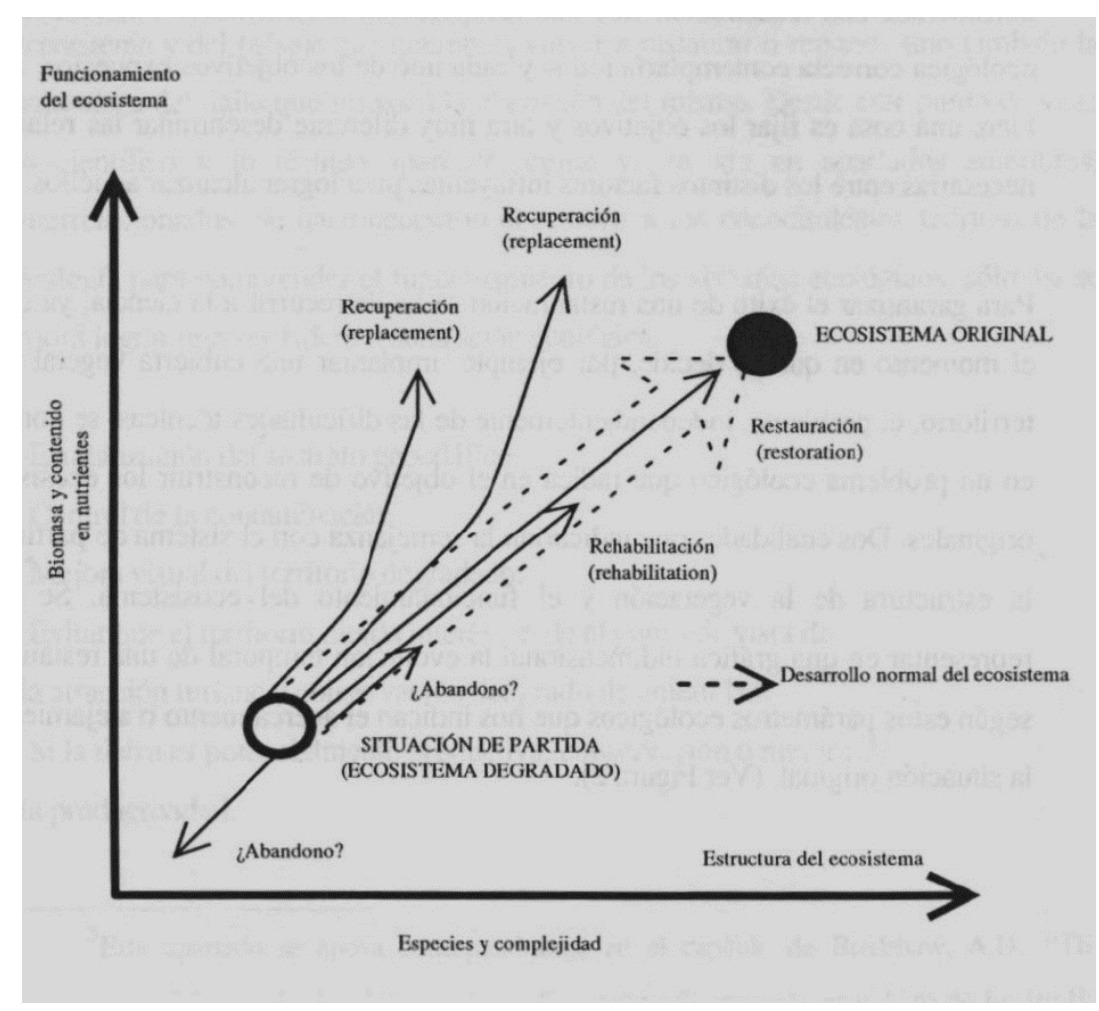

Figura 3.24. Posibles evoluciones de un ecosistema alterado (UDPP, 2002)

En cualquier caso, pese al intento de diferenciación de la terminología referida, restauración, rehabilitación y recuperación son términos que se suelen emplear indistintamente (UDPP, 2002), dado que las fronteras de sus definiciones no son muy nítidas. 


\subsubsection{Contenido y alcance de la recuperación de espacios degradados.}

Siguiendo con el análisis teórico efectuado por GÓMEZ OREA (2004), la recuperación de un espacio degradado se inicia, con en cualquier intervención, con la generación de la idea de intervenir, sigue con una reflexión sobre la viabilidad técnica, económica, social y ambiental de la intervención y continúa, explícita o implícitamente, con las siguientes fases típicas (Figura 3.25):

- Fase de planificación: diseño de la imagen objetivo o plan maestro de la intervención.

- Fase de proyecto: elaboración de anteproyectos y de proyectos.

- Fase de construcción: ejecución de las obras proyectadas.

- Fase de gestión: explotación o funcionamiento y conservación de lo ejecutado.

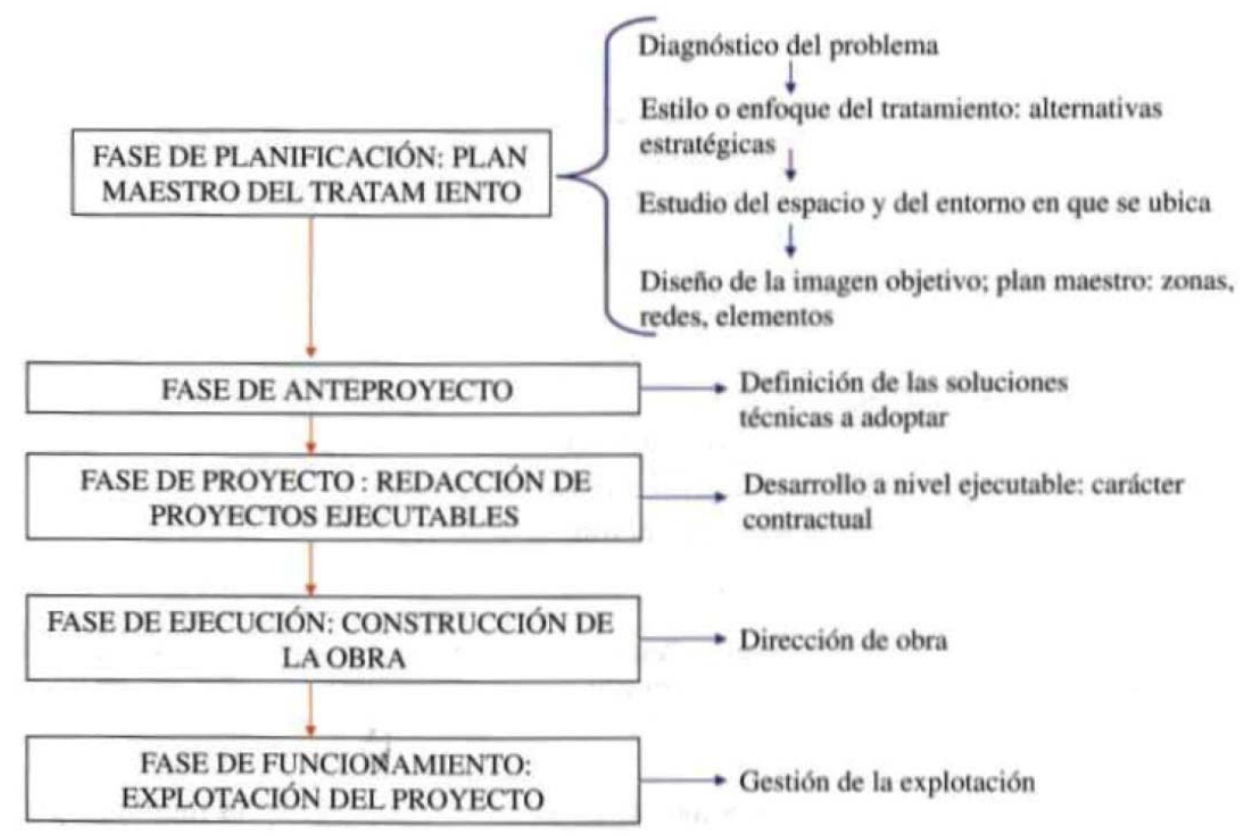

Figura 3.25. Fases por las que pasa el tratamiento de un espacio degradado y contenido de cada una de ellas (GÓMEZ OREA, 2004)

En cuanto a la organización documental del plan maestro, este puede tener la siguiente estructura:

- Presentación.

- Oportunidad del plan y encaje legal, en su caso.

- Viabilidad.

- Estilo, metodología y equipo redactor.

- Diagnóstico por temas e integrado. Análisis DAFO.

- Objetivos específicos. Imagen objetivo.

- Actuaciones: programas, subprogramas, proyectos y otras acciones.

- Cronograma de ejecución: PERT, diagrama de flujos, diagrama de barras, etc. 
- Normativa general y asociada a la zonificación representada en la imagen objetivo.

- Evaluación ambiental del plan.

- Planos informativos, interpretativos o de diagnóstico y de propuestas (imagen objetivo $y$ otros). Los planos pueden insertarse en el texto en el lugar que les corresponda o disponerse en bloque.

- Presupuesto del plan. Estudio económico-financiero.

- Gestión del plan.

- Anejos informativos e interpretativos o de diagnóstico.

- Fuentes documentales utilizadas.

- Bibliografía.

Los anteproyectos y proyectos se organizan según la forma clásica establecida por la legislación en materia de contratación de las administraciones públicas y en la Norma UNE 157000 2002:

- Memoria y anejos a la memoria.

- Planos.

- Pliego de condiciones.

- Mediciones.

- Presupuesto.

Asimismo, deberán incluir otros documentos obligatorios, como Estudio de seguridad y salud, Estudio geotécnico (si lleva construcciones), Gestión de residuos (en su caso), Programa de control de calidad y vigilancia ambiental y Plan de conservación y mantenimiento de la obra.

El contenido fundamental y las determinaciones de estos documentos se pueden esquematizar como sigue:

Memoria

- Antecedentes

- Objetivos del proyecto e identificación de los problemas a resolver

- Condicionantes ambientales

- Descripción técnica de las alternativas planteadas

- Ingeniería del proyecto, con justificación de las soluciones adoptadas

- Evaluación socioeconómica

- Evaluación ambiental

- Programación de las obras

- Normas de explotación

- Plazo de ejecución y garantía

- Clasificación del contratista

- Resumen del presupuesto

Anejos

- Características del medio físico

- Elección de especies

- Tipificación de las zonas de actuación 
- Diseño y descripción de las soluciones técnicas propuestas

- Plan de la obra

- Justificación de precios

- Estudio de seguridad y salud

- Estudio geotécnico

- Programa de control de calidad y vigilancia ambiental

- Plan de conservación

Planos

- Plano de situación o mapa topográfico de la zona donde radica el proyecto

- Planos temáticos de las características del medio físico de la zona de estudio

- Plano de actuaciones, donde se esquematiza su ubicación

- Plano de siembras y plantaciones

- Planos de otras soluciones propuestas: disposición de mantas orgánicas, pantallas contra el ruido, muros y obras de fábrica, etc.

Pliego de condiciones técnicas

- Descripción de la obra

- Materiales

- Ejecución de las obras

- Maquinaria y aperos

- Personal

- Medición y abono de las obras

- Obligaciones del contratista

- Condiciones generales

Mediciones

Presupuestos

- Cuadros de precios

- Cuadro de precios no 1: Precios de las unidades de obra en cifra y letra

o Cuadro de precios no 2: Precios de las unidades de obra descompuestos

- Presupuestos

- Presupuestos parciales (por capítulos)

o Presupuesto de ejecución material

o Presupuesto de ejecución por contrata o de licitación

En los proyectos de restauración o recuperación ambiental son fundamentales las fases descriptiva, de diagnóstico y proyectual; tal como concluyen RASTROLLO et al. (2012), que proponen una metodología para el manejo sencillo de la información social, ecológica y paisajística. 


\subsubsection{Bases ecológicas y paisajísticas de la recuperación de espacios degradados.}

Una de las grandes aportaciones de la ecología al conocimiento del territorio ha sido la de ir desvelando su naturaleza holística, interrelacionada. De esta forma, las acciones aisladas repercuten, en mayor o menor grado, en el entorno con el que se relacionan. El territorio no está formado por compartimentos estancos. Si es cierto que se pueden definir individuos separados de los demás, también es cierto que siempre se relacionan entre sí; es necesario, por tanto, conocer el modo de esta relación. La naturaleza unitaria del territorio, el hecho de integrar elementos en relación, viene indicada, por ejemplo, por los impactos ambientales negativos (UDPP, 2002). Por ello, cuando hablamos de recuperar o restaurar desde un punto de vista ecológico estamos hablando de corregir degradaciones que a su vez están interrelacionadas (la pérdida de cubierta vegetal y la erosión, por ejemplo).

Pero se puede ir más allá de la casuística y alcanzar el conocimiento de cómo funciona el territorio como ente global, con el fin de evitar actuaciones erróneas que no prevean las consecuencias que van a desencadenar. $Y$ entonces se muestra con mayor fuerza la necesidad de la base científica que ofrece la ecología, que permite un conocimiento a priori del territorio, que servirá para diseñar correctamente las actuaciones a llevar a cabo, o para lograr identificar los impactos significativos generados por una actividad, trabajo que supone el primer paso cuando se procede a restaurar. Por tanto, el enfoque ecológico de la recuperación se basa en el conocimiento del territorio y en los elementos y las relaciones que lo integran.

En este sentido también se debe tener en cuenta que el proceso restaurador no debe ser entendido de forma estática, sino considerando su desarrollo en el tiempo. La acción restauradora no termina con el fin de las tareas técnicas. A partir de ese momento se inicia un proceso de evolución, de sucesión ecológica, suponiendo que las acciones previas hayan sido correctamente diseñadas.

En este estudio se está considerando la técnica de recuperación ambiental o recuperación de espacios degradados, si bien teniendo en cuenta que tiene una importante base ecológica. No obstante, una parte del ámbito académico y científico habla directamente de restauración ecológica, al considerar que esta variable posee una especial trascendencia. Particular relevancia revisten las investigaciones realizadas sobre restauración ecológica de ecosistemas agrarios en la unidad docente de Ecología de la Universidad de Alcalá. Entre otros estudios, cabe citar a REY BENAYAS (2012), quien señala que la restauración ecológica es capaz de aumentar la biodiversidad y los servicios ecosistémicos en los agro-sistemas con el objetivo de contrarrestar los impactos ambientales negativos de la intensificación agrícola; algunas actuaciones propuestas (como una especie de "manicura" a los campos agrícolas) son la introducción de setos vegetales, charcas y cajas-nido para depredadores de roedores. BENAYAS y BULLOCK (2012) relacionan una serie de tipos de intervención relacionadas con la agricultura ambientalmente amigable; se trata de acciones específicas en superficies muy reducidas que renaturalizan los paisajes agrícolas sin competir por el uso de la tierra. Recientemente, BARRAL et al. (2015) demuestran que la restauración ecológica de los ecosistemas agrarios es efectiva y que, por ello, puede ser recomendada para mejorar la biodiversidad y generar servicios ecosistémicos, cuantificando esta mejora en un $73 \%$. 
Por otra parte, desde un punto de vista perceptivo, podemos señalar que conseguir un paisaje de calidad es un objetivo consustancial al tratamiento de recuperación de cualquier espacio degradado. Sin olvidar que la mayor parte de la percepción se realiza por la vista, hay que considerar que tal percepción es polisensorial, por lo que el objetivo citado exige completar la búsqueda de la armonía visual con la posibilidad de disfrute de las manifestaciones sonoras y olfativas, incluso con el logro de una atmósfera de misterio, de unión con la naturaleza, u otras sensaciones que se perciben, por una especie de ósmosis, a través de todas las potencias corporales. Utilizar especies en la revegetación cuya estructura favorezca el sonido de la fronda, favorecer la penetración de aves canoras, o de animales que se puedan identificar por los ruidos que producen, plantar especies aromáticas o evocadoras de misterio, etc., son acciones que completan la percepción visual con la de otros sentidos (GÓMEZ OREA y VILLARINO, 2004).

Estos autores señalan que más allá de la armonía interna y calidad perceptual del espacio recuperado, está la integración paisajística en el medio en que se inscribe, que puede orientarse en dos direcciones. En primer lugar, la semejanza o búsqueda de una apariencia similar al entorno. En segundo, el contraste, que pretende introducir diferencias conspicuas pero armoniosas con el entorno. Ambas son válidas, pero la segunda es más difícil de lograr.

Los cambios que el hombre introduce en el paisaje no suponen siempre una merma de sus cualidades, pero sí alteran la expresión visual de la escena o su función como testimonio de una evolución conjunta, ya que ese paisaje, en estado de equilibrio dinámico, no es otra cosa que la resultante de la interacción del hombre con el medio. Esta idea dinámica del paisaje puede sugerir que los cambios que se producen en él son asumibles, afirmación válida mientras la modificación introducida por el hombre era tan paulatina que se absorbía fácilmente y una generación apenas lo notaba; pero la asombrosa capacidad transformadora del hombre actual, frecuentemente introduce discordancias severas.

La recuperación paisajística pasa, en ocasiones, por la recomposición de los elementos más característicos de la escena; otras opera a través de nuevas formas, materiales, colores y texturas, pero en muchas otras solo es posible eliminar los elementos más impactantes para conseguir un escenario aceptable. Es el caso de la localización de muchas antenas de telefonía móvil en las proximidades de las iglesias de los núcleos rurales, o bien la instalación de aerogeneradores de parques eólicos próximos a conjuntos histórico-artísticos con castillo, como Ampudia (Figura 3.26). Es en este sentido donde operan las herramientas de prevención ambiental, licencia ambiental o evaluación de impacto ambiental, principalmente. 

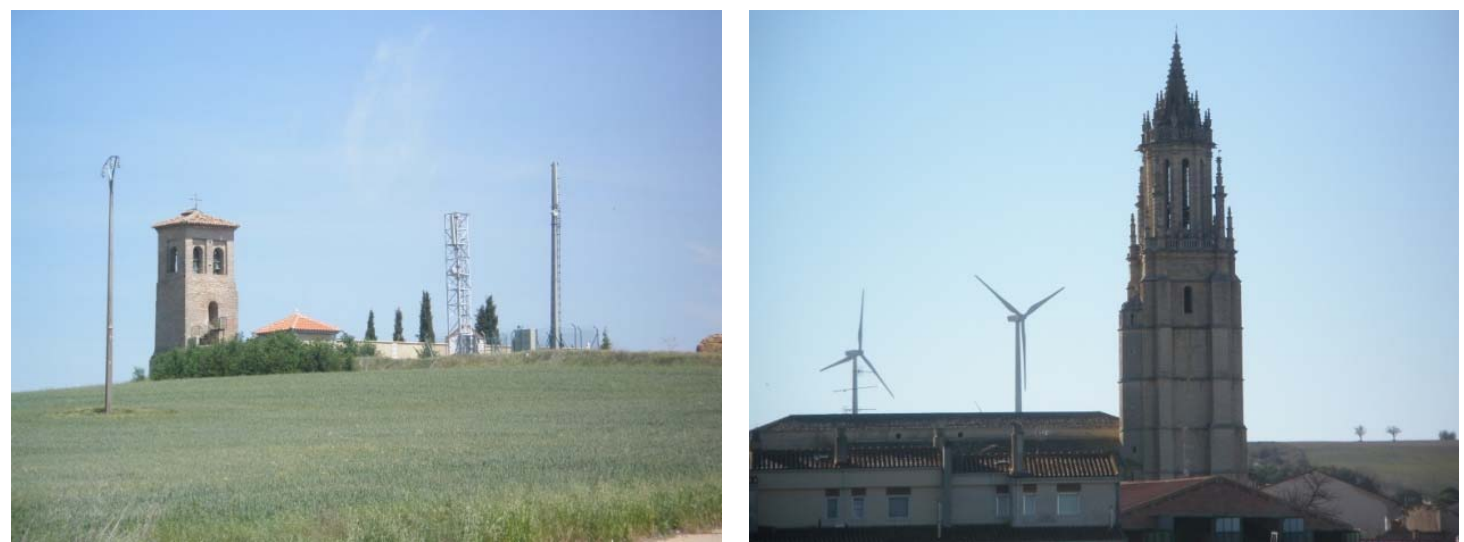

Figura 3.26. Impactos visuales irrecuperables: izquierda, antenas contiguas a la iglesia de Quintanilla de la Cueza; derecha, aerogeneradores alrededor del conjunto histórico-artístico de Ampudia.

\subsubsection{Diseño de la recuperación y definición de usos futuros.}

Como en cualquier actividad, en la restauración resulta fundamental una buena planificación para conseguir el resultado adecuado. Esta debe basarse en el conocimiento de distintos tipos de fuentes de información, como son (UDPP, 2002):

- Reconocimiento topográfico de la zona de actuación y su entorno, con el nivel de detalle y la escala apropiados para el proyecto.

- Valoración ambiental de la zona. Es necesario disponer de estudios del clima, suelo y características ecológicas de la zona, así como valorar los aspectos visuales de la misma y sus potencialidades respecto a los posibles usos.

- Consecuencias e implicaciones del proyecto. Es muy importante conocer la influencia que el desarrollo de un determinado proyecto tendrá en el medio, su relación con otras actividades existentes, las restricciones legales y de planeamiento existentes, la influencia que ejercerá en el tráfico, etc.

- Necesidades del futuro usuario. Es útil determinar las verdaderas necesidades del usuario, separando lo esencial de lo accesorio, y estableciendo las prioridades de dichos requerimientos.

- Función. El planificador debe conocer los aspectos técnicos y funcionales de la actividad a la que se pretende destinar la zona objeto de recuperación. Otro aspecto importante es conocer la intensidad del uso tras la recuperación.

- Aspectos temporales. Se deben considerar dos tipos de escalas temporales: el periodo de desarrollo del proyecto de recuperación y, después, la duración o vida útil de dicho proyecto.

- Costes de inversión. Es imprescindible valorar el proyecto desde el punto de vista de la inversión, para poder determinar su viabilidad o las necesidades de financiación.

- Necesidades y costes de mantenimiento. El objetivo del proyecto de recuperación no es el proyecto en sí, sino su posterior utilización (uso y disfrute). Por tanto, la recuperación no finaliza con la ejecución de las obras; a la hora de planificar un uso hay que pensar 
en su mantenimiento (necesidades y costes), para evitar problemas posteriores en el funcionamiento.

Dentro de estos aspectos citados, en Tierra de Campos cabe destacar la importancia de que los costes sean reducidos y que el mantenimiento sea sencillo o nulo, teniendo en cuenta la amplia extensión de la comarca y su carácter rural deprimido, con unas inversiones públicas muy exiguas.

Los usos a que pueden destinarse los espacios degradados una vez recuperados son muy numerosos. Se destacan los siguientes:

Agrícola. Es el uso más utilizado en el caso de explotaciones mineras, sobre todo si la topografía es suave (Figura 3.27). Este uso tiene la ventaja de que la instalación de vegetación resulta más barata que si se trata de especies forestales; por el contrario, los factores limitantes de este uso son el drenaje, las características químicas de los terrenos y la conservación estricta de toda la tierra vegetal. En este uso se pueden incluir tanto los cultivos herbáceos como los leñosos del tipo de los frutales.

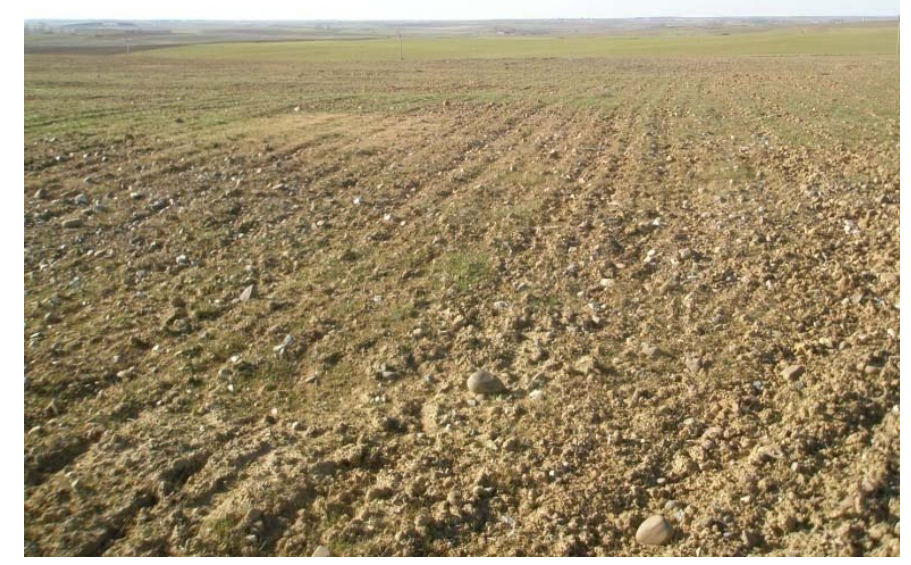

Figura 3.27. Vista del vertedero de inertes de Cisneros, para las obras del ferrocarril de alta velocidad Palencia-León, una vez restaurado como uso agrícola.

Forestal. La plantación de árboles y arbustos resulta una alternativa válida al uso agrícola, sobre todo en terrenos con suelos de peor calidad, de pequeña extensión o con pendientes significativas (Figura 3.28). Además, este uso posee un valor añadido ambiental, mayor si cabe en Tierra de Campos debido a la ausencia prácticamente total de vegetación forestal. Los factores críticos a la hora de desarrollar este uso son la existencia de sustancias tóxicas en los suelos, sus características físicas y la disponibilidad de nutrientes, ya que de ellos dependerá la posibilidad de instalación de las especies forestales. Estos condicionantes se pueden solventar con una adecuada elección de especies del amplio abanico existente, pudiéndose incluir las nobles para producción de madera de calidad. 


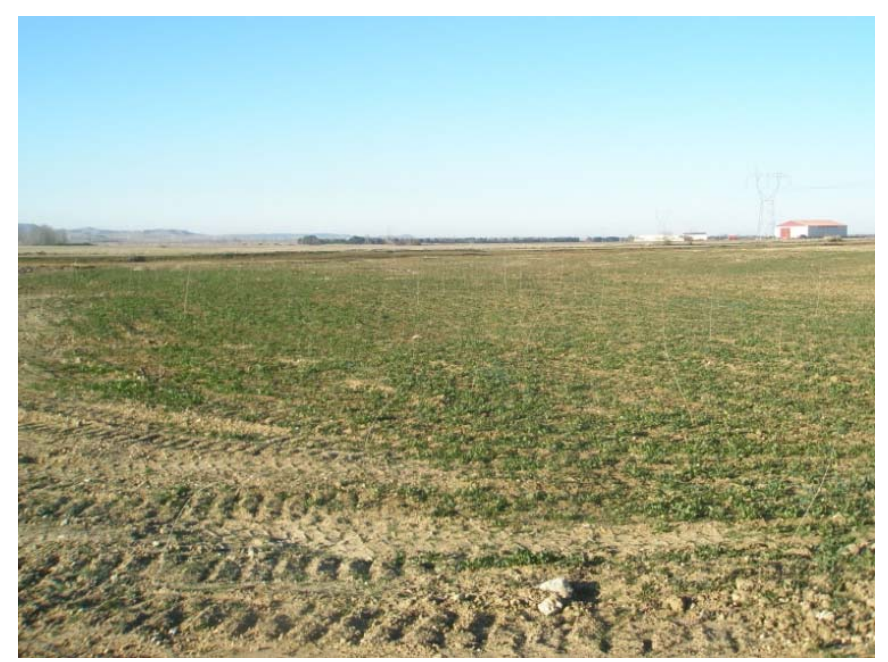

Figura 3.28. Uso forestal (plantación de frondosas ripícolas, aunque todavía no se aprecien) en el préstamo P1 para el ferrocarril de alta velocidad Palencia-León, en Grijota

Conservación de la naturaleza. En el caso de existir terrenos abandonados durante un periodo prolongado, los procesos de colonización natural pueden encontrarse muy avanzados. Ello sucede en muchas explotaciones de áridos o préstamos que afectaron a los acuíferos superficiales, dejando una lámina de agua temporal en superficie que se convierte en hábitat de especies de fauna acuática. Ejemplos en Tierra de Campos son los préstamos asociados a la autovía del Camino de Santiago (Figura 3.29), que se han convertido en lagunas de cierta importancia. Este uso tiene el inconveniente de que, si no se gestiona adecuadamente, puede ser un foco de vertidos ilegales.

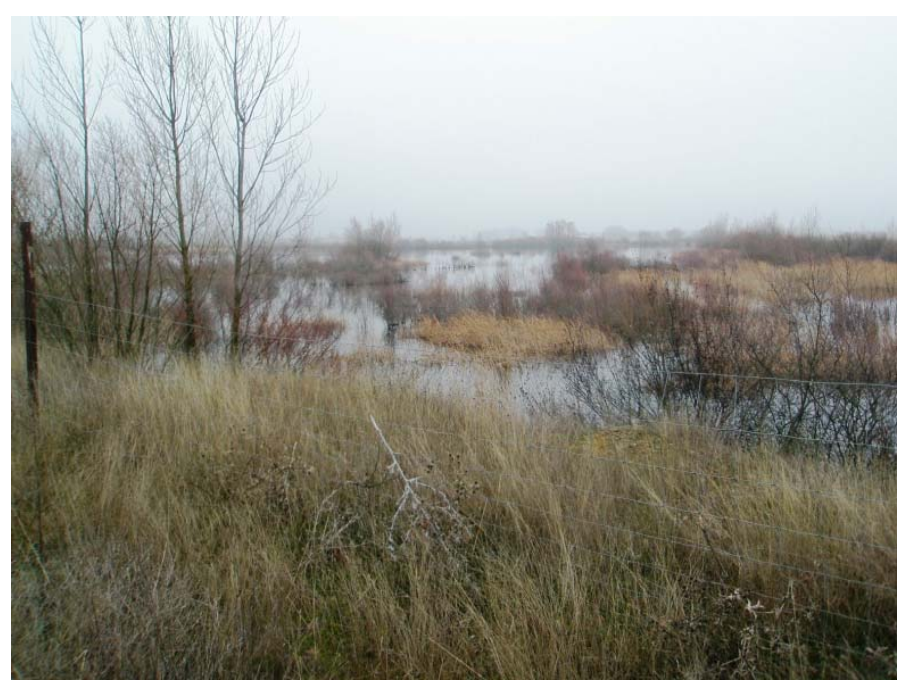

Figura 3.29. Antiguo préstamo para la autovía Camino de Santiago en Calzada de los Molinos, que actualmente se ha convertido en una laguna perfectamente naturalizada. 
Industrial y urbanístico. Aquellas actividades que proporcionen zonas excavadas próximas a áreas urbanas son susceptibles para albergar actividades urbanísticas y comerciales. Los factores que condicionan el uso derivarán de las características geotécnicas y topográficas de los terrenos. Este uso exigirá la clasificación urbanística como suelo urbanizable. Un ejemplo podría ser el de los huecos de las canteras de arcilla existentes en la periferia de la ciudad de Palencia (Figura 3.30), próximos a zonas industriales y cuya restauración para fines agrícolas, forestales o naturales resulta muy compleja.

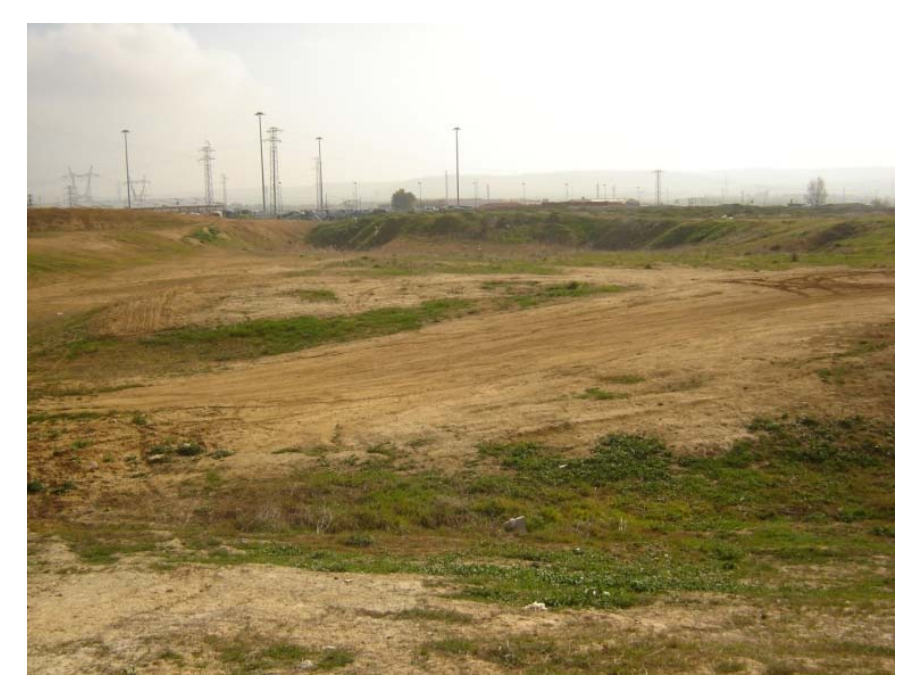

Figura 3.30. Vista de la cantera de arcilla El Pilar, en las proximidades de una zona industrial en Palencia.

Recreativo. Terrenos abandonados próximos a zonas residenciales pueden ser adecuados para instalar distintos tipos de actividades deportivas. La disponibilidad de agua condicionará la posibilidad de desarrollar actividades asociadas a este elemento, tales como el remo, el baño, etc. Las explotaciones mineras ubicadas en las proximidades de zonas de interés natural o cultural pueden ser adecuadas para actividades recreativas asociadas al disfrute de la naturaleza y la educación. En Tierra de Campos es paradigmático el uso complementario recreativo dado al canal de Castilla -utilizado en primera instancia para el regadío-, que es usado para realizar rutas de senderismo, de bicicletas, piragüismo, tránsito en barcaza, interpretación de la naturaleza, etc. Los embalses para riego también pueden tener este uso, como el de Villada o el que se está construyendo en Villalón de Campos, Boadilla de Rioseco, Villafrades de Campos y Herrín de Campos.

Sanitario ambiental. Los usos sanitarios ambientales más comunes son los vertederos de estériles y basuras y los depósitos de agua y abastecimiento. Los vertederos deben realizarse de forma muy controlada, evitando procesos de contaminación debido a posible permeabilidad de los terrenos.

Es importante señalar que, en muchos casos, las restauraciones no tienen como objetivo habilitar la zona para ningún uso específico, sino mejorar el acabado y conseguir la adecuación paisajística de la zona una vez realizadas las obras que implica la actividad que en ella se 
desarrolla. El caso más generalizado es el de restauración de taludes en carreteras (o en cualquier otra infraestructura lineal). La restauración de estas zonas permite la adecuación paisajística de la zona al entorno, así como un mejor acabado de las obras en sí, ya que se disminuyen los riesgos de erosión en taludes y los problemas de drenaje en las cunetas.

\subsubsection{Actuaciones básicas en la recuperación.}

La recuperación de espacios degradados persigue dos objetivos generales: alcanzar una topografía final estructuralmente estable que minimice los riesgos geofísicos y facilite el drenaje natural del agua superficial; y conseguir la integración del conjunto en el paisaje natural circundante (UDPP, 2002).

Para la consecución del primero de los objetivos se incidirá en el modelado del terreno. En los trabajos de recuperación tiene gran importancia conseguir enlazar el área restaurada con la topografía sin alterar y, a la vez, facilitar la instalación de una cubierta vegetal que con el paso del tiempo sea coherente con la vegetación y usos que caracterizan el territorio.

El otro de los objetivos de la recuperación de zonas alteradas es la integración en el paisaje que las rodea. Actividades como la extracción de recursos mineros y de materiales para la construcción, la realización de obra civil (carreteras, ferrocarriles, embalses, etc.), la deposición de vertidos o el abandono de instalaciones dejan superficies alteradas que se traducen en un deterioro y pérdida de calidad del paisaje. Todas ellas marcan huellas visibles y duraderas en el paisaje que en muchos casos deprecian los valores visuales y deben ser tratadas para recuperarlos.

Para conseguir estos objetivos generales, se suelen llevar a cabo las siguientes actuaciones:

\section{GESTIÓN DE LA TIERRA VEGETAL}

El suelo es un complejo y delicado sistema constituido por partículas minerales en diferente estado de transformación, agua, sustancias químicas disueltas, materia orgánica más o menos descompuesta y organismos vivos, que se ha formado por la acción lenta pero continuada (génesis edafológica) de los elementos atmosféricos, climáticos y bióticos, incluido el hombre, sobre la parte superior de la corteza terrestre a lo largo del tiempo (GÓMEZ OREA, 2004). Cinco factores determinan la formación del suelo: el clima, la roca madre, las formas del terreno y los procesos, los seres vivos y el tiempo. El suelo cumple tres importantes funciones muy relacionadas pero diferentes: recurso natural, soporte de vida y receptor de efluentes. El cumplimiento de las funciones del suelo depende de sus propiedades: físicas (textura, estructura, morfología, etc.), químicas (capacidad de intercambio catiónico, reacción del suelo, etc.) y biológicas (presencia de microfauna, organismos vegetales, hongos, bacterias...).

La degradación física del suelo se refiere a la alteración o destrucción de la estructura y/o la morfología del suelo; ambas determinan factores de productividad y de degradación tan importantes como la infiltración, el flujo y almacenamiento de agua, la capacidad de aireación, 
la difusión de calor, la facilidad a la penetración de las raíces, la resistencia a la compactación y a la erosión.

Por todo ello, la protección del suelo, también denominado tierra vegetal o cubierta vegetal, es una de las actuaciones prioritarias en la recuperación. Es coincidente con una medida correctora recogida siempre en cualquier procedimiento de prevención ambiental de una obra que afecte a una cierta extensión territorial: la retirada selectiva de la tierra vegetal y su posterior acopio en cordones de reducida altura, con objeto de evitar las pérdidas de sus propiedades. El problema radica en los espacios alterados que carecen de tierra vegetal, al no haberse retirado esta previamente o haber sido mal gestionada; en estos, deberá importarse un volumen mínimo para la implantación de una cierta cobertura vegetal.

Por consiguiente, el primer paso sería la extracción de la capa superior de suelo vegetal de la superficie a ocupar por cualquier obra o sus elementos auxiliares, para su posterior utilización en la restauración de los terrenos. A fin de facilitar los procesos espontáneos de colonización vegetal, se simultaneará -siempre que sea posible- dicha extracción con la operación de desbroce, de manera que se incorporen propágulos de la vegetación existente en el terreno. Es fundamental no mezclar la tierra vegetal con el resto de horizontes edáficos no fértiles (GÓMEZ OREA, 2003). Ello es importante en Tierra de Campos, donde es difícil realizar una diferenciación cromática clara de los distintos horizontes.

La tierra así obtenida se acopiará en las zonas previstas para ello, preferentemente perimetrales a la obra, llanos y de fácil drenaje. Ello contribuirá a reducir el impacto visual de la obra o actividad. El mantenimiento se realizará con el mínimo posible de labores; su utilización deberá programarse de manera que se minimicen los tiempos de almacenamiento y de permanencia de superficies desnudas.

Los proyectos deberán incorporar un balance de tierra vegetal. Para realizarlo se tendrá en cuenta que el espesor medio se estima en $30 \mathrm{~cm}$ y que la superficie a extender supone la total alterada que no va a tener otro uso: taludes, plataformas, préstamos, vertederos, zonas auxiliares, etc. En las zonas agrarias se debe tener especial cuidado en conservar todo el volumen de tierra vegetal, ya que esta es muy codiciada por los agricultores de parcelas colindantes.

\section{MODELADO DEL TERRENO}

Los objetivos fundamentales que debe conseguir el modelado son (UDPP, 2002):

- Construir una topografía sin problemas de estabilidad y que se integre en el sistema de drenaje natural.

- Que el acabado superficial sea capaz de favorecer y dinamizar la sucesión vegetal.

- La solución topográfica adoptada debe integrarse en el paisaje circundante.

La permanencia de la forma adoptada, con o sin movimiento topográfico, exige que los procesos dinámicos, superficiales o internos, que se puedan generar estén previstos y controlados. Por ejemplo, no existirá riesgo de erosión, de desprendimientos o de cualquier movimiento en masa. En Tierra de Campos son especialmente evidentes los procesos erosivos ocasionados en taludes de desmonte de infraestructuras lineales (Figura 3.31), cuando estos no se conforman con 
pendientes adecuadas (superiores a $2 \mathrm{~V}: 3 \mathrm{H}$ ) y su altura es elevada. La disposición de los materiales utilizados en la remodelación se acercará lo más posible a la que ocupaban en su lugar de origen.

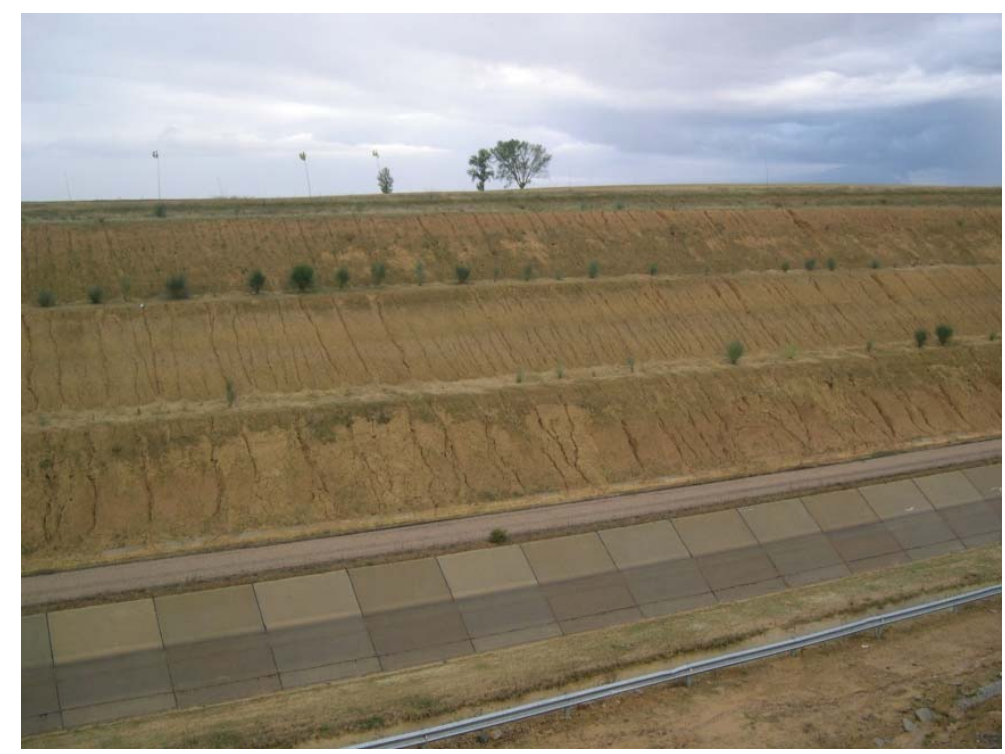

Figura 3.31. Erosión en regueros producida en los taludes de desmonte del canal Esla-Carrión, en Villacarralón. Sus pendientes son pronunciadas y no tienen tierra vegetal.

Otro factor a considerar en el modelado del terreno es el efecto desestabilizador del agua que, además, puede ser un medio de transporte de la contaminación, como ocurre en los vertederos. Es necesario, por estas razones, diseñar un sistema eficaz de drenaje específico para las condiciones climáticas y las características y propiedades de los materiales que forman la estructura a drenar.

Desde el punto de vista estético, los principios generales para conseguir la integración paisajística de los terrenos remodelados, son los siguientes (ARAMBURU, 1993 y UDPP, 2002):

- Reproducir la topografía previa a la actuación siempre que sea posible. En caso contrario, asemejar lo más posible la remodelación a las formas características o dominantes en la zona (Figura 3.32). Es preciso recordar la presencia de suaves lomas que caracteriza al paisaje de Tierra de Campos.

- Evitar la introducción de elementos o formas que denoten artificialidad (líneas rectas, ángulos muy marcados, regularidad de formas geométricas, simetrías, etc.). Un ejemplo son los macizos que quedan en las explotaciones mineras protegiendo los apoyos de las líneas eléctricas, con formas geométricas muy marcadas.

- Cuando se aprovechan formas o elementos existentes en la zona en restauración o resultado del desarrollo de la actividad, aunque no estén de acuerdo con el entorno, a veces podrán permanecer sin cambios cuando sus condiciones estructurales lo permitan. Conviene tener en cuenta que con la recuperación ambiental no siempre es posible cambiar o integrar visualmente la totalidad de la zona alterada. 
- Mantener la escala del paisaje, es decir, la relación entre las dimensiones de sus elementos.

- No disminuir el tamaño de la cuenca visual preexistente, introduciendo elementos que por su tamaño o emplazamiento limiten las vistas.

- El remodelado del terreno no es una acción finalista, sino que puede cumplir un papel destacado durante el desarrollo de la actividad. Es decir, la remodelación del terreno debería ser gradual e incluso formar parte del propio proyecto constructivo o de explotación; ello es evidente en la técnica de transferencia aplicada a determinadas explotaciones mineras.

- Ocultar, en lo posible, la actividad, especialmente desde los puntos principales de observación. La magnitud del impacto visual decrece cuando disminuye la posibilidad de ver la alteración, es decir, con la existencia de obstáculos visuales.

- La idea soporte debe ser copiar las formas del paisaje natural, en el que los procesos naturales y el paso del tiempo consiguen resultados de gran calidad que pueden ser reproducibles.

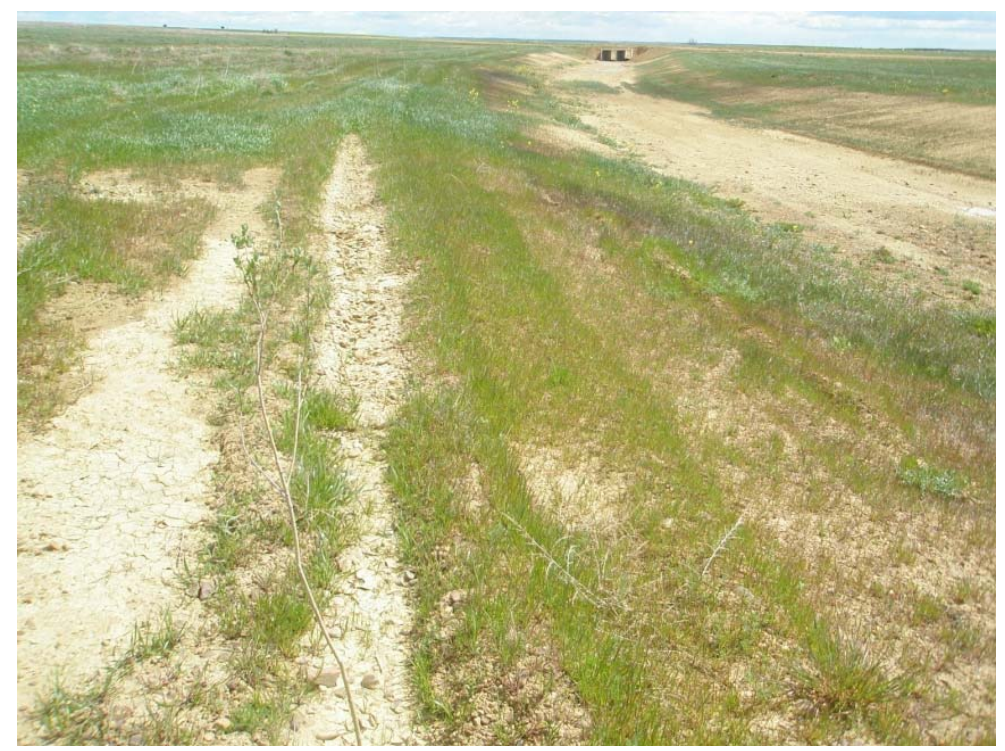

Figura 3.32. Adecuada remodelación del terreno en el préstamo PR1 para la línea de alta velocidad Palencia-León, en Becerril de Campos

\section{RETIRADA Y GESTIÓN DE RESIDUOS}

En aquellos casos en que el espacio ha sido degradado por la acción de obra civil, es frecuente la presencia de restos muy diversos: hormigones, asfaltos, trozos de materiales prefabricados, de casetas de obra, etc. o de instalaciones que es preciso retirar como paso previo a cualquier intervención (GÓMEZ OREA, 2004). Particularmente importantes son los tramos abandonados de antiguas carreteras, que han de ser demolidos, retirados los materiales y gestionados adecuadamente. En las obras de cierta envergadura, el promotor debe contar con un punto limpio donde lleve a cabo una retirada selectiva de residuos y un posterior traslado a gestor 
autorizado. Durante las obras se deben realizar campañas periódicas de retirada de residuos y, en cualquier caso, una limpieza final una vez que las obras hayan finalizado.

Lo mismo ocurre cuando el espacio a recuperar ha sido objeto de deposición espontánea o incontrolada de residuos. En el medio rural este es un aspecto especialmente evidente en determinadas zonas de los espacios periurbanos, fundamentalmente públicos: márgenes de caminos, vías pecuarias, regueros, etc. Actualmente se produce una paradoja ya que, aunque la legislación en materia de residuos es estricta al objeto de procurar su reciclaje y reutilización, en la práctica se está convirtiendo en la aparición de conductas inadecuadas, sobre todo con los escombros. En teoría, en todas las obras mayores los promotores tienen la obligación de trasladar los residuos a plantas de reciclaje de residuos de construcción y demolición. En las obras menores, el Ayuntamiento debería ser responsable de coordinar su retirada, almacenamiento y posterior traslado a dicha planta pero, al no tener capacidad técnica en muchas ocasiones para llevarla a cabo, la consecuencia es el vertido descontrolado en las zonas marginales (Figura 3.33).

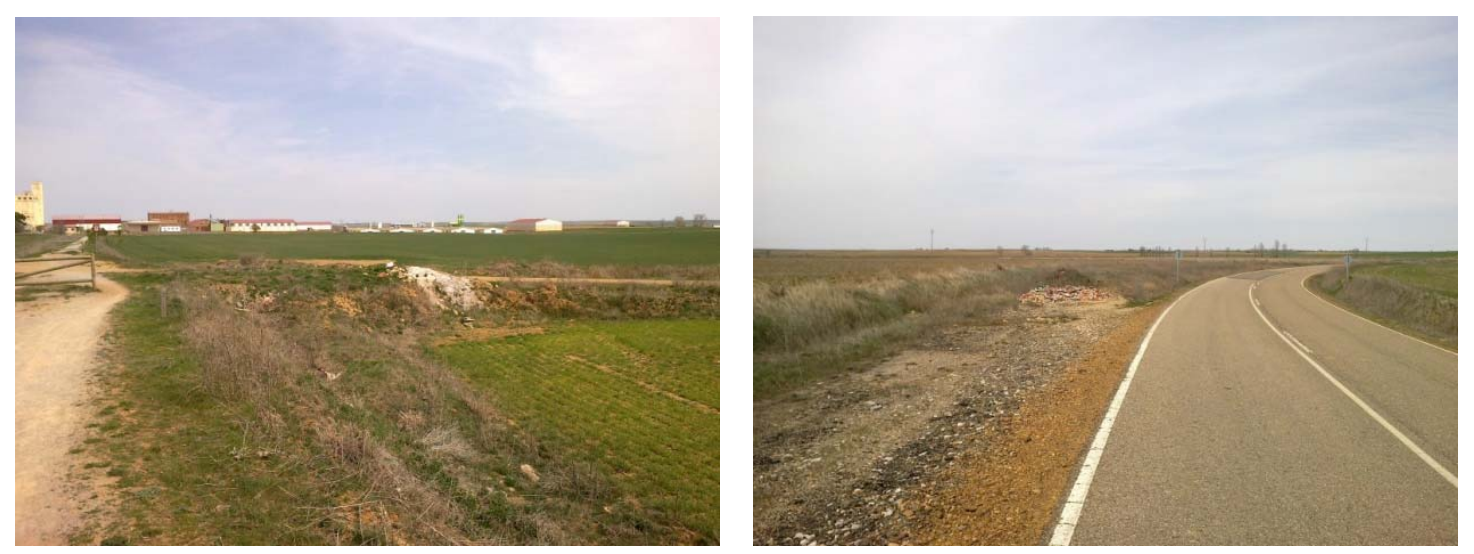

Figura 3.33. Escombros en margen de camino en Villalón de Campos (izquierda) y en margen de carretera (Tamariz de Campos).

\section{REALIZACIÓN DE DRENAJES}

No será posible producir un diseño funcional y estéticamente integrado del área recuperada si no se estudian los aspectos relacionados con el drenaje o, lo que es lo mismo, con la permanencia, circulación y evacuación del agua, tanto durante la ejecución del proyecto de recuperación como durante su funcionamiento y abandono. Es decir, las estrategias para el drenaje de una zona deben ser formuladas durante el proceso proyectual y solo así estarán íntimamente unidas a las características espaciales, visuales y funcionales del resultado final del proyecto.

El drenaje de áreas recuperadas tiene que cumplir las mismas funciones que cumple el drenaje natural no alterado y para ello debe proporcionar las mismas utilidades (UDPP, 2002):

- Prevención de inundaciones. Los sistemas de drenaje artificiales se establecen para regular la permanencia y circulación del agua de escorrentía y de infiltración cuando los 
sistemas naturales son insuficientes o no existen. De esta forma, los problemas de inundación, tanto en la superficie drenada como en las zonas adyacentes, disminuyen.

- Prevención de la erosión. Un sistema de drenaje bien proyectado previene los efectos que acarrea la erosión, problema que no es admisible en las áreas restauradas. Los procesos erosivos destruyen el acabado constructivo, disminuyen la calidad visual, cambian las características del suelo, colmatan los sistemas de drenaje existentes y aumentan la sedimentación. Especial importancia poseen en los taludes de infraestructuras lineales.

- Disminución del riesgo de encharcamiento temporal. El encharcamiento temporal del sistema radical de las plantas, de las infraestructuras, caminos, aparcamientos y otras instalaciones auxiliares puede limitar su plazo de utilidad. El sistema de drenaje no solo debe solucionar los problemas generales en el área recuperada, sino también situaciones puntuales. En los espacios agrícolas de Tierra de Campos, debido a la naturaleza impermeable del sustrato, se han realizado tradicionalmente numerosos drenajes o regueras complementarias a la red hidrológica natural, generalmente en las divisorias de parcelas; cuando las parcelas se concentran, los agricultores tienden a eliminarlos, provocando posteriores encharcamientos en años húmedos.

- Mantenimiento de la calidad del agua. El impacto negativo de las actuaciones en el sistema hidrológico natural debe ser minimizado tanto como sea posible. Es decir, el drenaje construido que se establezca no tiene que afectar al drenaje natural con cambios en la cantidad o calidad del recurso agua.

- Recarga de acuíferos. Disminuir la recarga de acuíferos por facilitar el drenaje superficial de aguas limpias puede tener efectos inducidos no esperados. Una forma de drenaje es no alterar las condiciones naturales de las superficies de recarga; sin embargo, es inevitable drenar las superficies que por sus características o componentes aumentan el riesgo de contaminación del agua subterránea. En lo referente a esta, es más importante mantener la calidad que un previsible aumento de la cantidad.

- Protección de los hábitats de fauna. La red de drenaje superficial construida debe conseguir la conexión entre las partes del drenaje natural que fueron fragmentadas por el desarrollo de la actividad que generó el espacio alterado. La continuidad de hábitats es esencial para la conservación de la fauna, tanto terrestre como acuática.

- Creación de zonas atractivas. En el medio urbano el sistema de drenaje es subterráneo y, por tanto, no perceptible. Cuando nos trasladamos al medio rural puede, además de realizar todas las funciones que le sean exigidas, aumentar la calidad visual y ambiental del medio; por ejemplo, cuando se crean humedales o se restauran riberas en el entorno de los pueblos.

En cuanto a los sistemas de drenaje, existen diversos métodos o tipos, y con frecuencia pueden combinarse entre sí en zonas o en situaciones particulares:

- Canales abiertos. Probablemente, el método de canales o zanjas abiertas es el más antiguo de los empleados. Pueden abrirse con pendientes muy reducidas y admitir corrientes de agua de muy variada naturaleza. Su mantenimiento es simple, ya que cualquier desperfecto se aprecia con facilidad. Como inconvenientes, ocupan gran extensión de tierra, pudiendo interferir en labores de cultivo y suponer una barrera para 
la circulación y el tráfico. En este grupo se encuentran las cunetas de guarda, las de pie, las zanjas de interceptación y las bajantes de las infraestructuras lineales de transporte (Figura 3.34).

- Drenajes superficiales. Consiste en alterar el nivel de la superficie de la zona, normalmente en pendiente, mediante la formación de lomos cuya cima sobrepasa el nivel de los surcos, de manera que el agua escurre desde los lomos a los surcos, corriendo por estos hasta llegar al canal abierto, canal perimetral de pluviales, situado en la parte inferior.

- Drenajes subterráneos. Consiste en abrir una serie de canales bajo la superficie del suelo, conectados entre sí o con desagüe por separado en un canal abierto o en otro punto de recogida. Los drenajes subterráneos formados por tubos se conocen como drenajes tubulares o californianos, y los abiertos en el propio suelo, sin revestimiento alguno, drenajes de zapa o topo. Ambos sistemas pueden utilizarse por separado o de forma combinada.

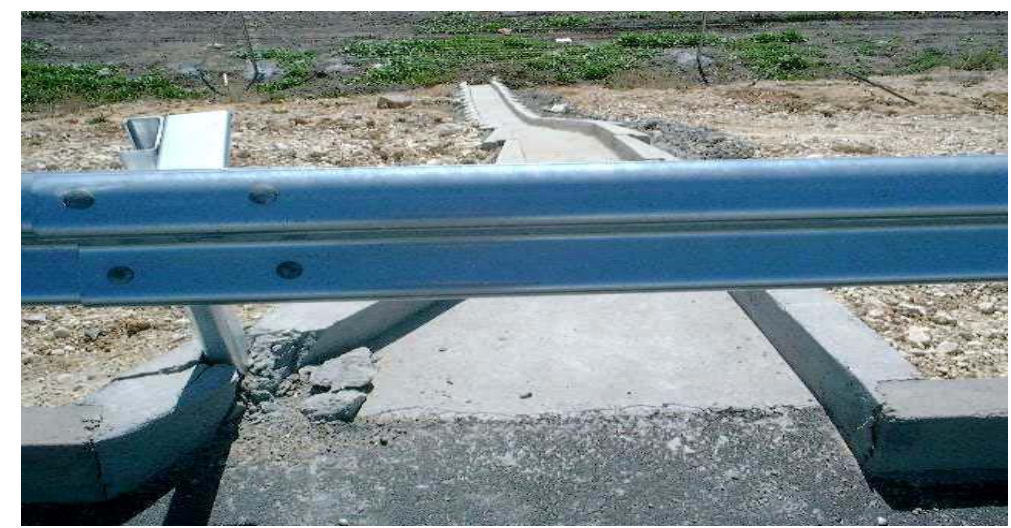

Figura 3.34. Corrección hidrológica (bajante) en la autovía del Camino de Santiago.

\section{ESTABLECIMIENTO DE LA CUBIERTA VEGETAL}

Teniendo en cuenta que la implantación de la cubierta vegetal es la actuación más importante en la recuperación de espacios degradados, se ha decidido desarrollarla con un mayor detalle. El contenido de este apartado está basado sobre todo en la información contenida en GÓMEZ OREA (2004), RAMOS (1970) y UDPP (2002), más aportaciones puntuales (JUNTA, 1995; SERRADA, 1993) y personales, con especial incidencia en la aplicación que puede tener al paisaje de campiñas cerealistas de Tierra de Campos.

\section{OBJETIVOS, FUNCIONES Y DISEÑO}

La creación de una cubierta vegetal, en la totalidad o en parte de su superficie, es un tratamiento generalmente necesario en la recuperación de cualquier espacio degradado. Normalmente la revegetación se realiza en un medio desfavorable (suelos esqueléticos, fuertes pendientes, existencia de fenómenos erosivos, etc.), lo que hace indispensable la intervención humana tanto 
si se desea reconstruir la vegetación potencial, una etapa de la sucesión ecológica o simplemente una cobertura vegetal alóctona destinada a conseguir fines específicos.

La revegetación deberá cumplir dos objetivos básicos (GÓMEZ OREA, 2004):

- Conseguir una masa vegetal estable. Ello depende de su adaptación a las condiciones ecológicas del lugar, por ello la forma obvia de conseguirla consiste en fomentar la colonización natural a partir de las especies existentes en el ámbito circundante. Cuando esto no es posible o el plazo es excesivamente dilatado, suele hacerse imprescindible el recurso a la implantación directa de la cubierta vegetal que se desea o de las etapas iniciales de su sucesión ecológica, de tal manera que su evolución conduzca en última instancia a la aparición de la vegetación climácica. Por otro lado, el sistema es más estable cuanto más diversificado es, es decir, cuantos más nichos se ocupan. La valoración positiva de las especies nativas no debe implicar el rechazo de las exóticas, que las pueden sustituir con ventaja en relación con el plazo, la estética, las funciones que se demanda a la cubierta vegetal u otras dificultades: terreno sin retazos de vegetación originaria, deterioro edafológico o insuficiente disponibilidad en viveros.

- Minimizar el mantenimiento. Debe procurarse que la plantación tienda por sí misma a formar sistemas capaces de auto mantenerse y que, a ser posible, puedan progresar hacia estructuras más complejas de forma natural. Se pretende que sean sistemas persistentes a pesar de las perturbaciones. Los tratamientos de tipo "ajardinado" son sistemas inestables que se mantienen de forma artificial gracias a costosos aportes periódicos de riegos, abonados, fitosanitarios, etc. Necesitan, por tanto, un alto coste de mantenimiento que hay que evitar. La utilización de especies adecuadas a las condiciones ambientales reducirá, e incluso hará innecesarias este tipo de acciones.

Por otro lado, la implantación de una cubierta vegetal estable cumple muy variadas e importantes funciones, que se describirán a continuación:

- Incremento de la biodiversidad. Se suele aceptar el principio de diversidad a la hora de proyectar una comunidad vegetal; por ello se prefieren comunidades mixtas, heterogéneas en cuanto a especies y estratificada en altura con presencia de árboles, arbustos y hierbas, imitando a la naturaleza. Si las especies están bien elegidas, se benefician mutuamente y poco a poco la masa va evolucionando en el sentido de optimizar las sinergias propias de los ecosistemas naturales. Asimismo, la masa vegetal diversa y multiestratificada invitará a la penetración de comunidades animales que encontrarán en ella alimento y refugio. La fauna, a su vez, favorecerá la viabilidad de la masa vegetal y contribuirá a que el conjunto evolucione hacia un ecosistema maduro, cuya homeostasis favorecerá su estabilidad y permanencia.

- Mejora del paisaje perceptual. En este sentido, el diseño puede orientarse en dos direcciones: hacia el contraste con el entorno -buscando una composición nueva y diferente del paisaje circundante-, o hacia la integración con el entorno -recreando el paisaje circundante-. En la actualidad parece dominar la segunda opción, lo que se consigue combinando especies que aparecen en el medio natural próximo y 
distribuyéndolas según las pautas que lo caracterizan. Este es el enfoque que debería tenerse en cuenta en la revegetación de buena parte de los espacios degradados del paisaje cerealista de Tierra de Campos, donde confluirían la función ecológica con la estética o perceptual. Por el contrario, en los espacios periurbanos podría adoptarse también el primer enfoque, ya que sus condiciones son obviamente diferentes.

- Estabilización y protección del suelo. El entramado que forman las raíces en un terreno actúa como una especie de armazón que le aporta coherencia a los materiales y los sujeta contribuyendo a su estabilidad. Por otro lado, la cubierta vegetal evita la erosión: su sistema radicular contribuye a inmovilizar los materiales del suelo, mientras que su sistema aéreo protege al suelo de la acción directa de la lluvia o del viento (cuya energía cinética reduce considerablemente), aumentando la infiltración y reduciendo la escorrentía superficial. Asimismo, una cubierta vegetal estable contribuye a crear un microclima en las proximidades del suelo que favorece su evolución edáfica: reduce la insolación y las variaciones de temperatura y humedad bruscas, incrementa el contenido en materia orgánica por la descomposición de sus tejidos, fomenta la presencia y actividad de la microflora y microfauna del suelo, equilibra el contenido nutricional del suelo... y todo ello se traduce en una mejora de la estructura, humectación, permeabilidad, penetrabilidad, capacidad de oxidación y estabilización de los nutrientes naturales.

- Mejora de las condiciones hidrológicas. Una cubierta vegetal estable, suficientemente densa y adecuadamente estratificada actúa de forma positiva sobre el ciclo hidrológico: aumenta la interceptación, favorece la infiltración y recarga de los acuíferos subterráneos $\mathrm{y}$, por tanto, disminuye la escorrentía superficial. Además contribuye a que las aguas presenten indicadores de calidad elevados para diferentes utilizaciones.

- Función recreativa. Los espacios revegetados podrán ser utilizados como solaz y recreo para una población cuya tendencia a la urbanización le hace apetecer los espacios naturales o naturalizados. En ellos se podrá pasear, disfrutar en bicicleta, recolectar plantas aromáticas, hongos y setas, etc. En Tierra de Campos es especialmente importante esta función ya que, aunque aparentemente se trata de una comarca rural poco antropizada, la agricultura intensiva que se desarrolla ha hecho prácticamente desaparecer los espacios públicos y el arbolado donde se podría desarrollar la actividad recreativa. Especial relevancia tienen los jardines de los pueblos, como lugar de esparcimiento de los vecinos, y los espacios degradados periurbanos, que pueden restaurarse y revegetarse para formar parte de las zonas verdes del pueblo.

- Reserva de la fauna cinegética y silvestre. En el paisaje agrícola cerealista, la presencia de manchas arbustivas y arbóreas tienen una importancia fundamental para el refugio de la fauna frente a posibles predadores, así como en su reproducción. Hay que tener en cuenta que la caza se ha convertido en un recurso muy demandado y capaz de generar unas rentas suplementarias notables para la economía rural, especialmente si se cuida y mejora mínimamente su hábitat (JUNTA DE CYL, 1992). El paisaje de campiñas cerealistas posee un potencial cinegético muy elevado en caza menor (perdiz, codorniz, 
liebre, conejo, etc.), por lo que cualquier medida encaminada a la revegetación de cualquiera de sus espacios degradados contribuiría a mejorar sustancialmente su hábitat. La restauración con vegetación de los ecosistemas agrarios, para favorecer la fauna silvestre, es una actuación cada vez más tenida en cuenta a nivel europeo (REY BENAYAS y BULLOCK, 2015).

- Formación de pantallas. Las pantallas vegetales más características son aquellas que pretenden ocultar algún elemento distorsionante (naves agroganaderas, plantas de tratamiento de minerales...). Pueden tener incluso motivos funcionales, como ocurre en las carreteras o autovías, donde ciertas barreras lineales de vegetación orientan al conductor sobre la dirección de la carretera, evitan deslumbramientos o interrumpen corrientes de aire que pueden, en ciertos puntos, amenazar la estabilidad de los vehículos.

- Material de construcción biológico. En algunas ocasiones se utilizan plantas vivas o partes de ellas como material de construcción en combinación con otros materiales clásicos, como piedra, hormigón, madera, telas metálicas, mallas de plástico, geotextiles, mantas orgánicas, etc., a obras de muy diversa naturaleza. Esta combinación de materiales vivos e inertes ha dado origen a lo que viene denominándose biotecnología o bioingeniería, campo en el que se han desarrollado numerosas técnicas muy especializadas e ingeniosas.

- Sumidero de $\mathrm{CO}_{2}$. Cuando los terrenos agrícolas u otros degradados sin vegetación pasan a tener una cubierta forestal se inicia un proceso de captura de carbono atmosférico. El crecimiento de los árboles se construye sobre la captación de $\mathrm{CO}_{2}$ que, una vez forma parte de la biomasa vegetal, puede incorporarse al suelo como materia orgánica tras su descomposición, permanecer sobre el suelo en forma de madera muerta u hojarasca, o permanecer durante periodos más o menos largos en los productos derivados de la madera. En el proyecto INIA-SUM2006-00023-C05 se cuantifica el flujo de carbono en varios ejemplos de plantaciones forestales productoras: encina trufera, pino piñonero, chopo y frondosas para madera de calidad. En este sentido se debe tener en cuenta que, según el protocolo de Kioto, cuando los árboles se cortan o mueren, dejan de contabilizarse a efectos de fijación, pues se asume que acaban rápidamente en la atmósfera; por lo tanto, el balance una vez cortado el árbol es nulo, a diferencia de los combustibles fósiles cuyo balance siempre es negativo (FAFCYLE, 2010).

- Regulación climática. Aunque evidentemente las plantaciones forestales por sí mismas no son capaces de modificar el clima, sí que pueden modificar ligeramente a escala local determinados parámetros climáticos: en el entorno de las zonas arboladas se suavizan las temperaturas, la humedad aumenta, etc.

En el diseño con especies vegetales se deben seguir una serie de pautas que se basan en los factores utilizados para medir la naturalidad de un territorio (UDPP, 2002): 
- Preferencia por la disposición irregular de la vegetación. En la naturaleza existen pocas líneas rectas. En el espacio rústico (el campo) se deben evitar, pero en el urbano o periurbano (los pueblos) o en los caminos rurales y carreteras no tendrían por qué obviarse. No debe olvidarse que la población del medio rural tiene preferencias subjetivas hacia la vegetación ordenada.

- Sencillez y claridad del diseño; la naturaleza nos da muchos ejemplos de ello. Por otro lado, así la ejecución de los proyectos de restauración será más sencilla y efectiva.

- No abusar de las especies con colores brillantes que, generalmente, corresponden a especies propias de otras latitudes.

- Evitar la creación de terrazas u otras formaciones artificiales que cambien sensiblemente la disposición del perfil natural del suelo. Nuevamente se ha de tener en cuenta la morfología característica de Tierra de Campos, de llanuras suavemente onduladas.

- Preferir -que no es lo mismo que exigir- las especies autóctonas sobre las exóticas.

- Considerar la posibilidad de introducir escalonadamente las especies. Es decir, no pretender alcanzar el equilibrio estructural y funcional con una sola actuación.

- Seleccionar, entre las posibles especies vegetales, las que sean adecuadas al uso final que se pretende, a las condiciones ambientales del lugar y que se desarrollen mejor y más rápidamente. No tiene nada que ver una zona periurbana ajardinada con una ribera de un río o arroyo.

- No dudar en aprovechar las posibilidades de los productos y materiales disponibles en el mercado ambiental, como abonos, enmiendas orgánicas, protectores, tutores, geomallas, etc., que han evolucionado mucho en los últimos años. Aunque, eso sí, restringiendo su uso por su carestía a las zonas más urbanas o a aquellas donde sea inevitable.

- Preparar el suelo de tal manera que las dificultades de instalación sean mínimas. Siempre será posible volver a acondicionarlo una vez que la vegetación está instalada.

- Es preferible utilizar muchas plantas de tamaño reducido que pocas de mayor tamaño. Es lo que se realiza en las repoblaciones forestales, con éxito en la mayoría de las ocasiones. No hay que olvidar que el objetivo es conseguir la mayor cantidad de vegetación con el menor coste económico. Hay que tener en cuenta que, con el paso del tiempo, la mortalidad puede ser importante.

- El éxito final no se alcanzará si no se establece un programa de cuidados o de mantenimiento, aunque sea mínimo. Los dos años siguientes a la implantación de la vegetación son fundamentales para su futuro afianzamiento.

\section{SELECCIÓN DE ESPECIES}

Gran parte del éxito de la recuperación se centra en la selección de especies vegetales. Dada la variada gama de factores que pueden condicionar la selección, no es posible ni conveniente establecer un único método sistemático, detallado y rígido; el método de selección ha de ser abierto y flexible. Por ello, resulta prudente diseñar un método de selección basado en aproximaciones sucesivas al problema, que permita la detección de condicionantes particulares en cada caso (ecológicos, paisajísticos, técnicos, económicos, sociales, etc.), en vez de establecer 
a priori y de forma genérica un orden de importancia de los factores ambientales y realizar una criba secuencial de especies según el criterio prefijado.

En cualquier caso, se exponen a continuación unos criterios básicos para la selección:

Adaptación al medio. En la creación de hábitats con especies arbóreas, arbustivas o herbáceas se deben seleccionar aquellas capaces de tolerar las condiciones del medio, a ser posible entre las especies circundantes. Ello es así porque cada especie tiene sus limitaciones climáticas, fisiográficas y biológicas. Entre los parámetros ecológicos cuyos valores pueden indicar la aptitud mayor o menor de una especie podemos citar: humedad, pendiente, temperatura, luz y exposición, altitud, características químicas del suelo y contenido en materia orgánica, estructura, textura y aireación del suelo, etc. En Tierra de Campos, tal vez los valores más críticos sean la presencia de suelos excesivamente arcillosos y la sequía y el calor estivales.

Adecuación a los objetivos previstos. El conocimiento del uso o usos que se quieren desarrollar en una zona degradada resulta básico para desarrollar un esquema de trabajo adecuado. La consideración más importante es la elección de plantas que sirvan para el objetivo planteado, sea este de control de la erosión, estético, de producción, etc. Por ejemplo, las especies herbáceas podrán instalarse rápidamente en pendientes estables donde evitarán la erosión en los primeros años mejor que los árboles o arbustos. El uso mayoritario que se plantea en la recuperación de espacios degradados en este estudio es el de mejora del paisaje, tanto desde el punto de vista ecológico como el estético.

Preferencia por las especies autóctonas. Aunque en ocasiones la introducción de especies exóticas puede resultar lo más adecuado para unas determinadas circunstancias, es preferible en general utilizar especies autóctonas, al presentar considerables ventajas sobre otro tipo de mezclas. La vegetación existente en el área es un indicador excelente del tipo de comunidades que pueden desarrollarse en ella, y de las especies que tendrán más posibilidades de supervivencia en ese hábitat. Las condiciones producidas por la introducción de especies autóctonas serán también las más apropiadas para la futura aparición de otras especies asociadas. Asimismo, estas especies serán la base para el posible establecimiento de la fauna indígena. Tierra de Campos es una comarca totalmente antropizada desde hace miles de años; por ello, no debería ser un inconveniente insalvable la utilización de especies exóticas en la recuperación. No obstante, en principio parece más indicado que estas especies se restrinjan a los espacios periurbanos o a aquellos más alterados.

Agresividad de las especies. En este punto es necesario actuar conforme a los objetivos de la restauración a corto, medio y largo plazo. Si lo que se busca es un tapizado rápido, conviene utilizar especies agresivas que colonicen la zona en un plazo breve de tiempo. Si se busca la diversidad de especies, será mejor que antes de introducir especies invasoras, se establezcan otras menos agresivas, de forma que cuando en una segunda fase aparezcan aquellas, no engullan a las más débiles que estarán ya más evolucionadas.

Disponibilidad de plantas y semillas. Si la planta seleccionada no puede obtenerse, de nada sirve el proceso anterior, por lo que este es un importante aspecto a considerar. Además de la disponibilidad de las plantas en viveros cercanos, conviene conocer su forma de producción, la procedencia del material vegetal y otras características que aseguren la adaptación de las 
plantas. Afortunadamente, en los últimos años se han creado varios viveros en Castilla y León que disponen de una gran variedad de planta para la recuperación de espacios degradados en las campiñas cerealistas.

Necesidad de mantenimiento. La creación de una comunidad vegetal que se mantenga por sí misma es una meta ecológica importante. Esto tiene además implicaciones económicas, pues en la mayoría de los casos se quieren minimizar los costes, por lo que habrá que seleccionar plantas que requieran el mínimo mantenimiento, teniendo en cuenta que alguno será normalmente necesario. Si no es posible un mantenimiento posterior adecuado, no deben utilizarse plantas que requieran podas, riegos o fertilizaciones periódicas. Ello es importante hasta en los espacios ajardinados de las poblaciones rurales, al carecer en general los Ayuntamientos de los medios personales para llevar a cabo un correcto mantenimiento.

Presencia de predadores, plagas y enfermedades. La existencia de animales que se alimentan de las plantas existentes puede ser un factor negativo muy serio a considerar en la revegetación. En Tierra de Campos, los mayores riesgos se presentan en el caso del ganado ovino, los conejos y los topillos, cuando tienen lugar explosiones demográficas de ambas especies. En el caso de plagas y enfermedades de difícil control, puede ser inevitable descartar algunas especies que según el resto de los factores resulten recomendables; es el caso de Ulmus minor debido a la grafiosis, enfermedad causada por hongos de transmisión asociada a insectos.

Integración paisajística. Una vez seleccionadas las especies que cumplen los requisitos fundamentales, entran en juego los criterios de diseño. En este sentido, la distribución de las especies debe acercarse lo más posible a lo que sería su expansión natural. Para ello hay que considerar la forma, tamaño, textura y color de las plantas a utilizar:

- Forma: es más importante cuando se trata de individuos aislados, ya que dentro de un grupo la forma se hace menos notable. No conviene, en cualquier caso, mezclar en un grupo individuos de formas muy diferentes, pues demasiada variedad resulta en desorden y resta calidad estética al diseño efectuado.

- Tamaño: es necesaria su consideración para el espaciado de las plantas. Los tamaños de las plantas conviene elegirlos para las distintas especies de forma que el diseño de las plantaciones se acerque o imite a la naturaleza.

- Textura: varía con la distancia al observador y depende de las texturas adyacentes, debido al contraste con ellas. Varía también con las estaciones, en el caso de especies caducifolias. Las perennifolias poseen una textura más consistente, un grano visual más uniforme.

- Color: las flores, frutos, hojas y ramas son las que aportan el color, que está también influido por las variaciones estacionales. Como en otros elementos de diseño, una excesiva variedad cromática crea una sensación de confusión y desorganización que estropea otros efectos visuales positivos. Sin embargo, cierta variedad reduce la monotonía y crea un agradable efecto al observador. Especial consideración debe prestarse a los coloridos de las frondosas en el otoño.

En una línea similar a los criterios de selección de especies mencionados, LÓPEZ LILLO y RAMOS (1969) consideran que la integración en el paisaje de infraestructuras y construcciones, debería realizarse con especies que crezcan espontáneamente en la zona en cuestión, pero sin que sea 
de forma obligada. Así, en el caso de la meseta castellana, dos de las principales especies arbóreas naturales serían la encina y el pino piñonero, pero su crecimiento es muy lento, por lo que se podría acudir a otras aunque no fuesen autóctonas. Por ello se debe buscar un equilibrio entre la vegetación indígena y la importada, en función de lo que convenga a cada proyecto. El catálogo vegetal útil para un lugar comprende todas las plantas que puedan vivir en él y que sirvan a la idea del proyecto.

En las declaraciones de impacto ambiental sobre proyectos desarrollados en Castilla y León se suele redactar el apartado referente a la restauración vegetal como "se emplearán especies autóctonas o propias de la zona". Con esta idea se pretende dar preferencia a las plantas espontáneas, pero sin descartar otras que puedan adaptarse a la zona.

En cualquier caso, un requisito básico para utilizar una determinada especie es su rusticidad o resistencia, entendida como la capacidad de adecuación a un medio humanizado. También es importante considerar su duración, es decir, su longevidad natural, sobre todo si el objetivo es integrar construcciones. En cuanto a la diversidad específica, también se debería buscar un equilibrio en función del objetivo y características del proyecto (LÓPEZ LILLO y RAMOS, op.cit.).

En cuanto a la forma del vegetal, estos autores consideran tres variables fundamentalmente que pueden condicionar la elección de especies:

- Estructura: disposición de tronco y ramas (esqueleto, silueta, aspecto geométrico).

- Textura: abundancia, disposición, duración, forma y tamaño de las hojas.

- Color de hojas, flores y frutos, así como su dinamismo y duración.

El libro Valoración del paisaje natural, ampliamente citado en este apartado, incluye una serie de cuadros de gran interés con listados de especies vegetales apropiadas a una serie de requerimientos, algunos de ellos de interés en el presente estudio, como árboles y arbustos según tamaño, persistencia o no de la hoja, color de la hoja, época de floración o de fructificación; árboles para alineaciones; árboles y arbustos para suelos arcillosos, etc.

En cuanto al proceso de selección (UDPP, 2002), como punto de partida conviene contar con una clasificación del territorio conforme a las condiciones ecológicas (exposición, cercanía al agua, etc.) y a los objetivos propuestos. De este modo se establecen las distintas áreas del proyecto y, posteriormente, se elabora una lista de especies para cada una de ellas. Del tipo de áreas a tratar y de la adecuación a las mismas de las especies, surgen los condicionantes que marcarán el uso de la vegetación y, por tanto, una selección previa. El siguiente paso consiste en analizar para las especies elegidas, su adecuación a los objetivos de la recuperación, que indirectamente compromete a la decisión de utilizar plantas autóctonas o alóctonas, o de mayor o menor agresividad. Entrarían también aquí en consideración los criterios de diseño. Finalmente, en un tercer paso, habrá que recurrir a las especies que pueden facilitar los viveristas, así como considerar su necesidad de mantenimiento.

En la última fase puede ocurrir que haya especies muy interesantes con las que en principio no se podrá contar. Esto da lugar a un proceso de vuelta atrás para elegir otras especies tal vez menos adecuadas pero accesibles. En cualquier caso, una magnífica fuente de información para 
la selección de especies son las experiencias de revegetación en zonas de similares características.

En una línea similar a lo anteriormente descrito, OTERO et al. (1999) señala que la elección de especies ha de pasar por tres fases: en la primera se analizarán los factores ecológicos; en la segunda, los factores biológicos; y en la última, los factores económicos y estéticos (Figura 3.35).

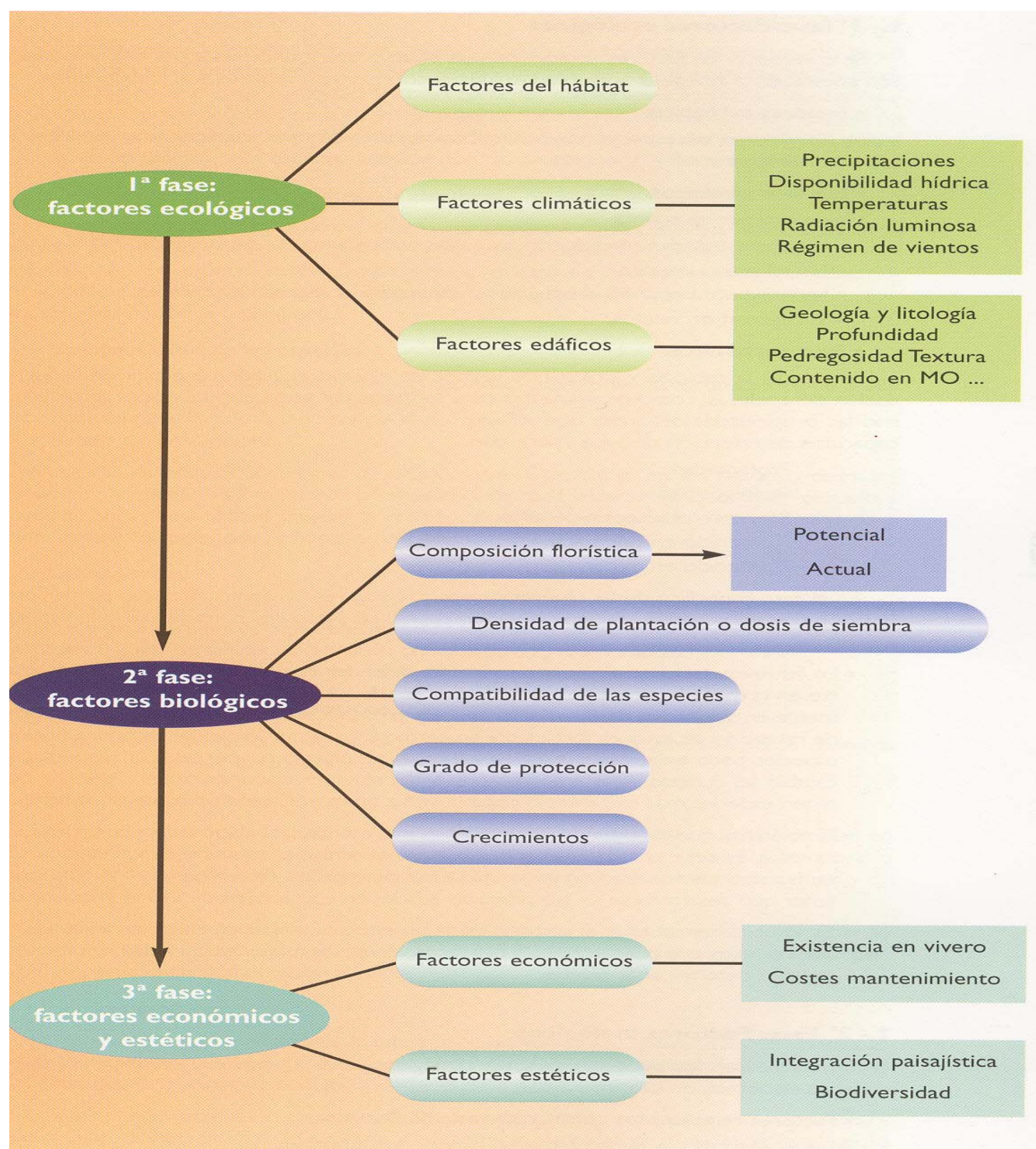

Figura 3.35. Fases de la elección de especies (OTERO et al., 1999)

\section{TÉCNICAS DE INSTALACIÓN DE LA VEGETACIÓN}

\section{Preparación del terreno}

La implantación de vegetación se realiza, en general, sobre suelos y terrenos que no están en las mejores condiciones para el logro del establecimiento de las especies vegetales a introducir. 
En el caso de las siembras, el éxito de la germinación se ve comprometido por el apelmazamiento de los suelos -consecuencia sobre todo del trasiego de maquinaria durante las obras, en su caso-, que no permite que la imbibición de agua por la semilla se logre con la rapidez necesaria. Tampoco permite la aireación suficiente de la semilla enterrada y, además, la falta de porosidad del suelo hace de este un medio no idóneo para suavizar y regularizar las condiciones térmicas que requiere una buena germinación. En el caso de las plantaciones, los suelos compactos no retienen fácilmente el agua ni facilitan el desarrollo de las delgadas y débiles raicillas de la planta que se ha colocado en el suelo, con lo que se dificulta en gran medida su arraigo.

En cualquier caso, para conseguir una adecuada implantación de la vegetación propuesta será necesaria la realización de una serie de actuaciones:

\section{Laboreo del terreno}

Es el tratamiento superficial o profundo del terreno sobre suelos que presentan dificultades para la implantación de vegetación. Es una operación encaminada a mullir el suelo, alterando la disposición de los horizontes, hasta una profundidad aproximada de 25 ó $30 \mathrm{~cm}$. Puede realizarse en cualquier momento en que el contenido en humedad sea bajo, pues de lo contrario es difícil trabajar y hay un serio peligro de ulterior compactación.

En el caso de siembras se debe efectuar un escarificado superficial del suelo previamente al extendido de tierra de calidad. Como complemento del laboreo, puede ser necesaria la eliminación de piedras o de cualquier otro objeto extraño.

Para las plantaciones, hay que tener en cuenta que los árboles, arbustos y matas necesitan suelos bien drenados, aireados y moderadamente fértiles para que el arraigo tenga éxito. La preparación del terreno puede ser areal o bien puntual. La preparación areal es mecanizada y, dependiendo del método, afectará a un determinado porcentaje de la superficie; el más utilizado en Tierra de Campos es el subsolado, que podrá ser lineal, pleno o cruzado. El subsolado se realiza mediante tractor acoplado con rejones, que mueven una profundidad mínima de 50 $\mathrm{cm}$. La preparación puntual es el ahoyado, que podrá ser manual o mecanizado; en este último caso los métodos más empleados son el ahoyado mecanizado con bulldozer (en laderas), el ahoyado con barrena y el ahoyado con retroexcavadora. Las dimensiones del hoyo oscilan entre los $30 \times 30 \times 30 \mathrm{~cm}$ y los $60 \times 60 \times 60 \mathrm{~cm}$, de acuerdo con el tamaño de la planta a introducir. En cualquier caso, la preparación del terreno debe efectuarse con la mayor antelación posible respecto de la plantación (preferentemente en verano), para favorecer la meteorización de las tierras.

\section{Extendido de tierra vegetal}

En el caso de que, durante la obra, se hubiese retirado selectivamente la tierra vegetal, se deberá proceder ahora a su extendido en la superficie a revegetar. En caso contrario, si fuese necesario, se habrá de acudir a algún préstamo de suelos aceptables. Las superficies sobre las que se extienda se escarificarán ligeramente con anterioridad. Se debe evitar el paso sobre la tierra vegetal de maquinaria pesada que pueda ocasionar su compactación, especialmente si aquella está húmeda. 
Si se opera sobre taludes, la carga y distribución debe hacerse con pala cargadora y camiones basculantes, que repartirán la tierra adecuadamente. Cuando la pendiente no permita que la tierra vegetal se sostenga por sí misma, se tendrá que recurrir a técnicas especiales, tales como el extendido de redes vegetales, geotextiles, etc.

\section{Incorporación de enmiendas y abonos}

Se define como enmienda la aportación de sustancias que mejoren la condición física del suelo. Pueden ser enmiendas húmicas (para añadir materia orgánica), calizas (para llevar el pH de suelos ácidos a valores adecuados próximos a la neutralidad) o de arena (para mejorar la textura del suelo, a más aireada, en caso de suelos pesados); en Tierra de Campos serían aplicables la primera y la última de ellas.

Los abonos pueden ser orgánicos, es decir, sustancias orgánicas de cuya descomposición resulta un aporte de humus y una mejora en la textura y estructura del suelo; o minerales, que son aquellos productos que proporcionan al suelo otros elementos fertilizantes. Estos últimos suelen ser de nitrógeno, fósforo, potasio y oligoelementos.

\section{Drenajes}

Esta actuación se refiere para casos puntuales, como la plantación de especies de gran tamaño en suelos pesados. En el caso de los hoyos, se debe colocar una capa filtrante de grava en el fondo de los mismos de forma que, a ser posible, queden en la base los elementos más gruesos, sobre ellos los más finos, y encima una capa de arena de río lavada.

\section{$\underline{\text { Siembras }}$}

Sembrar es colocar una semilla sobre la superficie del suelo, recubriéndola con una capa del mismo de mayor o menor espesor, o depositar una semilla en el fondo de un surco de poca profundidad, tapándolo seguidamente para que dé lugar a una nueva planta. En la restauración debe tenderse, salvo excepciones, a la búsqueda de la diversidad, por lo que es preferible realizar siembras pluriespecíficas con mezclas de hasta 12 especies en las que haya gramíneas, leguminosas y leñosas de carácter pionero.

La siembra puede realizarse con una máquina sembradora o bien de forma manual, para lo que requiere entonces personal cualificado capaz de hacer una distribución uniforme de la semilla. Los momentos más indicados para la siembra son durante el otoño y la primavera, por este orden de preferencia, en días sin viento y con suelo poco o nada húmedo.

La siembra conlleva una serie de ventajas frente a la plantación: es más barata, se realiza más rápidamente, puede realizarse en terrenos difíciles, protege antes de la erosión, puede ejecutarse durante un periodo más amplio, etc. Entre los inconvenientes, cabe citar que tiene más riesgo de supervivencia, es difícil calcular la densidad adecuada, solo es posible en lugares de condiciones ecológicas favorables y puede ser difícil adquirir grandes cantidades de semilla. 
Una opción barata en Tierra de Campos es utilizar semillas de las sobrantes de las plantas seleccionadoras, que son más rústicas, aun cuando se debe asegurar siempre el equilibrio entre gramíneas (colonización rápida) y leguminosas (estabilidad a medio plazo).

\section{$\underline{\text { Hidrosiembras }}$}

La hidrosiembra es una técnica habitual para la recuperación de taludes (infraestructuras lineales, canteras, vertederos, etc.), cuyo fin básico es frenar los procesos erosivos lo antes posible en zonas desprovistas de vegetación o que no reúnen condiciones para una instauración de la vegetación natural a corto plazo. Este aspecto es importante, ya que existen taludes donde -si se ha realizado una adecuada gestión y extensión de la tierra vegetal- la revegetación natural puede producirse muy pronto, en cuyo caso no se precisa la hidrosiembra.

Consiste en la proyección sobre el terreno de una mezcla de semillas, abonos, aditivos y agua, sobre la que posteriormente, o en una sola operación, se extiende una capa de mulch. Esto se realiza mediante una máquina hidrosembradora que tiene un tanque con unas palas agitadoras en su interior. En él se produce la mezcla que posteriormente se lanzará a través del cañón de la hidrosembradora.

Como en la siembra normal, se utilizará una mezcla con gramíneas, leguminosas y leñosas de bajo porte. Las clases de mulch más frecuentes son celulosa, heno picado y paja de cereal picada. Los abonos pueden ser húmicos o minerales. Como aditivos se pueden utilizar inóculos de Rhizobium, productos hormonales, fungicidas y estabilizadores.

\section{Plantaciones}

Plantar es colocar una planta, criada en otro lugar distinto al del asiento (vivero), introduciendo su sistema radical de forma que esté en perfecto contacto con la tierra y se logre, asimismo, su estabilidad mecánica, para que una vez arraigada siga desarrollándose. El proceso de plantación conlleva los siguientes aspectos:

Replanteo: Es importante recordar aquí uno de los objetivos de la restauración, consistente en la integración de la obra en el entorno. Por eso a la hora del replanteo conviene mirar la naturaleza circundante -sobre todo en las zonas no urbanas- para tratar de imitar la disposición de su vegetación, su patrón de distribución. Y en cualquier caso, evidentemente, seguir el diseño previsto según el objetivo concreto de la restauración.

Las plantaciones pueden estructurarse en individuos o en grupos. Los individuos corresponden a elementos arbóreos o arbustivos de tamaño pequeño o mediano, y los grupos pueden reunir distintas combinaciones de árboles y arbustos. Los árboles pueden utilizarse aisladamente o en grupos, y debe considerarse la separación de individuos dentro de un grupo y la separación de los grupos entre sí, así como la regularidad de su distribución, según que el objetivo tenga fines de jardinería o quiera representar masas relativamente bien estructuradas. Normalmente los grupos tratan de representar un repoblado natural, y se disponen con el fin de generar bosquetes asimilables a los naturales.

Conviene ubicar primero los árboles y buscar después los huecos que, respetando las distancias mínimas establecidas, se dedicarán a la colocación de arbolillos, arbustos, matas, etc. Como 
datos aproximados, los árboles distarán entre sí 4-6 m; los arbustos 2-3 m; las matas se colocarán a una densidad de 1-6 plantas $/ \mathrm{m}^{2}$; y las tapizantes se plantarán entre 8 y 25 por $\mathrm{m}^{2}$.

Época de la plantación: La plantación debe realizarse, en lo posible, durante el periodo de reposo vegetativo, y evitando los días de heladas fuertes, lo que suele excluir de ese periodo los meses de diciembre, enero y parte de febrero. El trasplante realizado en otoño presenta ventajas en los climas de largas sequías estivales y de inviernos suaves, porque al llegar el verano la planta ha emitido ya raíces nuevas y está en mejores condiciones para afrontar el calor y la falta de agua. En lugares de inviernos crudos como Tierra de Campos es aconsejable llevar a cabo los trasplantes en los meses de febrero o marzo, aunque también podría realizarse en octubre y noviembre. Las matas en maceta o cepellón pueden sobrepasar estas fechas, y en general las coníferas es preferible plantarlas en otoño.

Transporte desde el vivero y almacenamiento: Debe cuidarse que no se sequen las raíces, tomando asimismo las máximas precauciones para evitar magulladuras, roturas y otros daños físicos tanto a las raíces como a los tallos o ramas de las plantas. Para que no se rompan o se deterioren los cepellones, debe ponerse sumo cuidado al bajar del camión las plantas que estén dispuestas de esta forma. Nunca deben apilarse unas encima de otras, o tan apretadamente que puedan resultar dañadas por la compresión o el calor. Cuando se trate de plantas a raíz desnuda, deberán almacenarse cubriendo dichas raíces con arena o tierra húmeda; especial atención se ha de prestar con las heladas en Tierra de Campos.

Tipos de plantación: La plantación puede realizarse de diferentes formas, aunque las más comunes son las siguientes:

- Plantación a raíz desnuda. Se efectuará, como norma general, con los árboles y arbustos de hoja caediza que no presenten especiales dificultades para su posterior enraizamiento. Previamente se procederá a eliminar las raíces dañadas por el arranque o por otras razones, cuidando de conservar el mayor número posible de raicillas, y a efectuar el "pralinage", operación que consiste en sumergir las raíces, inmediatamente antes de la plantación, en una mezcla de arcilla, abono orgánico y agua (a la que cabe añadir una pequeña cantidad de hormonas de enraizamiento), que favorece la emisión de raicillas e impide la desecación del sistema radical. La planta debe presentarse de forma que las raíces no sufran flexiones, especialmente cuando exista una raíz principal bien definida, y debe rellenarse el hoyo con una tierra adecuada en cantidad suficiente para que el asentamiento posterior no origine diferencias de nivel. Tras la plantación es necesario un riego abundante que expulse el aire y facilite, por la compactación producida, el contacto de las raicillas con el suelo.

- Plantación con cepellón (Figura 3.36). Es obligada para todas las coníferas de cierto desarrollo y para otras especies de hoja persistente. El cepellón debe estar sujeto de forma conveniente para evitar que se agriete o se desprenda. En los trasplantes de ejemplares de gran tamaño o desarrollo, debe seguirse uno de los sistemas de envoltura en yeso, escayola, madera, etc. y cuidarse que el transporte a pie de obra se haga de modo que no haya roturas internas en el cepellón. Al rellenar el hoyo e ir apretando la 
tierra por tongadas, se debe hacer de forma que no se deshaga el cepellón que rodea a las raíces. Es preciso también un riego abundante.
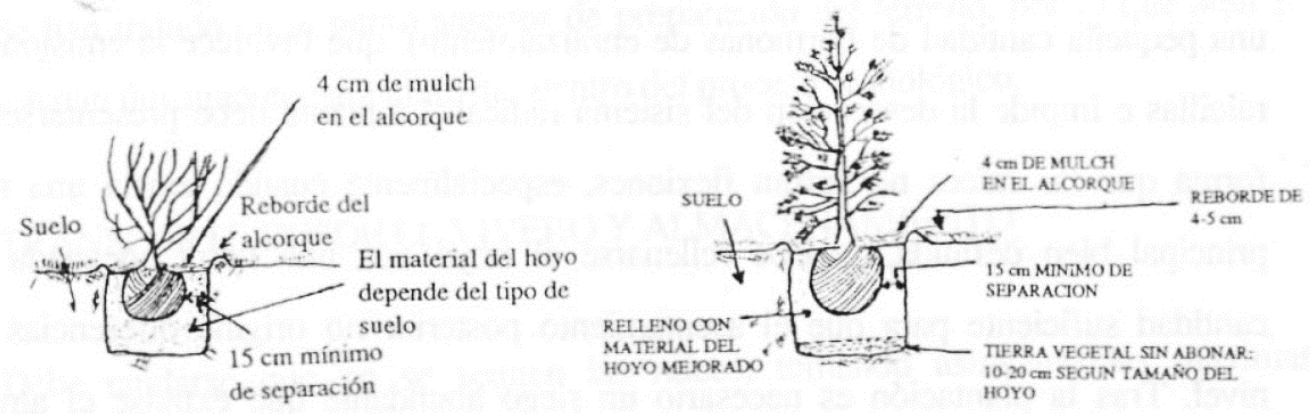

Figura 3.36. Sección típica de plantación de arbusto (izquierda) y de planta perennifolia (derecha). El tamaño del hoyo dependerá del volumen del cepellón (UDPP, 2002)

- Propagación vegetativa. Es una técnica de plantación en la que se utilizan partes de plantas desarrolladas que se implantan en la zona a restaurar. Puede realizarse por esquejes (fragmento herbáceo o leñoso que emite raíces y brotes), estaquillas (esquejes leñosos de 30-40 cm, figura 3.37)), varetas (esquejes leñosos de 40-200 cm) o división de planta (partición de una planta madre en distintas completas). Estos sistemas presentan la ventaja de que no es necesario recurrir al vivero, pues pueden recogerse en el campo, además de saber que es un material conocido y adaptado a las condiciones del medio. En todos los casos se requieren condiciones de humedad, utilizándose principalmente como especies las frondosas riparias: chopos, sauces, álamos, etc.
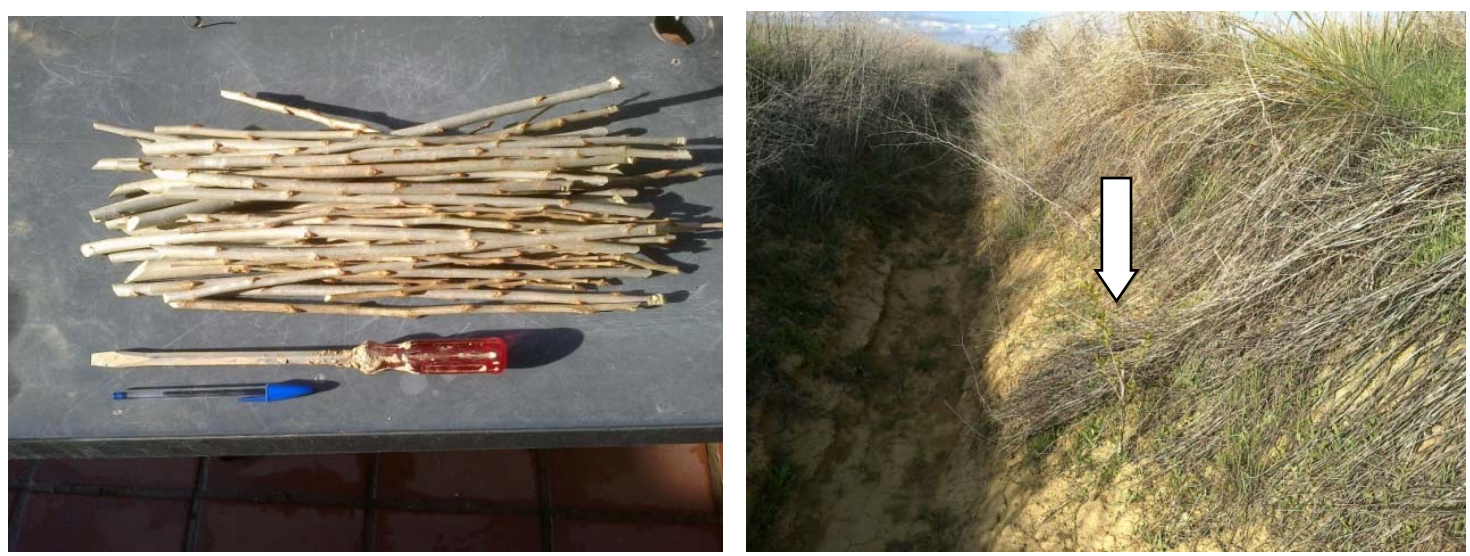

Figura 3.37. Izquierda, estaquillas de chopo lombardo; derecha, estaquilla brotada de chopo en reguera de Villalón de Campos.

Colocación de la planta y operaciones complementarias: Es la acción de la plantación propiamente dicha (Figura 3.38). En el momento de la colocación, los árboles y arbustos deben centrarse, colocarse rectos y orientarse correctamente dentro de los hoyos y zanjas, al nivel 
adecuado para que, cuando prendan, guarden con la rasante la misma relación que tenían en su anterior ubicación. Es conveniente que en el fondo del hoyo se mantenga una cierta capa de tierra fértil movida, con objeto de favorecer el primer crecimiento de las raíces.

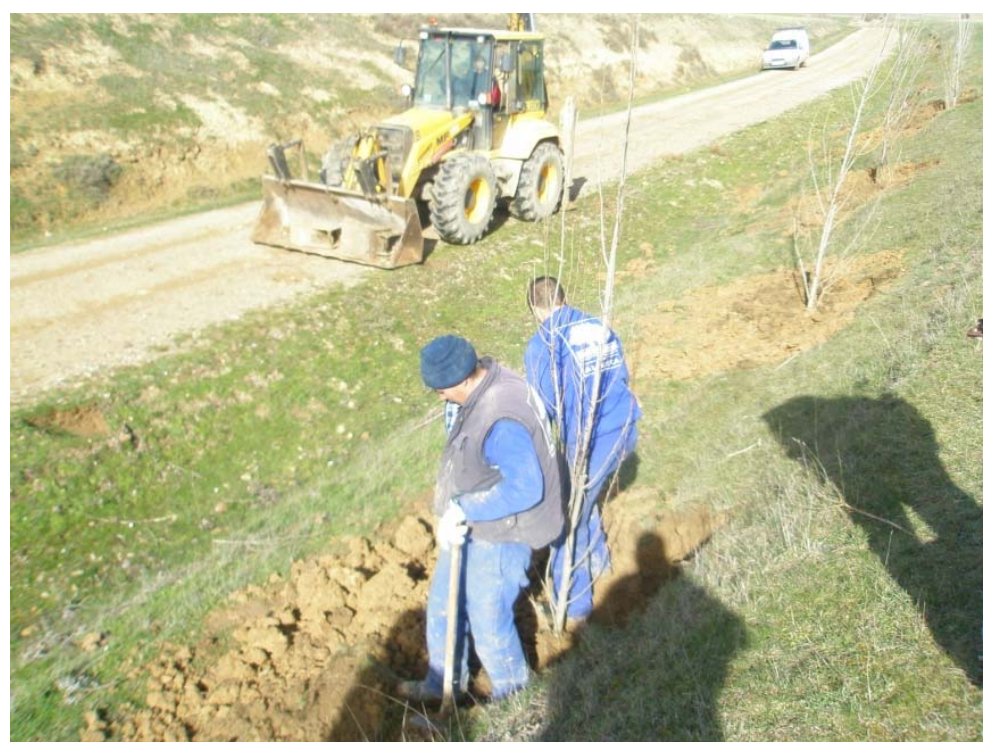

Figura 3.38. Plantación de frondosas en el Camino de Santiago: retroexcavadora que realiza los hoyos y operarios colocando la planta.

Puede ser necesario el uso de tutores -sobre todo para plantas de tamaño medio y grande, por problemas con el viento habituales en la comarca-, que son estacas rectas que, clavadas en el suelo y unidas a la planta, le ayudan a mantener la posición vertical en sus primeros estadios de desarrollo (Figura 3.39).

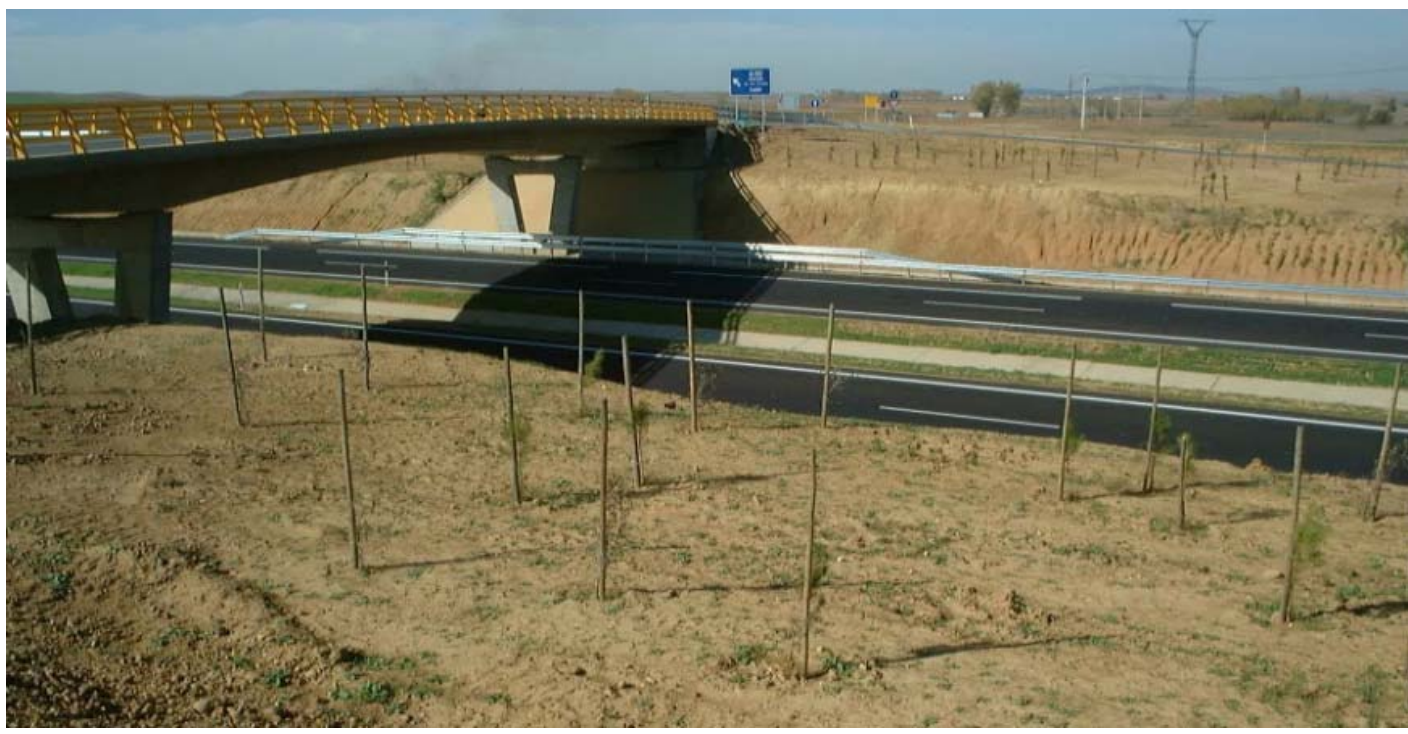

Figura 3.39. Pinos con tutores en la autovía del Camino de Santiago, en Osorno 
Los protectores son instrumentos cuyo objetivo es ayudar a la planta en su crecimiento, reduciendo la competencia animal y vegetal y proporcionando unas condiciones de desarrollo idóneas. Presentan las siguientes ventajas:

- Reducen los daños originados por conejos, topillos y ganado ovino.

- Señalizan la plantación frente a las prácticas agrarias.

- Protegen físicamente durante los desbroces químicos o mecánicos.

- Aceleran el crecimiento, al acumular calor y humedad.

- Protegen de la competencia vegetal vecina.

Los más empleados son los tubos, generalmente cilíndricos, de materiales plásticos biodegradables. Es aconsejable que estén perforados, con objeto de que no se concentre en el interior un ambiente con una elevada temperatura. En algunos casos puede rodearse la planta con una malla plástica o metálica semirrígida, solución más barata y que puede proteger a la planta frente a determinados animales.

Es aconsejable la realización de un alcorque alrededor de cada planta, para que retenga el mayor volumen posible de precipitación. En el caso de terrenos en ladera, este alcorque tendrá la forma de microcuenca. Teniendo en cuenta que las precipitaciones anuales en Tierra de Campos son escasas y existe el periodo seco crítico estival, se debería considerar la aplicación de todas las tecnologías de captación de precipitaciones horizontales y escorrentías para zonas secas (NAVARRO et al., 2009).

Finalmente, la cubrición del entorno de la planta con una capa de mulch (el acolchado) favorecerá el mantenimiento de la humedad edáfica, necesaria sobre todo en la época estival. La paja -tan abundante en la comarca- podría ser un excelente material para realizar esta labor. El estiércol con paja sería idóneo, pues su lenta disgregación mejoraría la calidad del suelo.

\section{CUIDADOS CULTURALES Y MANTENIMIENTO}

Los cuidados culturales y el mantenimiento comprenden los trabajos, tareas y labores que se deben realizar en la zona restaurada para conseguir que la vegetación instalada se desarrolle de una manera óptima, acorde con los objetivos de la restauración.

Como norma general debe primar la idea de que las labores de mantenimiento deben ser las mínimas posibles, por lo que suponen de costo y obligación. Cuando por las razones que sean se consideren, se dirigirán a procurar que el esfuerzo económico y social realizado perdure en el tiempo.

En general, los cuidados mínimos que deben llevarse a cabo son los siguientes:

Riego

El riego es la manera artificial de aplicar agua a las plantas de modo que pueda ser aprovechada al máximo por ellas. La absorción de agua se realiza a través del suelo y está condicionada por la cantidad, distribución y calidad del agua. La planta comienza a padecer sequía cuando es 
incapaz de absorber agua o cuando la velocidad de captación es menor que la pérdida que padece por transpiración. En Tierra de Campos, con una precipitación de en torno a 400 $\mathrm{mm} / \mathrm{año}$, el riego puede ser conveniente en determinadas plantaciones durante los dos primeros años de desarrollo: frondosas, plantas de más de una savia, ornamentales, suelos excesivamente secos,... La periodicidad de riego podría ser semanal (ideal) o quincenal (más factible) en la época estival, especialmente durante agosto y septiembre.

En la restauración de zonas naturales no se suele realizar ninguna instalación de riego (goteo, aspersión, a manta, etc.); se utilizan depósitos móviles (cubas) o sistemas combinados con arquetas de distribución (ayudados de motobombas) y camiones cuba. El riego debe efectuarse en las primeras horas de la mañana o en las últimas de la tarde y nunca coincidiendo con días de fuerte viento, para evitar una evaporación intensa del agua. Se debe evitar el uso de mangueras con presiones elevadas, para no alterar el alcorque o descalzar las raíces. En cambio, en determinadas zonas verdes de los pueblos sí que es totalmente recomendable la instalación de riego automático, bien sea goteo o bien aspersión.

\section{Fertilización y control de calidad del substrato}

Las plantaciones y siembras exigen aportación de nutrientes según la textura de los suelos y su riqueza, debido fundamentalmente a la pérdida de nutrientes por lavado del suelo por lluvia, o por el desarrollo de las plantas. Estas aportaciones pueden ser periódicas o restringirse exclusivamente a los primeros años de desarrollo de las plantas.

En el caso de árboles y arbustos habrá que poner a su disposición cantidades adecuadas de fertilizantes en las diferentes fases de su desarrollo: floración, foliación, etc., mientras que en los casos de vegetación herbácea se recomienda la utilización de enmiendas, abonos orgánicos o abonos químicos de asimilación lenta, en dosis apropiadas según cada caso. Aunque se pueden aportar nutrientes en cualquier época del año, es conveniente aplicarlos durante la temporada de invierno y, con criterio general, al finalizar esta. Para comprobar las carencias nutricionales de las plantas se deberán efectuar controles anuales.

Los fertilizantes que son aconsejables aplicar dependen de las carencias nutricionales que se hayan presentado, del tipo de sustrato sobre el que se planta o siembra, del pH, de la presencia de especies vegetales competidoras, etc., pero básicamente estarán formados por nitrógeno, fósforo y potasio, que son los elementos nutritivos fundamentales para el desarrollo: fertilizantes del tipo N-P-K de liberación lenta.

\section{Tratamientos fitosanitarios}

La presencia de hongos patógenos e insectos fitófagos junto a los árboles y arbustos implantados es común en el medio restaurado. Si el desarrollo de esta biocenosis es normal, se puede decir que existe un equilibrio biológico, y tanto los componentes como la estructura del ecosistema se conservan a lo largo del tiempo. Sin embargo, tanto estos factores bióticos como otros abióticos pueden romper el equilibrio dinámico. Los desequilibrios más frecuentes que se registran a cargo de los seres vivos son los ocasionados por los hongos patógenos y por los insectos fitófagos que producen el fenómeno "plaga". Cuando se hace notable su presencia de forma conspicua a través del debilitamiento de las plantas $y$, a su vez, pueden influir de forma 
significativa en la estabilidad de la cubierta vegetal de la zona restaurada, se deben eliminar mediante los tratamientos fitosanitarios.

Las especies alóctonas son generalmente mucho más vulnerables a estos seres vivos patógenos; las consecuencias de su acción van desde el debilitamiento y la disminución del crecimiento hasta la muerte de la masa arbórea.

En cuanto al tratamiento, la postura más racional es aquella que tiende al empleo de sistemas selvícolas sencillos (siempre que se pueda) y que fomenta la presencia de una fauna útil para la defensa contra las plagas. Esta práctica consiste en la realización de podas de limpieza de las ramas y partes enfermas y en el favorecimiento de predadores insectívoros. Solo en el caso de que los insectos $u$ hongos causantes de las plagas aumentaran sus ataques con poblaciones descontroladas, se actuaría con tratamientos químicos.

Siega

La labor de siega consiste en la eliminación de la parte aérea de la vegetación anual y bianual, por encima de 3-5 cm del suelo, por medios manuales o mecánicos. Se realiza preferentemente sobre las superficies hidrosembradas o sembradas a voleo (para favorecer su desarrollo), así como sobre aquellas superficies donde se han realizado nuevas plantaciones (para eliminar la competencia de las plantas o simplemente para ser más visibles). También se efectúa por motivos de protección contra incendios - de la propia zona restaurada y, por extensión, de otras zonas próximas- pues muchas de estas zonas restauradas poseen mayor riesgo debido a su cercanía a carreteras o a zonas urbanas.

Repetición de la siembra

Después de efectuada la siembra o hidrosiembra, y pasado un tiempo prudencial de uno a dos meses por regla general, si no se observa la germinación de las especies sembradas es necesario repetir la actuación de nuevo. Evidentemente, se realizará si la época es la adecuada (otoño y primavera).

Además, como labor de mantenimiento está el recebado o resiembra de aquellas zonas que por alguna razón han perdido el tapiz vegetal: trasiego por las obras, pisoteo, enfermedades fúngicas, mala aireación, etc. En este caso, los riegos, abonados y la protección física de la zona sembrada son fundamentales para conseguir el objetivo pretendido.

\section{Eliminación de malas hierbas en zonas sembradas}

En ocasiones se debe acometer la eliminación y retirada de plantas que pueden suponer un peligro para la estabilidad y diversidad de la zona restaurada. Por regla general, estas plantas son de estructura herbácea (Oxalis, sp., tréboles, amarantháceas, poligonáceas, etc.), aunque en ocasiones son rebrotes de plantas leñosas muy agresivas que tienen carácter invasor. El origen puede ser muy diverso; bien de los alrededores o bien del material vegetal utilizado en la restauración. 


\section{Desbroces}

Este cuidado cultural corresponde a la eliminación total o parcial del material leñoso -matas, subarbustos y arbustos- por motivos de diseño, tratamientos fitosanitarios o por problemas de competencia entre especies vegetales leñosas (sobre todo con el arbolado).

En otras ocasiones, para rejuvenecer una planta, eliminar partes enfermas, limpiar zonas extensas cubiertas de matas en las que se acumulan restos orgánicos e inorgánicos, etc., o bien para dar otro aspecto paisajístico a una zona restaurada, se deben cortar las especies leñosas a ras del suelo. Esta operación, lógicamente, solo se efectuará con aquellas especies que tengan capacidad de brotar de cepa: retamas, rosales silvestres, etc. En estos casos hay que tener en cuenta la época, para no perjudicar a la fauna (época de anidamientos), a la propia planta o al uso de la zona restaurada.

Binas

Sobre todo cuando se trata de restauraciones arbóreas con fines productivos es conveniente la realización de binas, que consiste en romper la costra superficial que aparece en los suelos arcillosos. Tiene la finalidad de conservar la humedad del suelo y se deberá realizar al final de la primavera.

Si el marco de la plantación permite la mecanización, se utilizarán binadores, girocultores o gradas, bien de discos o de púas, actuando entre filas de plantas lo suficientemente separado de ellas como para no dañar su parte aérea o su sistema radical. Conviene completar esta operación mecánica con una labor manual en las proximidades de la planta, empleando la azada, el escavillo o el rastrillo.

En el caso de que la densidad de plantación no permita la mecanización de la labor, se recurrirá a la bina manual, actuando en una superficie de $1 \mathrm{~m}^{2}$ alrededor de cada planta

\section{Reposición de marras en plantaciones}

Se entiende por marras los fallos habidos en las plantaciones realizadas. Al final del verano siguiente a la plantación se deberá comprobar la presencia de ejemplares arbóreos o arbustivos muertos por cualquier causa. La proporción de plantas secas frente al total plantado será indicativo del tipo de problema que ha podido producir la muerte de las plantas: sequía, falta de riego, enfermedad, mala calidad de la vegetación, deficiente plantación, competencia con otras especies, etc.

La necesidad de reponer marras dependerá de si la densidad inicial planteada era suficientemente elevada como para preverlas; en caso contrario, se suele estimar un porcentaje mínimo de en torno a un $20 \%$ para reponer marras.

\section{Colocación de vientos y tutores}

Cuando las plantas tienen una altura mayor a $1 \mathrm{~m}$ y existe un cierto desequilibrio entre la parte aérea y la subterránea, es conveniente sujetarlas con un tutor, que es una estaca de madera que se hinca en la tierra y se ata al tallo. 
Si el tutor no es suficiente, será necesaria la colocación de vientos, que son cuerdas o cables que se atan por un extremo al tronco del árbol a la altura conveniente y por otra al suelo. Se deberá proteger la zona de contacto con la planta convenientemente para no producir heridas. Será necesario vigilar periódicamente el estado de conservación de los tutores y los vientos, con objeto de que realicen eficazmente su función.

\section{Aclareo y eliminación de malas hierbas}

En las zonas donde la densidad de árboles resulta excesivamente alta o superior a la diseñada inicialmente para cubrir los objetivos previstos, será necesario efectuar un aclareo de la vegetación, con el fin de conseguir una densidad adecuada. Este tipo de prácticas suele ser aplicada en superficies sembradas a voleo, donde no es fácil predecir la distribución espacial de las especies. También lo es en plantaciones arbóreas mal diseñadas o mal ejecutadas; por ejemplo en plantaciones de pino piñonero en medianas o zonas auxiliares de infraestructuras de transporte lineales, donde a veces se utilizan marcos de separación de 1 a $3 \mathrm{~m}$ similares a los de los arbustos, conociendo que el porte de esta especie precisa de marcos más amplios.

Para algunas restauraciones con objetivos específicos, una actuación esencial en la plantación es suprimir la vegetación anual que crece alrededor de los ejemplares plantados. Es más importante controlar dicha vegetación, que la que crece entre los árboles; ello se debe a que la competencia por la humedad y los nutrientes del suelo es más intensa en las proximidades de la zona radical de la planta. Resulta conveniente realizar un desherbado en el momento de la plantación y una o dos veces anualmente hasta que la planta alcance $1 \mathrm{~m}$ de altura.

Otra situación donde puede ser necesaria la eliminación de malas hierbas es la de sendas o caminos diseñados exclusivamente para las rutas a paseo o en bicicleta (vías verdes o similares). Si el tránsito no es muy intenso, la vegetación herbácea de los márgenes invade rápidamente el carril, perdiendo su funcionalidad.

El sistema de eliminación de la vegetación puede ser manual, mecánico o químico; siempre se aplicará el método menos perjudicial para el entorno y la propia planta. También se tomarán las medidas oportunas en cuanto a la seguridad de los operarios que manejan los herbicidas y en algunas ocasiones las plantas deberán protegerse de su efecto. Es fundamental su aplicación en días sin viento.

\section{Poda}

La poda es la eliminación selectiva de ramas o partes de ramas de una planta por uno o varios motivos: la seguridad de las personas en su entorno, la salud del árbol, la estética, el control de la forma y estructura del árbol, el control de su crecimiento o el incremento de insolación en su copa para incrementar la fructificación.

Aunque el método de poda es variable dependiendo de la especie, hay algunas normas generales que deben seguirse: eliminar todas las ramas secas, rotas y enfermas, efectuar la poda sobre las ramillas laterales para definir el crecimiento futuro, no superar una altura de poda de $1 / 3$ de la copa, etc. Si se poda correctamente, la poda ligera puede llevarse a cabo en cualquier época del año. 


\subsubsection{Técnicas específicas de recuperación}

\subsubsection{Elementos de estabilización de taludes}

Los elementos físicos de estabilización pueden utilizarse en la restauración, si bien en la mayor parte de los casos son diseñados y construidos en la obra proyectada como elementos integrantes de la misma, bien constructivos, bien de defensa y estabilización del terreno.

Es necesaria, cualquiera que sea su misión, la adecuada integración en el entorno. Buscando este fin se han producido, en las dos últimas décadas, distintos dispositivos que aúnan solidez y adaptación paisajística. Estos elementos permiten el empleo de medidas de restauración vegetal, que a su vez contribuyen a la sujeción de las partes superficiales del terreno. Realizaremos a continuación una somera descripción de los más importantes (UDPP, 2002 y LÓPEZ GIMENO, 1999).

\subsection{ESTABILIZACIÓN MEDIANTE ELEMENTOS RESISTENTES}

\section{$\underline{\text { Anclajes }}$}

Es una técnica de sostenimiento que, en esencia, consiste en anclar en el interior de las rocas una barra de material resistente que aporta una resistencia a tracción y, confinando al macizo rocoso, permite aprovechar las características resistentes propias de las rocas facilitando así su sostenimiento. En Tierra de Campos rara vez será de aplicación, dada la naturaleza terrosa del sustrato.

$\underline{\text { Muros }}$

Según su función, se pueden distinguir muros de sostenimiento, de contención y de revestimiento. Los muros de sostenimiento se construyen separados del terreno natural, rellenándose posteriormente con material granular. Los muros de contención generalmente son excavados, y se construyen para contener un terreno que, sin la acción del muro, sería probablemente inestable. La instalación de estos muros permite reducir la altura efectiva.

Finalmente, la misión de los muros de revestimiento -construidos en el mismo plano del taludes proteger de la erosión y meteorización además de proporcionar un peso estabilizador. Suelen combinarse con vegetación, con el fin de ayudar a la estabilidad, lograr un enmascaramiento del talud o ayudar a la integración del muro.

Según los materiales empleados, los muros se pueden clasificar como: muros de gravedad de fábrica, muros aligerados (en L o con contrafuertes), muros jaula, muros de escollera, muros de gaviones (Figura 3.40), muros de tierra armada, muros de apeo, muros anclados, muros de mampostería en seco y muros de ladrillos. 


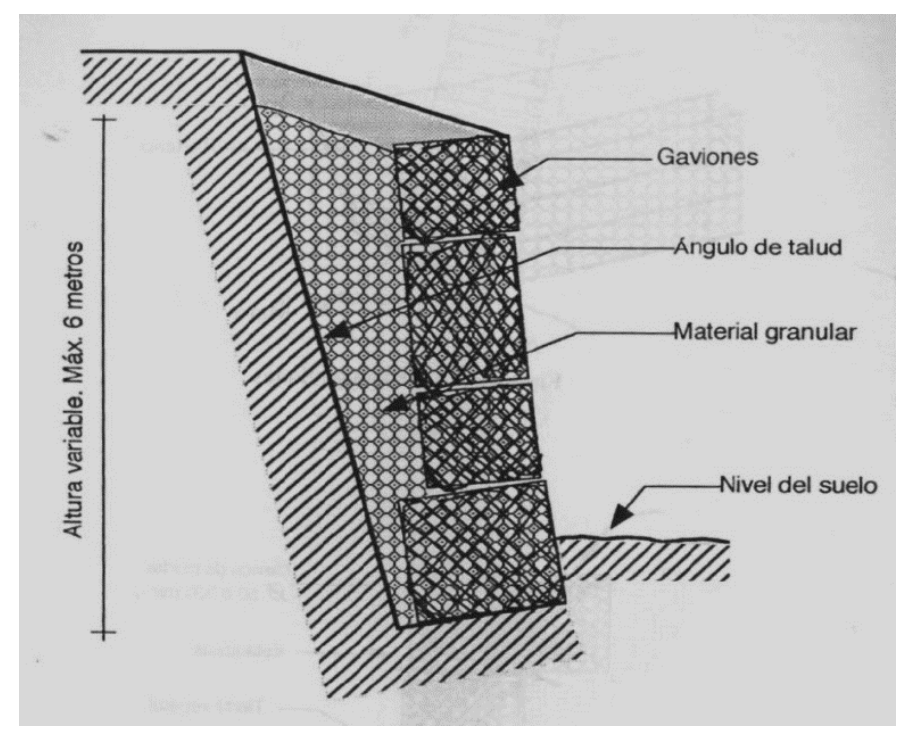

Figura 3.40. Muro de gaviones inclinado (UDPP, 2002)

Otros muros han sido diseñados más recientemente con el fin de cumplir la función de estabilización y, al tiempo, lograr la integración más perfecta, bien por sus materiales y disposición, bien por la inclusión de la vegetación en el paramento del muro. En este grupo se pueden citar: muros de elementos arriostrados, muros abiertos de elementos modulares y muros verdes.

\subsection{ELEMENTOS FÍSICOS DE CORRECCIÓN SUPERFICIAL}

\section{Mallas de guiado de piedras}

Son mallas de alambre metalizado, normalmente galvanizadas, que cubren los taludes para controlar la caída de fragmentos de roca y guiarlos hacia una zanja situada al pie del talud. Pueden ser de utilidad en zonas en que los afloramientos rocosos ocupan una superficie amplia del talud, con una pendiente en todo caso superior a $45^{\circ}$ y un cuarteamiento superficial apreciable. No es el caso de Tierra de Campos, salvo situaciones puntuales en las cuestas de transición del páramo a la campiña. El negativo efecto estético que provoca la malla protectora deberá ser mitigado, en los casos en que sea posible, mediante hidrosiembra y plantaciones en pie de desmonte, bermas, salientes ocasionales, etc.

\section{Material sintético proyectado (gunitado)}

Este sistema se fundamenta en materiales inertes de distinto origen, que se proyectan sobre el talud y en el que quedan fijados por sustancias aglomerantes.

En algunos casos, para fijar taludes que puedan tener pequeños desprendimientos, se ha utilizado el sistema de hormigón proyectado (Figura 3.41), que no permite la instalación de la vegetación y, como elemento de fuerte contraste con el entorno, no consigue la integración paisajística. 


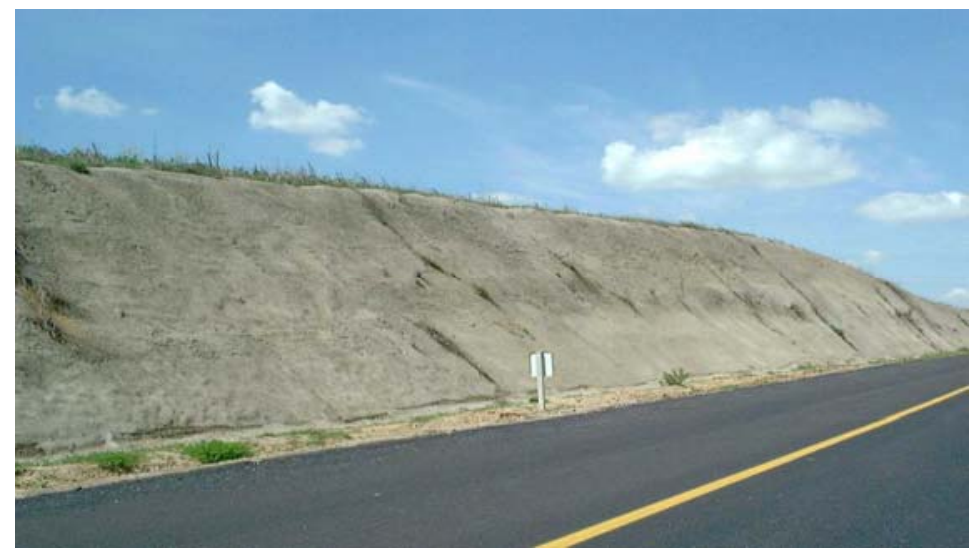

Figura 3.41. Hormigón proyectado en talud de desmonte en la carretera VA-905, en Moral de la Reina. Tal como se puede apreciar, se trata de una solución muy artificial.

\section{Corazas metálicas}

Consisten en un encofrado metálico especial, formado en esencia por dos telas metálicas que encierran entre sí un espesor determinado de grava o canto rodado de pequeñas dimensiones, formando así una especie de colchón metálico, absolutamente flexible y de gran eficacia protectora. Se ha empleado para proteger los márgenes de algún tramo del Canal de Castilla, en las proximidades de Medina de Rioseco.

\section{Entramados y celosías de sujeción}

Existe un gran número de diseños, cuyos resultados son muy similares, entre los que cabe destacar la estabilización japonesa mediante entramados de hormigón armado. El entramado es colocado sobre el talud diagonalmente y sujetado en sus vértices mediante estacas o barras de acero; posteriormente los compartimentos son rellenados con tierra vegetal y sembrados. Normalmente solo se aplica en zonas urbanas.

\section{Bloques huecos de hormigón}

Este método de estabilización implica el uso de unos bloques huecos que, una vez depositados sobre el talud, se rellenan con tierra para ser posteriormente sembrados o plantados. Se trata en general de medidas muy caras cuya utilización se limita a pendientes fuertes y a terrenos urbanos o muy cercanos a las ciudades.

\section{Encachados}

Suelen emplearse en mayor proporción en obras urbanas o periurbanas. Las piedras, materiales rústicos del lugar, se ajustan a la pendiente, son de contorno irregular, y entre ellas se pueden dejar huecos que son rápidamente colonizados por las plantas de los alrededores. También se aplica en algunos taludes de determinadas obras (pasos superiores, por ejemplo) de infraestructuras lineales de transporte (Figura 3.42). 


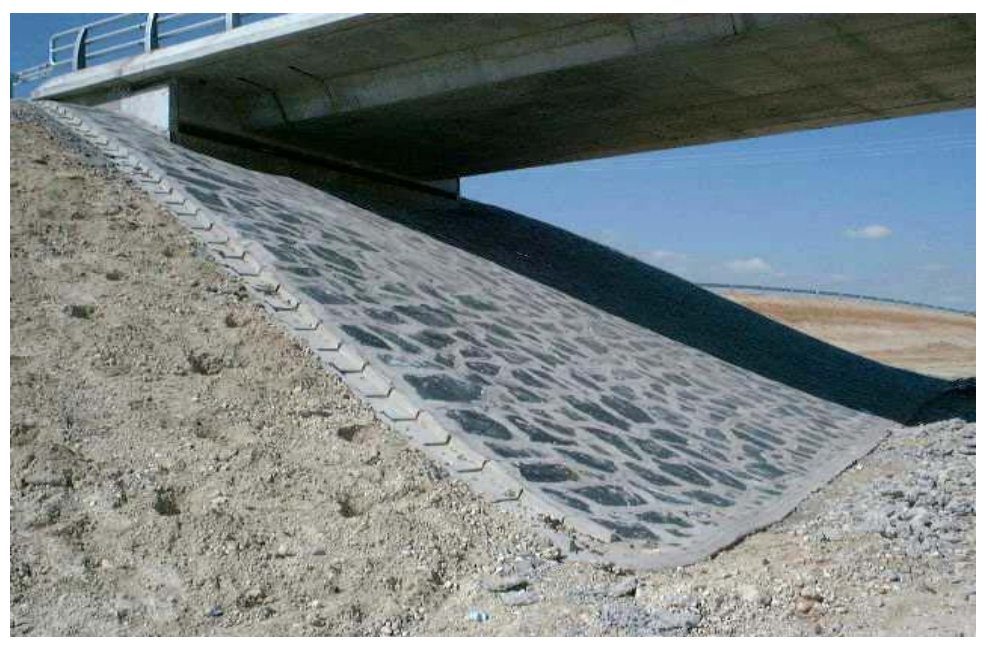

Figura 3.42. Encachado en paso superior de la autovía Camino de Santiago, en este caso rejuntado con cemento.

\subsection{ELEMENTOS ORGÁNICOS DE CORRECCIÓN SUPERFICIAL}

\section{$\underline{\text { Geotextiles }}$}

El geotextil es un producto permeable de apreciable deformabilidad, en forma de láminas, constituido por fibras poliméricas entrelazadas. Se fabrican como esteras, entretejidas o no, para situarlas sobre el suelo, superficial o subsuperficialmente. Puede tener varias funciones: drenaje, separación de capas de suelo, filtración, refuerzo, protección..., aunque la que aquí se comenta es la de constituir un soporte de suelo que pueda propiciar posteriormente la revegetación de los taludes.

\section{$\underline{\text { Geoyute }}$}

Son mallas cuya composición es del $100 \%$ de fibra de yute. El papel principal de la malla es proteger y promover la cubierta vegetal durante su periodo formativo, contribuyendo de esta forma al control de la erosión. Además tiene otras ventajas: es biodegradable, absorbe el impacto de la lluvia, es flexible, su descomposición aporta materia orgánica al suelo, se puede hidrosembrar antes o después de su instalación, etc.

\section{Mantas orgánicas}

Son mantas compuestas por materiales orgánicos que se colocan sobre el terreno para evitar o reducir la erosión y permitir un rápido establecimiento de la vegetación (Figura 3.43). Según su composición se diferencian los siguientes tipos de mantas: de coco, de esparto, de paja y mixtas. 


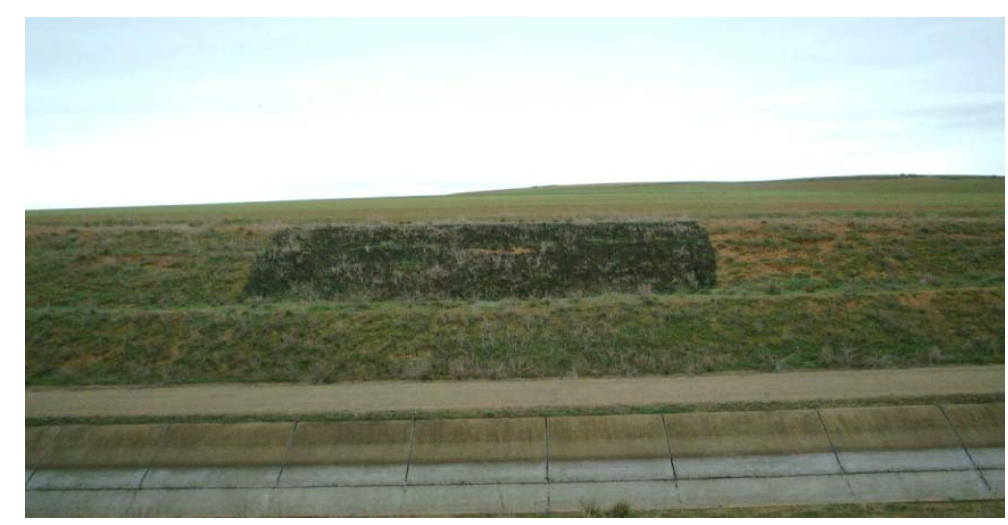

Figura 3.43. Manta orgánica en el canal Esla-Carrión

\section{Elementos modulares de revestimiento (geoceldas)}

Entre este tipo de elementos se puede citar la estructura hexagonal de poliéster, para revestimiento de taludes. Esta estructura hexagonal se introduce unos centímetros en el talud, o se fija con pernos, posteriormente se rellena de tierra, en la que se siembran herbáceas o se plantan leñosas.

\subsection{TÉCNICAS DE BIOINGENIERÍA EN EL TRATAMIENTO DE TALUDES}

La bioingeniería del suelo y la estabilización biotécnica son técnicas de tratamiento de taludes en las que se utiliza la vegetación como elemento principal de estabilización y control de la erosión. La vegetación puede utilizarse empleando diferentes procedimientos, que describiremos de acuerdo con lo expuesto por MATAIX (1999):

Las construcciones vivas engloban las técnicas convencionales de revegetación, cuya función principal es la prevención y el control de la escorrentía superficial, junto con otras técnicas específicas de la bioingeniería del suelo, en las que se utilizan esquejes de especies leñosas ramas y tallos, fundamentalmente- para desarrollar una cubierta vegetal estable y autosuficiente que actúe como un componente estructural para el refuerzo y estabilización del talud.

En las construcciones mixtas, en las que se utilizan elementos vivos e inertes de forma combinada, los elementos inertes (gaviones, escolleras, revestimientos, etc.) en un primer momento proporcionan al talud resistencia frente a los procesos erosivos y de inestabilidad, pero su importancia como agentes de estabilización va disminuyendo progresivamente al desarrollarse la cubierta vegetal.

A continuación haremos una breve reseña de cada una de estas técnicas: 


\section{CONSTRUCCIONES VIVAS}

\section{Estaquillado}

Consiste en introducir en el suelo estaquillas de plantas leñosas, con capacidad para arraigar y desarrollar una planta adulta, de longitud y grosor suficiente para que puedan ser clavadas en el suelo como estacas (Figura 3.44). Cuando las estaquillas arraigan crean una matriz de raíces que estabilizan el suelo por refuerzo y cohesión de sus partículas, y reducen el exceso de humedad. Generalmente se utilizan estaquillas de sauce o chopo. Este tipo de plantas enraízan rápidamente y comienzan a drenar el talud al poco tiempo de ser instaladas, y además son capaces de desarrollarse en sustratos carentes totalmente de suelo.

Esta técnica está especialmente recomendada para reparar pequeños deslizamientos y asentamientos originados por un exceso de humedad en el suelo, en sitios en los que las condiciones de inestabilidad no sean graves.
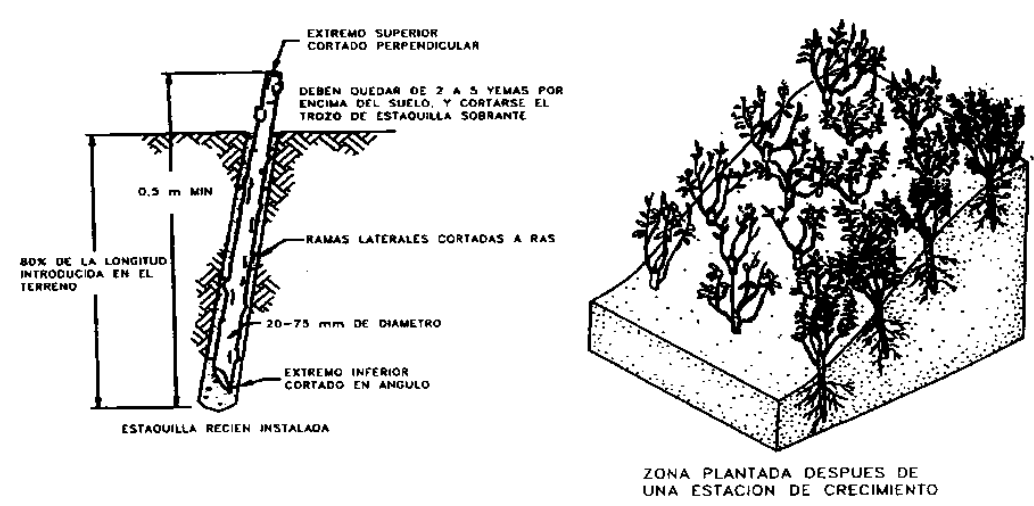

Figura 3.44. Técnica de estaquillado (MATAIX, 1999)

\section{$\underline{\text { Fajinas }}$}

Son manojos de ramas y tallos atados en forma de huso que se colocan en el fondo de zanjas poco profundas, excavadas transversalmente siguiendo el contorno del talud, y que se recubren parcialmente de tierra (Figura 3.45). Para evitar que se muevan pueden fijarse con estacas de madera o con estaquillas de la misma especie empleada en la construcción de las fajinas.

Las fajinas constituyen una técnica de estabilización muy efectiva que protege los taludes frente a deslizamientos superficiales y que permite escalonar o banquear la pendiente de los taludes cuando la excavación es difícil. 


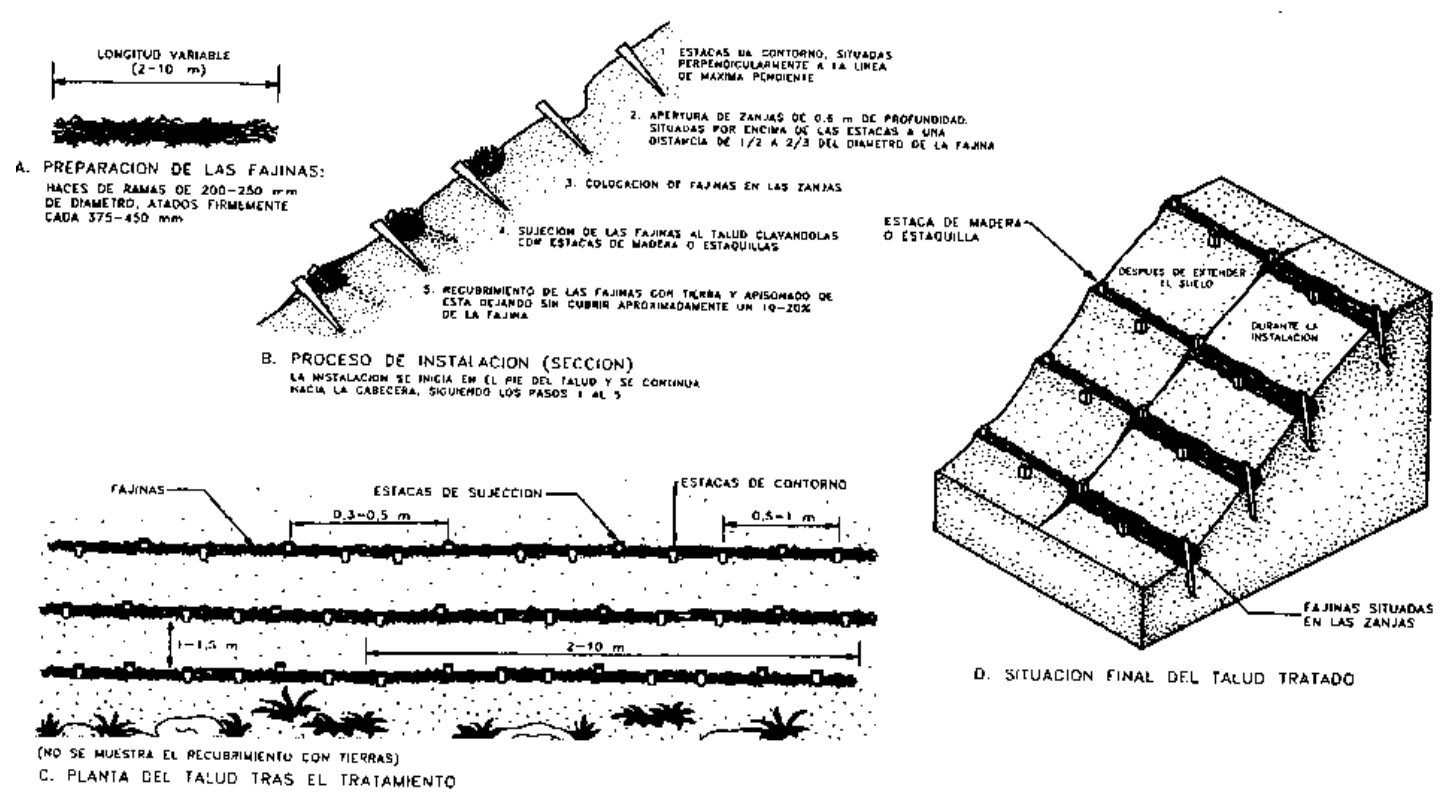

Figura 3.45. Esquema de fajinas (MATAIX, 1999)

\section{Escalones de matorral (setos vivos)}

Esta técnica consiste en situar ramas de especies leñosas con capacidad para enraizar en pequeñas zanjas o entre capas sucesivas de tierra a lo largo de la pendiente de los taludes, de manera que formen una especie de terrazas o escalones (Figura 3.46). Difiere de las fajinas en la orientación de las ramas y la profundidad a la que éstas se sitúan. En los escalones de matorral las ramas se orientan más o menos perpendicularmente al perfil del talud y se introducen hasta dos metros dentro de él, mientras que las fajinas se sitúan paralelas al perfil del talud y se entierran muy someramente.

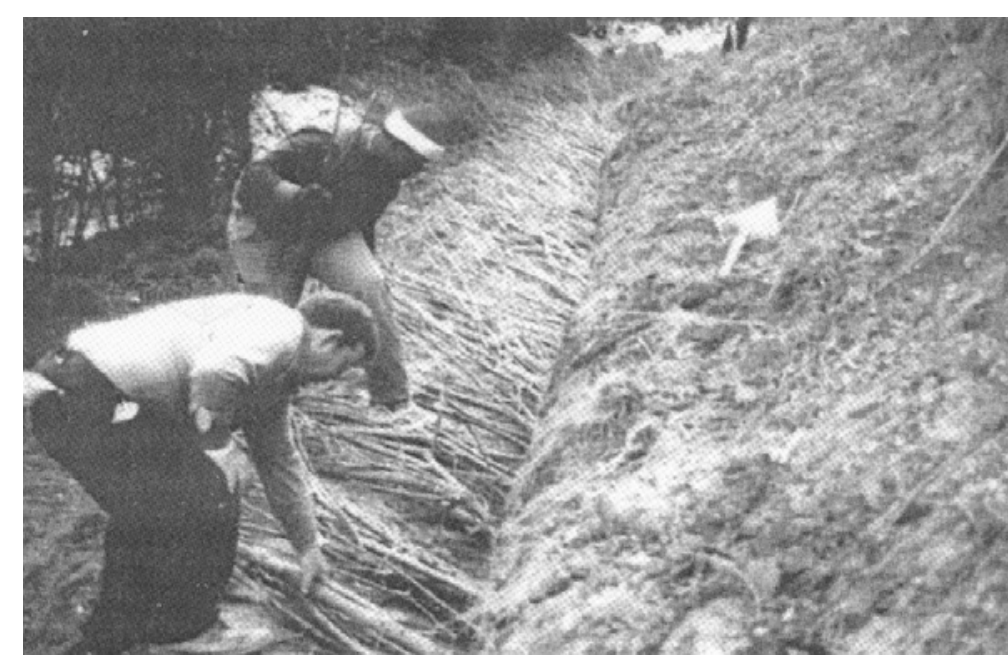

Figura 3.46. Fotografía de la técnica de escalones de matorral (MATAIX, 1999) 


\section{$\underline{\text { Reparación de cárcavas con material vivo }}$}

Es una técnica muy parecida a la de los paquetes de matorral, pero más adecuada para reparar depresiones ocasionadas por erosión superficial, como regueros profundos y cárcavas. Consiste en rellenar el reguero o la cárcava que se pretende reparar con capas alternas de ramas y tierras compactadas (Figura 3.47). Las ramas proporcionan un efecto inmediato de refuerzo del suelo tras su instalación, disminuyen la velocidad de circulación del agua de escorrentía y actúan como una barrera-filtro que retiene el material arrastrado.

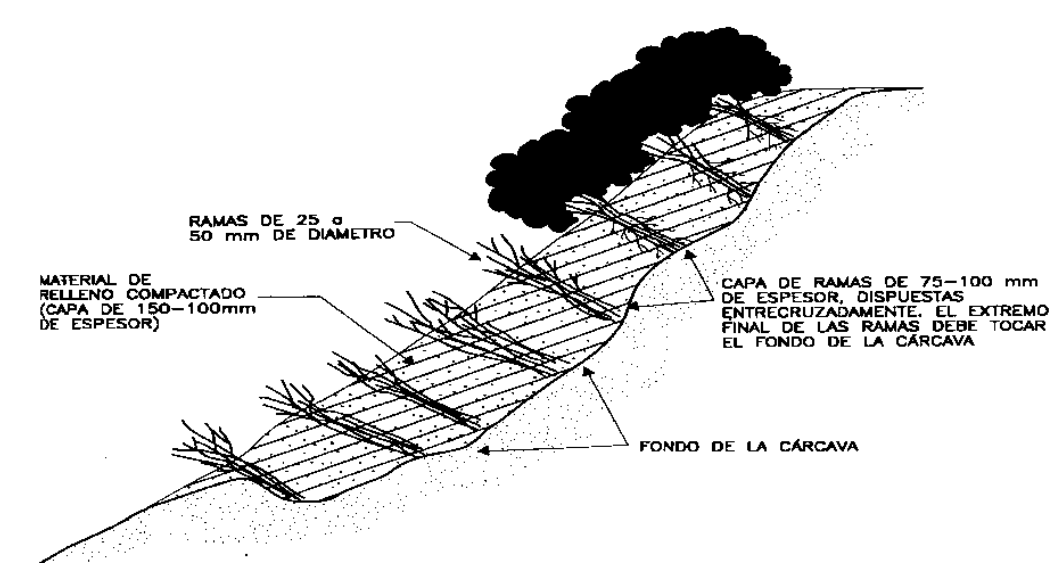

Figura 3.47. Técnica de reparación de cárcavas con material vivo (MATAIX, 1999)

\section{CONSTRUCCIONES MIXTAS}

\section{Estructuras de tierra reforzada}

Es una técnica muy similar a la de los escalones de matorral. La diferencia entre ambas estriba en que en las estructuras de tierra reforzada se alternan capas de tierras y ramas de poco espesor con capas mucho más gruesas de tierras de relleno que van envueltas en un geotextil (Figura 3.48).

Las sucesivas capas de tierras de relleno reforzadas por la envoltura de geotextil forman una estructura que, en un primer momento, actúa como un muro de contención, sujetando el talud. Cuando las ramas arraigan, emiten raíces en toda su longitud, las cuales se introducen entre la cubierta de geotextil y el material de relleno, formando con ellas una masa coherente y sólida, y penetran dentro del talud anclando firmemente toda la estructura.

Esta técnica es una alternativa a los muros de contención convencionales que permite estabilizar taludes de gran pendiente. Las capas de matorral actúan como drenajes horizontales que evacúan el exceso de humedad de los taludes mejorando sus condiciones de estabilidad. Se puede utilizar también para proteger taludes expuestos a socavación periódica o a fuerzas de tracción, como sucede en las orillas de los canales y cursos naturales de agua. 


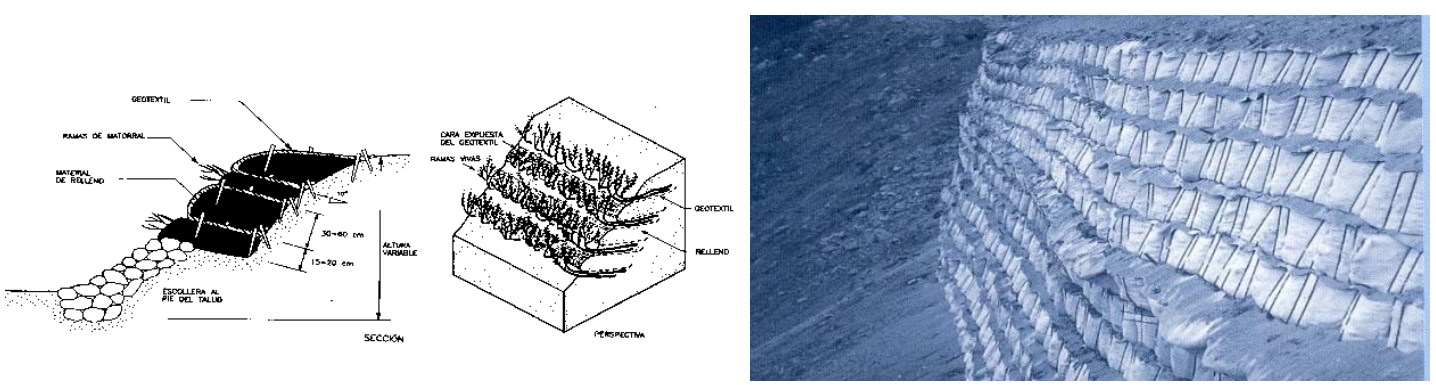

Figura 3.48. Esquema y fotografía de la estructura de tierra reforzada (MATAIX, 1999)

\section{Muros verdes o muros jardinera}

Son muros huecos con forma de cajón, construidos con madera, que se rellenan con tierras y en cuya cara frontal se introducen varas y ramas de especies leñosas, las cuales enraízan dentro de la estructura y en el talud (Figura 3.49).

En un primer momento, la estructura de madera rellena de tierras sujeta el talud, actuando como un muro de contención. Pero una vez que se ha producido el enraizamiento y las plantas se han desarrollado suficientemente, la vegetación gradualmente va tomando posesión de las funciones estructurales que realizaban hasta ese momento los elementos de madera con los que está construido el muro, hasta que llegan a ser el principal elemento de estabilización.

Esta técnica es apropiada en el tratamiento de taludes para cuya estabilización es necesario construir un muro bajo de contención y en los que es importante, además, cuidar los aspectos paisajísticos y de integración visual. Proporciona inmediata protección contra la erosión y, cuando la vegetación se desarrolla, estabilidad a largo plazo, aunque no resiste la acción de fuerzas laterales intensas.

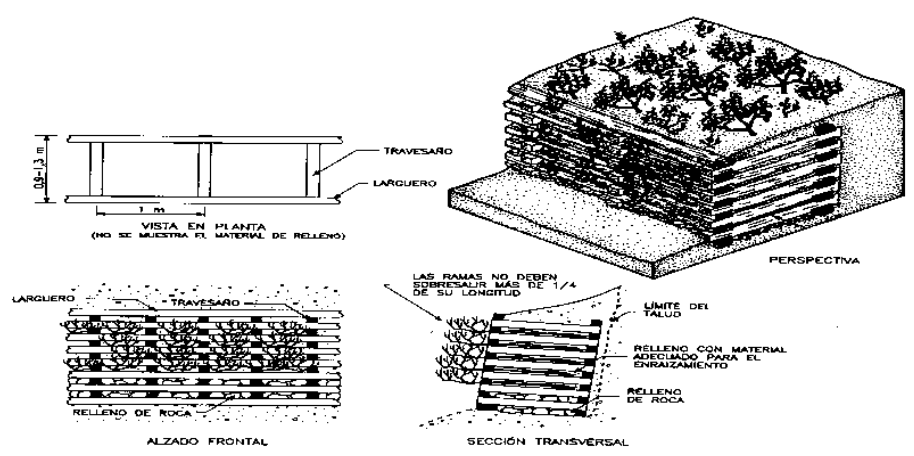

Figura 3.49. Esquema de la técnica de muros verde (MATAIX, 1999) 


\section{Enrejados vivientes}

Es una estructura tridimensional en enrejado construida con madera, que se ancla a la superficie del talud y se rellena con tierras (Figura 3.50). En los vanos que deja esta estructura, alternando con las capas de relleno, se instalan capas de ramas de matorral, con una disposición similar a la de los escalones de matorral.

El principal propósito del enrejado de madera es sujetar el suelo aportado y facilitar el establecimiento de la vegetación. Sus funciones en cuanto a elemento estructural de estabilización son prácticamente nulas. Es la vegetación la que cumple estas funciones, una vez se desarrolla a partir de las ramas que se insertan en los huecos del enrejado.

Esta técnica permite revegetar taludes de gran pendiente (por encima de $45^{\circ}$ ) sin necesidad de tener que remodelarlos. La instalación del enrejado es sencilla y requiere muy pocos trabajos previos de limpieza y excavación en el talud y poco volumen de suelo para rellenar la estructura.

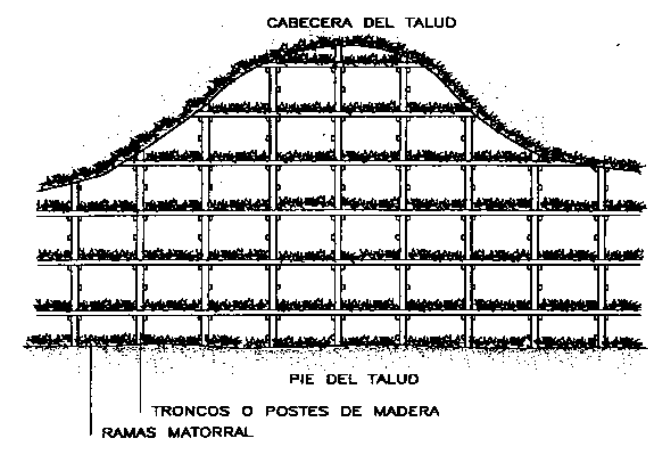

Figura 3.50. Esquema del enrejado viviente (MATAIX, 1999)

\section{Estaquillado de escolleras}

Esta técnica consiste en introducir estaquillas de matorral a través de las juntas y huecos que dejan las piedras que recubren el talud, hasta clavarlas firmemente en el mismo (Figura 3.51). El estaquillado puede realizarse una vez concluido el revestimiento del talud o de forma simultánea con su ejecución.

Las raíces de las plantas desarrolladas a partir de las estaquillas drenan el exceso de agua del talud y crean una densa matriz en el suelo sobre el que se asienta el revestimiento rocoso, que refuerza el efecto de protección superficial de éste y evita el arrastre de finos por debajo y entre las piedras que lo forman. 


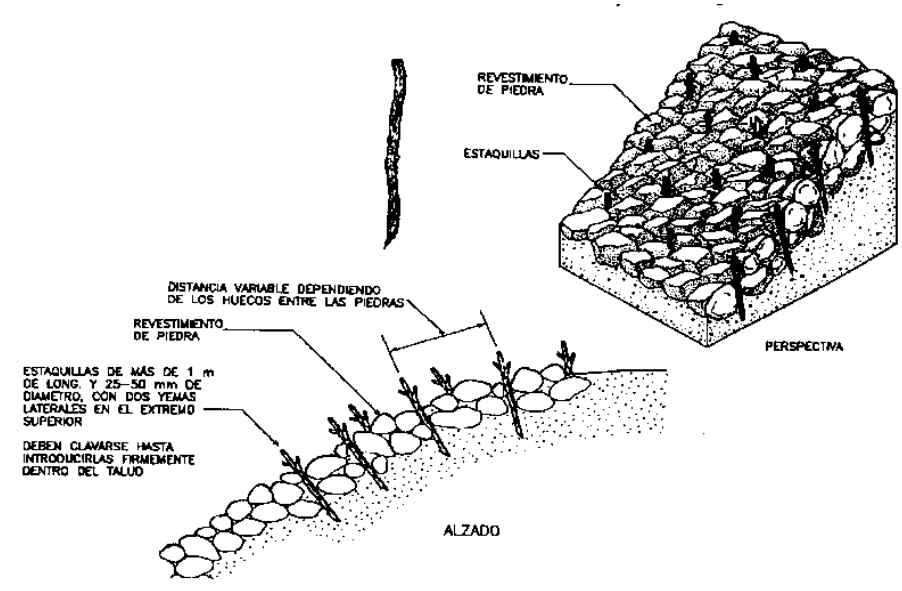

Figura 3.51. Esquema del estaquillado de escolleras (MATAIX, 1999)

\section{Muros de gaviones con vegetación}

Para revegetar los muros construidos con gaviones, se colocan capas de ramas de matorral entre los sucesivos gaviones que componen el muro (Figura 3.52). Opcionalmente, pueden introducirse algunas ramas dentro de los propios gaviones.

Las raíces que desarrollan las ramas se introducen entre el relleno de los gaviones y alcanzan el talud arraigando en él y consolidando así la estructura. La vegetación, por tanto, refuerza la estructura del muro de gaviones y la hace más resistente, al tiempo que le da una apariencia más natural, aunque es el muro de gaviones quien estabiliza el talud. Es una técnica adecuada cuando es necesario cuidar estéticamente el acabado de las obras.

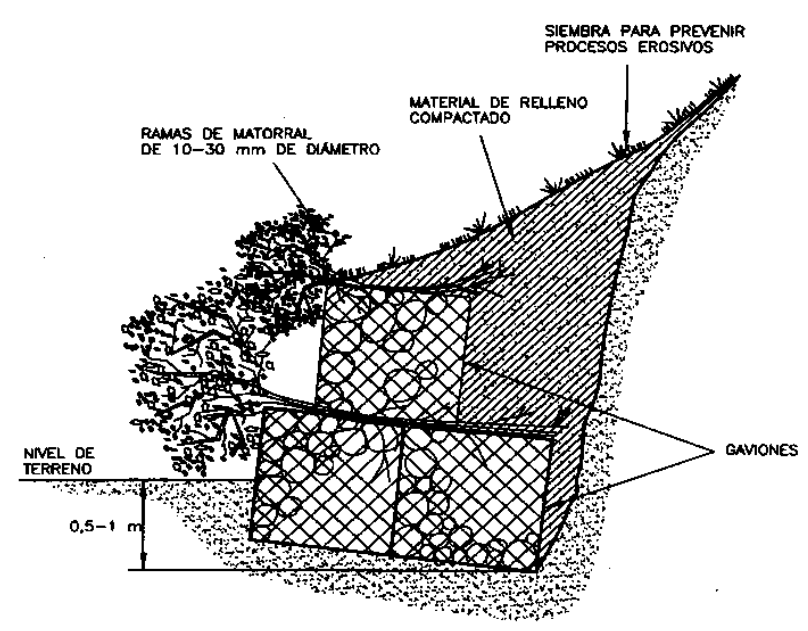

Figura 3.52. Muro de gaviones con vegetación (MATAIX, 1999) 


\section{Muros de roca y vegetación}

Son muros de contención construidos con piedras superpuestas y no cementadas, entre las que se introducen ramas de matorral que, al desarrollarse, enraízan en la superficie del talud (Figura 3.53). Las raíces que emiten estas ramas forman una red que envuelve las piedras del muro y lo ancla al talud, reforzando y protegiendo así la estructura.

Este tipo de muros, a diferencia de los muros de contención convencionales, no resiste la presión de fuerzas laterales intensas. Es adecuado cuando lo que se pretende es reducir la pendiente de la base del talud y protegerlo del socavamiento y el descalce. Su aspecto, una vez la vegetación se ha desarrollado, es más natural que el de los muros convencionales.

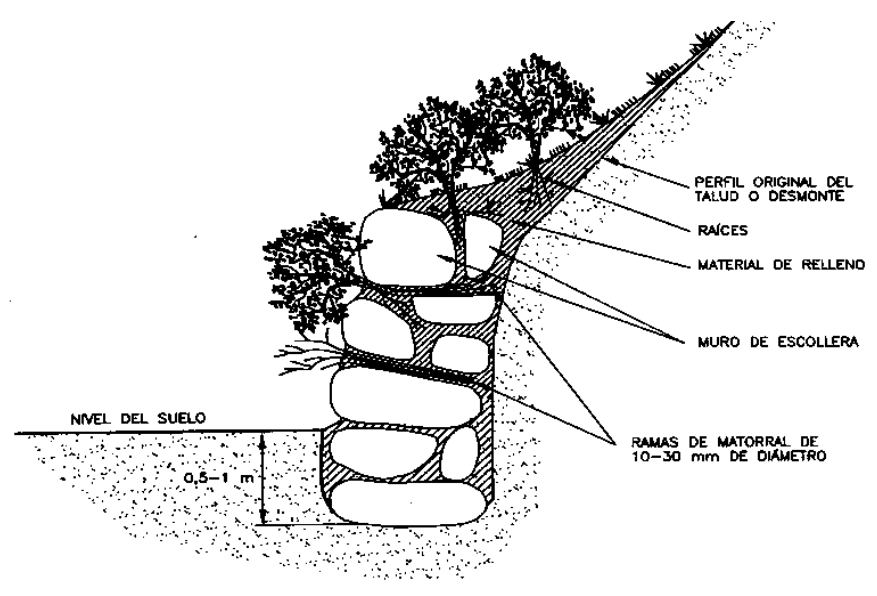

Figura 3.53. Esquema del muro de roca y vegetación (MATAIX, 1999)

\section{Tratamiento vegetal de muros de contención y de otro tipo de revestimientos}

Las técnicas de revegetación de las aberturas frontales de muros de contención convencionales y de las estructuras de confinamiento celular, son similares. Básicamente consisten en rellenar estas estructuras con tierras de calidad adecuada e introducir entre el relleno estaquillas, ramas $u$ otro tipo de material vegetal con capacidad de enraizamiento.

En los muros de contención la función de la vegetación se limita a mejorar la apariencia estética de la estructura y protegerla de la acción de los elementos. En las estructuras de confinamiento celular, por el contrario, la vegetación es el elemento principal de estabilización. Los elementos inertes únicamente sirven para contener las tierras aportadas y evitar que se muevan pendiente abajo.

La revegetación de muros de contención y revestimientos no porosos, es decir, en los que no quedan huecos libres entre los elementos que componen la estructura, se realiza rellenando con tierras el espacio que queda entre estas estructuras y la superficie del talud, y sembrando y/o plantando la superficie de relleno. 
En los muros escalonados, la vegetación se introduce en las bermas, también previo relleno con tierras de calidad adecuada, por métodos convencionales de plantación y siembra.

\subsubsection{Elementos de estabilización de cauces y cuencas degradadas}

Estos elementos tienen como finalidad disminuir o evitar la erosión del cauce y riberas, y aumentar la estabilidad de los taludes para evitar deslizamientos y desplomes. También son de aplicación a las cuencas degradadas con problemas de erosión. Se diferencian dos tipos de estructuras:

\subsection{ESTRUCTURAS TRANSVERSALES O DIQUES}

Los diques dan respuesta a la tipología de problemas asociados a la consolidación de laderas y lechos de torrentes, barrancos y ramblas, la retención de caudales sólidos, la laminación de caudales líquidos y la recarga de acuíferos, fenómenos que caracterizan y dan personalidad a los espacios vocacionalmente forestales (TRAGSA, 1994).

De acuerdo con este documento, al que nos referiremos en este apartado, en el funcionamiento de un dique se deben distinguir tres etapas: la primera de colmatación; la segunda, durante e inmediatamente después del aterramiento; la tercera, cuando el lecho se ha consolidado.

Los diques, por su función, se clasifican en de consolidación, retención, laminación y recarga. Por el método de cálculo, de gravedad, arco-gravedad, arco y elementos sueltos. Finalmente, la clasificación por el tipo de fábrica suele ser la más habitual (Figura 3.54):

- Mampostería (seca, gavionada, hidráulica)

- Hormigón (masa, ciclópeo, armado, pretensado)

- Materiales sueltos (tierra, tierra armada, escollera, mixtos)

- Otros materiales (madera, acero, mixtos)

Los diques están previstos en la parte superior de su estructura de una cubeta de desagüe o vertedero para la evacuación de las aguas. Otro elemento son los mechinales, diseñados para facilitar la evacuación de las aguas y, cuando el dique esté aterrado, para disminuir los empujes. También es necesario realizar disipadores de energía, para reducir los efectos perturbadores aguas abajo del cauce. 

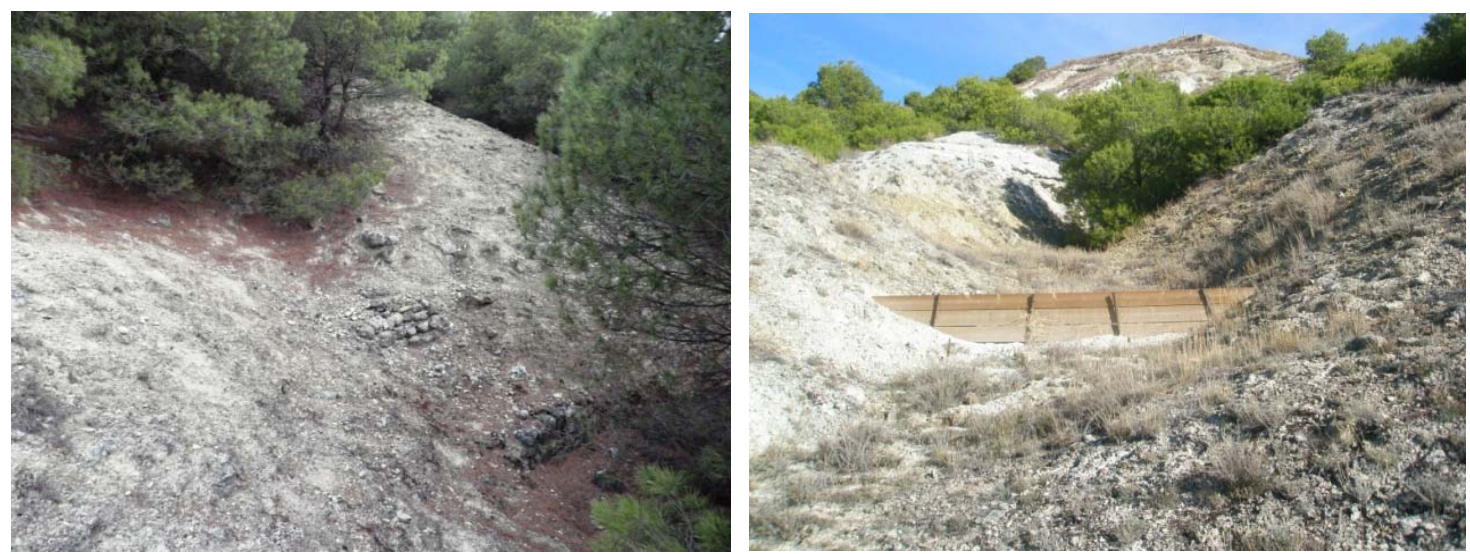

Figura 3.54. Izquierda, diques de piedra suelta caliza en restauración hidrológico-forestal en laderas con cárcavas en Torremormojón (realizada por la Confederación Hidrográfica del Duero, hacia 1960). Derecha, dique con madera instalado recientemente en las mismas laderas, dentro de las medidas compensatorias por la construcción del parque eólico El Castre.

\subsubsection{2. $\quad$ ESTRUCTURAS LONGITUDINALES}

El objetivo fundamental de las obras de protección que se realizan en zonas concretas de los cauces es impedir la erosión de sus márgenes, originada por la excesiva velocidad del agua y son, por tanto, obras localizadas de protección de curvas, obras de cruce o zonas de materiales débiles cuyo colapso acarrearía la inundación de los terrenos adyacentes.

En el caso más común, es decir, cuando se trata de proteger una curva en la que la velocidad del agua, para caudales medios, supera a la crítica de arrastre del material, los métodos de protección se dividen en dos grandes grupos:

\section{Máscaras superficiales}

Los problemas fundamentales que deben resolverse son encontrar un material que resista la velocidad de arrastre y solucionar satisfactoriamente el enlace entre la pantalla y el lecho, de forma que no se produzca la socavación de la parte más baja, con el inevitable desplome posterior.

Dentro de la directriz básica de intentar utilizar al máximo los materiales existentes en la zona, las soluciones de este tipo son muy heterogéneas y varían desde la simple empalizada de troncos hasta el muro de hormigón, pasando con la repoblación con especies vegetales adecuadas, la ejecución de una pantalla inclinada de hormigón hidráulico o asfáltico, la protección con escollera, la estabilización con suelo-cemento e incluso la construcción de un muro de gaviones.

El revestimiento de márgenes con estructuras permanentes puede ir acompañado del empleo de vegetación con el fin de proteger tanto la ribera como los taludes próximos al cauce. En estos pueden registrarse largos periodos de sequía estival y este carácter ha de tenerse en cuenta a la hora de diseñar la implantación de la vegetación. 


\section{Espigones}

Los espigones son obras construidas de formas muy diversas -muros de hormigón, gaviones, diques de escollera e incluso del propio material del cauce- cuya función es crear una perturbación local en el régimen hidráulico del río, de forma que no se modifique la distribución natural de velocidades y no se produzcan erosiones.

\subsubsection{Pantallas sónicas}

Las pantallas sónicas suelen tener como fin principal la reducción del ruido procedente del tráfico, ya sea el procedente de carreteras como el de vías férreas. Suelen ser construcciones grandes y complicadas, que marcan y dividen el territorio. Su coste de construcción y mantenimiento es elevado y se espera de ellas que permanezcan en el lugar muchos años. Serán observadas todos los días por los habitantes que vivan junto a ellas y por los conductores que transiten por las vías, razón por la cual su diseño es muy importante. Por consiguiente, se puede asegurar que, además de la efectividad en la reducción del ruido, el factor estético es el principal en este tipo de construcciones, tanto en zonas urbanas como en periurbanas (UDPP, 2002).

En los paisajes rurales la necesidad de construir pantallas sónicas vendría fundamentalmente dada en determinados tramos de confluencia de las principales infraestructuras lineales de transporte (carreteras nacionales, autovías y líneas de ferrocarril) con las poblaciones, cuando la distancia es muy reducida. Hay que señalar que, incluso, en muchas ocasiones esta distancia es cero, como el caso de las travesías de las carreteras nacionales aún no circunvaladas (la carretera nacional Palencia Benavente, por ejemplo, a su paso por Villalón de Campos, Villacid de Campos, Becilla de Valderaduey, Villanueva del Campo, etc.)

Algunas estrategias para el diseño de pantallas sónicas son su integración en el entorno, que pasen a formar parte del paisaje rural en sus líneas generales o que sean diseñadas como un hito de especial significación arquitectónica o artística.

De acuerdo con la referencia citada, las pantallas sónicas pueden encuadrarse dentro de alguno de los siguientes grupos constructivos:

\subsection{PANTALLAS EN TIERRA}

Cuando se desee formar una barrera de grandes dimensiones, esta puede ser la solución adecuada. Las pantallas de tierra permiten una armonización con el entorno y amplias posibilidades en el diseño de la vegetación. Esta es la solución óptima en medios periurbanos o rurales, cuando se quiera aislar una zona urbana de una vía de comunicación. Precisa de gran cantidad de espacio para su ejecución y con el tiempo puede naturalizarse, llegándose a convertir en pequeños ecosistemas.

\subsection{PANTALLAS DE ELEMENTOS PREFABRICADOS}

Para este tipo de barreras se utilizan elementos prefabricados con formas geométricas diversas. Su construcción suele ser sencilla; las piezas están construidas permitiendo sostener tierra y vegetación y son capaces de alojar sistemas de drenaje y riego. Las pantallas sónicas construidas con elementos prefabricados suelen utilizarse cuando no se dispone de espacio suficiente para 
hacer una pantalla de tierra y se necesita una barrera verde, con una apariencia lo más natural posible. Con el paso de los años y bajo buenas condiciones para la plantación, este tipo de pantalla aparecerá cubierta y verde, aportando calidad al entorno.

\subsection{BARRERAS DE SONIDO}

Esta es la pantalla más habitual en zonas urbanas y la más artificial de todas. Es la que mejor se adapta al medio urbano por razones constructivas, de diseño y espaciales. Admite todo tipo de materiales (hormigón, ladrillos, madera, acero, aluminio, cristal y plexiglás) y puede ser complementada por vegetación para mejorar su integración en el medio.

\subsubsection{Pasos de fauna}

Las infraestructuras humanas que ocupan el territorio pueden facilitar los movimientos de las personas y de los recursos, con carreteras, ferrocarriles y canales, o limitarlos con cerramientos y presas. Los efectos ambientales más importantes a que dan lugar tienen su origen en la fragmentación de hábitats y el efecto barrera. Ambos condicionan la conducta y los movimientos tanto de las poblaciones humanas como animales. Es decir, actúan como fronteras que cambian la permeabilidad territorial y dividen el ecosistema que intersectan. En este sentido hay que recordar que el mantenimiento de la conectividad ecológica es fundamental en la ecología del paisaje.

Una vez ejecutada la actuación, solo es posible actuar reconstruyendo los pasillos naturales seccionados o instalando nuevas estructuras realizadas con materiales naturales o artificiales. Estas últimas se conocen genéricamente con el nombre de pasos de fauna -siempre menos eficaces que los naturales-, cuya finalidad es mitigar los impactos ambientales que afectan a los vertebrados terrestres o acuáticos. Se conciben y diseñan para aumentar la movilidad, romper el aislamiento genético y disminuir el riesgo de atropello de las poblaciones animales afectadas por la construcción y funcionamiento de las actividades humanas (UDPP, 2002).

Los pasos de fauna son especialmente aplicables para el caso de infraestructuras de transporte. Las carreteras y ferrocarriles se caracterizan por una sucesión de terraplenes y desmontes, que fragmenta el hábitat que atraviesan. Su presencia organiza y dirige los movimientos de los animales terrestres hacia determinadas zonas que se convierten en pasos de fauna obligados, como las obras de fábrica del drenaje y los pasos -superiores o inferiores- para el servicio de la propia infraestructura o de las personas.

El establecimiento de corredores vegetales, paralelos a las vías de comunicación, de bordes festoneados, con distintos estratos y anchura variable, coopera en la organización de los movimientos de la fauna hacia los pasos establecidos y los naturales. En este caso, como en tantos otros, también se imita a la naturaleza.

Existen prescripciones técnicas para el diseño de pasos de fauna de infraestructuras de transporte (MMA, 2006), que detallan numerosos aspectos de estas técnicas: selección de la ubicación, densidad, elección del tipo de estructura, dimensiones, etc. En este estudio se describen los diferentes tipos de pasos de fauna, de los que seleccionaremos los que tienen mayor aplicación para la comarca. En Tierra de Campos se han diseñado o adaptado pasos de fauna sobre todo en las grandes infraestructuras lineales: autovía A-6 Madrid-La Coruña, autovía 
Camino de Santiago León-Burgos, línea de ferrocarril de alta velocidad Palencia-León, así como en alguna nueva variante de carretera; en el resto de infraestructuras normalmente las propias obras de las vías sirven como pasos de fauna.

Paso superior específico para la fauna. Son pasos superiores a las infraestructuras que permiten una óptima integración en el entorno, dando continuidad a la cobertura vegetal y a los hábitats situados a ambos lados de la infraestructura (Figura 3.55). Su anchura mínima es de $20 \mathrm{~m}$. La tipología constructiva puede ser puente, tablero o bóveda. Se debe extender una capa de tierra vegetal de $50 \mathrm{~cm}$ aproximadamente, sobre la que se plantarán especies arbustivas autóctonas en los bordes del paso. Se instalarán pantallas opacas en los márgenes laterales del paso. Se realizarán plantaciones y se instalará el cerramiento perimetral de manera que guíen a la fauna hacia las entradas del paso. Los tramos más adecuados para su instalación son aquellos donde la infraestructura discurre entre desmontes. Existe un paso superior específico para el lobo en la autovía del Camino de Santiago en Ledigos, en el límite norte de Tierra de Campos, que conecta dos zonas forestales fragmentadas.
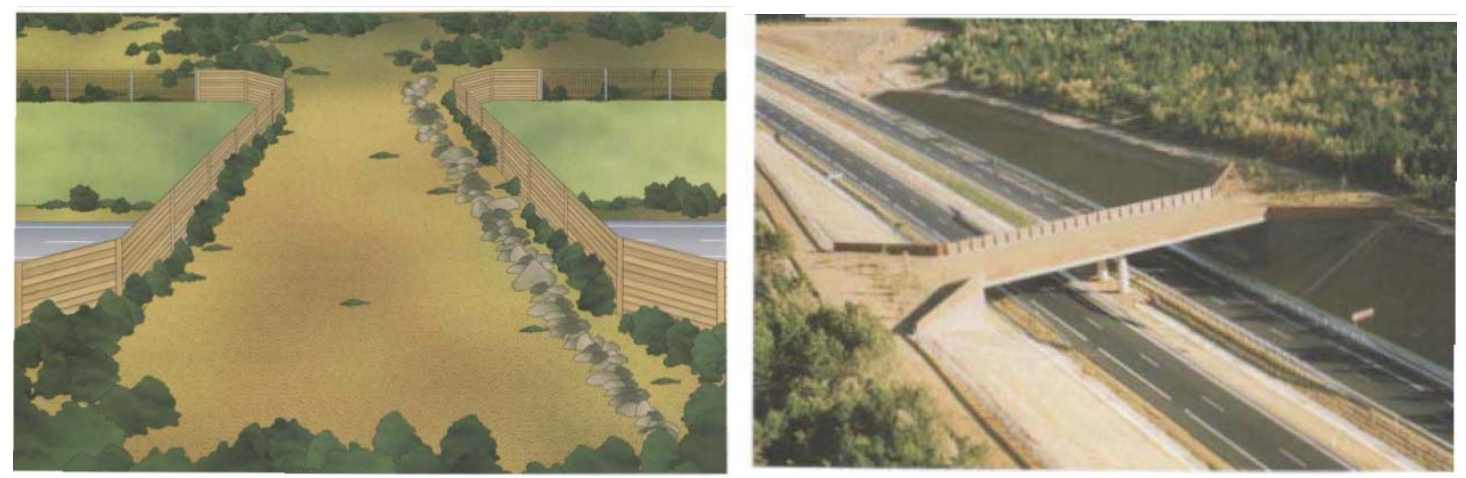

Figura 3.55. Izquierda, dibujo esquemático de un paso superior específico para la fauna. Derecha, paso superior en Ledigos (MMA, 2006)

Paso superior multifuncional. Son pasos superiores construidos para la restitución de caminos o vías pecuarias, adaptados también al paso de fauna silvestre (Figura 3.56). Las modificaciones consistirán en mantener la base de la plataforma con sustrato natural, o al menos dos franjas laterales revegetadas. La anchura mínima es de $10 \mathrm{~m}$. La tipología constructiva puede ser puente o tablero. Se instalarán pantallas opacas en los márgenes laterales del paso. Se realizarán plantaciones y se instalará el cerramiento perimetral de manera que guíen a la fauna hacia las franjas laterales destinadas al paso de fauna. También es más adecuada su construcción cuando la infraestructura discurra entre desmontes. 


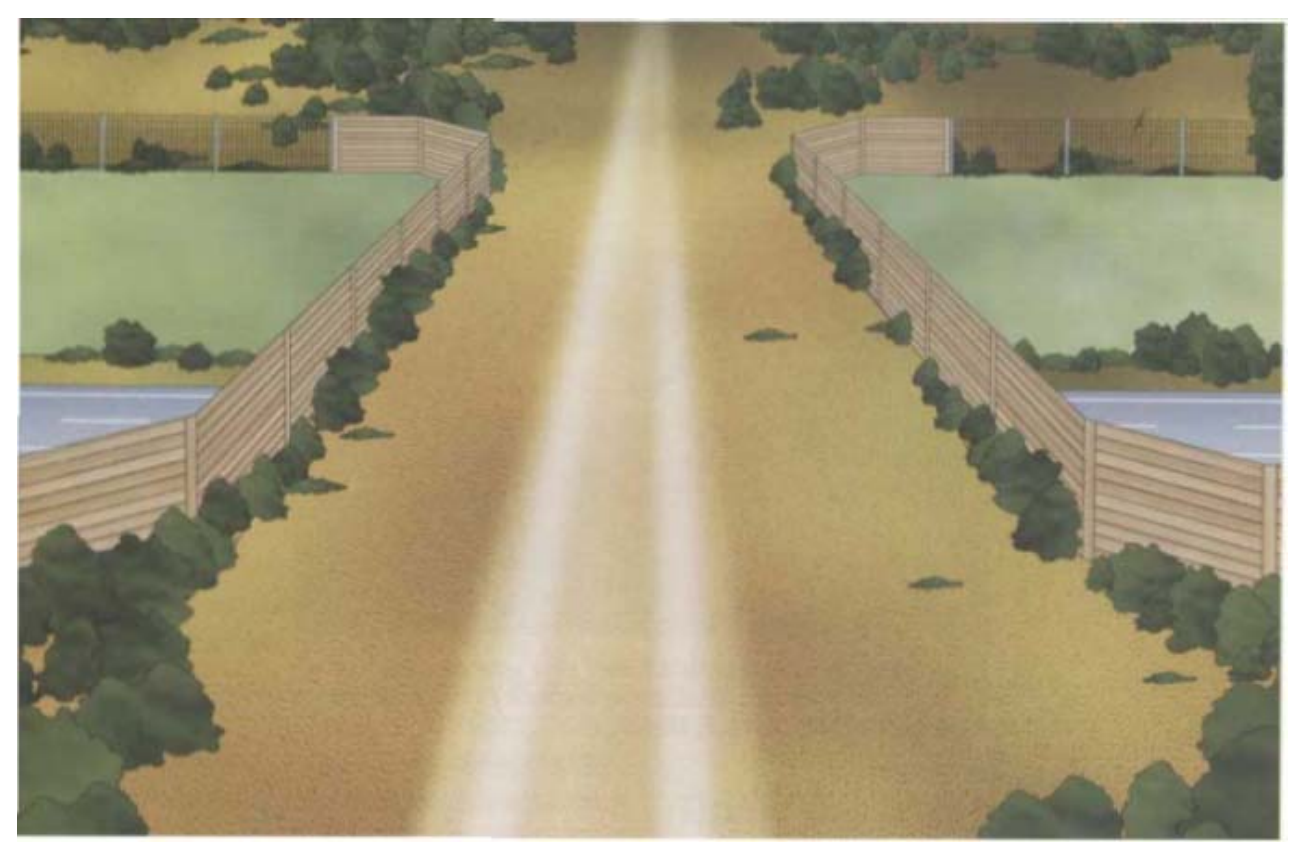

Figura 3.56. Dibujo de un paso superior multifuncional (MMA, 2006)

Viaducto adaptado. Los viaductos, en los que la plataforma de la vía se dispone sobre pilas, son estructuras que permiten conservar intactos o poco alterados los hábitats asociados a cursos fluviales, que albergan una notable diversidad biológica y canalizan los desplazamientos de fauna. Las medidas de adaptación de un viaducto al paso de fauna consisten básicamente en minimizar la afectación a la vegetación de ribera y al lecho del río durante la fase de construcción, sobredimensionar la estructura para conservar los hábitats del curso fluvial y sus márgenes, y mantener la morfología del terreno recurriendo lo mínimo posible a estructuras artificiales de estabilización (Figura 3.57). La longitud del viaducto se proyectará, además de atender a los condicionantes hidráulicos, con una extensión que permita cubrir toda la franja ocupada por vegetación de ribera y 10 m más a cada lado de la misma. Se evitará en lo posible la alteración de las comunidades vegetales bajo el viaducto y su entorno. 

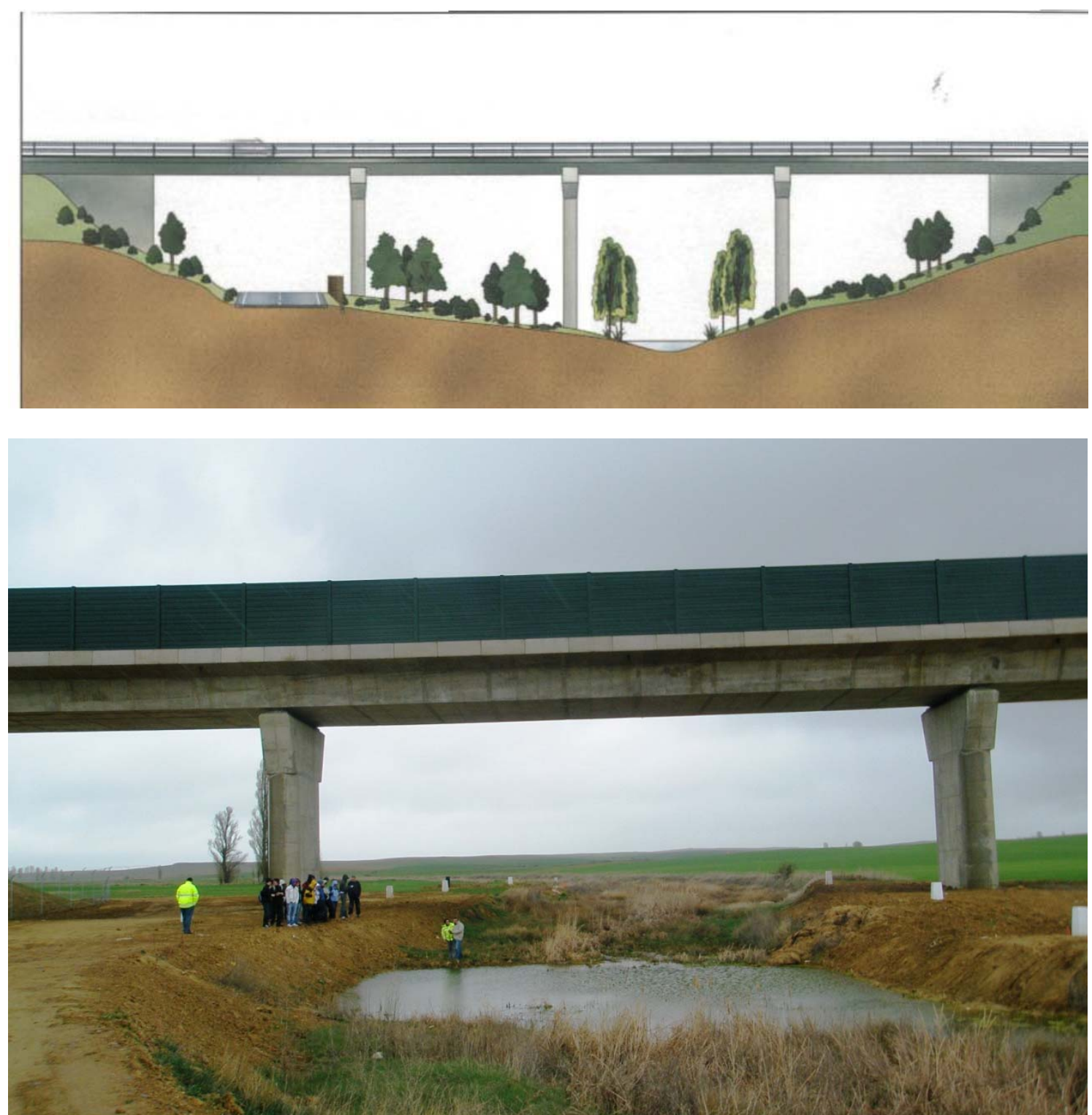

Figura 3.57. Arriba, distribución de distintos usos bajo un viaducto: curso fluvial, sectores revegetados que se mantienen secos y una carretera en las proximidades de uno de los estribos (MMA, 2006). Abajo, adaptación de viaducto como paso de fauna en Tierra de Campos, en el tramo de AVE Valle del Retortillo-Pozo de Urama.

Paso inferior específico para grandes mamíferos. Los pasos inferiores consiguen una alta efectividad para el paso de fauna aunque presentan más dificultades para conectar hábitats, ya que permiten un crecimiento limitado de la vegetación. Son adecuados para restablecer la permeabilidad en los tramos en los que el trazado de la infraestructura discurra sobre terraplén. La altura mínima es de 3,5 m. Las tipologías constructivas son de tipo pórtico o bóveda. Deberá asegurarse un buen drenaje de la estructura con el objeto de evitar la inundación del paso. Su base debe mantener sustrato natural. Se realizarán plantaciones y se instalará el cerramiento perimetral de manera que guíen a la fauna hacia los accesos del paso (Figura 3.58). 


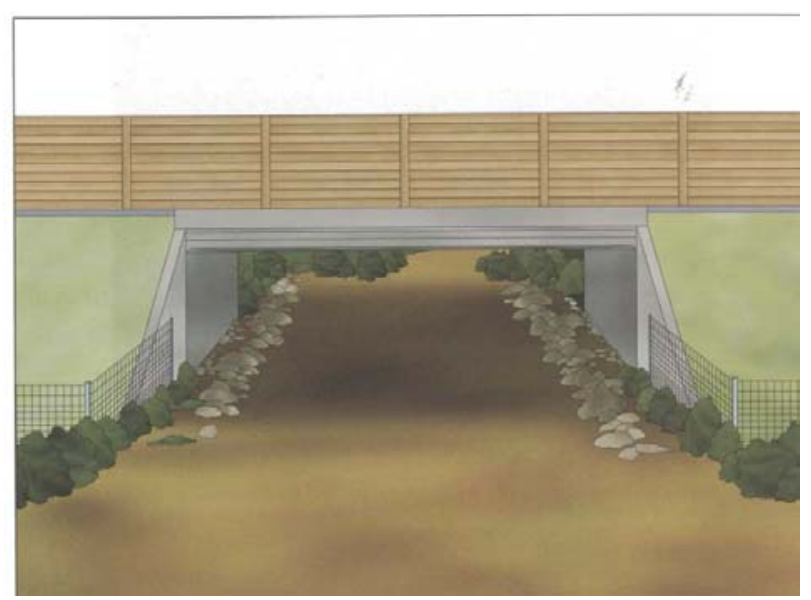

Figura 3.58. Esquema de un paso inferior especifico (MMA, 2006).

Paso inferior multifuncional. Se trata de pasos inferiores destinados a la restitución de caminos o vías pecuarias que pueden adaptarse para favorecer su uso como pasos de fauna. Las modificaciones consisten en mantener la base del paso como sustrato natural o bien conservar dos bandas laterales sin pavimentar. La altura mínima es de 3,5 m. Las tipologías constructivas serán estructuras de sección abierta: pórtico o bóveda. Deberá asegurarse un buen drenaje de la estructura. Como en anteriores casos, se realizarán plantaciones y se instalará el cerramiento perimetral de manera que guíen a la fauna hacia los accesos del paso (Figura 3.59).
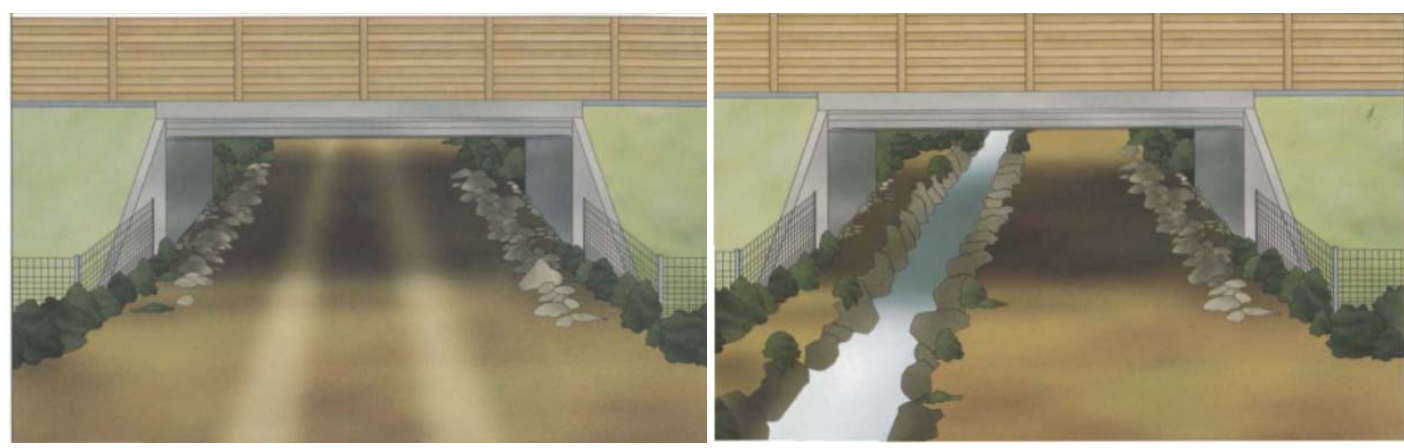

Figura 3.59. Esquema de un paso inferior multifuncional. En el dibujo de la derecha se dispone una acequia en uno de los márgenes de la estructura (MMA, 2006).

Paso inferior específico para pequeños vertebrados. En los tramos donde se requiera aumentar la permeabilidad para pequeños vertebrados y en los que no se disponga de suficientes drenajes que puedan adaptarse para el paso de fauna, será necesario construir pasos adecuados para las especies de pequeño y mediano tamaño. Son adecuados para los tramos en los que el trazado de la infraestructura discurra sobre terraplén. Las dimensiones mínimas son de $2 \times 2 \mathrm{~m}$. La tipología constructiva es en cajón. Se debe asegurar un buen drenaje y se realizarán las mismas plantaciones y cerramientos que en casos anteriores (Figura 3.60). 


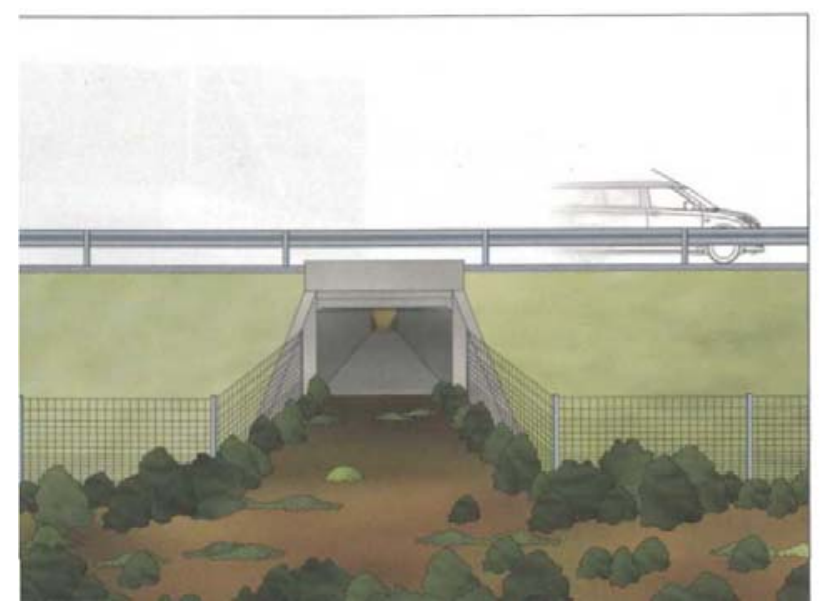

Figura 3.60. Esquema de un paso inferior específico para pequeños vertebrados (MMA, 2006).

Drenaje adaptado para animales terrestres. La adaptación de obras de drenaje es un sistema eficaz para facilitar el paso de vertebrados de pequeño y mediano tamaño (particularmente de mamíferos), ya que coinciden con vaguadas o fondos de valle que canalizan el desplazamiento de muchas especies $y$, además, se trata de estructuras poco perturbadas por la actividad humana. Se requieren pocas modificaciones para adaptar estas obras: utilizar materiales adecuados, construir banquetas laterales que se mantengan secas y acondicionar adecuadamente los accesos. Las dimensiones mínimas serán de $2 \times 2 \mathrm{~m}$. Las tipologías constructivas serán pórtico, bóveda o cajón. Se realizarán plantaciones y se instalará el cerramiento perimetral de manera que guíen a la fauna hacia los accesos del paso (Figura 3.61). Son tal vez los pasos de fauna más utilizados.
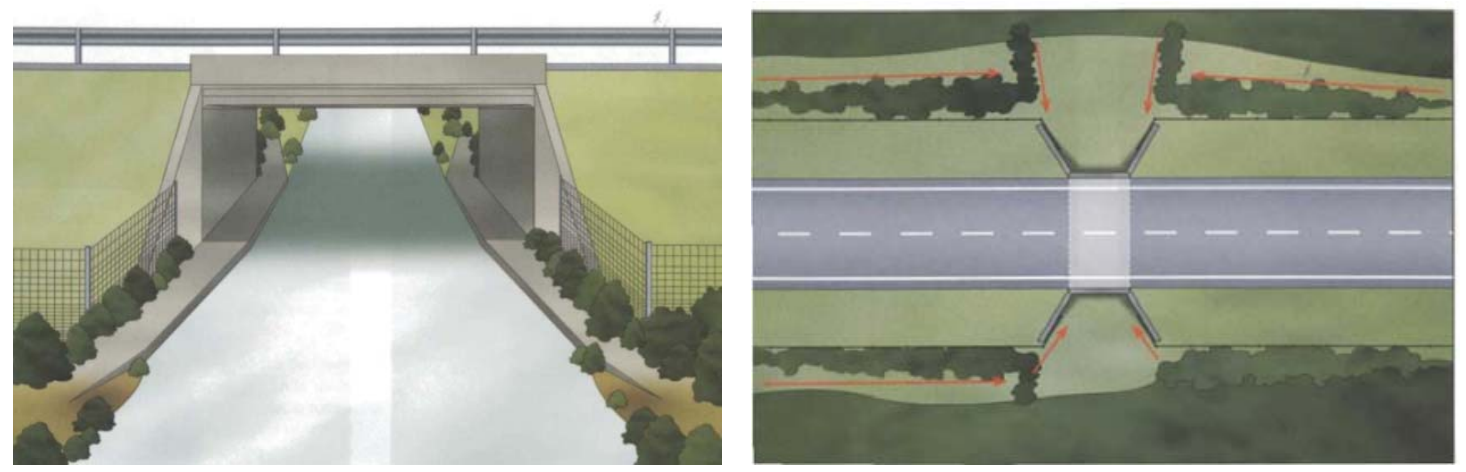

Figura 3.61. Izquierda, esquema de un drenaje adaptado para animales terrestres; derecha, distribución de las plantaciones en los accesos a los pasos de fauna (MMA, 2006).

Drenaje adaptado para peces. Todas las estructuras por las que discurre un curso de agua permanente deben adaptarse para facilitar el paso de peces y otros animales acuáticos. Esta adaptación debe permitir el movimiento de los peces tanto a favor como en contra de la 
corriente. Las actuaciones básicas para la adaptación van destinadas a conseguir que la estructura permita mantener unas condiciones del sustrato similares a las del curso fluvial y a evitar los obstáculos al desplazamiento de la fauna. Para ello, la estructura tendrá la mínima longitud posible, y deberá mantener una profundidad de la lámina de agua, una anchura y una pendiente lo más parecidas posibles a los del curso fluvial (Figura 3.62). Las tipologías constructivas serán pórtico o bóveda.

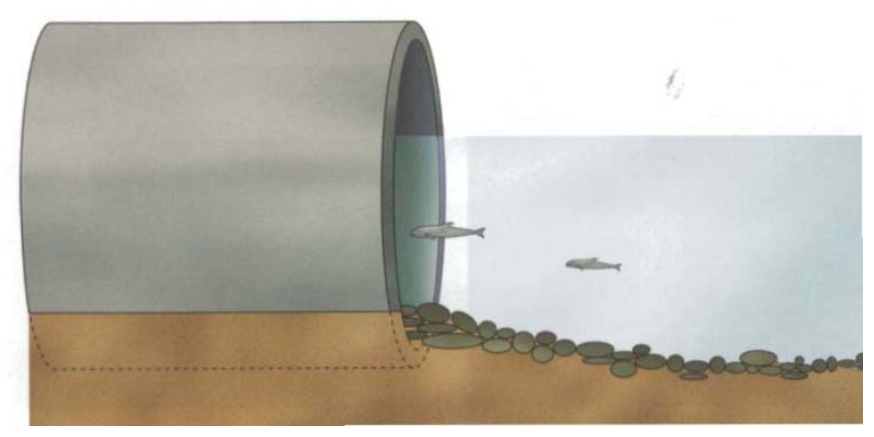

Figura 3.62. Dibujo de un drenaje adaptado para peces (MMA, 2006).

Pasos para anfibios. Los anfibios tienen requerimientos muy particulares, ya que no tienen capacidad para orientar sus desplazamientos buscando el acceso al paso de fauna. Por ello, la efectividad de las estructuras destinadas a este grupo depende, en gran medida, de la instalación de un cerramiento específico, que actúa como una estructura de guía destinada a interceptar sus desplazamientos y conducirles hacia los pasos. Las mejores tipologías constructivas son los cajones (Figura 3.63).

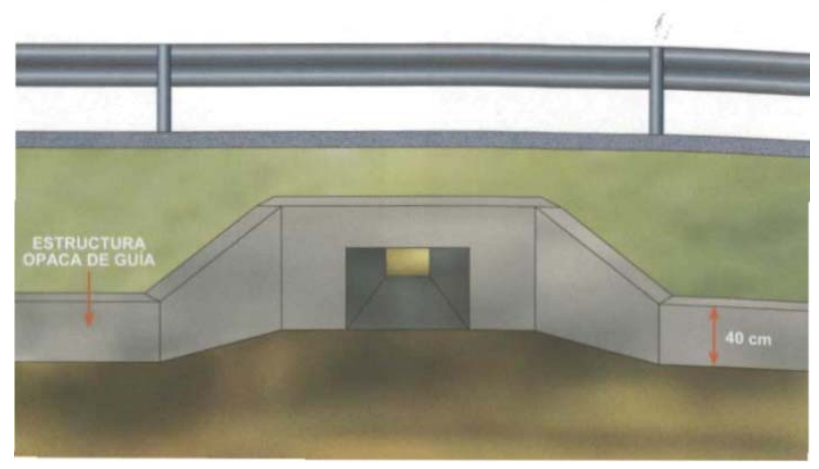

Figura 3.63. Esquema de un paso para anfibios (MMA, 2006). 


\subsection{Diversificación del paisaje agrario de Tierra de Campos: setos vivos, sotos y bosques isla.}

\subsubsection{Historia de una profunda transformación.}

El paisaje creado mediante la agricultura tradicional era muy diferente al actual. Tal vez, uno de los mayores elementos diferenciadores del mismo era la existencia de una enorme cantidad de setos vegetales -arbolados y arbustivos- que separaban las parcelas, habitaban los taludes, acompañaban los márgenes de los cursos fluviales o moraban en algún perdido. Este paisaje reticulado (bocage) era característico de todos los espacios agrícolas europeos (Figura 3.64), aunque su predominancia era mayor en los territorios de clima más oceánico. Su origen podía ser tanto residual de la vegetación forestal primitiva como de nuevas plantaciones con fines diversos.
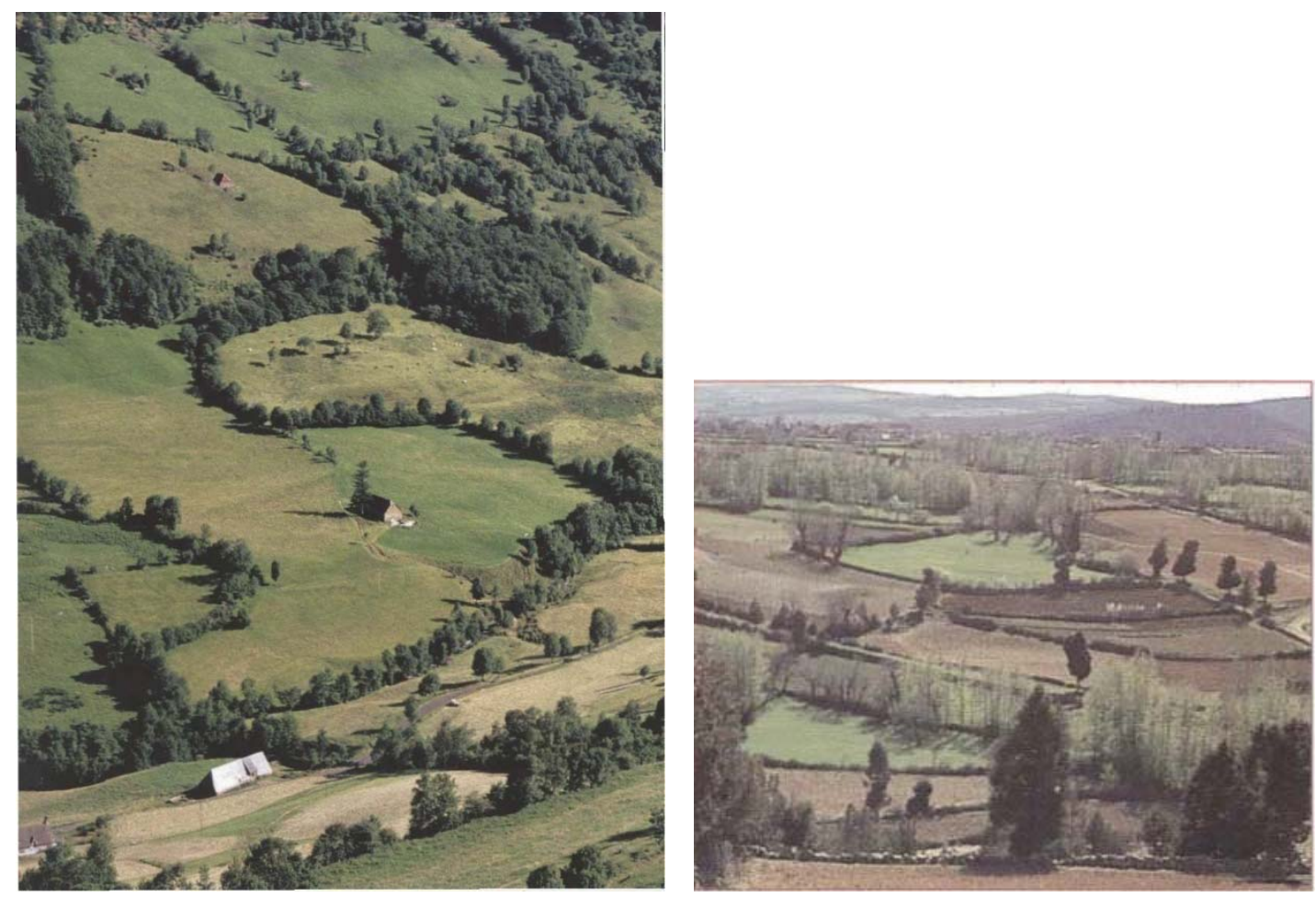

Figura 3.64. Fotografías ilustrativas de setos: GAMBIER (2009) y JUNTA DE CYL (1992).

El cambio de una agricultura tradicional a otra mecanizada intensiva, a partir de la década de los 50 del siglo pasado, acarreó entre sus consecuencias la eliminación de buena parte de los setos. A ello contribuyó en buena medida la concentración parcelaria de los terrenos llevada a cabo en prácticamente todo el continente europeo. BUREAUX (2009) afirma con profunda tristeza que ha sido testigo de una "auténtica masacre" por la destrucción de muchos setos en la región de Bretaña (Francia). GAMBIER (2009) estima que entre los años 1960 y 1980 fueron destruidos $600000 \mathrm{~km}$ de setos y taludes boscosos en Francia, que correspondería a la mitad de su longitud total. DE ANDRÉS et al. (2003) indican que entre 1947 y 1985 se destruyeron en Inglaterra más de 204000 km de bandas verdes. En el Alto Ampurdán Catalán, se ha registrado una pérdida del 
$46 \%$ de los setos entre 1957 y 1987. En España, estos autores estiman que la pérdida de vegetación forestal en terrenos agrícolas puede rondar las 200000 ha, un millón de kilómetros lineales.

No se conocen datos en la comarca castellana y leonesa de Tierra de Campos, pero se puede suponer -a la vista del estado actual- que los niveles de destrucción de setos vivos han sido superiores a la media nacional y europea. Es probable que, tras las primeras etapas de roturación del bosque de quercíneas original (varios siglos antes de Cristo), se mantuviese durante bastante tiempo un mosaico en el que las encinas conformasen la base de los setos delimitadores de las fincas. Este paisaje se iría simplificando a medida que aumentaba la presión sobre la leña y la maximización de la superficie cultivable. En la actualidad, prácticamente el último reducto de este mosaico en Tierra de Campos se mantiene en el entorno del Raso de Villalpando, entre Cañizo y Villalpando, que ha salvado incluso una concentración parcelaria relativamente reciente (Figura 3.65). 

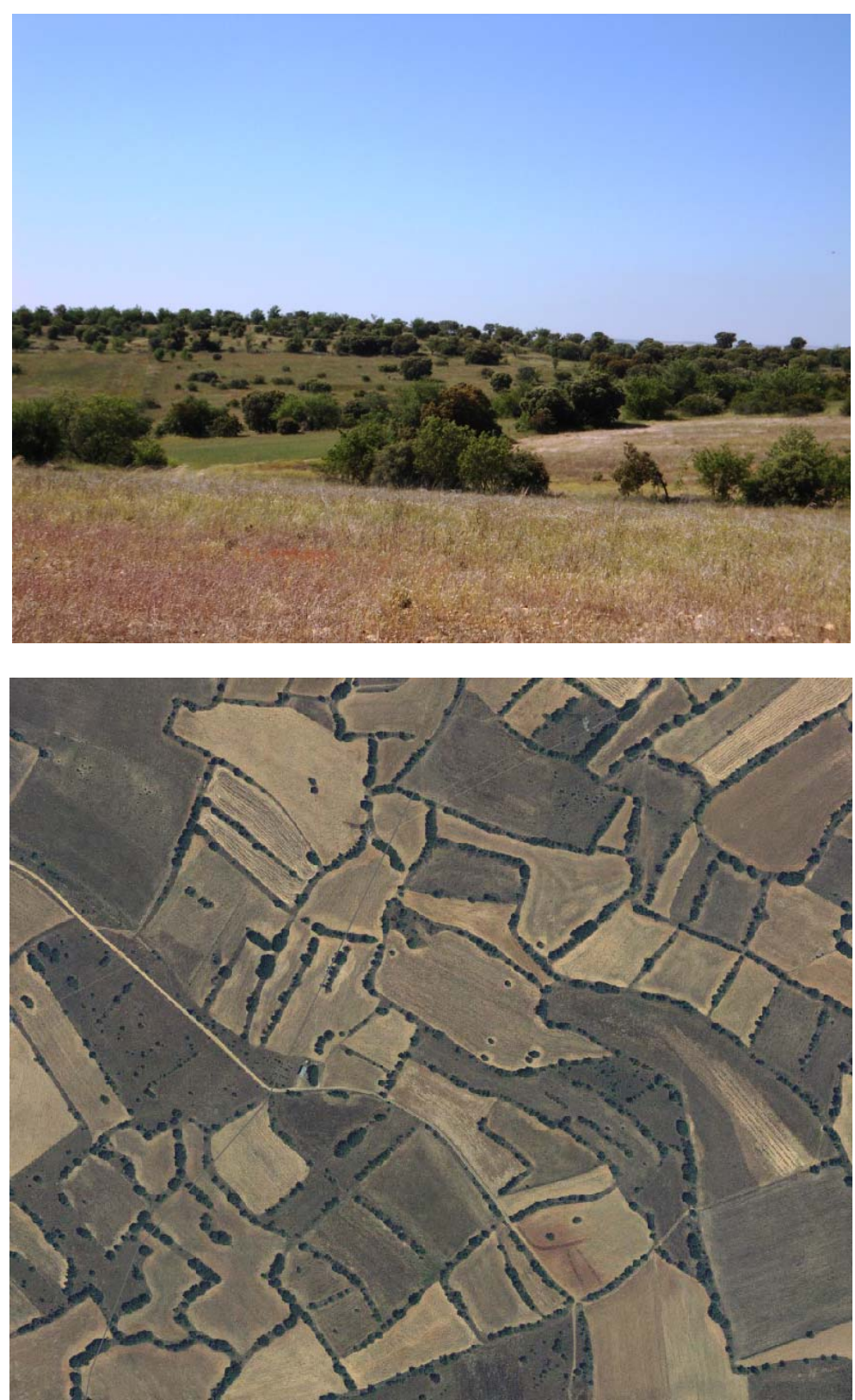

Figura 3.65: Arriba, mosaico de setos arbolados de encinas y otras especies acompañantes, como almendros, en Villalpando. Abajo, ortofotografía de 2011 de la zona, en el límite de los términos municipales de Cañizo y Villalpando. Parece un espejismo en Tierra de Campos.

No obstante, en la campiña cerealista mesetaria los escasos setos existentes (Figura 3.66) son arbustivos con ejemplares arbóreos aislados, estando compuestos fundamentalmente por zarza o escaramujo (Rosa canina), gayomba o sebe (Spartium junceum), endrino (Prunus spinosa), rebrotes de olmo (Ulmus minor) y, en las zonas húmedas, por espino albar (Crataegus monogyna), sauce (Salix, sp.) o chopo castellano (Populus nigra). 

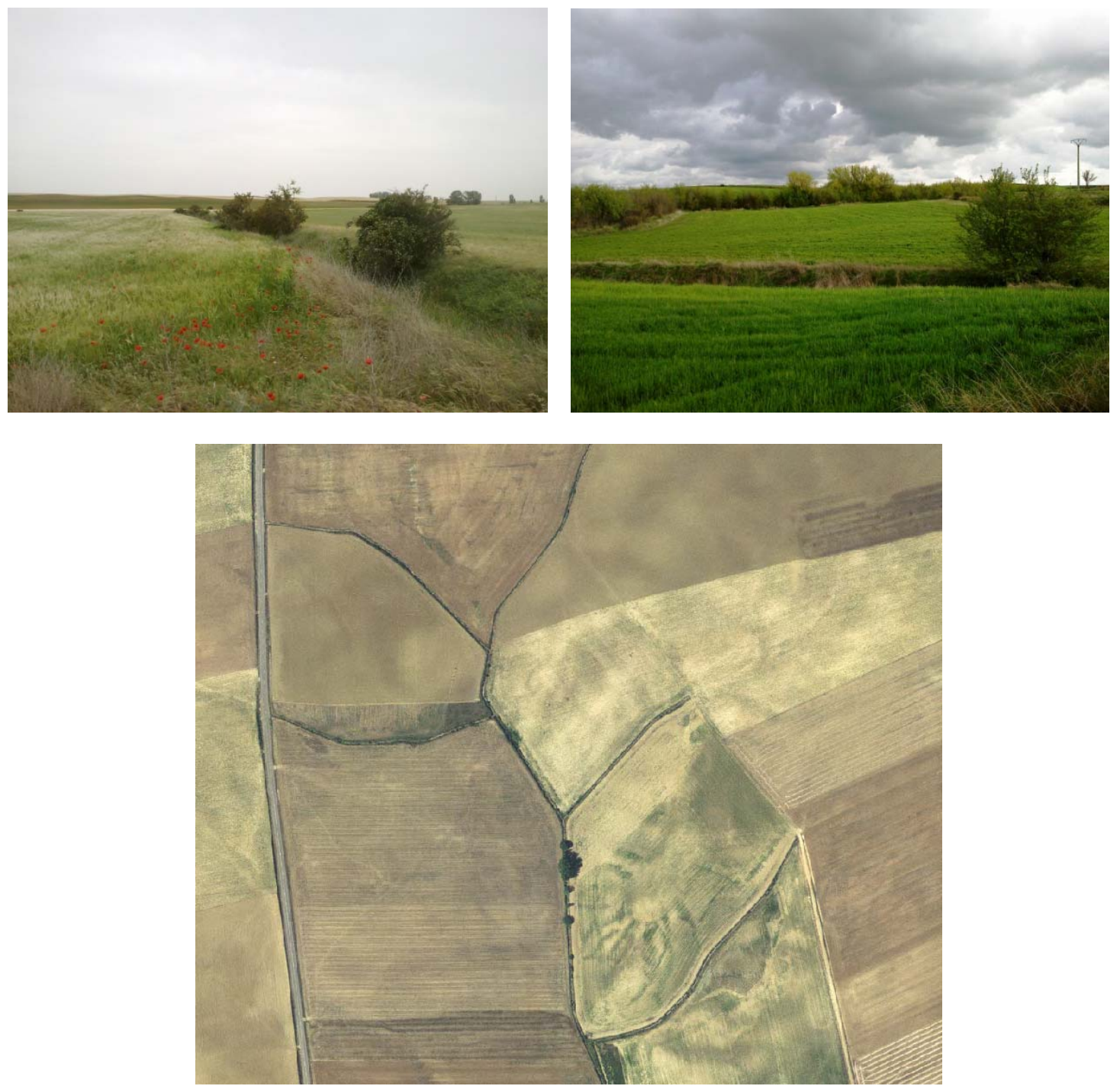

Figura 3.66. Setos situados en regueras de Villalón de Campos (izquierda) y Fontihoyuelo (derecha). Abajo, ortofotografía de uno de los escasos setos de este último municipio.

El modelo agrícola intensivo ha supuesto una simplificación del paisaje, que está provocando importantes cambios en la cantidad y diversidad de la flora y de la fauna silvestre tradicionalmente asociada a los espacios agrarios. Asimismo, la fragmentación de hábitats conlleva el aislamiento de las poblaciones de flora y fauna con el consiguiente riesgo de consanguinidad y falta de viabilidad futura de las poblaciones (DE ANDRÉS et al., 2003)

En Castilla y León, las transformaciones agrícolas realizadas a partir de la mitad del siglo pasado, en particular las actuaciones de concentración parcelaria, fueron eliminando pequeños enclaves naturales existentes en las tierras agrícolas -como setos, linderos, baldíos, eriales o ribazos- que resultan imprescindibles para la vida silvestre que sobrevive en ellos, al utilizarlos como lugar de cría, refugio o alimentación. Tradicionalmente existían estos linderos entre campos, a veces en forma de setos arbustivos o de hileras de árboles, lo que componía un rico marco natural integrado en la vida de los pueblos. Por ello, en la actualidad resulta preciso evitar urgentemente un deterioro mayor, actuando además de forma activa (Figura 3.67) para recuperar, en lo posible, estos enclaves naturales perdidos (JUNTA DE CYL, 1992). 


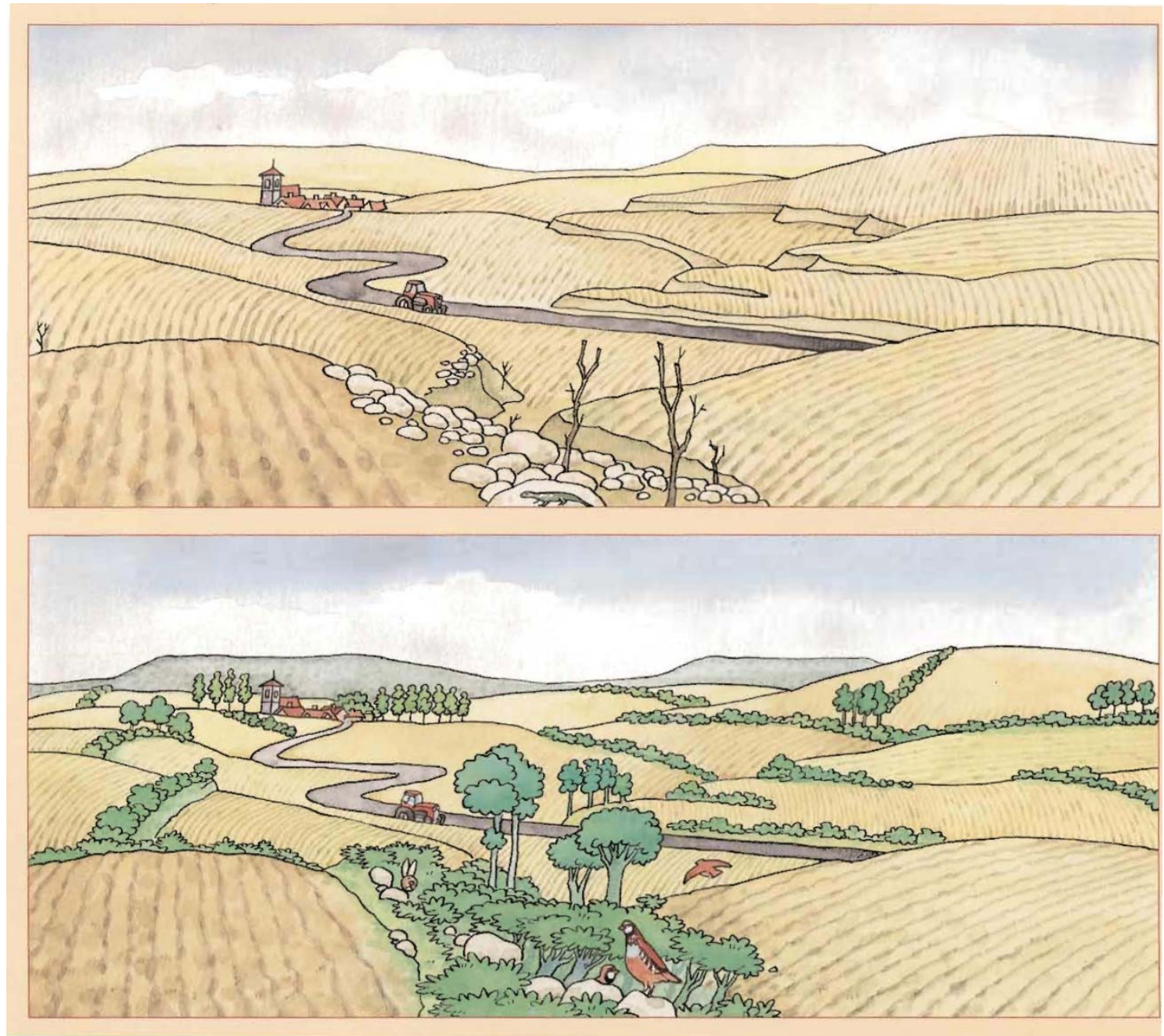

Figura 3.67. Esquema gráfico de la mejora del paisaje cerealista que entrañaría la creación de setos vivos (JUNTA $D E C Y L, 1992)$.

Resulta bien conocida la importancia que tiene para la fauna silvestre tanto la presencia de un mosaico de cultivos, como la existencia de pequeños remanentes de vegetación natural en lindes, setos, caminos, riberas, etc. Así, DE ANDRÉS et al. (2003) citan un estudio realizado en 1991 por la facultad de Biología de la Universidad de León, en el que se llegaron a contabilizar más de ochenta especies de aves nidificantes en los setos de una zona agrícola. REY BENAYAS (2012) indica los beneficios de la restauración ecológica con setos vivos para aumentar la biodiversidad y servicios ecosistémicos de los paisajes agrícolas.

\subsubsection{Funciones de los setos vivos.}

La presencia de setos vegetales en los espacios agrarios supone una gran cantidad de ventajas, debido a su diversidad de funciones. Relataremos a continuación las más importantes:

- Mejora de la calidad visual del paisaje. Los setos proporcionan contrastes de color con los suelos agrícolas (tanto con las hojas, como con las flores y frutos), diversidad de 
texturas y estructuras (introduce el estrato arbustivo y arbóreo), ruptura de las rígidas formas geométricas, aparición de una cierta verticalidad (Figura 3.68), etc.

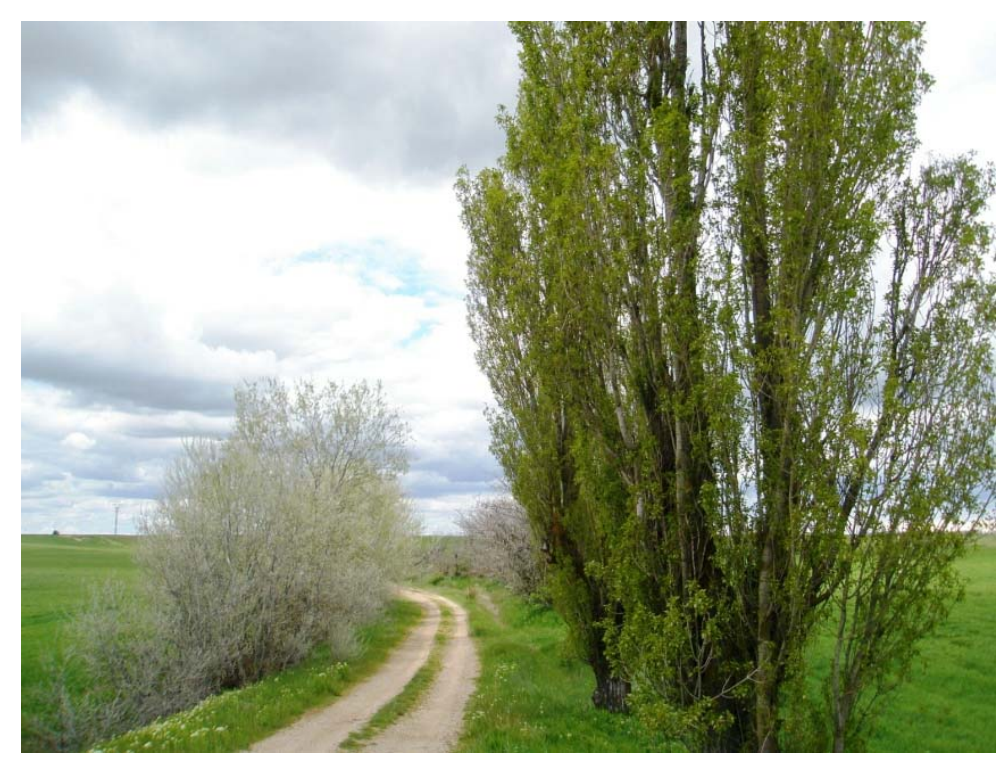

Figura 3.68. Seto arbóreo y arbustivo en márgenes de camino rural en Castromocho.

- Reserva de biodiversidad. Los setos vivos constituyen un reservorio de especies vegetales, que pueden ser arbóreas, arbustivas y herbáceas y, en función de su calidad, un hábitat idóneo para multitud de especies de fauna invertebrada y vertebrada. A modo de ejemplo, ORIA DE RUEDA y DÍEZ (2002) indican que en el espino majoleto (Crataegus monogyna) -una de las especies típicas de los setos vivos de Tierra de Campos (Figura 3.69)- crían y se alimentan de sus frutos multitud de aves y mamíferos, como mirlos, zorzales, palomas torcaces, estorninos, raposos, etc.

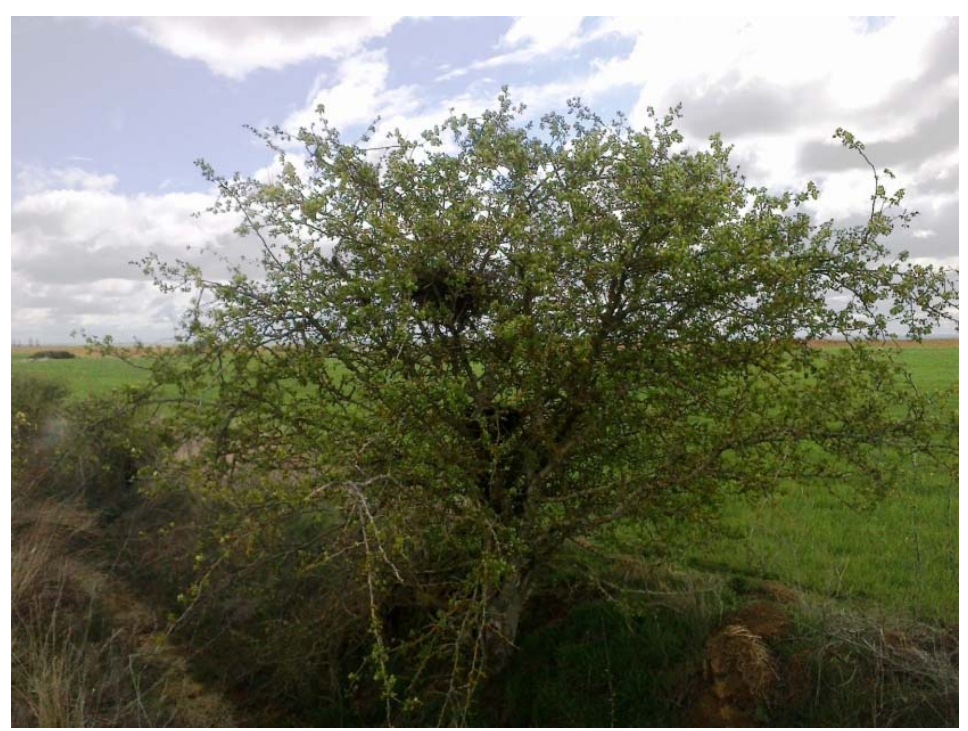

Figura 3.69. Espino majoleto con varios nidos en Villalón de Campos. 
- Conectividad ecológica. Los setos que mantienen una cierta continuidad son unos magníficos corredores biológicos, fundamentales en un paisaje con un dominio casi absoluto de su matriz agrícola. En ellos, la fauna puede desplazarse contando con la protección proporcionada por la vegetación. En estas franjas, también se puede regenerar naturalmente -bien sea por rebrote o con el apoyo de las aves- la flora y vegetación autóctona.

- Mejora del hábitat cinegético. Las franjas cubiertas fundamentalmente por matorral de los linderos o pequeños arroyos son el único refugio para las especies cazables: perdices, codornices, liebres, conejos, etc. La riqueza cinegética de un coto es directamente proporcional a la existencia de setos vivos. De hecho, el Manual de buenas prácticas cinegéticas en Castilla y León (ESTUDIOS Y PROYECTOS LÍNEA, 2010) contempla las plantaciones de escaramujo, espino albar y endrino como una buena práctica de mejora del hábitat para las especies cinegéticas de Tierra de Campos.

- Papel en la lucha biológica. La presencia de setos vegetales y de su fauna asociada es una adecuada alternativa a los tratamientos químicos o quemas que se realizan para el control de plagas agrícolas, como la del topillo campesino. En este sentido, los setos desempeñan un papel principal en una agricultura respetuosa con el medio ambiente.

- Reducción de la velocidad del viento. Con la densidad y altura adecuadas, se pueden diseñar setos cortavientos, que ocasionarían una reducción de la sequedad de los terrenos adyacentes; recordemos que Tierra de Campos es especialmente ventosa. En este caso sería conveniente la introducción de coníferas como diversas especies de cupresáceas.

- Control de la escorrentía y la erosión. Cuando los setos cubren taludes, su papel es fundamental para mejorar los niveles de infiltración de agua en el suelo y, con ello, reducir las tasas de escorrentía y transporte de sedimentos sólidos.

- Protección de los espacios públicos. La presencia de setos vegetales permite proteger espacios de propiedad pública, como regueras, arroyos, márgenes de expropiación de carreteras, cunetas de caminos rurales, parcelas públicas, etc. La experiencia demuestra que en la comarca existe una gran presión agrícola sobre estos terrenos marginales, que genera muchas intrusiones.

- Delimitación de parcelas agrarias. Este era uno de los usos prioritarios del mantenimiento de los setos vegetales. La colocación de mojones de hormigón en los vértices de las parcelas, en las concentraciones parcelarias, hizo perder esa función. No obstante, con el tiempo, muchos mojones se mueven o desaparecen; la vegetación, en cambio, es un elemento permanente que contribuiría a eliminar posibles discusiones sobre límites de propiedad.

- Conformar pantallas vegetales. Un seto denso puede contribuir en buena medida a reducir el impacto visual provocado por elementos no armónicos, más en el caso de 
contener un estrato arbóreo: grandes naves, huertos solares, plantas de tratamiento de minerales, subestaciones eléctricas, etc. No se trata tanto de ocultar en su totalidad una vista desagradable (que sería imposible) como de favorecer la calidad visual del entorno y su naturalidad.

- Integrar paisajísticamente las vallas metálicas. En los espacios periurbanos de los pueblos existen numerosas parcelas delimitadas mediante vallas con postes metálicos y mallas de triple torsión, cuyo impacto podría ser minimizado sustancialmente con la implantación de setos vegetales (Figura 3.70). Una opción muy interesante en este sentido es la introducción de plantas trepadoras, como la madreselva o la hiedra.

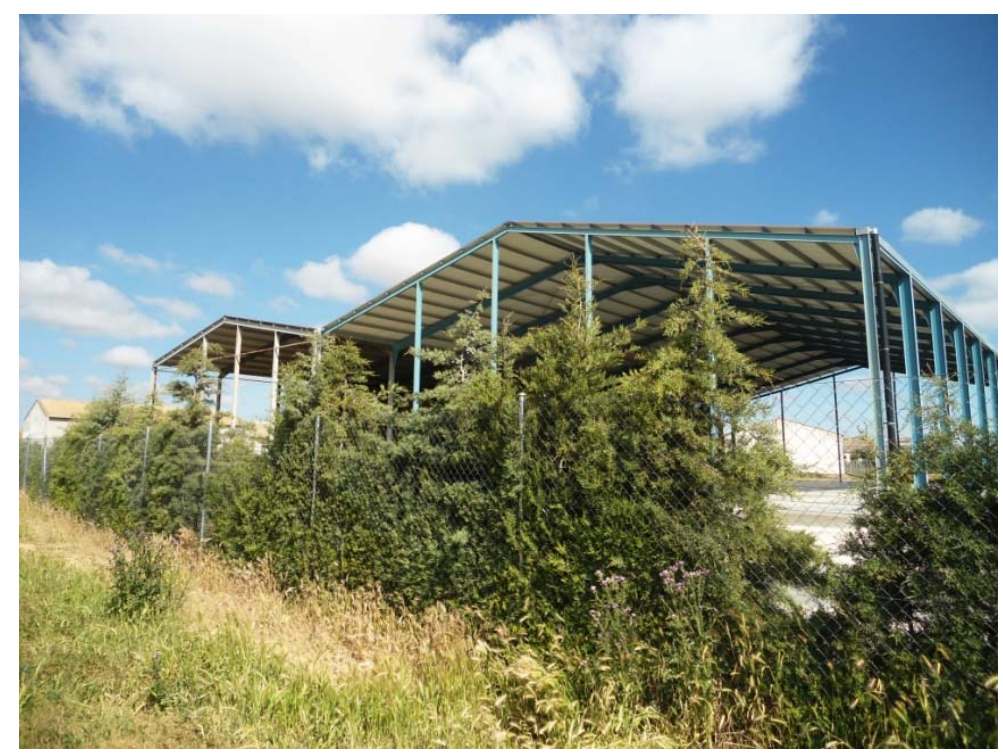

Figura 3.70. La plantación de este seto de Cupressus arizonica en Villalón de Campos, mitiga el impacto visual de la valla metálica y de las naves agrícolas del interior de la parcela.

- Producción de bienes secundarios. Si los setos tienen la diversidad y densidad suficiente, ofrecen algunas producciones estimables: leñas, frutos silvestres, plantas medicinales, miel, setas, caracoles, etc.

\subsubsection{Creación de setos vivos.}

Si se desea recuperar un paisaje agrícola en el que coexistan vida silvestre y cultivos productivos, las actuaciones deben ir dirigidas a crear en los límites de las fincas una mínima franja de terreno sin cultivar -1 ó 2 m podrían ser suficientes- donde se desarrolle la vegetación espontánea (Figura 3.71). Esto conllevaría que, tomando como ejemplo una parcela de 10 ha, crear este margen supondría reducir tan solo un 1 \% aproximadamente de su superficie útil cultivable. Aunque la franja se irá poblando de plantas espontáneas, si se desea obtener un seto desarrollado con cierta rapidez, se deberán plantar árboles y arbustos. Los mejores setos para 
la vida silvestre son aquellos en que coexisten la vegetación herbácea, arbustiva y arbórea (JUNTA DE CYL, 1992).

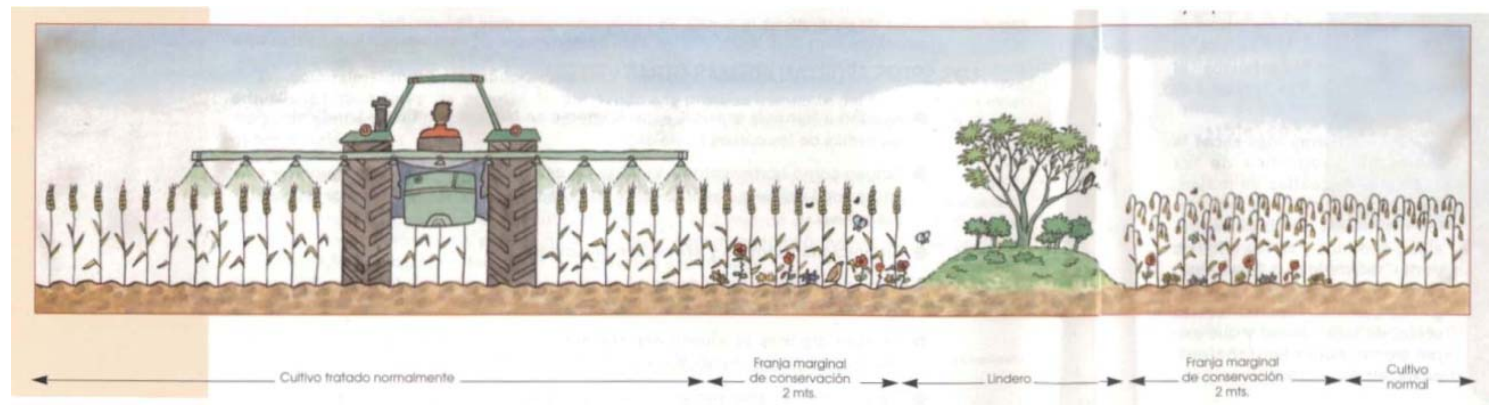

Figura 3.71. Modelo de creación de seto en un lindero de parcelas agrícolas (JUNTA DE CYL, 1992).

No obstante, la repoblación forestal es interesante realizarla de forma dispersa no solo en las lindes entre parcelas, sino también aprovechando otras áreas marginales para la agricultura, como los márgenes de caminos y vías pecuarias, los bordes de regueras y arroyos, las pequeñas parcelas públicas sobrantes tras la concentración parcelaria, los tesos y cuestas, etc.

GAMBIER (2009) señala que los arbustos autóctonos son la mejor elección para crear setos vivos, tanto en el medio rústico como incluso en los espacios ajardinados. Su generosa floración y sus coloridos frutos les otorgan cualidades ornamentales; una prolongada aclimatación les aporta rusticidad; se adaptan con facilidad al clima y al suelo, y resisten el hielo y enfermedades que necesitan tratamientos de importancia.

Este autor considera que se deben contemplar 10 etapas para tener éxito en la plantación de un seto campestre, que serán analizadas desde la perspectiva de su posible aplicación a las parcelas rústicas de Tierra de Campos:

Etapa 1: Elaboración de planos esquemáticos con el diseño de la plantación. Resulta conveniente evitar la monotonía; un seto campestre no es necesariamente lineal y de altura constante, sino más bien al contrario: un seto sinuoso y ondulante parece más natural. Además, para dar más relieve a los setos es oportuno plantar árboles o frutales intercalados.

Etapa 2: Tener en cuenta el clima y la exposición. El clima de la meseta norte -y por ende, el de Tierra de Campos- es continental y homogéneo en toda su extensión, aunque se debe considerar la posible existencia de microclimas locales. Es conveniente reflexionar sobre el efecto del cambio climático que parece suavizar los inviernos y prolongar los periodos de sequía. Finalmente, es muy importante tener en cuenta la insolación; en una reguera o arroyo, por ejemplo, siempre hay un talud orientado más a la solana y otro más a la umbría (en este hay más probabilidades de arraigo).

Etapa 3: Evaluación del suelo. Las principales variables a analizar son: textura, estructura, contenido en materia orgánica, profundidad, pH y humedad. Los suelos en Tierra de Campos, por lo general son arcillosos, de estructura deficiente, muy bajos en materia orgánica, profundos y básicos. Por su naturaleza arcillosa, son impermeables, por lo que mantienen la humedad gran 
parte del año. El abono -mineral u orgánico- puede ser una opción para mejorar la fertilidad y estructura del suelo.

Etapa 4: Diseñar la composición del seto sobre criterios precisos. Por ejemplo, se pueden introducir arbustos de frutos carnosos para atraer a los pájaros, o melíferos si se desea producir miel. Otros criterios pueden ser buscar un follaje coloreado en otoño, generar flores perfumadas o favorecer a los insectos auxiliares. Es conveniente elaborar un módulo o secuencia de plantación para cada seto, intercalando espacios libres (Figura 3.72).

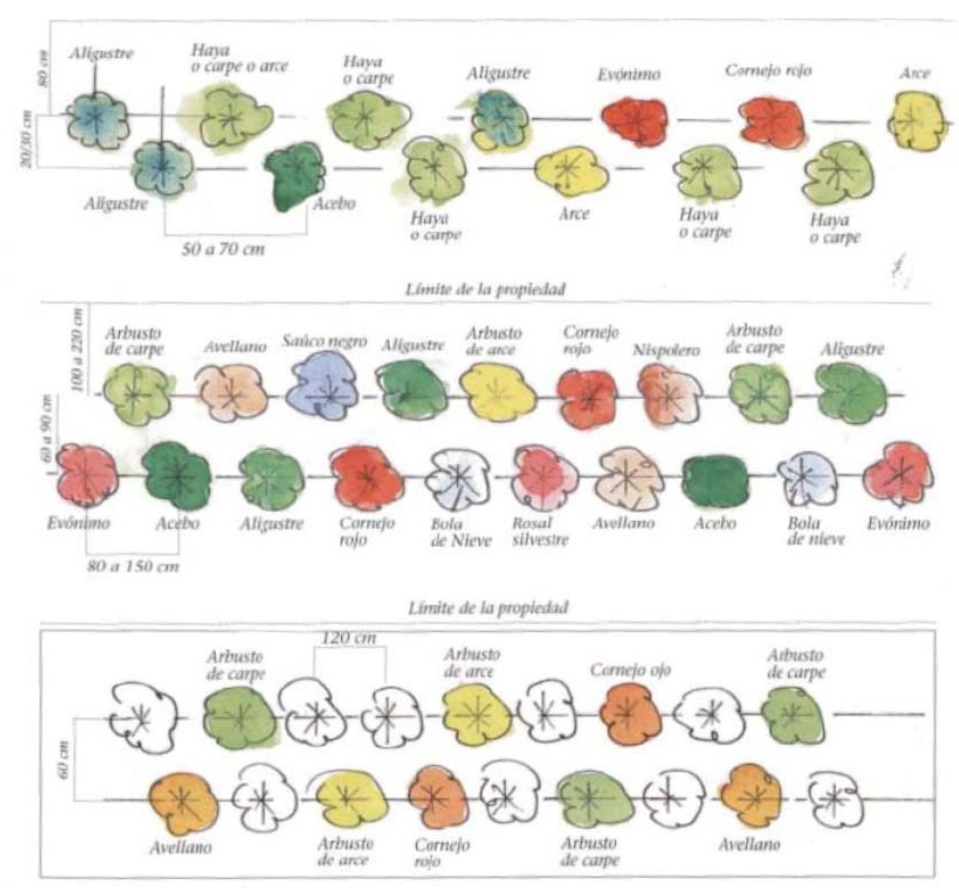

Figura 3.72. Ejemplos de módulo de plantación de setos (GAMBIER, 2009).

Etapa 5: Obtener plantas de buena calidad. Conviene acudir a viveros especializados en la producción de plantas forestales, que dispondrán de planta autóctona. Es preferible elegir plantas de una o dos savias, en contenedor, con un buen equilibrio entre la parte aérea y la subterránea y que, finalmente, sea de procedencias locales.

Etapa 6: Evitar los contenciosos de propiedad. Para las plantaciones a lo largo de caminos vecinales o carreteras, se debe consultar a la administración competente su normativa específica. En el resto de colindancias con particulares -salvo que existan ordenanzas municipales- hay que acudir al Código Civil que, entre otras cuestiones, regula una distancia mínima a la línea divisoria de $0,5 \mathrm{~m}$ en el caso de arbustos y de $2 \mathrm{~m}$ para árboles altos (Figura 3.73). El Decreto 2661/1967 aumenta esta última distancia a $3 \mathrm{~m}$ para coníferas y $4 \mathrm{~m}$ para frondosas. 


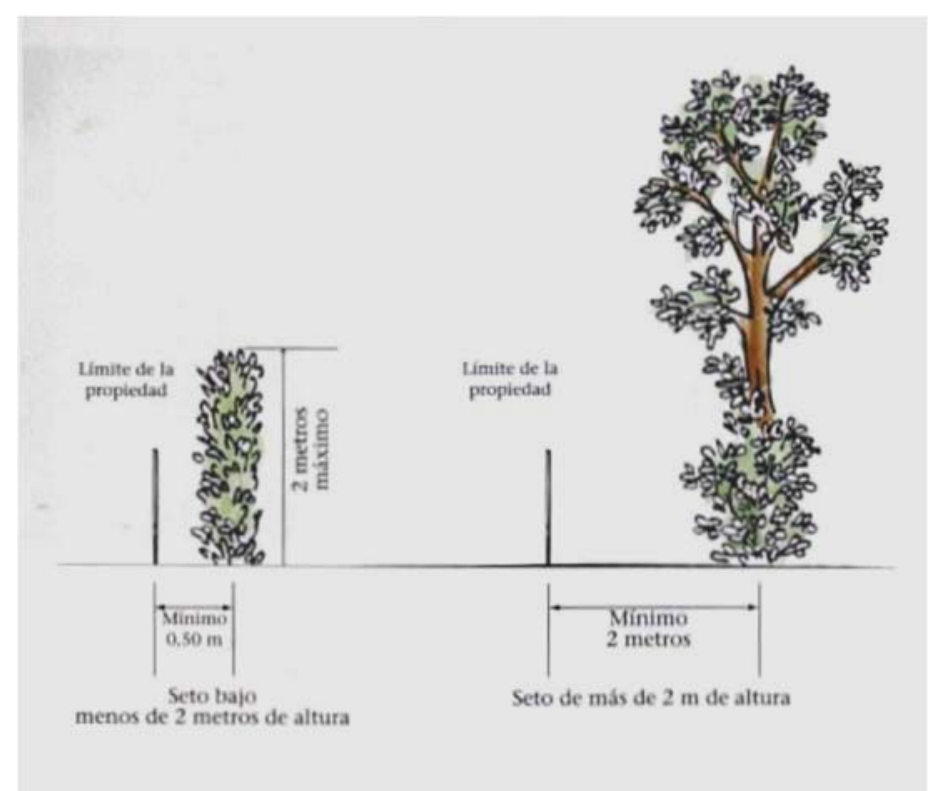

Figura 3.73. Distancias mínimas de plantación según el Código Civil (GAMBIER, 2009)

Etapa 7: Preparar el terreno con cuidado. Esta es una de las labores fundamentales para la creación de un seto vivo. Se aconseja realizar una cava en una franja de $1 \mathrm{~m}$ de anchura mínima y 0,50 m de profundidad, para mullir y descompactar el suelo. Si es necesario, se extenderá una capa rica en materia orgánica en superficie. El pase de un subsolador con uno o dos rejones puede ser una solución con alto rendimiento. Es conveniente llevar a cabo esta operación con el terreno seco.

Etapa 8: Normas de plantación. En primer lugar, es preciso proteger los arbustos desde su llegada del vivero, sobre todo si es planta a raíz desnuda. La plantación debe efectuarse durante el periodo de reposo vegetativo, de noviembre a finales de marzo; si la planta es con contenedor, se puede ampliar este periodo. Antes de la plantación es conveniente hidratar las raíces, incluso con una mezcla de agua, arcilla y abono orgánico. Para cada planta se realizará un hoyo de profundidad mayor a la ocupada por la parte radical, dejándose tierra fina en el fondo del mismo. La planta deberá quedar bien anclada, de forma que estirándola ligeramente hacia arriba, no debería ceder. Finalmente, si fuese necesario se colocarán protectores frente a los animales.

Etapa 9: Acolchado. El acolchado es la colocación de una cobertura alrededor de la planta, con objeto de evitar la aparición de otras especies competitivas y mantener la humedad del suelo. Esta cubierta puede estar formada por materiales naturales (paja, helechos, virutas de madera, etc.) o bien por artificiales (láminas plásticas, fieltro, cartón, losetas, etc.). Los acolchados naturales son más ecológicos y considerablemente más baratos; además, su degradación aportará materia orgánica al suelo. En Tierra de Campos resultaría extraordinariamente eficaz la utilización de paja como acolchado, preferiblemente una capa gruesa $(20 \mathrm{~cm})$ compactada y mejor regularmente regada para evitar que el viento la desplace.

Etapa 10: Poda y mantenimiento del seto. Las podas pueden ser de formación o de mantenimiento, teniendo estas últimas las variantes de aclarado, rejuvenecimiento $y$ 
renovación. Esta etapa está más indicada para los setos creados en las parcelas de los espacios periurbanos, donde su gestión es más intensa y puede haber mayores problemas de propiedad. No obstante, un seto libre también necesitaría podas cada cierto tiempo, para conformarlo según las especies que lo forman y mejorar su floración y fructificación. El periodo más adecuado para la poda de los arbustos caducos es a finales de invierno, mientras que para los perennes es a finales de verano o después del invierno.

GAMBIER (op.cit.) incluye unos listados de especies para setos, de acuerdo con tres criterios fundamentales; exponemos a continuación las especies susceptibles de plantación en Tierra de Campos de acuerdo con los requerimientos ecológicos de esta comarca:

Plantas autóctonas para setos campestres

- Arce común (Acer campestre)

- Cornejo (Cornus sanguinea)

- Espino albar (Crataegus monogyna)

- Retama negra (Cytisus scoparius)

- Bonetero (Euonymus europaeus)

- Higuera (Ficus carica)

- Aligustre (Ligustrum vulgare)

- Endrino (Prunus spinosa)

- Encina (Quercus ilex)

- Aladierno (Rhamnus alaternus)

- Escaramujo (Rosa canina)

- Sauce blanco (Salix alba)

- Saúco (Sambucus nigra)

Plantas con carácter ornamental

- Árbol del paraíso (Eleagnus angustifolia)

- Bonetero del Japón (Euonymus japonicus)

- Licio (Lycium barbarum)

- Celinda (Philadelphus coronarius)

- Gayomba (Spartium junceum)

- Lilar (Syringa vulgaris)

- Tamariz (Tamarix spp.)

$\underline{\text { Plantas trepadoras y volubles }}$

- Hiedra (Hedera helix) 
- Madreselva (Lonicera etrusca)

- Zarzamora (Rubus ulmifolius)

Para el caso particular de setos y cerramientos ornamentales (MAPA, 1991), cuya función principal es la ocultación de aspectos ingratos de las construcciones, como casetas de servicio, depósitos de residuos, tanques metálicos, postes o mallas metálicas (situadas fundamentalmente en los espacios periurbanos), la elección de especies se podría ampliar a algunas exóticas adaptadas a la zona, como el ciprés (Cupressus sempervirens), ciprés de Arizona (Cupressus arizonica), ciprés de Monterrey (Cupressus macrocarpa), leylandi (Cupressocyparis leylandii), thuya (Thuja orientalis), aligustre (Ligustrum japonicum), madreselva (Lonicera nitida), piracanta (Pyracantha coccifera), etc.

\subsubsection{Sotos.}

Los sotos constituyen formaciones vegetales que se desarrollan en las márgenes de los cursos hídricos y, como tales, también se denominan bosques en galería, bosques de ribera o bosques riparios (Figura 3.74). Se encuentran íntimamente unidos a las vías naturales de drenaje y están integrados por especies distintas a las de los ecosistemas adyacentes. Los sotos ribereños, al ser sistemas terrestres en los que el agua no es un factor limitante, presentan una elevada productividad y diversidad de especies vegetales, siendo un refugio ideal para un gran número de animales, tanto terrestres como acuáticos, por lo que presentan una fauna muy rica y variada (DE ANDRÉS et al., 2003).

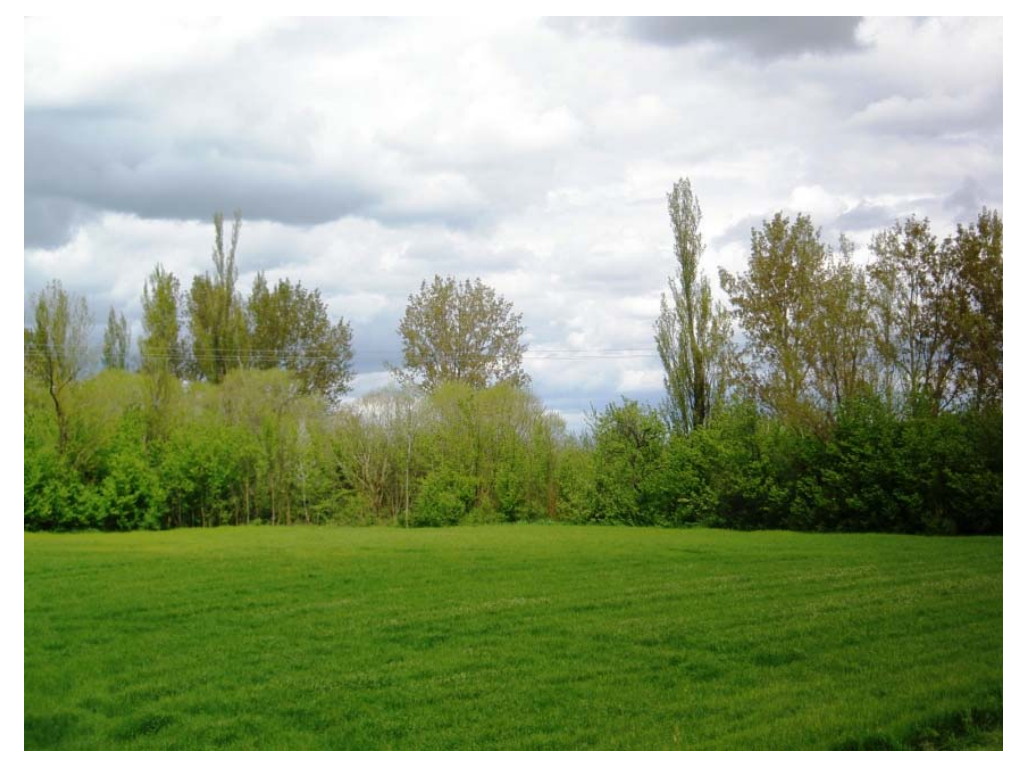

Figura 3.74. Soto en los márgenes del río Valdeginate, en Castromocho.

Gran parte de los beneficios de los sotos son compartidos con los producidos por los setos vivos; no en vano se trata de elementos vegetales de gran similitud. En este caso, la función principal es garantizar la estabilidad de los márgenes de los ríos y arroyos, disminuyendo la erosión causada en las crecidas. El resto de ventajas (biodiversidad, conectividad ecológica, mejora del 
paisaje visual, etc.) son incluso superiores, teniendo en cuenta que normalmente se trata de bandas de mayor anchura y densidad vegetal, ligadas además a cursos fluviales.

En una sección transversal de un curso de agua de Tierra de Campos en un hipotético estado natural, se distinguirían probablemente tres bandas arboladas en función de su distancia al cauce del río. En primer lugar y ocupando las zonas más próximas al agua se encontrarían las saucedas. A continuación, con humedad permanente, se situarían las choperas y alamedas. Finalmente, afectadas por inundaciones esporádicas, se encontrarían las olmedas.

En cuanto al diseño de la plantación de un soto, DE ANDRÉS et al. (2003) exponen unos principios básicos:

- Lo recomendable es que la plantación se realice a lo largo de toda la ribera. Su anchura será la mayor posible, aunque un criterio es que sea al menos la del cauce $y$, como mínimo, 5-6 m.

- La plantación debe ser diversa y heterogénea (Figura 3.75), tomando ejemplo de los tramos de otros cauces en buen estado de conservación. Muy frecuente es encontrar distribuciones en mosaico de individuos de la misma especie, intercalados con ejemplares sueltos distribuidos de manera irregular.

- La plantación se debe realizar al tresbolillo, a una distancia aproximada de 1 m entre sí.

- La primera banda de vegetación debe quedar en contacto con la lámina de agua, para ofrecer un refugio a la fauna acuática, dar sombra al cauce y aportar materia orgánica.

- La función de estas bandas de vegetación siempre es múltiple, y va asociada tanto al control de la erosión de los márgenes como a la mejora de la calidad de las aguas y al suministro de hábitat para la fauna acuática. 


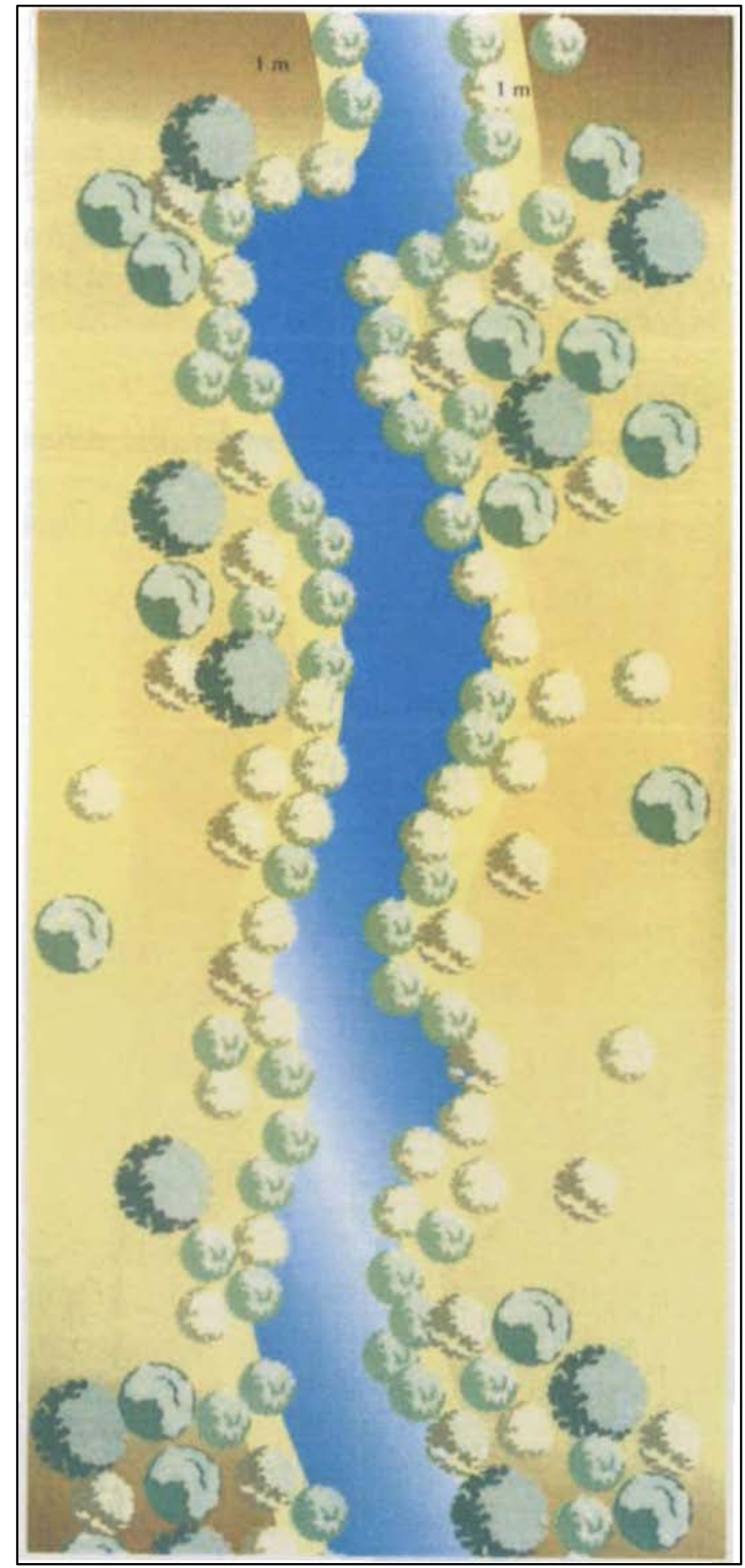

Figura 3.75. Esquema de plantación de un soto (DE ANDRÉS et al., 2003)

\subsubsection{Bosques isla.}

Los pequeños bosquetes de árboles son también elementos muy interesantes de diversificación del paisaje agrario (Figura 3.76). Su origen puede ser natural -reductos de la vegetación primitiva- 0 , de modo más mayoritario, procedentes de plantaciones realizadas por el hombre 
en diversos momentos históricos. En Tierra de Campos aún se conservan alamedas dispersas de gran interés botánico, que probablemente tendrían un fin productor para la construcción. Las antiguas olmedas -hoy desaparecidas o reducidas a vegetación arbustiva- también serían ejemplos de bosques isla en la comarca.

En el caso extremo, estos enclaves forestales pueden estar formados por un grupo mínimo de árboles, o incluso por un ejemplar individual. No por ello su función es despreciable. Su presencia puede conllevar un considerable aumento de la calidad del paisaje, especialmente en su aspecto visual.
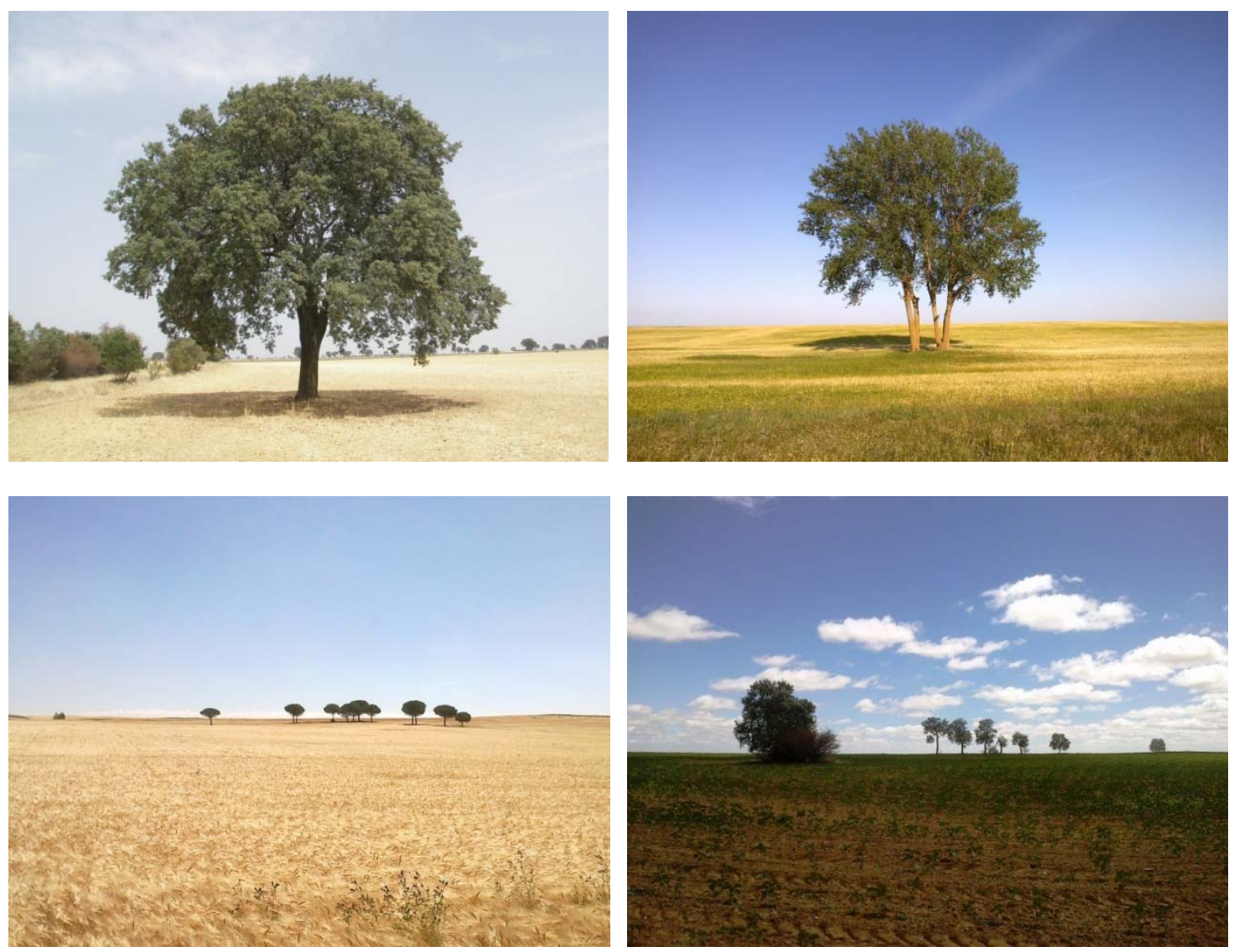

Figura 3.76. Arriba izquierda, encina de gran porte en Paredes de Nava; arriba derecha, dos chopos que parecen uno en Villalón de Campos; abajo izquierda, pinarcillo en Herrín de Campos; abajo derecha, grupo de álamos que antaño rodearon un majuelo.

Para el diseño de un bosque isla, DE ANDRÉS et al. (2003) indican que es necesario tener en cuenta las siguientes recomendaciones (Figura 3.77):

- Se debe buscar una armonía entre los distintos elementos que lo van a componer, tanto en su ubicación como en la variedad de especies a utilizar.

- Los árboles de mayor diámetro necesitan estar suficientemente espaciados para evitar la competencia entre sí. La distancia de separación recomendada es de $3 \mathrm{~m}$. 
- Si se incluyen arbustos, se repartirán de forma gradual, de manera que los de menor tamaño queden en la periferia de la formación. Como separación entre pies basta con $2,5 \mathrm{~m}$.

- La separación entre las hileras de una banda boscosa debe ser de unos $2 \mathrm{~m}$.

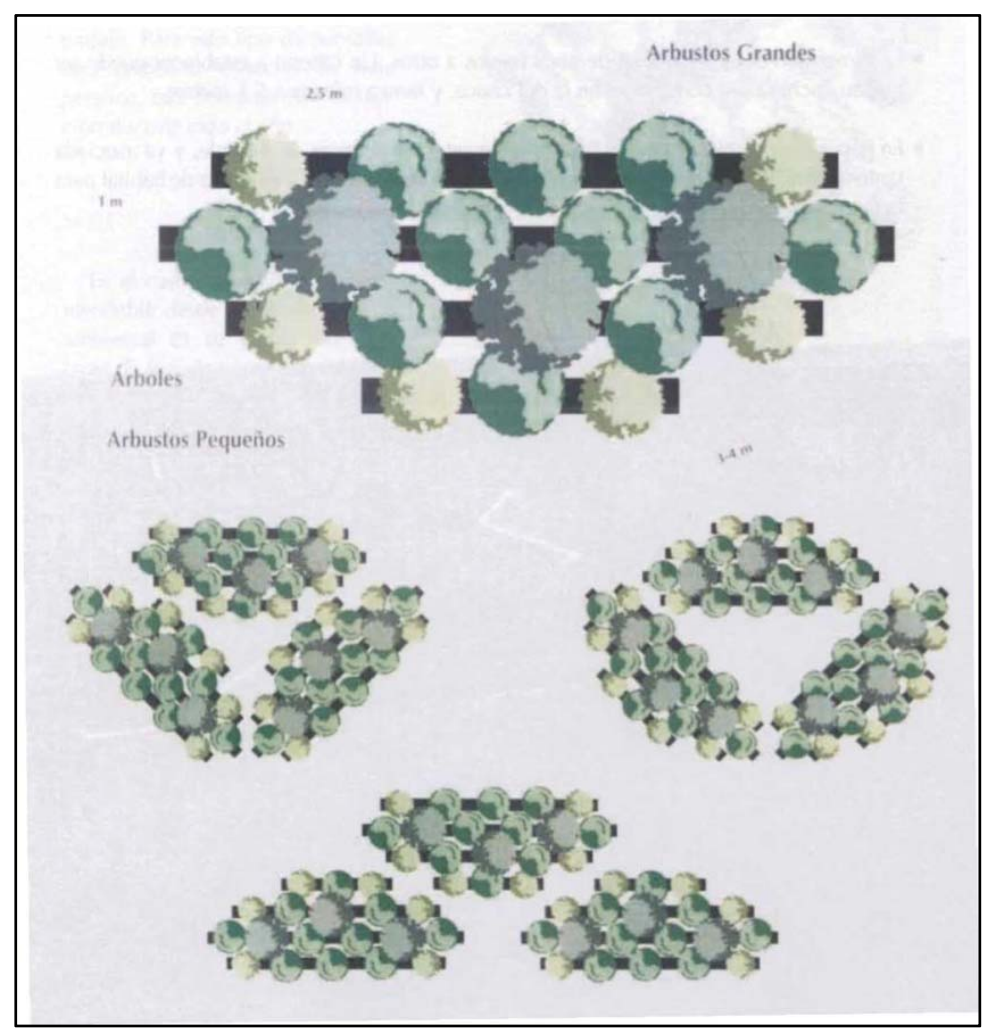

Figura 3.77. Esquema de plantación de bosques isla (DE ANDRÉS et al., 2003)

En el caso de Tierra de Campos tal vez se podrían aumentar las distancias apuntadas por los citados autores para el caso de los árboles, de modo que se evitasen futuros clareos en años posteriores, considerándose apropiadas separaciones de en torno a $5 \mathrm{~m}$. Ahora bien, si no se plantea la adopción de cuidados culturales, puede resultar conveniente la plantación con altas densidades teniendo en cuenta las previsibles marras.

\subsubsection{Las medidas de condicionalidad de la Política Agraria Común.}

En los últimos años, la Política Agraria Común (PAC) ha dado un giro considerable en cuanto a la importancia de la variable ambiental en su contenido, siendo uno de sus objetivos precisamente la diversificación del paisaje agrario. De este modo, el Reglamento (CE) 1782/2003, del Consejo, de 29 de septiembre de 2003, por el que se establecen disposiciones comunes aplicables a los regímenes de ayuda directa en el marco de la Política Agraria Común, introduce, en su artículo 3, la obligación de cumplir los requisitos legales de gestión citados en su Anexo III, y las buenas 
condiciones agrarias y medioambientales que establezcan los Estados miembros en virtud de su artículo 5, para todos los agricultores que reciban pagos directos. El Reglamento (CE) 796/2004, de la Comisión, de 21 de abril de 2004, establece, entre otras, disposiciones para la aplicación de la condicionalidad, marcando las bases para la determinación de las reducciones y exclusiones de los pagos directos por incumplimiento de los requisitos legales de gestión y de las buenas condiciones agrarias y medioambientales. A través de esta normativa, la Unión Europea asume el papel que debe jugar la agricultura y la ganadería en la conservación del medio ambiente.

El Real Decreto 2352/2004, de 23 de diciembre, sobre aplicación de la condicionalidad en relación con las ayudas directas en el marco de la política agraria común, establece en su artículo 4 las buenas condiciones agrarias y ambientales a cuyo cumplimiento estarán sujetos los productores que reciban pagos directos. Esta norma estatal fue derogada y modificada a través del Real Decreto 486/2009, de 3 de abril, por el que se establecen los requisitos legales de gestión y las buenas condiciones agrarias y medioambientales que deben cumplir los agricultores que reciban pagos directos en el marco de la política agraria común, los beneficiarios de determinadas ayudas de desarrollo rural, y los agricultores que reciban ayudas en virtud de los programas de apoyo a la reestructuración y reconversión y a la prima por arranque del viñedo. La reciente revisión de la Política Agraria Común para el periodo 2014-2020 es aún más ambiciosa y persigue continuar en la denominada "ecologización" (greening) del campo; su trasposición a la normativa estatal ha dado lugar a una nueva modificación a través del Real Decreto 1078/2014, de 19 de diciembre, por el que se establecen las normas de condicionalidad que deben cumplir los beneficiarios que reciban pagos directos, determinadas primas anuales de desarrollo rural, o pagos en virtud de determinados programas de apoyo al sector vitivinícola.

En el ámbito de la Comunidad Autónoma de Castilla y León, la Orden AYG/1039/2007, de 5 de junio, establece los requisitos legales de gestión y las buenas condiciones agrarias y medioambientales que deberán cumplir los agricultores que reciban ayudas directas de la Política Agraria Común, que se detallan en su anexo II. A efectos de esta Orden, las exigencias que los productores deben cumplir, en materia de condicionalidad, estarán comprendidas en los siguientes ámbitos:

- Medio ambiente.

- Salud pública, Zoosanidad y Fitosanidad.

- Bienestar animal.

- Buenas condiciones agrarias y medioambientales.

Las principales medidas relacionadas con la diversificación del paisaje se encuentran en el primero de los ámbitos -el medio ambiente-, en el cumplimiento de la norma no 1: Directiva 79/406/CEE del Consejo, de 2 de abril de 1979, relativa a la conservación de las aves silvestres. El requisito 1 supone establecer medidas de protección del hábitat y superficies para todas las especies de aves. Estas son de dos tipos: 
1.1 Crear zonas de refugio para la fauna silvestre mediante alguna de las siguientes actuaciones:

1.1.1 Crear setos leñosos, mediante el abandono permanente del cultivo de franjas de una longitud de $10 \mathrm{~m}$ lineales por hectárea de explotación y con una anchura de $2 \mathrm{~m}$.

1.1.2 Dejar cada año sin recoger un porcentaje de la superficie destinada a cultivos herbáceos extensivos de secano (cereales, oleaginosas, proteaginosas y leguminosas grano) declaradas en la solicitud única en forma de rodales (máximo de tres por explotación), o franjas lineales de anchura mínima de $2 \mathrm{~m}$ y que en el conjunto de la explotación represente una superficie equivalente al 1 por mil de la superficie de cultivos herbáceos de secano.

No obstante lo anterior estarán exentos de cumplir con las medidas anteriores los agricultores que incluyan en sus alternativas, un porcentaje del $10 \%$ de cultivos que proporcionan refugio para las aves en la época estival (girasol, leguminosas plurianuales, maíz, remolacha, patatas). En principio, en Tierra de Campos se ha aplicado esta exención de forma generalizada, por lo que no se aprecia la creación de setos leñosos o franjas sin recolectar.

1.2 Plantar o mantener especies arbóreas. El requisito consiste en plantar o mantener protegido respecto de la superficie que representan las parcelas de cultivo (tierras arables) de su explotación, al menos un árbol al año por cada cinco hectáreas, manteniéndose la exigencia durante cinco años, de forma que después de cinco años se asegure la permanencia futura de un árbol por hectárea plantado o protegido.

Los árboles que se planten preferiblemente corresponderán a alguna de las especies que figuran en los cuadernos de cada zona del programa de forestación de tierras agrarias, elegidas por el agricultor y adquiridas en viveros en los que se asegure la trazabilidad de su procedencia y su garantía sanitaria. Para asegurar esta condición, la Consejería de Medio Ambiente efectuó varias convocatorias por comarcas para la distribución de árboles, estableciendo las bases reguladoras en la Orden MAM/1416/2007, de 5 de septiembre. Así, por ejemplo, en la comarca agraria de la Tierra de Campos vallisoletana, en otoño de 2010 se repartieron un total de 141483 plantas, correspondiendo a pino piñonero (65\%), quejigo (13\%), encina (11\%), almendro (8\%), nogal (2\%), fresno (1\%) y laurel (menos de $1 \%)$.

Se permite la plantación o mantenimiento concentrado de un número máximo de plantas equivalente a 250 árboles, en una única parcela, respetándose una superficie por árbol de cinco metros cuadrados (2,25 $\mathrm{m}$ de distancia). En la entrega de los árboles se aconsejaba a los agricultores que se plantasen a distancias mayores; aun así, las densidades de plantación son en general muy altas, con marcos normales de $3 \times 3 \mathrm{~m}$. Normalmente se concentran las plantaciones en "picones" o espacios marginales por lo que, a la postre, se formarán pequeños bosques-isla (Figura 3.78). En algunos casos, el agricultor diseña plantaciones lineales, que generarán setos arbolados. 


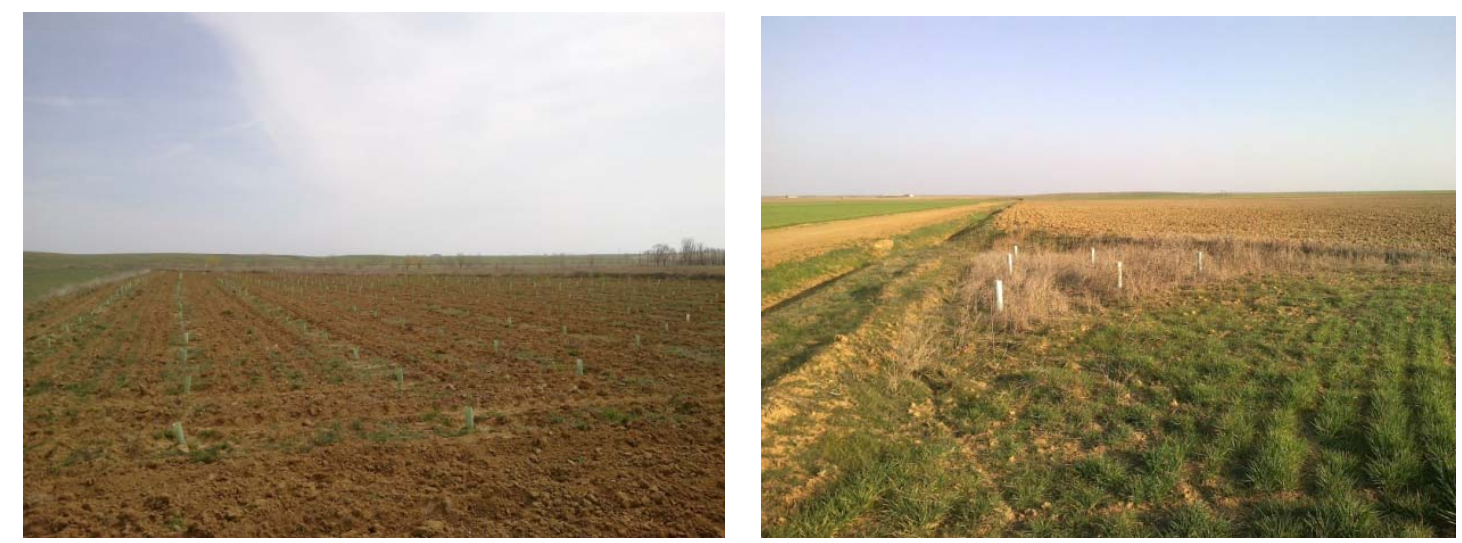

Figura 3.78. Plantación de árboles en Tamariz de Campos (izquierda) y Gatón de Campos (derecha), como medida de condicionalidad de la PAC.

El requisito 2 consiste en preservar las especies que constituyen los hábitats naturales de las especies de aves migratorias amenazadas y en peligro de extinción. La primera de las medidas está relacionada con la diversificación del paisaje:

2.1 Mantener los elementos estructurales naturales del terreno, especialmente los relacionados con la red fluvial y de cañadas. En la Orden se definen los elementos estructurales: los ribazos provistos de vegetación herbácea, arbustiva o arbórea; las terrazas y zanjas de contorno en el caso de laboreo a nivel y las barreras vivas vegetales perpendiculares a la pendiente que, mediante el control de las escorrentías, protegen el suelo de la erosión; las islas y enclaves de vegetación natural, rocas que se encuentren en el interior de la parcela, charcas y abrevaderos naturales. En Tierra de Campos los principales elementos estructurales naturales del terreno son los linderos, las regueras y los arroyos. En la práctica, la medida radica en el control de las quemas de estos elementos.

Recientemente se ha publicado la Orden AYG/1129/2014, de 19 de diciembre, por la que se regulan las medidas de agroambiente y clima, contenidas en el Programa de Desarrollo Rural de Castilla y León 2014-2020 y cofinanciadas por el Fondo Europeo Agrícola de Desarrollo Rural (Feader). Esta norma, que se está comenzando a poner en marcha, dispone normas adicionales de condicionalidad ambiental. Entre ellas -a efectos paisajísticos- se destaca la obligación de dejar un $5 \%$ de franjas sin cultivar en las ZEPA que contengan humedales de importancia internacional (en Tierra de Campos, Villafáfila y La Nava-Campos Norte).

\subsubsection{La forestación de tierras agrícolas.}

La forestación de tierras agrícolas es una de las medidas de acompañamiento de la Política Agraria Común que se desarrolla a partir del Reglamento CEE 2080/1992, de ayudas a las medidas forestales en agricultura, incorporado al marco jurídico español mediante los Reales Decretos 378/1993 y 152/1996. Pretende fomentar el abandono de tierras para reducir los excedentes agrícolas. Posteriormente se publica el Reglamento CE 1698/2005, relativo a la ayuda al desarrollo rural a través del Fondo Europeo Agrícola de Desarrollo Rural (FEADER). El Real Decreto 6/2001, que deroga los anteriormente citados, señala que las ayudas se dirigen 
principalmente a promover la forestación de tierras agrícolas, contribuyendo a diversificar la actividad agraria, así como las fuentes de renta y de empleo, ayudando a la corrección de los problemas de erosión y desertización que sufren determinadas zonas españolas, así como a la conservación y mejora de los suelos, la conservación de la fauna y flora, la regulación del régimen hidrológico de las cuencas y a una gestión del espacio natural compatible con el equilibrio del medio ambiente, favoreciendo el desarrollo de ecosistemas forestales beneficiosos para la agricultura.

Esta línea de subvenciones establece la concesión de una ayuda para la forestación de tierras agrícolas que incluye los costes de plantación, una prima anual por hectárea forestada para cubrir los costes de mantenimiento durante un periodo de hasta cinco años y una prima anual por hectárea para cubrir durante un periodo máximo de veinte años las pérdidas de ingresos que suponga la forestación de tierras cultivadas antes de ella (prima compensatoria).

Se puede considerar la forestación de tierras agrícolas como una medida más de diversificación del paisaje agrario ya que, al fin y al cabo, con esta actuación se crearán bosques-isla en un medio dominado por cultivos.

Para la aplicación de esta medida se implementó en Castilla y León un programa regional con una orientación plenamente forestal y medioambiental, dividiendo la comunidad en 13 comarcas naturales y estas, a su vez, en 35 zonas en función de sus características ecológicas (Figura 3.79). La demanda de las ayudas ha superado las previsiones, cifrándose la superficie afectada en más de 140000 ha (EZQUERRA, 2007), valor que en la actualidad será más elevado. No obstante, cabe señalar que la mayor parte de las solicitudes se concentran en zonas de páramos o de media montaña, por lo que en las comarcas netamente agrarias como Tierra de Campos, la acogida ha sido relativa. 


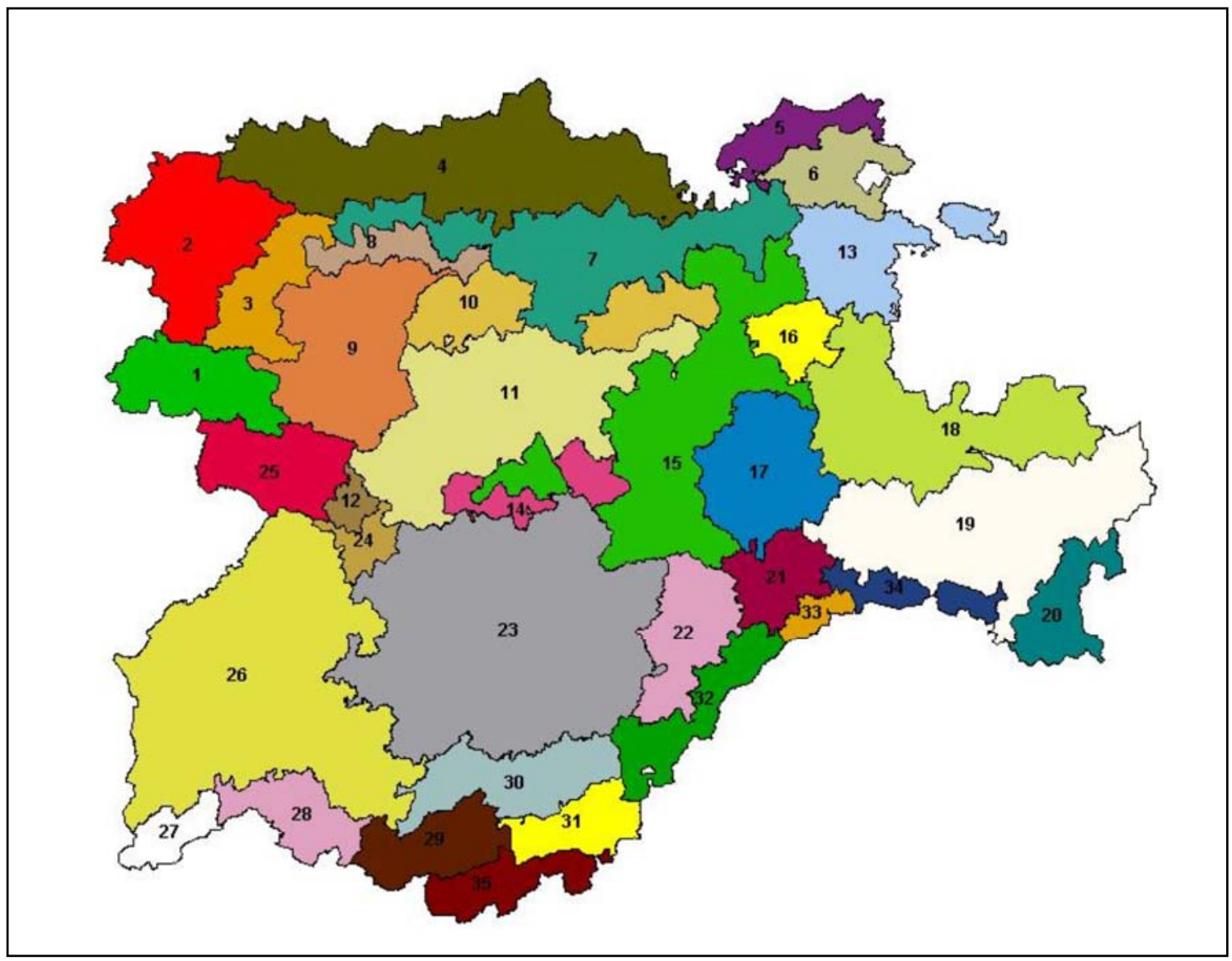

Figura 3.79. Distribución de Castilla y León en Zonas. Las que corresponden a Tierra de Campos son la 11 (básicamente), la 10 y la 12.

Con un fin eminentemente divulgativo, se ha editado un Manual de Forestación (JUNTA DE CASTILLA Y LEÓN, 1995, con modificaciones posteriores), que expone de forma sencilla las principales actuaciones que se deben realizar, incluyéndose la preparación del terreno, la implantación vegetal y las labores de mantenimiento, así como otros aspectos relacionados, como la maquinaria y aperos, las características de la planta forestal o el control de calidad de la obra.

En la Orden MAM/39/2009 (CONSEJERÍA DE MEDIO AMBIENTE, 2009) se establecen las bases reguladoras para la concesión de estas ayudas en Castilla y León, indicándose una serie de objetivos:

- Incrementar la superficie de masas forestales que hasta el momento, por el uso de dichos terrenos agrícolas o por las condiciones de partida del suelo, no se encontraban poblados por especies arbóreas.

- Crear una cubierta vegetal como instrumento de protección frente a las catástrofes naturales.

- Mitigar los efectos negativos del cambio climático dado el carácter de almacén de carbono y sumidero de $\mathrm{CO}_{2}$ de las masas arboladas que se pretenden crear, contribuyendo así al cumplimiento del protocolo de Kyoto. 
- Transformar sistemas naturales con escaso valor natural, consiguiendo aumentar la biodiversidad, especialmente en los terrenos procedentes de cultivos agrícolas, y dar respuesta a la, cada vez más acentuada, necesidad de la población de disponer de espacios medioambientales adecuados para el esparcimiento.

- Retirar tierras de cultivo con problemas de erosión del suelo, o que puedan contribuir al mantenimiento de la calidad del agua, prevención de catástrofes naturales y desertización del territorio.

- Mantener los puestos de empleo creados en las zonas rurales como consecuencia de la actividad económica generada durante el periodo 1993-2006 por la gestión de la ayuda implantada por la medida de forestación de tierras agrarias.

- Incrementar la superficie forestal arbolada en compensación por la pérdida de esta a causa de los incendios forestales.

Uno de los aspectos de esta Orden de mayor significación para la zona de estudio es que se excluyen de la forestación los terrenos incluidos en las zonas de especial protección para las aves (ZEPA) La Nava-Campos Norte, La Nava-Campos Sur y Lagunas de Villafáfila, que ocupan una parte considerable de Tierra de Campos.

En esta Orden también se aprueban los Cuadernos de cada una de las zonas, así como los Requerimientos técnicos para la realización de trabajos de forestación de tierras agrícolas, documento que es una especie de pliego de condiciones muy detallado de todas las actuaciones que pueden llevarse a cabo: forestación, obras complementarias, trabajos de mantenimiento, etc.

La convocatoria de las ayudas se realiza mediante Ordenes anuales (CONSEJERÍA DE FOMENTO Y MEDIO AMBIENTE, 2013), en las que se regulan aspectos tales como los beneficiarios, las actuaciones subvencionables, los terrenos susceptibles de forestación o la forma de presentación de solicitudes.

El Cuaderno de Zona no 11 (Campos Centro) -que se corresponde con la mayor parte de Tierra de Campos- contiene muchos aspectos prácticos para la aplicación de la forestación de tierras agrícolas en esta comarca. En primer lugar, incluye una clave de estaciones (hasta 12) en que se puede clasificar la Zona en función del tipo de suelo y la pendiente. También recoge una relación de especies (Tabla 3.1) que pueden emplearse en las repoblaciones forestales, diferenciando entre las categorías de aconsejables, posibles y accesorias. 
Tabla 3.2. Relación de especies que pueden emplearse en la Zona 11 (CMA, 2009)

\begin{tabular}{|c|c|c|c|c|}
\hline \multicolumn{5}{|c|}{ Coniferas } \\
\hline \multirow{2}{*}{ Nombre cientifico } & \multirow{2}{*}{ Nombre vulgar } & \multicolumn{3}{|c|}{ Tipo } \\
\hline & & a & b & c \\
\hline Juniperus oxycedrus & Enebro de la Miera & & & • \\
\hline Iuniperus thurifera & Sabina albar & & & - \\
\hline Pinus halepensis & Pino carrasco & • & • & \\
\hline Pimus pinaster* & Pino negral & • & • & \\
\hline Pinus pinea & Pino piñonero & $\bullet$ & $\bullet$ & \\
\hline \multirow{2}{*}{\multicolumn{5}{|c|}{ - Pinus pinaster no está recomendado en los términos municipales de Valladolid y Za }} \\
\hline & & & & \\
\hline \multirow{2}{*}{ Nombre científico } & \multirow{2}{*}{ Nombre vulgar } & \multicolumn{3}{|c|}{ Tipo } \\
\hline & & a & b & c \\
\hline Alnus glutinosa & Aliso & & & $\bullet$ \\
\hline Amygdalus communis & Almendro & & & $\bullet$ \\
\hline Crataegus monogyna & Espino majuelo & & & $\bullet$ \\
\hline Fraxinus angustifolia & Fresno del país & $\bullet$ & $\bullet$ & \\
\hline Juglans sp. & Nogal & & $\bullet$ & 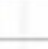 \\
\hline Populus alba & Álamo blanco & $\bullet$ & & 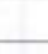 \\
\hline Populus nigra & Chopo del país & $\bullet$ & & 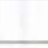 \\
\hline Populus $x$ euramericana & Chopo (producción) & & $\bullet$ & 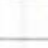 \\
\hline Populus $x$ interamericana & Chopo (producción) & & $\bullet$ & 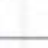 \\
\hline Prunus avium & Cerezo & & $\bullet$ & $\bullet$ \\
\hline Prunus spinosa & Endrino & & & $\bullet$ \\
\hline Quercus faginea & Quejigo & - & $\bullet$ & 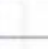 \\
\hline Quercus ilex & Encina & $\bullet$ & $\bullet$ & 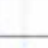 \\
\hline Retama sphaerocarpa & Retama de bolas & & & $\bullet$ \\
\hline Rosa canina & Escaramujo & & & $\bullet$ \\
\hline Rosmarinus officinalis & Romero & & & $\bullet$ \\
\hline Salix alba & Sauce blanco & & & $\bullet$ \\
\hline Sorbus domestica & Serbal & & & $\bullet$ \\
\hline Spartium junceum & Retama negra & & & $\bullet$ \\
\hline a: aconsejables & b: posibles & & & \\
\hline
\end{tabular}

El Cuaderno detalla las procedencias de las especies (Tabla 3.2), así como el tamaño y tipo de la planta a emplear, con objeto de asegurar su arraigo y adaptación al entorno. Asimismo se definen las densidades y marco de plantación para las distintas especies (Tabla 3.3). En este sentido se establece que, para que la prima compensatoria sea concedida, la superficie forestada deberá encontrarse en buen estado vegetativo y con una densidad de planta viva, uniformemente distribuida por la parcela, no inferior al $70 \%$ de la densidad inicial a partir del sexto año desde el que se certificó como realizada definitivamente la repoblación. 
Tabla 3.4. Procedencias de las especies, tamaño y tipo de planta en la Zona 11 (CMA, 2009).

\begin{tabular}{|c|c|c|c|c|c|c|}
\hline ESPECIE & PROCEDENCIA (") & CATEGORIA & uso & TIPO & $\begin{array}{l}\text { TAMAÑO } y \\
\text { VOLUMEN } \\
\text { CONTENEDOR }\end{array}$ & $\begin{array}{c}\text { OTRAS } \\
\text { CARACTERISTICAS }\end{array}$ \\
\hline Almus glutinosa (1) & $\begin{array}{l}\text { RIU n } 16 \text { y } 17 \\
\text { RIU n } n^{0} 17 \text { y } 16\end{array}$ & $\begin{array}{l}\text { Identificado } \\
\text { Identificado }\end{array}$ & $\begin{array}{l}\text { Recomendada } \\
\text { Homologada }\end{array}$ & $\begin{array}{c}162 \mathrm{se} \\
\mathrm{rd}\end{array}$ & $\begin{array}{l}+ \text { de } 300 \mathrm{cc} . \\
\text { + de } 1,25 \mathrm{~m}\end{array}$ & \\
\hline Amygdalus commmanis (3) & $\begin{array}{l}\text { RIU n } n^{\circ} 16 \text { y } 17 \\
\text { RIU n' } 17 \text { y } 16 \\
\end{array}$ & & $\begin{array}{l}\text { Recomendada } \\
\text { Homologada }\end{array}$ & $\begin{array}{c}1 \delta 2 \mathrm{se} \\
\mathrm{rd}\end{array}$ & $\begin{array}{l}+ \text { de } 300 \mathrm{cc} \\
+ \text { de } 1.25 \mathrm{~m}\end{array}$ & \\
\hline Pinus halepensis & $\begin{array}{l}\text { 19.- Repoblaciones de la } \\
\text { Meseta Norte } \\
\text { 9.- Maestrazgo-Los Serranos } \\
\text { 14.- Bética Septentrional }\end{array}$ & $\begin{array}{l}\text { Seleccionado } \\
\text { Seleccionado } \\
\text { Seleccionado }\end{array}$ & $\begin{array}{l}\text { Recomendada } \\
\text { Aceptada } \\
\text { Aceptada }\end{array}$ & $162 \mathrm{se}$ & + de $200 \mathrm{cc}$ & \\
\hline Pinus pinaster & 8.- Meseta Castellana & Seleccionado & Recomendada & $\begin{array}{l}162 \mathrm{se} \\
\mathrm{rd} 2 \mathrm{~s}\end{array}$ & + de $200 \propto c$ & \\
\hline Pimus pined & 1.- Meseta Norte & Seleccionado & Recomendada & $162 \mathrm{se}$ & + de $200 \propto c$ & \\
\hline Populus $x$ euramericana (5) & Catálogo Nacional de Clones & Controlado & Recomendada & rd & $+\operatorname{de} 5 \mathrm{~m}$ & \\
\hline Quercus faginea & $\begin{array}{l}\text { 5.- Páramos Leoneses* } \\
\text { 6.- Salamanca-Zamora } \\
\text { 7.-Páramos Castellanos* }\end{array}$ & $\begin{array}{l}\text { Identificado } \\
\text { Identificado } \\
\text { Identificado }\end{array}$ & $\begin{array}{l}\text { Recomendada } \\
\text { Posible } \\
\text { Recomendada }\end{array}$ & $\begin{array}{l}1 \mathrm{se} \\
2 \mathrm{se}\end{array}$ & $\begin{array}{l}+ \text { de } 235 \mathrm{cc} \\
+ \text { de } 300 \mathrm{cc}\end{array}$ & $\begin{array}{l}\text { - Para la provincia de } \\
\text { Valladolid, } 5 \text { y } 7\end{array}$ \\
\hline Quercus illex & 2. Cuenca Central del Duero & Identificado & Recomendada & $\begin{array}{l}1 \mathrm{se} \\
2 \mathrm{se}\end{array}$ & $\begin{array}{l}+ \text { de } 235 c c \\
+ \text { de } 300 c c\end{array}$ & \\
\hline Retama sphacrocarpa (2) & $\begin{array}{l}\text { RIU } n^{0} 16 \text { y } 17 \\
\text { RIU n } n^{\circ} 17 \text { y } 16\end{array}$ & & $\begin{array}{l}\text { Recomendada } \\
\text { Aceptada }\end{array}$ & $162 \mathrm{se}$ & + de $200 c c$ & \\
\hline Juniperus axycedrus (4) & $\begin{array}{l}\text { RIU n } 16 \text { y } 17 \\
\text { RIU n } 17 \text { y } 16\end{array}$ & $\begin{array}{l}\text { Identificado } \\
\text { Identificado }\end{array}$ & $\begin{array}{l}\text { Recomendada } \\
\text { Aceptada }\end{array}$ & $263 \mathrm{se}$ & + de $300 c c$ & \\
\hline
\end{tabular}

rd raiz desnuda

1 se Una savia en envase forestal

2 se Dos savias en envase forestal

Tabla 3.5. Densidades y marco de plantación en la Zona 11 "Campos Centro" (CMA, 2009).

\begin{tabular}{|c|c|c|c|c|}
\hline Especie & Pendiente & Densidad & Marco & Observaciones \\
\hline \multirow[t]{3}{*}{ Pinus pinea* } & $>10 \%$ & 1100 & $3 \times 3 \mathrm{~m}$ & $\begin{array}{l}\text { También en suelos de mala } \\
\text { calidad }\end{array}$ \\
\hline & \multirow[t]{2}{*}{$<10 \%$} & 1100 & $4 \times 2,25 \mathrm{~m}$ & \\
\hline & & 800 & $\begin{array}{l}4 \times 3 \mathrm{~m} \text { ó } \\
3,5 \times 3,5 \mathrm{~m}\end{array}$ & \\
\hline \multirow[t]{2}{*}{ Pinus halepensis } & Indiferente & 1600 & $2,5 \times 2,5 \mathrm{~m}$ & \\
\hline & Indiferente & 1100 & $3 \times 3 \mathrm{~m}$ & \\
\hline Pinus pinaster & Indiferente & 1600 & $2,5 \times 2,5 \mathrm{~m}$ & \\
\hline \multirow[t]{3}{*}{ Quercus ilex/Quercus faginea } & $<30 \%$ & $1100-1600$ & $\begin{array}{l}2,5 \times 2,5 \mathrm{~m} \text { ó } \\
3 \times 3 \mathrm{~m}\end{array}$ & \\
\hline & $>30 \%$ & 1100 & $2,5 \times 2,5 \mathrm{~m}$ & \\
\hline & Indiferente & 800 & $4 \times 3 \mathrm{~m}$ & Válido para /uniperus sp. \\
\hline $\begin{array}{l}\text { Frondosas planta grande o } \\
\text { pequeña }\end{array}$ & Indiferente & $600-800$ & $\begin{array}{l}4 \times 4 \mathrm{~m} \text { ó } 4 \times 3 \\
\mathrm{~m}\end{array}$ & \\
\hline $\begin{array}{l}\text { Frondosas planta grande o } \\
P . x \text { interamericana }\end{array}$ & & 400 & $5 \times 5 \mathrm{~m}$ & \\
\hline Chopos de producción & & $333 / 278$ & $\begin{array}{l}5 \times 6 \mathrm{~m} \text { ó } 6 \times 6 \\
\mathrm{~m}\end{array}$ & \\
\hline Nogal para fruto & & 300 & $6 \times 5,5 \mathrm{~m}$ & \\
\hline
\end{tabular}

*Cuando haya presencia de roedores y sea necesario proteger las plantas, la densidad de

Pinus pinea podrá reducirse a 800 pies/ha

**Ahoyado con retroaraña: 800 pies/ha $(3,5 \times 3,5 \mathrm{~m})$ ó 1100 pies/ha $(3 \times 3 \mathrm{~m})$

**Ahoyado manual: máximo 800 pies/ha $(3,5 \times 3,5 \mathrm{~m})$

Finalmente, el aspecto más práctico del Cuaderno de Zona es la descripción de las estaciones que se han definido previamente, donde se concretan las especies y la preparación del terreno. La inmensa mayoría del territorio de Tierra de Campos se corresponde con la estación 3, de suelo arcilloso y pendiente inferior al $10 \%$. 
Tabla 3.6. Características de la estación 3, que es la más representativa de Tierra de Campos (CMA, 2009).

\begin{tabular}{|c|l|l|}
\hline \multicolumn{2}{|c|}{ Estación 3 } \\
\hline $\begin{array}{c}\text { Especies aconsejables } \\
(0-100 \%)\end{array}$ & Pinus pinea & Pino piñonero \\
\hline $\begin{array}{c}\text { Especies posibles } \\
(0-30 \%)\end{array}$ & $\begin{array}{l}\text { Quercus faginea } \\
\text { Quercus ilex } \\
\text { Pinus halepensis }\end{array}$ & $\begin{array}{l}\text { Quejigo } \\
\text { Encina } \\
\text { Pino carrasco }\end{array}$ \\
\hline $\begin{array}{c}\text { Especies accesorias } \\
(0-20 \%)\end{array}$ & $\begin{array}{l}\text { Retama sphaerocarpa } \\
\text { Rosmarinus officinalis } \\
\text { Amygdalus communis } \\
\text { Spartium junceum } \\
\text { Sorbus domestica }\end{array}$ & $\begin{array}{l}\text { Retama de bolas } \\
\text { Romero } \\
\text { Almendro }\end{array}$ \\
\hline Preparación del terreno & $\begin{array}{l}\text { Arado con desfonde lineal con o sin gradeo posterior } \\
\text { Subsolado doble/pleno/cruzado (pte. }<10 \%) \text { con o sin gradeo previo }\end{array}$ \\
\hline Observaciones & $\begin{array}{l}\text { El arado con desfonde lineal se recomienda en terrenos con suficiente } \\
\text { profundidad de suelo o con horizonte de compactación en profundidad. }\end{array}$ \\
\hline
\end{tabular}

En consecuencia, podemos afirmar que una forestación de tierras agrícolas típica en Tierra de Campos tendría las siguientes características:

- Plantación de pino piñonero como especie principal, intercalándose otras como encina, almendro o retama negra.

- Empleo de plantas de procedencias regionales, de una savia, con cepellón.

- Preparación del terreno principalmente con subsolado doble.

- Densidad de 1100 plantas/ha, a un marco de $4 \times 2,25 \mathrm{~m}$ ó $3 \times 3 \mathrm{~m}$.

\subsection{Valorización del paisaje de Tierra de Campos}

En el diccionario de la Real Academia Española se entiende por valorar "reconocer, estimar o apreciar el valor o mérito de una persona o una cosa". La valoración del paisaje sería, por consiguiente, la acción de reconocer, estimar o apreciar el valor de un determinado paisaje. Esta es la línea seguida en la publicación citada de LÓPEZ LILLO Y RAMOS (1969), que fue pionera en España.

Por otro lado, en este mismo diccionario se entiende por valorizar "aumentar el valor de una cosa". Es decir, la valorización del paisaje sería el aumento del valor de ese paisaje o, lo que es lo mismo, la acción de aumentar el reconocimiento, estima o aprecio del valor de un determinado paisaje. El Observatorio del Paisaje de Cataluña utiliza este concepto de valorización del paisaje, definiéndolo en términos comprensivos como la puesta en valor de un paisaje. Hay que reconocer que la denominación "puesta en valor" es más utilizada actualmente 
tanto para éste como para muchas otras materias (patrimonio, naturaleza, recursos humanos, etc.), aunque se debe recordar que se trata de un galicismo.

Finalmente, el diccionario de la RAE define revalorizar como "devolver a una cosa el valor o estimación que había perdido", término que también podría ser de aplicación al paisaje en general, pero que no lo es para Tierra de Campos.

En cualquier caso, en este apartado utilizaremos el concepto de valorización del paisaje de Tierra de Campos, entendiendo que se asume que este paisaje posee un cierto valor, pero a su vez que este valor puede ser aumentado considerablemente.

A continuación se describirán una serie de espacios e infraestructuras a través de las cuales el paisaje de la comarca puede ser valorizado. Casi todas ellas existen, pero desde luego son susceptibles de aumento notable y extensión a muchas otras localizaciones.

\subsubsection{Cascos históricos}

Como se podrá comprobar en el apartado correspondiente, Tierra de Campos posee un magnífico patrimonio histórico-artístico y muy interesantes muestras de arquitectura tradicional, merced a su rica historia. Uno de los rasgos más característicos de la comarca -que verdaderamente llama la atención de los turistas que nunca la han visitado- es la monumentalidad de sus iglesias (Figura 3.80), presentes en todos los pueblos. Junto a ellas se encuentran presentes castillos, monasterios, conventos, casas señoriales, rollos jurisdiccionales y muchos otros bienes de interés cultural. Su trazado medieval y características tipológicas del caserío hacen que muchos de los pueblos posean un encanto especial, que en algún caso les han hecho merecedores de catalogarse como conjuntos histórico-artísticos (Ampudia, Medina de Rioseco).

En cualquier caso, se debe tener en cuenta que la política en materia de patrimonio siempre va ligada a la conservación de los entornos de los bienes, lo que entronca directamente con el concepto de paisaje, en este caso cultural. Es aquí donde se afianza la idea de que las iglesias no son nada sin sus plazas o sus calles adyacentes; que monumentos, casas tradicionales, pavimentos o incluso mobiliario urbano forman un conjunto que da valor a un paisaje singular.

La arquitectura popular en tierra posee un gran valor en Tierra de Campos, dada su singularidad y su carácter sostenible. No obstante, presenta serios riesgos de conservación, como consecuencia de la falta de valoración por los propietarios y la necesidad de mantenimientos periódicos. En la actualidad están surgiendo grupos de investigación y experimentación (grupo Tierra, en la Universidad de Valladolid o la Red construTIERRA, promovida en la Escuela de Ingenieros Agrónomos de Madrid) que pretenden valorizar esta peculiar arquitectura, conscientes incluso del gran potencial de desarrollo turístico que posee (CID y CAÑAS, 2009). 


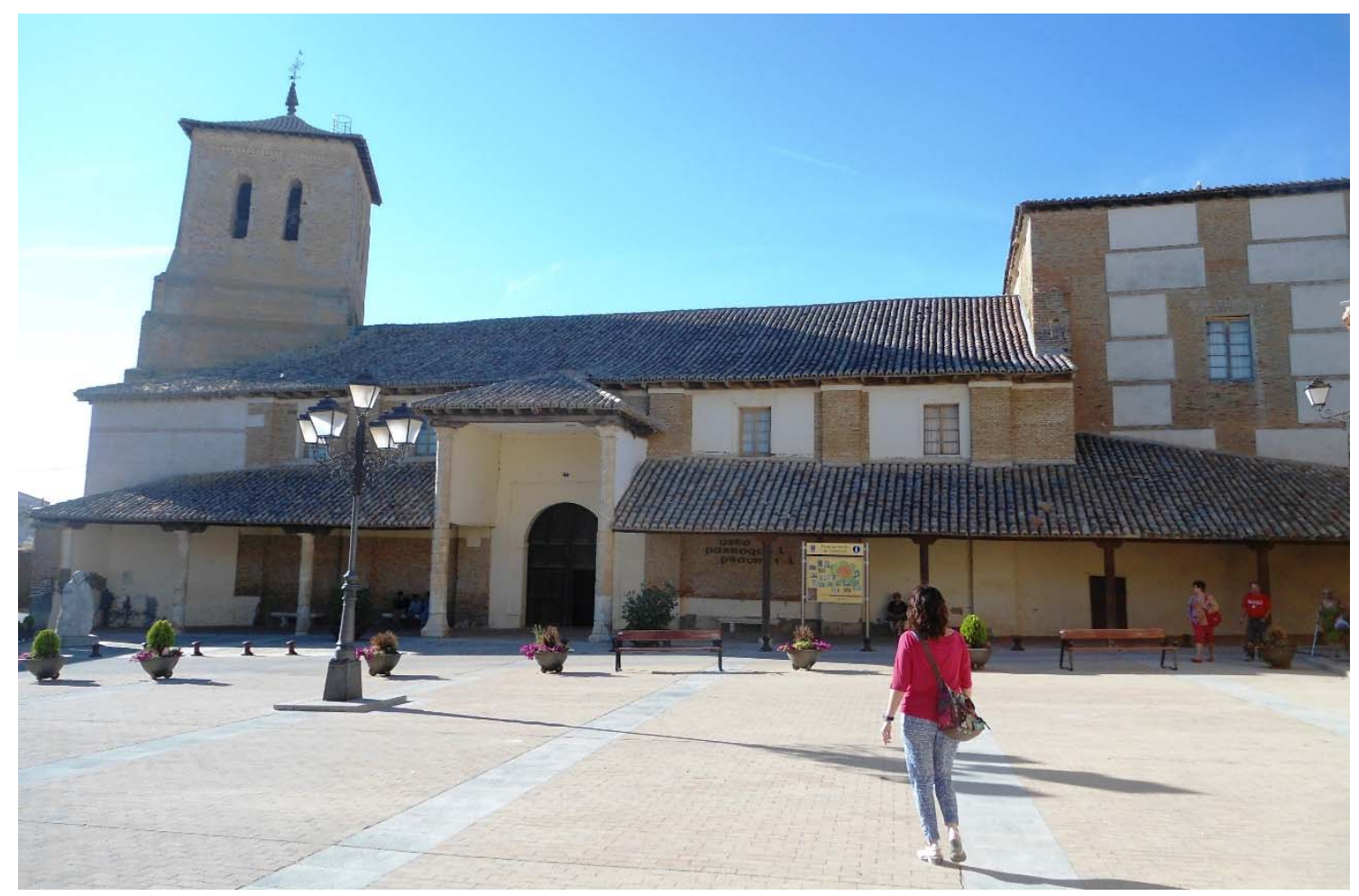

Figura 3.80. Iglesia de San Pedro, cuyo interior alberga un museo parroquial de arte sacro.

Lo cierto es que todo este paisaje urbano se encuentra absolutamente infravalorado, dado que Tierra de Campos es una comarca desconocida para gran parte de los españoles. Sin embargo, aquellos que la visitan movidos por una inquietud cultural no salen de su asombro cuando contemplan algunas de sus joyas patrimoniales.

Para valorizar el patrimonio cultural edificado de los pueblos existen un buen número de fórmulas que, de aplicarse de un modo coherente y global para toda la comarca, podrían resultar sin duda eficaces:

- Promoción de la comarca como destino cultural y natural, superando los ámbitos provinciales.

- Señalización en las principales carreteras.

- Existencia de oficinas de información y turismo en todos los municipios de interés, que estén abiertas al público al menos los fines de semana y los periodos vacacionales. En ellas se deben ofrecer folletos con los valores de cada pueblo, pero también de otras posibilidades turísticas de la comarca.

- Señalización y cartelería de los valores patrimoniales y de las rutas a visitar en el interior de los núcleos urbanos.

- Uso museístico de las iglesias de forma compatible con el uso que posean al culto.

- Apertura de los principales monumentos, como mínimo en los periodos festivos y vacacionales. 


\subsubsection{Parques y jardines urbanos}

Una de las características de los pueblos de Tierra de Campos es la extensión de su caserío; son todas ellas localidades compactas, pero de una superficie elevada, debido a que las edificaciones son relativamente bajas, a su elevada población en épocas pasadas y a la necesidad de disponer de amplias calles y plazas para el trasiego de carros, caballerías y mercancías. La situación actual y los requerimientos de los pueblos son diametralmente diferentes, pero una de las consecuencias positivas es que estos disponen de amplios espacios públicos en los cascos urbanos donde se pueden acometer interesantes actuaciones de arquitectura del paisaje: creación de parques y jardines, acondicionamiento de paseos urbanos arbolados, recuperación de parterres, etc. (Figura 3.81). En estas zonas verdes -evidentemente además de la vegetaciónse puede incluir mobiliario urbano (bancos, mesas, papeleras), fuentes, esculturas..., aunque se deben tener en cuenta dos premisas fundamentales: su adaptación al entorno y la facilidad de mantenimiento.
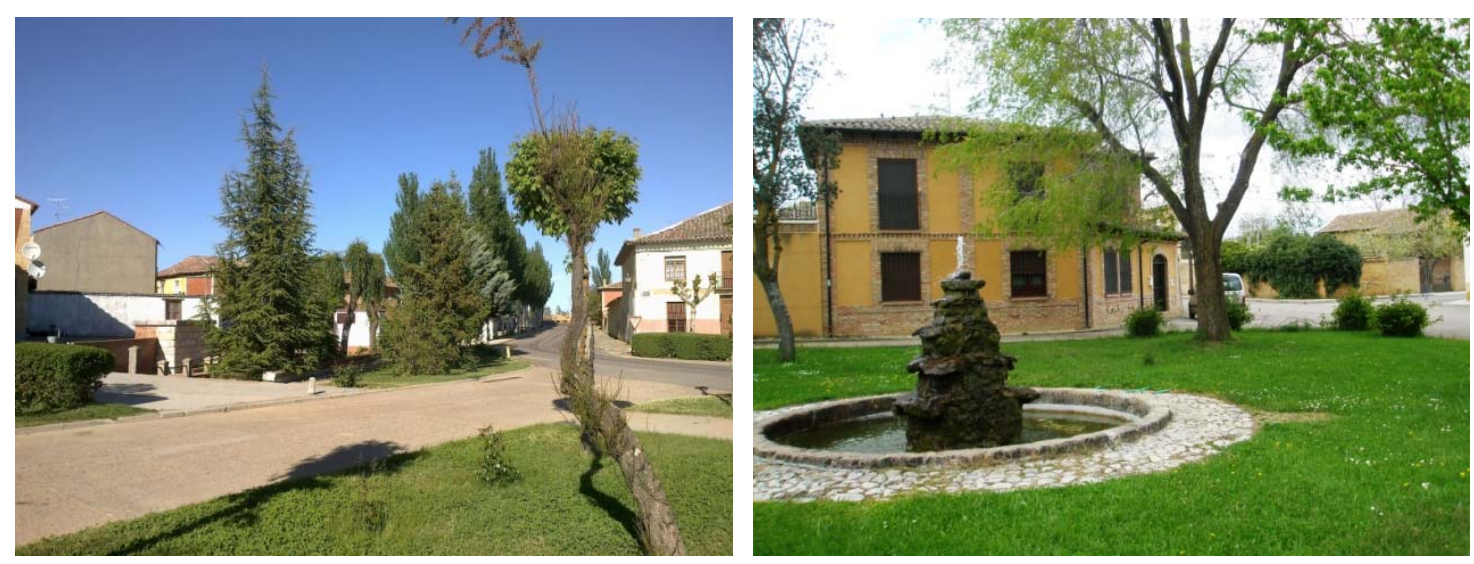

Figura 3.81: Dos pueblos pequeños ejemplares en cuidado de las zonas verdes urbanas: Cuenca de Campos (izquierda) y Abarca de Campos (derecha).

Se debe enfatizar que la imagen de los pueblos cambia sustancialmente cuando se realizan actuaciones de esta naturaleza. En el lenguaje popular se suele afirmar que "es un pueblo cuidado". Lo que es evidente es que, ante el fenómeno dramático de la despoblación de Tierra de Campos, los pueblos cuidados siempre pueden tener la esperanza de que nuevas familias se asienten allí o que simplemente los vecinos que se fueron conserven sus viviendas para regresar en vacaciones o los fines de semana.

\subsubsection{Parques periurbanos y anillos verdes}

En prácticamente todos los pueblos existen espacios públicos degradados o susceptibles de acondicionamiento como zonas verdes. Generalmente se sitúan en las zonas periurbanas, donde finalizaba el casco histórico tradicional -muchas veces amurallado- y se han ido realizando transformaciones sobre todo en las últimas décadas: desecaciones de lagunas mediante su relleno con tierras, creación de caminos de circunvalación, pequeños terrenos sin un uso 
definido, zonas de depósito de escombros, etc. Estos espacios suelen ser en su conjunto de una calidad paisajística baja, con mezcla desordenada de usos, presencia de naves, depósitos de residuos... En algunos de los pueblos de Tierra de Campos se han ido realizando actuaciones de adecentamiento de los espacios (Figura 3.82), aunque actualmente dominan claramente los espacios aún degradados. Lo que sí que es cierto es que la recuperación de estas zonas permitiría mejorar la calidad del conjunto y crear nuevos espacios verdes susceptibles de un uso recreativo.

De forma paralela existe la posibilidad de conformar una red de zonas verdes perimetrales a los cascos urbanos que además pudiese tener continuidad en forma de anillo verde. Esta idea se ha desarrollado en ciudades como Vitoria de forma muy exitosa, recibiendo un galardón europeo como ciudad verde. Pero desde luego sería susceptible de extrapolación al medio rural y, en particular, a buena parte de los pueblos de Tierra de Campos. En la actualidad son numerosas las personas que diariamente realizan paseos por motivos saludables a lo largo de distintos itinerarios de su localidad, en general atravesando espacios periurbanos y sin alejarse excesivamente de las viviendas. El diseño de un anillo o ruta verde en el entorno de los pueblos conllevaría dos beneficios fundamentales: la recuperación de las zonas degradadas por las que atraviesa y la creación de un paseo diseñado con un criterio paisajístico. No se debe olvidar que, tal como se ha comentado anteriormente, para la población rural es importante el orden y la coherencia en la adecuación de los espacios verdes públicos.

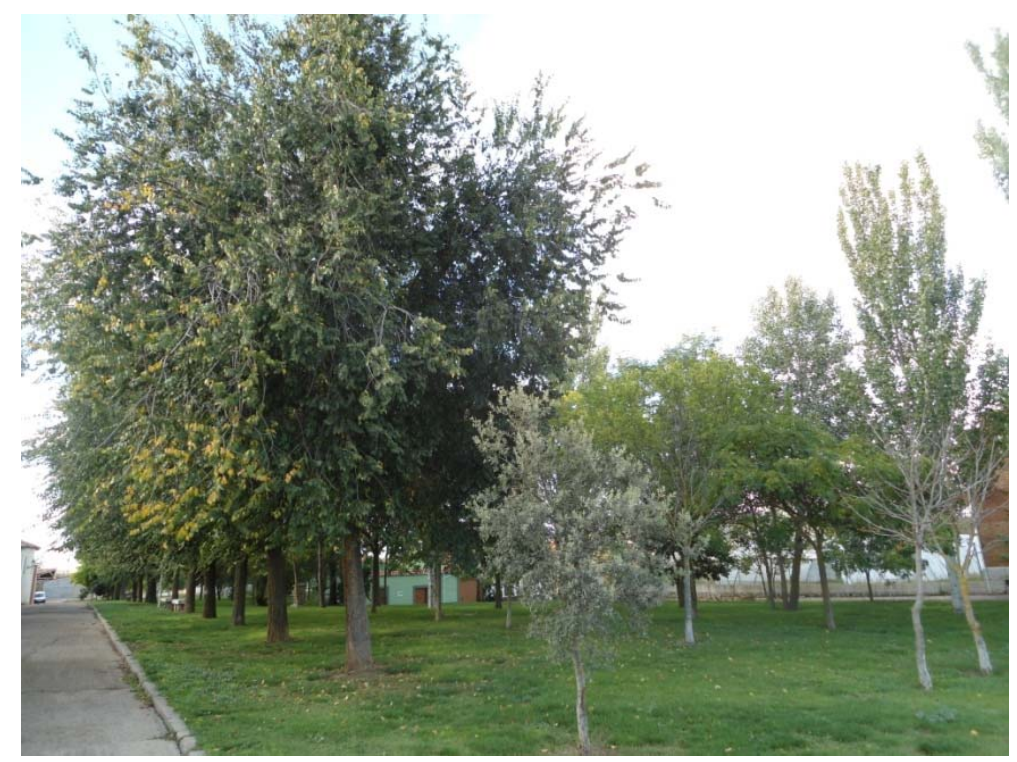

Figura 3.82. Parque de la laguna del Tinte en Villalón de Campos, ejemplo de espacio periurbano anteriormente degradado (fue una laguna rellena de escombros).

\subsection{4. Áreas recreativas. Las ermitas.}

El concepto de área recreativa surge en la segunda década del siglo pasado, cuando se percibe la necesidad que tiene la población por el esparcimiento y el descanso en contacto con la naturaleza. Tal vez son los montes de utilidad pública los lugares que acogen las primeras zonas de este tipo en España, a las que se dota de pequeños refugios, fuentes, barbacoas, bancos, 
mesas, etc. Poco a poco estos espacios verdes se van extendiendo a toda la geografía, llegando a muchos pueblos de Tierra de Campos. Es curioso, porque en esta comarca gran parte de las áreas recreativas coinciden con las ermitas (Figura 3.83); seguramente no sea casual, ya que son los lugares de mayor querencia para los vecinos. Estas suelen estar situadas a escasos kilómetros del casco urbano, en algunos casos su acceso es por un camino o carretera arbolada, pueden disponer también de pradera con arbolado e incluso de instalaciones de uso público. Pero todavía hay muchos pueblos en que estos espacios se encuentran totalmente desaprovechados, a falta de arreglos de los edificios, plantaciones de arbolado en el entorno, mejora de paseos, dotación de infraestructuras o señalización adecuada. Su adecuación constituiría un doble beneficio: por una parte la mejora del paisaje agrario -ya que la mayoría se encuentran lejos del casco urbano- y por otra la disposición de un área de disfrute para los vecinos en un lugar querido y en contacto con la naturaleza.
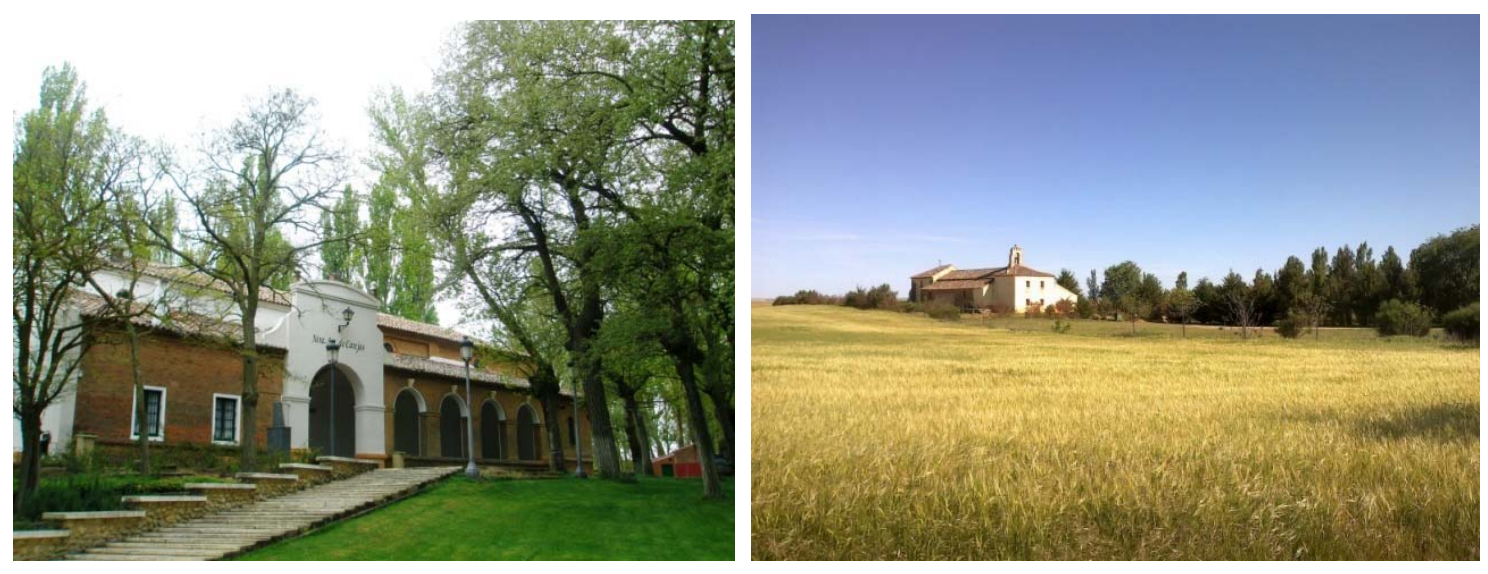

Figura 3.83. Ermita de Carejas, en Paredes de Nava (izquierda) y ermita de San Bernardino, en Cuenca de Campos (derecha), dos de los mejores ejemplos de adecuación recreativa en Tierra de Campos.

\subsubsection{Senderos y caminos}

En los paisajes agrícolas si algo hay son caminos. La superficie está totalmente humanizada desde antiguo y existen accesos a todos los lugares. Por su parte, uno de los objetivos básicos de las concentraciones parcelarias ha sido la creación de una red de caminos rurales para que todas las parcelas tuviesen su correspondiente acceso. Además por bastantes términos municipales de Tierra de Campos discurren vías pecuarias, antiguas vías del ferrocarril, caminos paralelos a canales de riego u otros que son susceptibles de tener un uso para el senderismo, la bicicleta o los paseos a caballo.

Ahora bien, para que esto ocurra se tienen que dar varias circunstancias: que el itinerario discurra por un paisaje de cierta calidad, que el firme sea adecuado y que la ruta esté adecuadamente señalizada conforme a unos criterios homologados. A continuación describimos sucintamente los tipos de senderos y caminos más representativos que tienen alguna aplicación en Tierra de Campos: 


\section{Senderos de gran y pequeño recorrido}

La Federación española de senderismo homologa tres tipos de senderos: los GR (gran recorrido), diseñados para rutas de más de un día de duración e indicados con marcas en forma de rayas rojas y blancas, los PR (pequeño recorrido), diseñados para itinerarios de varias horas de duración e indicados con marcas amarillas y blancas y los SL (locales), planteados para senderos locales con marcas verdes y blancas. Estos últimos no están reconocidos por la Federación de Castilla y León, en aras a la simplificación de tipologías. La señalización de los senderos se completa con otro tipo de indicaciones, como las direccionales (que indican dirección, distancia y tiempo a los siguientes hitos del trazado), las de inicio (que están dispuestas en los principales puntos de acceso al recorrido y describen de una forma concisa el camino) y los carteles interpretativos, que proporcionan interesante información sobre aspectos naturales, culturales e históricos del ámbito de influencia del sendero (FRECHILLA, 2007). En la comarca están homologados los senderos GR 26 "Tierra de Campos" y GR 89 "Canal de Castilla", magníficamente descritos por este autor y que permiten realizar una gran ruta circular pasando por Valladolid, los montes Torozos, Tierra de Campos, el Canal de Castilla y Palencia.

\section{$\underline{\text { Caminos Naturales }}$}

Estos senderos son construidos por el Ministerio de Agricultura, Alimentación y Medio Ambiente, en colaboración con otras administraciones territoriales que se encargan a posteriori de su mantenimiento. Se acondicionan sobre antiguas infraestructuras de transporte y dedicados a usos senderistas, ciclistas y ecuestres, permiten el acercamiento de la población al medio natural, promoviendo el conocimiento de la naturaleza y los paisajes, así como el desarrollo rural. Antiguas vías del ferrocarril, canales, caminos de sirga, vías pecuarias, sendas e incluso antiguos caminos públicos vuelven a ser utilizados por una población que demanda cada día más el contacto con la naturaleza y disponer de espacios tranquilos en los que poder ejercer actividades recreativas y deportivas alejadas del tráfico motorizado. Los Caminos Naturales poseen también una tipología de señalización homologada.

Desde 1993 se han acondicionado $8700 \mathrm{~km}$ a lo largo de toda España. En Tierra de Campos existe al menos el Camino Natural a lo largo de la antigua vía del "Tren Burra", entre Villalón de Campos y Cuenca de Campos (Figura 3.84), con una longitud aproximada de $5 \mathrm{~km}$. Recientemente se ha redactado un proyecto de ampliación de esta ruta hasta Boadilla de Rioseco. También se encuentra pendiente de ejecución otro tramo de esta antigua vía del ferrocarril: la que discurre entre Palencia y Castromocho, hasta el Canal de Castilla. 


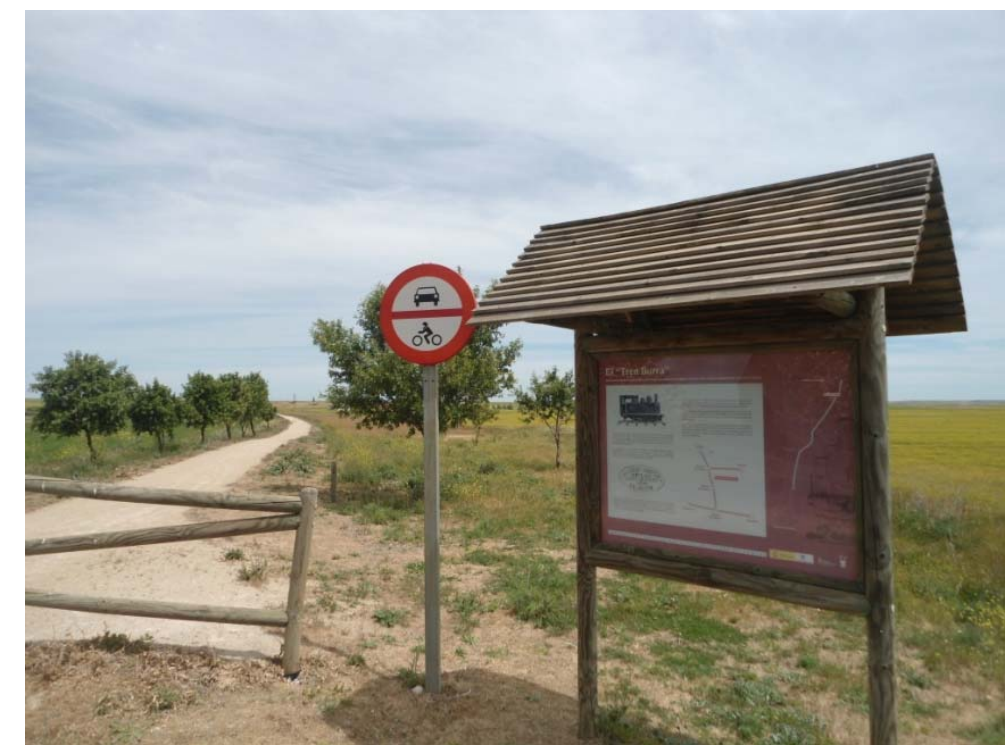

Figura 3.84. Cartel interpretativo en la Vía Verde de Tierra de Campos, tramo Villalón de Campos-Cuenca de Campos, sobre el antiguo "tren burra".

\section{Senderos de Espacios Naturales}

La planificación del uso público de los espacios naturales protegidos incluye la realización de pequeñas rutas en lugares emblemáticos de los mismos donde, al igual que los casos anteriores, se acondiciona una senda y se la dota de una señalización e interpretación adecuada. En Tierra de Campos hay un espacio natural declarado protegido, la Reserva Natural de las lagunas de Villafáfila, que cuenta con varios tramos señalizados para realizar a pié o en bicicleta alrededor de varias lagunas; especialmente agradable resulta la ruta situada en la Casa de la Reserva que recorre el parque de fauna recreado con ecosistemas acuáticos y una red de observatorios de avifauna. También hay pequeños tramos acondicionados en las lagunas de Tamariz de Campos, Boada de Campos o La Nava, aunque en cualquier caso, todavía puede haber mucho camino por recorrer en la gestión del uso público de estos espacios.

\section{Caminos de Santiago.}

Desde luego el sendero más universal, que además discurre durante una parte de su recorrido por Tierra de Campos, es el Camino de Santiago. Es la gran ruta religiosa, cultural, natural y, por qué no, lúdica y deportiva. Aunque se trata de un camino histórico, en los últimos años se ha convertido en un auténtico fenómeno de masas; cada año es recorrido por miles de peregrinos, buena parte de ellos extranjeros. A través del Camino se pueden descubrir múltiples paisajes, tal como describen ESCRIBANO y LÓPEZ (2011) para La Rioja. El Camino francés, que es el más representativo, atraviesa todo el norte de la comarca, desde Itero de la Vega hasta Sahagún, pasando por poblaciones como Frómista, Población de Campos, Carrión de los Condes o Terradillos de los Templarios. El trazado rural discurre por caminos rurales, normalmente afirmados con zahorra, que en alguno de sus márgenes tiene arbolado. La señalización es bien sencilla: las conocidas flechas amarillas, aunque es difícil perderse por el gran número de senderistas que lo transitan. Durante su recorrido se atraviesan muchos pueblos que suelen 
contar con albergues, áreas recreativas de descanso y que muestran a los visitantes su rico patrimonio histórico-artístico. Es, por tanto, un magnífico ejemplo de valorización del paisaje.

En los últimos años se ha promocionado considerablemente el denominado Camino de Madrid. Se trata de un apéndice del camino francés, recuperado en 1999, que siguiendo antiguas rutas históricas parte desde la capital de España, atraviesa la sierra de Guadarrama, pasa por Segovia y Valladolid, se introduce en los páramos y montes Torozos y finalmente desciende a Tierra de Campos hasta llegar a Sahagún. Aunque, evidentemente, el flujo de peregrinos no tiene nada que ver con su hermano mayor, sí que es cierto que en los últimos años se observa un lento pero continuo ascenso. Hay asociaciones encargadas de señalizar este camino y de gestionar los albergues que se han ido construyendo. Puede ser otra buena oportunidad para valorizar el paisaje de Tierra de Campos.

\section{Vías pecuarias}

Las vías pecuarias son caminos históricos utilizados tradicionalmente para el traslado de la ganadería de ovino e incluso la trashumancia. Son bienes de dominio público, protegidos por ley. Se clasifican en cañadas ( $75 \mathrm{~m}$ de anchura), cordeles $(37,5 \mathrm{~m}$ ) y veredas (18 m). Se trata de una auténtica red de propiedad pública que teje el territorio, en especial el de Castilla y León. Prácticamente todos los términos municipales tienen alguna vía pecuaria, aunque buena parte de las pequeñas han sido rectificadas y reducida su entidad con las concentraciones parcelarias. No obstante, todavía pueden tener una función de rutas para el senderismo, el cicloturismo o el tránsito ecuestre a nivel local.

En Tierra de Campos tienen una especial relevancia dos cañadas reales: la Leonesa Occidental y la Leonesa Oriental; la primera atraviesa Medina de Rioseco y se dirige hacia León y la segunda traza una ruta curva entre Palencia y Carrión de los Condes. Ambas constituyen una magnífica oportunidad para valorizar el paisaje de las zonas que atraviesa.

\section{$\underline{\text { Otras rutas }}$}

Aunque sería conveniente que todos los senderos y caminos estén de un modo u otro homologados, con objeto de que se pueda tener un mayor conocimiento de ellos y su gestión sea homogénea, lo cierto es que existen muchos otros recorridos que se están revalorizando en los últimos tiempos o que tienen un gran potencial. Así, por ejemplo en la publicación "Rutas de senderismo de Castilla y León" (ESCAPA, 2009) se incluyen varias situados en Tierra de Campos: el mirador de Tierra de Campos en Autilla del Pino, la paleta del cubista en Pozo de Urama, la senda de los peregrinos en Villalcázar de Sirga o el convento de las Fuentes en Aguilar de Campos.

\subsubsection{Miradores}

Un mirador es un punto alto desde donde se divisa una superficie muy extensa de terreno. Es tal vez uno de los elementos que mejor permiten valorar el paisaje en su integridad, pero también son enclaves para la contemplación serena y reparadora. La Guía de Miradores de Castilla y León (ALONSO, 2006) diferencia entre mirador y panorámica. El mirador es el lugar que 
está más o menos acondicionado para la observación, con pretiles protectores, paneles interpretativos, asientos, zonas de sombra, papeleras, que es la infraestructura más elemental y necesaria. La panorámica se ha de entender como aquella que se observa desde una posición que carece de los elementos y mobiliario que tiene un mirador.

Tierra de Campos es una comarca afortunada en este sentido, ya que su configuración geomorfológica -campiñas de llanuras rodeadas en buena parte por páramos- permite la contemplación de miles de hectáreas sin mucha dificultad (Figura 3.85). Apenas hay $100 \mathrm{~m}$ de diferencia de altitud entre ambas unidades, pero la cuenca visual que se alcanza desde el borde de los páramos es inmensa. La guía citada incluye dos paradigmáticos: el mirador de Tierra de Campos en Autilla del Pino (que también aparece en el primer listado de paisajes sobresalientes de España del ICONA, en 1975) y el mirador del Roto en Urueña. En estas posiciones de borde de páramo hay otros, como las ruinas del castillo de Torremormojón o el castillo de Montealegre. Pero también sobre cerros testigos, como el emblemático del Cristo del Otero en Palencia o el antiguo castillo de Torrelobatón. Las torres de las iglesias pueden convertirse en magníficas atalayas, como la denominada "giralda de Castilla" en Ampudia o la torre de Villalba de la Loma, e incluso otras infraestructuras más singulares, como un depósito de abastecimiento de agua en Cuenca de Campos o una torre metálica en la antigua estación de ferrocarril en Mazariegos.
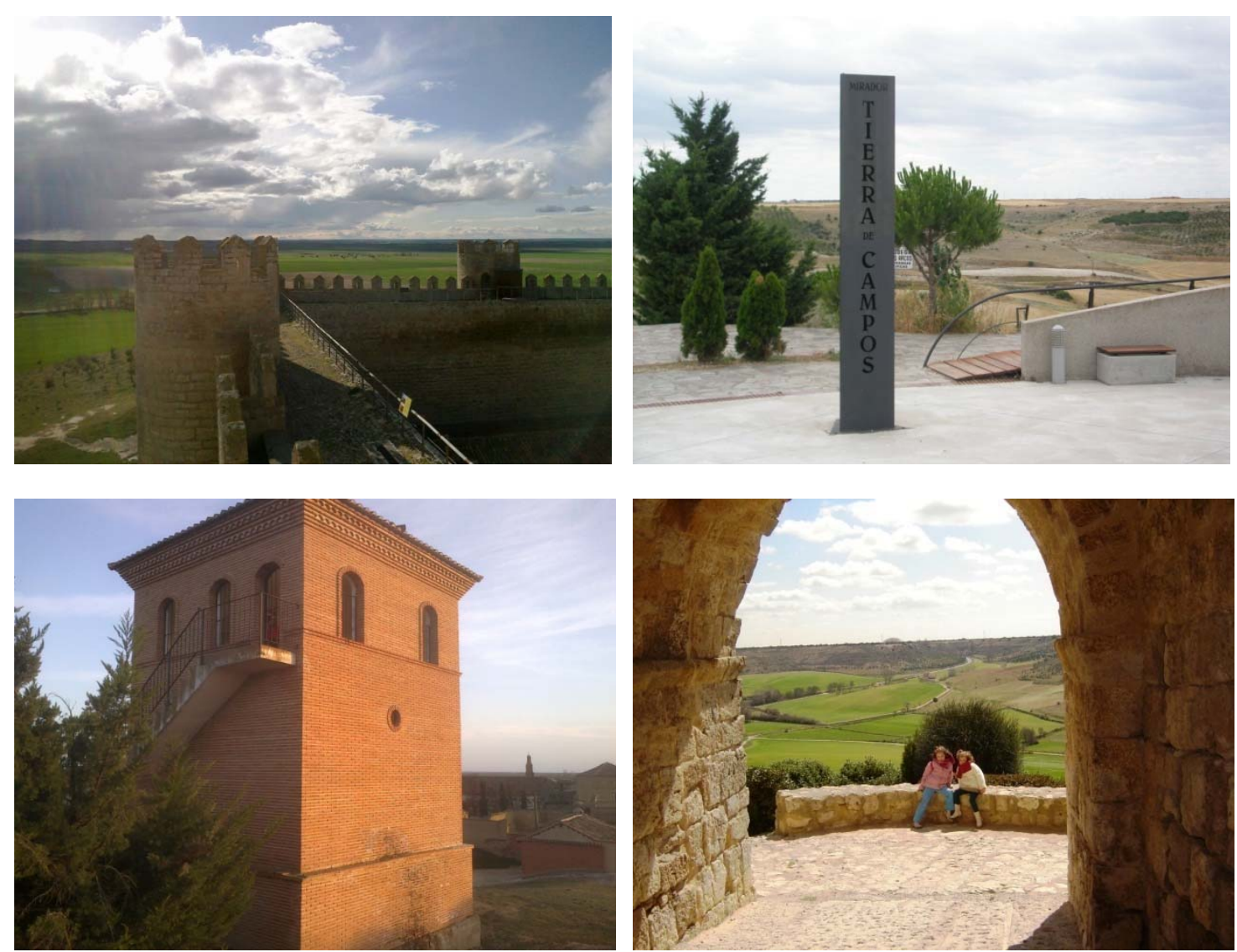

Figura 3.85. Cuatro miradores de tipologías diferentes: arriba izquierda, castillo de Montealegre; arriba derecha, páramo de Autilla del Pino; abajo izquierda, depósito en Cuenca de Campos; abajo derecha, mirador en la muralla de Urueña. 


\subsubsection{Centros de interpretación de la naturaleza}

Los centros de interpretación de la naturaleza son infraestructuras de uso público, generalmente de un espacio natural protegido, constituidas por un edificio más o menos emblemático en cuyo interior se instala un equipamiento didáctico que permite a los visitantes informarse e interpretar el paisaje de la zona. Por ello también son denominados centros de visitantes; en Castilla y León se trata de homologarlos con la denominación casas del parque.

El primer centro construido en Tierra de Campos es el de las lagunas de Villafáfila (Figura 3.86); se trata de un complejo muy original formado por un gran palomar (que es realmente el centro), un pequeño complejo lagunar, una serie de observatorios de avifauna también con forma de palomar y un sendero que los recorre. En la laguna de la Nava existe un centro de visitantes en una antigua casona en Fuentes de Nava y otro de similares características en Boada de Campos.

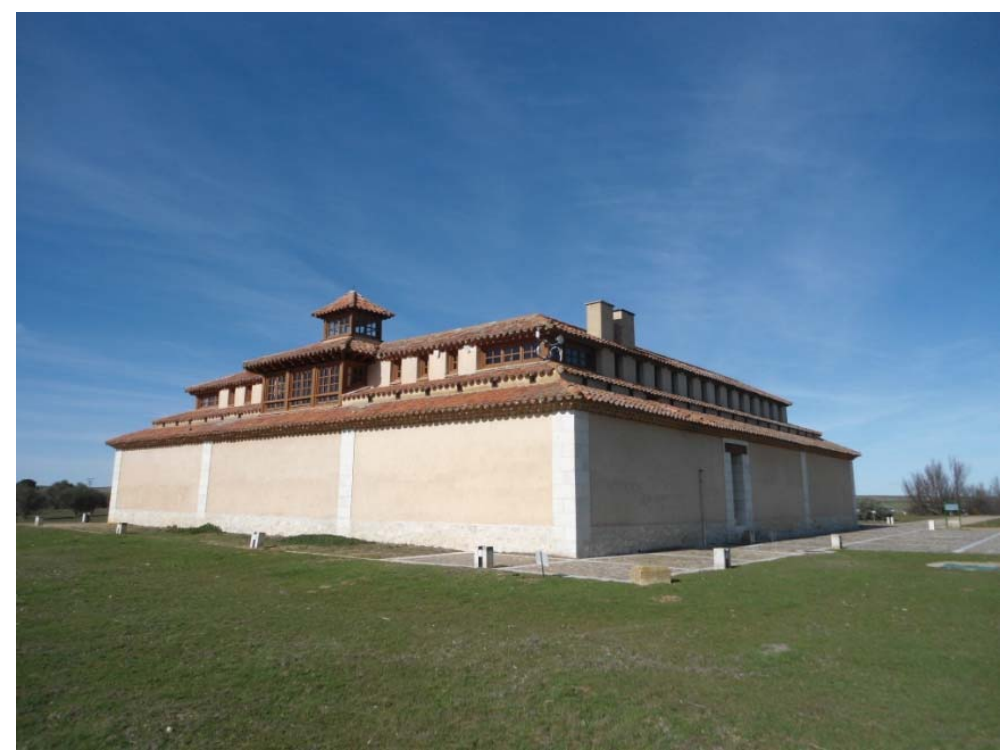

Figura 3.86. Casa de la Reserva de las lagunas de Villafáfila

Además de en espacios naturales protegidos, pueden existir centros de interpretación de la naturaleza en otras zonas, como el CIN Matallana u otros con temáticas específicas, como el de la caza en Saelices de Mayorga o el de la avifauna en Monasterio de Vega.

\subsubsection{Observatorios de avifauna}

Se trata de otra de las infraestructuras de uso público, ligadas en este caso a la observación de fauna acuática de lagunas. Con ello se pretende que los visitantes se concentren en un punto concreto relativamente alejado de la lámina encharcada, evitando molestias a la avifauna. Existen observatorios de diferente tipología, aunque los más utilizados son las casetas de obra y las que utilizan madera como material constructivo. En Tierra de Campos se ha empleado el primer tipo en las lagunas de Villafáfila -con palomares de formas diferentes- $y$ en la laguna de la Nava. En la laguna de Boada de Campos y en la de Tamariz de Campos, los observatorios son 
de madera más sencillos. También se pueden construir observatorios en embalses o balsas de riego que alberguen avifauna de interés, como el que está previsto en la gran balsa del sector $\mathrm{V}$ de regadío Esla-Carrión, entre las localidades de Villalón de Campos y Boadilla de Rioseco.

\subsection{Resumen del capítulo}

El paisaje es la manifestación externa del territorio, aunque con matices según sean las disciplinas que se acerquen a esta materia. Existen dos enfoques básicos para su estudio: el ecológico (que tiene que ver con los procesos del medio) y el visual (relacionado con la percepción y la estética). El Convenio Europeo del Paisaje ratifica una concepción amplia del paisaje, como "cualquier parte del territorio tal como la percibe la población, cuyo carácter sea el resultado de la acción y la interacción de factores naturales y/o humanos".

Existen múltiples estudios que relacionan directamente un paisaje de alta calidad ligado a la naturaleza con la mejora del estado anímico de las personas, con su calidad de vida, bienestar y salud. En ellos suelo haber coincidencia en señalar el importante valor de la vegetación y del agua, así como del orden en su configuración.

El paisaje rural, definido como el espacio que no es natural ni urbano, tiene una gran importancia tanto en valor superficial como funcional; sus elementos singulares y arquitectura tradicional contribuyen a conformarlo. Dentro de él, el agrícola ha sufrido una gran transformación en la segunda mitad del siglo pasado, como consecuencia de su tecnificación, pasando a ser un paisaje mucho más simplificado; el caso más extremo es el paisaje cerealista, donde prima la producción a gran escala. El Atlas de los Paisajes de España encuadra este tipo de paisaje en la asociación Campiñas, encontrándose las de Tierra de Campos dentro de las Campiñas de la Meseta Norte.

Paisaje y medio ambiente son dos conceptos asociados. El paisaje puede definirse como la expresión externa del medio ambiente, por lo que es un indicador del estado de los ecosistemas; también puede considerarse como recurso socioeconómico. Dentro de los problemas medioambientales de las campiñas de Tierra de Campos, destacan la pérdida de biodiversidad, la contaminación agraria difusa, la despoblación rural y la degradación de los cascos urbanos tradicionales y su entorno.

Los instrumentos preventivos de gestión ambiental son unas eficaces herramientas para la protección del paisaje. Particularmente interesantes en Tierra de Campos son la planificación urbanística, la calificación ambiental y la evaluación de impacto ambiental de proyectos.

La recuperación ambiental o recuperación de espacios degradados es la técnica para reconvertir espacios cuyo estado es insatisfactorio por otros que nos satisfagan. Es el instrumento curativo fundamental para corregir impactos y mejorar la calidad del paisaje de Tierra de Campos, así como una oportunidad para afrontar la despoblación y promover su desarrollo económico.

Las actuaciones básicas en la recuperación de espacios degradados son la conservación y reutilización de la tierra vegetal, el modelado del terreno según formas naturales, la retirada y correcta gestión de residuos, la realización de drenajes y el establecimiento de la cubierta vegetal. Esta última cumple muchas funciones, debiendo conseguir una masa vegetal estable y 
de mínimo mantenimiento; para ello es fundamental realizar una adecuada elección de especies adaptadas al medio. La instalación de la vegetación requiere de una serie de técnicas que han de realizarse de forma rigurosa, que se agrupan en preparación del terreno, siembras de herbáceas y plantaciones de árboles y arbustos. Los cuidados culturales deberán ser los mínimos posibles, aunque no deben obviarse en los primeros años tras la implantación, en especial el riego en determinados casos.

Existen también otras técnicas de recuperación específicas para espacios degradados particulares: taludes importantes, cauces y cuencas degradadas, pantallas sónicas y pasos de fauna. Su utilización en Tierra de Campos es muy puntual.

La diversificación del paisaje agrario es otro instrumento fundamental para mejorar la calidad del paisaje de Tierra de Campos, que fue profundamente simplificado en la segunda mitad del siglo XX. La primera medida a través de la que se puede articular es la creación de setos vivos, que conlleva innumerables beneficios ecológicos, visuales y de muy variada índole. La segunda, los sotos, son complejas formaciones vegetales desarrolladas en los márgenes de los ríos y arroyos que, además de los beneficios anteriores, tienen una importante función protectora de los cursos fluviales. La tercera son los bosques isla, de tamaño y formas variados, que se pueden crear en muchos espacios marginales. Las medidas de condicionalidad de la Política Agraria Común y la forestación de tierras agrarias son unas adecuadas herramientas para llevar a cabo la diversificación del paisaje de Tierra de Campos.

Hay muchas posibilidades para aumentar el valor del paisaje de Tierra de Campos, alguna de las cuales ya se han puesto en marcha. En los pueblos y su entorno destaca la creación de parques y jardines sostenibles -tanto urbanos como periurbanos-, así como el diseño de anillos verdes. Existe una amplia red de senderos y caminos históricos con gran uso potencial para el senderismo, ciclismo y turismo ecuestre. Es muy sencillo instalar miradores desde donde contemplar una gran cuenca visual de Campos. Finalmente, sobre todo en espacios naturales, los centros de interpretación de la naturaleza y los observatorios de avifauna son infraestructuras de uso público muy interesantes para interpretar el paisaje. 

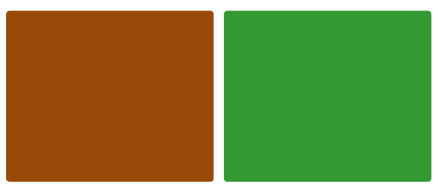

\section{ZONA DE ESTUDIO}




\section{ZONA DE ESTUDIO: TIERRA DE CAMPOS}

\subsection{Origen y toponimia}

Tierra de Campos es una comarca natural situada en la comunidad autónoma de Castilla y León, que se extiende por las provincias de Palencia, Valladolid, Zamora y, en menor medida, León. Se trata, tal vez, de una de las comarcas españoles con mayor identidad. De hecho, los geógrafos que han estudiado Tierra de Campos (VACA, 1992) siempre han destacado su inconfundible, significativa e individualizada personalidad, apreciable tanto en sus rasgos fisiográficos (litología arcillosa, relieve de modelado banal, hidrografía indecisa y con tendencia al endorreísmo, suelos pardocalizos, clima extremado y semiárido), como en sus caracteres económicos (campiña de prolongada llanura desprovista de vegetación arbórea, con un monocultivo cerealista, poblamiento concentrado y compacto, con aldeas y villas de escaso vecindario apiñadas en torno a la iglesia o al castillo).

El topónimo específico con que se denomina esta comarca tiene una gran tradición histórica, pese al efecto destructor que tuvo la delimitación provincial artificial de Javier de Burgos de 1833, que fragmentó Tierra de Campos en cuatro provincias. Se trata de una de las denominaciones comarcales de mayor abolengo (GARCÍA FERNÁNDEZ, 1985); tiene un arraigo de tiempo muy profundo, ha logrado pervivir y sigue vivo, transmitiéndose espontáneamente de generación en generación. No hay más que comprobar la cantidad de localidades de la comarca que poseen en su nombre el complemento "de Campos". No obstante, el fuerte peso institucional de las provincias en Castilla y León ha provocado que no se reconozca la importancia de sus comarcas y, en particular, llegar a situaciones tan absurdas como la disgregación de la Tierra de Campos en palentina, vallisoletana, zamorana o leonesa.

Su origen está en los llamados Campos Góticos (Campi Gothici o Campi Gothorum), zona de especial importancia para el Reino Visigodo debido a que el grueso de la población visigótica se asentó primeramente en dicha comarca a fines del siglo $\mathrm{V}$, cuando fue expulsada del sur de la Galia por el expansionismo de los francos. Más tarde esta población se dispersó por otros puntos de la antigua Hispania o se asentó en Toledo, la capital de su reino.

La primera alusión como Campos Góticos a esta comarca campesina aparece por primera vez en la Crónica de Albelda, redactada el año 881, la más antigua actualmente conocida del ciclo de la Reconquista, al narrar las incursiones de saqueo realizadas por Alfonso I en el valle del Duero, "Campos quos dicunt Goticos usque ad flumen Dorium eremauit, et xpistianorum regnum extendit». Se suele afirmar que esta denominación proviene de la etapa visigoda, lo que es corroborado por numerosos autores (VACA, 1992). Otros historiadores señalan que el nombre fue impuesto posteriormente a la época visigoda por los pueblos hispanorromanos del norte y hacía referencia a una zona geográfica que rebasa los límites de lo que hoy se conoce como Tierra de Campos, de modo que vendría a designar genéricamente el territorio comprendido entre la cordillera Cantábrica y el río Duero. En esta zona, su población -aún bajo dominio musulmán-conservaba las estructuras e instituciones del fenecido reino toledano, de ahí que se designara con el nombre de godos a sus habitantes.

De Campos Góticos se pasó a la actual denominación de Tierra de Campos, siendo la primera vez que aparece documentada en la Primera Crónica General de España del rey Alfonso X - 
donde se narra la destrucción de toda la Tierra de Campos debido a la invasión musulmana- o incluso un poco antes, hacia el año 1224 en la Crónica Latina de los Reyes de Castilla.

Para el diccionario de la Real Academia Española, el término campo posee, entre otras acepciones, la de "terreno extenso fuera de poblado/tierra laborable/en contraposición a sierra o monte"; por su parte, campiña equivale a "espacio grande de tierra labrantía"; mientras que, finalmente, define tierra como "territorio o distrito constituido por intereses presentes 0 históricos". Así pues, el topónimo Tierra de Campos vendría a reconocer el aspecto que primero se percibe de esta comarca, la llanura -elemento que le confiere una personalidad propia-, al tiempo que a sus habitantes conciencia de pertenencia a tal espacio.

\subsection{Aproximación histórica}

Siguiendo en esencia la información contenida en GONZÁLEZ GARRIDO (1941), los primeros habitantes históricos de Tierra de Campos fueron los vacceos (varios siglos antes de Cristo), gentes que practicaban una agricultura de tipo colectivista y ganadería trashumante. En aquella época la comarca ya era definida por las crónicas como una región "libre y descubierta" y "un país abierto, de trigales, tierra desarbolada". Al inicio de la era cristiana fue ocupada militarmente por los romanos, posteriormente por los pueblos del Norte vándalos y suevos, y más tarde por los visigodos como feudatarios de Roma que consolidan definitivamente su poder en el siglo VII, adquiriendo entonces la denominación de Campos Góticos (Campi Gothorum). "Agradó tanto la región de los vacceos a los godos cuando vinieron a España y la señorearon dice el Arcediano del Alcor - que hicieron en ella gran parte de su asiento y la llamaron «Campi gothorum»; mas quedole después el nombre de Campos». Los pueblos que ocupaban el ámbito geográfico de la Tierra de Campos se sublevaron durante el reinado de Leovigildo, pero dicha rebelión fue pronto sofocada con consecuencias devastadoras para la región.

En la época de la invasión musulmana, durante los siglos VIII y IX, pasó a ser una zona fronteriza, semidespoblada; sus habitantes, que nunca la abandonaron totalmente puesto que siempre hubo un contingente de bucelarios en labores de defensa, buscaban refugio durante las épocas de peligro en las zonas montañosas próximas. Aquello que no había sucumbido completamente durante la invasión musulmana era devastado y arruinado con las razias de los cristianos, siendo especialmente notables las campañas de Alfonso I, quien se llevó consigo a los mozárabes para repoblar el territorio asturiano. Durante dicha época, la Tierra de Campos formaba un amplio desierto estratégico.

A mediados del siglo IX comenzó a ser poblada más intensamente por los monarcas asturleoneses con repoblaciones de gentes del norte y de mozárabes procedentes de territorios dominados por los musulmanes. Estas repoblaciones se iniciaron con el monarca Ordoño I y avanzaron considerablemente durante el reinado de su hijo Alfonso III.

Frontera entre León y Castilla, Tierra de Campos fue escenario de guerras y disputas entre ambos reinos durante los siglos siguientes, cuyo territorio fue varias veces repartido. Aun así, si bien la comarca sufrió los rigores de las luchas, fue favorecida por la presencia frecuente de los reyes y nobles en sus villas más importantes, donde celebraron cortes, concertaron tratados, 
concedieron mercados, etc. Durante el periodo medieval, el poder político se desarrollaba a través de los condes como representantes de los soberanos reales, quienes ejercían su señorío sobre extensos territorios, aunque los concejos tuviesen una cierta autonomía administrativa. Otro elemento muy importante de poder se desarrolla alrededor de los monasterios (Sahagún, Grajal de Campos, Matallana, Carrión de los Condes, Ribas de Campos, etc.) cuyo poder político y económico era ciertamente significativo.

En los últimos tiempos medievales y renacentistas (en torno al siglo XV), debido a la importancia económica de la agricultura cerealista y de la ganadería de lanar, se produjo un periodo de esplendor y de esta época datan los monumentos que se pueden ver en algunos de sus pueblos más importantes.

Con la llegada de la mecanización agrícola y el abonado mineral para los cereales, y el consiguiente cambio de una agricultura tradicional necesitada de gran cantidad de mano de obra a otra productivista, su importancia económica fue mermando de forma continua. En referencia a su historia moderna, en los años 60 y 70 del siglo XX se produjo una fuerte emigración de la zona rural hacia las capitales de provincia y hacia otras zonas industriales, principalmente, País Vasco, Madrid y Barcelona, lo que hizo disminuir intensamente su población. En esos años comienza un éxodo rural que lamentablemente continúa hasta nuestros días.

\subsection{Delimitación geográfica}

Cualquier intento por fijar con precisión los límites y contornos de una región o comarca geográfica resulta complicado, puesto que no son claramente determinantes para constituirse en línea de separación de las unidades geográficas limítrofes; en consecuencia, se suele considerar que los límites son "elásticos". En el caso de Tierra de Campos esto se ve agravado dado que nunca ha existido una unidad institucional que la delimite; las divisiones administrativas, fiscales, eclesiásticas o jurisdiccionales han sido cambiantes y no coincidentes entre sí, convirtiéndose de esta manera en elemento de ruptura y no de unidad de un espacio geográfico muy homogéneo (YUN, 1987).

Dos antecedentes históricos de delimitaciones administrativas establecidas durante la Edad Media en esta comarca, aun no coincidentes geográficamente, son la merindad de Campos y el arcedinato de Campos (VACA, 1992). La merindad de Campos era una de las quince circunscripciones administrativas en que, según el Becerro de las Behetrías de Castilla, estaba organizada la parte del reino castellano comprendida entre el mar Cantábrico al norte, el río Duero al sur, la sierra de Urbión al este, y el río Esla al oeste, a mediados del siglo XIV. Su superficie aproximada era de unos 1800 kilómetros cuadrados, y en ella se ubicaban setenta y un núcleos de población.

Por su parte, el arcedinato de Campos era una de las cuatro grandes circunscripciones del obispado de Palencia. Se extendía desde el curso medio del río Sequillo hasta el curso medio del Carrión, teniendo como eje central el arroyo de Valdeginate y la laguna de la Nava. Su superficie era de algo más de 1500 kilómetros cuadrados y en total poseía ochenta núcleos de población. 
Dentro de las distintas delimitaciones geográficas realizadas de Tierra de Campos, la línea mayoritaria es la seguida por González Garrido (1941) y apoyada por otros autores como Terán, Revenga Carbonell, Pérez Díaz, Peña Sánchez y el mismo Programa para el Desarrollo de Tierra de Campos (1962) -aunque ampliada-, que otorgan a la comarca una superficie aproximada de 4400 kilómetros cuadrados. De acuerdo con González Garrido, los elementos geográficos de importancia que delimitan Tierra de Campos son: "al Norte las bajas llanuras pliocenas o cuaternarias de León en que se asientan las últimas estribaciones de la cordillera Cantábrica, entre Sahagún y Carrión de los Condes, con sus aledaños; al Este, las estribaciones comprendidas o regadas por los ríos Carrión y Pisuerga; al Sur, los alcores y laderas de los montes Torozos, con la vega del Sequillo, y al Oeste, las salinas de Villalpando y el río Cea más arriba". Esta delimitación es también la seguida en el libro Tierra de Campos (LANCIA, 2004), que fundamentalmente expone de forma ilustrada el magnífico patrimonio histórico-artístico que posee la comarca (Figuras 4.1 y 4.2 ).

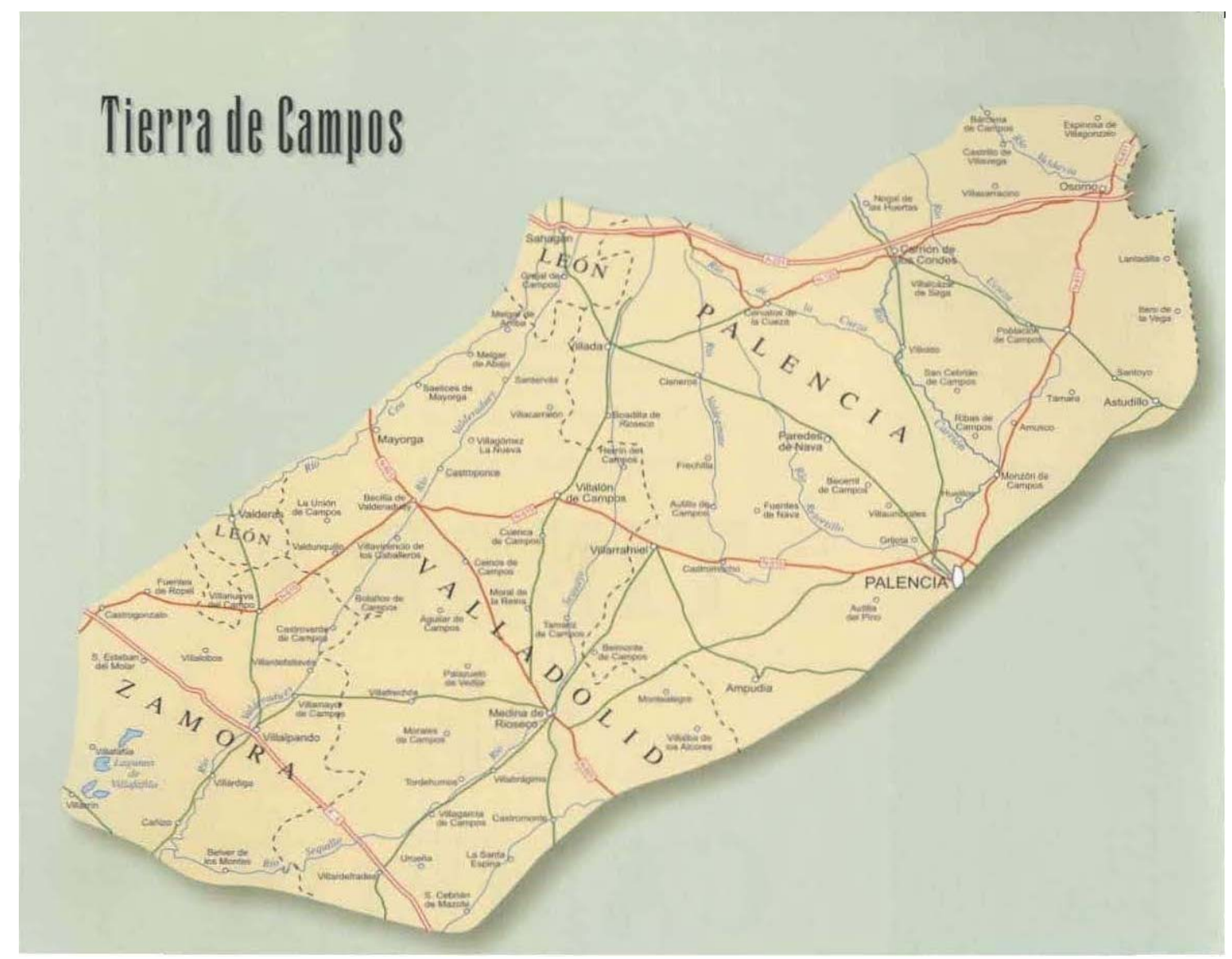

Figura 4.1. Mapa de la comarca natural de Tierra de Campos (LANCIA, 2004).

Como ya se ha indicado, una de las delimitaciones más precisas y detalladas de la comarca que se ha realizado es obra del abogado, periodista y escritor riosecano Justo González Garrido, en su ensayo La Tierra de Campos. Región Natural, de 1941 (Figura 4.3), a pesar de las dificultades que el propio autor señala para realizar esta labor. De acuerdo con la síntesis efectuada por LANCIA (2004), el punto más noroccidental de la comarca se alcanza en la conjunción actual de 
las actuales provincias de León, Palencia y Valladolid, comprendiendo en su interior el término de Grajal de Campos. El límite septentrional, al atravesar el río Sequillo, marca una suave inflexión descendente por Villemar y Villalcón, cruza el río Valdeginate y baja a Abastas, siguiendo después horizontalmente entre Villanueva del Rebollar y Cardeñosa de Volpejera, hasta encontrar la orilla derecha del río Carrión en el término de Villoldo. Quedarían pues fuera de la comarca terracampina los pueblos que llevan el apellido de la Cueza y la localidad de Bustillo del Páramo, que morfológicamente poseen otra configuración.

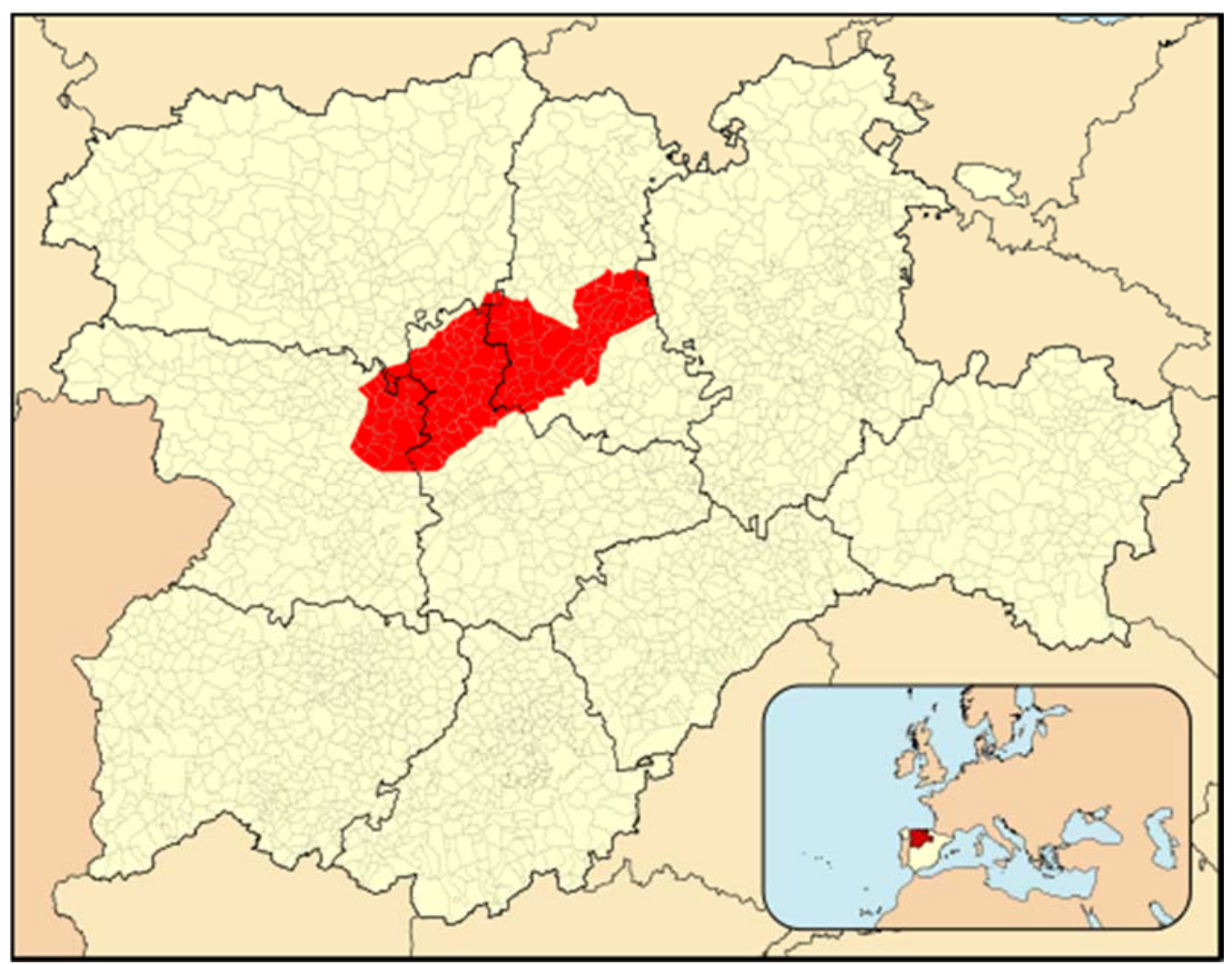

Figura 4.2. Mapa de Tierra de Campos realizado a partir de la delimitación de GONZÁLEZ GARRIDO (1941)

La fresca vega del Carrión marca el límite desde Villoldo a Carrión de los Condes. La línea divisoria que asciende aún unos kilómetros por los términos de Villaherreros, Fuente-Andrino y Osorno constituye el límite septentrional de la comarca, tanto para el mencionado González Garrido como para Antonio Ponz. Pese a todo, por encima de esta línea divisoria quedan pueblos con el apellido de Campos, como Bárcena de Campos Al norte el terreno verdea algo en verano y los valles y llanos son más jugosos, como consecuencia de las mayores precipitaciones. El terreno se encrespa un poco, y en las lindes de las tierras de cultivo aparecen frecuentemente los arbustos y matas leñosas que las sombrean de verde. La interrupción vegetativa estival es menor en estas tierras norteñas.

Osorno marca el inicio de la frontera oriental, que baja hasta Osornillo, a orillas del Pisuerga. Este río marca el límite hasta Itero de la Vega y Melgar de Yuso. Al lado opuesto, las tierras de Castrojeriz inician otra planicie más alta y fría. Entre el río Pisuerga y el canal de Castilla, por los 
términos de Las Cabañas de Castilla, Marcilla de Campos y Requena de Campos, las tierras son más frescas y sueltas que las duras arcillas del resto de la comarca.

Más abajo está Támara de Campos, desde donde la divisoria se contrae, huyendo de alcores y páramos, para encontrar el término de Amusco, a orillas del Ucieza, pequeño río encauzado, que poco después entrega su caudal al Carrión en Monzón de Campos. No lejos, sobre un altozano, se alza Fuentes de Valdepero. Hacia oriente se extiende la alineación ininterrumpida de cuestas margosas que coronan los páramos del Cerrato, comarca más accidentada y caliza. Del otro lado, Husillos, al borde del Carrión, en un paisaje de inusitada frondosidad y frescura en comparación con la aridez y sequedad propias de la comarca. Cerca de Palencia se divisan, disecados por la erosión sobre el llano, dos cónicos cerros testigo. El más famoso de ellos es el del Otero. Palencia, la ciudad más populosa de Tierra de Campos, se encuentra al margen, en un extremo, rodeada de huertas que se aprovechan de las acequias de riego del canal de Castilla. Al este, entre los ríos Pisuerga y Esgueva, se encuentra el Cerrato. Del lado de poniente, el extremo norte de los montes Torozos, una altiplanicie menos desolada.

Saliendo de Palencia, después de cruzar el canal de Castilla a un kilómetro de la ciudad, parece seguir un corto trayecto por la actual carretera $\mathrm{N}-610$, entre las faldas de los montes y la laguna de la Nava, en el término de Villamartín de Campos, y dirigirse después al suroeste por bajo de Autilla del Pino, hacia Torremormojón, al pie de la colina donde se yerguen los restos de su castillo. Quedan atrás, sobre un altozano, los del de Paradilla del Alcor. En pie, se conservan los magníficos castillos de Ampudia y Montealegre de Campos, en la cadena de los Alcores, que junto al desaparecido de Valdenebro de los Valles marcaban claramente la línea de defensa de estas tierras otrora fronterizas entre los reinos de León y Castilla. Las últimas tierras cerealistas de la campiña son las de Villerías de Campos y Palacios de Campos, ya que en las proximidades de Medina de Rioseco aparecen tímidamente algunas arboledas.

Aquí, la línea sinuosa de los páramos que marcan el confín de Campos «dibuja una marcada flexión, describiendo en las cuestas que se alzan al sur y en el gran cerro testigo al este de la localidad amplios senos surcados por vivas barrancadas y galaches labrados en los flancos margosos por la acción erosiva de las lluvias, sin que llegue a encubrirlas en parte una rala y enteca vegetación.» Afortunadamente, esto ha cambiado con las repoblaciones forestales de las laderas, que han modificado sustancialmente este paisaje fronterizo. Los montes Torozos suponen en esta parte el confín meridional de la comarca, quedando dentro de ella la baja llanura de los términos de Villabrágima, Tordehumos y Villagarcía de Campos. Más allá de Villagarcía las arcillas van perdiendo dureza y compacidad, mientras adquieren un tono rojizo y una composición más suelta y arenosa. Mucho más al sur comienza la comarca de Toro.

Por los términos de Villanueva de los Caballeros y San Pedro de Latarce reaparecen algunas suaves lomas pobladas de robles y encinas, ya en el confín de la provincia de Zamora. Sigue la línea el curso del Sequillo por Belver de los Montes, recostado en la ladera de unos cerros, y a poco, cerca de Castronuevo, el río confluye con el Valderaduey. La Tierra de Campos se encuentra allí con otra comarca natural muy similar, también dedicada casi en exclusiva a la producción de cereal: la Tierra del Pan. Más arriba, formando un extremo, la Lampreana, en el valle del Salado, Ilanura pantanosa de sales alcalinas. En invierno inunda gran parte de los 
términos de Revellinos de Campos, Tapioles, Villafáfila y Otero de Sariegos -ahora espacio natural protegido-, dejando al descubierto en verano las arcillas salíferas que forman su suelo.

Remontando el curso del Valderaduey se advierten los restos discontinuos de un manchón diluvial en una faja de dos kilómetros de ancho que se acentúa por San Martín de Valderaduey y Villárdiga, hasta Villalpando, reapareciendo después más al norte y hacia oriente, como un "enclave" geológico: el Raso de Villalpando. Por cima de Villalpando, los mantos pliocenos y cuaternarios se ensanchan, cubriendo los términos de Villamayor de Campos, Villar de Fallaves, Castroverde de Campos, Cerecinos de Campos y Villanueva del Campo. Los contornos de la comarca en esta zona se muestran desdibujados y algo imprecisos, si bien los pueblos mencionados anteriormente se incluyen desde tiempos antiquísimos en Tierra de Campos por motivos de identificación con los caracteres comarcales.

De Fuentes de Ropel y Roales de Campos, la línea se acerca al río Cea, casi en su confluencia con el Esla, internándose de nuevo por la provincia de Valladolid por Valdunquillo y La Unión de Campos hacia Castrobol. Allí sigue el curso fluvial del Cea hacia el norte. En la parte oriental del río, se sitúan las tierras secas y áridas de Campos. Al oeste, vegas frondosas y bajas. Mayorga, Saelices de Mayorga, Monasterio de Vega, Melgar de Abajo y Melgar de Arriba son pueblos ribereños pertenecientes a la demarcación terracampina, cuya alineación cerraría el perímetro que comenzó en el entorno de Grajal de Campos. 

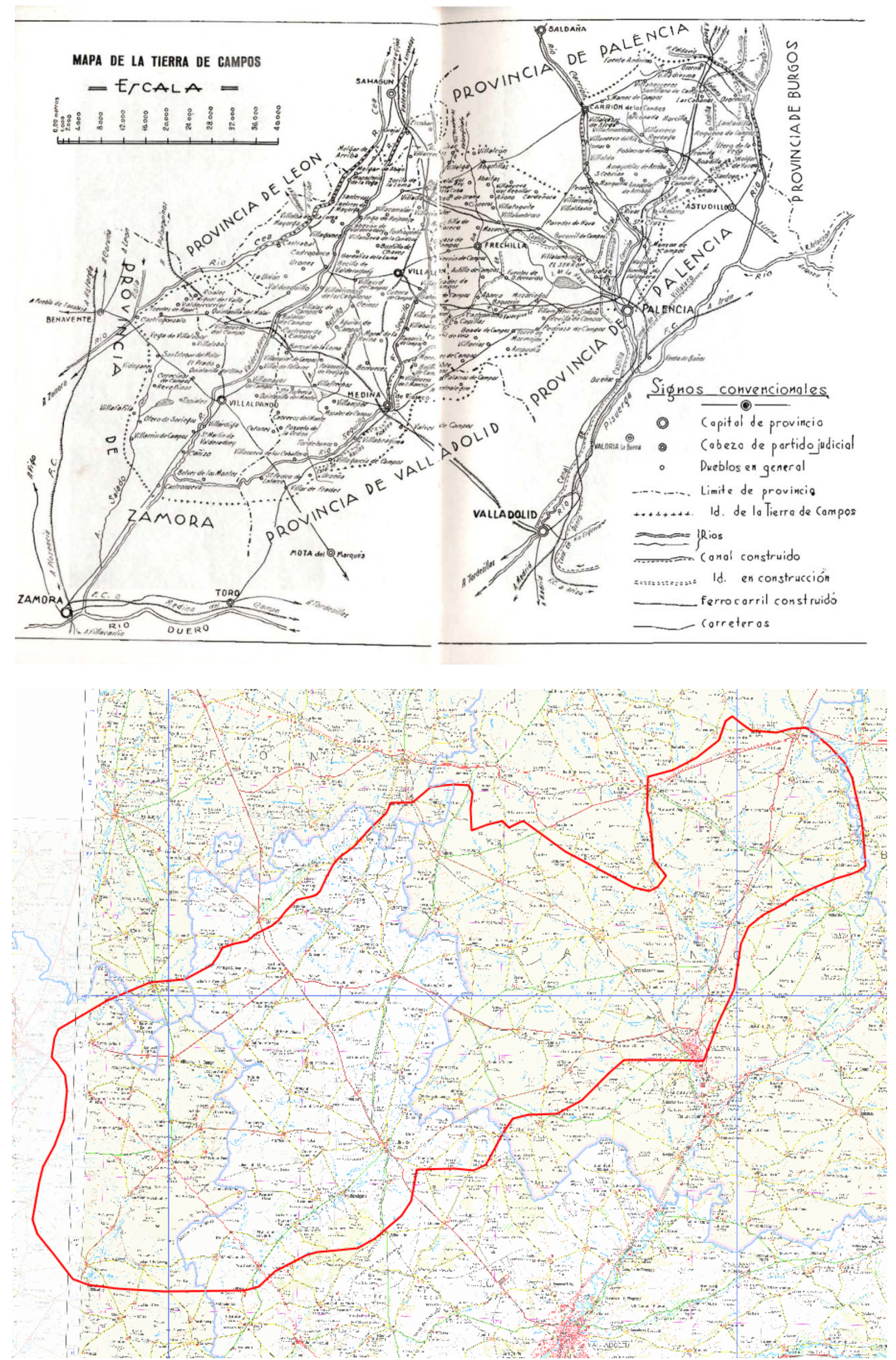

Figura 4.3. Mapa de La Tierra de Campos (GONZÁLEZ GARRIDO, 1941). La imagen superior es el plano original del autor y, la inferior, una aproximación de la comarca en el mapa topográfico actual. 
La demarcarción así trazada por González Garrido comprende un polígono de forma muy irregular, con $350 \mathrm{~km}$ de contorno, y cuya superficie es aproximadamente de $4400 \mathrm{~km}^{2}$, repartida entre 167 pueblos.

Tal como se ha señalado anteriormente, otra de las delimitaciones geográficas más utilizadas para Tierra de Campos es la recogida en el Programa para el desarrollo de Tierra de Campos (CETC, 1962). Según el Consejo Económico de Tierra de Campos -organismo promotor-, la comarca está formada por el conjunto de terrenos llanos o ligeramente ondulados pertenecientes en su mayor parte a las provincias de Palencia, Valladolid y Zamora y, en menor proporción, a la de León, encuadrada en líneas generales por los ríos Pisuerga al Este; Cea y Esla por el Oeste; la línea sinuosa formada por las colinas que constituyen la parte baja de las montañas de Palencia y León por el Norte y, finalmente, por el Sur el límite septentrional de los Montes Torozos y la Tierra del Pan zamorana. Aunque la delimitación es geográfica, el hecho de que con carácter pragmático se incluyan términos municipales completos o incluso otros municipios con vínculos funcionales, hace que su superficie, $5700 \mathrm{~km}^{2}$, sea superior a la referida por González Garrido.

\subsection{Geomorfología}

En las delimitaciones geográficas realizadas por los diferentes autores también se trazan los rasgos característicos de esta comarca, aunque sean de épocas dispares. Así, DANTín (1922) define a la Tierra de Campos como una "extensa comarca natural... región llana, poco ondulada, de clima extremado, seco... cultivos de cereales..." y ya hace una lectura del paisaje como "hondamente desolado". El citado Programa para el desarrollo de Tierra de Campos indica que esta unidad geográfica está formada por "el conjunto de terrenos llanos o ligeramente ondulados...".

GONZÁLEZ GARRIDO (1941) define Tierra de Campos como una extensa planicie desarbolada, de suaves y ligeras ondulaciones, dedicada casi en su totalidad al cultivo de cereales y con apariencias muy homogéneas y características en toda su extensión. En esta comarca o región natural todo es uniforme: la constitución geológica, el suelo, el aspecto de los campos, la climatología, la deslumbrante luminosidad del paisaje y la fisonomía de los pueblos cuya principal materia constructiva es la arcilla. Son años estos en que todavía se construía en adobe y tapial, y se revocaba en barro, por lo que este es uno de los rasgos tal vez más característicos del paisaje pasado; ya no tanto, por desgracia, del presente. No sucede así con la increíble "luminosidad del paisaje", que continúa siendo una de las percepciones visuales de mayor intensidad en la comarca.

El relieve de la comarca terracampina se presenta estructurado en dos unidades morfológicas de naturaleza distinta: la campiña que la constituye en su inmensa mayoría y los páramos que la rodean (VACA, 1992). Según este autor, la campiña constituye el nivel inferior de las llanuras más deprimidas de la cuenca de sedimentación terciaria y cuaternaria de la parte septentrional del valle del Duero. Se trata de un conjunto de llanuras arcillosas de intensa coloración amarillento-rojiza, ligeramente onduladas y divididas por la acción erosiva de los afluentes de la margen derecha del río Duero que recorren la comarca de norte a sur y arrastran arenas y otros 
materiales aluviales que, depositados en las orillas de los imprecisos valles, forman las típicas vegas. El aspecto de este conjunto de llanuras es uniforme, monótono y de gran horizontalidad (Figura 4.4). La altitud media está comprendida entre los 700-800 m sobre el nivel del mar.
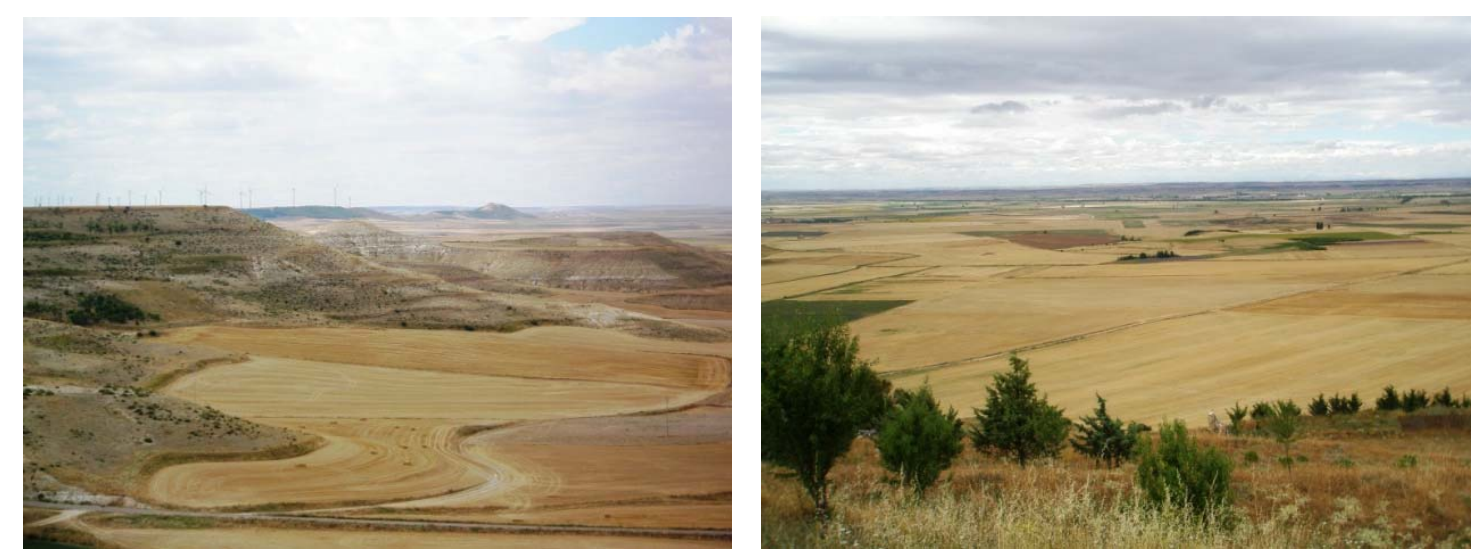

Figura 4.4. Dos vistas de Tierra de Campos desde el mirador de Autilla del Pino: a la izquierda, laderas de transición al páramo calcáreo; a la derecha, campiña en su inmensidad.

Según este autor, el origen de la campiña se atribuye al desmantelamiento de los páramos pontienses causado por varios procesos erosivos que los han hecho retroceder hasta el lugar que actualmente ocupan, al tiempo que se producía el allanamiento de los interfluvios. El resultado final de ese doble proceso de desmantelamiento/allanamiento fue la creación de este nivel de campiña surcada por pequeños y perezosos cursos de agua, a veces intermitentes y separados por alargadas lomas de forma amesetada (Figura 4.5). 


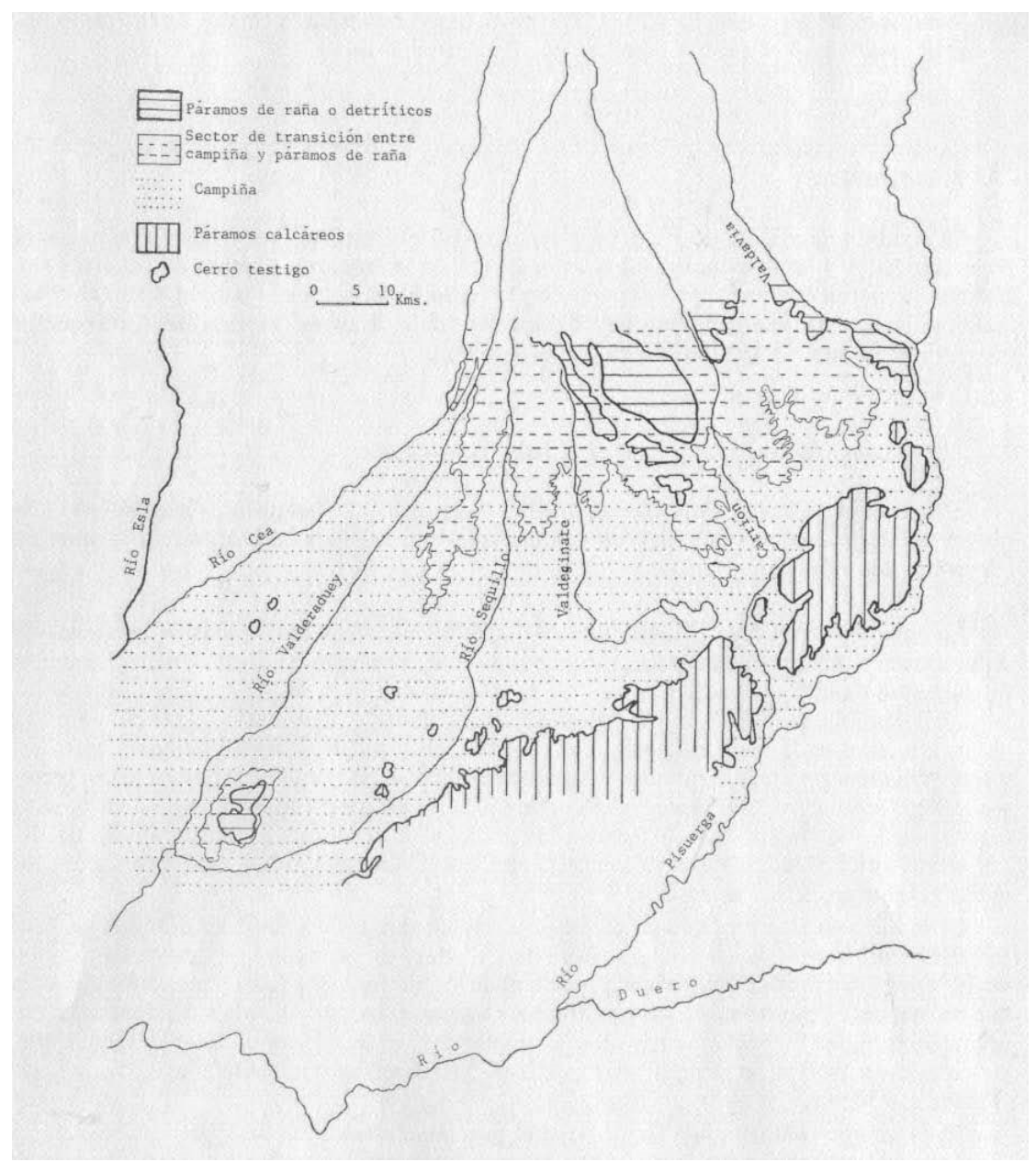

Figura 4.5. Mapa esquemático del relieve de Tierra de Campos (VACA, 1992)

Los páramos que circundan la campiña, salvo por el suroeste, se elevan unos cien metros, aproximadamente, por encima de ella. Entre ellos cabe distinguir los páramos de raña o páramos detríticos palentinoleoneses, al norte y noroeste, y los páramos calcáreos, al este (páramos de Castrojeriz y de Cerrato) y al sur (páramos del Alcor o Montes Torozos).

Los páramos de raña o detrítico palentinoleoneses constituyen el límite septentrional de la comarca de Tierra de Campos; la transición entre la campiña y estas parameras, que puede situarse en torno a los valles de los ríos Cueza y Ucieza, se realiza de forma insensible, en una suave y prolongada pendiente de inclinación norte-sur. Su manto de raña, formado por cantos rodados, conglomerados y otros materiales de naturaleza silícea que provienen de los derrubios de la cordillera Cantábrica y recubren los sedimentos terciarios, ha protegido la formación miocena infrayacente de arcillas y su completo desmantelamiento por la acción erosiva de los ríos Cea, Carrión, Pisuerga y afluentes. Sin embargo, estos ríos han excavado valles planos, de morfología disimétrica, con una ladera oriental elevada y escarpada y la otra de talud con suave pendiente, $y$ han conseguido fragmentar la superficie de la paramera en mesas o plataformas interfluviales de orografía plana y de una altitud media entre 900 y 1100 metros. 
Los páramos que rodean la campiña por el este y sur son plataformas techadas por una cobertura de calizas pontienses y se elevan unos cien metros sobre el nivel de aquella. El contacto entre estos dos niveles estructurales se realiza normalmente a través de cuestas y laderas de suave declive o por medio de taludes escarpados y abruptos. Su topografía resulta de una planitud verdaderamente asombrosa, mucho más llana y monótona que la de la campiña, ya que el caparazón calcáreo que los recubre impide la formación de valles de erosión que pudieran romper su homogeneidad, al tiempo que su horizontalidad dificulta el drenaje de las aguas de lluvia que tienden a encharcarse en pequeñas hondonadas, para, finalmente, evaporarse o filtrarse a través de las fisuras de las roca y reaparecer en la ladera en forma de fuente, cuando existe alguna capa subyacente de materiales impermeables. Su altitud media oscila entre los 900 metros de los orientales y los 830 metros de los meridionales.

En ocasiones, sobre todo en la zona meridional, irrumpen en la propia campiña sectores residuales de estos páramos, aislados por la acción erosiva de las aguas; son los conocidos cerros testigos, oteros o motas (Figura 4.6), colinas planas en forma de artesa volcada o de cono truncado que viene determinada por la mayor consistencia de la capa calcárea que los remata.

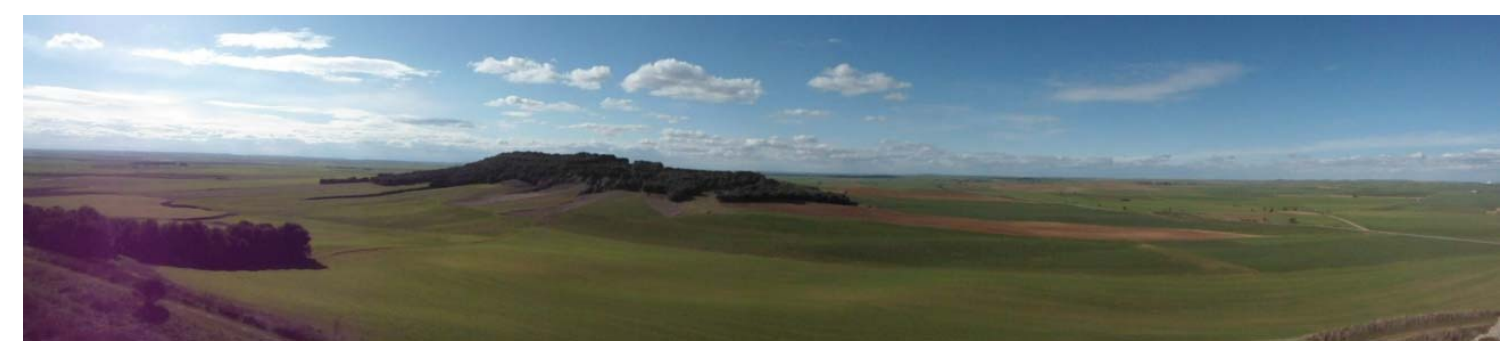

Figura 4.6. Panorámica de cerro testigo en Tordehumos, desde otro contiguo donde se ubicaba su castillo.

Esta estructura geomorfológica de la comarca de Tierra de Campos ha favorecido en gran medida su antigua vocación agrícola. Al carecer la campiña de obstáculos orográficos importantes que impidan la acción del arado y del azadón, presenta indudables ventajas para el cultivo en general, y en particular para el de los cereales y la vid. Además, su horizontalidad, su reducida pendiente y el escaso caudal de sus ríos han facilitado los acarreos, transportes y desplazamientos.

\subsection{Clima}

Siguiendo con la caracterización de las bases ecológicas de Tierra de Campos realizada por VACA (op.cit.), se puede afirmar que el clima de esta comarca es muy semejante al continental extremo y árido de la Meseta castellanoleonesa. En relación con las temperaturas, uno de los rasgos identificadores es la intensidad y duración de los inviernos, de seis e incluso siete meses anuales (de noviembre a abril), con unas temperaturas medias inferiores a los $10^{\circ} \mathrm{C}$ e incluso en algunos meses (diciembre y enero), a los $5{ }^{\circ} \mathrm{C}$. Durante estos meses suelen generalizarse las heladas diarias que paralizan todo proceso vegetativo. Por el contrario, los veranos son cortos 
(julio y agosto) y, debido fundamentalmente a la elevada altitud, no muy calurosos, unos $20^{\circ} \mathrm{C}$ de media. Además presentan un rango de variación muy amplio entre el día y la noche, que puede llegar en muchas ocasiones a los $20^{\circ} \mathrm{C}$. Las subidas térmicas primaverales y descensos otoñales no suelen presentarse gradualmente escalonados, sino que los procesos de cambio térmico se ven bruscamente interrumpidos por caídas y subidas típicamente invernales o veraniegas.

Este ciclo térmico anual de Tierra de Campos y, principalmente, los saltos y retrocesos de las estaciones intermedias no favorecen el desarrollo de la vida vegetal. La crudeza y larga duración de los inviernos retrasa y acorta el ciclo vegetativo y ocasiona que la gama de cultivos quede muy reducida; solo aquellos menos exigentes soportan este régimen, como por ejemplo el trigo, la cebada, la avena y el centeno -en cuanto a los cereales-, determinadas leguminosas (la alfalfa o la veza), la vid y algunos frutales. Las heladas de primavera, sobre todo si son tardías, sorprenden a las plantas en fase de floración o maduración y producen la interrupción brusca de su ciclo natural, lo que ocasiona un notable descenso de sus rendimientos; al igual que también ocasionan una notable merma de la cosecha los fuertes calores primaverales.

A su vez, el régimen pluviométrico tampoco resulta muy favorable, según la caracterización mencionada (VACA, op.cit.). El escaso índice de precipitaciones coloca a esta comarca entre las isoyetas 400 y $500 \mathrm{~mm}$ y provoca una gran aridez ambiental, propia de los climas semiáridos. En general, el índice de precipitaciones es mayor en el norte (Cervatos de la Cueza, $527 \mathrm{~mm}$ de media anual), zona de contacto con el páramo detrítico, que en la zona meridional (Palencia, $375 \mathrm{~mm}$ y Villalpando $420 \mathrm{~mm}$ ). El régimen pluviométrico tiene un máximo principal en otoño y otro secundario en primavera, mientras que el mínimo tiene lugar sobre el invierno -el secundario-y durante el verano, el principal. Este último coincide con el máximo térmico, lo que incide de forma determinante en la aridez ambiental. Otro rasgo destacable de este régimen es la gran irregularidad, no solo estacional, sino también interanual, lo que origina la alternancia caprichosa de años de buenas y malas cosechas.

Estos rasgos climáticos están determinados por varios factores: la elevada altitud, que provoca el descenso y atemperamiento térmico de esta comarca con relación a otras de menor altitud; el aislamiento de las influencias marinas, pese a la relativa proximidad al océano Atlántico, al hallarse enclavada en una cuenca rodeada por un potente cinturón de montañas, que provoca la continentalización del clima mediterráneo, el bajo índice de precipitaciones y el carácter extremo de las temperaturas invernales; y la situación respecto a los anticiclones continental y de las Azores, que afecta principalmente al régimen pluviométrico e, indirectamente, a su cuantía: en invierno domina el primero, causando un largo periodo de frío intenso y un mínimo secundario de precipitaciones, mientras que en verano lo es el segundo, lo que origina una acusada aridez.

En el dosier de Tierra de Campos (CONSEJERÍA DE MAOT, 1994) se profundiza en el análisis del clima de la comarca, que lo califica como árido. Según la clasificación de Thornthwaite, la práctica mitad sur tendría un clima semiárido (D) mientras que el resto se encuadraría dentro del tipo subárido (C1). Los datos climatológicos aportados por los cinco observatorios termopluviométricos de la comarca presentan una relativa homogeneidad. Las precipitaciones anuales varían entre los 430 y $480 \mathrm{~mm}$. Noviembre y mayo son los meses más lluviosos, y agosto 
el más seco. La escasez de las precipitaciones se pone en mayor evidencia cuando se compara con los datos teóricos de evaporación potencial, que supera los $650 \mathrm{~mm}$ anuales.

La temperatura media anual oscila entre los $10,2^{\circ} \mathrm{C}$ de Ribas de Campos (al norte de la comarca) y los $12,7^{\circ} \mathrm{C}$ de Medina de Rioseco (al sur). La temperatura media del mes más frío (enero) varía entre $2,2{ }^{\circ} \mathrm{C}$ y $5{ }^{\circ} \mathrm{C}$, mientras que la del más cálido (julio) lo hace entre los $25{ }^{\circ} \mathrm{C}$ y $30^{\circ} \mathrm{C}$. La amplitud térmica media anual se incrementa de norte a sur, desde los $21,9^{\circ} \mathrm{C}$ hasta los $26,8^{\circ} \mathrm{C}$.

\subsection{Hidrografía}

Surcan el territorio terracampino varios ríos que discurren con un rumbo general norte-sur y que, a medida que avanzan hacia el sur, divergen cada vez más los orientales hacia el este y los occidentales hacia el oeste, para así bordear y salvar el obstáculo orográfico de los Montes Torozos y continuar su marcha hacia el colector común, el río Duero (VACA, 1992). De ellos cabe hacer una clasificación en dos grupos:

El río Cea (Figura 4.7) -que constituye el límite noroccidental de la comarca-, el río Carrión-que atraviesa perpendicularmente Tierra de Campos en su tramo oriental- y el río Pisuerga, que es el límite oriental de la comarca, son los cursos hídricos más importantes. Realmente estos ríos no se corresponden en cierta medida con las características climáticas de esta zona, tanto por su nacimiento, régimen y caudal como por su situación tangencial (excepto el Carrión) a la comarca de Campos. Nacen fuera de sus límites, en la vertiente meridional de la cordillera Cantábrica, a más de 2000 metros de altitud; sus regímenes son pluvionivales; sus caudales, además de permanentes, poseen cierta magnitud; y sus cauces superan los 150 kilómetros de longitud.

Los restantes (Salado, Valderaduey (Figura 4.8), Sequillo, Valdeginate, Cueza, Ucieza, etc.) son pequeños riachuelos que nacen en el interior de Tierra de Campos o en las proximidades de su límite septentrional, aprovechando los manantiales que brotan en la zona de contacto entre la campiña y los páramos de raña. Todos ellos presentan unas notas peculiares que provienen del relieve estructural y del régimen pluviométrico de esta comarca. Tales son:

- Un escurrimiento indeciso, motivado por la falta de fuertes pendientes, lo que origina cursos de agua tranquilos, casi estáticos, de continuas curvas y divagantes meandros que tienden a ensanchar los lechos poco profundos; se trata de ríos que prácticamente han encontrado su perfil de equilibrio, por lo que casi carecen de acción erosiva y aluvial.

- Una acusada irregularidad entre el prolongado estiaje y las épocas de lluvias, que les lleva desde la interrupción de su cauce en los meses de verano (fenómeno reflejado en el nombre de uno de ellos, Sequillo), ante la escasez de precipitaciones y la fuerte evaporación a que se ven sometidos, hasta las devastadoras crecidas causadas por un repentino periodo de intensas lluvias y por la impermeabilidad del terreno, que provocan el desbordamiento de sus cauces poco profundos y el anegamiento de grandes extensiones ribereñas.

- Fuertes alteraciones humanas para evitar inundaciones: encauzamientos, rectificaciones, eliminación de riberas, etc. 
- Una tendencia al endorreísmo, claramente manifiesta en las lagunas salitrosas de Villafáfila y de la Nava y más difuminada en el resto de la comarca, donde existe un gran número de lavajos, lagunales y salmoriales, utilizados por los naturales como abrevaderos y que vienen causados por la disposición del terreno en forma de cubetas. Seguramente, como afirma Martínez Sopena (1985) para la zona occidental de esta comarca, las zonas palustres y endorreicas eran más extensas en la Edad Media que en la actualidad, debido al proceso de colmatación que han sufrido, quien señala varios ejemplos (Grajal de Campos, Castroverde de Campos, Villacid de Campos, etc.) de municipios que contaban con amplias zonas lagunares.

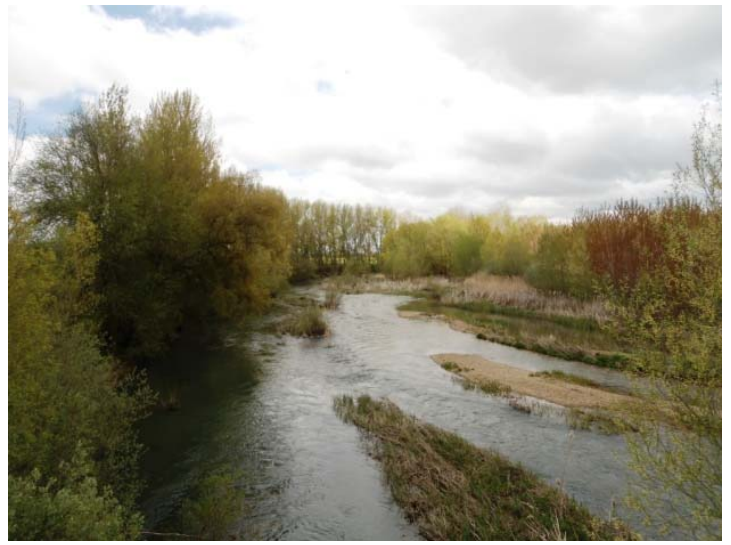

Figura 4.7. Río Cea en Melgar de Abajo.

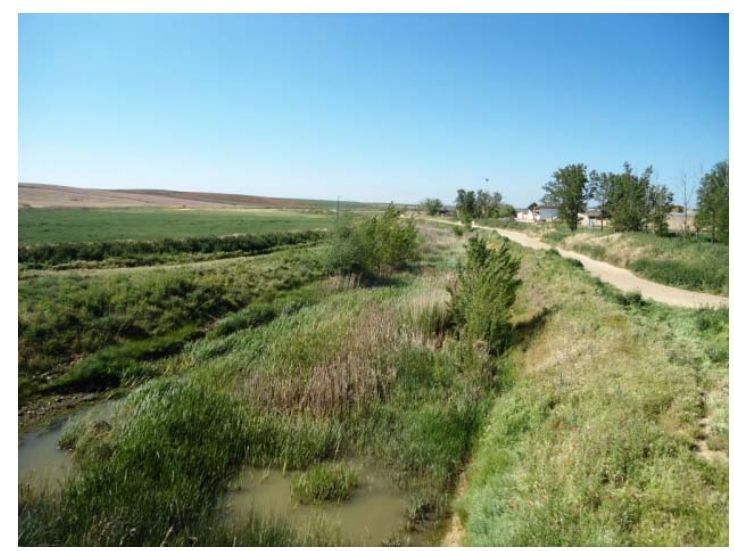

Figura 4.8. Río Valderaduey en Cañizo.

A estas corrientes más o menos estables, hay que sumar una extensa y nutrida red de arroyos y riachuelos intermitentes, que también ha sido mayoritariamente encauzada y rectificada en las concentraciones parcelarias. Las dificultades de drenaje lineal y una insuficiente infiltración a través de un suelo poco permeable dio lugar históricamente a la aparición de lagunas y lagunillas a lo largo y ancho de la comarca. Prácticamente todos los términos municipales poseían varias lagunas, que han sido paulatinamente desecadas por motivos de salud y para ganar terrenos agrícolas; para ello se realizaron drenajes rectilíneos (regueras) que evacuan la escorrentía hacia los cauces naturales (Figura 4.9).
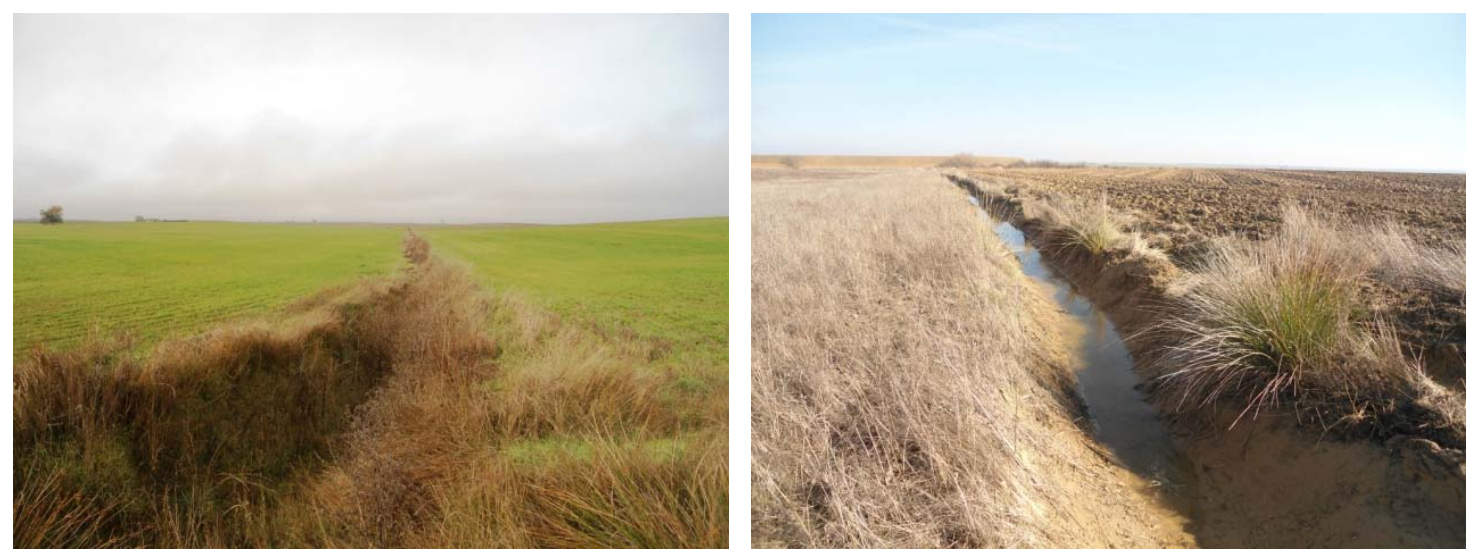

Figura 4.9. Dos pequeños arroyos o regueras rectificadas en Villalón de Campos. 
Englobada en el sistema terciario y acuífero del Duero, desde el punto de vista hidrogeológico la mayor parte de la superficie está constituida por formaciones de baja permeabilidad. Solamente en el lecho de los mayores ríos que atraviesan la comarca, las características detríticas de los materiales permiten una mayor permeabilidad. No obstante, en profundidad no se excluye la existencia de acuíferos más productivos. La calidad del agua subterránea es variable, existiendo amplias zonas con exceso de nitratos (CONSEJERÍA DE MAOT, 1994).

\subsection{Canales. El Canal de Castilla}

Por Tierra de Campos discurren varios canales destinados a trasvasar agua con destino al regadío, como el canal del Pisuerga en el límite nororiental, la acequia de Palencia, el canal de Macías Picavea en el entorno de Medina de Rioseco, o el recientemente construido canal CeaCarrión, que discurre por la zona central-norte de la comarca.

Pero entre ellos destaca de modo singular el Canal de Castilla, que representó para la comarca la obra más importante de las acometidas en los siglos XVIII y XIX; incluso fue una de las más significativas del periodo de la llustración en España (LANCIA, 2004). En el contexto del análisis del paisaje de Tierra de Campos se puede afirmar, sin lugar a dudas, que se trata de un proyecto emblemático: por la creación de un nuevo curso de agua en un entorno de total sequedad, por la belleza de sus complejas obras de ingeniería hidráulica o por tratarse de un auténtico anticipo de la integración paisajística de las grandes actuaciones humanas, al constituir en la actualidad un gran corredor verde. No en vano, en el ámbito técnico de la recuperación del paisaje, produce verdadera emoción el consejo del ingeniero Antonio de Ulloa -iimpartido hace 260 años!- de "hacer plantíos de árboles que hermoseen la obra y con raíces que aseguren más los fondos del canal y del dique". De hecho, los planos originales de Juan de Homar, fechados en 1806, contienen una alineación continua de árboles a lo largo de toda la traza del Canal.

Desde el siglo XVI se acariciaba la idea de abrir una gran vía fluvial en la meseta que estableciera comunicaciones y facilitara el comercio, incluso con el mar Cantábrico. No obstante, habría que esperar a la llegada de la Ilustración a España, en el siglo XVII, para que gobernantes preocupados con el progreso del país se replanteasen ya de forma seria la idea. De este modo, en 1751 se encarga el proyecto al ingeniero y marino español Antonio de Ulloa y al ingeniero francés Carlos Lemaur para, en 1753, iniciarse las obras en Calahorra de Ribas. Después continuarían bajo la supervisión del también ingeniero ilustrado Juan de Homar, auténtico valedor de que el proyecto se hiciese realidad. Esta gran obra civil de vía fluvial que atravesaría Castilla de norte a sur se complementaba con la ejecución de caminos carreteriles de Madrid a Tierra de Campos (al sur) y de Reinosa a Santander (al norte); todo ello con el propósito de abastecer de trigo a la capital del reino y de exportarlo a ultramar. Este objetivo prioritario se compatibilizaría con la creación de una red de riego a través precisamente de una de las comarcas más áridas de la región.

Aunque en 1792 ya entró en servicio una parte del Canal, realmente las obras duraron en total casi un siglo, hasta 1849, cuando el 8 de noviembre llegaron las aguas hasta Medina de Rioseco. El acontecimiento se celebró en la iglesia de Santa María de Mediavilla con un solemne tedeum 
y la colocación de una lápida conmemorativa. En ese momento se asumió la imposibilidad de alcanzar Reinosa, dándose por finalizado el ramal norte en Alar del Rey.

Hay que recordar que el Canal de Castilla se diseñó a imagen y semejanza del francés de Languedoc o del Midi, el gran hito de la ingeniería civil europea del siglo XVII. La ejecución del proyecto incluía no solo la apertura de la caja por la que fluirían las aguas captadas de los ríos Carrión y Pisuerga, sino también toda una serie de obras de ingeniería (acueductos, puentes, esclusas (Figura 4.10), dársenas, aliviaderos, retenciones) que servirían para salvar los desniveles y vallejas existentes, así como para regular el nivel de las aguas del canal (FRECHILLA, 2007).
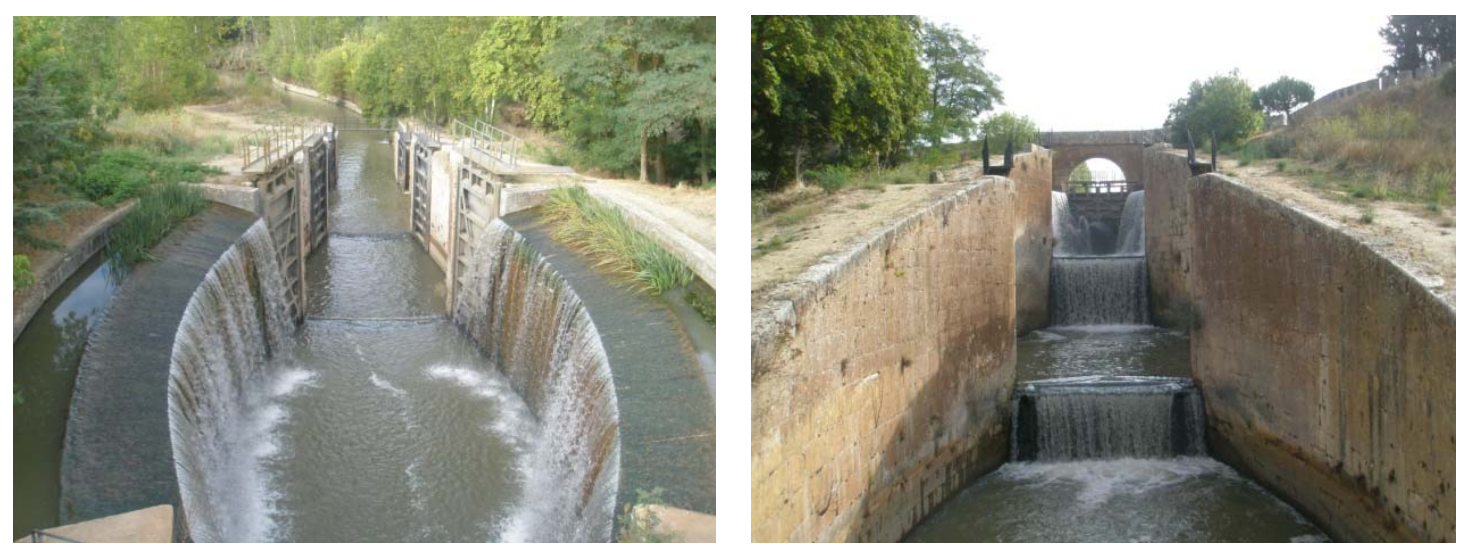

Figura 4.10. Vistas del impresionante grupo de esclusas de Calahorra de Ribas.

En la magnífica obra literaria "Castilla en Canal" de GUERRA GARRIDO (2008), acompañada con fotografías de Eduardo Margareto, se destaca el motivo ilustrado que impulsó la construcción de esta extraordinaria obra de ingeniería en Castilla: dotar al "granero de España" de una vía de transporte competitiva que facilitase la salida de sus productos agrícolas, principalmente trigo, al puerto de Santander desde donde se exportaba a las colonias de ultramar. Además de facilitar la comunicación entre las aisladas ciudades castellanas, repoblaría sus descampados, estimularía la creación de industrias y procuraría el resurgimiento del país. La ejecución del proyecto es calificada como una auténtica epopeya civil: un esfuerzo colectivo a favor de la civilización. Todo ello para, en reiterada frase de los padres de la llustración, "el fomento de la sociedad y la felicidad del pueblo".

A lo largo de varios capítulos relatados a modo de itinerarios de una ruta literaria y paisajística, este autor-Premio Nacional de las Letras Españolas y Premio Castilla y León de las Letras- narra sus vivencias como andariego del Canal de Castilla. Así, se apesadumbra con el menosprecio que han tenido las grandes infraestructuras (autovía, ferrocarril, carreteras) y los polígonos industriales con el ramal del Sur. Se alegra al destacar el valor añadido del Canal por conformar un grafismo verde sobre el fondo monocromático de la planicie. Se maravilla ante la belleza de sus numerosas obras de ingeniería hidráulica, aunque se lamenta de no poder contemplar algunas de ellas -como las grandes esclusas- en funcionamiento. Se ensimisma ante el enorme número de grandiosas fábricas de harina que acompañan su recorrido (Figura 4.11), modernidad histórica tan hecha trizas. Ya en el ramal de Campos, se admira al contemplar poblaciones tan 
monumentales como Medina de Rioseco, con hasta cuatro iglesias catedralicias. Disfruta de la cómoda marcha que la sombra de los árboles procura y se estremece con el contraste que provocan en el desnudo secano de la planicie. Confía en la suerte para que abandonados castillos, como el de Belmonte de Campos, pervivan. Destaca el valor de los palomares como símbolo de Tierra de Campos y del adobe como humilde material de construcción. Se alarma ante la progresiva desertización de los pueblos por los que atraviesa el Canal; apenas hay pueblos con escuela y en las escuelas apenas hay niños. Se esperanza al comprobar cómo la antigua fábrica de harinas de Abarca de Campos se convierte en museo de arte contemporáneo, ¡Ay, si ahora lo viese, una esperanza más truncada por el infortunio!. Siente una profunda sensación al contemplar en Tierra de Campos tanta cantidad de cielo, tan alto, diáfano y transparente, tan impoluto y sutilmente dilatable. Se acongoja al vislumbrar torres de iglesias tan hermosas como la de Santa María en Castromocho y la de Santa Eulalia en Paredes de Nava. Compara las tres esclusas consecutivas de Calahorra de Ribas con unas musicales cataratas; es el comienzo del ramal Norte en la confluencia del Canal de Castilla con el río Carrión y el paisaje acuático y ribereño es espectacular. Admira la belleza de la cuádruple esclusa de Frómista y de la iglesia románica de San Martín; aquí se juntan el Canal de Castilla y el Camino de Santiago, la más grande epopeya cívica y la más arriscada apuesta espiritual. Se asombra al caminar por un jardín en galería de chopos en Osorno, jamás hubiera sospechado esta vegetación en medio de un secarral; los chopos son bellos, arrulladores, dan sombra y además sujetan el suelo. Contempla con asombro la presa de retención de San Andrés, allí donde confluyen las aguas del río Pisuerga con el Canal, en el ramal norte. Ya al final del camino, al valorar la magnitud de la obra, siente una profunda amargura al preguntarse la suerte de los más de 4500 presidiarios que trabajaron en condiciones próximas a la esclavitud en las obras. Y continuamente apela a que, en el fondo, el Canal de Castilla es reflejo de la querencia del secano castellano por alcanzar el mar, siempre la mar.
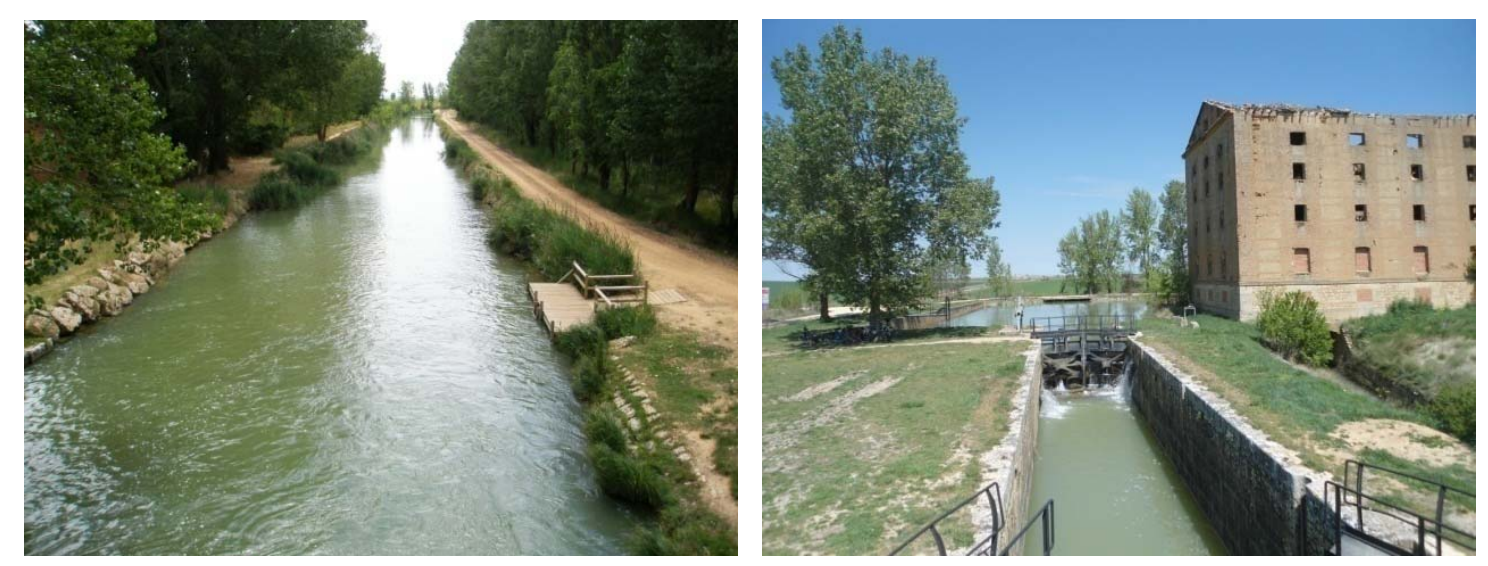

Figura 4.11. Izquierda, vista del Canal de Castilla en Abarca de Campos; derecha, esclusa 7 y antigua fábrica de harinas en las cercanías de Tamariz de Campos.

En cuanto al trazado del Canal de Castilla (Figura 4.12) -incluyendo sus tres ramales Norte, de Campos y Sur-, presenta una configuración de " $Y$ " invertida. Toma el Canal las aguas del río Pisuerga en Alar del Rey para recorrer el primer tramo (Ilamado Ramal Norte) hasta Calahorra de Ribas, en un trayecto de $75 \mathrm{~km}$ en los que salva el desnivel por medio de 24 esclusas. El ramal 
de Campos parte de Calahorra de Ribas hasta Medina de Rioseco, con un proyecto de $78 \mathrm{~km} \mathrm{y}$ solamente 7 esclusas porque es el más llano. El ramal Sur comienza en El Serrón-Grijota y culmina en la dársena de Valladolid, recorriendo $54 \mathrm{~km}$ en los que se instalan 18 esclusas. La longitud total del canal de Castilla es de $207 \mathrm{~km}$ y salva un desnivel de $142 \mathrm{~m}$ por medio de 49 esclusas.

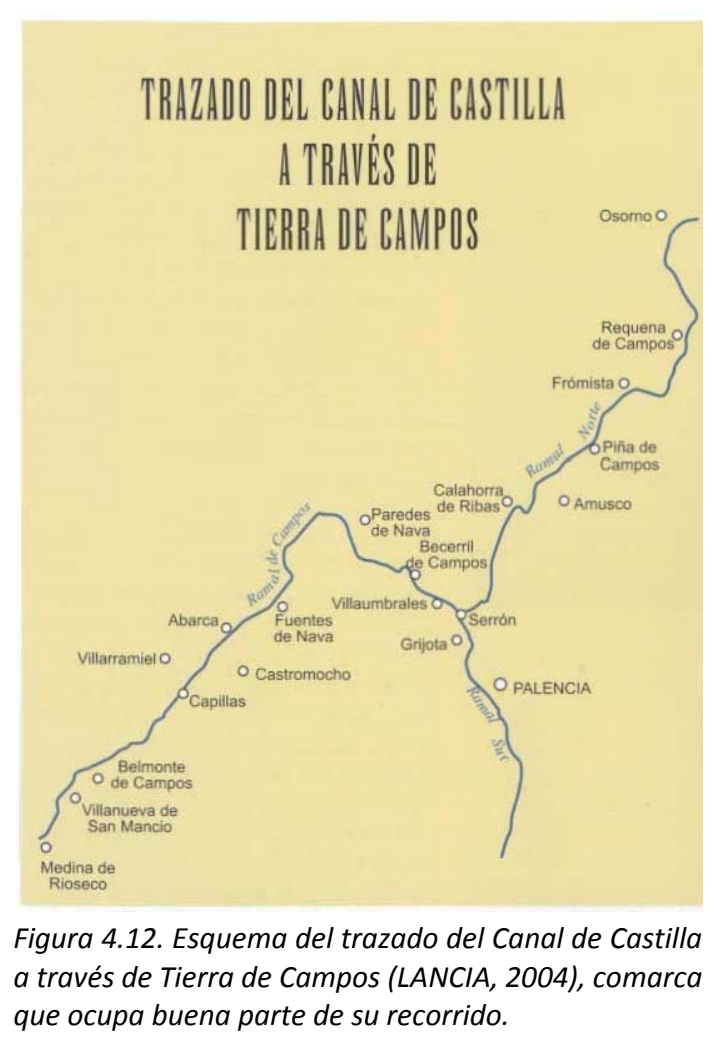

Tal como se ha apuntado, el Canal se construyó para facilitar las comunicaciones y el transporte de mercancías por medio de barcazas, de las que llegaron a circular hasta 360 simultáneamente. Incluso se implantaron 4 diligencias fluviales para realizar un servicio de pasajeros entre Valladolid y Palencia. Además su apertura significó también el desarrollo de la agricultura y ganadería al facilitar la salida de sus productos, y en sus orillas se levantaron fábricas de harina, textiles, de curtidos y astilleros para la construcción de barcazas, lo que acarreó el desarrollo económico de su entorno. Basta señalar que en sus orillas se alzaron más de 40 nuevas industrias, la mayoría de ellas fábricas de harinas.

Con la llegada del ferrocarril en la segunda mitad del siglo XIX, el transporte por el Canal fue perdiendo importancia, hasta quedar relegada su utilización a canal de riego y abastecimiento de agua de las poblaciones cercanas. Aunque a primeros del siglo XX se realizaron diversas mejoras para modernizar sus estructuras, no se logró frenar su declive, siendo definitivamente cerrado a la navegación el año 1959.

No obstante, desde finales del siglo XX se percibe que el Canal de Castilla es un recurso cultural, natural y económico de primera magnitud. Se trata de un elemento singular del patrimonio que 
trasciende el campo de la ingeniería hidráulica para dirigirse al de la arquitectura, que con sus obras embellece su entorno, y al del medio ambiente, que a través de la vegetación que jalona sus orillas da vida a su alrededor. En 1991 se declara Bien de Interés Cultural, con categoría de Conjunto Histórico; paralelamente se redactan diversos planes territoriales que afectan a su entorno, con la intención de proteger el patrimonio asociado al Canal y el paisaje a su alrededor. El Ministerio de Medio Ambiente ha llevado a cabo importantes proyectos de recuperación ambiental e hidrológica que, entre otras actuaciones, han permitido la delimitación de su superficie pública, la rehabilitación de los caminos de sirga para su uso recreativo a todo lo largo del Canal, la consolidación del cauce o la realización de plantaciones vegetales en sus márgenes.

Recientemente se han habilitado tramos para la navegación con fines turísticos (Figura 4.13), en Herrera de Pisuerga, Villaumbrales y Medina de Rioseco. En la primera de las dos localidades terracampinas, Villaumbrales, la Diputación de Palencia ha construido en la Casa del Rey un museo temático dedicado al Canal de Castilla. Allí mismo se ubica el embarcadero del barco turístico Juan de Homar -que funciona a propulsión eléctrica y es totalmente ecológico-, desde donde realiza un recorrido de $5 \mathrm{~km}$ hasta la primera arqueta de riego. Medina de Rioseco es tal vez la población donde más se ha desarrollado el uso turístico en torno al Canal, existiendo un centro de recepción de viajeros. La Diputación de Valladolid gestiona con éxito viajes diarios de la embarcación Antonio de Ulloa, planteándose tres opciones: de una hora (7 km ida y vuelta), de dos horas y media a la $7 \underline{a}$ esclusa ( $14 \mathrm{~km}$ y subida a la esclusa) y de tres horas y media a la $6 \underline{a}$ esclusa ( $16 \mathrm{~km}$, subida a la esclusa, parada en el acueducto y degustación). En verano la oferta turística se complementa con el programa "La aventura del Canal", que incluye el alquiler de piraguas, bicicletas, car a pedales e incluso una barca eléctrica. Asimismo, los caminos de sirga son frecuentemente utilizados para pasear, correr o ir en bicicleta. 

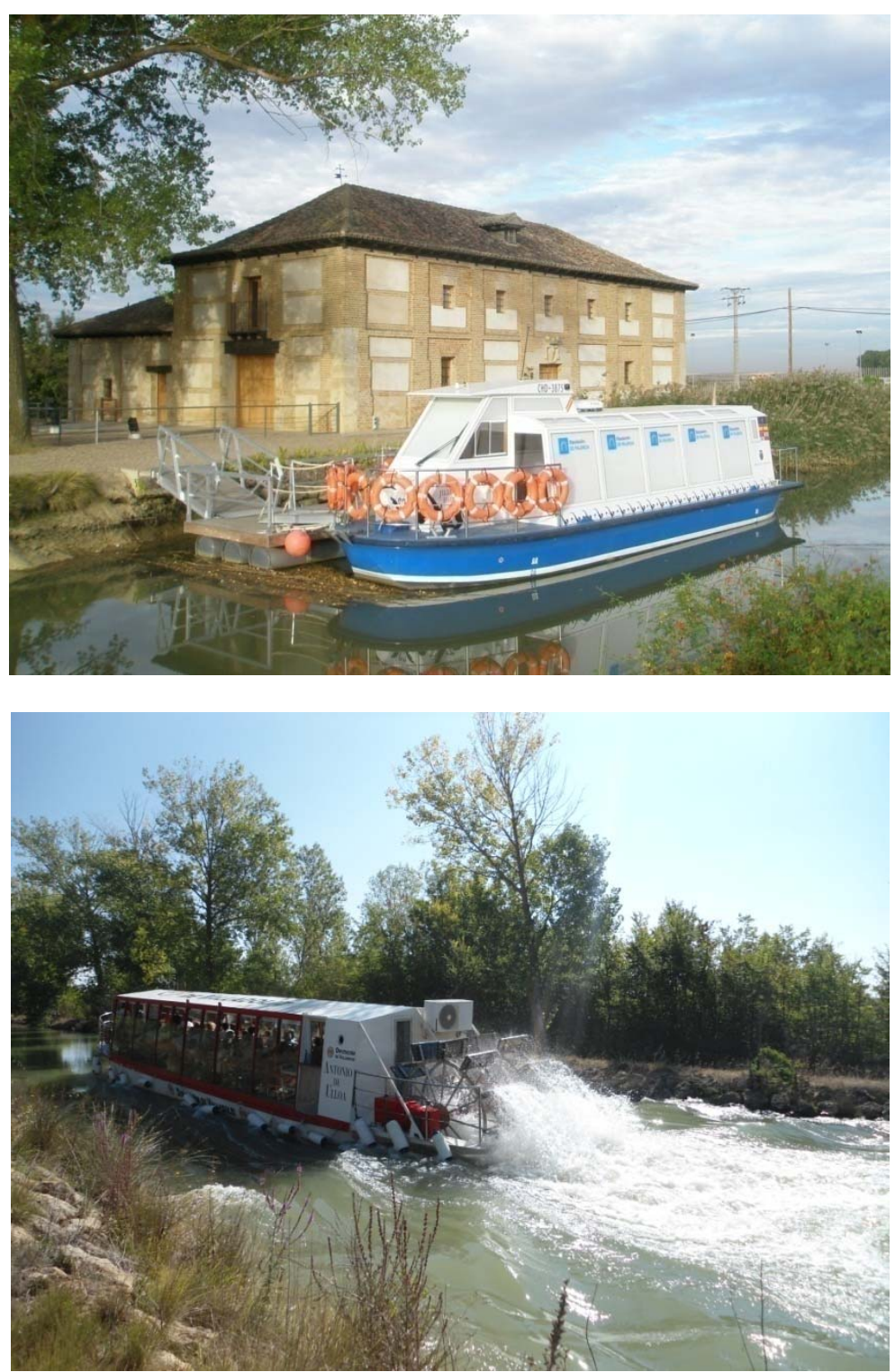

Figura 4.13. Arriba, museo temático del Canal de Castilla y embarcación turística Juan de Homar, en Villaumbrales. Abajo, embarcación Antonio de Ulloa en la ruta desde Medina de Rioseco hasta Tamariz de Campos (7 $\underline{a}$ esclusa).

El uso del Canal de Castilla para caminar o ir en bicicleta es tal vez uno de los que más se encuentran en auge en esta primera parte del siglo XXI. Las dársenas de Medina de Rioseco y Palencia acogen diariamente a un buen número de vecinos para realizar ejercicio físico en contacto con la naturaleza. Periódicamente se organizan marchas de senderismo entre algunas de las localidades por las que discurre el Canal. Aunque tal vez una de las iniciativas más interesantes que se están llevando a cabo en los últimos años es el Gran Premio Canal de Castilla, que pretende consolidarse como una carrera ciclista y una marcha cicloturista similar a las grandes clásicas ciclistas europeas (Roubaix, Flandes, Eroica, etc.), al tiempo que persigue conseguir un desarrollo turístico adicional por los territorios que atraviesa basado en el uso de la bicicleta. 
Recientemente se han editado varias guías y libros que ayudan a interpretar el recorrido desde una perspectiva natural y cultural amplia. Una de las publicaciones más representativas es $E I$ Canal de Castilla. Guía para caminantes (SÁEZ HIDALGO, 2001). Este autor señala que las posibilidades del Canal desde un punto de vista turístico y cultural son inmensas, tal y como ya se ha atestiguado en las experiencias desarrolladas desde hace años en otros países europeos y que, en nuestro caso, tan solo han comenzado a ser explotadas. En esta guía se desarrolla un completo relato de los avatares históricos del proyecto, describiéndose todos los elementos construidos de una forma ordenada geográficamente para cada uno de los ramales del Canal. De este modo se detallan esclusas, acueductos, presas, puentes, molinos, batanes o edificaciones asociadas a la obra, e incluso se acompañan interesantes apuntes de las poblaciones y elementos del patrimonio histórico-artístico por las que atraviesa el Canal de Castilla. La cantidad es enorme, prueba indudable del valor que tiene la ruta desde el punto de vista cultural y de ingeniería. De igual modo se apunta la importancia paisajística y ecológica de las choperas que jalonan el curso, así como de las lagunas creadas en el entorno a partir de infiltraciones del propio Canal, que dan vida a numerosas especies de fauna. Los chopos tienen una importancia fundamental, sobre todo en el ramal de Campos, ya que -en palabras del autoraportan una agradable nota de frescor y colorido que rompe la tópica monotonía de las tierras castellanas. El resto de vegetación natural que acompaña al Canal en sus márgenes (Figura 4.14) posee en determinadas épocas del año una especial belleza.

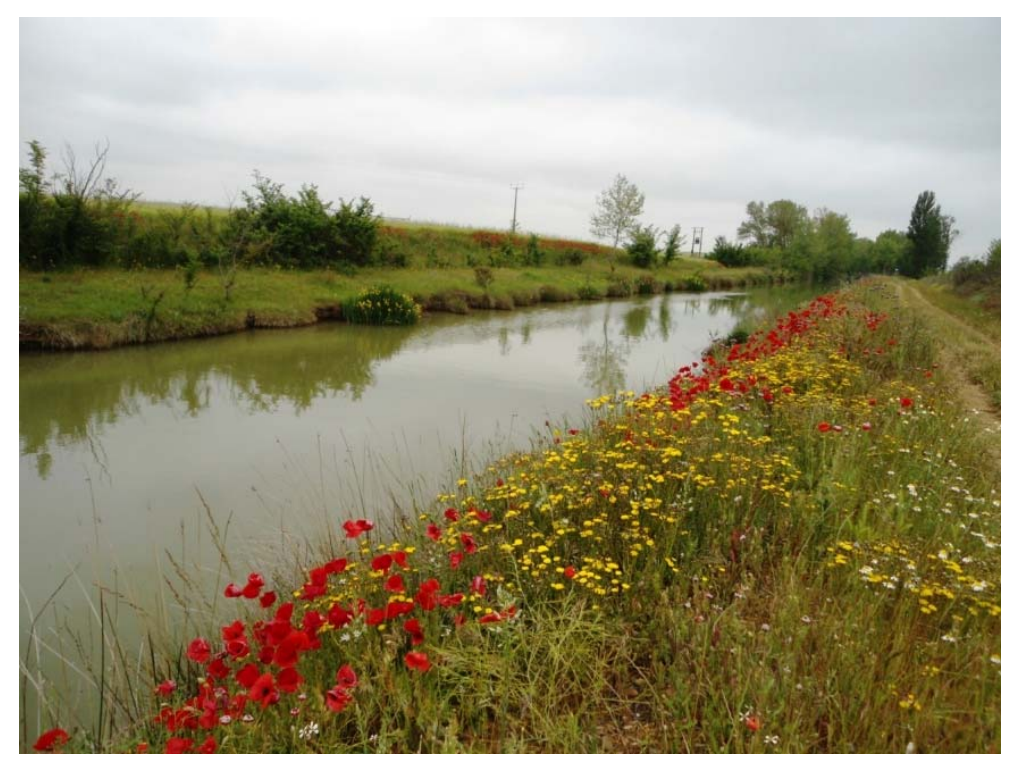

Figura 4.14. Canal de Castilla a su paso por Castromocho, con sus márgenes floridos en mayo.

En otras publicaciones más divulgativas (ECLÉCTICA, 2006) se vuelve a destacar el valor de esta fabulosa obra de ingeniería de la llustración española, realizada con unos medios técnicos que nada tienen que ver con los que se pueden contar en nuestros días. En esta guía se detallan quince rutas -no establecidas por jornadas, sino más bien por recorridos temáticos- a través de las cuales el viajero puede sumergirse en un paisaje que transcurre entre los mansos caminos 
de sirga y los pétreos elementos que le dieron forma y que comparten su naturaleza con la de los monumentos presentes en las poblaciones que conforman su entorno histórico.

En la obra de FRECHILLA (2007) -que es un verdadero compendio de la comarca- se describe el sendero de Gran Recorrido GR 89 "Canal de Castilla" que, junto al sendero GR 26 "Tierra de Campos", trazan una ruta circular que une por caminos Valladolid, Medina de Rioseco, Paredes de Nava y Palencia. En el GR 89 se detallan seis etapas de entre 15 y 20 kilómetros para recorrer en una jornada. A través de ellas, el autor realiza una descripción integral del paisaje que atraviesa el Canal y del propio conformado por esta maravillosa obra de ingeniería (Figura 4.15). Tal vez su mayor virtud sea la de añadir el componente de la naturaleza al de otros mayormente tratados, como la historia, la ingeniería hidráulica, el patrimonio histórico-artístico o la etnografía. De este modo analiza el importante papel de la vegetación en el Canal de Castilla, que en la primera fase de transporte por embarcaciones se reduciría a la plantación de chopos en los márgenes exteriores a los caminos de sirga (los interiores debían permanecer limpios para facilitar el arrastre de las barcazas por las caballerías de mulas). Tras la reconversión del Canal a regadío, su aspecto ha ganado en naturalidad y biodiversidad: los chopos han seguido creciendo y colonizando nuevos espacios; a su amparo han prosperado otras especies como el olmo (aunque actualmente presente porte arbustivo), el fresno, el sauce o el aliso, y se ha facilitado la aparición de formaciones palustres como juncales, carrizales o espadañales de anea. También descubre la cantidad de aves forestales que viven en los sotos ribereños: palomas torcaces, tórtolas comunes, bisbitas o carboneros comunes; rapaces nocturnas como el búho campestre y la lechuza común; acuáticas como los ánades azulones, fochas, somormujos o porrones; grandes aves como las garzas y los cormoranes, así como pequeños pájaros gregarios que se alimentan en los cultivos y descansan en los árboles del soto, como el gorrión molinero, el gorrión chillón, el ruiseñor bastardo o el chochín. Además destaca el gran valor natural que poseen las lagunas asociadas al Canal o situadas en su entorno, como son el propio conjunto de lagunas del Canal de Castilla, la laguna de Tamariz, la laguna de Boada y la laguna de la Nava.

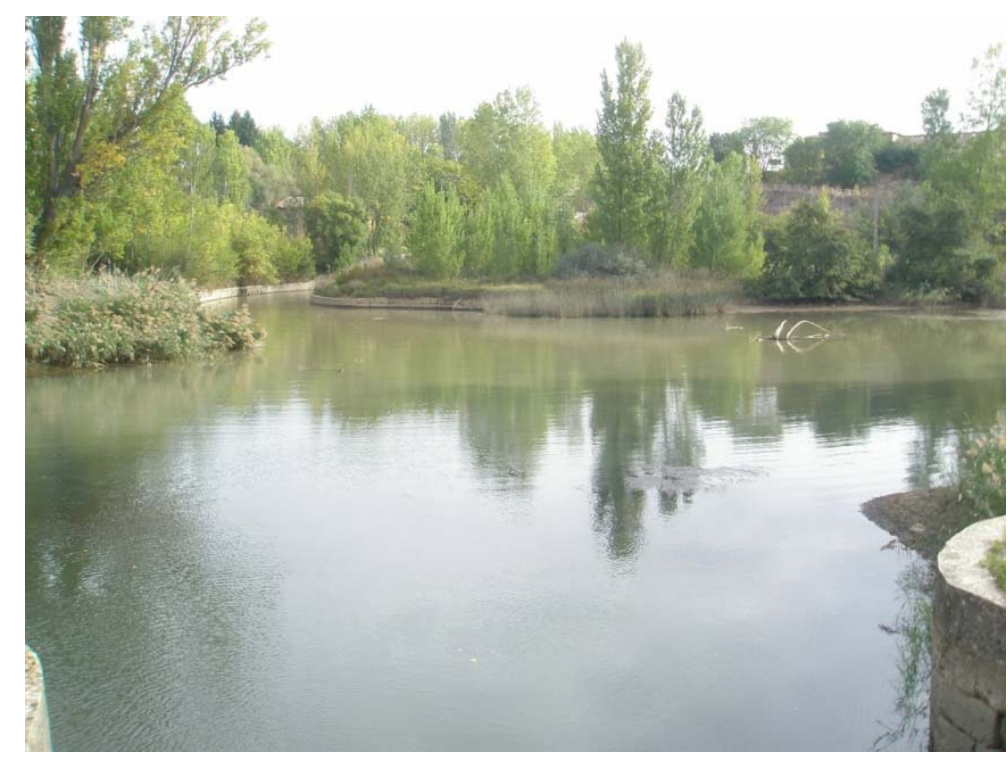

Figura 4.15. Confluencia del Canal de Castilla con el río Carrión en Calahorra de Ribas. 
En resumen, el Canal de Castilla es uno de los hitos más significativos del paisaje de Tierra de Campos. Su valor es inmenso desde varios puntos de vista: ingenieril, histórico, arquitectónico, cultural o natural. Como contrapunto, resulta especialmente urgente la protección y restauración del ingente patrimonio arquitectónico asociado al Canal, que en muchos casos se encuentra en un punto cercano a la irreversibilidad. La concienciación de la sociedad y de las administraciones públicas es fundamental, porque aún posee un tremendo potencial para el desarrollo rural del territorio que atraviesa

\subsection{Suelos}

En la campiña de Tierra de Campos se dan varios tipos de suelos: pardocalizos, aluviales, de terraza y salinos (VACA, 1992). Los más extendidos son los pardocalizos sobre material no consolidado, que se sitúan en los interfluvios y laderas y solo se ven interrumpidos por los depósitos aluviales de los ríos que atraviesan la comarca. Estos suelos se caracterizan porque en su composición entra un porcentaje muy elevado de arcilla, que aumenta progresivamente en profundidad, lo que motiva que sean suelos fuertes y consistentes. Son suelos relativamente profundos y admiten una gran cantidad de agua durante las estaciones lluviosas, que almacenan en sus horizontes profundos hasta la estación estival. En términos generales, su composición química es apropiada para el cultivo cerealista. GARCíA FERNÁNDEZ (1966) apunta que su proporción en fósforo y potasio no es la idónea para dar unos buenos rendimientos pero, en cambio, el contenido de cal es en general elevado. Sin embargo, presentan la desventaja de ser muy pobres en materia orgánica.

Los suelos aluviales se hallan a ambos lados de los principales ríos de la comarca, en los sectores de inundación de los valles fluviales, en las llamadas vegas. Por lo general presentan mayor potencialidad que los anteriores, tanto por su situación como por su riqueza en elementos nutritivos y en materia orgánica. Son los suelos más ricos de la comarca, apropiados para la práctica intensiva de la horticultura y de otros cultivos exigentes en agua.

Los suelos de terrazas se localizan, como los anteriores, a lo largo de los ríos, cubriendo superficies más o menos amplias sobre sus terrazas, con una continuidad muy variable. Posiblemente la característica principal en su composición es la presencia de un alto contenido de gravas, de distinto tamaño, disposición y naturaleza. Son de gran tamaño y de considerable proporción las de los ríos que descienden de la cordillera Cantábrica, mientras que las de las terrazas bajas suelen ser más arenosas. Tradicionalmente estos suelos han sido dedicados preferentemente a la viticultura y al cultivo del centeno.

Finalmente, los suelos salinos de la campiña no constituyen superficies continuas y son poco representativos; aparecen como manchas dispersas y aisladas. Coinciden con los sectores de más deficiente drenaje, como las lagunas de Villafáfila y de la Nava y los pequeños y numerosos lavajos que se desecan durante el estiaje. Provienen de la acumulación de sales en los horizontes edáficos provocada por el endorreísmo, la sequedad y la intensa evaporación de los meses estivales. En estos suelos solo puede crecer una vegetación peculiar, resistente a la salinidad, tal como las salicornias, juncales y carrizales. 
Entre los suelos de los páramos que rodean las campiñas hay que hacer, a su vez, una diferenciación entre los pertenecientes a los páramos de raña y los relativos a los páramos calcáreos.

Los que recubren las plataformas de raña son suelos pardocalizos asentados sobre gravas cuarcíticas. Son suelos más secos que los de la misma tipología de la campiña, al poseer a poca profundidad potentes estratos de caliza. Químicamente se trata de suelos bastante pobres, tanto en materia orgánica como en sustancias nutritivas, y de escasa fertilidad.

Los suelos que recubren los páramos pontienses de Castrojeriz, Cerrato y Torozos, también son pardocalizos. Se hallan constituidos por una capa poco profunda arable, generada sobre el manto calizo que protege estos páramos. Se trata de suelos pobres y poco fértiles, con alto contenido en calcio, lo que condiciona los cultivos.

En el estudio de los suelos de Tierra de Campos en Palencia (RUIPÉREZ y GONZÁLEZ, 1991), extrapolable a los suelos agrarios de toda la comarca, realizado con un tamaño de muestra superior a 400, se establecen resultados de los parámetros edáficos más significativos con vistas a su cultivo, cuyas principales conclusiones resumimos a continuación:

- La media del valor de materia orgánica es del $1 \%$, que es excesivamente bajo (el mínimo se suele cifrar en un $2 \%)$.

- La media del valor de nitrógeno total, 0,12\%, se encuentra dentro de la normalidad pero en sus niveles más bajos, por lo que se requiere aportar fertilizantes nitrogenados.

- El valor medio de fósforo (15 ppm) es aceptable, pero con gran variabilidad, por lo que este nutriente debe ser vigilado de cara a la producción.

- La media de los valores de carbonatos totales es de 9,4\%, abarcando desde los suelos muy calizos (un $80 \%$ ) hasta los que no tienen nada de carbonato.

- El pH medio es del 8,3, lo que indica que estamos ante suelos básicos.

- La mayoría de los suelos de esta comarca tienen unas cantidades de arcilla altas; sus posibilidad de fertilidad son altas, pero se ven condicionadas por los bajos niveles de materia orgánica y nutrientes.

También se han realizado mapas de suelos por instituciones científicas (CSIC-IRNA, 1993), que establecen que en Tierra de Campos las principales unidades y subunidades de suelos corresponden a regosoles calcáreos, cambisoles cálcicos y luvisoles cálcicos. En las vegas de los ríos y arroyos son los fluvisoles calcáreos los que dominan.

\subsection{Vegetación}

Desde el punto de vista biogeográfico, Tierra de Campos -como buena parte de Castilla y Leónse encuentra en la denominada Región Mediterránea que, a diferencia de la Región Eurosiberiana, se caracteriza por las escasas precipitaciones y unos veranos secos y calurosos (ORIA DE RUEDA, 2007). Este territorio está sometido a un clima típicamente mediterráneo, donde se desarrolla una vegetación xerófila adaptada precisamente a la sequía y al calor estival. 
En este sentido, es opinión generalmente compartida que la vegetación clímax de los sectores central (campiña) y marginales (páramos) de Tierra de Campos estuvo constituida por el bosque esclerófilo mediterráneo, compuesto por formaciones leñosas de frondosas de hoja persistente y coriácea, adaptadas a climas con periodos áridos. La encina (Quercus ilex) es la especie prototipo de esta formación (Figura 4.16). Resulta un árbol muy resistente ante condiciones adversas, hasta límites bastante amplios: lo mismo soporta el calor que el frío, la solana que la umbría; posee una gran vitalidad por el desarrollo de su sistema radicular, que penetra profundamente en el terreno, incluso a través de las duras capas calizas de los páramos, para apropiarse de la humedad y de las sustancias nutritivas precisas; se adhiere a los terrenos mediocres y pobres, tanto calizos como silíceos, y solo rehúye los encharcados y tolera mal los margosos y arcillosos muy compactos (VACA, 1992).

En este primitivo bosque esclerófilo, junto a la encina, es de suponer la existencia en los suelos detríticos de los páramos de raña, formando bosques mixtos, de robles o rebollos (Quercus pyrenaica), y de quejigos (Quercus faginea) en los suelos calizos de los páramos pontienses.

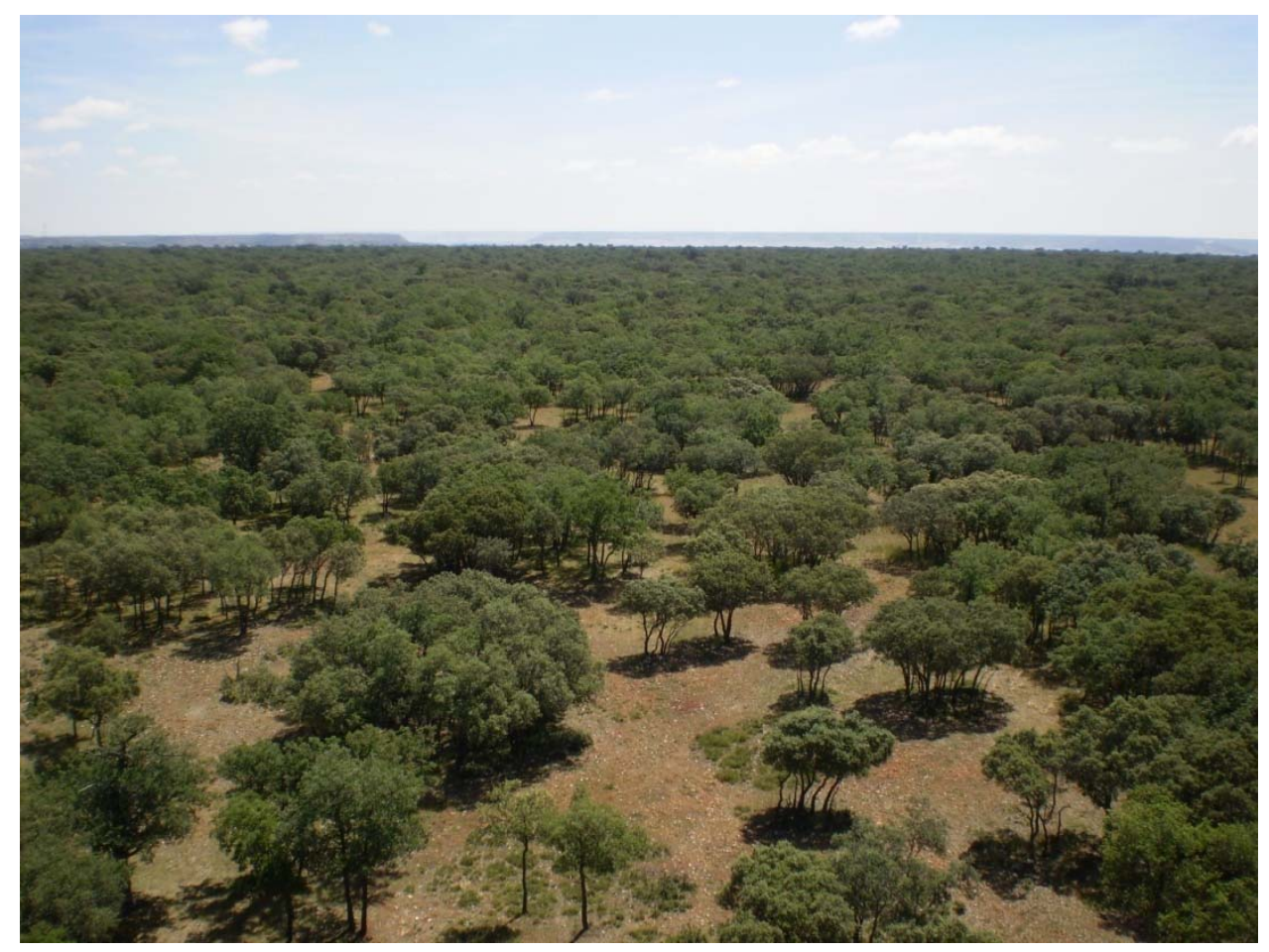

Figura 4.16. Vista del Monte EI Viejo (Palencia), en el borde del páramo calcáreo.

El origen de este bosque esclerófilo de encinas, robles y quejigos que cubrió la cuenca duriense se remonta a la finalización del último periodo frío, es decir, de la glaciación Würm, que tuvo lugar unos 10000 años antes de nuestra era. La llegada del Holoceno supuso un cambio drástico en el clima (FRANCO et al., 2007), con aumentos notables de las temperaturas y de las precipitaciones, lo que conllevó en la Península Ibérica la modificación de un paisaje vegetal con presencia de vegetación esteparia, brezales, pinares, enebrales y sabinares hasta la 
recuperación de los bosques templados y mediterráneos (caducifolios, marcescentes y esclerófilos).

Las condiciones edáficas de los depósitos miocénicos y las condiciones climáticas de Campos resultan apropiadas para la instalación de este tipo de formación vegetal, por lo que puede admitirse la hipótesis de que el bosque esclerófilo también constituyó la formación clímax de Tierra de Campos, salvo en dos zonas en las que resulta difícil admitir su presencia: las distintas manchas de los terrenos salitrosos, más extendidas en la zona Villafáfila-Salado, donde no cabe pensar en otras formaciones vegetales distintas a las propiamente heliófilas, y los terrenos aluviales situados a los largo de las márgenes de los ríos, donde debido al constante nivel de agua subterránea hay que suponer la presencia de especies ripícolas (choperas, alamedas, saucedas, olmedas, etc.).

Este paisaje vegetal primitivo es confirmado por PLANS (1970), quien señala que buena parte de la comarca estaba cubierta por bosques esclerófilos de encinas y quejigos, atravesados por auténticas junglas lineales de especies ripícolas a lo largo de los ríos; con la excepción de los enclaves desarbolados ligados a máxima concentración salina yesosa, como las zonas próximas a las lagunas de la Nava y Villafáfila.

La Memoria y Mapa de las series de vegetación de España (RIVAS-MARTíNEZ, 1987) constata que la vegetación potencial de Tierra de Campos -el estado maduro del ecosistema o clímaxcorresponde a bosques densos de quercíneas. De este modo, la inmensa mayoría de su territorio se engloba en la serie de la encina: 22a "Serie supramediterránea castellano-maestrazgomanchega basófila de Quercus rotundifolia o encina. (Junipero thuri-ferae-Querceto rotundifoliae sigmetum). VP, encinares". El sector nororiental de la comarca y las cuestas del páramo de Torozos corresponde a la serie del quejigo: 19b "Serie supra-mesomediterránea castellano-alcarreño-manchega basófila de Quercus faginea o quejigo. (Cephalanthero longifoliae-Querceto fagineae sigmetum). VP, quejigares". Finalmente, a lo largo de sus ríos y arroyos se extienden las series riparias I "Geomegaseries riparias mediterráneas y regadíos", que fundamentalmente son del tipo basófila mediterránea (Olmedas).

No obstante, para comprender la profunda transformación del paisaje vegetal hasta nuestros días, resulta fundamental tener en cuenta la acción humana (ORIA DE RUEDA, 2007). Desde la antigüedad el hombre ha eliminado unas especies arbóreas en algunos lugares, ha mantenido otras y ha modelado e instaurado bosques seminaturales de distintas especies, tanto frondosas como coníferas. La segregación de usos se originó ya en el Neolítico y se afianzó sobre todo tras la dominación cultural céltica (con los pueblos vacceos), originando un mosaico de paisajes destinados a la producción de los distintos recursos: pastos, leñas, cortezas, frutos, maderas o cultivos. De hecho, no hay que descartar que los bosques primitivos que cubrían esta comarca ya fuesen siendo eliminados hace 6000 o 7000 años por fuego y pastoreo. Así lo atestiguan diversos registros paleobotánicos de la Cuenca del Duero, como los de Espinosa de Cerrato (localidad del páramo oriental cercana a Tierra de Campos), donde además se ha comprobado una importante presencia de pinares y abedulares en la primera mitad del Holoceno (FRANCO et al., 2007).

En VACA (1992) se hace un magnífico relato de la previsible evolución de la vegetación arbolada en la comarca hasta la Edad Media. Así, este autor señala que con anterioridad al siglo III a. de 
C. la situación originaria de la vegetación de Tierra de Campos sufrió un cambio bastante pronunciado. De entonces datan las primeras noticias escritas sobre esta comarca y, en particular, sobre su paisaje vegetal; corresponden a escritores griegos y romanos como Estrabón, Apiano o Avieno, que historiaron la conquista de Hispania por los romanos. Según una narración de Apiano acerca de la campaña de Lúculo (HOPFNER, 1954), los páramos estaban poblados por espesos bosques de Quercus que cubrían amplias zonas por donde transitaban grandes ejércitos romanos sin ser percibidos, mientras que, por el contrario, la zona de las arcillas terracampinas es caracterizada por su pobreza o total ausencia de arbolado. La vasta campiña situada entre Pallantia e Intercatia era la principal zona triguera de los vacceos.

En consecuencia, hay que atribuir al campesino prerromano una intensa y progresiva actividad de rozar el bosque de la campiña hasta su práctica desaparición o, al menos, su degradación en monte bajo residual. Se ha de tener en cuenta, asimismo, que esta labor tuvo que ser realizada en un largo periodo de tiempo, ya que no es fácil la conversión del bosque de quercíneas al suelo agrícola, por la gran capacidad de rebrote de estas especies; ello hubo de ser realizado seguramente con quemas frecuentes y pastoreo o laboreo continuado. Es previsible también que los bosques de la campiña fuesen incluso más densos y con ejemplares arbóreos de mayor porte que los existentes en los páramos, teniendo en cuenta que originariamente los suelos eran más profundos y de mayor calidad.

La posterior presencia romana y visigoda en Tierra de Campos no parece que influyera de forma notable en la situación del bosque esclerófilo ni que con ellos se invirtiera esta tendencia a su degradación, a pesar de las normas dictadas por los visigodos que prohibían el pastoreo de los bosques y sancionaban los desafueros cometidos contra los árboles. Tampoco la corta estancia de los bereberes, después de la conquista de la Península por los musulmanes, debió suponer un cambio apreciable en el cuadro de la vegetación.

Es posible que en los primeros siglos medievales la campiña sufriera alguna pequeña modificación. Estas llanuras se convirtieron en "tierra de nadie", como un vasto desierto estratégico, frontera en los conflictos bélicos entre cristianos y musulmanes. Al disminuir notablemente su población, tal vez se redujo la superficie cultivada, con una cierta regeneración del bosque primitivo en los campos abandonados, hasta su nueva reexplotación, después de la conquista y colonización de esta comarca por los cristianos del norte durante los siglos IX y X. Entonces se iniciaría una nueva etapa en la historia de la vegetación de Tierra de Campos caracterizada por la progresiva degradación del bosque esclerófilo. Una vez asentados los territorios bajo dominio cristiano, la actividad agrícola se desarrolla en mayor medida, aunque fue la actividad ganadera la determinante en el deterioro del bosque, debido a la presión ejercida por la gran densidad de la cabaña ganadera que pastaba de modo extensivo por el terrazgo. De hecho, MARTíNEZ SOPENA (1985) comenta que, ya en el siglo XII, el viajero Aymerich Picard se asombraba de este paisaje "sin árboles", al atravesar el Camino de Santiago por estas tierras. Aun así, a finales del siglo XV se talaron muchas extensiones boscosas con el fin de satisfacer las necesidades de leña y madera. Únicamente quedaron pequeñas manchas residuales de monte, aisladas entre sí y diseminadas por amplias zonas dedicadas al cultivo del cereal, como el monte al norte de Belver de los Montes y en el Raso de Villalpando, ya citado por Fernando Colón, hijo del descubridor, en el siglo XVI y que, en parte, ha sido conservado hasta nuestros días; el monte Becerril (Figura 4.17) o el monte de la Cepuda en Paredes de Nava. 

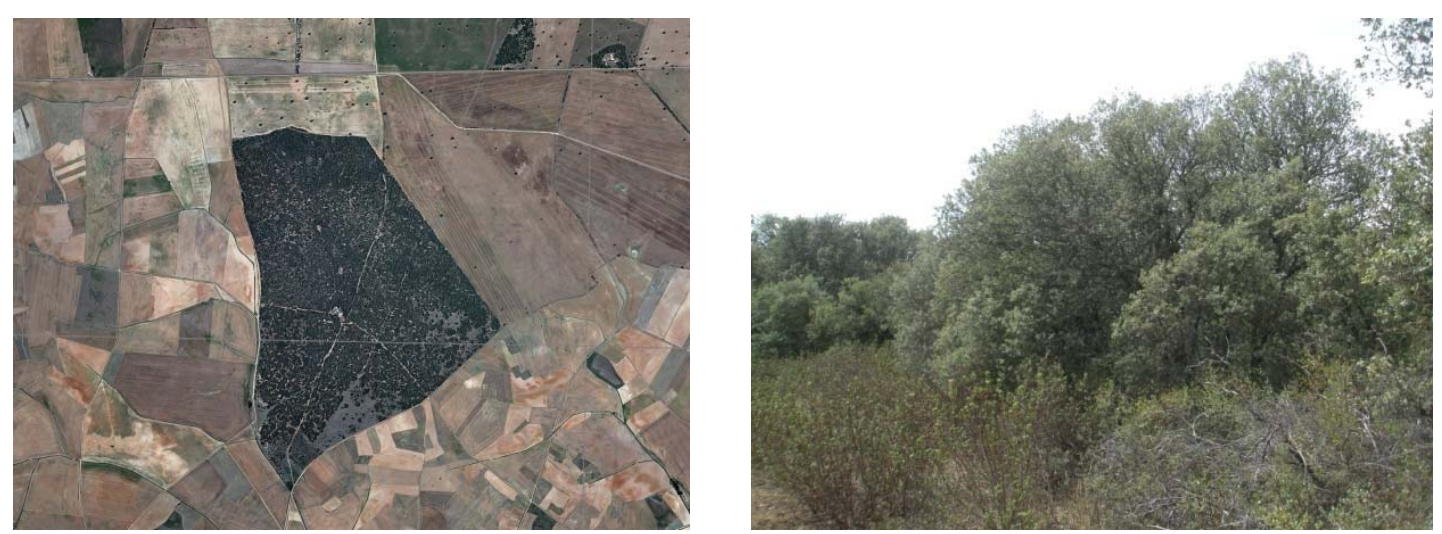

Figura 4.17. Izquierda, ortofotografía del Monte Becerril, en Becerril de Campos: un enclave forestal de 166 ha en pleno medio agrícola. Derecha, encinar en el Monte Becerril.

El pastoreo de los ganados, en especial, debió ocasionar importantes y, a veces, irreparables daños al arbolado, pues fue frecuente que los reyes medievales otorgaran a los pastores de los señores concesiones para ramonear en los montes, así como generalizada la costumbre de prender fuego al bosque durante el otoño para obtener mejores pastos en la primavera siguiente. De hecho, la actividad pecuaria dispuso sin límites del espacio forestal gracias al apoyo del Honrado Concejo de la Mesta, hermandad de ganaderos que fue favorecida por las leyes para que la Corona de Castilla fuese la principal suministradora de lana del mercado europeo (GIL, 2007). Evidentemente, también la continua búsqueda de nuevos terrenos de cultivo por los labradores, a medida que la población de las campiñas aumentaba, contribuyó de manera decisiva a la progresiva destrucción del bosque original.

Aun así, el paisaje de la Edad Media, a pesar de que ya era eminentemente agrícola, no estaba exento de arbolado o de vegetación arbustiva. Existen numerosas referencias documentales y toponímicas que ayudan a interpretar el paisaje vegetal en el siglo XIV. Así, poblaciones como Valdesalce, Olmillos, Quintanilla del Olmo, Valdeolmillos o Población del Soto se refieren a zonas frescas de la comarca, en el entorno de ríos y arroyos. Belmonte, Montealegre o Paredes del Monte hacen referencia a la presencia del bosque de quercíneas en la zona de transición de la campiña con el páramo calcáreo; incluso con presencia en algunas zonas de enebro (Valdenebro). En las proximidades de los páramos de rañas la toponimia también hace mención al roble (Villanueva del Rebollar). Un pago de Villalón de Campos -municipio con casi el $100 \%$ de su superficie actualmente cultivada- se denomina reguera del Monte.

También en el suroeste, el raso de Villalpando, islote de páramo de raña situado en el interfluvio Sequillo-Valderaduey, aparecía poblado en esta época por un espeso bosque esclerófilo. Atestiguan esta existencia, además de los topónimos de Quintanilla del Monte, Cabreros del Monte, Cotanes del Monte y Belver de los Montes, la referencia concreta a los encinares de Mayorga y de Villalpando hecha por don Juan Manuel en el Libro de la Caza.

Al tiempo que estos bosques de encinas, quejigos, robles y árboles ripícolas, también poblaban la comarca terracampina diversos arbustos y matorrales de carácter xerófilo, como distintas especies de genistas, retamas y zarzas -Escobar, Cardeñosa, Espinosilla, Fuente Andrino, 
Valdespina, Matallana, Morales, etc.--, así como plantas herbáceas esteparias, como el albarcín o barceo, el hinojo, la mielga, el tamarisco, el heno, los juncales y cañaverales, etc., a las que indudablemente aluden los topónimos mayores de Berceo, Boada, Boadilla, Bóveda, Cañizo, Cespedosa, Estabarcio, Melgar, Prado, Támara, Tamariz, Valdehunco, Valdunquillo, etc. Los frutales también están presentes en las denominaciones de varios pueblos: Moral de la Reina y Perales son dos ejemplos de ello.

La existencia de arbolado en Tierra de Campos en siglos pasados es también referida por otros autores. Así, DUQUE (2003) señala que en el siglo XVI en Palacios de Campos había "huertas, árboles en algunos lugares, vid con abundantes guindales". Este mismo autor (2006) indica el importante papel de las Ordenanzas y de la autoridad de los guardas en el Villalón de Campos del siglo XVI. Estos "pueden denunciar todas las infracciones y preguntar a quienes traigan cepas, sarmientos, leñas, uvas, agraces, guindas, mielgas u otras frutas"; lo que da una idea de cómo era el paisaje terracampino en aquellos siglos: un mosaico con retazos de monte, muchos viñedos y numerosos frutales.

Durante el periodo de la llustración, varios científicos y técnicos extranjeros fueron contratados por la Corona para fomentar el desarrollo del país. A su llegada recorrieron España, y advirtieron en sus obras de la decadencia de los espacios arbolados cuando no de su carencia. Uno de ellos, el irlandés Guillermo Bowles (1775) señaló la ausencia general de arbolados en nuestro país en su libro Introducción a la Historia natural y a la geografía Física de España, afirmando que las causas verdaderas de esta miseria son la desidia y la ignorancia. A la Tierra de Campos la encontró "pelada y sin árboles", lo que achacaba a que sus naturales aborrecen los árboles, diciendo que solo servirían para multiplicar los páxaros, que les comen el trigo y la uva. El campesino, ganadero a la par que agricultor, solo veía en los árboles la sombra que proyectan y unas ávidas raíces, culpándoles de ser destructores de sembrados y refugio de aves granívoras (GIL, 2007). Por desgracia, este sentimiento se ha transmitido de generación a generación, perdurando aún en nuestros días.

Madoz da noticias sobre la escasa extensión del bosque hacia 1840, que en Tierra de Campos ha variado poco hasta el día de hoy. A principios del siglo XX, el escritor regeneracionista Julio Senador (1915) relata un panorama extraordinariamente árido de la meseta castellana (Figura 4.18), con innumerables citas sobre este tenor ("Hay también árboles y grupos de árboles aislados. En los países cultos son numerosos. Aquí no"). De mediados del siglo pasado es la referencia del viajero inglés Richard Ford (CONSEJERÍA DE MAOT, 1994) que tilda a esta comarca "feísima por falta de agua, árboles...". 


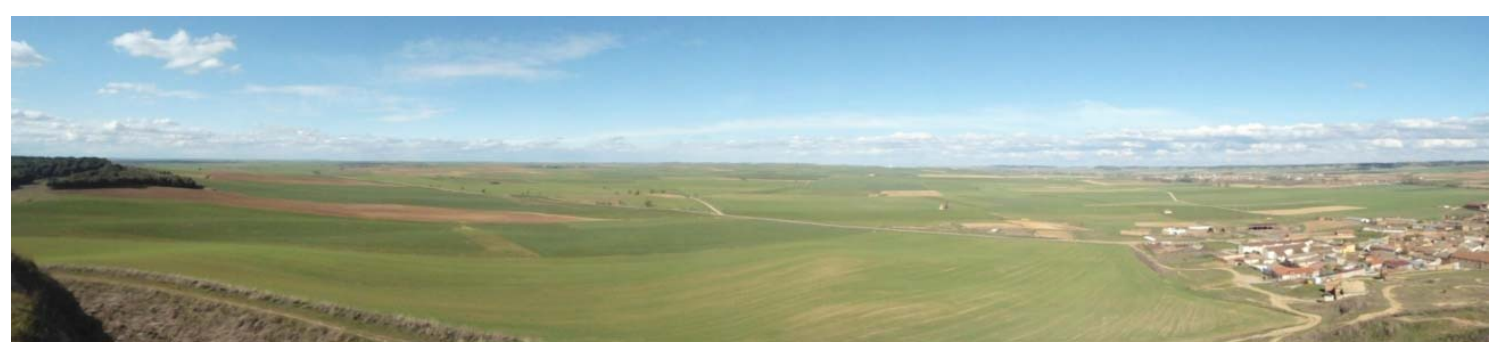

Figura 4.18. Panorámica de Tierra de Campos desde el castillo de Tordehumos, sin prácticamente atisbo alguno de vegetación arbolada.

En sentido contrario, a lo largo de la Historia se han dado tímidos avances por los gobernantes para revertir el proceso deforestador. Las primeras medidas fueron tomadas por Carlos I, que promulgó una pragmática sobre la Formación de nuevos plantíos de monte y arboleda y de ordenanzas para conservar los viejos y nuevos. La preocupación por aumentar la superficie forestal continuó con el gobierno de otros monarcas como Felipe II, Felipe V o Fernando VI, quienes promulgaron diversas ordenanzas para el aumento y conservación de montes y plantíos (EZQUERRA, 2007). No obstante, su aplicación en Tierra de Campos seguramente halló en la población una considerable resistencia, debido a las presiones de ganaderos y agricultores para mantener las tierras de pasto y cultivo. Posteriormente, y con carácter de iniciativa individual, en el siglo XIX alcaldes y gobernadores plantaron pequeños bosques de pinos, álamos u olmos.

Desde finales del siglo XVIII, la llustración propició el desarrollo de las infraestructuras de comunicación y, en muchos de sus márgenes, promovió la plantación de árboles (chopos, álamos, olmos, acacias, etc.). Así, como ejemplo, DUQUE (2005) indica que en 1863 ya se había acondicionado con árboles a ambos lados de la carretera entre Villalón de Campos y Medina de Rioseco. Estas plantaciones lineales constituyeron las únicas masas arboladas de Tierra de Campos, hasta que hace unas décadas fueran taladas por los requerimientos funcionales y de seguridad de las nuevas carreteras. En esta época se realizaron plantaciones lineales en los márgenes del canal de Castilla, sobre todo de chopos, que actualmente constituyen un auténtico corredor arbolado en la comarca. Ya a comienzos del siglo XX, en distintos tramos de los márgenes del ferrocarril de vía estrecha (el "tren burra") que atravesaba la comarca según diferentes trayectos, también se plantaron árboles (chopos lombardos, almendros, acacias, etc.) que aún se conservan en nuestros días, a pesar de haber sido desmanteladas las vías.

ORIA DE RUEDA y DÍEZ (2002) señalan que en las antiguas ordenanzas municipales de multitud de pueblos castellanos, se obligaba a todos los vecinos a plantar un cierto número de árboles de ribera y se prohibía descuajar los existentes.

La Confederación Hidrográfica del Duero ha realizado diferentes actuaciones de revegetación arbórea durante el siglo pasado en algunos de los ríos de la comarca: fundamentalmente en la vega del Carrión (Figura 4.19) -tanto con vegetación autóctona de ribera como con choperas de producción-, en algunos canales de riego y, de forma más tímida, en algunos ríos o arroyos (Valderaduey, Valdeginate). De hecho, es de las primeras administraciones modernas que comienza la actividad repobladora, como lo atestiguan por ejemplo las plantaciones realizadas 
en la ribera del Carrión en la década de 1930 o en las laderas de Villagarcía de Campos hacia el año 1940. También realizó contratos para la plantación de chopos la Junta de Castilla y León, a través de sus servicios forestales.

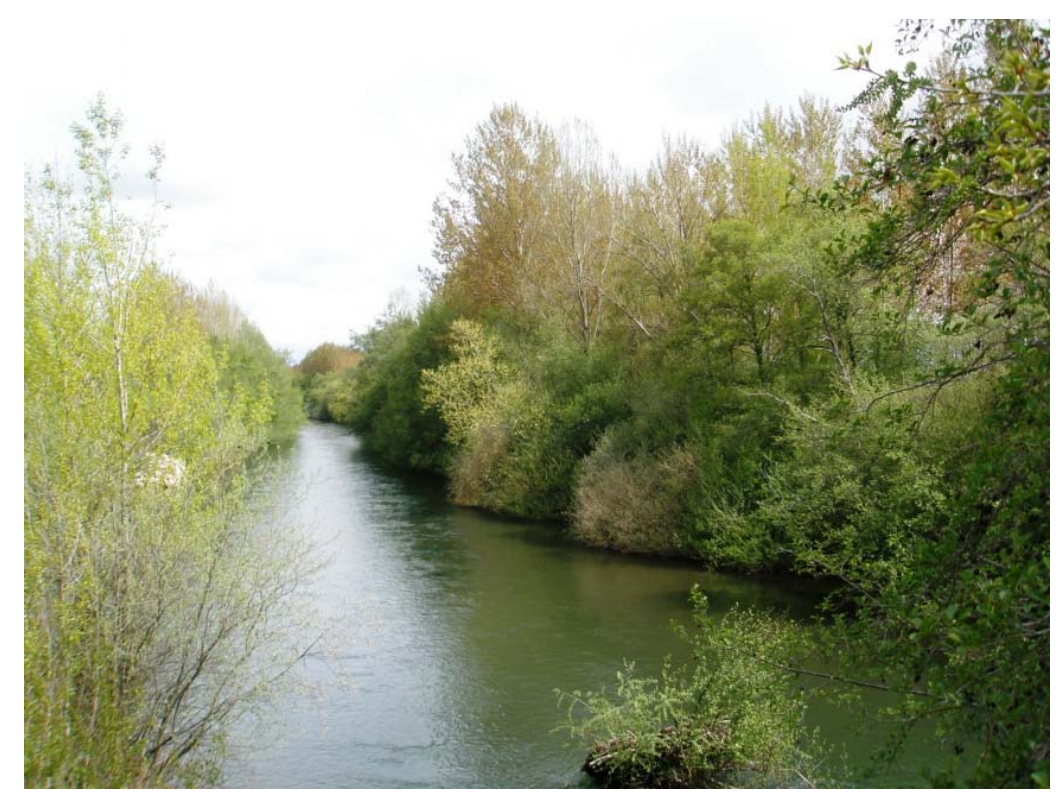

Figura 4.19. Ribera del río Carrión, en Villoldo, con abundante vegetación arbórea.

Aunque situadas en los límites comarcales, tal vez una de las actuaciones restauradoras que más ha cambiado el paisaje vegetal de Tierra de Campos en la actualidad, son las repoblaciones realizadas en las laderas de transición de la campiña con los páramos calcáreos (Figura 4.20). Su comienzo data de mediados del siglo pasado por el Patrimonio Forestal del Estado, de acuerdo con el ambicioso Plan General para la Repoblación Forestal de España, utilizándose como especie fundamental el pino carrasco, además de algún ejemplar de ciprés y, más recientemente, pino piñonero. Estas reforestaciones han tenido continuidad con los servicios forestales de la Junta de Castilla y León. Su finalidad era básicamente de tipo protectorhidrológico, teniendo en cuenta los fenómenos erosivos causados por las fuertes pendientes de las laderas y su escasa vegetación. Actualmente, pinares casi maduros cubren extensas superficies de laderas en Palencia, Ampudia, Torremormojón, Medina de Rioseco, Villagarcía de Campos, etc. 


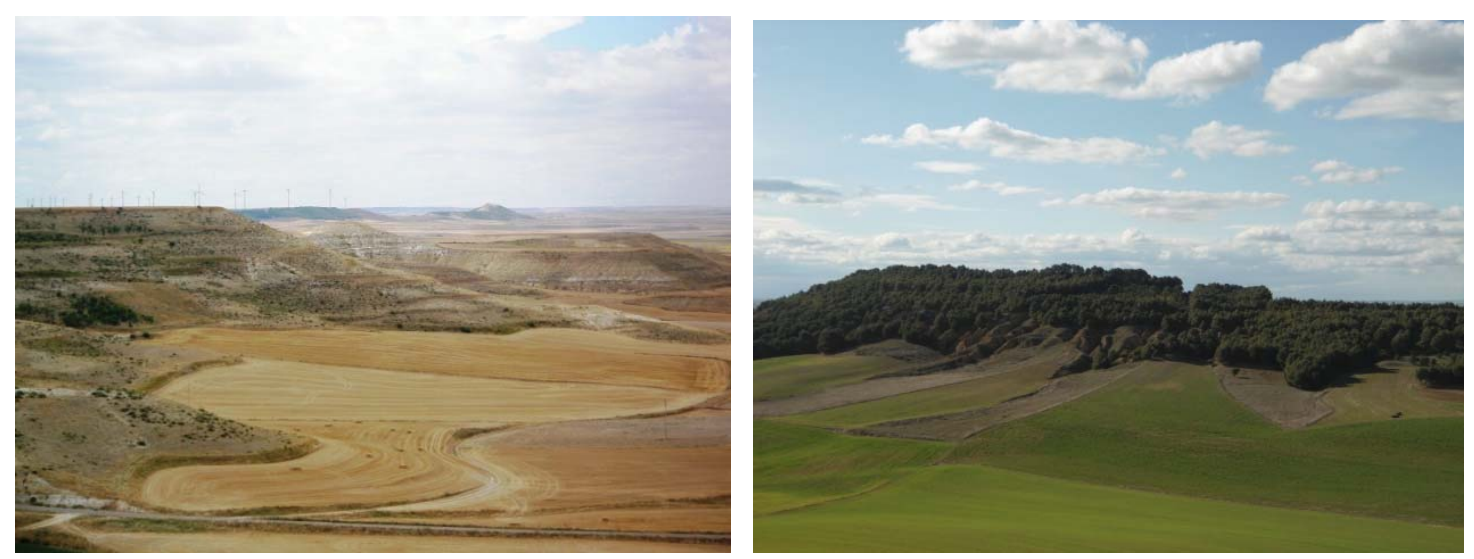

Figura 4.20. Izquierda, laderas aún deforestadas en Autilla del Pino; derecha, ladera repoblada en Tordehumos.

En la actualidad, Tierra de Campos es una de las comarcas más deforestadas de la región (ORIA DE RUEDA, 2007). De lo que debió ser un gran bosque de encinas (Quercus ilex), robles (Quercus pyrenaica) y quejigos (Quercus faginea), interrumpido por enclaves encharcadizos o salinos, solo se mantienen algunos retazos como los de Villalpando, Paredes de Nava, Becerril de Campos, Perales (Figura 4.21), Villanueva del Rebollar, etc.

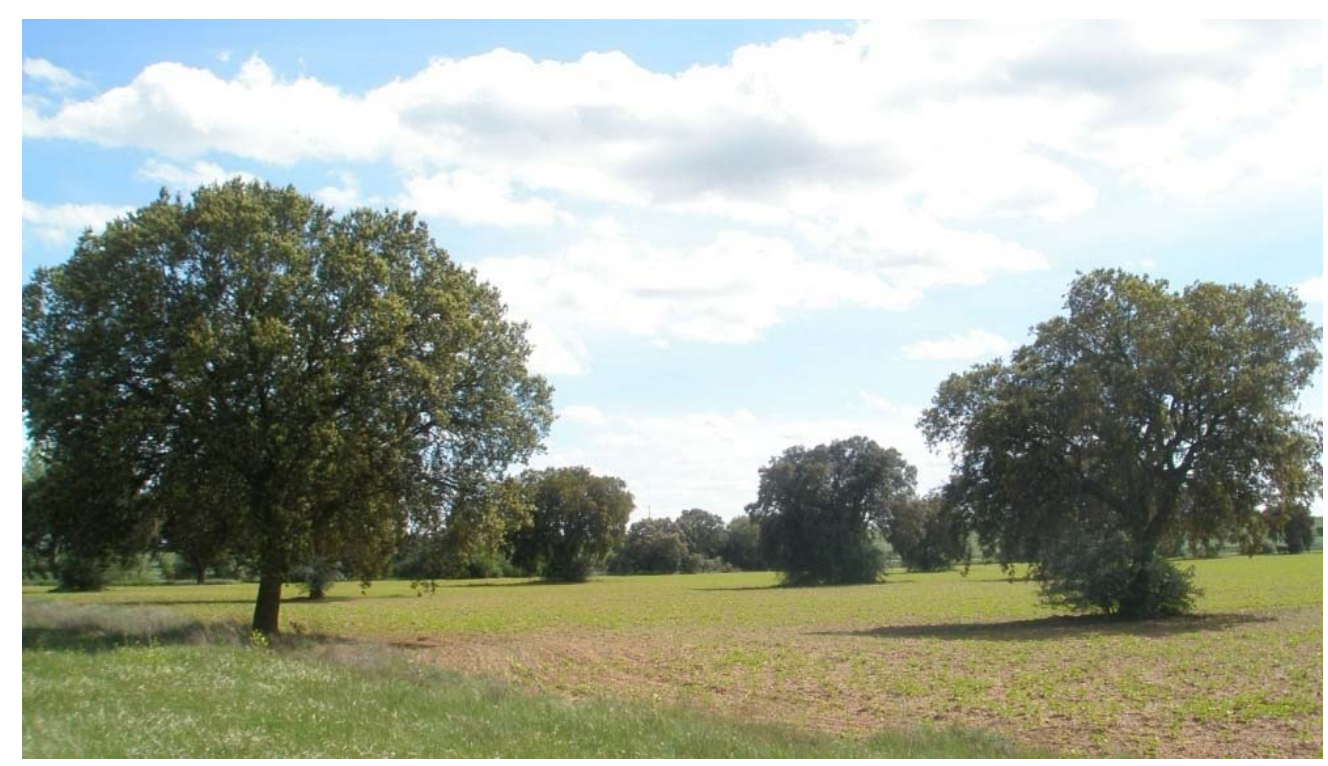

Figura 4.21. Encinar roturado en Perales, en el que aún se conservan buenos ejemplares de esta especie.

Pese a la roturación general del territorio, aún se pueden encontrar pequeños adiles o trozos sin cultivar, así como tesos o elevaciones con restos del matorral serial del encinar meseteño y terracampino, como Dorycnium pentaphyllum, Thymus zygis, Helianthemum hirtum, Rosa corymbifera, etc. Algunas veces incluso aparecen algunas carrascas aisladas, matas de monte bajo de encina o quejigo que han resistido estoicamente al descuaje y roza continua. 
En las vegas y vaguadas perduran algunas de sus riberas, donde se mantienen bosques isla en forma de arboledas naturales de Populus canescens y Populus alba, que abundan en orlas espinosas con Crataegus monogyna, Rosa canina, Prunus spinosa, Prunus cerasifera, etc. En las riberas mejor conservadas (Cea o Carrión) aparecen además otros árboles ripícolas como el chopo del país (Populus nigra), el aliso (Alnus glutinosa), el sauce (Salix spp.), el fresno (Fraxinus angustifolia) o el chopo híbrido de producción (Populus $x$ euroamericana). En forma arbustiva debido a la grafiosis, todavía vemos multitud de restos de olmedas que constituían los llamados bosques carreteros, protegidos por su valor estratégico en la construcción y reparación de útiles agrícolas.

En el resto del territorio -y, por consiguiente, en la inmensa mayoría de la superficie comarcalla vegetación arbustiva o arbórea ocupa un lugar totalmente residual en la campiña cerealista. La presencia de árboles se limita a ejemplares aislados o en pequeños grupos, como pinos piñoneros (Pinus pinea), encinas (Quercus ilex) (Figura 4.22) o almendros (Amygdalus communis) en linderos de las tierras de labor, y chopos lombardos (Populus nigra var. itálica), álamos (Populus alba) y sauces (Salix spp.) en los arroyos. En estos cursos de agua temporales -con una mayor humedad edáfica- es donde se refugia la mayor parte de la vegetación arbustiva de orlas espinosas citada anteriormente. Tanto en las riberas como en los humedales endorreicos pueden aparecer tamarizales, adaptados a suelos pesados y salinos, como el Tamarix gallica y el Tamarix africana. En estas zonas húmedas tiene importancia la vegetación palustre, siendo las especies más representativas los carrizos (Phragmites sp.) y las aneas o espadañas (Typha sp.), que llegan a tapizar por completo algunos cauces de escaso caudal y zonas encharcadas. Finalmente, en algunos linderos de parcelas, márgenes de caminos y carreteras también se cuenta con retazos de vegetación arbustiva: Rosa canina, Prunus spinosa, Spartium juceum, etc.
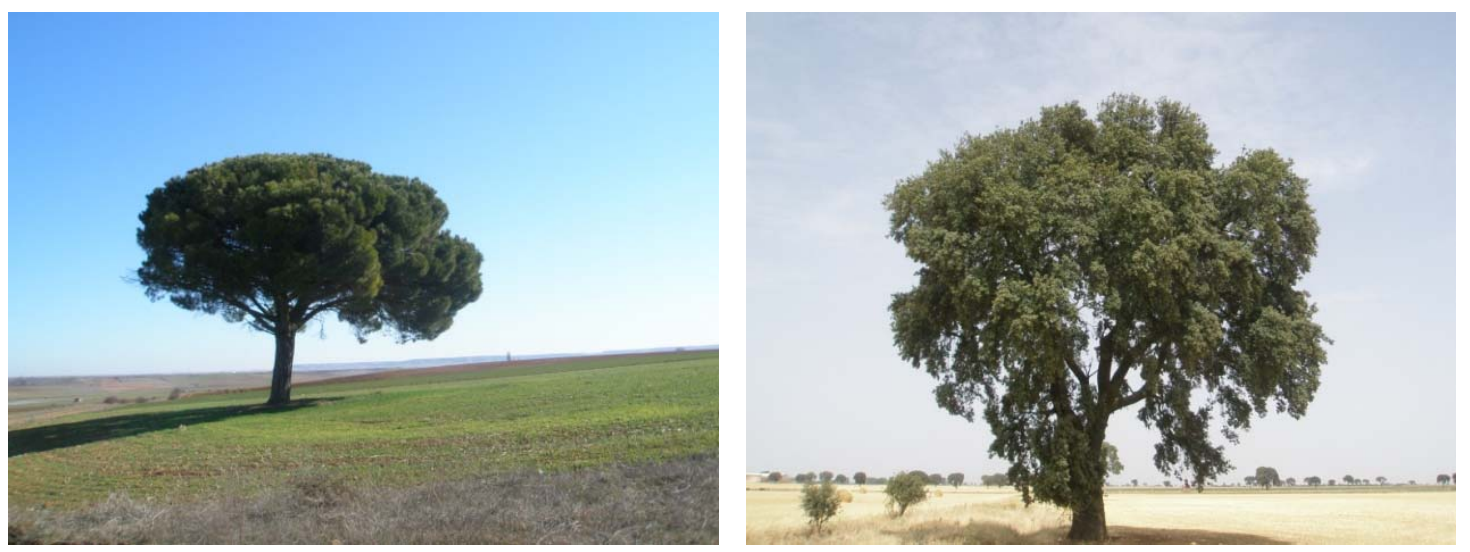

Figura 4.22. Izquierda, pino piñonero en Villaumbrales; derecha, encina en Paredes de Nava.

A pesar de su escasez, la importancia ambiental de la vegetación arbustiva y arbórea es muy relevante. En primer lugar en términos ecológicos, como reservorio de biodiversidad y configuración de corredores ecológicos en la inmensa matriz agrícola. También es muy importante el papel como alimentación y refugio de la fauna de la zona: perdices, codornices, aláudidos, etc., sobre todo cuando los espacios son tan abiertos. La calidad del paisaje aumenta directamente con la presencia y variedad de árboles y arbustos: por cambios de textura, 
contrastes cromáticos, incorporación de puntos y líneas en un territorio de marcado componente superficial, o incluso de la variable vertical en una escena con claro predominio de la horizontalidad.

\subsection{Intensificación de la agricultura}

La llanura de Castilla y León y, en particular la comarca de Tierra de Campos, ha sido escenario de una actividad humana intensa desde tiempos remotos; la agricultura y la ganadería fueron el motor de sus sociedades $\mathrm{y}$, a la vez, se convirtieron en el principal factor del proceso regresivo del antiguo bosque mediterráneo (SANZ-ZUASTI et al, 1995). Si, tal como se ha venido relatando, el proceso destructor de los bosques originales de Tierra de Campos data de al menos tres siglos antes de Cristo, en la segunda mitad del siglo XX se produce una nueva y profunda transformación del paisaje, aunque esta vez motivada por un fuerte cambio de la actividad agrícola. Hasta esas fechas la agricultura tradicional tenía un carácter minifundista y muy poco tecnificado, que daba lugar a una economía basada en general en el autoconsumo. Las parcelas tenían un tamaño reducido (del orden de $1 \mathrm{ha}$ ) y cada labrador disponía de un buen número de ellas repartidas por todo el término municipal. Una explotación media podía rondar las 25 ha, muy inferior a las actuales, por lo que las familias debían complementar la renta con el mantenimiento de ganado doméstico en los corrales: marranos, vacas, gallinas o incluso ovejas.

Las principales producciones obtenidas en estos campos eran los cereales -fundamentalmente el trigo y en menor medida la cebada-. Su especialización triguera ha sido la razón del apelativo que Tierra de Campos ha tenido de granero de Castilla, y esta de España. El cereal se cultivaba mediante la alternancia bienal barbecho-sembradura (también llamado de año y vez, dividiendo la explotación en dos hojas), se usaba tracción animal y la utilización de abonos era muy escasa.

También ocupaban cierta superficie de terreno los viñedos, aquí denominados majuelos, que podían alcanzar un porcentaje del $20 \%$ del total. En particular, el cultivo de la vid fue importante en Campos; hay que reseñar que el vino era un elemento clave en la dieta alimenticia de una comarca antaño muy poblada y que aún sobraba algo para comerciar. No en vano buena parte de los pueblos conservan bodegas tanto en el interior de las viviendas como en zonas adyacentes a los cascos urbanos. De hecho, hay documentos históricos que señalan que en algunos municipios como Medina de Rioseco y su entorno, la principal riqueza agrícola en el siglo XVII no eran los cereales, sino el viñedo (GONZÁLEZ GARRIDO, 1941). Lamentablemente, la enfermedad de la filoxera hizo descuajar la mayoría de los majuelos a principios del siglo XX, que solamente fueron replantados en parte en las décadas siguientes. En los majuelos se solían plantar almendros y otros árboles frutales (manzanos, perales, cerezos, nogales, guindales, ciruelos), así como linderos de zarzas y sebes, por lo que eran terrenos que proporcionaban una gran diversidad al paisaje agrícola.

Las leguminosas también estaban presentes, pero en un menor porcentaje, teniendo una finalidad de autoconsumo, alimento para el ganado o mercado local; los principales cultivos eran las lentejas, las muelas, los titos forrajeros o los garbanzos. 
La existencia de huertas en los alrededores de todos los pueblos también fue notoria, con presencia tanto de hortalizas como de frutales de varias especies; un cierto porcentaje de la población vivía incluso en ellas, ya que necesitaban mucha mano de obra permanente. También existían los denominados "cercados o fincas de recreo" en otras partes de cada término municipal, con majuelos, plantaciones de frutales (almendros sobre todo) y arbustos en los linderos.

Aunque, al menos en el siglo XX, no consta la existencia de olivares en Tierra de Campos, parece ser que en el pasado sí que los hubo, como los documentados en el siglo XVIII en Villafrechós y otros pueblos cercanos.

Como resultado de este laborioso y secular proceso agrícola, se va creando un paisaje antrópico con una alta diversidad, manifestada en la presencia de cultivos diversos separados por linderos vegetales, pequeñas lagunas, fuentes, cursos de agua y ribazos de contorno sinuoso y caminos y senderos en tierra adaptados a la fisiografía natural y, por tanto, de trazado irregular. La riqueza ecológica también es grande, constituyendo un hábitat con una variada comunidad de mamíferos (liebre, conejo, zorro o incluso lobo) y aves (avutardas, sisones, alcaravanes, gangas y ortegas, aguiluchos, cernícalos, aláudidos, perdices, codornices, palomas, etc.).

A partir de los años cincuenta del siglo pasado, las estructuras agrarias sufren una intensa transformación a causa de la mecanización y modernización de las técnicas agrarias. Se sustituye la tracción animal por los tractores, lo que conlleva que las labores agrícolas sean más rápidas y completas. Aumenta considerablemente la superficie explotada por agricultor, lo que provoca una gran reducción de la mano de obra agrícola y, por ende, desencadena el éxodo rural hacia las ciudades, donde se estaba produciendo un importante desarrollo de la industria. Paulatinamente se va reduciendo el cultivo de año y vez, suprimiéndose el barbecho por la labor continua de cereal. Además, se ponen en cultivo baldíos y zonas marginales cuya explotación ahora es posible por la aparición de la maquinaria. A su vez, la economía agrícola pasa del autoconsumo al mercado de precios regulados, que favorece de forma casi exclusiva el cereal. Las campiñas de la comarca evolucionan en pocos años de un paisaje agrario variado y teselado a un monocultivo de cereales sin casi solución de continuidad.

No obstante, la principal causa de la homogeneización del paisaje vino como consecuencia de las concentraciones parcelarias promovidas por los Servicios de Estructuras Agrarias, que durante las décadas sesenta y setenta del siglo pasado afectaron a la práctica totalidad de la llanura de Castilla y León. Si bien es cierto que este proceso modernizó las estructuras agrarias y facilitó las labores agrícolas, mediante el aumento del tamaño de las parcelas y la creación de una red moderna de caminos rurales, los efectos sobre el paisaje han sido devastadores: se eliminan los setos vegetales que antaño servían para separar algunas parcelas, se rectifican arroyos y se descuajan ribazos, se construye una red de caminos regular y rectilínea, eliminándose los senderos tradicionales, las vías pecuarias se modifican y reducen hasta hacerlas coincidir con los caminos, etc.

En cuanto a la distribución de cultivos, uno de los cambios más perceptibles fue la progresiva sustitución del trigo por la cebada a partir de la década de los setenta del siglo pasado, fundamentalmente con destino al pienso para el ganado. También lo fue de forma significativa el arranque de muchos viñedos, motivado por la irrupción de la enfermedad conocida como la 
filoxera a principio del siglo XX, la Ley de Reservas -que premiaba su paso al cultivo de trigo en los años cuarenta y cincuenta de dicho siglo- y la disminución de mano de obra especializada. Ello conllevó como efecto desfavorable colateral, el arranque de todas las sebes y los árboles frutales que poblaban los majuelos.

En la actualidad, el tamaño medio de una parcela oscila entre 20-25 ha y el de una explotación agraria se aproxima a las 175 ha, valores mucho más altos que los mencionados en la agricultura tradicional. En la distribución de los cultivos pesa considerablemente la subvención a cada uno de los mismos de la PAC y la realización de rotaciones que mejoren el suelo y permitan su aprovechamiento anual. Una distribución estimada en una explotación tipo de Tierra de Campos sería la siguiente:

- Cebada $40 \%$

- Trigo $5 \%$

- Girasol $30 \%$

- Vezas $15 \%$

- Alfalfa $10 \%$

Tal como se puede apreciar, el cultivo cerealista ya no es monolítico, lo que repercute notablemente en el paisaje agrícola. El destino de la mayoría de ellos, al igual que la paja del cereal, es para alimentación animal, salvo el girasol que es para producción de aceite y el trigo que sirva para la producción de harina.

De este modo, una explotación tipo se divide en dos hojas, a la que se añade la zona dedicada a alfalfa (especie vivaz, que puede durar hasta 8 años). La primera (hoja A) corresponde al cereal y la segunda (hoja B) al girasol y las vezas. Las leguminosas (alfalfa y vezas) tienen la gran ventaja de que fijan nitrógeno en el suelo y, por consiguiente, no necesitan fertilización (factor económico muy a tener en cuenta). Por su parte, el girasol tampoco suele ser abonado y su raíz pivotante mejora notablemente la estructura del suelo, que no necesita laboreos posteriores.

En cuanto al ciclo de labores -y a salvo de condicionantes meteorológicos-, el cereal de la hoja A se siembra a primeros de octubre por siembra directa en la hoja que el año anterior fue B. En diciembre-enero se realiza un abonado de cobertera N-P-K de liberación lenta, cuando la planta es pequeña. En febrero se aplica un herbicida para matar las malas hierbas, tanto de hoja ancha como estrecha. En marzo se vuelve a realizar un abonado, esta vez solo nitrogenado para fomentar el crecimiento. La cosecha suele realizarse a primeros de julio y el empacado de la paja es posterior. En diciembre (o incluso antes si hay tempero) se acomete el alzado del rastrojo con arado, para que el barbecho resultante sea meteorizado con las heladas del invierno.

Nos encontramos ahora con una parcela para su cultivo con girasol, que el año anterior fue hoja A. En marzo-abril se prepara el terreno mediante gradeo, pase de rastra, aplicación de un herbicida total y posterior siembra. Justo antes de nacer las plántulas, se vuelve a aplicar otro herbicida de preemergencia. Ya no vuelve a haber más tratamientos hasta su cosecha en septiembre. 
Las vezas por su parte se suelen sembrar en septiembre, aplicándose en algún caso un herbicida en marzo para hoja estrecha. La siega del forraje es en mayo (la mayoría) y la correspondiente para grano (la minoría), en julio.

Como hemos señalado, la alfalfa -al igual que las vezas- no se fertilizan. El primer corte se realiza en abril, el segundo en junio y el tercero y último en septiembre.

Otro de los cambios importantes del paisaje agrícola de Tierra de Campos es la transformación en regadío de diferentes áreas de la comarca, fundamentalmente ligadas a cursos de agua naturales (destacando las vegas de los ríos Carrión y Pisuerga) o a canales de riego (como el entorno del Canal de Castilla). Es relevante la redacción por la administración del "Plan Tierra de Campos" en 1965, que pretendía la transformación completa de la comarca, señalando como primer objetivo la puesta en regadío de alrededor de 272000 ha. Este ambicioso objetivo está muy lejos de cumplirse, debido a los importantes costes económicos de las obras, aunque en los últimos años se están desarrollando proyectos que utilizan el agua procedente del embalse de Riaño a través del canal de los Payuelos o del canal Cea-Carrión. En las zonas transformadas en regadío esto conlleva la irrupción de otros cultivos más productivos, como la remolacha o incluso el maíz, así como la instalación de infraestructuras para el regadío como los pivots, aspersores, pozos, instalaciones de bombeo, transformadores y líneas eléctricas asociadas, etc.

\subsection{Fauna}

Desde que el hombre inició su andadura como agricultor y ganadero, ha ido transformando el medio para acomodarlo a sus necesidades, roturando la mayor parte de Tierra de Campos para el cultivo del cereal y de la vid hasta conformar un nuevo ecosistema desarbolado en el que se desenvuelve una rica fauna esteparia (ROJO, 2007). Aquí las herbáceas son la vegetación dominante, los refugios son escasos y los ciclos vitales se adecuan a los agrícolas: la explosión de vida y posibilidades de la primavera; la cosecha del verano, en el que desaparece buena parte de las fuentes de alimento y refugio; y el otoño e invierno de tierras desnudas, heladas y barbechos.

En cuanto a los mamíferos, el de mayor tamaño es el lobo ibérico (Canis lupus) que, junto con el zorro (Vulpes vulpes) han sabido adaptarse perfectamente al ambiente estepario. El resto de las especies animales que pueden encontrarse en la llanura cerealista son de mediano y pequeño tamaño, como la liebre (Lepus granatensis) -que puede considerarse el mamífero más representativo de los espacios abiertos de la Península Ibérica-, la comadreja (Mustela nivalis) o los topillos (Microtus arvalis), base fundamental de la pirámide trófica de estos ecosistemas y de conocidas fluctuaciones demográficas. El conejo (Oryctolagus cuniculus), más propio de ambientes montunos, también puede verse en algunos eriales o márgenes de caminos. El grupo de los murciélagos aparece desigualmente repartido, estando mejor representado en los escasos ambientes forestales y ribereños de la comarca o en los edificios en ruinas de los pueblos; las principales especies son: murciélago ribereño, rabudo, grande de herradura, pequeño de herradura, ratonero gris, ratonero grande y ratonero ribereño. Por último, habría que citar la nutria en algunos tramos de los cursos fluviales (FRECHILLA, 2007) 
Sin embargo, quizá los representantes faunísticos más emblemáticos de la llanura cerealista son las aves. Y el primer gran grupo por excelencia son las aves esteparias. La denominación de estepa que se aplica a las llanuras cerealistas de la meseta norte viene por extensión del nombre que reciben las extensas llanuras euroasiáticas donde la vegetación clímax son herbazales que crecen sobre suelos muy fértiles (SANZ-ZUASTI y GARCÍA, 2006). A pesar de posibles discrepancias en la designación de este hábitat, lo cierto es que este tipo de paisaje agrícola profundamente transformado, de amplios horizontes, relieve suave y dominado por una vegetación de escaso porte, está habitado por un grupo de aves que se agrupan bajo la denominación de aves esteparias y que comparten características muy similares en toda su distribución mundial. Las aves esteparias se adaptan a un hábitat con unas condiciones muy desfavorables para la vida: el clima extremo con precipitaciones escasas y desigualmente repartidas, la falta de refugio -que ha promovido el desarrollo de un plumaje críptico-, o las dificultades para obtener alimento en todas las épocas del año.

La Ilanura cerealista de Castilla y León, y Tierra de Campos en particular, alberga una de las comunidades de aves esteparias de mayor interés de toda Europa. 16 de las 17 especies que caracterizan las estepas ibéricas se encuentran presentes como nidificantes en estos paisajes. Hay que destacar además que algunas de las más emblemáticas especies conservan en este territorio las poblaciones más numerosas de la Península lbérica, como es el caso de la avutarda (Otis tarda), con varios miles de individuos en la comarca (Figura 4.23). Más escaso y difícil de encontrar es el sisón, una avutarda de menor tamaño y plumaje críptico. Otras aves características de estos medios abiertos son el alcaraván, la ortega y la ganga. Sin embargo, el grupo de aves esteparias más abundante y fácil de encontrar son los aláudidos, pájaros cantores cuyos principales representantes son alondras, cogujadas, calandrias y terreras.

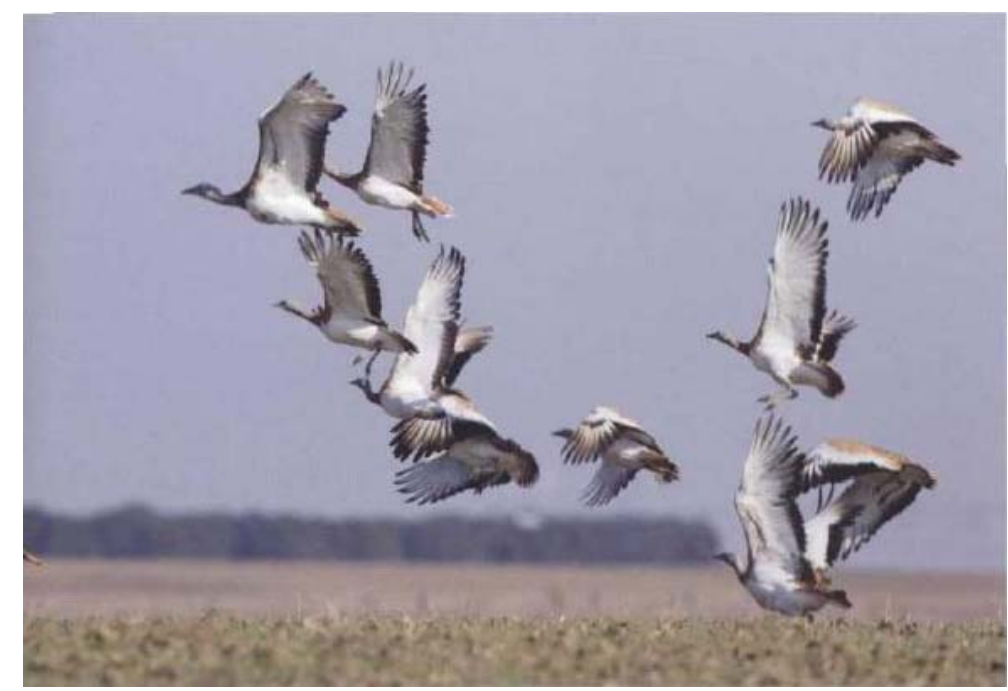

Figura 4.23. Grupo de machos de avutarda (SANZ ZUASTI y GARCÍA, 2006)

El segundo grupo de aves de mayor importancia en la comarca son las acuáticas, que abarca a un elevado número de especies y está ligado a las lagunas endorreicas de Tierra de Campos (Figura 4.24) y a aquellas que se generan en el entorno del Canal de Castilla. En los pasos 
migratorios y durante la invernada este grupo adquiere su mayor relevancia, con infinidad de patos (ánades azulones, rabudos y frisos, cucharas, tarros blancos, cercetas comunes, silbones europeos, porrones comunes y moñudos...) invadiendo las láminas de agua durante el día, y limícolas (chorlitejos, andarríos, archibebes, combatientes, grandes bandadas de avefrías) y garzas (garceta común, garceta grande, garza real) frecuentando las orillas. Para el comienzo del otoño tiene lugar la llegada masiva de los gansos, especialmente del ánsar común, cuyas salidas -a la madrugada- y llegadas -al atardecer- en formación se convierten en un auténtico espectáculo visual y sonoro; junto a esta especie hay otros gansos más escasos, como el ánsar careto grande, el ánsar piquicorto, el ánsar campestre o la barnacla cariblanca. En la época reproductora están presentes como especies más destacadas el aguilucho lagunero, la cigüeñuela, el fumarel cariblanco y el común, el avetorillo común u otras citadas como las garzas real e imperial. Dentro de las paseriformes, son de destacar el carricero común y el carricerín común. 

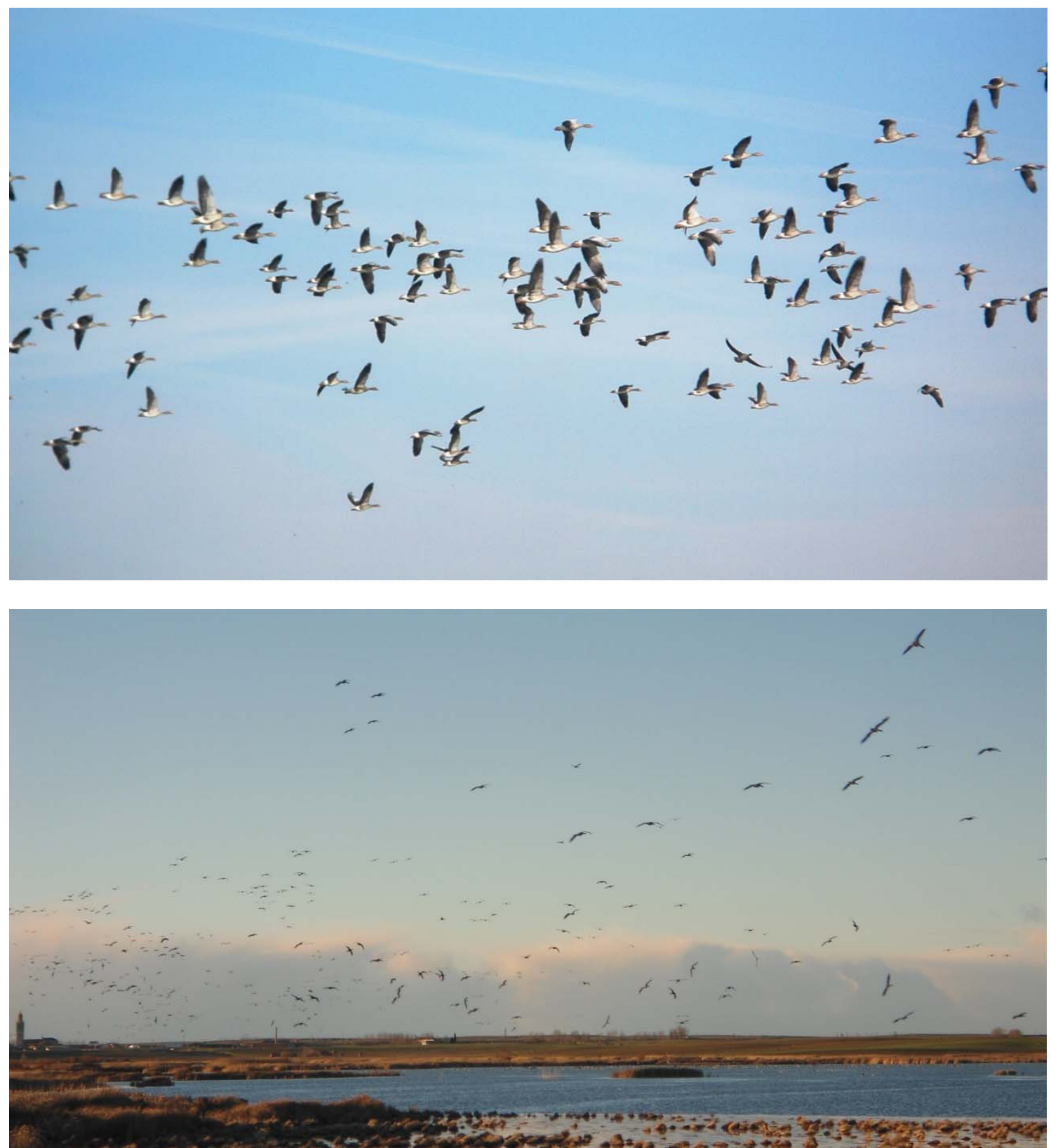

Figura 4.24. Arriba, bandada de gansos en las lagunas de Villafáfila. Abajo, imagen de un atardecer de invierno en la laguna de la Nava, con miles de gansos regresando a las aguas para pasar la noche.

El tercer grupo está constituido por las aves rapaces, muy bien representado a lo largo de todo el año pero, especialmente, durante la invernada. Cabe citarse el cernícalo común y el primilla, el aguilucho cenizo y el pálido, el aguilucho lagunero, el milano negro y el real, así como el busardo ratonero. En cuanto a las rapaces nocturnas, las más numerosas son el mochuelo boreal, el búho chico, la lechuza común, el autillo y el búho campestre (FRECHILLA, 2007). Todos ellos tienen una gran importancia en el control de las poblaciones de topillos $u$ otras especies perjudiciales para la agricultura.

Dentro de las aves cinegéticas, destacamos a la perdiz roja, que es una de las especies más emblemáticas y representativas de los agrosistemas de Castilla y León. Tradicionalmente, la 
"patirroja" ha sido la reina de la caza menor, de gran importancia social en Tierra de Campos. En estos medios, su población depende de la calidad de su hábitat: mosaico parcelario, diversidad florística y de invertebrados, presencia de linderos y ribazos arbustivos, arbolado disperso, maraños de paja en los rastrojos, zonas encharcadas...; aspectos todos ellos que lamentablemente han ido desapareciendo con la intensificación de la agricultura. Otra especie característica es la codorniz, especie granívora migradora, que viene a nuestras latitudes hacia el mes de mayo; prefiere espacios frescos incluyendo a las zonas con regadío. Los córvidos consideradas especies dañinas y, por tanto, abatibles- son muy numerosos en Tierra de Campos: urracas, corneja, graja, grajilla, etc.

Finalmente, en el grupo de aves del medio urbano cabe citar al gorrión común como el más abundante. Le acompañan con la llegada de la primavera golondrinas, aviones y vencejos. Otras aves como palomas domésticas, estorninos negros, colirrojos, tizones o las citadas lechuzas, también encuentran en este medio un lugar propicio para nidificar (SANZ-ZUASTI y GARCÍA, 2006).

Las áreas agrícolas con carácter estepario se encuentran entre los ecosistemas más amenazados de Europa, por delante de las zonas húmedas y los bosques, debido principalmente a la rapidez con que el hombre transforma y destruye estos hábitats. Las principales amenazas son la intensificación de la agricultura (concentraciones parcelarias y transformaciones en regadío), cambios de los usos del suelo agrícola (reforestación de tierras agrarias si fuesen masivas, construcciones y actividades en suelo rústico, etc.) y la fragmentación del hábitat estepario por la construcción de nuevas infraestructuras (sobre todo líneas eléctricas). La degradación de este medio ha provocado que gran parte de estas especies se encuentren amenazadas, destacando la avutarda y el cernícalo primilla al estar consideradas como especies globalmente amenazadas y vulnerables a nivel mundial.

A pesar del interés de las pseudoestepas ibéricas en el contexto europeo, hasta 1991 no se protege el primer espacio natural de llanura cerealista en Castilla y León: la Reserva Natural de las Lagunas de Villafáfila. No obstante, a partir de 2000 se declaran un total de 70 Zonas de Especial Protección para las Aves (ZEPA) en esta región, como aplicación de la Directiva 79/409/CEE del Consejo, de 2 de abril de 1979, relativa a la conservación de las aves silvestres, de las que 13 están consideradas de alto valor para las aves esteparias, la mayoría situadas en Tierra de Campos: las citadas Lagunas de Villafáfila, Penillanuras-Campos, Oteros-Campos, La Nava-Campos, Camino de Santiago, etc.

Una iniciativa singular de protección de este tipo de hábitat ha sido el Programa de zona de las estepas cerealistas de Castilla y León, aprobado en 1993 y aplicado puntualmente en la comarca. Entre sus actuaciones principales, se incluyen las siguientes:

- Mejora y protección del suelo en los terrenos de barbecho mediante el enterramiento de la paja del cereal.

- Aumento de la superficie de barbecho.

- Reducción del empleo de fertilizantes químicos fitosanitarios.

- Creación de bosquetes y linderos promoviendo el cultivo de variedades autóctonas.

- Aumento de leguminosas y alfalfas.

- Prohibición de la quema de rastrojos. 
- Retraso de determinadas labores agrícolas hasta después de la época de cría de las aves.

El futuro de las lagunas y lavajos de la llanura cerealista es bastante pesimista ante una problemática de muy difícil solución (SANZ-ZUASTI y GARCÍA, 2006). Es difícil determinar la superficie de humedales perdida en la segunda mitad del siglo por la política agresiva de drenajes -en el caso de cultivos- o de rellenos con escombros, para las múltiples lagunillas existentes en el entorno de los núcleos de población. La aprobación del Catálogo de Zonas Húmedas por la Junta de Castilla y León ha sido un paso importante para la conservación de estos espacios de tanta importancia ecológica. Otro ha sido la restauración reciente de algunas de ellas (La Nava, Boada de Campos, Tamariz de Campos, las lagunas del Canal de Castilla), cuya gestión posterior es crucial para asegurar la conservación de sus valores naturales y favorecer su potencial uso público.

\subsection{Espacios naturales protegidos y Red Natura 2000}

Aunque en los comienzos de la política de conservación la protección de espacios naturales ha ido ligada a territorios montañosos, actualmente cuentan con alguna figura de protección varias zonas de la comarca de Tierra de Campos (Figura 4.25), que ocupan una considerable extensión (en torno a la mitad de su superficie). Casi todas tienen el nexo común de ser ZEPA (Zonas de Especial Conservación para las Aves), de acuerdo con lo estipulado por la Directiva 2009/147/CE del Parlamento Europeo y del Consejo, de 30 de noviembre de 2009, relativa a la conservación de las aves silvestres. Sus valores naturales radican en la presencia de una importante cantidad de aves esteparias y, puntualmente, de aves acuáticas en el entorno de humedales. Algunas, como La Nava-Campos de Palencia se encuentra en proceso de inicio para su declaración como espacio natural protegido. Tal vez, el espacio que mayor protección ostenta es el de las Lagunas de Villafáfila, que es ZEPA y espacio natural protegido. Finalmente, con una menor extensión superficial existen unas zonas lineales protegidas como LIC (Lugar de Interés Comunitario) merced a la Directiva 92/43/CEE del Consejo, de 21 de mayo, relativa a la conservación de los hábitats naturales y de la fauna y flora silvestres: son las riberas del Cea y del Carrión y, puntualmente, los humedales del Canal de Castilla. 


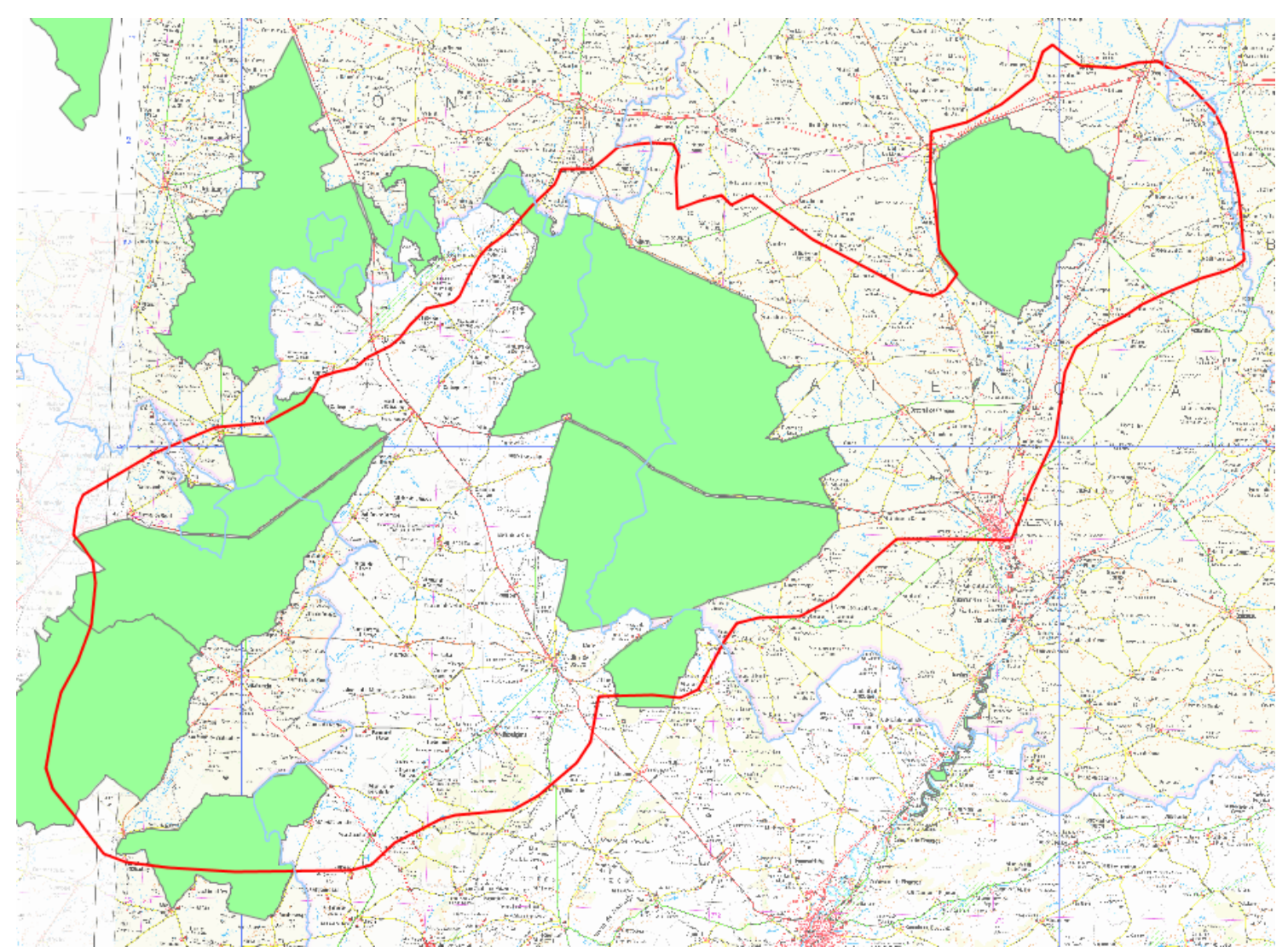

Figura 4.25. Plano topográfico de Tierra de Campos donde se refleja, en verde, la importante superficie ocupada por espacios naturales con algún tipo de protección. A esta superficie habría que añadirle las riberas de los ríos principales.

La gestión de estos espacios naturales corresponde a la Consejería competente en Medio Ambiente de la Junta de Castilla y León. A continuación los describiremos de forma resumida, utilizando básicamente la información contenida en http://www.jcyl.es/web/jcyl/Medio Ambiente y en SANZ-ZUASTI et al. (2004).

\section{Reserva Natural de Lagunas de Villafáfila}

Al suroeste de Tierra de Campos, en la provincia de Zamora, se localiza el complejo lagunar de Villafáfila, que constituye uno de los más importantes humedales de todo el norte peninsular y, sin duda, el más significado enclave para las aves acuáticas, esteparias y migradoras de Castilla y León (Figura 4.26). La Reserva Natural de Lagunas de Villafáfila cuenta con una superficie de 32682 ha y fue declarada protegida por Ley 6/2006, de 5 de julio. Este espacio es también Reserva Nacional de Caza, ZEPA y humedal del Convenio Internacional Ramsar.

Formado por tres lagunas principales -Salina Grande, Barillos y Salinas- y otra serie de humedales más pequeños, está enclavado sobre suelos arcillosos alrededor de la cuenca semiendorreica del río Salado. En años de máxima inundación, el complejo lagunar ocupa una superficie de hasta 600 ha.

Dos son las comunidades vegetales que aparecen claramente definidas en este Espacio Natural. Por un lado la estepa cerealista, dominada por los cultivos de cebada, trigo y alfalfa de secano, 
con una monotonía aplastante solo rota por alguna pequeña alameda y unos escasos ejemplares de pino piñonero. Por otro, las lagunas, cuya vegetación está influida por los ciclos de inundación-sequía a las que se ven sometidas, la elevada salinidad del suelo y el estricto clima dominante en la zona (mediterráneo-semiárido-continental).

En torno a las zonas encharcadas se localiza un territorio dominado por las tierras de cultivo y en el que se asienta una de las aves más emblemáticas de Villafáfila: la avutarda. Los cerca de 2000 ejemplares de esta gran ave que aquí viven forman su mayor población a nivel mundial. También son reseñables las ingentes cantidades de ánsares comunes que eligen estas lagunas para pasar el invierno.
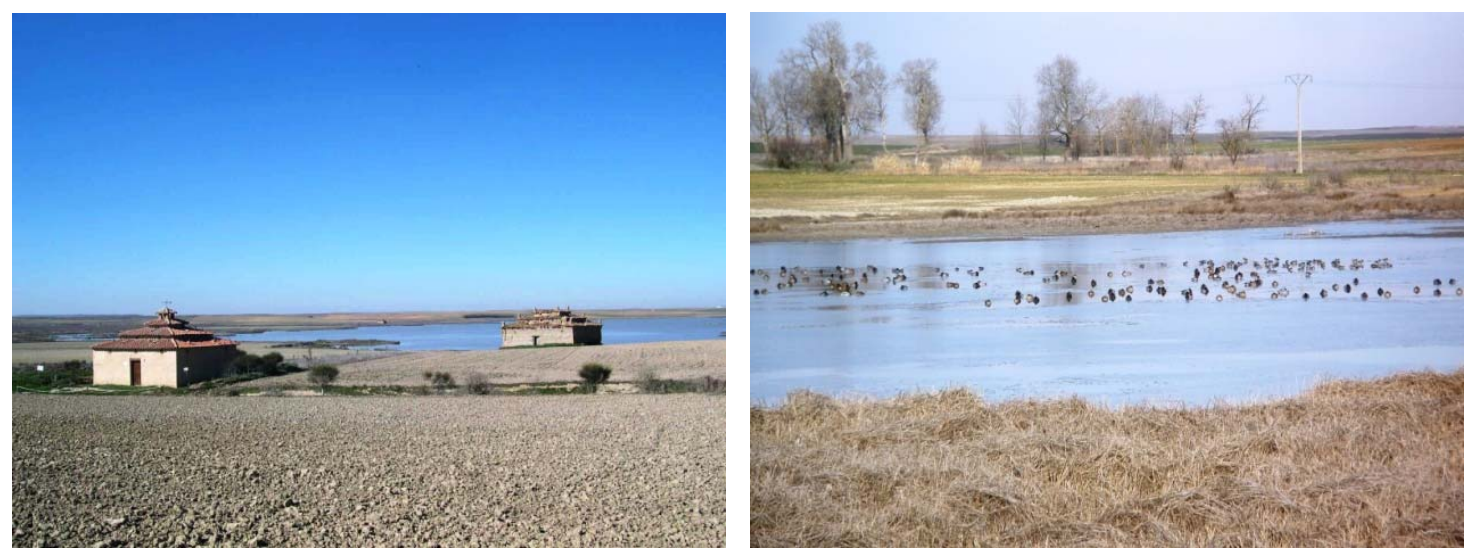

Figura 4.26. Izquierda, palomares y laguna de Salina Grande en Otero de Sariegos. Derecha, acuáticas en laguna de Villardón, en Villarrín.

La orografía y las peculiares características geológicas son las responsables de la formación de las lagunas salinas, que confieren a esta zona húmeda una importancia sobresaliente en la Península Ibérica, al ser casi la única representante de un ecosistema antiguamente abundante $y$, que por diversas circunstancias, ha desaparecido, constituyéndose en refugio de una importante avifauna asociada al agua, a la vez que la pseudoestepa cerealista circundante alberga una importante población de aves esteparias. Esta importancia ornitológica permitió su declaración como Zona de Especial Protección para las Aves, al cumplir la avutarda, cernícalo primilla, cigüeñuela y grulla los criterios de selección.

La importancia radica tanto en las especies que invernan en las lagunas como en las que viven en la dura y áspera estepa cerealista que circunda las zonas encharcadas. Entre las primeras se alcanzan las máximas concentraciones entre noviembre y febrero, pero la mayor diversidad se consigue entre abril y junio. Son las anátidas las aves que en mayor número y de una forma más espectacular se pueden encontrar en el Espacio Natural, destacando especialmente el ánsar común, junto a otras especies como el ánade real, cerceta común, pato cuchara, ánade silbón, ánade rabudo, ánade friso, tarro blanco, porrón común. Reseñar también la presencia de otras aves migradoras como las fochas o las limícolas (avefría, correlimos común, combatiente, cigüeñuela, chorlito gris, chorlito dorado). También es posible observar de una forma más o menos esporádica o temporal especies como la grulla común, gaviota reidora, espátula, cerceta carretona, aguilucho lagunero, ánade rabudo, ánade friso, avoceta, aguja colinegra, agachadiza 
común, archibebe común, zarapito real,... contribuyendo a acrecentar el valor ornitológico de este Espacio. Junto a esta gran variedad ornítica asociada al agua, se encuentra una comunidad de aves diferente, colonizadora de los amplios espacios abiertos y secos; se trata de la avutarda, amenazada en muchos países y escasa en España, mantiene aquí la mayor población de Europa (unas 2600 aves), junto a ella el sisón, la ortega, la ganga, el alcaraván, la collalba gris, el triguero, la totovía, etc. enriquecen este área. Estas zonas abiertas son también el hábitat de nidificación y campeo de una amplia gama de rapaces: aguilucho cenizo, aguilucho pálido, cernícalo primilla, halcón peregrino, alcotán, esmerejón,...

Una parte de la Reserva Natural está propuesto como Lugar de Interés Comunitario (LIC), en concreto una superficie de 4220 ha. Se trata de las propias lagunas salinas endorreicas, caracterizadas por su pequeña profundidad y un ciclo hídrico anual muy marcado, rodeadas por la pseudoestepa cerealista de secano. Incluye parte del arroyo del Salado y su red de drenaje. Su calidad e importancia se debe a que es un complejo lagunar de carácter salino de alto valor por los hábitats halófilos que aparecen ligados a las cubetas de las lagunas, juncales de Juncus maritimus, herbazales de Hordeum marinum, comunidades de Cressa cretica en las zonas con eflorescencias salinas.

En cuanto a la vulnerabilidad, la principal amenaza para la zona es la transformación del hábitat. Dado que cada vez la agricultura está más supeditada a la política comunitaria, basta que se subvencione un determinado cultivo para que cambie el paisaje agrícola. Además sobre la zona se cierne un proyecto de regadío que afectaría seriamente al ecosistema.

\section{ZEPA Penillanuras-Campos Norte}

El espacio protegido, con 13242 ha de extensión, forma parte de la comarca de Tierra de Campos entre los ríos Cea y Valderaduey, en los límites provinciales de Valladolid, Zamora y León. EI paisaje se caracteriza por su relieve llano, con pequeñas colinas aisladas, dedicado a cultivos cerealistas que alternan en una pequeña proporción con pastizales, zonas arbustivas y pequeños bosquetes de encina y pino piñonero. La presencia de numerosos arroyos origina sotos aislados en ocasiones bien desarrollados. Hay algunas lagunas temporales con un buen desarrollo de la vegetación palustre. El $8 \%$ de la superficie de la ZEPA está ocupada por cultivos de regadío.

Los campos agrícolas de cereal de secano constituyen un hábitat favorable para varias especies de aves esteparias, destacando la población reproductora de sisón (75-90 machos reproductores), además del aguilucho cenizo, cernícalo primilla, avutarda (141 individuos) y ortega.

En cuanto a la vulnerabilidad, la existencia de superficies regables en los límites de la ZEPA indica que actuaciones para la mejora del regadío existente y transformación de nuevas superficies que no superen el $10 \%$ de la superficie total de la zona se considera compatible con los objetivos de conservación que determinan la declaración como zona ZEPA. Por otro lado, se considera sin efecto apreciable la instalación de industrias de transformación de productos agrarios y/o alimentarios, fundamentalmente si su ubicación se produce en el entorno de los núcleos urbanos. 


\section{ZEPA Penillanuras-Campos Sur}

Este espacio ocupa un área de 23800 ha, situado al noreste de la provincia de Zamora e incluyendo una pequeña parte de la de Valladolid; limita al sur con la reserva natural Lagunas de Villafáfila y al norte con la ZEPA Penillanuras-Campos Norte. De hecho estas dos ZEPA, que están separadas por la carretera nacional $\mathrm{N}-610$, conforman realmente un único espacio de 37042 ha, de características físicas idénticas. El 12 \% de su superficie está ocupada por cultivos de regadío.

En cuanto a las poblaciones reproductoras de aves esteparias destaca el sisón (con 150-200 machos reproductores), avutarda (595 aves) y aguilucho lagunero. La vulnerabilidad frente a actuaciones es la misma que en la ZEPA homóloga.

\section{ZEPA La Nava-Campos Norte}

La Zona de Especial Protección para las Aves "La Nava-Campos Norte" ocupa una extensión de 54936 ha en la parte central de la comarca de Tierra de Campos, a caballo entre las provincias de Valladolid y Palencia. El espacio incluye una extensa llanura cerealista atravesada por varios ríos y arroyos (principalmente el Sequillo y el Valdeginate), por el ramal de Campos del Canal de Castilla y por el canal del trasvase Cea-Carrión.

La zona se caracteriza por su relieve llano o ligeramente ondulado, prácticamente deforestado, con solo pequeños bosquetes aislados de pinos o encinas. También existen pequeñas alamedas con árboles de buen porte en las riberas. EI 7 \% de la superficie de la ZEPA corresponde a cultivos de regadío.

El espacio incluye la laguna de la Nava, humedal de gran importancia en el contexto regional, que mantiene todo el año extensas superficies de pastizales de encharcamiento temporal y canales con vegetación palustre bien desarrollada. Esta laguna y su entorno están también clasificados como Lugar de Interés Comunitario (LIC), con un área de 1013 ha. La actual Laguna de la Nava es el resultado de distintos trabajos de recuperación, ya que la enorme laguna (el mar de Campos) que originariamente existía fue desecada hace décadas; la zona húmeda actual cuenta con una superficie aproximada de 375 ha (un $10 \%$ de la original). La irrupción de esta lámina de agua en el árido paisaje de Tierra de Campos tiene una gran importancia ecológica y visual (Figura 4.27). También se han recuperado los humedales de Boada de Campos (de unas 60 ha) y Pedraza de Campos (72 ha), situadas en la homóloga ZEPA La Nava-Campos Sur. Todas estas lagunas han proporcionado un lugar muy favorable para el asentamiento de una importante comunidad de aves acuáticas. Destaca la nidificación de garza imperial, aguilucho lagunero y de varias especies de limícolas, las concentraciones de cigüeña común, la migración de espátula y carricerín cejudo y la invernada de gansos y patos. Entre las lagunas de La Nava y Boada se llegan a contar más de 30000 gansos. 


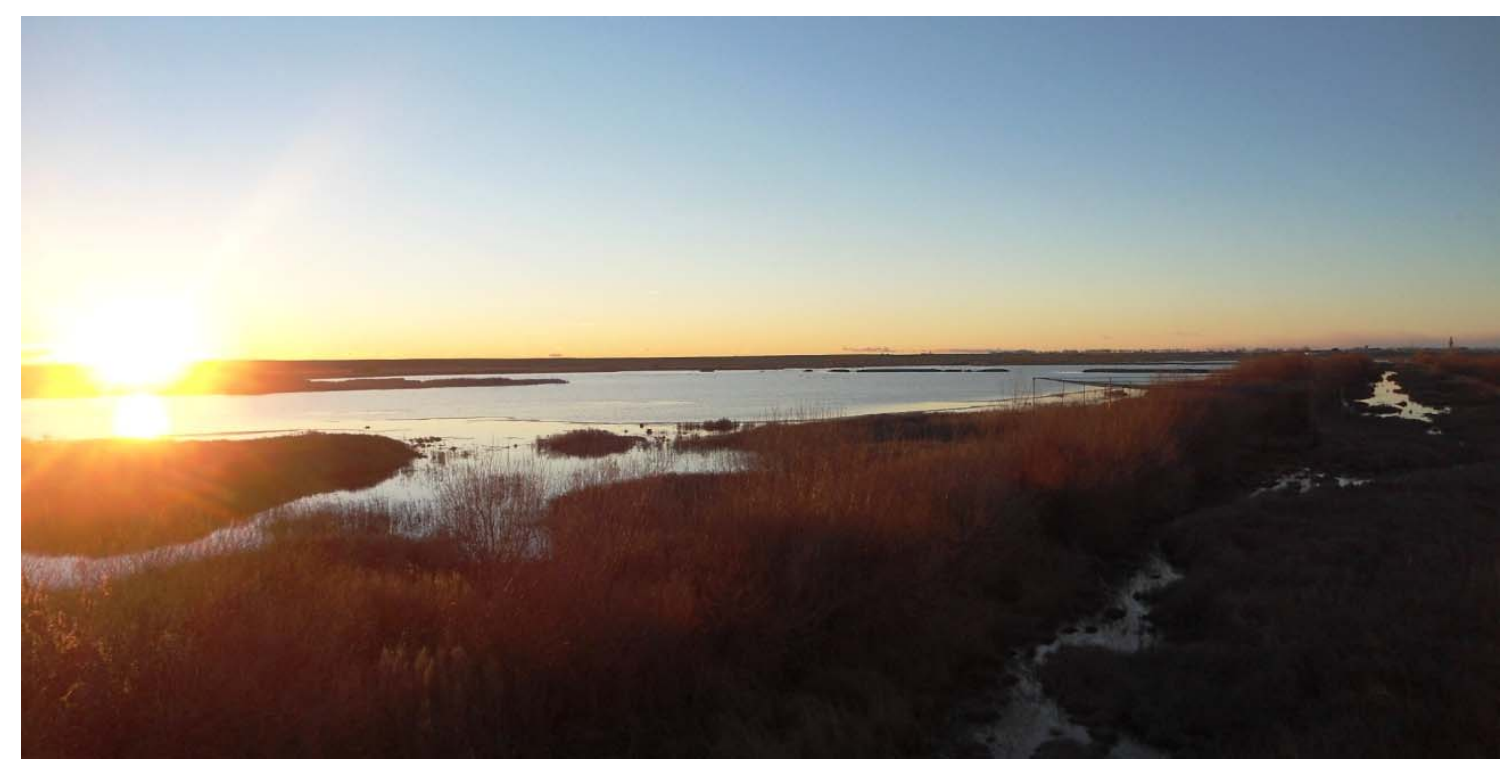

Figura 4.27. Atardecer en la laguna de la Nava.

El espacio también tiene un gran interés para las aves esteparias, con importantes poblaciones reproductoras de avutarda (780 ejemplares) y de cernícalo primilla, así como de aguilucho cenizo, sisón, ortega, calandria y terrera común.

En cuanto a la vulnerabilidad de la ZEPA, se considera que transformaciones en regadío que no superen el $15 \%$ de su superficie se consideran compatibles con los objetivos de conservación que determinan su declaración. También se consideran compatibles la posible transformación en autovía de la actual carretera Palencia-Benavente y la instalación de industrias de transformación de productos agrarios y/o agroalimentarios, fundamentalmente si su ubicación se produce en el entorno de los núcleos urbanos.

\section{ZEPA La Nava-Campos Sur}

Este espacio, que ocupa una superficie de 39210 ha, está separado de la ZEPA La Nava-Campos Norte por la carretera nacional N-610 Palencia-Benavente, por lo que realmente conforman una gran mancha de 94146 ha de características geográficas y valores naturales afines. En este caso, el porcentaje de superficie ocupado por cultivos de regadío es del $10 \%$.

Como su homólogo septentrional, este espacio tiene un gran interés para las aves esteparias, con importantes poblaciones reproductoras de avutarda (247 ejemplares) y de cernícalo primilla, así como de aguilucho cenizo, sisón, ortega, calandria y terrera común. Los motivos de vulnerabilidad también son idénticos en ambos espacios.

\section{ZEPA Camino de Santiago}

El espacio, que cuenta con una superficie de 22698 ha, incluye una serie de llanuras cerealistas situadas en el centro de la provincia de Palencia -extremo noreste de Tierra de Campos-, atravesadas por el Canal de Castilla y limitadas por las vegas del Carrión en el oeste y del Pisuerga en el este, donde se asientan cultivos de regadío. La escasa vegetación natural que se conserva 
se limita a algunas zonas de paramera, pastizales, pequeñas áreas con matorrales y encinares poco desarrollados. Existen buenos ejemplos de bosques de ribera en el río Carrión y en el Canal de Castilla. El área incluye también algunos humedales de interés asociados a dicho canal, caracterizados por el gran desarrollo de la vegetación palustre.

La calidad e importancia de la ZEPA se debe a la población reproductora de avutarda (421 aves), así como de aguilucho lagunero, avetorillo y garza imperial. Los principales factores de vulnerabilidad de la zona proceden de cambios o transformaciones de las actuales formas de cultivo.

\section{ZEPA Y LIC Lagunas del Canal de Castilla}

Se trata de un conjunto de varias decenas de lagunas asociadas al Canal de Castilla (Figura 4.28), situadas en su margen derecha, originadas principalmente por filtraciones de agua del propio Canal. El nivel de las lagunas está relacionado con el del Canal, que es máximo en la época estival. Su superficie total es de unas 70 ha.

El régimen hídrico de las lagunas facilita la presencia de macrófitas acuáticas que sirven de zona de cría a las mayores colonias de garza imperial y aguilucho lagunero. Otras especies de interés son el avetorillo y de las tres especies de polluelas.

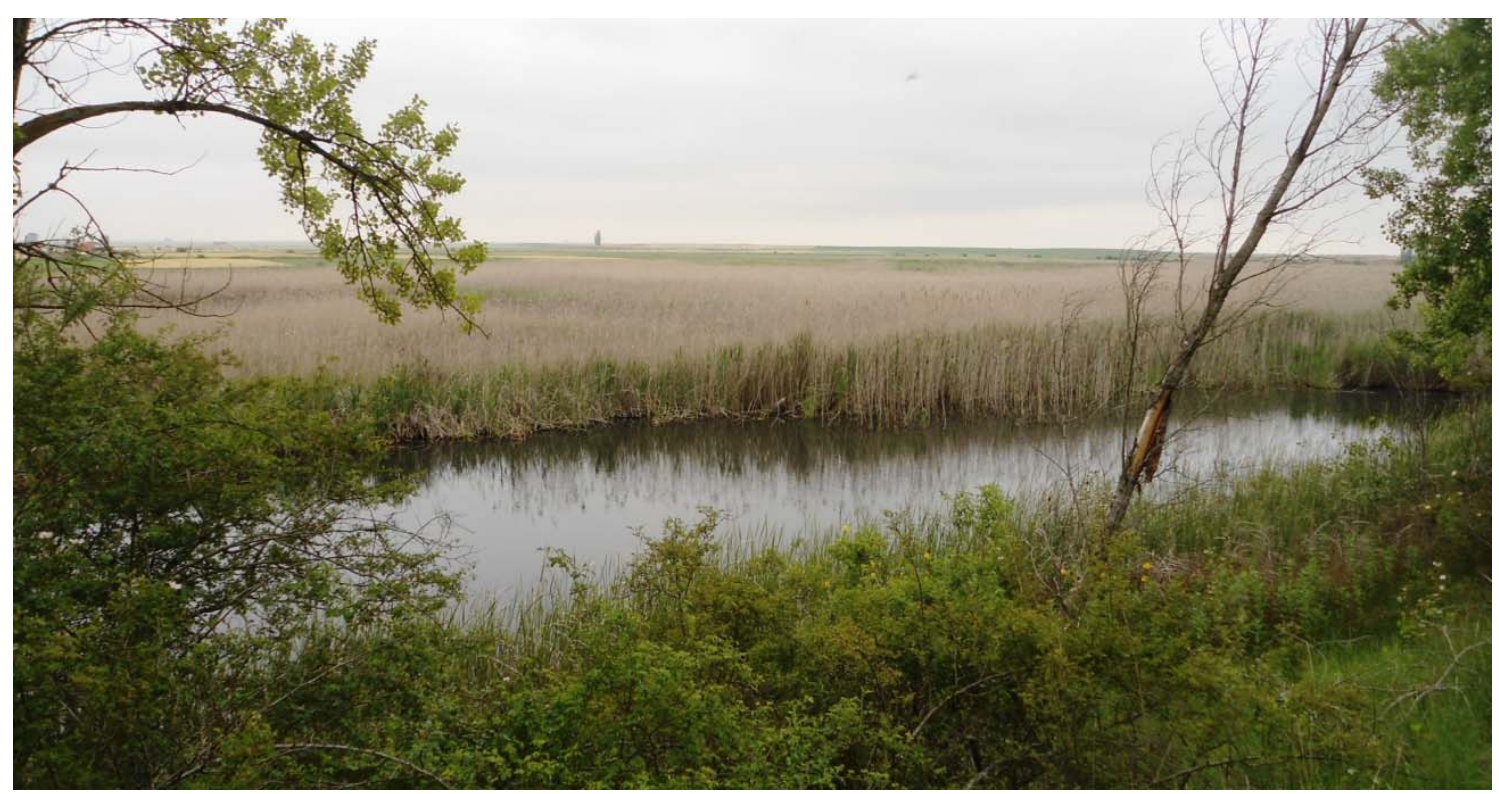

Figura 4.28. Una de las lagunas del Canal de Castilla, en Castromocho.

Respecto a la vulnerabilidad del espacio, en general los ecosistemas están bien conservados, aunque como factores de riesgo cabe citar la quema para pastos y los intereses para su desecación en las superficies de propiedad particular. 


\section{$\underline{\text { LIC Canal de Castilla }}$}

Se encuentra declarado como LIC un tramo del Canal de Castilla situado entre Las Cabañas de Castilla y Olmos de Pisuerga, en el límite de las provincias de Palencia y Burgos, que ocupa un total de 122 ha. De esta superficie, una pequeña parte atraviesa la comarca de Tierra de Campos en su extremo nororiental.

Su calidad e importancia se debe a la presencia de hábitats de ribera bien conservados. Sirve además de corredor natural que enlaza las lagunas del Canal de Castilla y las riberas de los principales ríos palentinos.

\section{$\underline{\text { LIC Riberas del río Carrión y afluentes }}$}

Este Lugar incluye varios tramos fluviales de la subcuenca del río Carrión: 3 tramos del río Carrión, un tramo del río Cueza y el arroyo Valle, ocupando un total de 678 ha. Se define por el curso fluvial más una franja de unos $100 \mathrm{~m}$ de ancho a cada lado del río. De esta superficie, una parte considerable se encuentra en la comarca de Campos, desde Carrión de los Condes hasta las proximidades de Palencia.

Respecto de su calidad e importancia cabe reseñar que el lugar incluye varios tramos fluviales que cuentan con buenas poblaciones de distintas especies de peces continentales, así como la presencia de nutria y desmán ibérico. Destacan los hábitats fluviales, en especial los bosques de galería de sauces y álamos.

La vulnerabilidad de este Lugar procede de la intensificación de los usos agrícolas (ampliación de cultivos en detrimento de vegetación natural), plantaciones de choperas de producción y la reducción de la calidad de las aguas por vertidos de aguas residuales.

\section{$\underline{\text { LIC Riberas del río Pisuerga y afluentes }}$}

En este caso, el Lugar incluye varios tramos fluviales de la subcuenca del río Pisuerga. En Tierra de Campos corresponde un pequeño tramo que constituye el límite oriental de la comarca. Su calidad e importancia deriva de la presencia de buenas poblaciones de distintas especies de peces continentales, así como los hábitats fluviales, en especial los bosques galería de sauces y álamos. Los motivos de vulnerabilidad son idénticos a los del LIC Riberas del río Carrión y afluentes.

\section{$\underline{\text { LIC Riberas del río Cea }}$}

Este Lugar ocupa una superficie total de 754 ha e incluye dos tramos del río Cea: uno perteneciente a la provincia de León y otro, aguas abajo, que se corresponde con la provincia de Valladolid; este último es el que se encuentra en Tierra de Campos, constituyendo su límite noroccidental (Figura 4.29).

En cuanto a su calidad e importancia, los tramos fluviales presentan un buen estado de conservación; hay presencia de nutria y la vegetación de la ribera del Cea supone una verdadera isla en la extensa campiña ocupada fundamentalmente por cultivos herbáceos de secano (saucedas, alamedas, y algunas alisedas y fresnedas). 


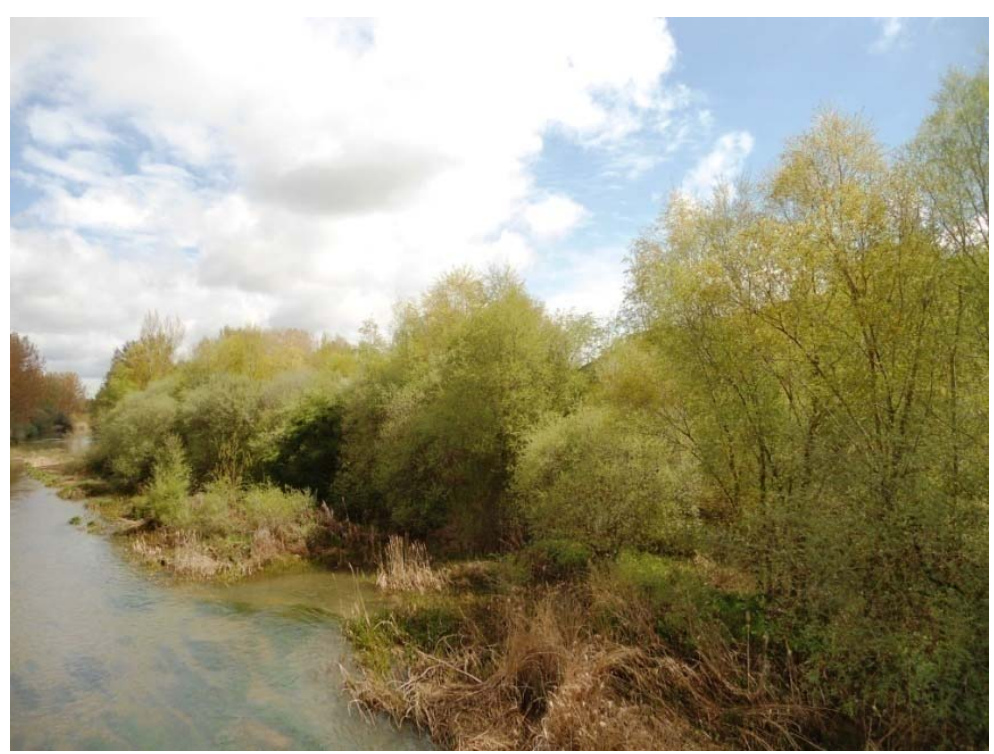

Figura 4.29. Ribera del río Cea en Melgar de Abajo.

La vulnerabilidad de este Lugar procede de la intensificación de los usos agrícolas (ampliación de cultivos en detrimento de vegetación natural), plantaciones de choperas de producción, extracciones de áridos, sustitución de pastizales por cultivos y la reducción de la calidad de las aguas por vertidos de aguas residuales.

\subsection{Socioeconomía}

El desarrollo de este apartado se realizará a partir de la información contenida en los dos dosieres sobre Tierra de Campos incluidos en la revista Medio Ambiente (CONSEJERÍA DE M.A. Y O.T., 1994 y 1999), con aportaciones y actualizaciones personales. Como delimitación geográfica de la comarca, se utiliza la establecida en el Plan de Desarrollo Económico y Social de Tierra de Campos, en su redacción inicial. Este ámbito territorial es similar aunque ligeramente superior al establecido por Justo González Garrido y otros autores, incluyendo términos municipales completos y otros municipios limítrofes como Sahagún, Valderas o Astudillo (5700 $\mathrm{km}^{2}$ por $4400 \mathrm{~km}^{2}$ ).

\section{$\underline{\text { Territorio y población }}$}

La comarca de Tierra de Campos, al igual que la mayoría de Castilla y León, ha experimentado importantes cambios en su organización territorial a partir de las décadas de los sesenta y setenta del siglo pasado. La cohesión de la trama comarcal tradicional se resintió como consecuencia del despoblamiento, la crisis y la polarización en las capitales. Además, los pequeños centros perdieron su papel de intercambiadores de ideas y productos y con ello se disipó el sentido de pertenencia a la comunidad comarcal, sustituido por el de la provincia, con las capitales provinciales convertidas en los verdaderos nudos de la red urbano rural (MARTÍNEZ DE PISÓN, 2002). 
Los 163 municipios considerados ocupan una extensión de aproximadamente el $6 \%$ de Castilla y León. La mayor parte de ellos constan únicamente de una localidad, resultando el espaciado medio entre entidades de población de 2,6 km. Esta estructura tiene fiel reflejo en el tipo de poblamiento, concentrado en el núcleo.

Tabla 4.1. Datos generales de Tierra de Campos (GEOSISTEMA, 1994; INE). Superficie: $5742 \mathrm{~km}^{2}$. Municipios: 163. Entidades de población: 213.

\begin{tabular}{lcc} 
Uso del suelo & Superficie (ha) & Porcentaje (\%) \\
\hline Cultivo secano & 466887 & 81,3 \\
\hline Cultivo regadío & 42378 & 7,4 \\
\hline Prados & 12679 & 2,2 \\
\hline Forestales & 18973 & 3,3 \\
\hline Otros & 33462 & 5,8 \\
\hline
\end{tabular}

Los datos de distribución de usos del suelo (Tabla 4.1) no dejan lugar a dudas: cerca del $90 \%$ de la superficie de Tierra de Campos está dedicada al cultivo agrícola herbáceo, correspondiendo la mayoría al secano. Residuales son las praderas (con un $2 \%$ ) y los espacios forestales (con un $3 \%$ ). En el capítulo de otros (casi un $6 \%$ ) se englobarían los cascos urbanos, infraestructuras u otros usos improductivos.

Tabla 4.2. Evolución de la población en Tierra de Campos (GEOSISTEMA, 1994, actualizado)

\begin{tabular}{cccccc}
\hline Año & TC total & TC rural & \% anual & \% periodo & \% acumulado \\
\hline $\mathbf{1 9 0 0}$ & 180986 & 165047 & & & \\
\hline $\mathbf{1 9 4 0}$ & 181609 & 147326 & $-0,27$ & $-10,74$ & $-10,74$ \\
\hline $\mathbf{1 9 5 0}$ & 191494 & 149725 & 0,16 & 1,63 & $-9,28$ \\
\hline $\mathbf{1 9 6 0}$ & 182358 & 134142 & $-1,04$ & $-10,41$ & $-18,72$ \\
\hline $\mathbf{1 9 7 0}$ & 158508 & 100138 & $-2,53$ & $-25,35$ & $-39,33$ \\
\hline $\mathbf{1 9 8 1}$ & 153208 & 79128 & $-2,10$ & $-20,98$ & $-52,06$ \\
\hline $\mathbf{1 9 9 1}$ & 149605 & 67616 & $-1,45$ & $-14,55$ & $-59,03$ \\
\hline $\mathbf{2 0 0 1}$ & 140338 & 59500 & $-1,20$ & $-12,00$ & $-63,95$ \\
\hline $\mathbf{2 0 1 3}^{*}$ & 130629 & 49980 & $-1,60$ & $-16,00$ & $-69,72$ \\
\hline
\end{tabular}


*Población estimada de Tierra de Campos a partir de una muestra de 31 localidades

TC total: Población total de Tierra de Campos (con Palencia)

TC rural: Población de Tierra de Campos sin Palencia

\% anual: Porcentaje anual de variación de la población en el periodo considerado

\% periodo: Porcentaje de variación de la población de TC rural en el periodo considerado

\% acumulado: Porcentaje acumulado de variación de la población de TC rural desde 1900

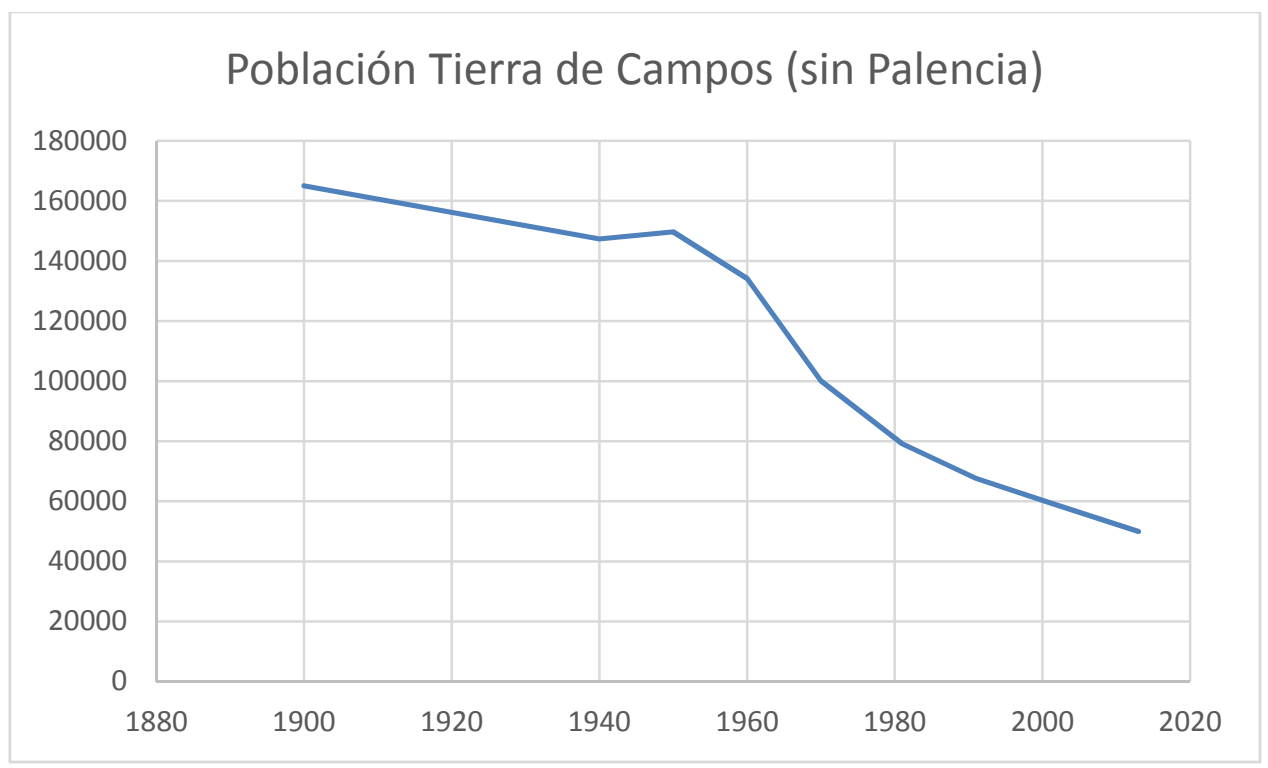

Figura 4.30. Gráfica de la evolución de la población en la Tierra de Campos rural.

En cuanto a la demografía (Tabla 4.2 y Figura 4.30), excluyendo del cómputo a Palencia capital, el volumen de población media del municipio en 1991 era de 417 habitantes, sensiblemente inferior a la media regional. El $23 \%$ de los municipios no alcanzan los 100 habitantes y en torno al $33 \%$ se hallan entre los 100-250 habitantes. Entre 1000 y 2000 habitantes solo hay 10 municipios, mientras que exclusivamente 6 se encuentran entre los 2000 y 5000 . En la actualidad las cifras confirman la despoblación sin freno en toda la comarca, que hace engrosar los rangos de población inferiores.

Si se analizan las cifras de población de Tierra de Campos sin contar a Palencia (la realmente rural) se puede constatar que, exceptuando un estancamiento entre 1920 y 1950, el número de habitantes no ha hecho más que disminuir desde la mitad del siglo XX hasta la actualidad. Los datos son demoledores. El porcentaje de pérdida de población para los periodos considerados se ha mantenido relativamente constante, lo que en tasas anuales supone entre un 1 y un $2,5 \%$ de descenso. Como se puede apreciar, el éxodo rural en Tierra de Campos no solamente alcanza a las décadas de los 50 y 60 del siglo pasado, se mantiene sin freno hasta la actualidad. Mayor 
dramatismo, si cabe, se constata al analizar los datos del porcentaje acumulado de pérdida de población desde 1900, que en 2013 alcanza el 69,72 \%. Es decir, un pueblo tipo que en 1900 tenía 1000 habitantes, mantuvo esta población más o menos hasta 1950, pero a partir de esta fecha la fue perdiendo paulatinamente hasta llegar a $\mathbf{3 0 0}$ habitantes en la actualidad. Lo mismo para una localidad con 200 habitantes en 1900, ahora solo tendría 60 personas viviendo; por desgracia, numerosos pueblos se encuentran en esta situación (Villagómez la Nueva, 69 habitantes; Villalán de Campos, 47; Villanueva de la Condesa, 63; Villamuriel de Campos, 62; por poner algunos ejemplos)

Las localidades más afectadas por esta sangría han sido las más pequeñas; las medianas y mayores (Carrión de los Condes, Paredes de Nava, Villalón de Campos, etc.) han conseguido ralentizar el descenso debido en buena medida al aporte de los pueblos pequeños, pero cuando ya no hay aporte posible la caída es libre. Tan solo Medina de Rioseco mantiene a duras penas sus 5000 habitantes. En la última década se han apreciado indicios de una cierta ralentización de la caída de la población terracampina, justificada en la llegada de un importante contingente de emigrantes (búlgaros, rumanos, marroquíes, etc.) que puede alcanzar hasta el $20 \%$ de la población rural.

Incluso para mayor desconsuelo, cabe precisar que los datos de población actuales son los del padrón municipal recogidos por el Instituto Nacional de Estadística (INE). En ellos no se tiene en cuenta que una parte considerable de la población empadronada en una cierta localidad reside de forma habitual en la ciudad, "bajando al pueblo" algunos fines de semana y "para el tiempo bueno".

Si establecemos comparaciones con otros territorios, el drama demográfico se mantiene. La densidad de población de Tierra de Campos no llega a $9 \mathrm{hab} / \mathrm{km}^{2}, 4$ veces inferior a la de Castilla y León-ya de por sí baja- ( 27 hab/ $\mathrm{km}^{2}$ ) y 10 veces inferior a la de España (93 hab/km²).

Por otra parte, el saldo vegetativo negativo (mueren muchos que nacen) y la elevada esperanza de vida, además de la emigración de la población más joven, derivan en una estructura demográfica muy envejecida y con una elevada edad media, lo que a su vez repercute en la capacidad de la sociedad terracampina para emprender.

La crisis económica que actualmente está viviendo el país no hace más que agudizar un problema crónico que afecta al medio rural y, en particular, a Tierra de Campos. Afirmándolo con la crudeza que requiere la realidad, en los pueblos hay una crisis permanente. Hay personas que se jubilan y, con el dinero ahorrado, se van a la ciudad al menos a pasar los periodos más fríos. Matrimonios que también se trasladan cuando sus hijos van a estudiar a la Universidad. Agricultores que trabajan en el pueblo pero viven en la ciudad. Jóvenes titulados universitarios que ya solo vienen al pueblo algunos fines de semana y periodos estivales. Ancianos que son trasladados a residencias de mayores. Personas que se quedan en paro y emigran a buscar trabajo en lugares más populosos. La situación no puede tildarse más que de trágica (Figura 4.31). 


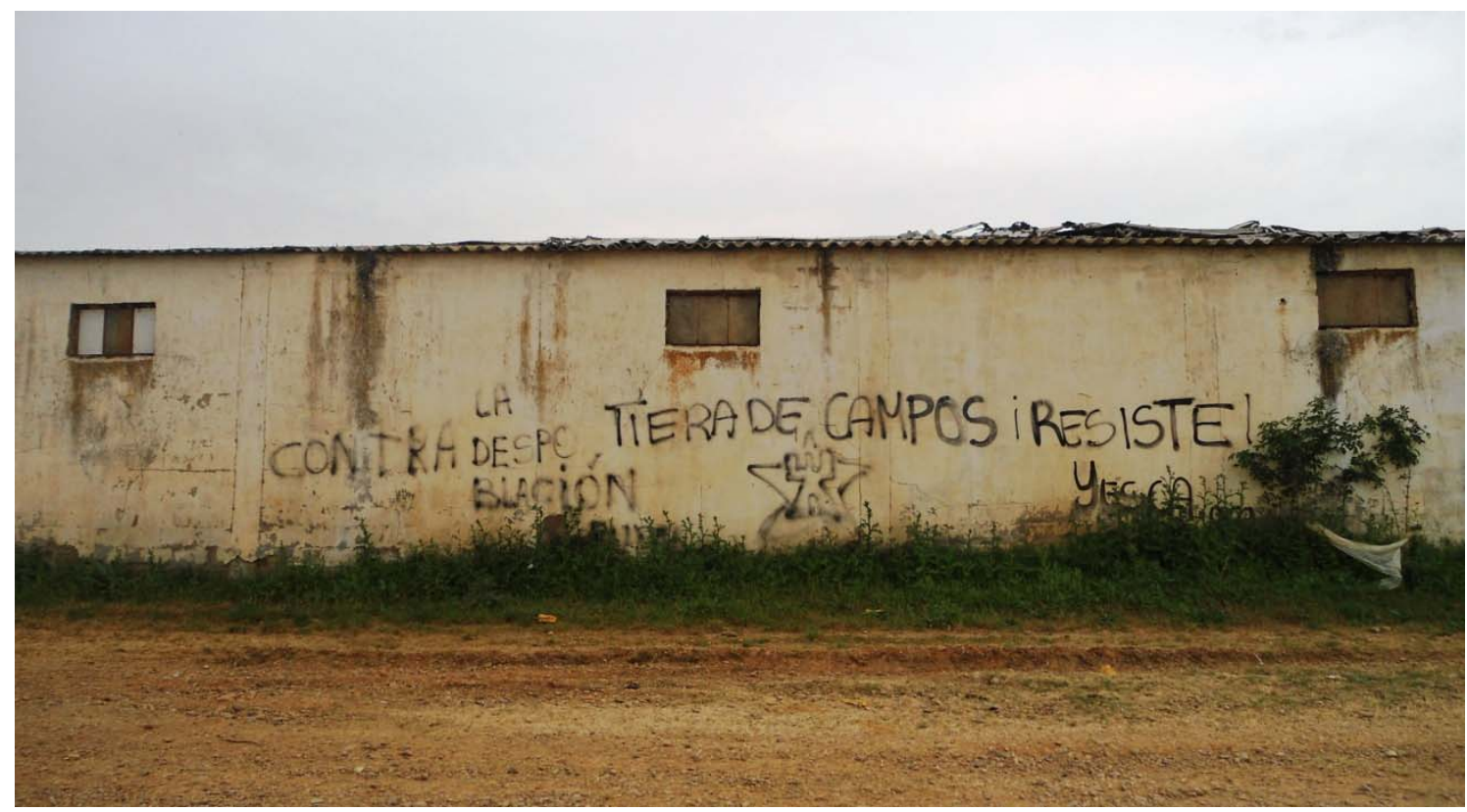

Figura 4.31. La imagen lo dice todo. Pintada contra la despoblación en una nave semiderruida de un entorno degradado en Berrueces.

A primeros de los años 70 del siglo pasado, Pedro Martín Ruiz -agente de desarrollo del IRYDAapuntaba las principales causas del éxodo rural producido en las décadas anteriores: rápido desarrollo de la industria y los servicios en otras zonas del país, deseo de vivir en grandes áreas urbanas (ante un esquema de mayor calidad de vida), crisis agraria debido al descenso del precio del cereal dentro de una economía en proceso de integración en el Mercado Común, crisis de los valores del campo (los hijos de los agricultores no quieren seguir en el medio rural, aceptándose como irreversible la falta de porvenir del pueblo) y la crisis de los núcleos rurales (el proceso de emigración de la población agraria tiene un efecto multiplicador en el resto de sectores laborales). Sucede que lo que no gusta no es ya solo el trabajo agrícola, sino el medio en que se vive. Los lugares de preferencia para la emigración de los habitantes de Tierra de Campos son País Vasco, Valladolid, Madrid y Palencia.

Este autor distingue cinco periodos entre 1900 y 1970:

- De 1900 a 1920: Se produce una catástrofe agrícola por la plaga de la filoxera, que obliga a descepar el viñedo cultivado en una parte importante de las tierras $y$, como consecuencia, a emigrar a Latinoamérica a una parte de la población.

- De 1920 a 1940: La población se estabiliza, salvo en el periodo de la guerra civil española.

- De 1940 a 1950: La población sube ligeramente. La agricultura en este periodo es rentable gracias a la protección de que goza y a la escasez de alimentos en la posguerra.

- De 1950 a 1960: Comienza el gran proceso de industrialización del país, que provoca la emigración al norte de buena parte de la mano de obra agrícola, jornaleros principalmente.

- De 1960 a 1970: La tónica es la misma que en el decenio anterior, pero con mayor intensidad. A pesar de que el crecimiento vegetativo es muy alto, la emigración genera unos descensos de población elevadísimos, sobre todo en los pueblos de pequeño tamaño. 
Martín Ruiz -en la línea del Plan de Tierra de Campos- propone tres soluciones para el problema de la despoblación: la transformación del secano en regadío, la promoción de una cierta industrialización que transforme los productos agrícolas y el desarrollo de los servicios de los pueblos, especialmente de las cabeceras de comarca. Incluso apunta al potencial turístico de la zona -ihace 40 años!-: río Carrión, Canal de Castilla, caza, pesca, bellos parajes, patrimonio... Pero todo ello debe ser inducido y planificado con urgencia por la Administración, porque espontáneamente no se producirá. Solo así podrían llegar los beneficios económicos residuales de otras zonas industrializadas y congestionadas del país; en caso contrario sería demasiado tarde, cuando ya no hubiese apenas población. Y acaba con una frase clarividente: "De esta forma, la agricultura no sería solo el arte de cultivar la tierra sino, también, de emplearla inteligentemente".

Cuatro años antes, TORBADO (1966) recogía con pesimismo los objetivos previstos en el Plan de Tierra de Campos aprobado por Decreto del Gobierno de 1965:

- Aceleración de las obras de regadío de la zona oriental (sistema Carrión-Pisuerga) e iniciación del pantano de Riaño, juzgado como pieza básica para los regadíos occidentales.

- Intensificación de la Concentración Parcelaria y creación de empresas agrarias, individuales o colectivas.

- Fomento de la ganadería y de la producción forrajera, reducción de la superficie de barbechos e intensificación de la producción de remolacha azucarera en los regadíos.

- Industrialización de la zona, tanto mediante la creación de industrias agrarias como de otro tipo, de alta utilización de mano de obra femenina.

- Investigación agraria y divulgación de técnicas de cultivo.

- Fusión de municipios.

- Fomento de la educación en sus niveles primarios, secundarios y de formación profesional.

- Aceleración de las obras complementarias de infraestructura, urbanización, alumbrado, condiciones higiénicas, centros sanitarios, etc.

El Plan de Tierra de Campos se llevó a cabo de una forma parcial y constituyó un sonoro fracaso. Efectivamente, promovió la concentración parcelaria de toda la superficie de Tierra de Campos, pero con un gran coste medioambiental y una notable merma inducida de efectivos laborales. La transformación de secano en regadío ha afectado a un porcentaje de superficie de la comarca muy reducido. Tal vez la mayor gravedad se halla en el hecho de que la industrialización propiciada ha sido prácticamente nula, al contrario de lo conseguido en las zonas urbanas y periféricas del país. En las cuestiones relativas a la mejora de la calidad de vida de la población, hay que señalar que no se fusionaron municipios, aunque sí que es verdad que ha habido logros constatables en el fomento de la educación, en la sanidad y la urbanización de los pueblos. En suma, un balance esencialmente negativo, en el que hay que destacar que el citado Plan y sus desarrollos posteriores no han servido para frenar la galopante despoblación que aún hoy sufre la comarca. El escritor Jesús Torbado relataba en 1966 "Las cosas están muy mal, según los campesinos dicen. Y ellos desconfían de que se las arreglen. También yo"; sus palabras leídas casi 50 años después no pueden ser más clarividentes. 


\section{El sistema productivo}

Aunque no lo parezca, en Tierra de Campos sí que hubo una considerable actividad industrial en la primera mitad del siglo XX. Por citar algún ejemplo, en Piña de Campos se instaló en 1941 una cerámica que llegó a dar trabajo a 100 obreros; en Osorno se montó una fábrica de galletas en 1942 con 60 obreros, en Amusco existía una floreciente industria textil artesana, Villalón de Campos contaba con cuatro fábricas de harinas, Medina de Rioseco tenía tres fundiciones, etc. Por desgracia las reconversiones han dado al traste con casi todas ellas. En la actualidad, la industria en la comarca es muy limitada, reduciéndose a las localidades de mayor población: Medina de Rioseco, Carrión de los Condes, Paredes de Nava,... En cualquier caso, se trata de industrias de pequeño tamaño, con un carácter eminentemente local (queserías, talleres mecánicos, carpinterías, preparados agroalimentarios). Muy pocas excepciones confirman esta regla, como la que abastece a la industria de la automoción en Medina de Rioseco, que cuenta con unos 200 empleados.

La actividad agraria ha sido tradicionalmente fundamental para Tierra de Campos, como lo atestigua el hecho de que el $90 \%$ de su superficie tiene un uso agrícola. No obstante, la mecanización del campo que tiene lugar a partir de mediados del siglo pasado es la causa fundamental del descenso general de la población. El cambio es espectacular, pero dramático en términos poblacionales. El aumento constante de la superficie que trabaja un agricultor es directamente proporcional al descenso de la cifra de agricultores y, en consecuencia, del total de habitantes de la comarca. Además, se abandonan las huertas, frutales u otros cultivos como la vid que necesitan de una mayor mano de obra. Por otro lado, las labores de la agricultura de secano se concentran en determinadas épocas del año (sementera, abonado y tratamiento con herbicidas, cosecha), de modo que incluso una parte de los agricultores ya viven en la ciudad, desplazándose puntualmente a sus explotaciones en los momentos requeridos.

La Política Agraria Común (PAC) y el mercado global determinan totalmente los cultivos a que se dedican las tierras de Campos. Dentro de ellos son los cereales de grano los que constituyen el principal aprovechamiento, pudiendo ser calificados de verdadero monocultivo. Cebada y trigo se alternan no obstante con cultivos forrajeros y girasol, que son alternativas planteadas para la rotación de los terrenos en los últimos años. El regadío, con una importancia relativa ligada a la vega del Carrión, al Canal de Castilla y a otras zonas puntuales, no ha propiciado un cambio radical de las explotaciones o de los tipos de cultivo.

En cuanto a la ganadería, también ha sufrido una intensificación importante en las últimas décadas. Hasta los años setenta del siglo pasado era normal contemplar cómo en el interior de los pueblos coexistían las viviendas con los apriscos de ovejas, las cuadras de vacas, los corrales con gallinas o las marraneras. Esta actividad era complementaria a la agraria o incluso a otras diferentes; en parte incluso se dedicaba al autoconsumo. Paulatinamente, los ganaderos se han ido especializando, de modo que actualmente gestionan grandes granjas intensivas de ovino (para producción de leche, lana y lechazos), vacuno (leche y terneros), porcino (cebo o cría de lechones) o avícola (huevos o pollos). Particularmente significativa ha sido la reducción de pastores de ovejas -y el consiguiente pastoreo de rastrojos-, ahora transformados en ganaderos que gestionan modernas explotaciones intensivas con un considerable mayor número de cabezas lanares. Aunque también se ha producido un descenso de la población dedicada a la 
ganadería, no ha sido tan acusado como en el caso de la agricultura. De hecho, la necesidad del cuidado continuo de los animales hace que pueda afirmarse que la ganadería realmente fija población en el medio rural.

La distribución de la población activa en Tierra de Campos muestra el claro predominio de la actividad agraria (37\% de los ocupados, cifra muy alta en el entorno europeo) y el reducido desarrollo del sector servicios ( $38 \%$ ) en comparación con el porcentaje regional. El peso de la construcción (11 \%) es similar al que tiene Castilla y León, en tanto que la industria presenta un reducido $14 \%$. Aunque estos datos confirman el marcado carácter agrario de la economía comarcal, hay que reseñar que el sector está experimentando en los últimos años una constante reducción de sus efectivos, siendo los servicios las únicas actividades en crecimiento. Por otra parte, el paro es reducido en la comarca, pero ello obedece no tanto a la capacidad de la economía para absorber a los nuevos activos, como a la emigración de estos hacia los centros urbanos más dinámicos. (CONSEJERÍA DE MEDIO AMBIENTE, 2002).

\section{$\underline{\text { Servicios e infraestructuras }}$}

Sobre los servicios se puede decir que en líneas generales se agrupan en las cabeceras de comarca: Villalpando, Medina de Rioseco, Villalón de Campos, Sahagún, Paredes de Nava, Mayorga, Carrión de los Condes, etc. Es allí donde se ubican los centros de salud, pequeñas unidades administrativas, colegios y, en algún caso, institutos de bachillerato o de formación profesional. En la mayoría de los casos, el personal funcionario que los atiende vive en las ciudades y se traslada diariamente a cada una de las localidades.

En cuanto a los centros de enseñanza -públicos, salvo alguna excepción-, se organiza un sistema de transporte que conduce diariamente a los escolares de las pequeñas poblaciones, mediante rutas en general de más de media hora de duración. En estos pueblos (más de dos tercios de la comarca), sus colegios han ido desapareciendo como una lenta agonía, hasta que ya no se alcanzaba el ratio mínimo de alumnos exigible. En la actualidad los centros existentes mantienen sus unidades educativas con un número reducido de alumnos por clase, lo que conlleva una alta calidad de enseñanza, pero con la espada de Damocles acechando, porque la progresiva disminución del alumnado conllevará la eliminación de más centros, unas rutas de transporte más largas y una pérdida general del nivel de servicios. De ahí a llevar a los niños a estudiar a la ciudad y trasladar así a toda la familia, no hay más que un paso.

Con la asistencia sanitaria la situación es similar. El nivel de bienestar alcanzado por el país en los últimos años (al menos hasta la actual crisis económica) ha conllevado la garantía de una sanidad pública universal, que también llega al medio rural al menos en la atención primaria. Pero el equilibrio es precario, cualquier recorte presupuestario en esta materia podría repercutir directamente en la calidad del servicio, y así constituir una causa más de abandono de la población. En los pueblos pequeños existen consultorios atendidos por médicos algún día a la semana. Las localidades que tienen centros de salud atienden diariamente a la población y cuentan -de momento- con un servicio de urgencias nocturno. Solo los mayores municipios disponen de consultas de especialistas algún día a la semana. En la mayoría de las ocasiones, esta consulta se ha de realizar en los hospitales situados en las capitales de provincia, adonde también se dirigen las urgencias complicadas; los trayectos en buena parte de las localidades superan la hora de duración. 
En cuanto a los servicios sociales, también en los municipios mayores existen centros de acción social (CEAS) de las diputaciones provinciales. Las residencias de ancianos son en general privadas y últimamente se han ido implantando incluso en pequeñas localidades. Sin lugar a dudas se trata de un gran beneficio para el medio rural -muy envejecido- por el propio servicio social que conlleva, el empleo de un buen número de trabajadores locales y la oportunidad que supone si se logra captar residentes de un medio urbano más congestionado.

Respecto de las comunicaciones se puede afirmar que en la actualidad la red de carreteras comarcal se encuentra en un estado bastante aceptable. Tierra de Campos es atravesada tangencialmente por tres autovías: Cantabria-Meseta por el Este, Camino de Santiago por el Norte y Madrid-Coruña por el Oeste; ninguna de ellas estructura la comarca, son realmente vías de alta capacidad de paso entre ciudades del país, aunque también dan servicio a las poblaciones adyacentes. Más estructurantes son las carreteras nacionales (por ejemplo la N-610 y la N-601) $y$, sobre todo, la red autonómica de carreteras, que en los últimos años ha mejorado sustancialmente su calidad. Intersticialmente, el territorio se teje con una malla de carreteras de titularidad provincial, de configuración técnica más limitada, pero que también ha experimentado una notable mejoría. En todos los casos, las características orográficas de Tierra de Campos permiten trazados de las vías muy rectilíneos, por lo que temporalmente los trayectos se acortan sustancialmente respecto de otros territorios; a ello también ayuda los escasos niveles de tráfico.

Con el transporte público la situación es diametralmente diferente. El otrora ferrocarril de Castilla (conocido popularmente como el tren burra) que prácticamente cosía la comarca Valladolid, Medina de Rioseco, dirección Noroeste, Villalón de Campos, Villada, Palencia, etc.-, lamentablemente desapareció en 1967, en pleno éxodo rural. Actualmente solo perviven las líneas de ferrocarril convencionales Palencia-León y Palencia-Santander, que atraviesan y dan servicio a varias poblaciones de la comarca. Eso no pasará cuando se haya construido en su totalidad la línea de ferrocarril de alta velocidad Palencia-León, que únicamente atravesará el territorio en una malla nacional que une ciudades; el medio rural es un simple espectador de la faraónica infraestructura. En cuanto a las líneas de transporte de viajeros por carretera, están orientadas a las comunicaciones con las capitales provinciales y se mantienen gracias a la subvención pública con un número muy reducido de usuarios. Recientemente se ha puesto en marcha un interesante programa de transporte a la demanda, más flexible en cuanto a los requerimientos reales de la población.

\section{Del productivismo agrario al postproductivismo: la necesaria diversificación}

Tal como señala BARAJA (1997) y se corrobora con la situación actual, en los espacios agrarios en general, y en Tierra de Campos en particular, se está produciendo un cambio que todavía tiene mucho de coyuntural, pero que lentamente se va consolidando. Se trata del tránsito de un modelo agrario de corte productivista hacia otro postproductivista. Es lo más moderno y lo que está sucediendo en los países europeos de nuestro entorno; lleva parejo una nueva consideración tanto de lo agrario como de lo rural en su conjunto, en toda su dimensión económica, social y medioambiental. Las sucesivas modificaciones de la Política Agraria Común (PAC) -y desde luego la más reciente- han ido en esta línea: las subvenciones a las rentas agrarias deben condicionarse a una política de conservación de la naturaleza activa. Además, hay 
consenso en admitir que el desarrollo rural no debe concebirse exclusivamente como desarrollo agrario.

Estas ideas han encontrado una forma de aplicación dentro del marco normativo comunitario: las iniciativas Leader. A través de las estrategias diseñadas por los Grupos de Acción Local (GAL) -en Tierra de Campos hay varios- se llevan a cabo acciones o proyectos concretos dentro de una serie de medidas que van desde la formación profesional, la restauración del patrimonio, las ayudas a las pequeñas y medianas empresas, la valorización "in situ" de las producciones agrarias o el fomento del turismo rural. Ejemplos concretos de proyectos subvencionados con estas iniciativas son la restauración de palomares, la valorización del patrimonio históricoartístico, la construcción o rehabilitación de casas rurales o centros de turismo rural con restaurantes, el apoyo a pequeñas industrias agroalimentarias o la promoción de los mercados comarcales. Estos programas constituyen otra forma de entender el desarrollo rural y están poniendo de relieve la potencialidad del espacio rural como área de esparcimiento y ocio para la población rural. Pero también evidencian las dificultades que existen a la hora de encontrar alternativas viables que permitan mantener el tejido humano de una comarca en claro declive poblacional.

Por otra parte, hay un aspecto poblacional que se está dando puntualmente, pero que puede tener un gran potencial. Se trata de personas que trabajan en las ciudades y residen en los pueblos; porque allí tienen a su familia o porque así lo deciden voluntariamente (neorurales). Es el caso inverso ya citado de la mayoría de funcionarios que gestionan los servicios en la comarca. Esto sucede en muchos otros territorios rurales (Cataluña, Madrid, comunidades del norte de España, etc.), que convierten los pueblos en zonas residenciales, y es muy incipiente en Tierra de Campos. Pero puede ser una de las esperanzas para esta tierra si el abandono no es total, se mantienen unos servicios mínimos y se cuidan los pueblos y su entorno.

Y es que la situación socioeconómica de Tierra de Campos es muy diferente de otros espacios rurales de Castilla y León o de España. En el primer caso, no hay más que ver las diferencias con comarcas rurales próximas mucho más desarrolladas, como la Ribera del Duero y la Tierra de Pinares; en estas la diversidad paisajística ha jugado un papel fundamental en la diversificación productiva (vino, madera, industria agroalimentaria, turismo, etc.). Qué curiosa paradoja: Tierra de Campos posee unos suelos más productivos, pero la eliminación de los viñedos y el arbolado y la apuesta única por el cultivo cerealista se ha demostrado letal para la comarca.

A escala nacional hay diferencias mucho más acusadas. Así, por ejemplo, REGUANT (2014) señala que en Cataluña el éxodo rural se moderó en los años 70 del siglo pasado, y en los 90 entró en clara recuperación a partir de una diversificación productiva orientada a la agroalimentación y a los servicios. Actualmente las comarcas rurales catalanas tienen hoy más población que en 1955, comienzo de la despoblación generalizada. Entre los factores que contribuyen a afianzar la población en el medio rural, este economista señala al regadío, la ganadería intensiva y la transformación de sus productos, la mejora de las comunicaciones, servicios completos de calidad y un cuidado exquisito del paisaje. Atención a este último detalle. 


\subsection{Arquitectura tradicional}

\section{Análisis tipológico}

BENITO (1998) en su magnífica obra "La arquitectura tradicional de Castilla y León", señala que Tierra de Campos se corresponde con el modelo 12 de los inventariados: "Núcleos en origen cercados, de disposición continua y edificación con corral posterior. Campiñas septentrionales", que a continuación se describirá. En ellos el tejido urbano aparece configurado y desarrollado en función de la calle. Las manzanas son grandes, irregulares y de perímetro envolvente. Las parcelas son también grandes con el corral al fondo, cuerpo edificado y fachada recayente a la calle. Una o dos alturas con vivienda en planta baja.

En cuanto a las referencias históricas de este modelo, cabe señalar que en la repoblación medieval sufrió un intenso proceso de inmigración y génesis urbana, que se formalizó en un conjunto generalizado de villas cercadas; no en vano en el siglo XVI era la zona más densa de la región. El trazado está generado por la muralla, sus puertas y edificios singulares y las calles en segundo término; formas cerradas y envolventes en el perímetro urbano.

Sobre el tejido interno cabe considerar que el sistema de agrupación es en grandes parcelas con edificación en fachada y corral posterior, agrupadas en manzanas de disposición continua y núcleos de considerable tamaño con perímetro cercado. Las manzanas tienen forma irregular, se pueden encontrar 10-20 en los núcleos de tamaño medio y su superficie es considerable. Las parcelas también tienen forma irregular, tendente a la rectangular; su superficie es de 200-550 $\mathrm{m}^{2}$.

En relación con la imagen física de los núcleos, en llano se observa el conjunto de disposición horizontal; la imagen está formada por las traseras adosadas a la cerca, casi siempre de barro, sobre ella emerge el volumen del templo parroquial. Las aperturas visuales son escasas y la zona de borde, muy nítida y contrastada, definida por la antigua línea de muralla. Las plazas tienen una situación central, irregular, de planta muy variada; en ellas se sitúa la edificación civil, a veces la iglesia y porticados. Las calles constituyen el elemento básico del asentamiento; son largas, rectas y generalmente anchas; a ellas recaen las fachadas, adosadas por sus medianerías.

La edificación tiene en origen una sola planta, aunque a veces el desván superior se configura como una planta independiente. El programa de vivienda se desarrolla básicamente en planta baja, con el portal o zaguán, la cocina, sala y dormitorios o alcobas. Las cuadras suelen estar más ligadas al corral, que a menudo tienen una gran puerta trasera o "portalón", por donde salían los animales de tiro a realizar las labores agrícolas. Existe una notable superficie destinada a pajares, importante para dar de comer al ganado y "enrojar" en las glorias (calefacciones subterráneas).

\section{Materiales}

La arquitectura popular o tradicional de Tierra de Campos es uno de los elementos más significativos de la comarca (Figura 4.32). Su geomorfología de llanuras sedimentarias suavemente onduladas, con suelos arcillosos y ausencia de piedra, ha sido la causa de que el material mayoritariamente empleado para la construcción haya sido la tierra. 0 , más 
precisamente, el barro: la mezcla de tierra previamente cribada, envuelta con paja trillada y agua, y amasada convenientemente en montones o "parvones" depositados en el suelo.

Con la mezcla lista para ser trabajada, se podían fabricar adobes, ladrillos o tapiales. Los dos primeros se hacían prensando el barro en moldes rectangulares de madera, denominados "mecales". Si las piezas resultantes se dejaban secar al sol, se obtenían adobes, pero si se cocían al horno, el producto eran ladrillos; en ambos casos sus tamaños son variables. Por el contrario, para hacer tapiales o muros la mezcla se vertía directamente en encofrados fabricados con tableros de madera, que podían alcanzar dimensiones importantes (FRECHILLA, 2007). Las fachadas de adobes o tapiales se revocaban con la misma mezcla de barro y paja, mediante la acción conocida como "capeado", "embarrado" o "trullado". El ladrillo se reservaba para la cimentación de paredes maestras, para el recercado de huecos o para fachadas principales de personas más pudientes. La piedra es anecdótica en Campos; la poca que hay es caliza y procede de los montes Torozos, restringiéndose su uso a alguna iglesia o casa solariega.

La estructura de una vivienda tradicional se basaba generalmente en el empleo de paredes maestras, bien de tapial, bien de un asta de adobe (la anchura es la longitud de un adobe, usualmente grande). Las paredes intermedias se realizaban con una estructura "de poste y carrera", que resulta ser un entramado mezclado con pies derechos de maderos. Los forjados también se hacían con viguetas de madera, la mayoría recicladas, en general de pino y algunas veces en roble. Sobre los forjados y la cubierta se extendía una capa de barro, que servía de aislante y para dejar las superficies más o menos a nivel. Los canes de madera sujetaban un veral en general estrecho. La cubierta se remataba en teja curva árabe, material que también procede de la arcilla, moldeado y secado en hornos. Puertas y ventanas se fabricaban de madera, generalmente de proporciones reducidas, siendo mayor siempre la dimensión vertical que la horizontal. En algunos casos, los huecos tenían recercados en yeso blancos. 

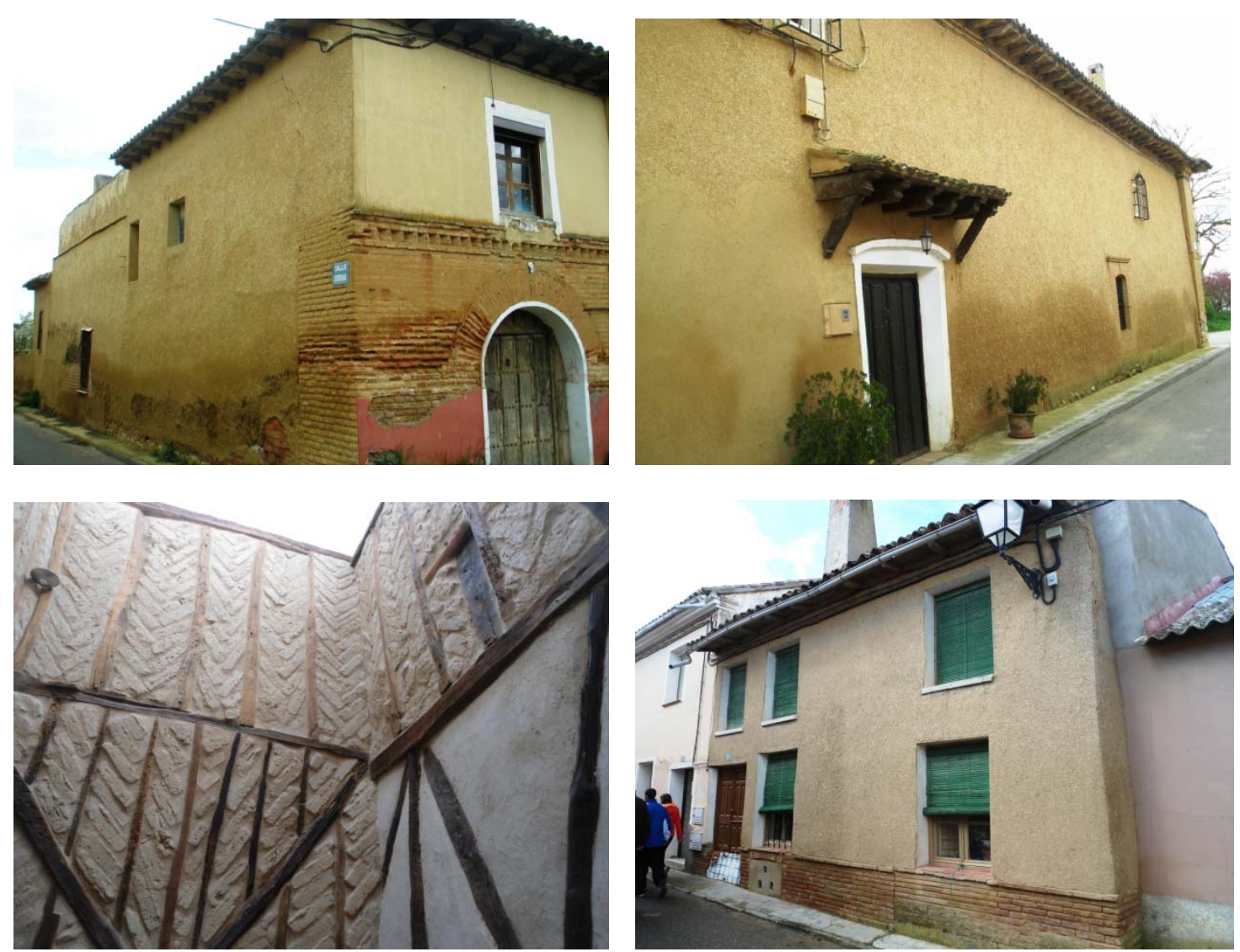

Figura 4.32. Tres ejemplos de viviendas tradicionales: en Abarca de Campos (las dos superiores) y en Melgar de Abajo (abajo derecha). Abajo a la izquierda, paredes interiores descubiertas con adobes y estructura "en poste y carrera" en Villalón de Campos.

La arquitectura en barro o en tierra -como es fácil de interpretar- es austera, barata y propia de la zona. Resulta además (aunque antes no se supiese) totalmente ecológica, sostenible y bioclimática; el barro es un material muy aislante, que protege del calor del verano y mantiene la temperatura en invierno por su gran inercia térmica. Pero tiene un gran enemigo: el agua. La Iluvia, sobre todo en las fachadas sometidas a vientos dominantes, golpea indefectiblemente sobre las paredes de barro de modo que, poco a poco, descubre la paja y a la larga provoca su desconchado. Ello conllevaba que los trullados habían de ser periódicos. En algunas localidades se implementaban morteros a la cal, que eran más compactos y menos vulnerables a la lluvia. Pero es que, además, la humedad de capilaridad también afecta sustancialmente a las paredes de barro, sobre todo si no se ventila convenientemente la casa o se impermeabilizan las paredes. Ello se hizo patente después de la pavimentación con hormigón de los núcleos urbanos; la humedad del suelo tenía que ascender por las paredes de barro, suponiendo una merma de su capacidad estructurante. Si a todo esto le añadimos que tradicionalmente barro ha sido asociado a pobreza, suciedad y calamidades, no es difícil comprender la aversión de los pobladores de Campos a este material: durante las últimas décadas buena parte de las viviendas que se han mantenido han visto cubiertas sus fachadas con revocos o revestidos de ladrillo. Al menos, el adobe está ahí; peor suerte han corrido las construcciones en peor estado de conservación (Figura 4.33): demolidas, convertidas en solares o sustituidas por nuevas edificaciones. 

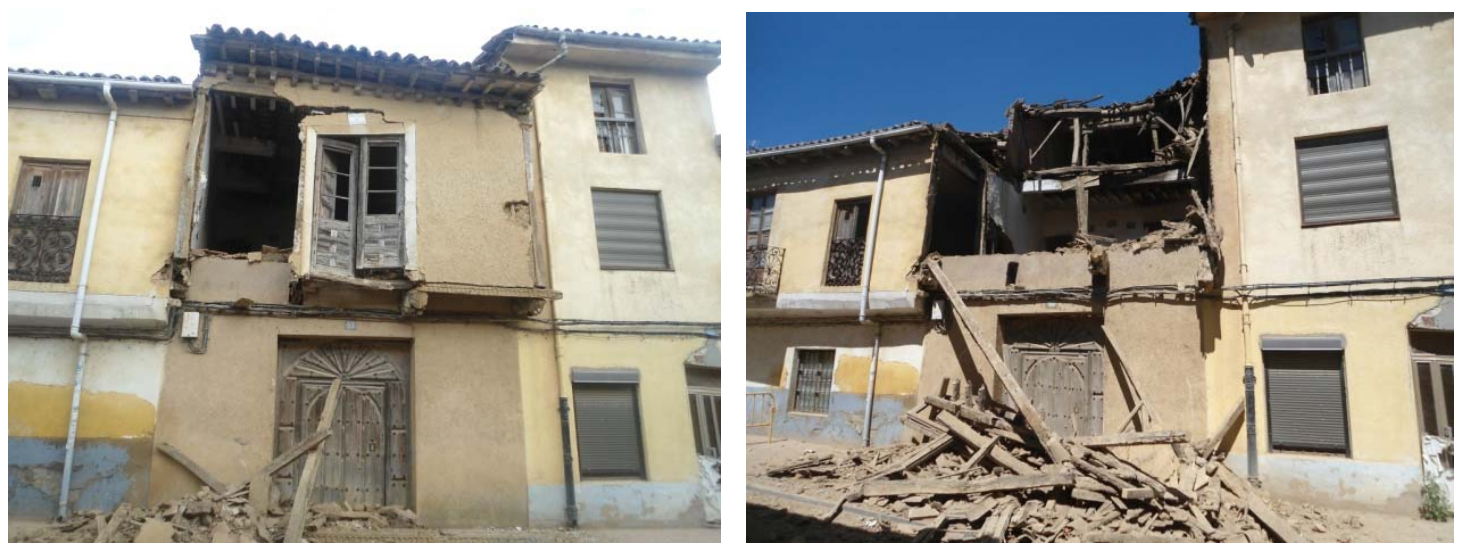

Figura 4.33. Dramática secuencia del derrumbe por abandono en 2014 de un ejemplo de arquitectura tradicional en Villalón de Campos, datada del siglo XVI.

A pesar de que actualmente en Tierra de Campos la arquitectura del barro está en peligro de extinción, cabe decir que este sistema, tanto por su color, textura y volúmenes creados alcanza un altísimo valor estético. Es un elemento de identidad de la comarca y, como tal, debería ser conservado (Figura 4.34). Aunque para ello fuese necesario recurrir a tecnologías modernas que permiten superar su vulnerabilidad, como el impregnado de las fachadas con productos compactantes permeables o el empleo de cemento en las amasadas, con morteros bastardos o a la cal.
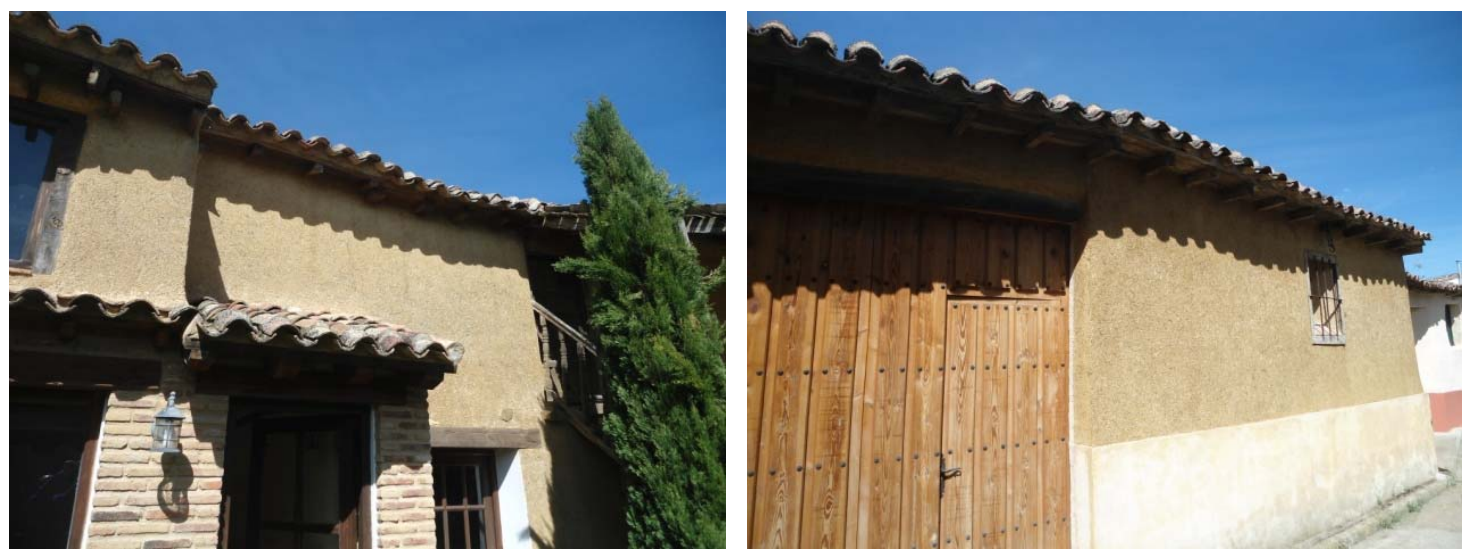

Figura 4.34. Corral y portalón restaurados de una casa en Villalón de Campos

\section{$\underline{\text { Las bodegas }}$}

Tal como se ha reseñado anteriormente, en Tierra de Campos existía una superficie significativa dedicada a viñedos, los aquí conocidos como majuelos. La mayoría de la producción se dedicaba al autoconsumo; en este sentido, se debe tener en cuenta que la población de la comarca era mucho mayor y que el vino se consumía con más asiduidad de lo que se hace actualmente. 
La existencia de tesos -promontorios o terrenos elevados- en las cercanías de los pueblos y su naturaleza edáfica arcillosa, facilitaba la creación de bodegas horadadas en la tierra. Buena parte de los pueblos de Campos tiene su zona de bodegas. En estas cuevas se realizaban los distintos procesos para fabricar el vino, desde la elaboración del mosto hasta su crianza y conservación; aquí juegan un papel fundamental las bodegas, en cuanto que mantienen su temperatura baja y constante a lo largo de todo el año.

El exterior de las zonas de bodegas suele ser semejante: entradas a las mismas con pequeñas puertas, superficie en tierra para que transpire y existencia de zarzeras o chimeneas para limpiar el aire de la cueva. Por desgracia, la falta de uso y la despoblación ha hecho que buena parte de las bodegas se hayan derruido. Se han salvado las que sirven de merendero, magnífico lugar lúdico para los días de calor estivales.

Por otra parte, en algunos pueblos de Tierra de Campos tienen gran importancia las bodegas situadas en el interior de las viviendas. Son estas también cuevas horadadas en la tierra, que parten generalmente del portal de la casa y descienden a cotas inferiores con la limitación de no coincidir con el nivel freático. Los respiraderos se deben conducir a los patios. En este caso, a la función vitivinícola de las bodegas se debe asociar la de almacén de productos alimentarios o incluso el comercio de los mismos. Un caso particular son los denominados silos, depósitos subterráneos destinados a almacenar sobre todo legumbres; allí se trataban y cerraban para su correcta conservación durante todo el año.

Unas y otras conforman una parte muy importante del patrimonio cultural de Tierra de Campos y de Castilla y León. Deberían ser catalogadas en los planes urbanísticos municipales para asegurar su conservación pero, sobre todo, tener una política activa de rehabilitación y valoración, pues es este el mejor modo de mantener el patrimonio.

\section{Los palomares}

Nos encontramos aquí con el elemento más identificativo y emblemático de Tierra de Campos. A su valor como factor constitutivo del patrimonio cultural y edificado de la comarca hay que sumarle su valor paisajístico, ya que surge desde el mismo paisaje agrícola y asimismo lo enriquece (Figura 4.35). No es casual que los palomares se hayan construido casi exclusivamente en Castilla y León y que, en ella, la mayoría correspondan a Tierra de Campos. Ni tampoco lo es que el producto cerámico artesano más representativo de la comarca sea el palomar. 


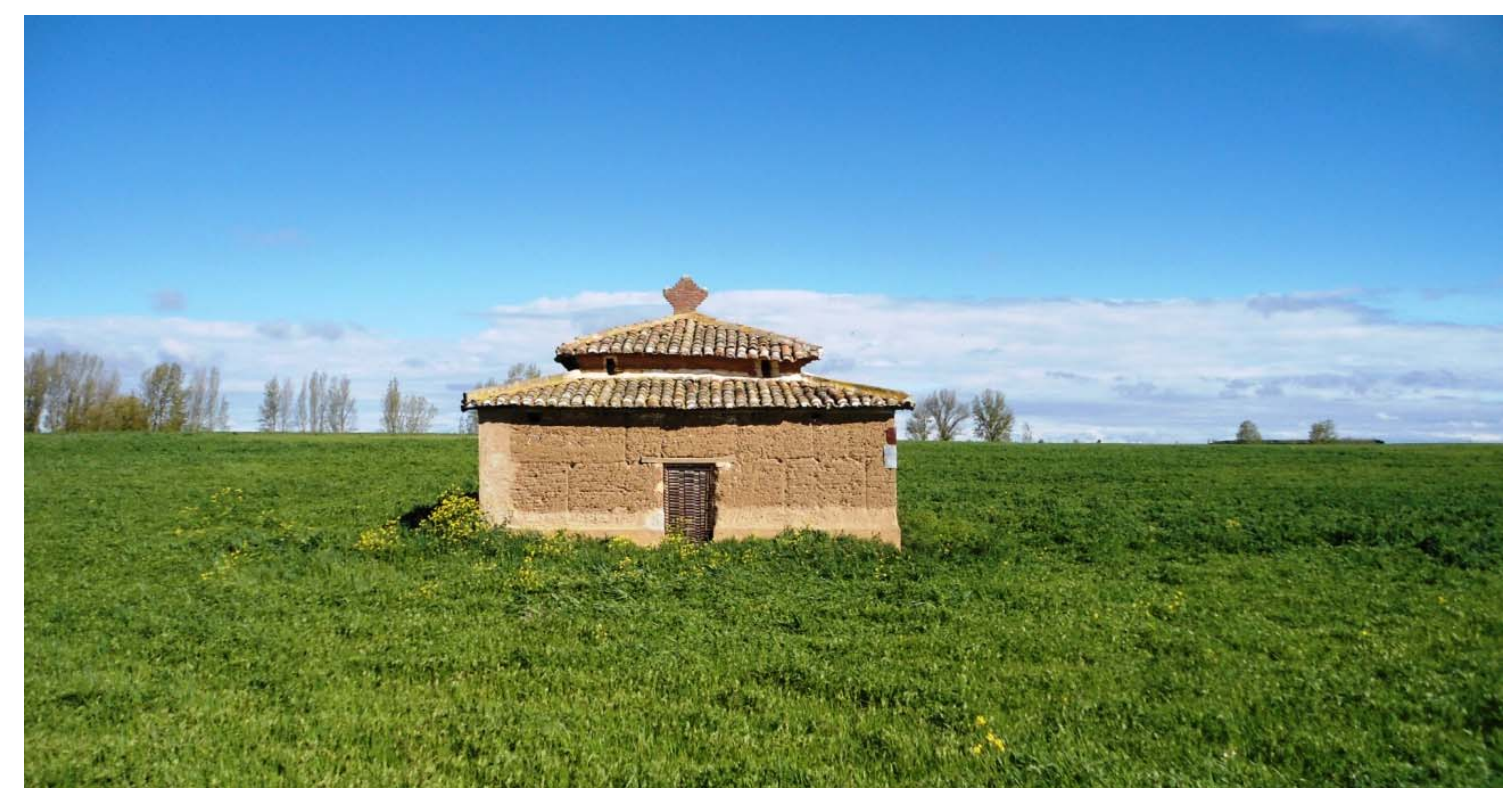

Figura 4.35. Palomar en Monasterio de Vega

Los palomares son construcciones aisladas situadas a las afueras de los pueblos, construidas con adobes y más corrientemente con tapial, teniendo cubierta de teja árabe. Su planta puede ser cuadrangular, rectangular o circular (Figura 4.36). En su interior se levantan paredes paralelas o concéntricas en tierra, en donde se horadan pequeños orificios -los nichos o nidales- para criar los pichones, que es el principal producto de los palomares y una fuente de nutrición humana. Las palomas se mantienen en estado silvestre alimentándose del grano de los campos, entrando y saliendo de estos edificios singulares por pequeños huecos situados en los tejados. El otro producto secundario es la palomina, excremento de estas aves que constituye un buen abono orgánico.

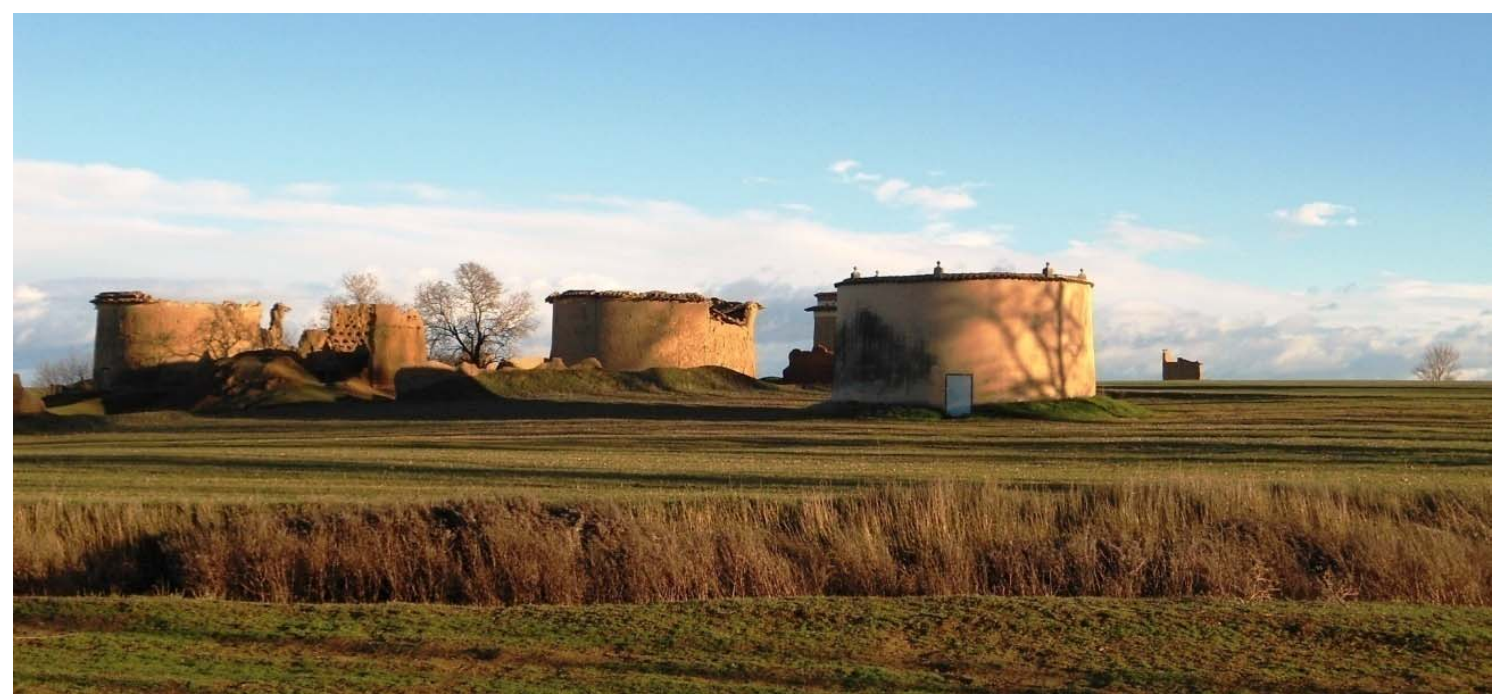

Figura 4.36. Grupo de palomares de planta circular en Guaza de Campos. 
Lamentablemente, una parte considerable de los palomares de Tierra de Campos se han derrumbado, al perder su funcionalidad. No es difícil encontrar en casi todos los pueblos restos de estas edificaciones, hallándose al aire sus paredes interiores o incluso ya convertidos en montones de tierra. No obstante, se debe reconocer que en las últimas décadas se han restaurado bastantes palomares, en buena medida debido a una correcta política de valorización del patrimonio llevado a cabo por los grupos de acción local con las iniciativas Leader. En estos casos se ha retejado convenientemente y se han protegido las paredes exteriores con enfoscados de cemento acabados en color blanco o con revocos de mortero bastardos o a la cal en color tierra.

\subsection{Patrimonio histórico-artístico}

Exponer en un apartado el patrimonio histórico-artístico de Tierra de Campos no es tarea fácil. La historia que ha tenido esta comarca y el esplendor de que ha gozado, sobre todo en determinadas épocas, han propiciado que cuente con un riquísimo patrimonio monumental. Para tratar de ser sintéticos, se ha realizado una recopilación esquemática del contenido del libro Tierra de Campos (LANCIA, 2004) que, de una forma detallada e ilustrada, documenta por zonas y términos municipales las obras más valiosas. Se ha seguido un orden cronológico por las principales épocas artísticas, destacándose la arquitectura religiosa, que es la que más abunda.

Vestigios romanos: Pocos son los restos de aquella época; los más importantes son la calzada romana de Carrión de los Condes, la villa romana de Quintanilla de la Cueza, y el puente y la calzada en Becilla de Valderaduey.

Del Siglo X : Destacamos el castillo de Grajal de Campos, el monasterio de Monasterio de Vega y la iglesia de San Cebrián de Mazote, de estilo mozárabe.

Románico (S.X-XIII): En toda la comarca terracampina existen al menos 25 edificios representativos del románico (Figura 4.37), destacando la iglesia de San Martín de Frómista, la ermita del Castillo de Támara de Campos, el monasterio de la Santa Espina, la ermita de Nuestra Señora de la Anunciada en Urueña, la iglesia de Santa María y la fachada de la iglesia de Santiago en Carrión de los Condes, la torre de la iglesia de Santa Eulalia en Paredes de Nava, la iglesia de Manquillos y el monasterio de monjas benedictinas en San Pedro de Dueñas. 

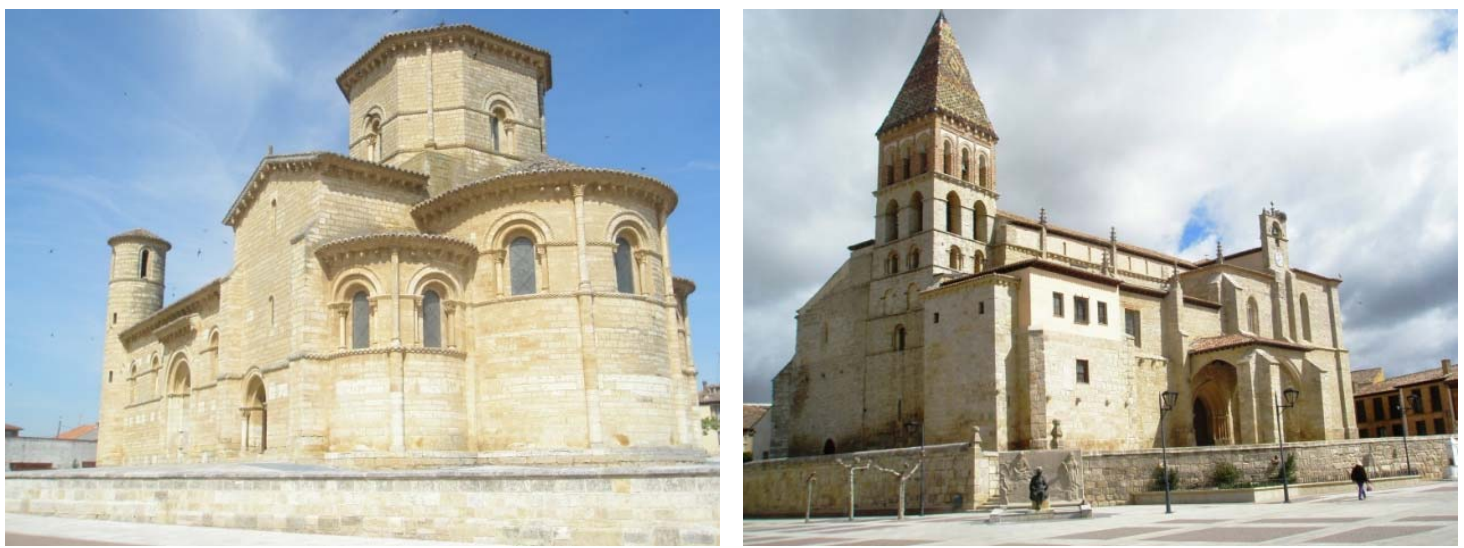

Figura 4.37. A la izquierda, iglesia de San Martín de Frómista; derecha, iglesia de Santa Eulalia de Paredes de Nava

Románico-Mudéjar (S.XII-XIII): es remarcable la utilización del ladrillo en templos románicos como los de Sahagún: iglesias de San Lorenzo y de San Tirso; así como en la iglesia de San Gervasio y San Protasio en Santervás de Campos. También son de estilo románico-mudéjar las iglesias de Santa María la Antigua y la de San Andrés en Villalpaldo, así como la iglesia de Santa María del Río en Castroverde de Campos.

Mudéjar (S.XII-XIV): existen alrededor de 30 templos mudéjares en la comarca, algunos en buen estado y otros de los que solo se conserva el artesonado (por ejemplo en la ermita de la Piedad de Osorno, en el convento de Santa Clara de Astudillo, o en la iglesia de San Juan Bautista en Villalón de Campos) o la torre (por ejemplo la torre de la antigua iglesia de Santa Cecilia en Villalán de Campos, y las torres de las iglesias de Grajal de Campos, Villada, Melgar de Arriba, Melgar de Abajo o Monasterio de Vega). A pesar de ello, destacamos una obra mudéjar que ha sido declarada Monumento Histórico Artístico Nacional: el artesonado de la iglesia de San Facundo y San Primitivo en Cisneros. Un ejemplo de templo mudéjar en buen estado de conservación es el de San Justo y Pastor en Cuenca de Campos. Otros vestigios mudéjares son los arcos de Arrejas y Santiago en Valderas.

Morisco (S.XV-XVI): Portada islámica del palacio de doña María Padilla del convento de Santa Clara en Astudillo

Gótico (S.XII-XVI): Como mínimo hay 36 ejemplos de arquitectura gótica en Tierra de Campos. Destacamos los siguientes templos: iglesia de San Juan Bautista en Santoyo, iglesia de San Hipólito en Támara de Campos, iglesia de San Miguel en Piña de Campos, la colegiata de San Miguel en Ampudia, la iglesia de la Santa Espina, la colegiata de San Luis (llamada "El Escorial de Campos") en Villagarcía de Campos, la iglesia de Santa María la Blanca en Villalcázar de Sirga, el Real Monasterio de Santa Clara en Carrión de los Condes, y la iglesia de Santa María en Fuentes de Nava -declarada Monumento Nacional-.

En cuanto a otros monumentos de estilo gótico, caben destacar los Rollos Jurisdiccionales erigidos en varias localidades: Aguilar de Campos, Bolaños de Campos, Mayorga y destacando entre ellos el de Villalón de Campos por su belleza escultórica. 
Castillos de esta época: Monzón de Campos, Fuentes de Valdepero, Astudillo, Autillo del Pino, Torremormojón (en ruinas), Ampudia (restaurado y en magnífico estado de conservación, Figura 4.38), Montealegre de Campos, Villalba de los Alcores, villa-fortaleza medieval de Urueña, y torre del antiguo castillo de Belmonte de Campos.

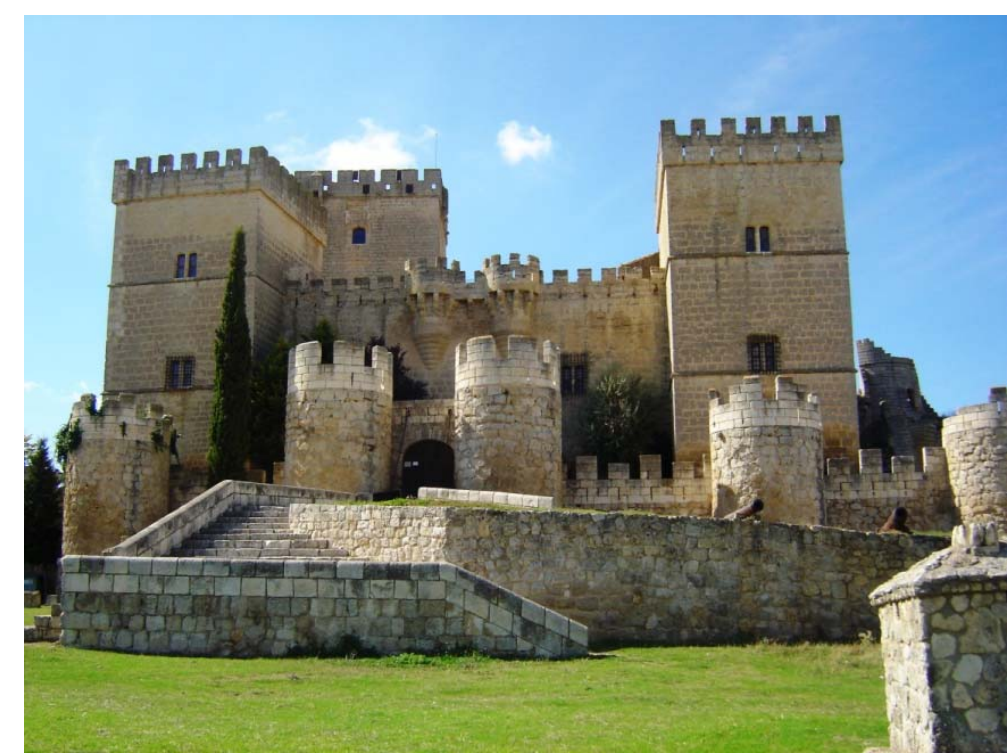

Figura 4.38. Castillo de Ampudia

Palacios: a destacar el palacio de Grajal de Campos y el palacio de los Cuadrillero en Palazuelo de Vedija.

Gótico-Mudéjar (S.XIV-XVI): En esta comarca también destacan numerosos templos de estilo gótico-mudéjar, siendo muy representativos los siguientes: la iglesia de San Miguel y la iglesia de San Juan Bautista de Villalón de Campos, la iglesia de San Andrés de Aguilar de Campos (Figura 4.39), la iglesia de Santa María del Castillo en Cuenca de Campos, la iglesia de San Pedro en Gatón de Campos, la torre de la iglesia de San Fructuoso en Villada, la iglesia de San Esteban en Villamayor de Campos; siendo asimismo muy relevante el santuario de la Peregrina en Sahagún, recientemente restaurado. 


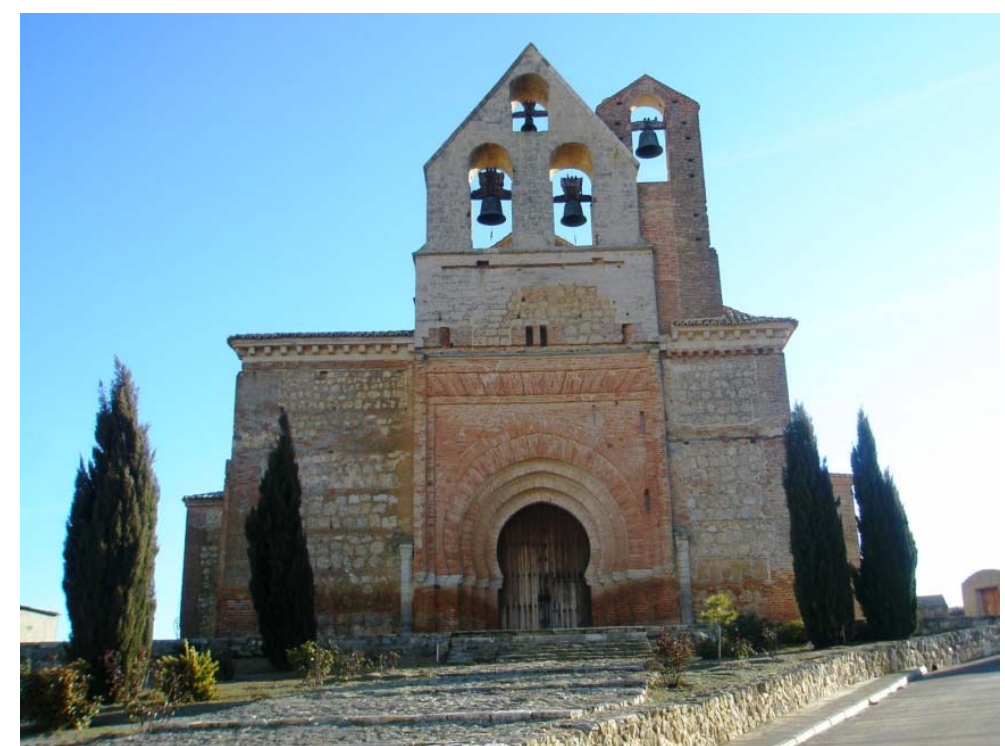

Figura 4.39. Iglesia de San Andrés de Aguilar de Campos

Renacimiento (S.XV-XVI): También podemos disfrutar en la comarca de varios monumentos renacentistas, como el palacio de los Hierro en Osorno (actual Ayuntamiento), la portada plateresca de la iglesia de San Juan Bautista en Santoyo, el claustro de estilo plateresco castellano del monasterio de San Zoilo en Carrión de los Condes, la iglesia de Santa María (que fue sinagoga judía) en Paredes de Nava, la iglesia de San Martín en Becerril de Campos, el palacio de Abarca de Campos, la portadas platerescas de las iglesias de San Esteban y Santa María en Castromocho; finalmente destacamos la torre de la iglesia de Fuentes de Nava, llamada la "Estrella de Campos" por su esbeltez y belleza, así como la Capilla de los Benavente, en la iglesia de Santa María de Medina de Rioseco, Ilamada también la "Capilla Sixtina de Castilla y León".

Barroco (S.XVII): De esta época son relevantes los siguientes ejemplos: la iglesia del monasterio de San Zoilo en Carrión de los Condes, la iglesia del convento de Santa Brígida en Paredes de Nava, la iglesia de San Sebastián de Abarca de Campos, la iglesia de Santa María, en Frechilla, destacando de esta última su órgano que es de los más valiosos de Tierra de Campos. También es de estilo barroco la espléndida torre de la iglesia de Santa María en Medina de Rioseco (Figura 4.40), así como el colegio seminario de San Mateo en Valderas, la iglesia de San Miguel de Roales de Campos, la iglesia de Santo Tomás de Quintanilla del Molar, la iglesia de San Pelayo y San Cucolate en Villardefrades y el inacabado templo de San Andrés en esta última localidad. 


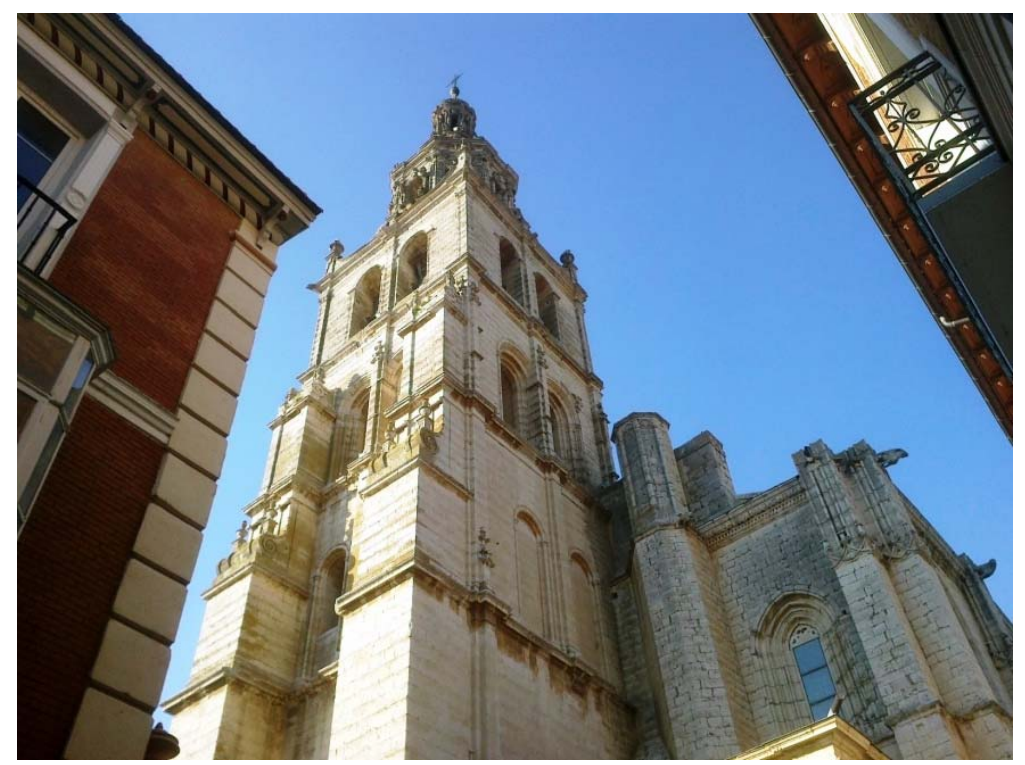

Figura 4.40. Torre de la iglesia de Santa María, en Medina de Rioseco

Neoclasicismo (S. XVIII-XIX): Es de este estilo arquitectónico la iglesia de San Miguel de Villarramiel.

Conviene destacar que, aparte del valioso patrimonio detallado, existen números ejemplos de arquitectura modernista, de principios del S.XX, por ejemplo en Becerril de Campos o en Villarramiel.

Y por último mencionar el valioso contenido artístico y escultórico que albergan todos los templos antes citados; resultando en muchos casos, que su deterioro o conservación depende de la restauración y mantenimiento de los edificios.

\subsection{Resumen del capítulo}

Tierra de Campos es una comarca natural de gran identidad, que se extiende por las provincias de Palencia, Valladolid, Zamora y, en menor medida, León. Sus límites no están definidos claramente, aunque se puede estimar su superficie dependiendo de la fuente entre 4400 y 5700 $\mathrm{km}^{2}$.

Los principales habitantes históricos de la comarca fueron los vacceos, varios siglos antes de Cristo. Fue ocupada posteriormente por romanos, los pueblos del Norte y los visigodos, de quienes procede la denominación de Campos. Después de ser zona fronteriza durante la ocupación musulmana, es repoblada a partir del siglo IX por los reinos cristianos del norte de la península. Durante la Edad Media y el Renacimiento Tierra de Campos adquiere su máximo esplendor, siendo una de las comarcas de mayor densidad demográfica del país. El cambio de una agricultura tradicional a otra productivista a mediados del siglo XX fue el detonante del éxodo rural que perdura hasta nuestros días. 
Desde el punto de la geomorfología, Tierra de Campos está constituida básicamente por campiñas (llanuras suavemente onduladas) limitadas por los páramos detríticos (al norte) y los calcáreos (al sur).

El clima es netamente continental, con inviernos frescos y fríos y veranos secos y cálidos; otoño y primavera presentan rasgos más benignos. Las precipitaciones oscilan entre los 400 y $450 \mathrm{~mm}$ anuales.

En cuanto a la hidrografía, se distinguen dos grandes grupos de ríos: Cea, Carrión y Pisuerga (con grandes caudales) y Salado, Valderaduey, Sequillo, Valdeginate, Cueza y Ucieza (caudales irregulares muy inferiores, encauzados y rectificados). A ellos hay que sumarle una tupida red de arroyos intermitentes que también, en su mayoría, han sido encauzados. Una buena parte de las lagunas que antaño abundaban en la comarca han sido drenadas.

Dentro de los varios canales construidos en la comarca, destaca de modo singular el Canal de Castilla: magnífica obra civil de ingeniería hidráulica acometida en los siglos XVIII y XIX que, además del riego, tiene un uso recreativo de gran potencial debido a su belleza y a la frondosidad vegetal de sus márgenes.

En relación con los suelos, cabe señalar que en Tierra de Campos dominan los pardocalizos. Tienen un bajo contenido en materia orgánica y nitrógeno, siendo arcillosos y básicos.

La vegetación climácica en la comarca son los bosques de encina, con franjas de vegetación ripícola en las riberas de ríos y arroyos. Este bosque primitivo fue talado para su cultivo desde varios siglos antes de Cristo, de forma que actualmente quedan minúsculos retazos de lo que fue. Aun así, durante varios siglos el paisaje agrícola estuvo acompañado de una gran variedad de árboles y arbustos que conformaban un auténtico mosaico. El cambio de una agricultura tradicional a otra productivista, a mediados del siglo pasado, y las concentraciones parcelarias ocasionaron una simplificación de este paisaje diverso, de modo que árboles y arbustos desaparecieron o quedaron relegados a zonas marginales.

La fauna de Tierra de Campos está adaptada al hábitat cerealista, de forma que el grupo más representativo es el de las aves esteparias, con la avutarda a la cabeza. En esta comarca nidifica una de las poblaciones más numerosas de esta especie protegida de la Península Ibérica.

Una parte importante de Tierra de Campos está declarada espacio natural, bien sea como laguna y entorno (Villafáfila y la Nava, como principales) o bien como hábitat de especies de avifauna cerealista (Zonas de Especial Protección para las Aves, ZEPA). También están protegidas las riberas de los ríos principales, Cea y Carrión.

Del análisis socioeconómico hay que destacar sin lugar a dudas el éxodo rural que sufre la comarca desde 1950, que ha hecho reducir la población de Tierra de Campos en un 70 \% y que, por desgracia, aún se mantiene. Además se trata de una población muy envejecida, con mentalidad inmovilista y baja capacidad para emprender.

La arquitectura tradicional se corresponde con el tipo de "Núcleos en origen cercados, de disposición continua y edificación con corral posterior", que usa como materiales básicos el 
barro, la madera y la teja curva árabe. El elemento singular que más caracteriza a Tierra de Campos es el palomar, de gran valor estético y perfecta integración en el paisaje.

Tierra de Campos cuenta con un magnífico patrimonio histórico-artístico, sobre todo de arquitectura monumental religiosa. En todos los pueblos hay una o varias iglesias, que destacan entre el caserío. Los estilos artísticos fundamentales son el románico, el gótico y el renacentista, con la singularidad de sus variantes mudéjares. 

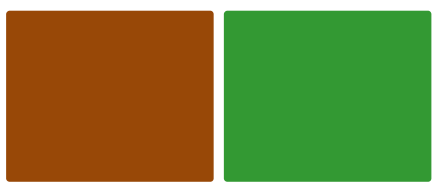

\section{MATERIAL Y MÉTODOS}




\section{MATERIAL Y MÉTODOS}

Los materiales y métodos que se han utilizado en este estudio lo han sido en función de los objetivos trazados en el mismo. Teniendo en cuenta que un mismo método puede haberse empleado para varios fines, se ha creído conveniente estructurar este apartado de acuerdo con cada una de las metodologías utilizadas. Estas han sido las siguientes:

\section{1.- Fuentes documentales.}

Se han estudiado y valorado varias fuentes documentales sobre las materias abordadas en los antecedentes, zona de estudio y parte de los resultados, complementadas con la experiencia personal.

Para ello, en primer lugar, se ha realizado una revisión bibliográfica de cada una de las materias abordadas: paisaje, paisaje rural, paisaje de campiñas cerealistas, medio ambiente y paisaje, instrumentos preventivos de gestión ambiental, recuperación de espacios degradados y valorización del paisaje. En todas ellas se ha tenido en cuenta su aplicación a la comarca natural de Tierra de Campos, tratando de no entrar en consideraciones excesivamente generales. La descripción de todos los rasgos identificativos de Tierra de Campos también se ha elaborado a partir de bibliografía especializada. Las búsquedas se han realizado de diversas maneras: conocimiento propio, consultas a especialistas, búsqueda por google académico con palabras claves, utilización de centros de documentación de Castilla y León, etc.

En segundo lugar, todos los apartados mencionados se han redactado con la base de la experiencia personal del autor, que es extensa tanto en los aspectos técnicos como en el conocimiento de Tierra de Campos; no en vano es natural y residente en la comarca.

\section{2.- Sistemas de información geográfica.}

Utilización del gvSIG como Sistema de Información Geográfica de apoyo de uso gratuito, tanto en la descripción de la zona de estudio como en los resultados. En este sentido, se ha contado con la información del SIGMENA (Sistema de Información Geográfica de Medio Natural, de la Consejería de Fomento y Medio Ambiente de la Junta de Castilla y León), así como de otras administraciones públicas (Consejería de Agricultura y Ganadería, Centro de Información Territorial, Administración del Estado, etc.).

\section{3.- Base de datos de fotografías de Tierra de Campos.}

Esta base de datos se ha empleado con objeto de apoyar e ilustrar los textos, generada a partir de numerosas visitas técnicas a lo largo de toda la comarca. Este aspecto se ha considerado esencial en un estudio sobre paisaje, donde las imágenes contribuyen en buena medida a interpretar lo expuesto. En la mayoría de los casos se ha empleado una cámara digital SONY Cyber-shot DSC-W510, de 12,1 Mega píxeles, zoom óptico 4x, lente grande angular de $26 \mathrm{~mm}$ y pantalla LCD de $2,7^{\prime \prime}$. Las fotografías se han tomado en formato de alta resolución, ocupando una media de $4000 \mathrm{~KB}$ por archivo digital.

La base se organiza en tres carpetas o grupos fundamentales: PAISAJE DE TIERRA DE CAMPOS; EXPEDIENTES EIA Y RM; y PAISAJE VILLALÓN. En ellas se archivan fotografías de Tierra de Campos 
de una temática y localización muy variadas, fruto de los numerosos viajes del autor por toda la geografía comarcal.

La primera de ellas contiene 34 subcarpetas, que tratan tanto materias generales como localizaciones concretas o proyectos específicos. En ellas se guardan un total de 1020 archivos digitales, en formato imagen jpg. El listado ordenado por orden alfabético es el siguiente:

- Árbol por hectárea

- Arroyo Berruez

- Camino de Santiago

- Camino turístico Tamariz de Campos

- Canal de Castilla

- Canal Esla-Carrión

- Carreteras

- Castillo Montealegre de Campos

- Cuenca de Campos

- Ermita Carejas Paredes de Nava

- Ermita Cuenca y mejora del entorno

- Escombros

- Estaquillas

- Forestación Becerril de Campos

- Fuentes Villalón de Campos

- Instalaciones suelo rústico

- La Nava

- Laguna Boada

- Líneas eléctricas

- Mirador Autilla del Pino

- Mirador Cuenca de Campos

- Naves agroganaderas

- Nieve y varios

- Paisaje general

- Patrimonio

- Raso de Villalpando

- Restauración Villalón de Campos

- Repoblación laderas Ampudia

- Repoblación Frechilla

- Torremormojón

- Urueña

- Vegetación

- Vía Verde

- Villafáfila

El segundo grupo son proyectos que han sido sometidos a alguno de estos procedimientos de prevención ambiental: Evaluación de Impacto Ambiental (EIA) o Restauración de Minería (RM). La parte más utilizada es la constituida por los proyectos analizados en el Anejo 1, que se 
distribuye en 8 carpetas con varias subcarpetas, que en total contienen 703 archivos, de igual formato. Hay una segunda parte formada por 35 proyectos sometidos a evaluación de impacto ambiental en la Tierra de Campos palentina (no incluidos en el Anejo 1, Figura 5.1), de los que se dispone de un total de 854 fotografías. Finalmente, la tercera parte de este segundo grupo está formada por 12 proyectos de restauración minera en el mismo ámbito (no incluidos en el Anejo 1, Figura 5.2) con 248 fotografías.

Tabla 5.1. Expedientes de Evaluación de Impacto Ambiental (excepto los del Anejo 1)

\begin{tabular}{|c|c|c|}
\hline Expediente & Proyecto & Términos municipales \\
\hline EIA/3/1993 & Explotación de arcilla Monzón & Monzón de Campos \\
\hline $\mathrm{EIA} / 25 / 2002$ & Explotación de arcilla Lámpara & Grijota \\
\hline $\mathrm{EIA} / 59 / 2002$ & Parque eólico Cuesta Mañera & Ampudia \\
\hline EIA/60/2002 & Parque eólico La Muñeca & Ampudia \\
\hline EIA/45/2004 & Explotación áridos La Judía, El Cuerno y la Ulloa & Grijota \\
\hline $\mathrm{EIA} / 38 / 2005$ & Plan Parcial Arenales & Becerril de Campos \\
\hline EIA/6/2007 & Emisario y EDAR Villarramiel & Villarramiel \\
\hline EIA/9/2007 & Concentración de la zona de Támara de Campos II & Támara de Campos \\
\hline $\mathrm{EIA} / \mathbf{1 0} / 2007$ & Explotación de ganado porcino & Grijota \\
\hline$E I A / 14 / 2007$ & Explotación de áridos San Cebrián & San Cebrián de Campos \\
\hline EIA/15/2007 & Concentración parcelaria Lantadilla II & Lantadilla \\
\hline $\mathrm{EIA} / 28 / 2007$ & Explotación de áridos Las Fuentecillas & Perales \\
\hline $\mathrm{EIA} / 47 / 2007$ & Plan Parcial residencial sector 1 & Villamartín de Campos \\
\hline EIA/48/2007 & Plan Parcial residencial sector 2 & Villamartín de Campos \\
\hline EIA/49/2007 & $\begin{array}{l}\text { Plan Parcial residencial sector SU-S3. Finca Dehesa } \\
\text { de Villafruela }\end{array}$ & Perales \\
\hline EIA/6/2008 & Explotación de áridos Ribas & Ribas de Campos \\
\hline $\mathrm{EIA} / \mathbf{1 6 / 2 0 0 8}$ & Plan Parcial residencial Llena Paneras & Carrión de los Condes \\
\hline$E I A / 24 / 2008$ & Plan Parcial industrial sector 3 Villamartín & Villamartín de Campos \\
\hline $\mathrm{EIA} / 27 / 2008$ & Plan Parcial residencial sector Hoyo de la Plata II & Grijota \\
\hline EIA/28/2008 & Plan Parcial residencial sector El Tarragoso I & Grijota \\
\hline $\mathrm{EIA} / 35 / 2008$ & Emisario y EDAR & Paredes de Nava \\
\hline EIA/46/2008 & Plan Parcial residencial Los Fresnos & Carrión de los Condes \\
\hline
\end{tabular}




\begin{tabular}{|c|c|c|}
\hline Expediente & Proyecto & Términos municipales \\
\hline EIA/64/2008 & $\begin{array}{l}\text { Parque eólico Paredes y línea eléctrica de } \\
\text { evacuación }\end{array}$ & Paredes de Nava y varios más \\
\hline$E I A / 12 / 2009$ & $\begin{array}{l}\text { Parque eólico Encinillas y LAT SET Encinillas SET Las } \\
\text { Tadeas }\end{array}$ & Paredes de Nava \\
\hline EIA/18/2009 & Explotación de áridos Los Girasoles & Husillos \\
\hline $\mathrm{EIA} / 21 / 2009$ & Plan Parcial residencial sector El Hito & Grijota \\
\hline $\mathrm{EIA} / 25 / 2009$ & Parque eólico experimental Valdelarroñada & Autilla del Pino \\
\hline$E I A / 26 / 2009$ & Plan Parcial residencial Cañada Real & Grijota \\
\hline$E I A / 33 / 2009$ & Instalación fotovoltaica Cantillo & Lomas \\
\hline $\mathrm{EIA} / 2 / 2010$ & Explotación de áridos Villaumbrales & Villaumbrales \\
\hline $\mathrm{EIA} / 8 / 2010$ & Explotación de áridos La Susana & Becerril de Campos \\
\hline $\mathrm{EIA} / \mathbf{1 0} / 2010$ & Explotación de áridos PR-1C & Paredes de Nava \\
\hline $\mathrm{EIA} / 2 / 2011$ & $\begin{array}{l}\text { Estabulación para vacuno de leche y fosa de } \\
\text { purines }\end{array}$ & Ribas de Campos \\
\hline $\mathrm{EIA} / 3 / 2011$ & Plan Parcial residencial El Tarragoso II & Grijota \\
\hline EIA/6/2013 & LAT para la evacuación del parque eólico Encinillas & Paredes de Nava y 3 más \\
\hline $\mathrm{EIA} / 7 / 2013$ & $\begin{array}{l}\text { Nueva delimitación con ordenación detallada } \\
\text { sector residencial La Pinilla } 2\end{array}$ & Grijota \\
\hline
\end{tabular}

Tabla 5.2. Expedientes de Restauración de Minería

\begin{tabular}{lll}
\hline Expediente & \multicolumn{1}{c}{ Proyecto } & \multicolumn{1}{c}{ Términos municipales } \\
\hline $\mathbf{R M} / \mathbf{2} / \mathbf{2 0 0 0}$ & Cantera Los Sotillos & Villoldo \\
\hline $\mathbf{R M} / \mathbf{6 / 2 0 0 0}$ & Ampliación Áridos San Roque & Lantadilla \\
\hline $\mathbf{R M} / \mathbf{1 8 / 2 0 0 0}$ & San Gregorio & Villaumbrales \\
\hline $\mathbf{R M} / \mathbf{4 / 2 0 0 1}$ & Áridos Villaherreros 2 & Villaherreros \\
\hline $\mathbf{R M} / \mathbf{6 / 2 0 0 2}$ & Áridos Valdecaraza & Becerril de Campos \\
\hline $\mathbf{R M} / \mathbf{1 / 2 0 0 9}$ & Cantera caliza El Consumo & Amusco \\
\hline $\mathbf{R M} / \mathbf{4 / 2 0 1 0}$ & $\begin{array}{l}\text { Préstamo Cervatos para el tramo de LAV Valle del } \\
\text { Retortillo - Pozo de Urama }\end{array}$ & Cervatos de la Cueza \\
\hline $\mathbf{R M} / \mathbf{6 / 2 0 1 0}$ & $\begin{array}{l}\text { Vertedero Cisneros para la LAV Palencia-León, } \\
\text { subtramo Valle del Retortillo - Pozo de Urama }\end{array}$ & Cisneros \\
\hline
\end{tabular}




\begin{tabular}{|c|c|c|}
\hline Expediente & Proyecto & Términos municipales \\
\hline $\mathrm{RM} / 3 / 2011$ & $\begin{array}{l}\text { Préstamo PR3 y Ampliación PR3 de la LAV } \\
\text { Palencia-León, subtramo Becerril de Campos - } \\
\text { Valle del Retortillo }\end{array}$ & $\begin{array}{l}\text { Becerril de Campos y Paredes de } \\
\text { Nava }\end{array}$ \\
\hline $\mathrm{RM} / 4 / 2011$ & $\begin{array}{l}\text { Préstamo P1 de la LAV Palencia-León, subtramo } \\
\text { Grijota - Becerril de Campos }\end{array}$ & Grijota \\
\hline RM/5/2011 & $\begin{array}{l}\text { Préstamo P2 de la LAV Palencia-León, subtramo } \\
\text { Pozo de Urama - Río Cea }\end{array}$ & Villada \\
\hline RM/6/2011 & $\begin{array}{l}\text { Vertedero PK6 de la LAV Palencia-León, subtramo } \\
\text { Becerril de Campos - Valle del Retortillo }\end{array}$ & Paredes de Nava \\
\hline
\end{tabular}

En la tercera carpeta se encuentran todas las fotografías de los Recorridos paisajísticos por Villalón de Campos (Anejo 3), clasificadas en 34 carpetas que contienen 1114 archivos digitales.

En total, la base de datos tiene 3939 fotografías. Evidentemente, dado su tamaño, solo se han insertado en el texto aquellas que son más representativas y poseen mejor calidad. Pero todas son importantes, ya que en cualquier momento se pueden visualizar para realizar una correcta interpretación de un proyecto concreto, un paisaje determinado o cierta localización.

\section{4.- Proyectos representativos de obras que afectan al paisaje de Tierra de Campos (Anejo 1): análisis documental y trabajo de campo.}

Se trata de nueve proyectos que han sido sometidos a algún trámite preventivo ambiental (Evaluación de Impacto Ambiental, EIA; Restauración de Minería, RM; y Calificación Ambiental o Licencia Ambiental, LA) y que son representativos de obras o actividades de naturaleza sectorial: agricultura, ganadería, infraestructuras, energía, etc. Se corresponden con ocho expedientes, ya que los dos primeros proyectos se engloban en un único procedimiento preventivo. Por otra parte, son proyectos en los que se han llevado a cabo algún tipo de medidas correctoras o de recuperación ambiental que, por consiguiente, pueden ser evaluadas. La práctica mayoría se sitúan en la provincia de Palencia (aunque son totalmente representativos de la comarca), dado que el autor trabaja en el Servicio Territorial de Medio Ambiente de esa provincia y ha sido partícipe de su tramitación y seguimiento ambiental durante varios años. Los proyectos elegidos son los siguientes (entre paréntesis se indica el número de expediente, que incluye el año de tramitación):

- Concentración parcelaria de los términos municipales de Herrín de Campos, Villafrades de Campos, Villalón de Campos y Boadilla de Rioseco (EIA/20/2003).

- Transformación en regadío del sector IV de la zona regable del canal del trasvase Esla Campos (EIA/20/2003).

- Explotación de ganado ovino en Ampudia (LA/57/2010).

- Explotación de ganado ovino en Cisneros (LA/76/2010).

- Variante de carretera de Villada (EIA/10/1996).

- Explotación de la zona de préstamos PR-1 asociada al proyecto de construcción de la plataforma corredor norte-noroeste de alta velocidad tramo Palencia-León, 
subtramo Becerril de Campos - Valle del Retortillo. Términos municipales de Becerril de Campos y Paredes de Nava (Palencia) (RM/3/2010).

- Línea eléctrica aérea de alta tensión entre las subestaciones de transformación de Ampudia y Grijota (EIA/22/2004).

- Parque eólico El Castre, en Torremormojón (EIA/65/2002).

- Polígono industrial sector 1 en Paredes de Nava (EIA/46/2003).

En todos ellos se ha revisado tanto el expediente administrativo como todos los documentos técnicos de interés para los objetivos previstos. Estos se han agrupado en tres apartados comunes: PROYECTO (anteproyectos, proyectos, etc.), CONDICIONANTES AMBIENTALES (estudios de impacto ambiental, proyectos de restauración del medio natural, proyectos de recuperación ambiental, declaraciones de impacto ambiental, memorias ambientales) y EJECUCIÓN (informes de vigilancia ambiental, resultados de las visitas y conclusiones del seguimiento ambiental). Aunque todos los proyectos analizados tienen esta misma estructura, no todos tienen el mismo desarrollo y grado de detalle; así, por ejemplo, el proyecto al que se ha dado más importancia es la concentración parcelaria, dado que se considera que es el más significativo en Tierra de Campos.

Se ha hecho una síntesis de los aspectos prácticos de dichos documentos, sobre todo en aquello relacionado con el paisaje y la recuperación ambiental. Asimismo se han realizado varias visitas técnicas a la zona; en algunos casos en fase de obra y, en todos, en la fase de funcionamiento, de modo que se da lugar al apartado más importante: "conclusiones del seguimiento ambiental". En las obras sometidas a evaluación de impacto ambiental, se ha valorado su impacto y comprobado el cumplimiento de las condiciones relativas al paisaje contenidas en el proyecto, el estudio de impacto ambiental y en la declaración de impacto ambiental. En las obras con alguna otra autorización medioambiental, se ha comprobado el cumplimiento de las condiciones relativas al paisaje contenidas en el proyecto y en la autorización.

En el caso de que los proyectos analizados cuenten a su vez con planes o proyectos de recuperación, en el seguimiento ambiental se realizará un análisis de acuerdo con el protocolo indicado en el Anejo 2. De este modo, se estudiarán los parámetros allí indicados que sean constatables (disponibilidad terrenos, uso tierra vegetal, cobertura vegetal, funcionalidad red de drenaje, etc.), así como otros específicos de cada proyecto.

Otro objetivo de este análisis es validar la utilidad de los instrumentos de prevención ambiental, especialmente la evaluación de impacto ambiental, para proteger y corregir los impactos sobre el paisaje de campiñas de Tierra de Campos. Con este objeto, se han procesado los datos de seguimiento, obteniéndose conclusiones en cada uno de los factores ambientales con incidencia sobre el paisaje analizados (protección del suelo, protección de la vegetación, remodelación topográfica, etc.) sobre el grado de cumplimiento, importancia ambiental y eficacia, que dan idea de cómo ha sido la integración paisajística del proyecto. En aquellos casos donde fue posible, se ha determinado el porcentaje del presupuesto de las medidas correctoras o el plan de restauración sobre el presupuesto total de la obra, para comprobar la viabilidad económica de la integración ambiental. 


\section{5.- Selección de proyectos de recuperación ambiental singulares (Anejo 2): análisis documental y trabajo de campo.}

Son proyectos que se han ejecutado en la comarca de Tierra de Campos; se trata de actuaciones relativamente sencillas, de cuyo seguimiento se pueden extraer conclusiones interesantes para su aplicación generalizada. Se han incluido los siguientes proyectos:

- Realización de plantaciones, construcción de área de descanso y tramo accesible en el Camino de Santiago en la provincia de Palencia

- Repoblación forestal de una parcela sobrante de vía pecuaria, en el término municipal de Herrín de Campos

- Repoblación forestal de laderas en el término municipal de Ampudia

- Repoblación forestal de una parcela de masa común en el término municipal de Frechilla

- Restauración hidrológico-forestal y posterior tratamiento selvícola y plantación de diversificación en la cuesta de Coruñeses, término municipal de Medina de Rioseco

- Recuperación ambiental y adecuación de la "Ruta de los Parques" en Villalón de Campos

- Adecuación de camino turístico en el término municipal de Tamariz de Campos

- Rehabilitación de antigua vía del ferrocarril como Vía Verde "Tierra de Campos", tramo Cuenca de Campos - Villalón de Campos

- Restauración del arroyo Berruez en el término municipal de Villalón de Campos.

Se ha analizado la documentación técnica de cada proyecto en aquellos casos en que existía su disponibilidad; en caso contrario se han realizado consultas a los promotores de los mismos. En todos ellos se han realizado una o varias visitas técnicas a las zonas objeto de las actuaciones, como seguimiento ambiental, comprobándose el cumplimiento y eficacia de las actuaciones planteadas.

Se pretende analizar si cada proyecto de recuperación ambiental es coherente con los antecedentes expuestos de esta disciplina técnica y si ha contribuido a corregir impactos, mejorar la calidad o valorizar el paisaje de Tierra de Campos. Para ello se ha planteado un protocolo de evaluación donde se han estudiado una serie de parámetros relacionados con la recuperación del paisaje, además de los específicos de cada caso concreto. El enfoque se ha realizado mediante respuestas a preguntas sencillas ya elaboradas, para las que se toman como base una serie de variables.

- ¿ ¿Hay suficiente superficie disponible para restaurar? Cuantificación, disponibilidad de terrenos, presión de propietarios colindantes.

- ¿Es adecuado el uso elegido para la recuperación? Tipo de uso, viabilidad futura.

- ¿Se reutiliza adecuadamente la tierra vegetal? Retirada selectiva previa, conservación, reutilización en la restauración, distribución homogénea, profundidad.

- ¿Se ha realizado una correcta adecuación morfológica de los terrenos? Pendiente de taludes, formas naturales.

- En caso de existir, ¿se han retirado y gestionado adecuadamente los residuos? Tipo de residuos, grado de presencia, forma de retirada o gestión, depósitos posteriores.

- ¿Es funcional la red de drenaje? Realización de cunetas, construcción de otro tipo de drenajes, mantenimiento de arroyos o desagües, conservación de estas infraestructuras. 
- ¿Existen procesos de erosión? Presencia de surcos, deslizamientos, depósitos.

- ¿Se ha conseguido una adecuada cobertura de vegetación? Superficie o longitud afectada, tipo de vegetación (arbolada, arbustiva, herbácea), especies, densidad, método de plantación, cuidados, marras, calidad, crecimiento, etc.

- ¿Se han utilizado técnicas específicas de recuperación? Escolleras, diques, estaquillas, pasos de fauna, etc.

- ¿La recuperación mejora el paisaje visual de Tierra de Campos? Color, textura, calidad visual, reducción de impactos visuales, aumento de la capacidad de absorción visual, integración paisajística de edificaciones e instalaciones.

- ¿ ¿La recuperación mejora el paisaje ecológico de Tierra de Campos? Creación de manchas y/o corredores, conectividad ecológica, grado de naturalidad, diversidad.

- ¿La recuperación contribuye a valorizar el paisaje de Tierra de Campos? Creación de zonas verdes, caminos turísticos, miradores, observatorios de avifauna, etc.

El seguimiento ambiental de los proyectos de recuperación ambiental se realiza a partir de las cuestiones planteadas en este protocolo. No obstante, no se sigue un orden estricto de estas variables, ya que la argumentación depende de la naturaleza del proyecto. Tampoco se tratarán los parámetros que no hayan sido afectados en la actuación o aquellos que no puedan ser constatables.

\section{6.- Recorridos paisajísticos en Villalón de Campos (Anejo 3): trabajo de campo.}

El objetivo de esta parte de la metodología es caracterizar la matriz de Tierra de Campos no afectada por grandes proyectos, que son los analizados en los apartados anteriores. Se trata de estudiar pequeñas actuaciones que afectan al paisaje, pero que son mucho más numerosas y están distribuidas uniformemente por todo el territorio: espacios periurbanos, naves agropecuarias, carreteras locales, líneas eléctricas de no tan alta tensión, huertos solares, etc. Por otra parte, con ello se puede analizar el paisaje con más detalle, tanto en el plano espacial como en el temporal. De igual modo, es posible el estudio de las pequeñas recuperaciones ambientales que se realizan en un término municipal -que realmente son muy numerosas-, así como la estimación de las recuperaciones potenciales que pueden llevarse a cabo en cada espacio.

Para ello se ha seleccionado el término municipal de Villalón de Campos. Es el pueblo del autor, que conoce muy al detalle, pero además se trata de un término localizado en el centro de la comarca y muy representativo de Tierra de Campos. Su extensión es elevada respecto de la media (7000 ha), por lo que este estudio tiene un sólido contenido. Villalón de Campos tiene en 2014 poco más de 1800 habitantes, y se encuentra inmerso en el grave problema general de despoblación de la comarca. Participa de todos los rasgos básicos de Tierra de Campos en cuanto a Historia, geomorfología, clima, suelos y avifauna esteparia. En cuanto a la red hidrográfica, no discurren por su término grandes ríos; el de mayor caudal es el arroyo Berruez, tributario del río Sequillo, pero sí que tiene una compleja red de arroyos y regueras. Es un término municipal dedicado al cultivo agrícola en aproximadamente el $99 \%$ de su extensión, por ello no posee prácticamente arbolado; aquí la concentración parcelaria de mediados de los sesenta del siglo pasado hizo realmente estragos. Además, se está ejecutando una reconcentración parcelaria al objeto de poner en regadío una parte del término. Una buena parte del término forma parte de la ZEPA La Nava-Campos. En Villalón de Campos tiene un cierto peso relativo el sector servicios, ya que es cabecera de otras localidades menores, pero también es importante el agrícola y el 
ganadero (hay muchas explotaciones intensivas). Posee un rico patrimonio histórico-artístico, con un rollo gótico, tres templos gótico-mudéjares y una ermita barroca, así como interesantes muestras de arquitectura tradicional con gran riesgo de deterioro. Cabe señalar que, a pesar de la escasez general de arbolado del término, en los últimos años se han realizado numerosas actuaciones de recuperación ambiental -tanto en las zonas urbanas y periurbanas, como en el campo- que merece la pena analizar.

El planteamiento inicial consistía en la realización durante un año de una serie de recorridos por el término municipal, bien sea caminando o en bicicleta, mediante los cuales se barriese la mayor parte de la superficie. Se han recorrido los caminos rurales, todas las carreteras, algunos arroyos y una muestra de los espacios periurbanos. Con ello se consigue analizar la variación temporal del paisaje agrícola, así como estudiar la mayor parte de las actuaciones humanas, impactos sobre el paisaje, recuperaciones ambientales y posibles potenciales en el término municipal. Se han realizado en total 34 Recorridos paisajísticos, desde junio de 2013 hasta mayo de 2014 (ambos meses inclusive), que barren una superficie aproximada de un $75 \%$ del término, así como una muestra de su espacio urbano y periurbano. La longitud total muestreada es de $227 \mathrm{~km}$.

Tabla 5.3. Recorridos paisajísticos en Villalón de Campos

\begin{tabular}{|c|c|c|c|}
\hline Recorrido & Fecha & Nombre & L (km) \\
\hline 1 & $15 / 06 / 2013$ & Ruta exterior, la Florida y Vía & 14,2 \\
\hline 2 & $23 / 06 / 2013$ & Vereda del camino de León & 6,4 \\
\hline 3 & $24 / 08 / 2013$ & Carretera Fuentes & 4,8 \\
\hline 4 & $18 / 10 / 2013$ & Ronda exterior & 14,2 \\
\hline 5 & $19 / 10 / 2013$ & Carretera de Fontihoyuelo & 8 \\
\hline 6 & $23 / 10 / 2013$ & Ruta de los parques (recuperaciones) & 4,5 \\
\hline 7 & $25 / 10 / 2013$ & Carretera de Boadilla & 11,6 \\
\hline 8 & $27 / 10 / 2013$ & Carretera y ermita de Fuentes & 6 \\
\hline 9 & $01 / 11 / 2013$ & Cementerio & 0,5 \\
\hline 10 & $02 / 11 / 2013$ & Colada de Sahagún y arroyo Berruez & 10,7 \\
\hline 11 & $07 / 11 / 2013$ & Ruta de los parques & 4,5 \\
\hline 12 & 09/11/2013 & $\begin{array}{l}\text { Colada de Villalón a Villada, San Salva y ruta larga por el } \\
\text { Rosario }\end{array}$ & 5,3 \\
\hline 13 & $12 / 11 / 2013$ & El Arco y límite de término & 6 \\
\hline 14 & $16 / 11 / 2013$ & Huerta el Moral y San Andrés & 1 \\
\hline 15 & $19 / 11 / 2013$ & Villarrobejo, camino de circunvalación y San Juan & 1,2 \\
\hline
\end{tabular}




\begin{tabular}{|c|c|c|c|}
\hline Recorrido & Fecha & Nombre & $\mathrm{L}(\mathrm{km})$ \\
\hline 16 & $21 / 11 / 2013$ & Ruta de los parques (actuaciones/degradaciones) & 4,5 \\
\hline 17 & $06 / 12 / 2013$ & Carretera de Fuentes & 6 \\
\hline 18 & $14 / 12 / 2013$ & Vereda camino de Cisneros y Valdelafuente & 6,7 \\
\hline 19 & $11 / 01 / 2014$ & Valdelafuente a Trinchas & 4,6 \\
\hline 20 & $12 / 01 / 2014$ & Trinchas, balsa y Villacilda & 4,8 \\
\hline 21 & $25 / 01 / 2014$ & Colada de Villalón a Guaza y carretera de Herrín & 9,8 \\
\hline 22 & $01 / 02 / 2014$ & Arroyo Berruez y camino de Villafrades & 6,3 \\
\hline 23 & $08 / 02 / 2014$ & Carretera de Palencia & 7,8 \\
\hline 24 & $15 / 02 / 2014$ & Fuente Murcia y antigua vía del ferrocarril & 7,9 \\
\hline 25 & $22 / 02 / 2014$ & Camino de Villabaruz y fuente el Toro & 6,4 \\
\hline 26 & 08/03/2014 & Ruta de los parques (recuperaciones potenciales) & 4,5 \\
\hline 27 & $15 / 03 / 2014$ & Camino de Villabaruz y Vía verde & 6 \\
\hline 28 & $22 / 03 / 2014$ & Carretera de Valladolid & 3,2 \\
\hline 29 & $12 / 04 / 2014$ & Colada de Carreceinos y fuente Cortaelaire & 8,7 \\
\hline 30 & $18 / 04 / 2014$ & Colada de Villacid y fuente el Cuquillo & 6,4 \\
\hline 31 & $02 / 05 / 2014$ & Ruta de los parques & 4,5 \\
\hline 32 & $04 / 05 / 2014$ & Carretera de Benavente & 8 \\
\hline 33 & $12 / 05 / 2014$ & Vereda de Mayorga a Herrín & 12 \\
\hline 34 & $24 / 05 / 2014$ & Carretera de Bustillo y colada de Cabezón-Villalón & 9,9 \\
\hline
\end{tabular}

En cada Recorrido se ha elaborado una ficha, a la que se acompaña una descripción gráfica con las fotografías más representativas. La guía de factores que se consideran en cada uno de ellos es la siguiente: 


\section{RECORRIDOS PAISAJÍSTICOS / Guía de factores considerados}

\section{RECORRIDO: NOMBRE}

- Fecha: día y hora de inicio.

- Medio: caminando / en bicicleta.

- Itinerario: punto inicial - localizaciones intermedias - punto final.

- Longitud (m).

- Condiciones meteorológicas: despejado / nublado, humedad / sequedad del terreno, otras variables.

- Características de la vía: material del firme (asfalto / hormigón / zahorra / tierra), estado del firme, anchura plataforma.

\section{CARACTERÍSTICAS DEL PAISAJE}

- Entorno inmediato de la vía: cunetas; altura, pendiente y revegetación taludes; desmonte / terraplén; anchura y revegetación márgenes etc.

- Espacio agrícola: estado de los cultivos (barbecho, sembrado, espigado, rastrojo), tipo de cultivos (cereal, leguminosas, girasol), tonalidad dominante, etc.

- Agua: ausencia, presencia (charcos, agua en circulación, lagunas).

- Ruido: inapreciable, puntual, considerable, molesto, muy molesto. Fuente del ruido.

- Olores desagradables: inexistentes / puntuales / considerables / desagradables / muy desagradables. Fuente del olor.

- Vegetación: forma (herbácea silvestre, arbustos, árboles aislados, bosquetes), abundancia. Si zonas ajardinadas, características. Estado y color de las hojas.

- Fauna: presencia de ganado, avistamiento de fauna silvestre (mamíferos, perdices, pájaros, rapaces, avutardas, patos, etc.).

- Actuaciones humanas: líneas eléctricas, naves agrícolas, naves industriales, viviendas, granjas, huertas, vallados, depósitos de agua, plantas de tratamiento, explotaciones mineras, etc.

- Elementos singulares: edificios catalogados, ermitas, palomares, fuentes, etc. 


\section{DEGRADACIONES DEL PAISAJE}

Concretar, en función de los siguientes factores:

- Alteración de la morfología general

- Pérdida o cambios en la vegetación

- Fragmentación del hábitat

- Modificación de la naturalidad

- Cambio de las características visuales básicas

- Introducción de elementos extraños

- Intrusión visual de elementos

- Desaparición de la armonía

- Abandono o deterioro de usos tradicionales

- Cambio en los elementos dominantes

- Acumulación de residuos

- Pérdida del valor singular del paisaje

En el caso de existir alguna degradación, efecto compatible / moderado / severo / crítico

\section{RECUPERACIONES DEL PAISAJE}

- Espacios verdes periurbanos (VER): tipo (jardín / paseo / parterre), especies arbóreas y arbustivas, marco, edad, altura, crecimiento, hoja, estado vegetativo, vegetación herbácea, cuidados culturales, etc.

- Plantaciones de ecocondicionalidad del árbol/ha (AHA): forma (superficial / alineación), superficie, especies, marco, protectores, cuidados culturales, crecimiento, porcentaje marras, etc.

- Fuentes (FUE): depósito, abrevadero, superficie, especies, marco, edad, altura, crecimiento, hoja, estado vegetativo, vegetación herbácea, cuidados culturales, etc.

- Particulares (PAR): huerto con frutales, árboles de jardinería, setos, parterres, etc.

- Restauraciones específicas (RES): similares factores.

\section{RECUPERACIONES POTENCIALES}

- Actuaciones: extensión tierra vegetal, modelado del terreno, retirada y gestión de residuos, drenajes, hidrosiembras o siembras, plantaciones arbóreas y arbustivas, cuidados culturales y mantenimiento, técnicas específicas (estabilización de taludes, estabilización de cauces, pantallas sónicas, pasos de fauna). 
La calificación de buena parte de las variables analizadas es propia, estableciendo un rango sencillo de valoración. En el caso de las degradaciones del paisaje, se utilizan los factores apuntados por GÓMEZ OREA y VILLARINO (2004). Para su valoración se emplea la clasificación de impacto compatible, moderado, severo y crítico (solo se citan casos de estos tres últimos) de la legislación estatal de evaluación de impacto ambiental:

- Impacto moderado: Aquel cuya recuperación no precisa prácticas protectoras o correctoras intensivas, y en el que la consecución de las condiciones ambientales iniciales requiere cierto tiempo.

- Impacto severo: Aquel en el que la recuperación de las condiciones del medio exige la adecuación de medidas protectoras o correctoras, y en el que, aun con esas medidas, aquella recuperación precisa un período de tiempo dilatado.

- Impacto crítico: Aquel cuya magnitud es superior al umbral aceptable. Con él se produce una pérdida permanente de la calidad de las condiciones ambientales, sin posible recuperación, incluso con la adopción de medidas protectoras o correctoras.

De forma paralela, en cada recorrido se hicieron una serie de mediciones sencillas mediante muestras, de las que se pueden extraen interesantes resultados: altura y pendiente de los taludes de los caminos; altura y pendiente de los taludes de las carreteras; altura y pendiente de los taludes de la antigua vía del ferrocarril; anchura de los arroyos, así como altura y pendiente de sus taludes (Figura 5.1). El material básico utilizado fue una simple cinta métrica.

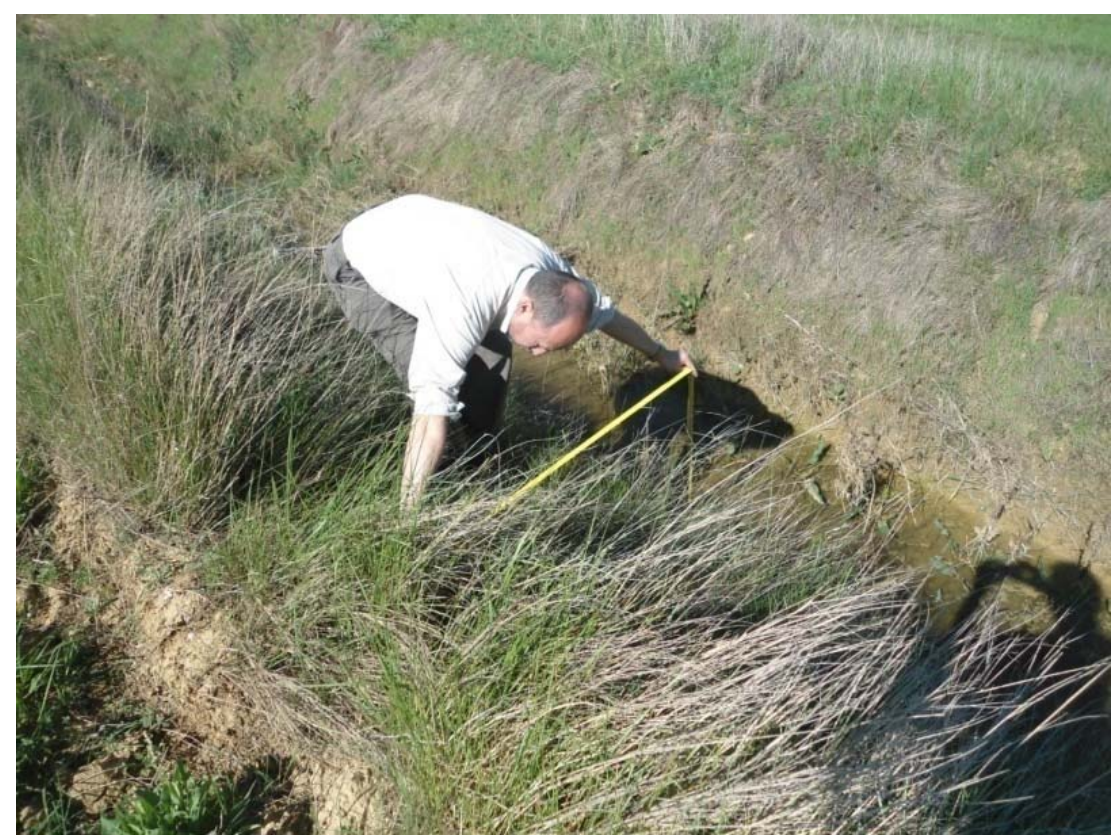

Figura 5.1. Medición de la pendiente de un talud de arroyo, a través de su componente vertical y horizontal. 
En total se han realizado 65 muestras de mediciones en caminos, 29 en carreteras, 47 en arroyos y 4 en la antigua vía del ferrocarril.

Finalmente, a partir de los Recorridos paisajísticos se ha realizado el seguimiento ambiental de varias recuperaciones del paisaje llevadas a cabo en el término municipal de Villalón de Campos. En aras de alcanzar una homogeneidad con el resto del estudio, el análisis se ha basado en los parámetros constatables incluidos en el protocolo para proyectos del Anejo 2, que se completará con las especificidades de cada actuación. 

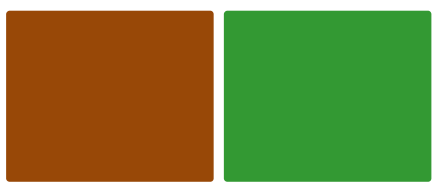

\section{RESULTADOS Y DISCUSIÓN}




\section{RESULTADOS Y DISCUSIÓN}

\subsection{Caracterización del paisaje de Tierra de Campos}

\subsubsection{Paisaje de campiñas cerealistas vs Paisaje de Tierra de Campos}

Como se puede apreciar en el listado expuesto en los antecedentes, recogido en el Atlas de los paisajes de España, el paisaje de campiñas de Tierra de Campos es una de las unidades del subtipo Campiñas del Norte del Duero. Es la que tiene mayor extensión e incluso posee unas características muy similares a las otras próximas; no en vano muchos autores (SANZ-ZUASTI, 1995) consideran que todas las campiñas situadas al norte del río Duero podrían denominarse con el apelativo de Tierra de Campos.

MARTÍNEZ DE PISÓN (2002) también hace una somera enumeración de los aproximadamente cincuenta paisajes de Castilla y León, distinguidos como comarcas tradicionales fundamentalmente por criterios fisiográficos y de asentamientos humanos. De entre ellos destaca, por su carácter de identidad, el paisaje de Tierra de Campos.

En cualquier caso, por tratarse de un paisaje representativo dentro de los definidos para las campiñas de la Meseta Norte, los redactores del Atlas de los paisajes de España han seleccionado al paisaje de campiñas de Tierra de Campos como uno de sus ejemplos o "paisajestipo", razón por lo que se cuenta con una ficha detallada que permite su caracterización y que ha servido de base para la caracterización que se hace a continuación. Ello afianza una de las bases del presente estudio, al considerar que Tierra de Campos es un paisaje paradigmático dentro de los paisajes de campiñas de Castilla y León e incluso de muchos paisajes agrícolas cerealistas españoles.

\subsubsection{Organización del paisaje}

Geomorfología: una extensa campiña suavemente ondulada

El territorio conocido en la antigüedad como Campigotorum y posteriormente llamado Tierra de Campos, abarca una parte importante de las provincias de Valladolid, Palencia y Zamora, y una pequeña porción de la de León. Esta campiña se desarrolla sobre materiales geológicos del Terciario (Mioceno medio y superior), que confieren al paisaje una gran uniformidad geomorfológica. La abundancia de materiales margosos y arcillosos, así como la ausencia de elementos resistentes a la erosión, propician una topografía ligeramente ondulada, apenas modificada por la incisión de la red fluvial. La impermeabilidad de los materiales arcillosos y el predominio de las formas muy suaves, favorecen la aparición de charcas temporales, que suelen desaparecer a lo largo del seco y caluroso estío, así como de varias áreas endorreicas. Los valles, cubiertos en sus fondos de limos y arcillas mezclados con cantos cuaternarios, presentan una disposición longitudinal con escasa pendiente y dibujan sinuosos trazados en los que se conservan muy escasos sotos.

El clima extremo de la meseta castellana se traduce en estas campiñas en veranos muy calurosos y secos, mientras que en los inviernos son frecuentes densas nieblas y heladas de irradiación. Se 
trata de un clima mediterráneo con una marcada continentalidad, manifiesta en una fuerte acentuación de los contrastes térmicos, tanto durante el día como a lo largo de las estaciones. Las Iluvias se distribuyen anualmente con bastante irregularidad, con una pluviometría media anual entre los 400 y $500 \mathrm{~mm}$, teniendo dos máximas estacionales, una en otoño y otra primaveral, acompañadas por una fuerte aridez estival.

Usos del suelo: un extenso abertal de cereales y barbechos

La práctica totalidad de Tierra de Campos está ocupada por cultivos cerealistas de secano, con claro predominio de la cebada sobre el trigo desde fines de los años sesenta del siglo XX, y con presencia en menores proporciones del girasol, alfalfa, vezas, guisantes, lentejas, garbanzos, etc. En los últimos decenios se han llevado a cabo transformaciones en regadío puntuales -muy por debajo de las previsiones del ambicioso Plan de Tierra de Campos (1965)- que han originado la aparición de nuevos cultivos como las patatas o la remolacha, o de variedades de los anteriores de mayor rentabilidad.

Como consecuencia de la política de concentración parcelaria que afectó a toda la comarca en los años sesenta y setenta del siglo XX, las parcelas se han engrandecido y regularizado, se ha construido una red de caminos rectilíneos y se han rectificado y dragado los arroyos y regueras al objeto de evitar encharcamientos.

La tradicional compartimentación de los campos en hojas de sembradura y barbechos dentro de cada término (cultivo de año y vez), además de erradicada por la propia concentración parcelaria, ha conocido en los últimos decenios una reducción muy importante de los barbechos blancos y un avance de las siembras, gracias en parte a la introducción de semillas de ciclo corto. La alternancia cromática de antaño entre ocres barbechos y verdes sembraduras en primavera, se ha tornado en los últimos tiempos en homogéneas y extensas superficies de cereal y, durante el verano, en monótonas y doradas rastrojeras, solo interrumpidas por el colorido del girasol y el verde de las alfalfas. Por el contrario, el hecho de realizar siembras tempranas en un importante porcentaje provoca que el contraste citado entre verdes y marrones se manifieste con intensidad en los periodos otoñal e invernal.

Los rebaños de ovejas conducidas por el pastor, otro elemento indisociable de la economía y de la imagen tradicional de Tierra de Campos, continúan deambulando por caminos y rastrojos, aunque con menor presencia que antaño, como consecuencia de la modificación del sistema de cultivo (alzados de los rastrojos y siembras tempranas) que reduce la superficie pastable, y de la progresiva estabulación en naves de ganadería intensiva.

Poblamiento tradicional: pequeños núcleos compactos en los que destacan las torres de las iglesias

Una tupida red de núcleos urbanos (los pueblos) -antaño densamente poblados, hoy la mayoría con escaso número de habitantes- se extiende por la campiña terracampina, con emplazamientos que no parecen seguir un patrón definido, aunque domina la proximidad a los cursos hídricos. La arquitectura tradicional de los pueblos de Tierra de Campos se caracteriza por su integración en el paisaje, con un alto grado de mimetismo, que ha constituido uno de sus rasgos más característicos. Esta estrecha relación material entre edificaciones tradicionales y 
paisaje obedece al empleo de materiales constructivos de la tierra, fundamentalmente tapial y adobe, posteriormente revocados con paja y barro, creando el "trullado" o "capeado" de las fachadas.

Los núcleos urbanos son concentrados, estando en sus orígenes en general amurallados. El hábitat se organiza en torno a una plaza que, junto con las calles más importantes, suele estar porticada en las villas mayores. Domina el caserío de una o dos plantas sencillo, lo que aumenta su fusión con el terreno, presentando los núcleos un perfil bajo y homogéneo, donde solo destacan las torres y espadañas de las iglesias, algún castillo y los grandes silos de cereal.

En la actualidad existen pocas viviendas situadas en el exterior de los núcleos urbanos, aunque hasta mediados del siglo XX era relativamente frecuente la presencia de caseríos en el campo abierto: conjunto de varias construcciones de carácter agropecuario (muros de delimitación, corrales, apriscos, almacenes, etc.), junto con viviendas e incluso alguna iglesia. Su tipología arquitectónica, materiales y características formales eran similares a la de los pueblos.

Uno de los elementos arquitectónicos más característico del paisaje de Tierra de Campos son los palomares (Figura 6.1). Se suelen situar en el entorno de los pueblos y presentan una gran variedad morfológica: circulares, cuadrados, rectangulares o mixtos. Antaño tuvieron un importante valor económico, como aporte gastronómico (los palominos) y fuente de abono (la palomina) para el terreno. La mayoría están construidos en tapial y revocados en barro y paja. Hoy en día muchos se han perdido o se encuentran en un deficiente estado de conservación, consecuencia de su pérdida de funcionalidad, aunque afortunadamente un buen número de ellos se han podido restaurar merced a una acertada política de subvenciones de distintas administraciones.
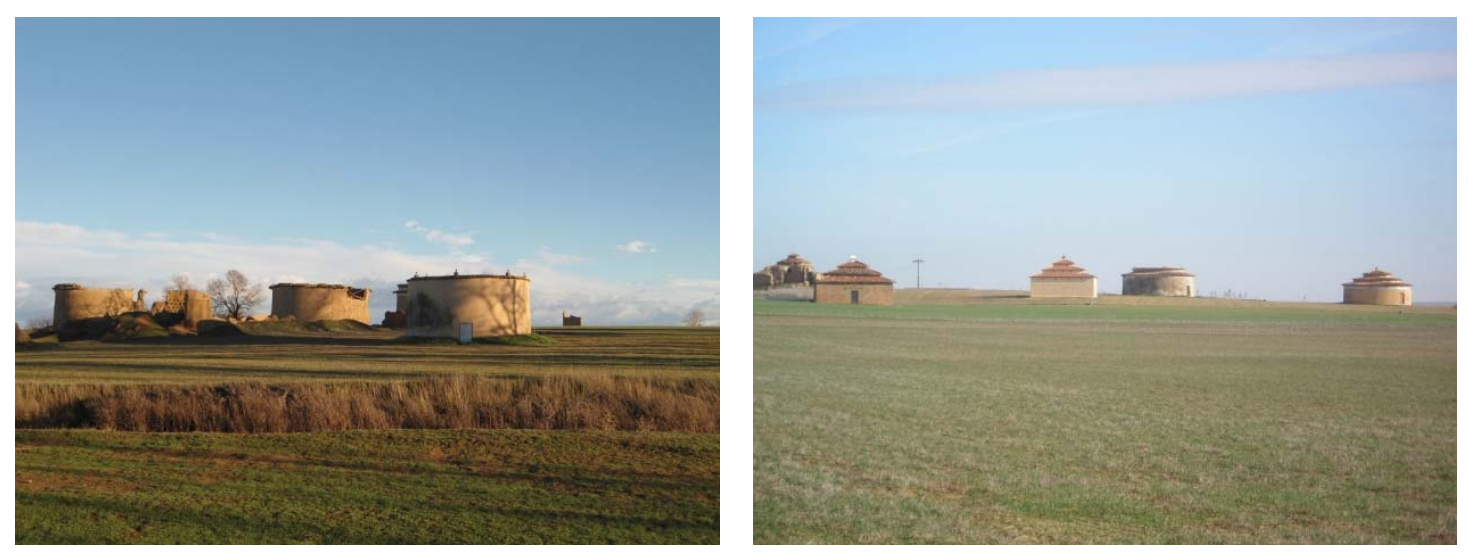

Figura 6.1. Palomares en Guaza de Campos (izquierda) y Villárdiga (derecha).

\subsubsection{Dinámica del paisaje}

A pesar de los importantes cambios que ha experimentado este paisaje en los últimos años (concentración parcelaria, intensificación del sistema de cultivo, cierta difusión del regadío), no se ha producido una pérdida significativa de su identidad. Tierra de Campos sigue conformando un paisaje agrícola de campiñas cerealistas. Su carácter continúa radicando en el mantenimiento 
sobre decenas de miles de hectáreas de una cubierta herbácea en campos abiertos, sin apenas elementos perturbadores recientes. La conversión en regadío de una parte del terrazgo, más apreciable en el sector oriental, ha supuesto cierta diversificación de cultivos y mayores contrastes cromáticos durante el verano, pero en conjunto, el paisaje mantiene la imagen de un inmenso abertal.

No obstante la concentración parcelaria y la intensificación de la agricultura sí que han ocasionado modificaciones en la estructura y textura del paisaje. Tal como se ha ido apuntando en apartados anteriores, el paisaje se simplificó sustancialmente en la segunda década del siglo pasado: parcelas de mayor extensión, arroyos rectificados sin arbolado, caminos rectilíneos sin zarzas, eliminación de los viñedos con los frutales que les acompañaban, etc.

En los últimos años se aprecian ciertos síntomas de una mayor diversificación en el cultivo agrícola, que deja de ser abrumadoramente cerealista para introducir un cierto porcentaje de leguminosas y otros cultivos oleaginosos, como el girasol. Ello se deriva de las consideraciones económicas de la Política Agraria Común y de la implantación de la rotación de cultivos.

Un carácter más localizado, aunque perceptible también en el paisaje, tienen los cambios morfológicos de los núcleos de población. Muchos de los pequeños y numerosos pueblos del tupido sistema tradicional de asentamientos han perdido población y funciones, con un deterioro apreciable de su fisionomía constructiva de tapial o adobe. En las áreas periurbanas han ido aflorando naves agropecuarias de grandes volúmenes y difícil integración, a las que se unen -sobre todo en las localidades de mayor población- instalaciones industriales, parques de maquinaria y construcciones variadas que desvirtúan en algunos casos los perfiles tradicionales de estas villas.

Existen otras transformaciones ligadas al desarrollo económico general de la sociedad que, por su envergadura, alteran el paisaje de campiñas de Tierra de Campos: autovías, ferrocarriles de alta velocidad, explotaciones mineras, líneas eléctricas, parques eólicos, instalaciones solares, etc. La comarca agraria se constituye como tierra de paso de numerosas infraestructuras lineales y albergue de proyectos energéticos. Realmente, estos proyectos no están promovidos desde el propio territorio, aunque se asientan en él y sobre él generan impactos significativos.

\subsubsection{Percepción visual del paisaje}

Las formas del relieve suavemente alomadas de estas campiñas favorecen perspectivas amplias, monótonas en su configuración y distribución y con un patrón compositivo muy simple. Los cielos de Tierra de Campos son uno de los elementos más característicos del paisaje, por el gran porcentaje de escena que ocupan, su diversidad estacional o su claridad debida a la general presencia de anticiclones y la ausencia de contaminación atmosférica (Figura 6.2). Amaneceres y atardeceres son a menudo espectaculares en estas tierras, y pueden ser percibidos con total nitidez. Incluso el paisaje nocturno, normalmente claro y estrellado, confiere una peculiar impronta al territorio. 

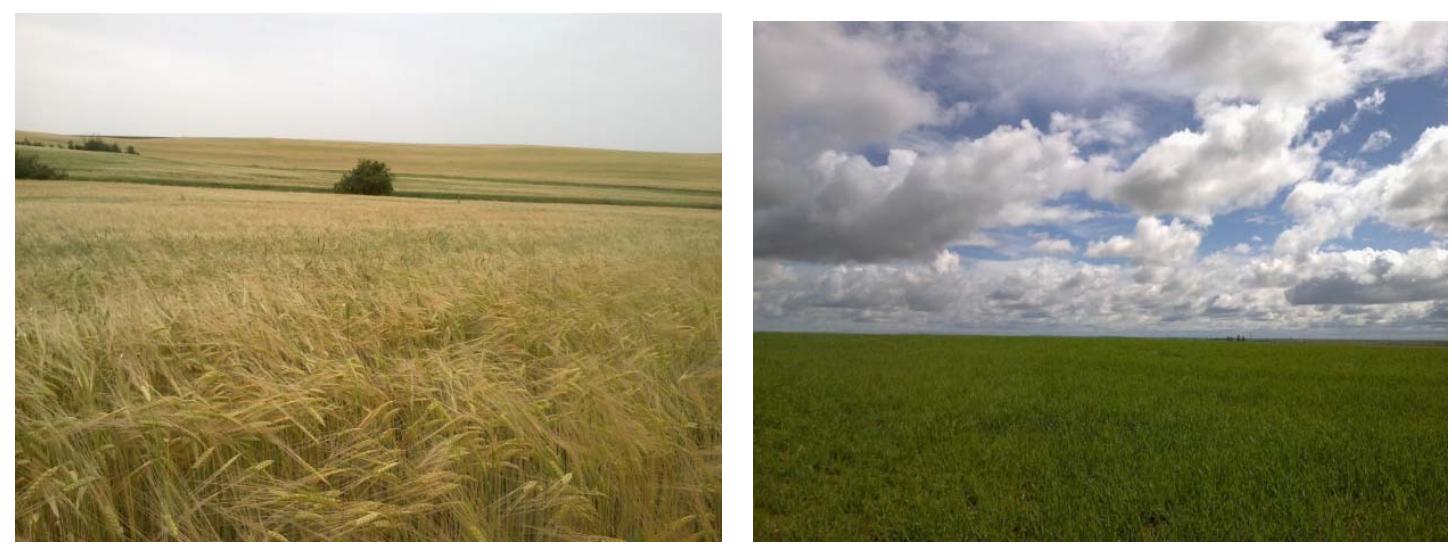

Figura 6.2. Izquierda, vista característica de paisaje cerealista en Villalón de Campos. Derecha, en la misma localidad, espectacular cielo nublado.

En estas panorámicas destacan los caminos y carreteras que conducen en disposición radial a los pueblos, usualmente a las torres de las iglesias principales, así como retazos de vegetación contiguos a algún arroyo. A su vez, estas vías de comunicación dan acceso a visiones tanto de primeros planos como de amplias panorámicas. Los páramos que bordean Tierra de Campos (Montes Torozos, El Cerrato, Páramo palentino-leonés) constituyen magníficas atalayas para la contemplación de estas campiñas en gran parte de su extensión. No en vano una de ellas -el mirador de Tierra de Campos de Autilla del Pino- figura en el Inventario Nacional de Paisajes Sobresalientes (ICONA, 1975), que es una de las primeras aproximaciones de catalogación de paisajes protegidos realizadas en nuestro país.

La Tierra de Campos, por su homogeneidad de usos y su gran extensión, ofrece una imagen neta y rotunda del paisaje de las campiñas ibéricas, constituyendo éste su valor perceptivo más notable.

\subsubsection{Características visuales básicas}

Las características visuales básicas son el conjunto de rasgos que caracterizan visualmente un paisaje o sus componentes y que pueden ser utilizados para su análisis y diferenciación; son color, forma, línea, textura, escala y espacio. Sus relaciones pueden describirse en términos de su contraste visual, dominancia visual e importancia relativa de cada una de ellas. El análisis de las características visuales básicas y sus relaciones constituye la base utilizada para valorar la calidad, la fragilidad o el impacto visual. En este apartado, se seguirá la línea establecida por SMARDON (1979), ESCRIBANO etal. (1987) y MOPT (1993) para describir el paisaje visual de campiñas de Tierra de Campos.

El colores la característica visual más significativa: es la propiedad de reflejar la luz con una particular intensidad y longitud de onda, que permite al ojo humano diferenciar objetos que de otra forma serían idénticos. Las características básicas del color son el espectro, el tono y el brillo. El espectro varía desde los colores más cálidos en el entorno del rojo hacia los más fríos en torno al azul; en general podemos atribuir una cierta dominancia a los colores más cálidos. 
El tono varía desde el claro al oscuro; se establece una mayor dominancia de los tonos claros, en especial el blanco. El brillo varía desde los colores más brillantes hasta los colores mates; superficies brillantes tienden a atraer la atención del espectador, superponiéndose a todos los demás colores.

El contraste visual presente todo el año entre las superficies agrícolas -dominadas por colores cálidos- y un cielo amplio y mayoritariamente despejado, es uno de los rasgos más característicos del paisaje de Tierra de Campos. A su vez, existen contrastes estacionales claros, de acuerdo sobre todo con la marcha de los cultivos y en especial del cereal (Figura 6.3). Del análisis de los datos aportados por los Recorridos paisajísticos en Villalón de Campos (Anejo 3), se obtiene la Tabla 6.1 de colores dominantes:

Tabla 6.1. Variación mensual de los colores por dominancia en las parcelas agrícolas.

\begin{tabular}{cccc}
\hline Mes & Color $\mathbf{1}$ & Color 2 & Color 3 \\
\hline junio & ocre & verde & \\
\hline julio & ocre & verde & amarillo \\
\hline agosto & ocre & verde & amarillo \\
\hline septiembre & ocre & verde & marrón \\
\hline octubre & marrón & ocre & verde \\
\hline noviembre & marrón & ocre & verde \\
\hline diciembre & marrón & verde & \\
\hline enero & verde & marrón & \\
\hline febrero & verde & marrón & \\
\hline marzo & verde & marrón & \\
\hline abril & verde & marrón & \\
\hline mayo & verde & marrón & \\
\hline
\end{tabular}

Tal como se puede apreciar, en verano predominan los tonos ocres, los marrones en otoño y en verano y primavera los verdes. El segundo color corresponde a los cultivos complementarios (leguminosas y girasol), que incluso incorporan interesantes matices en un tercer color durante una época del año (especialmente vistoso el amarillo de los girasoles en verano). También hay valiosos contrastes cromáticos en las transiciones temporales de las fases de los cultivos, como la floración morada de las leguminosas en primavera o la tonalidad verdoso-ocre del cereal cuando irrumpen los calores primaverales. 

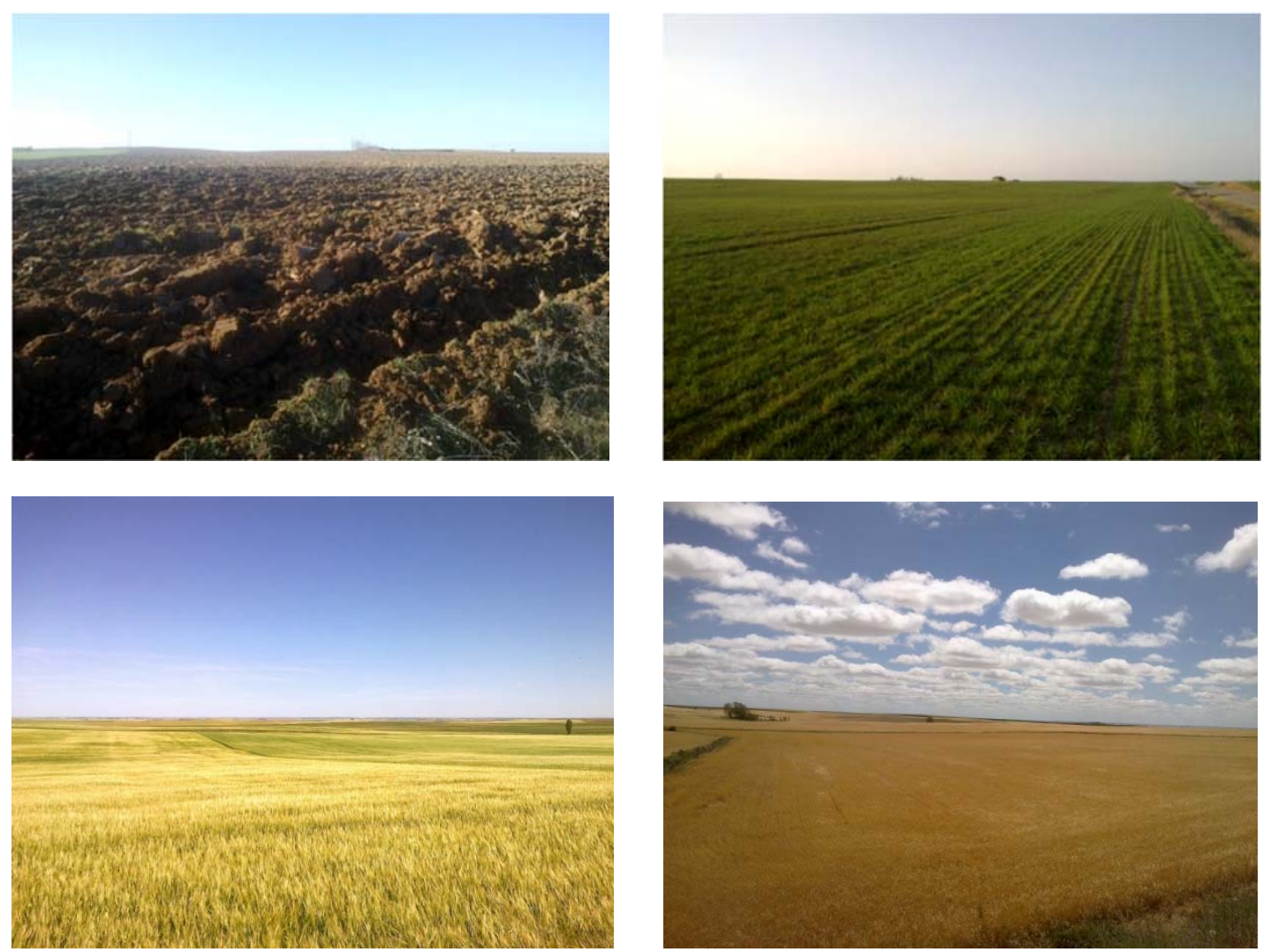

Figura 6.3. Diversas vistas de parcelas agrícolas de Villalón de Campos: barbecho (arriba izda.), cereal nacido (arriba dcha.), cebada en crecimiento (abajo izda.) y cebada madura (abajo dcha.)

Un dato muy interesante -que desmonta ciertos tópicos- extraído de la tabla anterior, es el porcentaje global de los colores en un año completo. Si consideramos un factor de corrección del 0,6 al color dominante, 0,4 o 0,3 al segundo y 0,1 al tercero, obtenemos la siguiente relación:

- Verde: $41 \%$

- Marrón: $33 \%$

- Ocre: $25 \%$

- Amarillo: $2 \%$

Como se puede apreciar, los colores cálidos en su conjunto (marrón y ocre) -ligados a sequedadtodavía son mayoritarios, pero de forma aislada el verde es claramente mayoritario, con un porcentaje de aparición notable.

Un interesante factor complementario en el análisis del color del paisaje de Tierra de Campos es el determinado por la vegetación natural, aunque el porcentaje de superficie que ocupa sea muy escaso en relación con los cultivos. Por un lado, la herbácea, teniendo en cuenta el contraste cromático que supone la aparición de vegetación ruderal de floración vistosa (amapolas, margaritas, amarillas) en los márgenes de caminos y carreteras en primavera (e incluso en alguna parcela donde no se haya utilizado excesivo herbicida). Por otro, el fantástico papel que juega la floración de los arbustos en primavera: comienzan las densas flores blancas del espino albar, le siguen las más pequeñitas y rastreras del endrino, posteriormente aparecen 
las grandes flores blancas y rosas del escaramujo o zarza y, finalmente lo hacen las amarillas vivas de las sebes. Por último, la función del arbolado: carácter perenne de pinos y encinas, preciosa floración temprana del almendro, brillo de los álamos o denso verdor de olmos y chopos en verano son algunas de las características visuales de los árboles, que aparecen precisamente cuando más se los necesita, cuando el paisaje agrícola presenta mayor sequedad.

No obstante, a buen seguro estos contrastes de colores fueron más acentuados hasta la realización de las concentraciones parcelarias y la intensificación de la agricultura. El mosaico cromático debía ser sin duda mayor, dado que las parcelas eran más pequeñas, existían majuelos con frutales, se conservaban linderos arbustivos y ribazos, había árboles en arroyos y márgenes de carreteras, no se trataban las tierras con herbicidas, etc.

Otro aspecto a destacar en el análisis del color es la relativamente reciente construcción de numerosas naves agropecuarias en el espacio periurbano y en el suelo rústico de las campiñas agrícolas (Figura 6.4). Aunque el espacio ocupado sea relativamente pequeño, en ocasiones su color resulta dominante en la escena, sobre todo cuando se utilizan blancos o variaciones cromáticas en los paramentos y tonalidades brillantes en las cubiertas metálicas. A menor escala y sobre todo en los núcleos de mayor población, también existen otras construcciones industriales que generen contrastes cromáticos por dominancia.
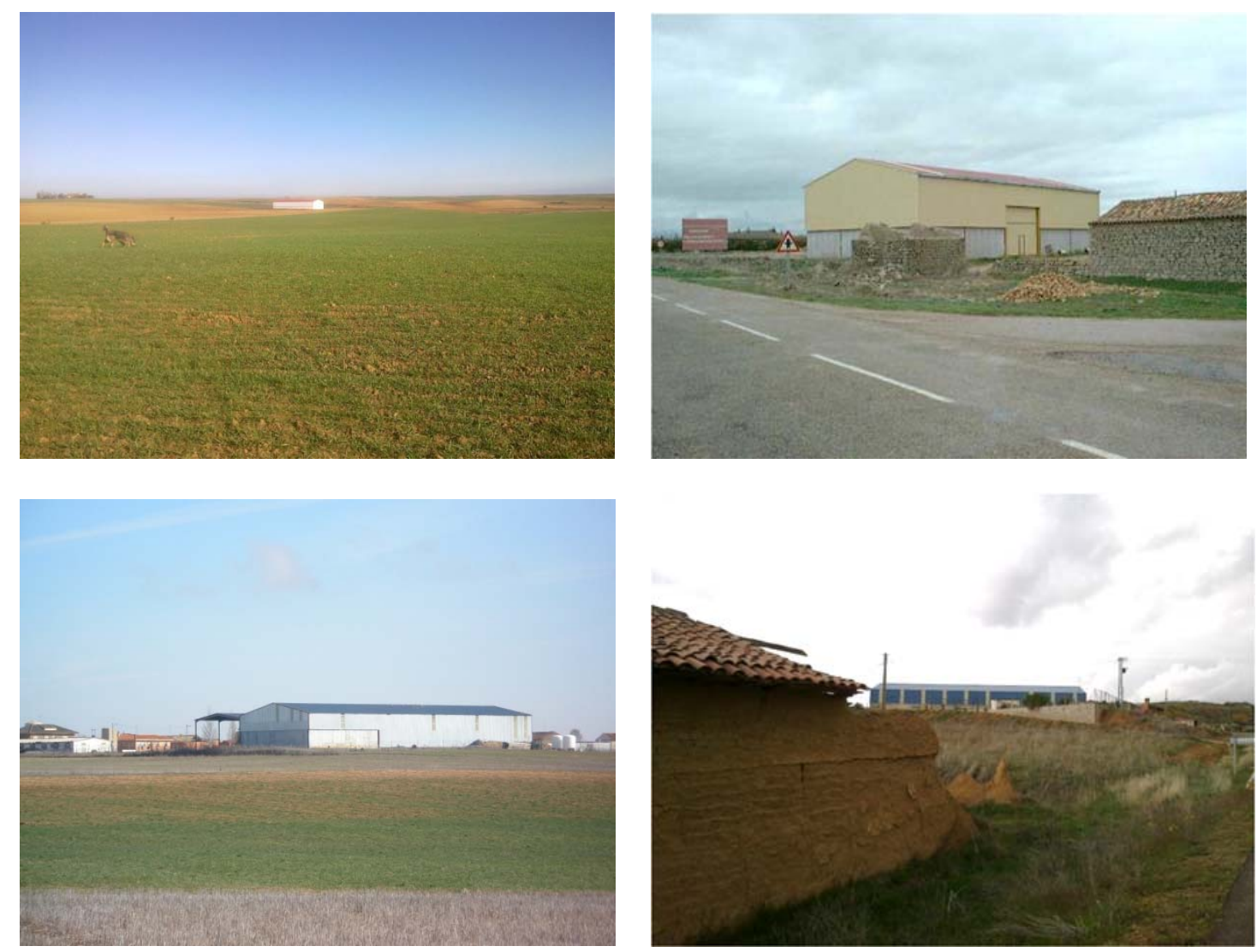

Figura 6.4. Naves agroganaderas de diversos colores: blanco en Villalón de Campos (arriba izda.), ocre en Montealegre de Campos (arriba dcha.), aluminio brillante en San Martín de Valderaduey (abajo dcha.) y azul en Fontihoyuelo (abajo dcha.) 
La forma es el volumen o figura de un objeto o de varios objetos que aparecen unificados visualmente. Las formas regulares, compactas, verticales, escarpadas, tienden a ser dominantes en paisajes de características contrarias. Existen formas bidimensionales, como las láminas de agua o las llanuras, y otras tridimensionales, consecuencia de la topografía del terreno o de la presencia de objetos. En el paisaje de campiñas de Tierra de Campos predominan claramente las formas horizontales o bidimensionales (llanuras suavemente onduladas, Figura 6.5), determinadas por la presencia de superficies adyacentes que contrastan sobre todo en color (las parcelas agrícolas). La tridimensionalidad aparece con los núcleos de población, aunque esta es relativa debido a la escasa altura de las edificaciones; es ahí donde destaca la verticalidad de las iglesias y alguna otra construcción singular, como los silos de almacenamiento de cereal hoy en desuso. Tal como hemos señalado, en el suelo rústico también provocan contrastes y cierta dominancia las naves agropecuarias, con sus formas regulares, compactas y opacas; aun cuando en estas construcciones domina el plano horizontal sobre el vertical.

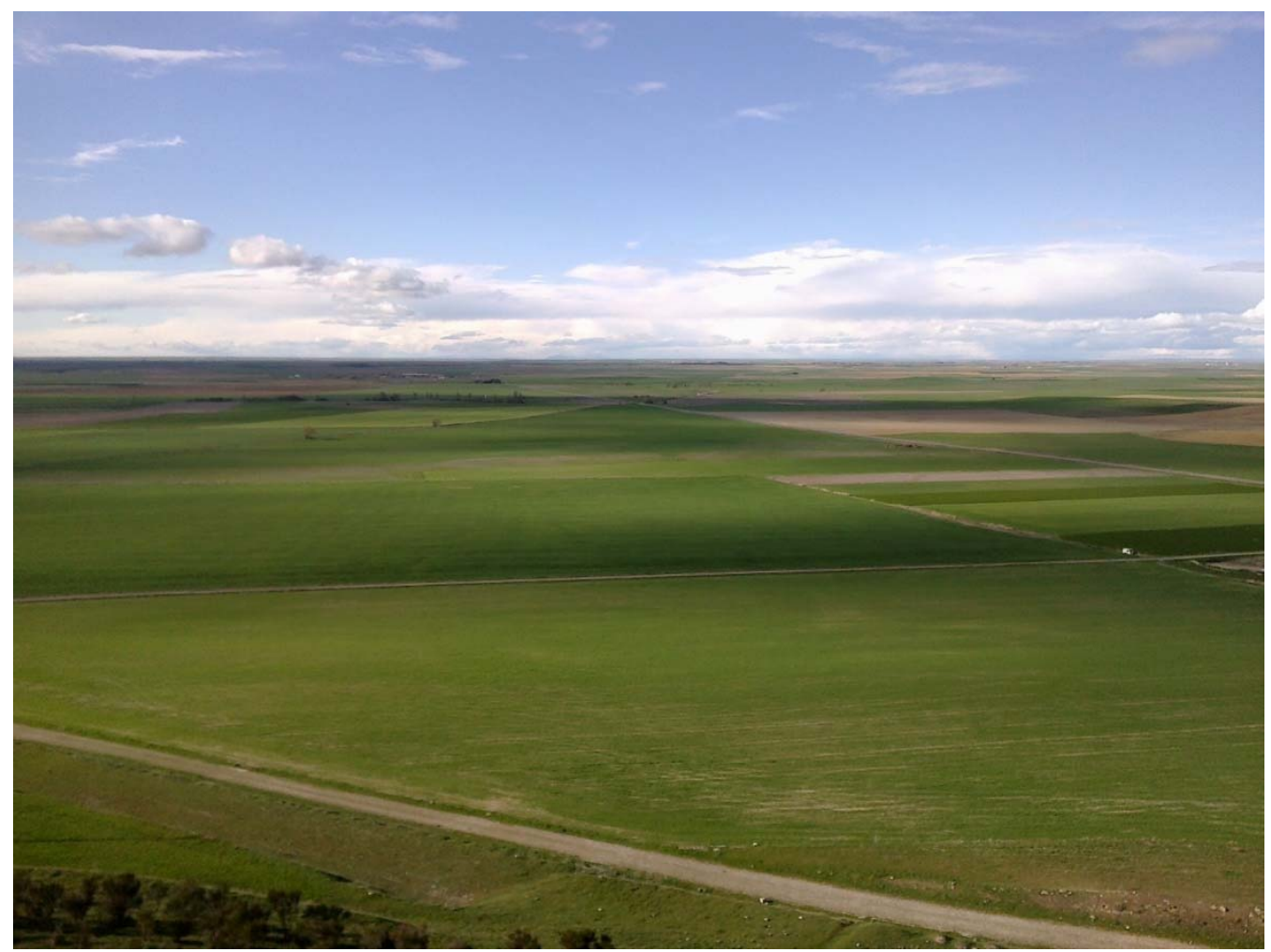

Figura 6.5. Vista de Tierra de Campos desde el castillo de Montealegre de Campos, donde se puede apreciar el predominio absoluto de la componente horizontal en la escena.

La línea es el camino real o imaginario que percibe el observador cuando existen diferencias bruscas entre los elementos visuales (color, forma, textura) o cuando los objetos se presentan con una secuencia unidireccional. Las líneas verticales y escarpadas que interrumpen el horizonte tienden a dominar sobre las líneas suaves horizontales. En el paisaje de campiñas, la línea juega un papel importante (Figura 6.6): existen líneas contrastadas en los límites entre parcelas, las siembras, los maraños recién segados e hilerados, los caminos rurales, los arroyos y la nítida línea del horizonte; pero también -y debido a la amplia visibilidad- en las 
infraestructuras como carreteras, líneas eléctricas, canales, ferrocarriles, etc. La mayoría de estas líneas son rectas, dado el carácter antrópico de la actuación. No obstante, cabe decir que en las últimas décadas el carácter rectilíneo ha aumentado notablemente: las concentraciones parcelarias rectificaron caminos y arroyos antes sinuosos, se han encauzado ríos y eliminado buena parte de sus riberas, las nuevas infraestructuras de transporte se diseñan con trazados rectilíneos aun a costa de generar desmontes y terraplenes, algo que también crean los canales, la longitud de líneas eléctricas de transporte y distribución (en este caso sí, por definición, netamente rectilíneas) ha aumentado notablemente, etc. También es destacable el carácter dominante de los elementos verticales (antenas de telefonía móvil, apoyos de las líneas eléctricas, aerogeneradores, etc.) sobre las abiertas Ilanuras horizontales cerealistas.
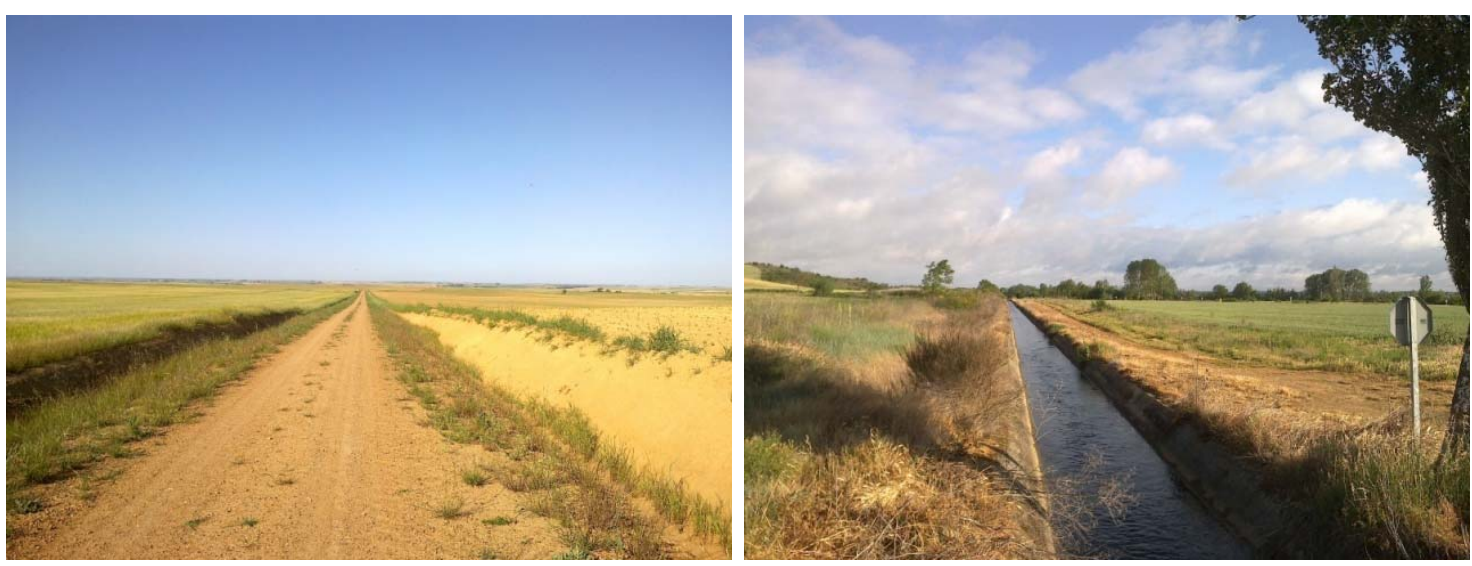

Figura 6.6. Existen múltiples ejemplos de presencia de la componente línea en el paisaje: izda. Camino rural en Boadilla de Rioseco; dcha. canal en Villafolfo (Paredes de Nava).

La textura es la manifestación visual de la relación entre luz y sombra motivada por las variaciones existentes en la superficie de un objeto. Esta propiedad de los objetos puede extenderse al paisaje, en el que la textura se manifiesta no solo sobre los objetos individualizados, sino también sobre las superficies compuestas por la agregación de pequeñas formas o mezclas de color que constituyen un modelo continuo de superficie. La vegetación es una gran creadora de textura a través de sus formas, variedad de tonalidades y, sobre todo, de su densidad y disposición espacial o regularidad (GÓMEZ OREA y VILLARINO, 2004). En consecuencia, en el paisaje rural las diferencias en cuanto a textura se dan sobre todo por la presencia de vegetación arbolada. Por ello, el paisaje de campiñas de Tierra de Campos es en su inmensa mayoría un paisaje de grano fino, con presencia muy puntual de arbolado disperso o en grupos (Figura 6.7); en estos casos - debido a su singularidad- el contraste interno es muy alto. Un aspecto singular es el barbecho, donde el juego de luces y sombras juega un papel relevante. 

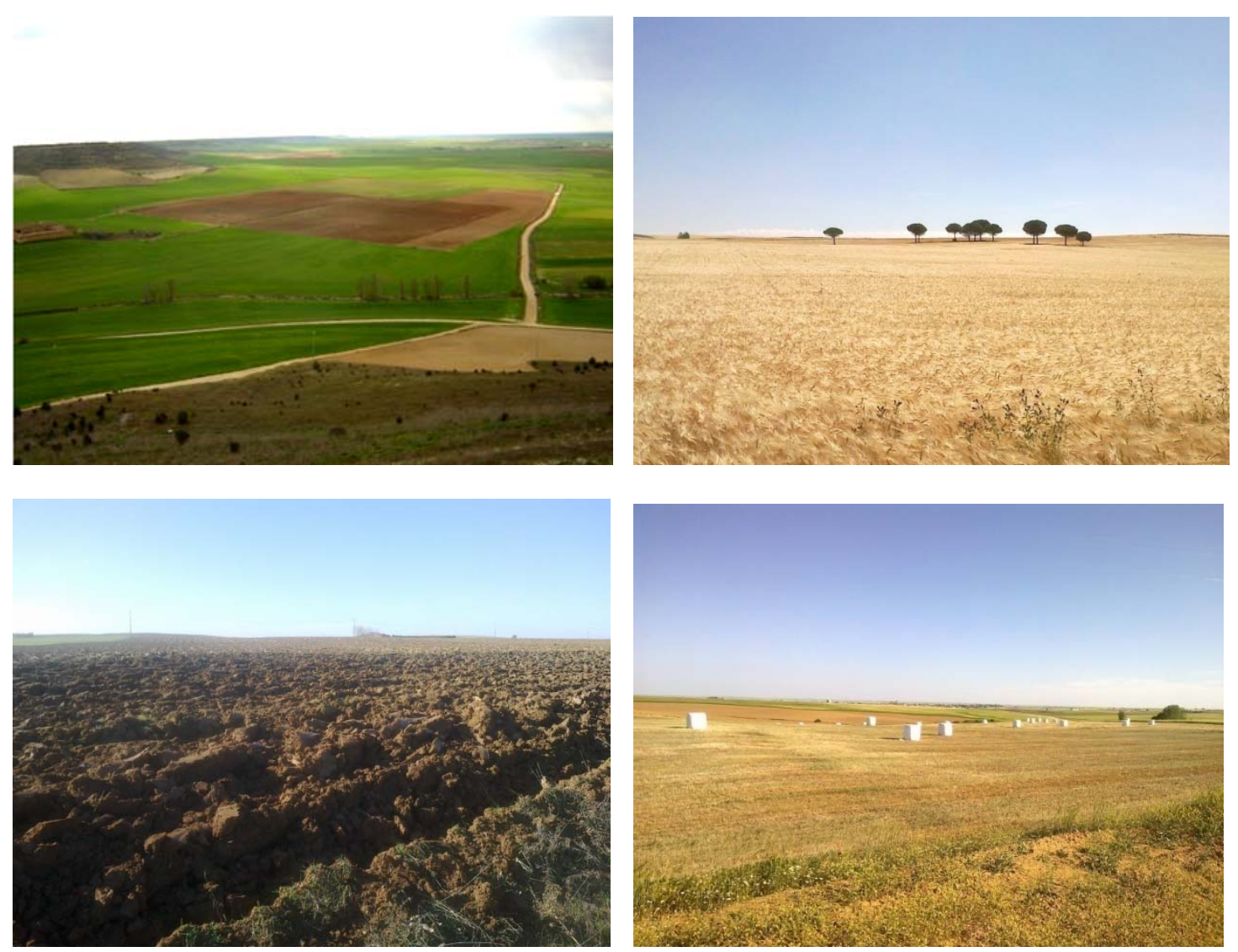

Figura 6.7. La escasez general de arbolado provoca la ausencia de texturas marcadas en el paisaje de Tierra de Campos: arriba izquierda, panorámica del paisaje cerealista desde Urueña; arriba derecha, grupo de pinos piñoneros en Herrín de Campos. A escalas más reducidas, la textura adquiere mayor importancia: abajo izquierda, barbecho en Villalón de Campos; abajo derecha, balas de alfalfa en Boadilla de Rioseco.

La escala es el tamaño o extensión de un elemento integrante del paisaje. Esta característica se puede considerar en sentido absoluto o relativo, siendo este último el más utilizado, sobre todo para analizar las actuaciones humanas (la relación existente entre su tamaño y el entorno donde se ubica). Las naves agropecuarias y demás construcciones en suelo rústico son objetos grandes, de aspecto pesado y compacto; no obstante, su situación en un entorno abierto hace que su escala relativa no sea muy elevada. Más gráciles son otras infraestructuras como las líneas eléctricas (incluidos sus apoyos metálicos), los pivotes de riego, etc. Por el contrario, en las antenas de celosía de telefonía móvil y, sobre todo, en los parques eólicos, la escala suele dominar en la escena. En todos los casos, la dimensión y escala será más o menos relativizada en función de la distancia desde donde suele ser observada (Figura 6.8). 

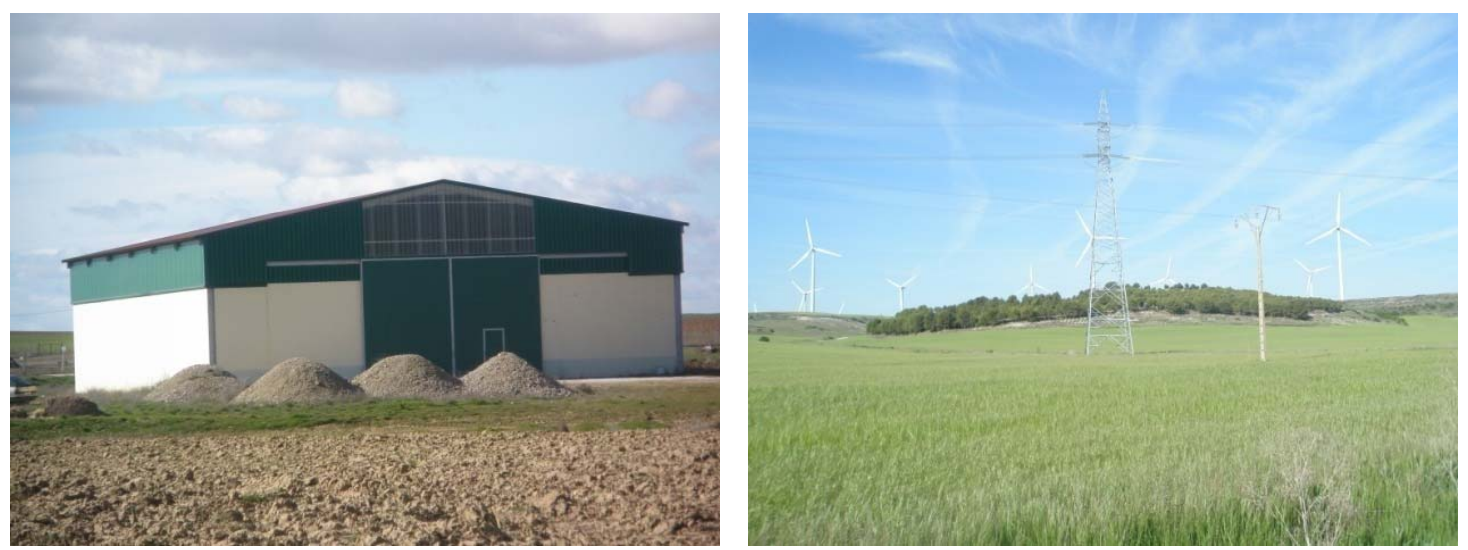

Figura 6.8. Ejemplos de elementos dominantes por escala: izquierda, nave agrícola en Cisneros; derecha, aerogeneradores y líneas eléctricas en Ampudia.

El espacio o escena es un elemento visual complejo que engloba el conjunto de cualidades del paisaje determinadas por la organización tridimensional de los objetos y los espacios libres o vacíos. Estas cualidades se pueden matizar en tres vertientes: en primer lugar, la composición escénica o distribución de los objetos para formar un paisaje dando distintos tipos de escena: panorámica (sin límites para la visión, predominando los elementos horizontales y el cielo dominando la escena), encajada (definida por barreras visuales), focal (líneas que convergen hacia un punto que domina la escena), o dominada por una componente singular (árbol aislado, cascada, forma prominente, o espesura. Otro aspecto significativo es la posición espacial o situación topográfica de los objetos en el paisaje, que afecta a su prominencia o visibilidad sobre la llanura, en el fondo del valle, a media ladera, en la línea de cumbre. Por último, es importante destacar el papel del fondo contra el que se ve un objeto: el propio terreno o la vegetación que lo cubre, otros objetos distintos o similares al observado, el agua, el cielo, etc. En general, los objetos vistos contra el cielo o el agua, destacan más que si se ven sobre el terreno, por lo que serán dominantes en el paisaje, así como aquellos situados en posiciones prominentes o vulnerables del paisaje (GÓMEZ OREA y VILLARINO, 2004).

En Tierra de Campos predominan los paisajes panorámicos (Figura 6.9): no existen límites aparentes para la visión, predominando los elementos horizontales con el primer plano y el cielo dominando la escena. También son relevantes los focalizados, teniendo en cuenta que las carreteras comarcales y locales (principales puntos de observación) suelen converger hacia los pueblos, que son los puntos focales que dominan la escena. Las construcciones existentes en suelo rústico y otras instalaciones (líneas eléctricas) se ubican en llano y se recortan contra el terreno y contra el cielo -en la mayor parte de ocasiones- como principales fondos escénicos. Especial importancia tienen en este caso los parques eólicos, ubicados en el borde superior de la ladera que conduce a los páramos, de gran visibilidad y que también se recortan claramente contra el cielo. En este sentido, se debe tener en cuenta que los objetos vistos contra el cielo destacan más que cuando se ven sobre el terreno o sobre la vegetación; si, además, su posición es elevada resaltará en mayor grado. 


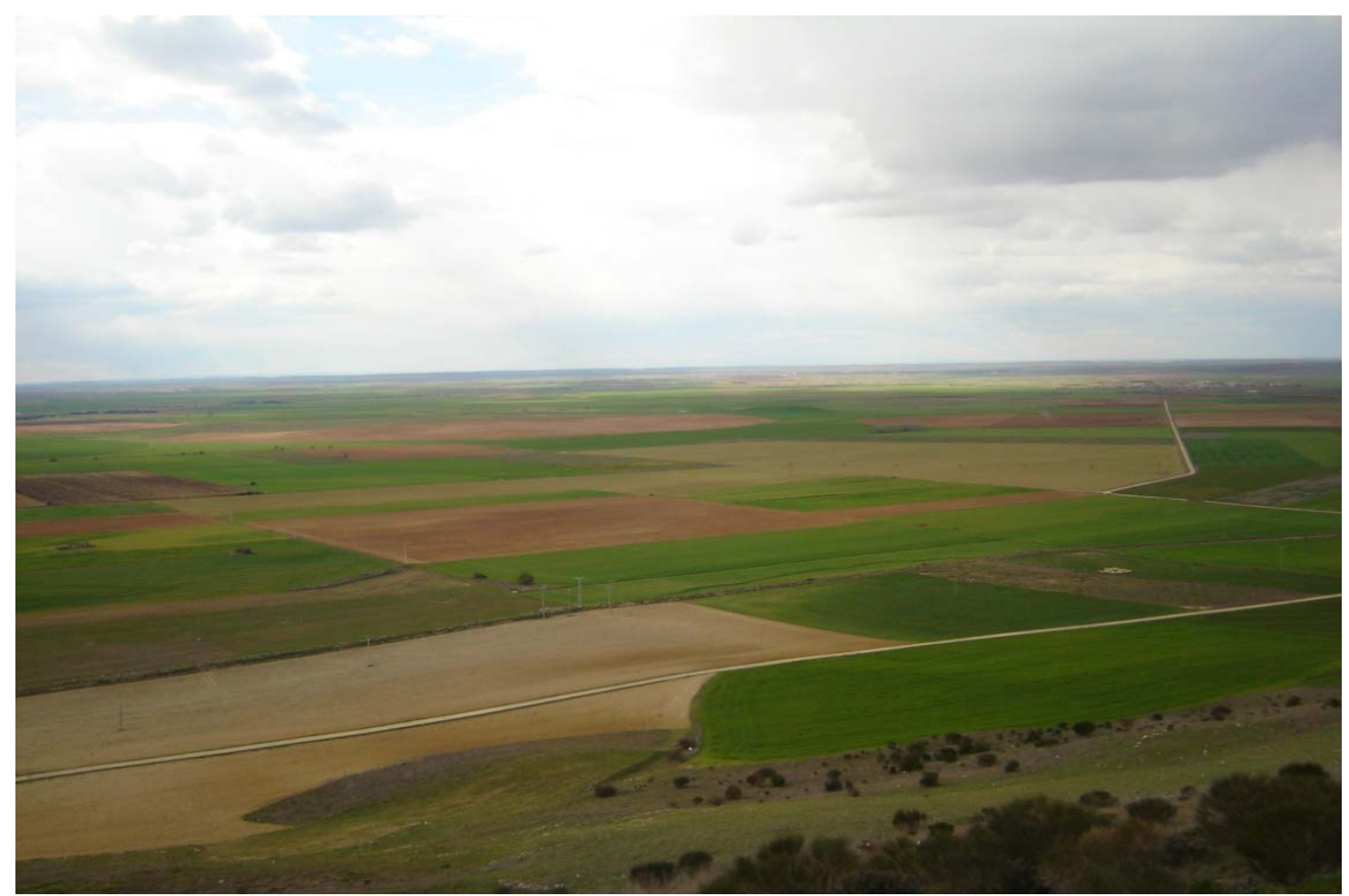

Figura 6.9. Las escenas panorámicas son características de Tierra de Campos. Vista desde la muralla de Urueña.

\subsubsection{Calidad visual}

La calidad visual de un paisaje es el valor del recurso visual o, dicho de una forma similar, es el mérito de un paisaje a ser conservado. Se trata de una variable cuya valoración es muy compleja, pues en el fondo se trata de cuantificar la belleza del paisaje intentando reducir al máximo la subjetividad. El territorio posee unas cualidades intrínsecas residentes en sus elementos naturales o artificiales que son percibidas por el observador a través de sus mecanismos fisiológicos y psicológicos; por ello la belleza se aprecia de forma distinta según los observadores. Además del problema perceptivo de la belleza, surge una nueva complicación: la adjudicación posterior de un valor.

Hay muchos métodos para valorar la calidad visual, aunque en esencia se pueden clasificar en tres:

- Métodos directos. La valoración se realiza a partir de la contemplación de la totalidad del paisaje; surge aquí el problema de la subjetividad, que trata de acotarse.

- Métodos indirectos. La valoración se hace a través del análisis de los componentes del paisaje y de categorías estéticas.

- Métodos mixtos. Valoran directamente, realizando después un análisis de componentes para averiguar la participación de cada uno en el valor total. 
Un modelo general de calidad visual del paisaje es el referido en ESCRIBANO et al. (1987), que define en primer lugar la calidad visual intrínseca que tiene la unidad, analiza posteriormente la calidad visual del entorno inmediato y, finalmente, la calidad visual del fondo escénico.

Dentro de los métodos indirectos de valoración de la calidad visual del paisaje destacan los aplicados por la USDA Forest Service y el Bureau of Land Management (BLM) de Estados Unidos (Figura 6.10). Ambos organismos coinciden en valorar la calidad visual a partir de las características visuales básicas, forma, línea, color, textura, de los componentes del paisaje (fisiografía, vegetación, agua, etc.). 


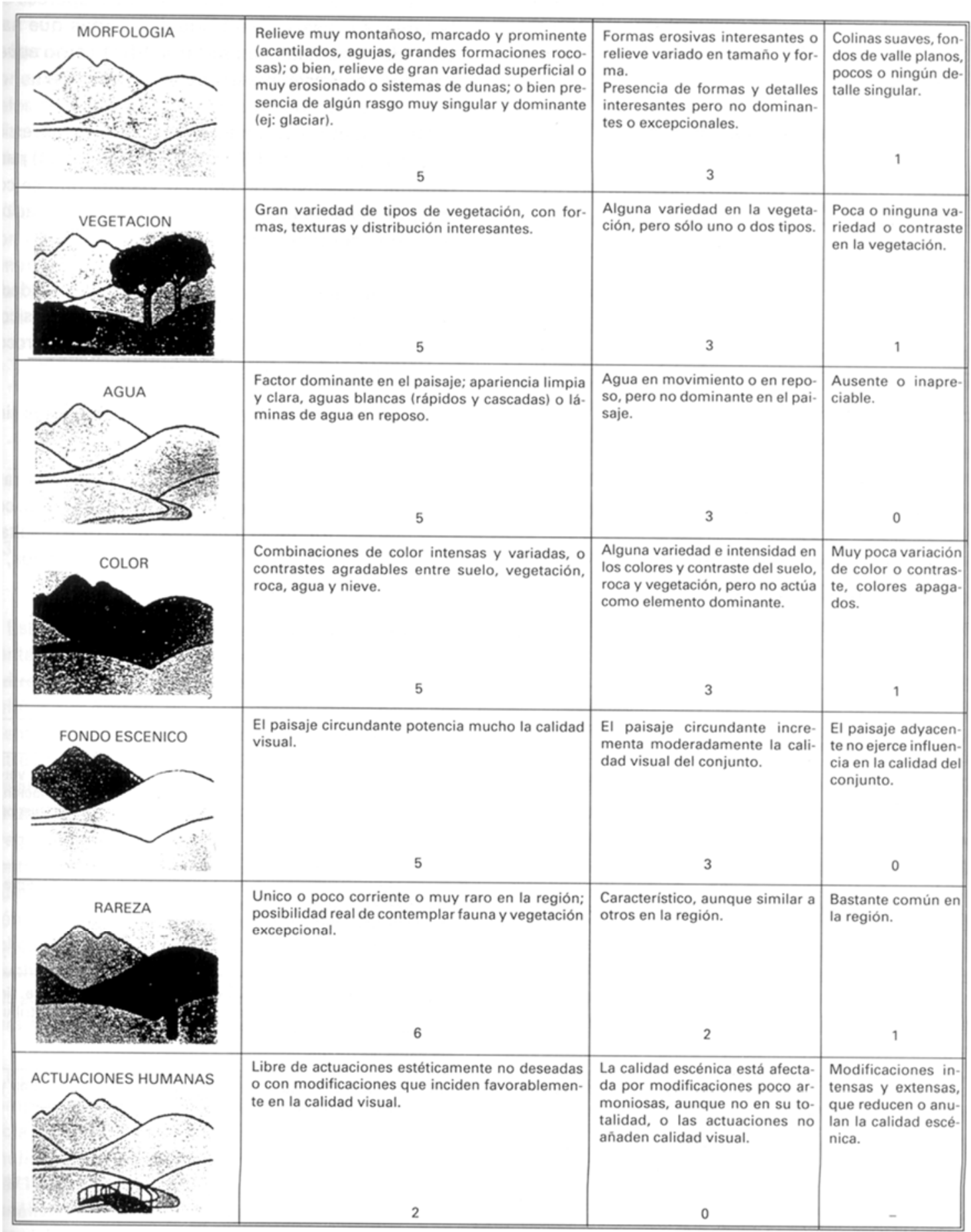

Figura 6.10. Inventario/evaluación de la calidad escénica. Criterios de ordenación y puntuación (BLM, 1980; tomado de MOPT, 1993)

La aplicación de estos criterios de calidad visual para el paisaje actual de Tierra de Campos resulta muy interesante. En una primera aproximación, se pueden extraer las siguientes conclusiones a la vista del análisis de las características visuales realizado anteriormente: 
- En cuanto a la morfología, el valor es claramente 1, teniendo en cuenta que en este paisaje predominan las formas suaves.

- En relación con la vegetación, asumiendo su escasa variedad o contraste (práctico dominio del cereal), el valor también es 1 .

- El agua es un factor ausente o inapreciable en el paisaje de Tierra de Campos, salvo en los entornos de los humedales, por tanto su valor es 1 .

- En el caso del color, la valoración es intermedia (3), dado que sí que existe cierta variedad en los colores y contrastes del suelo y la vegetación.

- En cuanto al fondo escénico, se ha de tener en cuenta que la gran extensión de Tierra de Campos hace que el paisaje adyacente no ejerza una gran influencia en la calidad del conjunto. A pesar de ello, sobre todo en la zona sur cercana a las repoblaciones forestales en las laderas de transición con los páramos calcáreos y en otras áreas periféricas próximas a riberas, el paisaje circundante incrementa moderadamente la calidad visual del conjunto. Por ello se puede estimar este valor como 1.

- En lo referente a la rareza, hay que señalar que buena parte de Tierra de Campos está declarada como Zona de Especial Protección para las Aves (ZEPA) sobre todo por la presencia de aves esteparias y puntualmente por aves propias de zonas húmedas, por lo que este valor se puede aproximar al máximo (4).

- Sobre las actuaciones humanas, nos encontramos en un valor intermedio (0), teniendo en cuenta que estas ni inciden favorablemente ni reducen la calidad visual.

La valoración resultante de acuerdo con los criterios de BLM (1980) es de 11 puntos, por lo que la calidad visual del paisaje de campiñas de Tierra de Campos se encuentra en la clase $C$, que es la inferior de las tres posibles: "Áreas con características y rasgos comunes en la región fisiográfica considerada" (de 0 a 11 puntos). En cualquier caso, la mayor virtualidad de este sencillo método de valoración se halla en la detección de las características visuales donde es posible realizar mejoras por medio de la recuperación ambiental. En principio, las cuatro en las que ello puede ser factible son la vegetación (existe un gran margen, de 1 a 5), el agua (de 0 a 5), el color (de 3 a 5) y las actuaciones humanas (de 0 a 2). Existe una alta probabilidad de alcanzar la clase B: "Áreas que reúnen una mezcla de características excepcionales para algunos aspectos y comunes para otros" (de 12 a 18 puntos) e incluso en el caso óptimo la clase A: “Áreas que reúnen características excepcionales para cada aspecto considerado" (de 19 a 33 puntos).
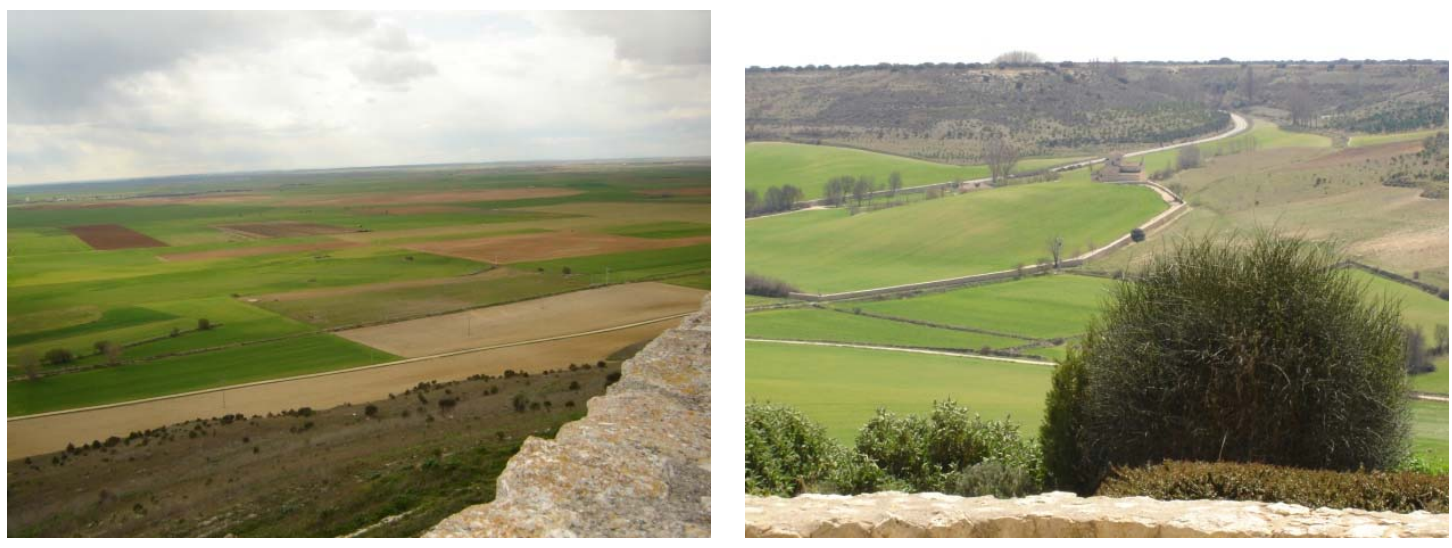

Figura 6.11. Dos vistas realizadas desde la muralla de Urueña. En la fotografía de la derecha, se percibe un paisaje de una mayor calidad visual, con una presencia mayor de vegetación y de actuaciones humanas integradas. 
OTERO et al. (2007) realizan una interesante aproximación a la valoración cuantitativa de la calidad del paisaje en España, que se plasma en un mapa (Figura 6.12). Se utiliza un criterio de clasificación del paisaje basado fundamentalmente en los tipos de relieve, altitud, posición en influencia, uso del suelo y núcleo de población. Los autores concluyen que, en una escala de 0 a 10, la calidad media del paisaje de España es de 4,94. También señalan que los espacios naturales protegidos son las áreas de mayor calidad de paisaje, donde incluso hay diferencias con aquellos cuyo factor de protección no es el paisaje (como por ejemplo las Zonas de Especial Protección para las Aves, ZEPA), cuya calidad es menor.

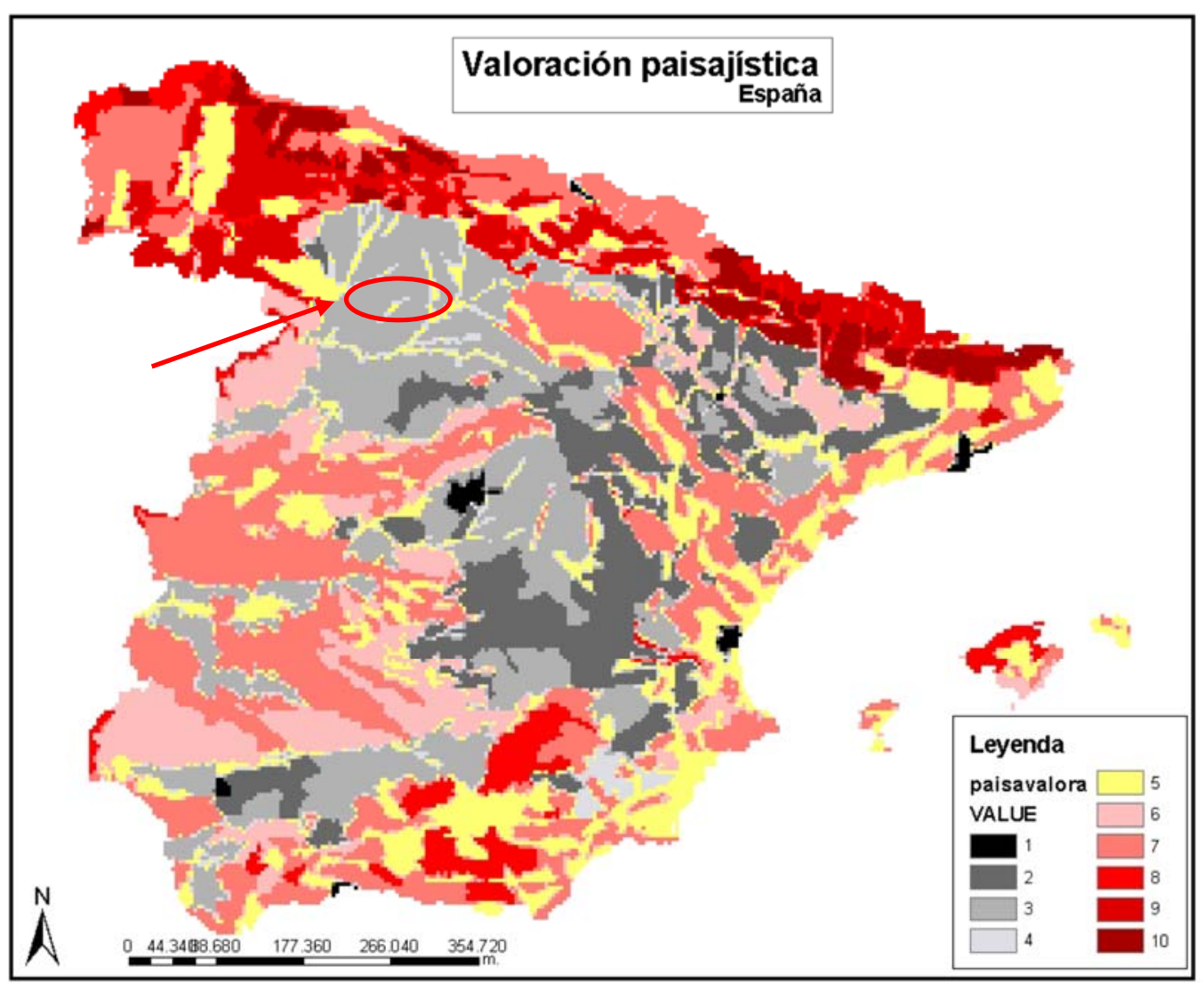

Figura 6.12. Mapa de calidad del paisaje de España (OTERO et al., 2007). La flecha indica la posición de Tierra de Campos.

En este mapa también se obtienen importantes conclusiones de cara al presente estudio. El valor proporcionado a la calidad del paisaje de la mayoría del territorio de Tierra de Campos está en el entorno del 3. De hecho, en la tabla de las asociaciones de paisaje, incluyen a Tierra de Campos en las "Ilanuras de la Meseta Norte", que tienen un valor de 2,5; por consiguiente, manifiestamente mejorable. Se trata de los datos más bajos de la calidad del paisaje en España. Como excepción, precisamente obtienen un valor de 5,17 las zonas aledañas a las riberas de los ríos Pisuerga, Carrión y Cea; allí donde las restauraciones de ribera, las plantaciones de chopos y los regadíos de los últimos años juegan un gran papel en la diversificación del paisaje.

\subsubsection{Fragilidad visual}

Se define la fragilidad visual como la susceptibilidad de un paisaje al cambio cuando se desarrolla un uso sobre él. Expresa el grado de deterioro que el paisaje experimentaría ante la incidencia 
de determinadas actuaciones. Este concepto es similar al de vulnerabilidad visual y opuesto al de capacidad de absorción visual, que es la aptitud que tiene un paisaje de absorber visualmente modificaciones o alteraciones sin detrimento en su calidad visual. Según lo señalado, a mayor fragilidad visual corresponde menor capacidad de absorción visual y viceversa (MOPT, 1993). Teniendo en cuenta que la superficie de Tierra de Campos es muy grande, la fragilidad es una cualidad intrínseca del territorio y, por tanto, independiente del tipo de actividad a desarrollar en el mismo.

Para analizar la fragilidad visual, AGUILÓ (1981) establece tres tipos de factores:

- Factores biofísicos derivados de los elementos característicos de cada punto. Entran aquí la pendiente, orientación y vegetación, considerada en diversos aspectos (altura, densidad, variedad cromática, estacionalidad, contraste cromático con el suelo). La integración de estos factores da lugar a un único valor que mide la fragilidad visual del punto.

- Factores de visualización, derivados de la configuración del entorno de cada punto; entran aquí los parámetros de la cuenca visual o superficie vista desde cada punto, tanto en magnitud como en forma y complejidad. Todos estos parámetros se agregan en un único valor que mide la fragilidad visual del entorno del punto.

- Factores histórico-culturales, que tienden a explicar el carácter y las formas de los paisajes en función del proceso histórico que los ha producido y son, por tanto, determinantes de la compatibilidad de forma y función de futuras actuaciones con el medio.

Según el modelo propuesto por este autor, la fragilidad visual de un punto del territorio es función de los elementos y características ambientales que definen al punto y su entorno. Se define así la fragilidad visual intrínseca, independiente de la posible observación, a la que es necesario añadir ciertas consideraciones referentes a la posibilidad real de visualizar la futura actuación por parte de un observador. Esta es la razón por la que se considera un "valor adquirido" de la fragilidad visual, cuando a la caracterización intrínseca se le añade el matiz de la accesibilidad potencial a la observación. Todas estas consideraciones se esquematizan en la Figura 6.13 mostrada a continuación. 


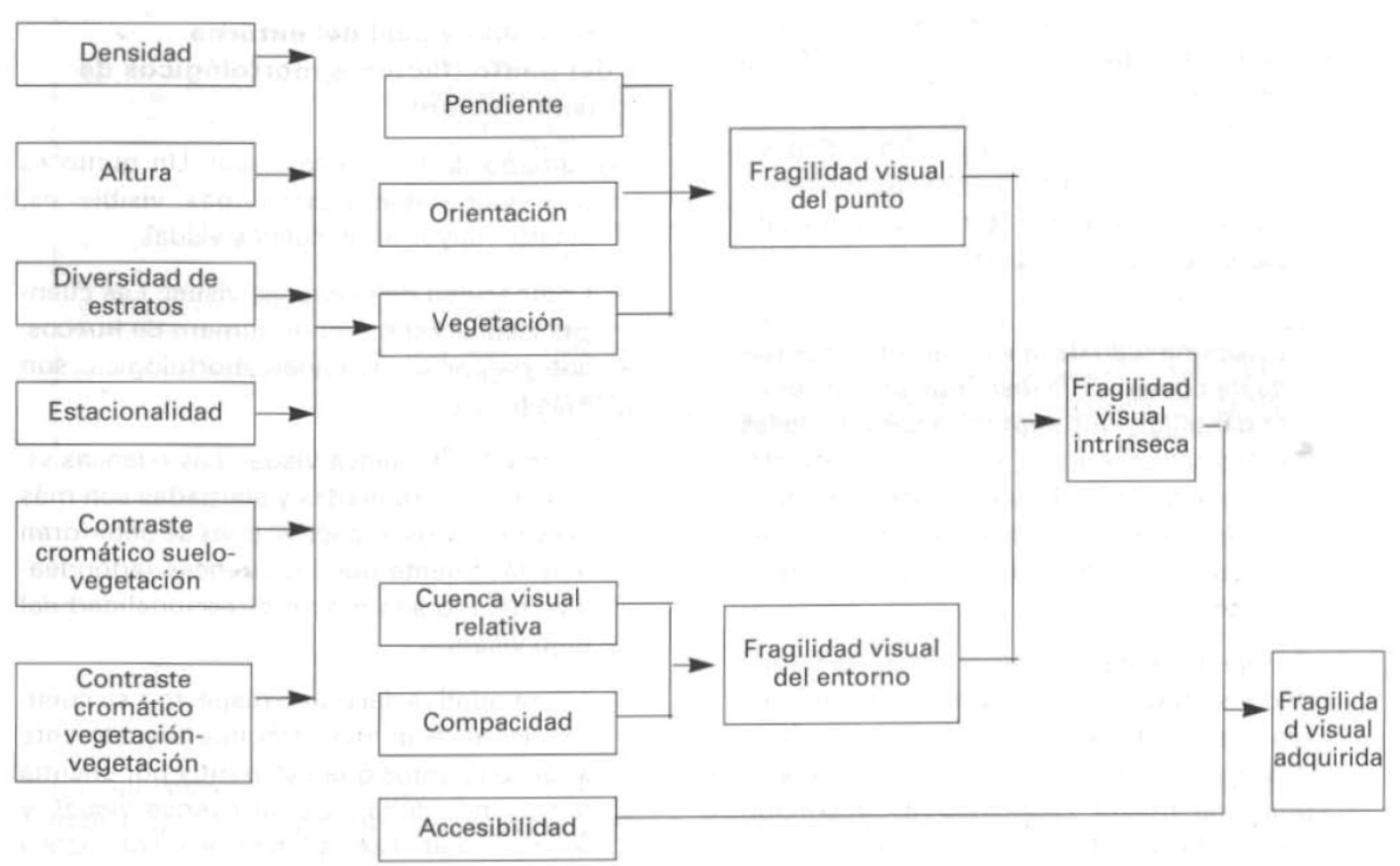

Figura 6.13. Modelo general de fragilidad visual (ESCRIBANO et al., 1987).

A continuación se analizará desde un punto de vista cualitativo cómo afectan cada una de las variables consideradas a la fragilidad visual del paisaje de campiñas de Tierra de Campos, de acuerdo con el razonamiento general efectuado por AGUILÓ (1981).

1.- Fragilidad visual del punto (factores biofísicos)

\section{Vegetación}

- Densidad. A mayor densidad de vegetación, expresada por el porcentaje de suelo cubierto por la proyección horizontal de las especies leñosas, menor fragilidad visual intrínseca. En este caso, el valor de densidad es prácticamente nulo.

- Contraste cromático suelo-vegetación. La fragilidad visual intrínseca crece con la magnitud del contraste de color entre suelo y vegetación. En general este contraste es reducido, teniendo en cuenta que toda la superficie está cultivada, salvo cuando irrumpen superficies de barbechos en los sembrados.

- Altura. Esta variable representa el valor enmascarante de la vegetación. Cuanto mayor es la complejidad de la estructura de la vegetación (mayor número y densidad de estratos), menor es el nivel de fragilidad visual. Salvo ejemplares arbóreos muy puntuales, este valor es también prácticamente nulo.

- Contraste cromático. La diversidad cromática dentro de la propia cubierta vegetal favorece el "camuflaje" de las actuaciones humanas, sobre todo si esa gama abundante de colores no obedece a una pauta claramente definida y se distribuye de forma caótica. Las situaciones de mayor fragilidad visual vienen definidas por las manchas monocromáticas, como en las que encontramos en este paisaje, donde resulta mayoritaria la cubierta vegetal herbácea de cereal de secano. 
- Estacionalidad. La pérdida de opacidad, la disminución del efecto pantalla, que supone la pérdida de las hojas caducas, es un factor que aumenta -aunque sea de forma temporal durante el otoño-invierno- la fragilidad visual de las zonas que sustentan aquel tipo de vegetación. Tierra de Campos es una de estas zonas, ya que la vegetación arbórea mayoritaria corresponde a frondosas de ribera (chopos y álamos).

Tal como se puede apreciar, la práctica ausencia de vegetación arbórea y arbustiva en Tierra de Campos es un factor causante de la elevada fragilidad del territorio. En consecuencia, la implantación de vegetación variada -sobre todo arbórea- es un aspecto clave sobre los que puede actuar la recuperación ambiental, tratándose de un factor directo de reducción de la fragilidad visual y consiguiente aumento de la capacidad de absorción visual frente a actuaciones humanas (Figura 6.14).

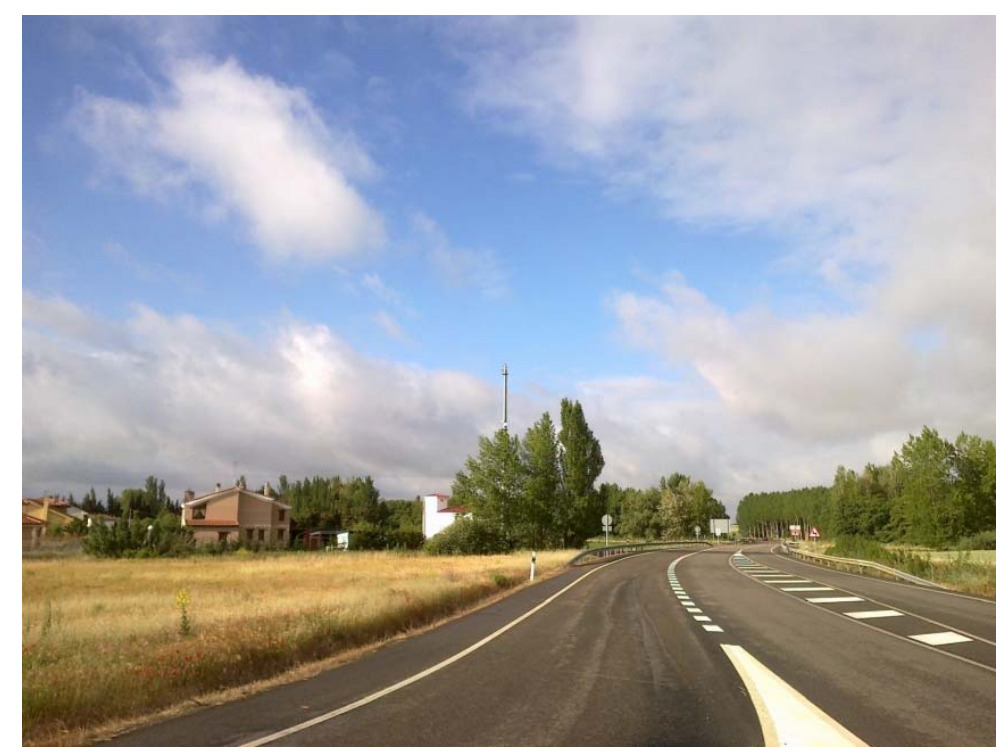

Figura 6.14. La presencia de chopos en Villoldo hace aumentar la capacidad de absorción visual ante instalaciones como antenas de telefonía móvil o construcciones descontextualizadas.

Pendiente. La fragilidad visual es directamente proporcional a la pendiente. De acuerdo con este factor, en la mayor parte de Tierra de Campos las pendientes son suaves; solo son elevadas en las cuestas que conectan los páramos con la campiña o en los pequeños tesos, donde en consecuencia aumenta la fragilidad visual.

Orientación. Existe una mayor fragilidad en las zonas más iluminadas normalmente para el observador. El Sur y el Oeste son, en este sentido, más frágiles que las exposiciones al Norte y al Este. También existe una mayor fragilidad en las zonas cuya orientación obligue al espectador a una mayor visualización a contraluz durante un tiempo más prolongado. Esta variable tiene una influencia puntual, no interviene en la valoración general de la fragilidad visual del paisaje de campiñas de Tierra de Campos. 
2.- Fragilidad visual del entorno del punto (factores morfológicos de visualización)

Tamaño de la cuenca visual. Un punto es más vulnerable cuanto más visible es, cuanto mayor es su cuenca visual. En Tierra de Campos cualquier punto posee una cuenca visual muy amplia.

Compacidad de la cuenca visual. Las cuencas visuales con menor número de huecos, con menor complejidad morfológica, son más frágiles. Esto ocurre en el paisaje de estudio, dado el predominio de las llanuras.

Forma de la cuenca visual. Las cuencas visuales más alargadas son más sensibles a los impactos que las redondeadas, debido a la mayor direccionalidad del flujo visual. En Tierra de Campos predominan las cuencas redondeada, debido a la ausencia de accidentes orográficas, con una menor fragilidad por este factor.

Altura relativa del punto respecto a su cuenca visual. Son más frágiles visualmente aquellos puntos que están muy por encima o muy por debajo de su cuenca visual, y menos frágiles aquellos otros cuya cuenca está a su mismo nivel. La visión desde distinta altura lleva unos ángulos de incidencia mayores y una mayor "exposición a las vistas". En el paisaje de estudio esto sucede claramente para puntos situados en las crestas de los páramos (los parques eólicos son un claro ejemplo) y en toda la franja situada en la campiña a pie de páramo. En el resto de las campiñas, salvo para actuaciones de elevada altura, la fragilidad debido a este factor es reducida.

3.- Fragilidad derivada de las características histórico-culturales del territorio.

Estos factores se deben a la existencia o a la proximidad a puntos y zonas singulares. Los valores singulares, en cuanto que constituyen puntos de atracción y focalizan la visión, añaden fragilidad visual, tanto a los propios puntos donde se sitúan, como a su entorno inmediato. La selección de estos puntos podrá regirse por criterios de:

Unicidad. Edificios, monumentos o parajes de carácter único, o por lo menos escaso. Podría ser el caso de los palomares o los humedales protegidos.

Valor tradicional. Parajes o formaciones morfológicas fuertemente enraizados en la vida local, utilizados como referencias cotidianas o constituidos, de alguna forma, como símbolos comarcales. No parece que sea un caso general en Tierra de Campos, salvo alguna localización municipal concreta (fuentes, pequeños tesos, miradores, etc.).

Interés histórico. Monumentos importantes en la historia de la región, con trascendencia fuera del ámbito local. En este caso los ejemplos son numerosos, debido al gran peso histórico de la comarca; tal vez los más trascendentes sean los castillos (Figura 6.15), los conjuntos históricoartísticos, las iglesias y las ermitas que surcan cada una de las localidades de la comarca. 


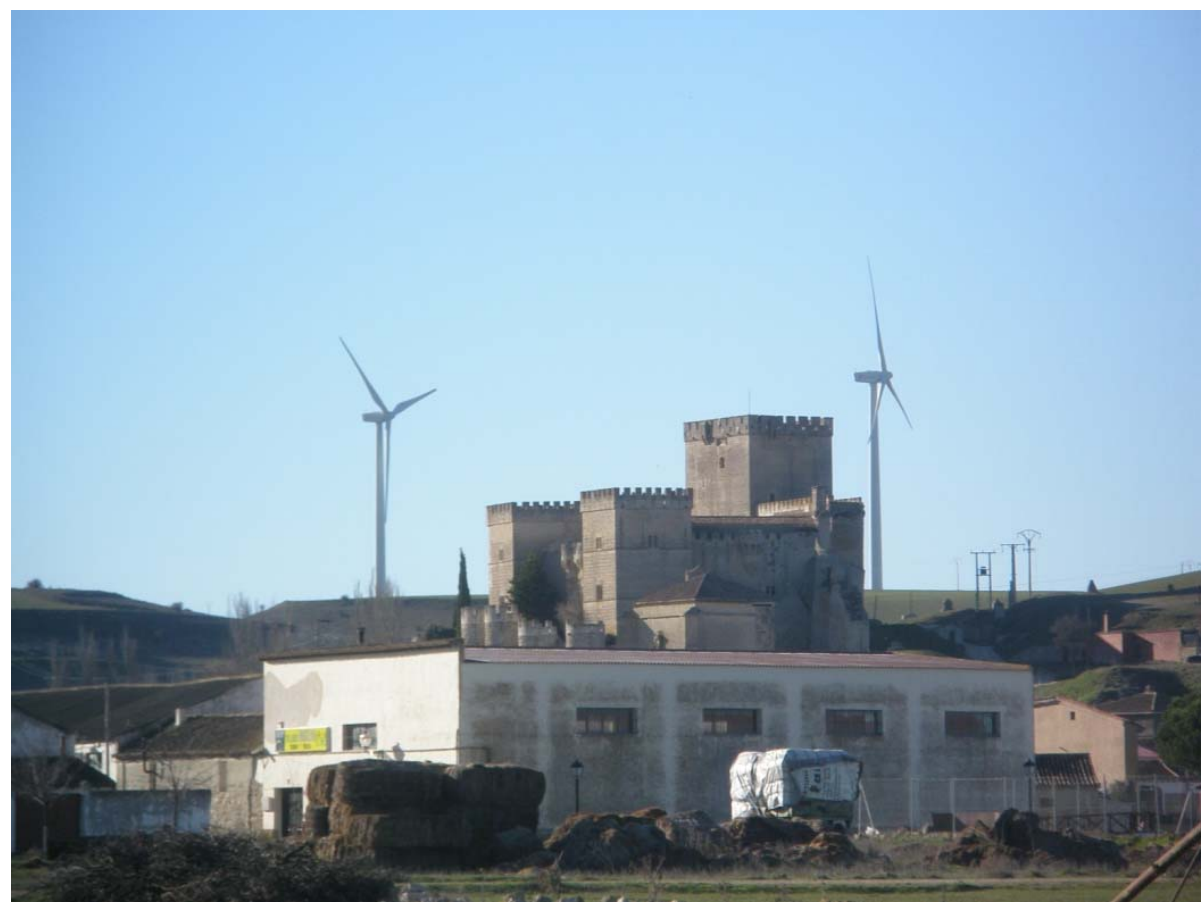

Figura 6.15. Parque eólico próximo al castillo de Ampudia. Toda la localidad está catalogada como conjunto histórico-artístico.

\section{4.- Accesibilidad de la observación.}

Distancia a carreteras y pueblos. La fragilidad visual adquirida aumenta con la cercanía a pueblos y carreteras (aumento de la presencia potencial de observadores). En este sentido se ha de tener en cuenta que, aunque la población de la comarca es reducida, la densidad de las localidades es muy alta (la distancia media entre pueblos oscila entre 5 y $10 \mathrm{~km}$ ), siendo también densa la red de carreteras locales. Particular importancia tienen las zonas próximas a infraestructuras de transporte de alta capacidad, como las carreteras nacionales, autovías y líneas ferroviarias de alta velocidad que atraviesan Tierra de Campos.

Accesibilidad visual desde carreteras y pueblos. La fragilidad visual de cada punto del territorio aumenta con la posibilidad que tiene cada punto de ser visto desde esos núcleos de potenciales observadores. Cuanto mayor sea el número de veces que un punto es visto al recorrer una carretera, mayor será la fragilidad visual de aquel punto. La ausencia de accidentes orográficos, así como la de vegetación arbolada, hace que la accesibilidad visual desde carreteras y pueblos de cualquier actuación sea muy elevada, por lo que la fragilidad visual debido a este factor también lo será.

La combinación de la fragilidad visual del punto y del entorno define la fragilidad visual intrínseca de cada punto del territorio, y la integración global con el elemento accesibilidad, la fragilidad visual adquirida.

Un caso particular es la metodología para la evaluación de la capacidad de absorción visual (CAV) propuesta por YEOMANS (1986) y también recogida en MOPT (1993). Este parámetro es el 
opuesto a la fragilidad visual, definido como la capacidad del paisaje para acoger actuaciones propuestas sin que se produzcan variaciones en su carácter visual, lo que centra la atención. Su valoración se realiza también a través de los factores biofísicos, que se integran en la siguiente fórmula:

$$
\mathrm{CAV}=\mathrm{S} \times(\mathrm{E}+\mathrm{R}+\mathrm{D}+\mathrm{C}+\mathrm{V})
$$

$\mathrm{S}=$ pendiente (a mayor pendiente menor CAV). Este factor se considera el más significativo, por lo que actúa como multiplicador.

$\mathrm{E}=$ estabilidad del suelo (a mayor $\mathrm{E}$, mayor CAV).

$\mathrm{R}$ = capacidad de regeneración de la vegetación (a mayor $\mathrm{R}$, mayor CAV).

$\mathrm{D}=$ diversidad de la vegetación (a mayor $\mathrm{D}$, mayor CAV).

$\mathrm{C}=$ contraste de color de suelo y roca (a mayor $\mathrm{C}$, mayor $\mathrm{CAV}$ ).

$\mathrm{V}=$ contraste suelo-vegetación (a mayor $\mathrm{V}$, mayor CAV).

Los valores asignados a los distintos parámetros según este modelo se muestran en la Tabla 6.2. 
Tabla 6.2. Valores de la capacidad de absorción visual (C.A.V.), tomado de MOPT. (1993) de acuerdo al original de YEOMANS (1986).

\begin{tabular}{|c|c|c|c|}
\hline \multirow{2}{*}{ Factor } & \multirow{2}{*}{ Características } & \multicolumn{2}{|c|}{ Valores de C.A.V. } \\
\hline & & Nominal & Numérico \\
\hline \multirow{3}{*}{$\begin{array}{l}\text { Pendiente } \\
\text { P }\end{array}$} & Inclinado (pendiente > 55\%). & BAJO & 1 \\
\hline & $\begin{array}{l}\text { Inclinación suave } \quad(25-55 \% \\
\text { pendiente). }\end{array}$ & MOOERADO & 2 \\
\hline & $\begin{array}{l}\text { Poco inclinado }(0-25 \% \text { pen- } \\
\text { diente). }\end{array}$ & ALTO & 3 \\
\hline \multirow{3}{*}{$\begin{array}{c}\text { Diversidad de vegetación } \\
\text { D }\end{array}$} & Eriales, prados y matorrales. & BAJO & 1 \\
\hline & Coniferas, repoblaciones. & MODERADO & 2 \\
\hline & $\begin{array}{l}\text { Diversificada (mezcla de cla- } \\
\text { ros y bosques). }\end{array}$ & ALTO & 3 \\
\hline \multirow{3}{*}{$\begin{array}{l}\text { Estabilidad del suelo y } \\
\text { erosionabilidad } \\
\text { E }\end{array}$} & $\begin{array}{l}\text { Restricción alta, derivada de } \\
\text { riesgo alto de erosión e } \\
\text { inestabilidad, pobre rege- } \\
\text { neración potencial. }\end{array}$ & BAJO & 1 \\
\hline & $\begin{array}{l}\text { Restricción moderada debido } \\
\text { a cierto riesgo de erosión e } \\
\text { inestabilidad y regenera- } \\
\text { ción potencial. }\end{array}$ & MODERADO & 2 \\
\hline & $\begin{array}{l}\text { Poca restricción por riesgo } \\
\text { bajo de erosión e inestabili- } \\
\text { dad y buena regeneración } \\
\text { potencial. }\end{array}$ & ALTO & 3 \\
\hline \multirow{3}{*}{$\begin{array}{c}\text { Contraste suelo-vegetación } \\
\qquad \mathrm{V}\end{array}$} & $\begin{array}{l}\text { Bajo potencial de regenera- } \\
\text { ción. }\end{array}$ & BAJO & 1 \\
\hline & $\begin{array}{l}\text { Contraste visual moderado } \\
\text { entre el suelo y la vegeta- } \\
\text { ción. }\end{array}$ & MODERADO & 2 \\
\hline & $\begin{array}{l}\text { Contraste visual bajo entre el } \\
\text { sueio y la vegetación adya- } \\
\text { cente. }\end{array}$ & ALTO & 3 \\
\hline \multirow{3}{*}{$\begin{array}{c}\text { Vegetación. Regeneración } \\
\text { potencial } \\
\text { R }\end{array}$} & $\begin{array}{l}\text { Potencial de regeneración } \\
\text { bajo. }\end{array}$ & BAJO & 1 \\
\hline & $\begin{array}{l}\text { Potencial de regeneración } \\
\text { moderado. }\end{array}$ & MODERADO & 2 \\
\hline & Regeneración alta. & ALTO & 3 \\
\hline \multirow{3}{*}{$\begin{array}{l}\text { Contraste de color roca-suelo } \\
\text { C }\end{array}$} & Contraste alto. & BAJO & 1 \\
\hline & Contraste moderado. & MODERADO & 2 \\
\hline & Contraste bajo. & ALTO & 3 \\
\hline
\end{tabular}

Aplicando esta tabla para la unidad de paisaje de campiñas de Tierra de Campos, se obtienen los siguientes valores:

- Pendiente $=3$, ALTO (excepto en las laderas que conducen a los páramos, cuyo valor es de 2, MODERADO)

- Diversidad de vegetación = 1, BAJO

- Estabilidad del suelo $=2$, MODERADO

- Contraste suelo-vegetación = 2, MODERADO

- Vegetación. Regeneración potencial = 1, BAJO

- Contraste de color roca-suelo = no se valora (no aflora roca en superficie) 
Más que para realizar una valoración cuantitativa de la capacidad de absorción visual exacta de este paisaje, teniendo en cuenta que los factores litológicos son invariables, con esta metodología se extraen dos conclusiones fundamentales:

- La fragilidad visual de la mayoría del paisaje de Tierra de Campos es alta y, por consiguiente, su capacidad de absorción visual es reducida.

- Especialmente elevada es la fragilidad visual en la línea de cumbres de los páramos.

- El incremento de la vegetación supone el aumento de la capacidad de absorción visual. Este aspecto es crucial de cara a justificar la recuperación ambiental del paisaje de Tierra de Campos.

\subsubsection{Impacto visual}

Se puede definir impacto visual como el efecto que causa la ejecución de una determinada obra en el paisaje, entendido este desde la óptica de percepción visual. En principio, este impacto puede ser positivo -si mejora la calidad visual del paisaje- o lo que es más usual, negativo, si disminuye su calidad visual.

ARAMBURU (1993) señala que conviene diferenciar los conceptos de impacto en el paisaje e impacto visual en el paisaje. Cuando nos referimos al impacto en el paisaje, este tiene una connotación territorial, en un contexto general, mientras que el impacto visual tiene una connotación particular a un territorio, paisaje limitado por lo que el observador es capaz de percibir. La aproximación es por tanto distinta, determinada por el contenido del paisaje, en el primer caso, y por los límites del espacio que rodea al observador (cuenca visual) y su contenido, en el segundo.

La evaluación del impacto en el paisaje se puede abordar a través del conocimiento de la capacidad de absorción visual del territorio, aptitud para admitir cambios sin notable quebranto de sus aspectos visuales, también llamada fragilidad visual como anteriormente se indicó, expresión del grado de deterioro que el paisaje experimenta ante la incidencia de determinadas actuaciones.

De acuerdo con este concepto, los puntos del territorio con alta capacidad de absorción visual gozan de unas características específicas que permiten que los efectos de las acciones desarrolladas en ellos "se vean poco", o "destaquen poco", produciendo un menor impacto en la configuración paisajística del lugar. Lo contrario ocurrirá en los puntos del territorio con baja capacidad de absorción visual, que podrían describirse como puntos de alta fragilidad visual.

Continuando esta línea argumental, la citada autora indica que existen aspectos básicos determinantes de la capacidad de absorción visual:

- Configuración del lugar y de sus alrededores: La complejidad topográfica y las estructuras geomorfológicas cerradas aumentan la capacidad de absorción visual, porque reducen el número de puntos desde los que se puede ver el lugar en cuestión.

- Pendiente: Las laderas con fuertes pendientes "se ofrecen" más a la vista que las zonas llanas, que son más absorbentes. 
- Fisonomía de la vegetación: Cuanto mayor es la altura, cobertura y densidad de la vegetación, más se incrementa la capacidad de absorción visual de la zona en cuestión.

- Accesibilidad: Sin duda los aspectos relacionados con la accesibilidad son los más discutidos, ya que constituyen características extrínsecas y coyunturales, de posible cambio, y no propiamente intrínsecas de cada territorio. Pero los accesos constituyen muchas veces la principal fuente de "posibilidades de ver", independientemente de las características morfológicas y de cubierta vegetal del territorio.

De acuerdo con el análisis anterior, el paisaje de campiñas cerealistas de Tierra de Campos posee en general una baja capacidad de absorción visual y, por consiguiente, es susceptible a que los cambios que se produzcan en él produzcan un notable quebranto de su manifestación externa. Aspectos como su simplicidad topográfica (relieves abiertos suavemente alomados), la práctica ausencia de vegetación forestal (monocultivo cerealista) o su alta accesibilidad (la red de carreteras es muy densa) permiten inferir que los impactos visuales generados serán altos, lo que se acrecienta en las zonas próximas a los páramos.

El impacto visual que una actividad causa en un territorio queda determinado por los límites del espacio visual que rodean la actuación. Su magnitud se analiza a través de las concordancias y discordancias que existen al comparar el contraste visual, la dominancia espacial, la compatibilidad e importancia relativa de los elementos visuales característicos de la actividad en el paisaje en que se ubica. El impacto será más severo a medida que aumente el grado de contraste (diferencia) entre las características de los elementos visuales del proyecto y del paisaje circundante, la dominancia espacial (que dependerá del tamaño y situación espacial del proyecto así como del fondo escénico contra el que es visto) y la intrusión visual, que es función de la posición que la alteración ocupa en relación con los componentes dominantes del paisaje (ARAMBURU, 1993).

En la medida en que la actuación sea más o menos discordante con el entorno el impacto será mayor o menor, discordancia que vendrá determinada por el volumen o escala de la actuación en relación con la cuenca visual, por el tipo de materiales utilizados en la construcción de los elementos físicos que la forman, por su color y por las formas o diseño de dichos elementos (GÓMEZ OREA, 2003).

La valoración del impacto visual de un determinado proyecto se suele incluir en la evaluación de impacto ambiental conjunta del mismo. No obstante, las fases que tendría si se analizase de forma independiente serían las siguientes (MOPT, 1993):

1. Información sobre el proyecto: Diseño y organización espacial, colores, formas, dimensiones, elementos auxiliares, características de funcionamiento, nivel de ruido, de polvo, etc.

2. Descripción del paisaje circundante: Carácter del paisaje en que se ubica el proyecto, grado de influencia antrópica, carga histórico-cultural, componentes del paisaje, valor para la conservación, etc.

3. Determinación de la cuenca visual: Área de influencia visual del proyecto.

4. Selección de puntos de vista: Lugares de posible concentración de observadores, puntos con mejor vista sobre el lugar que ocupará el proyecto, recorridos, puntos más "sensibles" visualmente, etc. 
5. Realización de una simulación visual: Simulación de las vistas del proyecto desde los puntos de vista seleccionados.

6. Identificación y valoración de los posibles impactos a partir de la simulación: Elementos del paisaje eliminados por la actuación, grado de contraste visual de la actuación proyectada con su entorno (contraste de formas, colores, líneas o texturas), dominancia por escala de la actuación, intrusión por posición que puede suponer la actuación en el paisaje, etc. La severidad de los impactos está a su vez condicionada por la extensión de la superficie afectada visualmente por los mismos y por el carácter del paisaje en que se localiza la actuación y su valor para la conservación.

7. Evaluación: Impacto aceptable, no aceptable o corregible.

8. Propuesta de medidas protectoras o correctoras: La incorporación de estas medidas al proyecto es fundamental para mitigar los impactos detectados.

De acuerdo con esta línea expositiva, podemos indicar los tipos de proyectos que generan mayores impactos visuales en el paisaje de campiñas cerealistas de Tierra de Campos:

Las naves agro-ganaderas, repartidas por todo el territorio pero preferentemente ubicadas en los espacios periurbanas, sobre todo cuando sus colores generan fuertes contrastes visuales (Figura 6.16): cubiertas metálicas brillantes, paramentos blancos o de otros colores estridentes, presencia de bandas de colores, etc. Su impacto se acrecentará si es elevado su volumen y su localización es poco acertada: proximidades a iglesias $u$ otros bienes culturales, prominencias del terreno, cercanía a miradores, etc. Aunque afortunadamente, su presencia es escasa, es reseñable el impacto causado por tipologías constructivas que no emplean la tradicional cubierta "a dos aguas", como las naves "wonder".

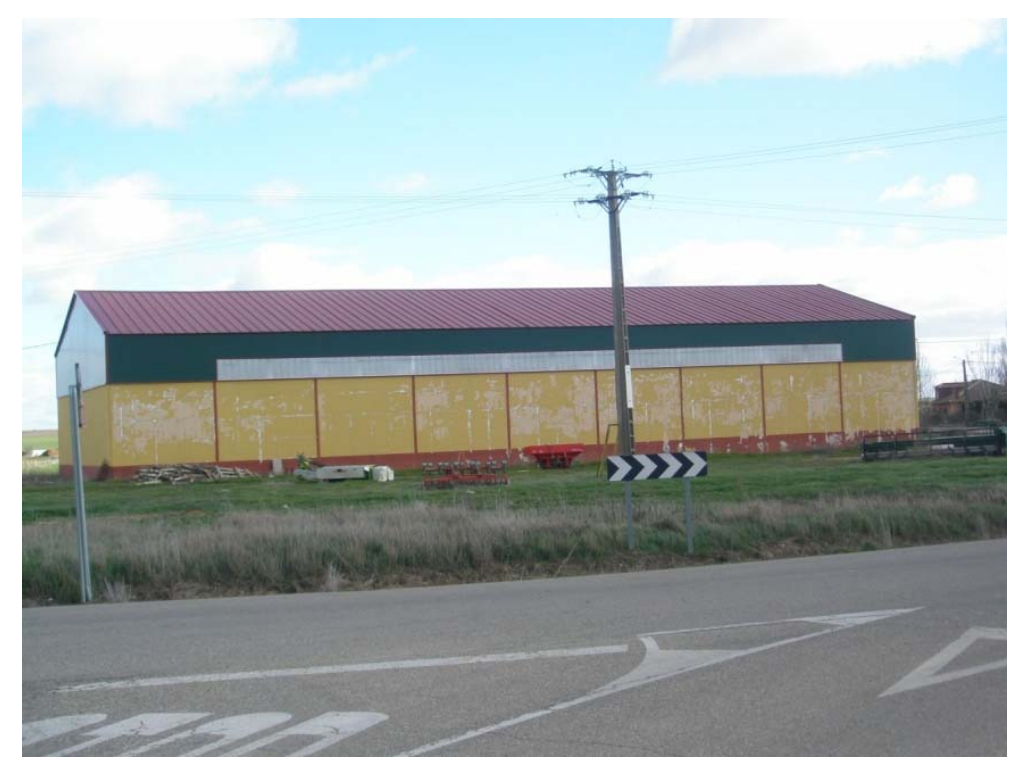

Figura 6.16. Nave agrícola en Cisneros, que provoca un fuerte impacto visual por contraste de color y dominancia en escala.

Otras construcciones o instalaciones en suelo rústico ajenas a los usos agrarios: plantas de tratamiento de minerales, depuradoras, plantas fotovoltaicas, estaciones transformadoras de 
energía eléctrica, antenas de telefonía móvil, etc. (Figura 6.17). La intensidad de su impacto visual será mayor si es alto el contraste visual con el terreno, si la ubicación es errónea, si su volumen es elevado, etc.
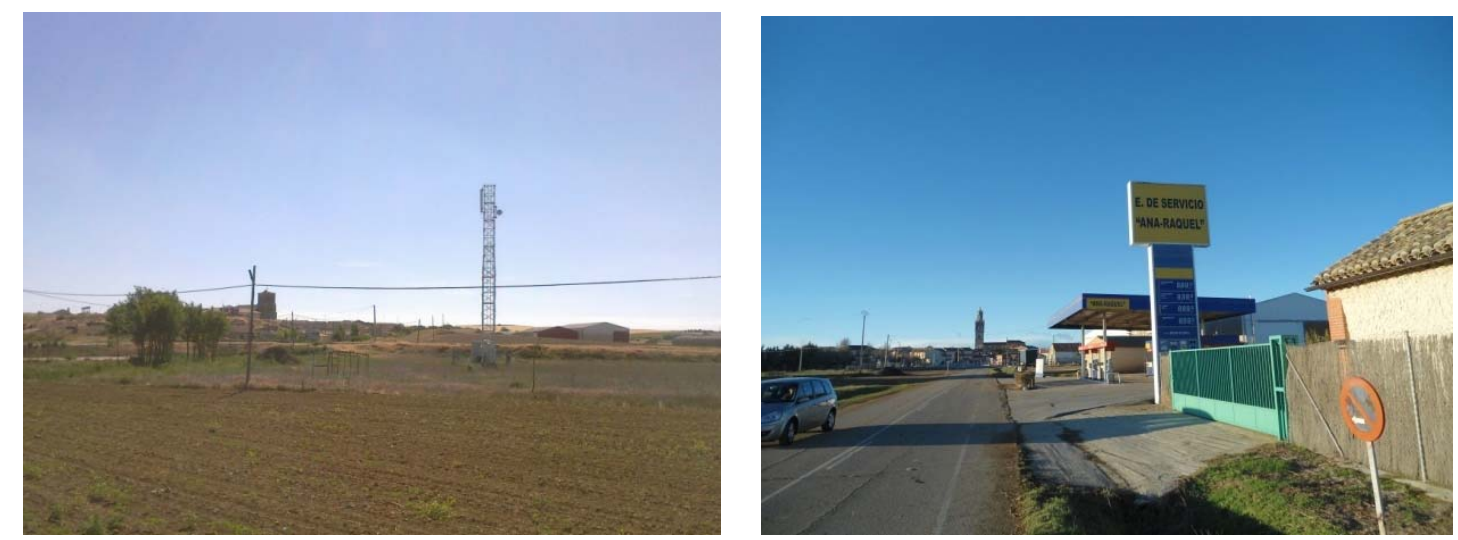

Figura 6.17. Izquierda, antena de telefonía móvil y cable de teléfono en Herrín de Campos; derecha, estación de servicio en Fuentes de Nava.

Viviendas cuya tipología arquitectónica está alejada de la tradicional. La alteración del paisaje rural se da fundamentalmente en los espacios periurbanos: construcciones "tipo chalet" exentas del tejido urbano, cubiertas sin teja curva, colores de las fachadas que contrastan excesivamente con los ocres y tierras tradicionales, tipologías foráneas, distribución de huecos sin armonía, carpintería estridente, etc.

Líneas eléctricas. Su impacto dependerá sobre todo del voltaje, que implica mayores alturas y volúmenes de sus apoyos. No obstante, en el medio rural predominan las líneas de media tensión, de distribución a las poblaciones. En muchas ocasiones, el impacto se debe a la falta de planificación en su trazado, que provoca excesivas densidades de líneas.

Parques eólicos. En las campiñas cerealistas de Tierra de Campos se han instalado de momento pocos parques eólicos, pero sí que es de notar su presencia en los páramos circundantes y en alguna zona de teso (Figura 6.18). Su impacto visual desde la campiña es muy alto, debido a su gran envergadura, la ruptura con la línea del horizonte, la gran visibilidad, la elevada accesibilidad, etc. 


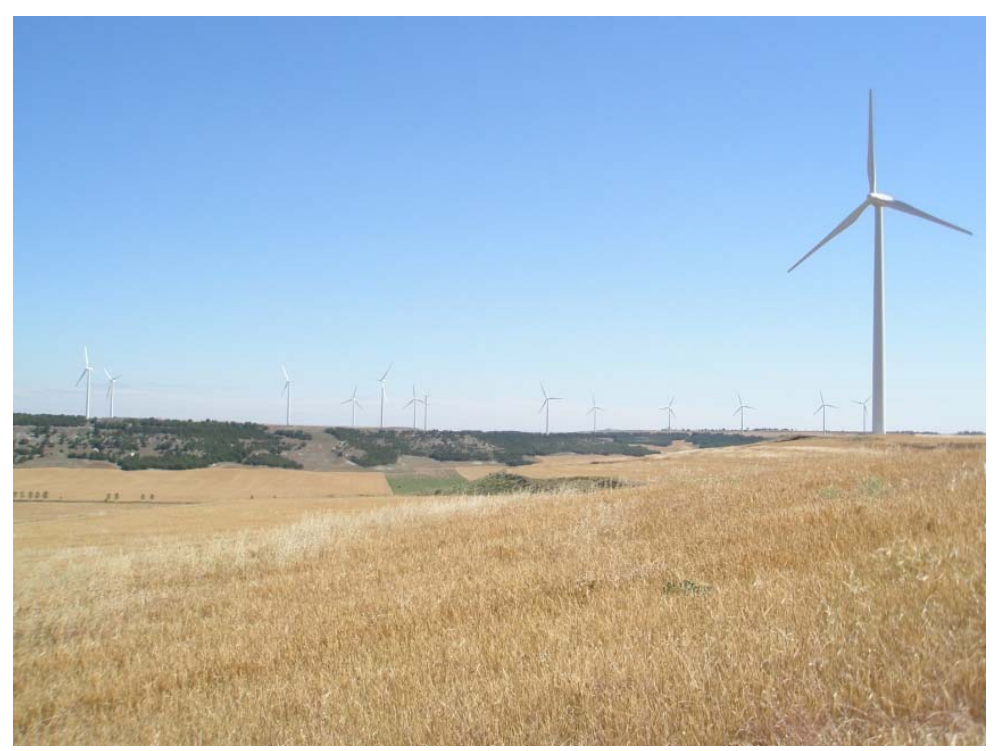

Figura 6.18. Parque eólico en Ampudia

Autovías. Las carreteras locales y comarcales (autonómicas) están en general integradas en el paisaje, porque su entidad y requerimientos funcionales no son muy elevados. En el caso de las nacionales, su mayor impacto puede deberse a la construcción de variantes a poblaciones, que implica a su vez la construcción de pasos inferiores o superiores para dar acceso a las vías que intersecta. En cuanto a las autovías, su impacto es considerablemente más elevado, porque su envergadura es mayor y son más exigentes sus requerimientos funcionales: elevados movimientos de tierra, necesidad de préstamos y vertederos, generación de altos desmontes (Figura 6.19) y terraplenes, presencia de vallados, construcción de pasos a distinto nivel, enlaces, construcción de puentes, viaductos, etc. En algunos de estos aspectos su impacto puede reducirse mucho e incluso llegar a ser positivo si su diseño es acertado (caso de puentes) o si se implementan medidas correctoras intensas.

Ferrocarriles de alta velocidad. Los impactos son similares a las autovías (Figura 6.19), aunque pueden ser incluso superiores por la necesidad de su electrificación en todo su trazado, lo que implica además la construcción de grandes subestaciones y líneas eléctricas aéreas. Estas líneas de alta velocidad suelen ir en terraplén en casi todo su trazado, lo que las hace muy visibles desde una amplia cuenca visual. 

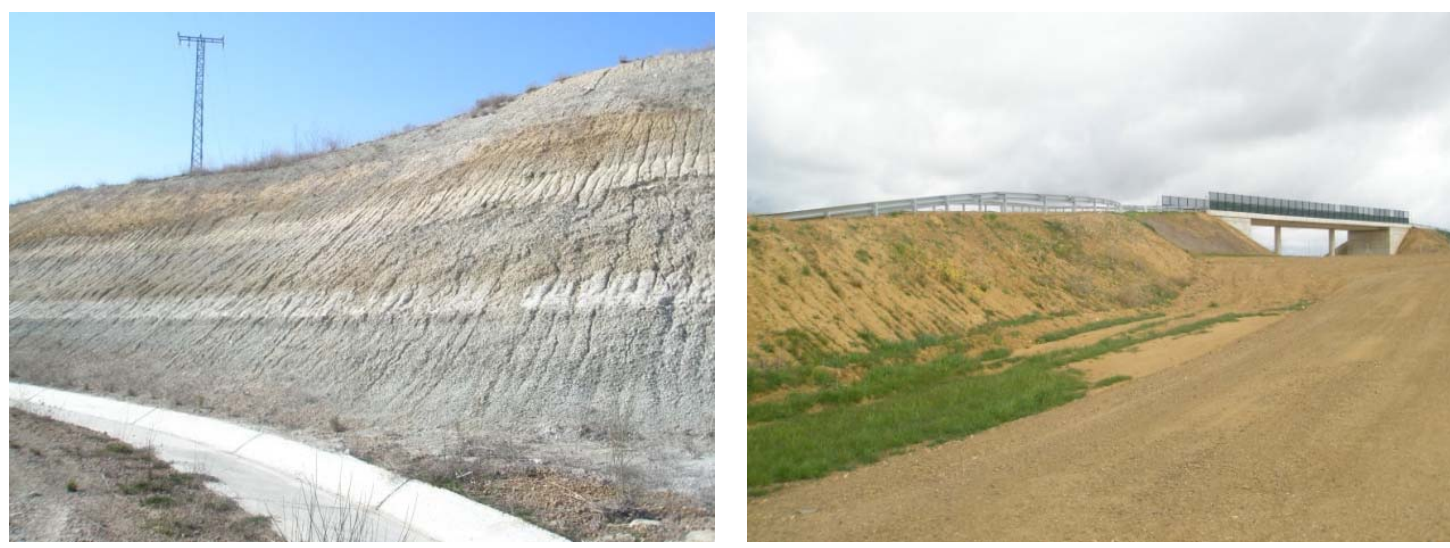

Figura 6.19. Movimientos de tierra ocasionados en autovía en Grijota y en línea de ferrocarril de alta velocidad en Cisneros.

\subsubsection{Ecología del paisaje}

La ecología del paisaje es una disciplina que surge a finales de la década de 1930, de la mano del geógrafo Carl TROLL (1939), que acuña el término landscape ecology y lo define como el estudio de toda la complejidad de relaciones causa-efecto que existen entre las comunidades de seres vivos y sus condiciones ambientales en una sección específica de paisaje.

A partir de esa fecha, la ecología del paisaje se va consolidando y así surgen otras definiciones complementarias, como el estudio de las interacciones entre los aspectos temporales y espaciales del paisaje y sus componentes de flora, fauna y culturales (FORMAN y GODRON, 1986). Esta disciplina se centra en tres cuestiones fundamentales:

1. Las relaciones espaciales entre elementos del paisaje o ecosistemas.

2. Los flujos de energía, nutrientes minerales y especies entre los elementos.

3. La dinámica ecológica del mosaico paisajístico a lo largo del tiempo.

VILA et al. (2006) realizan un análisis conceptual de esta materia, que presentan como una visión holística de la realidad, que intenta integrar al máximo su extremada y dinámica complejidad. La interpretación del paisaje se fundamenta en una aproximación de carácter estructuralmorfológica y a la vez funcional. Las unidades morfológicas y estructurales que componen el paisaje están relacionadas desde un punto de vista funcional, al producirse entre ellas intercambios de energía, materiales, organismos, información, etc. Evidentemente, los cambios en la composición estructural y morfológica del paisaje tienen su origen en la propia dinámica ecológica y está fuertemente condicionada por la actividad antrópica, especialmente en los paisajes más humanizados.

\subsubsection{Elementos del mosaico territorial}

La base para la interpretación del paisaje es el mosaico territorial, que está compuesto por tres grandes tipos de elementos:

- Las manchas (o fragmentos) son las diferentes unidades morfológicas que se pueden diferenciar en el territorio. 
- Los corredores son las conexiones existentes entre unos fragmentos y otros.

- La matriz es el elemento del paisaje que ocupa una mayor superficie y presenta una mayor conexión, jugando el papel dominante en el funcionamiento del paisaje. Es el elemento que, por lo general, rodea las manchas.

Este modelo matriz-mancha-corredor controla fuertemente todos los movimientos, flujos y cambios de los sistemas naturales y de la población. En el paisaje de campiñas de Tierra de Campos estos tres elementos están claros: la matriz está formada por la superficie de cultivo agrícola, que ocupa la inmensa mayoría del territorio; las manchas son los pequeños enclaves no agrícolas (montes, humedales, eriales, etc.) y los corredores son las riberas, ribazos, lindes $u$ otras franjas cubiertas por vegetación (Figura 6.20).

La descompensación de estos elementos es obvia: no hay más que tener en cuenta que en muchos términos municipales de la comarca, la superficie agrícola supera el $95 \%$ del total. El uso agrario dominante ha reducido hasta la mínima expresión la presencia de vegetación natural en Tierra de Campos, de forma que en la actualidad solo quedan pequeños bosquetes de encinas o algunas choperas y alamedas ligadas a cursos fluviales. Las manchas de vegetación arbolada han sido arrinconadas a lo largo de la historia a meros testigos, conservados casi de forma milagrosa. Y los corredores, fundamentalmente como consecuencia de los procesos de concentración parcelaria (que eliminan lindes, ribazos, sotos, etc.) y los encauzamientos de ríos y arroyos (que destruyen sus riberas), han disminuido su longitud de manera alarmante.
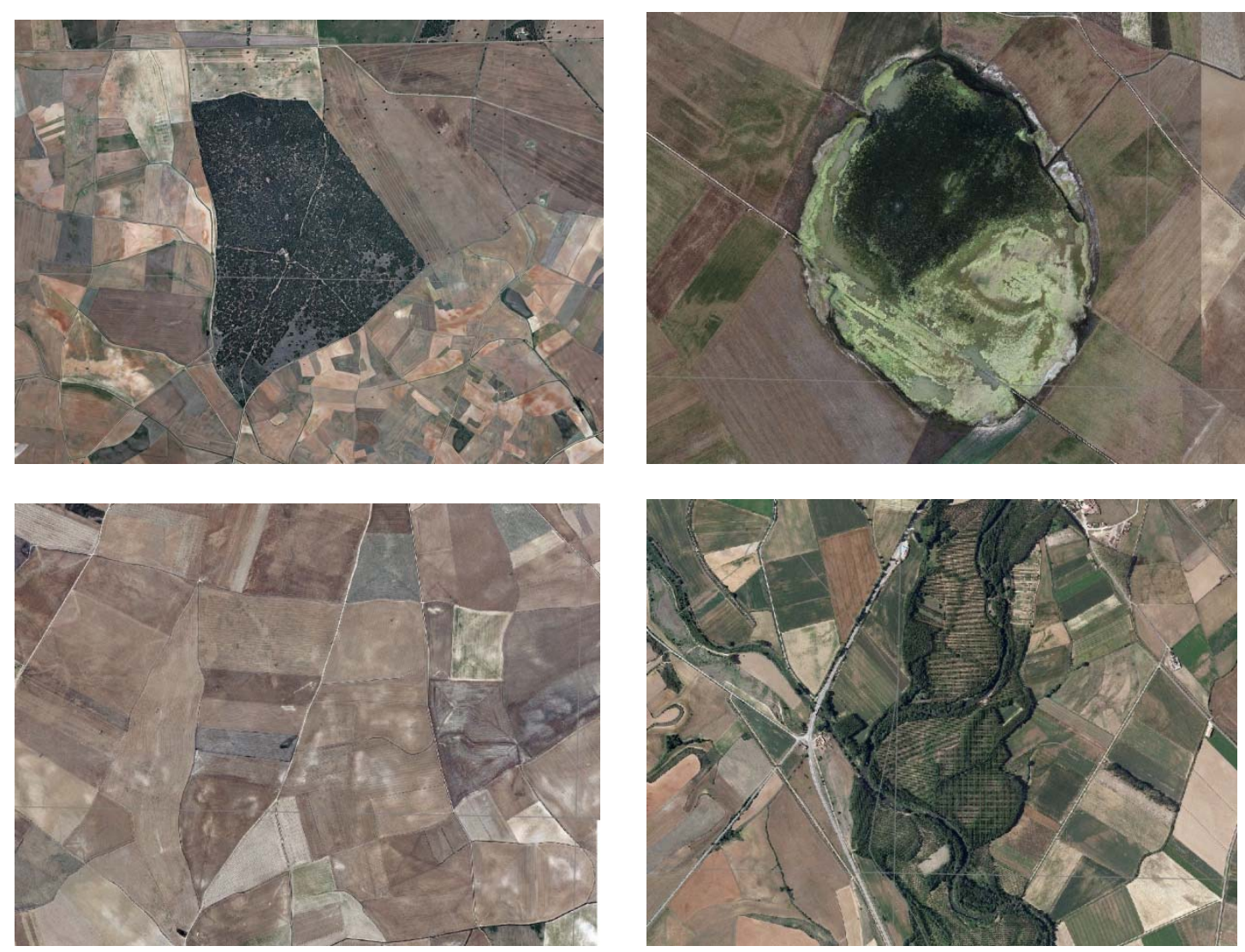

Figura 6.20. Ortofotografía superior izquierda, mancha de encinas en Becerril de Campos. Superior derecha, mancha como laguna en Boada de Campos. Inferior izquierda, matriz agrícola en Castromocho. Inferior derecha, corredores riparios en Villoldo. 
¿Cómo se podría compensar esta deficiente distribución? En primer lugar, se debe ser consciente de la dificultad de aumentar la superficie de las manchas en detrimento de la matriz agrícola; mientras sea económicamente rentable el mantenimiento de los cultivos herbáceos, estos se conservarán, entre otras cosas por la política agraria común y la tremenda inercia agrícola que poseen estas tierras. No en vano, la forestación de tierras agrícolas no ha tenido prácticamente incidencia en este paisaje. No obstante, la recuperación del paisaje podría incidir de forma muy positiva en el aumento de corredores: existen muchos kilómetros de riberas de pequeños arroyos y ríos desprovistos de vegetación, de márgenes de carreteras, autovías o ferrocarriles, de bordes de caminos agrícolas, de vías pecuarias, de canales de riego, etc. En casi todos estos casos, la anchura suele ser reducida, pero la longitud es muy elevada.

La superficie de las manchas muestra una clara correlación con la biodiversidad que puede albergar. Su forma también tiene una importancia primordial; en general, una actividad humana moderada favorece la diversificación de las formas; en cambio, una actividad humana intensa supone una simplificación de la variabilidad. En este sentido, cabe argüir que, en Tierra de Campos, la biodiversidad se encuentra básicamente en los escasos reductos formados por los pequeños montes de quercíneas existentes y los humedales.

Los corredores desempeñan un papel fundamental para permitir la interconexión entre las distintas manchas y reducir el denominado efecto distancia, que determina la presencia de un menor número de especies en los fragmentos más aislados. Estos elementos han de facilitar la conectividad, es decir, la capacidad de los organismos para desplazarse entre fragmentos o manchas separadas de un determinado tipo de hábitat.

\subsubsection{Conectividad del paisaje}

La conectividad del paisaje (también llamada conectividad ecológica) se puede definir como el grado en que éste facilita los flujos ecológicos (tales como el intercambio de individuos y genes) a través de las zonas de hábitat distribuidas a lo largo del territorio (Figura 6.21). La conectividad es considerada clave para fomentar la persistencia y variabilidad genética de las poblaciones de flora y fauna, contribuyendo a mitigar los efectos negativos de la fragmentación de los hábitats y a permitir la adaptación de las especies a los desplazamientos en sus áreas óptimas de distribución debidos al cambio climático y otros factores. Este concepto se ha desarrollado considerablemente en los últimos años, diseñándose diversas metodologías, índices y herramientas informáticas para su análisis (SAURA y TORNÉ, 2009). 

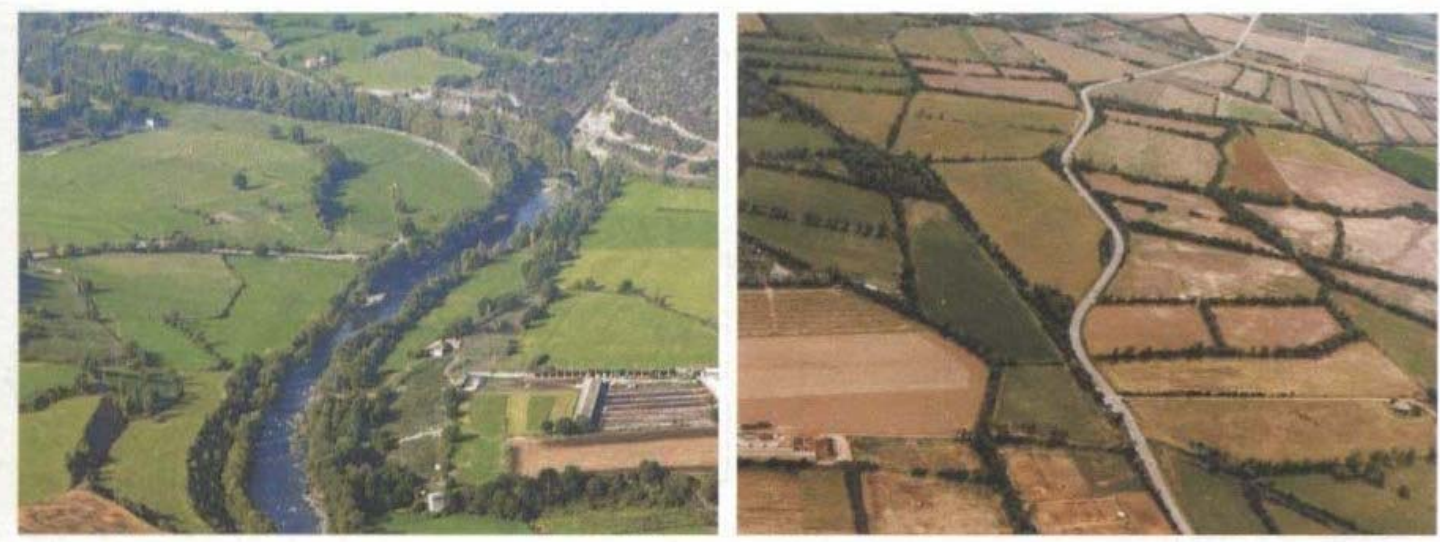

Figura 6.21. Ejemplos de conectores del paisaje: izquierda, curso fluvial; derecha, márgenes de cultivos con vegetación arbustiva (MMA, 2006). El caso de la izquierda podría darse en las riberas de los grandes ríos de Tierra de Campos, no así en ningún modo el de la derecha.

Un análisis más pormenorizado permite diferenciar hasta cinco funciones propias de los corredores (FORMAN, 1995). En primer lugar, la función de hábitat, que permite diferenciar entre corredores lineales (caracterizados por estar dominados por especies generalistas) y corredores de franja (que disponen de una dimensión suficiente para permitir la presencia de especies propias de hábitats más especializados). En el paisaje de campiñas de Tierra de Campos son los primeros los más abundantes, aunque tienen también importancia las franjas definidas por las laderas de transición a los páramos. En segundo lugar sigue la función de conducción, que es la que facilita el desplazamiento de elementos en su interior (animales, plantas, nutrientes, semillas, personas, agua, etc.); esta función está condicionada por la amplitud del corredor, su longitud o la presencia de discontinuidades. En Tierra de Campos, las riberas de los ríos principales (Cea, Carrión y Pisuerga) son los corredores más amplios, largos y continuos, que fundamentalmente conducen elementos ligados a medios hídricos; hay riberas de ríos intermedios que también poseen ciertos corredores de interés (Figura 6.22), aunque muchas otras han desaparecido casi totalmente. Lamentablemente, no hay corredores asociados a vegetación xerofítica autóctona mediterránea. La tercera función es la de filtro, al suponer una barrera absoluta para determinadas especies o elementos y parcial o inexistente para otras. Especial importancia en los medios agrícolas tienen las riberas, en cuanto que filtran los elementos que pueden contaminar las aguas de los ríos (fertilizantes, herbicidas, etc.). La cuarta función es la de fuente, al permitir la distribución y expansión de especies desde el corredor hasta la matriz. Aquí juega un papel fundamental la recuperación ambiental, teniendo en cuenta que puede generar "fuentes" desde donde manen especies hacia el "desierto" de la matriz agrícola. La quinta y última función es la de sumidero, que da refugio o absorbe especies y otros tipos de elementos procedentes de la matriz circundante. Su aplicación en el paisaje agrícola sería similar al de filtro, de modo que los corredores podrían absorber parte de los elementos perniciosos utilizados en la agricultura y ganadería intensiva (por ejemplo, los nitratos). 

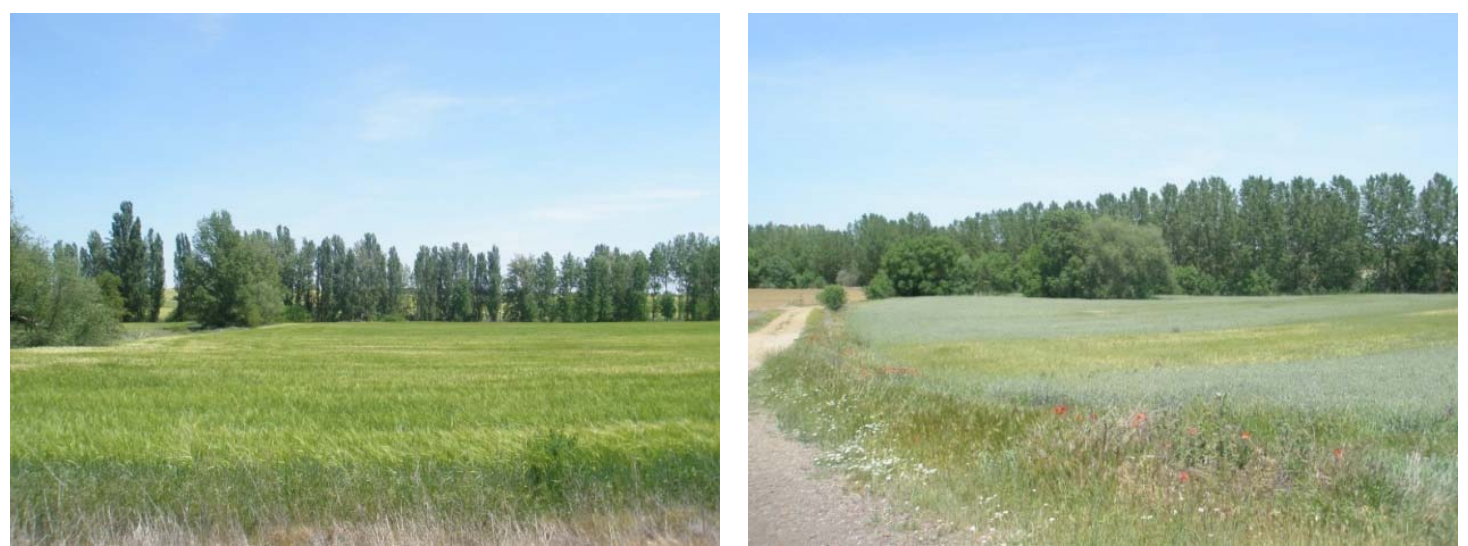

Figura 6.22. Ribera del río Templarios en Moratinos (izquierda) y ribera del río Cueza en Cervatos de la Cueza (derecha).

\subsubsection{Fragmentación del hábitat}

Otra de las variables fundamentales en ecología del paisaje es la fragmentación del hábitat, cuyas consecuencias inmediatas son el aumento del número de manchas, la disminución de su tamaño medio y el aumento de su aislamiento. La fragmentación suele ser consecuencia de la ejecución de infraestructuras lineales: carreteras, autovías, ferrocarriles, canales de riego, líneas eléctricas, etc. En Tierra de Campos las afecciones a las manchas no son tan evidentes, al ser estas escasas y de pequeño tamaño; aunque podrían ser críticas en el caso de alterar zonas húmedas o afectar a especies protegidas. Es paradigmático el ejemplo de la carretera local Fuentes de Nava-Mazariegos, que divide en dos la laguna de la Nava. El mayor problema radica en la fragmentación de la propia matriz agrícola, que pierde parte de sus cualidades en cuanto a hábitat de fauna esteparia. No olvidemos que el aprovechamiento cerealista tradicional ha constituido el hábitat de numerosas especies de aves esteparias y un ambiente muy propicio para las poblaciones de avutardas, lo que confiere al paisaje un alto valor ecológico.

\subsubsection{La percepción del paisaje ecológico}

En contra del tópico de la subjetividad absoluta de la valoración del paisaje que suele presidir muchos estudios del mismo, hay autores que consideran que "sobre gustos hay mucho escrito". Con este aserto, RUIZ y BENAYAS (1993) profundizan en la idea de la percepción del paisaje desde el ámbito de la ecología, en la línea de la definición dada por GONZÁLEZ BERNÁLDEZ (1981): "percepción multisensorial de un sistema de relaciones ecológicas", señalando entre otras cuestiones que la estética del paisaje se basaría en los mecanismos de selección de hábitat que prevalecieron en el pasado evolutivo de nuestra especie. En ellos habría que incluir influencias culturales recientes y específicas ante medios concretos con los que interaccionan poblaciones humanas. El hecho de que la estética del paisaje dependa en gran medida de un componente hereditario del ser humano también es defendido por APPLETON (1993), que sugiere que la percepción ambiental es la clave para el comportamiento de supervivencia y en ella juega un importante papel la visibilidad. Este autor destaca el valor que se da desde 
diferentes disciplinas -sobre todo, la pictórica- a los paisajes de perspectiva dominante, como las vastas llanuras cerealistas castellanas.

En esta línea de investigación sobre preferencias paisajísticas, LÓPEZ DE SANTIAGO (1993) expone la encuesta realizada a escala internacional a unos 4.900 sujetos entrevistados procedentes de muy diversos países, a los que se mostró pares de fotografías de 36 grupos de unidades paisajísticas a escala de biomas mundiales. Los tipos de paisaje más apreciados son aquellos que muestran cascadas, selva tropical, lagos cristalinos de montaña y ríos en bosques tropicales. Los menos apreciados son los desiertos con una vegetación poco desarrollada de xerófitos, escenas muy impactadas o intervenidas en el medio rural, marismas, gargantas y cañones y las zonas áridas y erosionadas. En valores intermedios se hallan los paisajes adehesados, los bosques y aquellos moderadamente intervenidos por actividades antrópicas, con cultivos y pastizales productivos y que presentan retazos de vegetación silvestre. Realizando una extrapolación de acuerdo con esta escala, el paisaje de campiñas cerealistas de Tierra de Campos se situaría en un nivel medio bajo, entendiendo que en él dominan los cultivos productivos sin práctica presencia de vegetación espontánea.

Curiosamente, estas aproximaciones científicas a la estética del paisaje desde la ecología, nos permiten deducir que realmente la línea divisoria entre paisaje ecológico y visual no es muy nítida. La calidad del paisaje visual suele ser coincidente con la del paisaje ecológico y, de igual modo, los impactos visuales suelen ser manifestaciones externas de impactos ecológicos.

\subsection{Deterioros del paisaje de Tierra de Campos}

De acuerdo con la línea argumental de GÓMEZ OREA y VILLARINO (2004), en la actualidad la actividad humana, con su enorme capacidad transformadora, manifiesta una fuerte tendencia a la agresión, a degradar aquello sobre lo que interviene, con una intensidad dependiente del valor preexistente y de la energía de la acción. En este apartado se van a diagnosticar los deterioros paisajísticos de la comarca, que servirán de base para definir los espacios degradados objeto de recuperación. Teniendo en cuenta la amplitud del cometido y su gran variabilidad, se han definido dos ámbitos: las grandes obras -analizadas desde una perspectiva territorial- y las pequeñas actuaciones -estudiadas desde una perspectiva local, ya que son más numerosas-. Los deterioros del paisaje de ambos ámbitos serán agrupados y sintetizados con objeto de tener una imagen conjunta.

Se hace constar que en este apartado no se pone en cuestión la necesidad o funcionalidad de ninguna de las obras o actuaciones que originan las degradaciones diagnosticadas. Todas ellas forman parte del paisaje y contribuyen a su caracterización; incluso algunas mejoran alguno de sus atributos. No obstante, es necesario focalizar el análisis en los impactos y efectos sobre el paisaje (la parte negativa) precisamente para poder diagnosticar el tratamiento de recuperación. 


\subsubsection{Impactos paisajísticos de grandes obras a escala comarcal}

Para la elaboración de este apartado se ha utilizado la información aportada por los proyectos incluidos en el anejo 1, que son representativos de obras que afectan al paisaje de Tierra de Campos y que han sido sometidos a algún procedimiento de prevención ambiental. Algunos de los tipos de proyectos también han tenido reflejo en los Recorridos paisajísticos del anejo 3. Complementariamente se extraen conclusiones de otros proyectos o actuaciones que se han realizado en la comarca y de los que se ha realizado algún tipo de seguimiento ambiental por el autor. En cada uno de los tipos de obras se realizará una pequeña descripción y un detalle sucinto de los principales impactos sobre el paisaje, considerándose exclusivamente los de la fase de funcionamiento o explotación.

\subsubsection{Concentraciones parcelarias}

De un modo similar a las leyes anteriores, la actual Ley 1/2014, de 19 de marzo, Agraria de Castilla y León, señala que la concentración parcelaria tiene como finalidad la ordenación de las fincas rústicas, en orden a promover la constitución y el mantenimiento de explotaciones agrarias de estructura y dimensiones adecuadas, que permitan su mejor aprovechamiento, incrementando la rentabilidad de la actividad. Su consecución requiere de un largo procedimiento técnico-administrativo, que comienza con un estudio técnico previo y culmina con un proyecto y acuerdo de concentración, mediante el que se redistribuye la propiedad de modo que se reduce el número de parcelas por propietario y se aumenta su tamaño.

Paralelamente se lleva a cabo un proyecto de obras, cuyas actuaciones prioritarias son la ejecución de una nueva red de caminos o el acondicionamiento de la existente y la rectificación y limpieza de los arroyos y desagües (Figura 6.23). Evidentemente, la forma de realizar las obras ha variado desde las décadas de los sesenta y setenta -en que se comienzan en Tierra de Campos- y las actuales, que ya son reconcentraciones la mayoría y cuentan con un plan de restauración.
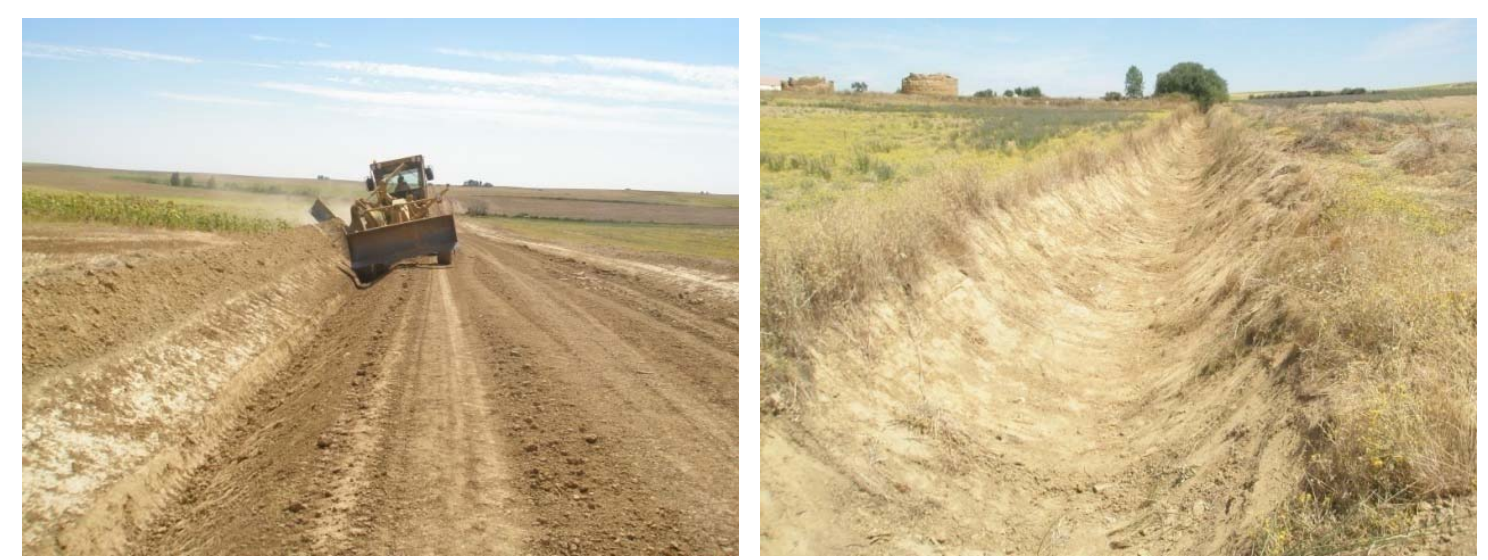

Figura 6.23. Obras de reconcentración parcelaria en Boadilla de Rioseco; a la izquierda, construcción de caminos; a la derecha, limpieza de arroyos. 
En cualquier caso, se trata de una actuación muy dura sobre el territorio, por la que ha pasado todo el territorio de Tierra de Campos y en la que destacamos los siguientes impactos sobre el paisaje:

- Eliminación de linderas arbustivas y arbóreas. La creación de grandes parcelas y el monocultivo cerealista hacen innecesarias las linderas de vegetación para los nuevos propietarios.

- Eliminación del arbolado situado en el interior de las parcelas, en caso de cambio de propietario, que no suele tener interés en su conservación. Esta fue seguramente también la causa del arranque de muchos majuelos y frutales: para los nuevos dueños no constituían el mismo valor.

- Reducción significativa de la longitud de regueras. Las que antaño delimitaban parcelas ahora quedan en el interior de otra mayor; el nuevo propietario las suele labrar, aun a riesgo de posteriores encharcamientos.

- Eliminación de la vegetación de los márgenes de caminos y arroyos, como consecuencia de las obras. Además, en caso de rectificaciones la vegetación queda en parcelas privadas, por lo que también es cortada con casi total probabilidad.

- Creación de caminos excesivamente rectilíneos (para dar lugar a parcelas geométricas), no adaptados a la orografía del terreno, que generan más movimientos de tierras y una pérdida de naturalidad.

- Encauzamiento y rectificación de arroyos y regatos, que también pierden su naturalidad y sus valores hidrológicos y ecológicos.

- Reducción de la anchura y rectificación de las vías pecuarias, que quedan confinadas a los caminos rurales, aunque se compense la superficie en parcelas sobrantes.

- Erosión en taludes de desmonte cuya altura sea elevada y su pendiente pronunciada. 

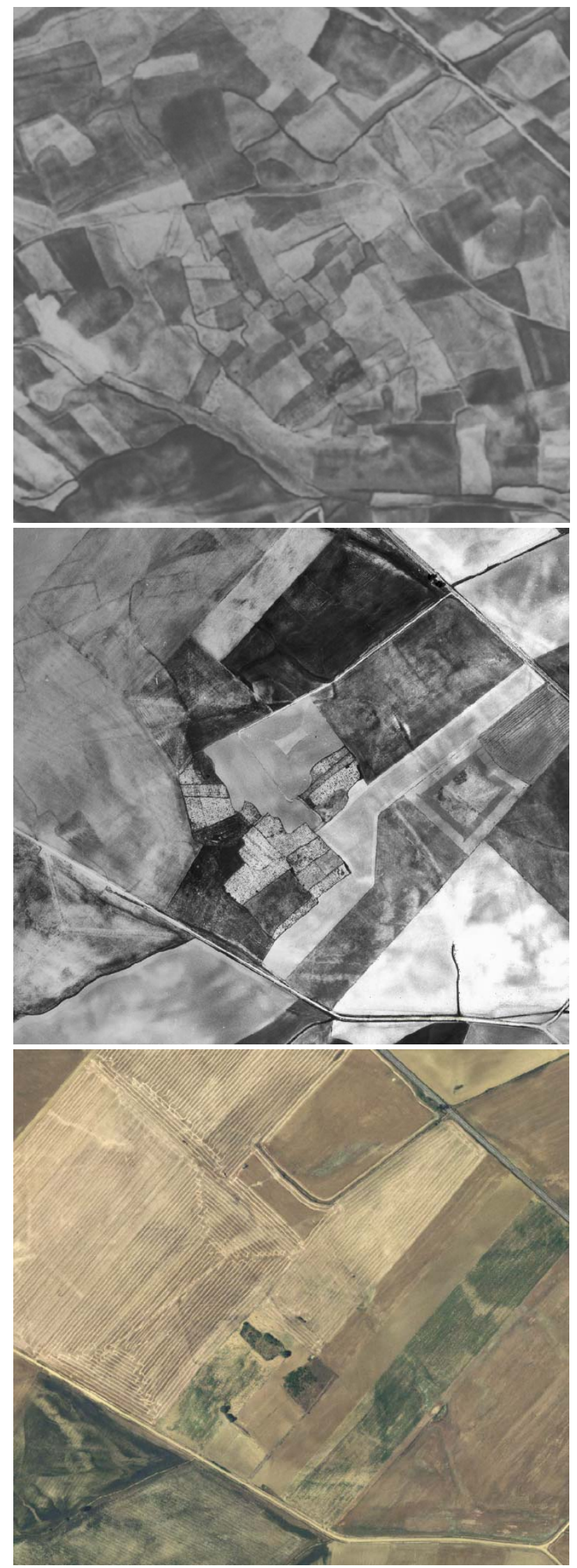

Figura 6.24. Intensísimas transformaciones producidas por dos concentraciones parcelarias en Villalón de Campos. La primera ortofotografía procede del vuelo americano de 1956, con el parcelario típico de la agricultura tradicional. En la segunda (del entorno de 1980) se perciben los efectos de la primera concentración. En la última ortofotografía de 2011 se aprecian los cambios producidos por la reciente segunda concentración parcelaria. 


\subsubsection{Transformaciones en regadío}

Los proyectos de regadío suelen ser posteriores en el tiempo a las concentraciones parcelarias, ya que el riego exige unos requerimientos más exigentes en cuento al tamaño y forma regular de las parcelas. Así como las concentraciones han afectado a toda la superficie de Tierra de Campos, las transformaciones de regadío tienen un ámbito considerablemente menor. Actualmente solo se riegan las vegas de los ríos Carrión y Pisuerga, algo de las del río Cea, los entornos del canal Macías Picavea, canal de Castilla, acequia de Palencia, canal del Pisuerga así como otros ámbitos puntuales. En proyecto están varios ligados al canal Cea-Carrión; en particular, el del sector IV es uno de los proyectos analizado en el anejo 1.

Los antiguos canales estaban construidos en tierra, aprovechando la naturaleza arcillosa de los suelos de Campos; en la actualidad se utiliza como material el hormigón. Evidentemente los requerimientos funcionales de mínima pendiente exigen un gran movimiento de tierras y un conjunto de infraestructuras hidráulicas asociadas muy complejas. Suelen contar con caminos paralelos de servicio.

Las balsas de regulación poseen tamaños proporcionales a la superficie regable. Los taludes interiores se suelen recubrir con lámina impermeable de polietileno o bien con piedra de escollera. Los exteriores en general se siembran con herbáceas. Poseen caminos de servicio, estación de bombeo, caseta de control, línea eléctrica, transformador y otras infraestructuras e instalaciones asociadas.

El proyecto de regadío en sí consta, en esencia, de la creación de una red de tuberías (ahora subterráneas), con válvulas, ventosas, tapones y desagües e hidrantes como puntos de toma de agua. En cada uno de estos últimos enganchará cada agricultor el equipo que considere oportuno, aunque últimamente es mayoritario el uso de pívots.
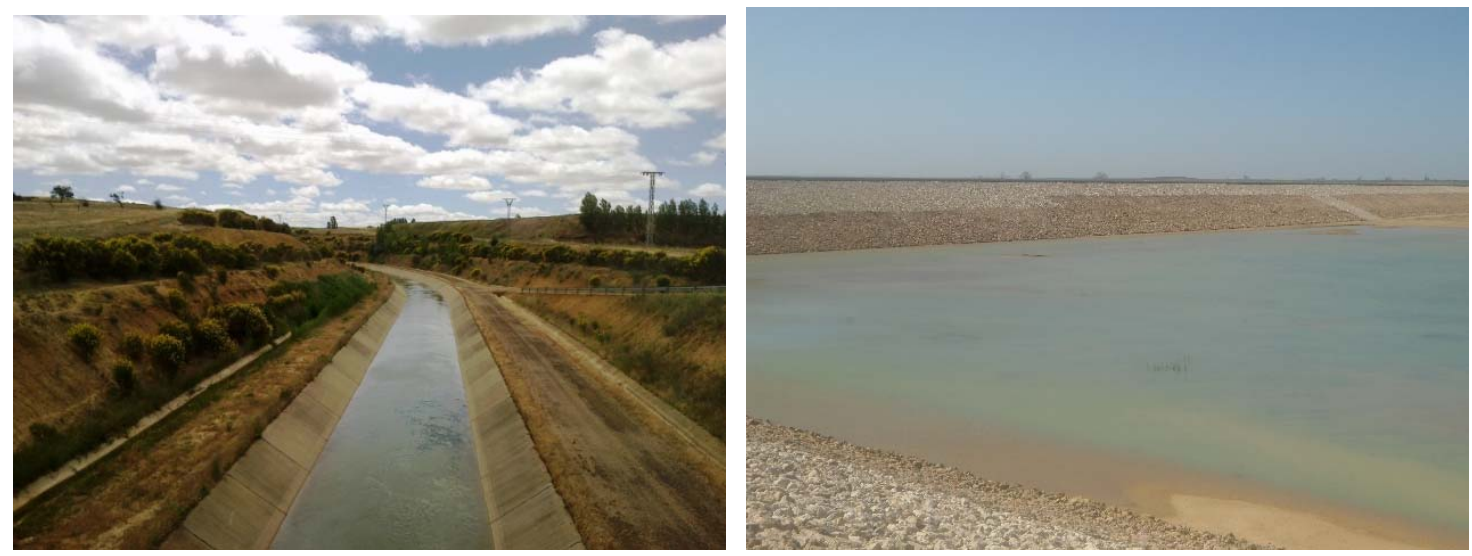

Figura 6.25. Izquierda, canal Cea-Carrión en Villacarralón; derecha, interior de la gran balsa de regadío en construcción en el sector IV.

En esencia, el impacto sobre el paisaje de Tierra de Campos de las transformaciones en regadío es positivo, ya que estas generan importantes superficies cuyos cultivos (maíz, girasol, alfalfa, etc.) aprovechan la estación estival para maximizar su crecimiento y que, por tanto, crean zonas 
verdes intercaladas en el árido secano ocre (Figura 6.26). Además, canales y balsas contienen sustanciales volúmenes de agua que, tal como se ha visto anteriormente, es uno de los principales elementos de un paisaje de calidad.
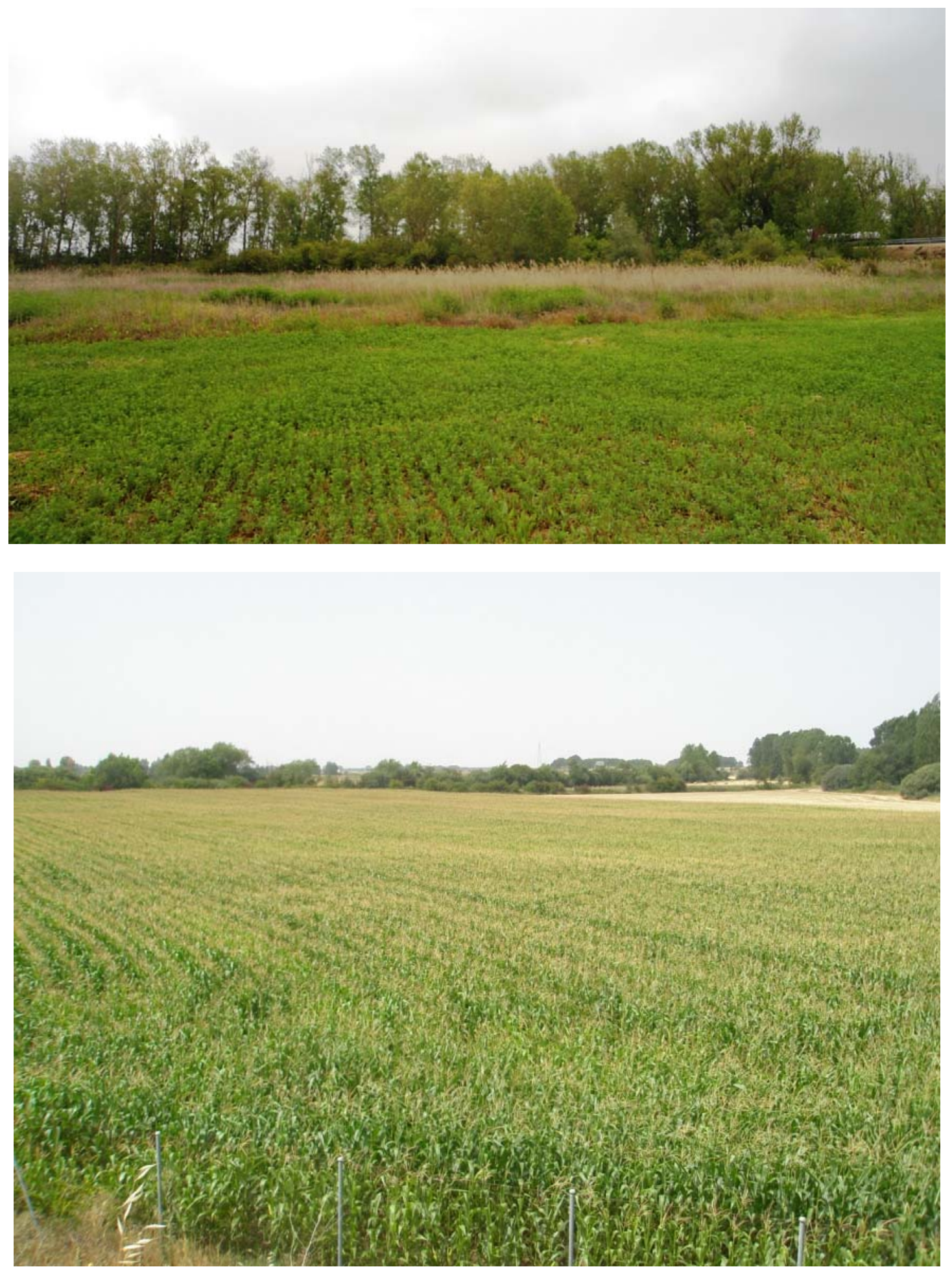

Figura 6.26. Arriba, en primer plano, alfalfa en una zona regable del Canal de Castilla en Villarramiel. Abajo, maizal en Carrión de los Condes en pleno agosto. 
Los principales impactos paisajísticos negativos son los siguientes:

- Generación de importantes desmontes y terraplenes, tanto en canales como en balsas. Los primeros, si su pendiente es excesiva, son muy difíciles de cubrir con vegetación, por lo que sufren intensos procesos erosivos.

- Impacto visual, en su caso, por la lámina de impermeabilización de polietileno negra, que es un elemento muy artificial. Es más difícil que esto ocurra cuando se emplea piedra de escollera, salvo que esta no sea de la zona.

- Si no tienen un diseño adecuado, las casetas de bombeo y de control pueden ocasionar un cierto impacto visual.

- Impacto generado por la presencia de líneas eléctricas y transformadores.

- La presencia de pívots para el riego de las parcelas supone un impacto visual debido a su envergadura, por la introducción de elementos extraños a la pauta general que caracteriza la escena.

\subsubsection{Explotaciones de ganadería intensiva}

En Tierra de Campos se ha desarrollado considerablemente la ganadería intensiva en las últimas décadas. Dominan las explotaciones de ganado ovino (Figura 6.27), pero también hay de vacuno, porcino y avícola. Actualmente todas se ubican en suelo rústico, con una determinada distancia al casco urbano, dependiendo de la actividad. En esencia constan de una o varias naves normalmente cerradas donde se alojan los animales y se localizan las instalaciones auxiliares (ordeñadoras o lechería, por ejemplo). La estructura puede diseñarse a base de pilares y cerchas metálicas o de hormigón; los paramentos pueden combinar zócalo de hormigón, ladrillos de termoarcilla o planchas sándwich metálicas, siendo la cubierta metálica o de fibrocemento. En el exterior se instalan las tolvas del grano, que suelen ser metálicas en su color, se ubica el estercolero y se almacenan las pacas de forraje y otros útiles. Todo el recinto está generalmente vallado con malla metálica.

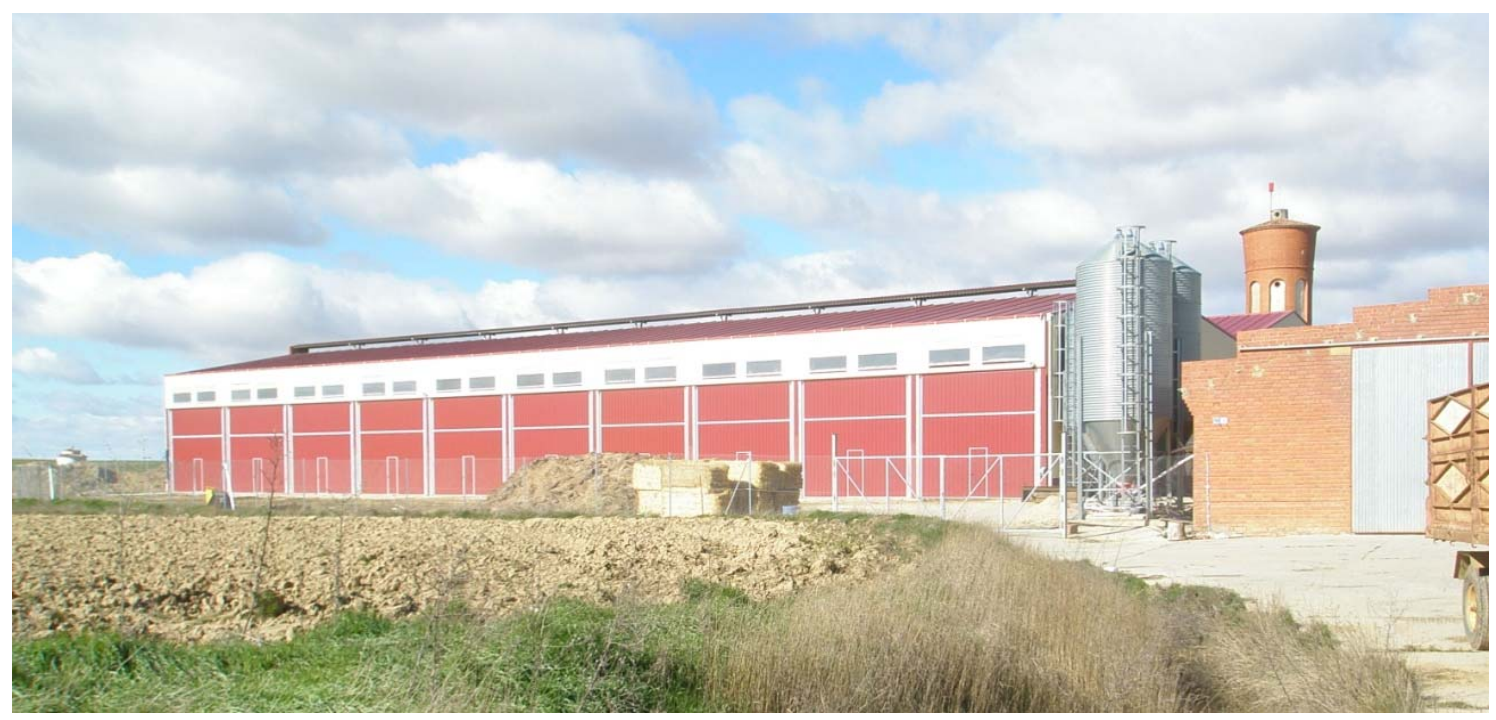

Figura 6.27. Granja de ovino en Cisneros. 
Los principales impactos sobre el paisaje generados por las explotaciones ganaderas intensivas son los siguientes:

- Impacto visual de las naves, teniendo en cuenta que suelen tener gran magnitud. En función de cómo sean sus acabados en paramentos y cubiertas, así será el cambio de las características visuales básicas; en los dos casos analizados las paredes son ocres y las cubiertas rojizas, que son los colores recomendados más integrados en el paisaje agrario. La cercanía al casco urbano también aumentaría este impacto, por intrusión visual de elementos y desaparición de la armonía.

- Otra de las percepciones afectadas por estas explotaciones es la olfativa. El estiércol utilizado para cama del ganado y el acumulado en los estercoleros provoca olores desagradables, que son mayores si la granja está próxima al núcleo urbano, si los vientos dominantes se dirigen a este y en la época estival. La distancia mínima exigida se encuentra en el entorno de $500 \mathrm{~m}$, encontrándose las dos explotaciones analizadas en el límite.

- El vallado metálico también genera un impacto visual debido a su artificialidad. Similar es el caso de los silos, sobre todo en los primeros años tras su colocación, dado que brillan notablemente.

- El posible desorden de la zona exterior a las granjas, la acumulación de materiales o maquinaria, o la presencia de residuos son factores que generan impacto sobre el paisaje.

\subsubsection{Infraestructuras lineales de transporte}

En este apartado consideramos las grandes infraestructuras lineales de transporte: líneas de ferrocarril, autovías y nuevas carreteras. La red convencional de carreteras será tratada en el apartado de degradaciones paisajísticas a escala inferior. Por Tierra de Campos atraviesa en su parte oriental la línea de alta velocidad (AVE) Palencia-León, que se encuentra en avanzado estado de ejecución. Existen tres autovías construidas: la A-6 Madrid-La Coruña (Oeste de la comarca), la A-231 Camino de Santiago (por el Norte, en dirección horizontal) y la A-67 Cantabria-Meseta (dirección Norte-Sur). Se han construido recientemente varias variantes de carretera, entre las que se encuentran la analizada Variante de Villada.

El primer documento técnico para tramitar estas infraestructuras es el estudio informativo, donde básicamente se definen las alternativas y se selecciona la más idónea; en esta fase se realiza la evaluación de impacto ambiental. Posteriormente, salvo que se redacte un anteproyecto, el documento más importante es el proyecto de construcción. La funcionalidad y seguridad son aspectos básicos en el diseño de estas grandes obras.

En estas infraestructuras la pieza fundamental es la traza, con una anchura variable. Para salvar las dificultades orográficas e hidrográficas, así como otras infraestructuras, se diseñan puentes, viaductos, pasos superiores e inferiores, marcos, obras de drenaje y otra serie de estructuras necesarias. Algunas de ellas pueden ser singulares desde un punto de vista de ingeniería civil, pudiendo mejorar la calidad del paisaje. Las correcciones hidrológicas (bajantes, bordillos, etc.) también son un capítulo importante en las vías. En los tramos en que la vía discurre en terraplén 
se suelen instalar biondas de protección. Es usual la construcción de caminos de servicio por ambos lados de la infraestructura, que suele estar vallada.

Autovías y carreteras generan espacios auxiliares o marginales como desmontes, terraplenes (Figura 6.28), enlaces, glorietas, márgenes, medianas, etc. Parte de ellas también se crean en las líneas de ferrocarril, donde destaca además de la obra civil toda una infraestructura eléctrica asociada.

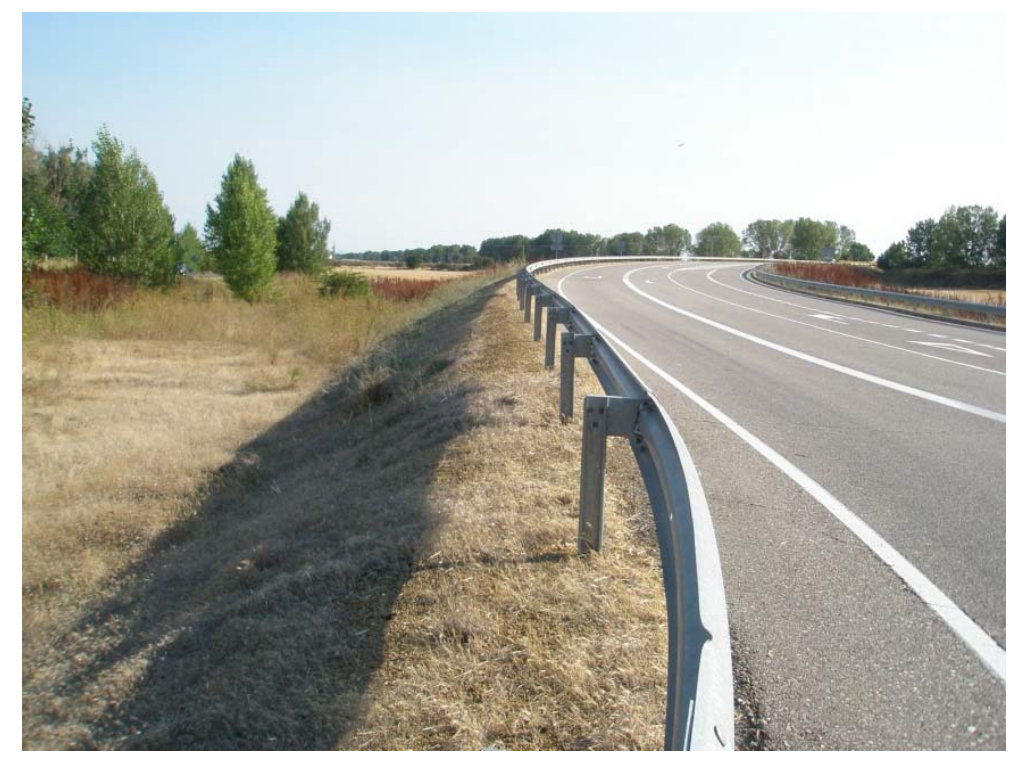

Figura 6.28. Vista de un tramo de la variante de Villada, que en este caso discurre en terraplén.

Las infraestructuras lineales de transporte juegan un doble papel en el paisaje: por un lado lo degradan en cuanto que afectan a una parte sustancial del territorio y, por otro, desde una perspectiva visual, constituyen itinerarios desde se pueden contemplar los paisajes.

Los impactos sobre el paisaje son bastante comunes para todas las infraestructuras de transporte. Obviamente, su magnitud depende de la entidad de la obra. También puede haber ciertas particularidades para cada una de ellas. A continuación apuntamos los fundamentales:

- Elevado movimiento de tierras debido a los exigentes requerimientos funcionales de escasa pendiente longitudinal, que conlleva una alteración severa de la morfología general del terreno.

- Generación de una sucesión de desmontes y terraplenes, de considerable altura. La pendiente de los terraplenes suele ser más suave y se restauran vegetalmente mejor que los desmontes, por lo que su impacto visual es mayor.

- En los taludes de desmonte de cierta altura (mayor de $3 \mathrm{~m}$ ) y pendiente elevada (más de $30^{\circ}$ ) se forman con rapidez regueros de erosión que con el tiempo pueden derivar en pequeñas cárcavas o desmoronamientos.

- Teniendo en cuenta la alta superficie afectada por las obras, es probable que se afecte a vegetación arbolada y arbustiva. 
- Todas las infraestructuras lineales -y estas en particular- ocasionan un fuerte efecto barrera sobre la fauna, sobre todo por el vallado, que puede originar la fragmentación del hábitat de determinadas especies.

- En las líneas de ferrocarril de alta velocidad se genera un impacto visual añadido por la infraestructura eléctrica asociada, como consecuencia de la introducción de elementos extraños.

- En algún tramo del AVE Palencia-León, una medida correctora para evitar el efecto barrera sobre la avutarda, como la instalación de paneles blancos en las vallas metálicas, ocasiona un impacto visual adicional.

\subsubsection{Explotaciones mineras, préstamos y vertederos}

La geología uniforme de Tierra de Campos hace que las explotaciones mineras propiamente dichas se encuentren muy centradas en el aprovechamiento de arcilla para plantas cerámicas. Ejemplos de canteras de cierto tamaño los encontramos en las cercanías del cerro del Otero en Palencia, en Monzón de Campos o en Piña de Campos. Antes era común la presencia de pequeñas canteras en muchos pueblos que tenían cerámicas tradicionales para la fabricación de ladrillos o tejas. Las áreas de transición con los páramos detríticos y las llanuras aluviales, en cambio, disponen de cantos rodados que pueden servir como explotaciones de áridos para la construcción.

En cualquier caso, la mayor parte de la superficie de extracción se debe a préstamos para las grandes infraestructuras de obra pública: carreteras, autovías, AVE (Figura 6.29), caminos de concentraciones parcelarias, etc. Si las infraestructuras deben ir en terraplén es necesaria la extracción de importantes volúmenes de tierra para elevar la cota. Por otra parte, la zahorra y otros firmes de las obras se obtienen de terrenos que tengan áridos de proporciones adecuadas para la capacidad portante requerida.

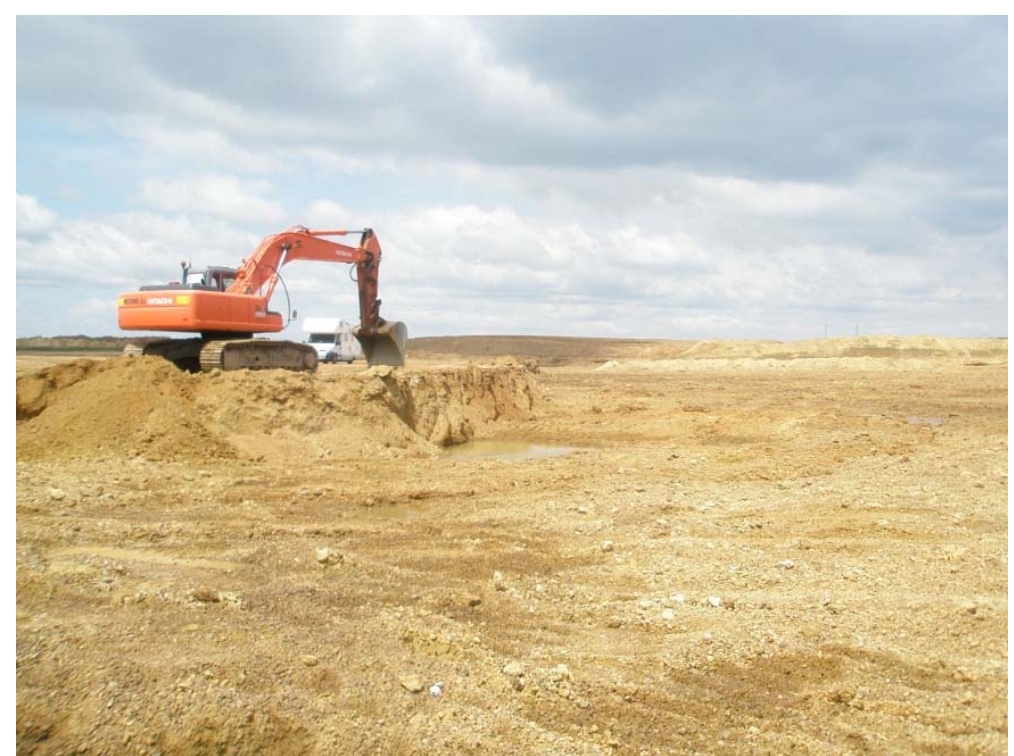

Figura 6.29. Préstamo en el tramo del AVE Palencia-León "Becerril-Valle del Retortillo". 
Cualquier explotación de este tipo afecta a una superficie importante; pensemos que un tramo de 15-20 kilómetros del ferrocarril de alta velocidad puede conllevar una superficie de préstamo de más de 100 ha. Una vez desmontada la capa de tierra vegetal (de unos $40 \mathrm{~cm}$ de espesor) comienza la extracción del material con retroexcavadoras de gran volumen de cazo, carga en camiones y transporte directamente a obra o a una planta de tratamiento. Si la profundidad es excesiva, se puede afectar a la capa freática, por lo que la plataforma se inunda de agua. En el perímetro se generan taludes finales, que dependiendo del grado de cumplimiento de las medidas preventivas ambientales, pueden ser más o menos tendidos.

Los vertederos de inertes son menos habituales, siendo en todo caso consecuencia de la existencia de un volumen sobrante de tierras en las grandes obras. Ambientalmente lo idóneo es depositar este volumen en los huecos creados anteriormente; si ello no es posible, se crean montículos o terraplenes.

Los principales impactos paisajísticos de estas obras son los siguientes:

- Alteración de una importante superficie de terreno, cuyo uso generalmente cambia.

- Modificación de la configuración morfológica original. En Tierra de Campos suele transformarse de llanuras onduladas a plataformas horizontales cortadas por los taludes (en el caso de los préstamos) o a pequeños cerros (en los vertederos).

- Posible alteración de la red hidrográfica, si se afecta al trazado de algún arroyo.

- Generación de taludes en el perímetro de las extracciones, que suelen tener una pendiente pronunciada. Si estos no se restauran con vegetación, se desarrollan procesos erosivos y una afección visual negativa; en el extremo, las canteras de arcilla suelen dejar unos taludes casi verticales. Los taludes de terraplén de los vertederos son en general más tendidos, aunque sobre ellos pueden aparecer los mismos efectos.

- Existe un riesgo importante de que, si las plataformas de extracción no tienen un uso posterior definido, estas se conviertan en zonas de depósito ilegal de residuos.

\subsubsection{Líneas eléctricas de alta tensión}

Las líneas eléctricas son las instalaciones que tienen como función el transporte de la energía eléctrica desde los puntos de generación a los puntos de consumo. Pueden ser de baja tensión $(<1 \mathrm{kV})$ o de alta tensión ( $>1 \mathrm{kV})$. Dentro de las segundas, las de 2 a y 3 a categoría alcanzan hasta $66 \mathrm{kV}$, que son las líneas de distribución entre los núcleos de población. Las de 1a categoría son grandes infraestructuras que transportan la energía eléctrica producida en una central generadora, o la distribuyen entre subestaciones, siempre a unos voltajes muy altos $(132,220$, $440 \mathrm{kV}$ ) para que las pérdidas sean reducidas. Tierra de Campos es una comarca de paso, por lo que buena parte de este tipo de líneas eléctricas corresponde a líneas de transporte de Red Eléctrica de España, de $440 \mathrm{kV}$, entre grandes subestaciones eléctricas como La Mudarra o Grijota. Existen también proyectos, como el contemplado en el anejo 1, de evacuación de la energía producida en parques eólicos, con un voltaje de 220 kV.

Las líneas eléctricas cuentan con cuatro elementos principales: apoyo, conductores, aisladores y herrajes. Los apoyos de las grandes líneas son de celosía, de diferentes tipologías y alturas 
comprendidas entre los 25 y $50 \mathrm{~m}$ (Figura 6.30). Los apoyos de las pequeñas pueden ser también de hormigón y su altura oscila entre los 10-15 m.

La subestación eléctrica es el conjunto formado por paramenta y edificios, necesario para realizar alguna de estas funciones: transformación de la tensión, frecuencia, número de fases, rectificación, compensación factor de potencia y conexión de dos o más circuitos. Las subestaciones transforman entre el umbral de alta tensión, mientras que los centros de transformación reducen de alta a baja tensión (HERRERO, 2004).

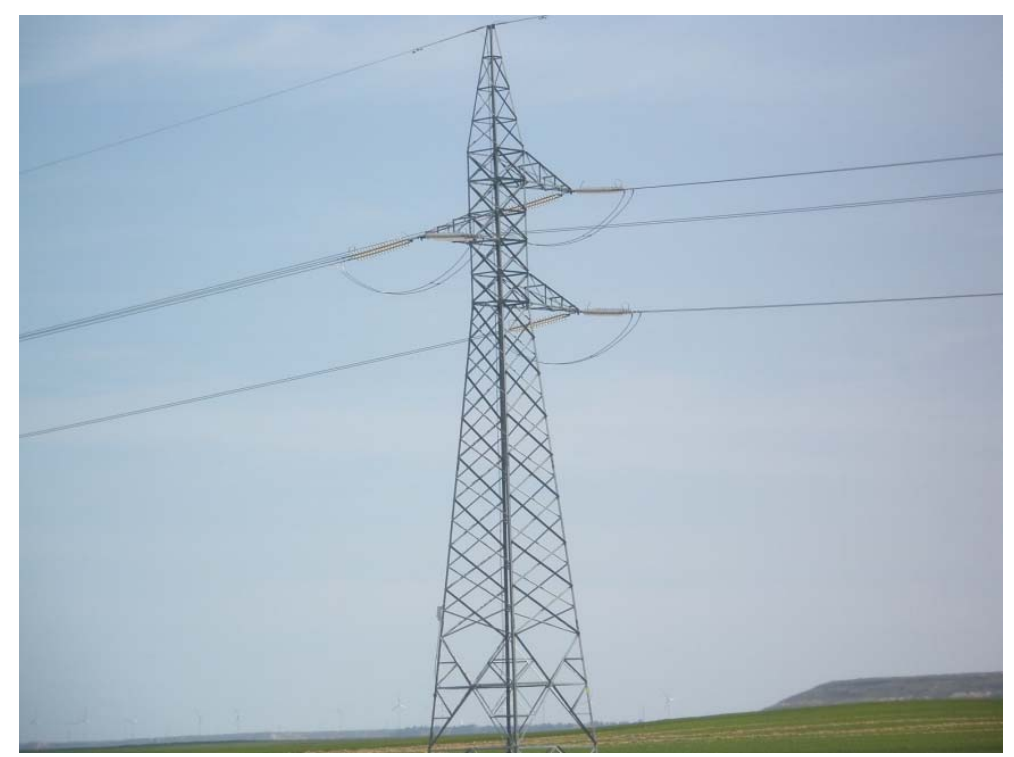

Figura 6.30. Imagen de un apoyo de la línea de alta tensión Ampudia-Grijota.

Documentalmente, la instalación de una línea eléctrica de alta tensión de 1a categoría suele conllevar la redacción de un anteproyecto con varias alternativas y una solución elegida, que se somete al trámite ambiental que corresponda. Los impactos paisajísticos más comunes son los siguientes:

- Impacto visual debido a la introducción de elementos extraños en la escena de gran envergadura. Los apoyos generan una clara dominancia visual sobre cualquier otro elemento del paisaje. El grado del efecto dependerá de la situación del apoyo: será mayor sin duda si la visión recorta contra el cielo (caso de líneas que discurran por el borde de los páramos o cercanas a las carreteras); en otros casos que recorte sobre el terreno el impacto se amortigua. De igual modo, si la línea tiene un deficiente trazado, puede haber apoyos que constituyan una intrusión visual sobre elementos singulares, como pueblos, torres de iglesias o ermitas.

- Fragmentación del hábitat por los riesgos de colisión de avifauna con el cable de tierra, que tiene menor diámetro y, por consiguiente, es menos visible. Particularmente grave es este efecto en la comarca para las grandes aves esteparias, como la avutarda, que tienen un lento comportamiento de vuelo. Los riesgos por electrocución son mínimos 
actualmente porque es adecuado el diseño de crucetas, aislamientos y distancia entre conductores.

- Pueden existir otros efectos menores dependiendo de la ubicación de los apoyos, como alteración morfológica (si están en pendiente) o afectación a vegetación.

- El significado visual de las líneas de alta tensión también puede influir en la percepción de la población sobre posibles riesgos de salud y seguridad (ESCRIBANO, 2011; LÓPEZRODRÍGUEZ y ESCRIBANO, 2013).

- Las subestaciones eléctricas y, en menor medida, los centros de transformación también ocasionan un importante impacto visual, debido a la artificialidad del conjunto.

\subsubsection{Parques eólicos}

Un parque eólico es una central que genera energía eléctrica a través del aprovechamiento de la fuerza del viento. Su principal elemento son los aerogeneradores, que constan de una torre troncocónica, una góndola y palas que giran como consecuencia del viento. La altura de la torre depende de la potencia; como referencia, 60-70 m para los de 1,5 MW. Con el diámetro de las palas ocurre lo mismo: $60 \mathrm{~m}$ aproximadamente para dicha potencia. Los acabados son metálicos en tono blanco-gris mate. Como el desarrollo tecnológico de esta energía ha sido muy alto en los últimos años, la potencia unitaria de los aerogeneradores ha evolucionado de igual manera: de los 0,85 MW iniciales a los 2,5 MW que se están promoviendo actualmente.

Los aerogeneradores producen la energía eléctrica a una tensión de $690 \mathrm{~V}$, que pasa a $20 \mathrm{kV}$ en un transformador situado en la base de la torre. Mediante líneas subterráneas colectoras, la energía generada es enviada a la subestación del parque, que transforma de nuevo la tensión a la de evacuación por las líneas eléctricas, que puede ser 66, 132, 330 o 400 kV. También se construye un centro de control, edificio donde se recoge toda la información del funcionamiento de los aerogeneradores (HERRERO, 2004).

La obra civil es importante en este tipo de proyectos. En primer lugar la excavación y construcción de grandes zapatas de hormigón armado para los aerogeneradores. En segundo lugar, la excavación de zanjas para las líneas de interconexión de los aerogeneradores y de estos con la subestación. Finalmente es necesaria la creación o adecuación de una red de accesos tanto para la obra como para la explotación, que se basa en caminos bien afirmados con zahorra.

El procedimiento administrativo de autorización de un parque eólico es bastante complejo. Los documentos técnicos más importantes son el anteproyecto (que se somete a evaluación de impacto ambiental) y el proyecto de construcción.

En Tierra de Campos la construcción de parques eólicos ha estado restringida a la periferia: a los páramos calizos (Torozos) por el Sur (Figura 6.31) y a la transición con los detríticos por el Norte (entorno de Sahagún), espacios de mayor altitud y donde el aprovechamiento del viento es viable. En el interior de la comarca hay algún ejemplo de parque eólico en funcionamiento en cerros o páramos testigo, como el entorno de Palencia, Becerril de Campos o Villanueva del Rebollar. 


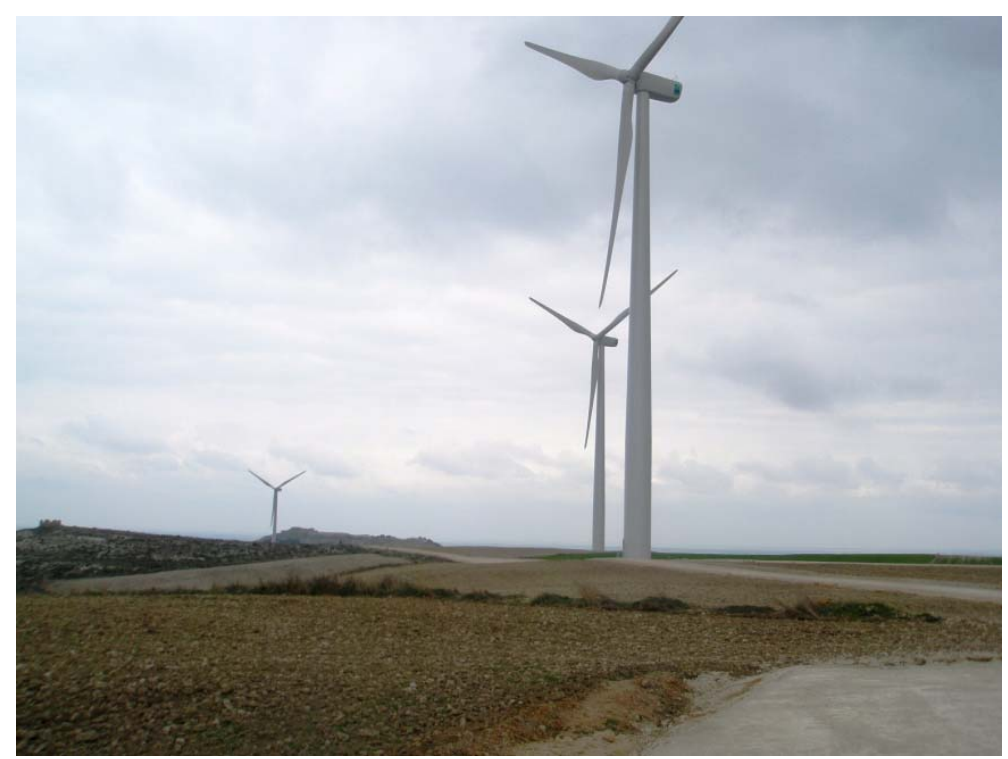

Figura 6.31. Parque eólico El Castre, en Torremormojón.

Los principales impactos paisajísticos de los parques eólicos son:

- Impacto visual severo, debido a la envergadura de los aerogeneradores. Las cuencas visuales son inmensas; los parques pueden ser vistos de forma nítida desde una distancia de $20 \mathrm{~km}$. Se trata de un elemento dominante, artificial y extraño a la pauta general de la escena, bien es cierto que el tiempo y la asociación a energía limpia y renovable provocan una cierta comprensión en el espectador. En caso de cercanía a núcleos de población o elementos singulares (castillos, ermitas) se producen efectos de intrusión visual. Es muy importante el efecto acumulativo y sinérgico con otros parques eólicos, que determina una capacidad de acogida o un límite de saturación de un determinado territorio. El color blanco-gris mate juega a su favor, ya que los aerogeneradores se integran en mayor medida en el fondo escénico, sobre todo en días nublados. Por la noche también existe un impacto significativo, mayor en el caso de luz blanca con destellos y si no hay coordinación entre los aerogeneradores.

- Impacto visual de las líneas eléctricas de evacuación y de la subestación eléctrica, relatado en su apartado específico, así como del edificio de control.

- Impacto visual de la red de accesos, sobre todo si están construidos a media ladera, donde se generan más desmontes y terraplenes.

- Efecto ecológico barrera sobre la avifauna, en particular la de gran envergadura (buitres, rapaces, avutardas, etc.) que puede chocar con las aspas. En los informes de vigilancia ambiental se constata que hay pérdidas constantes de individuos en muchos parques eólicos, pudiendo concentrarse en determinados aerogeneradores situados en rutas más querenciosas.

- Efecto barrera de las líneas eléctricas de evacuación, que en conjunto con el anterior pueden ocasionar una cierta fragmentación del hábitat, sobre todo en caso de grandes alineaciones. 
- En determinadas ocasiones pueden generarse impactos sobre otros elementos del paisaje, como vegetación, patrimonio, montes de utilidad pública, vías pecuarias, etc.

\subsubsection{Urbanizaciones residenciales y polígonos industriales}

Evidentemente, no se trata de una obra común en Tierra de Campos. Tanto en uno u otro caso, se circunscribe a las grandes poblaciones de la comarca: Villalpando, Valderas, Medina de Rioseco, Mayorga, Villalón de Campos, Paredes de Nava, Carrión de los Condes, etc. o a otras situadas en las proximidades de Palencia, como Grijota.

Las urbanizaciones desarrollan sectores de suelo clasificados como urbanizables o urbanos no consolidados (de uso residencial o industrial), mediante planes parciales o estudios de detalle. Una determinada superficie se diseña en un espacio edificable, viales y aparcamientos, zona de equipamiento y espacios libre públicos, con unos porcentajes fijados en la legislación urbanística. En la mayoría de los casos se ubican en las zonas aledañas al casco urbano consolidado, aunque puede haber situaciones de desorden urbanístico como el caso de Grijota, donde muchas urbanizaciones residenciales distan varios kilómetros del centro del pueblo.

Los planes parciales o instrumentos de planeamiento de ordenación detallada -que son los documentos que se someten al procedimiento de evaluación de impacto ambiental- establecen las condiciones de la edificación y las bases del posterior proyecto de urbanización. En este se desarrolla la construcción de los viales y las redes de abastecimiento, saneamiento, eléctricas, de telecomunicaciones y otros tipos. 

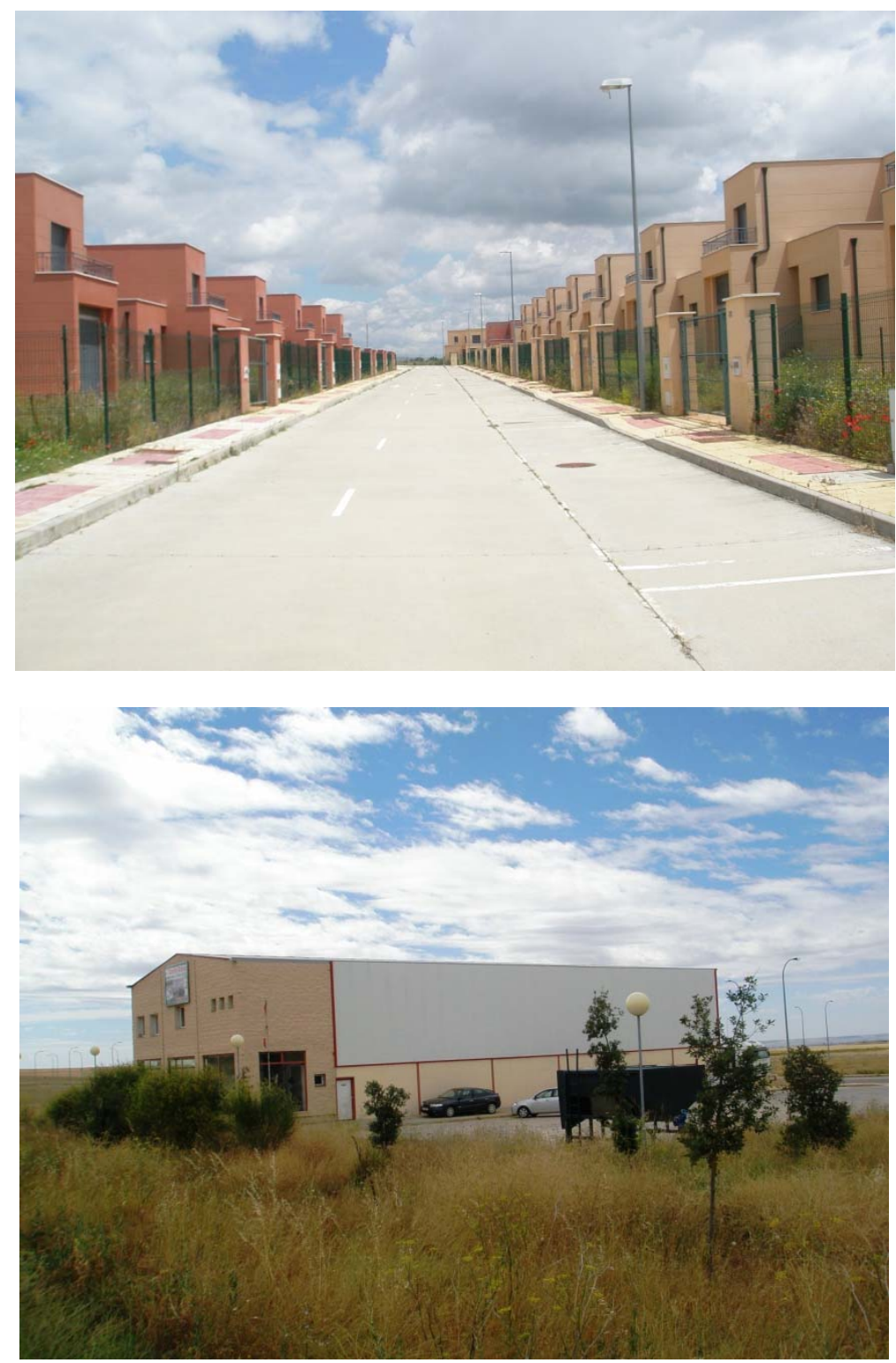

Figura 6.32. Arriba, urbanización residencial en Grijota, donde se puede apreciar un vial principal y las viviendas. Abajo, polígono industrial en Paredes de Nava; en primer plano, los espacios ajardinados y al fondo una de las primeras naves edificadas.

Los principales impactos sobre el paisaje de las urbanizaciones son los siguientes:

- Impacto visual provocado por las naves industriales, que suelen ser voluminosas y tener acabados estridentes. A ello se le añaden otros elementos artificiales característicos de estas zonas: carteles, depósitos, contenedores, etc.

- Ocupación de superficies de terreno que, en función de sus valores originales, ocasionará los consiguientes efectos sobre el paisaje.

- Impacto sobre el territorio en caso de que las urbanizaciones no sean colindantes con el casco urbano: se trata de desarrollos que no son sostenibles y que acrecientan los impactos ambientales, entre ellos el paisajístico. 
- En las urbanizaciones residenciales hay situaciones en que el diseño de las viviendas no es respetuoso con la arquitectura tradicional y el paisaje de la comarca. No se trata de construir como antes, pero sí de respetar en cierto modo las tipologías edificatorias características, los acabados, los colores, etc. También se afecta al paisaje urbano cuando existe desconexión entre la trama urbana existente y la nueva urbanización (esta se considera aislada y no integrada en el conjunto).

- Si el ajardinamiento de los espacios libres públicos no se realiza a la vez que la urbanización, se crean zonas marginales susceptibles del depósito incontrolado de residuos, crecimiento espontáneo de vegetación u otras situaciones generadoras de impacto sobre el paisaje.

\subsubsection{Degradaciones paisajísticas a escala municipal}

Uno de los apartados de cada ficha de los 34 Recorridos paisajísticos en Villalón de Campos (anejo 3) recoge las degradaciones del paisaje. Recordemos que se trata de itinerarios por buena parte de su término municipal (se puede estimar que se barre aproximadamente el $75 \%$ de su superficie), incluyéndose una muestra de sus espacios urbanos y periurbanos. Con ello se trata, en este caso, de valorar los deterioros paisajísticos a pequeña y mediana escala (los de gran escala se encuentran en el anejo 1), que por otro lado son los más numerosos (Tabla 6.3). Se considera que estas degradaciones son muy representativas del paisaje de Tierra de Campos. En una columna se indica las veces que la degradación ha sido citada en los 34 Recorridos. La mayor virtualidad de esta metodología reside en la detección de los deterioros paisajísticos, así como en la estimación de órdenes de magnitud que pueden servir para establecer comparaciones, aunque con ciertas cautelas.

Tabla 6.3. Degradaciones paisajísticas de los Recorridos en Villalón de Campos.

\begin{tabular}{lcc}
\hline \multicolumn{1}{c}{ DEGRADACIÓN PAISAJíSTICA } & IMPACTO & CITAS \\
\hline Residuos puntuales en márgenes y cunetas & moderado & 21 \\
\hline Arroyos encauzados y rectificados, sin naturalidad & severo & 16 \\
\hline Caminos excesivamente rectilíneos, sin naturalidad & severo & 15 \\
\hline Líneas eléctricas, subestaciones y transformadores & moderado/severo & 10 \\
\hline $\begin{array}{l}\text { Pérdida de patrimonio y tipología arquitectónica } \\
\text { tradicional }\end{array}$ & crítico & 6 \\
\hline Edificaciones urbanas con acabados no adecuados & moderado & 6 \\
\hline Proliferación de vallados metálicos & moderado & 5 \\
\hline Carreteras totalmente rectilíneas, sin vegetación & severo & 6 \\
\hline Eliminación reciente de vegetación arbolada o arbustiva & severo/crítico & 4 \\
\hline Desmoronamientos puntuales en taludes & moderado & 3 \\
\hline Naves de gran volumen y colores discordantes & moderado/severo & 3 \\
\hline Puertas traseras impactantes & moderado & 3 \\
\hline Explotaciones ganaderas en suelo urbano & severo & 3 \\
\hline Solares urbanos sin delimitar con muro & moderado & 3 \\
\hline
\end{tabular}




\begin{tabular}{lcc}
\hline \multicolumn{1}{c}{ DEGRADACIÓN PAISAJÍSTICA } & IMPACTO & CITAS \\
\hline Desorden urbanístico en espacios periurbanos & severo & 3 \\
\hline Plantas de tratamiento & severo & 3 \\
\hline Eliminación vegetación en márgenes de carreteras & moderado & 3 \\
\hline Naves en suelo urbano & severo & 2 \\
\hline Ruina de casas antiguas & severo & 2 \\
\hline Intrusión vías pecuarias u otras propiedades públicas & moderado & 2 \\
\hline Antenas de telefonía móvil & severo & 2 \\
\hline Silo de trigo & severo & 1 \\
\hline Escombrera municipal & severo & 1 \\
\hline Antigua extracción sin restaurar & moderado & 1 \\
\hline Desecación fuente del campo & severo & 1 \\
\hline Desorden del cableado en zona urbana & severo & 1 \\
\hline Pavimentación urbana en estado deficiente & moderado & 1 \\
\hline Espacios libres públicos sin ajardinar & moderado & 1 \\
\hline Proliferación de carteles publicitarios & moderado & 1 \\
\hline Polígono industrial discordante & severo & 1 \\
\hline Delimitación huerta con materiales discordantes & moderado & 1 \\
\hline Ausencia de criterios estéticos en casco histórico & severo & 1 \\
\hline
\end{tabular}

Del análisis de esta tabla se observa que se detectan un total de 32 degradaciones en el paisaje, con una gran variabilidad, que pasamos a describir según nos encontremos en el espacio agrícola, periurbano o urbano:

\section{Espacio agrícola}

Residuos puntuales en márgenes y cunetas. Se trata del deterioro más citado (en un $62 \%$ de los recorridos) que, aun siendo de impacto moderado, indica la generalización por toda la superficie de esta mala práctica ambiental. También se detecta en los espacios periurbanos. Casos tipo son el pequeño montón de escombros en la cuneta de un camino (Figura 6.33) o las botellas de plástico esparcidas por la cuneta de una carretera. El problema de esta degradación es que, aunque en volumen no sea muy cuantiosa, se encuentra repartida por las vías de comunicación donde se camina o se va en bicicleta. 


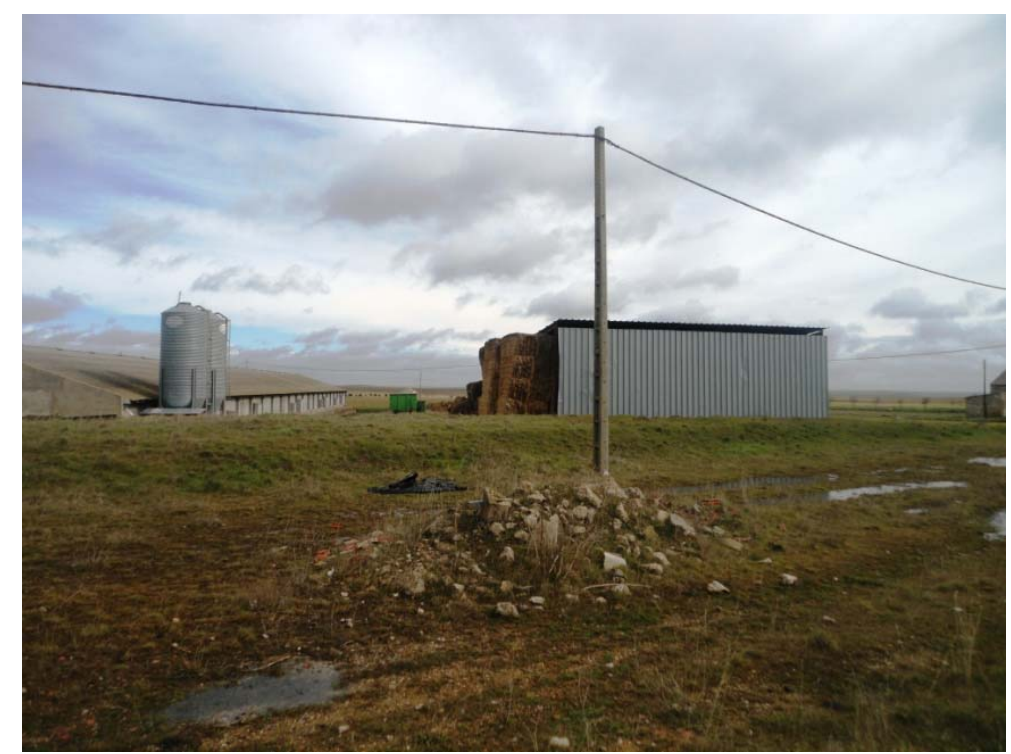

Figura 6.33. Montón de escombros en el margen de la carretera nacional $\mathrm{N}$ 610.

Arroyos encauzados y rectificados, sin naturalidad. Esta degradación se cita en 16 de los recorridos, aunque abarca al $100 \%$ de los realizados en el espacio agrícola. Su impacto es severo y se deriva de las rectificaciones y encauzamientos que tuvieron lugar en la primera concentración parcelaria, que dieron lugar a una red hidrográfica muy regular, sin naturalidad hidrológica y con total ausencia de vegetación (Figura 6.34).

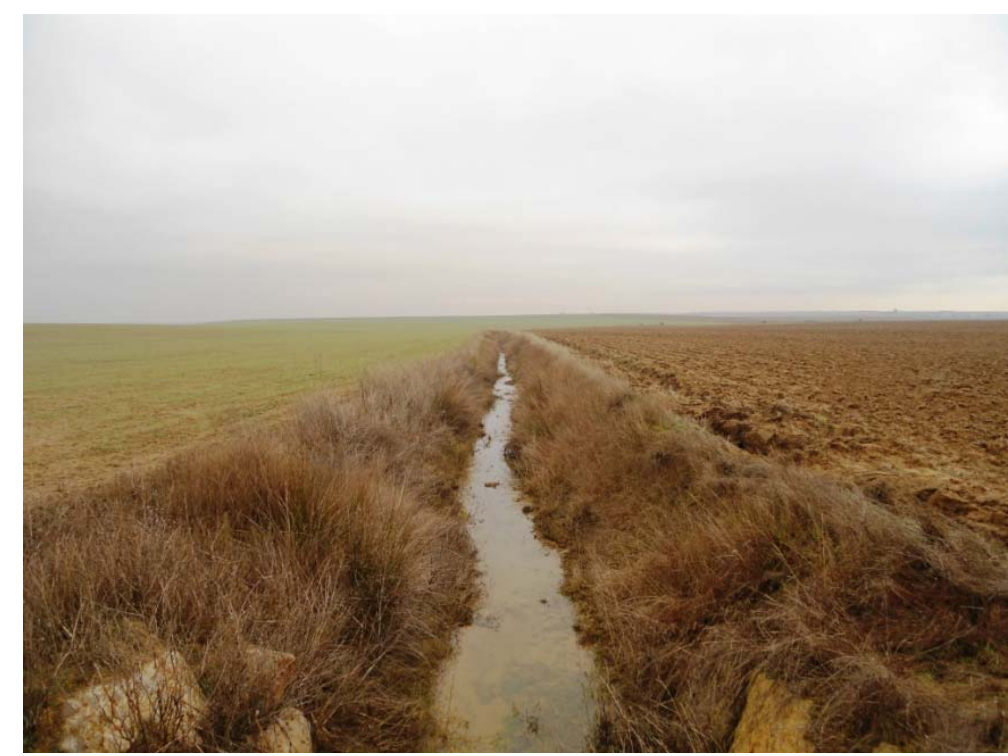

Figura 6.34. Vista de un arroyo/reguera típico de Tierra de Campos, totalmente rectilíneo y sin vegetación en los márgenes. Recorrido paisajístico 20 "Trinchas, balsa, Villacilda". 
Caminos excesivamente rectilíneos, sin naturalidad. El resultado es similar al anterior: 15 de los 34 recorridos, pero la inmensa mayoría de los realizados en el campo. Los únicos caminos que se salvarían de este impacto severo son los conformados sobre alguna vía pecuaria cuya traza se mantuvo. Los caminos rectos no se adaptan a la fisiografía natural del terreno, generan desmontes y regularizan en exceso el territorio (Figura 6.35). La severidad del impacto se debe, tanto en este caso como en el anterior, a la extensión del mismo ya que abarca a todo el territorio agrícola.

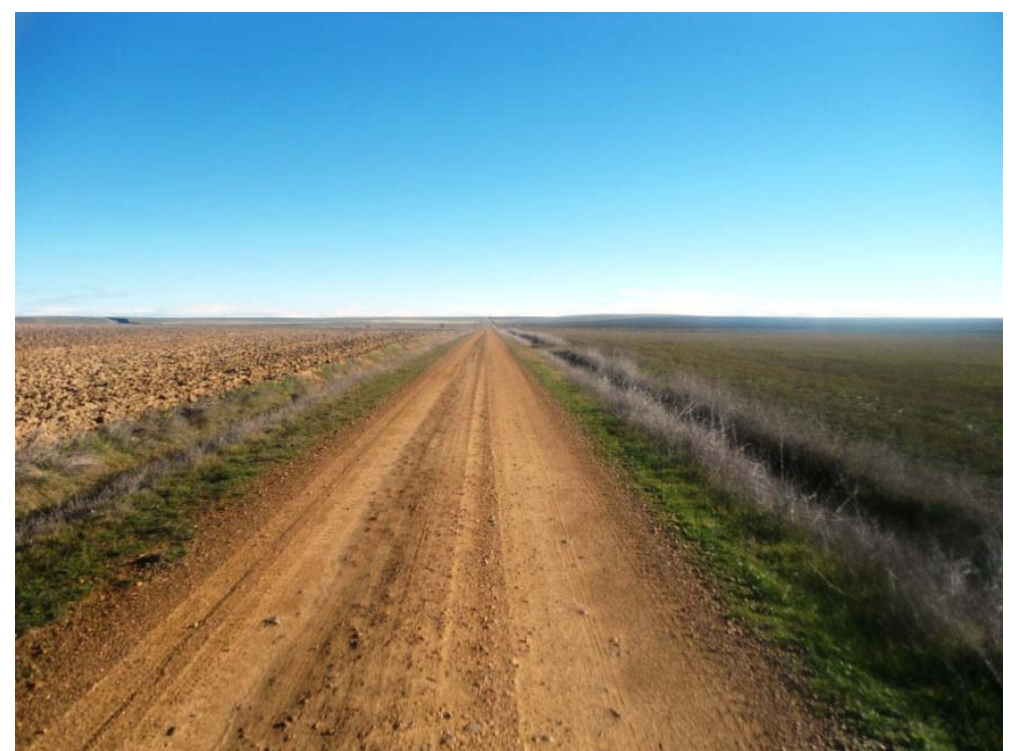

Figura 6.35. Los caminos rectos como este -de Villalón de Campos a Herrín de Campos- son una constante en Tierra de Campos; ni una brizna de vegetación en sus márgenes.

Líneas eléctricas de menor voltaje, subestaciones y transformadores. Estas infraestructuras energéticas también generan unos impactos significativos (Figura 6.36), aunque a esta escala dominan las de 20-30 kV, cuya envergadura es relativamente reducida. Aunque en la mayoría de los casos su impacto es moderado, la proliferación de las mismas o su intrusión en elementos singulares aumenta su afección hasta hacerla severa. 


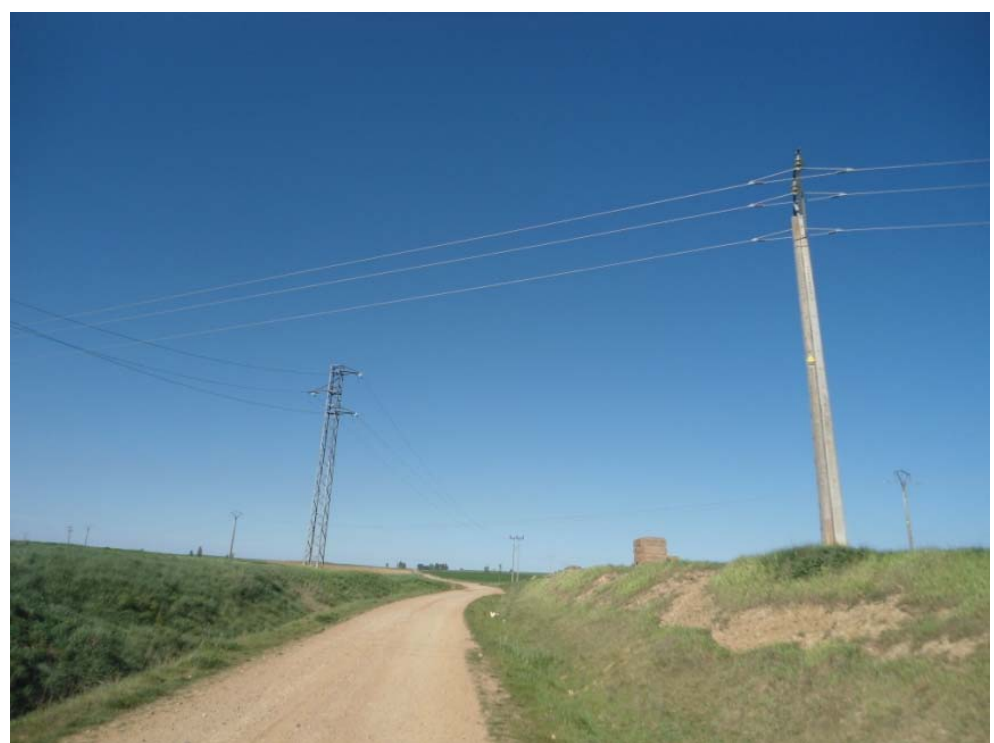

Figura 6.36. Proliferación de líneas eléctricas en la colada de Villacid de Campos (Recorrido 30).

Carreteras totalmente rectilíneas, sin vegetación. Aunque esta degradación solo se haya citado en 6 ocasiones, su magnitud es relevante: abarca 6 de las 7 carreteras existentes en el término municipal de Villalón de Campos. El trazado actual se ha ido rectificando por motivos funcionales (Figura 6.37), perdiendo naturalidad y generando taludes de desmonte y terraplén. La anchura ha aumentado pero, sobre todo, en décadas anteriores se eliminaron todos los árboles que cubrían ambos márgenes de las vías y que constituían una de las principales causas de diversidad paisajística desde su creación (a partir de 1850). A esto hay que añadirle la degradación ocasionada por el tratamiento actual de la vegetación de las cunetas, que se elimina con herbicida, con las negativas consecuencias ecológicas y sobre el paisaje inmediato a la carretera.

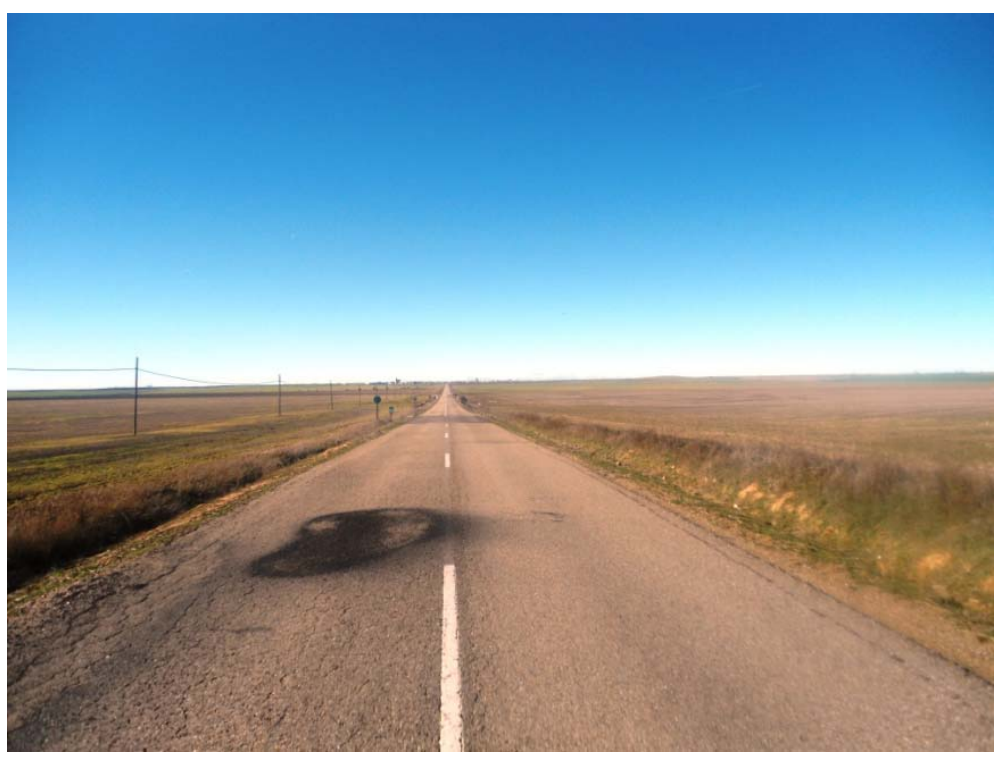

Figura 6.37. La componente lineal no puede ser más evidente en la carretera de Herrín de Campos a Villalón de Campos. En los márgenes no se atisba ni la más mínima zarza. 
Eliminación reciente de vegetación arbolada o arbustiva. Resulta especialmente grave que se siga detectando en la actualidad la corta de vegetación arbórea y arbustiva, cuando nos encontramos en un paisaje tan desolado ya devastado en épocas anteriores. Lo cierto es que se detectaron cuatro casos (corta de chopos o eliminación de un ribazo fueron ejemplos) cuyo impacto se calificó de severo o crítico (Figura 6.38).

Desmoronamientos puntuales en taludes. Cuando la altura y la pendiente de los taludes de desmonte en caminos o carreteras son elevadas, suelen suceder fenómenos de erosión en forma de regueros -primero-y de desmoronamientos después (Figura 6.39). El riesgo es mayor cuando hay ausencia de cubierta vegetal. Los efectos son varios: visual, pérdida de suelo, estabilidad de la ladera y colmatación de las cunetas.
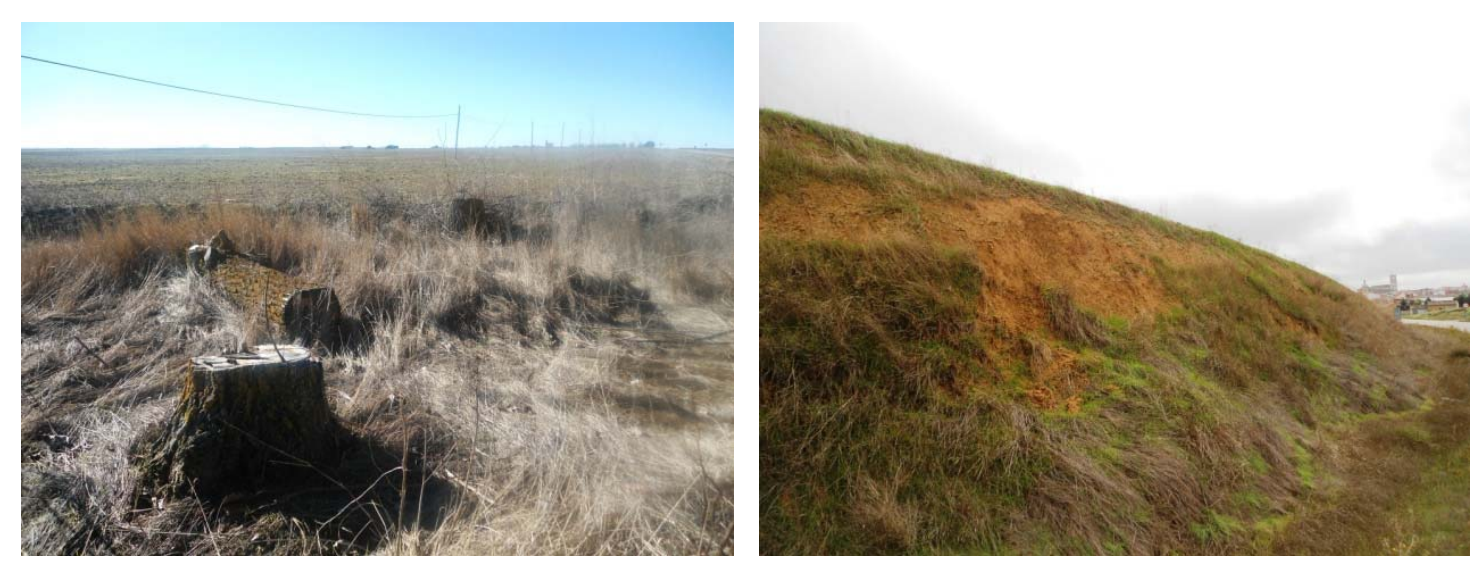

Figura 6.38 (izquierda). Corta de chopos en margen de carretera Herrín de Campos-Villalón de Campos. Figura 6.39 (derecha). Desmoronamientos en desmonte de carretera Villalón de Campos-Fontihoyuelo.

Plantas de tratamiento. En los Recorridos paisajísticos por Villalón de Campos se han detectado 3 plantas de este tipo, entendiendo por ello varios procesos: fabricación de hormigón, almacén de áridos, almacén de prefabricados, depósito de residuos inertes, etc. El impacto se califica como severo sobre todo por la existencia de tolvas de gran altura, que a menudo están pintadas en colores corporativos estridentes. Los depósitos de los materiales ocasionan también impactos visuales ya que no suele haber pantallas de ocultación.

Naves de gran volumen y colores discordantes. La existencia de grandes naves en suelo rústico, con colores discordantes, también resulta un deterioro de impacto moderado o severo (Figura 6.40). Especialmente impactantes resultan los paramentos con franjas de colores estridentes y las cubiertas metálicas brillantes sin lacar. Este impacto ha sido estudiado por numerosos autores (CAÑAS y AYUGA, 1994; CAÑAS et al., 1996; GARCíA et al., 1997) que, entre otras cuestiones, suelen coincidir en la recomendación de diseños de construcciones basados en los tradicionales, el empleo de colores terrosos de la zona y la diferenciación de las cubiertas (más oscuras) de los paramentos.

Intrusión en vías pecuarias u otras propiedades públicas. Este aspecto, más que una degradación paisajística en sí ya que no se percibe, resulta en una pérdida potencial de diversificación en una propiedad pública, tan escasas en Tierra de Campos. Nos referimos fundamentalmente a vías 
pecuarias, parcelas de restauración del medio natural de la concentración parcelaria u otras de titularidad pública, que suelen ser de superficie reducida. El problema suele ocurrir cuando la parcela en cuestión limita con otra agrícola (evidentemente no lo hay cuando limita con un camino o reguera) y no se realizan labores de deslinde y restauración; las intrusiones son paulatinas pero persistentes.

Antenas de telefonía móvil. Se detectan dos impactos severos por la presencia en suelo rústico de estas infraestructuras de radiocomunicación. Su dimensión vertical contrasta en fuerte medida con la componente mayoritariamente horizontal de campos y edificaciones (Figura 6.41). El impacto se agudiza cuando se hace obligatorio -por seguridad de aviación civil- que las torres sean pintadas con bandas rojas y blancas. De igual modo, se minimiza en su conjunto cuando las antenas comparten ubicación e infraestructuras.
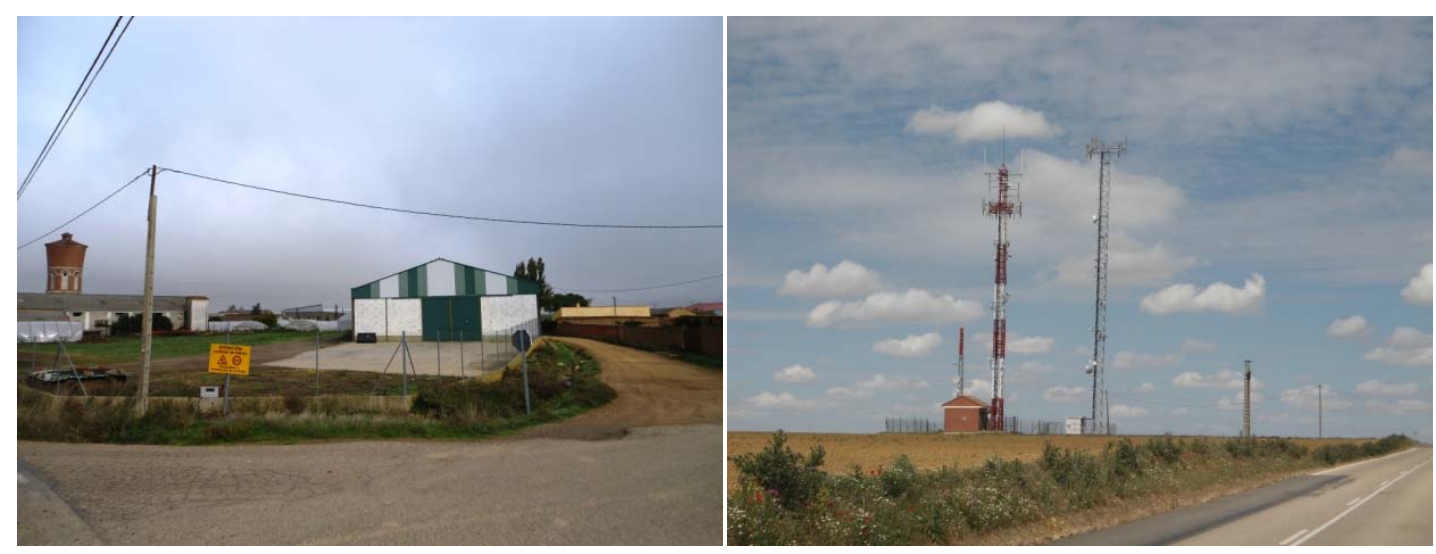

Figura 6.40. Nave agrícola en Recorrido paisajístico 8 (izquierda). Figura 6.41. Antenas de telefonía móvil en Recorrido 34 (derecha).

Escombrera municipal. Tradicionalmente la mayoría de los escombros generados por los vaciados de solares, derribos de edificaciones u obras en general, se destinaban a rellenar huecos naturales existentes (así se han desecado varias lagunas en Villalón de Campos) o antiguas extracciones minerales. En las últimas décadas ha aumentado considerablemente el volumen de escombros, lo que ha obligado a diseñar escombreras, como el caso que nos ocupa (Figura 6.42). Esta genera un impacto paisajístico severo, tanto en percepción visual ya que es muy visible, como en riesgo de contaminación y afectación a procesos ecológicos, ya que también se depositan residuos de muy diversas clases. 

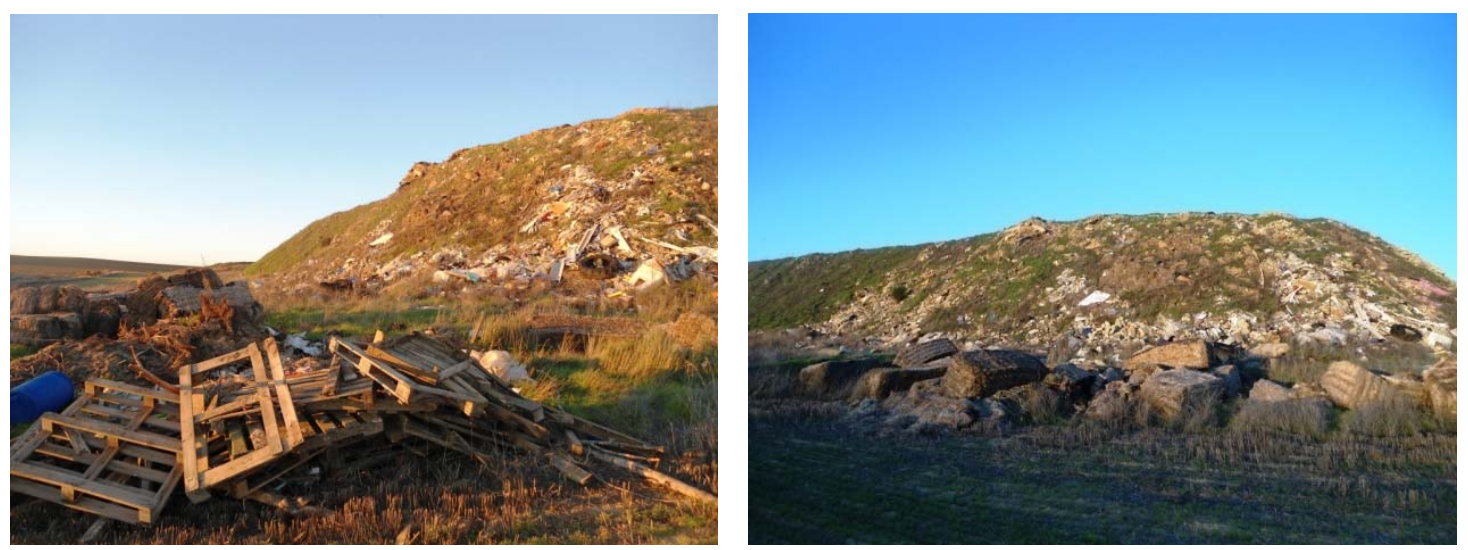

Figura 6.42. Dos imágenes de la escombrera municipal de Villalón de Campos (Recorrido 13).

Finalmente, en el espacio agrícola se detectan varias degradaciones paisajísticas con tipologías diferentes, aunque con una importancia relativa debido a su localización puntual. En este grupo se englobarían una antigua extracción sin restaurar, la desecación de una fuente del campo y la delimitación de una huerta con materiales discordantes.

\section{Espacio periurbano}

Proliferación de vallados metálicos. Se trata de la degradación más numerosa, aunque de carácter moderado. Tal vez debido al carácter castellano lo cierto es que, cuando se puede, la primera actuación que se realiza en las pequeñas parcelas que rodean los pueblos es su vallado. Este se realiza con postes y mallas metálicas de simple torsión de unos $2 \mathrm{~m}$ de altura, que suelen acabarse en alambres con pinchos, que son materiales de gran artificialidad.

Desorden urbanístico en espacios periurbanos. Se trata de una degradación importante para las poblaciones de tamaño medio a alto, que han tenido un cierto desarrollo industrial. En los Recorridos paisajísticos se observan 3 impactos severos derivados de la existencia de otros tantos espacios. Teniendo en cuenta que los usos del suelo no están muy definidos en el planeamiento o que el rigor en la aplicación urbanística es muy laxo (que suele ser lo que ocurre), lo cierto es que en la periferia de los pueblos y preferentemente en los accesos por las carreteras, conviven talleres mecánicos, gasolineras, almacenes, naves ganaderas, naves agrícolas, industrias, líneas eléctricas, merenderos y otros usos variados. Estas edificaciones se han ido consolidando paulatinamente, de una forma desordenada (Figura 6.43), de modo que no ha habido una urbanización previa con viales, zonas para equipamientos, espacios verdes, infraestructuras, etc. Todo ello transmite una imagen muy negativa de los pueblos, de desorden y desidia. 


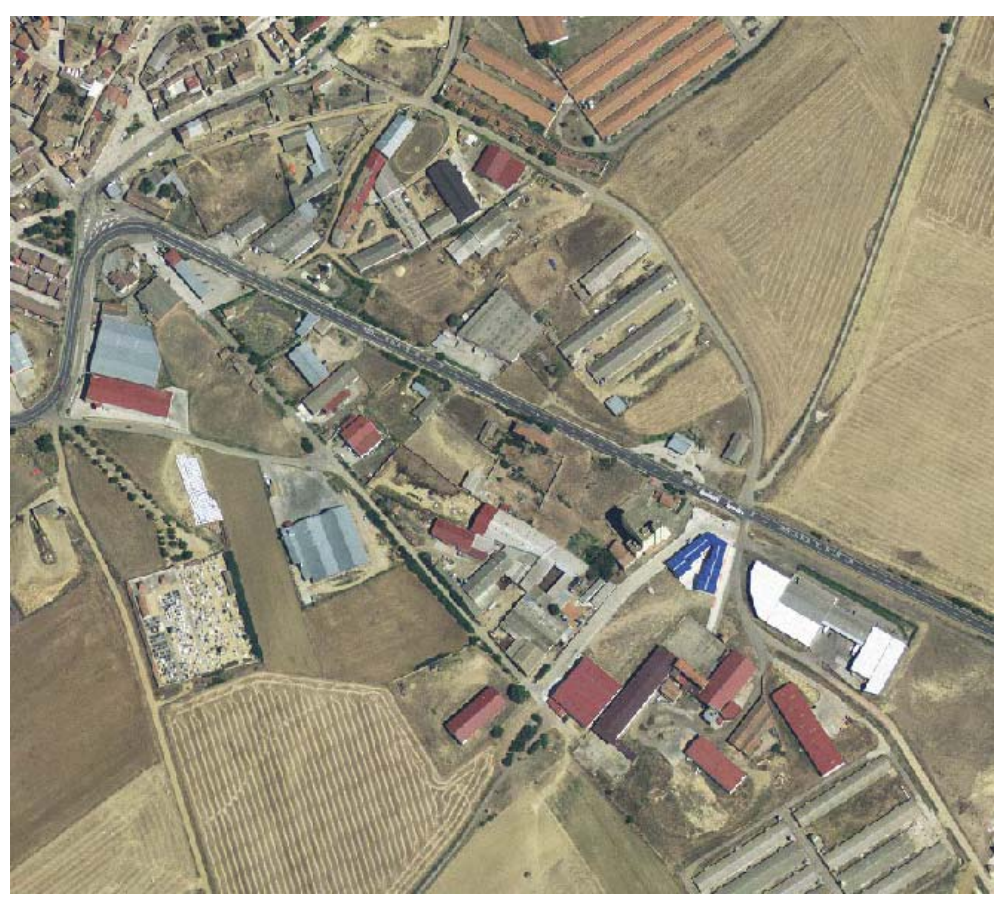

Figura 6.43. Ortofotografía que muestra el desorden de una zona periurbana de Villalón de Campos, en el entorno de la carretera nacional 610, con construcciones de todo tipo asentadas sin una urbanización previa.

Silos de trigo. A mediados del siglo pasado, el Servicio Nacional de Productos Agrarios (SENPA) creó estos grandes almacenes de cereal en muchos pueblos de Tierra de Campos, que se conocen popularmente como silos. Su volumen y altura (más de $20 \mathrm{~m}$ ) son enormes (Figura 6.44), compitiendo con las torres de las iglesias que son los elementos más singulares del paisaje rural. Las tipologías son muy variadas, aunque su conformación funcional compacta es similar. Su integración en el paisaje se trataba de conseguir con acabados ocres de los paramentos. Los objetivos principales de la red nacional de silos eran posibilitar la compra de toda la cosecha de trigo a los agricultores y conservar una reserva para garantizar el consumo del país. La finalización del régimen de monopolio triguero por parte del Estado hacia 1985 hizo que los silos perdiesen su función. Aunque su efecto sobre el paisaje es notable, hay autores que los consideran elementos singulares del mismo -AZCÁRATE (2009) habla de las catedrales olvidadas-, que pueden ser reutilizados para otros usos interesantes. En este estudio incluimos el silo como degradación del paisaje en cuanto que se trata de una edificación notoria que actualmente carece de uso. 


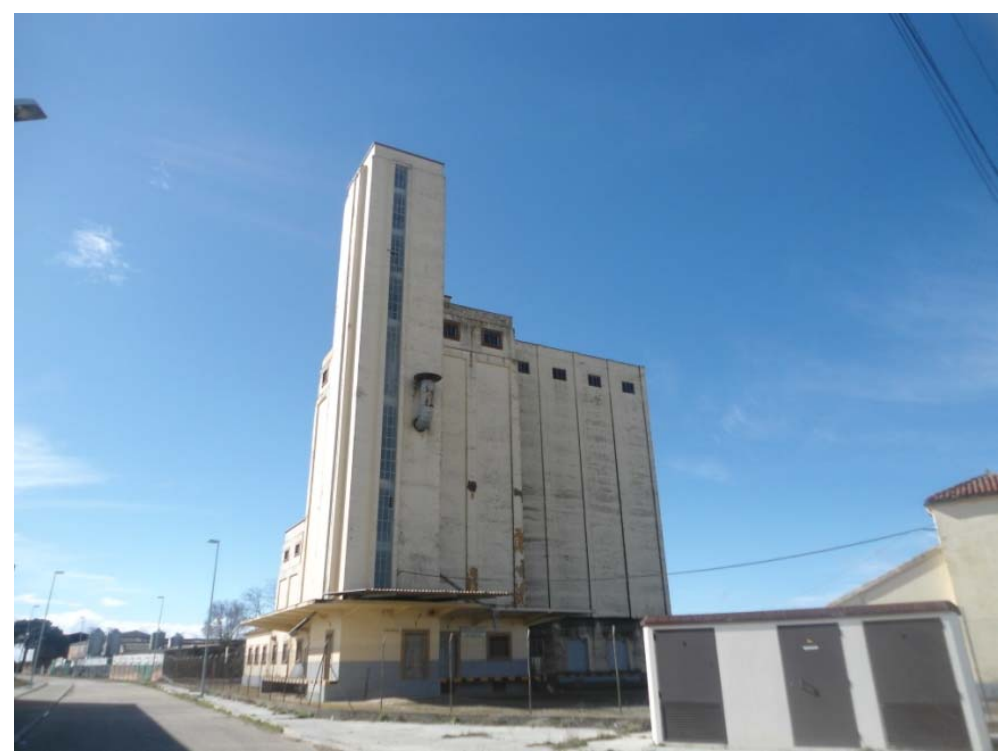

Figura 6.44. Silo de trigo de Villalón de Campos.

Espacios libres públicos sin ajardinar. En los espacios periurbanos nos encontramos con zonas de propiedad municipal, no pavimentadas, que tienen un uso potencial como zonas verdes: márgenes de calles, plazuelas, enlaces de carreteras o caminos, etc. Cuando estas superficies no se cuidan, dan lugar al depósito de basuras o escombros, al aparcamiento irregular o a otros usos inadecuados.

Proliferación de carteles publicitarios. Es esta una degradación característica de los espacios periurbanos de las ciudades. En Tierra de Campos únicamente se detecta en la entrada de los pueblos por carreteras importantes (nacionales sobre todo) o en las proximidades de las autovías salvando las prohibiciones legislativas en esta materia, que dejan margen a una determinada distancia de las vías o en suelo urbano. En los Recorridos paisajísticos por Villalón de Campos únicamente se detecta puntualmente en la entrada al pueblo por la carretera N-610. También tienen cierta relevancia los carteles que coloca la Administración en las obras públicas y que, en muchas ocasiones, se olvida de retirar (Figura 6.45). Todos ellos afean la imagen de los pueblos, al tratarse generalmente de grandes carteles ubicados en las zonas más visibles, que es precisamente las que han de ser más cuidadas.

Polígono industrial discordante. En los suelos industriales de las ciudades generalmente no hay criterios estéticos especiales de diseño de las naves o fábricas. En el caso de los pueblos, el problema es que no suele haber zonas del término clasificadas estrictamente como suelo industrial; es más común la existencia de un suelo rústico común donde se asienten con carácter excepcional usos variados. También puede darse el caso contrario: que los terrenos sean de uso predominante industrial pero que en la práctica también alberguen usos agropecuarios. En el Recorrido paisajístico 23 se observa la presencia de un micropolígono industrial promovido por la Diputación, que genera un impacto paisajístico severo por cambio de las características visuales básicas: paramentos blancos y azules y cubierta azul (Figura 6.46). Da la impresión que 
se trata de diseños estándar aplicados para cualquier comarca, donde además se prima el contraste a la integración.
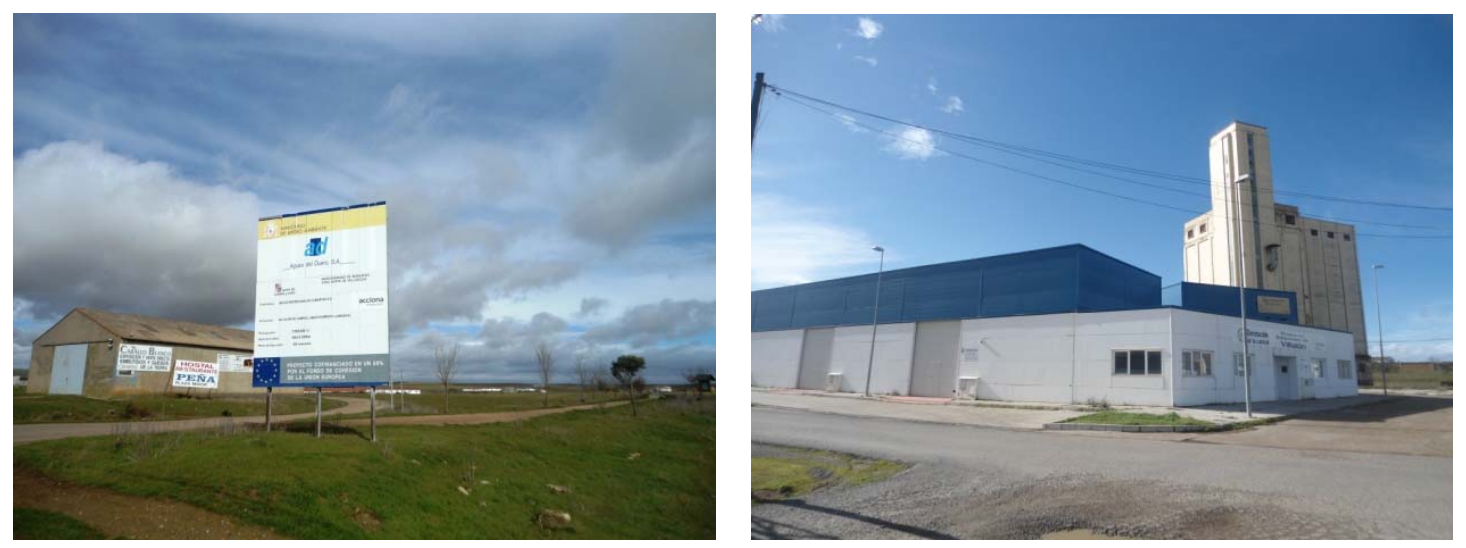

Figura 6.45 (izquierda). Carteles variados, entre los que destaca uno de una obra terminada hace más de 10 años. Figura 6.46 (derecha). Micro polígono industrial en el acceso por la carretera de Palencia (Recorrido 23).

\section{Espacio urbano}

Pérdida de patrimonio y tipología arquitectónica tradicional. Ya se ha comentado anteriormente que Tierra de Campos posee un riquísimo patrimonio histórico-artístico, así como una característica arquitectura tradicional, basada fundamentalmente en el empleo de la tierra como material de construcción. En los Recorridos del anejo 3 se detectan 6 impactos críticos, aun cuando estos se engloban por grupos, lo cual quiere decir que individualmente podrían ser muchos más. Iglesias cerradas con problemas serios de conservación, antiguos hospitales, conventos y monasterios perdidos, estaciones singulares del ferrocarril destruidas, multitud de casas de barro singulares derribadas (Figura 6.47) o enmascaradas por nuevos edificios que no respetan la tipología arquitectónica tradicional son algunos ejemplos de la pérdida de patrimonio, que es común en la comarca y sin duda en otros territorios. Todos ellos son impactos críticos, porque ya es imposible su recuperación. El patrimonio cultural es la herencia que recibimos de nuestros antepasados y que deberíamos transmitir a otras generaciones, aunque, para ello, lo fundamental es conservarlo. 


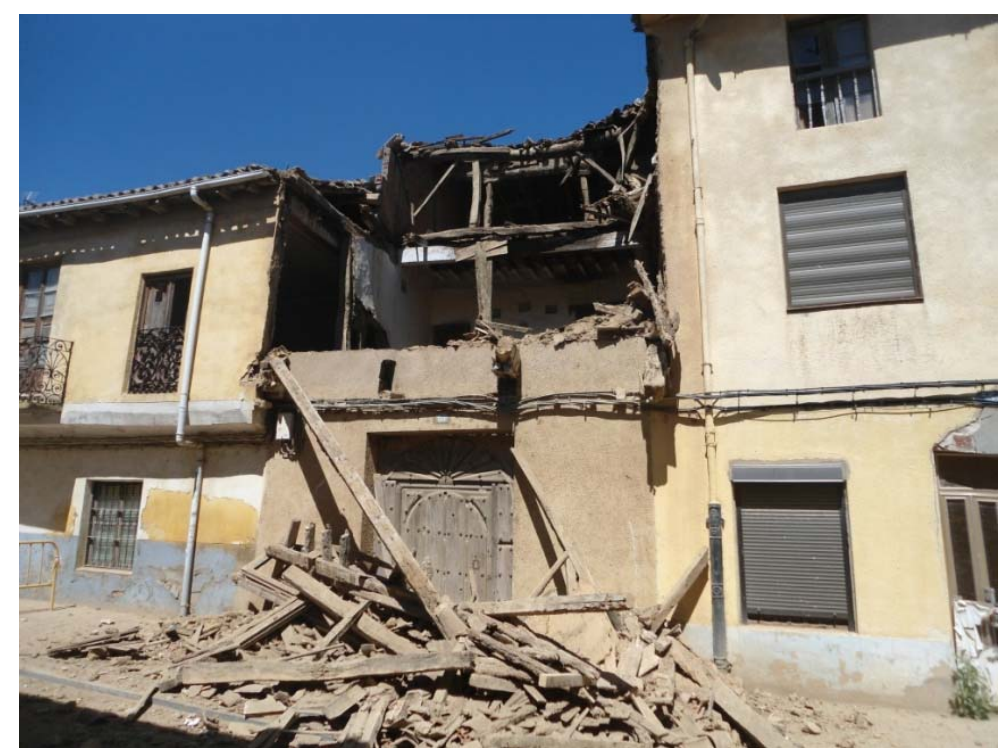

Figura 6.47. Impacto crítico provocado por el derrumbe de una casa del siglo XVI en Villalón de Campos, que conservaba restos de origen judío.

Edificaciones urbanas con acabados no adecuados. Nos encontramos en los Recorridos con 6 impactos moderados, aunque realmente se refieren a todos los itinerarios que discurren por suelo urbano. Aunque, en general, Villalón de Campos es un pueblo relativamente bien integrado, lo cierto es que siempre aparecen fachadas en cemento gris sin pintar, muros o paredes en ladrillo hueco sin revestir, cubiertas con fibrocemento o placas metálicas (algunas incluso sin lacar), medianeras sin tratar, etc. Todos estos casos se suelen referir a edificaciones que no son viviendas y cuyo uso es secundario, donde además no se han respetado (y no se han hecho cumplir) las condiciones estéticas de las normas urbanísticas. Ello se traduce en una pérdida de la calidad ambiental del espacio urbano y en una imagen de desidia (Figura 6.48).

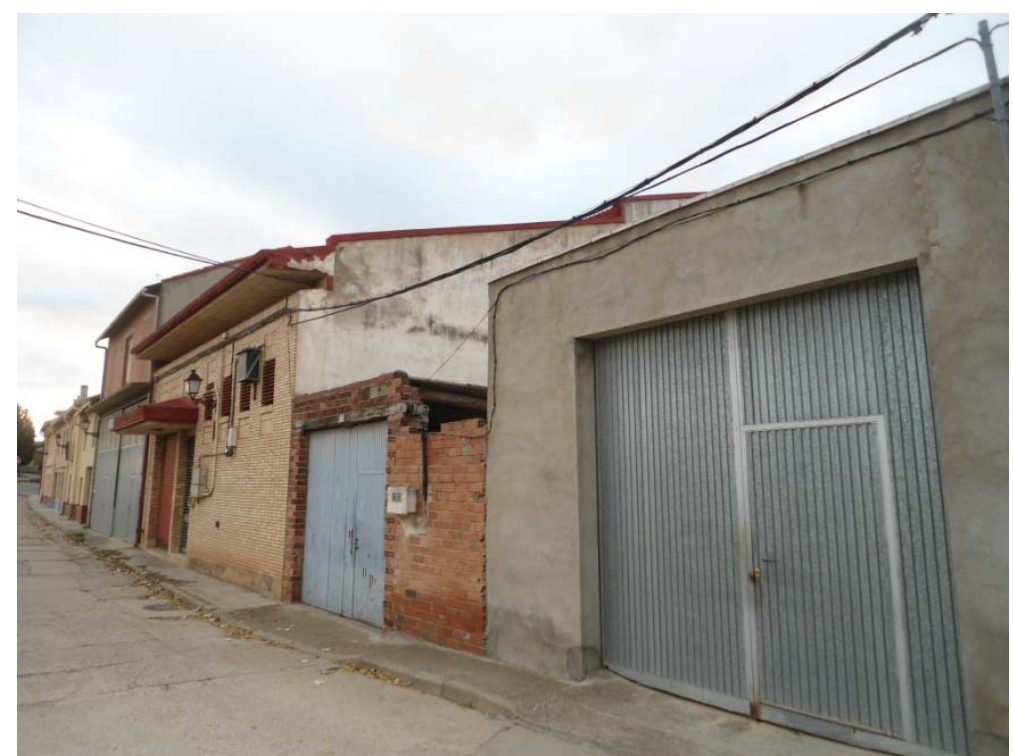

Figura 6.48. Acabados exteriores inadecuados en una calle urbana del Recorrido paisajístico 16. 
Puertas traseras impactantes. De modo similar a la degradación anterior, aunque con un carácter un poco singular, consideramos el caso de las puertas traseras. Se trata de un impacto moderado y, por tanto, fácilmente recuperable. En las calles más secundarias, y sustituyendo a los antiguos portalones de madera, nos encontramos con una proliferación de grandes puertas metálicas, algunas sin pintar y otras con acabados estridentes, que en conjunto dañan la imagen del conjunto urbano.

Explotaciones ganaderas en suelo urbano. Hasta los años 70 del siglo pasado era común que la mayoría de los labradores también tuviesen ganado en los corrales de sus casas. Cuando comienza la intensificación de la ganadería, algunas de las explotaciones (de ovino, sobre todo) se dirigen fuera de la zona de viviendas pero aún dentro del casco urbano. En ese momento la legislación ambiental no era tan estricta o no lo fue su aplicación. En los Recorridos del anejo 3 se detectan tres casos, calificados como de impacto severo, aunque lo cierto es que esta degradación es común a la inmensa mayoría de los pueblos de Tierra de Campos. Los efectos paisajísticos y ambientales son numerosos: olores desagradables por el estiércol o los purines, molestias, suciedad de las calles, presencia de grandes naves, etc.

Solares urbanos sin delimitar con muro. La despoblación de Tierra de Campos y la consiguiente falta de desarrollo urbanístico provocan la existencia generalizada de solares en el interior de los cascos urbanos. En los Recorridos se detectan 3 impactos, calificados como moderados, aunque todos los pueblos cuentan con un gran número de ellos, que se mantienen durante largos periodos de tiempo. Las normas urbanísticas suelen obligar a tapiar con un muro de fábrica los solares, pero en muchos casos no se cumple, dando lugar a vistas desagradables, tanto de las medianeras adyacentes como de lo que se almacena en su interior. Si, además, la delimitación se realiza con un mallazo metálico, la degradación aumenta notablemente.

Naves en suelo urbano. El deficiente rigor urbanístico provoca también que, a veces, se construyan naves agrícolas en suelo urbano. Ello genera la irrupción en la alineación exterior de grandes fachadas con portalones metálicos y tipología totalmente diferente a la de la vivienda tradicional. También los materiales suelen ser inadecuados, como los indicados en una degradación característica anterior.

Ruina de casas antiguas. Realmente en este caso se trata de una degradación doble: la propia pérdida de patrimonio tradicional que supone y la existencia en sí de un edificio en mal estado. En los Recorridos paisajísticos se han detectado casos de ruina en dos de ellos, calificado su impacto como severo, aunque se puede afirmar que en los pueblos de menor tamaño es una de las degradaciones de mayor calado. Además de la imagen negativa que conlleva, refleja una situación verdaderamente pesimista sobre la situación socioeconómica de la comarca, que por otro lado es tan real como dramática.

Desorden del cableado en zona urbana. Es otra de las degradaciones derivadas de la ausencia de control y rigor urbanístico municipal. Por las fachadas transita una ingente red de cableado que cruza, una y otra vez, las calles sin ningún orden (Figura 6.49).

Pavimentación urbana en estado deficiente. Hacia la mitad del siglo pasado se urbanizó y pavimentó la práctica totalidad del vial urbano de los pueblos de Campos, en su mayoría con paños de hormigón. Paulatinamente, sobre todo por los rigores climatológicos, este pavimento 
se ha ido degradando con blandones, pequeños baches o afloramiento del árido. Por otro lado, las reparaciones suelen ser puntuales, lo que aumenta la heterogeneidad de los acabados. Esto genera una degradación que va en detrimento de la calidad ambiental del conjunto urbano.

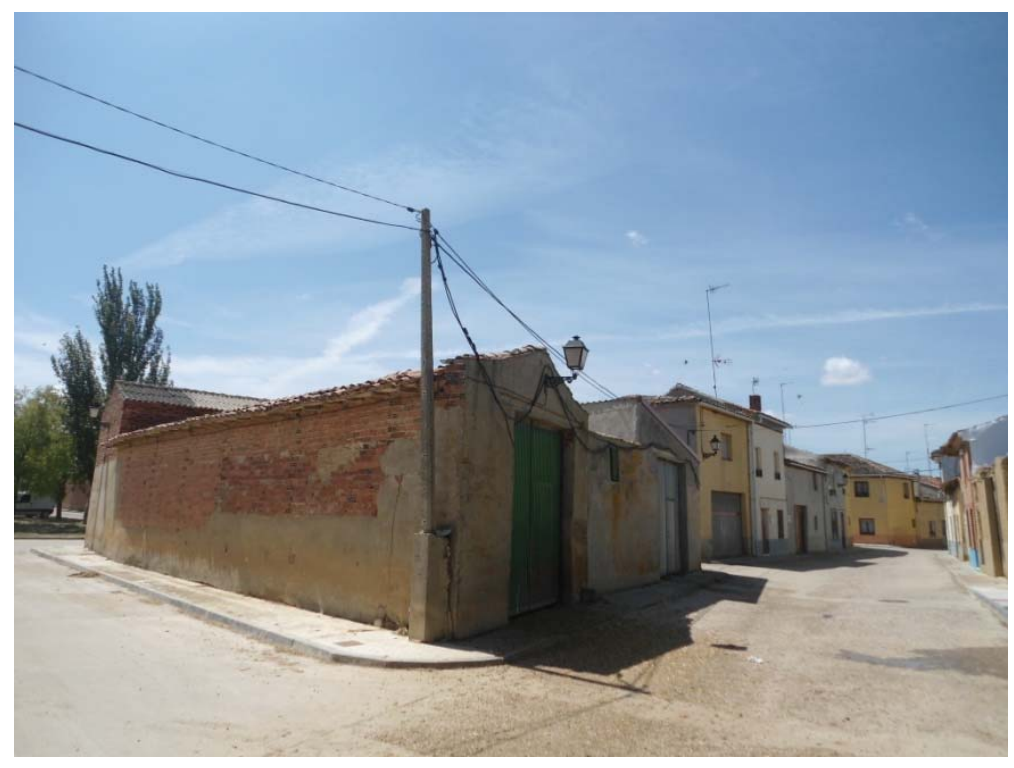

Figura 6.49. Imagen de una zona urbana del Recorrido 15, en la que se pueden apreciar varias de las degradaciones mencionadas: presencia de un aprisco de ovejas, suciedad de las calles, acabados inadecuados, puertas traseras, cableado desordenado, deficiente pavimento...

Ausencia de criterios estéticos en casco histórico. El casco histórico de muchos pueblos de Tierra de Campos aún conserva interesantes valores de la arquitectura tradicional y conforma espacios de gran singularidad. Son estas zonas las que realmente caracterizan a los pueblos y sobre las que deriva un gran potencial turístico. En algunos casos, sobre todo en poblaciones de mediano o mayor tamaño como Villalón de Campos, en las calles importantes (Recorrido 35) se aprecian un conjunto de degradaciones que, sin ser graves individualmente, dañan la imagen del conjunto histórico. Es el caso de carteles luminosos, pilares de soportales con acabados dispares, falta de regulación de aparcamientos, presencia de contenedores de basura, etc.

\subsubsection{Síntesis de degradaciones características del paisaje de Tierra de Campos}

En los apartados anteriores se han analizado los efectos sobre el paisaje de los proyectos de obras incluidas en el anejo 1 (de mayor envergadura), así como todas aquellas actuaciones recogidas en el anejo 3 (de menor envergadura, pero mucho más numerosas). Con objeto de realizar una síntesis de todos ellos, de los que además se destaquen aquellos más importantes, se ha realizado una agrupación siguiendo la caracterización de degradaciones de GÓMEZ OREA y VILLARINO (2004), aplicada al paisaje de Tierra de Campos: 
1.- Alteración de la morfología general, o de formas significativas del relieve. Afortunadamente, salvo casos puntuales como el de las grandes infraestructuras lineales, esta degradación no ha tenido lugar con carácter general en el paisaje terracampino, que ha mantenido su geomorfología natural de llanuras suavemente onduladas. La línea ferrocarril de alta velocidad Palencia-León (Figura 6.50), así como las autovías Camino de Santiago y Cantabria-Meseta, sí que han ocasionado fuertes alteraciones de la morfología general, debido a los requerimientos funcionales (mayores en el AVE) que provocan la generación de numerosos desmontes y terraplenes, con pendientes superiores a las naturales.
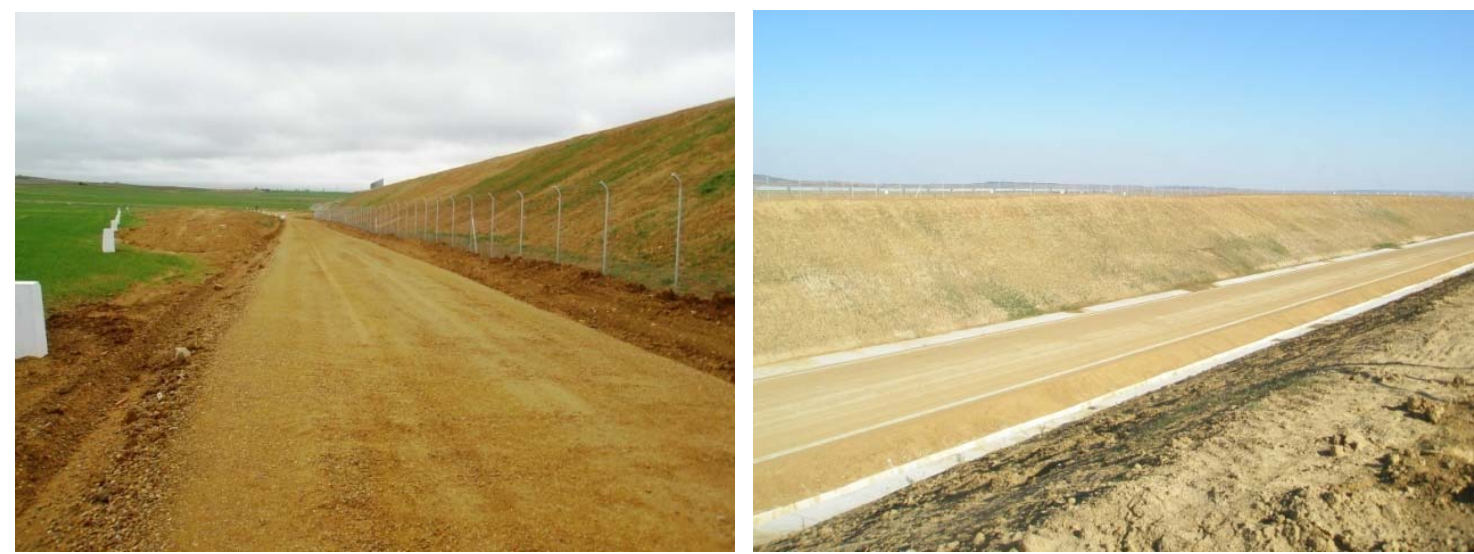

Figura 6.50. Fuertes terraplenes (izquierda) y desmontes (derecha) en el AVE tramo Valle del Retortillo - Pozo de Urama.

2.- Pérdida de vegetación. En sentido opuesto, tal vez sea esta una de las mayores degradaciones del paisaje de Tierra de Campos que, a lo largo de la historia -pero de forma más acentuada en las últimas décadas- ha perdido prácticamente toda su vegetación arbustiva y arbórea, como consecuencia principalmente de la agricultura intensiva que se desarrolla en su territorio y las concentraciones parcelarias (Figura 6.51). Linderos arbustivos, bosquetes y ribazos han ido eliminándose como consecuencia de redistribuciones de la propiedad y rectificaciones de caminos y arroyos. Aún en la actualidad se siguen eliminando los escasos retazos de vegetación arbustiva, con excusas tales como servir de reservorio de topillos o de malas hierbas. También han sido y son relevantes las cortas de arbolado y desbroce de las márgenes de las carreteras, así como los encauzamientos y dragados periódicos de los cursos hídricos. 


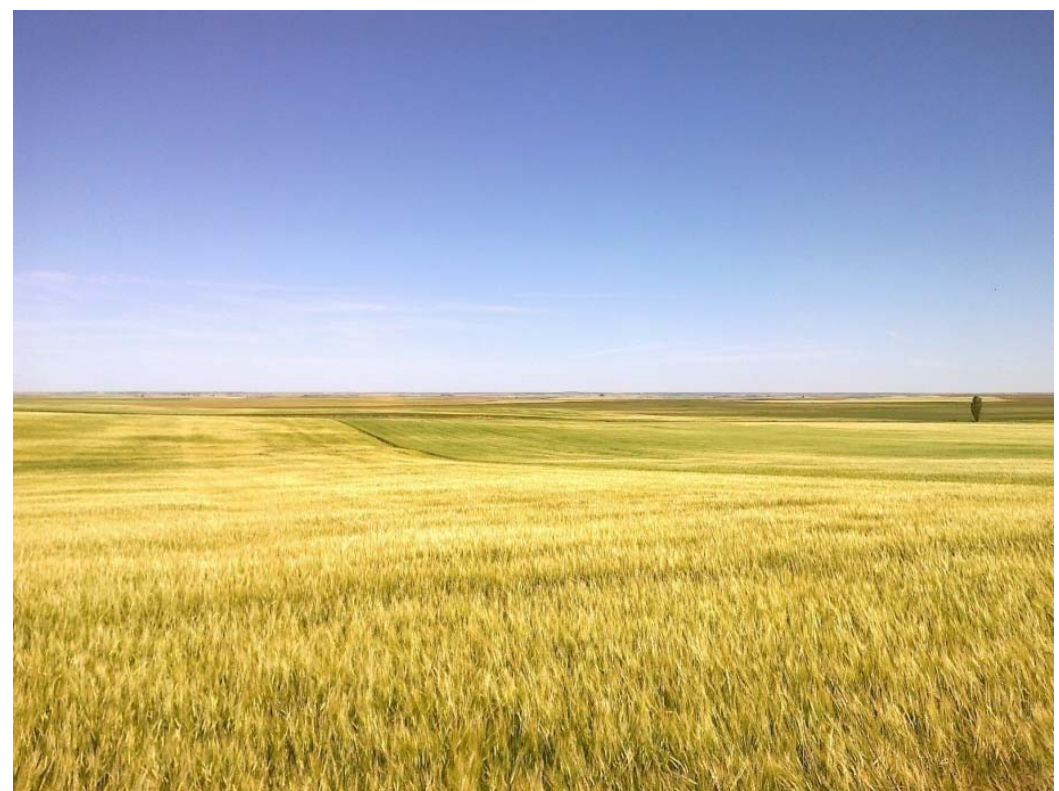

Figura 6.51. En general, el paisaje de Tierra de Campos conserva su morfología natural, aunque una de sus mayores degradaciones es la eliminación prácticamente total de la vegetación arbórea y arbustiva (Villalón de Campos).

3.- Fragmentación del hábitat. En la ecología del paisaje, esta es una de las principales alteraciones producidas por la acción humana. En Tierra de Campos, la pérdida de la conectividad ecológica se produce sobre todo en la matriz agrícola, que es la dominante; puntualmente puede producirse en algún corredor (riberas) y, mucho más difícil por su escasez, en alguna mancha forestal. Los proyectos que más pueden afectar a esta variable son las infraestructuras lineales que constituyen una barrera para el movimiento de la fauna silvestre, sobre todo la avifauna esteparia. De entre ellos, destacan las líneas eléctricas aéreas, causantes de importantes daños por electrocución y colisión; en la actualidad, con objeto de no afectar a la ZEPA La Nava-Campos, se está potenciando excesivamente un corredor de líneas en su límite oriental (LAT Ampudia-Grijota, LAT de evacuación del parque eólico Cruz de Carrutero, por ejemplo), que está originando considerables daños a la avifauna. Las grandes infraestructuras de transporte, por su parte, pueden afectar al trasiego de mamíferos, anfibios y reptiles; ello en Tierra de Campos puede darse en el AVE Palencia-León, así como en las autovías A-6, Camino de Santiago y Cantabria-Meseta, sobre todo cuando atraviesan zonas de mayor naturalidad.

4.- Modificación de la naturalidad, introducción de formas geométricas, como sustitución de líneas naturales por rectas, etc. Esta causa de degradación es directamente aplicable a las rectificaciones de ríos, arroyos y pequeños cauces hídricos, que se han convertido en simples canales de desagüe, así como a los caminos rurales, cuyo trazado se ha hecho rectilíneo en las concentraciones parcelarias, para dar lugar a parcelas más geométricas (Figura 6.52). En general es aplicable a todas las obras que afecten a una determinada extensión territorial y, en particular, visible en buena parte de los proyectos seleccionados en el anejo 1. 

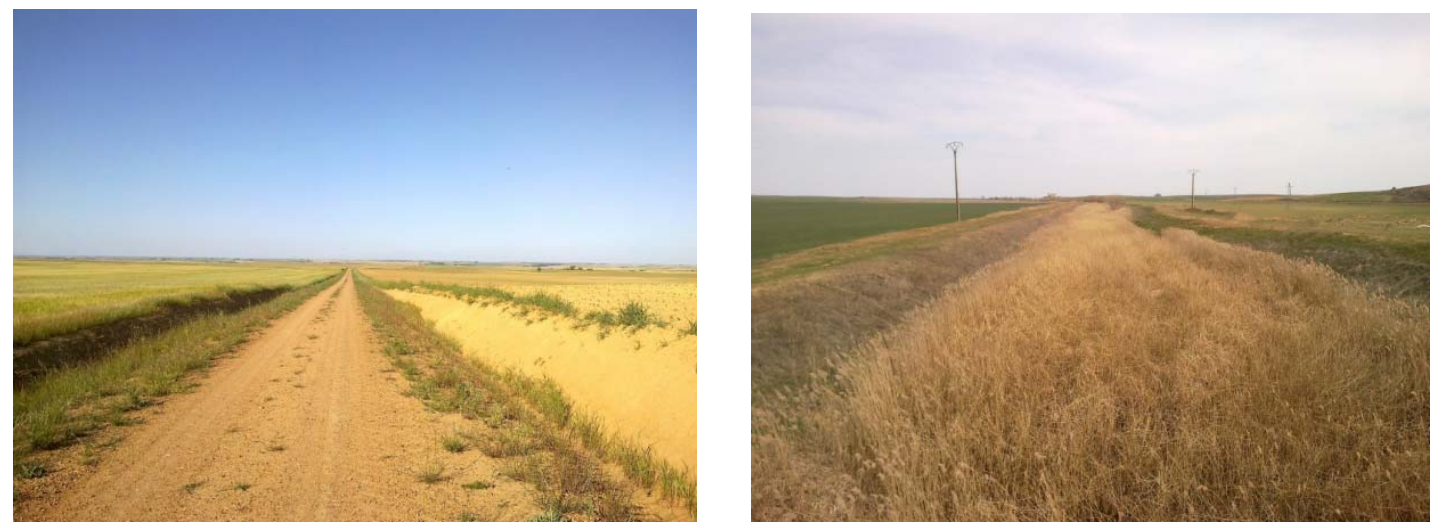

Figura 6.52. Izquierda, camino rectilíneo en Boadilla de Rioseco; derecha, río Sequillo rectificado y dragado en Tamariz de Campos. En ambos casos se constata la ausencia de vegetación.

Tal como se puede apreciar en los Recorridos paisajísticos en Villalón de Campos (anejo 3), la modificación de la naturalidad es una constante en Tierra de Campos, porque se produce en la parcelación agrícola, en la infraestructura más común de la comarca -los caminos rurales- y en los miles de kilómetros de arroyos y regueras que surcan el territorio.

5.- Cambios de las características visuales básicas: En Tierra de Campos, debido a la dominancia de los tonos y ocres, la presencia de construcciones con colores llamativos se convierte en uno de los principales factores de degradación del paisaje (Figura 6.53). También existen alteraciones de la escala, con determinadas naves o construcciones de gran envergadura.

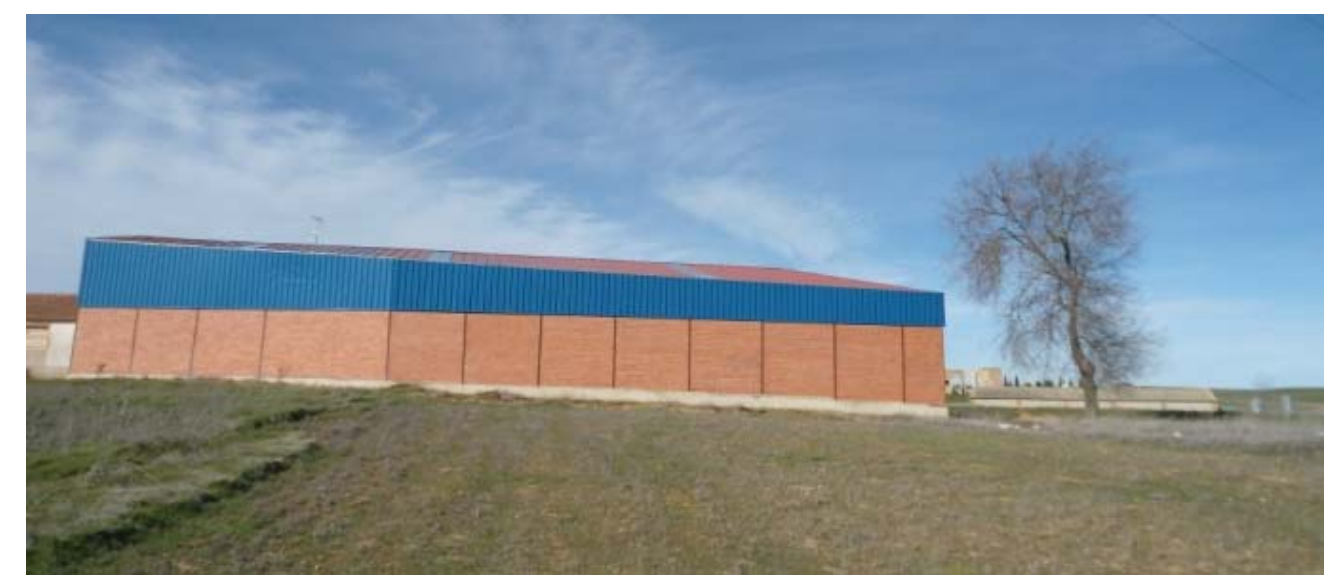

Figura 6.53. Nave agrícola en Moral de la Reina

Es este uno de los mayores factores de degradación del paisaje de Tierra de Campos. Tal como se aprecia en las fichas del anejo 1, en los espacios periurbanos y las salidas por las carreteras de Villalón de Campos se agolpan numerosas naves e instalaciones que en muchos casos tienen colores estridentes o no armónicos con los generales de la comarca. Particularmente graves resultan el impacto crítico provocado por el silo de cereal y los severos de la gasolinera y las 
tolvas de las plantas de tratamiento. Este tipo de degradaciones son comunes en buena parte de los pueblos de Tierra de Campos.

6.- Introducción de elementos extraños a la pauta que caracteriza la escena. Uno de los elementos positivos del paisaje de Tierra de Campos es la escasa presencia de elementos artificiales, fundamentalmente debida a la baja densidad de población, lejanía de grandes urbes y dominio de la actividad agro-ganadera. Sin embargo, las instalaciones ajenas a las prácticas tradicionales destacan en gran medida en la escena, como por ejemplo los huertos solares (Figura 6.54). Otras construcciones similares en suelo rústico, que por su carácter requieren una autorización de uso excepcional, son las plantas de tratamiento de áridos, las subestaciones eléctricas, las antenas de telefonía móvil, etc. Buena parte de ellas se detectan en los Recorridos paisajísticos del anejo 3, tratándose de impactos moderados o severos, según su envergadura.

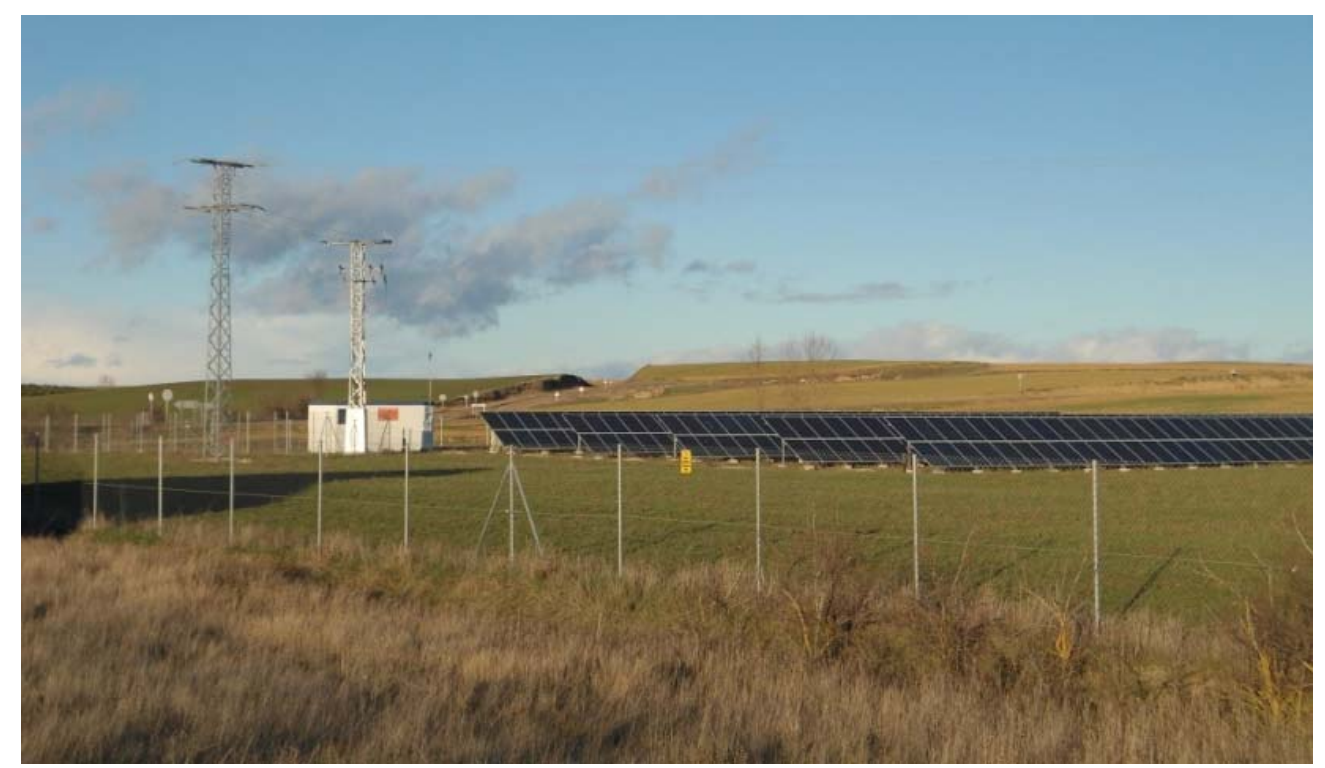

Figura 6.54. Huerto solar en Frechilla.

7.- Intrusión visual de elementos. Una escasa sensibilidad paisajística de los promotores, sumada al hecho de que el paisaje sea poco valorado en los procedimientos preventivos -tanto ambientales como urbanísticos- hace que se seleccionen ubicaciones erróneas para muchas instalaciones o construcciones (Figura 6.55), que alteran las vistas características sobre elementos significativos como iglesias, castillos, conjuntos histórico-artísticos, etc. 

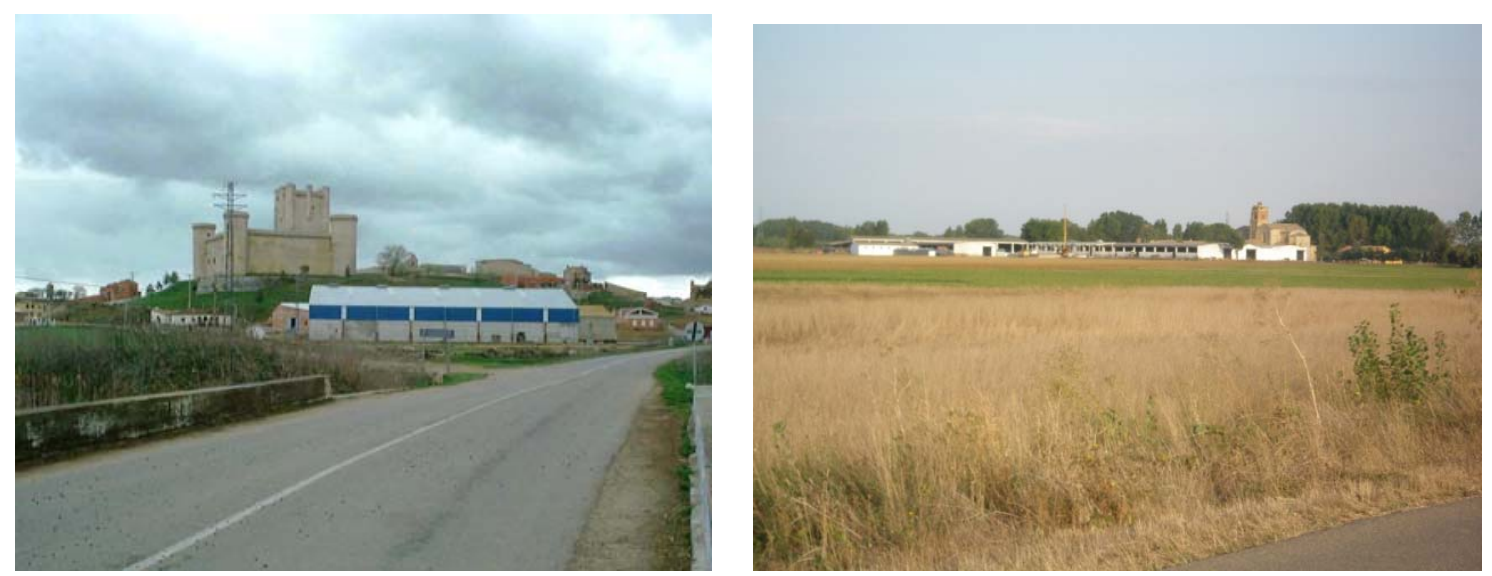

Figura 6.55. Intrusión visual de una nave agrícola sobre el castillo medieval de Torrelobatón (izda.) o de una explotación de vacuno intensivo en un monasterio cisterciense de Ribas de Campos (dcha.)

Un aspecto que se debe tener en cuenta es que, en Tierra de Campos, prácticamente todas las carreteras conducen a las plazas de los pueblos, donde radican las iglesias de mayor valor histórico-artístico. Si no se percibe la gravedad de la intrusión visual, se puede perder uno de los mayores potenciales de desarrollo rural, cual es el valor del patrimonio. En los Recorridos paisajísticos del anejo 3 se detecta un caso especialmente grave en la entrada por la N-610 a Villalón de Campos, extrapolable seguramente a muchas otras localidades, donde una gasolinera afecta totalmente las vistas a una iglesia gótico-mudéjar. Paradigmático es el parque eólico que irrumpe en las vistas características del castillo y el conjunto histórico-artístico de Ampudia. Son también numerosos los casos de afecciones al patrimonio causadas por ubicaciones cercanas de antenas de telefonía móvil o líneas eléctricas.

8.- Desaparición de la armonía. En otras ocasiones se produce la pérdida del potencial de vistas o su calidad, como cuando aparecen elementos degradantes en las vistas típicas desde los miradores de los páramos, como los de Autilla de Campos, Montealegre de Campos o Urueña. Una simple nave azul puede alterar la armonía de toda la cuenca visual, en un paisaje enormemente frágil.

9.- Abandono o deterioro de los usos que definen el paisaje. Salvo contadas excepciones, en Tierra de Campos no se han abandonado los usos tradicionales que caracterizan su paisaje: el uso agro-ganadero se mantiene en todo el territorio, aunque cada vez se hace más intensivo. Ahora bien, dentro de este uso, una de las mayores pérdidas acaecidas en la segunda mitad del siglo pasado fue la eliminación de los majuelos (viñedos), que contribuían en gran medida a la diversificación del paisaje. Tal vez uno de los aspectos que están aconteciendo en los últimos años es el progresivo estabulamiento de forma permanente del ganado ovino, que se concentra en las explotaciones intensivas; más que un factor de degradación, la reducción de la presencia de los rebaños de ovejas en las rastrojeras podría considerarse como la pérdida de uno de los elementos consustanciales del paisaje de campiñas cerealistas.

10.- Cambio en los elementos dominantes. La mayor transformación del paisaje en este sentido se produce en las zonas ocupadas por parques eólicos donde los aerogeneradores -gracias a su 
envergadura- se convierten en elementos dominantes, anulando o minusvalorando otros elementos singulares: torres de iglesias, arbolado, palomares, etc. El entorno de la villa de Ampudia -conjunto declarado conjunto histórico-artístico- vuelve a ser un caso paradigmático (Figura 6.56). También es elevada la dominancia provocada por la instalación de los grandes apoyos de las líneas eléctricas de alta tensión, sobre todo en los corredores de las líneas de transporte, como el que parte de la subestación de La Mudarra con destino al noroeste de España. Otro ejemplo común en la comarca de cambio de dominancia está constituido por los silos de cereales, construcciones de tremenda envergadura que compiten con las torres de las iglesias.
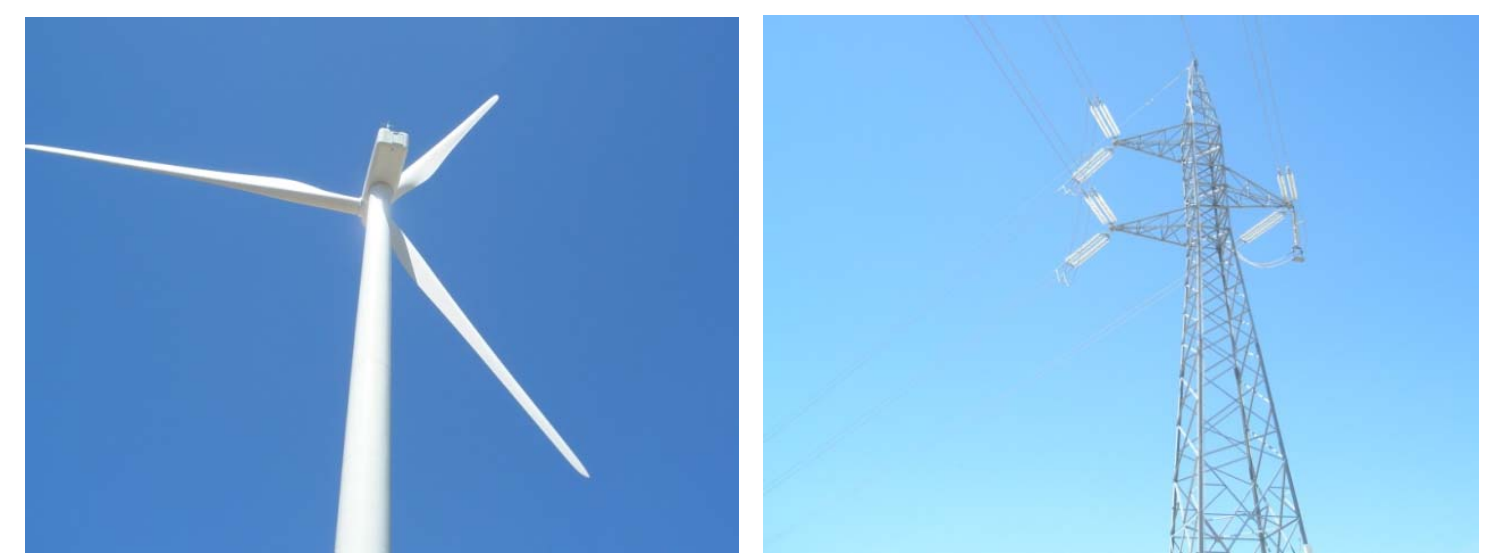

Figura 6.56. Detalles de un aerogenerador y un apoyo de línea eléctrica en Ampudia, donde se puede apreciar su envergadura.

11.- Acumulación de residuos, suciedad o contaminación. Aunque tal como hemos señalado, la densidad demográfica de la comarca es baja, también se producen vertidos espontáneos de residuos: escombros, ruedas, plásticos, grandes enseres, etc. Como el grado de ocupación funcional del territorio es altísimo, los depósitos no se realizan en las parcelas agrícolas, sino generalmente en los márgenes de caminos o en las pequeñas parcelas públicas existentes, usualmente en los espacios periurbanos. También es notable la presencia de residuos en las cunetas de las carreteras, tal como se constata en los Recorridos paisajísticos del anejo 3. Es significativa, asimismo, la presencia de estercoleros en las proximidades de las explotaciones ganaderas que rodean los cascos urbanos, que además de un cierto impacto visual, generan olores considerables en el entorno y pueden contaminar las aguas superficiales y subterráneas. Finalmente, las calles cercanas a las explotaciones de ovino ubicadas en casco urbano suelen tener excesiva suciedad por el estiércol acumulado, si este no se limpia periódicamente.

12.- Pérdida del patrimonio cultural o, dicho de otro modo, del valor testimonial, significado o singularidad del paisaje. El patrimonio cultural es la herencia que nos legaron nuestros antepasados y que deberíamos conservar como rasgo de identidad de un territorio. En el paisaje de campiñas de Tierra de Campos uno de los elementos más singulares es el palomar. La falta de funcionalidad y su construcción térrea ha propiciado que gran parte de ellos se haya derrumbado en las últimas décadas (Figura 6.57), lo que está significando una terrible pérdida del patrimonio cultural etnográfico y, por ende, de la calidad de contenidos del paisaje. Igual 
sucede con otros elementos singulares como las casetas de era o las fuentes, ambos muy necesarios para la realización de las labores agrícolas anteriormente a su mecanización. También es de destacar la progresiva desaparición de las huertas y sus casas de campo, que antaño ocupaban los buenos suelos de alrededor de los cascos urbanos y aportaban al paisaje una mayor diversidad y complejidad.
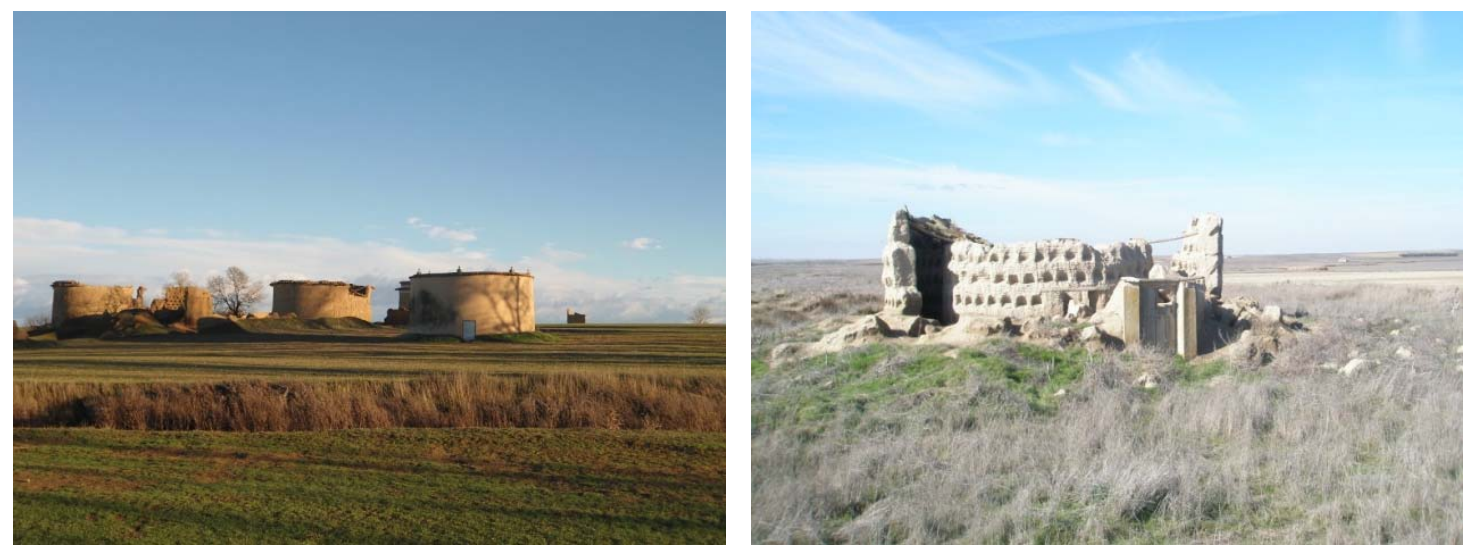

Figura 6.57. Izquierda, palomares en estado de degradación en Guaza de Campos; derecha, palomar derruido en Otero de Sariegos.

En el paisaje urbano de Tierra de Campos -en los pueblos- la degradación más característica es la pérdida sustancial del patrimonio arquitectónico popular de Tierra de Campos, protagonizada por las casas de adobe, tapial y barro, así como de otras edificaciones singulares. También lo es la construcción de nuevas viviendas o edificaciones sin respeto en su diseño a la tipología tradicional. Más grave, sin duda, es la pérdida del patrimonio histórico-artístico: desgraciadamente cada pueblo tiene ejemplos de derrumbes de monasterios, conventos, iglesias, ermitas... (Figura 6.58). El caso más crítico es el abandono total del pueblo: Villacreces, el ejemplo, iqué paradoja de nombre!
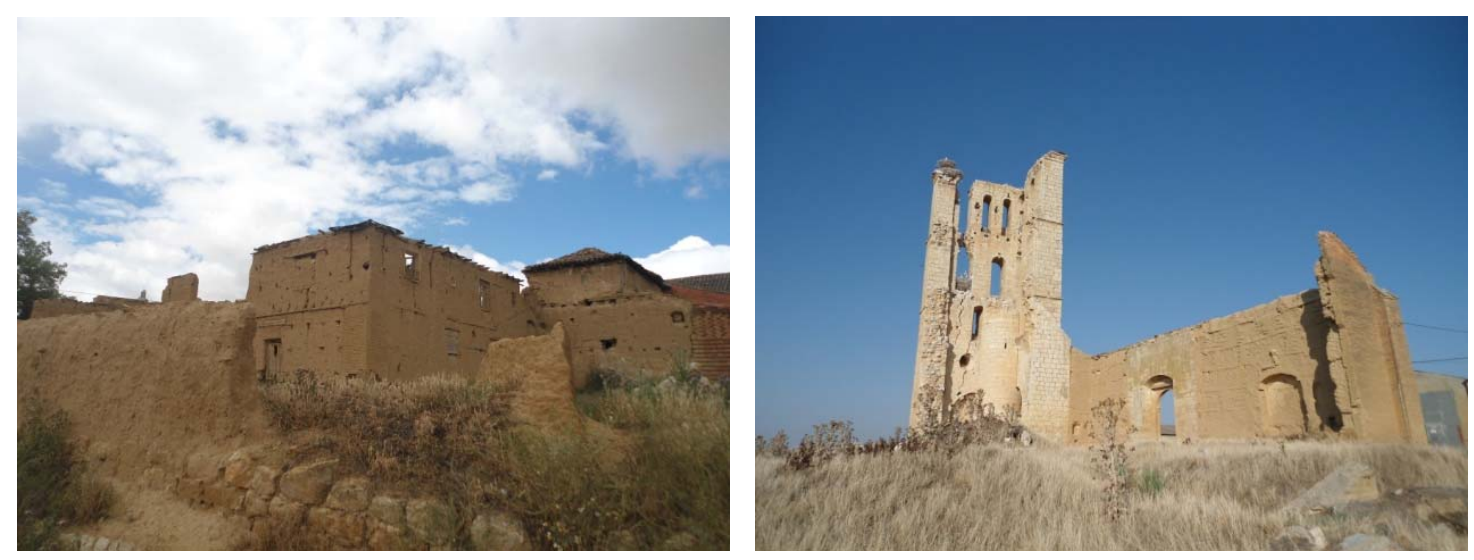

Figura 6.58. A la izquierda, ruinas de viviendas de adobe en Baquerín de Campos, pueblo fustigado por la emigración (ahora ya demolidas). A la derecha, la imagen del estado actual de la iglesia de San Juan Bautista de Tamariz de Campos, del siglo XVI, es un lamento hecho fotografía. 
Las tres alteraciones más significativas al paisaje de Tierra de Campos son la pérdida de vegetación (que afecta tanto al paisaje ecológico como al visual), el cambio de las características visuales básicas (afecta al paisaje visual) y la pérdida del patrimonio cultural (afecta al paisaje visual y, evidentemente, al cultural).

\subsection{Recuperación ambiental de los espacios degradados de Tierra de Campos}

El enfoque de recuperación, cambiar una situación insatisfactoria por otra que no lo sea, tiene una aplicación muy clara al paisaje, respecto del cual el término restauración es inaplicable porque, una vez alterado, es prácticamente imposible volver a la estructura, funcionalidad y atributos originales. En ocasiones se podrá recuperar alguna característica específica del paisaje primitivo, pero generalmente es preferible dirigir las aspiraciones hacia la creación de uno nuevo de la mejor calidad posible.

\subsubsection{Tratamientos generales de recuperación del paisaje de Tierra de Campos}

Para abordar, de una forma general, los tratamientos de recuperación del paisaje de la comarca se tomarán como partida los señalados por GÓMEZ OREA y VILLARINO (2004), que serán particularizados en función de los datos obtenidos en los anejos y las consideraciones que se han ido apuntando en los capítulos anteriores.

1.- Naturalización de las obras que conlleven movimientos de tierras. Ya se ha constatado que el paisaje de Tierra de Campos está constituido por amplias campiñas suavemente onduladas; en ellas no hay líneas rectas ni pendientes acusadas, la red hidrográfica natural tiene un contorno sinuoso y las primeras vías de comunicación se adaptaban al terreno. Los proyectos actuales de infraestructuras (caminos rurales, carreteras, autovías, líneas de ferrocarril, canales, balsas de riego, etc.) poseen otros requerimientos funcionales, quedando la integración en el terreno en una posición marginal en cuanto a su diseño. No obstante, se deberían cumplir unos requisitos mínimos para que su naturalización sea la máxima posible: adoptar trazados que no sean excesivamente rectilíneos, tratar de compensar el movimiento de tierras para que se minimicen las extracciones o los vertederos de inertes, procurar que no sean elevadas las alturas de desmontes y terraplenes, reducir al máximo su pendiente (máxima en todo caso $2 \mathrm{~V}: 3 \mathrm{H}$ ), redondear las aristas, etc. (Figura 6.49). Algunos de estos criterios son igualmente aplicables a las explotaciones mineras, préstamos de materiales y vertederos de inertes, que se generan a partir de las obras anteriores y que afectan a grandes superficies de terreno. En todos estos casos, el hecho de que las remodelaciones topográficas sean cuidadas y procuren formas naturales, hace que se consiga de una forma espontánea la restauración herbácea de los terrenos. 


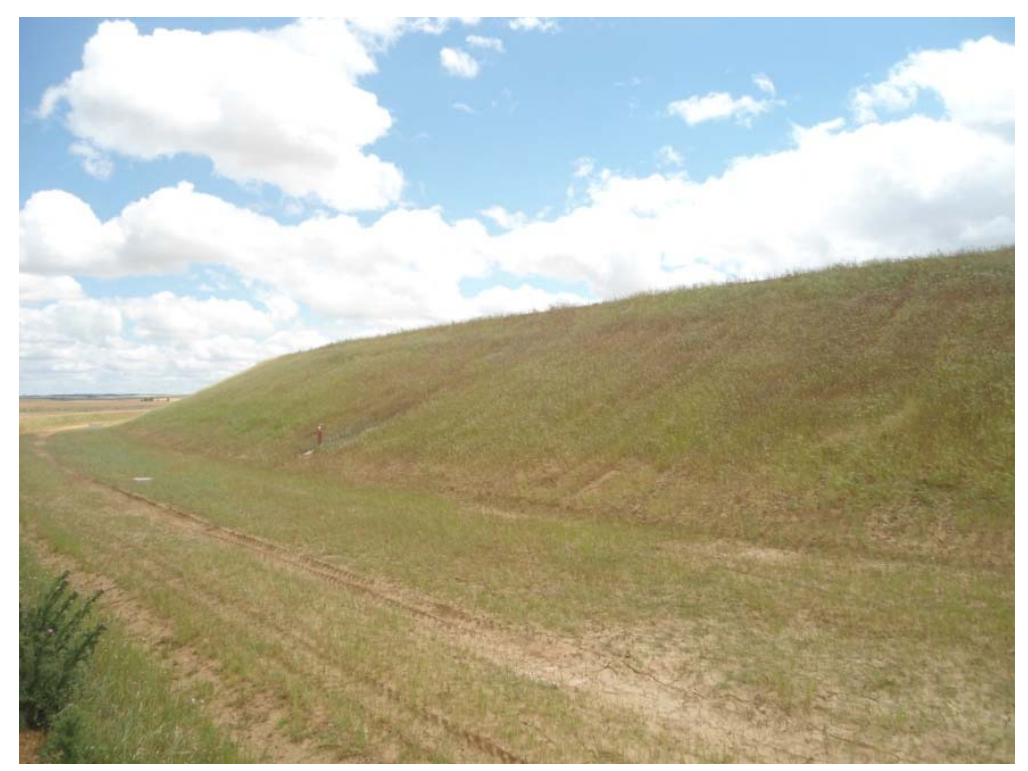

Figura 6.59. Ejemplo de naturalización de un gran talud de terraplén de la balsa de riego del sector $V$ Esla-Carrión. A pesar de su altura, la pendiente es relativamente reducida, lo que favorece su cobertura con herbáceas.

2.- Restauración vegetal con árboles y arbustos. Se ha indicado en numerosas ocasiones en los apartados anteriores que una de las principales degradaciones paisajísticas de Tierra de Campos es la falta de vegetación arbustiva y arbórea. Las causas son múltiples y no se van a repetir aquí, pero lo cierto es que la comarca fue mayoritariamente un bosque en las épocas anteriores al asentamiento humano sedentario, se conservó durante siglos como un sistema agrario tradicional que convivió con notables teselas de vegetación, y en la actualidad presenta escasísimos ejemplares de árboles y arbustos. Por ello se considera que el grueso del tratamiento de recuperación ambiental debe ir dirigido hacia la restauración vegetal (Figura 6.60). Son muchos y variados los beneficios que conlleva la vegetación y, como tales, han de ser aprovechados para mejorar la calidad del paisaje de Tierra de Campos. La forma adecuada de llevar a cabo las plantaciones ya se ha relatado en los antecedentes, por lo que tan solo se exponen a continuación una serie de consideraciones básicas sobre este tratamiento:

- Las plantaciones vegetales han de abarcar la máxima superficie a recuperar posible, utilizando cualquier espacio disponible. En otras palabras, utilizando un antiguo lema publicitario de la Diputación de Zamora, "Donde un árbol cabe, ¿por qué no lo hay?". Para ello se debe hacer de la necesidad virtud, es decir, aprovechar al máximo todos los espacios degradados para introducir árboles y arbustos.

- La elección de especies es fundamental (ver listado aparte) y, en el caso de los árboles, muy importante la diferenciación entre zonas secas y húmedas. Estas últimas han de ser prioritarias, ya que el crecimiento de la vegetación será mayor.

- Debido a las características limitantes del clima y el suelo de Tierra de Campos, todo el procedimiento de restauración vegetal (ver antecedentes), desde la preparación del terreno al mantenimiento de los primeros años, ha de realizarse con el máximo rigor. 
- La restauración vegetal debe ser persistente; los millones de hectáreas repoblados en España en las últimas décadas solo han podido realizarse gracias a la perseverancia.
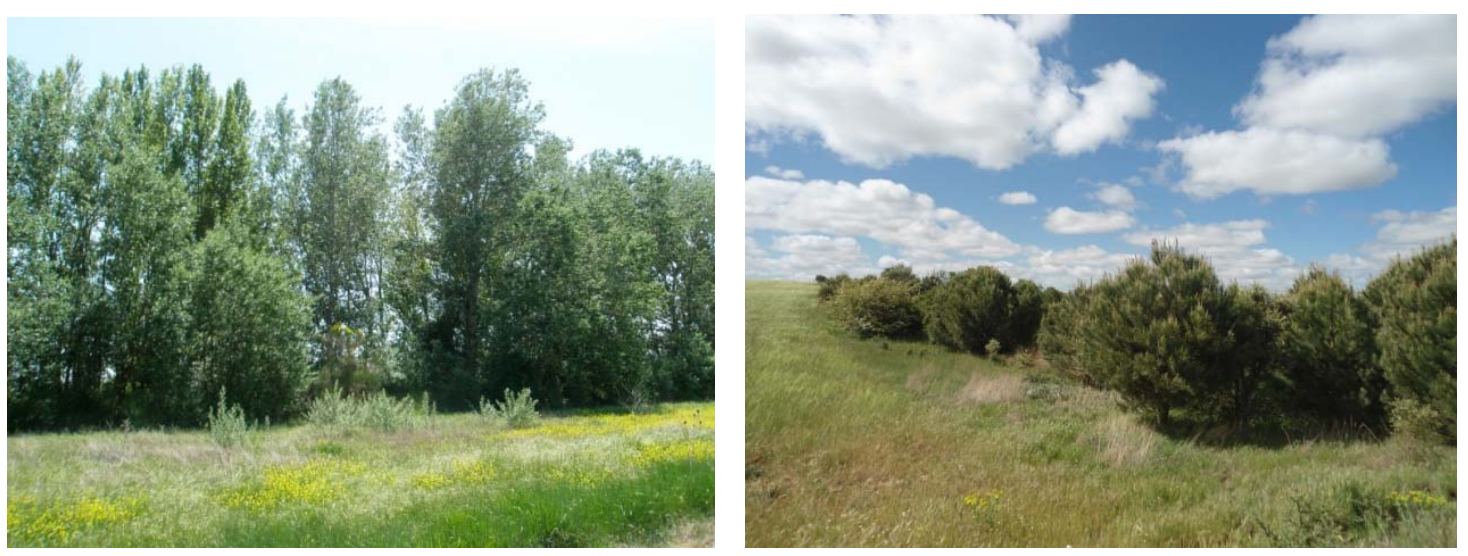

Figura 6.60. Restauraciones vegetales en el río Templarios, en Villelga (izquierda), y repoblación forestal en Herrín de Campos (derecha).

3.- Limpieza, retirada y restauración de depósitos de escombros. En principio, todos los ayuntamientos de Tierra de Campos disponen de un sistema de gestión de residuos urbanos, que tiene su base en la disposición de contenedores de basura, vidrio y cartón en los pueblos. Lo que ya no es tan evidente es que todos ellos realicen la limpieza de sus calles con la periodicidad que se requiere; no es este un asunto baladí, ya que se trata de un buen indicador del cuidado con el que se atiende un municipio. Resulta fundamental, asimismo, la limpieza de otros espacios periurbanos (aunque la periodicidad sea mayor): lugares próximos a explotaciones de ovino, solares abandonados, márgenes de calles, etc. De igual modo, es conveniente la retirada de los depósitos de escombros que aparecen en márgenes de caminos o pequeñas parcelas públicas, así como la restauración y clausura de escombreras. En estos últimos casos, resulta fundamental que paralelamente se lleve a cabo una gestión municipal eficaz que facilite la recogida de escombros y su posterior entrega a planta de reciclaje de residuos de construcción y demolición.
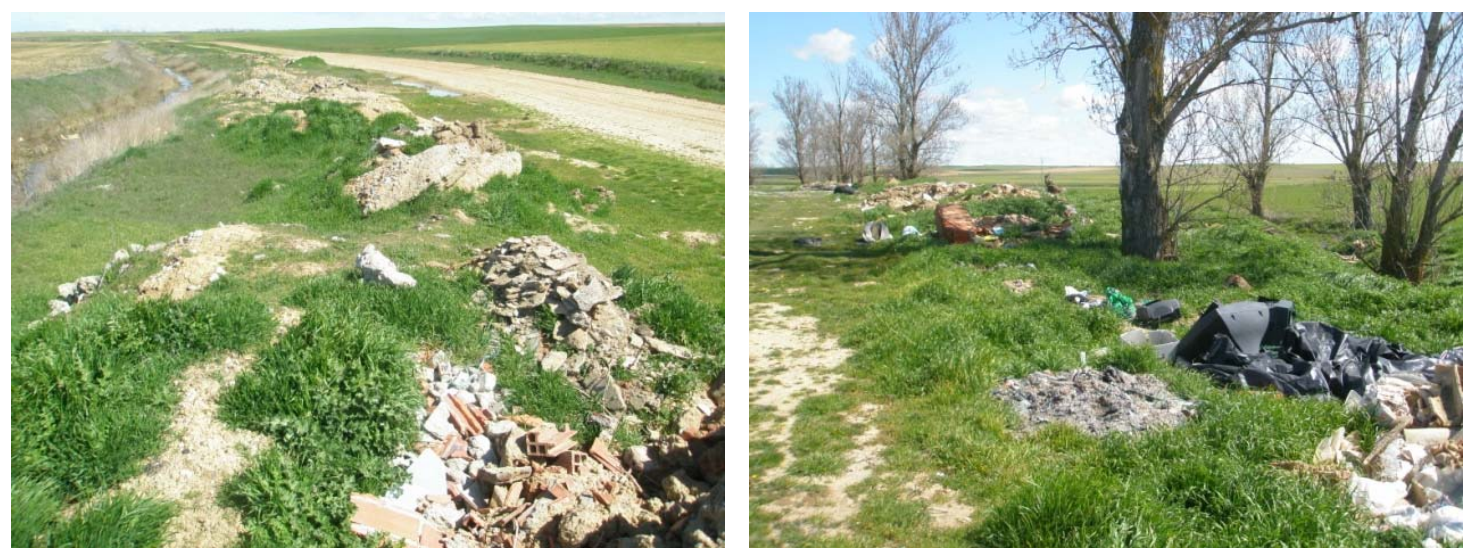

Figura 6.61. Dos zonas de depósito incontrolado de residuos y escombros en Herrín de Campos (izquierda) y Boadilla de Rioseco (derecha), afortunadamente ya restauradas. 
4.- Eliminación o reubicación de los elementos degradantes. Eliminar o cambiar la ubicación de cualquier elemento incoherente en la armonía de un paisaje o que suponga un obstáculo a su contemplación (Figura 6.62), es una norma de carácter general, cuya aplicación no siempre es posible. Se trata de la solución más eficaz pero más difícil. El momento más idóneo para su valoración sería el previo a la autorización (herramientas preventivas), porque posteriormente es prácticamente imposible eliminar la alteración. En algunas ocasiones de pequeña entidad, este tratamiento sí que puede llevarse a cabo, como la basura de los márgenes de las carreteras (que ha de ser limpiada periódicamente), los depósitos incontrolados de residuos (que deben ser retirados y gestionados adecuadamente) o los estercoleros en lugares inadecuados (que pueden ser reubicados).

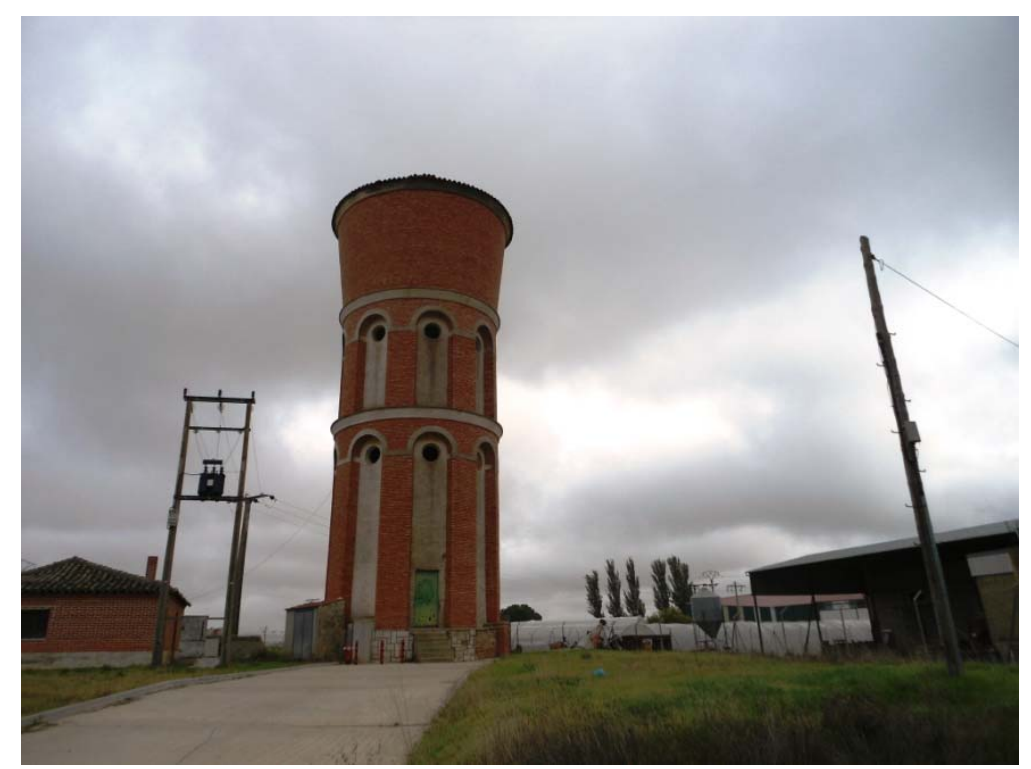

Figura 6.62. En la imagen se perciben dos alteraciones a un antiguo depósito de agua catalogado urbanisticamente -transformador y apoyo de línea eléctrica-, cuya retirada es relativamente sencilla.

5.- Restitución o mejora de los atributos de calidad. Esta idea exige identificar, de la forma más objetiva posible, los atributos más significativos y valiosos que caracterizaban el paisaje para intentar restablecerlos. La distribución y ordenación de tales atributos permite crear composiciones con grandes cualidades estéticas: se trata, en suma, de recomponer la armonía (agregación ordenada y coherente de las partes), y de proporcionar variedad, fuerza, personalidad o unicidad al nuevo paisaje). Uno de los atributos más significativos del paisaje de campiñas cerealistas de Tierra de Campos anterior a las primeras concentraciones parcelarias (década de los sesenta del siglo pasado) era la presencia de setos vegetales en los lindes de muchas parcelas, lo que proporcionaba una gran diversidad estética y ecológica. Por consiguiente, la creación de setos arbóreos y arbustivos allá donde se pueda (márgenes de caminos, vías pecuarias, arroyos, márgenes de carreteras, etc.) conllevará un innegable aumento de la calidad del paisaje. Otra posibilidad de este tratamiento radica en la restauración de los palomares (Figura 6.63) -que es uno de los elementos más significativos del paisaje castellano- o de otros bienes del patrimonio etnográfico como las fuentes del campo. 
Finalmente, la recuperación del patrimonio histórico-artístico y arquitectónico tradicional de Tierra de Campos debe ser uno de los hitos en cualquier tratamiento paisajístico.

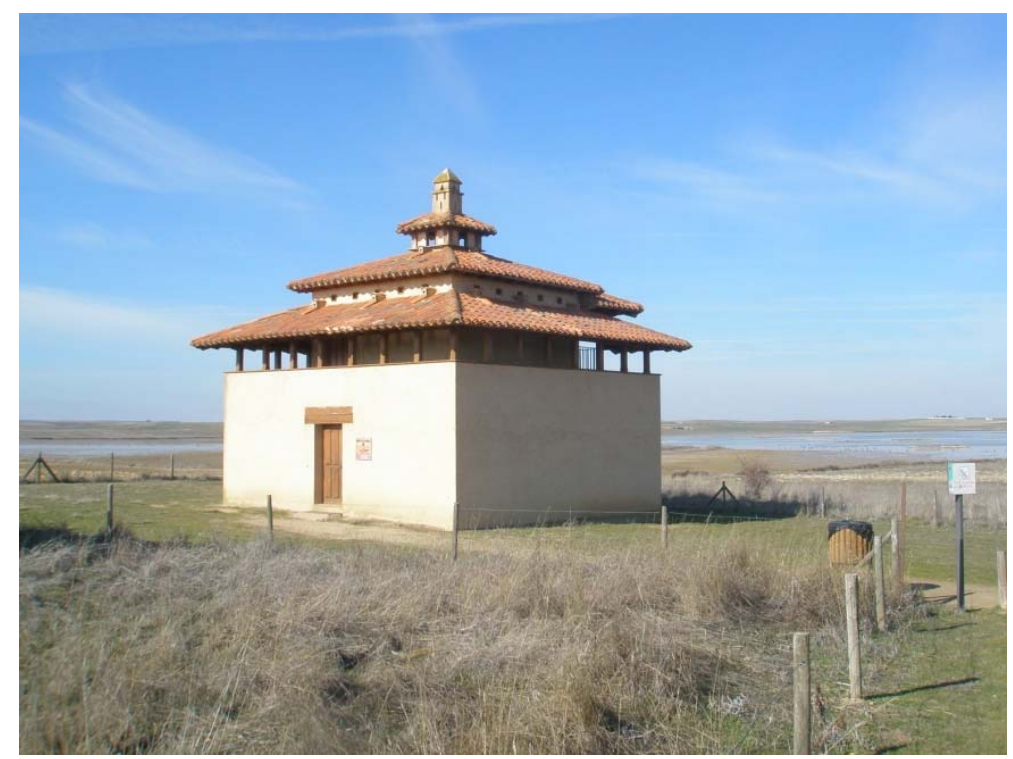

Figura 6.63. Magnífico ejemplo de valorización de atributos de calidad: palomar en Otero de Sariegos que mejora el paisaje y sirve como mirador de las lagunas de Villafáfila.

6.- Integración de los nuevos componentes. Este enfoque pretende conseguir que los elementos degradantes se inserten en el paisaje, buscando la similitud con el inicial o creando uno nuevo. Es el caso de la integración mediante su tratamiento vegetal de los taludes creados en las obras de construcción de las grandes infraestructuras lineales, o de las canteras de arcilla. En otras ocasiones pueden ser los materiales los que permitan la integración, como la utilización de piedra de la zona en las escolleras de protección de los cauces o mortero bastardo en muros o edificios. Asimismo, el color juega un papel fundamental en la integración: los colores ocres y terrosos han de estar en la paleta de cualquier edificación. La integración no debe evitar la necesidad de planificar una adecuada ubicación de los elementos degradantes; por ejemplo, la alteración provocada por las naves ganaderas contiguas al monasterio cisterciense de Ribas de Campos solo se corregirá de forma leve mediante su integración (Figura 6.64), porque se parte de un impacto casi crítico. 


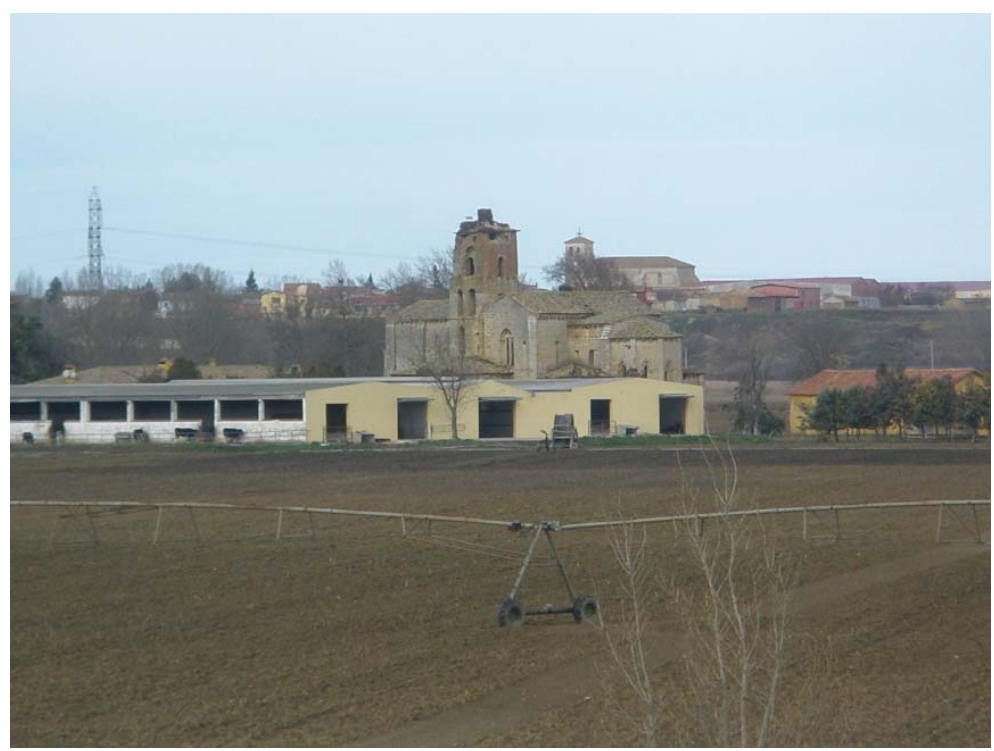

Figura 6.64. Fotografía de las naves ganaderas contiguas al monasterio de Ribas de Campos, tomada en enero de 2014, una vez pintados en tonos ocres sus paramentos frontales. Tal como se puede apreciar, el impacto visual del blanco inicial se reduce sensiblemente.

7.- Potenciación de los elementos nuevos más valiosos. Se trata de hacer, cuando lo merezca, del elemento distorsionante un elemento relevante, modificando su función sensorial y hasta la cultural. No hay que olvidar que existen obras fruto de la mano del hombre que, en cualquier ubicación, siempre mejoran el marco. En Tierra de Campos puede ser el caso de determinados puentes y viaductos de la autovía del Camino de Santiago, así como de otras estructuras de la línea de ferrocarril de alta velocidad (Figura 6.65). Este enfoque, muy adecuado para zonas humanizadas, precisa que la calidad del elemento potenciador sea alta y destaque por su diseño, por la composición o por los materiales utilizados.

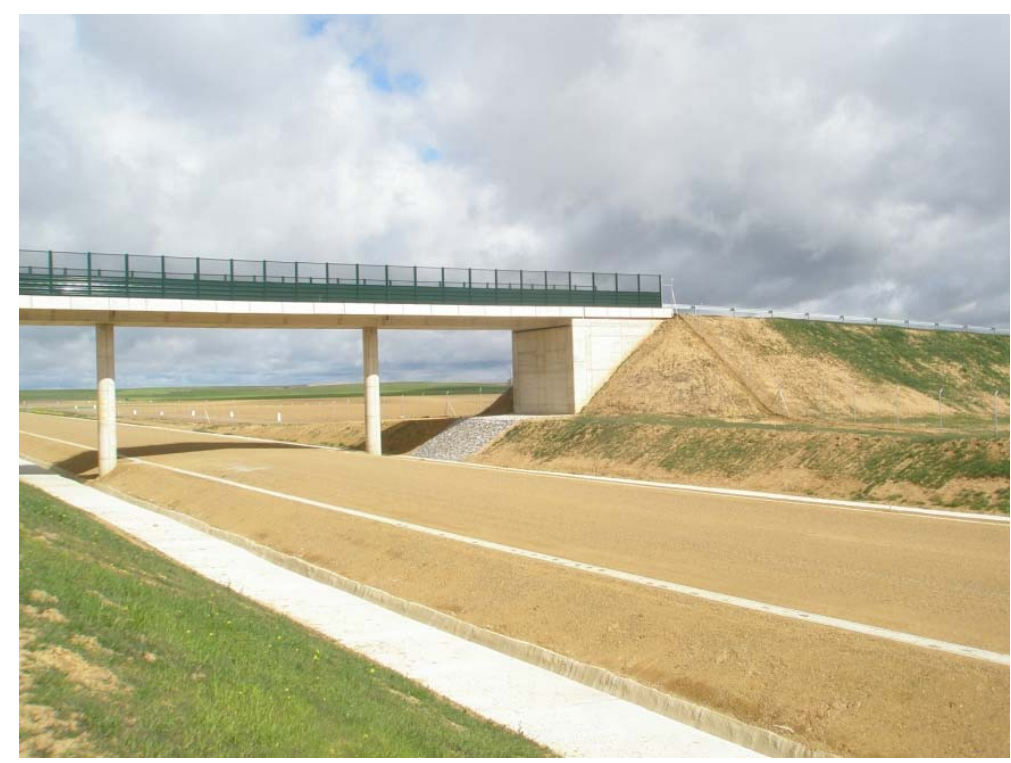

Figura 6.65. Paso superior en el AVE Palencia-León, que embellece el paisaje por su integración, armonía y gracilidad de sus formas. 
8.- Ocultación de los elementos negativos. Este tratamiento pretende reducir las cuencas visuales mediante pantallas que impidan la observación directa de los elementos discordantes o no integrados. En los cascos urbanos, la pantalla más eficaz sería el muro de fábrica; en espacios periurbanos o rústicos, donde es usual la instalación de vallados metálicos de delimitación de las parcelas, es de aplicación sencilla la colocación de mallas de brezo, cañas o material plástico verde (Figura 6.66).
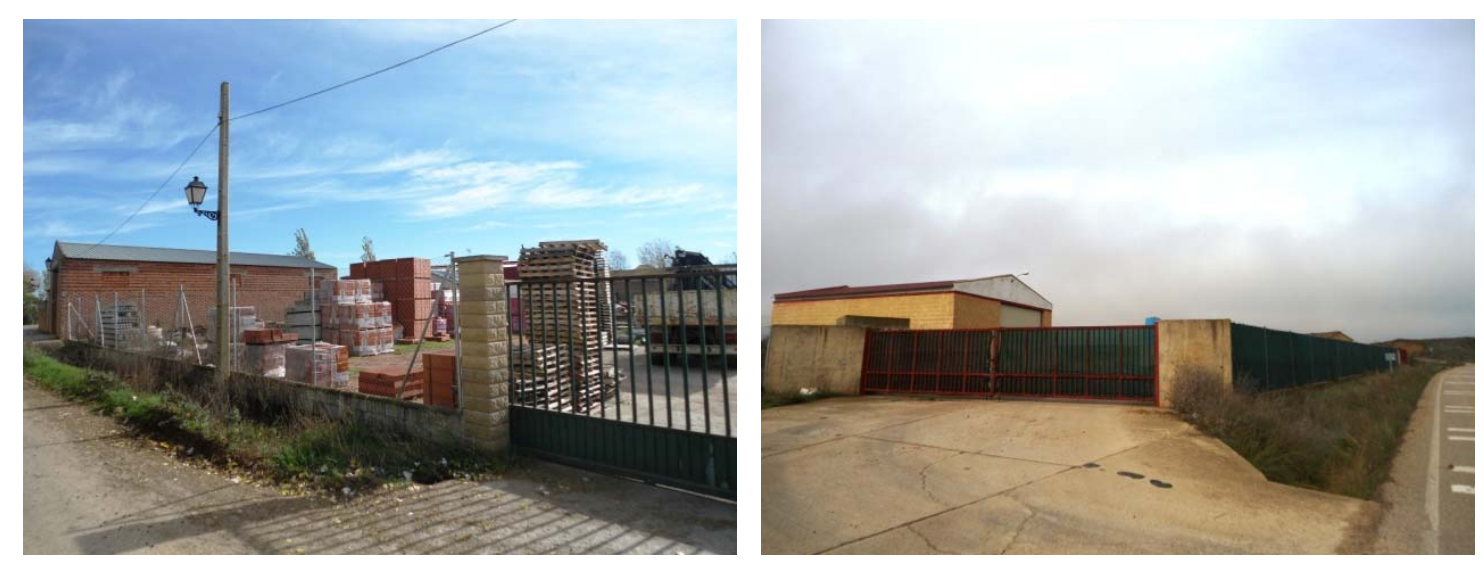

Figura 6.66. Dos parcelas similares de almacén de materiales detectadas en los Recorridos paisajísticos en Villalón de Campos; la de la izquierda sin ocultación, la de la derecha, con malla de plástico verde.

Una solución más natural, aunque requiere de más tiempo para cumplir el objetivo, es la implantación de pantallas vegetales, bien sea con setos arbustivos o bien con árboles y arbustos perimetrales (Figura 6.67). Es conveniente emplear vegetación autóctona o propia de la zona, aunque en determinadas situaciones es útil la selección de especies exóticas de crecimiento rápido. En cualquier caso, la utilización de pantallas no debe dejar sin corregir otros impactos, como puede ser el caso de las plantaciones de cupresáceas en carreteras, realizadas para ocultar la erosión de sus taludes de desmonte.
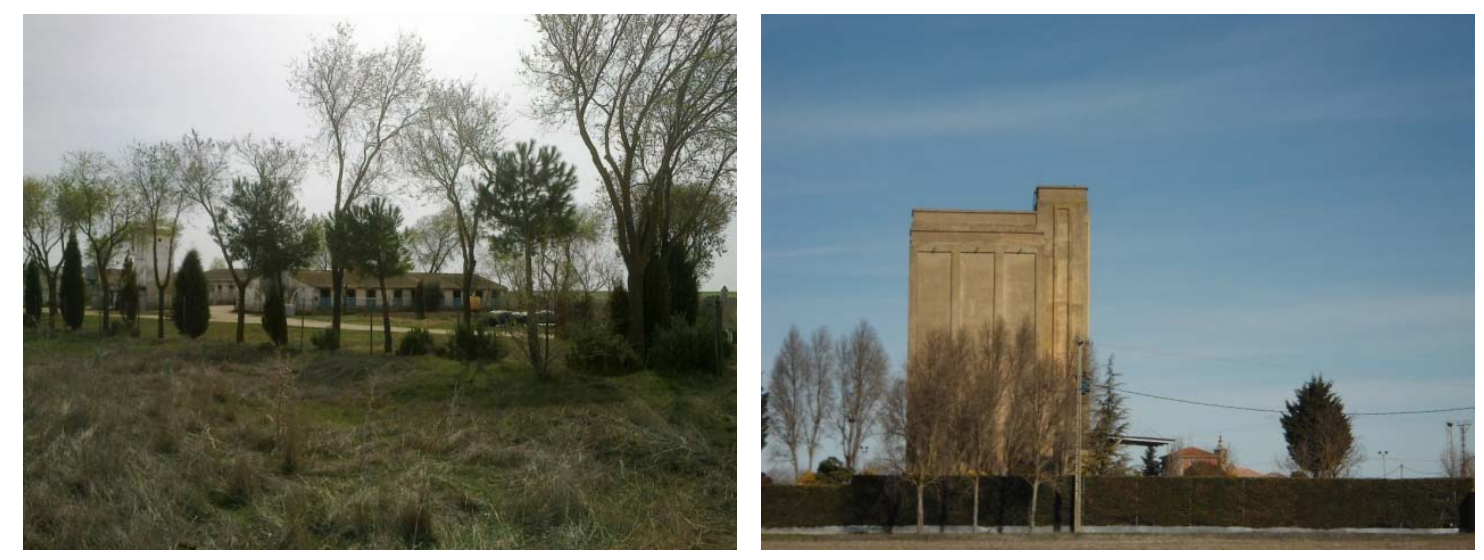

Figura 6.67. Izquierda, pantalla vegetal formada por pinos piñoneros, cipreses, olmos y romeros en una explotación porcina de Cuenca de Campos. Derecha, silo de almacenamiento de cereal integrado cromáticamente y con pantalla vegetal. 
9.- Camuflaje de elementos impactantes. Consiste en modificar las características del elemento impactante de tal forma que le haga parecer lo que no es, o se disimule su aspecto (Figura 6.68). Podría decirse que se asemeja a los trampantojos: dibujos que se plasman en las fachadas ciegas de grandes edificios y cambian su apariencia dura por escenas que parecen reales, propias de su entorno. Esta solución busca un mimetismo o enmascaramiento de las construcciones, o elementos nuevos, con el medio. En este caso no sería adecuado hablar de una armonía, ya que este concepto no es aplicable a elementos uniformes.
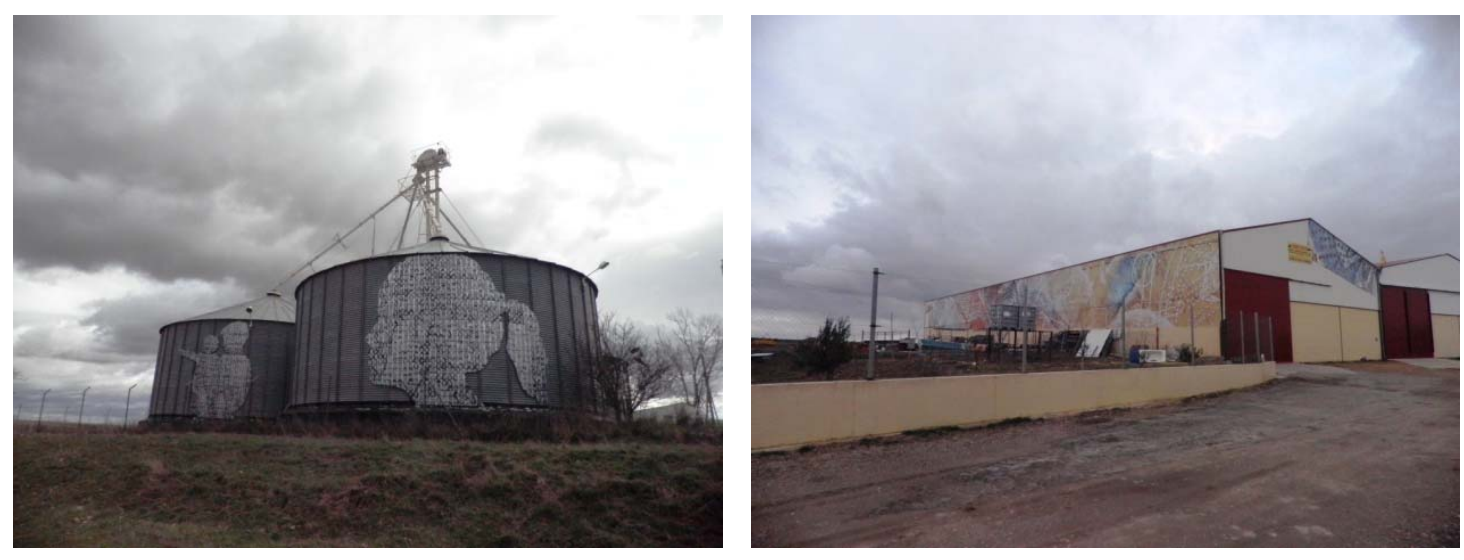

Figura 6.68. Construcciones en suelo rústico disimuladas con motivos artísticos en Boadilla de Rioseco. A la izquierda, cientos de fotografías componen la imagen de niños en silos de grano; a la derecha, un mural pintado en los paramentos de una nave agraria.

En ocasiones, la pintura de ese elemento discordante, con los colores que predominan en la zona, enmascara su presencia. Es el caso del cambio del metalizado de las torres de tendidos aéreos, por el color del trasfondo o por uno que no brille. Otras veces se trata de construir con materiales de la zona, o diseñar los elementos de más incidencia visual según diseño de la tipología del lugar. Es el caso de los antiguos depósitos de agua de muchos pueblos, que simularon la forma de los palomares y que ahora se encuentran en los catálogos de protección urbanística (Figura 6.69).

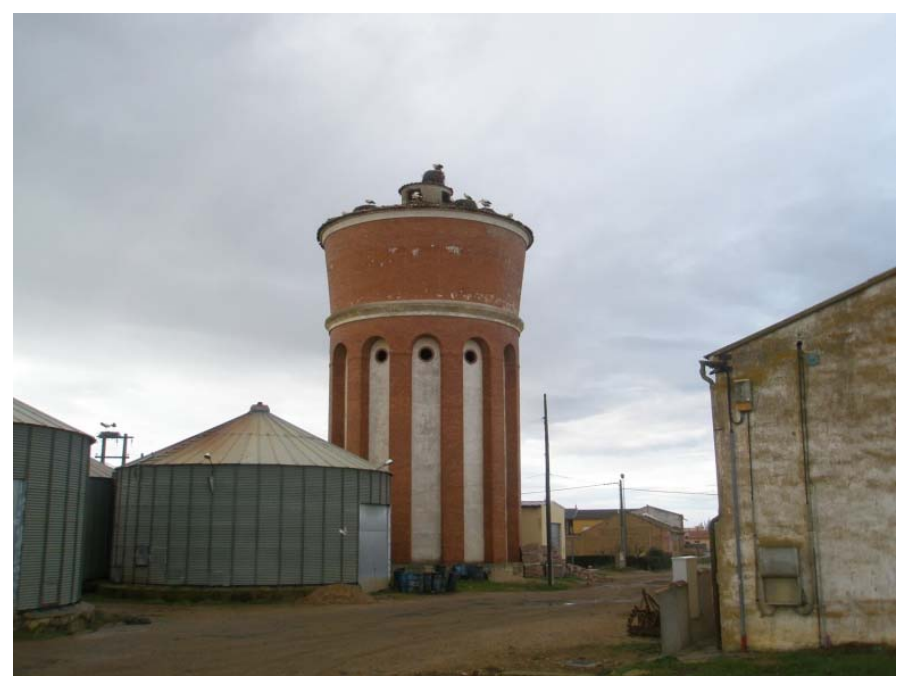

Figura 6.69. Depósito de agua en Becerril de Campos, en el que anidan numerosas cigüeñas. 
10.- Cambio de los puntos focales de atracción visual. Se trata de una especie de engaño a la percepción que pretende motivar a los observadores para que orienten sus miradas a los puntos focales, o a los elementos del paisaje más valiosos, y desviarlos de los deteriorados. Podría consistir, por ejemplo, en la plantación de árboles que dirigieran la vista hacia un fondo o elemento atractivo, y la sustrajera de los laterales próximos si contuvieran degradaciones. Se materializa este enfoque situando elementos llamativos, o atractivos a la vista, en zonas diferentes a las afectadas por una alteración con el fin de que esta pase desapercibida. Este tratamiento sería muy aplicable para las carreteras de entrada a los pueblos, que generalmente conducen en línea recta a las iglesias, donde con plantaciones lineales en los márgenes se podrían resaltar estos elementos del patrimonio además de desviar la atención de los deterioros de los espacios periurbanos.

\subsubsection{Actuaciones de recuperación ambiental}

Se han diagnosticado 14 espacios degradados diferenciados en Tierra de Campos. En cada uno de ellos se realizará una sintética caracterización y se definirán una serie de actuaciones (Tabla 6.4), recogiéndose 56 en total. A su vez, en ellas se plantearán subactuaciones o unidades de obra.

Tabla 6.4. Actuaciones de recuperación ambiental planteadas en los espacios degradados de Tierra de Campos

1. Espacios con agricultura intensiva afectados por concentraciones parcelarias

- Restauración vegetal de márgenes de caminos

- Restauración vegetal de arroyos y regueras

- Restauración vegetal de parcelas sobrantes

- Plantaciones de diversificación en las parcelas agrícolas

\section{Espacios afectados por transformaciones en regadío}

- Restauración vegetal de márgenes de canales

- Creación de senderos por los caminos de servidumbres

- Naturalización de balsas de riego

- Creación de observatorios de avifauna en balsas de riego

- Integración paisajística de edificaciones ligadas al regadío

3. Espacios afectados por infraestructuras lineales de transporte

- Recuperación ambiental de zonas afectadas por autovías y nuevas carreteras

- Recuperación ambiental de zonas afectadas por ferrocarriles de alta velocidad

- Recuperación ambiental de zonas afectadas por ferrocarriles convencionales existentes

- Recuperación paisajística de carreteras existentes 


\section{Espacios afectados por explotaciones mineras, préstamos y vertederos}

- Restauración de extracciones

- Restauración de vertederos

\section{Espacios afectados por infraestructuras energéticas}

- Ocultación parcial de huertos solares

- Ocultación o integración de centros de transformación y subestaciones eléctricas

- Restauración de las zonas ocupadas por aerogeneradores y apoyos de las líneas eléctricas

- Restauración de márgenes de caminos de acceso

- Integración de infraestructuras energéticas mediante plantaciones vegetales

- Creación de miradores

- Instalación de salvapájaros en las líneas eléctricas de alta tensión

\section{Ríos y arroyos desnaturalizados}

- Rehabilitación de ríos y arroyos desnaturalizados

\section{Zonas húmedas degradadas}

- Restauración de zonas húmedas

\section{Vías pecuarias y del ferrocarril sin uso}

- Restauración de cañadas y cordeles como grandes corredores ecológicos

- Recuperación de veredas y pequeñas vías pecuarias

- Rehabilitación como Vía Verde de las antiguas vías del ferrocarril

\section{Fuentes y pequeñas parcelas públicas degradadas}

- Restauración natural de fuentes

- Restauración forestal-natural de pequeñas parcelas públicas

\section{Espacios deforestados y/o erosionados}

- Restauración hidrológico-forestal de laderas desarboladas

- Repoblación forestal de eriales y terrenos agrícolas marginales

- Tratamientos selvícolas y plantaciones de diversificación en laderas repobladas

\section{Escombreras y vertederos de residuos}

- Restauración de vertederos de residuos

- Restauración de escombreras

- Restauración de espacios afectados por depósitos puntuales de escombros

\section{Entorno de construcciones en suelo rústico}

- Integración de paramentos y cubiertas

- Realización de pantallas vegetales 


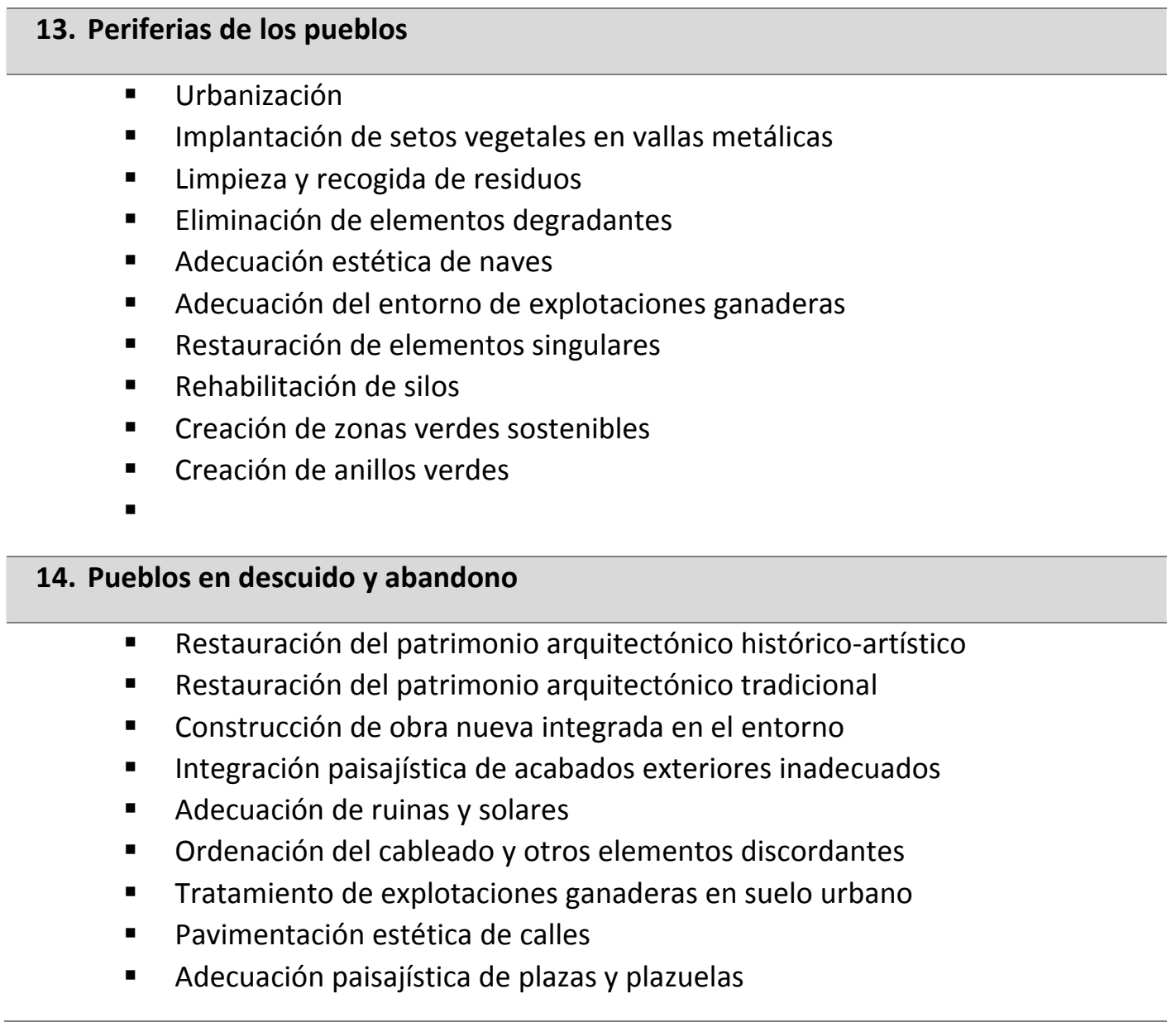

\subsubsection{Espacios con agricultura intensiva afectados por concentraciones parcelarias}

Nos encontramos con el primero y más amplio de los espacios degradados de Tierra de Campos, no en vano puede ocupar aproximadamente el $90 \%$ de su superficie. Está constituido por toda la matriz agrícola, caracterizada por la presencia de grandes parcelas, dominio del cereal, alto desarrollo tecnológico, caminos rectilíneos y arroyos y regueras encauzadas y rectificadas. Se trata de un espacio muy simplificado, con escasísima vegetación arbustiva o arbórea.

Esta recuperación es probablemente la más importante, teniendo en cuenta la entidad del espacio degradado; por ello será tratada con mayor detalle. Las actuaciones de recuperación ambiental planteadas son las siguientes:

\section{Restauración vegetal de márgenes de caminos.}

La longitud de los caminos rurales en Tierra de Campos es muy elevada. Para tener una referencia, en las 15970 ha de la zona de concentración parcelaria de Herrín de Campos, Villafrades de Campos, Villalón de Campos y Boadilla de Rioseco, la longitud total de los caminos es de 343,141 km, lo que supone una densidad de 0,021 km/ha o de $21 \mathrm{~km}$ cada 1000 ha. Si tenemos en cuenta que cada camino posee dos márgenes, nos podemos hacer una idea del potencial de esta malla de cara a la recuperación paisajística de esta comarca agraria. 
Por otro lado, en los Recorridos paisajísticos del anejo 3, con un tamaño de muestra de 65 mediciones, se han obtenido datos muy interesantes a tener en cuenta en esta actuación, reflejados en la Tabla 6.5 .

Tabla 6.5. Porcentaje de los distintos rangos de altura (longitud de pendiente) en los taludes de los caminos de Villalón de Campos.

\begin{tabular}{ccc}
\hline Rango de altura $(\mathrm{m})$ & Mediciones & Porcentaje \\
\hline $\mathbf{0}-\mathbf{1}$ & 18 & 28 \\
\hline $\mathbf{1}-\mathbf{2}$ & 41 & 63 \\
\hline $\mathbf{2}$ & 6 & 9 \\
\hline
\end{tabular}

La pendiente media es de $34^{\circ}(2 \mathrm{~V}: 3 \mathrm{H})$, relativamente tendida. El $28 \%$ de los taludes son de terraplén y el $72 \%$ de desmonte, teniendo en cuenta que siempre se ha tomado el que tiene mayor altura. Es decir, estos datos constatan que existe una importante superficie susceptible de ser restaurada vegetalmente.

Se descarta la restauración vegetal en los taludes menores de $1 \mathrm{~m}$, para evitar problemas con los colindantes (intrusión de la cuneta, aplicación de herbicidas, etc.).

Además de restaurar estas zonas alteradas, las plantaciones cumplirían otras funciones: evitar intrusiones de colindantes en las cunetas, minimizar la erosión de los taludes, generar corredores ecológicos, integración paisajística de las obras amortiguando la regularidad del camino, etc. (Figura 6.70).

Teniendo en cuenta que se trata de terrenos públicos, la actuación debiera ser promovida por la Administración: en principio la Consejería de Agricultura y Ganadería como promotora de las concentraciones parcelarias. Como en la mayoría de los casos estas ya se han realizado hace muchos años, la titularidad de los terrenos corresponde a los Ayuntamientos, quienes podrían promover estas recuperaciones.

Se plantean los siguientes tipos de plantación:

Tipo C1: taludes con longitud entre 1 y $2 \mathrm{~m}$.

- Plantación de arbustos.

- Sería preferible en ambos márgenes; en caso contrario, alternar cada margen priorizando desmontes, mayor altura o umbrías.

- Planta localizada a mitad del talud, para no molestar ni al propietario contiguo ni alterar el funcionamiento de la cuneta.

- Separación aproximada entre ejemplares de $5 \mathrm{~m}$.

- Distribución de planta por bosquetes.

- Planta de 1 savia con envase.

- Preparación del terreno mediante ahoyado con retroexcavadora pequeña o barrena, profundidad $40 \mathrm{~cm}$.

- Colocación de protectores perforados (posible presencia de ovejas y tratamientos con herbicidas). 
- Formación de alcorque.

- Riego 2 años y reposición de marras.

- Especies recomendadas: Escaramujo (Rosa canina), retamas negra (Spartium junceum) y blanca (Retama sphaerocarpa), tamariz (Tamarix sp.), endrino (Prunus spinosa), romero (Rosmarinus officinalis), genista (Cytisus scoparius), etc.

Tipo C2: taludes con longitud mayor de $2 \mathrm{~m}$ y de caminos próximos a pueblos.

- Plantación de árboles.

- En principio, en las dos márgenes.

- A mitad del talud.

- Separación entre plantas, aproximadamente $5 \mathrm{~m}$. Si se ponen en las dos márgenes, se podría ampliar esta distancia a $8 \mathrm{~m}$.

- Distribución de planta por bosquetes.

- Planta de 1 savia con envase.

- Preparación del terreno mediante ahoyado con retroexcavadora o barrena, profundidad $40 \mathrm{~cm}$.

- Se podría valorar la conveniencia de utilizar planta de 2 savias y hoyos de $100 \mathrm{~cm}$.

- Formación de alcorque.

- Riego 2 años y reposición de marras.

- Colocación de protectores para proteger del ganado ovino y otros posibles daños.

- Especies recomendadas: Almendro (Amygdalus communis) (debería ser la especie principal, en torno a un $50 \%$ ), encina (Quercus ilex), quejigo (Quercus faginea), olmo (Ulmus minor), serbal o jerbo (Sorbus domestica), acerolo (Crataegus azarolus), etc; en zonas periurbanas se podría emplear acacia (Robinia pseudoacacia), plátano (Platanus hybrida) o incluso Cupressus. Si hay humedad, emplear chopo (Populus nigra) y álamo (Populus alba).

Tipo C3: caminos de circunvalación con sobreancho (solo se da en algunas concentraciones parcelarias, como la analizada en el anejo 1).

- Plantación de árboles y arbustos.

- En principio, en los dos márgenes (o en el margen del sobreancho, si es único).

- Los arbustos se colocarán como lindero en la colindancia con la parcela particular, para evitar intrusiones. Los árboles se pueden plantar en el borde de la arista exterior del talud (inicio del margen).

- Separación entre arbustos, entre 3-4 m. La correspondiente a árboles se puede aumentar a $6 \mathrm{~m}$.

- Distribución de la planta por bosquetes.

- Planta de 1 savia con envase.

- Para los arbustos, preparación del terreno mediante subsolado lineal; para los árboles, o este mismo método o ahoyado con retroexcavadora o barrena. En ambos casos, profundidad $40 \mathrm{~cm}$.

- Se podría valorar la conveniencia de utilizar planta de 2 savias y hoyos de $100 \mathrm{~cm}$.

- Riego 2 años y reposición de marras.

- Colocación de protectores para el ganado ovino. Al menos, señalización de las plantaciones en el margen.

- Especies recomendadas: Dentro de los arbustos, escaramujo (Rosa canina), retamas negra (Spartium junceum) y blanca (Retama sphaerocarpa), tamariz (Tamarix sp.), 
endrino (Prunus spinosa), romero (Rosmarinus officinalis), genista (Cytisus scoparius), etc. Dentro de los árboles, almendro (Amygdalus communis) (debería ser la especie principal, en torno a un $50 \%$ ), encina (Quercus ilex), quejigo (Quercus faginea), olmo (Ulmus minor), serbal o jerbo (Sorbus domestica), acerolo (Crataegus azarolus), etc. En la elección de especies es interesante acudir a aquellas que tengan capacidad de rebrote, pues hay que prever posibles limpiezas de los taludes de los caminos con motoniveladoras.

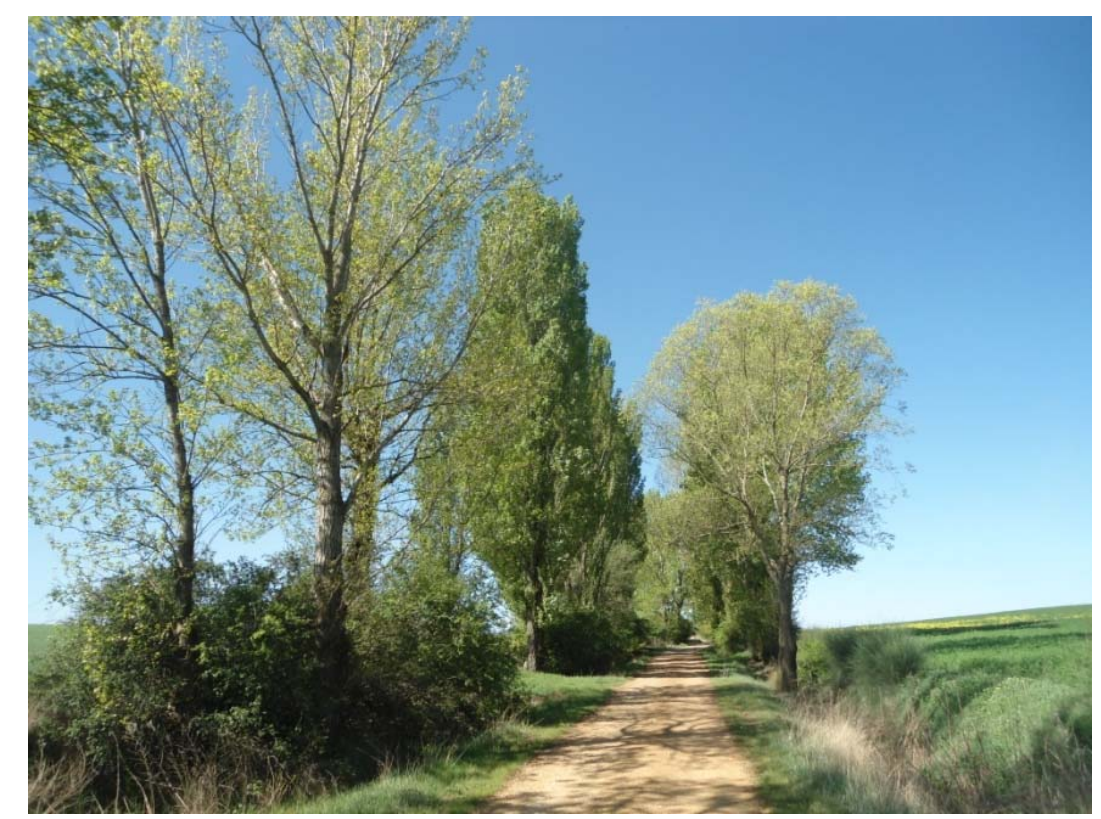

Figura 6.70. Imagen ideal de márgenes restaurados de camino rural, con mezcla de vegetación arbustiva y arbórea (Recorrido paisajístico 30).

\section{Restauración vegetal de arroyos y regueras}

La red hidrográfica de segundo orden también supone una importante magnitud en Tierra de Campos. En la zona de concentración parcelaria mencionada de Herrín de Campos, Villafrades de Campos, Villalón de Campos y Boadilla de Rioseco, de 15970 ha, la longitud total de desagües es de 295,355 km, lo que supone una densidad de 0,018 km/ha ó $18 \mathrm{~km}$ cada 1000 ha. Ello da idea de la gran posibilidad que supone la restauración de toda esta red que cose el territorio.

En la muestra de 47 mediciones realizadas en los Recorridos paisajísticos (anejo 3) se obtienen los datos mostrados en las Tablas 6.6 y 6.7, fundamentales para planificar esta actuación.

Tabla 6.6. Porcentaje de los distintos rangos de anchura en los arroyos y regueras de Villalón de Campos.

\begin{tabular}{ccc} 
Rango de anchura $(\mathbf{m})$ & Mediciones & Porcentaje \\
\hline $\mathbf{0}-\mathbf{2}$ & 0 & 0 \\
\hline $\mathbf{2}-\mathbf{3}$ & 21 & 45 \\
\hline $\mathbf{3}$ - $\mathbf{4}$ & 11 & 23 \\
\hline $\mathbf{4}$ - $\mathbf{5}$ & 8 & 17 \\
\hline
\end{tabular}




\begin{tabular}{ccc}
\hline $5-6$ & 4 & 9 \\
\hline$>6$ & 3 & 6
\end{tabular}

Tabla 6.7. Porcentaje de los distintos rangos de altura (longitud de pendiente) en los arroyos y regueras de Villalón de Campos.

\begin{tabular}{ccc}
\hline Rango de altura $(\mathbf{m})$ & Mediciones & Porcentaje \\
\hline $\mathbf{0}$ - 1 & 10 & 21 \\
\hline $\mathbf{1}$ - 2 & 31 & 66 \\
\hline $\mathbf{2}$ - 3 & 6 & 13 \\
\hline
\end{tabular}

La pendiente media de los taludes es de $40^{\circ}(1 \mathrm{~V}: 1,2 \mathrm{H})$.

Las finalidades de esta restauración son, sobre todo, hidrológicas, ecológicas y paisajísticas, aunque también contribuyen a proteger los márgenes frente a colindantes y a evitar que los cauces se vayan llenando de sedimentos.

Como en el caso anterior, la Consejería de Agricultura y Ganadería habría de ser la primera Administración responsable de la realización de esta actuación. En segunda instancia correspondería a la Confederación Hidrográfica del Duero, como organismo gestor del dominio público hidráulico.

En principio, se pueden definir tres tipos de plantaciones:

- Tipo A1: cauces menores (con altura de talud menor a $1 \mathrm{~m}$ o anchura inferior a $3 \mathrm{~m}$ )

o Plantación sobre todo de arbustos y sauces (se excluyen los tramos con presencia de matorral).

- En una sola margen, para que se pueda limpiar en su caso.

- Las plantas se localizarán a mitad del talud.

o Módulos de $200 \mathrm{~m}$, alternando márgenes. No obstante, conviene plantar en los taludes de mayor pendiente y en orientaciones norte (mayor humedad).

o Separación entre ejemplares de $5 \mathrm{~m}$.

o Distribución por bosquetes (por grupos de una misma especie).

o Planta de 1 savia con envase.

o Posible colocación de protectores.

o Método de preparación del terreno: ahoyado con retroexcavadora, barrena o similar, profundidad $40 \mathrm{~cm}$.

- Especies recomendadas: sauces (Salix, sp.), espino albar (Crataegus monogyna), escaramujo (Rosa canina) (Figura 6.71), tamariz (Tamarix gallica o Tamarix africana), etc. 


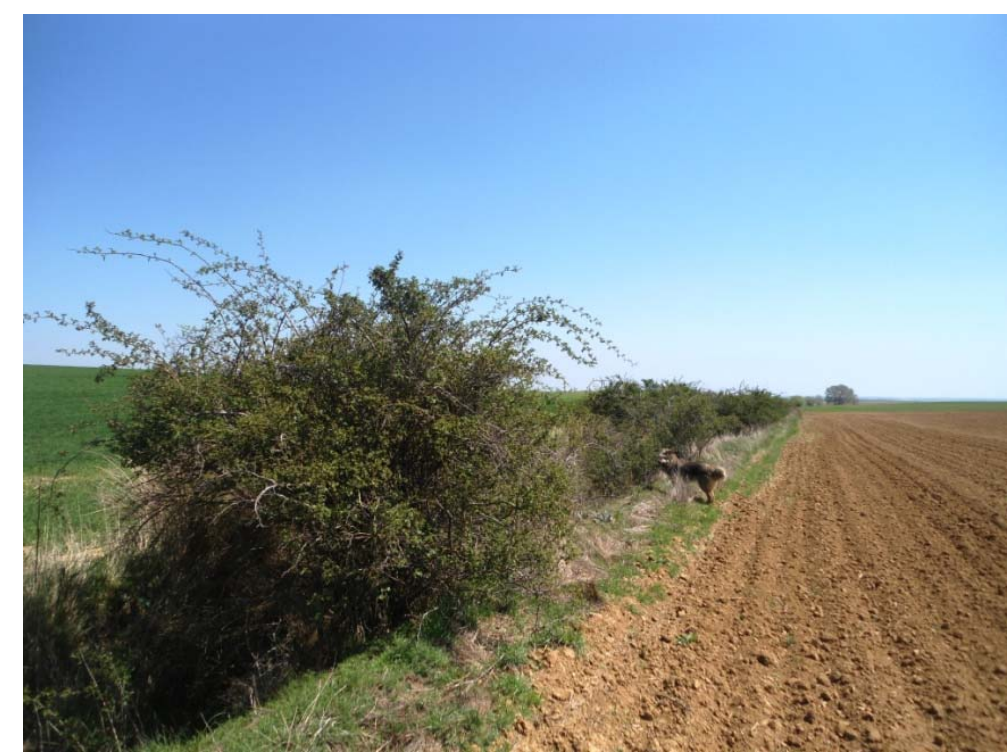

Figura 6.71. Reguera con vegetación arbustiva de escaramujos.

- Tipo A2: cauces mayores (con altura de talud mayor a $2 \mathrm{~m}$ o anchura superior a $3 \mathrm{~m}$ )

o Plantación sobre todo de árboles.

o En una sola margen.

o A mitad del talud.

o Módulos de $200 \mathrm{~m}$, alternados.

o Separación entre plantas de $5 \mathrm{~m}$.

o Distribución por bosquetes.

o Planta con envase o a raíz desnuda 1-2 savias.

o Ahoyado con retroexcavadora, profundidad $100 \mathrm{~cm}$.

o Especies: Chopo (Populus nigra) (40\%), álamo (Populus alba) (40\%), otras como fresno (Fraxinus angustifolia), sauce (Salix sp.), espino albar (Crataegus monogyna), etc. $(20 \%)$.

- Tipo A3: zonas puntuales con humedad permanente en cauces de los tipos anteriores

o Estaquillado (chopo, álamo, sauce, tamariz).

o Selección de estaquillas de la zona. Ramas de crecimiento del último año.

o Longitud mínima de $40 \mathrm{~cm}$. Más de $1 \mathrm{~cm}$ de grosor.

- Profundizar $2 / 3$ de la estaquilla.

o Separación $5 \mathrm{~m}$.

o Localización en margen del talud orientado a umbría. 


\section{Restauración vegetal de parcelas sobrantes}

En las concentraciones parcelarias recientes se deja un pequeño porcentaje de superficie de parcelas marginales dedicado a la restauración del medio natural, para compensar los daños sobre el medio ambiente. Como ejemplo representativo, en la concentración de Herrín de Campos, Villafrades de Campos, Villalón de Campos y Boadilla de Rioseco (analizada en el anejo 1), se han dejado 82 parcelas que ocupan 48,20 ha (0,30\% de la superficie total). En otras concentraciones más antiguas, existen parcelas de masa común que no fueron utilizadas en el proceso ni son labradas, y que también son susceptibles de restauración por ser públicas.

Aunque la superficie relativa de estas parcelas sea reducida respecto del total a concentrar, su importancia es muy grande, ya que están distribuidas por la inmensa matriz agrícola. Su repoblación conllevará una considerable mejora ecológica y paisajística del medio cerealista, caracterizado por la escasez de arbolado.

Como en el caso de los caminos, la primera Administración pública responsable de la recuperación de estas zonas debería ser la Consejería de Agricultura y Ganadería. Teniendo en cuenta que posteriormente su titularidad pasa a ser municipal, esta actuación podría ser promovida por las entidades locales.

Se plantean dos tipos de plantación, con un subtipo común para ambos:

- Tipo P1: zonas secas

o Plantación de árboles.

o Método de preparación del terreno: subsolado lineal.

o Marco de plantación 4×3 m (833 pies/ha).

o Profundidad $40 \mathrm{~cm}$.

o Planta de 1 savia con envase.

o Mezcla íntima de especies.

o Riego 2 años y reposición de marras.

- Convendría señalizar el perímetro de la plantación para evitar daños por ganado ovino.

o Especies recomendadas: Pino piñonero (40 \%), encina (20\%) quejigo (20 \%) y otras como olmo, jerbo, acerolo (20\%).

- Tipo P2: zonas húmedas próximas a arroyos.

- Plantación de árboles.

o Separación $4 \mathrm{~m}$, al tresbolillo (625 pies/ha).

o Por bosquetes.

- Planta a raíz desnuda de 1-2 savias.

o Ahoyado con retroexcavadora, profundidad $100 \mathrm{~cm}$.

- Riego 2 años y reposición de marras.

- Convendría señalizar el perímetro de la plantación para evitar daños por ganado ovino.

o Especies: Chopo castellano ( $40 \%$ ), álamo blanco (40 \%), otras como fresno, sauce, etc. ( $20 \%$ en total) 
- Subtipo 1-2: linderos con parcelas agrícolas (en los dos casos anteriores)

o Plantación de arbustos con el objetivo prioritario de delimitar la propiedad.

- Subsolado lineal con posible caballón de separación.

o Una única línea, separada $0,50 \mathrm{~cm}$ de la parcela colindante.

o Profundidad $40 \mathrm{~cm}$.

o Separación $3 \mathrm{~m}$.

o Planta de 1 savia con envase.

o Por bosquetes.

o Especies recomendadas: Escaramujo, retama negra (prioritaria, ya que crece muy rápido), retama blanca, tamariz, endrino, romero, genistas, etc.

\section{Plantaciones de diversificación en las parcelas agrícolas}

En este caso se trata de terrenos particulares, lo que conlleva una mayor dificultad para su ejecución. Aunque, como se ha relatado en los antecedentes, la diversificación del paisaje agrícola con setos, sotos ribereños y bosques isla tiene importantes beneficios ecológicos e incluso económicos, lo cierto es que los agricultores de Tierra de Campos no llevan a cabo estas actuaciones por sí mismos.

En la declaración de impacto ambiental sobre el proyecto de concentración parcelaria de Herrín de Campos, Villafrades de Campos, Villalón de Campos y Boadilla de Rioseco (ver anejo 1) se incluía la medida correctora de realizar plantaciones arbustivas por las lindes de las parcelas, dejando para ello una anchura mínima de 1,5 m. Esta condición no se ha cumplido, se imagina que por dificultades para llevarse a cabo y voluntad de la Administración para afrontarla. Aun cuando a buen seguro entraña dificultad, lo cierto es que desde un punto de vista paisajístico sería muy adecuada.

Por otra parte, el hecho de no existir delimitaciones físicas en los límites de las parcelas conlleva en muchos casos conflictos entre propietarios: en el mejor de los casos solo hay dos pequeños mojones en los extremos, que están muy alejados entre sí. Los arbustos, aunque fuesen de pequeño tamaño (matas), tendrían esta función de constituir un límite físico.

Teniendo en cuenta además de lo anterior la aplicación de la medida de condicionalidad de la PAC (1 árbol/ha) en los Recorridos paisajísticos del anejo 3, así como las previsiones de la modificación de la Política Agraria Común, esta actuación podría llevarse a cabo bajo los siguientes supuestos:

- Con la aceptación de los propietarios colindantes y con la promoción de la Administración, plantaciones de matas arbustivas en las lindes de las parcelas: endrino, romero, salvia, espliego, etc., cuyo crecimiento es reducido y mínimas las molestias al cultivo. La precaución fundamental es no afectar con las aplicaciones de herbicida.

- La ecologización (greening) del campo previsto en la modificación de la PAC debiera dirigirse en buena medida -al menos en Tierra de Campos- a la creación de áreas de interés ecológico con vegetación arbustiva y arbórea, que ocupen el mayor porcentaje posible de superficie cultivable. Si las expectativas del $7 \%$ previsto por la Comisión fuesen excesivas, cualquier aproximación ya sería un avance. Con los datos de la 
aplicación de la medida de 1 árbol/ha en Villalón de Campos, la superficie dedicada a este fin tan solo alcanza el $0,1 \%$, por lo que se puede intuir lo que se conseguiría con un porcentaje notablemente superior.

- En todo caso, la actuación debiera seguir el modelo de diversificación paisajística incluido en los antecedentes, de creación sobre todo de setos (alineaciones de arbustos y árboles), sotos en las proximidades de los arroyos (también alineaciones) y bosques isla.

- Las especies deben ser autóctonas o propias de la zona, incluidas en los listados incluidos en este estudio, pero abriéndose el abanico a almendros y otros frutales, que seguramente serán mejor vistas por los agricultores. Plantas de 1 ó 2 savias, de procedencias locales u homologables ecológicamente.

- Es fundamental una preparación del terreno adecuada, proponiéndose mejor el subsolado lineal con profundidad mínima de $40 \mathrm{~cm}$, realizado en el verano previo a la plantación.

- También son recomendables, asimismo, protectores, alcorques, riegos los dos primeros años, desherbados, acolchados y otros sencillos cuidados culturales que aseguren la pervivencia de las plantaciones. 
Orillas de caminos y cañadas.
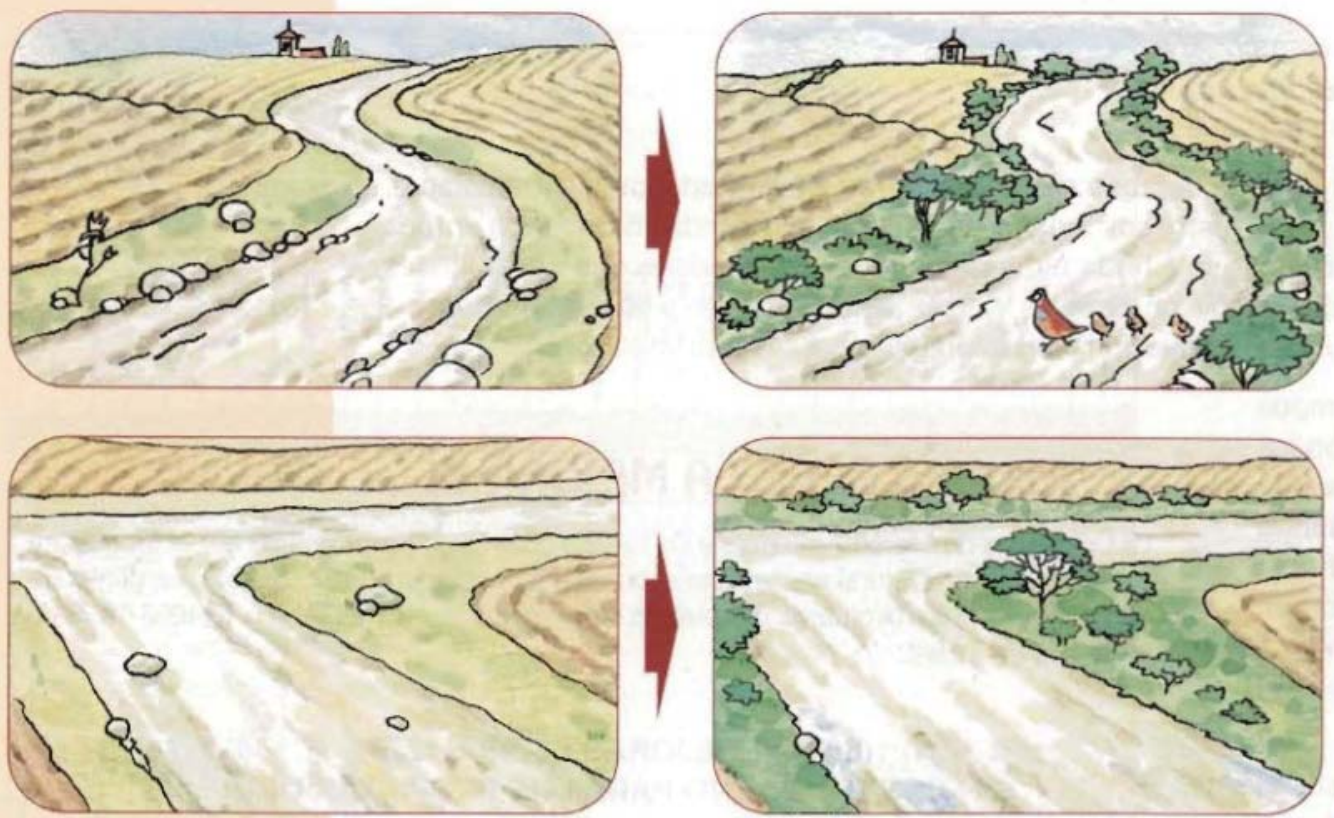

Las cuestas de los páramos.
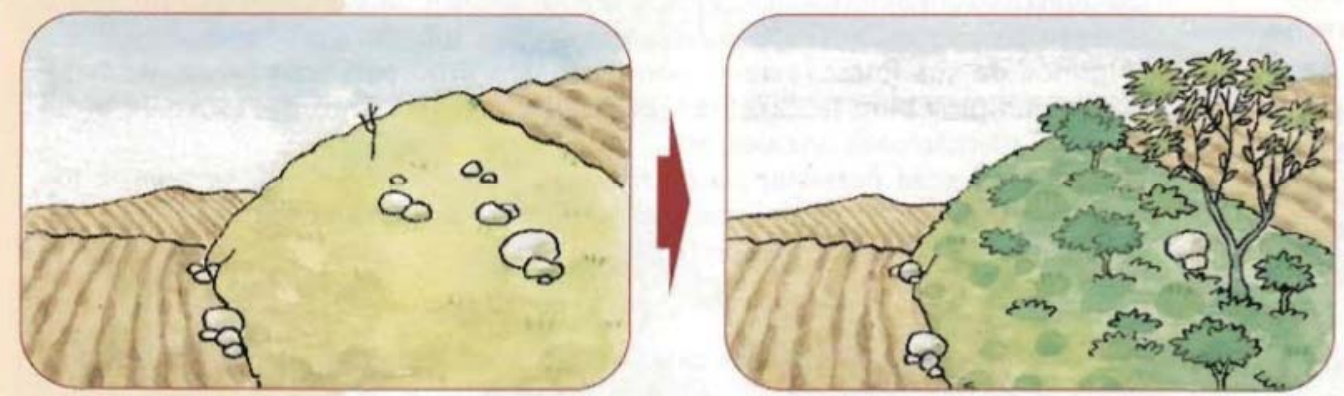

Pequeñas tierras sobrantes tras la concentración.
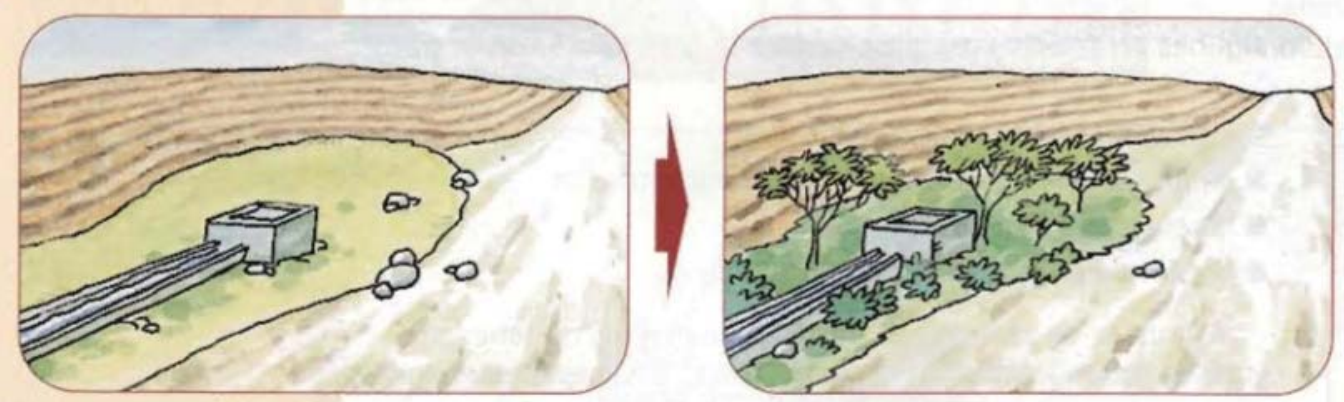

- Bordes de pequeños cursos de agua.
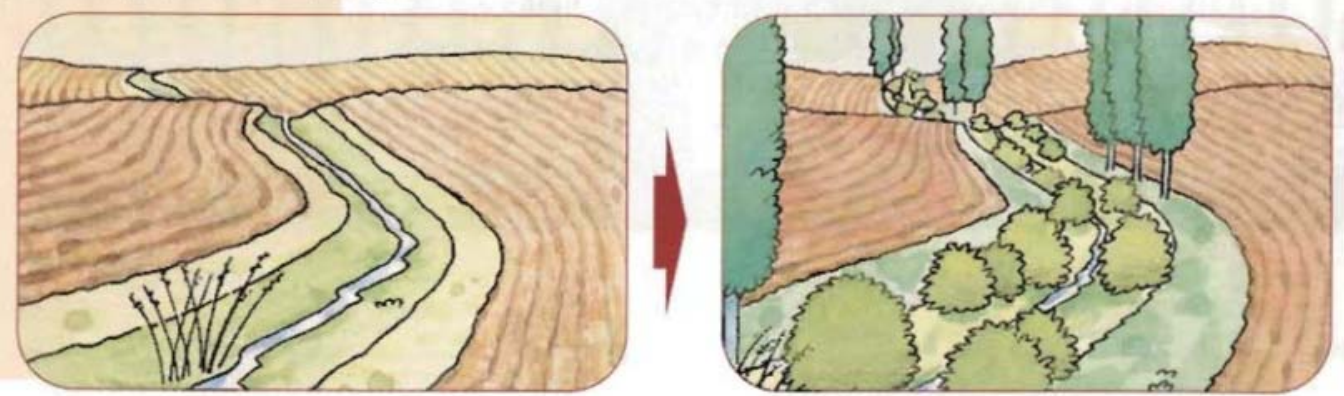

Figura 6.72. Ilustración del resultado de varios tipos de restauraciones vegetales en espacios degradados por concentraciones parcelarias (JUNTA DE CYL, 1992) 


\subsubsection{Espacios afectados por transformaciones de regadío}

Tal como se ha mencionado anteriormente, estos espacios ocupan un porcentaje reducido respecto de la superficie total agrícola. No obstante, su papel en la recuperación es importante por dos razones: porque los impactos que generan han de ser corregidos y porque están ligados con el agua, que es uno de los componentes que proporcionan mayor valor al paisaje. Se caracterizan por la existencia de canales de riego, acequias, balsas, así como las instalaciones propias en cada parcela agrícola: hidrantes, pívots, aspersores, cañones, etc.

Las principales actuaciones de recuperación ambiental que se plantean son las siguientes:

\section{Restauración vegetal de márgenes de canales}

Evidentemente, el espejo al que mirarse debería ser el Canal de Castilla: no hay mayor ejemplo de integración ambiental, y eso que se construyó en el siglo XVIII. En la actualidad nos encontramos con canales de hormigón, de carácter menos natural y más funcionales, pero donde también se pueden acometer labores de recuperación.

Los taludes de desmonte son tal vez la zona de más urgente actuación. Considerando que se han tendido adecuadamente (pendiente inferior a $2 \mathrm{~V}: 3 \mathrm{H}$ ), lo idóneo es extender la tierra vegetal previamente retirada y sobre ella realizar una hidrosiembra. Puntualmente se podrán utilizar mantas orgánicas para que la tierra no resbale por el talud. Con posterioridad es conveniente la plantación de arbustos; muchos casos no admiten más que esta fórmula, ya que no se han realizado las actuaciones anteriores. El pie del talud -por su mayor grado de humedad- es una buena zona para plantar árboles.

Los taludes de terraplén tienen una restauración mucho más fácil. En teoría se debe extender la tierra vegetal previamente retirada, no siendo necesaria en muchas ocasiones la realización de hidrosiembra, pues se produce una regeneración espontánea de herbáceas. La plantación de arbustos tiene también alta viabilidad; incluso la de arbolado, sobre todo en las zonas bajas que poseen mayor humedad.

En el caso de que los caminos de servidumbre de los canales posean un cierto sobreancho, es una franja idónea para plantar árboles en forma de alineación, eligiéndose las especies en función del mayor o menor grado de humedad del suelo. En caso contrario, al menos es aconsejable la plantación de arbustos en las cunetas cuyos taludes tengan una altura mayor de $1 \mathrm{~m}$.

Finalmente, en determinados canales -el canal Cea-Carrión es muestra de ello- se realizaron expropiaciones de numerosas parcelas adyacentes a la traza, como zonas auxiliares necesarias en la obra. Estas parcelas son ahora públicas, se encuentran parcialmente intrusadas y suelen estar cubiertas por herbáceas, generalmente sobrepastoreadas. La primera subactuación propuesta es su amojonamiento o delimitación física de la propiedad; en los lindes consolidados resultaría urgente realizar una plantación arbustiva. La segunda subactuación es la plantación de arbolado, diferenciando zonas húmedas de secas en la elección de especies; en los nuevos canales predominarán estas últimas, ya que las pérdidas de agua son mínimas. En último lugar (como en otras plantaciones propuestas) se debe prohibir el pastoreo, al menos hasta que la vegetación se haya afianzado. 


\section{Creación de senderos por los caminos de servidumbre}

Nuevamente tenemos como mejor referencia al Canal de Castilla (Figura 6.73). No hay mejor entorno para pasear o ir en bicicleta que un camino llano en contacto con el agua. Además, si asumimos la restauración del anterior apartado, ello se conjuga con la entrada en escena de la vegetación.

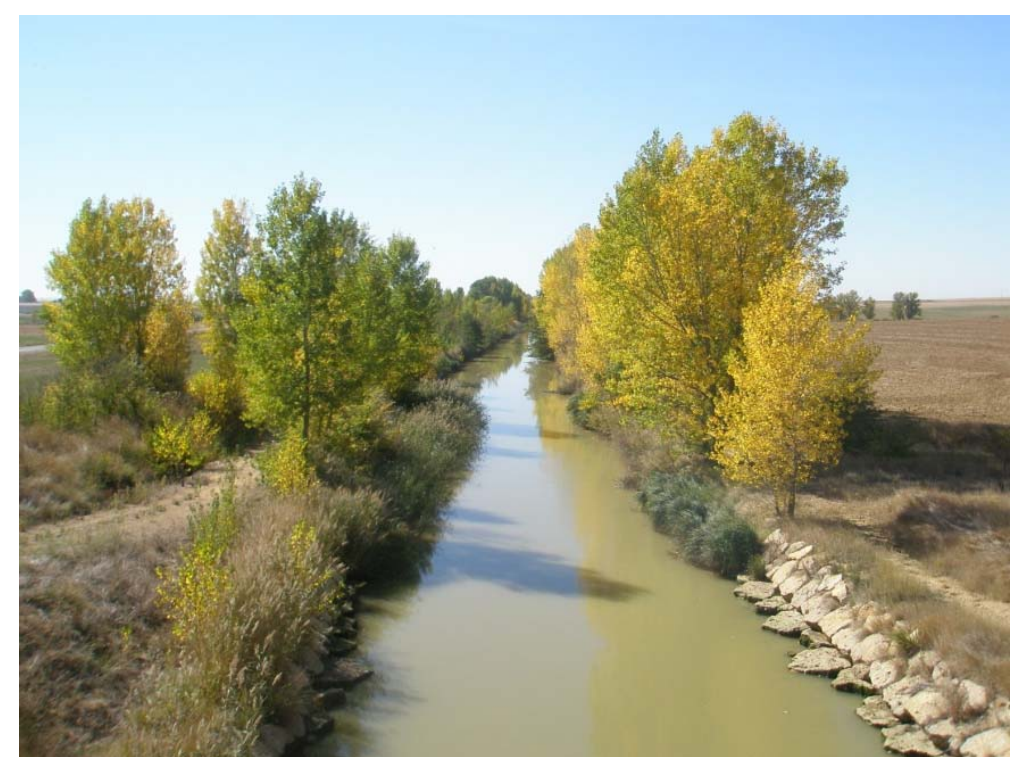

Figura 6.73. Ramal de Campos del Canal de Castilla, paradigma de uso funcional (regadio) compatible con el ecológico y el recreativo.

Se aconseja incluir estos caminos -o bien algún tramo de ellos- en alguna red de senderos homologados de los indicados en los antecedentes, de modo que así se asegure su continuidad, adecuada señalización y otros requerimientos necesarios para su uso adecuado.

\section{Naturalización de balsas de riego}

La creación de una balsa de riego es una magnífica oportunidad de mejora del paisaje, por la irrupción de una zona de agua en un entorno eminentemente árido. Del seguimiento de las medidas de integración ambiental del Proyecto de transformación en regadío del sector IV de la zona regable del canal Esla-Carrión, se puede inferir que hay bastantes posibilidades de actuación para conseguir un área naturalizada.

En primer lugar, la cuestión básica para que se puedan restaurar los taludes interiores de una balsa es que no se hayan cubierto con lámina de polietileno que, por otra parte, ocasiona un gran impacto visual. Tanto los taludes en tierra como los protegidos con escollera son susceptibles de restauración. La selección de especies tendrá en cuenta no afectar a la estabilidad del talud (raíces de reducido crecimiento), así como la oscilación hídrica dentro de la balsa. Son muy recomendables los tratamientos de bioingeniería.

Los taludes de terraplén son más fáciles de restaurar y no tienen tantas exigencias de estabilidad e impermeabilidad como los de desmonte. Lo ideal es que sus pendientes sean inferiores a $30^{\circ}$ y que sobre ellos se haya extendido tierra vegetal. De este modo, se suele producir una revegetación espontánea de herbáceas; en caso contrario, se debería realizar una hidrosiembra. 
Posteriormente es recomendable la plantación de arbustos e incluso de árboles al pie del talud, que son zonas con mayor humedad.

Las balsas suelen tener alguna zona marginal de ocupación en su entorno que es susceptible de plantación de arbolado. Con ello se contribuye a integrar los taludes generados, las casetas de bombeo y las instalaciones eléctricas y a diversificar el paisaje. Como en todos los casos que se están analizando, es fundamental realizar una adecuada elección de especies para zonas secas o húmedas.

Es conveniente que el lecho de la balsa tenga una topografía final irregular, ya que con ello se consigue que, en el periodo final de riego, la balsa contenga zonas encharcadas muy necesarias para la fauna acuática.

Una medida muy útil para recrear la idea de islotes naturales en las lagunas -muy utilizadas como zona de estancia y nidificación de la avifauna acuática-, es la colocación de plataformas suspendidas en la superficie de la balsa, que habrán de ser firmemente ancladas en el fondo.

\section{Creación de observatorios de avifauna en balsas de riego}

La acumulación de agua en una balsa en Tierra de Campos se convierte inmediatamente en un magnífico hábitat para la avifauna acuática; no en vano esto se ha comprobado con cualquier restauración de humedal en la comarca (La Nava, Boada, Tamariz, etc.), debido a su carácter pseudoestepario y a que sea zona de paso de numerosas especies.

Por ello, una medida de valorización del nuevo paisaje creado es la construcción de observatorios de avifauna en zonas elevadas. Para su diseño, un modelo a seguir es el empleado en las lagunas de Villafáfila, donde se han construido casetas-miradores a modo de palomares, con paramentos terrosos y cubierta de teja árabe.

\section{Integración paisajística de edificaciones ligadas al regadío}

En los proyectos de transformación en regadío de cierta envergadura es necesaria la construcción de diversas edificaciones: estaciones de bombeo, edificios de control, casetas con válvulas, hidrantes, etc. Su integración en el paisaje de Tierra de Campos exige, con carácter general, que los paramentos tengan acabados ocres o terrosos y las cubiertas sean rojizas o de color teja. Se puede optar por materiales tradicionales (enfoscados con morteros a la cal y empleo de teja árabe o mixta curva) o incluso por materiales modernos más funcionales (planchas de hormigón pigmentadas en masa y cubiertas metálicas con acabado tipo teja). 

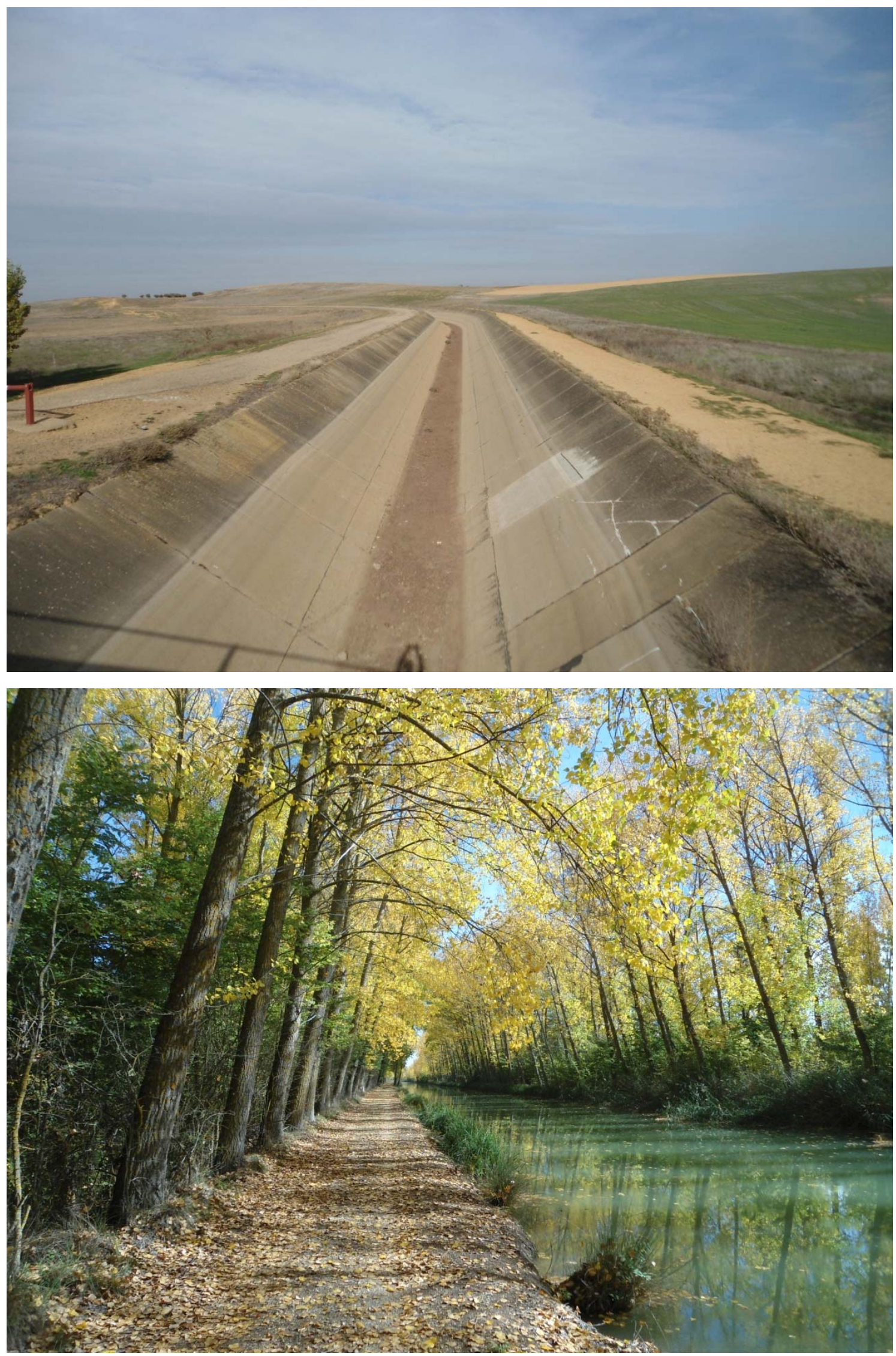

Figura 6.74. El contraste entre el canal Cea-Carrión (Villacarralón) y el canal de Castilla (Tamariz de Campos) no precisa comentarios. Aunque parezca mentira, ambos son grandes infraestructuras hidráulicas dedicadas al regadio y ambos están en Tierra de Campos; la diferencia estriba en su naturalización. Da la impresión de que, en los 200 años que distan de su construcción, no hayamos aprendido nada. 


\subsubsection{Espacios afectados por infraestructuras lineales de transporte}

Las infraestructuras lineales de transporte conforman una red que malla totalmente el territorio. Tal como ya hemos comentado, por Tierra de Campos discurren infraestructuras de primer orden, como autovías y ferrocarriles de alta velocidad (fundamentalmente de paso), y una tupida red de carreteras de segundo orden que conecta las localidades. Desde el punto de vista de la recuperación ambiental, estos espacios suponen un doble acicate: por un lado han de ser corregidos los impactos producidos por las obras y, por otro, constituyen zonas susceptibles de ser revegetadas y así diversificar el paisaje. En este sentido cabe recordar la importancia que da el Consejo de Europa (2009) a la creación de alineaciones arboladas en los márgenes de las carreteras; en Tierra de Campos se trataría de restaurar y mejorar la situación previa a los años 60 del siglo pasado, cuando buena parte de las vías contaban con árboles de gran porte en ambas márgenes (chopos lombardos, álamos, olmos, etc.).

Se proponen las siguientes actuaciones básicas:

\section{Recuperación ambiental de zonas afectadas por autovías y nuevas carreteras}

En estos casos, las medidas de recuperación ambiental se incluyen en el procedimiento preventivo de evaluación de impacto ambiental lo que, en teoría, debiera ser suficiente para garantizar la integración paisajística de estas infraestructuras. Teniendo en cuenta el seguimiento del Proyecto de variante de Villada analizado en el anejo 1, el de otros ya ejecutados en Tierra de Campos, así como distintos análisis aquí realizados, apuntamos a continuación de un modo sintético las medidas más importantes de recuperación del paisaje:

- Retirada selectiva previa de la tierra vegetal de todas las zonas alteradas, para su posterior uso en la restauración.

- Remodelación topográfica de los taludes de desmonte (especialmente, por los riesgos de erosión) y terraplén con formas naturalizadas y pendientes inferiores a $2 \mathrm{~V}: 3 \mathrm{H}$. Hidrosiembra (tras la extensión de la tierra vegetal) y plantación de arbustos.

- Remodelación de márgenes, enlaces, glorietas, zonas auxiliares, medianas, etc., con posterior plantación de árboles y arbustos.

- Demolición y restauración de tramos sin uso de antiguas carreteras (que pueden servir como zonas de descanso).

- Adecuación de pasos de fauna (Figura 6.75).

- Restauración de las características de la red hidrológica afectada.

- Plantación de arbustos en las vallas perimetrales.

- Valorización de los puentes o grandes estructuras que posean interés paisajístico. 


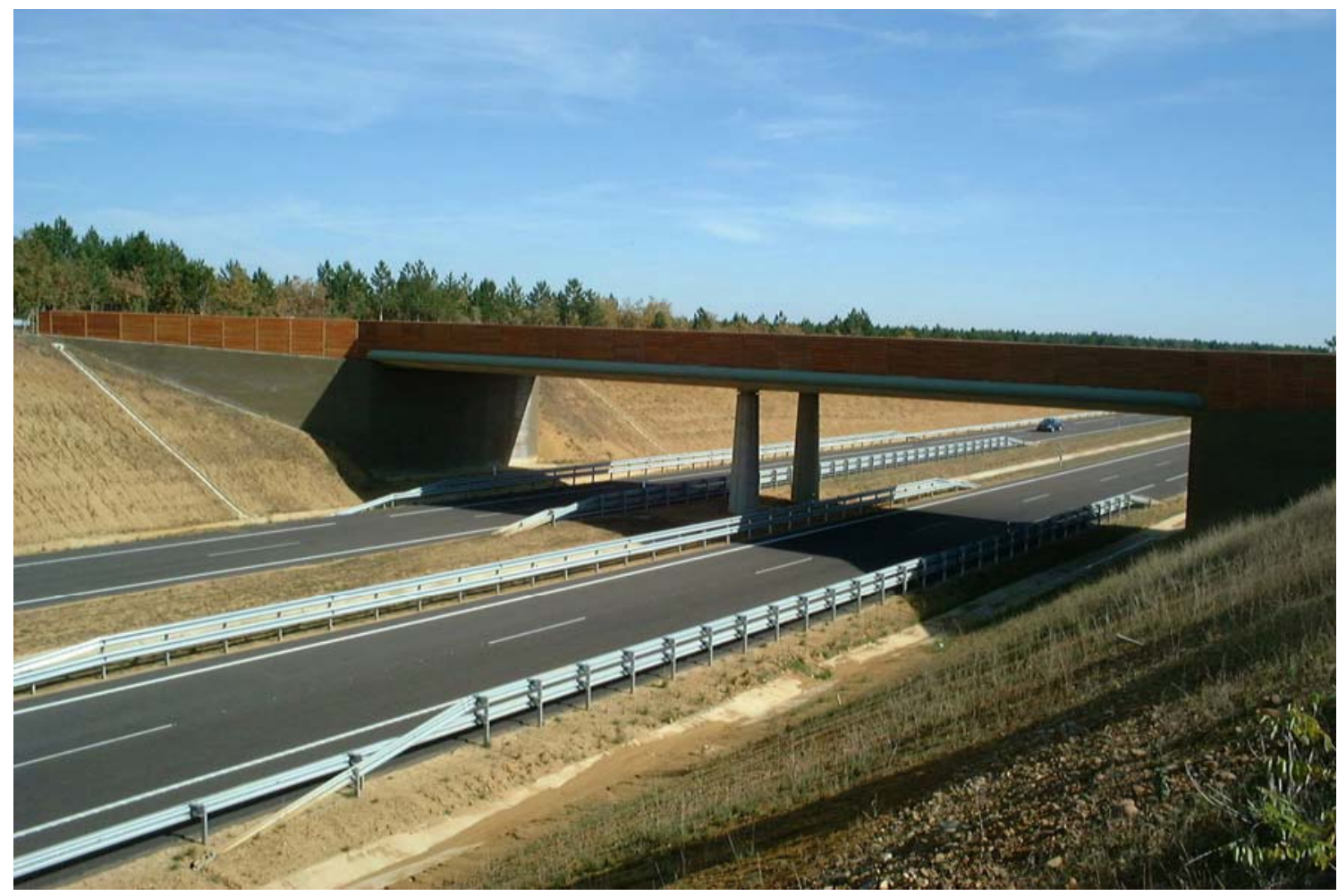

Figura 6.75. Paso de fauna superior en Ledigos, en la autovía Camino de Santiago que, en sí misma, es una estructura que mejora el paisaje. Se pueden observar también remodelaciones de taludes de desmontes, hidrosiembras y correcciones hidrológicas.

\section{Recuperación ambiental de zonas afectadas por ferrocarriles de alta velocidad}

El seguimiento ambiental genérico realizado sobre la construcción del tramo Palencia-León de la línea de ferrocarril de alta velocidad, que atraviesa Tierra de Campos, permite identificar una serie de unidades básicas para la recuperación de estas zonas, que son bastante coincidentes con las apuntadas en el apartado anterior. En esta infraestructura lineal, los requerimientos funcionales son aún más exigentes, en cuanto a trazados rectilíneos, perfil longitudinal de muy escasa pendiente o necesidad de que la plataforma discurra en terraplén; todo ello provoca que los movimientos de tierra sean mayores.

- Retirada selectiva previa de la tierra vegetal de todas las zonas alteradas, para su posterior uso en la restauración.

- Remodelación topográfica de los taludes de desmonte y terraplén (mayoritarios) con formas naturalizadas y pendientes inferiores a $2 \mathrm{~V}: 3 \mathrm{H}$. Realización posterior de hidrosiembra (tras la extensión de la tierra vegetal) y plantación de arbustos (Figura 6.76).

- Remodelación de zonas auxiliares y otros espacios afectados por la construcción, con posterior plantación de árboles y arbustos.

- Adecuación de pasos de fauna, que en este caso tienen gran relevancia, ya que la plataforma se encuentra totalmente vallada. En la mayoría de los casos se aprovechan los pasos inferiores (multifuncionales), aunque también se realizan pasos inferiores 
específicos. En el cruce con los ríos se construyen viaductos adaptados para favorecer la permeabilidad ecológica.

- Restauración de las características de la red hidrológica afectada.

- Plantación de árboles y arbustos en las vallas perimetrales. Con esta medida se mitigaría el impacto visual generado por los terraplenes y la infraestructura eléctrica. Además, se fomentaría la elevación del vuelo de las aves de gran envergadura que podrían colisionar con dicha infraestructura.

- Integración paisajística de las edificaciones necesarias para la gestión del ferrocarril de alta velocidad.

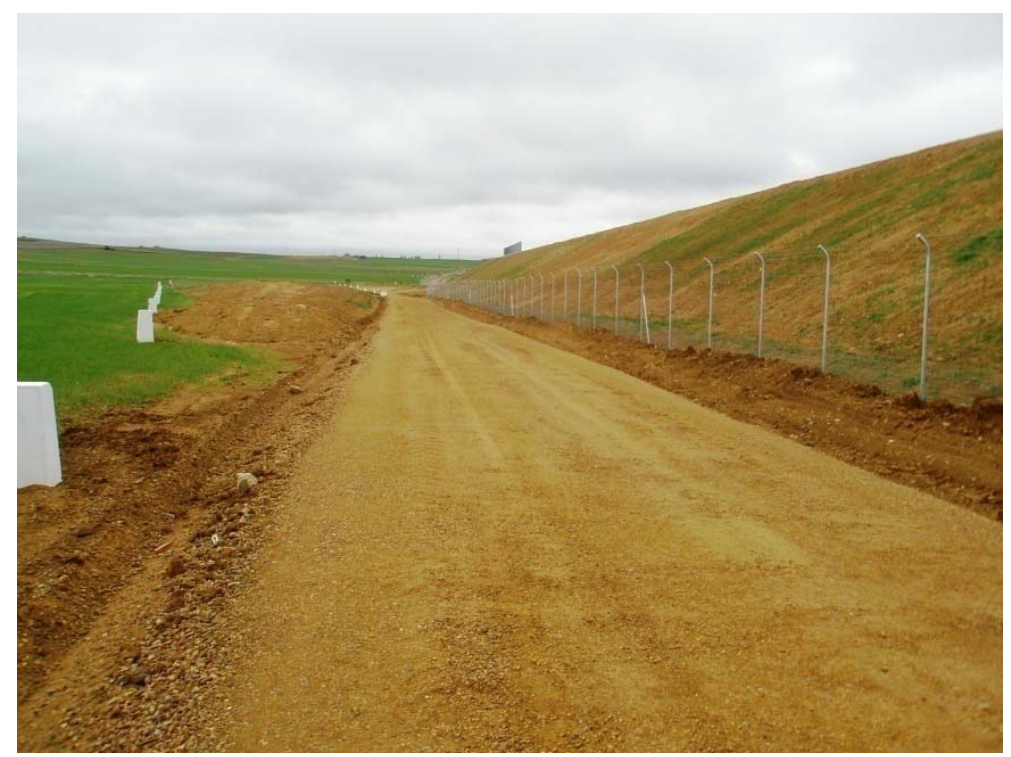

Figura 6.76. Vista de un talud de terraplén en el tramo Palencia-León de la línea de alta velocidad, donde comienza a nacer la vegetación herbácea tras la hidrosiembra. También se observa el vallado perimetral, un camino de servicio y zonas colindantes (el dominio público está delimitado por los mojones) donde se podrían realizar plantaciones de árboles y arbustos.

\section{Recuperación ambiental de zonas afectadas por ferrocarriles convencionales existentes}

En Tierra de Campos, la red de ferrocarriles convencionales es bastante reducida; se limita a contados tramos como la línea Palencia-León o la Palencia-Santander. Los tratamientos que podrían realizarse son los siguientes:

- Restauración de taludes erosionables, fundamentalmente de desmonte, incluyéndose su remodelación, revegetación y posible realización de actuaciones de bioingeniería en casos puntuales.

- Retirada y adecuada gestión de depósitos de residuos en los márgenes.

- Desbroce periódico de los márgenes, preferiblemente sin el uso de herbicidas.

- Plantaciones de árboles y arbustos en zonas de dominio público colindantes que no afecten a la seguridad de la línea. 
- Naturalización de algunos pasos inferiores como pasos de fauna.

- Restauración y valorización paisajística de estaciones y otros edificios ligados al ferrocarril.

\section{Recuperación paisajística de carreteras existentes}

Bajo este epígrafe consideramos la red de carreteras locales de doble sentido que teje el territorio, englobando las nacionales, autonómicas y provinciales. Constituye la inmensa mayoría de las infraestructuras lineales de transporte de Tierra de Campos y posee un gran potencial paisajístico (ESPAÑOL, 2005). Más teniendo en cuenta que en la actualidad se encuentran totalmente desarboladas y sin casi retazos arbustivos, algo que no ocurría en el pasado.

En los Recorridos paisajísticos del anejo 3 se observa la magnitud longitudinal que suponen las carreteras en un término municipal. Las carreteras que atraviesan el término de Villalón de Campos alcanzan una longitud total de $29,65 \mathrm{~km}$, lo que supone una densidad de 0,004 km/ha o $4 \mathrm{~km}$ cada 1000 ha. Si tenemos en cuenta que cada tramo de carretera posee dos márgenes, podemos inferir el gran potencial que adquieren estos terrenos para la recuperación del paisaje de Tierra de Campos.

Además, de la muestra de 29 mediciones realizada, se extraen otros datos interesantes de cara a la recuperación ambiental:

- El $62 \%$ de los taludes corresponden a desmonte, el $38 \%$ a terraplén.

- El $10 \%$ de los taludes tienen una altura (longitud de pendiente) inferior a $1 \mathrm{~m}$, el $69 \%$ se encuentra entre 1 y $2 \mathrm{~m}$, mientras que el $21 \%$ tiene una altura superior a $2 \mathrm{~m}$. La altura media es de $1,66 \mathrm{~m}$, lo que indica que existe una doble franja considerable susceptible de su revegetación.

- La pendiente media de los taludes es de $30^{\circ}(1 \mathrm{~V}: 1,7 \mathrm{H})$, aceptable para su restauración.

La primera y fundamental subactuación propuesta en las carreteras es la restauración vegetal de sus márgenes (Figura 6.77). Descartando los taludes de menos de $1 \mathrm{~m}$, que pueden verse afectados por los tratamientos de limpieza de cunetas, en el óptimo esta medida podría llevarse a cabo en el resto de los taludes (un $90 \%$ de los mismos). En los situados entre 1 y $2 \mathrm{~m}$ se propone una plantación de arbustos con las características del tipo C1 citado de los caminos de concentración parcelaria. En los taludes de más de $2 \mathrm{~m}$ de altura -particularmente en los terraplenes que tengan biondas- y en las entradas a los pueblos (donde no existan riesgos de seguridad vial) se propone una plantación de árboles de alineación con características aproximadas a las del tipo C2 de los caminos. Las ventajas serían de muy diverso índole:

- Mejora del paisaje interior a la carretera.

- Mejora del paisaje exterior, del conjunto de Tierra de Campos.

- Estabilidad de los taludes y reducción de los niveles erosivos.

- Evitación de intrusiones por los colindantes.

- Integración de las construcciones periurbanas y guiado focal hacia los elementos más valiosos (generalmente, las torres de las iglesias). 
- Creación de corredores ecológicos.

- Mejora del guiado y la confortabilidad de la conducción.
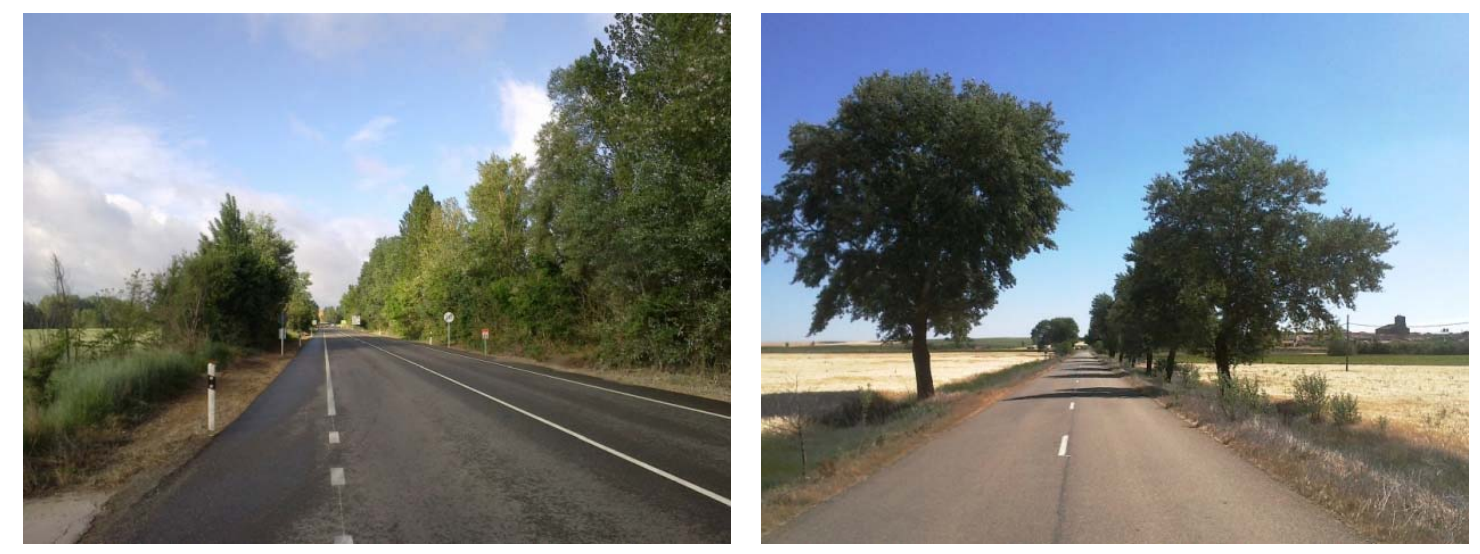

Figura 6.77. Dos imágenes objetivo a alcanzar de márgenes con vegetación en las carreteras de Tierra de Campos. A la izquierda, carretera de Carrión de los Condes a Villoldo. A la derecha, entrada a Herrín de Campos.

En segundo lugar, se plantea la creación de carreteras paisajísticas en los espacios naturales protegidos; en Tierra de Campos, especialmente en la Reserva Natural de las Lagunas de Villafáfila y en la Laguna de la Nava (la carretera que une Fuentes de Nava con Mazariegos es especialmente significativa). Ello supone cuidar todos los elementos auxiliares que forman parte de la infraestructura de la carretera: barreras quitamiedos de maderas o mixtas, señalización específica, utilización de hormigón coloreado en tierra, taludes con muretes, etc.

La tercera subactuación propuesta es la creación de miradores, sobre todo en las carreteras que transiten entre los páramos y las campiñas. El mirador es la instalación paisajística por antonomasia, permitiendo contemplar amplias vistas sin asumir riesgos en la conducción. Necesita de una pequeña zona acondicionada generalmente con zahorra artificial, delimitación de aparcamientos, depósitos de recogida de residuos, carteles interpretativos del fondo escénico y el muro de borde. Todos los materiales y acabados deberán estar integrados en el entorno: madera, hormigón coloreado, mortero bastardo, teja árabe, etc. Se debe pensar en que el mantenimiento sea sencillo.

En cuarto lugar, se plantea la creación de paseos laterales en determinadas carreteras, también denominados carriles bici o de paseo. En los Recorridos paisajísticos se observa que la carretera que conduce a la ermita de Fuentes es muy demandada como zona de paseo por los vecinos de Villalón de Campos. Esto mismo sucede en numerosos pueblos de la comarca donde, además, los habitantes prefieren pasear por carreteras porque, a pesar del riesgo vial, les ofrecen una mayor seguridad. El requisito fundamental es que tengan bajos niveles de tráfico. Si se utiliza la plataforma de la carretera (solución más económica), es fundamental disponer un poyete bajo para aislar calzada y paseo. Estos paseos deben estar asociados al ajardinamiento de los márgenes, con primacía del arbolado.

En quinto lugar, se propone restaurar y valorizar los puentes de las carreteras, fundamentalmente aquellos que puedan constituir un hito en el paisaje de Tierra de Campos (Figura 6.78). A escala pequeña, como ejemplo, en el Recorrido paisajístico 21 del anejo 3 se 
detectan los bellos puentes construidos con ladrillo de tejar en la carretera de Herrín de Campos a Villalón de Campos, que podrían ser señalizados para su observación por posibles paseantes. A escala mayor, los numerosos puentes construidos sobre los ríos Carrión, Pisuerga y Cea, conforman el paisaje ribereño desde la ingeniería civil y en muchos casos contribuyen a realzarlo.

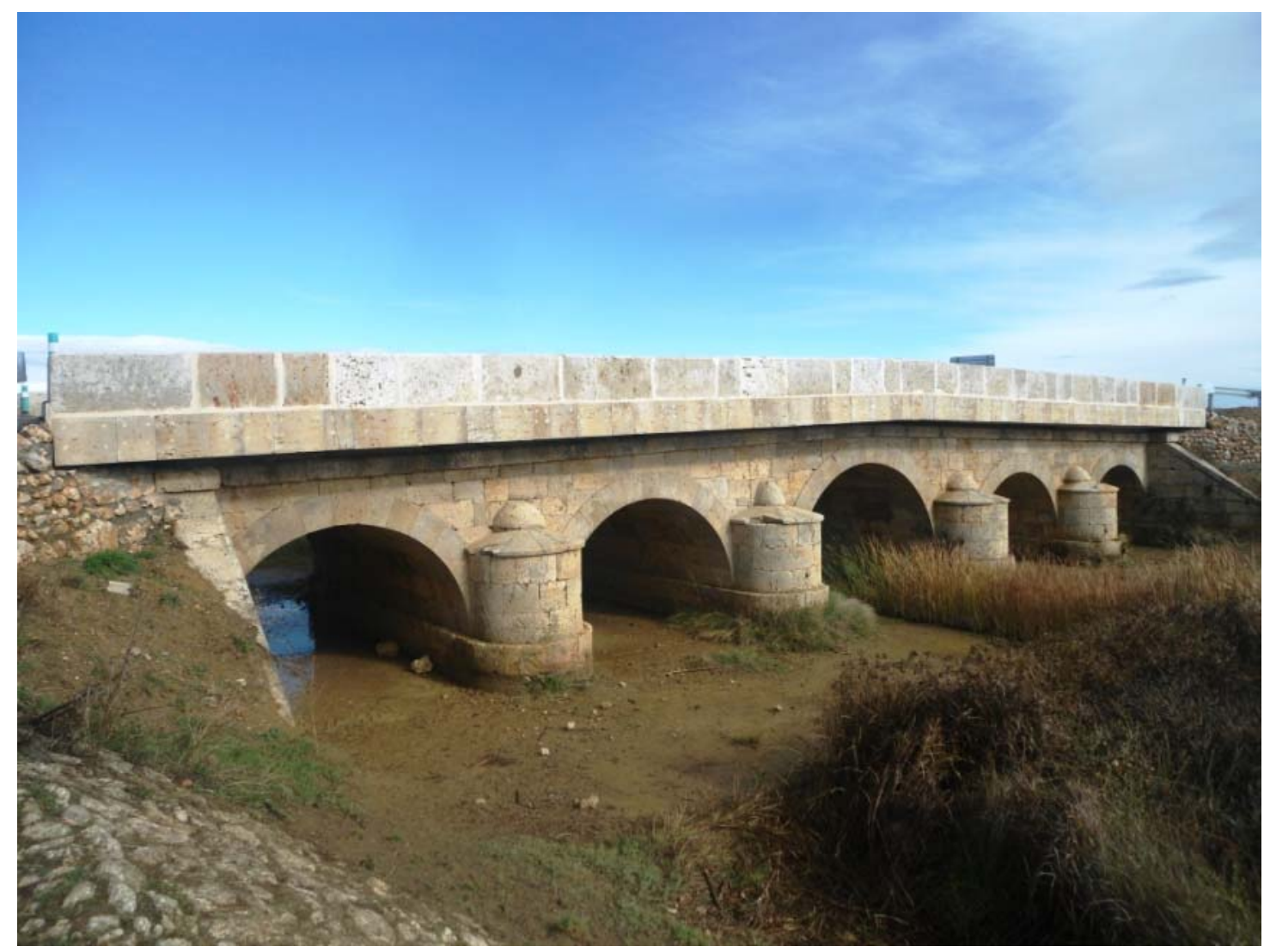

Figura 6.78. Puente sobre el río Valdeginate en Autillo de Campos, recientemente restaurado. Merecería la pena acondicionar y anunciar el entorno para que pudiese ser adecuadamente contemplado, ya que desde la carretera no se llega a apreciar.

Finalmente, se propone de forma rutinaria la limpieza de las cunetas de las carreteras. En todos los Recorridos se ha observado la acumulación de plásticos, neumáticos, botellas y residuos de variada naturaleza, y eso que el tráfico en casi todas las vías analizadas es relativamente reducido. La responsabilidad de esta tarea ha de recaer en la empresa concesionaria del mantenimiento de la carretera, con la supervisión de la administración competente. La gestión posterior dependerá del tipo de residuos recogido. 

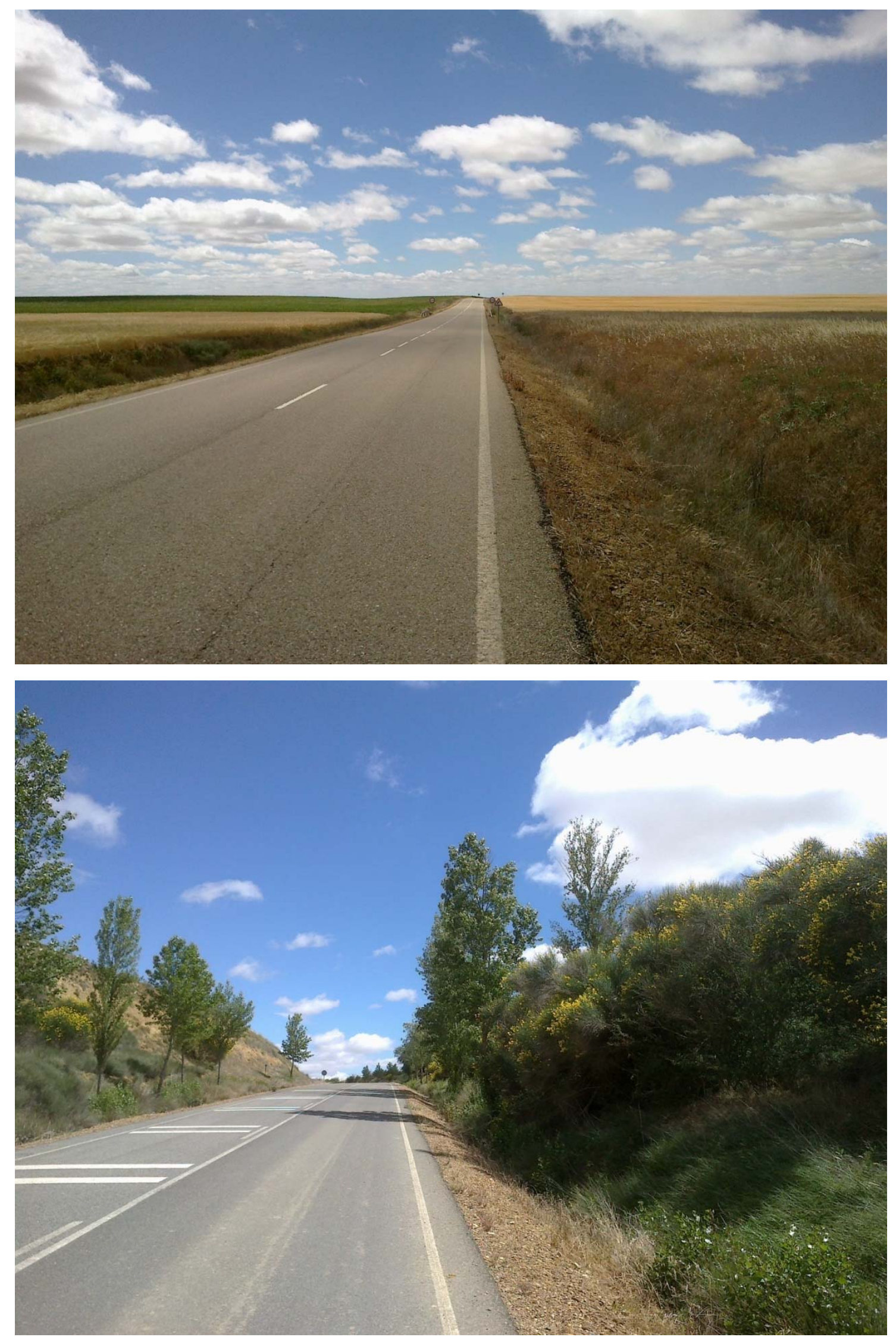

Figura 6.79. Dos tramos totalmente diferentes ubicados en la misma carretera provincial VP-4011; en la fotografía inferior se observa la mejora paisajística generada por la presencia de arbustos y árboles en los márgenes. 


\subsubsection{Espacios afectados por explotaciones mineras, préstamos y vertederos}

Se trata de espacios muy ligados a la obra pública y, sobre todo, a la infraestructura lineal de transporte, pero que por sus características específicas merecen otro tratamiento. Son localizaciones puntuales donde se han realizado intensos movimientos de tierras; en los dos primeros casos extracciones, en el tercero depósitos. También constituyen una oportunidad para la diversificación del paisaje, ya que son terrenos que no pueden volver a ser agrícolas en la mayoría de los casos.

\section{Restauración de extracciones}

Es el caso más habitual. La ejecución de estas actuaciones sigue un proyecto específico (o incluido en el de la obra pública), al que debe acompañar un Plan de restauración. Del seguimiento ambiental del caso analizado en el anejo 1: Explotación de la zona de préstamos $P R-1$ asociada al proyecto de construcción de la plataforma corredor norte-noroeste de alta velocidad tramo Palencia-León, subtramo Becerril de Campos - Valle del Retortillo. Términos municipales de Becerril de Campos y Paredes de Nava (Palencia), así como de otros casos similares, se considera que la restauración de estos espacios en Tierra de Campos debería contemplar los siguientes aspectos:

- Retirada selectiva previa de la tierra vegetal, en al menos una capa de $40 \mathrm{~cm}$ de espesor.

- Remodelación topográfica de los terrenos, de modo que se consiga una morfología lo más natural posible. Nuevamente hay que acudir a la geomorfología de Tierra de Campos, de llanuras suavemente onduladas.

- Restauración de la red hidrográfica en caso de que esta se haya visto afectada.

- Los taludes finales perimetrales se deben tender a una pendiente inferior a $1 \mathrm{~V}: 3 \mathrm{H}$, para evitar fenómenos de erosión y conseguir su naturalización.

- Descompactación y nivelado de la plataforma.

- Extensión de la tierra vegetal por toda la superficie alterada, incluidos los taludes.

- Posible siembra de taludes en caso de que no exista regeneración natural herbácea, con posterior plantación de arbustos.

- En función del uso futuro de los terrenos, entre otras actuaciones, se podrá realizar una plantación de chopos (chopera), una plantación de especies autóctonas diferenciando zonas secas y húmedas -esto es fundamental- (uso natural-forestal) o dejar parte del hueco como laguna semipermanente (zona húmeda, Figura 6.80). 


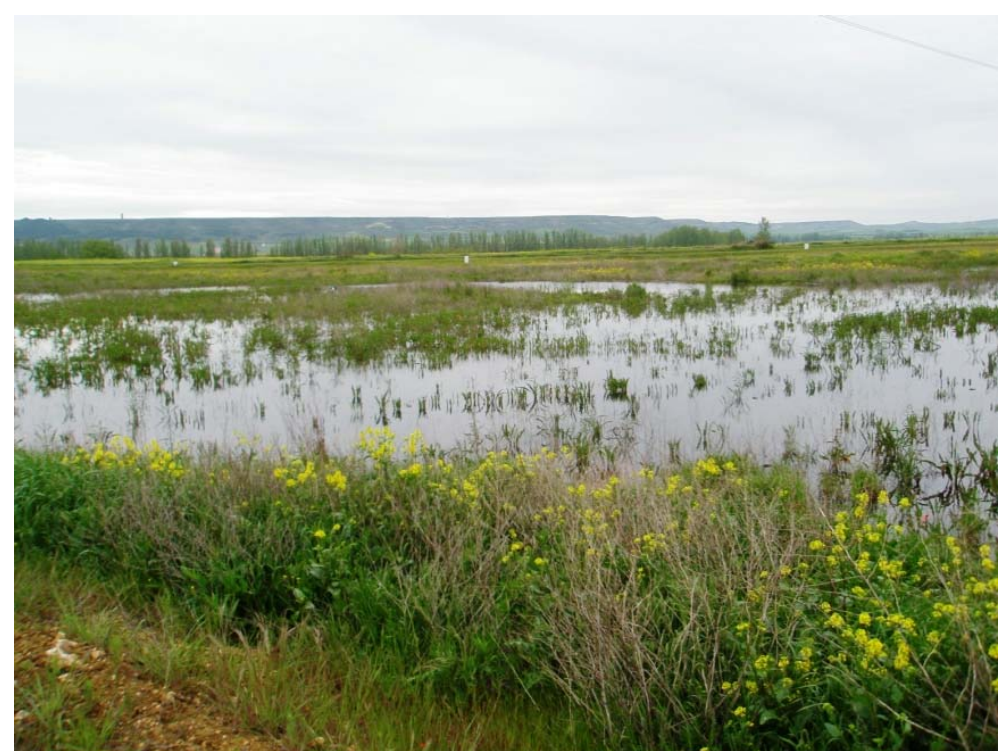

Figura 6.80. Restauración de gravera (préstamo P1) en Grijota, en las obras del AVE Palencia-León. El uso dado a los terrenos es el natural, constituyendo una zona húmeda con vegetación pratense en los taludes y arbolado de ribera en las zonas no inundadas.

\section{Restauración de vertederos}

La restauración de un vertedero de inertes es más sencilla que una extracción. Evidentemente, la ubicación del vertedero es fundamental, ya que cuanto más deprimida esté más fácil será la recuperación. En teoría, ejecución y restauración deben estar unidas desde el comienzo; con ello se minimizan los costes económicos y se asegura la integración paisajística. Así lo contemplaremos aquí, considerando las siguientes unidades básicas:

- Retirada previa de la tierra vegetal de la superficie objeto del vertedero.

- Comienzo del depósito en tongadas de reducido espesor.

- Remodelación topográfica, creando formas naturales redondeadas. La pendiente de los taludes finales de terraplén debería ser inferior a $1 \mathrm{~V}: 2 \mathrm{H}$.

- Correcciones hidrológicas, en caso necesario.

- Extensión de la tierra vegetal por toda la superficie, en especial por el terraplén.

- Hidrosiembra del talud, con una mezcla de gramíneas y leguminosas autóctonas, y posterior plantación de arbustos.

- En función del uso final del resto de la superficie del vertedero (plataforma), siembra para uso agrícola o plantación de árboles para uso natural.

\subsubsection{Espacios afectados por infraestructuras energéticas}

Bajo este epígrafe englobamos las superficies próximas a líneas eléctricas de alta tensión (de voltaje superior a $66 \mathrm{kV}$ ), subestaciones eléctricas, parques eólicos y huertos solares. Son zonas muy alteradas paisajísticamente por unas infraestructuras voluminosas, dominantes y 
artificiales. En determinados casos se puede dar una fragmentación del hábitat de especies de avifauna de interés.

En general, estos proyectos están sometidos a evaluación de impacto ambiental o algún otro procedimiento preventivo ambiental, en el que se establecen medidas protectoras y, en ciertos casos, de recuperación que no suelen ser suficientes para mitigar los impactos producidos. Del seguimiento de los proyectos del parque eólico El Castre, en Torremormojón, y de la línea eléctrica aérea de alta tensión entre las subestaciones de transformación de Ampudia y Grijota (anejo 1), así como de otros de menor envergadura analizados en los Recorridos paisajísticos del anejo 3, se pueden deducir unas actuaciones básicas de recuperación en Tierra de Campos:

\section{Ocultación parcial de huertos solares}

Evidentemente, la recuperación de este espacio degradado no puede condicionar su funcionamiento, en este caso la captación de energía solar, por lo que la ocultación de las placas solo podrá ser realizada en parte. En cualquier caso, también se podrá jugar con la exposición solar, de forma que las pantallas pueden adquirir mayor altura en alguno de los lados del perímetro.

Teniendo en cuenta que los huertos solares están vallados, se plantea como mejor opción la plantación de un seto vegetal perimetral. Convendría elegir una mezcla de especies de las posibles para la comarca, que contuviese perennes y caducifolias, siguiendo un cierto patrón. La distancia de separación no debiera exceder de $3 \mathrm{~m}$. Se deben realizar todos los cuidados posibles (riego, sobre todo) para asegurar el rápido crecimiento de la plantación, dado que es este el principal objetivo.

\section{Ocultación o integración de centros de transformación y subestaciones eléctricas}

El caso ideal sería la inclusión del aparallaje eléctrico en un edificio integrado paisajísticamente, lo que no suele ser factible. Mayor viabilidad supone la construcción de un muro de 4-5 m de altura, de bloques ocres de hormigón o enfoscado en color tierra. En el caso de existir edificios de control, habrán de tener los paramentos ocres o terrosos y cubierta tipo teja. Esto se puede complementar, si es posible, con la plantación de arbustos en zonas adyacentes (Figura 6.81).

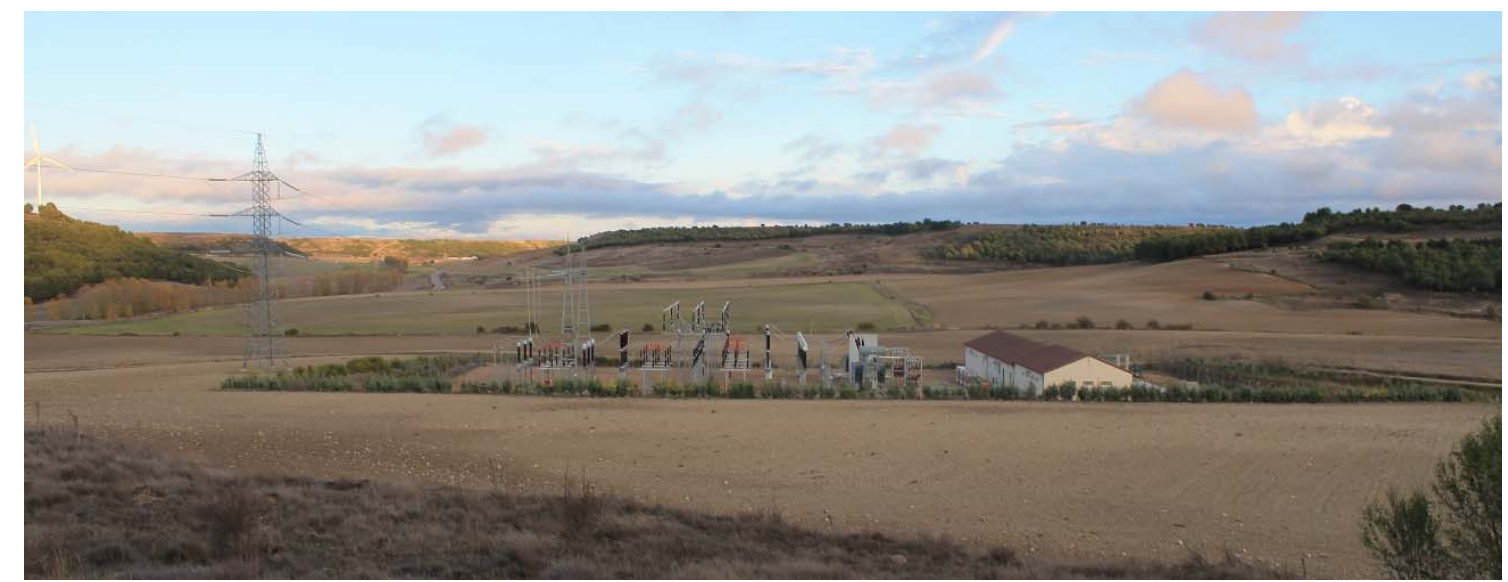

Figura 6.81. Subestación eléctrica de un parque eólico en Ampudia con una adecuada integración paisajística: edificio de control con paredes ocres y cubierta rojiza; y pantalla vegetal perimetral que comienza a realizar su función (Fotografía Jesús Roldán). 


\section{Restauración de la zona ocupada por aerogeneradores y apoyos de líneas eléctricas}

Nos estamos refiriendo a superficies reducidas, las que se encuentran estrictamente debajo de estas infraestructuras. La restauración contemplaría la remodelación topográfica del terreno, la extensión de la tierra vegetal previamente retirada y la siembra de herbáceas, en su caso. Es posible también plantar arbustos en estas zonas.

\section{Restauración de márgenes de caminos de acceso}

Para la construcción de parques eólicos y, en algún caso, de líneas de alto voltaje, es necesario trazar nuevos caminos. Su restauración conlleva tender los taludes de las cunetas a pendientes suaves y realizar las plantaciones mencionadas en los caminos de las concentraciones parcelarias (tipos 1 y 2 ).

\section{Integración de infraestructuras energéticas mediante plantaciones vegetales}

El paisaje de Tierra de Campos se ha caracterizado anteriormente como extremadamente frágil, es decir, muy susceptible al deterioro cuando se desarrolla un uso de tal envergadura como el energético. Para disminuir su fragilidad y aumentar, por consiguiente, su capacidad de acogida, una de las medidas más eficaces es favorecer el aumento de la vegetación, sobre todo arbolada (Figura 6.82). Es evidente que con las plantaciones arbóreas no se ocultan los aerogeneradores ni las líneas eléctricas, pero sí que se mitiga su impacto paisajístico a través de la mejora de uno de los atributos de calidad del paisaje.

Llevar a cabo esta medida es económicamente sencillo pero de gestión complicada. Requiere en primer lugar fijar una franja de actuación, que puede ser por ejemplo $200 \mathrm{~m}$ a cada lado de una línea eléctrica. En segundo, conseguir la disponibilidad de los terrenos -que preferentemente serán públicos-, buscando baldíos, márgenes de caminos, arroyos, vías pecuarias, etc. Finalmente, la ejecución será más compleja, al tratarse de muchas zonas dispersas. En cualquier caso se debe encontrar un equilibrio entre el cumplimiento del objetivo de integración vegetal de la línea y la practicidad de su consecución y mantenimiento.

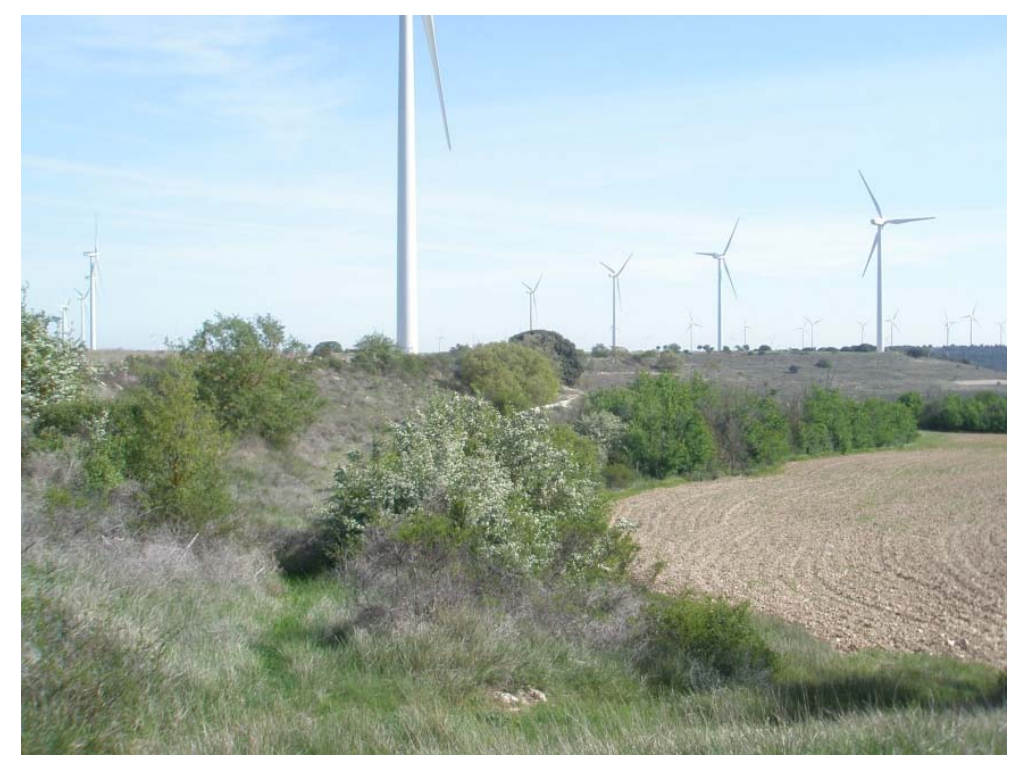

Figura 6.82. El impacto paisajístico de este parque eólico de Ampudia es sin duda menor por la presencia de estos rodales de vegetación arbórea y arbustiva. 


\section{Creación de miradores}

Los parques eólicos están siempre situados en las zonas altas, allí donde el potencial de la fuerza del viento es mayor; en Tierra de Campos, en los bordes de los páramos. Como en otros espacios degradados se produce una paradoja: por una parte esta situación preeminente provoca un mayor impacto visual pero, a la vez, supone acceder a ubicaciones desde donde se pueden contemplar vistas inmejorables. La creación de un mirador no supone una infraestructura muy compleja: pequeña zona acondicionada de zahorra, aparcamientos, barandilla, depósitos de basuras y carteles interpretativos (Figura 6.83). A este se le puede añadir un área recreativa. Lo ideal es integrar el mantenimiento del mirador dentro de la política de divulgación de la empresa, de forma que se conjugue la generación de energía limpia renovable con la interpretación del paisaje.

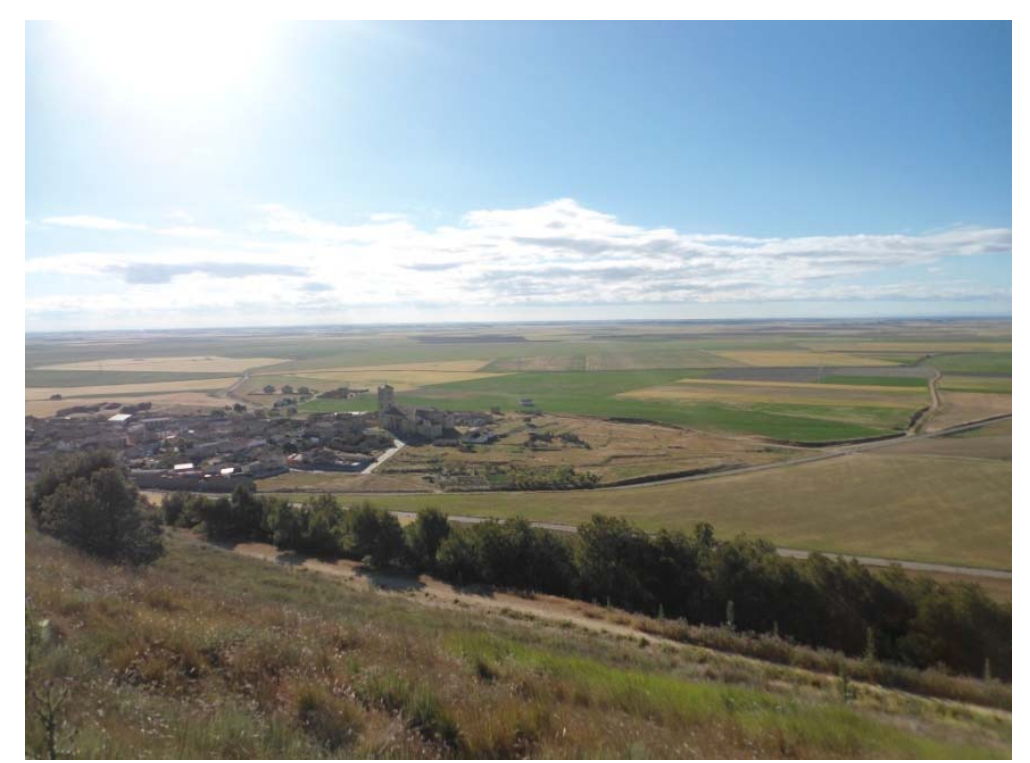

Figura 6.83. Vista desde el mirador del parque eólico el Castre, construido además en la zona adyacente al castillo de Torremormojón: energía renovable, patrimonio y paisaje unidos.

\section{Instalación de salvapájaros en las líneas eléctricas de alta tensión}

Con objeto de minimizar la colisión de las aves con el cable de tierra de las líneas de alta tensión (de menor diámetro y, por tanto, menos visible), y así reducir el efecto barrera de estas infraestructuras, se instalan dispositivos salvapájaros. En algún tipo de línea se instala en todos los conductores, ello depende de la reglamentación y de la posible ubicación en Zona de Especial Protección para las Aves (ZEPA). Estos pueden ser espirales de plástico naranja o tiras negras de neopreno. Es posible que sean más eficaces las primeras por su vistosidad, aunque provocan un mayor impacto visual; las segundas aunarían ambos objetivos.

\subsubsection{Ríos y arroyos desnaturalizados}

Siguiendo a GONZÁLEZ DEL TÁNAGO y GARCÍA DE JALÓN (2004), se considera que un río está degradado cuando presenta algún aspecto deficiente en su composición, en su estructura o en su funcionamiento. La inmensa mayoría de los ríos y arroyos de Tierra de Campos se encuentran 
desnaturalizados fundamentalmente por las alteraciones sufridas en sus cauces (rectificados y dragados) y, en consecuencia, en sus llanuras de inundación (que desaparecieron).

Las causas de estas alteraciones se derivan de finales del siglo XIX y principios del XX. Los cursos hídricos de Tierra de Campos presentan naturalmente unos cauces sinuosos, de escaso calado $y$ considerable anchura, características derivadas de su flujo intermitente: secos en verano y con elevado caudal en las épocas lluviosas. Ello conllevaba inundaciones periódicas de las llanuras colindantes, que ocasionaban estragos en los cultivos e incluso en las localidades ribereñas; tan solo citar como ejemplos las graves riadas producidas en Villafrades de Campos y en Castroponce de Valderaduey, que incluso provocaron la necesaria reconstrucción de todo este último pueblo. Para remediar esta situación, el Estado acometió importantes obras de rectificación y encauzamiento de la inmensa mayoría de los ríos y arroyos de la comarca -a excepción de los principales: Pisuerga, Carrión y Cea (Figura 6.85)-, que fueron seguidas de dragados y limpiezas periódicas de los cauces. Ni que decir tiene que la vegetación de sus márgenes también fue eliminada, dando lugar a unos cauces totalmente desnaturalizados, con abundante vegetación helófita y cuya llanura de inundación fue invadida por los cultivos agrícolas (Figura 6.84).

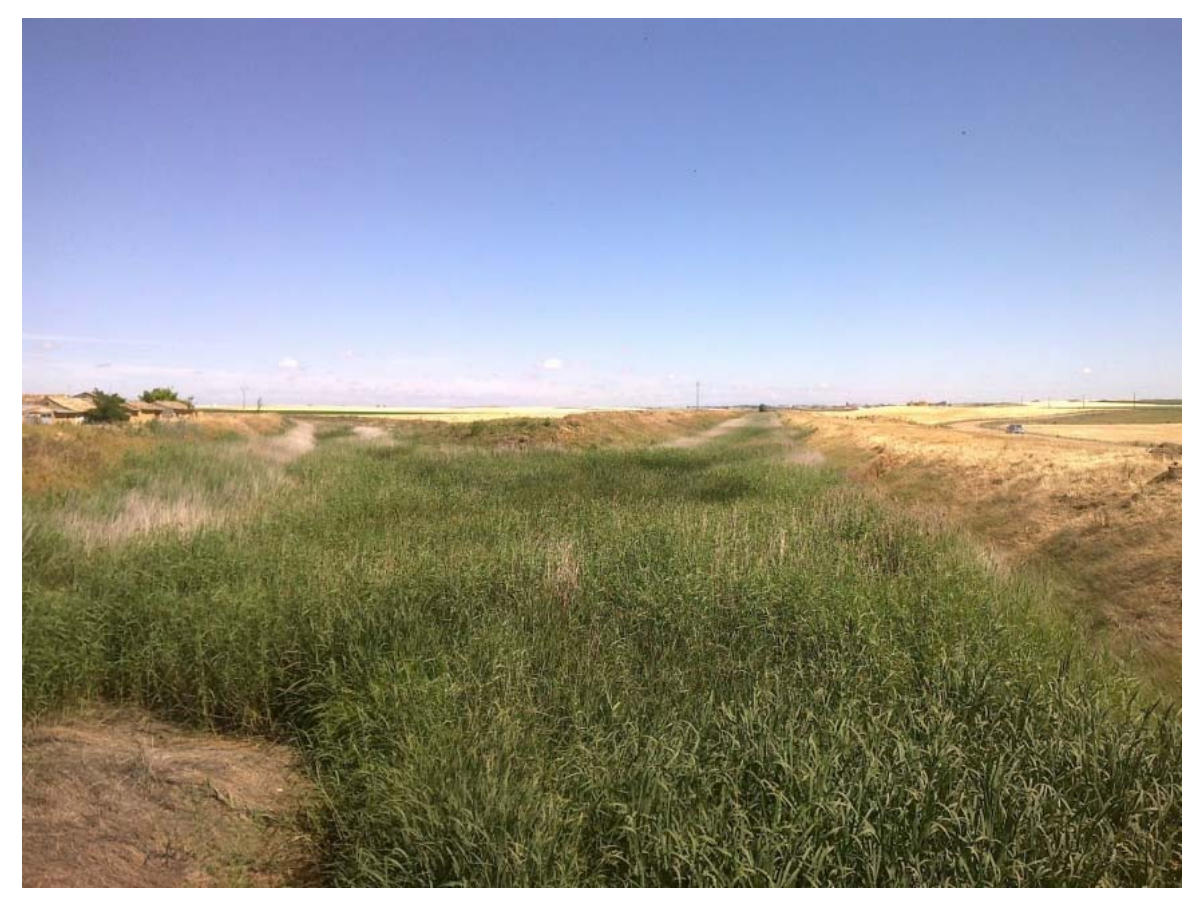

Figura 6.84. Tremenda imagen del grado de desnaturalización que alcanza la confluencia del arroyo Berruez con el río Sequillo en Villafrades de Campos. Tal como se aprecia, ambos cauces presentan una abundancia de especies helófitas que, ante la ausencia de arbolado que proporcione sombra, invaden el lecho y provocan el efecto contrario al perseguido originalmente: el taponado de los cursos ante las riadas. 


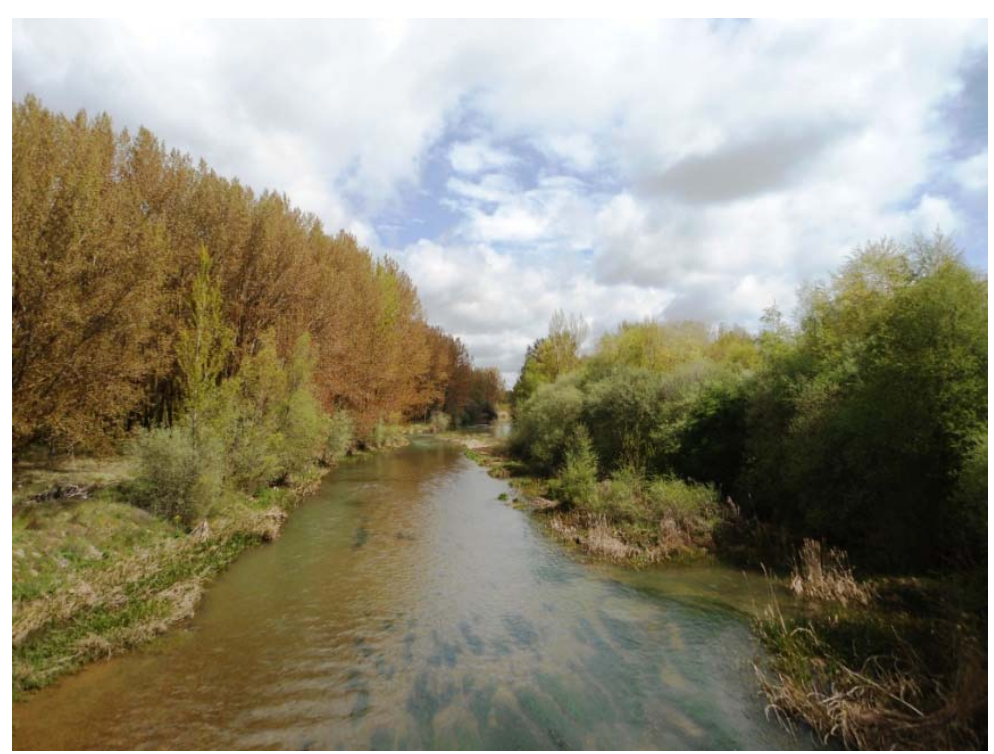

Figura 6.85. La ribera del río Cea, a su paso por Melgar de Abajo, presenta un alto grado de naturalidad, con abundante presencia de vegetación riparia variada y en todos sus estratos.

En los ríos, la tierra extraída del cauce se extendió en los márgenes del mismo, creando las denominadas motas, que aumentaban el calado y disminuían por consiguiente el riesgo de inundación. En la mayoría de los casos, debido a la gran presión ganadera de ovino, las motas han sido pastoreadas hasta el límite, impidiendo la regeneración natural de la vegetación riparia. No obstante, en algunos casos la Confederación Hidrográfica del Duero ha ido realizando plantaciones de chopos lombardos que han naturalizado parcialmente los cursos hídricos.

El gran problema existente para plantear la restauración de los cursos fluviales de Tierra de Campos radica en la falta de terreno público disponible en las riberas. A partir de los encauzamientos se fue consolidando la propiedad privada en la antigua llanura de inundación, que fue cultivada de inmediato, por lo que el terreno disponible se restringe en la mayoría de los casos al cauce.

Dentro de las posibles soluciones para recuperar estos ríos y arroyos desnaturalizados, GONZÁLEZ DEL TÁNAGO y GARCÍA DE JALÓN (op.cit.) plantean como solución ideal su restauración. Ello se referiría a la recuperación del estado y procesos naturales del río, es decir, que el río vuelva a tener espacio suficiente para desarrollar procesos de erosión y sedimentación y pueda mantener una morfología en equilibrio dinámico con el régimen de caudales circulante; que el régimen de caudales sea un reflejo de la variación espacio-temporal de las condiciones hidrológicas de la cuenca vertiente; y que el río vuelva a recuperar gradualmente su estructura biológica, en términos de fauna y flora. Los trabajos de restauración comprenderían la recuperación de la sinuosidad primitiva del cauce, la retirada de motas y barreras longitudinales y la disminución de los taludes laterales (recuperación de la conectividad del cauce con sus riberas).

En las condiciones actuales estos objetivos son muy difíciles de llevar a cabo; para ello se requeriría la realización de verdaderos proyectos integrales de restauración, que estuviesen apoyados en una disponibilidad pública de terrenos suficiente en ambos márgenes del río. 
Además conllevaría ineludiblemente la oposición de localidades y colectivos agrícolas -que poseen una gran capacidad de presión ante la clase política-, que verían resucitar el fantasma de las inundaciones; podría ser rebatible técnicamente, pero muy difícil mediáticamente.

Por consiguiente, se considera que la opción aconsejable para mejorar la calidad paisajística y ecológica de los ríos y arroyos de Tierra de Campos es su rehabilitación. Este término, según los citados autores, alude a una actuación inicial de restauración, aplicada con frecuencia a los ríos con una situación muy deteriorada, con lo cual solo se pretenden recuperar los procesos del río parcialmente. Siempre se considera positiva para el ecosistema fluvial, aunque se acepta el mantenimiento de límites al funcionamiento natural del río. Esta opción es la contemplada en el Proyecto de restauración del arroyo Berruez, en el término municipal de Villalón de Campos, analizado en el Anejo 2. En consecuencia, la actuación que aquí se plantea, y las unidades de obra que conlleva es la siguiente:

\section{Rehabilitación de ríos y arroyos desnaturalizados}

- Aunque resulte una tarea compleja, sería aconsejable realizar un deslinde y amojonamiento previo del dominio público hidráulico que conllevase una ampliación de la superficie de actuación. Ya hemos señalado anteriormente que una buena opción sería clasificar parcelas públicas (de Restauración del Medio Natural) en las concentraciones parcelarias.

- Se debe realizar la retirada y gestión adecuada de los residuos depositados en el cauce, que por desgracia siempre se encuentran presentes, en mayor o menor cantidad: escombros, ruedas, plásticos, somieres, etc.

- Resulta fundamental disminuir la pendiente de los taludes del cauce, que en muchos casos se encuentra cercana a los $45^{\circ}(1 \mathrm{~V}: 1 \mathrm{H})$. Se procurará no afectar a la vegetación existente, sobre todo arbolada.

- La eliminación de las motas longitudinales es conflictiva. Por una parte mejoraría la conectividad ecológica entre el cauce y sus riberas aunque, como estas son inexistentes, conllevaría el riesgo de una posterior intrusión de esa superficie por los cultivos colindantes. Además, su existencia permite que, al ser mayor la longitud de pendiente, la superficie disponible para plantaciones sea más elevada. Por tanto, en principio no se aconseja la eliminación total de las motas, aunque se aumentase la anchura del cauce.

- La última fase de la rehabilitación consiste en la realización de plantaciones vegetales, generalmente en la parte media de los taludes. Estas serán fundamentalmente de especies arbóreas (chopo castellano -se considera prioritaria-, álamo, sauces, fresno, etc.), aunque con cierto porcentaje de arbustivas (escaramujo, tamariz, espino albar, etc.). Es muy importante que se trate de especies autóctonas, de la procedencia más cercana posible. En el caso de los árboles es fundamental que el hoyo creado sea profundo, llegando a un nivel edáfico húmedo. Las plantaciones se suelen realizar por rodales, cambiando de margen de forma alternativa; conviene dejar zonas sin plantar por si se realizan labores de limpieza del cauce. También se pueden utilizar estaquillas, siempre que se asegure su permanente contacto con humedad. 

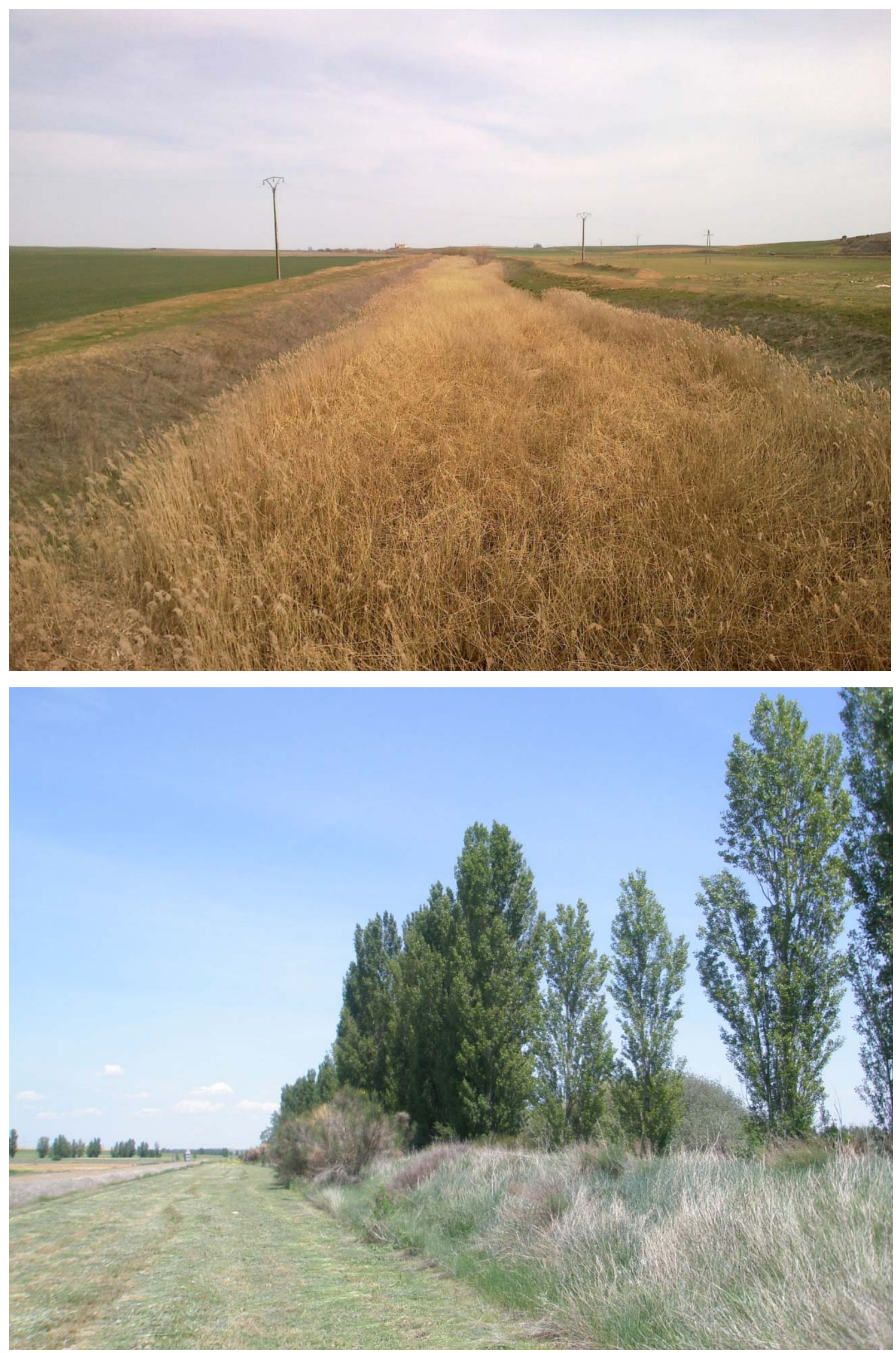

Figura 6.86. Dos imágenes de un mismo río en las que se aprecia lo que supone para el paisaje la restauración. En la superior se observa el cauce absolutamente desnaturalizado del río Sequillo en Tamariz de Campos. En la inferior se aprecia el importante papel de los chopos en la naturalización del mismo río en Villacidaler. 


\subsubsection{Zonas húmedas degradadas}

De acuerdo con la definición dada por el Convenio de Ramsar, un humedal es una zona de la superficie terrestre que está temporalmente inundada, regulada por factores climáticos y en constante interrelación con los seres vivos que la habitan. Las zonas húmedas son ecosistemas complejos, cuya principal función consiste en ser hábitat de numerosas especies vegetales y animales, muchas de ellas protegidas. Además cumplen otras muy diversas: alta producción de biomasa, gran actividad microbiana, depuración del agua, regulación hidrológica, control de sedimentos, aumento de la biodiversidad, mejora del paisaje, observación de la naturaleza, investigación científica, etc.

Tierra de Campos es una comarca con una abundante presencia de zonas húmedas, normalmente insertas en espacios naturales protegidos: lagunas de Villafáfila, laguna de La Nava, laguna de Boada, laguna de Tamariz de Campos, lagunas del Canal de Castilla, etc. Algunas de ellas son naturales y se mantienen como tales (Villafáfila). Otras lo fueron y han sido restauradas al menos en parte (La Nava, Boada). Algunas han surgido como consecuencia de obras públicas antiguas, como las asociadas al Canal de Castilla. Finalmente, existen otras que surgen -naturalizadas o restauradas- a partir de préstamos de obras públicas recientes (autovía del Camino de Santiago, línea del ferrocarril de alta velocidad Palencia-León, carreteras convencionales, etc.) o de explotaciones de áridos.

La recuperación de zonas húmedas tiene una gran importancia para la mejora del paisaje cerealista. En cuanto al paisaje perceptivo visual, las mejoras son notables: introducción de una lámina de agua en un terreno netamente terrestre y predominantemente seco, posibilidad de observación de un buen número de aves, revegetación en su entorno, etc. La percepción sonora es igualmente significativa: las últimas horas del día son momentos de una gran agitación de sonidos diversos de la avifauna acuícola. Respecto del paisaje ecológico, la creación de este tipo de ecosistemas mejora la biodiversidad de las zonas húmedas y de un entorno considerable; se convierten en manchas naturales en la matriz agrícola y, por tanto, en elementos de dispersión.

Partiendo del principio general de dotar de la mayor variedad posible al diseño de zonas húmedas, las líneas maestras de su recuperación debieran tener en cuenta los siguientes criterios (UDPP, 2002):

\section{Restauración de zonas húmedas}

- Cuanta más superficie ocupe la zona a tratar, más posibilidades de diseño se tendrán. Suele ser efectivo trazar los contornos irregulares, creando ensenadas y zonas de abrigo (Figura 6.87).

- El perfil debe ser variado tanto en profundidades como en pendientes. Esto favorecerá la diversidad de formas de vida animal o vegetal de posible instalación. Por ejemplo, las pendientes serán suaves -hasta el $10 \%$ - en las zonas de estancia de aves; y podrán ser mayores -hasta el $20 \%$ - en las que solo se pretenda la instalación de una cubierta de vegetación freatófita.

- Las pendientes acusadas podrán utilizarse en algunas áreas en las que se quiera limitar el crecimiento de plantas en las orillas y dejar zonas de agua libre junto a ellas. También se puede jugar en las riberas con el microrelieve, permitiendo crear hábitats para 
diferentes especies. La pendiente del fondo de la laguna será igualmente heterogénea, lo que permitirá crear unas condiciones variadas para el hábitat de la fauna y flora acuáticas. Hay que tener en cuenta que cada especie requiere unas profundidades mínimas para vivir.

- Igualmente, con el fin de favorecer la creación de diferentes hábitats animales y vegetales, se podrán utilizar diferentes sustratos para modelar las orillas.

- Se puede marcar una profundidad de $2 \mathrm{~m}$ a partir de la cual los carrizos ya no crecen; de esta forma se crean láminas de agua libre.

- La vegetación de las orillas de las lagunas protege a estas de fenómenos de erosión provocados por el oleaje. Cuando este riesgo pueda ser elevado, se deberá acudir a soluciones combinadas de estructuras artificiales y vegetación para proteger y estabilizar estos bordes.

- Dentro de la zona húmeda deberá reservarse algún área con una altura del nivel del suelo ligeramente superior al de la lámina de agua habitual, con objeto de acoger las variaciones del nivel del agua en épocas de abundante lluvia. En estas áreas se emplearán especies vegetales que toleren un nivel freático alternante de estas características.

- Un elemento primordial en el diseño de zonas húmedas son las islas. Estas deberán situarse en las zonas de lámina libre y tendrán como misión aportar un hábitat aislado donde puedan criar aves y demás fauna con seguridad. A ser posible, las pendientes de su relieve serán suaves, al igual que en sus orillas y en la transición hacia el fondo de la laguna.
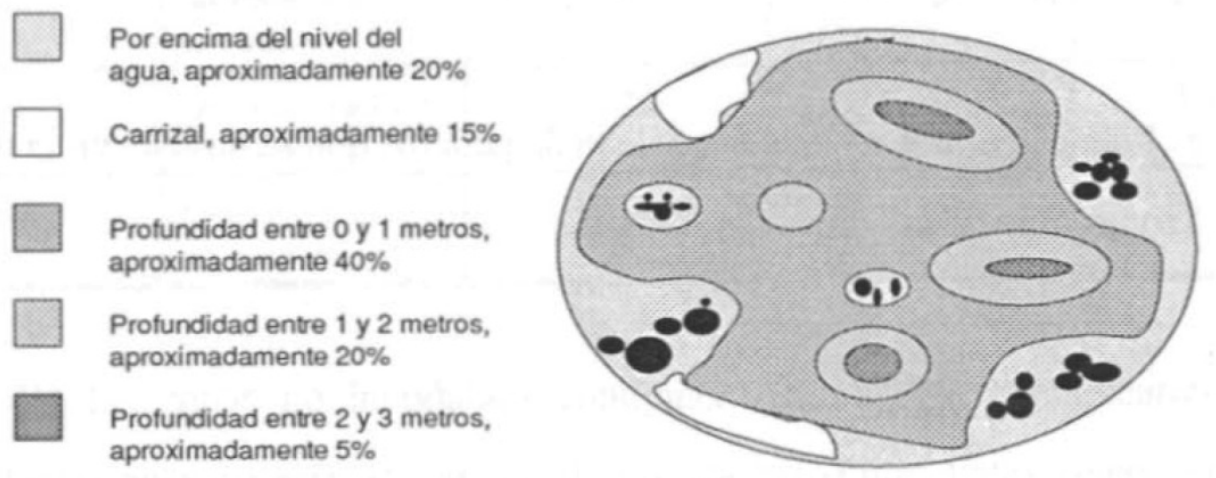

Figura 6.87. Ejemplo ideal representando una zona húmeda artificial (UDPP, 2002)

- Si hay árboles que vayan a quedar rodeados de agua al inundar la laguna, interesará mantenerlos, pues es frecuente que después sean utilizados como lugar de nidificación y descanso por las aves. 
- Se podrán dejar distribuidas rocas, árboles muertos y otros restos naturales en posiciones dispersas por todo el humedal (orillas e islas), ya que proporcionan alojamiento a peces, anfibios, etc.

- Se puede agrupar las plantas a utilizar en la revegetación de humedales en cinco grandes tipos: flotantes, sumergidas, hierbas emergentes, carrizos y plantas que tapizan el fondo sumergido. Algunos de los géneros a utilizar serían: Juncus, sp., Phragmite ssp., Typha sp., etc.

- En las zonas no inundables contiguas al humedal se realizarán plantaciones con especies arbustivas y arbóreas autóctonas, adaptadas a una menor humedad edáfica. Estas zonas son también importante para la laguna, pues serán utilizadas por su fauna.

- En ocasiones puede interesar crear setos que aíslen la zona húmeda de zonas urbanas próximas. En la medida de lo posible se tratará de que los caminos se encuentren lo más alejados posibles al menos de las zonas más sensibles; pueden ser un importante foco de escombros.

- Para favorecer el uso turístico-natural es conveniente construir observatorios de aves, suficientemente alejados de la laguna. La integración paisajística puede conseguirse a través del empleo de madera o bien -si son de obra- con paramentos terrosos y teja árabe.

- Este uso social también puede mejorarse mediante la creación de senderos peatonales -también alejados de las zonas críticas- que conduzcan a los visitantes hacia localizaciones donde puedan visualizar las aves sin molestarlas.

- Finalmente, dependiendo de la entidad de la zona húmeda restaurada, resulta acertada la construcción o rehabilitación de edificios típicos de la comarca (palomares, casas tradicionales) que sirvan como centros de interpretación de la naturaleza y liguen el turismo ornitológico con el desarrollo rural de los pueblos cercanos. 

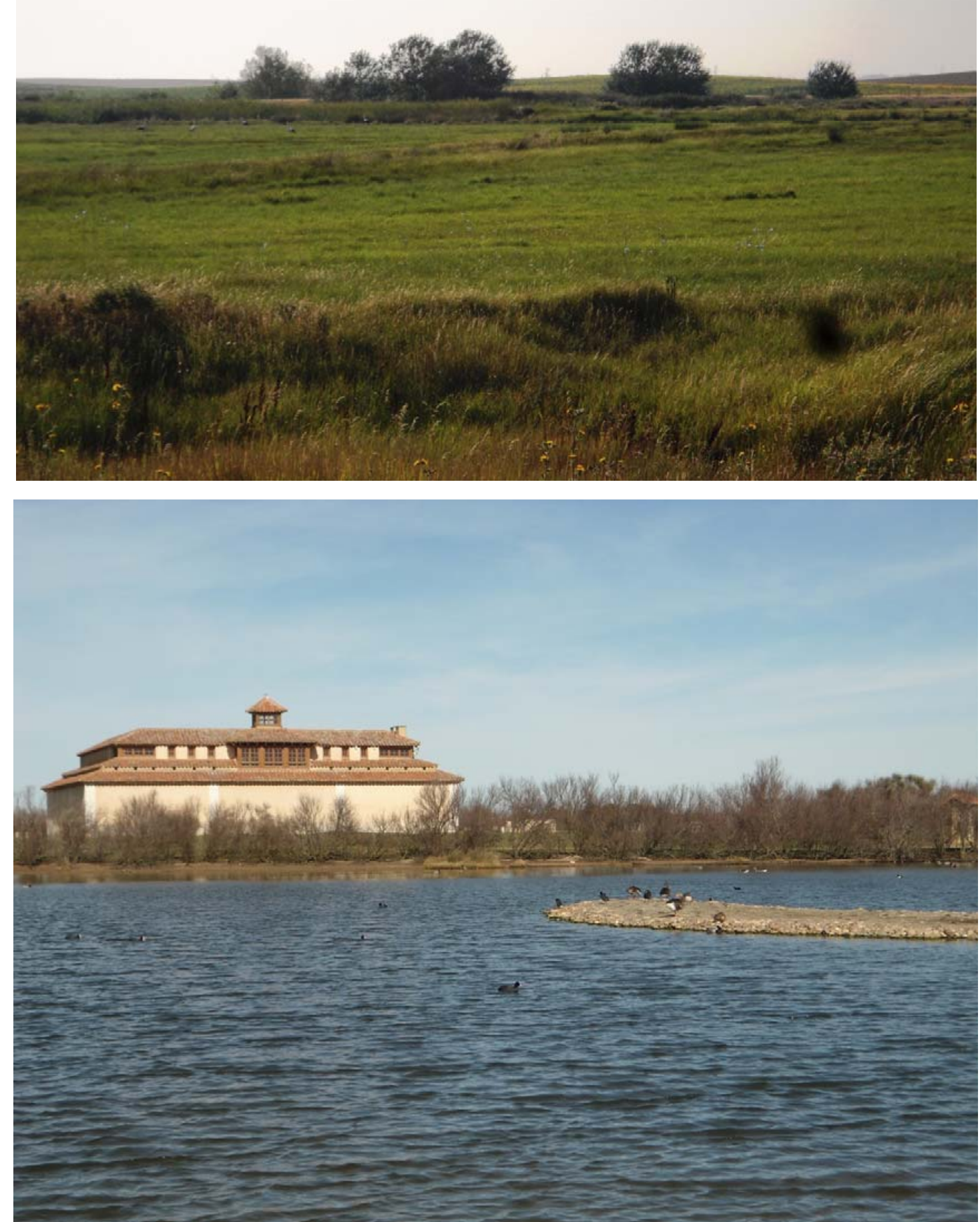

Figura 6.88. En la imagen superior se distinguen unas praderas colindantes al río Sequillo, en Tamariz de Campos, que constituían zonas húmedas antes de que este curso hídrico se encauzase; recientemente se ha restaurado precisamente una parte con aguas del Canal de Castilla. En la imagen inferior se observa la restauración de una laguna en el entorno de la Casa de la Reserva de las Lagunas de Villafáfila; magnífica actuación en la que se conjuga la recuperación de hábitats naturales, la valorización del patrimonio popular constituido por los palomares y el desarrollo turístico de la comarca. 


\subsubsection{Vías pecuarias y del ferrocarril sin uso}

En Tierra de Campos ha tenido gran importancia desde hace milenios el uso ganadero extensivo, fundamentalmente de ovino. Además, por ser tierra de paso entre las dehesas extremeñas y la montaña cantábrica, se ha ido creando una fabulosa red de cañadas ( $75 \mathrm{~m}$ de anchura), cordeles $(37,5 \mathrm{~m})$ y veredas $(18 \mathrm{~m})$ que vertebran el territorio como ahora lo hace la red de autovías o la de ferrocarriles de alta velocidad. Dentro de las primeras, la Cañada Real Leonesa Occidental (Figura 6.89) atraviesa la comarca de norte a sur, de forma sensiblemente paralela a la carretera nacional N-601 Valladolid-León; la Cañada Real Leonesa Oriental parte de Palencia y se dirige a Riaño cruzando Tierra de Campos en diagonal; finalmente, la Cañada de la Mendoza inicia su recorrido en Palencia para adentrarse pronto en el páramo de Torozos. Los cordeles son numerosos, aunque no están distribuidos homogéneamente; el entorno de Carrión de los Condes goza de la presencia de un buen número de ellos. Las veredas son las que han salido peor paradas: en la mayor parte de los casos han sido engullidas en las concentraciones parcelarias, reduciéndose su anchura hasta constituir exclusivamente caminos rurales de $10 \mathrm{~m}$ de anchura total. Las vías pecuarias son bienes de dominio público y están protegidas por una ley estatal, siendo gestionadas por la Consejería de Medio Ambiente de la Junta de Castilla y León.

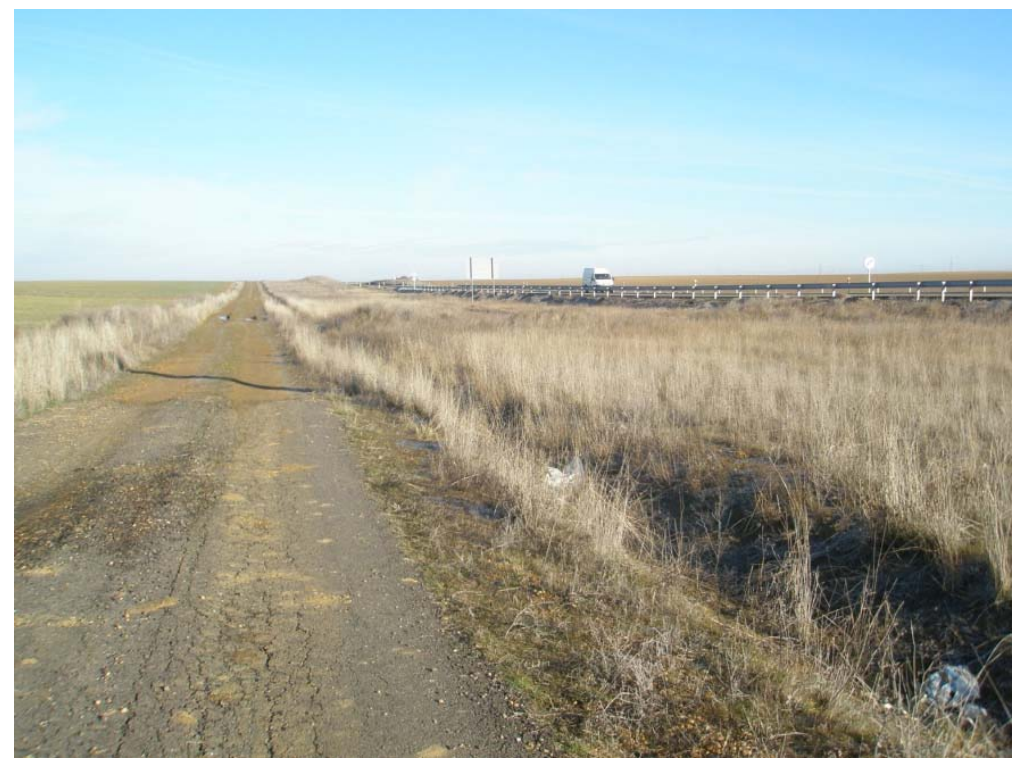

Figura 6.89. Vista de la Cañada Real Leonesa Occidental en Ceinos de Campos, donde discurre contigua a la carretera nacional N-610. En general se trata de un pastizal con un camino rural en su interior. Como otras vías pecuarias, está sometida a numerosas presiones: intrusiones de colindantes, ocupaciones ilegales, depósitos de escombros, etc.

El primer ferrocarril de vía estrecha de Tierra de Campos se inauguró en 1885: la línea procedente de Valladolid, que atravesaba Medina de Rioseco dirección Palanquinos. En 1915 entran en servicio las líneas Medina de Rioseco-Villalón de Campos, que en esta localidad se desdobla hacia Villada y hacia Palencia. Estas líneas tuvieron una gran importancia en el desarrollo comarcal, sobre todo en las décadas veinte y treinta del siglo pasado (illegaron a contar con 18 viajes diarios!); eran tiempos en que Tierra de Campos aún contaba con una gran densidad demográfica y donde la agricultura e industria derivada tenían un peso económico 
destacado. Con el éxodo rural languidecen hasta que, en 1969, son cerradas definitivamente. A partir de esta fecha se produce su progresivo desmantelamiento y la desidia en la conservación de sus edificios asociados, de gran valor arquitectónico. No obstante, su traza original llega hasta nuestros días milagrosamente casi intacta, siendo la propiedad del Ministerio de Fomento (FEVE) o de los Ayuntamientos respectivos. En los últimos años se han realizado rehabilitaciones puntuales como Vía Verde, como el de la denominada "Tierra de Campos" entre Cuenca de Campos y Villalón de Campos, de tan solo 4,5 km.

Las actuaciones que se proponen para estos dos tipos de "infraestructuras naturales" son las siguientes:

\section{Restauración de cañadas y cordeles como grandes corredores ecológicos}

La existencia de estas grandes vías pecuarias - de dominio público, no olvidemos- se convierte en una gran oportunidad para crear espacios forestales naturales compatibles con el uso pecuario. Su anchura, además, permite que en su interior se puedan construir o recuperar senderos o caminos naturales que permitan también un uso recreativo. Se plantean las siguientes unidades:

- Deslinde y amojonamiento de las cañadas y cordeles donde aún no se haya realizado esta delimitación de la propiedad (en particular, la Cañada Real Leonesa Occidental).

- Revisión permanente de los límites para evitar intrusiones de colindantes.

- Retirada y gestión adecuada de los depósitos de escombros y residuos de cualquier naturaleza.

- Eliminación de las ocupaciones ilegales: aperos, montones de paja, materiales o maquinaria de todo tipo, etc.

- Remodelación topográfica de las zonas que hayan sido alteradas en el pasado, por pequeñas extracciones de áridos, vertederos, escombreras, etc.

- Adecuación de un único camino rural que discurra a lo largo de la cañada, que disponga de una mínima plataforma (4-5 m), firme adecuado y cunetas. Se utilizarán los caminos existentes, favoreciéndose un trazado sinuoso.

- Plantación de arbustos en ambas linderas, a 0,50 m del límite, para consolidar la propiedad pública (utilizando escaramujo, endrino, retama, gayomba, etc.); distancia entre ejemplares, entre 3 y $5 \mathrm{~m}$. Preparación lineal o puntual del terreno.

- Plantación de árboles a baja densidad en el interior de la cañada o cordel, en forma de dehesa, con objeto de permitir el uso del terreno como pastizal. Se propone la encina como especie prioritaria, colocada irregularmente a una distancia aproximada de $6 \mathrm{~m}$, con protectores para el ganado y cuidados culturales máximos. Preparación puntual del terreno.

- Adecuación de senderos de Pequeño o Gran Recorrido (PR o GR) para valorizar el paisaje generado alrededor de estos corredores ecológicos. 


\section{Recuperación de veredas y pequeñas vías pecuarias}

Aunque, tal como hemos señalado anteriormente, la anchura de estas vías ha quedado sensiblemente reducida con las concentraciones parcelarias (Figura 6.90), un buen número de términos municipales de Tierra de Campos tienen clasificadas su propia red de vías pecuarias, que incluso suele conectarse entre términos próximos.
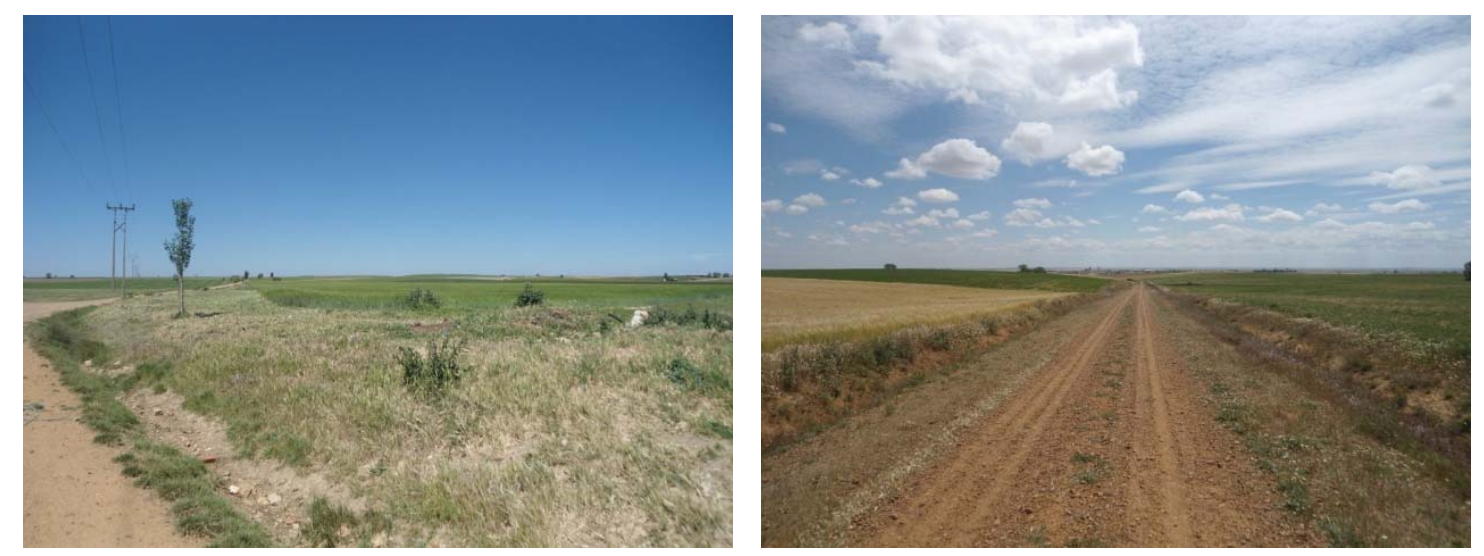

Figura 6.90. Dos imágenes de vías pecuarias en Villalón de Campos. A la izquierda, vereda de Mayorga a Herrín; cuenta con un sobreancho de unos $10 \mathrm{~m}$ sobre el camino y con dos de los típicos problemas asociados a estas vías: intrusiones de colindantes y depósitos de escombros. A la derecha, colada de Cabezón-Villalón, cuya traza coincide con un camino rural en su integridad.

De acuerdo con las conclusiones derivadas del análisis de los Recorridos paisajísticos en Villalón de Campos, que todavía mantiene una red de estas características, se plantean las siguientes unidades:

- Deslinde y amojonamiento de las vías pecuarias que tengan sobreancho respecto de los caminos rurales sobre los que se asientan. Las concentraciones deben tratar estas vías como parcelas independientes, para que así cuenten con los mojones necesarios. En el resto (mayoritario) de las vías la delimitación no es necesaria, ya que coinciden con el camino.

- Eliminación y gestión adecuada de todos los residuos depositados en sus márgenes. Esta medida debe ir asociada a la colocación de carteles de advertencia y a la colaboración de los ayuntamientos para evitar posteriores depósitos.

- Plantación lineal de árboles en las vías pecuarias con sobreancho. Separación entre ejemplares de 6-8 m, preparación puntual del terreno, cuidados culturales, protectores para el ganado. Se recomienda como especie prioritaria el almendro, que puede acompañarse con otras especies indicadas para zonas secas. Esta plantación se debe complementar con otra de arbustos en el límite colindante con parcelas agrícolas, para consolidar la propiedad.

- Plantación de arbustos en los taludes de más de $1 \mathrm{~m}$ y de árboles en aquellos de altura mayor a $2 \mathrm{~m}$. Se seguirá lo indicado en las actuaciones para los caminos de las concentraciones parcelarias, aunque las plantaciones deberían ser más intensas, ya que en estos casos la propiedad y gestión corresponde a la Consejería de Medio Ambiente. 
- Colocación de sencillos carteles indicativos con el nombre de la vía pecuaria, al objeto de su conocimiento y para que no se pierda este interesante patrimonio cultural. Ello puede ser complementado con la colocación de paneles informativos de la red de vías pecuarias municipal e, incluso, con la creación de senderos de Pequeño Recorrido (PR) que induzcan a su utilización para el paseo, la bicicleta o a caballo.

\section{Rehabilitación como Vía Verde de las antiguas vías del ferrocarril}

La experiencia del Proyecto de rehabilitación como Vía Verde del tramo Cuenca de CamposVillalón de Campos, analizado en el Anejo 2, permite aconsejar su extensión al resto de tramos existentes en Tierra de Campos. En ellos se plantean las siguientes unidades:

- Revisión de la propiedad y del estado legal de las vías. En aquellos tramos que hayan sido enajenados a particulares, se tratará de revertir a propiedad pública o, en caso contrario, buscar trazados alternativos que permitan su continuidad.

- Retirada y gestión de escombros en aquellos puntos donde se hayan producido depósitos ilegales.

- Reconstrucción de los puentes, mediante rollizos y tablas de madera tratada.

- Instalación de talanqueras de madera, para impedir el paso de vehículos a motor en los cruces con caminos o carreteras.

- Explanación de la plataforma. Extensión y compactación de una capa de zahorra como subbase y posterior extensión de una fina capa de gravilla artificial para el firme.

- Creación de cunetas para asegurar el drenaje.

- Plantación lineal de árboles al menos en uno de los márgenes de la Vía Verde. Preparación puntual del terreno, separación de $8 \mathrm{~m}$ entre ejemplares, cuidados culturales y de mantenimiento intensos. Para la elección de especies es necesario distinguir entre zonas secas (dominantes en la traza) de zonas húmedas (al pie de desmontes y terraplenes). Grupos de 10-15 árboles de la misma especie (almendros, pinos piñoneros, encinas, chopos, álamos, etc.).

- Señalización de la Vía Verde dentro del programa de Caminos Culturales del Ministerio, incluyéndose puntos kilométricos, indicaciones, paneles informativos, áreas estanciales, etc. 

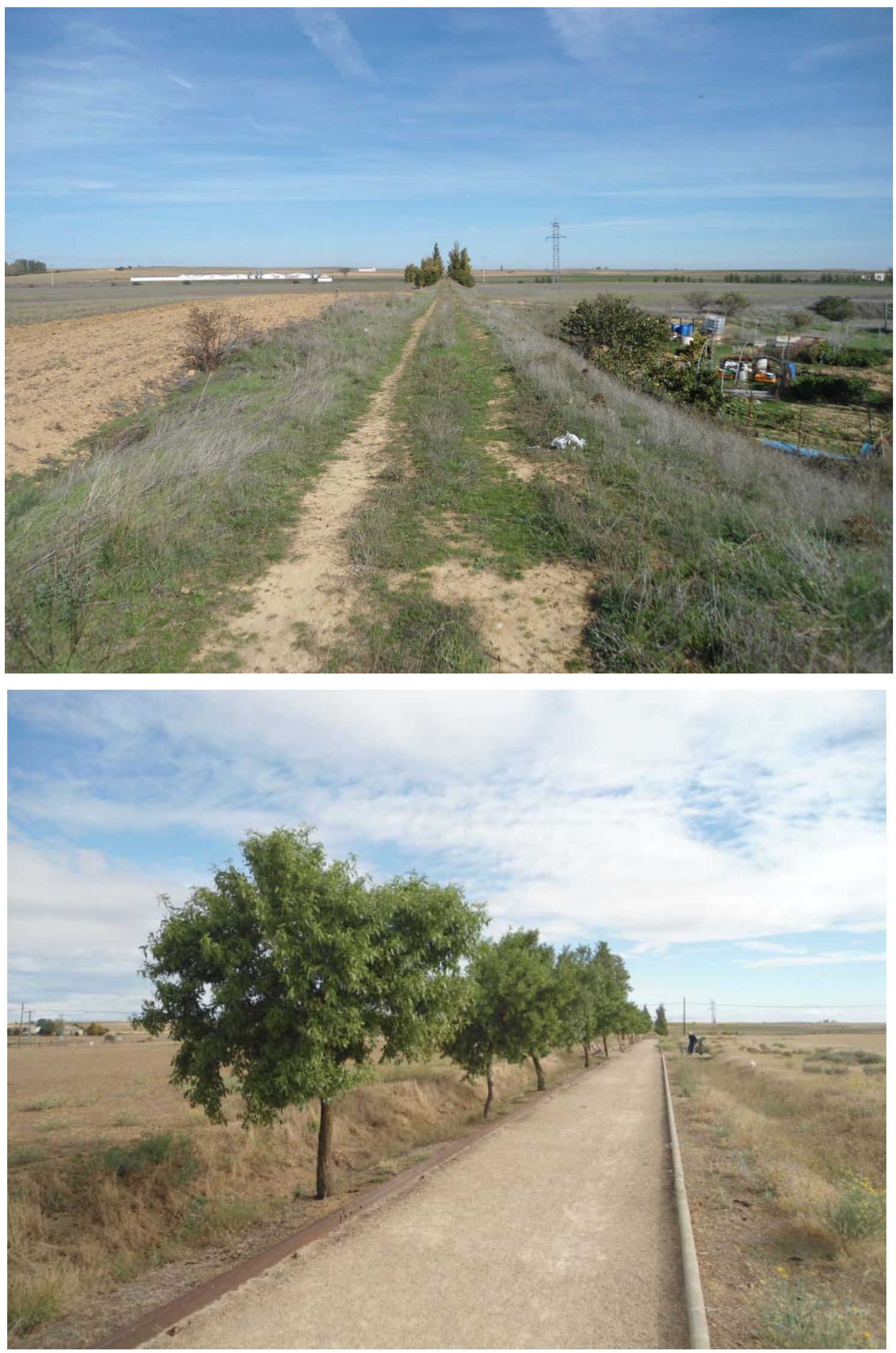

Figura 6.91. Imagen superior, antiguo trazado del ferrocarril de vía estrecha Villalón de Campos-Villada. Imagen inferior, tramo rehabilitado de la Vía Verde "Tierra de Campos" pocos metros más adelante; se observa la adecuación de la plataforma con gravilla fina, la recreación de la antigua vía del ferrocarril con los raíles de hierro y la plantación lineal de almendros, que tienen un buen desarrollo vegetativo. 


\subsubsection{Fuentes y pequeñas parcelas públicas degradadas}

Tal como se ha constatado en los Recorridos paisajísticos del Anejo 1, en muchos términos municipales de Tierra de Campos existen fuentes repartidas por el territorio, que tenían una importante función en la agricultura tradicional: para beber agua las personas -que pasaban tantas horas en el campo- y el ganado. El paso a la agricultura intensiva y la paulatina desaparición de la ganadería extensiva provocan que las fuentes ya no se utilicen y, por tanto, no se cuiden. No obstante poseen un gran valor para la mejora del paisaje cerealista, ya que constituyen auténticos oasis en medio de la aridez de los cultivos. Las fuentes suelen contar con un manantial derivado a un pequeño depósito, del que fluye el agua a un abrevadero (Figura 6.92). Normalmente se encuentran en el interior de una pequeña parcela pública, con un uso de pastizal en el que puede o no haber algún árbol.

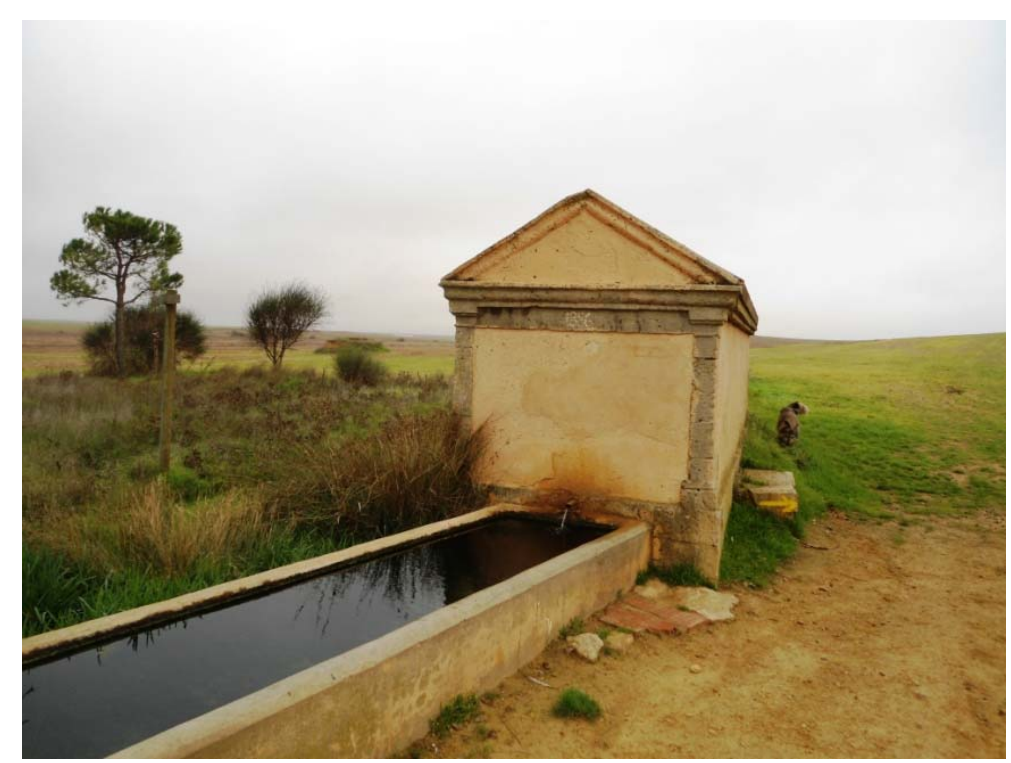

Figura 6.92. Fuente el Rosario en Villalón de Campos. Se observa el depósito del que fluye agua a un abrevadero. Su parcela es muy pequeña y posee algunos árboles y arbustos.

De igual modo, existen en Tierra de Campos pequeñas parcelas públicas sin un uso definido que proceden de sobrantes de vías pecuarias, propiedad municipal o de la comunidad autónoma, o bien que la concentración parcelaria las clasificó como Restauración del Medio Natural (Figura 6.93). Suelen tener una tipología similar al de las fuentes, pero sin contar con este recurso hídrico. Generalmente no están arboladas o podrían estarlo con mayor densidad. Un buen ejemplo es el analizado en el Anejo 2, "Repoblación forestal de una parcela en Herrín de Campos", realizada por la Consejería de Medio Ambiente. 


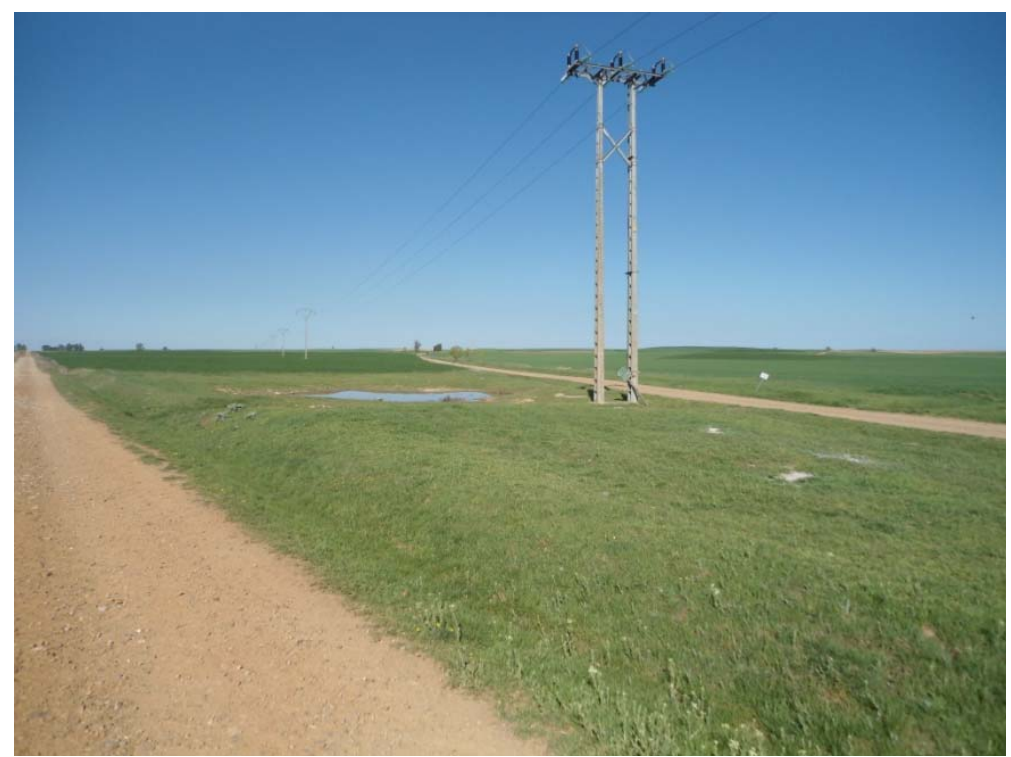

Figura 6.93. Ejemplo de una parcela de Restauración del Medio Natural; suelen ser "picones" donde no es rentable el uso agrícola. En caso de no realizar plantaciones, pueden ser ocupadas por los colindantes o ser foco de depósitos de escombros.

Las actuaciones que se plantean para esta tipología de espacio degradado, y las unidades de obra propuestas, son las siguientes:

\section{Restauración natural de fuentes}

- Delimitación de la propiedad, sobre todo en la colindancia con parcelas agrícolas; la mejor opción es la creación de una zanja con una motoniveladora, con posterior plantación de especies arbustivas rústicas (escaramujo, gayomba, retama, etc.).

- Restauración arquitectónica de los pequeños depósitos de agua, utilizando piedra caliza, ladrillo macizo, teja árabe, mortero terroso u otros materiales que aseguren su integración paisajística y el respeto a la tipología tradicional del patrimonio etnográfico.

- Restauración de la fuente en sí, recuperando en su caso el manantial, los drenajes, limpiando el depósito o sustituyendo el caño.

- Impermeabilización de los abrevaderos existentes para evitar fugas de agua.

- Creación de abrevaderos de mayor tamaño o charcas, aguas abajo de la fuente, para que además de abrevar el ganado sirvan de punto de agua para la fauna silvestre.

- Limpieza de escombros u otros residuos, en su caso, y gestión adecuada de los mismos.

- Plantación de árboles en la pradera, o en la parte de la misma que no sea excesivamente pisoteada por las ovejas (Figura 6.94). Es importante diferenciar zonas húmedas de secas. Preferencia por especies autóctonas de mínimo mantenimiento. Fundamental colocar protectores para el ganado. Riegos los dos primeros años.

- En su caso, poda de los árboles existentes si se han realizado restauraciones previas. 
- Señalización de las fuentes y creación de rutas a lo largo de las mismas.

- En alguna próxima a los pueblos, adecuación recreativa de las fuentes: colocación de mesas, bancos, pequeños refugios, vallado perimetral, etc.; asegurando la integración paisajística de las instalaciones, su rusticidad y su escaso mantenimiento.

\section{Restauración forestal-natural de pequeñas parcelas públicas}

- Delimitación de la propiedad, fundamentalmente cuando estas son colindantes con otras con parcelas agrícolas; de igual modo al caso anterior, con zanja y posterior plantación lineal de arbustos.

- Limpieza de escombros u otros residuos, en su caso, y gestión adecuada de los mismos.

- Plantación de árboles en toda su superficie Es importante diferenciar zonas húmedas de secas, aunque estas son más usuales. Las indicaciones son similares a las apuntadas anteriormente para la restauración de parcelas de sobrantes de las concentraciones parcelarias. Entre otras cuestiones: utilización de especies autóctonas, realización de alcorques, riegos al menos el primer año, colocación de protectores, etc.

- En su caso, poda de los árboles existentes si se han realizado restauraciones previas.

- Estas parcelas también se podrían señalizar, con el nombre de algún pago o similar, incluyéndolas en una red natural del término municipal. 

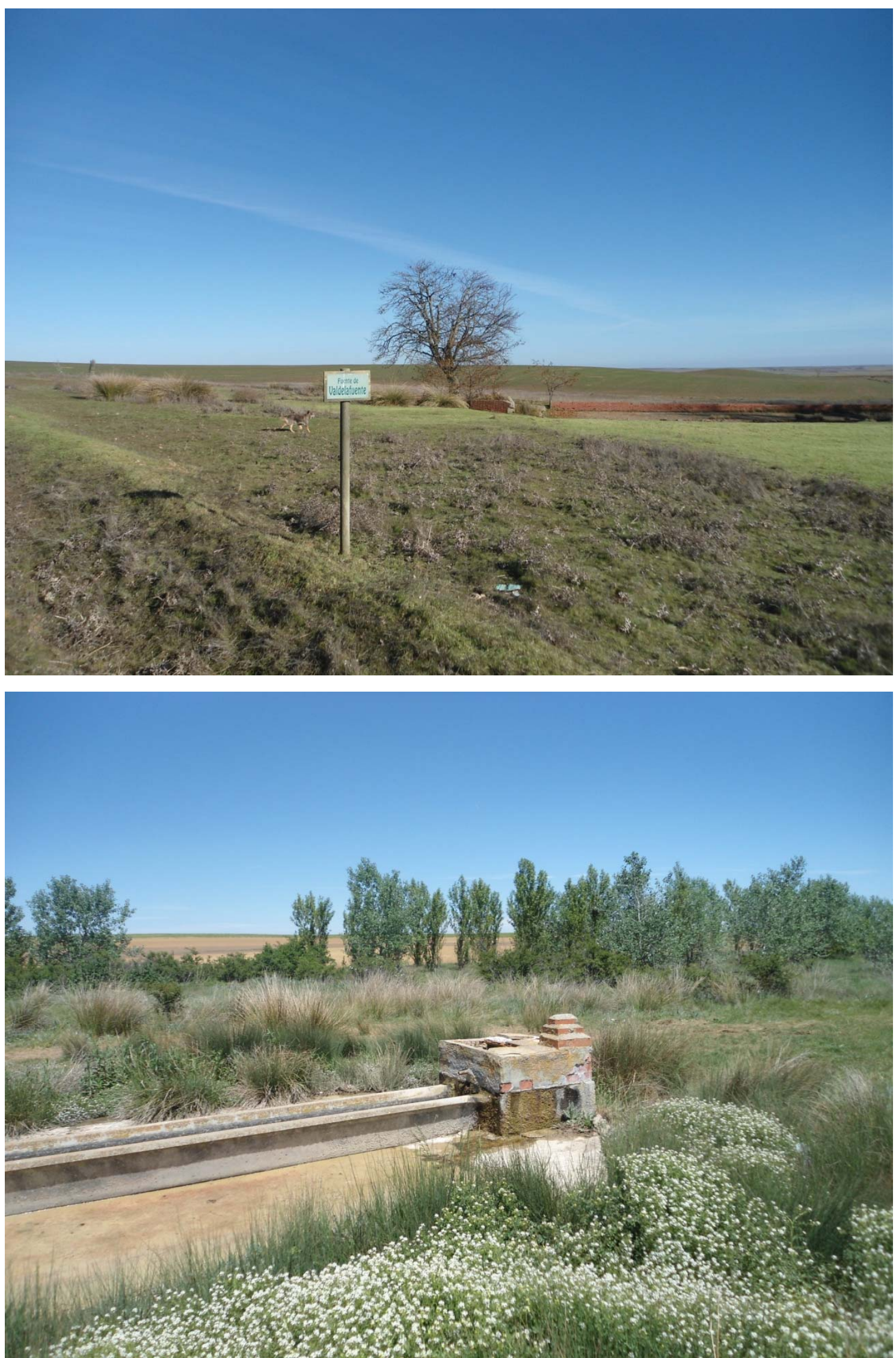

Figura 6.94. En estas dos imágenes se aprecia la diferencia que aporta el arbolado a la fuente Juan Palacios (inferior), en contraposición a la árida Valdelafuente (superior). 


\subsubsection{Espacios deforestados y/o erosionados}

En este tipo de espacio degradado se incluyen todos aquellos terrenos que tienen vocación forestal pero que no poseen una cobertura vegetal satisfactoria (Figura 6.95). Ocupan un porcentaje escaso de superficie respecto de la total de Tierra de Campos, pero poseen una gran importancia en términos cualitativos. Se incluyen los siguientes:

- Superficies en las laderas de transición del páramo calizo a la campiña que no han sido repobladas (por ejemplo, en Autilla del Pino) o que se cultivan teniendo fuertes pendientes. También se incluyen los cerros testigo u otros terrenos con elevada pendiente.

- Tesos, eriales, superficies marginales y otros terrenos agrícolas susceptibles de reforestación con pendientes suaves.

- Superficies, en las laderas mencionadas, que fueron repobladas con pino hace varias décadas (hacia 1960), pero que poseen elevadas densidades y escasa diversidad. También se incluyen aquellas repobladas mediante terrazas (a partir de 1980), que originaron un severo impacto paisajístico y una fuerte alteración morfológica del terreno.
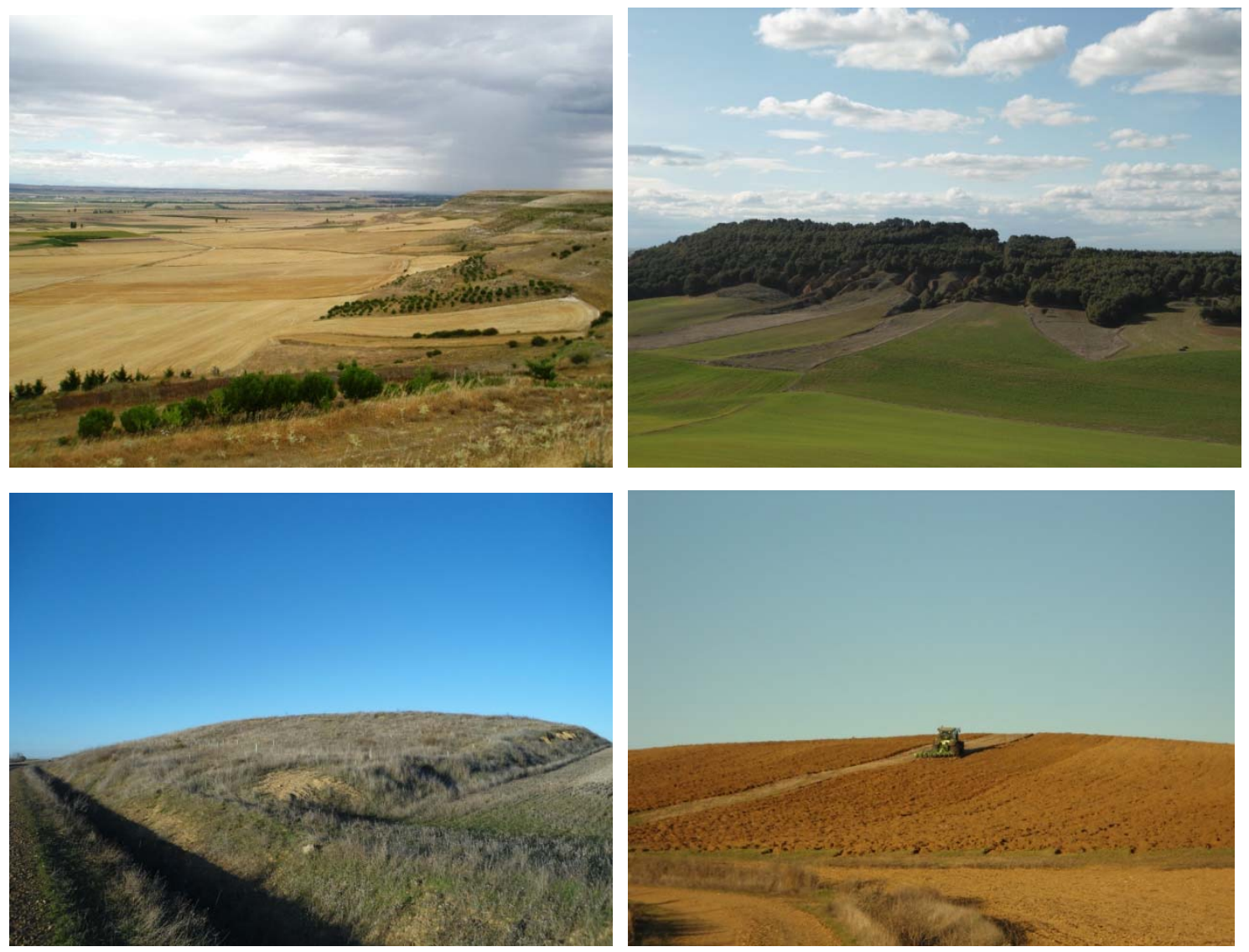

Figura 6.95. Arriba izquierda, laderas de Autilla del Pino parcialmente deforestadas e incluso cultivadas. Arriba derecha, cerro testigo en Tordehumos donde solamente se repobló con pino carrasco la zona alta de la ladera; además, el pinar presenta escasa diversidad. Abajo izquierda, teso en Villalón de Campos. Abajo derecha, parcela cultivada en el mismo término municipal, cuya pendiente hace predecir la existencia de fenómenos de erosión laminar.

Se proponen las siguientes actuaciones, con sus correspondientes unidades de obra: 


\section{Restauración hidrológico-forestal de laderas desarboladas}

La mayoría de las laderas que constituyen el límite de Tierra de Campos con los páramos calizos al Sur y al Este de la comarca, han sido repobladas por la administración forestal a partir de mediados del siglo XX. No obstante, aún existen laderas que por los motivos que fueren (oposición del Ayuntamiento, presión ganadera, cultivo, etc.), se encuentran en la actualidad en estado de erial, con ausencia de vegetación arbórea. Las pendientes suelen ser elevadas, superiores en general al $25 \%$. Las unidades más adecuadas para este tipo de obra son las siguientes:

- Creación de pequeños diques escalonados, en el caso de existir erosión por regueros o cárcavas. Es recomendable utilizar materiales con buena integración paisajística, como la piedra caliza del páramo, la tierra compactada o la madera. También se podrían utilizar otros tratamientos de bioingeniería con materiales vegetales.

- Adecuada preparación del terreno, siendo la técnica más recomendable el ahoyado mecanizado con buldócer, según líneas de máxima pendiente. Los hoyos deben tener una profundidad de más de $60 \mathrm{~cm}$. Para que estos sean suficientemente amplios, la entrada de los rejones en el suelo se ha de realizar en dos fases (en la segunda, se hincan un poco más arriba), de modo que además se conforme una pequeña microcuenca de recepción de agua. Otra preparación del terreno aconsejable para pendientes pronunciadas -aunque algo más costosa- es el ahoyado con retroaraña. En pendientes menos acusadas, se podría utilizar el método del subsolado lineal con buldócer.

- Adopción de una densidad de plantación situada en el entorno de las 1100 plantas/ha, teniendo en cuenta que el objetivo fundamental es de protección y que puede haber un cierto porcentaje de marras.

- Selección de varias especies vegetales; una distribución adecuada podría ser la siguiente: pino piñonero (50\%), encina y quejigo (30\%), arbustos (20\%). Aunque las primeras repoblaciones se realizaron al $100 \%$ con pino carrasco, esta especie se ha sustituido en las últimas décadas por el pino piñonero (Figura 6.96), que tiene una buena adaptación, aceptable crecimiento y la ventaja de la producción de piñón; no obstante, tampoco habría que descartar la utilización de pino carrasco con una adecuada homologación ecológica. A pesar de que el crecimiento de las quercíneas es menor al de las coníferas y que pueden tener más marras, es adecuada su utilización para favorecer la evolución ecológica desde fases tempranas. Dentro de los arbustos se puede incluir escaramujo, espino albar, endrino, retama y gayomba, que aumentarían la diversidad biológica y la protección frente a la erosión hídrica. Lo ideal es que se realice una mezcla pie a pie sobre el terreno, con objeto de que no sean precisos clareos o claras posteriores: los pinos tendrían en un futuro un espaciamiento adecuado (marco aproximado de $5 \times 5 \mathrm{~m}$ ) y bajo ellos se desarrollaría un dosel de quercíneas y matorral autóctono.

- Empleo de planta de una savia, en envase forestal, de procedencias locales, con buena proporción entre la parte aérea y la radical y adecuado estado fenológico. La plantación debe realizarse con esmero para propiciar el arraigo. 
- Creación de un alcorque o una microcuenca alrededor de la planta, al objeto de asegurar la máxima retención de agua de precipitación. Esta operación se podría complementar con la extensión de una pequeña capa de material vegetal a modo de "mulching".

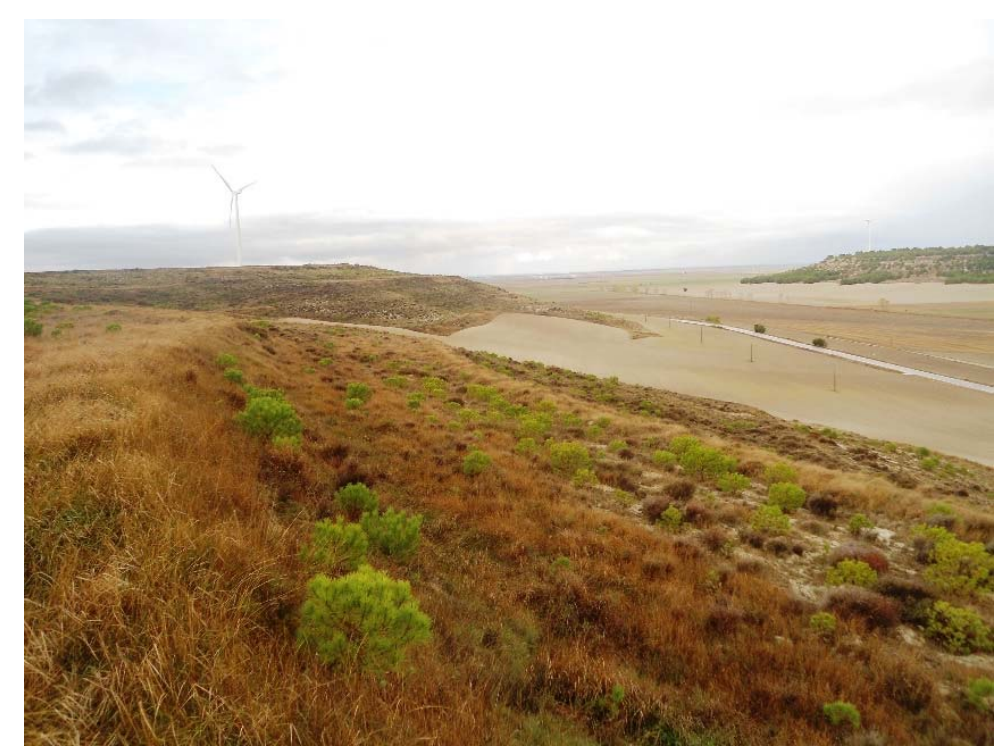

Figura 6.96. Repoblación forestal realizada en laderas de Ampudia, donde se observa que van despuntando los pinos piñoneros.

\section{Repoblación forestal de eriales y terrenos agrícolas marginales}

- Para terrenos secos (la mayoría), la preparación del terreno más recomendable es el subsolado lineal con buldócer. Normalmente este lleva consigo dos rejones, que han de profundizar $80 \mathrm{~cm}$, para mover la "suela de labor" (capa arcillosa especialmente compactada por las labores agrícolas superficiales). En los rejones se suelen acoplar "orejetas" para que alteren más terreno en profundidad. Los surcos quedan mejor preparados si se realizan en pasadas de ida y vuelta.

- En las zonas húmedas o en parcelas pequeñas, es aconsejable la utilización de una retroexcavadora que realice hoyos también profundos.

- La densidad de plantación puede situarse en la franja de 800 - 1100 plantas/ha, en función de la reposición o no de marras en los primeros años (Figura 6.97). En el caso de zonas húmedas, la densidad puede reducirse a los 400 pies/ha.

- Se deben seleccionar varias especies vegetales. En terrenos secos, una distribución adecuada podría ser pino piñonero (50\%), encina y quejigo (30\%), arbustos (20\%). Dentro de estos se incluirían: escaramujo, espino albar, endrino, retama y gayomba, que aumentarían la diversidad biológica y la protección frente a la erosión hídrica. Se puede plantear también la introducción de almendros en las zonas más humanizadas. Al igual que en el caso anterior, lo ideal es que se realice una mezcla pie a pie sobre el terreno, con objeto de que no sean precisos clareos o claras posteriores. En terrenos húmedos las especies más propias son: chopo castellano, álamo y sauce; podrían distribuirse por rodales o en mezcla pie a pie. 
- En los terrenos secos se emplea planta de una savia, en envase forestal, de procedencias locales y buenas cualidades fenológicas. Las frondosas utilizadas en las superficies frescas suelen ser a raíz desnuda.

- Es conveniente que entre la preparación del terreno y la plantación transcurran varios meses, con objeto de que el suelo sufra una cierta meteorización que aumente las posibilidades de arraigo.

- Se debe realizar un alcorque alrededor de la planta, para conseguir la máxima retención de agua de precipitación. Esta operación también se podría complementar con la extensión de una pequeña capa de material vegetal a modo de acolchado (la paja de cereal tan abundante en el entorno sería propicia).

- En caso de existir riesgo de daños a las plantas por conejos o topillos, se deben colocar protectores. La mejor opción son los de tipo "tubex" perforados, de $60 \mathrm{~cm}$, ligeramente hincados en el suelo y sujetos con un tutor. Los protectores también son eficaces si se pretende que la plantación sea visible, sobre todo allí donde exista posibilidad de intrusión por los colindantes o pastoreo por ganado ovino.
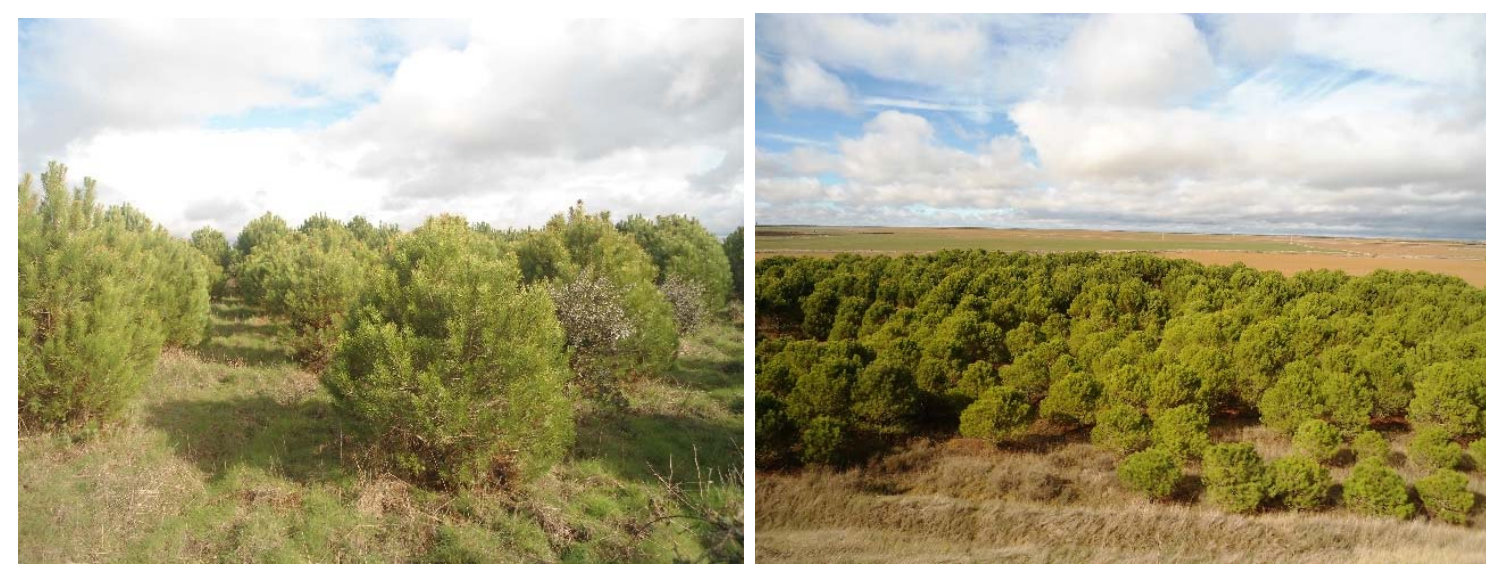

Figura 6.97. Repoblaciones recientes de pino piñonero como especie principal en Villoldo (izquierda) y Frechilla (derecha). En ambas también se introdujeron en pequeña proporción encina y quejigo, que también han arraigado aunque con un crecimiento menor.

\section{Tratamientos selvícolas y plantaciones de diversificación en laderas repoblados}

La mayoría de laderas de transición de las campiñas al páramo fueron repobladas por la administración forestal a partir de la década de los sesenta del siglo XX (Figura 6.98). Los terrenos estaban totalmente yermos; habían sido cultivados y pastoreados hasta el extremo, y presentaban fenómenos de erosión laminar, en regueros e incluso en cárcavas. Para conseguir la disponibilidad de los terrenos, se establecieron consorcios con los propietarios (en su mayoría Ayuntamientos), que aún están vigentes en la actualidad.

Como las repoblaciones eran protectoras, se utilizaron altas densidades de plantación (en torno a 1600 pies/ha). Las posteriores reposiciones de marras y el alto arraigo conseguido han hecho que lleguen hasta nuestros días pinares de pino carrasco (la mayoría) y de pino piñonero con una densidad muy alta (1300-1500 pies/ha). La competencia de los pies es muy elevada, teniendo en cuenta que se trata de unos suelos muy degradados, la ausencia de luz provoca que 
no se regeneren naturalmente otras especies autóctonas y, finalmente, el riesgo de incendios es muy alto debido a la excesiva biomasa. Para alcanzar una mayor estabilidad de la masa, disminuir el riesgo de incendios y procurar la introducción de frondosas autóctonas (que era el objetivo previsto por los ingenieros de Montes que diseñaron el vasto plan nacional de repoblaciones forestales), se proponen las siguientes subactuaciones:

- Clara de la masa arbórea, con objeto de reducir su densidad hasta los 250-400 pies/ha, en función de su edad y su estado. Hasta hace relativamente pocos años, las operaciones de apeo, desramado, tronzado, apilado de restos vegetales y saca de las trozas a cargadero se realizaban de forma manual. Estas labores suponían bajos rendimientos (más de 12 jornales/ha) y, en consecuencia, altos costes por ha. Actualmente estas actuaciones se pueden mecanizar mediante la apertura de calles en máxima pendiente, la corta de los árboles con procesadora adaptada y la saca con autocargador. Por el impacto paisajístico que se puede provocar, se debe minimizar la superficie afectada por las calles. Las trozas se pueden utilizar, de acuerdo con su calidad, para biomasa o para fabricación de tableros.

- Eliminación de los restos vegetales de las ramas mediante su trituración, empleando tractor de ruedas o cadenas y desbrozadora de martillos acoplada a su toma de fuerza. Los restos han de ser previamente acordonados, bien en las calles de saca o en las zonas más claras de la masa. Mediante esta operación se incorpora materia orgánica al suelo y se realiza una mayor protección de este frente a la erosión hídrica.

- Aprovechamiento para biomasa del árbol completo, en función de que exista rentabilidad (más de 40 t/ha), en cuyo caso no sería precisa la trituración de los restos vegetales. El autocargador sacaría los árboles completos o parte de los mismos a cargadero, donde se procesarían en una trituradora móvil para su carga y transporte a fábrica de pellets o a planta de generación eléctrica mediante su combustión. Con esta opción se abarata el tratamiento selvícola, pero se reduce el aporte de materia orgánica al suelo.

- En el caso de terrazas, realización de calles a lo largo de algunas de ellas (una de cada cuatro), sacrificando su arbolado. Además se deben realizar raspaderos en diagonal para unir las calles entre sí. Esta operación se puede realizar con buldócer estrecho o autocargador con pala frontal; en cualquier caso se debe evitar el decapado del suelo, procurando que la alteración morfológica sea mínima. Teniendo en cuenta que el riesgo de impacto es alto, se debe plantear un diseño previo minucioso de la operación en su conjunto.

- Plantaciones de frondosas (encina y quejigo) para diversificar el pinar. Con ello se consigue aumentar la biodiversidad del monte, favorecer su evolución ecológica y conseguir un dosel de quercíneas que, en caso de incendio, rebrotaría de cepa. Esta plantación puede tener una densidad aproximada de 150 pies/ha. La mejor opción de preparación del terreno es la realización de hoyos con un tractor de cadenas pequeño ( $90 \mathrm{CV}$ o similar, de $2 \mathrm{~m}$ de anchura para que se pueda mover adecuadamente), a cuya toma de fuerza se acopla una barrena helicoidal con orejetas, para no dejar compactadas las paredes. La profundidad del hoyo debe ser como mínimo de $60 \mathrm{~cm}$. La 
planta ha de ser de una savia, en envase forestal y de procedencia local. La plantación se realiza de forma manual. 

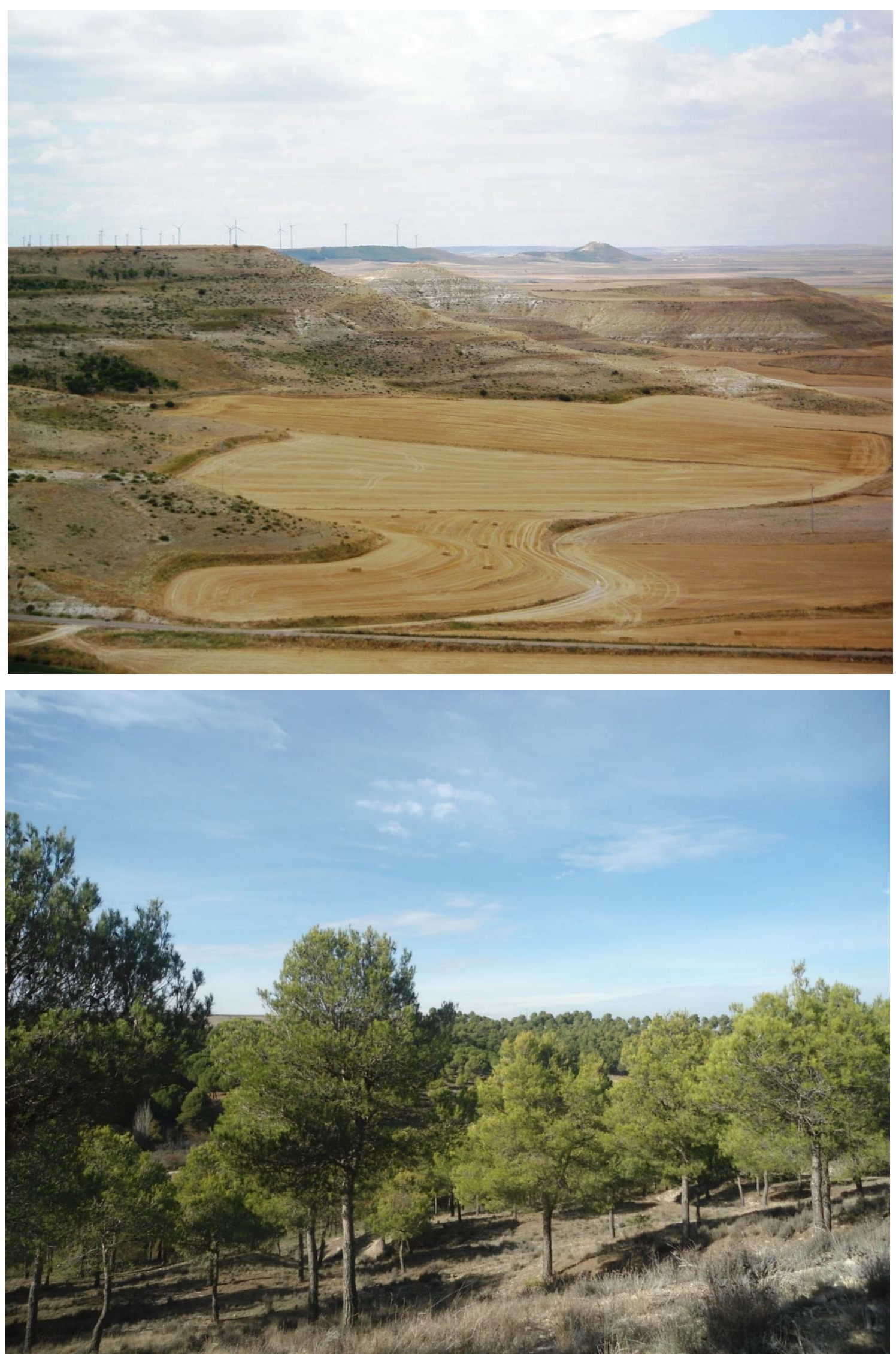

Figura 6.98. El contraste es patente en las imágenes de estas dos laderas. En la superior, se observan las cuestas de Autilla del Pino sin repoblar; en la inferior, las de Medina de Rioseco constituyen ya bosques casi maduros. 


\subsubsection{Escombreras y vertederos de residuos}

Desgraciadamente, la sociedad todavía no tiene una conciencia medioambiental suficiente como para gestionar de modo correcto la ingente cantidad de residuos que genera. En el medio rural, y en particular en Tierra de Campos, aunque el volumen de residuos sea menor, los problemas generados con los deshechos todavía son acusados (Figura 6.99). En general, se ha llegado a una gestión razonable en lo relativo a residuos sólidos urbanos, vidrio, envases y papel y cartón; la mayoría de los pueblos posee contenedores selectivos para cada tipo de residuos, que se derivan a plantas de tratamiento específicas. El mayor problema radica en los residuos de construcción y demolición, los popularmente conocidos como escombros. Hasta fecha reciente, los pueblos contaban con antiguos huecos de extracción u otros terrenos susceptibles de su relleno con escombros; la actual legislación sobre residuos exige su traslado a plantas de reciclaje de residuos de construcción y demolición, que en Tierra de Campos casi ni existen. Los ayuntamientos deben contar con zonas adaptadas al traslado de los residuos de obras menores, pero o bien no son efectivas o bien muchos vecinos deciden que es más fácil depositarlos directamente en las regueras o las cunetas de los caminos.

En consecuencia, en la actualidad nos encontramos tres subtipos de espacios degradados: los vertederos de residuos antiguos (la mayoría están restaurados), las escombreras tradicionales propiamente dichas y los depósitos puntuales de escombros repartidos por el territorio; hay que señalar, no obstante, que los límites entre los dos primeros son difusos. Es curioso que el mayor impacto sobre el paisaje es el generado por los depósitos puntuales ya que, aunque de pequeña cuantía, se encuentran repartidos por los principales puntos de visión (márgenes de caminos y carreteras, cunetas, etc.).
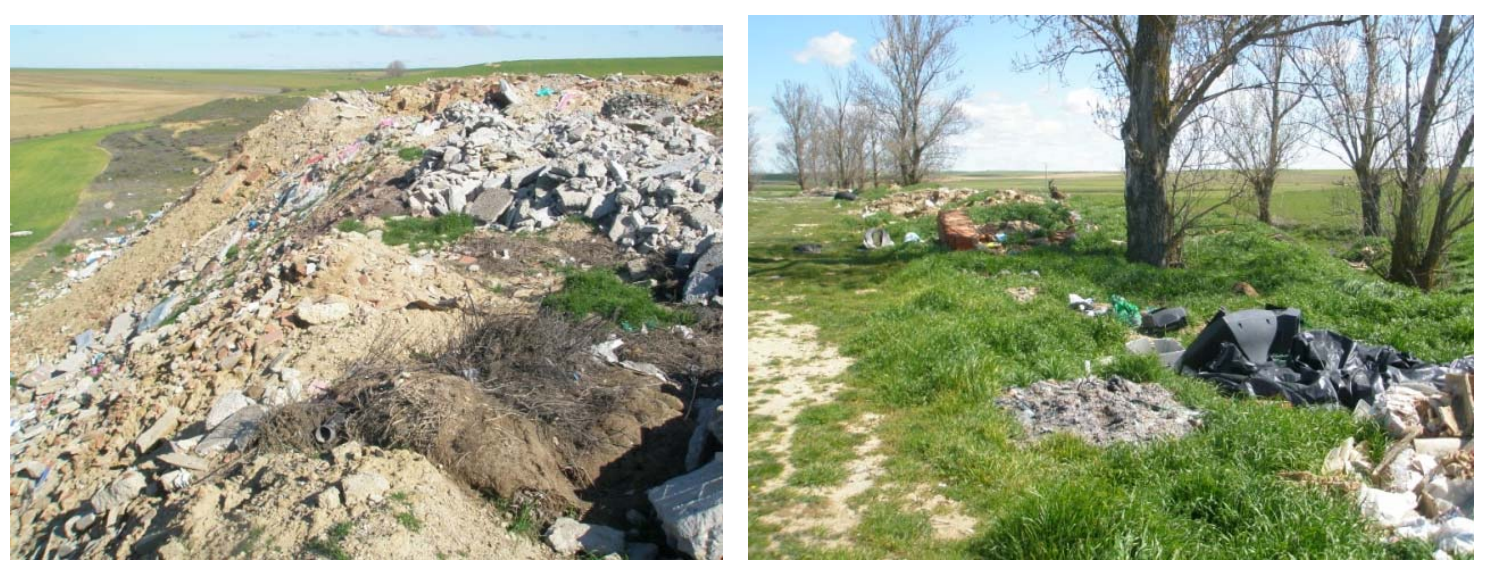

Figura 6.99. A la izquierda, escombrera municipal de Villalón de Campos, que se encuentra clausurada y pendiente de restaurar. A la derecha, depósitos puntuales de residuos en una antigua vía del ferrocarril en Boadilla de Rioseco.

Para recuperar estos espacios degradados, se plantean las siguientes actuaciones:

\section{Restauración de vertederos de residuos}

- Si el vertedero tiene suficiente entidad y los residuos pueden ser peligrosos, lo más riguroso es crear un nuevo hueco, que deberá ser impermeabilizado con un geotextil. Se realizarán los drenajes adecuados y se volverá a rellenar con los residuos. 
- En caso contrario, y teniendo en cuenta que los terrenos arcillosos de Tierra de Campos son muy impermeables, bastaría con compactar los residuos en el mismo vaso (Figura 6.100).

- Retirada selectiva -en caso de ser posible- de los residuos voluminosos y de aquellos más peligrosos.

- Tratamiento de desratización.

- Implantación de chimeneas de ventilación de gases, a base de columnas de grava con salida al exterior.

- Extensión de una capa de tierra inerte de espesor suficiente (mínimo $50 \mathrm{~cm}$ ), remodelada adecuadamente.

- Extensión de una capa de tierra vegetal, con un espesor de 20-30 cm.

- Siembra con una mezcla de gramíneas y leguminosas autóctonas.

- Plantación de arbustos y árboles en caso de que sea posible.

- Vallado del recinto para evitar posteriores vertidos.

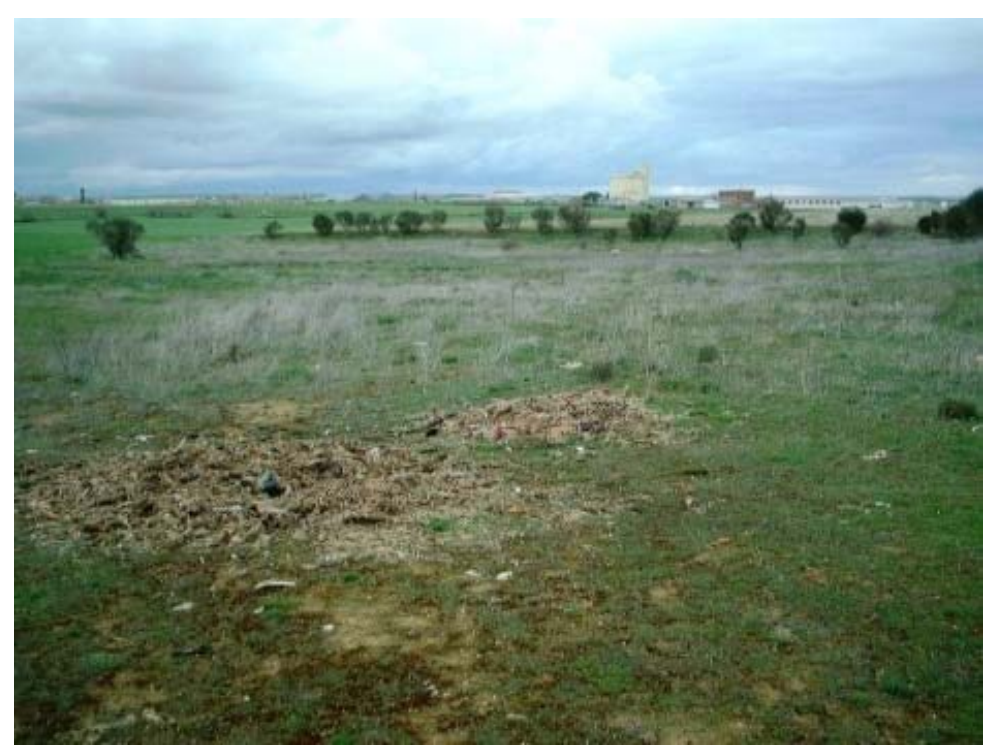

Figura 6.100. Restauración de antiguo basurero en Villalón de Campos. Sobre el pastizal creado se realizó una plantación perimetral de arbustos. El hueco no se impermeabilizó artificialmente, ni se instaló una valla perimetral. $\mathrm{Ha}$ habido vertidos posteriores, aunque afortunadamente no muy abundantes.

\section{Restauración de escombreras}

- Retirada selectiva -en caso de ser posible- de los residuos voluminosos y de aquellos más peligrosos.

- Extensión de una capa de tierra inerte de espesor suficiente (mínimo $50 \mathrm{~cm}$ ), realizándose una remodelación topográfica adecuada, con taludes tendidos.

- Extensión de una capa de tierra vegetal, con un espesor de 20-30 cm. 
- Siembra con una mezcla de gramíneas y leguminosas autóctonas.

- Plantación de arbustos y árboles.

- Señalización de prohibición de nuevos depósitos y del lugar donde se deberán depositar los escombros.

\section{Restauración de espacios afectados por depósitos puntuales de escombros}

- Retirada de los escombros en el plazo de tiempo más breve posible, para evitar el "efecto llamada" (Figura 6.101).

- Colocación de carteles advirtiendo de la prohibición de realizar depósitos ilegales.

- Realización de una campaña de sensibilización ciudadana, explicando el sistema de gestión adoptado; deberá estar especialmente dirigida a los principales actores: albañiles, maquinistas, constructores, etc. Es fundamental que este sistema sea especialmente fácil; que siempre resulte más sencillo hacerlo bien que mal. 

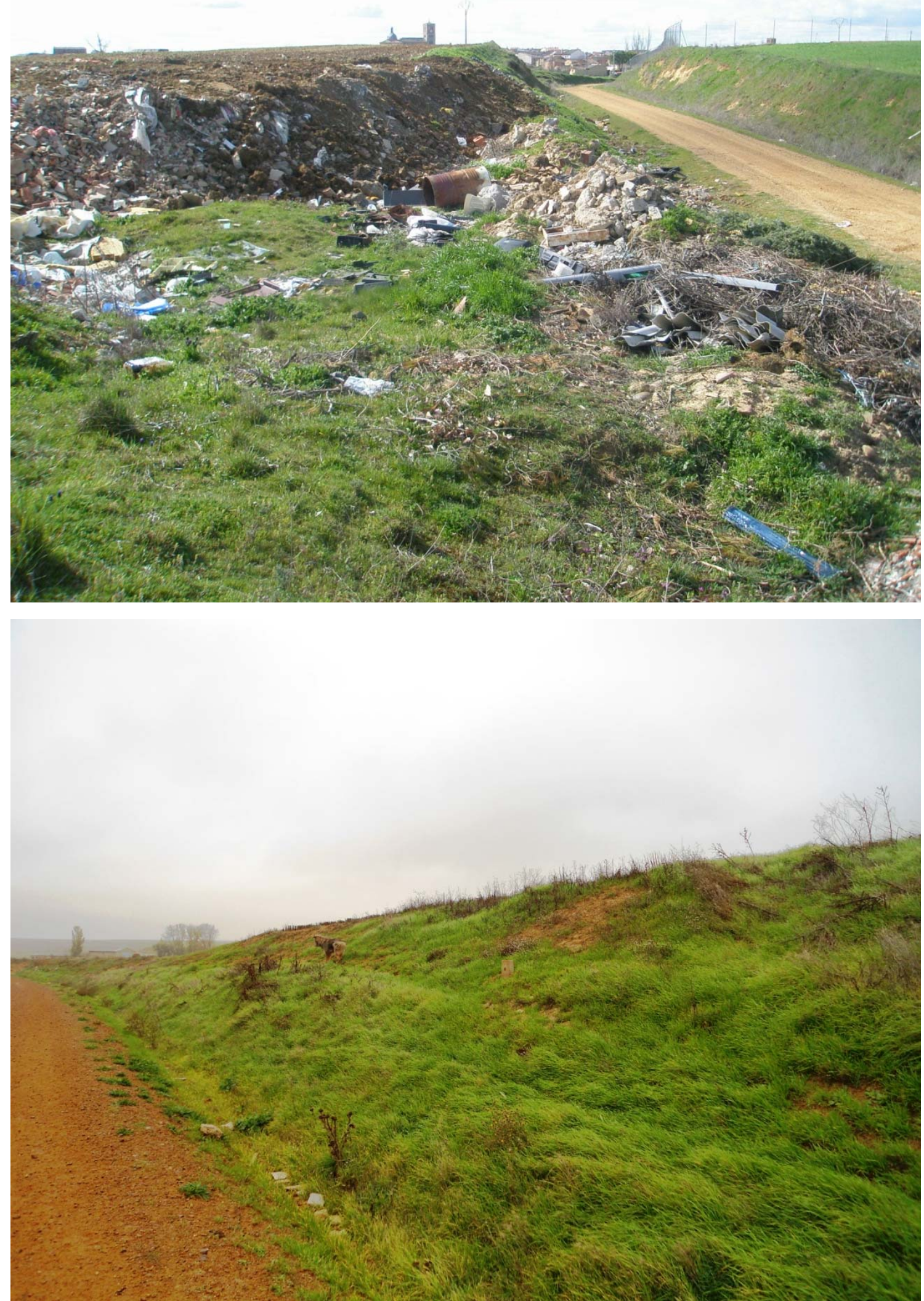

Figura 6.101. Antes y después de la restauración de una escombrera en Villalón de Campos, en el camino del Rosario. Posteriormente, además, se han plantado almendros y arbustos en el talud. 


\subsubsection{Entorno de construcciones en suelo rústico}

En este apartado nos referiremos al espacio situado alrededor de construcciones realizadas en suelo rústico: naves agroganaderas, huertos solares, antenas de telefonía, plantas de tratamiento de áridos o similares, depuradoras, etc. Teniendo en cuenta que estas construcciones tienen una amplia cuenca visual, y que por su diseño un buen número de ellas generan un severo impacto visual, se plantean dos actuaciones básicas para que se favorezca su integración en el paisaje:

\section{Integración de paramentos y cubiertas}

Evidentemente que estas construcciones, por su carácter funcional, no pueden reproducir o adaptarse a la tipología arquitectónica tradicional de Tierra de Campos. Sin embargo, en el caso de los edificios sí que es factible mantener unas pautas básicas: preferencia por la dimensión horizontal a la vertical, paramentos en tonos tierra (el mortero bastardo pigmentado en masa es el material ideal), cubiertas a dos aguas en tonos rojizos, evitar acabados brillantes metálicos, etc. Las rehabilitaciones de construcciones existentes se deberían adaptar a estas premisas a medida que se fueran realizando.

\section{Realización de pantallas vegetales}

Las pantallas vegetales no han de ser interpretadas como plantaciones perimetrales de árboles o arbustos que "tapen" la edificación, porque nunca lo van a conseguir y este no es su objeto. Mediante el empleo de la vegetación en el entorno de la construcción se pretende mejorar la calidad visual del conjunto, al introducir este elemento natural, con lo que se mitigan a la vez los hipotéticos impactos sobre el paisaje (Figura 6.102).

Las plantaciones deben incluir especies caducifolias y perennifolias. También es conveniente combinar arbustos - por ejemplo, a lo largo del vallado o el linde de la parcela- y árboles. Entre estos últimos se pueden incluir perfectamente a los frutales, que realizan el papel de pantalla teniendo a la vez un carácter funcional y por tanto amigable para los propietarios. En el caso de las naves agroganaderas (que es el más numeroso), la idea es reproducir la idea de granja tradicional, productiva pero integrada en el paisaje. 

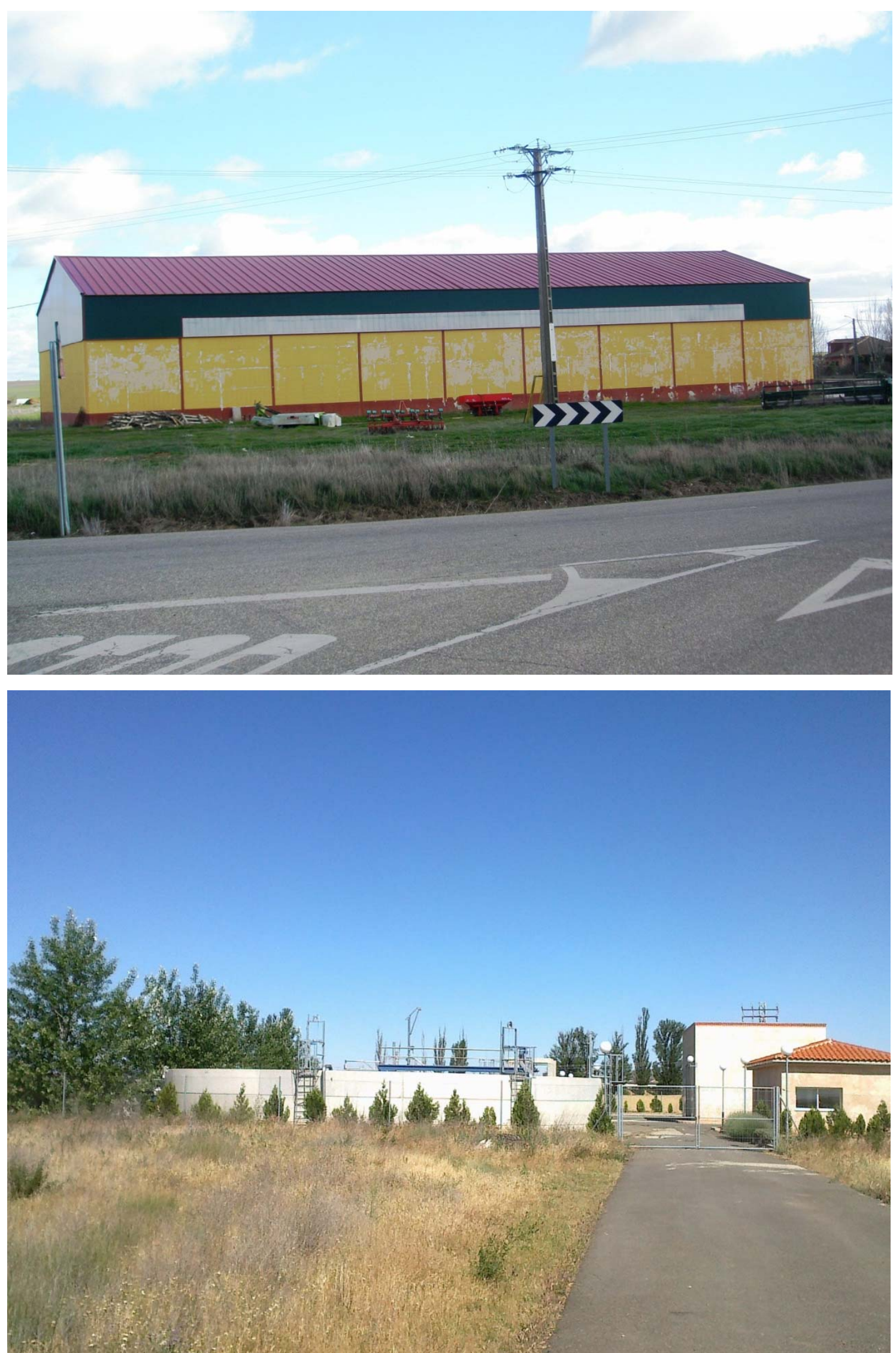

Figura 6.102. Contraste entre dos construcciones en suelo rústico. En la imagen superior, la nave agrícola de Cisneros genera un fuerte impacto visual por sus acabados llamativos. La depuradora de Villalón de Campos (imagen inferior) tiene sus paramentos de colores terrosos y una pantalla vegetal perimetral, por lo que resulta muy integrada en el paisaje. 


\subsubsection{Periferias de los pueblos}

Nos encontramos con una franja difusa de transición entre los cascos históricos de los pueblos y el campo propiamente dicho. Se trata del espacio periurbano de las poblaciones, lo que en el ambiente rural se conoce popularmente como "Ios atrases". En el lenguaje urbanístico la división no está muy clara y depende de los municipios, pudiendo englobar suelo urbano, urbanizable y rústico común. En la mayoría de los núcleos engloba naves agrícolas, explotaciones ganaderas, merenderos y otros terrenos vallados con malla metálica. A medida que estos aumentan, también se asientan en estos espacios silos, talleres mecánicos, pequeñas industrias, plantas de tratamiento o de hormigón, líneas eléctricas, gasolineras, depósitos variados, algunas viviendas, etc. Se trata en general de zonas desordenadas urbanísticamente, con mezcla de usos, sin infraestructura vial ni de otro tipo adecuada, con espacios libres públicos sin ajardinar, de fuertes impactos paisajísticos...

Buena parte de las degradaciones sobre el paisaje que se pueden producir en estos espacios han sido recogidas en los Recorridos paisajísticos en Villalón de Campos (anejo 3), donde además se han apuntado las posibles recuperaciones ambientales. A continuación se exponen las más significativas:

\section{Urbanización}

De acuerdo con el planeamiento urbanístico y con un orden de prioridades, es conveniente llevar a cabo -o culminar- la urbanización de muchas zonas que han tenido un desarrollo deficiente. El asfaltado de las calles, el abastecimiento de agua potable, el saneamiento, la conducción de las aguas pluviales (enterrada o superficial) y el tendido de otras posibles redes son actuaciones básicas que han de acometerse por los municipios. Bien es verdad que en muchas ocasiones se trata de legalizar situaciones irregulares urbanísticamente, fruto de falta de rigor en esta materia.

\section{Implantación de setos vegetales en vallas metálicas}

Por tratarse de terrenos particulares, en este caso la iniciativa ha de llevarla cada propietario, aunque se puede promover por la Administración. Teniendo en cuenta los miles de metros que resultan en cada pueblo de vallas metálicas que ocasionan fuertes impactos visuales, la plantación de arbustos a lo largo de todo el perímetro conllevaría unos grandes beneficios ambientales (Figura 6.103). En este caso se pueden utilizar tanto especies autóctonas como otras exóticas que puedan ser más funcionales para los objetivos previstos. Incluso se pueden introducir parras o frutales, que pueden ser especies "más amigables". 


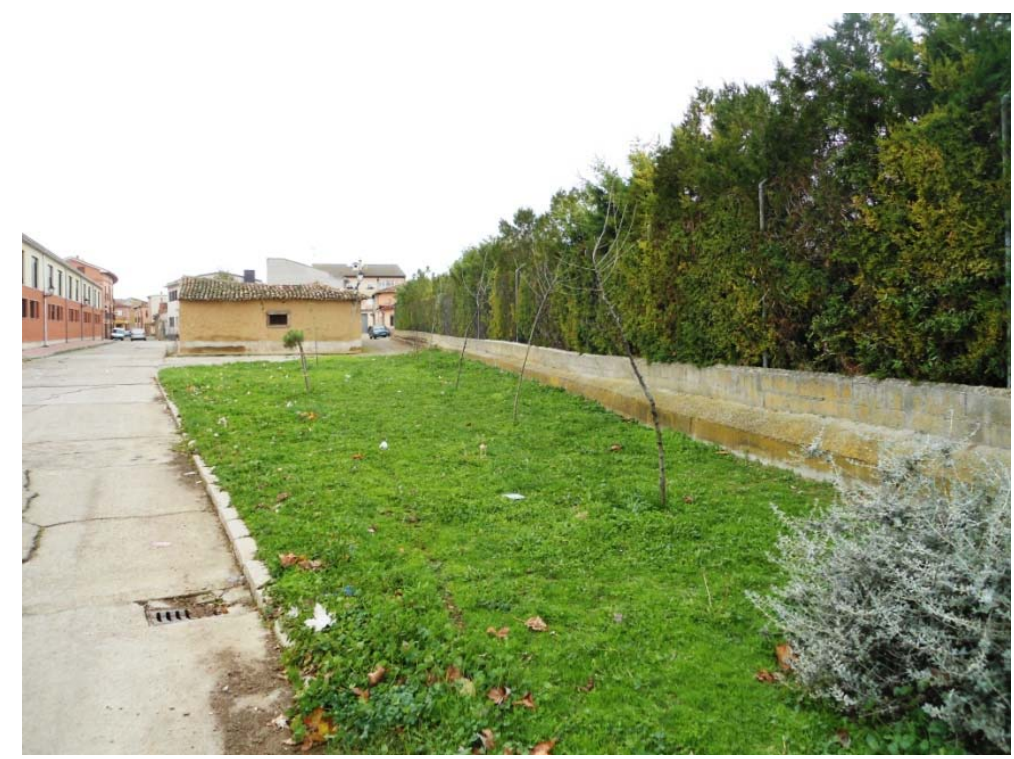

Figura 6.103. En la imagen del Recorrido paisajístico 14 se pueden apreciar dos de las actuaciones mencionadas: en primer plano, pequeña zona antes degradada y que ha sido mínimamente restaurada creando una pradera y plantando árboles; en segundo plano, seto de thuyas en valla metálica que delimita una explotación de ganado ovino.

\section{Limpieza y recogida de residuos}

Tal como en las zonas urbanas existe una práctica cotidiana de limpieza por parte de los empleados municipales de los pueblos, en los espacios periurbanos esto no se suele producir. De antemano cabe indicar que el primer responsable es el depositario del residuo, pero lo cierto es que la Administración debe velar en cualquier caso por la adecuada gestión en esta materia. Para que esta sea eficaz, se recomienda organizar un sistema de calidad de forma que periódicamente se revisen las zonas de depósitos habituales: cunetas, solares, etc. En paralelo, el Ayuntamiento deberá ponérselo siempre fácil a los vecinos, es decir, que su sistema de gestión de residuos sea transparente al público y cómodo de llevar a cabo: contenedores repartidos por el municipio, punto limpio...

\section{Eliminación de elementos degradantes}

En todos los municipios existen grandes carteles metálicos de publicidad privada, o bien institucional de obras públicas, cuya función ya ha pasado en muchas ocasiones varios años. Para evitar la desidia y la imagen de abandono -además del impacto paisajístico que provocanse propone su retirada y gestión adecuada.

En esta actuación también nos referimos a determinadas situaciones más complejas a la anterior, pero que con cierta perseverancia se pueden conseguir por los consistorios: apoyos de líneas eléctricas aéreas ubicados al lado de un elemento singular, líneas de teléfonos con trazados inadecuados, redes duplicadas, depósitos de materiales, etc.

\section{Adecuación estética de naves}

Para las nuevas naves, el planeamiento urbanístico debe tener unos criterios estéticos que han de cumplirse basados en la integración paisajística: cubiertas rojizas, paramentos ocres o 
terrosos, cubiertas a dos aguas, ausencia de elementos distorsionantes, alturas razonables, etc. En el caso de las existentes, se deben aprovechar las rehabilitaciones para conseguir su adaptación en el grado mayor posible.

\section{Adecuación del entorno de explotaciones ganaderas}

Se trata de explotaciones ganaderas existentes que se instalaron en un momento determinado y que, actualmente, se encuentran en zonas muy próximas al casco urbano, muchas veces en mezcla con otros usos. En estos casos se debe ser estrictos en el cumplimiento de las medidas impuestas en la licencia de actividad o ambiental, así como en la urbanística, que probablemente hacen alusión a la ubicación del estercolero, limpieza periódica, condiciones estéticas, condiciones de salubridad y otras que, en definitiva, persiguen el buen estado de la explotación.

\section{Restauración de elementos singulares}

Aparte de alguna construcción singular en algún municipio, tal vez las más comunes y características de Tierra de Campos son las bodegas, las casetas de era y los palomares (Figura 6.104). En los tres casos la pérdida de funcionalidad, su endeblez y el abandono poblacional ha aparejado su deterioro. Sin embargo, su valor paisajístico es muy alto y así debería ser considerado para justificar una política activa de restauración. Afortunadamente, las bodegas se han reconvertido en muchos casos en merenderos; en su adecuación se debe tener en cuenta el mantenimiento en tierra -sin pavimentar- del entorno (para asegurar su permeabilidad), la conservación de las zarzeras o respiraderos y la utilización de materiales tradicionales en las entradas (puertas de madera, enfoscados terrosos, piedra caliza en su caso, tejadillos de teja árabe, etc.). Las casetas de era tienen todas las de perder (de hecho, la inmensa mayoría han sido derruidas) por su reducido tamaño y la ausencia de uso alternativo; aun así se deberían mantener con su tipología original: enfoscados térreos, huecos pequeños y teja árabe. Por último, el palomar es el auténtico símbolo de Tierra de Campos y su recuperación debe ser absolutamente prioritaria para dar carácter a su paisaje. Por fortuna, así ha sido con muchos ellos en los últimos años merced a los programas de desarrollo rural europeos, política que debe perseverar hasta alcanzar a todos. La recuperación del palomar incluye su retejo con teja árabe, el revoco de sus paramentos en tonos terrosos (tal vez la mejor opción es el mortero con cemento blanco, arena roja y paja, pigmentado en masa) y la adecuación -en lo posible- de las paredes interiores que contienen los nichos. Incluso también deberían ser afianzadas las ruinas de los palomares, que poseen un gran valor estético y contribuyen a su interpretación. 

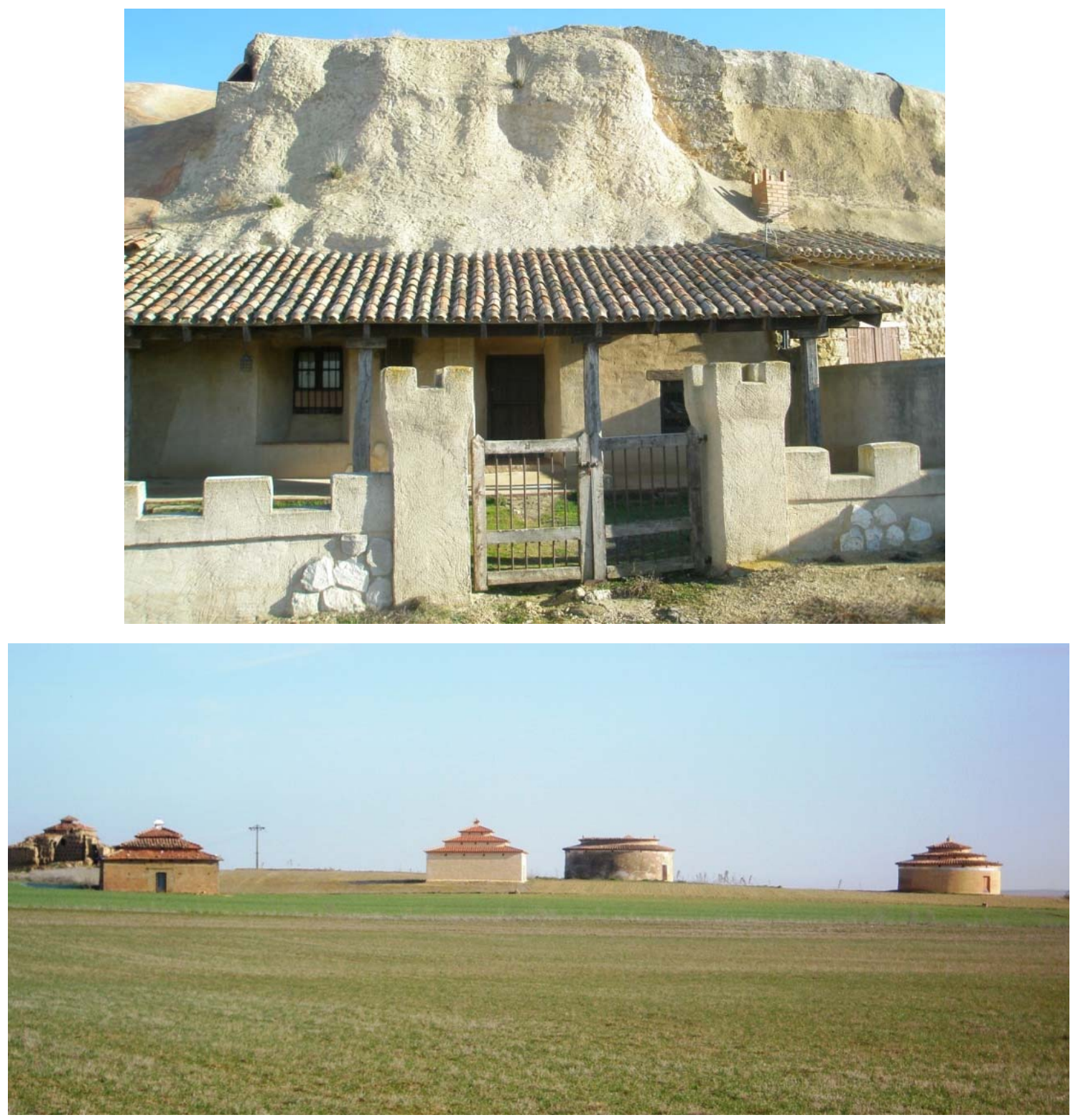

Figura 6.104. Arriba, buen ejemplo de recuperación de bodega en Aguilar de Campos; abajo, conjunto de varios palomares en Villárdiga, varios de ellos restaurados.

\section{Rehabilitación de silos}

Los grandes silos construidos en algunos pueblos para almacenar el cereal -actualmente en desuso- ocasionan un considerable impacto sobre el paisaje, debido a su magnitud. Como medida correctora básica, se considera que periódicamente deben ser pintados en color ocre claro, para minorar su efecto visual. Sin embargo, se deberían analizar diversas posibilidades para su rehabilitación:

$\checkmark$ Reutilización para su uso original (almacenamiento de grano) en las condiciones tecnológicas actuales.

$\checkmark$ Reutilización para un uso industrial (almacenamiento) compatible.

$\checkmark$ Reutilización para otros usos (cultural, mirador, centro de interpretación, etc.), mediante el vaciado o la redistribución interior. 


\section{Creación de zonas verdes sostenibles}

En la periferia de los pueblos -tal como se puede comprobar en los Recorridos paisajísticos del anejo 3- existen muchos terrenos públicos, aparentemente marginales, cuya función después de la urbanización debiera ser la de zona verde. Como las urbanizaciones no son completas en muchos casos, estos ajardinamientos (mucho más económicos) se pueden realizar de forma previa a su finalización. También hay otros terrenos degradados que no se urbanizarán, pero donde sí que se puede realizar una restauración ambiental. La tipología es muy variada: márgenes de calles o carreteras de entrada o circunvalación, intersecciones, picones perdidos, entorno de equipamientos públicos, márgenes de arroyos, etc. En este apartado también consideramos los pequeños jardines que pueden ser creados en algunas plazas del casco histórico de los pueblos.

En todos estos espacios se debe ir a una jardinería sostenible y de sencillo mantenimiento, habida cuenta de los escasos recursos y medios personales con que cuentan los ayuntamientos rurales. A continuación se citan los criterios básicos para crear y mantener zonas verdes sostenibles:

- Se debe restaurar como zona verde la máxima superficie de espacios degradados de que disponga el municipio. Si esta se consigue, será un elemento diferencial respecto de las zonas urbanas y, por tanto, un atractivo para vivir en las zonas rurales. Resultará muy sencillo superar los mínimos de zonas verdes establecidos por la Organización Mundial de la Salud (OMS), de $10-15 \mathrm{~m}^{2} / \mathrm{hab}$, y por la Unión Europea, de $15 \mathrm{~m}^{2} / \mathrm{hab}$.

- Las recuperaciones ambientales deben ser paulatinas pero continuadas en el tiempo, independientemente de las distintas corporaciones municipales. Para fomentarlas, la Junta de Castilla y León y las Diputaciones Provinciales deberían mantener líneas anuales de subvenciones que ayuden al menos con la concesión de planta.

- Las zonas verdes deben estar adecuadamente repartidas por la periferia del casco urbano, con objeto de que exista un adecuado equilibrio en el territorio.

- Los paseos arbolados son muy interesantes porque contribuyen a conectar la trama verde $y$, en los espacios periurbanos, minimizan numerosos impactos paisajísticos (Figura 6.106).

- En los pueblos con una mínima población, una piscina municipal bien ajardinada es un gran atractivo para la población veraneante.

- En los espacios verdes que no se encuentran muy atendidos resulta fundamental su delimitación física, ya que en caso contrario son frecuentemente invadidos por vehículos.

- Es importante que cuando se realicen obras de urbanización, sobre todo en espacios periurbanos, se dejen sin hormigonar o asfaltar pequeños parterres o alcorques donde realizar plantaciones de árboles y arbustos.

- La jardinería y el paisajismo requieren rigor técnico en las actuaciones: plantar un árbol y que se mantenga no es tan fácil como parece. Entre otras cuestiones, se consideran prioritarias en Tierra de Campos la adecuada preparación del terreno para las plantaciones, el cuidado de las plantas antes de su implantación, el riego de 
implantación, la realización de alcorques, y la planificación de varios riegos durante el verano posterior a la plantación.

- Es preferible utilizar especies autóctonas o propias de la zona, que se adaptan mejor a los requerimientos ecológicos de la comarca, siendo el abanico para elegir muy amplio. En el concepto de "propias de la zona" hay que considerar aquellas que, aun siendo alóctonas, se han demostrado muy adaptadas a la zona (por ejemplo la acacia). En este sentido, es muy importante diferenciar siempre entre zonas secas (mayoritarias) y húmedas.

- Por motivos de calidad visual, es importante que en todos los espacios verdes exista un equilibrio entre vegetación caduca y perenne.

- La creación de praderas naturales con arbolado es una opción muy sencilla para muchas zonas verdes de los pueblos; solo requiere de dos o tres siegas o desbroces al año. Desde luego que esta opción debe ser elegida antes que la utilización de herbicida para matar las hierbas.

- El riego solo se debe restringir a las mejores zonas, y siempre por aspersión o goteo y con programación automática.

- Se debe promocionar la presencia de fuentes con agua en movimiento en las zonas restauradas, teniendo en cuenta el importante papel del agua en los espacios ajardinados y en el paisaje de calidad en general.

- Dentro de las labores periódicas de mantenimiento que deben ser realizadas, se considera prioritaria la limpieza de bolsas, plásticos y otros pequeños residuos; asegurándose la suficiente instalación de papeleras. Hay otras acciones de mantenimiento que son también muy necesarias: revisión de los sistemas de riego, desperfectos en las infraestructuras recreativas, pintado de bancos, etc.

- Se debe realizar una planificación anual de todas las actuaciones de jardinería, que permita establecer prioridades, no dejar labores necesarias sin hacer, llevar a cabo el mantenimiento periódico, etc.

\section{Creación de anillos verdes}

Tal como se ha comprobado con el Proyecto de recuperación ambiental y adecuación de la Ruta de los parques en Villalón de Campos (anejo 2), es posible acometer de un modo sencillo la creación de anillos verdes perimetrales que sirvan de paseo o para ir en bicicleta por las zonas periurbanas (6.105). Si además estas rutas transitan por las zonas verdes creadas, mejor que mejor. Este tipo de actuaciones siguen la pauta de valorización del paisaje, que incluso puede ser interpretado. Es decir, se trata de asumir que nos encontramos en un paisaje dominante agroganadero, que se puede explicar con carteles y señales: el caminante transita por una calle, un camino, un aprisco de ovejas, una zona verde, una nave de fertilizantes, una granja de vacas..., y de todos estos elementos aprende, además de disfrutar del paseo. 


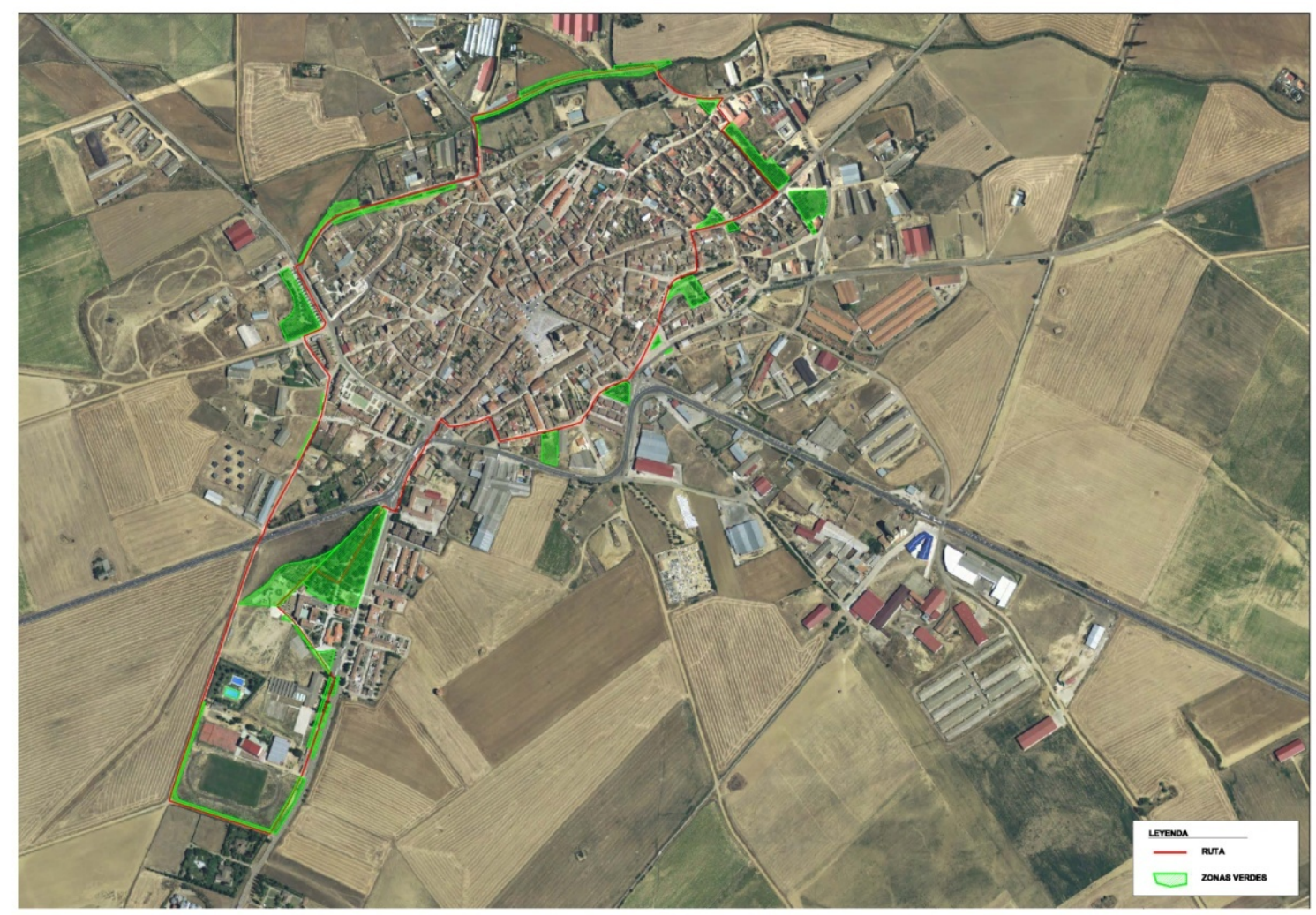

Figura 6.105. Imagen del Proyecto de recuperación ambiental y adecuación de la Ruta de los Parques en Villalón de Campos, que crea un anillo verde por la periferia de su casco urbano. 

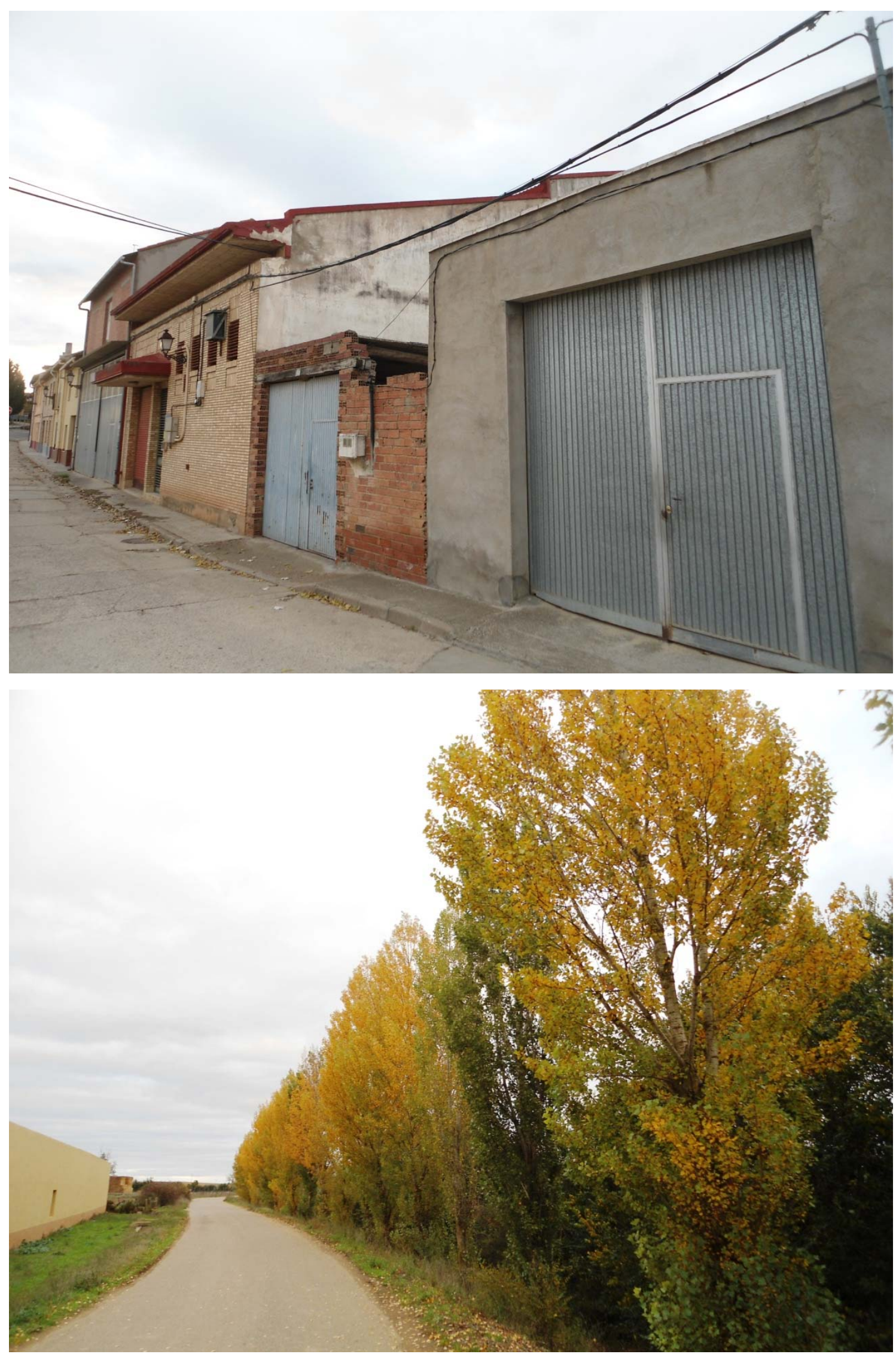

Figura 6.106. Dos imágenes de la periferia de Villalón de Campos. En la superior se observa una calle con un buen número de elementos disonantes en las fachadas de sus casas. En la inferior, la simple plantación de chopos en un arroyo antaño degradado ha generado un paseo peatonal ribereño de gran belleza. 


\subsubsection{Pueblos en descuido y abandono}

Tal como hemos señalado en el análisis socioeconómico de Tierra de Campos, su población ha ido decreciendo ininterrumpidamente desde 1950, lo que tiene fiel reflejo en el estado del caserío. Aun así, es cierto que hay diferencias entre las poblaciones e, incluso, dentro de ellas, según haya afectado el abandono y según sea el grado de restauración de las viviendas. En este tipo de espacio degradado incluimos los pequeños pueblos donde es más predominante el abandono y aquellas zonas urbanas del resto de los núcleos que sufren alteraciones precisamente por falta de un adecuado desarrollo urbanístico: destrucción del patrimonio, falta de adecuación a las tipologías arquitectónicas tradicionales, acabados inadecuados, presencia excesiva de solares, existencia de naves e incluso de explotaciones ganaderas, suciedad, ausencia de jardines, etc.

En cualquier caso, tal como se ha venido comentando en varias ocasiones, se considera que un pueblo que se cuide se puede salvar; la restauración de los paisajes cotidianos aporta calidad de vida a los vecinos y aprecio para posibles asentamientos. Las diferencias son ostensibles (Figura 6.113).

En este estudio no se pretende tratar la recuperación de los pueblos en su conjunto, labor que se antoja excesivamente ambiciosa. Se plantean actuaciones básicas desde la óptica de la recuperación ambiental del paisaje urbano, sin entrar en detalles arquitectónicos que no serían objeto de esta disciplina, pero que es necesario apuntar para mantener la coherencia con el tratamiento de todo el paisaje de Tierra de Campos.

\section{Restauración del patrimonio arquitectónico histórico-artístico}

En la descripción de la zona de estudio quedó atestiguado que la comarca posee un riquísimo patrimonio histórico-artístico fruto de su historia. Se trata de uno de los elementos singulares más característicos del paisaje, un recurso con un gran potencial y un valor en sí mismo (legado) que no podemos permitirnos el lujo de perder. Por ello, desde muchos puntos de vista, pero también desde el paisaje, la restauración de estos bienes culturales ha de ser prioritaria (Figura 6.107).

En los últimos años -en época de bonanza económica- se ha optado por restauraciones integrales con presupuestos elevados. En la línea del presente estudio, que pretende acometer actuaciones sostenibles, se plantea volver a las restauraciones puntuales de mantenimiento, que antaño eran comunes en nuestros templos: retejos periódicos, solucionar los problemas de humedades, enfoscados térreos exteriores y ventilación, mucha ventilación.

De forma paralela se considera totalmente necesario cuidar los entornos de los bienes. Esta idea que está muy cuajada en la legislación de Patrimonio entronca perfectamente con el concepto de paisaje como conjunto; es una aberración que en una plaza de una iglesia románica haya casas con puertas de aluminio y ladrillos vitrificados, por ejemplo. 


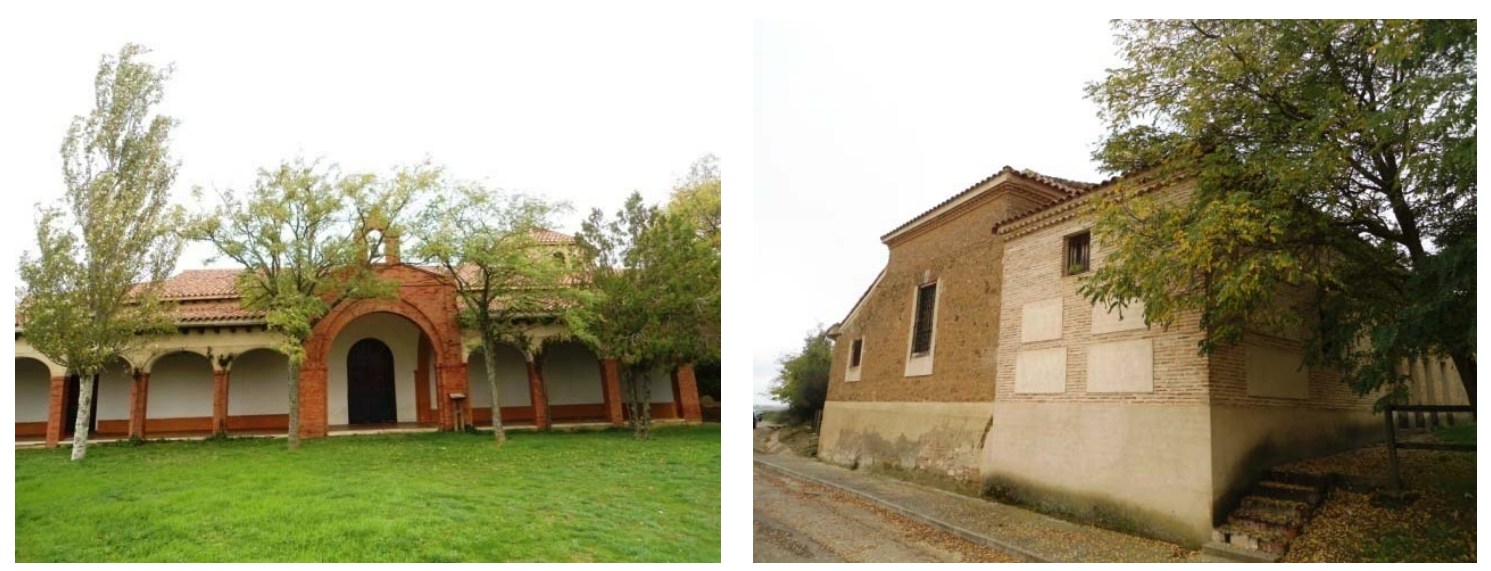

Figura 6.107. Restauración de la ermita de Fuentes (Recorrido 8) realizada hace 13 años, en la que, entre otras actuaciones, se ha colocado una teja mixta envejecida muy similar a la árabe (izquierda) y se han rematado paños exteriores en mortero bastardo y rejuntado otros de ladrillo de tejar (derecha).

\section{Restauración del patrimonio arquitectónico tradicional}

Otro de los elementos singulares del paisaje terracampino es la arquitectura popular, basada en el empleo de la tierra como material de construcción y en una tipología característica. Desde el punto de vista del planeamiento urbanístico, en los pueblos existen muchos ejemplos de casas o conjuntos catalogados con algún tipo de protección: integral (se debe mantener todo el edificio), parcial (el exterior) o ambiental (en caso de derribo, se deben reproducir las características externas). El problema es que, en una dinámica regresiva, esta protección a la defensiva no sirve; si hay abandono, al final irremisiblemente hay ruina.

Por ello, el mejor modo de conservar este patrimonio es restaurarlo. 0 , lo que es lo mismo, que desde las administraciones públicas se incentive la restauración a los particulares. La mejor experiencia en Tierra de Campos ha sido la desarrollada en el Área de Rehabilitación Integrada (ARI) "Tierras del Renacimiento", que ha afectado a los cascos históricos de Paredes de Nava, Fuentes de Nava, Becerril de Campos y Cisneros y donde se han rehabilitado 580 viviendas y adecuado 6 espacios urbanos.

En particular, respecto de la restauración y mantenimiento del capeado de barro de las fachadas, actualmente existen nuevas técnicas que protegen del efecto erosivo del agua de lluvia. Algunas son tradicionales y se han ido perfeccionando, como la utilización de morteros bastardos o a la cal. También hay que aprovechar el desarrollo industrial, con la aparición de nuevos productos como por ejemplo el "Toupret endurecedor de fondos", que se aplica directamente con brocha o pistola sobre el barro, siendo una cuestión importante que deja respirar la pared.

Evidentemente, esto no sirve de nada si desde los Ayuntamientos no se sigue con rigor en la obra nueva y en las rehabilitaciones una política de respeto a la tipología arquitectónica tradicional y adecuación al entorno. Aunque, también es verdad, lo que se restaura con acierto suele servir de espejo para posteriores actuaciones (Figura 6.108). 


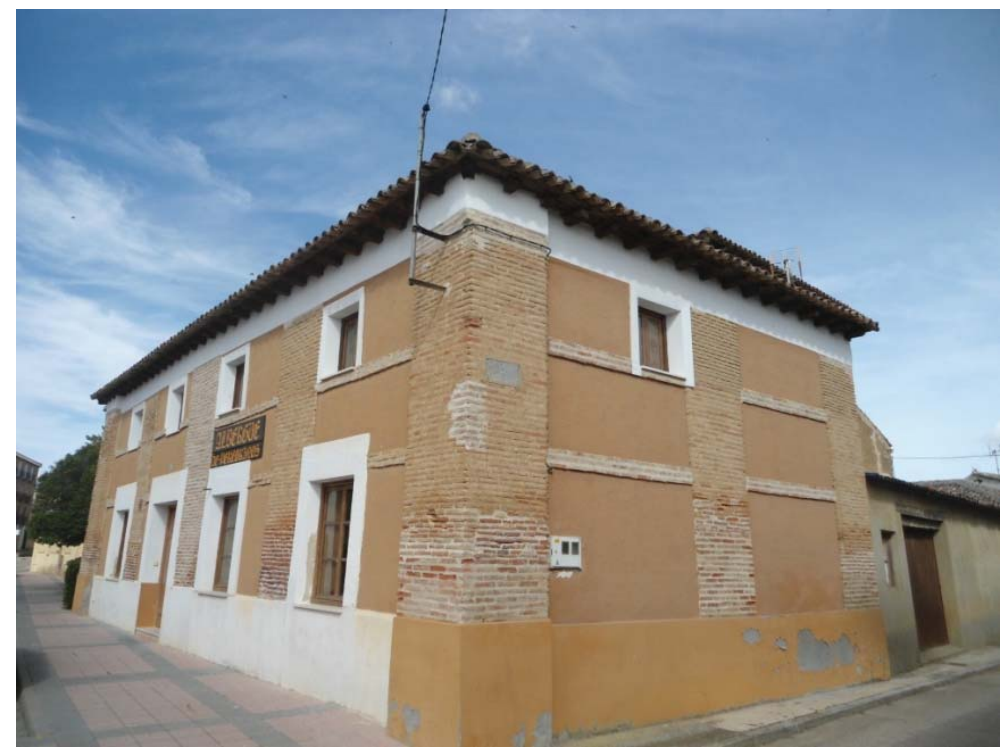

Figura 6.108. Albergue de peregrinos de Villalón de Campos (Recorrido 15) restaurado recientemente. Es un buen ejemplo de tipología arquitectónica tradicional: mezcla de pilares de ladrillo y paños en color tierra, recercados blancos de los huecos, carpintería de madera, canes del mismo material y teja árabe.

\section{Construcción de obra nueva integrada en el entorno}

Se proponen a continuación unos criterios estéticos básicos a aplicar en el casco histórico de los pueblos de Tierra de Campos (Figura 6.109):

- La altura de las edificaciones no debería ser superior en general a 6,5 m al alero, incluyéndose $\mathrm{PB}+1+$ bajo cubierta. En las poblaciones más importantes, determinadas zonas podrían construirse con una nueva planta: $\mathrm{PB}+2+$ bajo cubierta y una altura máxima de $9,5 \mathrm{~m}$.

- Las nuevas construcciones deben reproducir la diferenciación de fachadas del caserío anterior, de forma que no se visualicen fachadas corridas homogéneas de elevada longitud.

- Como criterio general de diseño, se debería adoptar el de sencillez como premisa y adaptación a la tipología arquitectónica tradicional de Tierra de Campos. Los ejemplos siempre han de ser las casas antiguas, aunque se realicen lecturas contemporáneas.

- Las cubiertas no deben tener pendientes pronunciadas, utilizándose preferentemente teja curva árabe. Fuera de los entornos protegidos podría emplearse teja mixta de acabados similares a la vieja. Bajo ningún concepto se han de rematar en fibrocemento o chapa metálica.

- Los huecos de puertas y ventanas tienen que ser proporcionados, con predominio de la dimensión vertical sobre la horizontal y disposición sobre ejes verticales. En los conjuntos históricos y los entornos de los bienes de interés cultural, la carpintería ha de ser de madera; en el resto este material también debiera ser preferente, aunque se podrían emplear otros en tonalidades oscuras. Se pueden disponer recercados blancos. La forja, en su caso, deberá pintarse en negro mate. 
- Las fachadas, en general, deberían enfoscarse en colores ocres o terrosos (similares al barro), bien sea con morteros pigmentados (preferible) o con pintura o revestimiento. También se puede emplear el ladrillo de tejar en tonos pardo-marrones. En caso de utilizarse, la piedra (siempre caliza) debería restringirse a los zócalos. De cualquier modo, se deben evitar los acabados llamativos o estridentes.

- Las medianeras o respaldos han de tener el mismo tratamiento dado a las fachadas.

- Los aleros se deberán construir principalmente a base de canes de madera sencillos; puntualmente podrán diseñarse con formas tradicionales de teja y ladrillo.
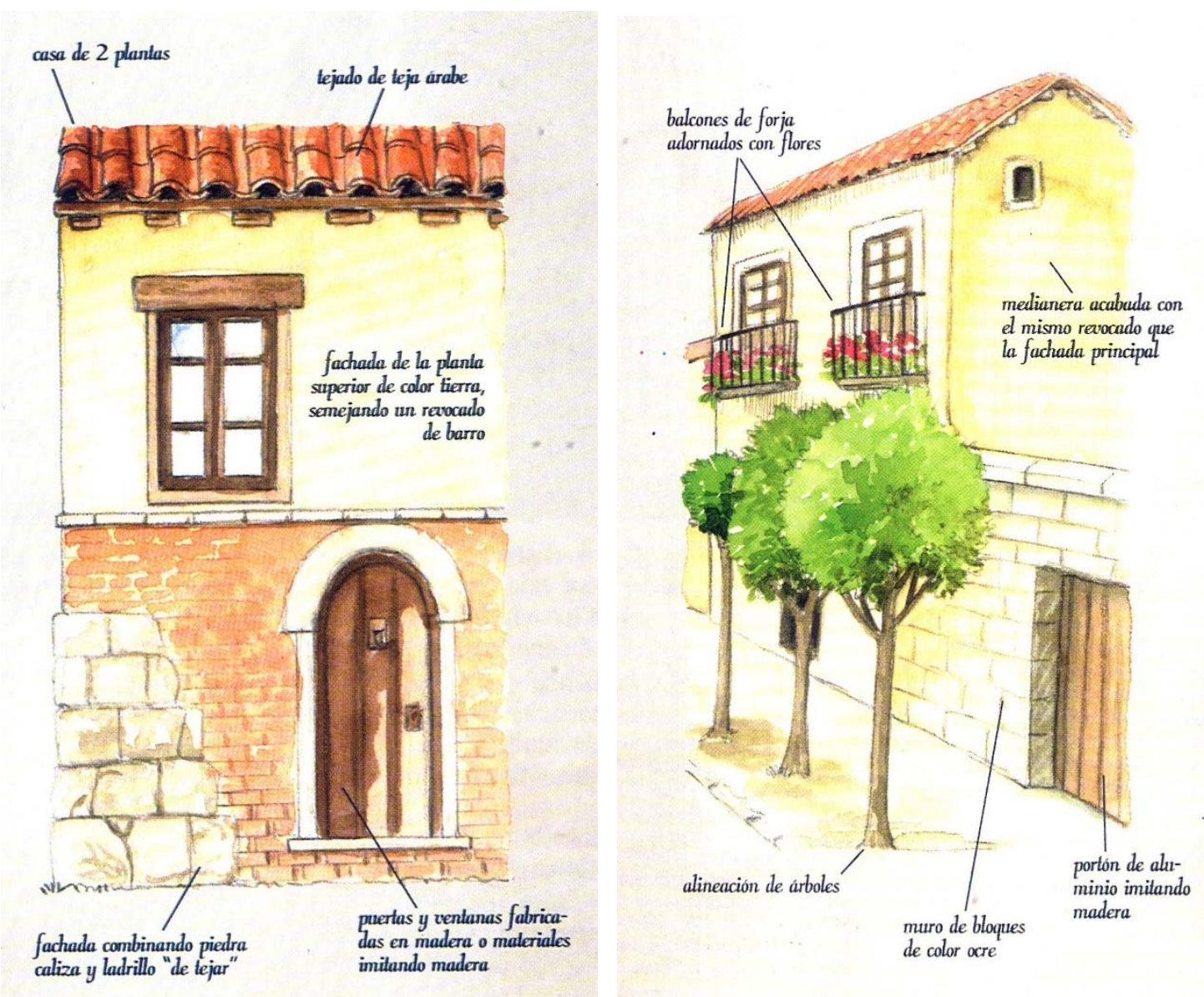

Figura 6.109. Ilustraciones-modelo con pautas arquitectónicas a seguir en los cascos históricos de los pueblos de Tierra de Campos (dibujos de Luis Frechilla, en BLANCO y FRECHILLA, 2009)

\section{Integración paisajística de acabados exteriores inadecuados}

Dada la diversidad de alteraciones paisajísticas advertidas previamente, se proponen una serie de subactuaciones básicas para integrar construcciones disonantes ya existentes; todas ellas tienen un cierto margen de discrecionalidad para favorecer la variedad:

- Revocar las paredes de ladrillo hueco con un mortero con acabado terroso; se aconseja la mezcla de cemento blanco, arena roja y un pigmento natural. A la masa se le puede añadir incluso paja picada. 
- Pintar dentro de la gama de ocres a tierras (con revestimiento pétreo liso) las fachadas rematadas en cemento gris (Figura 6.110).

- Las medianeras deben ser tratadas igual que las fachadas.

- Las fachadas altas de naves en suelo urbano deben descomponerse mediante sardineles u otras figuras compositivas tradicionales.

- El color de las puertas traseras metálicas debe ser armonizado con varias opciones básicas: aquí se propone los siguientes esmaltes sintéticos: marrón, verde oscuro y rojoinglés.

- Las cubiertas metálicas en su color deben ser lacadas en rojo-teja.
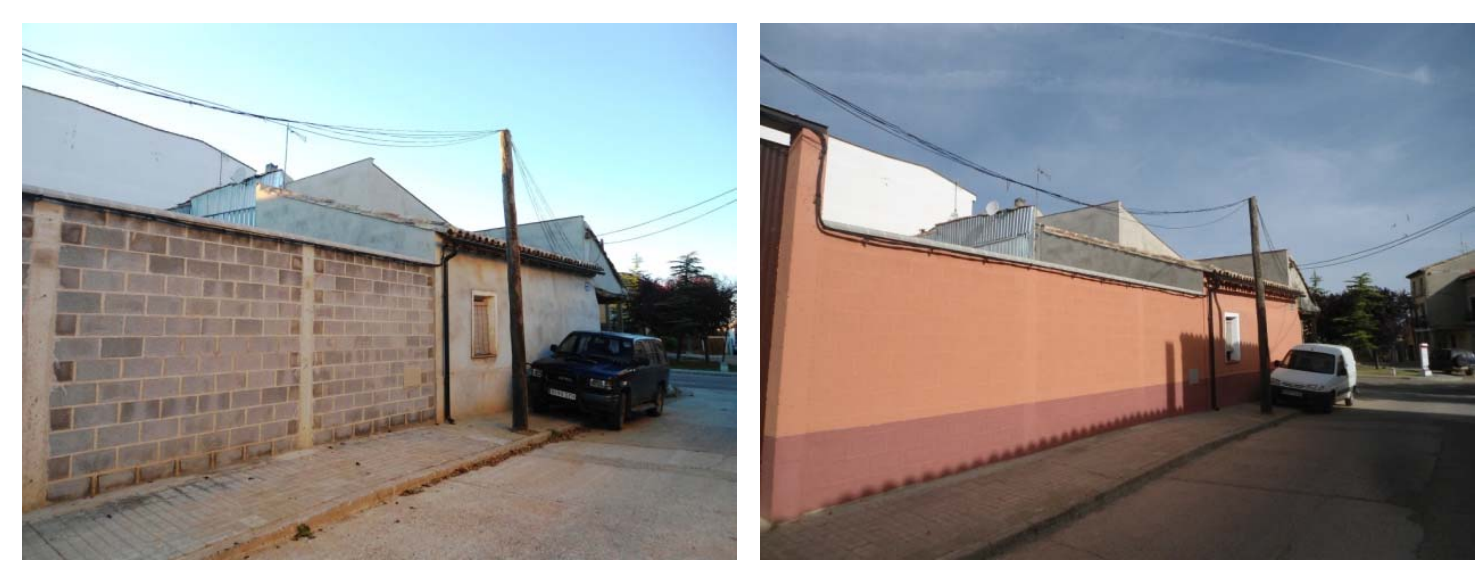

Figura 6.110. Antes y después de un muro gris pintado en el Recorrido paisajístico 15.

\section{Adecuación de ruinas y solares}

Por desgracia, en muchos casos ya no se ha llegado a tiempo. El estado de las edificaciones es tal que no permite su restauración, propiciando riesgo para las viviendas colindantes y personas. Además, la proliferación de ruinas en cualquier pueblo crea una sensación de degradación muy negativa. Ante esta situación, la solución pasa por el derribo y retirada de los escombros a una planta de residuos de construcción y demolición. Se deben consolidar las paredes medianeras y tratarse estéticamente como fachadas; si se utiliza el poliuretano proyectado como aislante deberá tener acabados ocres. Asimismo, resulta fundamental la construcción de un muro de una altura mínima de $3 \mathrm{~m}$; para ello se plantean varias soluciones constructivas: bloques de hormigón "Split" (rugoso) ocre, bloques de hormigón coloreado (ocre o tierra), bloque de hormigón en su color posteriormente pintado o muro de ladrillo enfoscado de mortero terroso (Figura 6.111). La cumbre se debe rematar en teja. 


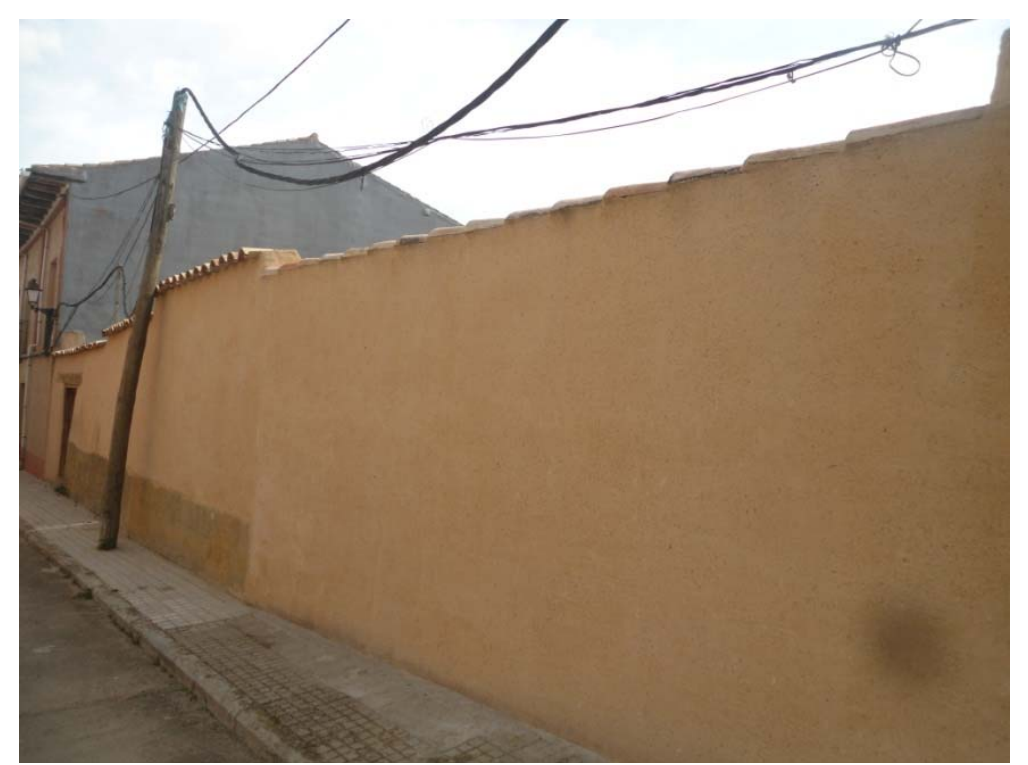

Figura 6.111. Buen ejemplo de muro de un solar en Villalón de Campos, con mortero terroso.

\section{Ordenación del cableado y otros elementos discordantes}

Por desgracia, en los cascos urbanos existen multitud de elementos que ocasionan impactos visuales negativos: cables y postes de la luz, cables del teléfono, pequeños transformadores, carteles publicitarios, etc. La mejor solución en la mayoría de estos casos es su soterramiento o eliminación; cuando ello no sea posible, siempre hay soluciones para que se ordenen en lo posible de modo que se minimicen los impactos generados.

\section{Tratamiento de explotaciones ganaderas en suelo urbano}

La ley de prevención ambiental considera que las explotaciones ganaderas deberían ubicarse en suelo rústico, pero excepcionalmente admite la legalización de algunas existentes. En este sentido, la administración debería plantear o exigir unas cuestiones básicas:

- Prescribir la reubicación fuera del casco urbano en el caso de que los impactos generados sobre la población sean críticos.

- Retirar periódicamente el estiércol y almacenarlo en cualquier caso en una zona rústica.

- Limpiar diariamente las calles.

\section{Pavimentación estética de calles}

La mayoría de la pavimentación de las calles de los pueblos de Tierra de Campos se realiza con paños de hormigón, que es la solución más económica. Su color grisáceo hace que se trate de un acabado neutro, que no destaca ni en sentido positivo ni en negativo en cuanto a estética. Para las reparaciones o las nuevas pavimentaciones con este material, se podrían tener en cuenta las siguientes mejoras (Figura 6.112):

- Separar los paños con adoquín de color rojizo, piedra caliza u otro material rústico diferente, para crear una trama un poco más heterogénea. 
- Utilizar para el hormigón canto rodado de mayor tamaño, que deberá ser lavado en superficie.

En los entornos protegidos, la pavimentación con adoquines pardo-rojizos resulta muy ornamental, más si va intercalada con bandas de piedra.

Desde luego, la peor solución es la adecuación del firme con asfalto, que resulta de una gran artificialidad y transmite mucho calor en verano.
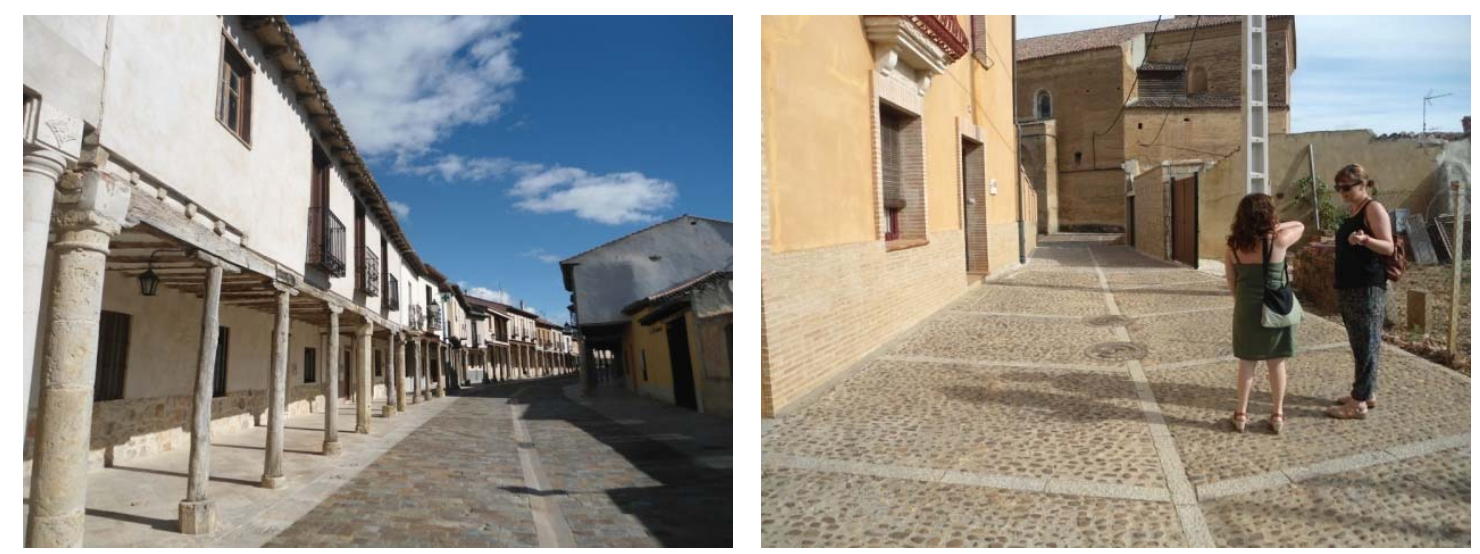

Figura 6.112. Pavimentaciones ornamentales en Ampudia (izquierda) y Grajal de Campos (derecha), que mejoran la calidad urbanística del conjunto.

\section{Adecuación paisajística de plazas y plazuelas}

En muchos pueblos existen plazas que han sido pavimentadas con hormigón en su integridad sirviendo, en el mejor de los casos, como zona de aparcamiento desordenada. Gran parte de estos espacios tienen interés por formar parte de una trama irregular medieval o por albergar edificios con tipologías arquitectónicas tradicionales, aunque la apariencia general es de descuido o, al menos, de falta de interés por potenciarlas.

No se plantean en este apartado las grandes obras que se realizan en las ciudades. En los pueblos todo debe ser más sencillo, austero y sostenible. Pero no se debe dejar de hacer porque existen múltiples soluciones. En este sentido, se indican algunas posibilidades:

- Ordenación de los aparcamientos para que ocupen solo una parte de calles o plazas.

- Disposición de algún parterre con vegetación.

- Instalación de fuentes; el agua en movimiento genera vida y relajación.

- Creación de alcorques donde realizar alguna plantación de arbolado de sombra.

- En caso de no ser posible lo anterior, colocación de jardineras para disponer arbustos o pequeños árboles.

- Colocación de esculturas en algún punto singular.

- Colocación de bancos de madera en las zonas adecuadas paisajísticamente. 

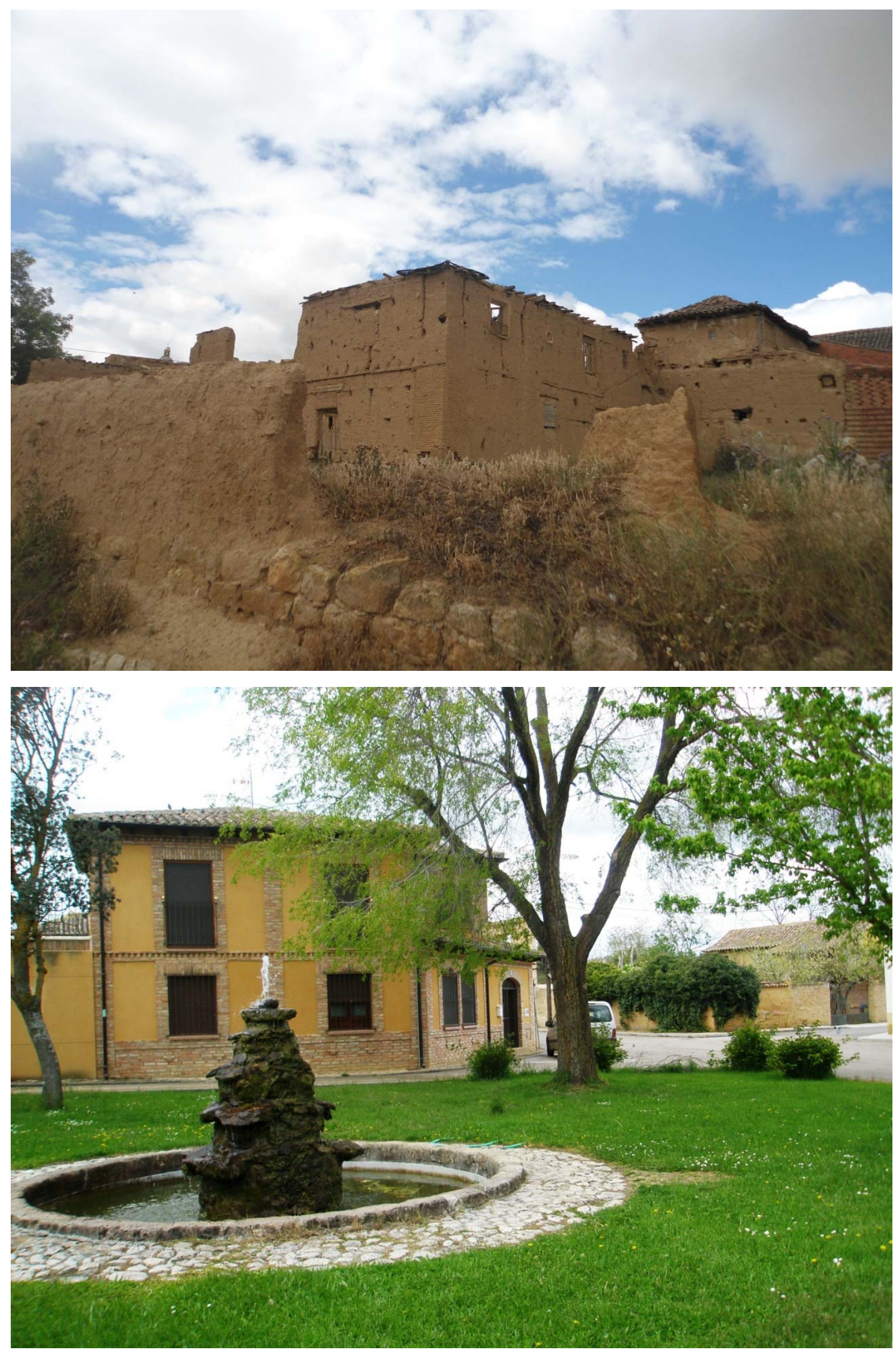

Figura 6.113. Son fotografías extremas, pero reflejan la realidad de muchos pueblos. En la superior se aprecia Baquerín de Campos prácticamente abandonado (estos edificios han sido recientemente derribados). En la inferior se observa una plazuela de Abarca de Campos; esta población tiene muy pocos habitantes pero ha demostrado una gran sensibilidad por su paisaje urbano. 


\section{4. ÁRBOLES Y ARBUSTOS UTILIZABLES EN LA RECUPERACIÓN DEL PAISAJE DE TIERRA DE CAMPOS}

El listado que se expone a continuación se ha elaborado principalmente a partir de la información documental y gráfica contenida en la Guía de árboles y arbustos de Castilla y León (ORIA DE RUEDA y DÍEZ, 2002) -cuyo orden por familias se ha seguido-, con aportaciones de la Guía de Incafo de los árboles y arbustos de la Península Ibérica (LÓPEZ GONZÁLEZ, 1982) y el libro "Árboles y arbustos" (RUIZ DE LA TORRE, 1979), seleccionando aquellas especies cuyo hábitat natural o potencial puede situarse en Tierra de Campos. También se ha tenido en cuenta su presencia real en el territorio, así como su existencia en viveros de la región. Se han clasificado en cuatro grandes grupos: árboles autóctonos para zonas secas, árboles autóctonos para zonas húmedas, árboles exóticos ornamentales rústicos y arbustos autóctonos (Tabla 6.8). 
Tabla 6.8. Árboles y arbustos utilizables en la recuperación del paisaje de Tierra de Campos.

\begin{tabular}{|c|c|c|c|}
\hline $\begin{array}{l}\text { Árboles autóctonos } \\
\text { para zonas secas }\end{array}$ & $\begin{array}{l}\text { Árboles autóctonos para } \\
\text { zonas húmedas }\end{array}$ & $\begin{array}{l}\text { Árboles exóticos } \\
\text { ornamentales rústicos }\end{array}$ & Arbustos autóctonos \\
\hline $\begin{array}{l}\text { Pino piñonero } \\
\text { (Pinus pinea L.) }\end{array}$ & $\begin{array}{l}\text { Aliso } \\
\text { (Alnus glutinosa L.) }\end{array}$ & $\begin{array}{l}\text { Ciprés } \\
\text { (Cupressus sempervirens L.) }\end{array}$ & $\begin{array}{l}\text { Majuelo o espino majoleto } \\
\text { (Crataegus monogyna J.) }\end{array}$ \\
\hline $\begin{array}{l}\text { Pino carrasco } \\
\text { (Pinus halepensis) }\end{array}$ & $\begin{array}{l}\text { Álamo blanco } \\
\text { (Populus alba L.) }\end{array}$ & $\begin{array}{l}\text { Ciprés de Arizona } \\
\text { (Cupressus arizonica glabra) }\end{array}$ & $\begin{array}{l}\text { Endrino } \\
\text { (Prunus spinosa L.) }\end{array}$ \\
\hline $\begin{array}{l}\text { Enebro de incienso } \\
\text { (Juniperus thurifera L.) }\end{array}$ & $\begin{array}{l}\text { Álamo cribero } \\
\text { (Populus canescens (Ait) Sm) }\end{array}$ & $\begin{array}{l}\text { Olmo siberiano } \\
\text { (Ulmus pumila L.) }\end{array}$ & $\begin{array}{l}\text { Zarzamora } \\
\text { (Rubus ulmifolius Sch.) }\end{array}$ \\
\hline $\begin{array}{l}\text { Enebro de la miera } \\
\text { (Juniperus oxycedrus L.) }\end{array}$ & $\begin{array}{l}\text { Chopo del país } \\
\text { (Populus nigra L.) }\end{array}$ & $\begin{array}{l}\text { Árbol del paraíso } \\
\text { (Eleagnus angustifolia L.) }\end{array}$ & $\begin{array}{l}\text { Escaramujo ( } \\
\text { Rosa canina L.) }\end{array}$ \\
\hline $\begin{array}{l}\text { Encina } \\
\text { (Quercus ilex L. subsp. } \\
\text { rotundifolia) }\end{array}$ & $\begin{array}{l}\text { Salce blanco } \\
\text { (Salix alba L.) }\end{array}$ & $\begin{array}{l}\text { Plátano } \\
\text { (Platanus hybrida Brot.) }\end{array}$ & $\begin{array}{l}\text { Rosal silvestre } \\
\text { (Rosa micrantha Borrer ex Sm.) }\end{array}$ \\
\hline $\begin{array}{l}\text { Coscoja } \\
\text { (Quercus coccifera L.) }\end{array}$ & $\begin{array}{l}\text { Mimbrera } \\
\text { (Salix fragilis L.) }\end{array}$ & $\begin{array}{l}\text { Falsa acacia } \\
\text { (Robinia pseudoacacia L.) }\end{array}$ & $\begin{array}{l}\text { Zumaque } \\
\text { (Rhus coriaria L.) }\end{array}$ \\
\hline $\begin{array}{l}\text { Quejigo } \\
\text { (Quercus faginea Lam) }\end{array}$ & $\begin{array}{l}\text { Salce gato } \\
\text { (Salix atrocinerea Brot.) }\end{array}$ & & $\begin{array}{l}\text { Bonetero } \\
\text { (Euonymus europaeus L.) }\end{array}$ \\
\hline $\begin{array}{l}\text { Olmo o negrillo } \\
\text { (Ulmus minor Mill.) }\end{array}$ & $\begin{array}{l}\text { Fresno de Castilla } \\
\text { (Fraxinus angustifolia Vahl.) }\end{array}$ & & $\begin{array}{l}\text { Tamariz } \\
\text { (Tamarix gallica L.) }\end{array}$ \\
\hline $\begin{array}{l}\text { Higuera } \\
\text { (Ficus carica L.) }\end{array}$ & & & $\begin{array}{l}\text { Tamariz } \\
\text { (Tamarix africana Por.) }\end{array}$ \\
\hline $\begin{array}{l}\text { Moral } \\
\text { (Morus nigra L.) }\end{array}$ & & & $\begin{array}{l}\text { Cornejo } \\
\text { (Cornus sanguinea L.) }\end{array}$ \\
\hline $\begin{array}{l}\text { Morera } \\
\text { (Morus alba L.) }\end{array}$ & & & $\begin{array}{l}\text { Aligustre } \\
\text { (Ligustrum vulgare L.) }\end{array}$ \\
\hline $\begin{array}{l}\text { Laurel } \\
\text { (Laurus nobilis L.) }\end{array}$ & & & $\begin{array}{l}\text { Jazmín silvestre } \\
\text { (Jasminum fruticans L.) }\end{array}$ \\
\hline $\begin{array}{l}\text { Maíllo } \\
\text { (Malus sylvestris Mill.) }\end{array}$ & & & $\begin{array}{l}\text { Saúco } \\
\text { (Sambucus nigra L.) }\end{array}$ \\
\hline $\begin{array}{l}\text { Piruétano } \\
\text { (Pyrus bourgaeana D.) }\end{array}$ & & & $\begin{array}{l}\text { Madreselva de soto } \\
\text { (Lonicera periclimenum L.) }\end{array}$ \\
\hline $\begin{array}{l}\text { Jerbo } \\
\text { (Sorbus domestica L.) }\end{array}$ & & & $\begin{array}{l}\text { Madreselva } \\
\text { (Lonicera etrusca G.) }\end{array}$ \\
\hline $\begin{array}{l}\text { Acerolo } \\
\text { (Crataegus azarolus L.) }\end{array}$ & & & $\begin{array}{l}\text { Torvisco } \\
\text { (Daphne gnidium L.) }\end{array}$ \\
\hline $\begin{array}{l}\text { Almendro } \\
\text { (Amygdalus communis L.) }\end{array}$ & & & $\begin{array}{l}\text { Retama loca } \\
\text { (Osyris alba L.) }\end{array}$ \\
\hline \multirow[t]{10}{*}{$\begin{array}{l}\text { Guindal } \\
\text { (Prunus cerassus L.) }\end{array}$} & & & $\begin{array}{l}\text { Gayomba o sebe } \\
\text { (Spartium junceum L.) }\end{array}$ \\
\hline & & & $\begin{array}{l}\text { Aliaga } \\
\text { (Genista scorpius (L.) DC) }\end{array}$ \\
\hline & & & $\begin{array}{l}\text { Escoba negra } \\
\text { (Cytisus scoparius (L.) Link }\end{array}$ \\
\hline & & & $\begin{array}{l}\text { Retama común } \\
\begin{array}{lll}\text { (Retama sphaerocarpa } \\
\text { Boiss) }\end{array} \\
\end{array}$ \\
\hline & & & $\begin{array}{l}\text { Escoba lebrela } \\
\text { (Dorycnium pentaphylum } \\
\text { Scop.) }\end{array}$ \\
\hline & & & $\begin{array}{l}\text { Garbancilleras } \\
\text { (Ononis spp.) }\end{array}$ \\
\hline & & & $\begin{array}{l}\text { Estepa negral } \\
\text { (Cistus laurifolius L.) }\end{array}$ \\
\hline & & & $\begin{array}{l}\text { Romero } \\
\text { (Rosmarinus officinallis L.) }\end{array}$ \\
\hline & & & $\begin{array}{l}\text { Hiedra } \\
\text { (Hedera helix L.) }\end{array}$ \\
\hline & & & $\begin{array}{l}\text { Acigüembre } \\
\text { (Ribes uva-crispa L.) }\end{array}$ \\
\hline
\end{tabular}


Tal como se observa en la Tabla 6.8, se han seleccionado 32 árboles y 27 arbustos; es decir, una cantidad total de 62 especies, que resulta muy elevada para que pueda ser tenida en cuenta en cualquier restauración del paisaje de Tierra de Campos. De entre los árboles, 18 son más apropiados para zonas secas, 8 para zonas húmedas y 6 son exóticos ornamentales rústicos.

En los grupos de especies autóctonas se han incluido aquellas introducidas desde muy antiguo y que se encuentran asilvestradas en el territorio. No se han incluido árboles exóticos ornamentales necesitados de riego ni arbustos exóticos ya que, aunque podrían medrar en los jardines de los pueblos de Tierra de Campos, se considera que no han de ser recogidos con carácter general en un listado de especies para la recuperación paisajística. Tampoco se han diferenciado arbustos para zonas secas o húmedas, ya que la delimitación para la mayoría de las especies es muy difusa.

Se realiza una sucinta descripción de las principales características ecológicas y paisajísticas de cada una de las especies, así como de su distribución o plantación en la comarca. Particularmente se añaden aspectos útiles para la recuperación ambiental, como la posibilidad de reproducción por estaquillas o esquejes, el crecimiento, la necesidad de mantenimiento, etc.

\subsection{1. Árboles autóctonos para zonas secas}

\section{Pino piñonero (Pinus pinea L.)}

Árbol perenne de 15 a $30 \mathrm{~m}$ de altura con inconfundible copa en forma aparasolada o redondeada, lo que le proporciona un inestimable valor ornamental (Figura 6.114). Tronco derecho y cilíndrico. Es una especie típicamente termófila y xerófila. Prefiere los suelos sueltos y arenosos, aunque puede habitar los suelos arcillosos. Los pinares piñoneros son masas característicamente aclaradas, debido a su heliofilia. Se suele olivar (podar) para favorecer su fructificación. Produce piñones comestibles muy sabrosos. Actualmente es la especie más utilizada en repoblaciones forestales realizadas en la comarca o incluso en las aledañas, aunque no es raro ver ejemplares viejos de pino piñonero en muchos términos municipales.
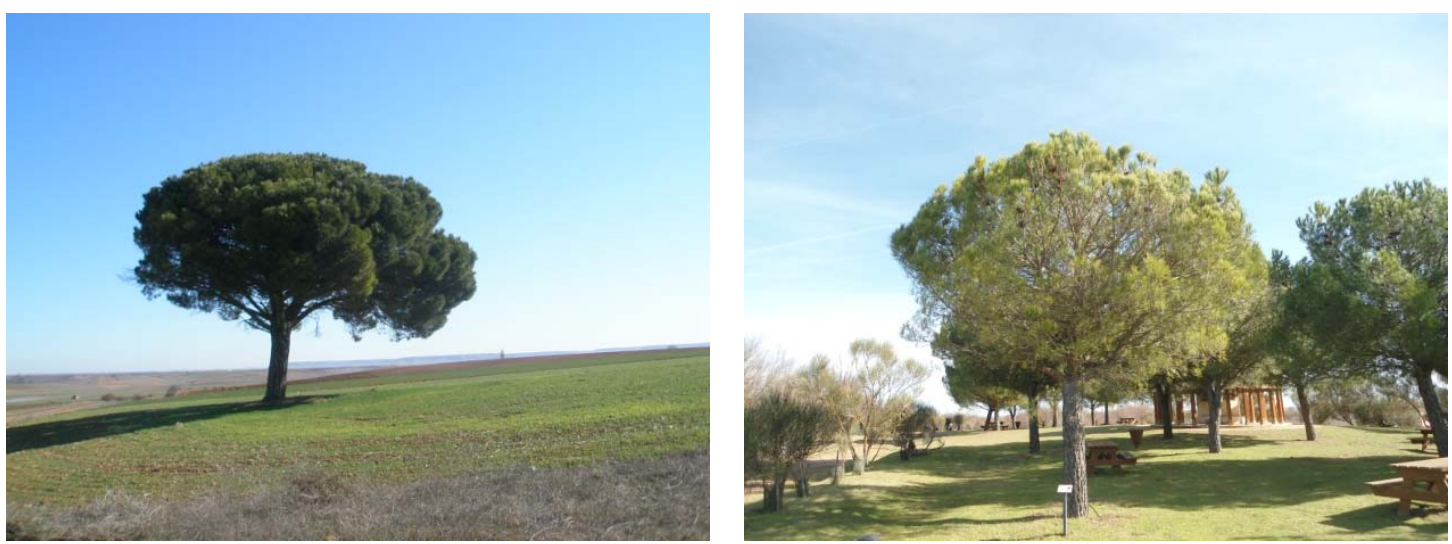

Figura 6.114. A la izquierda, bello ejemplar aislado de pino piñonero en Villaumbrales. A la derecha, bosquete en el entorno de la Casa del Parque de las Lagunas de Villafáfila. 


\section{Pino carrasco (Pinus halepensis Mill.)}

Árbol tortuoso de 3 a $20 \mathrm{~m}$ de altura con la parte superior del tronco y ramas de color blanquecino. Perenne. Copa irregular poco densa. Prefiere los suelos ricos en cal. Es muy resistente a la sequía, pero es sensible a las heladas y termófilo. Se ha utilizado en la primera época de las repoblaciones forestales realizadas en las laderas de transición a los páramos calcáreos, existiendo pinares maduros de 40-50 años que ya han sido aclarados.

\section{Enebro de incienso (Juniperus thurifera L.)}

Árbol perenne que puede alcanzar los $25 \mathrm{~m}$ de altura, pero que con frecuencia -debido a condiciones desfavorables de suelo- apenas consigue la talla de un arbolillo. Copa densa con forma cónica y corteza grisácea. El enebral es un bosque claro, propio de terrenos secos y climas fríos y luminosos, adaptado a condiciones extremas y muy resistente. Es de crecimiento muy lento. Aunque tuvo la época de mayor extensión en la era Terciaria, en la actualidad su distribución se restringe a las parameras calcáreas, en forma de ejemplares aislados. Su madera es muy apreciada.

\section{Enebro de la miera (Juniperus oxycedrus L.)}

Árbol o arbolillo perenne de 3 a $8 \mathrm{~m}$ de altura de corteza grisácea y copa cónica. Especie xerófila y muy resistente; es heliófila y pionera. Aunque su distribución natural se sitúa al sur de la comarca, podría utilizarse por su adaptación a condiciones extremas y su valor ornamental.

\section{Encina (Quercus ilex L. subsp. rotundifolia)}

Árbol perenne de 10 a $20 \mathrm{~m}$ de altura, de copa densa, amplia y redondeada. Tronco grueso y algo torcido, con corteza grisácea. Probablemente el encinar cubriría de forma natural la mayor parte de la comarca de Tierra de Campos. Actualmente perviven reductos boscosos y magníficos ejemplares aislados en algunos términos municipales (Paredes de Nava, Becerril de Campos, Berrueces, Cañizo, Figura 6.115). Gran resistencia y adaptabilidad a múltiples ambientes, entre los que se hallan los más extremos. Altísima longevidad y muy buena capacidad de rebrote. La producción más valorada ha sido como leña, por su alto valor calorífico.

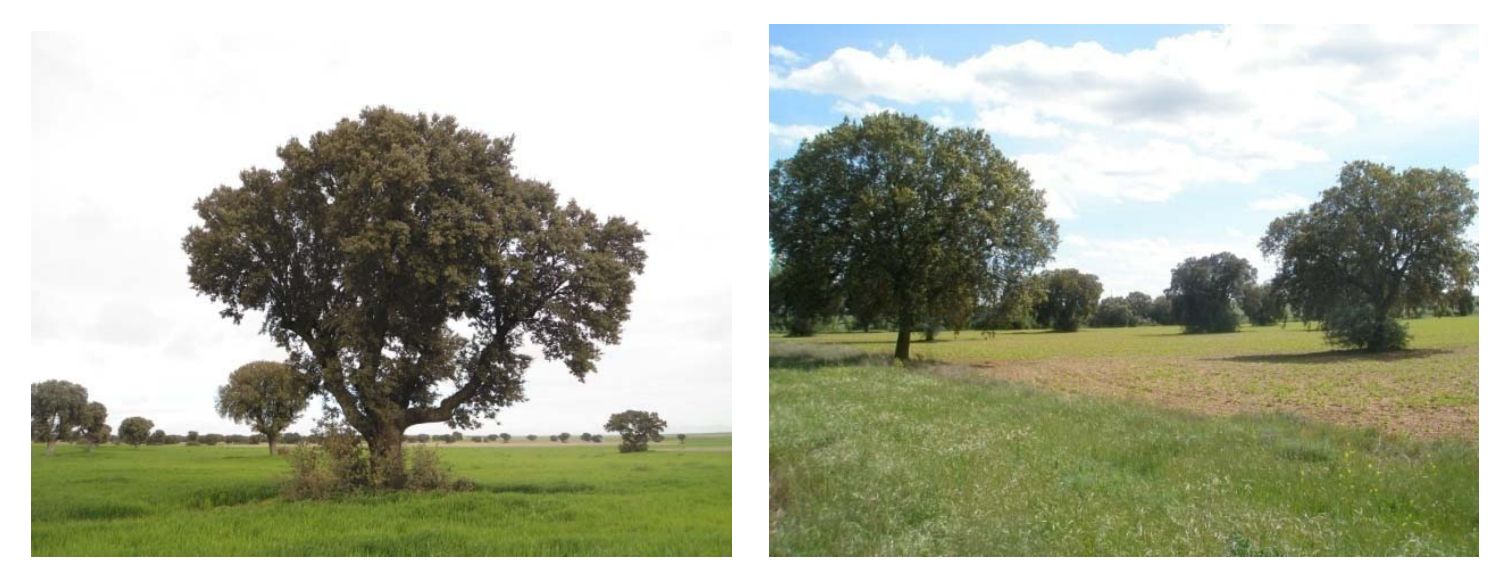

Figura 6.115. Grandes encinas en Cañizo (izquierda) y Perales (derecha). 


\section{Coscoja (Quercus coccifera L.)}

Mata arbustiva o arbolillo muy enmarañada, de 1 a $3 \mathrm{~m}$ de altura. Se ramifica abundantemente desde la base. Hojas persistentes de color verde claro por ambas caras. Es una especie xerófila y termófila, que medra en terrenos secos, preferentemente calizos. Aparece en los páramos calcáreos, aunque podría utilizarse en Tierra de Campos por su rusticidad.

\section{Quejigo (Quercus faginea Lam.)}

Árbol de hoja caediza de 7 a $30 \mathrm{~m}$ de altura, aunque a menudo forma montes bajos (Figura 6.116). Copa clara y de color verde claro en verano, redondeada o alargada. Especie xerófila, aunque prefiere terrenos umbrosos y frescos. Se suele asociar con la encina. Ocupa sobre todo los terrenos calizos o con margas, distribuyéndose por las cuestas y páramos calcáreos. La mayor producción ha sido para leña.

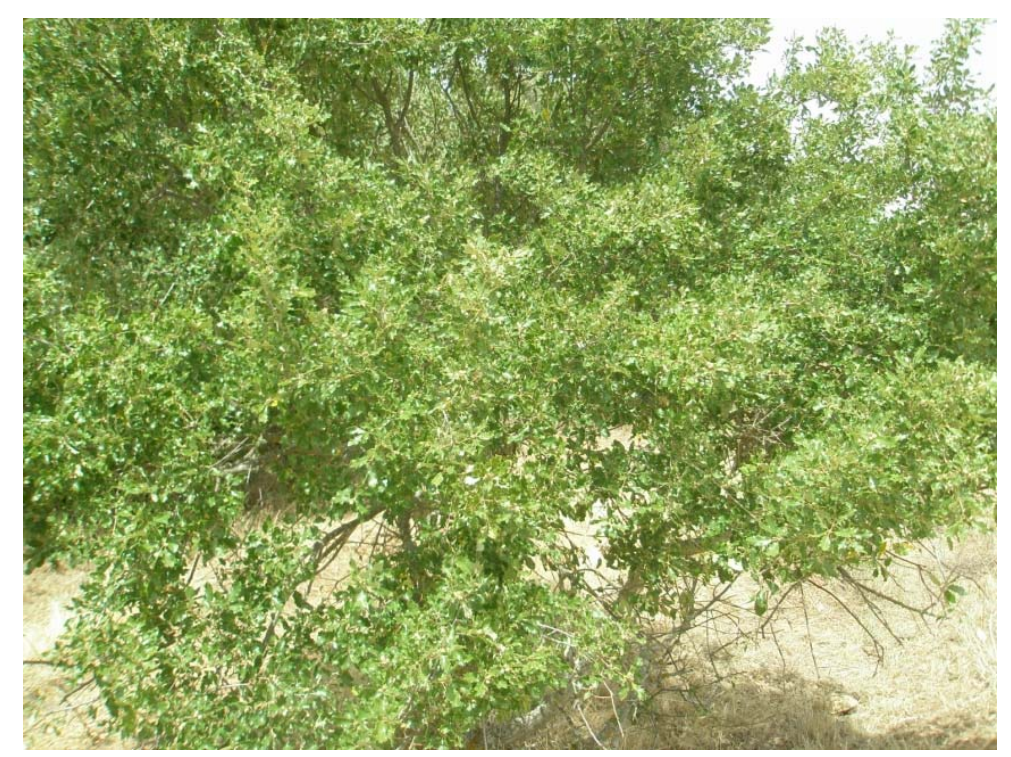

Figura 6.116. Quejigo en el monte Becerril, Becerril de Campos.

\section{Olmo o negrillo (Ulmus minor Mill.)}

Árbol caducifolio de 15 a $30 \mathrm{~m}$ de altura. Tronco de corteza fisurada y pardo oscura. Copa amplia, de follaje denso, largamente aovada. Es una especie de transición entre zonas secas y húmedas. En general medra en suelos profundos, ricos en nutrientes y aguantan terrenos arcillosos y compactos. Desde hace unos años se ha visto afectado por la enfermedad de la grafiosis, aunque subsisten muchos ejemplares como matas arbustivas (Figura 6.117). El negrillo ha sido un árbol muy plantado en Tierra de Campos, en ermitas, plazas, márgenes de carreteras, etc., debido a su frondosidad. Su madera ha sido siempre muy valorada. 


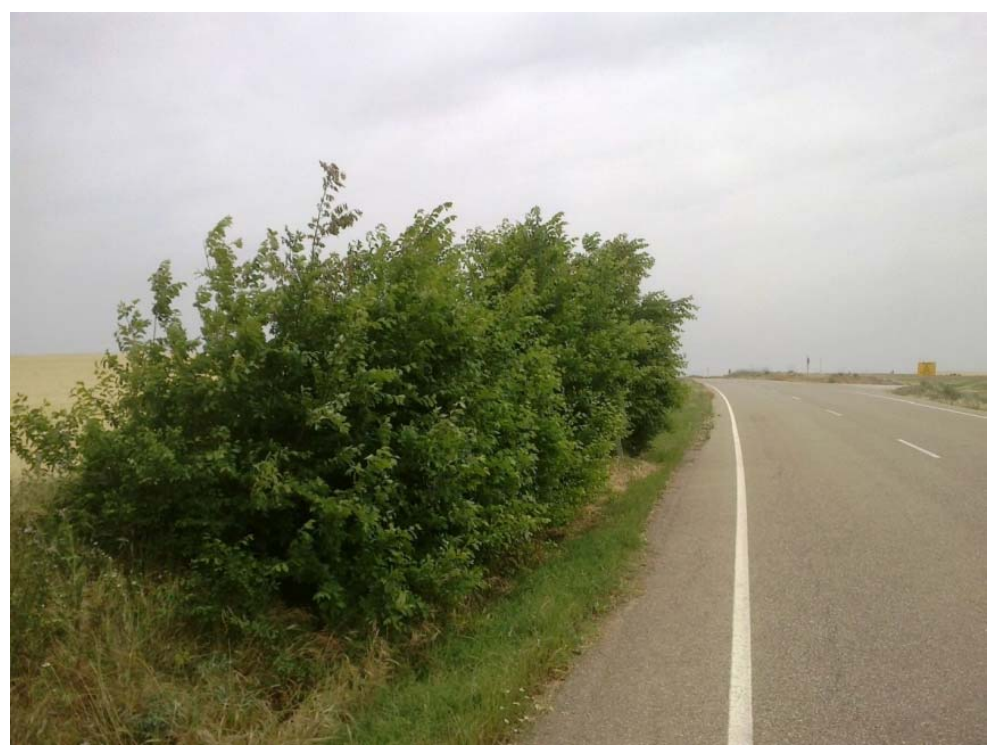

Figura 6.117. Brotes de olmo en margen de carretera en Villalón de Campos. A mediados del siglo pasado, las carreteras de la comarca estaban frecuentemente flanqueadas por robustos ejemplares de olmo.

\section{Higuera (Ficus carica L.)}

Arbolillo ramoso de tronco grisáceo y liso y grandes hojas caedizas, profundamente lobuladas, de color más claro por el envés. No suele superar los 6-8 $\mathrm{m}$ de altura (Figura 6.118). Aunque su hábitat natural se encuentra entre las rocas de los desfiladeros, en Tierra de Campos se ha plantado mucho en huertas y en patios y corrales del interior de las casas, sobre todo por su producción de higos. En general es una especie termófila que vive en parajes abrigados.

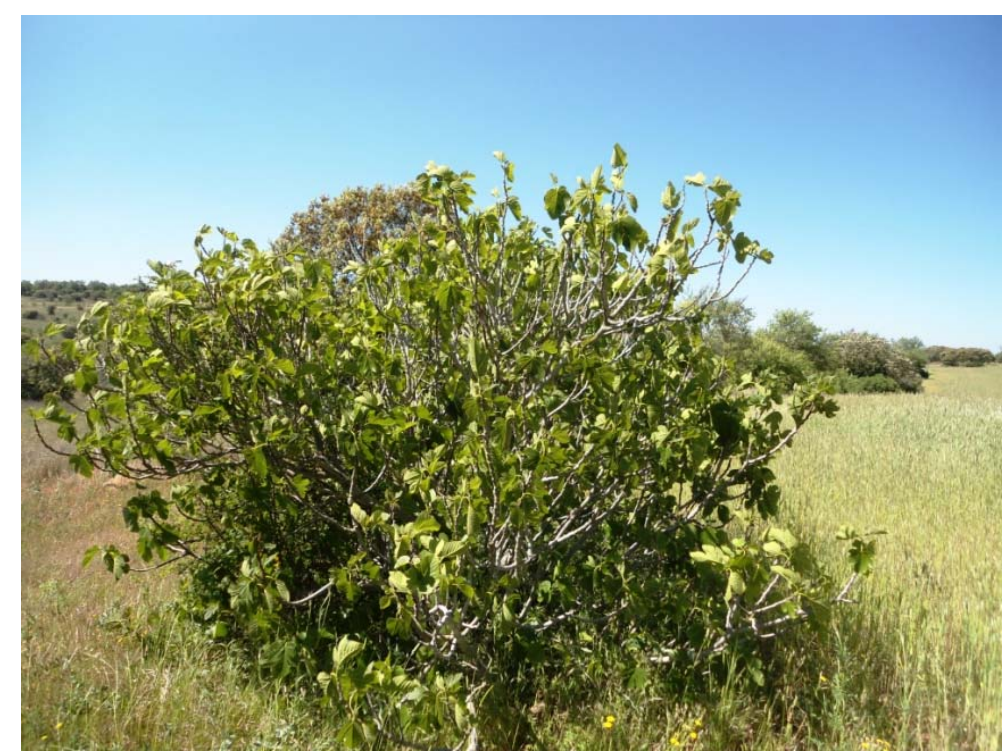

Figura 6.118. Higuera en el borde de una parcela agrícola en Cañizo. 


\section{Moral (Morus nigra L.)}

Arbolillo de 10 a $15 \mathrm{~m}$ de altura, de copa redondeada y tronco grueso de corteza negruzca y agrietada. Copa redondeada, con hojas caedizas grandes ovaladas (Figura 6.119). Plantado desde muy antiguo en huertas, plazas de pueblos y ermitas. Prefiere terrenos frescos en ambientes soleados y soporta bien el frío. Su fruto (la mora) es muy apreciado. Hay pueblos que tienen como referencia este árbol, como el terracampino Moral de la Reina.

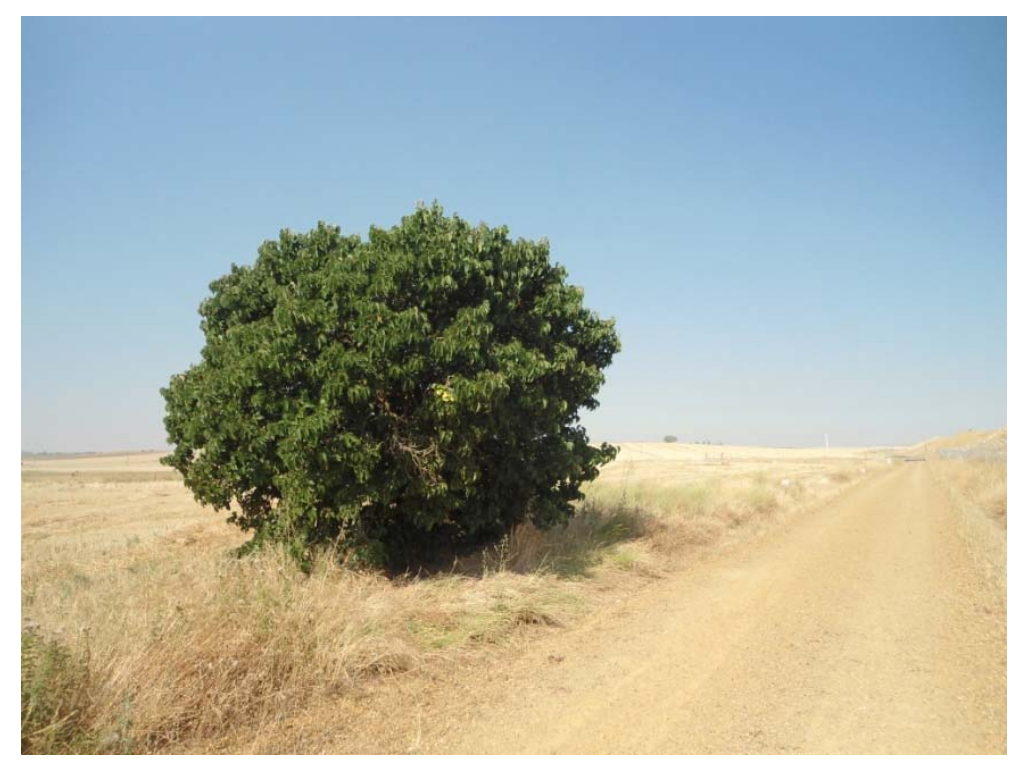

Figura 6.119. Moral aislado en el campo de Villada.

\section{Morera (Morus alba L.)}

Árbol de tamaño medio, caducifolio, con copa aovada o redondeada y tronco de corteza pardoblanquecina. También se ha cultivado en huertas y, en algún caso, como ornamental a lo largo de paseos. Prefiere los suelos algo sueltos y aguanta bien la sequía y el frío. Es una especie introducida desde hace varios siglos.

\section{Laurel (Laurus nobilis L.)}

Arbolillo de 3 a $12 \mathrm{~m}$ de altura, con hojas persistentes y lanceoladas. Copa densa y algo irregular. Es una especie propia de climas suaves, sin sequías estivales ni grandes heladas, pero que se cultiva desde antiguo en Tierra de Campos y otras comarcas agrícolas, sobre todo en huertas o corrales. Su hoja se utiliza en guisos y adobos.

\section{Maíllo (Malus sylvestris Mill.)}

Arbolillo o arbusto de 4 a $12 \mathrm{~m}$ de altura. Copa redondeada y tronco corto, con frecuencia retorcido. Hojas caedizas pequeñas. Florece en abril y mayo. El fruto son las maíllas. Aunque es propio de las montañas norteñas, su amplitud ecológica hace que también pueda ser utilizado en Tierra de Campos. En general prefiere suelos frescos y ricos, silíceos, arcillosos y más raramente calizos. Otra especie del mismo género es el manzano (Malus domestica Borkh.), cultivado sobre todo en las huertas. Le perjudican los fríos muy intensos, especialmente las heladas tardías. 


\section{Piruétano (Pyrus bourgaeana D.)}

Arbolillo espinoso de 3 a $10 \mathrm{~m}$ de altura, con hoja pequeña y caediza (Figura 6.120). Copa abierta. Flores blancas. Aparece disperso en los claros de los bosques y en los setos, pero su amplitud ecológica abarca a toda Castilla y León. Es una especie de media luz. Su fruto sirve de alimento a numerosas especies de fauna, que posteriormente constituyen una fuente de dispersión de las semillas. El peral (Pyrus communis L.) es una especie similar cultivada, que resiste los fríos intensos y es capaz de crecer en taludes margosos muy erosionados.

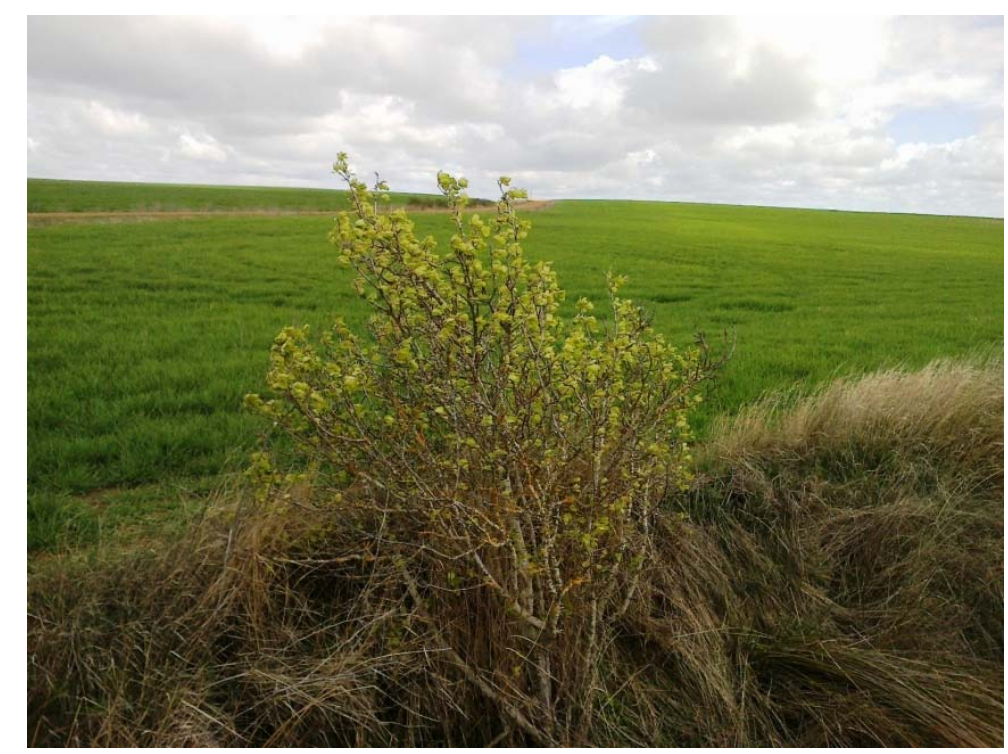

Figura 6.120. Piruétano en arroyo de Villalón de Campos.

\section{Jerbo (Sorbus domestica L.)}

Árbol o arbusto alto de 6 a $15 \mathrm{~m}$ de altura. Tronco derecho y copa anchamente cónica, globosa o trasovada. Corteza grisácea oscura. Hojas caedizas compuestas. Flores blancas en racimos cónicos, por lo que es una especie muy ornamental. El fruto son las jerbas. Crece esparcido por las márgenes y claros de bosques xerófilos, esclerófilos y subesclerófilos mediterráneos. Gran amplitud ecológica. Es una especie heliófila o de media luz. Se dispersa por los mamíferos salvajes.

\section{Acerolo (Crataegus azarolus L.)}

Arbusto o arbolillo de 3 a $10 \mathrm{~m}$ de altura, con ramas espinosas. Hojas caducas. Flores blancas en corimbos. Su fruto es apreciado y por ello se cultiva -las acerolas-, que también es consumido por numerosos animales. Se cría en terrenos secos y no demasiado fríos, pero su amplitud ecológica alcanza Tierra de Campos.

\section{Almendro (Amygdalus communis L.)}

Árbol frutal de 3 a $7 \mathrm{~m}$ de altura con frutos típicos (almendrucos). Hoja caduca. Tronco tortuoso de corteza muy rugosa. La floración es precoz y espectacular, a menudo en pleno invierno, lo que le proporciona un gran valor estético (Figura 6.121). Es árbol propio de terrenos secos y climas suaves, pues le afectan mucho las heladas tardías a la fructificación, pero ha sido muy 
utilizado en Tierra de Campos. Es una especie muy poco exigente. Especial interés posee en la restauración de paseos lineales.
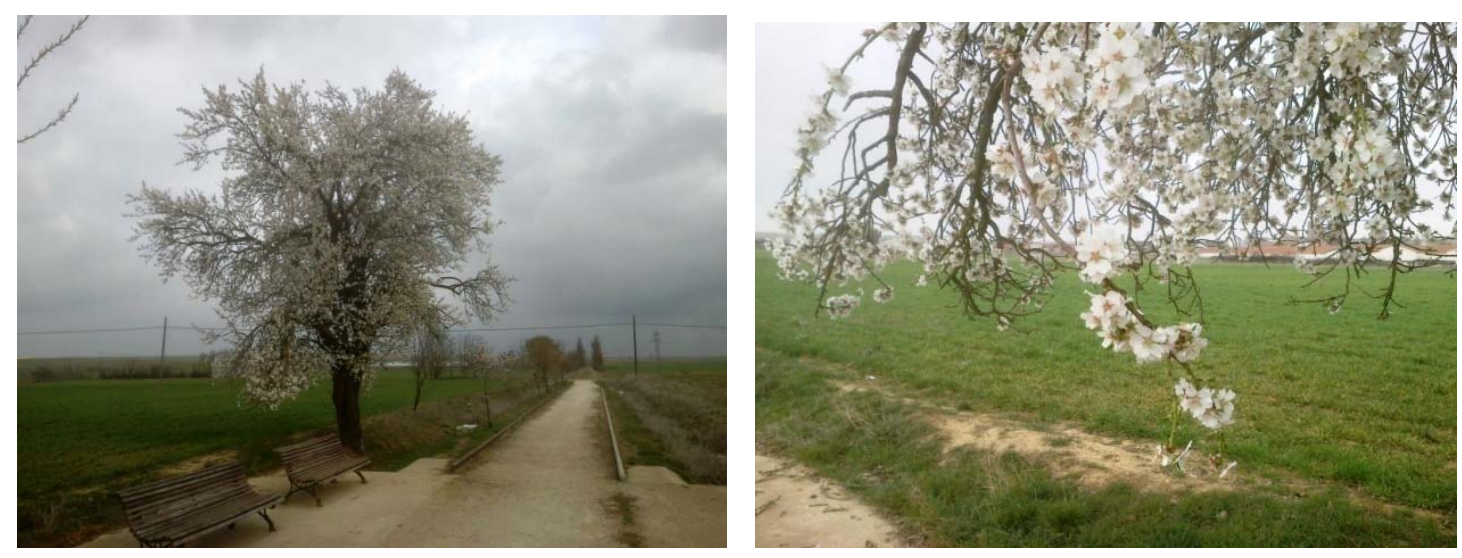

Figura 6.121. Almendro florido en Villalón de Campos.

\section{Guindal (Prunus cerassus L.)}

Arbolillo o arbusto parecido al cerezo, pero mucho más pequeño y ramoso. Produce numerosos renuevos y brotes de raíz, por lo que forma densas orlas arbustivas, conocidas como guindaleras (Figura 6.122). Hojas algo lustrosas. Su utilidad más conocida es la de servir para elaborar el tradicional licor de guindas, de propiedades digestivas. Especie muy propia de majuelos.

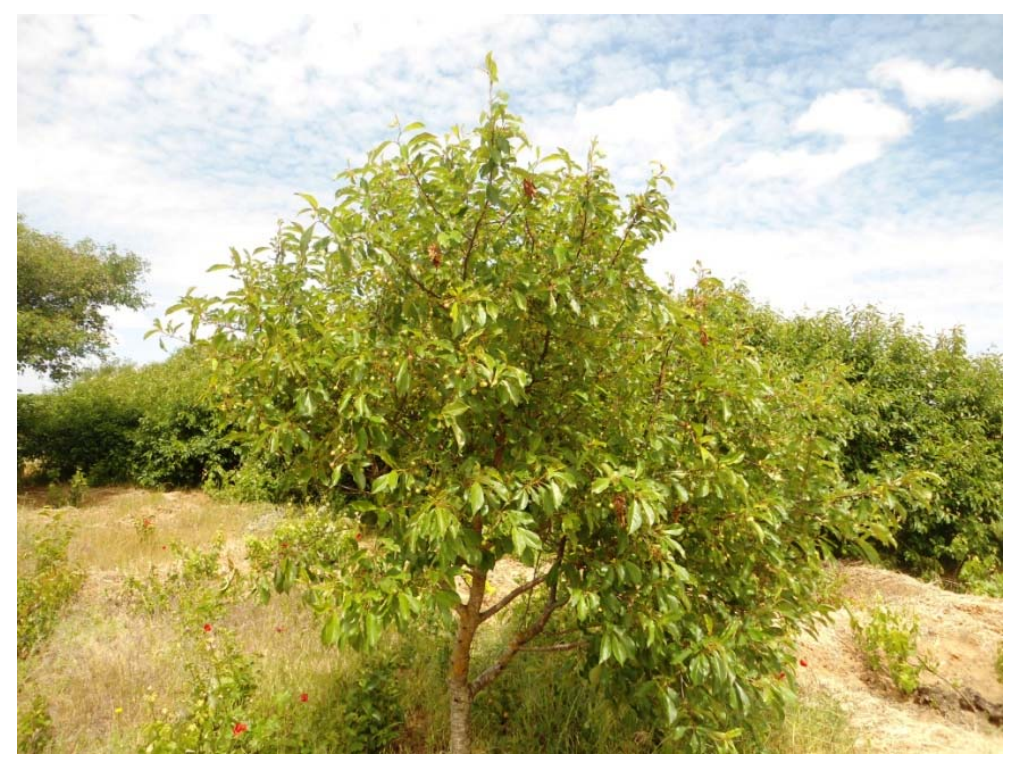

Figura 6.122. Guindal y guindaleras en un majuelo de Villalón de Campos.

\subsection{2. Árboles autóctonos para zonas húmedas}

\section{Aliso (Alnus glutinosa L.)}

Árbol de 20 a $25 \mathrm{~m}$ de altura, de tronco derecho y cilíndrico. Copa oval y alargada. Corteza lisa pardo grisácea. Hojas ovales, glabras y caedizas, color verde oscuro por el haz y más claro por el 
envés (Figura 6.123). Forma alisedas de cierta entidad en buena parte de las riberas de Castilla y León, aunque preferentemente en ríos de cierto caudal. Necesita tener sus raíces permanentemente embebidas en agua. Resiste la continentalidad y precipitaciones relativamente bajas. Es una especie heliófila, aunque puede comportarse como de media luz.
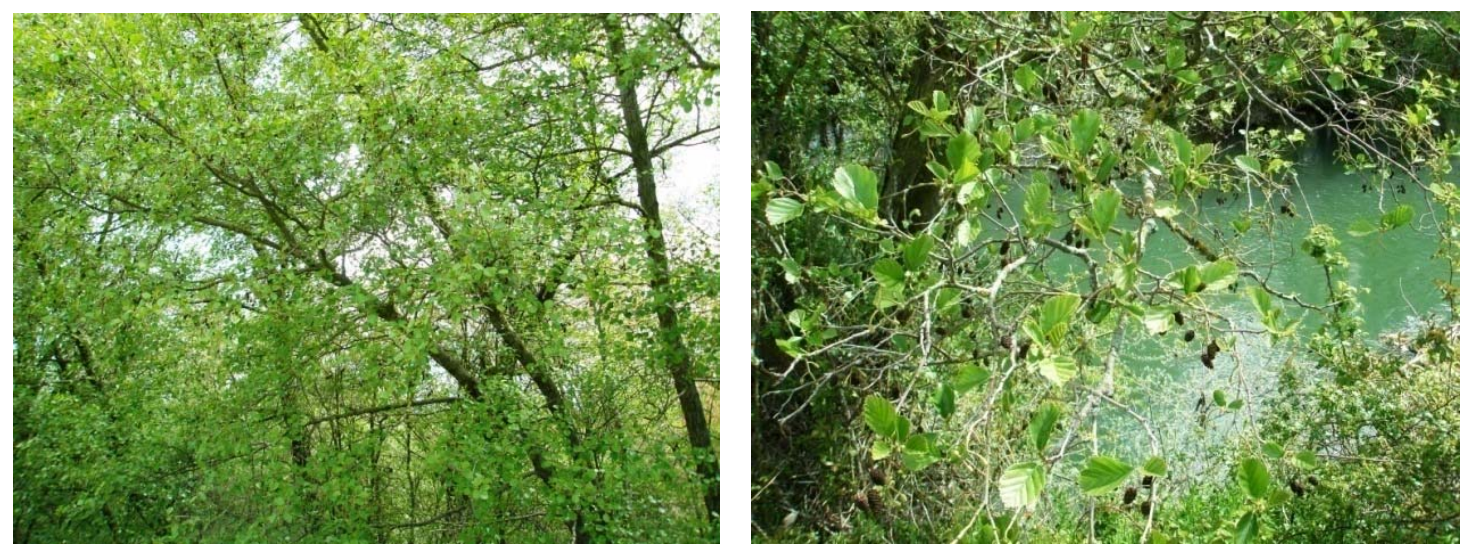

Figura 6.123. Alisos en la ribera del río Carrión, en Villoldo.

\section{Álamo blanco (Populus alba L.)}

Árbol de copa cónica y redondeada de característico color plateado, tronco y ramas de corteza blanca. Puede alcanzar una altura de $20 \mathrm{~m}$. Hojas caedizas de haz verde y envés aterciopelado. Crece en bosques de ribera de los tramos medios y bajos de las cuencas fluviales, con importante presencia en los cursos que cruzan Tierra de Campos (Figura 6.124), pero incluso puede vivir en zonas algo alejadas de corrientes de agua. Aguanta terrenos compactos y tolera altas temperaturas. Tiene un crecimiento relativamente rápido.

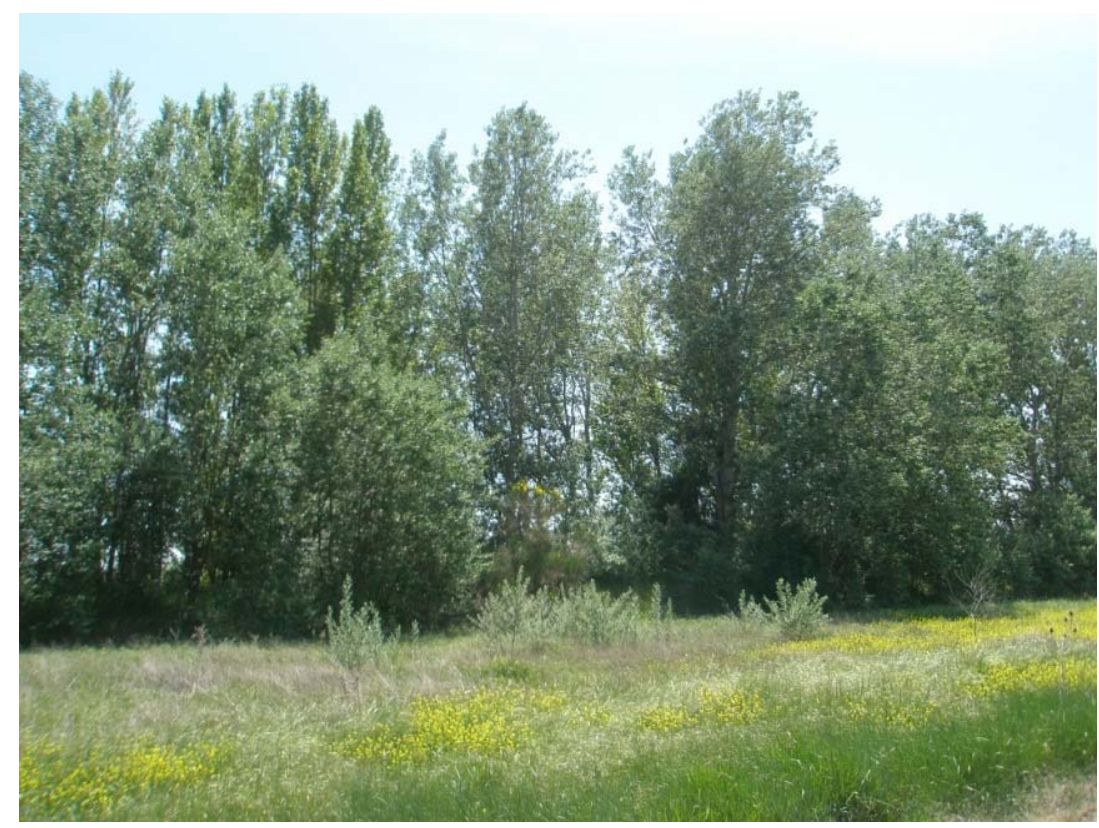

Figura 6.124. Alameda en la ribera del río Templarios, Villelga. 


\section{Álamo cribero (Populus canescens (Ait.) Sm)}

Árbol que puede alcanzar una altura de $38 \mathrm{~m}$, de características intermedias entre $P$. alba y $P$. tremula. Hojas caducas de envés blanquecino. Es el álamo propio de Tierra de Campos, que forma preciosas alamedas en pequeñas parcelas frescas de numerosos municipios (Figura 6.125). Se conservaban al ser el único suministro local de madera, así como lugar de descanso del ganado y como parajes recreativos. Es una especie heliófila y de rápido crecimiento.
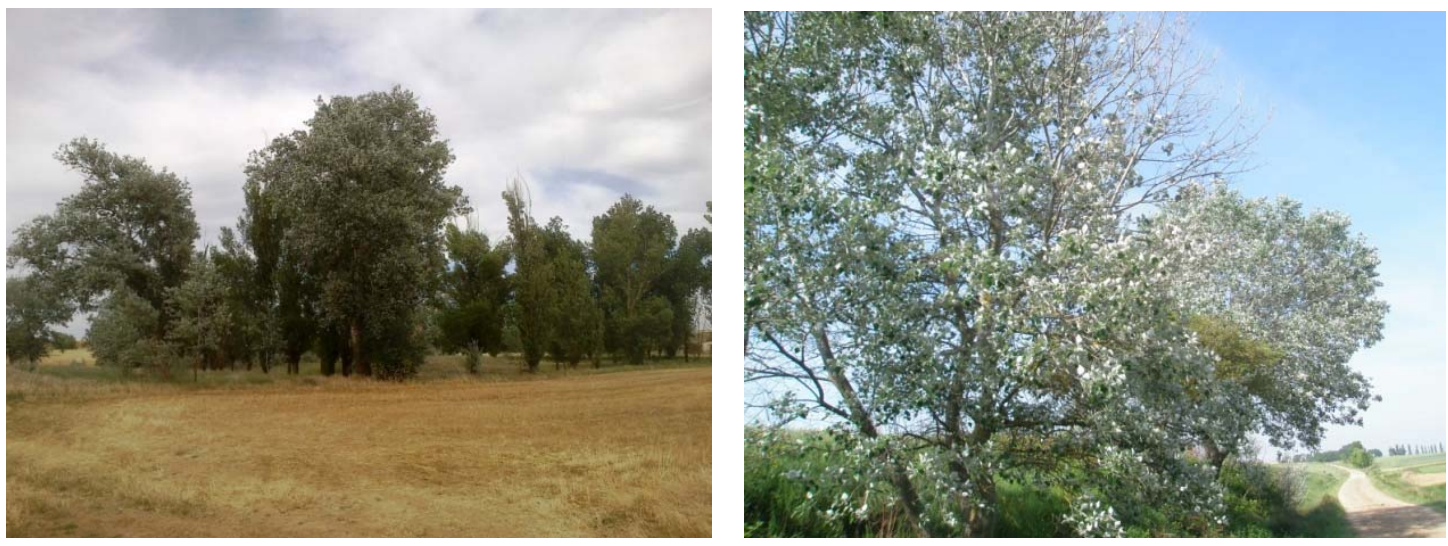

Figura 6.125. Izquierda, alameda en Santervás de Campos; derecha, álamos en el camino de Santiago.

\section{Chopo del país (Populus nigra L.)}

Árbol que llega a los $30 \mathrm{~m}$ de altura. La variedad pyramidalis o itálica, conocida como chopo "lombardo", que fue traída de Italia hace varios siglos y está naturalizada en el paisaje castellano, presenta un porte estrechamente columnar y puede superar los $36 \mathrm{~m}$ de altura (Figura 6.126). Esta variedad es muy ornamental porque su carácter vertical contrasta fuertemente con la horizontalidad del paisaje cerealista. En otoño aumenta notablemente su valor estético al adquirir sus hojas un característico color ocre previo a su caída. Corteza resquebrajada negruzca y hojas caedizas romboidales. Es el árbol con mayor presencia en Tierra de Campos; se encuentra en las riberas de los ríos principales, en arroyos y en algunas regueras de desagüe. Se multiplica muy bien por estaquilla. Crecimiento rápido.
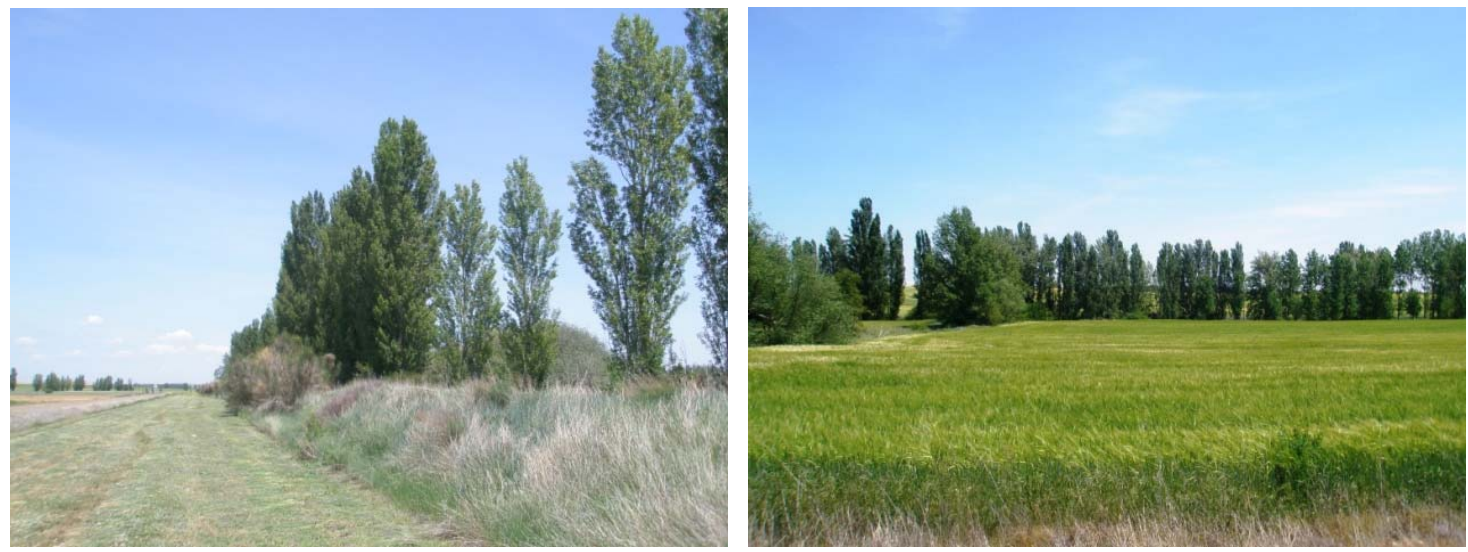

Figura 6.126. Chopos lombardos en las riberas de los ríos Sequillo (izquierda, Villacidaler) y Templarios (derecha, Moratinos). 


\section{Salce blanco (Salix alba L.)}

Árbol que alcanza los $25 \mathrm{~m}$ de altura, con corteza pardo grisácea. Copa alargada, algo irregular, aunque se suele redondear al brotar una vez desmochado. Hojas caducas lanceoladas, cubiertas de un pelo sedoso que da un tono plateado al árbol. Se mezcla con chopos y álamos en las riberas de los ríos principales. Requiere nivel freático elevado. Reproducción por estaquilla. Imprescindibles en la restauración de humedales y de riberas. Crecimiento rápido.

\section{Mimbrera (Salix fragilis L.)}

Árbol capaz de lograr un gran desarrollo, aunque a menudo presentan un porte típico trasmocho por el aprovechamiento del mimbre. Ramas flexibles, hojas lanceoladas, grandes y de haz verde oscuro y más claro y glauco en el envés. Se cría en las riberas de los cursos de agua, frecuentemente asociado con Salix alba.

\section{Salce gato (Salix atrocinerea Brot.)}

Arbolillo de 2 a $6 \mathrm{~m}$ de altura. Hojas caedizas de lombo oval o trasovado, verdes por el haz y grisáceas y claras por el envés. Muy abundante en riberas y zonas húmedas de toda Castilla y León. Como todas las especies de este género, se multiplica fácilmente por estaquilla. Muy interesante para proteger las orillas de los cauces, junto con otras especies del mismo género (Salix salvifolia, Salix purpurea o Salix eleagnos, Figura 6.127).
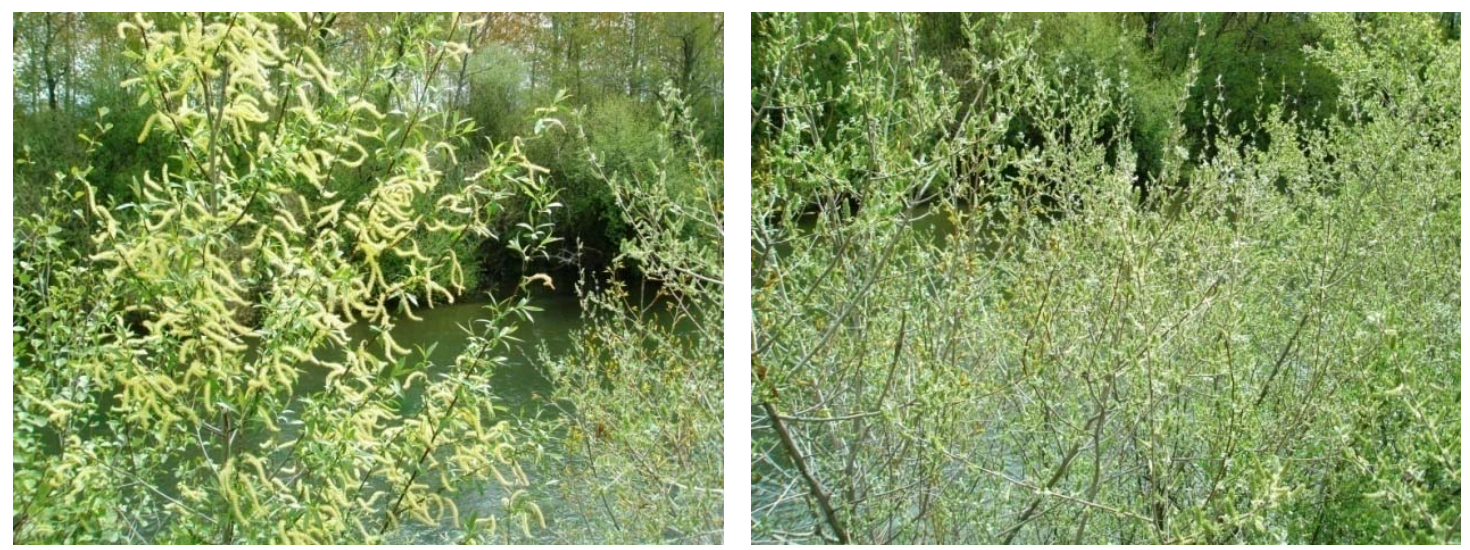

Figura 6.127. Diversos ejemplares de Salix en la ribera del río Carrión, en Villoldo.

\section{Fresno de Castilla (Fraxinus angustifolia Vahl.)}

Árbol de 5 a $25 \mathrm{~m}$ de altura, aunque con frecuencia aparecen los árboles mochos, debido al aprovechamiento de sus ramas y hojas. Corteza grisácea agrietada. Hojas caedizas lanceoladas de borde aserrado. Los fresnos se instalan en terrenos donde existe un nivel de agua freática oscilante al cabo del año. En Tierra de Campos aparece en algunas riberas de los ríos más caudalosos, preferentemente en la zona más septentrional. Incluso se ha plantado en los márgenes de carreteras. 


\subsection{3. Árboles exóticos ornamentales rústicos}

\section{Ciprés (Cupressus sempervirens L.)}

Árbol de copa alargada, compacta y oscura, de 15 a 25 m de altura. Corteza pardo grisácea. Hojas escamosas perennes. Es la especie típica de los cementerios (Figura 6.128), aunque también es una planta muy ornamental. Resiste el calor, la sequía y el frío. También se puede utilizar como setos y cortavientos. Se cultiva en la región mediterránea desde muy antiguo.

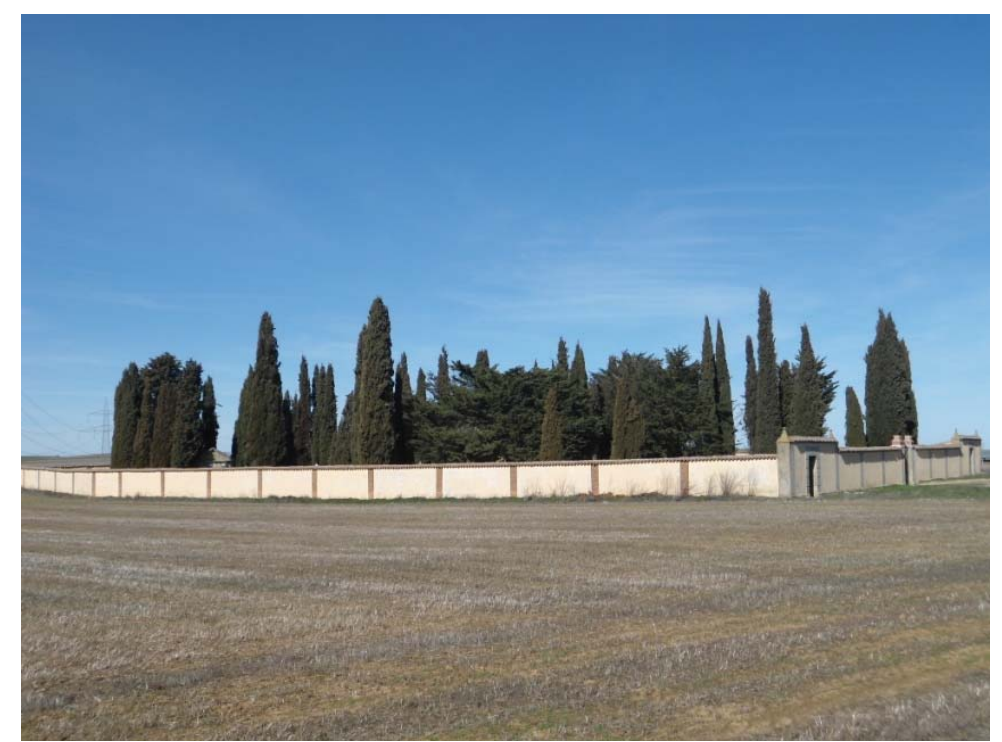

Figura 6.128. Cipreses en el cementerio de Castroverde de Campos.

\section{Ciprés de Arizona (Cupressus arizonica glabra)}

Árbol que puede alcanzar gran altura, de porte también alargado aunque más ancho que el Cupressus sempervirens (Figura 6.129). Tronco de corteza lisa. Procedente del norte de Méjico y suroeste de los Estados Unidos, se ha plantado mucho como ornamental, en la mayor parte de los casos como setos. Presenta un típico color azulado o plateado. Se ha empleado en algunas repoblaciones forestales de laderas en Campos. Tiene una enorme resistencia a la sequía y al calor, por lo que podría utilizarse en muchos espacios periurbanos de la comarca.
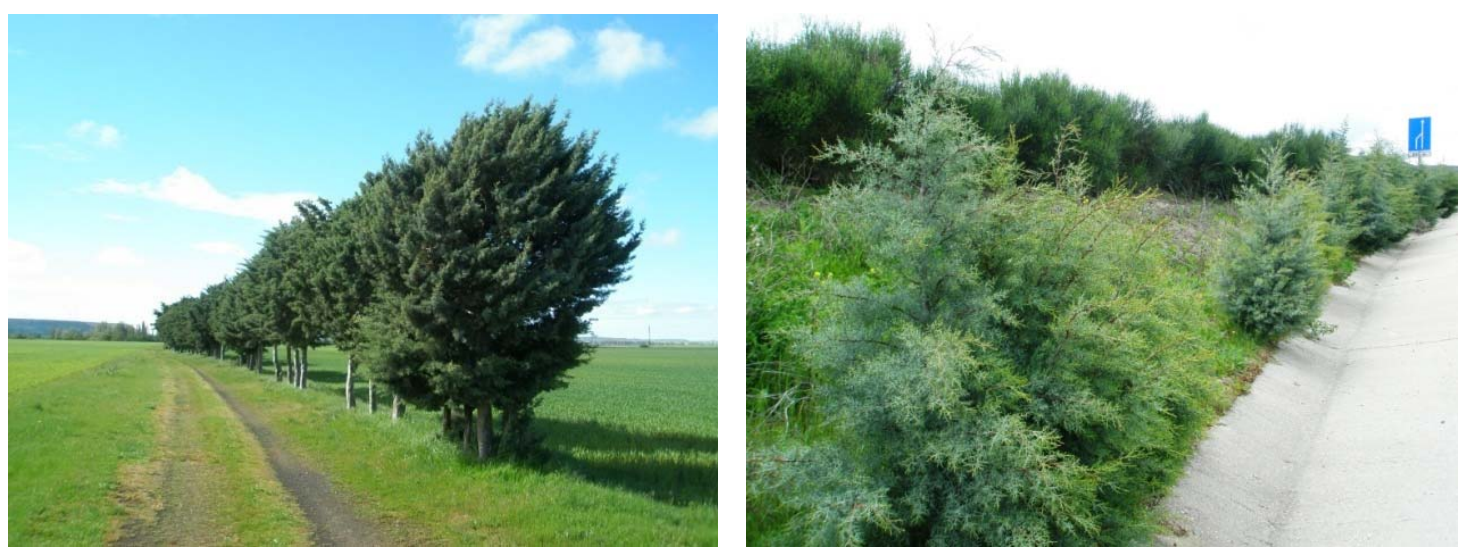

Figura 6.129. Izquierda, seto de arizónicas en Becerril de Campos. Derecha, plantación en margen de la autovía Variante Norte de Palencia. 


\section{Olmo siberiano (UImus pumila L.)}

Árbol de poco porte, aunque mediante podas puede alcanzar bastante altura. Corteza de color gris oscuro, fisurada longitudinalmente. Hojas caedizas pequeñas. Procede de Asia, aunque se emplea en España desde hace unos 40 años. Se ha utilizado considerablemente en jardinería ya que, a diferencia del Ulmus minor, es más resistente a la sequía y a la grafiosis, aunque de menor valor ornamental. Crecimiento relativamente rápido. Se adapta a todo tipo de suelos.

\section{Árbol del paraíso (Eleagnus angustifolia L.)}

Árbol de mediano tamaño, de 5 a $8 \mathrm{~m}$ de altura. Corteza agrietada y ramas espinosas. Hojas simples, caducas, alargadas y plateadas, y flores olorosas, lo que da a esta especie un gran valor ornamental. Originario de Asia occidental y central, se halla asilvestrado en España desde hace muchos siglos. En Tierra de Campos puede aparecer de forma naturalizada en las riberas y vegas del Carrión y del Ucieza. Se emplea como decorativo en parques, jardines y entornos de carreteras. Es una planta muy resistente.

\section{Plátano (Platanus hybrida Brot.)}

Árbol muy robusto que puede alcanzar $30 \mathrm{~m}$ de altura. Copa muy amplia, oval o redondeada, con ramificación abierta. Corteza de color pardo-rojizo, que se desprende en grandes placas de forma irregular, dejando cicatrices blanquecinas. Hojas caducas, grandes, palmeadas. Cultivado a lo largo de paseos y avenidas como árbol de sombra. Prefiere los suelos algo frescos y gusta de sitios abiertos y bien iluminados. En muchas ocasiones es sometido a fuertes podas tempranas, para conformar su porte y evitar la recogida de sus hojas, lo que limita su valor ornamental.

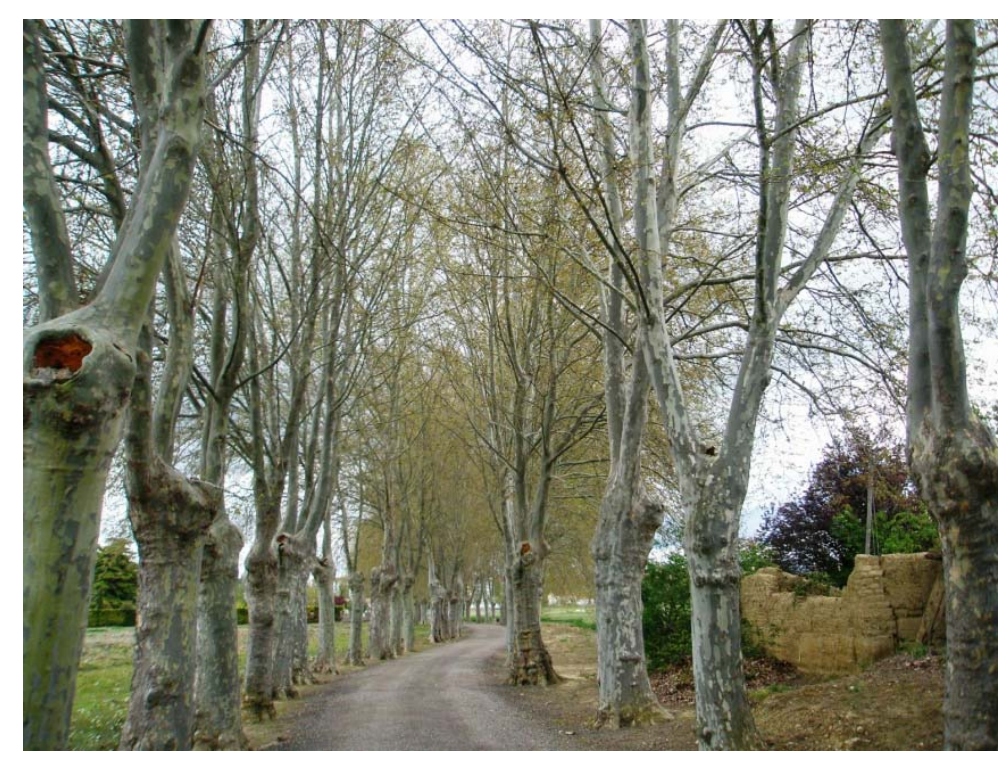

Figura 6.130. Plátanos en alineación en una zona de huertas de Palencia.

\section{Falsa acacia (Robinia pseudoacacia L.)}

Árbol que puede llegar hasta $25 \mathrm{~m}$ de altura. Ramas fuertes y algo tortuosas, con espinas. Hojas caducas pequeñas y ovales. Flores muy vistosas de color blanco, dispuestas en racimos, de olor fuerte y agradable. Procedente de Estados Unidos, está muy naturalizado en nuestro país desde 
antiguo en márgenes de caminos y carreteras, etc. Cultivada en parques, calles y paseos. Es una especie tremendamente rústica, que aguanta la sequía y todo tipo de suelos (Figura 6.131).
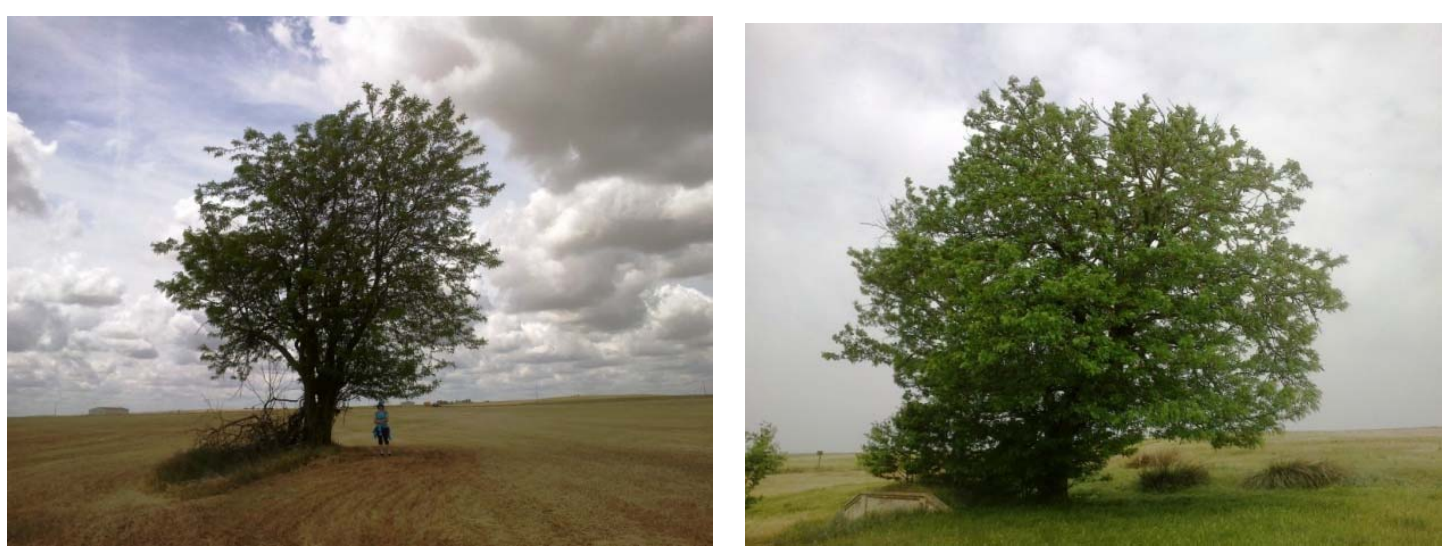

Figura 6.131. Ejemplares aislados de falsas acacias en el paisaje agrario de Villalón de Campos.

\subsubsection{Arbustos autóctonos}

\section{Majuelo o espino majoleto (Crataegus monogyna J.)}

Arbusto espinoso de 2 a $5 \mathrm{~m}$ de altura muy ramoso. Hojas caedizas con lóbulos profundos. Flores blancas muy vistosas y olorosas (Figura 6.132). Florece en mayo. Frutos rojos, conocidos como majoletas, que alimentan a multitud de aves y mamíferos. Muy característica de los setos vivos y sotos de Tierra de Campos. Prefiere algo de humedad.

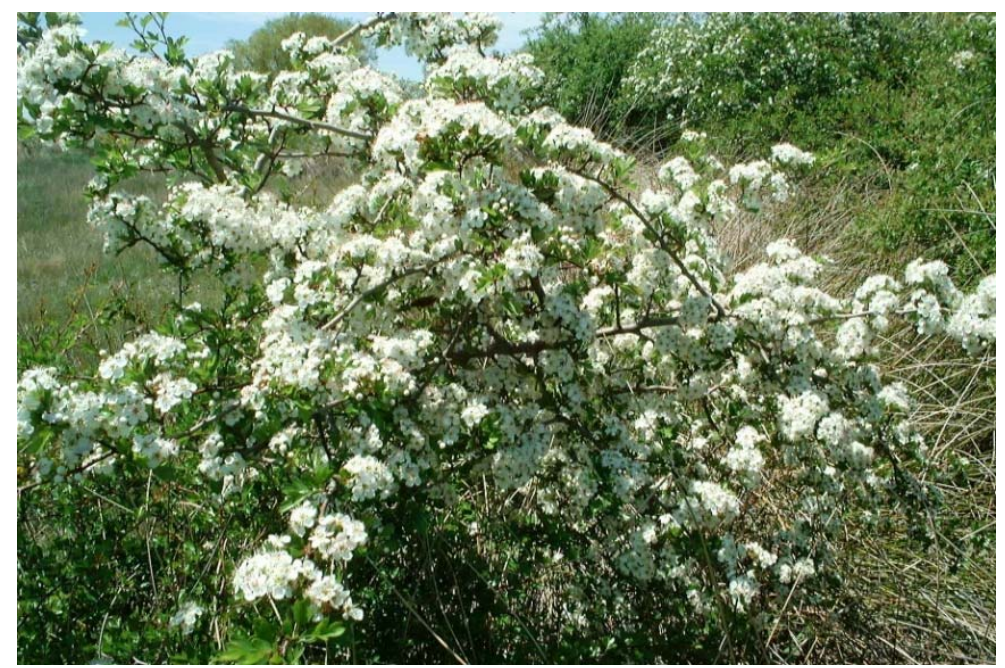

Figura 6.132. Espino majoleto en Villalón de Campos. Se encuentra situado junto a varios ejemplares más de esta especie en la fuente La Florida, que debe su nombre a la vistosidad de la flor de este arbusto.

\section{Endrino (Prunus spinosa L.)}

Arbusto espinoso de ramas entrecruzadas. Hojas caedizas pequeñas, lanceoladas, de margen aserrado. Flores blancas, profusas y precoces antes de que salgan las hojas. Florece en marzo y 
abril. El fruto es la andrina, de color azulado, que es apetecida por numerosas aves; también es utilizado para hacer pacharán. Madura al final del verano, manteniéndose bastante tiempo sobre la planta. Es una especie de gran amplitud ecológica, con gran presencia en las cunetas y regueras de Tierra de Campos (Figura 6.133). Es un arbusto excelente para formar setos, pues además de adaptarse a todo tipo de suelos, soporta muy bien la poda y rebrota con facilidad de raíz.
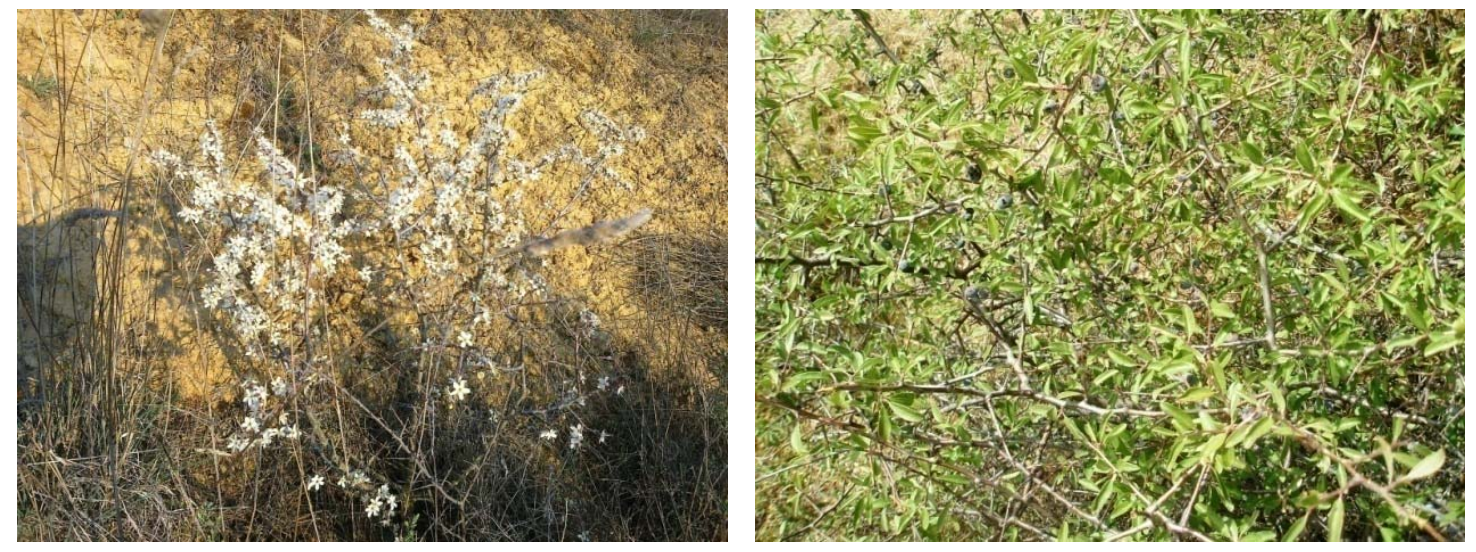

Figura 6.133. Endrino en flor (izquierda) en Fontihoyuelo y con fruto (derecha) en Becerril de Campos.

\section{Zarzamora (Rubus ulmifolius Sch.)}

Arbusto de tallos alargados, provisto todo él de espinas ganchudas y reptantes, que forma enmarañados zarzales. Se encuentra muy extendida, aunque en Tierra de Campos prefiere las zonas más frescas. Las flores son blancas o sonrosadas y forman ramilletes. Florece desde finales de mayo hasta agosto. Muchos animales dispersan sus frutos (las moras o zarzamoras), que además son muy apreciados en la repostería. Maduran a finales de verano. Se puede reproducir por estaquilla.

\section{Escaramujo (Rosa canina L.)}

Los escaramujos o rosales silvestres son arbustos enmarañados de 1 a $3 \mathrm{~m}$ de altura, con tallos y ramas armados de fuertes espinas. Hojas pequeñas aovadas y caedizas. Flores blancas o rosadas muy llamativas, que aparecen de mayo a julio. Los frutos (los tapaculos) tienen color rojizo, se mantienen mucho tiempo en la planta y sirven de alimento a numerosos animales que actúan como dispersadores de sus semillas (Figura 6.134). Es el arbusto más abundante de Tierra de Campos, apareciendo en cualquier margen de camino o carretera, arroyo, reguera, etc. Es una magnífica planta para utilizar en las restauraciones de espacios degradados de la comarca, ya que arraiga con facilidad, es muy rústica, tiene una gran capacidad de rebrote y se regenera de forma natural a través de las aves. 

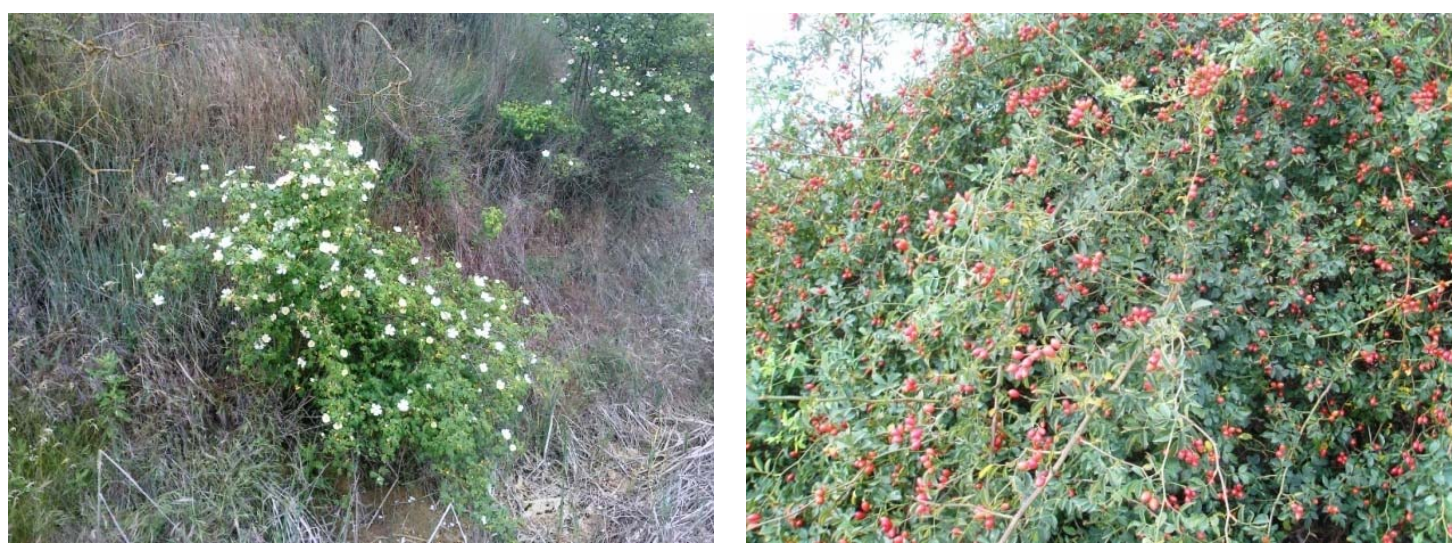

Figura 6.134. Escaramujo en flor (izquierda) en Villalón de Campos y en fruto (derecha) en Villaumbrales.

\section{Rosal silvestre o escaramujo (Rosa micrantha Borrer ex Sm.)}

Arbusto de hasta 3,5 m de altura, muy ramoso y enmarañado, con tallos armados de aguijones curvados. Hojas caducas pequeñas y aovadas o elípticas. Flores de tamaño pequeño, blancas o rosas pálido, que aparecen de mayo a julio. El fruto es un escaramujo globoso, de color rojo escarlata. Muy extendido por setos y claros de monte.

\section{Zumaque (Rhus coriaria L.)}

Arbusto de 1 a 3 m de altura. Sus ramas, así como la cara inferior de las hojas, están densamente cubiertas de pelos cortos que le dan un tacto suave y casi aterciopelado. Hojas grandes y caedizas. Flores blancas y después rojas en panojas ramificadas, densas y terminales. Florece en verano. Planta xerófila y mediterránea, amante de la luz. Es muy decorativo, sobre todo en otoño, por el color rojizo refulgente que toman sus hojas.

\section{Bonetero (Euonymus europaeus L.)}

Arbusto de 2 a $6 \mathrm{~m}$ de altura. Hojas grandes, lanceoladas y caedizas. Flores pequeñas blanquecinas o verdosas, que aparecen en primavera. Fruto capsular característico, que en la madurez es de vivísimo color rosa. Son un gran atractivo para las aves, que los consumen y dispersan sus semillas. Prefiere los suelos frescos. El bonetero es muy decorativo.

\section{Tamariz (Tamarix gallica L. y Tamarix africana Por.)}

Arbustos o arbolillos muy ramosos con hojas escamosas muy pequeñas. Alcanzan una talla de 3 a $5 \mathrm{~m}$. Las flores, blancas o rosadas, agrupadas en racimos alargados, también son diminutas. Son especies propias de lagunas, zonas húmedas o riberas, que toleran bien los fríos invernales de la meseta castellana. También son heliófilas, soportando altas temperaturas. En los parques y medianas de autovías se emplea con profusión el tamarindo (Tamarix parviflora DC.), de floración profusa en primavera de un color rosa vivo (Figura 6.135). Las especies de este género tienen un rápido crecimiento durante los primeros años. Se multiplican fácilmente por estaquilla. 


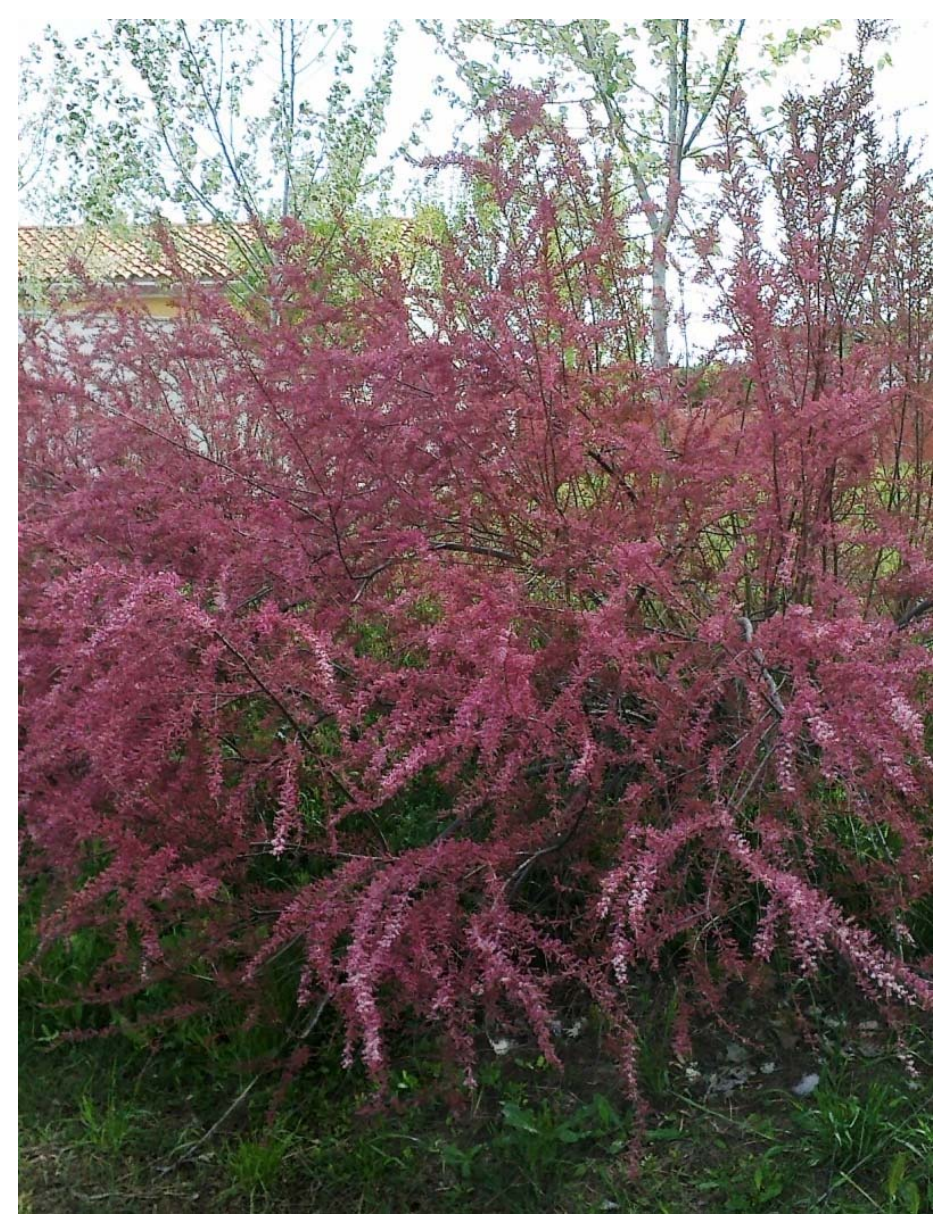

Figura 6.135. Tamarindo en flor en un parque periurbano de Villalón de Campos.

\section{Cornejo (Cornus sanguinea L.)}

Arbusto de 2 a $5 \mathrm{~m}$ de altura, de tallos ramosos y flexibles. Las ramas jóvenes son bastante rojizas. Hojas grandes, ovaladas y caedizas, que en otoño adquieren un precioso tono sangre. Inflorescencias en corimbos terminales con flores blancas, que se forman en mayo y junio. Frutos carnosos que aparecen en septiembre y son comidos y dispersados por numerosas especies de aves. Es una especie heliófila o de media sombra. Presenta una marcada preferencia por los terrenos calizos y frescos. Arbusto muy típico del sotobosque de las choperas naturales. Es una especie muy ornamental, que se puede emplear para formar setos densos de cerramiento de fincas.

\section{Aligustre (Ligustrum vulgare L.)}

Arbusto de 2 a $4 \mathrm{~m}$ de altura. Hojas caedizas, lanceoladas y de color verde fuerte. Inflorescencias en panículas terminales, con numerosas flores blancas, que aparecen a partir de mayo. Sus frutos negros alimentan a numerosos pájaros. Abunda por setos y riberas, prefiriendo suelos frescos y calizos.

\section{Jazmín silvestre (Jasminum fruticans L.)}

Arbusto de 1 a $2 \mathrm{~m}$ de altura, de tallos verdes y estriados. Hojas pequeñas con tres foliolos, de color verde intenso, que se mantienen todo el año salvo los inviernos muy duros. Sus flores 
amarillas -muy olorosas- aparecen a final de primavera y en verano. El fruto es una baya globosa de color negro, que madura en otoño. Tiene una gran amplitud ecológica, formando parte del sotobosque de encinares y otros bosques esclerófilos. Es una especie heliófila.

\section{Saúco (Sambucus nigra L.)}

Arbusto de 2 a $5 \mathrm{~m}$ de altura muy frondoso, que puede convertirse en pequeño arbolillo. Hojas caedizas compuestas de 5 a 7 foliolos alargados. Inflorescencias en panículas, compuestas de numerosas flores blancas; aparecen en mayo y junio. El fruto es una baya carnosa y negruzca, muy consumida por todo tipo de aves. Madura en agosto y septiembre. Es una especie nitrófila, cuyo hábitat es muy extenso, aunque prefiere suelos frescos.

\section{Madreselva de soto (Lonicera periclymenum L.)}

Enredadera de tallos flexuosos que se enroscan en arbolillos y arbustos. Hojas caedizas, verdes y ovaladas. Flores agrupadas en ramilletes, blancas o amarillentas, muy olorosas. Fruto carnoso rojizo en la madurez. Florece y fructifica en verano. Es una especie propia de bosques de ribera y setos de suelos frescos. Es una planta muy ornamental.

\section{Madreselva (Lonicera etrusca G.)}

Arbusto voluble de 1 a $3 \mathrm{~m}$ de altura, con ramas que a menudo toman un tinte rojizo. Hojas caducas, de forma elíptica u obovada. Flores blanco-amarillentas, que pueden adquirir un tinte algo rojizo. Florece de mayo a julio. El fruto es una baya ovoide de color rojizo. Muy frecuente en los montes calcícolas de encinas y quejigos. Es una planta de gran belleza muy adecuada para ser utilizada como ornamental, aunque habitualmente se prefieren otras madreselvas exóticas.

\section{Torvisco (Daphne gnidium L.)}

Mata arbustiva de 0,7 a 1,5 m de altura, de tallos rectos y hojas lanceoladas. Flores blancas y pequeñas, que se mantienen de forma prolongada. Fruto naranja o rojizo carnoso, que es dispersado por diversas aves. Es una planta típica de montes mediterráneos secos. En Tierra de Campos habita en los encinares (Figura 6.136).

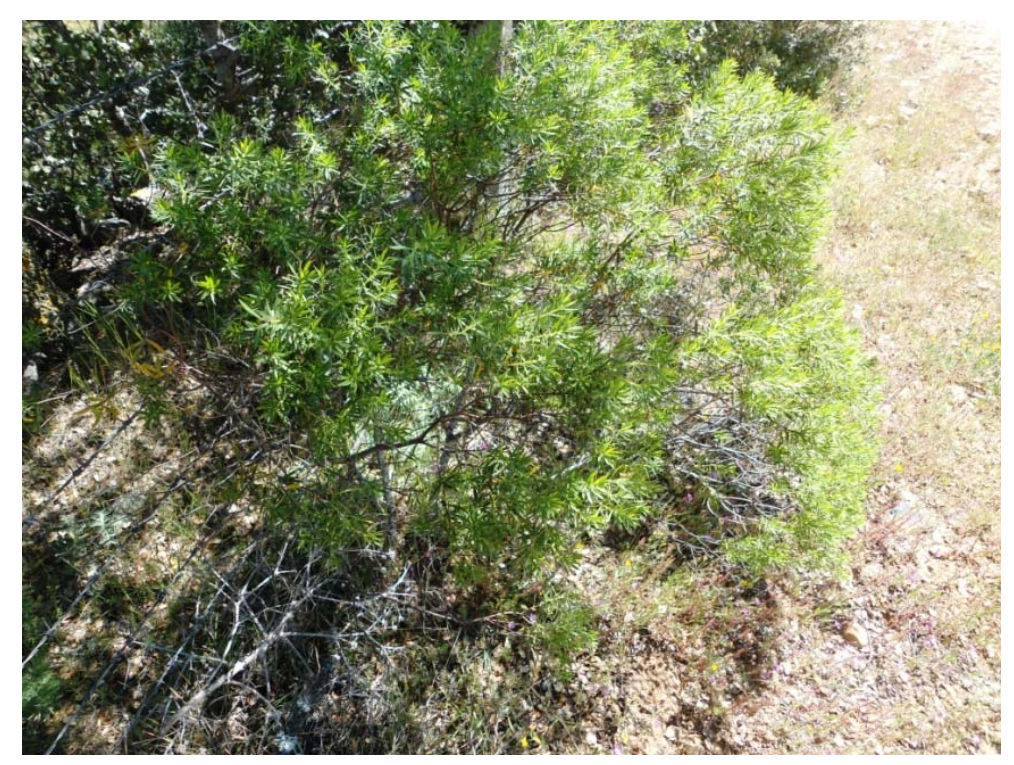

Figura 6.136. Torvisco en el monte del Raso de Villalpando. 


\section{Retama loca (Osyris alba L.)}

Mata arbustiva de $40 \mathrm{~cm}$ a $1,5 \mathrm{~m}$ de altura, de tallos verdes y estriados. Hojas pequeñas y lanceoladas. Flores muy poco visibles, fragantes y verdosas; florece de mayo a julio. Fruto anaranjado o de color rojo vivo, que más adelante torna a negro; madura en agosto y septiembre. Es una especie heliófila, extendida por los montes esclerófilos mediterráneos.

\section{Gayomba o sebe (Spartium junceum L.)}

Arbusto de 1 a 4 m de altura, con ramillas de color verde azulado, parecidas a juncos. Hojas simples, pequeñas y redondeadas. Flores profusas amarillas, grandes, muy olorosas, que hacen que esta especie sea muy ornamental (Figura 6.137). Florece en verano, de forma muy prolongada. El fruto es una larga legumbre aplanada. Especie heliófila, muy adaptada a la sequedad y a suelos pobres. Tiene un crecimiento rápido. En Tierra de Campos ha sido una de las plantas más utilizadas como setos vivos, resistiendo algunos reductos. Muy empleada en las medianas y márgenes de autovías y carreteras. También se ha utilizado para la mejora del hábitat cinegético, sirviendo de protección a perdices, liebres y conejos. Necesita que se le pode cuando envejece. Es planta melífera.
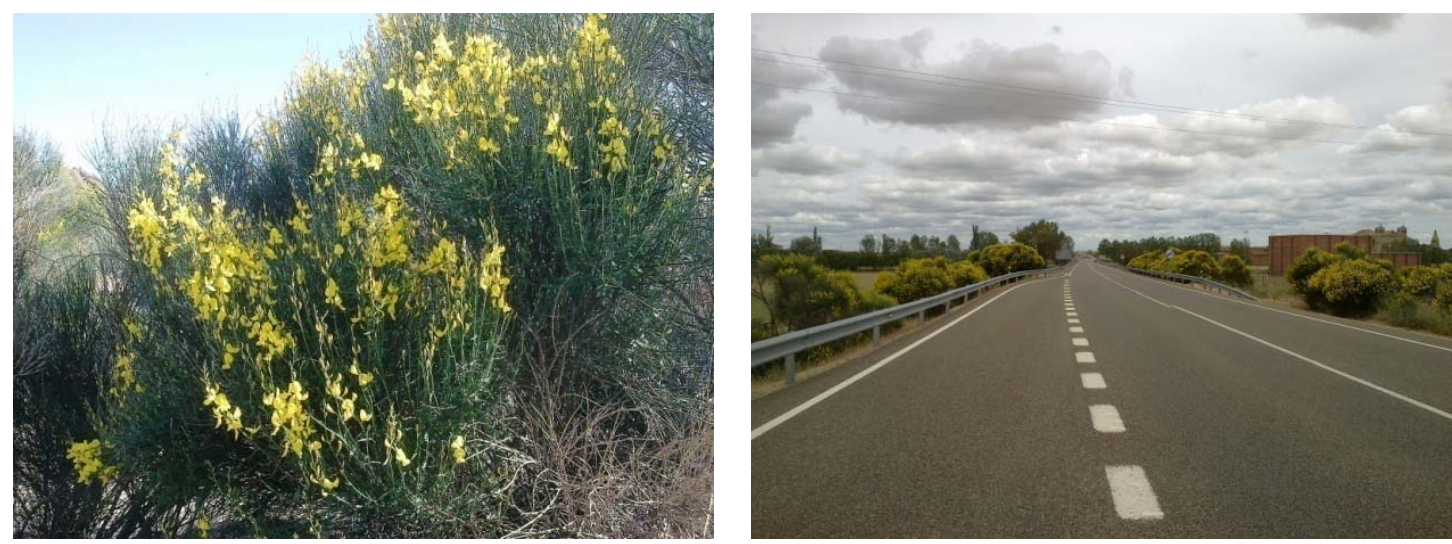

Figura 6.137. Sebe en flor en Cuenca de Campos (derecha); conjunto en márgenes de la carretera N-610 en Castromocho.

\section{Aliaga (Genista scorpius (L.) DC)}

Arbusto de escasa talla, que alcanza entre 0,4 a 1,5 m de altura. Muy ramificado, con ramas estriadas y provistas de fuertes espinas largas. Hojas escasas, sedosas en su cara inferior. Flores amarillas muy vistosas y abundantes, que aparecen de marzo a junio. Fruto en legumbre aplastada. Es una especie de gran amplitud ecológica, que prefiere los suelos calizos y es heliófila, asociándose a encinares, quejigares y enebrales. Es una planta pirófita y pionera que ocupa los campos de cultivo abandonados.

\section{Escoba negra (Cytisus scoparius (L.) Link}

Mata arbustiva de 1 a $2 \mathrm{~m}$ de altura, con ramas derechas y erguidas de color verde oscuro y superficie estriada. Hojas pequeñas en grupos de tres. Flores de color amarillo dorado, muy profusas y bastante grandes. Florece de abril a julio. Fruto en legumbre plana. Crece en los claros y bordes de los montes, prefiriendo los suelos silíceos. 


\section{Retama común (Retama sphaerocarpa (L.) Boiss)}

Arbusto de 1,5 a $3 \mathrm{~m}$ de altura de tallos erguidos, estriados y de color grisáceo. Flores amarillas muy pequeñas, que aparecen en verano (Figura 6.138). El fruto es una legumbre globosa. Es propia de terrenos secos, con gran amplitud ecológica. En bastantes lugares se ha plantado como ornamental la retama blanca (Retama monosperma), de flores blancas y más grandes, muy frecuente en los márgenes de carreteras y autovías.

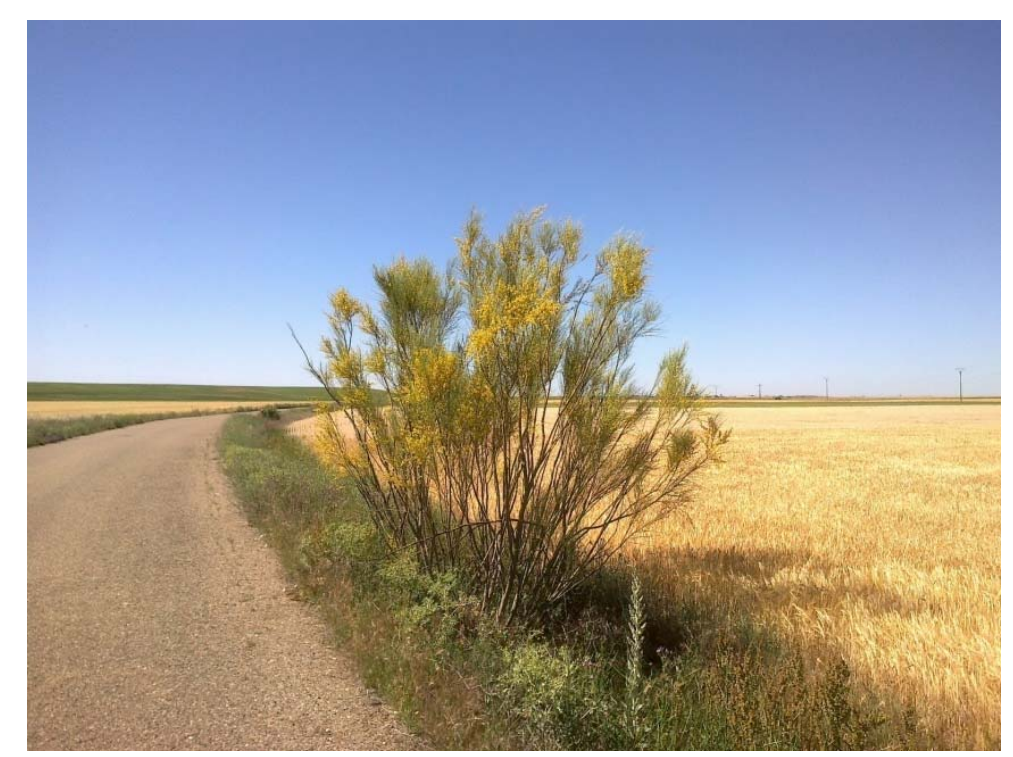

Figura 6.138. Retama común aislada en margen de camino rural asfaltado en Herrín de Campos.

\section{Escoba lebrela (Dorycnium pentaphyllum Scop.)}

Mata de 20 a $40 \mathrm{~cm}$ de altura de hojas grisáceas. Flores blancas, pequeñas y reunidas en grupos terminales. Es una especie que abunda por todas las comarcas secas e iluminadas, incluyendo Tierra de Campos. Protege la caza menor en las lindes y márgenes de cultivos y montes.

\section{Garbancillera (Ononis tridentata)}

Mata de 20 a $70 \mathrm{~cm}$ de altura, de hojas carnosas y ramas cubiertas de tomento blanco. Flores rosadas, que forman una inflorescencia en panícula. Florece de mayo a julio. Legumbre de $2 \mathrm{~cm}$ alargada. Medra en las laderas yesosas de Tierra de Campos y otras comarcas, en la transición de la campiña al páramo. Otra especie parecida que ocupa el mismo hábitat es Ononis fruticosa, de tamaño un poco menor. Las especies leñosas del género Ononis son muy resistentes y útiles para la protección de las laderas contra la erosión, pudiéndose emplear en la restauración hidrológico-forestal.

\section{Estepa negral (Cistus laurifolius L.)}

Arbusto aromático de 1 a $2 \mathrm{~m}$ de altura de ramas erguidas, peludas y pegajosas. La corteza es pardo rojiza. Hojas similares a las del laurel, lanceoladas. Flores grandes con pétalos blancos, con una mancha amarilla en la base. Florece de mayo a julio. Fruto en cápsula globosa de color pardo. Es una especie heliófila que vive en claros de montes degradados. Es muy pirófita. Resulta 
muy decorativa, utilizándose en jardinería mediterránea y restauración de espacios degradados, ya que es muy resistente a la escasez de agua.

\section{Romero (Rosmarinus officinallis L.)}

Arbustillo aromático de 0,5 a 1,5 m de altura de tallos erguidos y hojas densas y persistentes. Florece durante gran parte del año, con colores azules, rosas o blanquecinas. Es una planta mediterránea propia de zonas secas y soleadas, con una gran amplitud ecológica, habitando sobre todo zonas donde hubo encinares. Es una especie muy longeva, que puede alcanzar los 100 años de vida. Tiene un gran valor aromático, estético y gastronómico. La miel de romero es muy apreciada. Su crecimiento es relativamente rápido. Es una especie que podría ser muy útil para servir de linde entre parcelas.

\section{Hiedra (Hedera helix L.)}

Enredadera de hojas persistentes, anchas, ovales o palmeadas, de color verde oscuro. Las flores son poco vistosas. Tiene una gran amplitud ecológica y gran adaptabilidad, aunque prefiere medios frescos y umbrosos (sotos y riberas). Con sus raíces adventicias se adhiere a la corteza de los árboles. En Tierra de Campos puede tener gran utilidad para sustituir al césped en los jardines (requiere mucha menos agua) y para cubrir las vallas metálicas que limitan las parcelas periurbanas. Se multiplica vegetativamente con enorme vigor, para lo cual se utilizan esquejes leñosos.

\section{Acigüembre (Ribes uva-crispa L.)}

Arbusto de 1 a $1,5 \mathrm{~m}$ de altura, muy ramificado y provisto de fuertes espinas. Hojas palmeadas y caedizas. Florece de marzo a mayo, con color verdoso. Fruto con forma de pequeño limón amarillento o verdoso, comestible, que alimenta a numerosos animales. Es una planta típica de las orlas espinosas de los montes mediterráneos, así como de las sebes o setos vivos. Se ha cultivado con frecuencia en muchas comarcas rurales. Esta especie tiene una gran utilidad para fijar taludes. Se puede reproducir por estaquilla.

\subsection{Imagen-objetivo del paisaje de calidad de Tierra de Campos}

En los apartados anteriores se ha caracterizado el paisaje actual de Tierra de Campos, se han diagnosticado los impactos y degradaciones a que está sometido y, finalmente, se han definido un buen número de actuaciones de recuperación ambiental para cada uno de los espacios degradados. El objetivo último de la recuperación ambiental es conseguir que el paisaje de la comarca tenga la máxima calidad. Analizado desde una perspectiva global y sintética, las principales características de este paisaje recuperado de calidad serán las siguientes:

\section{1.- Tierra de Campos: paisaje agrícola pero más diverso}

Tal como se ha indicado en los antecedentes, no se considera que el cultivo agrícola cerealista en sí sea un espacio degradado, ya que posee un valor indudable y cumple una función para la sociedad; la degradación del paisaje agrícola actual viene dada por su falta de diversidad. En este estudio, por consiguiente, no se ha contemplado la reversión a otros usos del uso agrícola; tan solo, muy puntualmente, se ha definido una actuación de reforestación en los terrenos de 
pendientes muy acusadas, que son erosionables. Aunque pudiera ser positivo desde el punto de vista paisajístico -y seguramente desde otros más amplios- la introducción de otros cultivos tanto herbáceos como leñosos (ya hay experiencias positivas de olivos y nogales, por ejemplo), lo cierto es que la Política Agraria Común (PAC) condiciona totalmente el mantenimiento del uso cerealista generalizado actual.

Por otra parte -tal como también se ha justificado previamente- el cultivo agrícola posee unos valores paisajísticos indudables (contrastes cromáticos, amplitud visual, hábitat de especies esteparias protegidas, etc.) y es la matriz que da carácter al paisaje de la comarca. Es decir, Tierra de Campos deberá seguir siendo tierra de campos.

Dicho esto, el paisaje recuperado será indudablemente más diverso, merced a la vegetación arbustiva y arbórea implantada (Figura 6.139). Márgenes de caminos, regueras y pequeñas parcelas públicas constituirán una red de corredores ecológicos que conformará una trama natural extendida por todo el territorio. El porcentaje de superficie ocupada será muy reducido, pero su distribución homogénea permitirá diversificar el paisaje en un alto grado.

La diversificación conllevará la reducción de la fragilidad del paisaje de Tierra de Campos o, lo que es lo mismo, el aumento de su capacidad de absorción visual frente a alteraciones humanas. De este modo, líneas eléctricas, naves agropecuarias, plantas de tratamiento o cualquier otro tipo de instalación en suelo rústico, no serán tan directamente visualizadas y, por consiguiente, no generarán impactos tan severos. 


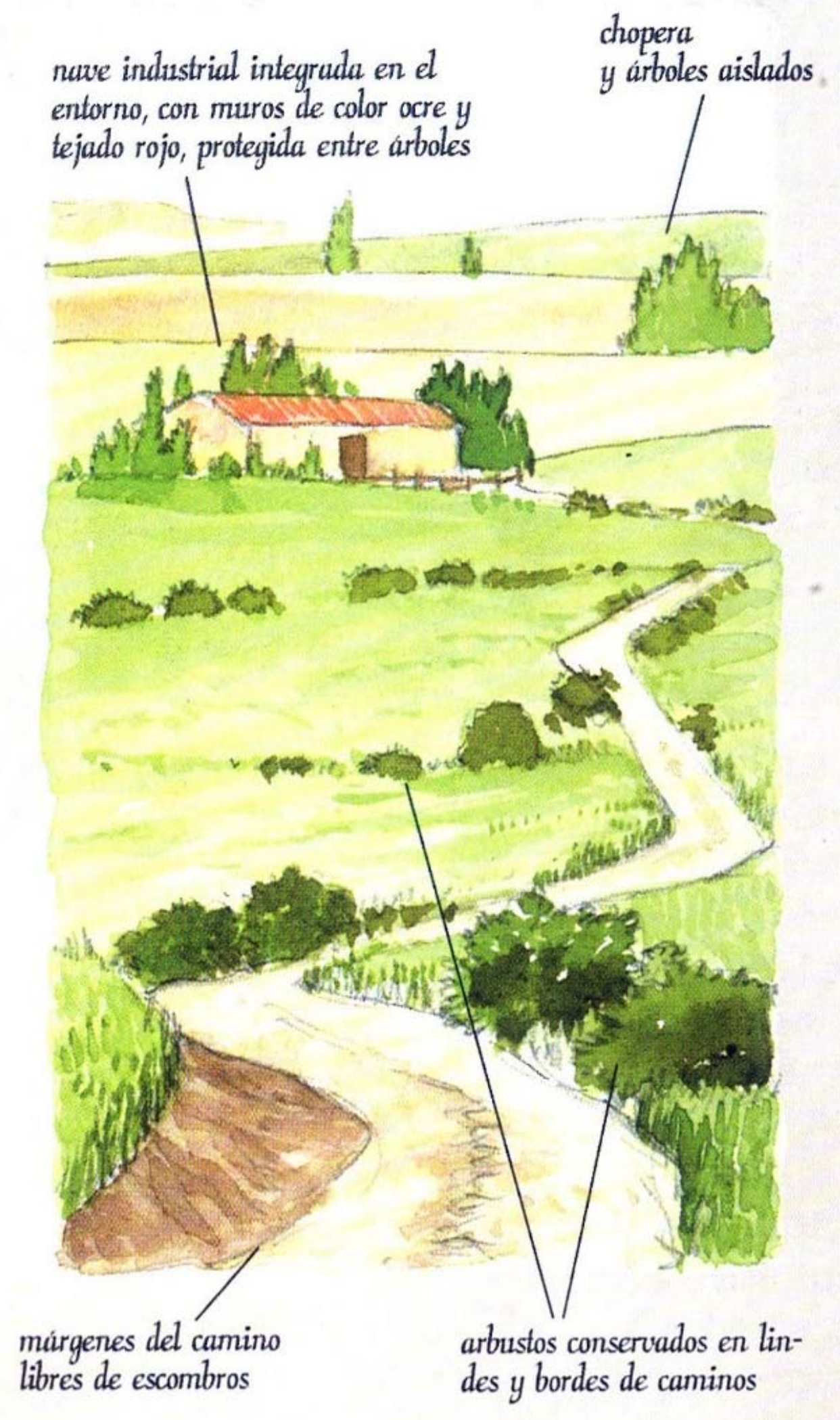

Figura 6.139. Ilustración de una imagen objetivo del paisaje agrario de Tierra de Campos (dibujo de Luis Frechilla, en BLANCO y FRECHILLA, 2009) 


\section{2.- Infraestructuras integradas y creadoras de nuevos paisajes}

Tal como se ha venido exponiendo en cada uno de los apartados, en un estudio de recuperación ambiental las infraestructuras tienen una doble lectura: por una parte generan impactos sobre el paisaje pero, por otra, inducen la creación de terrenos naturalizados en su entorno. De este modo, canales de riego (Figura 6.140), balsas de regadío, líneas de ferrocarril, autovías, carreteras e incluso parques eólicos, contienen zonas adyacentes que, al revegetarse, permiten su integración y a la vez mejoran notablemente el paisaje circundante.

A la vez, muchas de estas infraestructuras generarán nuevos paisajes; desde ellas se contemplarán vistas hasta ahora no valoradas (carreteras paisajísticas, miradores, paseos, etc.) que tienen un potencial turístico de gran recorrido para la comarca.

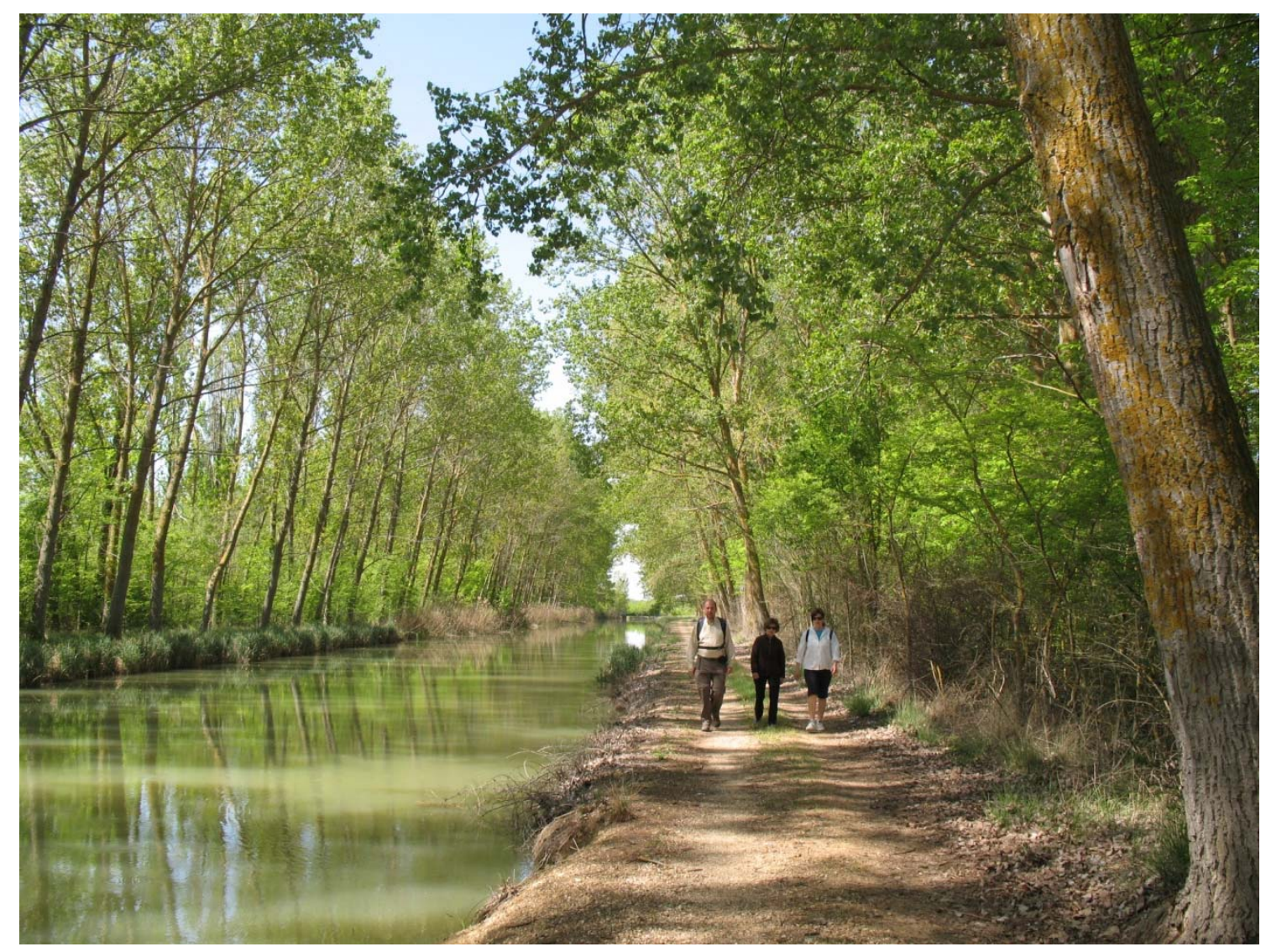

Figura 6.140. El Canal de Castilla es el paradigma de integración paisajística de una infraestructura.

\section{3.- Ríos, arroyos y vías pecuarias: grandes corredores ecológicos}

Los numerosos ríos y arroyos de segundo orden que surcan el territorio terracampino se convertirán -a través de la revegetación arbórea y arbustiva de sus márgenes- en corredores ecológicos de gran envergadura (Figura 6.141). La escasa anchura de las riberas recuperadas será compensada por su elevada longitud. Gracias a su distribución homogénea a lo largo de todo el territorio, las frondosas riberas serán visibles desde cualquier punto de la comarca y su 
verdor contrastará con la aridez de los cultivos en el periodo estival. A buen seguro, ello permitirá descubrir cursos hídricos hasta ahora desconocidos.

Cañadas, cordeles y algunas veredas se constituirán en corredores ecológicos de espacios un tanto diferentes a los anteriores, ya que en general no disponen de humedad edáfica. Sin embargo, su trazado permitirá crear una trama natural en la gran matriz agrícola, que sin duda tiene además un gran potencial de cara al senderismo, cicloturismo y otras actividades recreativas.

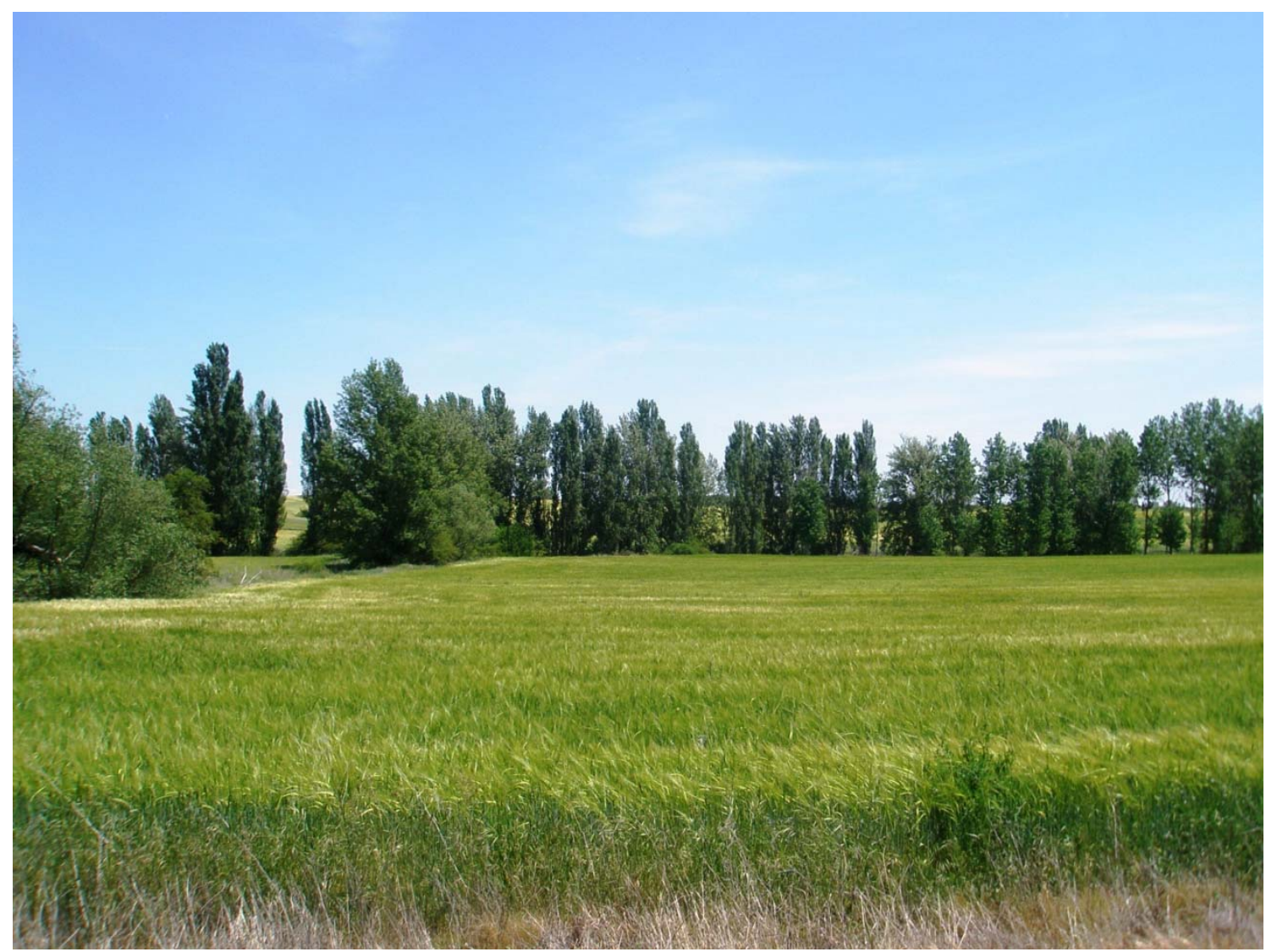

Figura 6.141. En el paisaje de calidad recuperado, todos los ríos y arroyos de Tierra de Campos tendrán riberas como esta, perteneciente al río Templarios en Moratinos.

\section{4.- El agua: elemento de valía del paisaje de calidad}

La recuperación ambiental de ríos, arroyos, humedales, canales y balsas de riego o fuentes permitirá crear espacios repartidos en el territorio, que introducirán una componente agua que tanta importancia tiene en la mejora de la calidad visual del paisaje y la creación de hábitats acuáticos naturales. Estos se añadirán a otros espacios naturales o ya recuperados, donde se ha constatado el valor que poseen los medios acuáticos en el paisaje agrícola de secano que nos ocupa.

La posterior valorización de muchos de estos espacios recuperados contribuirá a mejorar la percepción de Tierra de Campos que actualmente tiene la sociedad, como comarca de aridez acusada (Figura 6.142). 


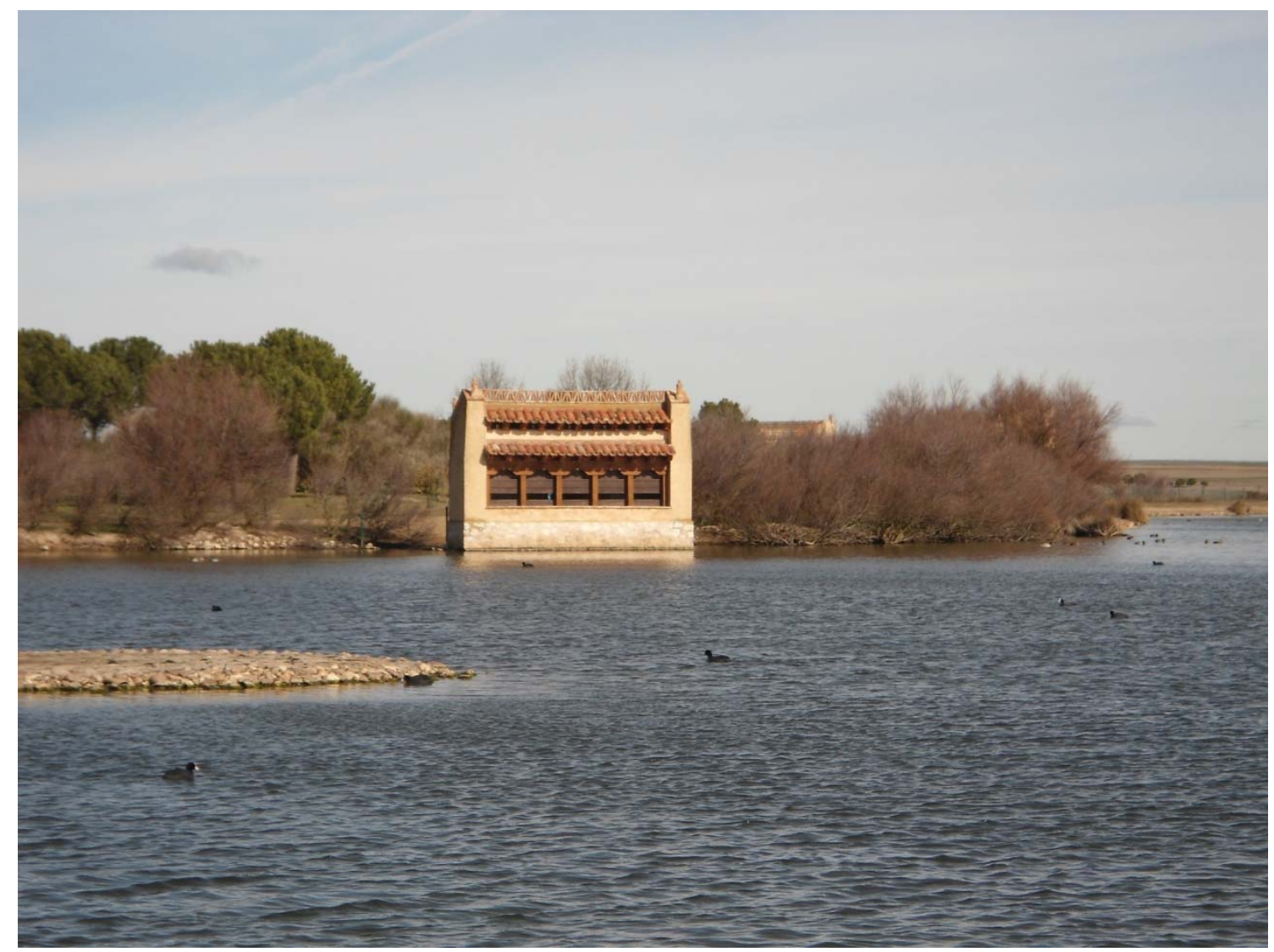

Figura 6.142. La Reserva Natural de Villafáfila es un magnífico ejemplo del valor ecológico, paisajístico y turístico que tienen los humedales, especialmente en un medio árido como el de Tierra de Campos.

\section{5.- Tierra de Campos: paisaje limpio sin contaminación}

La recuperación de escombreras y vertederos de residuos repartidos por todo el territorio y la adecuada gestión municipal de los deshechos que se vayan generando, permitirá eliminar un foco de contaminación y un importante impacto visual. Además, la limpieza periódica de residuos depositados en los márgenes de caminos, de carreteras o espacios periurbanos de los pueblos, generarán una imagen indudablemente positiva del paisaje de la comarca, que será reflejo de su calidad ambiental. Finalmente, la ordenación de las explotaciones ganaderas permitirá minimizar las molestias generadas por sus residuos generados.

\section{6.- Pueblos integrados y con muchas zonas verdes}

La urbanización de espacios periurbanos degradados, la adecuación estética de edificaciones e instalaciones y la eliminación de elementos discordantes permitirán mejorar la calidad ambiental de estas zonas tan heterogéneas. La restauración o rehabilitación de elementos del patrimonio singulares (palomares, bodegas, silos, etc.) contribuirá a orientar el foco visual más en los elementos de calidad que en los disarmónicos. La adecuación del entorno de las frecuentes explotaciones ganaderas ubicadas en la periferia de las poblaciones supondrá otra mejora ambiental muy necesaria.

De forma complementaria, la restauración de todos los espacios libres públicos como zonas verdes permitirá crear una trama vegetal repartida por toda la periferia, que minimizará 
impactos visuales negativos y mejorará la imagen a la entrada y salida de los pueblos. Los parques, jardines y paseos arbolados creados conformarán una malla que puede constituirse en anillo verde (Figura 6.143), cuyo uso por parte de los vecinos supondrá una mejora indudable del bienestar y salud de las personas del medio rural.

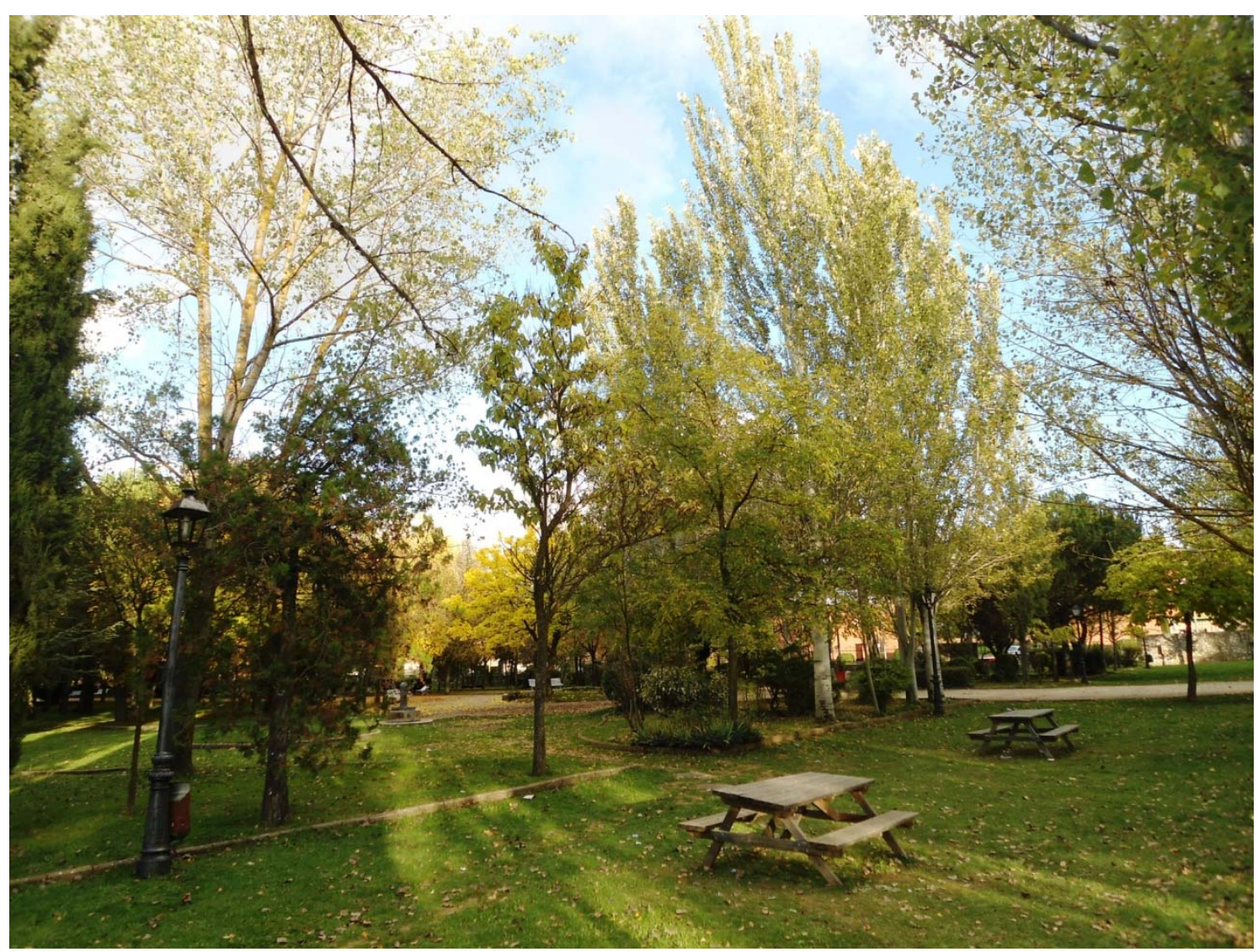

Figura 6.143. Parque del Paseo en Villalón de Campos, uno de los que constituyen la Ruta de los Parques trazada por la periferia del pueblo.

\section{7.- Pueblos cuidados con un patrimonio valorizado}

La puesta en marcha del amplio conjunto de actuaciones previstas en la recuperación ambiental de los núcleos urbanos de Tierra de Campos permitirá evitar el abandono y descuido que actualmente sufren muchos de ellos. La regresión social y económica de Tierra de Campos es indudable pero, lo que también es cierto, es que un pueblo que se descuida, paulatinamente se abandona y al final desaparece. Los pueblos cuidados serán pueblos con esperanza: allí será más fácil que se viva de forma permanente o que se recuperen viviendas para estancias vacacionales o de fin de semana. No es una utopía; en Francia todos los pueblos están cuidados y tienen vida; en España, en las villas cantábricas y pirenaicas sucede lo mismo.

Dentro de las recuperaciones planteadas, las más urgentes serán sin duda las que afecten a la rehabilitación del patrimonio histórico-artístico y del arquitectónico tradicional, que son los más vulnerables (Figura 6.144). Su valorización tiene un potencial incalculable en una comarca tan rica como Tierra de Campos. El mantenimiento de los entornos de los bienes de interés cultural, 
la mejora de plazas y plazuelas y la adecuación estética del conjunto urbano contribuirán a crear una agradable imagen de los pueblos, que debe resultar un elemento diferenciador con los medios urbanos.

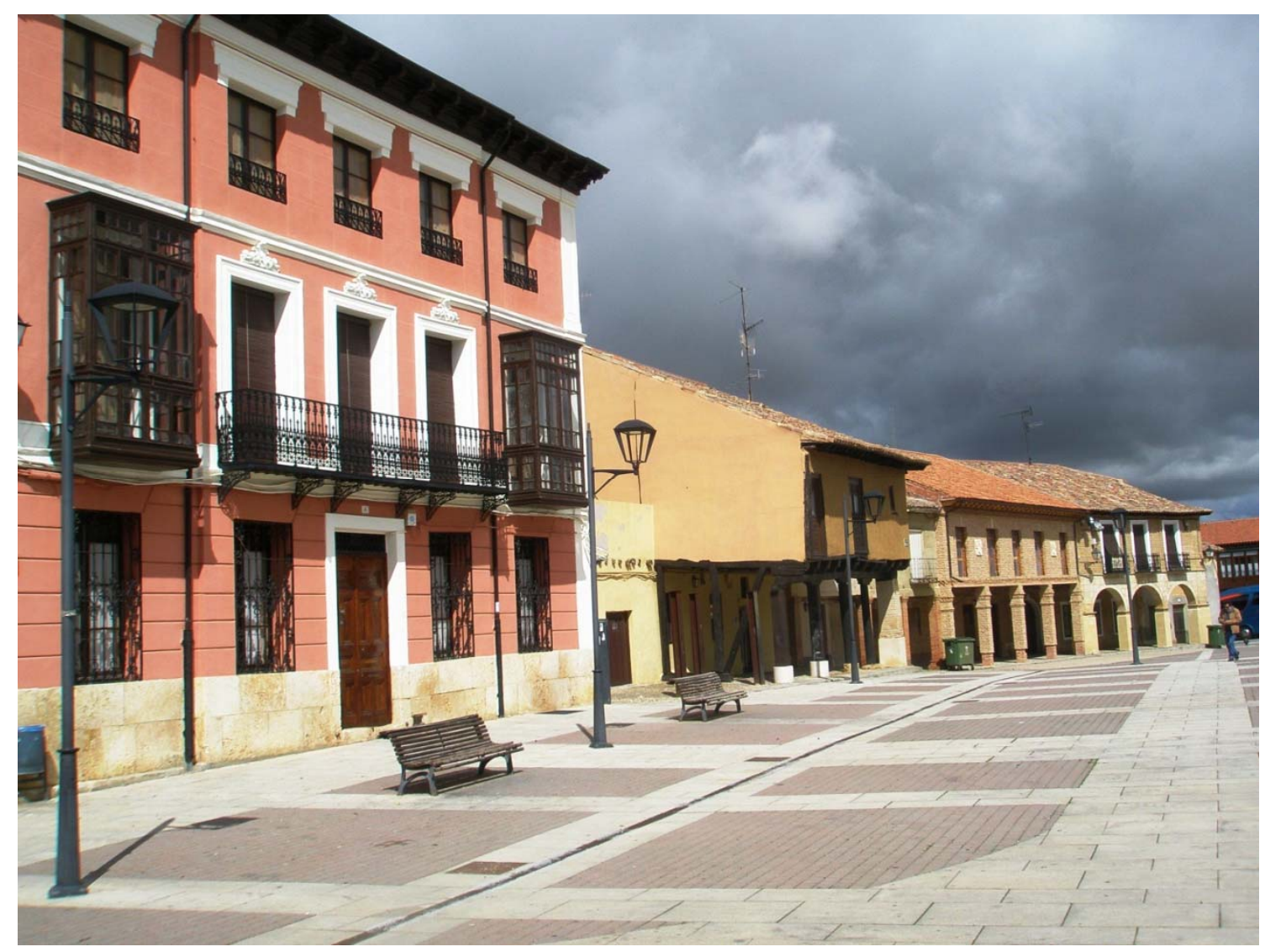

Figura 6.144. Bella estampa de un conjunto de edificios bien conservados en la plaza mayor de Paredes de Nava, que es uno de los pueblos que mejor mantiene su patrimonio en Tierra de Campos.

\subsection{Resumen del capítulo}

La caracterización del paisaje de Tierra de Campos se realiza con la base proporcionada por el Atlas de los Paisajes de España, que tipifica la mayoría de la comarca como "paisaje de campiñas de Tierra de Campos" y le considera representativo de las llanuras de la Meseta Norte. Este paisaje se organiza como una extensa campiña suavemente ondulada, con un uso del suelo abrumadoramente agrícola (siendo a su vez mayoritariamente cerealista) y un poblamiento de pequeños núcleos compactos. La dinámica del paisaje está marcada por el cambio de la agricultura tradicional a otra intensiva, junto con la transformación de estructuras propiciada con las concentraciones parcelarias que, a pesar de todo, no han modificado esencialmente el carácter de paisaje agrícola sin grandes perturbaciones antrópicas. Respecto de la percepción visual del paisaje, se describen las características visuales básicas (olor, forma, línea, textura, escala y escena), la calidad visual (que tiene unos valores bajos), la fragilidad visual (se considera alta) y el impacto visual (especificándose los numerosos proyectos que generan impactos visuales significativos en la comarca, debido a los factores anteriores). La ecología del paisaje de Tierra de Campos es analizada a través de los elementos del mosaico territorial (manchas, 
corredores y matriz), la conectividad del paisaje (una de las mayores justificaciones de la necesidad de recuperación ambiental), la fragmentación del hábitat (debido a las infraestructuras lineales) y la percepción del paisaje ecológico (el de Tierra de Campos tiene unas valoraciones relativamente bajas).

El primer acercamiento a los deterioros del paisaje de Tierra de Campos se realiza a través del impacto provocado por las grandes obras o actividades llevadas a cabo en el territorio, la mayoría públicas: concentraciones parcelarias, transformaciones en regadío, explotaciones de ganadería intensiva, infraestructuras lineales de transporte (carreteras, autovías y líneas de ferrocarril), explotaciones mineras (incluyendo préstamos y vertederos), líneas eléctricas de alta tensión, parques eólicos, urbanizaciones residenciales y polígonos industriales. El segundo se relaciona con las degradaciones producidas por las obras o actuaciones menores, realizadas a escala de término municipal, pero que son mucho más numerosas; abarcan los espacios agrario, periurbano y urbano. En síntesis, el diagnóstico de los deterioros característicos del paisaje de Tierra de Campos permite identificar un total de 12, de los que 3 se valoran como más significativos:

- Alteración de la morfología general

- Pérdida de vegetación (destacado)

- Fragmentación del hábitat

- Modificación de la naturalidad

- Cambio de las características visuales básicas (destacado)

- Introducción de elementos extraños a la pauta que caracteriza la escena

- Intrusión visual de elementos

- Desaparición de la armonía

- Abandono o deterioro de los usos que definen el paisaje

- Cambio en los elementos dominantes

- Acumulación de residuos, suciedad o contaminación

- Pérdida del patrimonio cultural (destacado)

El capítulo más importante de este apartado define cómo se ha de realizar la recuperación ambiental de los espacios degradados de Tierra de Campos. Después de plantear unos tratamientos generales de recuperación, expone los 14 tipos de espacios degradados de la comarca:

- Espacios con agricultura intensiva afectados por concentraciones parcelarias

- Espacios afectados por transformaciones en regadío

- Espacios afectados por infraestructuras lineales de transporte

- Espacios afectados por explotaciones mineras, préstamos y vertederos

- Espacios afectados por infraestructuras energéticas

- Ríos y arroyos desnaturalizados

- Zonas húmedas degradadas

- Vías pecuarias y del ferrocarril sin uso

- Fuentes y pequeñas parcelas públicas degradadas

- Espacios deforestados y/o erosionados

- Escombreras y vertederos de residuos 
- Entorno de construcciones en suelo rústico

- Periferias de los pueblos

- Pueblos en descuido y abandono

Para cada uno de estos espacios se concretan una serie de actuaciones, resultando 56 en total; predominan las restauraciones de la vegetación, aunque también hay otras variadas que inciden en otros factores del paisaje. Finalmente para cada actuación se marcan unas pautas para llevarla a cabo, se establecen unos criterios de aplicación o, incluso, se detallan las unidades de obra que conllevaría su ejecución.

Se incluye un amplio listado de especies vegetales utilizables en la recuperación ambiental de Tierra de Campos, clasificándolas en árboles autóctonos para zonas secas, árboles autóctonos para zonas húmedas, árboles exóticos ornamentales rústicos y arbustos autóctonos. En cada especie se detallan sus características morfológicas, los requerimientos ecológicos, sus valores paisajísticos y la utilización en la comarca.

El capítulo se culmina con una exposición literal y gráfica sobre cuál es la imagen-objetivo del paisaje de calidad de Tierra de Campos, una vez llevadas a cabo todas las actuaciones anteriormente definidas de recuperación ambiental. En síntesis, el paisaje recuperado de calidad de Tierra de Campos seguirá siendo agrícola, pero más diverso. Las infraestructuras estarán integradas y crearán nuevos paisajes. Los ríos, arroyos y vías pecuarias constituirán grandes corredores ecológicos. El agua será un elemento de valía del paisaje de calidad. Tierra de Campos será un paisaje limpio sin contaminación. Los pueblos de la comarca estarán integrados y poseerán abundantes zonas verdes. Y sus cascos urbanos estarán cuidados, con un patrimonio valorizado. 

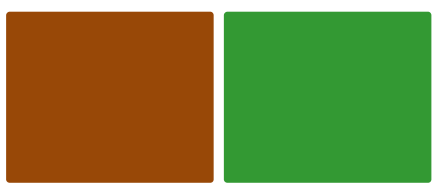

\section{CONCLUSIONES}




\section{CONCLUSIONES}

\section{La comarca de Tierra de Campos}

1.- El estudio de la historia, las características físicas y naturales, la socioeconomía y el patrimonio cultural de la comarca, permite concluir que Tierra de Campos posee una identidad muy definida, que debe ser tenida en cuenta como conjunto -al margen de sus divisiones provinciales- en cualquier planificación territorial futura.

2.- Del análisis de la bibliografía histórica documentada, las series de vegetación de la zona, las ortofotografías antiguas y las referencias toponímicas, así como del reconocimiento visual de los reductos de vegetación autóctona de la comarca, se infiere que -con anterioridad a la actuación humana sedentaria- Tierra de Campos estuvo poblada en su mayoría por un bosque mediterráneo. Tras su paulatina destrucción por los pobladores prerromanos, mantuvo -durante muchos siglos- significativos retazos de vegetación arbórea y arbustiva en el mosaico de tierras labradas. Sin embargo, este paisaje variado fue radicalmente modificado con el cambio de la agricultura tradicional a la intensiva, desarrollada a partir de la década de los 50 del siglo pasado, que propició el dominio actual casi absoluto del cultivo agrícola herbáceo.

3.- Estudiada la evolución de la población de la comarca desde 1900 hasta nuestros días, se puede concluir que la situación demográfica actual de Tierra de Campos es dramática. A este estado se ha llegado, entre otras causas, por el uso abrumadoramente mayoritario del suelo como agrícola cerealista de secano (sin diversificación alguna), que requiere de una mano de obra bajísima por unidad de superficie, sin que se transformen industrialmente sus productos en la zona.

4.- Se han detectado 25 problemas ambientales genéricos en las 7 áreas de actividad humana consideradas: agricultura, ganadería, infraestructuras de transporte, energía, industria, urbanismo y la propia actividad doméstica. De entre ellos destacan los derivados de la actividad agraria, dado que afectan a la inmensa mayoría del territorio.

5.- Tierra de Campos posee un magnífico patrimonio cultural edificado, tanto el popular basado en la tierra como el histórico-artístico mayoritariamente religioso, fruto de su relevante historia. Se ha constatado que, en muchos casos, este patrimonio presenta serios riesgos de conservación, por lo que se deberían adoptar medidas urgentes para su protección, rehabilitación y valorización.

\section{El paisaje de Tierra de Campos}

6.- Se ha demostrado que las principales características del paisaje de campiñas de Tierra de Campos son: geomorfología de llanuras suavemente onduladas, climatología continental extrema, abertales de cultivos con dominio claro del cereal, grandes parcelas con infraestructuras rurales regularizadas, ríos y arroyos en su mayoría rectificados y encauzados, núcleos urbanos compactos y ausencia prácticamente total de arbolado. Este último rasgo 
provoca que el paisaje de la comarca sea especialmente duro, principalmente en verano donde las condiciones de aridez son especialmente acusadas.

7.- Desde el punto de vista de la percepción visual, se ha constatado que el paisaje de Tierra de Campos tiene perspectivas amplias y es monótono en su configuración estructural. Posee sin embargo una considerable variedad cromática estacional, que se reduce a nivel superficial; no obstante, la reciente aplicación de rotación de cultivos deja unas distribuciones medias de colores sorprendentes. Su calidad visual es media-baja, debido fundamentalmente a la ausencia de vegetación natural y de agua. Se trata de un paisaje muy frágil (con una capacidad de absorción visual reducida frente a posibles impactos), motivada por las amplias cuencas visuales y la falta de una vegetación arbórea enmascarante.

8.- En cuanto al paisaje ecológico de Tierra de Campos, se ha comprobado que se caracteriza por la presencia de una matriz agrícola que ocupa en torno al $95 \%$ del territorio, exiguas manchas forestales y unos corredores lineales (linderas, ribazos y riberas) en franco retroceso. El resultado de esta distribución descompensada es que el paisaje posee una biodiversidad muy baja.

\section{Los deterioros del paisaje de Tierra de Campos}

9.- Se han detectado dos grandes bloques de degradaciones: las que tienen una escala comarcal y aquellas con una incidencia municipal. Aunque las realmente transformadoras del territorio son las primeras (dado que afectan a superficies amplias), las segundas tienen una gran implicación en el paisaje ya que -aunque poseen menor envergadura- son mucho más numerosas.

10.- Dentro de las grandes obras, el proyecto que más ha transformado con diferencia el paisaje es el de las concentraciones parcelarias -dado que ha afectado y simplificado toda su superficie- agrandando las parcelas, rectificando las infraestructuras y eliminando -como consecuencia- buena parte de los elementos estructurales naturales. Las infraestructuras lineales de transporte también han incidido significativamente en el mismo, como consecuencia de la fragmentación del territorio y los movimientos de tierra que generan. El resto de proyectos generan impactos fuertes, pero localizados.

11.- Se han detectado 32 degradaciones paisajísticas de la escala inferior. Poseen una gran variabilidad, aunque las que generan mayores impactos son la existencia de residuos en márgenes y cunetas, las líneas eléctricas de menor voltaje, la pérdida de patrimonio y tipología arquitectónica tradicional, las edificaciones urbanas con acabados inadecuados y las carreteras totalmente rectilíneas, sin vegetación.

12.- Se puede concluir que las tres alteraciones más significativas al paisaje de Tierra de Campos son la pérdida de vegetación (que afecta tanto al paisaje ecológico como al visual), el cambio de las características visuales básicas por la irrupción de formas y colores ajenos (afecta al paisaje visual) y la pérdida del patrimonio cultural edificado (afecta al paisaje visual y, evidentemente, al cultural). 


\section{Los instrumentos para proteger el paisaje de Tierra de Campos}

13.- Se constata una carencia técnica de los Ayuntamientos para gestionar y controlar adecuadamente los instrumentos preventivos del planeamiento urbanístico y la calificación ambiental, así como una excesiva cercanía a los vecinos, que en muchos casos les condiciona en su independencia.

14.- Se estima imprescindible el seguimiento de las obras sometidas a evaluación de impacto ambiental, que ha de ser asumida con el rigor necesario por el órgano sustantivo responsable en primera instancia- y por el órgano ambiental -responsable subsidiario y mayor conocedor de la materia-. En este sentido, se considera fundamental que todas las medidas correctoras se integren en el proyecto de construcción o que sean objeto de un proyecto de recuperación ambiental específico, incluyéndose en cualquier caso una dirección ambiental de obra.

\section{La técnica de recuperación ambiental aplicada a Tierra de Campos}

15.- Se concluye que la recuperación de espacios degradados o recuperación ambiental es una magnífica técnica para corregir impactos y mejorar la calidad del paisaje de Tierra de Campos. De entre todas sus virtudes, cabe destacar la mejora de la calidad de vida de sus habitantes y el motivo de prestigio que supone para la zona, que podrá alentar la localización de actividades económicas de vanguardia; estos aspectos representan una oportunidad para que Tierra de Campos afronte la terrible despoblación que le aqueja y promueva su desarrollo socioeconómico.

16.- Se comprueba que existen técnicas de recuperación ambiental suficientes para restaurar todas las tipologías de espacios degradados existentes en Tierra de Campos, desde los tratamientos convencionales hasta los casos más extremos de alteración, donde se pueden utilizar técnicas específicas.

17.- Se ha demostrado que la recuperación ambiental no es una técnica costosa. El porcentaje del presupuesto de los proyectos de recuperación analizados en relación al de sus proyectos de construcción asociados es de un 3,48 \%, que es un valor asumible teniendo en cuenta que representa el coste de integración ambiental de la obra. Igual sucede con los proyectos de restauración específicos, que manejan precios unitarios relativamente reducidos en relación con otro tipo de obras.

18.- Dentro de las actuaciones previas de recuperación, se consideran necesarias la realización de un modelado de los terrenos que genere formas suaves con pendientes reducidas y la adecuada gestión de la tierra vegetal, más en estos suelos tan escasos de materia orgánica.

19.- Se ha detectado que es prioritaria la implantación de vegetación en todos sus estratos. Teniendo en cuenta las características climáticas de la comarca, resultan fundamentales la adecuada elección de especies (preferentemente autóctonas o propias de la zona), la rigurosa instalación de la vegetación y, sobre todo, los cuidados culturales posteriores (especialmente el riego en el primer año). Debido a las carencias de vegetación en la 
comarca, siempre que sea posible, se debe dar prioridad a la elección de especies de crecimiento medio-rápido.

20.- El listado de especies vegetales seleccionado para su utilización en Tierra de Campos es muy extenso, con más de sesenta especies. En este sentido, se debe rebatir un argumento popular infundado que esgrime que "en Tierra de Campos no puede haber árboles"; tal como se ha constatado en este estudio, los ha habido en otras épocas y se pueden recuperar, siempre que se seleccionen bien y se implanten adecuadamente.

21.- Dentro de las técnicas específicas analizadas, se consideran especialmente aplicables -por su valor ecológico, facilidad de ejecución y bajo coste- las de bioingeniería para el tratamiento de taludes (en especial las estaquillas), los pequeños diques construidos con materiales naturales y los pasos de fauna adaptados a obras de infraestructuras lineales (sobre todo los drenajes).

22.- Para mejorar la calidad del paisaje de Tierra de Campos, se concluye que debe constituir una prioridad su diversificación con setos vivos, sotos y bosques-isla. La medida de condicionalidad del árbol/ha está siendo un tímido (aunque apreciable) paso en este sentido y la forestación de tierras agrarias podría resultar mucho más eficaz si se estimulase su aplicación en la comarca.

\section{La valorización del paisaje de Tierra de Campos}

23.- Se ha constatado que existen un buen número de zonas susceptibles y recursos para valorizar el paisaje de Tierra de Campos, tanto en los espacios cotidianos (parques urbanos y anillos verdes periurbanos) como en el campo (senderos, caminos, áreas recreativas). Por las características geomorfológicas de la comarca -enmarcada en páramos- los miradores constituyen atalayas para contemplar la inmensidad del horizonte, uno de los valores más destacados. Además, la presencia de abundantes zonas húmedas sin duda es más apreciada en centros de interpretación y observatorios de avifauna.

24.- De todos los casos analizados, el Canal de Castilla es el paradigma de integración paisajística de una obra de ingeniería civil en Tierra de Campos, donde además actualmente se están desarrollando actuaciones de valorización que pueden ser ejemplos para otras zonas estudiadas.

\section{La recuperación de los espacios degradados de Tierra de Campos}

25.- De los tratamientos generales que se pueden plantear para la recuperación de los espacios degradados de Tierra de Campos, se considera que -de acuerdo con las alteraciones más significativas a su paisaje- tres son los fundamentales: la restauración vegetal con árboles y arbustos, la integración paisajística de las edificaciones e infraestructuras y la restauración de los atributos de calidad (en especial el patrimonio). 
26.- La recuperación ambiental integral de Tierra de Campos constituye un proyecto de tremenda envergadura, que supondría una transformación radical del territorio hacia un paisaje de gran calidad. El modelo se plantea -a modo de cirugía- sobre una superficie relativamente reducida (no se afectan los cultivos), pero homogéneamente repartida por todo el territorio.

27.- El espacio degradado que afecta a la inmensa mayoría de Tierra de Campos es el agrícola intensivo afectado por concentraciones parcelarias. Su recuperación pasa por la realización de plantaciones de árboles y arbustos en márgenes de caminos, arroyos y regueras, parcelas sobrantes y linderas. Afectaría a pequeñas superficies distribuidas homogéneamente por todo el territorio, que en su conjunto tendrían un gran valor.

28.- Se ha podido detectar que las transformaciones en regadío son una magnífica oportunidad para valorizar la componente agua en un paisaje de aridez acusada como el de Tierra de Campos, fundamentalmente a través de la restauración de los márgenes de los canales y la naturalización del entorno de las balsas de riego. El objetivo es compatibilizar su funcionalidad con el uso recreativo.

29.- La recuperación ambiental de nuevas infraestructuras lineales de transporte, además de ser obligada en el marco de la evaluación de impacto ambiental, constituye otra ocasión para crear zonas verdes y corredores ecológicos paralelos a las obras, evitando siempre la fragmentación de hábitats. La gran red de carreteras existentes -que malla la comarca- ha de ser recuperada paisajísticamente, en especial a través de la plantación de árboles y arbustos en sus márgenes, tal como en su día fue diseñada (y en otras comunidades y países resulta tan común).

30.- Los espacios afectados por explotaciones mineras, así como por préstamos y vertederos derivados de la obra pública, suponen una considerable extensión superficial. El uso final de sus recuperaciones debería ser el natural o el forestal, teniendo en cuenta el mayoritario uso agrícola de la comarca y la necesidad de corregir y compensar los impactos generados.

31.- Las infraestructuras energéticas (parques eólicos, huertos solares y líneas eléctricas de alta tensión, fundamentalmente) ocupan superficies reducidas pero generan unos impactos severos en el paisaje. La recuperación, en lo posible, de estos espacios pasa básicamente por la integración de infraestructuras y la mejora de la capacidad de acogida del medio a través -sobre todo- de plantaciones de árboles en el entorno. Además, los parques eólicos se pueden convertir, por su ubicación, en excelentes miradores de Tierra de Campos.

32.- Se considera que la opción más factible para naturalizar los ríos y arroyos de la comarca cuyo estado de degradación es tan elevado- es su rehabilitación, entendida esta como una restauración parcial de sus procesos pero sin conllevar ocupaciones de sus antiguas llanuras de inundación. Aunque tienen un carácter más puntual, también es relevante la restauración y valorización de zonas húmedas degradadas y de fuentes, que constituyen auténticos oasis en la árida campiña cerealista.

33.- Las vías pecuarias que atraviesan Tierra de Campos se pueden convertir en excelentes corredores ecológicos gracias a su restauración vegetal, considerándose prioritaria su 
delimitación física para evitar intrusiones. Tanto estas como las antiguas vías del ferrocarril (rehabilitadas como Vías Verdes) son elementos lineales claves para valorizar el paisaje comarcal, a través de la práctica del senderismo, el ciclismo u otras actividades al aire libre.

34.- Aunque la superficie forestal en Tierra de Campos es muy escasa, su restauración y mejora es muy necesaria, ya que ocupa terrenos erosionables en laderas, que además tienen una visibilidad muy alta. En los espacios ya repoblados con pinos hace décadas, se está en condiciones de propiciar su evolución ecológica hacia masas de quercíneas autóctonas más estables.

35.- A pesar de que en términos cuantitativos no sea importante la cantidad de residuos generada en Tierra de Campos, sí que lo es en el aspecto cualitativo. Los vertederos de residuos urbanos que aún permanecen sin restaurar pueden generar problemas puntuales relevantes de contaminación. En cuanto a los residuos de construcción y demolición (escombros), además de recuperar las antiguas escombreras, es fundamental retirar los puntos de depósito incontrolado en márgenes y cunetas, así como realizar una gestión municipal que facilite su control desde la misma obra.

36.- La fragilidad del paisaje de Tierra de Campos hace que las construcciones en suelo rústico (plantas de tratamiento, naves, antenas, etc.) sean muy visibles. La recuperación de su entorno se debe plantear mediante su integración paisajística y la realización de pantallas vegetales perimetrales.

37.- Se ha constatado que en las periferias de los pueblos de Campos existe un considerable desorden urbanístico, que genera un gran espacio degradado perimetral a prácticamente todos ellos. Esta zona es muy visible, al tratarse de las entradas y salidas a las localidades. Se propone una recuperación integral de estos espacios periurbanos, que conjugue como actuaciones principales: urbanización, integración paisajística de edificaciones, restauración de palomares y otros elementos singulares y creación de anillos verdes sostenibles.

38.- Para aumentar la calidad de vida de los habitantes del medio rural, resultan vitales evitar el abandono y propiciar el cuidado de los pueblos. En estos espacios urbanos también se propone una rehabilitación integral, cuyas principales actuaciones sean la restauración del patrimonio -tanto histórico-artístico como tradicional- y la integración paisajística de la obra nueva.

\section{Conclusión general: imagen objetivo del paisaje de calidad de Tierra de}

\section{Campos}

Con las medidas propuestas en este trabajo y actuando en las zonas detectadas, el paisaje recuperado de calidad de Tierra de Campos mantendrá su personalidad agrícola, pero conjugando una mayor biodiversidad. Pequeños bosquetes, sotos y linderos salpicarán los campos de cultivo, propiciando -entre otros beneficios ambientales- hábitats adecuados a la fauna silvestre, la mitigación del cambio climático merced a la fijación de $\mathrm{CO} 2$ y el control de la erosión. Las infraestructuras estarán integradas e incluso crearán nuevos paisajes. Los ríos, 
arroyos y vías pecuarias constituirán importantes corredores ecológicos. El agua será recuperada como un elemento que aumentará la calidad del paisaje. Tierra de Campos será un paisaje limpio y con bajos niveles de contaminación, donde además se conseguirá neutralizar en buena medida la huella del carbono de la actividad humana en la zona. Los pueblos de la comarca estarán integrados paisajísticamente y poseerán abundantes zonas verdes de ocio y esparcimiento, que mejorarán el bienestar y la calidad de vida de su población. Sus cascos urbanos se mantendrán cuidados, con un patrimonio rehabilitado y más valorado, lo que sin duda fomentará el turismo en la comarca.

Y Tierra de Campos recuperará la esperanza. 

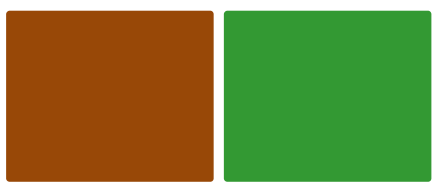

\section{PERSPECTIVAS \\ DE FUTURO}




\section{PERSPECTIVAS DE FUTURO}

\subsection{Puesta en marcha del modelo de recuperación ambiental del paisaje de Tierra de Campos}

El desarrollo más práctico de este estudio es la elaboración de un Plan de recuperación ambiental del paisaje de Tierra de Campos. Teniendo en cuenta el carácter pluriprovincial de la comarca, se propone que el promotor principal sea la Junta de Castilla y León, aunque posteriormente se articule a través de un consorcio con otras administraciones (Administración General del Estado, Diputaciones provinciales, Grupos de acción local, etc.).

Asumiendo, asimismo, que el paisaje afecta a variados sectores, es importante que en el Plan estén integradas las consejerías $u$ organismos competentes en cada uno de los sectores productivos donde se han planificado actuaciones. Es decir, la Consejería de Agricultura y Ganadería ha de estar presente en todo aquello relativo a los espacios afectados por concentraciones parcelarias y transformaciones en regadío; la Confederación Hidrográfica del Duero, en lo referente a rehabilitación de ríos y arroyos; las administraciones locales, en lo que afecte a los pueblos y sus periferias, etc.

El Plan ha de contener, entre otros aspectos, un mayor detalle de las actuaciones propuestas en este estudio, unas prioridades en la ejecución de las mismas, un calendario, una distribución de acuerdo con las competencias de cada administración y un seguimiento de su puesta en marcha.

El Plan se debe desarrollar en proyectos de recuperación ambiental de cada una de las actuaciones definidas. Teniendo en cuenta la magnitud de la empresa, se considera útil la elaboración previa de anteproyectos, donde se concreten con mayor detalle las actuaciones propuestas pero sin llegar a la máxima definición.

Una opción que debe ser tenida en cuenta es la posibilidad de realizar -y llevar a cabo- planes de recuperación del paisaje de ámbito municipal, en función de la predisposición para abordarlo de sus respectivas corporaciones municipales.

\subsection{Otras líneas de investigación}

Análisis demográfico en varias comarcas de la influencia de la diversidad del paisaje en el mantenimiento de la población rural. Así, incluso dentro de la comarca de Tierra de Campos se pueden comparar grupos de municipios con diferencias acusadas en la diversidad (mayor vegetación, presencia de agua, cultivos diferenciados, etc.). El análisis entre comarcas claramente diferenciadas puede ser más ilustrativo: por ejemplo, Tierra de Campos, Ribera del Duero y Tierra de Pinares.

Análisis de actuaciones de recuperación del paisaje similares a las aquí expuestas, realizadas en otras comarcas rurales -en el ámbito español o europeo- cuyas conclusiones puedan extrapolarse a campiñas cerealistas como las de Tierra de Campos. En especial deben valorarse aquellas donde se ha propiciado el mantenimiento de la población rural y la mejora de su bienestar. 
Seguimiento del estado de los proyectos evaluados en el Anejo 1 y en el Anejo 2 de este estudio, con objeto de valorar la eficacia de las actuaciones propuestas transcurridos varios años desde su ejecución.

El paisaje de Tierra de Campos es uno de los más representativos de las campiñas cerealistas de Castilla y León y, por extensión, de otras campiñas cerealistas españolas que, en su conjunto, ocupan una superficie de considerable importancia. Su configuración actual y degradaciones ambientales son en general comunes (monocultivos, grandes parcelas, escasa diversidad cromática y ecológica, ausencia de arbolado, contaminación agraria difusa, etc.) por lo que el modelo de recuperación ambiental que se plantea para esta comarca es sin duda extensible a otros territorios cerealistas del país.

Villalón de Campos, mayo de 2015

Raúl Blanco Esteban

Ingeniero de Montes 

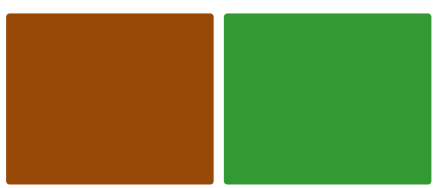

\section{BIBLIOGRAFÍA}




\section{BIBLIOGRAFÍA}

AGUILÓ, M.; 1981. Metodología para la evaluación de la fragilidad visual del paisaje. Tesis doctoral. E.T.S. Ingenieros de Caminos. Universidad Politécnica de Madrid.

AGUILÓ, M. et al.; 1993. Guía para la elaboración de estudios del medio físico. Contenido y metodología. Edit. Ministerio de Obras Públicas y Transportes. Madrid.

ALONSO, J.; 2006. Guía de miradores de Castilla y León. Las guías del Duero. Ediciones El Mundo. Valladolid.

ALONSO, L. y GUTIÉRREZ, J.M.; 2008. Viejos caminos de Castilla y León. Las guías del Duero. Ediciones El Mundo. Valladolid.

APPLETON, J.; 1993. Estética de la supervivencia. Ecosistemas, 6. Tema monográfico: "Descubrir el paisaje". Asociación Española de Ecología Terrestre.

ARA; 2005. Especial paisatge. El país que tenim. 15 de marzo de 2015.

ARAMBURU, M.P.; 1993. Evaluación y corrección del impacto visual. Ecosistemas, 6. Tema monográfico: "Descubrir el paisaje". Asociación Española de Ecología Terrestre.

AZCÁRATE GÓMEZ, C.A.; 2009. Catedrales olvidadas. La Red de Silos de España, 1949-1990. TG Ediciones. Pamplona.

BARAJA RODRÍGUEZ, E.; 1999. Dossier de Tierra de Campos. En: Medio Ambiente, no 11, primavera-verano 1999. Edit. Consejería de Medio Ambiente y Ordenación del Territorio. Junta de Castilla y León. Valladolid.

BAYÓN, S.; CLÉRIGO, Z.; CORTÉS, T.; FERNÁNDEZ, G. y MARCOS, J.L.; 2007. Caminos silenciosos: Las vías pecuarias: un patrimonio a conservar. Edita: Asociación de Investigación. Valladolid.

BENITO MARTÍN, F.; 1998. La arquitectura tradicional de Castilla y León. Consejería de Medio Ambiente y Ordenación del Territorio. Junta de Castilla y León. Valladolid.

BERDOULAY, V. y PHIPPS, M. (eds.) 1985. Paysage et système. Éditions de l'Université d'Ottawa, Ottawa.

BERNÁLDEZ, F.; 1981. Ecología y paisaje. Ed. Blume. Madrid.

BLANCO, R. y FRECHILLA, L.; 2009. El paisaje de Villalón de Campos. Características, conservación y mejora. Programa de educación ambiental de la asociación Villalón Vive.

BLM (U.S.D.I., Bureau of Land Management); 1980. Visual resource management program. Div. Of Recreation and Cultural Resource. Government Printing Office, Washington, D.C.: U.S.

BLM (U.S.D.I., Bureau of Land Management); 1980. Visual simulation techniques. Div. Of Recreation and Cultural Resource. Government Printing Office, Washington, D.C.: U.S. 
BOLÓS, M.; 2005. Prólogo. En: NAVÉS, F.; AROSAMENA, G.; RUIZ, B.; MARTÍNEZ, C.; GARCÍA, R. y SAMPERE, L.; 2005. Arquitectura del paisaje rural de la península lbérica, islas Baleares y Canarias. Ediciones Omega. Barcelona.

BOWLES, G.; 1775. Introducción a la Historia Natural y a la Geografía Física de España. Francisco Manuel de Mena. Madrid.

BUREAUX, C.; 2009. Prólogo. En GAMBIER, B. Setos vivos. Editorial De Vecchi. Barcelona.

CAÑAS, I. y AYUGA, F.; 1994. Agricultural buildings and landscape. Colour evaluation. XII World Congress on Agricultural Engineering. August 29 - September 1, 1994. Milano, Italy.

CAÑAS, I.; AYUGA, F. y ORTIZ, J.; 1996. Visual impact of agricultural building on landscape: method to asses it. International Conference on Agricultural Engineering. 23-26 September 1996. Madrid, Spain.

CEE; 1985. Directiva 85/337/CEE del Consejo, de 27 de junio de 1985, relativa a la evaluación de las repercusiones de determinados proyectos sobre el medio ambiente. DOCE L 175: 40-48(de 5 de julio de 1985).

CEE; 1992. Directiva 92/43/CEE del Consejo, de 21 de mayo, relativa a la conservación de los hábitats naturales y de la fauna y flora silvestres. DOCE L 206: 7-50 (de 22 de julio de 1992).

CEE; 1992. Reglamento (CEE) 2080/1992 del Consejo, de 30 de junio, por el que se establece un régimen comunitario de ayudas a las medidas forestales en la agricultura. DOCE L 215: 96-99.

CE; 2001. Directiva 2001/42/CE de 27 de junio de 2001 del Parlamento Europeo y del Consejo, de 27 de junio de 2001, relativa a la evaluación de los efectos de determinados planes y programas en el medio ambiente. DOUE L 197: 30-37 (de 21 de julio de 2001).

CE; 2005. Reglamento (CE) 1698/2005 del Consejo, de 20 de septiembre, relativo a la ayuda al desarrollo rural a través del Fondo Europeo Agrícola de Desarrollo Rural (FEADER). DOUE L 277: 2-61 (de 21 de octubre de 2005).

CE; 2009. Directiva 2009/147/CE del Parlamento Europeo y del Consejo, de 30 de noviembre de 2009, relativa a la conservación de las aves silvestres. DOUE L 20: 7-25 (de 26 de enero de 2010).

CIOLOS, D.; 2013. Los beneficios de una PAC más ecológica. El Norte de Castilla, 20 de febrero de 2013. Valladolid.

COLLADO, S. y CORRALIZA, J.A.; 2014. Ambiente e infancia. Curso de formación continuada a distancia. Consejo General de la Psicología de España.

COMUNIDAD DE CASTILLA Y LEÓN; 2015. Ley 4/2015, de 24 de marzo, del Patrimonio Natural de Castilla y León. BOCYL 61: 23956-24016 (de 30 de marzo de 2015).

CONSEJERÍA DE AGRICULTURA Y GANADERÍA; 2007. Orden AYG/1039/2007, de 5 de junio, por la que se establecen los requisitos legales de gestión y las buenas condiciones agrarias y medioambientales que deberán cumplir los agricultores que reciban ayudas directas de la Política Agraria Común. BOCYL 115: 12804-12815 (de 14 de junio de 2007). 
CONSEJERÍA DE AGRICULTURA Y GANADERÍA; 2014. Orden AYG/1129/2014, de 19 de diciembre, por la que se regulan las medidas de agroambiente y clima, contenidas en el Programa de Desarrollo Rural de Castilla y León 2014-2020 y cofinanciadas por el Fondo Europeo Agrícola de Desarrollo Rural (Feader). BOCYL 250: 87170-87207 (de 30 de diciembre de 2014).

CONSEJERÍA DE FOMENTO Y MEDIO AMBIENTE; 2013. Orden FYM/104/2013, de 19 de febrero, por la que se convocan ayudas, cofinanciadas por el Fondo Europeo Agrícola de Desarrollo Rural (FEADER), destinadas a la primera forestación de tierras agrícolas, para el año 2013. BOCYL 44: 16256-16286 (de 5 de marzo de 2013).

CONSEJERÍA DE MEDIO AMBIENTE; 2002. Ordenación y desarrollo sostenible en Tierra de Campos. Documento de bases. Solicitud de Life Medio Ambiente.

CONSEJERÍA DE MEDIO AMBIENTE; 2003. Resolución de 17 de marzo de 2003, de la Delegación Territorial de la Junta de Castilla y León en Palencia, por la que se hace pública la Declaración de Impacto Ambiental de Evaluación Simplificada sobre el Proyecto de Parque Eólico "El Castre", en los términos municipales de Pedraza de Campos y Torremormojón (Palencia), promovido por Elecdey, S.L. BOCYL 185: 12694-12697 (de 24 de septiembre de 2003).

CONSEJERÍA DE MEDIO AMBIENTE; 2003. Resolución de 15 de octubre de 2003, de la Delegación Territorial de la Junta de Castilla y León en Palencia, por la que se hace pública la Declaración de Impacto Ambiental de Evaluación Simplificada del Proyecto de Plan Parcial del Polígono Industrial Sector I, promovido por el Ayuntamiento de Paredes de Nava, en el término municipal de Paredes de Nava (Palencia). BOCYL 208: 14245-14246 (de 27 de octubre de 2003).

CONSEJERÍA DE MEDIO AMBIENTE; 2003. Resolución de 23 de octubre de 2003, de la Consejería de Medio Ambiente, por la que se hace pública la Declaración de Impacto Ambiental sobre proyectos de concentración parcelaria y transformación en regadío del Sector IV de la Zona Regable del Canal Esla-Carrión, en los términos municipales de Villalón de Campos, Villafrades de Campos y Herrín de Campos en la provincia de Valladolid, y Boadilla de Rioseco en Palencia, promovido por la Consejería de Agricultura y Ganadería de la Junta de Castilla y León. BOCYL 212: 14519-14524 (de 31 de octubre de 2003).

CONSEJERÍA DE MEDIO AMBIENTE; 2004. Resolución de 26 de noviembre de 2004, de la Consejería de Medio Ambiente, por la que se hace pública la Declaración de Impacto Ambiental sobre el proyecto de línea eléctrica de alta tensión 220 kV, S.E. Grijota-S.E. Ampudia, en los términos municipales de Grijota, Villaumbrales, Husillos, Villamartín de Campos, Pedraza de Campos y Ampudia (Palencia), promovido por Proyectos de Cogeneración, S.L. BOCYL 236: 17577-17579 (de 9 de diciembre de 2004).

CONSEJERÍA DE MEDIO AMBIENTE; 2007. Orden MAM/1416/2007, de 5 de septiembre, por la que se establecen las bases reguladoras de la distribución de árboles para cumplir los requisitos legales de gestión y las buenas condiciones agrarias y medioambientales exigidos a los agricultores de la Comunidad de Castilla y León que reciban ayudas directas de la Política Agraria Común. BOCYL 174: 17540 (de 6 de septiembre de 2007).

CONSEJERÍA DE MEDIO AMBIENTE; 2009. Orden MAM/39/2009, de 16 de enero, por la que se establecen las bases reguladoras para la concesión de ayudas a la primera forestación de tierras 
agrícolas, cofinanciadas por el Fondo Europeo Agrícola de Desarrollo Rural (FEADER), en el marco del Programa de Desarrollo Rural de Castilla y León 2007-2013. BOCYL suplemento al $n$ o 12: 54-87 (de 20 de enero de 2009).

CONSEJERÍA DE MEDIO AMBIENTE; 2010. Orden MAM/1287/2010, de 14 de septiembre, por la que se convoca la distribución de árboles para cumplir los requisitos legales de gestión y las buenas condiciones agrarias y medioambientales exigidos a los agricultores de la Comunidad de Castilla y León que reciban ayudas directas de la Política Agraria Común. BOCYL 187: 7312573145 (de 27 de septiembre de 2010).

CONSEJERÍA DE MEDIO AMBIENTE Y ORDENACIÓN DEL TERRITORIO; 1997. Resolución de 30 de julio de 1997, por la que se hace pública la Declaración de Impacto Ambiental sobre el estudio informativo E.I. 1.2.-P-9/AT de la variante de Villada, término municipal de Villada (Palencia), carretera C-611 de Tordesillas a Cistierna por Medina de Rioseco, Villalón de Campos y Sahagún, promovido por la Consejería de Fomento de la Junta de Castilla y León. BOCYL 149 (de 6 de agosto de 1997).

CONSEJO DE EUROPA; 2000. Convenio Europeo del Paisaje. Florencia (Italia).

CONSEJO DE EUROPA; 2008. Recomendación CM/Rec(2008)3 del Comité de Ministros a los Estados Miembros sobre las orientaciones para la aplicación del Convenio Europeo del Paisaje.

CONSEJO DE EUROPA; 2009. Road infraestructures: tree avenues in the landscape. V Council of Europe Conference on the European landscape convention. Strasburg, 30-31 March 2009.

CONSEJO ECONÓMICO DE TIERRA DE CAMPOS; 1962. Programa para el desarrollo de Tierra de Campos.

CORRALIZA, J.A.; 1993. Reacciones psicológicas a la estimulación escénica. Ecosistemas, 6. Tema monográfico: “Descubrir el paisaje". Asociación Española de Ecología Terrestre.

CORRALIZA, J.A.; 2014. Conexión entre naturaleza y bienestar. El síndrome de déficit de naturaleza. Jornades La salud i els espais naturals. 22 i 23 de setembre de 2014. Barcelona.

NIEUWENHUIJSEN, M.; 2014. El Proyecto Phenotype: efectes positius per a la salut de l'aire lliure en las poblacions tipiques de diferentes regions d'Europa. Centre de reserca en epidemiologia ambiental de Barcelona - CREAL. Jornades La salud i els espais naturals. 22 i 23 de setembre de 2014. Barcelona.

CSIC-IRNA; 1993. Estudio edáfico de la provincia de Valladolid. Mapa de suelos, escala 1:100.000 de la zona situada al norte del río Duero. R.B. Servicios editoriales, S.A. Salamanca.

DANTÍN CERECEDA, J.; 1922. Ensayos acerca de las regiones naturales de España.

DE ANDRÉS, C.; COSANO, I. y PEREDA, N.; 2003. Manual para la diversificación del paisaje agrario. Junta de Andalucía. Consejería de Medio Ambiente. Comité Andaluz de Agricultura Ecológica (CAAE).

DÍAZ PINEDA, F. et al.; 1973. Terrestrial ecosystems adjacent to large reservoirs. Eco-survey and diagnosis. International commiss. on large dams, XI Congress, 1973. 
DUQUE, C.; 2003. Palacios de Campos. Historia y patrimonio artístico (Formación, cénit y ocaso de una villa terracampina). Ed. Grupo Página. Valladolid.

DUQUE, C.; 2005. Villalón de Campos. Historia y patrimonio artístico. Del siglo XVII hasta nuestros días. Ed. Cultura \& Comunicación. Valladolid.

DUQUE, C.; 2006. Villalón de Campos. Historia y patrimonio artístico. Del siglo XIV al XVI. Ed. Cultura \& Comunicación. Palencia.

ECLÉCTICA; 2006. El Canal de Castilla, agua y piedra en el paisaje. Las Guías del Duero. Ed. El Mundo Castilla y León. Valladolid.

ESCAPA; 2009. Rutas de senderismo de Castilla y León. Las Guías del Duero. Ed. El Mundo Castilla y León. Valladolid.

ESCRIBANO, M.; DE FRUTOS, M.; IGLESIAS, E., MATAIX, C. y TORRECILLA, I.; 1987. El paisaje. Unidades temáticas ambientales de la Dirección General del Medio Ambiente. MOPU. Madrid.

ESPAÑOL ECHÁNIZ, I.; 1995. Paisaje, conceptos básicos. Apuntes de la asignatura El Paisaje y la Ingeniería Civil. Escuela Técnica Superior de Ingenieros de Caminos de Madrid. Madrid.

ESPAÑOL ECHÁNIZ, I.; 2005. Carretera local y paisaje. Asociación Española de la Carretera. Madrid.

ESTUDIOS Y PROYECTOS LÍNEA, S.L.; 2010. Manual de buenas prácticas cinegéticas en Castilla y León. Fundación del Patrimonio Natural de Castilla y León. Valladolid.

EZQUERRA, J.; 2007. La recuperación del espacio forestal. En: GIL, L.; y TORRE, M.; (Eds.). Atlas forestal de Castilla y León. Edit. Junta de Castilla y León. Consejería de Medio Ambiente.

FAFCYLE; 2010. Uso del bosque como sumidero de carbono en Castilla y León. Forestalis Castilla y León. Federación de Asociaciones Forestales de Castilla y León.

FLORES, C.; 1990. Pueblos y lugares de España. Ed. Espasa Calpe. Madrid.

FORMAN, R.T.T. \& GODRON, M.; 1986. Landscape Ecology. Edit. John Wiley and Sons. New York.

FORMAN, R.T.T.; 1995. Land Mosaic: The ecology of landscapes and regions. Cambridge University Press. New York.

FRANCO, F.; GARCÍA, M.; MALDONADO, J.; POSTIGO, J.M. y SAINZ, H.; 2007. La evolución cuaternaria del paisaje vegetal. En: GIL, L.; y TORRE, M.; (Eds.). Atlas forestal de Castilla y León. Edit. Junta de Castilla y León. Consejería de Medio Ambiente.

FRECHILLA, A.; CASARES, A. y PÉREZ, O.; Naturalización de cursos fluviales mediante plantación. Ejemplo de restauración arroyo Berruez, Villalón de Campos (Valladolid). Congreso Ibérico de Restauración Fluvial, 18-20 octubre 2011. León.

FRECHILLA, L.; 2007. GR 26 y GR 89. Los senderos de Tierra de Campos. Edit. Junta de Castilla y León. Consejería de Medio Ambiente. 
FULLER, D.; HAGGETT, C. y DUNSFORD, H.; 2008. Paisatge, tranquil.litat i salut. En: NOGUÉ, J.; PUIGBERT, L. y BRETCHA, G. (edit.) Paisatge y salut. Observatori del Paisatge de Catalunya. Generalitat de Catalunya. Departament de Salut.

GAMBIER, B.; 2009. Setos vivos. Editorial De Vecchi. Barcelona.

GARCíA FERNÁNDEZ, J.; 1966. Campos abiertos y campos cercados en Castilla la Vieja. En: Homenaje al Excmo. Señor D. Amando Melón y Ruiz de Gordejuela.

GARCÍA FERNÁNDEZ, J.; 1985. Castilla (Entre la percepción del espacio y la tradición erudita). Edit. Espasa-Calpe.

GARCÍA MARTÍN, P. (coordinador); 1992. Cañadas, cordeles y veredas. Consejería de Agricultura y Ganadería. Junta de Castilla y León. Valladolid.

GARCÍA, J.; AYUGA, F.; CAÑAS, I.; GARCÍA, L.; y HERNÁNDEZ, J.; 1997. Las nuevas construcciones ante la conservación del paisaje tradicional: un acercamiento a su estudio. Caso particular del Páramo Leonés. X Simposio de Cooperativismo y Desarrollo Rural. 11-13 abril 1997. Morillo de Tou, Huesca.

GENERALITAT DE CATALUNYA; [en línea]. Criterios y guías para la mejora del paisaje. http://www.catpaisatge.net [consultado en enero de 2013].

Generalitat De CATAlunYA; 2006. El Observatorio del Paisaje. Departament de Política Territorial i Obres Públiques.

GEOSISTEMA; 1994. Dossier de Tierra de Campos. En: Medio Ambiente, no 1, verano-otoño 1994. Edit. Consejería de Medio Ambiente y Ordenación del Territorio. Junta de Castilla y León. Valladolid.

GIL, L.; 2007. La ciencia de montes. En: GIL, L.; y TORRE, M.; (Eds.). Atlas forestal de Castilla y León. Edit. Junta de Castilla y León. Consejería de Medio Ambiente.

GIL, L.; 2010. Una desmedida devoción por los matorrales o porqué estabilizar el paisaje humanizado. En: 5o Congreso Forestal Español. Sociedad Española de Ciencias Forestales.

GÓMEZ OREA, D.; 2003. Evaluación de Impacto Ambiental. Edit. Mundi-Prensa. Madrid.

GÓMEZ OREA, D.; 2004. Recuperación de Espacios Degradados. Edit. Mundi-Prensa. Madrid.

GÓMEZ OREA, D. y VILLARINO, T.; 2004. El paisaje en la recuperación de espacios degradados. En GÓMEZ OREA, D.; Recuperación de Espacios Degradados. Edit. Mundi-Prensa. Madrid.

GONZÁLEZ BERNÁLDEZ, F.; 1981. Ecología y paisaje. Ed. Blume. Madrid.

GONZÁLEZ BERNÁLDEZ, F.; 1990. El porqué de la conservación del paisaje (hombre-ecologíapaisaje). I Jornadas sobre el paisaje. Grupo de Paisaje de la Asociación de Universitarios Segovianos. Horizonte Cultural. Segovia.

GONZÁLEZ GARRIDO, J.; 1941. La Tierra de Campos: Región natural. Edit. Diputación de Palencia y Ámbito Ediciones. 
GONZÁLEZ DEL TÁNAGO, M. y GARCÍA DE JALÓN, D.; 1995. Restauración de ríos y riberas. Escuela Técnica Superior de Ingenieros de Montes. Universidad Politécnica de Madrid.

GONZÁLEZ DEL TÁNAGO, M. y GARCÍA DE JALÓN, D.; 2004. Cursos de agua desnaturalizados. En GÓMEZ OREA, D.; Recuperación de Espacios Degradados. Edit. Mundi-Prensa. Madrid.

GUERRA GARRIDO, R.; 2008. Castilla en Canal. Ediciones Cálamo. Palencia.

GUERRA VELASCO, J.C.; 2010. Flora y fauna de Castilla y León. Las guías del Duero. EDICAL, S.A.

HERNÁNDEZ, C.; HOYOS, C.; MENDIZÁBAL, N.; SANZ, B. y SASTRE, M.A.; 2001. Diccionario del castellano tradicional. Ámbito ediciones. Valladolid.

HERRERO SINOVAS, M.; 2004. Líneas eléctricas, subestaciones y parques eólicos. Tipos, contenido de los proyectos y tramitación administrativa. Curso de evaluación de impacto ambiental de parques eólicos y líneas eléctricas. Consejería de Medio Ambiente. Junta de Castilla y León.

HOPFNER, H.; 1954. La evolución de los bosques de Castilla la Vieja en tiempos históricos. Contribución a la investigación del primitivo paisaje de la España central. En: Estudios Geográficos.

INSTITUTO NACIONAL PARA LA CONSERVACIÓN DE LA NATURALEZA (ICONA); 1975. Inventario Nacional de Paisajes Sobresalientes. Edit. Ministerio de Agricultura. Madrid.

INSTITUTO NACIONAL PARA LA CONSERVACIÓN DE LA NATURALEZA (ICONA); 1975. Técnicas de forestación. Edit. Ministerio de Agricultura. Madrid.

JUNTA DE CASTILLA Y LEÓN; 1992. La vida silvestre en el espacio agrario. Cómo mejorarla. Cuadernos de Medio Ambiente. Consejería de Medio Ambiente y Ordenación del Territorio.

JUNTA DE CASTILLA Y LEÓN; 1995. Manual de forestación. Consejería de Medio Ambiente y Ordenación del Territorio.

JUNTA DE CASTILLA Y LEÓN; 1998. Código de Buenas Prácticas Agrarias. Consejería de Agricultura y Ganadería.

JUNTA DE CASTILLA Y LEÓN; 2003. Ley 11/2003, de 8 de abril, de Prevención Ambiental de Castilla y León. BOCYL suplemento al no 71: 25-40 (de 14 de abril de 2003).

JUNTA DE CASTILLA Y LEÓN; 2006. Ley 6/2006, de 5 de julio, de Declaración de la Reserva Natural de Lagunas de Villafáfila (Zamora). BOCYL suplemento al no 136: 2-4 (de 14 de julio de 2006).

JUNTA DE CASTILLA Y LEÓN; 2014. Ley 8/2014, de 14 de octubre, por la que se modifica la Ley 11/2003, de 8 de abril, de Prevención Ambiental de Castilla y León. BOCYL no 200: 71278-71321 (de 17 de octubre de 2014).

KAPLAN, R. y KAPLAN, S.; 1989. The experience of Nature. A psychological perspective. Cambridge University Press, Nueva York.

LANCIA; 2004. Tierra de Campos. Ediciones Lancia. León. 
LÓPEZ GIMENO, C.; 1999. Manual de estabilización y revegetación de taludes. Madrid.

LÓPEZ GONZÁLEZ, G.; 1982. La guía de Incafo de los árboles y arbustos de la Península Ibérica. Ed. Incafo. Madrid.

LÓPEZ DE SANTIAGO, C.; 1993. En: RUIZ, J.P. y BENAYAS, J.; Sobre gustos hay mucho escrito. Ecosistemas, 6. Tema monográfico: "Descubrir el paisaje". Asociación Española de Ecología Terrestre.

LÓPEZ LILLO, A. y RAMOS, A.; 1969. Valoración del paisaje natural. Las plantas ornamentales. Escuela Técnica Superior de Ingenieros de Montes. Madrid.

LUGINBÜHL, Y.; 2008. Paisatge i benestar individual i social. En: NOGUÉ, J.; PUIGBERT, L. y BRETCHA, G. (edit.) Paisatge y salut. Observatori del Paisatge de Catalunya. Generalitat de Catalunya. Departament de Salut.

MARTín RUIZ, P.; Notas sobre el éxodo rural y la evolución de la población en una comarca de Tierra de Campos. IRYDA. www.magrama.es. [consultado en marzo de 2014]

MARTÍNEZ, P.; 1985. La Tierra de Campos Occidental. Poblamiento, poder y comunidad del siglo $X$ al XIII. Edit. Diputación de Valladolid.

MARTÍNEZ DE PISÓN, E.; 1993. El punto de vista geográfico. Ecosistemas, 6. Tema monográfico: "Descubrir el paisaje". Asociación Española de Ecología Terrestre.

MARTíNEZ DE PISÓN, E.; 2002. Paisajes de Castilla y León. En: JUNTA DE CASTILLA Y LEÓN; Espacios Naturales de Castilla y León. Lunwerg editores.

MATA, R. y SANZ, C. (dir.); 2004. Atlas de los paisajes de España. Edit. Ministerio de Medio Ambiente.

MINISTERIO DE AGRICULTURA, ALIMENTACIÓN Y MEDIO AMBIENTE; [en línea]. Paisaje. http://www.magrama.gob.es. [consultado en octubre de 2012].

MINISTERIO DE AGRICULTURA, ALIMENTACIÓN Y MEDIO AMBIENTE (MAGRAMA); 2013. Ley 21/2013, de 9 de diciembre, de evaluación ambiental. BOE 296: 98151-98227 (de 11 de diciembre de 2013).

MINISTERIO DE AGRICULTURA, ALIMENTACIÓN Y MEDIO AMBIENTE (MAGRAMA); 2014. Atlas de los paisajes agrarios de España. Madrid.

MINISTERIO DE AGRICULTURA, ALIMENTACIÓN Y MEDIO AMBIENTE (MAGRAMA); 2014. Real Decreto 1078/2014, de 19 de diciembre, por el que se establecen las normas de condicionalidad que deben cumplir los beneficiarios que reciban pagos directos, determinadas primas anuales de desarrollo rural, o pagos en virtud de determinados programas de apoyo al sector vitivinícola. BOE 307: 103829-103849 (de 20 de diciembre de 2014).

MINISTERIO DE AGRICULTURA, PESCA Y ALIMENTACIÓN; 1991. Setos y cerramientos ornamentales. Hojas divulgadoras. 
MINISTERIO DE AGRICULTURA, PESCA Y ALIMENTACIÓN; 2001. Real Decreto 6/2001, de 12 de enero, sobre fomento de la forestación de tierras agrícolas. BOE 12: 1621-1630 (de 13 de enero de 2001).

MINISTERIO DE MEDIO AMBIENTE; 2006. Prescripciones Técnicas para el diseño de pasos de fauna y vallados perimetrales. Documentos para la reducción de la fragmentación de hábitats causada por infraestructuras de transporte, número 1. Organismo Autónomo Parques Nacionales.

MINISTERIO DE MEDIO AMBIENTE; 2006. Ley 9/2006, de 28 de abril, sobre evaluación de los efectos de determinados planes y programas en el medio ambiente. BOE 102: 16820-16830 (de 29 de abril de 2006).

MINISTERIO DE MEDIO AMBIENTE; 2008. Real Decreto Legislativo 1/2008, de 11 de enero, por el que se aprueba el texto refundido de la Ley de Evaluación de Impacto Ambiental de proyectos. BOE 23: 4986-5000 (de 26 de enero de 2008).

MINISTERIO DE MEDIO AMBIENTE, Y MEDIO RURAL Y MARINO; 2009. Real Decreto 486/2009, de 3 de abril, por el que se establecen los requisitos legales de gestión y las buenas condiciones agrarias y medioambientales que deben cumplir los agricultores que reciban pagos directos en el marco de la política agraria común, los beneficiarios de determinadas ayudas de desarrollo rural, y los agricultores que reciban ayudas en virtud de los programas de apoyo a la reestructuración y reconversión y a la prima por arranque del viñedo. BOE 94: 35451-35466 (de 17 de abril de 2009).

MINISTERIO DE OBRAS PÚBLICAS Y URBANISMO; 1988. Real Decreto 1131/1988, de 30 de septiembre, por el que se aprueba el Reglamento para la ejecución del Real Decreto Legislativo 1302/1986, de 28 de junio, de Evaluación de Impacto Ambiental. BOE 239: 28911-28916 (de 5 de octubre de 1988).

MINISTERIO DE LA PRESIDENCIA; 1996. Real Decreto 261/1996, de 16 de febrero, sobre protección de las aguas contra la contaminación producida por nitratos procedentes de fuentes agrarias. BOE 61: 9734-9737 (de 11 de marzo de 1996).

MINISTERIO DE LA PRESIDENCIA; 2009. Real Decreto 975/2009, de 12 de junio, sobre gestión de los residuos de las industrias extractivas y de protección y rehabilitación del espacio afectado por actividades mineras. BOE 143: 49948-49992 (de 13 de junio de 2009).

MOSCOSO, D.J.; PECURUL, M. y CRISTÓBAL, R.; 2008. La contribució dels espais verds i els boscos a la millora de la salut. En: NOGUÉ, J.; PUIGBERT, L. y BRETCHA, G. (edit.) Paisatge y salut. Observatori del Paisatge de Catalunya. Generalitat de Catalunya. Departament de Salut.

NAVARRO, J.; MARTíNEZ DE AZAGRA, A. y MONGIL, J.; 2009. Hidrología de conservación de aguas. Captación de precipitaciones horizontales y escorrentías en zonas secas. Universidad de Valladolid. 
NAVARRO, J.; 2002. Control de la erosión en desmontes originados por obras de infraestructura viaria: Aplicación al entorno de Palencia capital. Tesis doctoral. Escuela Técnica Superior de Ingenieros de Montes. Universidad Politécnica de Madrid.

NAVÉS, F.; AROSAMENA, G.; RUIZ, B.; MARTíneZ, C.; GARCÍA, R. y SAMPERE, L.; 2005. Arquitectura del paisaje rural de la península Ibérica, islas Baleares y Canarias. Ediciones Omega. Barcelona.

ORIA DE RUEDA, J.A.; 2007. Un mosaico de ecosistemas. En: GIL, L.; y TORRE, M.; (Eds.). Atlas forestal de Castilla y León. Edit. Junta de Castilla y León. Consejería de Medio Ambiente.

ORIA DE RUEDA, J.A.; 2011. Los bosques de Castilla y León. Las guías del Duero. Ed. El Mundo.

ORIA DE RUEDA, J.A. y DÍEZ, J.; 2002. Guía de árboles y arbustos de Castilla y León. Junta de Castilla y León. Ediciones Cálamo. Palencia.

ORTIZ, A.; BAYLINA, M. y PRATS, M.; 2008. Paisatges quotidians i diversitat social i de gènere: la seva relació amb la salut i el benestar. En: NOGUÉ, J.; PUIGBERT, L. y BRETCHA, G. (edit.) Paisatge y salut. Observatori del Paisatge de Catalunya. Generalitat de Catalunya. Departament de Salut.

OTERO, I.; MANCEBO, S.; ORTEGA, E. y CASERMIRO, M.A.; 2007. Mapa de calidad del paisaje de España. Revista electrónica de Medio Ambiente. Universidad Complutense de Madrid.

OTERO, I.; MONZÓN, A.; GARCÍA, M.B.; CASERMEIRO, M.A. y CANGA, J.L.; 1999. Impacto ambiental de carreteras. Evaluación y restauración. Comunidad de Madrid. Asociación Española de la Carretera. Madrid.

PERAY, J.L. y PLASENCIA, A.; 2008. Paisatge, medi ambient i salut pública: implicacions per al cambi. En: NOGUÉ, J.; PUIGBERT, L. y BRETCHA, G. (edit.) Paisatge y salut. Observatori del Paisatge de Catalunya. Generalitat de Catalunya. Departament de Salut.

PLANS, P.; 1970. La Tierra de Campos. Edit. Consejo Superior de Investigaciones Científicas.

POL, E.; CASTRECHINI, A. y MASSO, A.; 2008. Paisatge i qualitat de vida. En: NOGUÉ, J.; PUIGBERT, L. y BRETCHA, G. (edit.) Paisatge y salut. Observatori del Paisatge de Catalunya. Generalitat de Catalunya. Departament de Salut.

PUERTO, A.; 1993. Cartografía y diversidad paisajística. Ecosistemas, 6. Tema monográfico: "Descubrir el paisaje". Asociación Española de Ecología Terrestre.

RAMÍREZ, G. y REGUERA, J.M.; 1995. Atlas del Territorio de Castilla y León. Edit. Junta de Castilla y León. Consejería de Cultura y Turismo.

RAMOS, A.; 1970. Ordenación del Paisaje. Pliego de condiciones técnicas para plantaciones, siembras y obras complementarias. Escuela Técnica Superior de Ingenieros de Montes. Madrid.

REGUANT, F.; 2014. ¿Existe éxodo rural en Cataluña? El Periódico. Barcelona.

RIVAS-MARTínEZ, S.; 1987. Mapa de series de vegetación de España y Memoria. ICONA. Ministerio de Agricultura, Pesca y Alimentación. Madrid. 
ROJO, L.I.; 2007. La otra fauna: la "estepa cerealista". En: GIL, L.; y TORRE, M.; (Eds.). Atlas forestal de Castilla y León. Edit. Junta de Castilla y León. Consejería de Medio Ambiente.

RUIPÉREZ, C. y GONZÁLEZ, J.L.; 1991. Los suelos de Tierra de Campos en Palencia. Ed. Diputación Provincial de Palencia. Palencia.

RUIZ DE LA TORRE, J.; 1979. Árboles y arbustos. Escuela Técnica Superior de Ingenieros de Montes. Madrid.

RUIZ, J.P. y BENAYAS, J.; 1993. Sobre gustos hay mucho escrito. Ecosistemas, 6. Tema monográfico: "Descubrir el paisaje”. Asociación Española de Ecología Terrestre.

SÁEZ HIDALGO, I.; 2001. El Canal de Castilla. Guía para caminantes. Edit. Junta de Castilla y León. Consejería de Educación y Cultura.

SALLENT, O.; 2008. L'activitat física i la contemplació del paisatge. En: NOGUÉ, J.; PUIGBERT, L. y BRETCHA, G. (edit.) Paisatge y salut. Observatori del Paisatge de Catalunya. Generalitat de Catalunya. Departament de Salut.

SANZ-ZUASTI, J. y GARCÍA, J.; 2006. Las aves esteparias de Castilla y León. Distribución, población y tendencia. Edit. Junta de Castilla y León. Consejería de Medio Ambiente.

SANZ-ZUASTI, J; SIERRA, G; SÁNCHEZ, C. y MARTíN, J.; 1995. Tierra de avutardas. La llanura cerealista de Castilla y León. Edit. Junta de Castilla y León. Consejería de Medio Ambiente y Ordenación del Territorio.

SANZ-ZUASTI, J.; ARRANZ, J.A. y MOLINA, I.; 2004. La Red de Zonas de Especial Protección para las Aves (ZEPA) de Castilla y León. Edit. Junta de Castilla y León. Consejería de Medio Ambiente.

SAURA, S. \& TORNÉ, J.; 2009. Conefor Sensinode 2.2: a software package for quantifying the importance of habitat patches for landscape connectivity. Environmental Modelling \& Software 24: 135-139.

SENADOR GÓMEZ, J.; 1915. Castilla en escombros. Ámbito ediciones. Diputación de Palencia. 1993.

SGPCCC, 2007. Resolución de 30 de enero de 2007, de la Secretaría General para la Prevención de la Contaminación y el Cambio Climático, por la que se formula declaración de impacto ambiental sobre el proyecto 19970041 FCA, corredor Norte-Noroeste de alta velocidad, tramo Palencia-León. BOE 53: 9093-9098 (de 2 de marzo de 2007).

SERRADA, R.; 1993. Apuntes de repoblaciones forestales. Escuela Universitaria de Ingeniería Técnica Forestal. Fundación Conde del Valle de Salazar. Madrid.

SMARDON, R.C.; 1979. Prototype Visual Impact Assessment Manual. State University of New York. Syracuse.

TORBADO, J.; 1966. Tierra mal bautizada. Un viaje por Tierra de Campos. Ámbito ediciones, S.A. Valladolid. 2001. 
TRAGSA; 1994. Restauración hidrológico forestal de cuencas y control de la erosión. Ed. Mundi Prensa. Madrid.

TROLL, C.; 1939. «Luftbildplan und okologische Bodenforschung». Zeitschraft der Gesellschaft fur Erdkunde Zu Berlin, no 74: 241-298.

UDPP (Unidad Docente de Planificación y Proyectos), 2002. Restauración de espacios degradados. Curso de especialización. ETS de Ingenieros de Montes. Universidad Politécnica de Madrid. Madrid.

ULRICH, R.S.; 1992. La salud y el paisaje. En: SAENZ DE MIERA, A. (coord.). La Sierra de Guadarrama: naturaleza, paisaje y aire de Madrid. 235-248. Comunidad Autónoma de Madrid.

VACA, A.; 1992. La Tierra de Campos y sus bases ecológicas en el siglo XIV. Studia histórica. Historia medieval, Vol. X.

VALLADARES, F.; BALAGUER, L.; MOLA, I.; ESCUDERO, A. y ALFAYA, V.; 2011. Restauración ecológica de áreas afectadas por infraestructuras de transporte. Bases científicas para soluciones técnicas. Fundación Biodiversidad. Madrid.

VALLERANI, F.; 2008. La pèrdua traumática del sentit del lloc: degradació del paisatge $\mathrm{i}$ patologies depressives. En: NOGUÉ, J.; PUIGBERT, L. y BRETCHA, G. (edit.) Paisatge y salut. Observatori del Paisatge de Catalunya. Generalitat de Catalunya. Departament de Salut.

VILA, J.; VARGA, D.; LLAUSÁS, A. y RIBAS, A.; 2006. Conceptos y métodos fundamentales en ecología del paisaje (landscape ecology). Una interpretación desde la geografía. Doc. Anál. Geogr. 48.

YEOMANS, W.C.; 1986. Visual Impacto Assessment: Changes in natural and rural environment. In: SMARDON, R.C.; PALMER, J.E. and FELLEMAN, J.P. (Eds). Foundations for Visual Project analysis. John Wiley and Sons, New York.

YUN, B.; 1987. Sobre la transición al Capitalismo en Castilla. Economía y sociedad en Tierra de Campos (1500-1830). Edit. Junta de Castilla y León. 


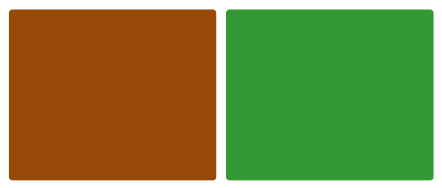

ANEJO 1.

Proyectos

representativos de obras que afectan al paisaje de Tierra de Campos 


\title{
A1.1. Concentración parcelaria de los términos municipales de Herrín de Campos, Villafrades de Campos, Villalón de Campos y Boadilla de Rioseco
}

\section{A1.1.1. Proyecto}

\author{
A1.1.1.1. Estudio Técnico Previo de la zona de concentración de Herrín, Villafrades, \\ Villalón (Valladolid) y Boadilla de Rioseco (Palencia) \\ Promotor: Consejería de Agricultura y Ganadería. Junta de Castilla y León \\ Autor: Moisés Redondo Gil (ingeniero agrónomo) \\ Fecha: diciembre de 2002
}

La figura del Estudio Técnico Previo en las concentraciones parcelarias es equivalente a la del anteproyecto que se utiliza en otras obras; se trata del primer documento técnico que sirve de base para el comienzo de un proceso largo y realmente complejo (en este caso su duración ha sido superior a 12 años). Posteriormente se desarrolla con dos proyectos que transcurren de forma paralela: el de concentración parcelaria propiamente dicha -que realiza una nueva planificación de las parcelas y de su propiedad- y el de infraestructura rural -que proyecta las obras públicas, sobre todo caminos y desagües-.

En los antecedentes de este Estudio se señala que el denominado Canal para la redotación del río Carrión, que trasvasa aguas desde el río Cea a los regadíos del bajo Carrión, fue construido durante los años 1996 y 1997. Tiene su inicio en el río Cea, a la altura de Galleguillos de Campos (León); atraviesa todo el norte de la provincia de Valladolid y desemboca en el Canal de Castilla, en el término municipal de Fuentes de Nava (Palencia).

La utilización para el riego de las aguas del canal y la concesión de las dotaciones correspondientes por la Confederación Hidrográfica del Duero exigen como condición previa la actuación de la Consejería de Agricultura y Ganadería de la Junta de Castilla y León en la planificación del regadío y en el desarrollo posterior de las redes de riego, así como las actuaciones en concentración parcelaria. Estas se consideran absolutamente necesarias como medio instrumental con el fin de conseguir la reestructuración adecuada a la nueva situación creada por el regadío. En efecto, la realización de la concentración parcelaria presenta las siguientes ventajas:

- Permite disponer de los terrenos necesarios para la ubicación de las balsas, realizando un descuento de forma alícuota entre los beneficiarios del riego.

- Posibilita ubicar dentro de la zona regable a agricultores sin posesiones en la misma e interesados en el riego.

- Permite, así mismo, sacar de la zona regable y reubicarles en otros sectores de los términos municipales a los propietarios no interesados en la transformación. 
De acuerdo con la planificación efectuada por la Consejería de Agricultura y Ganadería, la zona regable por el canal quedaría dividida en cinco sectores, correspondiendo el sector IV a los términos municipales de Boadilla de Rioseco, Herrín de Campos, Villafrades de Campos y Villalón de Campos.

Teniendo en cuenta que esta zona ya fue concentrada a finales de los años sesenta del siglo pasado, en este caso estaríamos hablando de una segunda concentración parcelaria. De este modo, el proceso de reconcentración parcelaria se inició mediante la solicitud de los cuatro ayuntamientos citados, con el aval de la firma de en torno al $50 \%$ de los propietarios afectados, de acuerdo con los artículos 17 y 71 de la Ley 14/1990, de 28 de noviembre, de Concentración Parcelaria de Castilla y León.

En el capítulo dedicado a la descripción de la zona, se indica que las superficies de los términos municipales afectados son las siguientes (Tabla A1.1):

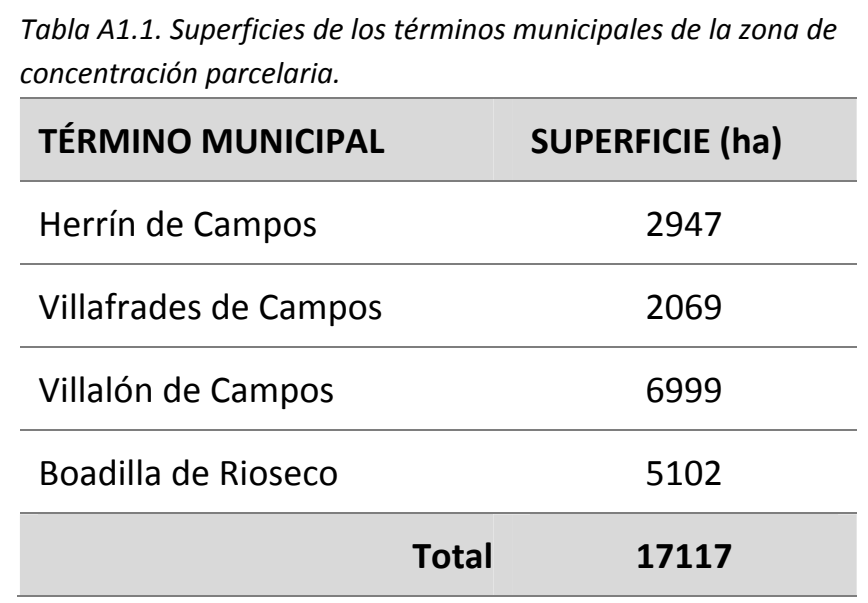

En la tabla A1.2, elaborada con datos del I.N.E. del censo agrario de 1999, se muestra el número de titulares de explotación con actividad sólo en la explotación y el número de titulares con otra actividad lucrativa.

Tabla A1.2. Titulares de explotación.

\begin{tabular}{|c|c|c|c|}
\hline \multicolumn{1}{|c|}{ Municipio } & $\begin{array}{c}\text { Titulares con actividad } \\
\text { sólo en la explotación }\end{array}$ & $\begin{array}{c}\text { Titulares con otra } \\
\text { actividad lucrativa }\end{array}$ & Total \\
\hline Herrín de Campos & 32 & 10 & 42 \\
\hline Villafrades de Campos & 7 & 5 & 12 \\
\hline Villalón de Campos & 110 & 33 & 143 \\
\hline Boadilla de Rioseco & 38 & 24 & 62 \\
\hline \multicolumn{1}{c|}{ Total } & $\mathbf{1 8 7}$ & $\mathbf{7 2}$ & $\mathbf{2 5 9}$ \\
\hline
\end{tabular}


Dentro del análisis agronómico, se recogen los datos básicos (Tabla A1.3) procedentes de los Acuerdos de la anterior concentración parcelaria y los del Catastro, donde se percibe cómo ha evolucionado la propiedad desde 1970 hasta 2000.

Tabla A1.3. Evolución de la propiedad en cada término municipal.

\begin{tabular}{|c|c|c|}
\hline \multicolumn{3}{|c|}{ HERRÍN DE CAMPOS } \\
\hline & Acuerdos Concentración & Catastro actual \\
\hline Número de propietarios & 518 & 362 \\
\hline Número de parcelas & 718 & 1083 \\
\hline Superficie total & 2777 ha & 2947 ha \\
\hline Número de parcelas por propietario & 1,39 & 2,99 \\
\hline Superficie media de las parcelas & 3,87 ha & 2,72 ha \\
\hline Superficie media por propietario & 5,36 ha & 8,14 ha \\
\hline \multicolumn{3}{|c|}{ VILLAFRADES DE CAMPOS } \\
\hline & Acuerdos Concentración & Catastro actual \\
\hline Número de propietarios & 332 & 227 \\
\hline Número de parcelas & 443 & 587 \\
\hline Superficie total & 2010 ha & 2069 ha \\
\hline Número de parcelas por propietario & 1,33 & 2,58 \\
\hline Superficie media de las parcelas & 4,53 ha & 3,52 ha \\
\hline Superficie media por propietario & 6,05 ha & 9,15 ha \\
\hline \multicolumn{3}{|c|}{ VILLALÓN DE CAMPOS } \\
\hline & Acuerdos Concentración & Catastro actual \\
\hline Número de propietarios & 1014 & 799 \\
\hline Número de parcelas & 1283 & 1876 \\
\hline Superficie total & 6685 ha & 6999 ha \\
\hline Número de parcelas por propietario & 1,27 & 1,46 \\
\hline Superficie media de las parcelas & 5,19 ha & 3,52 ha \\
\hline Superficie media por propietario & 6,57 ha & 6,90 ha \\
\hline \multicolumn{3}{|c|}{ BOADILLA DE RIOSECO } \\
\hline & Acuerdos Concentración & Catastro actual \\
\hline Número de propietarios & 641 & 648 \\
\hline Número de parcelas & 1327 & 1436 \\
\hline Superficie total & 4383 ha & 5102 ha \\
\hline Número de parcelas por propietario & 2,07 & 2,21 \\
\hline Superficie media de las parcelas & 3,29 ha & 3,55 ha \\
\hline Superficie media por propietario & 6,82 ha & 7,87 ha \\
\hline
\end{tabular}


Como puede apreciarse, disminuye el número de propietarios como era esperable, dado que entre unos y otros datos han transcurrido en torno a 30 años. En cuanto al aumento de parcelas, obedece al hecho de que en Catastro figuran tanto las incluidas como las excluidas de Concentración.

En el Estudio Técnico Previo se realiza un análisis sobre el aumento del margen bruto agrario como consecuencia de realizar la concentración parcelaria, que se cifra en un $33 \%$ respecto de la situación inicial. En los cultivos de secano las mejoras de la concentración se derivan del incremento de productividad, originado principalmente por la reducción de costes de la maquinaria agrícola. En los cultivos de regadío creados, se pretende aumentar la productividad transformada de M.S. por ha y año hasta las 18-21 t, según el potencial agroclimático de la zona. La alternativa de cálculo se plantea sobre la base de $40 \%$ de proteaginosas y cereales, $20 \%$ de alfalfa, $20 \%$ de maíz, $10 \%$ de girasol y $10 \%$ de remolacha.

En el anteproyecto de obras inherentes a la concentración parcelaria se plantean las siguientes actuaciones:

- Obras de saneamiento: limpieza y dragado de arroyos y desagües en una longitud de $224 \mathrm{~km}$.

- Diseño de una nueva red de caminos, con una longitud total prevista de $390 \mathrm{~km}$. En la zona no regable los caminos actuales se mantienen.

- Obras de fábrica: en los puntos de cruzamiento de los caminos con los arroyos, en aquellos bajos que sea necesario desaguar para el adecuado comportamiento del camino, en los cruces de camino y en los entronques con carreteras u otras vías principales. Consistirán en la colocación de caños de distinto diámetro de acuerdo con la sección hidráulica del desagüe.

- Obras de restauración del medio natural, que se establecerán en el estudio de impacto ambiental y en la declaración de impacto ambiental.

Las directrices que se establecen para elaborar el proyecto de concentración parcelaria son las siguientes:

- Se agrupará en el sector regable a todos los agricultores que demanden regadío, a los que se aplicará un descuento en sus aportaciones con el fin de obtener los terrenos necesarios para ejecutar las infraestructuras de regadío.

- Se procurará adjudicar a cada propietario, en el menor número posible de fincas de reemplazo, un conjunto de superficie y derechos cuyo valor sea igual al que se hubiera asignado en las bases de concentración a las parcelas y derechos que anteriormente poseía.

- Se procurará adjudicar fincas contiguas integradas en una misma explotación, aunque sean de diferentes propietarios.

- Se prevé un camino de circunvalación en cada uno de los municipios que integran la zona de concentración.

- Se pretende la puesta en regadío de una zona compacta de 2050 ha. Para ello, se agruparán las fincas de los propietarios que estén integradas en una misma explotación. 
- La realización de la concentración parcelaria se llevará a cabo siguiendo las directrices que se establezcan en la declaración de impacto ambiental.

A1.1.1.2. Proyecto modificado de concentración parcelaria de la zona de Herrín, Villafrades, Villalón (Valladolid) y Boadilla de Rioseco (Palencia)

Promotor: Consejería de Agricultura y Ganadería. Junta de Castilla y León

Autor: Julio César Mancebo Gordo (ingeniero agrónomo)

Fecha: septiembre 2008

El proceso de concentración parcelaria conlleva la reestructuración de las parcelas y la propiedad de la zona. Esto se lleva a cabo con el proyecto de concentración parcelaria, cuya primera versión corresponde a febrero de 2007, aunque aquí exponemos el documento definitivo fruto de varias modificaciones. Los criterios que se contemplaron a la hora de adjudicar los nuevos lotes fueron los siguientes:

- Atender, en su mayoría y dentro de lo posible, las peticiones formuladas por los propietarios.

- Reunir a los propietarios que pidieron juntos, debido a que constituyen o van a constituir una única explotación.

- A los propietarios residentes en los pueblos colindantes, atribuirles sus nuevas fincas de reemplazo lo más cerca posible de su residencia.

- Evitar, dentro de lo posible, compensaciones grandes entre las distintas clases de tierra.

- Para la adjudicación de los lotes de riego se ha partido de las peticiones realizadas individualmente, pero teniendo también en cuenta el criterio señalado de explotación conjunta.

Para elaborar el proyecto modificado se parte del proyecto y se introducen los cambios convenientes para resolver las alegaciones presentadas.

Con el fin de minimizar los efectos ambientales negativos, se han adjudicado una serie de fincas a "Restauración del medio natural" distribuidas por toda la zona de forma uniforme, de forma que sobre las mismas se lleven a cabo actuaciones de diversa índole (restauración del paisaje, plantación de especies autóctonas, etc.).

El resumen de la concentración parcelaria se muestra en la Tabla A1.4.

\begin{tabular}{lc} 
Tabla A1.4. Datos de la concentración parcelaria \\
\hline Superficie total incluida en la concentración & 16056 ha \\
\hline Superficie total a distribuir en proyecto & 15783 ha \\
\hline Número total de propietarios de la zona & 1275 \\
\hline Número total de parcelas incluidas & 4759 \\
\hline Número medio de parcelas/propietario & 3,74 \\
\hline Superficie media por propietario & $12,61 \mathrm{ha}$ \\
\hline
\end{tabular}




\begin{tabular}{lc}
\hline Superficie media por parcela & 3,37 ha \\
\hline Número de cultivadores & 104 \\
\hline Número de fincas de reemplazo de los propietarios & 2365 \\
\hline Número medio de fincas por propietario & 1,85 \\
\hline Superficie media por finca & 6,67 \\
\hline Índice de reducción & 2,01 \\
\hline
\end{tabular}

\section{A1.1.1.3. Acuerdo de concentración parcelaria de la zona de Herrín, Villafrades,} Villalón (Valladolid) y Boadilla de Rioseco (Palencia)

Promotor: Consejería de Agricultura y Ganadería. Junta de Castilla y León

Autor: Julio César Mancebo Gordo (ingeniero agrónomo)

Fecha: julio 2009

Una vez resueltas las alegaciones, elaborado el proyecto definitivo y valoradas las numerosas reclamaciones, se redacta el Acuerdo de concentración parcelaria. A partir de los planos parcelarios de las Bases, y con el dibujo de la red de caminos y obras proyectadas, se han confeccionado 23 polígonos (Figura A1.1). Estos se numeran de forma que cada centena corresponde a cada uno de los diferentes municipios. Cada polígono se divide en masas, numeradas independientemente para cada uno; todas ellas han sido planimetradas, así como sus distintas clases de tierra.

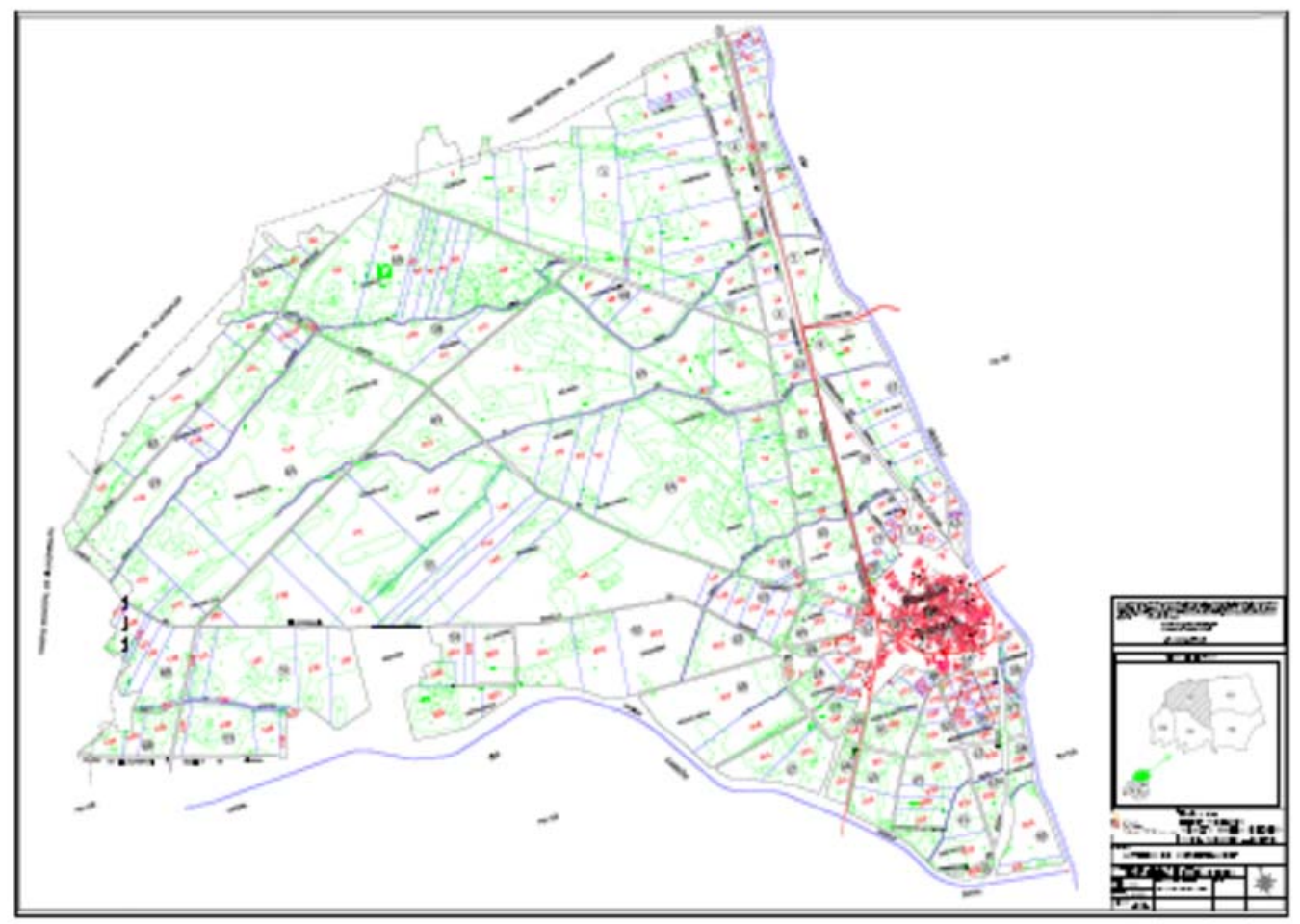

Figura A1.1. Imagen de la parcelación del polígono 101 de Boadilla de Rioseco, recogida en el Acuerdo de concentración parcelaria. 
Se ha aplicado un coeficiente general de reducción de la zona, que es del 0,98 para la superficie de secano y del 0,91 para las fincas de regadío, teniendo en cuenta en este último caso la construcción de una gran balsa, que ocupa una superficie aproximada de 145 ha.

En la Tabla A1.5 aparecen reflejados los datos definitivos de la concentración parcelaria, en comparación con los anteriores a este proceso.

Tabla A1.5. Resumen de la concentración parcelaria

\begin{tabular}{lrr}
\hline & ANTES & \multicolumn{1}{c}{ DESPUÉS } \\
\hline Superficie total incluida en la concentración & 16056 ha & 16008 ha \\
\hline Superficie total a distribuir en proyecto & 15776 ha & 15877 ha \\
\hline Número total de propietarios de la zona & 1266 & 1260 \\
\hline Número total de parcelas incluidas & 4759 & 2310 \\
\hline № medio de parcelas/propietario & 3,76 & 1,83 \\
\hline Superficie media por propietario & 12,68 ha & 12,60 ha \\
\hline Superficie media por parcela & 3,37 ha & 6,87 ha \\
\hline No de lotes de masa común & & 73 \\
\hline No de lotes de Restauración del Medio Natural & & 80 \\
\hline Superficie de Masa Común & & 282,58 ha \\
\hline Superficie Restauración del Medio Natural & & 24,4180 ha \\
\hline
\end{tabular}

\section{A1.1.1.4. Proyecto de infraestructura rural de la zona de concentración parcelaria de Herrín, Villafrades, Villalón y Boadilla de Rioseco-Fase I (Valladolid- Palencia)}

Promotor: Consejería de Agricultura y Ganadería. Junta de Castilla y León

Autor: Moisés Redondo Gil (ingeniero agrónomo)

Fecha: junio 2008

Tal como hemos señalado anteriormente, el proceso de concentración parcelaria de una determinada zona conlleva un procedimiento largo y complejo. Una vez aprobadas las bases provisionales, acordada la encuesta y aprobadas las bases definitivas, se redacta este proyecto como solución técnica adoptada para la materialización de la infraestructura rural de la zona, que engloba los términos municipales de Herrín de Campos, Villafrades de Campos, Villalón de Campos y Boadilla de Rioseco. Es decir, una vez que se ha definido el parcelario y la traza de las infraestructuras públicas, se proyectan las obras a realizar en ellas.

Las características generales de las actuaciones contempladas en este proyecto son las siguientes: 
1.- Red de caminos. Se plantean tres secciones tipo:

- Sección tipo I: caminos de nueva apertura con plataforma de $6 \mathrm{~m}$ de ancho y cunetas triangulares de $1,5 \mathrm{~m}$ de ancho y $0,75 \mathrm{~m}$ de profundidad. Los taludes son $1 \mathrm{~V} / 1 \mathrm{H}$ para el desmonte y $2 \mathrm{~V} / 3 \mathrm{H}$ para el terraplén. La longitud total es de $128815 \mathrm{~m}$.

- Sección tipo II: caminos de nueva apertura con plataforma de $10 \mathrm{~m}$ de ancho, y cunetas triangulares de $2 \mathrm{~m}$ de ancho y $1 \mathrm{~m}$ de profundidad. Se corresponden con circunvalaciones a los núcleos de Boadilla de Rioseco y Villalón de Campos. Iguales pendientes de taludes a los anteriores. La longitud total es de $11467 \mathrm{~m}$.

- Sección tipo III: caminos existentes que se acondicionan hasta formar una plataforma de $6 \mathrm{~m}$ de ancho y cunetas triangulares de 1,50 $\mathrm{m}$ de ancho y 0,75 $\mathrm{m}$ de profundidad, de igual pendiente. La longitud total de estos caminos es de 202859 $\mathrm{m}$.

Se proyectan las obras de fábrica necesarias para el saneamiento de los caminos, así como para salvar las interferencias de estos entre sí.

El afirmado de los caminos de circunvalación, caminos principales y los situados en las zonas de regadío se realizará con $20 \mathrm{~cm}$ de zahorra natural más $3 \mathrm{~cm}$ de sellado con material arena-arcilla. En el resto de caminos o tramos, $10 \mathrm{~cm}$ de zahorra natural más $3 \mathrm{~cm}$ de sellado. Se empleará un total de $343888 \mathrm{~m}^{3}$ de zahorra.

2.- Red de desagües. Se mantiene la red actual, si bien es necesaria la limpieza de todos los desagües. Se plantean tres secciones tipo:

- Sección tipo I: sección trapecial de $1 \mathrm{~m}$ de base, talud $1 / 1$ y calado variable entre 1,70 $\mathrm{m}$ y $1,20 \mathrm{~m}$. La longitud total es de $157371 \mathrm{~m}$.

- Sección tipo Il: sección trapecial de $2 \mathrm{~m}$ de base, talud $1 / 1$ y calado variable que oscila entre $1,00 \mathrm{~m}$ y 2,00 m. La longitud total es de $119412 \mathrm{~m}$.

- Sección tipo III: sección trapecial de $3 \mathrm{~m}$ de base, talud $1 / 1$ y calado variable que oscila entre $1,50 \mathrm{~m}$ y $3,00 \mathrm{~m}$. La longitud total es de $18572 \mathrm{~m}$.

En los desagües con mayor caudal se proyectan marcos prefabricados de diferentes dimensiones. También se plantean escolleras de roca en $810 \mathrm{~m}$.

Se demolerán las obras de fábrica innecesarias que obstaculicen el paso de desagües o en aquellos casos que, por necesidades de sección, sea preciso sustituirlas por otra.

Se contemplan 13 pasos/puentes peatonales sobre cursos de agua en las antiguas vías del ferrocarril, con vigas de madera tratadas y protegidos con barandilla de rollizos de pino tratados al autoclave. En los cruces de estas vías con los caminos se colocan barreras con rollizos de madera de pino.

El presupuesto de ejecución material es el siguiente:

1.- Red de caminos $8791830,89 €$

2.- Red de desagües $521269,40 €$ 
3.- Demoliciones y acondicionamientos $34869,68 €$

4.- Seguridad y salud $85960,23 €$

TOTAL $9433930,20 €$

3,53\% Actualización de tarifas 2008 $333017,74 €$

PRESUPUESTO DE EJECUCIÓN MATERIAL. $9766947,94 €$

\author{
A1.1.1.5. Proyecto modificado del proyecto de infraestructura rural de la zona de \\ concentración parcelaria de Herrín, Villafrades, Villalón y Boadilla de \\ Rioseco-Fase I (Valladolid-Palencia) \\ Promotor: Consejería de Agricultura y Ganadería. Junta de Castilla y León \\ Autor: Óscar J. Ramírez del Palacio (ingeniero agrónomo) \\ Fecha: abril 2013
}

Se redacta este proyecto como consecuencia de la problemática sobrevenida a lo largo del proceso de concentración parcelaria y del desarrollo del proyecto de infraestructura original: alteraciones en la distribución de la propiedad, aumento de la red de caminos, incremento del número y dimensión de las obras de fábrica de evacuación de las aguas, demolición y retirada a vertedero de los antiguos elementos de hormigón, rediseño de estructuras para asegurar la continuidad de la vía verde sobre el ferrocarril, etc.

En la memoria del proyecto se vuelven a contemplar con más detalle las características generales de las obras:

1.- Red de caminos.

Se proyecta una red de caminos con una longitud total de $330538 \mathrm{~m}$. Se proyectan dos tipos de trazas: los caminos o tramos de caminos de nueva apertura y los que ya existen. Entre estos últimos, se diferenciará aquellos que ya dispongan de una base granular y los que no. En cada caso se realizarán diferentes actuaciones, para su corrección, reparación y acondicionamiento.

En cuanto al movimiento de tierras, se ha trazado la rasante procurando equilibrar los desmontes y terraplenes con el fin de evitar distancias de transporte superiores a $500 \mathrm{~m}$. Se realizará la retirada de $10 \mathrm{~cm}$ de espesor de tierra vegetal en un volumen de $173908 \mathrm{~m}^{3}$, que se extenderá en las inmediaciones de los caminos o en ellos mismos. El volumen total de desmonte asciende a $282372 \mathrm{~m}^{3}$, y el de terraplén a $225166 \mathrm{~m}^{3}$; teniendo en cuenta un coeficiente de compactación de 1,15, se emplearán $258941 \mathrm{~m}^{3}$ de tierra procedente del desmonte, con lo que resta un sobrante de $23430,48 \mathrm{~m}^{3}$ medidos sobre terreno natural. Dada la escasa magnitud de los sobrantes $\left(0,07 \mathrm{~m}^{3} / \mathrm{m}\right.$ de camino), estos se extenderán en las inmediaciones de los caminos o en ellos mismos.

En relación con las secciones tipo, la práctica totalidad de los caminos que componen la red se construyen o acondicionan con una anchura de plataforma de $6 \mathrm{~m}$, que corresponden con las 
secciones tipo I y tipo III. Para los caminos de circunvalación de las poblaciones de Boadilla de Rioseco y Villalón de Campos, denominados con los mismos nombres, se construyen con plataforma de 8,6 m, que corresponden con la sección tipo II. Por último, se incluyen varias sendas en tierra compactada (sección tipo IV), como vías terminales que permiten el acceso a varias fincas de reemplazo.

Las secciones tipo son las siguientes:

- SECCION TIPO I: Caminos de nueva apertura con plataforma de 6,00 $\mathrm{m}$ de ancho entre aristas interiores y cunetas triangulares de $1,50 \mathrm{~m}$. de ancho y $0,75 \mathrm{~m}$ de profundidad. Los taludes son $1 \mathrm{~V} / 1 \mathrm{H}$ para el desmonte y el terraplén. El bombeo transversal es del 2 \%. La longitud total de caminos con esta sección es de $157876 \mathrm{~m}$.

- SECCION TIPO II: Caminos de nueva apertura con plataforma de 8,60 $\mathrm{m}$ de ancho entre aristas interiores y cunetas triangulares de $2,00 \mathrm{~m}$. de ancho y $1,00 \mathrm{~m}$ de profundidad. Los taludes son $1 \mathrm{~V} / 1 \mathrm{H}$ para el desmonte y el terraplén. El bombeo transversal es del 2 $\%$. La longitud total de caminos con esta sección es de $11395 \mathrm{~m}$.

- SECCION TIPO III: Caminos existentes que se acondicionan hasta formar una plataforma de $6,00 \mathrm{~m}$ de ancho entre aristas interiores y cunetas triangulares de 1,50 m. de ancho y $0,75 \mathrm{~m}$ de profundidad. Los taludes son $1 \mathrm{~V} / 1 \mathrm{H}$ para el desmonte y el terraplén. El bombeo transversal es del $2 \%$. La longitud total de caminos con esta sección es de $155608 \mathrm{~m}$. Dentro de este grupo se diferencian dos tipologías de caminos, según posean o no un firme de material granular previo. Así, en el caso de disponer de una base o subbase, en todo o parte de su trazado, se realizarán diversas actuaciones de corrección y reparación de la misma (desyerbe, escarificado, limpieza de cuentas y compactación). Este grupo de caminos tiene $27055 \mathrm{~m}$ de longitud total.

- SECCION TIPO IV: Caminos de nueva apertura en tierra compactada. Se realiza un mínimo acondicionamiento, con refino, planeo y compactado de la plataforma, que tendrá $6,00 \mathrm{~m}$ de ancho entre aristas interiores y cunetas triangulares de 1,00 $\mathrm{m}$ de ancho y $0,50 \mathrm{~m}$ de profundidad. Los taludes son $1 \mathrm{~V} / 1 \mathrm{H}$ para el desmonte y $1 \mathrm{~V} / 1 \mathrm{H}$ para el terraplén. El bombeo transversal es del $2 \%$. La longitud de caminos con esta sección es de $5659 \mathrm{~m}$.

Se proyectan las obras de fábrica necesarias para el saneamiento de los caminos, así como para salvar las interferencias de estos entre sí. Para estos casos se emplean pasos salvacunetas de $\varnothing$ 50 y $60 \mathrm{~cm}$ con sus correspondientes paramentos, así como caños de $\varnothing 40,50,60,80$ y $100 \mathrm{~cm}$, con sus arquetas y embocaduras.

Se realizará el afirmado con material granular seleccionado a tamaño máximo 2" en todos los caminos. Se adoptan los siguientes espesores de firme:

- Caminos de circunvalación de poblaciones, caminos principales y los situados en las zonas de regadío: $20 \mathrm{~cm}$ de zahorra más $3 \mathrm{~cm}$ de sellado con material arena-arcilla.

- Caminos existentes, con firme de material granular: $7 \mathrm{~cm}$ de zahorra.

- Resto de caminos: $10 \mathrm{~cm}$ de zahorra. 
Se empleará un total de $314351 \mathrm{~m}^{3}$ de zahorra natural, que se prevé extraer de explotaciones de áridos situadas en la zona de terrazas del río Cea, en las proximidades de la localidad de Mayorga (Valladolid).

Los caminos de circunvalación de poblaciones, caminos principales y los situados en las zonas de regadío se rematarán con $3 \mathrm{~cm}$ de material arena-arcilla como sellado y cierre del firme de las zahorras. En total se emplearán $21224 \mathrm{~m}^{3}$ de material arena-arcilla.

En los entronques de los caminos con las carreteras y en los accesos a las poblaciones (94 en total), se construirá, a lo largo de $30 \mathrm{~m}$ de camino y en toda su anchura, un pavimento de hormigón de $20 \mathrm{~cm}$ de espesor armado con malla electrosoldada.

\section{2.- Red de desagües.}

En relación con el trazado, se mantiene la red actual, si bien es necesaria la limpieza de todos los desagües, pues con el paso del tiempo y debido fundamentalmente al arrastre de sólidos se han ido tapando. Esto hace que su funcionalidad sea deficiente, produciéndose encharcamientos en las fincas colindantes. Las tierras procedentes de la excavación y limpieza se extenderán en las parcelas colindantes.

Se contemplan las siguientes secciones tipo:

- SECCION TIPO I: Sección trapecial de $1 \mathrm{~m}$ de base, talud variable según características del terreno natural y calado variable que oscila entre $0,70 \mathrm{~m}$. y 1,20 m. La longitud total es de $140261 \mathrm{~m}$.

- SECCION TIPO II: Sección trapecial de $2 \mathrm{~m}$ de base, talud variable según características del terreno natural y calado variable que oscila entre $1,00 \mathrm{~m}$ y $2,00 \mathrm{~m}$. La longitud total es de $110213 \mathrm{~m}$.

- SECCION TIPO III: Sección trapecial de $3 \mathrm{~m}$ de base, talud variable según características del terreno natural y calado variable que oscila entre $1,50 \mathrm{~m}$ y 3,00 m. La longitud total es de $9957 \mathrm{~m}$.

En cuanto a las obras de fábrica y elementos prefabricados, se proyectan en los desagües con mayor caudal marcos prefabricados de hormigón armado de diferentes dimensiones. Se proyectan 16 marcos de $2 \times 1,5 \mathrm{~m}$ y 3 marcos de $3 \times 2 \mathrm{~m}$. En determinados casos, se protege con escollera de roca de $30-60 \mathrm{~cm}$ de diámetro, necesitándose un volumen total de $5716 \mathrm{~m}^{3}$. En los cruces de los desagües menores con los caminos, donde se realicen con caños y la pendiente del desagüe sea elevada, se construye, en todo el perímetro del desagüe un revestido de hormigón de $15 \mathrm{~cm}$ de espesor y $5 \mathrm{~m}$ de longitud a la entrada y a la salida del caño, actuándose en $265 \mathrm{~m}^{2}$. En los marcos se coloca protección mediante barandilla metálica de acero galvanizado tipo jamón, de 1,20 $\mathrm{m}$ de altura con tubos de $38 \mathrm{~mm}$ de diámetro y $1,5 \mathrm{~mm}$ de espesor.

Por otra parte, con el objetivo de mejorar el saneamiento de diversas zonas se deberán ejecutar 22 nuevos desagües, que en total suman $9522 \mathrm{~m}$. En ocasiones, serán actuaciones puntuales en parcelas, o bien con esta nueva actuación se buscará la mejora de la red de desagües, conectando otros ya proyectados, o prolongando su recorrido inicial. 


\section{3.- Demoliciones y acondicionamientos.}

Se demolerán las obras de fábrica innecesarias que obstaculicen el paso de los desagües o en aquellos casos que, por necesidades de sección, sea preciso sustituirlas por otra. También se demolerán los caños existentes en los caminos actuales que se conservan, y que estén obstruidos.

La estimación de los residuos que se van a generar se codifica según la Lista Europea de Residuos publicada por Orden MAM/304/2002 de 8 de febrero y sus modificaciones posteriores. Asimismo, será de aplicación el R.D. 1481/2001, de 27 de diciembre, por el que se regula la eliminación de residuos mediante depósito en vertedero. Según estas normas, todos los residuos que se generarán serán de nivel II: generados principalmente en las actividades de la obra civil, incluidas las demoliciones. Se trata de residuos no peligrosos, que no experimentan transformaciones físicas, químicas o biológicas significativas. Por tanto, estos residuos serán inertes, no solubles ni combustibles, ni afectan negativamente a otras materias con las que entren en contacto de forma que pudieran dar lugar a contaminación del medio ambiente o perjudicar a la salud humana.

Se estima que se generarán $556 \mathrm{~m}^{3}$ de residuos de naturaleza pétrea (hormigón) y $18 \mathrm{~m}^{3}$ de naturaleza no pétrea (asfalto). Al no estar prevista su reutilización ni su valorización "in situ", se incluirán partidas específicas para su transporte y posterior gestión en vertederos autorizados.

En cuanto a los acondicionamientos, estando prevista la utilización de las antiguas líneas de ferrocarril como sendas de paseo y teniendo en cuenta que a lo largo del trazado existen 11 puntos donde están interrumpidas por pasos de agua abiertos, para dar continuidad a estas sendas se construyen pasos peatonales sobre los estribos existentes mediante vigas de madera de pino tratada al autoclave de 200×140 mm de sección y tarima de pino de $30 \mathrm{~mm}$ de espesor. Estos pasos tendrán unas dimensiones de $2 \times 1,5 \mathrm{~m}$ e irán protegidos por barandilla de rollizos de pino al autoclave de $12 \mathrm{~cm}$ de diámetro formada por postes, dos largueros horizontales y larguero transversal. En los cruces de estas vías con los caminos de proyecto se colocan barreras de madera de pino con rollizos de $12 \mathrm{~cm}$ de diámetro, formado por postes de 1,50 m de alto, larguero de 2,00 m y larguero diagonal. También se estiman necesarios 21 pasos de dimensiones más reducidas.

\section{4.- Señalización y protecciones.}

En este apartado se contempla la colocación de diversas señales: informativa, STOP, límite de velocidad, prohibido giro, camino cortado y límite de peso. También se incluye una losa de protección de tubería oleoducto, la sustitución de poste telefónico y una valla para el cercado de finca.

Finalmente, señalar que el presupuesto de ejecución material del proyecto modificado es de 10493.120 €, que representa un incremento del 7,43 \% respecto del presupuesto de ejecución material actualizado del proyecto original. 


\section{A1.1.2. Condicionantes ambientales}

A1.1.2.1. Estudio de Impacto Ambiental de la concentración parcelaria y transformación en regadío del sector IV Esla-Carrión (Palencia, Valladolid)

Promotor: Consejería de Agricultura y Ganadería. Junta de Castilla y León

Autores: Marcos del Pozo Manrique (ingeniero de montes), Mạ Jesús Rodrigo Gómez (ingeniero agrónomo) y Óscar García Cardo (ingeniero de montes)

Fecha: marzo 2003

Este Estudio evalúa en un mismo documento la repercusión ambiental de ambos proyectos de concentración parcelaria y transformación en regadío en los términos municipales de Herrín de Campos, Villafrades de Campos, Villalón de Campos y Boadilla de Rioseco. La ubicación en la Zona de Especial Protección para las Aves "La Nava-Campos" (norte y sur) hace que se hayan detallado las actuaciones que pueden afectar a los valores naturales de esta ZEPA (Figura A1.2).

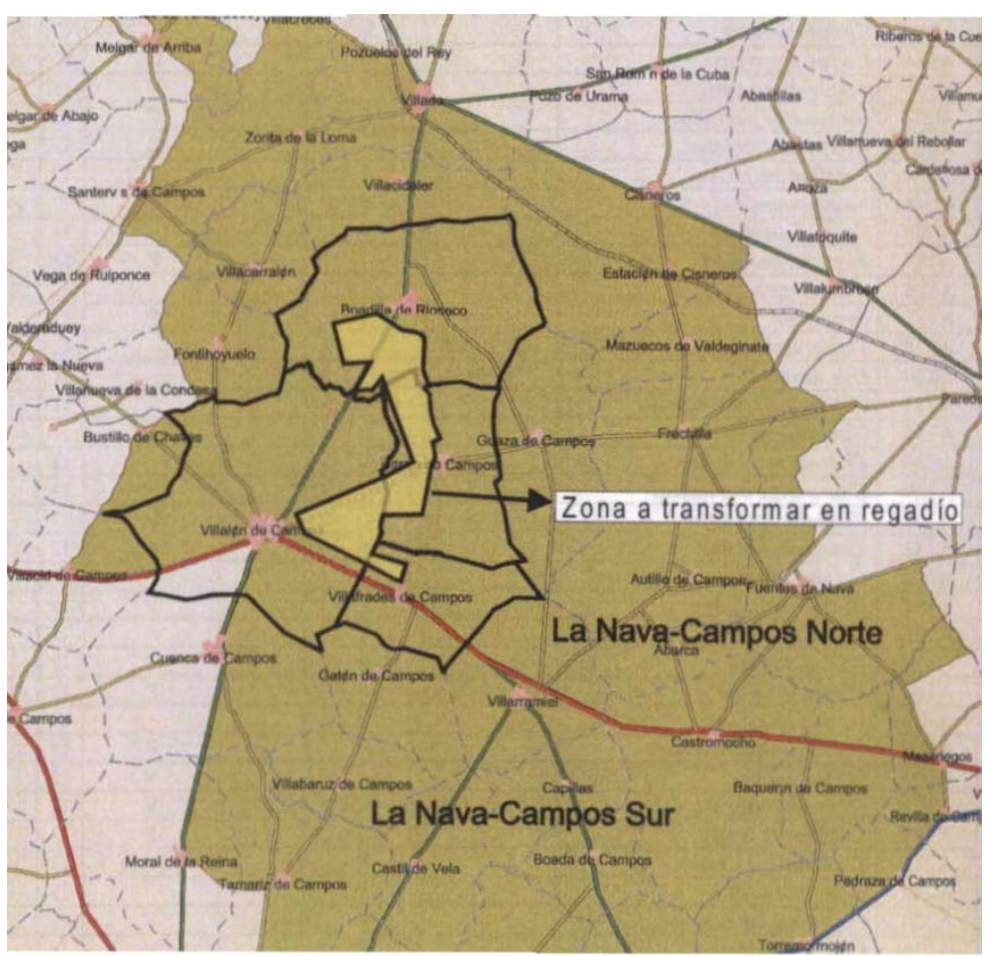

Figura A1.2. Situación de la zona de concentración parcelaria y transformación en regadío en el interior de la ZEPA La Nava-Campos.

Las principales medidas preventivas, protectoras y compensatorias que se proponen para la integración ambiental del proyecto son:

- Campañas informativas a los agricultores, asesorándoles en lo que se refiere a prácticas agrícolas, tipos de cultivos y protección de flora y fauna.

- Conservación y restauración vegetal de regueros, linderos y bordes de caminos, en una superficie mínima de 40 ha. 
- Elección de una época para la realización de las obras poco impactante para la avifauna.

- Incorporación a los tendidos eléctricos tanto existentes como proyectados de elementos que permitan su visualización e impidan la colisión de la avifauna esteparia.

- Restauración vegetal en aquellos puntos donde se requiera (taludes de la balsa de regulación, riberas, acequias, bordes de caminos, etc.).

- Creación de pasillos vegetales en la superficie a transformar en regadío para permitir el paso y tránsito de la fauna.

- Construcción de filtros verdes como depuradoras en los pueblos afectados.

- Establecimiento y señalización de senderos de pequeño recorrido aprovechando las vías pecuarias como caminos tradicionales.

- Restauración de palomares con vistas a ser empleados por el cernícalo primilla para su cría y reproducción.

- Construcción de bebederos seminaturales por su importancia para algunas aves esteparias.

- Restauración de varias escombreras.

- Seguimiento y estudio de la avifauna esteparia tras la implantación del regadío para poder evaluar el impacto y su adaptabilidad a este tipo de proyectos y así tomar medidas al respecto.

- Restauración vegetal de las inmediaciones de las principales fuentes, incluyendo en el dominio público aquellas que no lo están en la actualidad.

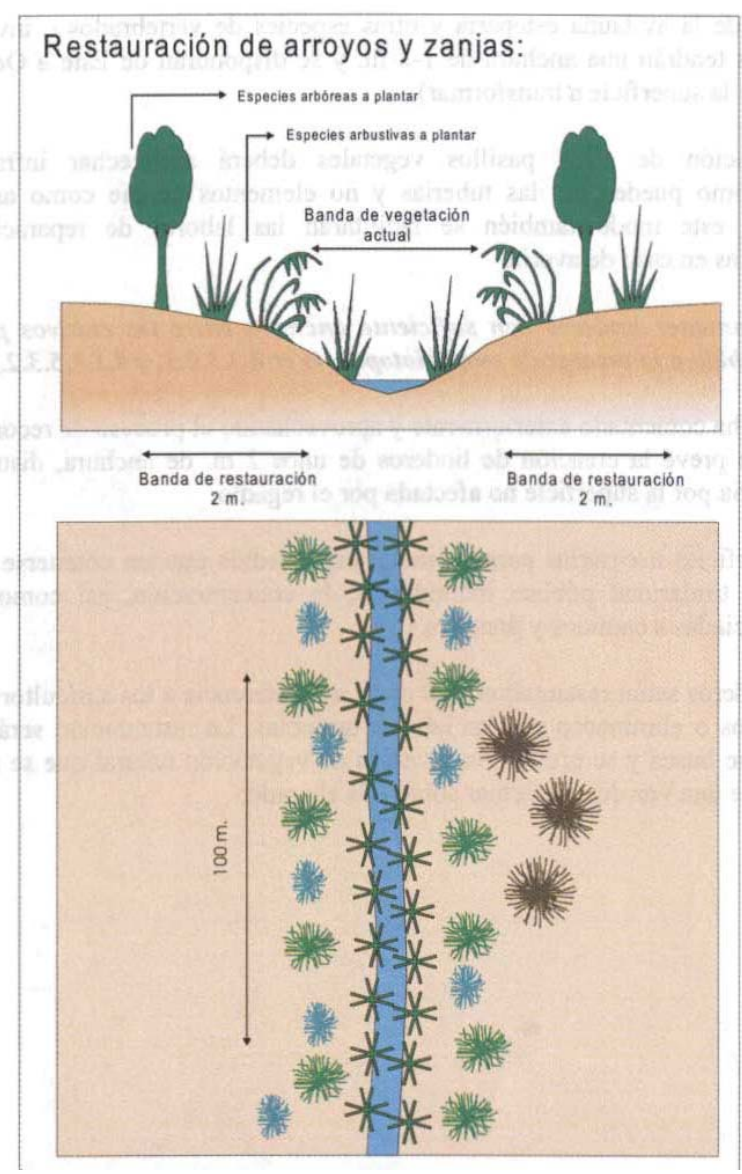

Figura A1.3. Modelo para la restauración de arroyos y desagües en la concentración parcelaria, extraído del Estudio de Impacto Ambiental. 
A1.1.2.2. Declaración de Impacto Ambiental, hecha pública por Resolución de 23 de octubre de 2003, de la Consejería de Medio Ambiente (BOCyL 31/10/2003).

La Declaración de Impacto Ambiental informa favorablemente el desarrollo de los proyectos de concentración parcelaria y transformación en regadío en los términos municipales de Herrín de Campos, Villafrades de Campos, Villalón de Campos y Boadilla de Rioseco, sujetos a una serie de condiciones. Las medidas preventivas o correctoras referidas al paisaje o a su restauración, además de las contempladas en el Estudio de Impacto Ambiental, son las siguientes (se mantiene la numeración original):

3.b) Se retirarán de forma selectiva los suelos ocupados por la traza de los nuevos caminos, balsa de riego, red de canalizaciones y otras zonas a alterar, reservando la tierra vegetal para su utilización en la restauración de los márgenes, zanjas, taludes y demás terrenos afectados. El sobrante, si lo hubiere, se utilizará para la restauración de otros espacios degradados de los cuatro términos municipales.

3.c) Con objeto de proteger las escasas zonas arboladas o ejemplares aislados, las parcelas con árboles deberán ser adjudicadas en el proceso de concentración parcelaria, en la medida de lo posible, a los propietarios actuales o bien a alguna administración pública.

Durante las obras se deberán adoptar precauciones para evitar o reducir la afección a zonas de arbolado, rodales, setos, alineaciones arbóreas o arbustivas singulares y especies vegetales de interés.

Se procurará que el drenaje de las regueras y arroyos afecte a la menor extensión superficial posible, respetándose escrupulosamente los ejemplares arbóreos y arbustivos existentes.

3.e) Con carácter general, las obras que se realicen en los caminos situados fuera de la zona regable serán exclusivamente de acondicionamiento, debiendo mantenerse sus trazas actuales.

Cuando se acondicionen los caminos deberán restaurarse las posibles zonas de vertido incontrolado de escombros que existan en sus proximidades. Incluso en determinados casos (caminos que conduzcan a ermitas, áreas recreativas o lugares de interés) se planteará la realización de plantaciones arbóreas o arbustivas en sus márgenes.

3.h) Se deberán restaurar las explotaciones de áridos utilizadas para el préstamo de materiales necesarios en la obra.

3.o) Se realizará un inventario de todas las fuentes existentes en los cuatro términos municipales afectados, con objeto de proceder a su acondicionamiento. En la fase de concentración parcelaria se deberá adjudicar a cada fuente una parcela de propiedad pública o de masa común, con una superficie mínima de una hectárea, dotándola del acceso correspondiente. La restauración de las fuentes deberá contemplar el arreglo de los depósitos, la construcción de abrevaderos, la plantación de árboles y arbustos y la adecuación recreativa.

El resto de parcelas públicas deberán dedicarse preferentemente a la mejora del medio natural, realizándose en ellas plantaciones arbóreas y arbustivas con especies autóctonas o propias de la zona. Teniendo en cuenta la escasez de espacios arbolados en los cuatro términos 
municipales, se intentará que las parcelas queden distribuidas por todo el territorio, de forma que constituyan refugios para la fauna y reservorios de biodiversidad.

3.p) Se procederá al deslinde, amojonamiento y señalización de todas las vías pecuarias que discurran por los términos municipales afectados. Posteriormente se deberá proceder a su restauración, que incluirá en su caso la retirada de escombros, la posible restitución topográfica y la realización de plantaciones arbóreas y arbustivas en sus bordes laterales, de forma que constituyan corredores ecológicos e itinerarios recreativos compatibles con el uso ganadero.

3.q) Se deberá restaurar como vía verde la antigua vía del ferrocarril de vía estrecha, en sus dos ramales (Villalón de Campos-Villada y Villalón de Campos-Palencia). Se incluirá la reposición de los pequeños puentes, la restitución topográfica en su caso, el acondicionamiento como camino para el tránsito de paseantes y ciclistas y la restauración vegetal en sus márgenes.

3.r) Se realizarán plantaciones arbustivas en las linderas que separan las parcelas y los márgenes de regueras y arroyos. En el caso de las linderas, tendrán una anchura mínima de 1,5 m; en el de los arroyos tendrán dos bandas a ambos lados de $2 \mathrm{~m}$ y, para los desagües, las bandas serán de $1 \mathrm{~m}$.

5. La Consejería de Agricultura y Ganadería deberá redactar proyectos de restauración, preferiblemente independientes, correspondientes a la concentración parcelaria y transformación en regadío.

A1.1.2.3. Proyecto de restauración del medio natural y adecuación ambiental de la zona de concentración parcelaria de Herrín, Villafrades y Villalón de Campos (Valladolid) y Boadilla de Rioseco (Palencia)

Promotor: Consejería de Agricultura y Ganadería. Junta de Castilla y León

Autores: Cristóbal Herranz Rosa (ingeniero agrónomo)

Fecha: borrador de alcance abril de 2014

El proyecto se redacta para paliar los efectos ambientales negativos de la concentración parcelaria. Durante este proceso se han creado 86 parcelas de Restauración del medio natural, que ocupan una superficie de 33,92 ha. También se identifican 28 fuentes en los cuatro términos municipales, a los que se ha dotado de una superficie pública de al menos 1 ha (a la mayoría) y de acceso.

Se considera que los objetivos de la restauración propuesta son los siguientes:

- Importancia paisajística

- Importancia ecológica: refugio y corredor para la fauna

- Importancia para el mantenimiento de la calidad de las aguas

- Importancia desde el punto de vista técnico o estructural

Se incluyen las siguientes unidades de obra: 


\section{1.- Plantaciones}

Se realizarán en la vía verde, en las parcelas de restauración del medio natural, en fuentes y en algún tramo de caminos y arroyos. La preparación del terreno se efectuará con tractor con rejón o con retroexcavadora, según el caso; la profundidad mínima es de $40 \mathrm{~cm}$, variando según el tamaño de la planta. Se prevén varios tratamientos: abonado, realización de alcorques, colocación de protectores $y$, en algún caso, de tutores, así como un primer riego de implantación. Se utilizará planta a raíz desnuda y planta en envase.

\section{2.- Acondicionamiento y restauración de fuentes}

Se incluyen partidas para la limpieza, rehabilitación de las fuentes, creación de lagunas ornamentales, zonas de ocio y recreo, caminos ornamentales, etc.

\section{3.- Colocación de señales y carteles}

Como complemento a la restauración en las fuentes y acondicionamiento de la vía verde, se colocarán señales y carteles preventivos, normativos, informativos, interpretativos y de hitos kilométricos (en el caso de la vía verde). En cada fuente se colocará un gran cartel informativo de medidas $85 \times 60 \mathrm{~cm}$. Para la vía verde se seguirá el manual de señalización elaborado por la Fundación de los Ferrocarriles Españoles.

A continuación se realizará una descripción sucinta de cada una de las actuaciones:

\section{1.- Plantaciones en fincas de Restauración del Medio Natural}

Se cuenta con 86 nuevas fincas, que ocupan una superficie asignada de 33,92 ha. Se delimitarán perfectamente estas parcelas, mediante la revisión del replanteo, amojonado y realización de una pequeña zanja en todo su perímetro mediante doble pase de motoniveladora (uno para abrir el surco de deslinde de la parcela y otro para nivelar la tierra extraída).

En las zanjas de separación de fincas se plantarán rodales de especies arbustivas, de tal modo que servirán de divisoria para evitar su ocupación por los propietarios colindantes.

En el resto de la parcela se llevarán a cabo tres tipos de plantaciones diferentes: tipo I para zonas húmedas-arroyos (20,13 ha), tipo II zonas secas I (5,01 ha) y tipo III zonas secas II (8,78 ha).

\section{2.- Plantaciones en fincas del entorno del Canal Cea-Carrión}

Se realizarán plantaciones en una superficie de 7,92 ha que corresponden a Masa Común próximas al Canal Cea-Carrión, no aptas para el cultivo y que contribuirán a integrar paisajísticamente esta infraestructura hidráulica. Se utilizarán los dos tipos de plantación para zonas secas.

3.- Plantaciones en vías pecuarias, bordes y linderos de caminos

Esta actuación se llevará a cabo en los caminos de circunvalación a Villalón de Campos y Boadilla de Rioseco que tienen un sobreancho y que pueden albergar árboles en uno o ambos márgenes. Estos caminos coinciden con vías pecuarias. En general se eligen almendros, cipreses, acacias y olmos. Serán plantaciones lineales, con separación entre ejemplares de $8 \mathrm{~m}$. 
También se plantarán arbustos en los taludes mayores de $3 \mathrm{~m}$ de algunos caminos, estimándose una longitud de plantación de $10 \mathrm{~km}$. Se eligen retamas, endrinos, escaramujos y romeros.

\section{4.- Acondicionamiento de las fuentes y su entorno}

En esta actuación se contemplan plantaciones de árboles y arbustos (incluyéndose alguno singular), limpieza del entorno, acondicionamiento de los pequeños edificios de las fuentes, reparación y sellado de abrevaderos y, en cuatro de ellas, creación de lagunas ornamentales de $200 \mathrm{~m}^{2}$.

5.- Acondicionamiento del trazado de ferrocarril para su uso como vía verde

Se plantea la rehabilitación del antiguo trazado del ferrocarril como vía verde, dando continuidad al tramo ya establecido entre Cuenca de Campos y Villalón de Campos (Vía Verde de Tierra de Campos), desde Villalón de Campos hasta Boadilla de Rioseco. Se llevarán a cabo las siguientes subactuaciones:

- Mejora del nivel de forestación a lo largo de todo el trazado $(11,1 \mathrm{~km})$ y en las áreas de descanso

- Acondicionamiento de la plataforma existente

- Mejora y limpieza de la red de evacuación de aguas de escorrentía

- Limpieza, poda, desbroce de márgenes y sacas de áreas de forestación incontrolada

- Creación de nuevas áreas de descanso

- Instalación de nuevo mobiliario, pasarelas y barandillas

- Reparación de la infraestructura dañada

- Colocación de carteles, señales e hitos kilométricos y paneles informativos e interpretativos temáticos

\section{6.- Restauración de vertederos}

Se contempla la restauración del vertedero municipal de Villalón de Campos, en una superficie de 2,53 ha. Se incluirá el acondicionamiento del terreno, la retirada de materiales y productos de desecho a vertedero controlado y la posterior plantación de árboles y arbustos para zonas secas.

\section{7.- Mantenimiento de plantaciones}

Se administrarán un total de 6 riegos durante la época estival en los dos años posteriores a la plantación. A la vez, se harán labores de mantenimiento, como la limpieza y eliminación de vegetación espontánea y el repaso de alcorques.

El presupuesto de ejecución material del proyecto de restauración, por capítulos, es el siguiente (Tabla A1.6): 
Tabla A1.6. Presupuesto del proyecto de restauración.

\begin{tabular}{|c|c|c|c|}
\hline Capítulo & Resumen & Importe (€) & $\%$ \\
\hline 1 & Plantaciones en fincas de Restauración del Medio Natural & 50216 & 17,29 \\
\hline 2 & Plantaciones en fincas del entorno del canal Cea-Carrión & 5906 & 2,03 \\
\hline 3 & Plantaciones en vías pecuarias, bordes y linderos de caminos & 30599 & 10,54 \\
\hline 4 & Acondicionamiento de las fuentes y su entorno & 47225 & 16,26 \\
\hline 5 & Acondicionamiento del trazado del ferrocarril como vía verde & 69109 & 23,80 \\
\hline 6 & Restauración de vertederos & 16685 & 5,75 \\
\hline 7 & Mantenimiento de plantaciones & 69693 & 24,00 \\
\hline \multirow[t]{2}{*}{8} & Señalización & 970 & 0,33 \\
\hline & TOTAL & 290403 & 100,00 \\
\hline
\end{tabular}

Teniendo en cuenta que el presupuesto de ejecución material del proyecto modificado de infraestructura rural es de $10493120 €$, el presupuesto del proyecto de restauración supone un $2,77 \%$ del mismo.

\section{A1.1.3. Ejecución}

\section{A1.1.3.1. Seguimiento de la obra e informes de vigilancia ambiental.}

Dentro de los proyectos analizados en el Anejo 1, este es el que se ha estudiado con mayor detalle, dado que las concentraciones parcelarias son las actuaciones más significativas y de mayor alcance en el paisaje rural agrario y, en particular, en el de Tierra de Campos. Este argumento, y el hecho de que la zona afectada por el proyecto sea la natural y de residencia del autor, hace que las "visitas de obra" hayan sido innumerables. Como referencia, cabe citar las 23 fechas en que se han realizado fotografías de modo sistemático: 16/11/09, 18/8/10, 20/8/10, 28/8/10, 13/9/10, 19/9/10, 23/11/10, 21/3/11, 15/8/11, 18/8/11, 23/9/11, 25/9/11, 3/10/11, $25 / 10 / 11,28 / 1 / 12,17 / 3 / 12,28 / 3 / 12,14 / 4 / 12,3 / 5 / 12,2 / 6 / 12,24 / 8 / 13,21 / 10 / 13$ y $11 / 10 / 14$, a las que se pueden añadir 26 de los 34 recorridos paisajísticos del anejo 3 realizados entre el $15 / 6 / 13$ y el $24 / 5 / 14$

También han servido como referencia para realizar este apartado los Informes de vigilancia ambiental de los proyectos de infraestructura rural y transformación en regadío elaborados por la Consejería de Agricultura y Ganadería. Sus autores han sido Isabel Otero Ferrero (ingeniera técnica agrícola e ingeniera técnica forestal, informe 1) y Alfonso Millán Ortega (ingeniero de montes, resto de informes). Tienen fechas de febrero 2011, julio 2011, febrero 2012 y mayo 2013.

Tal como se ha expuesto anteriormente, el Acuerdo de concentración parcelaria fue redactado en julio de 2009. A partir de este momento, y salvo reclamaciones puntuales, la distribución y 
propiedad de las parcelas resultó definitiva. Se colocaron mojones de hormigón en los vértices de las parcelas y desde otoño de ese año los nuevos propietarios tomaron posesión de las mismas.

Aunque actualmente la delimitación de la propiedad no tiene problemas geográficos, ya que está perfectamente georeferenciada y definida por coordenadas, los mojones tienen importancia en cuanto a delimitación física sobre el terreno. En este caso, estos hitos poseen un tamaño relativamente reducido (unos $40 \mathrm{~cm}$ de altura), siendo menor al de la anterior concentración; ello provoca que sean poco visibles y más susceptibles a su alteración (Figura A1.4).
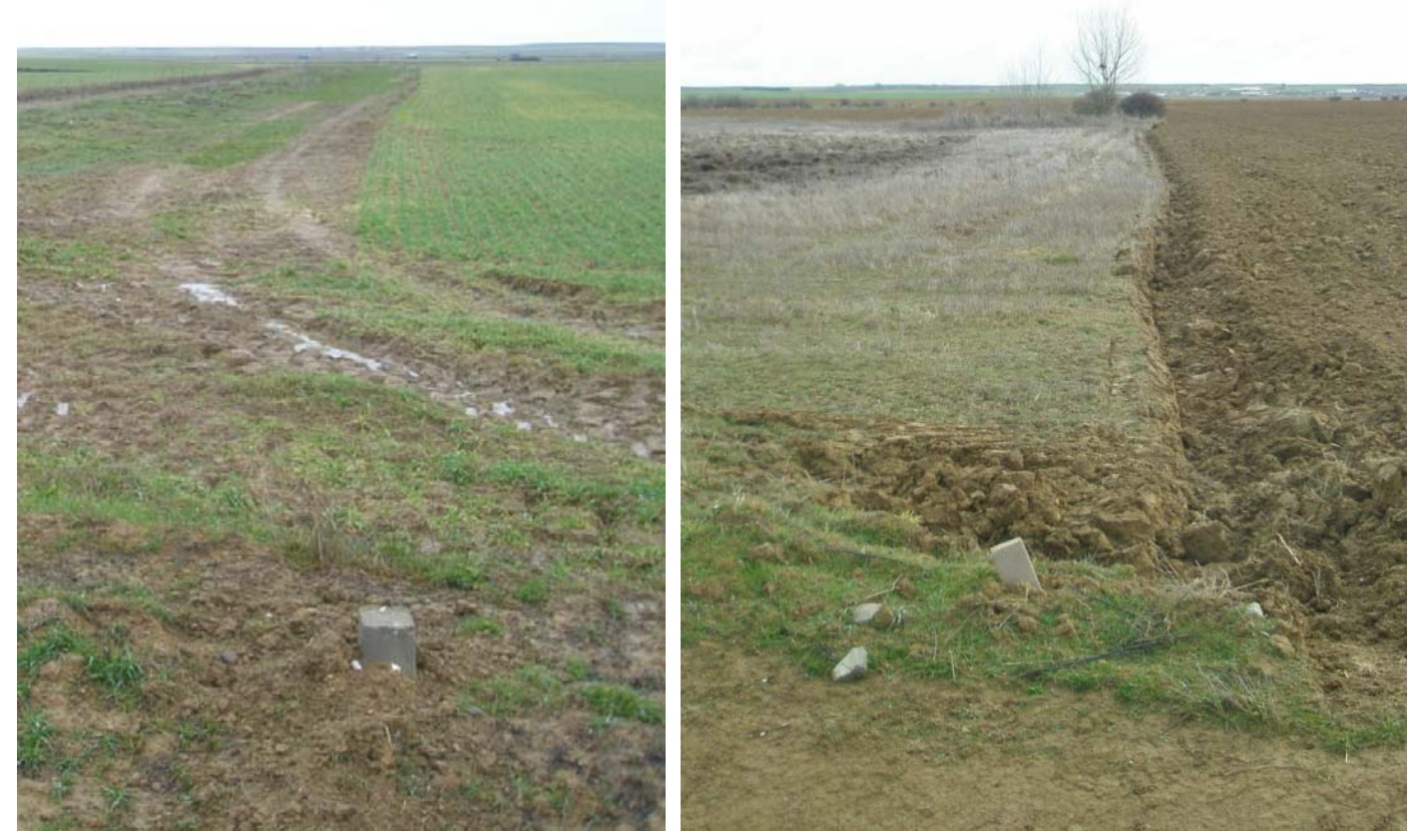

Figura A1.4. Dos fotografías de delimitación inicial de parcelas, con los mojones en primer plano. En muchas ocasiones, como en la vista de la derecha, se observa cómo estos hitos de hormigón son movidos e incluso eliminados.

En teoría, la operación previa para dar comienzo a las labores agrícolas en las nuevas parcelas es la creación de linderas, de común acuerdo entre los propietarios o agricultores colindantes. Tradicionalmente la lindera se concebía como una franja de al menos $50 \mathrm{~cm}$ de anchura, que debía permanecer intacta a lo largo de los años. La realidad actual es muy diferente: en la mayoría de los casos la lindera no existe o está reducida a la mínima expresión (Figura A1.5). 

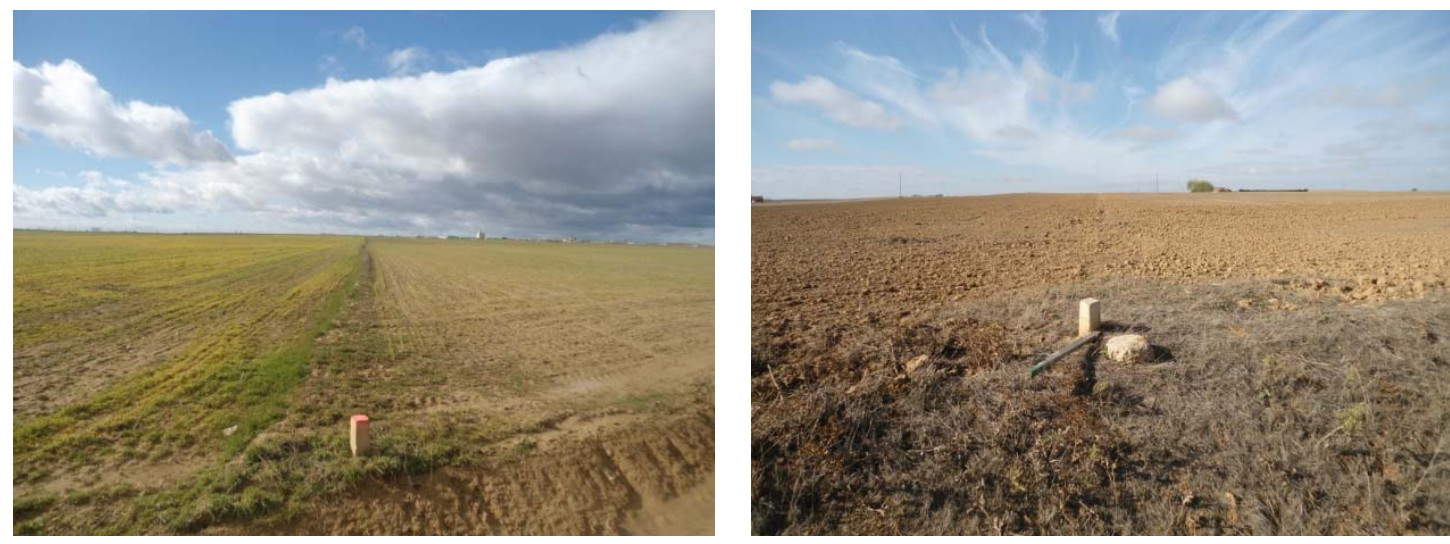

Figura A1.5. Dos imágenes de linderas imperceptibles. A la izquierda, lindera de dos parcelas recién sembradas de cereal; en este caso el mojón se mantiene en correcto estado, habiéndose pintado incluso para ser más visto. A la derecha, lindera entre dos parcelas recientemente labradas; tan solo el diferente tono marrón permiten distinguirlas.

El proyecto de infraestructura rural se adjudicó el 2 de octubre de 2009, fecha a partir de la cual comenzó su ejecución. Esta obra ha tenido varias anualidades y algún periodo de parada, llegando las obras incluso hasta 2015.

Las primeras actuaciones fueron las de limpieza de arroyos y desagües. Estas se realizaron con máquina tipo retroexcavadora a la que se acoplaba un cazo de limpieza, de modo que se extraía la tierra del cauce desde uno de sus márgenes. Tras un primer periodo donde la extracción abarcaba todo el cauce, se determinó que se afectaría básicamente al fondo del mismo y aproximadamente la mitad de sus taludes. Mediante esta operación se consiguió aumentar el calado -asegurando la funcionalidad del drenaje- y mantener buena parte de la vegetación existente en los taludes (Figura A1.6).
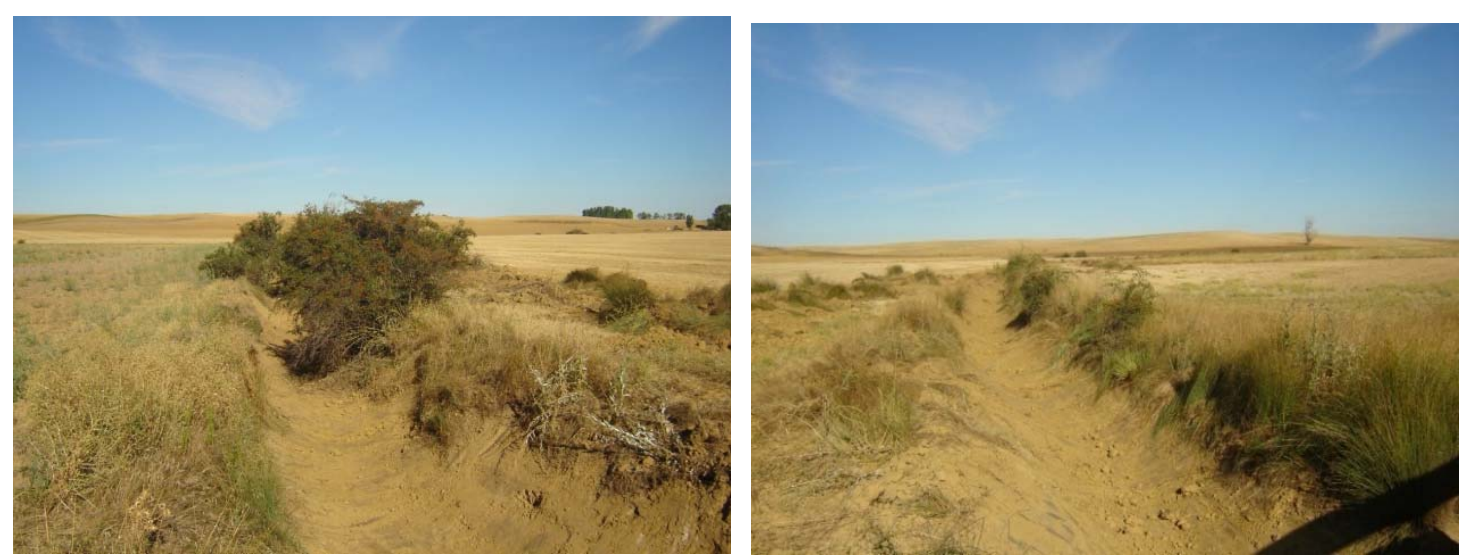

Figura A1.6. Dos ejemplos de limpieza de pequeños arroyos. En el de la izquierda se observa el mantenimiento de varias zarzas presentes en los taludes.

Posteriormente se llevaron a cabo las actuaciones relativas a caminos (Figura A1.7). En primer lugar se acondicionaron los caminos existentes, dotándoles de la anchura exigida en proyecto, perfilando las cunetas y taludes, explanando la plataforma y extendiendo y compactando la capa 
de zahorra precisa. Se han utilizado grandes motoniveladoras para la mayor parte de este proceso; la fase de compactación del firme se realizó con rodillos previa su humectación mediante tractor con cisterna. En los nuevos caminos previamente se hubo de realizar un movimiento de tierras con traíllas, que compensaba desmontes con terraplenes generando un perfil longitudinal de pendientes asumibles.
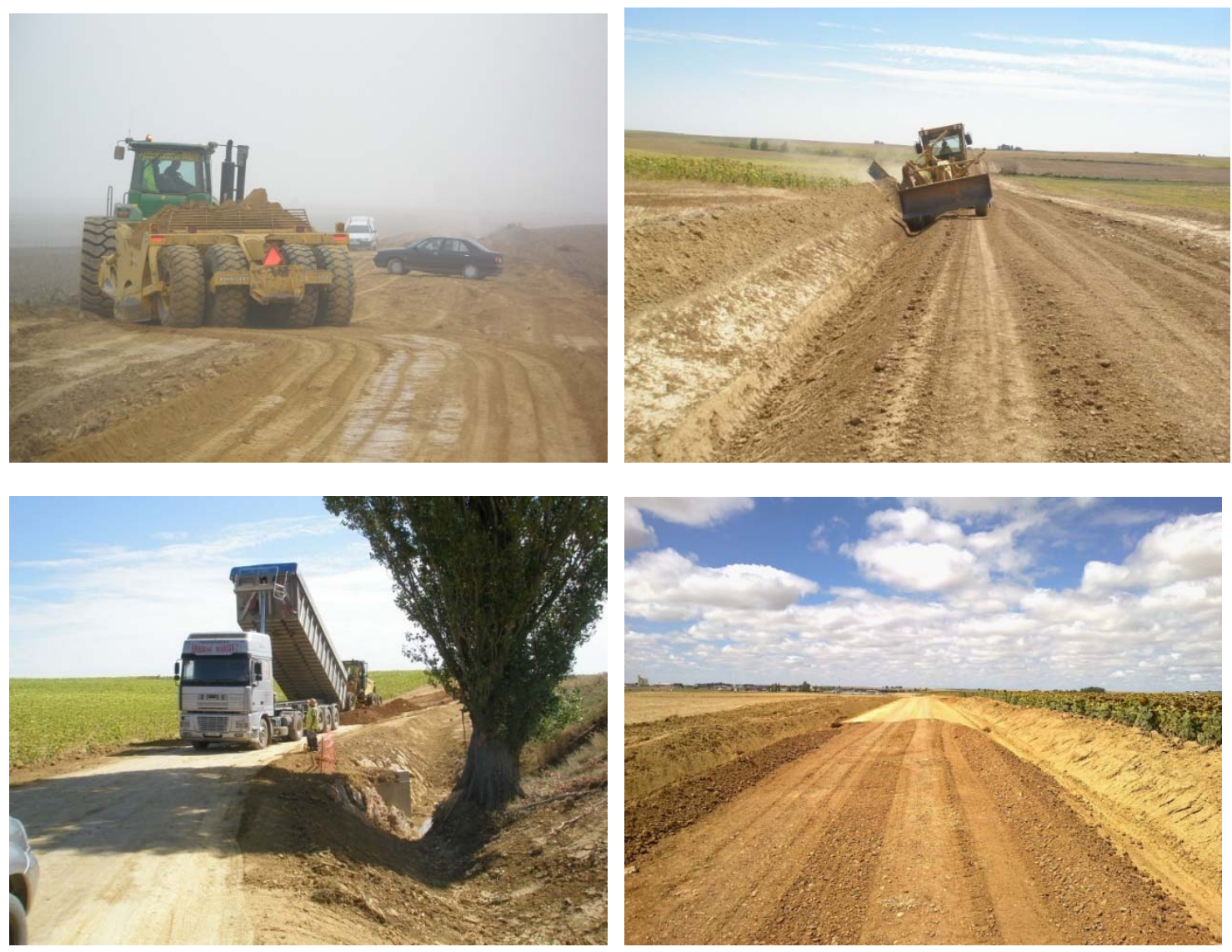

Figura A1.7. Varias imágenes de la fase de construcción o mejora de los caminos. Arriba izquierda, traíllas generando la traza de un nuevo camino. Arriba derecha, motoniveladora perfilando una cuneta. Abajo izquierda, descarga y extensión de zahorra en un camino ya explanado. Abajo derecha, camino en el que se ha extendido parcialmente zahorra.

Paralelamente se fueron realizando las actuaciones relativas a las obras de fábrica (pasos salvacunetas, caños, marcos), en la conexión de los caminos con los arroyos y desagües, así como los revestimientos asociados de hormigón o con escollera (Figura A1.8). Esto conllevó la retirada de los antiguos elementos de hormigón, que se dejaron en un primer momento en las inmediaciones; en fases posteriores se fueron retirando a un gestor de residuos de construcción y demolición. 

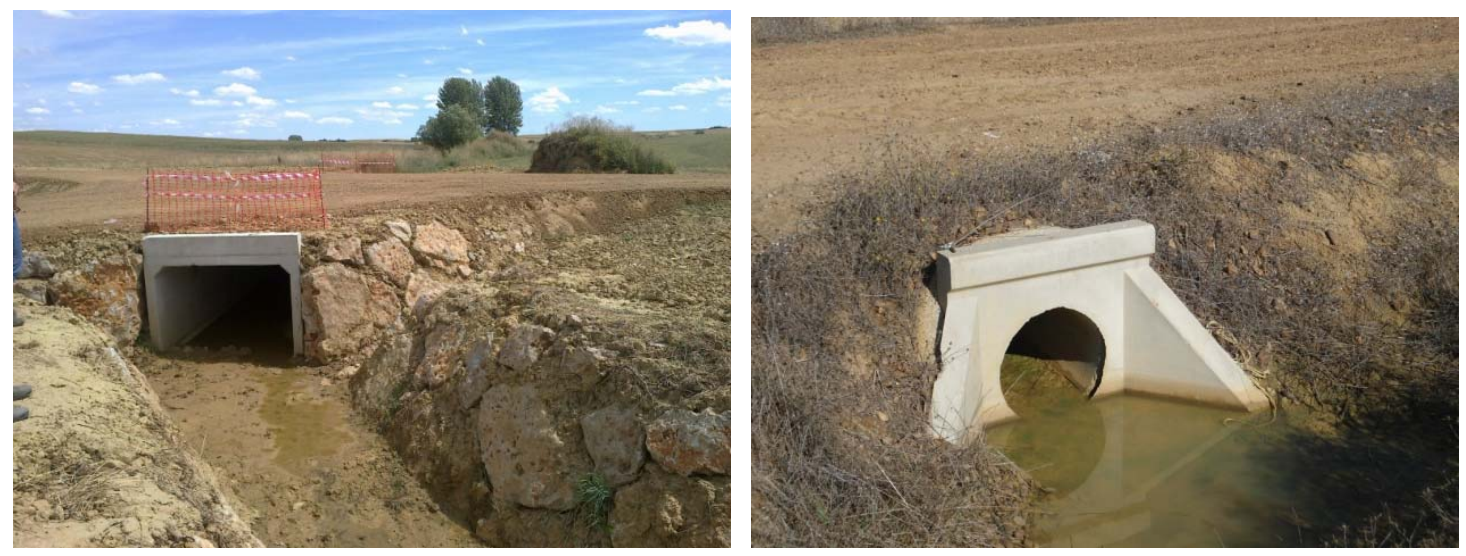

Figura A1.8. A la izquierda, marco de hormigón y escollera de protección de los taludes. En la imagen de la derecha se observa un caño y embocadura en el cruce de un desagüe con un camino.

En la última fase de la obra se realizó el sellado del firme de los caminos con una capa de arenaarcilla (Figura A1.9), se colocaron los pasos peatonales de madera en un ramal de la antigua vía del ferrocarril y se instalaron las señalizaciones y protecciones. Las vallas de protección en los puentes de mayor dimensión se realizaron con biondas metálicas con acabado exterior tipo madera (Figura A1.10).

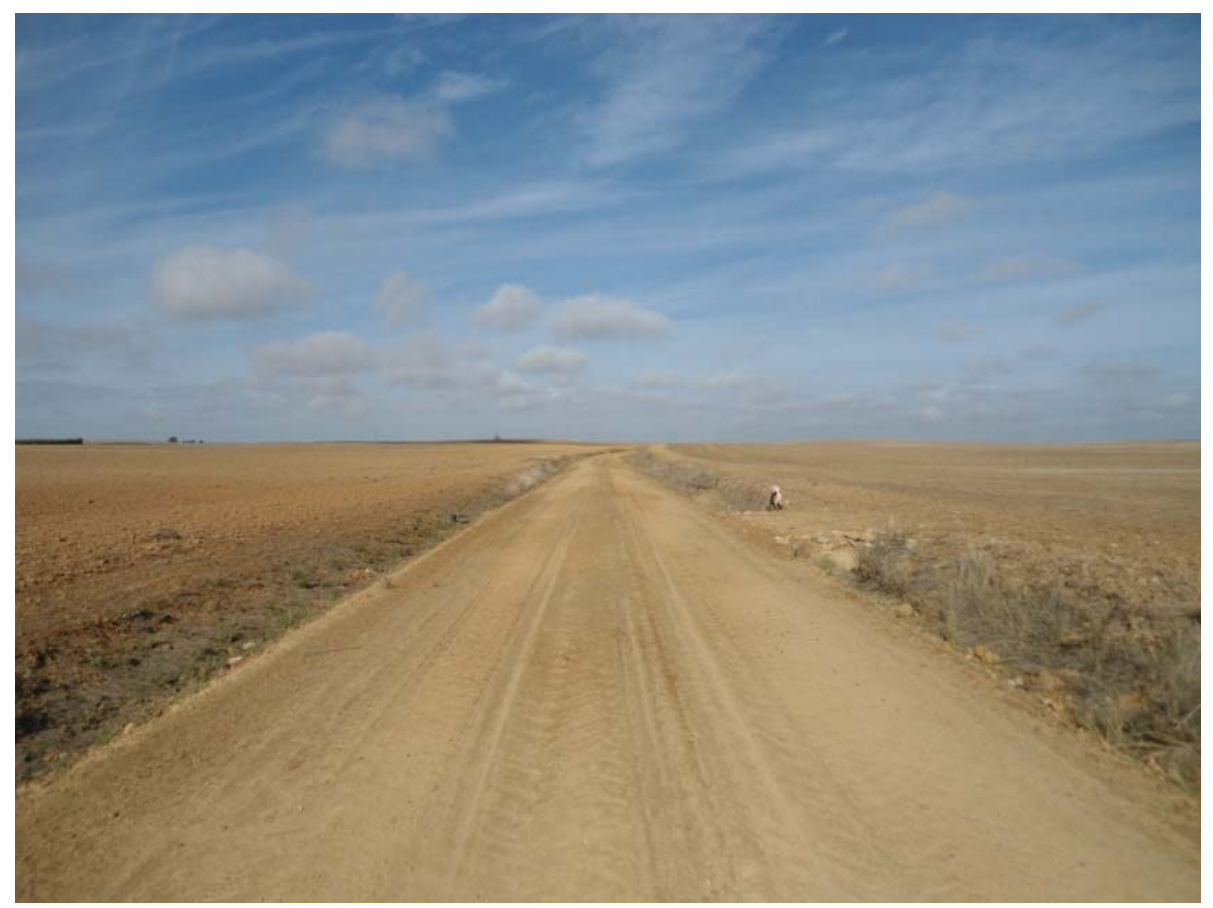

Figura A1.9. Camino en el que se ha extendido recientemente la capa de sellado arena-arcilla. También se puede apreciar cómo, después de tres años desde su perfilado, las cunetas se han ido cegando por arrastres de los cultivos colindantes. 

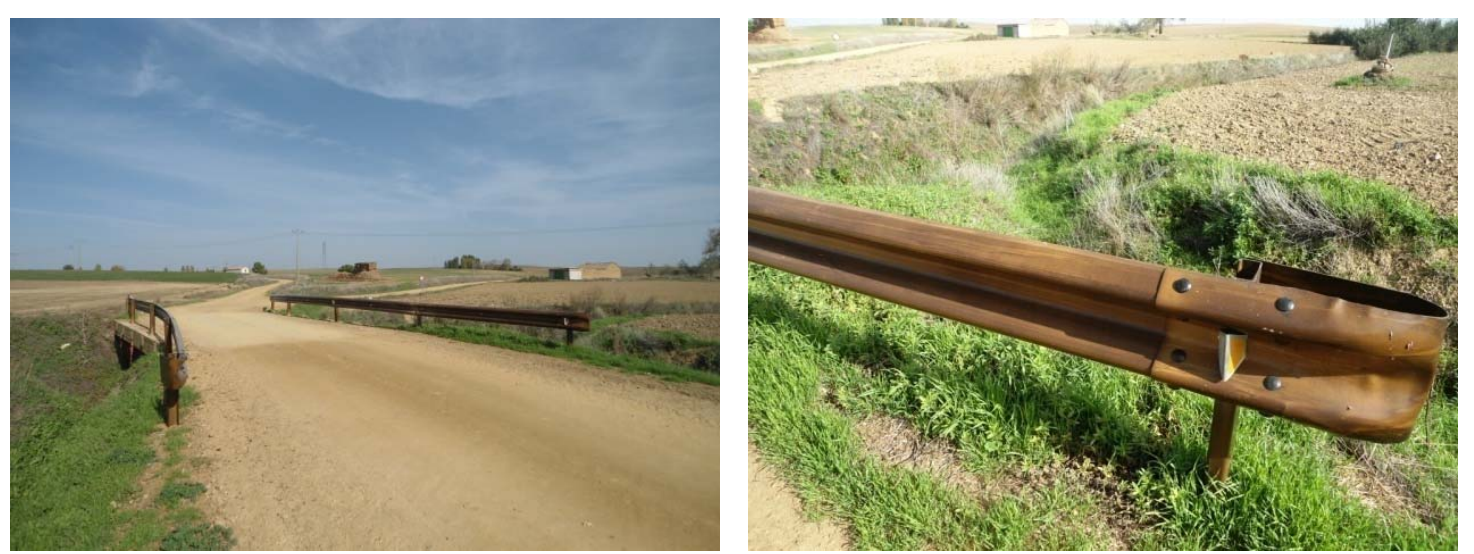

Figura A1.10. Bionda metálica de protección en el cruce de un camino con el arroyo Pajarillas. A la derecha se observa un detalle del acabado tipo madera.

\section{A1.1.3.2. Conclusiones del seguimiento ambiental.}

Se constata que el proceso de una concentración parcelaria de una zona es de una extraordinaria envergadura y genera unos severos impactos ambientales. Resulta fundamental, por consiguiente, que la variable ambiental se integre en el proyecto desde los primeros momentos de gestación hasta la configuración del nuevo parcelario y toda la fase de obra. La evaluación de impacto ambiental es fundamental como sistema preventivo y corrector del proyecto, pero más lo es llevarlo a la práctica hasta sus últimos detalles. En este caso se ha comprobado que, a pesar de encontrarnos en Red Natura 2000, este procedimiento preventivo ambiental ha sido considerado -al menos en la fase inicial- como una mera formalidad. Han sido necesarios varios requerimientos del órgano ambiental para que el promotor del proyecto adecuase el mismo a los condicionantes recogidos en la declaración de impacto ambiental, que no se debe olvidar que son vinculantes. En algunos casos los daños eran ya irreparables, en otros afortunadamente se han podido corregir las deficiencias. En este sentido, la figura del director ambiental recogida en la DIA es fundamental para asegurar la integración ambiental del proyecto, aunque para que sea eficaz ha de estar en un plano similar al de los directores de los proyectos, tanto de concentración parcelaria como de obras.

La concentración parcelaria ha aumentado notablemente el tamaño de las parcelas agrícolas, reduciendo en igual proporción la diversidad del mosaico paisajístico. Si sobre el papel el tamaño de las parcelas es de 7 ha aproximadamente, la realidad sobre el terreno -teniendo en cuenta su agrupación por explotaciones- es que este se acerca a las 20 ha de media.

Una de las consecuencias más negativas de la concentración de la propiedad es la eliminación de numerosas regueras situadas en el interior de las parcelas. Al no tener ya el papel de linderas el agricultor las rotura, perdiéndose la interesante vegetación que las acompaña. En años lluviosos se percibe claramente la importante función hidrológica que desempeñaban-y que en la agricultura tradicional tanto se valoraba-, más en los frecuentes casos de generación de encharcamientos y lagunas.

No se ha cumplido la condición 3.r) de la Declaración de Impacto Ambiental (DIA) que señalaba que se debían mantener linderas de 1,5 m de anchura, para su posterior plantación con 
arbustos. Tal vez esta era una de las medidas más ambiciosas de la DIA, que pretendía emular aunque solo fuese parcialmente- el paisaje agrícola tradicional donde las linderas arbustivas (los setos vivos) constituían un elemento característico del mismo. Para que la condición hubiese sido eficaz, se debería haber contemplado desde el primer momento en el proceso de la concentración parcelaria, descontándose la superficie correspondiente. Es probable que esta resultase excesiva desde el punto de vista del promotor, aunque también es cierto que se realizaron descuentos importantes para la creación de otras infraestructuras públicas, como los caminos o la balsa de riego. Haciendo analogía con otros sectores productivos, como las urbanizaciones -donde los propietarios ceden porcentajes importantes de la superficie para la creación de zonas verdes públicas- es curioso cómo la legislación agraria no contemple algo similar en este campo.

Tampoco se ha tenido en cuenta esta medida para las bandas de 1-2 $\mathrm{m}$ requeridas en ambos márgenes de regueras y arroyos (Figura A1.11), salvo en un porcentaje exiguo recogido en algunas parcelas de restauración del medio natural. En este caso la coordinación con la Confederación Hidrográfica del Duero hubiera sido fundamental, en la delimitación de un dominio público hidráulico que, repoblado con vegetación riparia, conllevaría dos beneficios sustanciales: defensa de los cauces frente a colindantes (actualmente se laborea al límite, con lo que paulatinamente se van cegando los arroyos) y creación de pequeñas riberas de gran valor ecológico (donde la vegetación tendría un rápido crecimiento por la presencia de humedad edáfica).

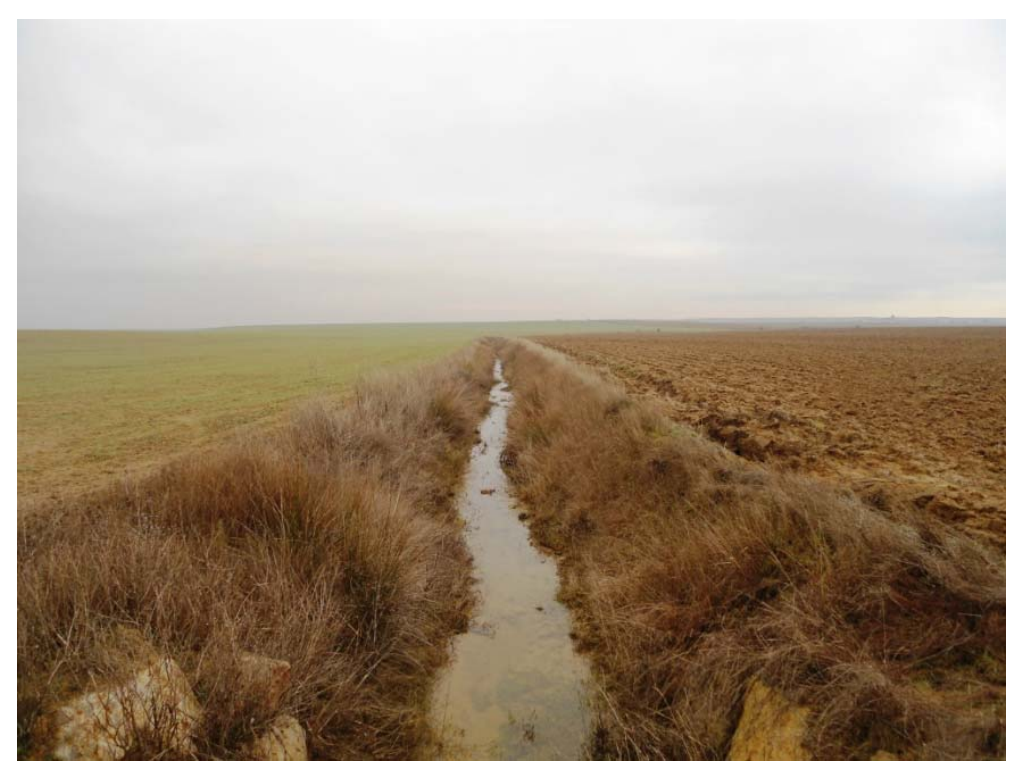

Figura A1.11. Arroyo principal con agua fluyendo en invierno. Se puede observar la ausencia de vegetación riparia y cómo los cultivos colindantes llegan hasta el cauce.

En la fase del proyecto de concentración parcelaria no se tuvo en cuenta en su totalidad la condición 3.q) de la declaración de impacto ambiental, que prescribía el mantenimiento e integridad de los dos ramales de la antigua vía del ferrocarril (tren burra). En particular, en 
primera instancia se eliminó un tramo de la línea Palencia-Villalón de Campos (el acceso a esta última localidad). Posteriormente, para asegurar su continuidad, se modificó su trazado haciéndolo paralelo a dos caminos de circunvalación. Fue una solución funcional, pero con ello se perdió una parte del trazado original sinuoso característico de esta vía.

No se han llevado a cabo por el promotor las campañas informativas a los agricultores previstas en el estudio de impacto ambiental para minimizar los daños sobre el medio natural. Con ellas tal vez se hubieran evitado impactos graves como la eliminación de regueras situadas en el interior de parcelas, ribazos arbustivos o la intrusión en parcelas públicas.

Resultó muy acertada la medida adoptada por el promotor de respetar la red hidrológica existente y realizar la limpieza parcial de arroyos y desagües en su parte inferior. Con ello se evitó la eliminación de los escasos árboles y arbustos existentes en esta zona de concentración parcelaria, cuya presencia se restringe a estas zonas húmedas y que poseen un tremendo valor ecológico, cinegético y paisajístico (Figura A1.12). Además se constata que, la presencia de arbustos en los taludes de los cauces, evita su intrusión en el desarrollo de las labores agrícolas colindantes. Sin embargo, cabe puntualizar que en los desagües de menor tamaño (donde generalmente no hay arbustos) se debería haber ampliado su anchura y calado para, posteriormente, restaurar vegetalmente sus taludes.

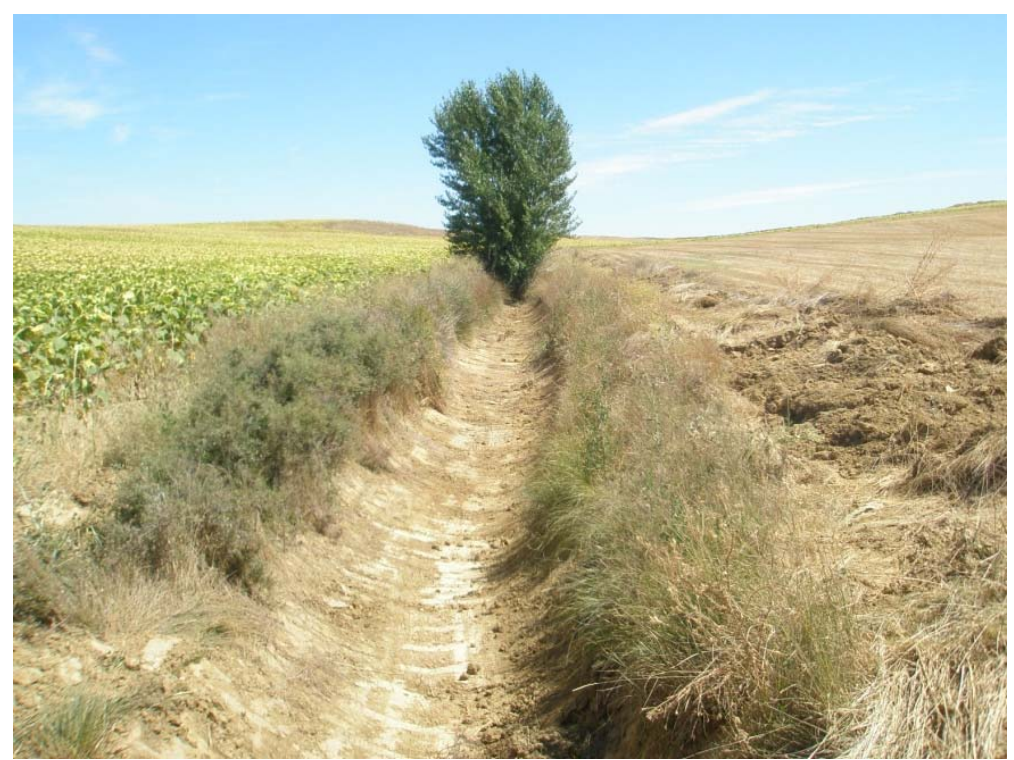

Figura A1.12. En el pequeño arroyo de la imagen, afortunadamente se ha respetado el chopo existente, que es el único árbol presente en el entorno.

El impacto ocasionado sobre la vegetación herbácea e higrófila como consecuencia de la limpieza de arroyos y desagües es compatible, ya que esta regenera con facilidad en uno o dos años (Figura A1.13). 


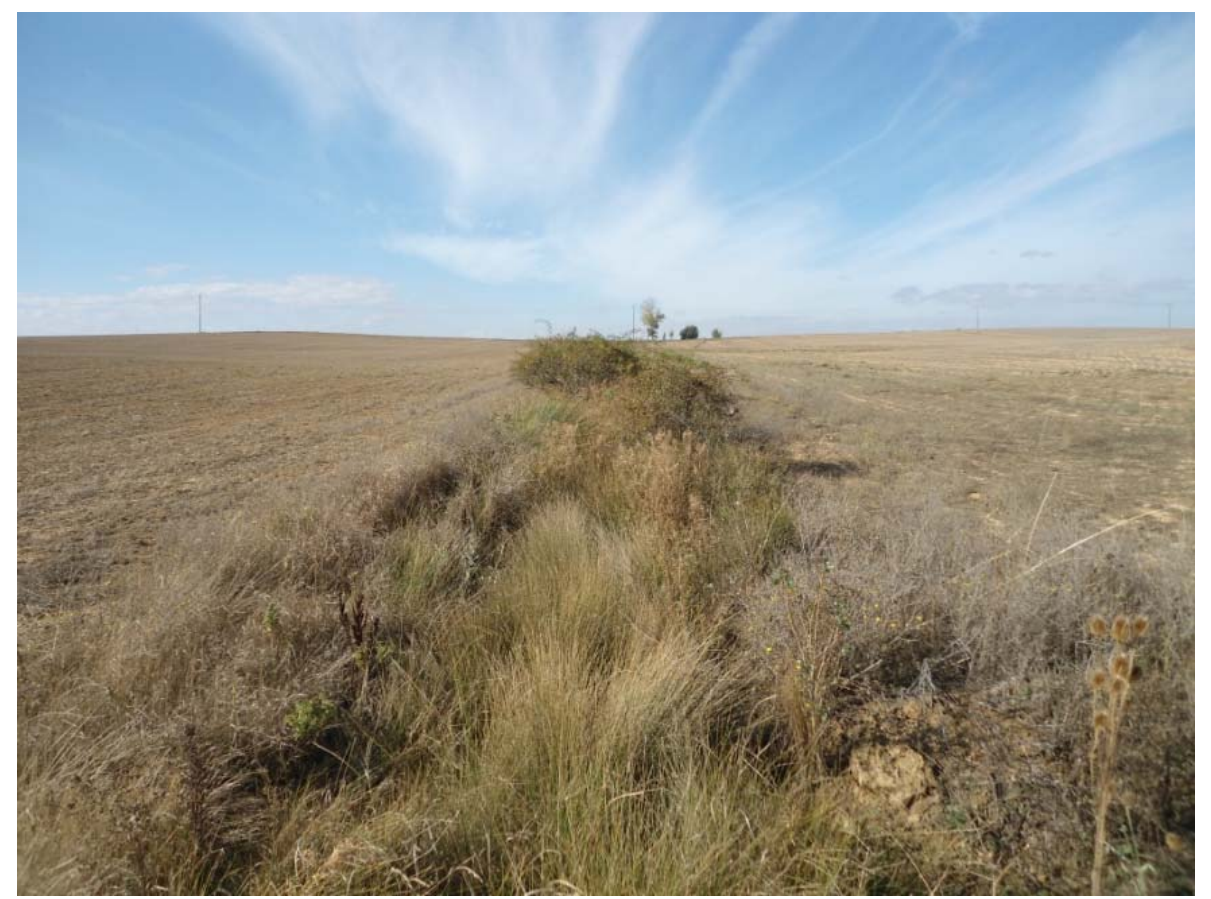

Figura A1.13. Cauce en el que se ha recuperado totalmente la vegetación higrófila y en el que se observa que se respetaron los escaramujos.

En el trazado de los nuevos caminos, sobre todo en el caso de Boadilla de Rioseco, no se tuvo en cuenta con el detalle adecuado la presencia de arbolado o setos arbustivos, que hubo que cortar cuando la traza los atravesaba. Este hecho fue percibido ya en obra, cuando era imposible modificar-aunque fuese ligeramente- las superficies afectadas, pues ya era firme el Acuerdo de concentración parcelaria.

Desde el punto de vista paisajístico es positivo que se haya mantenido un porcentaje considerable de los caminos existentes. Aunque a su vez buena parte de ellos ya se habían rectificado en la primera concentración parcelaria, algunos (sobre todo los que se asientan sobre vías pecuarias) poseen trazados algo irregulares y, por consiguiente, más naturalizados.

También es positivo para el paisaje visual la creación de nuevos caminos de circunvalación, como los realizados en Villalón de Campos y Boadilla de Rioseco. Aparte de su funcionalidad para el tránsito agrícola, crean posibles rutas para un potencial uso recreativo (de paseo, en caballo o en bicicleta) al unir caminos existentes radiales, además de generar nuevas vistas para los observadores.

No obstante, en el acondicionamiento de los caminos existentes la labor de perfilado de las cunetas no tuvo en cuenta la presencia de ejemplares arbustivos que, precisamente por su escasez, deberían haber sido conservados.

De acuerdo con las 65 mediciones realizadas en los Recorridos paisajísticos del anejo 3, la pendiente media de los taludes de los caminos es de $34^{\circ}(2 \mathrm{~V}: 3 \mathrm{H})$, que es algo más tendida que la proyectada ( $1 \mathrm{~V}: 1 \mathrm{H}$ para el desmonte y $2 \mathrm{~V}: 3 \mathrm{H}$ para el terraplén). Este valor es adecuado para 
terraplenes o desmontes con longitudes de pendiente inferiores a 1,5 m, pero cuando son desmontes mayores no se produce su revegetación natural, acusando fenómenos de erosión.

Tanto en el Estudio de Impacto Ambiental como en la DIA se prescribía el depósito de la tierra vegetal sobre los taludes de los caminos y la posterior plantación de vegetación arbustiva autóctona. En la obra no se extendió la tierra vegetal por los taludes, ya que se acordonó en los límites con las parcelas para su posterior reparto en las mismas. Este hecho, unido a la falta de siembras o plantaciones, ha provocado que los taludes de desmonte de mayor altura se encuentran desprovistos de vegetación, sean erosionables y provoquen un considerable impacto sobre el paisaje (Figura A1.14). En estos, transcurridos tres años desde su conformación, la cobertura herbácea se puede estimar en un $25 \%$.
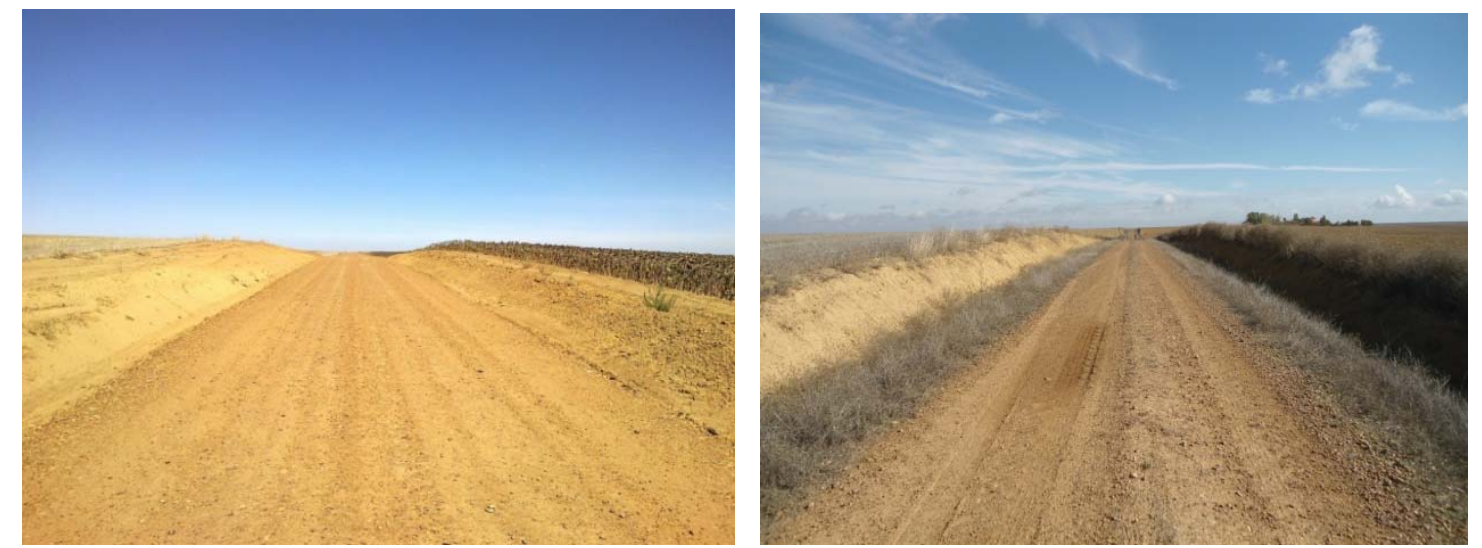

Figura A1.14. Imagen de taludes de desmonte de caminos en la primera fase después de las obras (izquierda). Actualmente una parte de ellos se han revegetado naturalmente (sobre todo los orientados al Norte), aunque son numerosos los taludes altos con una protección herbácea deficiente (la fotografía de la derecha es en la misma ubicación transcurridos tres años).

Aunque en la fase de obras pudiera parecer que la anchura de los caminos es excesiva y genera un cierto impacto visual, lo cierto es que transcurridos un par de años -y debido a que el tránsito agrícola es reducido- en muchos de ellos se generan dos bandas en ambos lados con vegetación herbácea. Tal como se aprecia en la figura anterior, estas franjas cuentan con una anchura de entre 0,80-1 m y tienen una gran importancia como hábitat natural.

Las cunetas juegan un importante papel en el drenaje de los caminos, aunque se ha observado que muchas de ellas (sobre todo cuando no hay taludes) se van cegando paulatinamente como consecuencia de laboreos excesivamente próximos de los cultivos colindantes (Figura A1.15). 


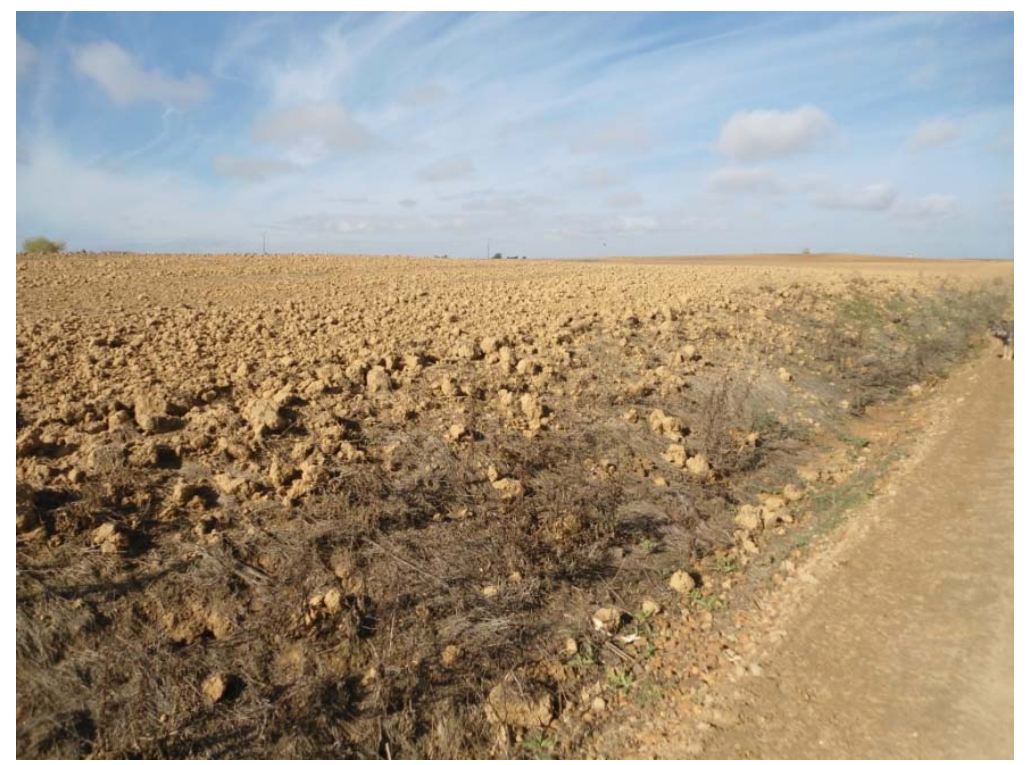

Figura A1.15. Cuando se apura en exceso el laboreo de las parcelas, la tierra se va depositando en la cuneta, que poco a poco pierde su función drenante o incluso desaparece. Si este talud tuviese arbustos, es probable que ejerciesen un papel de protección de la cuneta.

El impacto inducido por la necesidad de un importante volumen de zahorra para el firme de los caminos es significativo y frecuentemente minusvalorado en las obras de infraestructuras. En este caso, el aporte de zahorra se ha cifrado en $343888 \mathrm{~m}^{3}$, que ha sido extraída de explotaciones de la vega del río Cea. Para hacernos una idea, en una gravera de $3 \mathrm{~m}$ de profundidad de aprovechamiento, se necesitaría una superficie de 11,5 ha para este proyecto. Aunque se encuentre fuera de la zona de concentración parcelaria, es fundamental asegurar la legalidad y posterior restauración de estas explotaciones de áridos.

Se estima muy acertada la utilización de escollera de piedra caliza del páramo de Torozos para la protección de determinados taludes en la conexión de arroyos y caminos, dado que es un material de la zona con alta integración paisajística.

La utilización de zahorra con áridos naturales para el firme de los caminos es evidentemente más económica que la zahorra artificial (con áridos procedentes de plantas de machaqueo). La desventaja es que con el uso, y sobre todo en verano, las gravas de mayor espesor salen al exterior y ocasionan gran dificultad para caminar o circular en bicicleta por los caminos. En este sentido, el extendido y compactado de una capa última de sellado de arena-arcilla puede contribuir a mejorar el firme para estos usos, aunque también puede generar efectos negativos de formación de roderas en días lluviosos o polvo en verano; todo ello se comprobará en años posteriores.

Se ha constatado que un impacto ambiental significativo de las obras de infraestructura es la generación de un cierto volumen de residuos de construcción y demolición procedente de las antiguas obras de fábrica de hormigón (Figura A1.16). En caso de que no se presupueste una partida específica en el proyecto, estos residuos quedarían en los márgenes de los caminos; afortunadamente en esta obra, como consecuencia de la vigilancia ambiental, con posterioridad una parte se fueron trasladando a plantas de reciclaje. Otra posibilidad a considerar (más si hay 
que demoler acequias de riego) es la valorización in situ de los residuos, utilizándose como material de subbase previa su trituración en una planta móvil.

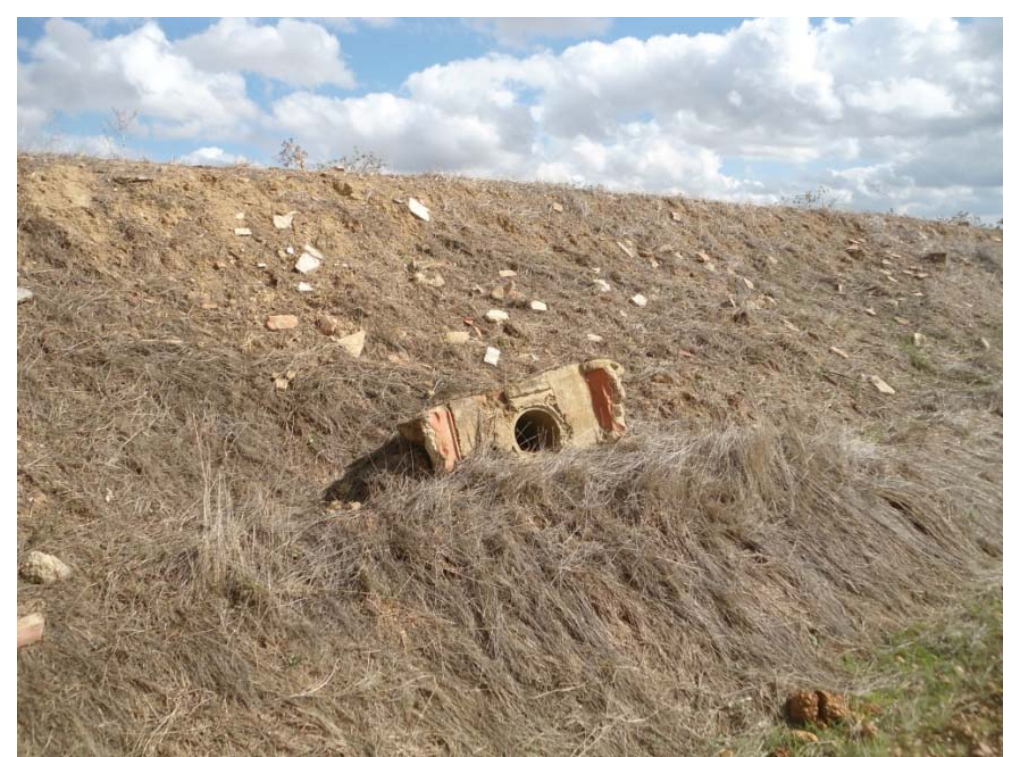

Figura A1.16. Talud de camino en el que se han depositado restos de antiguas obras de fábrica.

Uno de los aspectos más controvertidos en la fase de seguimiento ambiental ha sido el cumplimiento del apartado 3.o) de la DIA Fuentes y otros terrenos públicos. En varios informes se constató que no se había realizado el inventario requerido de las 31 fuentes existentes en la zona (que son auténticos oasis en Tierra de Campos) ni se habían dotado de una parcela asociada de 1 ha con acceso desde camino, encontrándose varias de ellas en el interior de parcelas privadas. Después de varias modificaciones se consiguió paliar parcialmente esta circunstancia, mediante permutas con parcelas de las juntas agropecuarias locales o de la masa común. Con ello, en principio se asegura su conservación al situarse en terrenos públicos o similares, aunque no se ha llegado a esa superficie mínima ideal para varias de ellas.

En este apartado de la DIA también se hace referencia a la escasez de espacios arbolados en la zona y, en consecuencia, a la necesidad de que la concentración parcelaria disponga la creación de parcelas de titularidad pública para realizar plantaciones. Cabe señalar que la superficie total de parcelas de restauración del medio natural en los cuatro términos municipales es de 33,92 ha. Teniendo en cuenta que la superficie de la zona a concentrar es de 16008 ha, el porcentaje de las mismas apenas supone un $0,21 \%$ que es un valor realmente bajo. Tampoco se cumple la medida contemplada en el Estudio de Impacto Ambiental de restaurar 40 ha de márgenes de arroyos; las parcelas de restauración de medio natural dedicadas a este fin tan solo ocupan 14 ha. Ni la del citado Estudio que hace mención a repoblar bandas de $3 \mathrm{~m}$ de anchura a ambos lados de $30 \mathrm{~km}$ de caminos. Este hecho podría haberse corregido con la modificación de parcelas de masa común (que ocupan unas 140 ha), destinándolas al menos en parte a restauración del medio natural.

En Tierra de Campos existe una doble problemática con la propiedad pública susceptible de restauración natural: es muy escasa y soporta una gran presión por parte de la colindante de 
uso agrícola. Este hecho se ha constatado con total intensidad en la zona de concentración parcelaria de Herrín de Campos, Villafrades de Campos, Villalón de Campos y Boadilla de Rioseco analizada. Tal como se ha visto, la propiedad pública se restringe a las parcelas de restauración del medio natural y a alguna otra puntual perteneciente a la Consejería de Fomento y Medio Ambiente. En numerosas visitas realizadas a estas parcelas, así como en los informes de vigilancia ambiental, se comprueba que 42 de las 79 parcelas de restauración (más de la mitad) han sido ocupadas por los colindantes al poco de tomar posesión, incluso con la modificación de los mojones colocados. Ello también ha sucedido con franjas públicas destinadas a caminos de circunvalación pero no ocupadas en su totalidad, por lo que pueden dedicarse a plantaciones. En este sentido, resulta fundamental la delimitación física de las parcelas, así como la realización de advertencias a los propietarios colindantes; sobre lo primero, se están realizando algunas cunetas en el perímetro que están resultando eficaces (Figura A1.17).

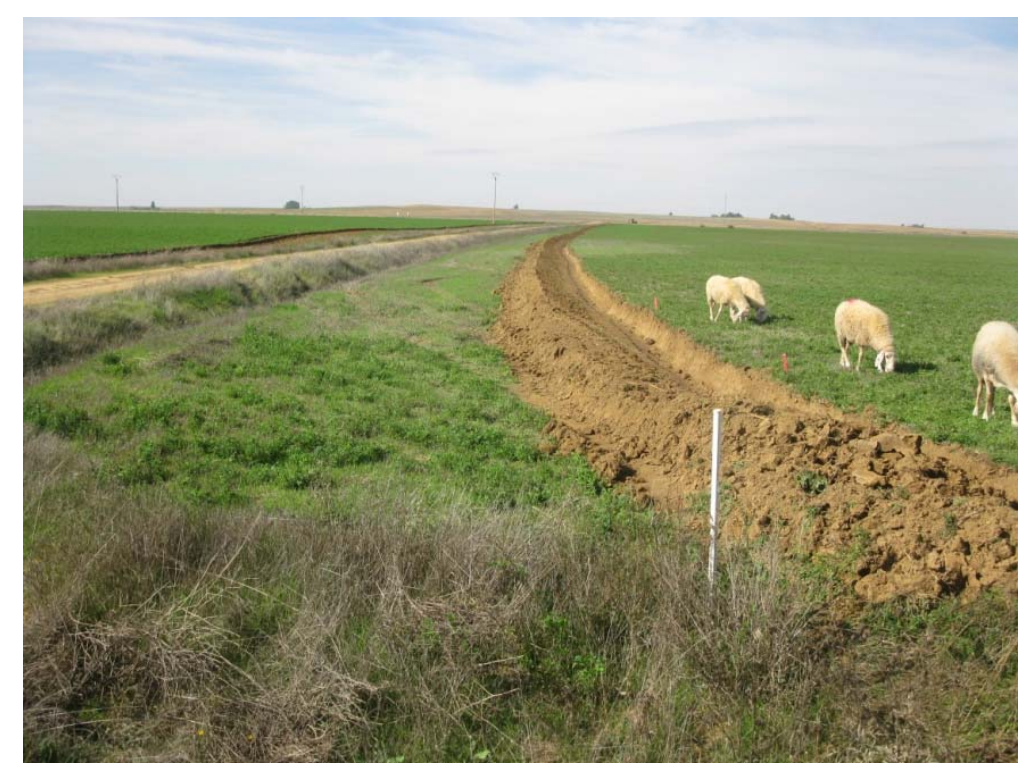

Figura A1.17. Zanja realizada para delimitar la franja pública situada en el margen de un camino de circunvalación que, tal como se aprecia, había sido intrusada. Estas franjas tienen una gran importancia para la posible futura creación de corredores vegetales.

Para corregir la ausencia de franjas públicas en márgenes de arroyos y caminos susceptibles de ser restauradas vegetalmente, así como en los linderos entre parcelas, el proyecto de restauración de medio natural debería ser suficientemente ambicioso como para incluir la plantación de árboles y arbustos en los taludes de mayor dimensión. El perfilado de cunetas y taludes de los caminos y la limpieza de los arroyos puede ser una oportunidad para generar superficie para plantar. No sería la medida ideal, pero sí que podría generar setos vegetales aunque fuesen discontinuos- que actuasen como corredores ecológicos y hábitat de especies silvestres. A priori, en los taludes de más de $1 \mathrm{~m}$ serán viables los arbustos y en aquellos de más de $2 \mathrm{~m}$, los árboles.

No se ha realizado el deslinde, amojonamiento y señalización de todas las vías pecuarias que discurran por los términos municipales afectados, de acuerdo con lo indicado en el apartado 3.p) de la DIA. Se estima que estas operaciones deberían haber sido realizadas en el momento 
de colocación de los mojones de las fincas particulares, para que estos terrenos de dominio público fuesen identificados desde el primer momento de la concentración. Lo cierto es que la mayoría coinciden con los caminos rurales, con $10 \mathrm{~m}$ de anchura, pero podrían existir pequeños márgenes donde fuese conveniente el afianzamiento de la propiedad pública. La consecuencia es que las únicas que poseen mayor anchura han siendo intrusadas por los nuevos propietarios colindantes (por ejemplo la Vereda de Mayorga a Herrín, que en su clasificación posee una anchura legal de 18-20 m; aunque hay que señalar que ha sido amojonada a primeros de 2015). No hay que olvidar que estos terrenos son bienes de dominio público, gestionados por la Consejería de Fomento y Medio Ambiente y, por consiguiente, espacios con disponibilidad para realizar restauraciones vegetales.

Con el proyecto de infraestructura rural se han ejecutado los pasos peatonales sobre desagües que cruzaban la antigua vía del ferrocarril, para su posterior restauración como vía verde. Su construcción en madera les dotan de belleza y adecuada integración en el paisaje (Figura A1.18), en sintonía con el tramo ya habilitado de la Vía Verde de Tierra de Campos entre Cuenca de Campos y Villalón de Campos. Se considera muy positiva la continuación de esta vía hasta la balsa de regadío, que tiene un gran potencial recreativo y turístico y contribuirá a valorizar el paisaje de la comarca. Por el contrario, es una lástima que no se haya incluido en el proyecto la restauración del tramo Villalón de Campos - Villafrades de Campos, que prácticamente podría conectarse con el resto del trazado hasta Palencia, cuya rehabilitación ya está proyectada.
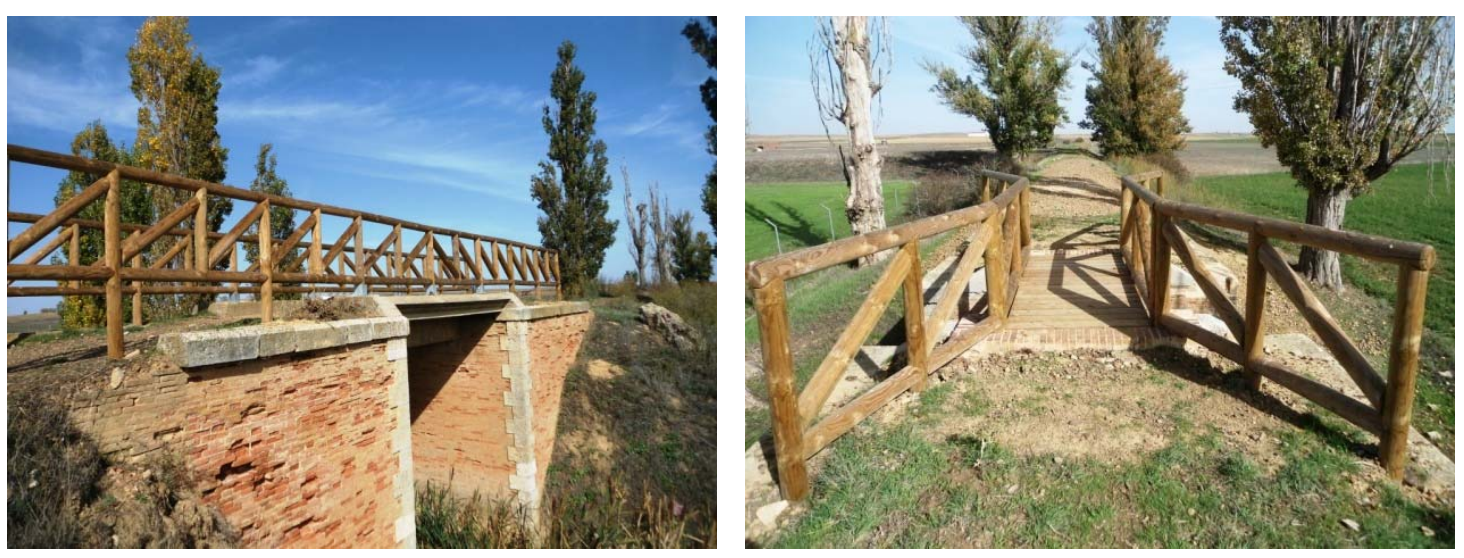

Figura A1.18. Imágenes del acondicionamiento de puentes de madera para la rehabilitación de la antigua vía del ferrocarril, en las que se comprueba su integración e incluso el realce de las estructuras primitivas.

La redacción de un Proyecto de Restauración del Medio Natural (PRMN) es positiva en sí, ya que supone la asunción de que los impactos generados por la concentración parcelaria necesitan de actuaciones específicas y detalladas en un documento técnico independiente. En este caso tal vez se haya dilatado excesivamente en el tiempo, lo que hace más difícil la corrección de determinados impactos.

Es adecuado el porcentaje dado a las plantaciones en el presupuesto del PRMN, que supera el $50 \%$, dado que es la actuación más necesaria. La elección de especies es, en general, correcta, aunque se observan algunas deficiencias de naturaleza ecológica, como el hecho de seleccionar vegetación alóctona en parcelas de restauración del medio natural (ejemplo, Cupressus arizonica en parcelas paralelas a arroyos). También es acertado que se dedique un capítulo 
específico al mantenimiento de las plantaciones, en especial a los riegos y a la reposición de marras.

Aun así, de acuerdo a lo prescrito en el Estudio de Impacto Ambiental y en la Declaración de Impacto Ambiental, las plantaciones de árboles y arbustos deberían haber abarcado una superficie considerablemente mayor. Teniendo en cuenta que no se ha cumplido la condición de restaurar las linderas o los márgenes de arroyos, se tendrían que haber incluido buena parte de los taludes de los caminos (los de altura mayor a $1 \mathrm{~m}$ ) y otra parte considerable de los taludes de los desagües y arroyos principales. Hay que tener en cuenta que la opción incluida en el PRMN (taludes de caminos de más de $3 \mathrm{~m}$, estimados en $10 \mathrm{~km}$ ) supone tan solo el 1,9\% de los márgenes de los caminos. Por su parte, el porcentaje de parcelas de RMN paralelas a arroyos es minúsculo respecto de la longitud total de estos. Las ventajas ecológicas y paisajísticas de esta actuación son innegables, pero también lo son las funcionales respecto de la preservación y consolidación frente a colindantes de las estructuras hidráulicas.

De las 140 ha clasificadas como Masa Común -excluidas las ocupadas por la balsa- únicamente se van a realizar plantaciones en 7,92 ha. Es un porcentaje exiguo teniendo en cuenta la necesidad de superficie pública en Tierra de Campos (y más en esta zona) donde realizar repoblaciones forestales para matizar un paisaje en que los cultivos agrarios superan el $99 \%$ de su superficie.

Es adecuada la inclusión en el PRMN de un capítulo específico dedicado a las fuentes, donde se contemplan unas subactuaciones que pueden ayudar a revalorizar estos espacios privilegiados en el árido paisaje de Tierra de Campos.

Se ha incluido otro capítulo en dicho proyecto referente a la rehabilitación como vía verde del ramal Villalón de Campos - Boadilla de Rioseco de la antigua vía del ferrocarril, lo cual es sin duda positivo desde el punto de vista de creación de un sendero natural como desde su complementariedad con el futuro uso natural-recreativo de la balsa de riego. No obstante, tal como ya se ha reseñado, no se ha cumplido la prescripción de la DIA de rehabilitar el otro tramo de vía afectado, el que une Villalón de Campos con Villafrades de Campos (ramal VillalónPalencia).

En el Proyecto de Restauración del Medio Natural no se han incluido capítulos referentes a otras prescripciones incluidas por el promotor en el Estudio de Impacto Ambiental, como la creación de filtros verdes en los tres municipios que no tienen depuradoras o la restauración de palomares.

Aunque el presupuesto del PRMN sea significativo, su porcentaje respecto del correspondiente al proyecto de infraestructura rural $(2,77 \%)$ es relativamente reducido teniendo en cuenta la envergadura del mismo y los impactos ambientales que ha generado. La concentración parcelaria de una determinada zona supone inevitablemente unos efectos sobre el medio natural, pero también se puede convertir en una oportunidad (por su capacidad de transformación del territorio) para corregir los impactos y recuperar el paisaje. Incluso, como así debería haber sido en este caso, para recuperar los tremendos efectos que en su día tuvieron las primeras concentraciones parcelarias. 


\title{
A1.2. Transformación en regadío del sector IV de la zona regable del canal del trasvase Esla-Carrión
}

\section{A1.2.1 Proyecto}

\author{
A1.2.1.1. Anteproyecto de zona regable del Canal Esla-Carrión (Sector IV) \\ Promotor: Consejería de Agricultura y Ganadería. Junta de Castilla y León \\ Autor: José Luis Sevilla Portillo y Francisco Javier Puertas Jorde (ingenieros agrónomos) \\ Fecha: marzo 2003
}

Este documento plantea una zona de riego por aspersión de 2050 ha en cuatro términos municipales: Villalón de Campos (650 ha), Villafrades de Campos (150 ha), Herrín de Campos (600 ha) y Boadilla de Rioseco (650 ha). Esta superficie supera en 1577 ha la superficie con dotación desde el canal Esla-Carrión (473 ha) propuesta por la Confederación Hidrográfica del Duero para este sector, por lo que es necesaria la construcción de una balsa de regulación capaz de almacenar el agua suministrada desde el canal en invierno.

Las principales obras inherentes al regadío son:

- Obra de toma y conducción desde el canal hasta la balsa de regulación.

- Balsa de regulación de $9,6 \mathrm{Hm}^{3}$, que afectará a una superficie de unas 130 ha. La balsa estará delimitada por un dique de $10 \mathrm{~m}$ de altura máxima, con taludes $1 \mathrm{~V} / 2,5 \mathrm{H}$ (el exterior con herbáceas y el interior recubierto con escollera), camino de coronación, aliviadero de badén con canal que conducirá el agua al río Sequillo, galería visitable, altura máxima del agua 9 m y caseta de válvulas.

- Red de riego capaz de suministrar agua a presión que cubra las necesidades hídricas. Las tuberías serán de PVC y su longitud total será de $43279 \mathrm{~m}$.

- Zanjas proyectadas de acuerdo con los tamaños de las tuberías, de modo que estas queden enterradas a un mínimo de $1 \mathrm{~m}$ de profundidad.

- Obras de fábrica necesarias para la correcta instalación de las tuberías, fundamentalmente cruces con carreteras, caminos, ríos y arroyos.

- Ventosas para eliminar el aire acumulado en las tuberías en los puntos altos de la red.

- Válvulas para el gobierno de la red y para independizar ramales o tramos frente a posibles fugas, roturas, averías, etc.

- Hidrantes como puntos de toma para la distribución del agua de riego, que estarán protegidos por una arqueta de hormigón prefabricado.

- Tapones y desagües, ubicados en las colas de las redes.

- Estación de bombeo, con toma desde la balsa de regulación, instalada en una caseta situada al lado de la toma, que servirá también para instalar los órganos de control de la automatización.

- Instalaciones eléctricas, que constarán de una línea eléctrica de media tensión de 1,5 km de longitud aproximada para el suministro de energía a las instalaciones de bombeo, 
centro de transformación, distribuciones de baja tensión y automatización de la red de riego.

- Equipos de filtrado, instalados a la salida de la estación de bombeo.

- Ensayo de campo con instalación de riego por goteo con la red enterrada en una parcela de 10 ha.

\section{A1.2.1.2. Proyecto básico de transformación en regadío del sector IV de la zona regable del canal del trasvase Esla-Campos}

Promotor: Consejería de Agricultura y Ganadería. Junta de Castilla y León

Autor: Alberto Hernáiz Ballesteros (ingeniero agrónomo), Francisco Javier Puertas Jorde (ingeniero agrónomo) y Javier Gregorio Arroyo (ingeniero de caminos, canales y puertos)

Fecha: marzo 2004

Este proyecto matiza los datos aportados en el anteproyecto, en cuanto que la superficie neta regable del sector IV es de 2017 ha en cuatro términos municipales: Villalón de Campos (655 ha), Villafrades de Campos (88 ha), Herrín de Campos (676 ha) y Boadilla de Rioseco (598 ha).

La zona regable tiene una concesión prevista de $400 \mathrm{l} / \mathrm{s}$, suficientes para las demandas iniciales pero no para la real de riego. Para hacer frente a la misma se plantea la construcción de una balsa de acumulación de aproximadamente $10 \mathrm{Hm}^{3}$ que pretende llenarse con aguas procedentes del canal Cea-Carrión, bombeando $2000 \mathrm{l} / \mathrm{s}$ hasta el 1 de abril. A partir de esta fecha comienza la campaña de riegos por la Confederación Hidrográfica del Duero, por lo que la concesión original de $400 \mathrm{l} / \mathrm{s}$ permitirá llenar la balsa.

El estudio geotécnico realizado a partir de los datos de 7 sondeos y 3 calicatas permite concluir que los materiales sobre los que se asientan las obras son predominantemente arcillas y arcillas más o menos limosas. De los ensayos de permeabilidad se deduce que los terrenos son prácticamente impermeables.

Se elige el sistema de riego por aspersión a la demanda, que presenta ventajas sobre el riego localizado:

- No son necesarias las costosas obras de nivelación y desagüe

- Considerable ahorro de agua de riego

- Economía de mano de obra

- Flexibilidad para adaptarse a las exigencias de agua de cada cultivo concreto

- Permitir la rápida adaptación a la práctica de riego para personas no experimentadas en el mismo

Las necesidades de agua se calculan para la siguiente alternativa de cultivos:

- $23 \%$ cereales

- $21 \%$ alfalfa

- $10 \%$ hortícolas

- $10 \%$ girasol 
- $13 \%$ maíz

- $7 \%$ patata

- $16 \%$ remolacha

Las obras incluidas en el proyecto son las siguientes:

\section{1.- Obras inherentes a la concentración parcelaria}

1.1 Obras de saneamiento: Consistirán en la limpieza y dragado de los arroyos de la zona en una longitud de $32254 \mathrm{~m}$.

1.2 Caminos: La anchura de los caminos será de $6 \mathrm{~m}$, que se afirmarán con $20 \mathrm{~cm}$ de zahorra. La longitud total será de $60476 \mathrm{~m}$.

1.3 Obras de fábrica: Consistirán en la colocación de caños o marcos prefabricados de hormigón de distinto diámetro, de acuerdo con la sección hidráulica del desagüe.

\section{2.- Obras inherentes al regadío}

\subsection{Balsa}

Se construirá semiexcavada en el terreno, aprovechando los materiales de la excavación para la formación de los taludes del terraplén. Tal como se ha señalado anteriormente, las arcillas del sustrato son muy impermeables, por lo que no es necesaria una impermeabilización adicional. Sus características se resumen en la Tabla A1.7.

Los terraplenes serán de forma trapezoidal con una anchura de coronación de $6 \mathrm{~m}$ e inclinación $1 \mathrm{~V}: 3 \mathrm{H}$ para el talud de aguas arriba y $1 \mathrm{~V}: 2,5 \mathrm{H}$ para el de aguas abajo. La altura media del terraplén respecto al fondo de la balsa será de 11,3 m. Se proyecta un camino de coronación de $4128 \mathrm{~m}$ de longitud, con firme de material granular. También se plantea un dren chimenea con una anchura total de $1 \mathrm{~m}$ para bajar la línea de filtración.

\begin{tabular}{lc}
\hline Tabla A1.7. Caracteristicas geométricas más destacables de la balsa \\
\hline Cota de coronación & $785,60 \mathrm{~m}$ \\
\hline Cota de fondo & $774,30 \mathrm{~m}$ \\
\hline Cota del agua & $784,30 \mathrm{~m}$ \\
\hline Resguardo & $1,30 \mathrm{~m}$ \\
\hline Superficie de fondo de la balsa & $958758 \mathrm{~m}^{2}$ \\
\hline Superficie de ocupación de la balsa & $1220224 \mathrm{~m}^{2}$ \\
\hline Volumen del embalse & $10183064 \mathrm{~m}^{3}$ \\
\hline Volumen de desmonte & $1836951 \mathrm{~m}^{3}$ \\
\hline Volumen de terraplén & $1725245 \mathrm{~m}^{3}$ \\
\hline Anchura del camino de coronación & $6 \mathrm{~m}$ \\
\hline Longitud del camino de coronación & $4128 \mathrm{~m}$
\end{tabular}


El talud interior de la balsa irá recubierto de escollera, con un tamaño mayor de $30 \mathrm{~cm}$ y un espesor de recubrimiento de $50 \mathrm{~cm}$.

Para el paso de las tuberías de toma y desagüe de la balsa se construirá una galería visitable de hormigón armado. Se proyecta un aliviadero y canal de descarga de hormigón armado, que verterá a un arroyo que discurre por debajo de la balsa. También una obra de desagüe de fondo y toma de agua para riego.

Aguas abajo del dique y anexo al contacto del talud con el terreno, se construirá una caseta de válvulas para el control y regulación del suministro de agua a la red de riego. Tendrá unas dimensiones de 5,70 x 8,70 m y 3,10 m de altura; los paramentos serán de ladrillo y la cubierta de teja curva.

De la caseta de válvulas partirán tres tuberías de fundición de 1400 m, una desde la estación de bombeo del canal, la segunda de la estación de bombeo a la red y la tercera al cuenco amortiguador.

Se proyectan dos caminos de acceso, uno a la coronación del dique (143 m) y otro al fondo de la balsa (165 m).

\subsection{Toma}

La toma del canal se realizará mediante una compuerta de $2 \times 2 \mathrm{~m}$, que permitirá la derivación de los caudales de toma. De ahí partirá una tubería de alimentación de 1,4 $\mathrm{m}$ de diámetro que, tras llegar a la estación de bombeo, impulsará a la balsa cubriendo el máximo caudal. La solución elegida para esta estación ha consistido en un grupo formado por $5+1$ bombas horizontales. El edificio para esta estación de bombeo está constituido por una nave de 25,4×10,4 m con un pequeño almacén para cuadros eléctricos.

\subsection{Estación de bombeo de la balsa}

Está compuesta de $5+1$ bombas horizontales de $500 \mathrm{~kW}$ y $2+1$ bombas de $92 \mathrm{~kW}$ para cubrir las

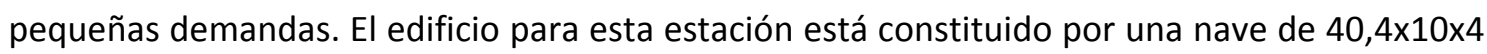
$m$ con una sala de control, aseos, una pequeña oficina y un almacén. Los paramentos se plantean en ladrillo visto.

\subsection{Tuberías}

Se prevé una red de riego para el sector capaz de suministrar agua a presión que cubra las necesidades de riego del mismo. El diseño de las redes se hará con tuberías de PVC de 6 atm y PVC orientado de 10 y $16 \mathrm{~atm}$. La longitud total de tuberías es de $47022 \mathrm{~m}$.

\subsection{Zanjas y obras de fábrica}

Las zanjas se proyectan de acuerdo con los tamaños de las tuberías, de forma que estas se encuentren enterradas un mínimo de $1 \mathrm{~m}$ por encima de la clave. Las obras de fábrica de la red de riego son las necesarias para la correcta instalación de las tuberías, proyectándose 11 cruces en camino, 8 cruces bajo cauce de arroyo y 1 cruce bajo cauce de río. 


\subsection{Ventosas}

Las ventosas se colocan al objeto de eliminar el aire acumulado en las tuberías en los puntos altos de la red. Se prevé un número de 76.

\subsection{Válvulas}

Para el oportuno gobierno de la red y a objeto de independizar ramales o tramos frente a posibles fugas, roturas, averías, etc., se incorporarán a la red un total de 21 válvulas.

\subsection{Hidrantes}

Son los puntos de toma para la distribución del agua de riego, que constan de un collarín de toma, mástil de salida de calderería de acero galvanizado, válvula de compuerta, válvula contador, filtro cazapiedras, etc. Todo el conjunto del hidrante estará protegido por una arqueta rectangular de hormigón prefabricado de $2 \times 1,5 \mathrm{~m}$ de planta por 1,5 $\mathrm{m}$ de profundidad, con tapa de chapa de acero galvanizada. Se instalarán 234 unidades.

\subsection{Tapones y desagües}

En las colas de las redes y en los puntos más bajos de las tuberías, se contará con 19 unidades de tapones, instalando junto a estos un desagüe.

\section{3.- Instalaciones eléctricas}

\subsection{Línea eléctrica y subestación}

Para el suministro de la energía eléctrica a las instalaciones de bombeo es necesario construir una subestación transformadora de 45/15, línea eléctrica de 15 kV de tensión con una longitud de $6 \mathrm{~km}$ y línea eléctrica enterrada de las mismas características.

\subsection{Centros de transformación}

Se construirán dos transformadores, uno en cada estación de bombeo.

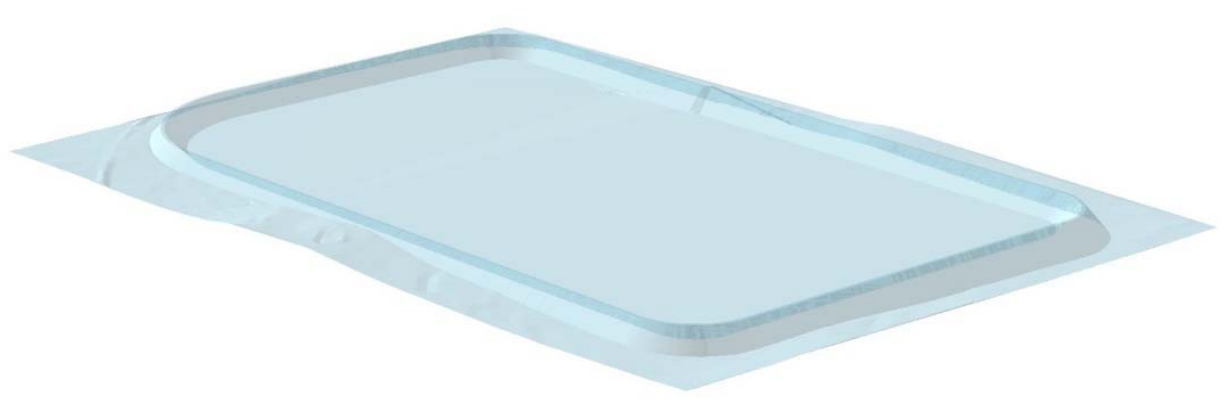

Figura A1.19. Simulación gráfica de la balsa de regadío. 
El presupuesto de ejecución material del Proyecto de transformación en regadío del sector IV de la zona regable del canal del trasvase Esla-Campos es de $20101901 €$.

A1.2.1.3. Proyecto de transformación en regadío del sector IV de la zona regable del canal del trasvase Esla-Carrión. Obras de interés general. Fase I

Promotor: ITACYL. Consejería de Agricultura y Ganadería. Junta de Castilla y León

Autor: David Martínez Paniagua (ingeniero agrónomo), María González Corral (ingeniera de caminos, canales y puertos) y Javier Gregorio Arroyo (ingeniero de caminos, canales y puertos)

Fecha: enero 2009

Este documento es el proyecto de ejecución que analiza con mayor detalle las actuaciones previstas en el proyecto básico de marzo de 2004. Hay pequeñas modificaciones respecto del mismo (Tabla A1.8); entre otras cuestiones se reduce ligeramente el tamaño de la balsa, se elimina un tramo de la línea eléctrica aérea propuesta para dotar de energía a la estación de bombeo (se aprovecha una existente, por lo que únicamente se debe construir un tramo de 86 m) y se disminuye el presupuesto de ejecución material (Tabla A1.9).

Tabla A1.8. Características geométricas más destacables de la balsa (actualizadas)

\begin{tabular}{lr}
\hline Cota de coronación & $784,00 \mathrm{~m}$ \\
\hline Cota de fondo & $772,00 \mathrm{~m}$ \\
\hline Cota del agua & $782,75 \mathrm{~m}$ \\
\hline Resguardo & $1,25 \mathrm{~m}$ \\
\hline Superficie de ocupación de la balsa & $1080195 \mathrm{~m}^{2}$ \\
\hline Volumen del embalse & $9963562 \mathrm{~m}^{3}$ \\
\hline Volumen de desmonte & $1795685 \mathrm{~m}^{3}$ \\
\hline Volumen de terraplén & $1953317 \mathrm{~m}^{3}$ \\
\hline Anchura del camino de coronación & $6 \mathrm{~m}$ \\
\hline Longitud del camino de coronación & $4145 \mathrm{~m}$
\end{tabular}


Tabla A1.9. Presupuesto de ejecución material

\begin{tabular}{|c|c|c|}
\hline Capítulo & Resumen & Importe $(€)$ \\
\hline 1 & Balsa & 12774239 \\
\hline 2 & Instalaciones anexas & 1533615 \\
\hline 3 & Estación de bombeo & 1022731 \\
\hline 4 & Camino & 46873 \\
\hline 5 & Arroyos & 89404 \\
\hline 6 & Tubería & 1832964 \\
\hline 7 & Restauración del medio natural & 703044 \\
\hline 8 & Seguridad y salud & 50121 \\
\hline \multirow[t]{2}{*}{9} & Electricidad & 583139 \\
\hline & TOTAL & 18636131 \\
\hline
\end{tabular}

\section{A1.2.2. Condicionantes ambientales}

A1.2.2.1. Estudio de Impacto Ambiental de la concentración parcelaria y transformación en regadío del sector IV Esla-Carrión (Palencia, Valladolid)

Este Estudio se realizó conjuntamente para los dos proyectos, siendo muchas medidas correctoras comunes a ambos. Por consiguiente, nos remitiremos al apartado correspondiente analizado con anterioridad de la Concentración parcelaria de Herrín de Campos, Villafrades de Campos, Villalón de Campos y Boadilla de Rioseco.

A1.2.2.2. Declaración de Impacto Ambiental, hecha pública por Resolución de 23 de octubre de 2003, de la Consejería de Medio Ambiente (BOCyL 31/10/2003).

Además de las medidas generales ya analizadas en el proyecto de concentración parcelaria, las condiciones específicas de la DIA referidas al proyecto de transformación en regadío son las siguientes:

3.b) Retirada selectiva de la tierra vegetal de la balsa y la red de canalizaciones, utilizando el sobrante para la restauración de espacios degradados de la zona. Esta medida es de gran trascendencia debido al enorme volumen de suelo sobrante como consecuencia de la construcción del hueco que forma la balsa. 
3.k) (últimos párrafos) La revegetación de los taludes exteriores a la balsa se realizará mediante hidrosiembra, previa la extensión de una capa de tierra vegetal, con el fin de proteger el suelo en un breve periodo de tiempo. Ello se completará con la plantación de arbustos y árboles característicos de zonas húmedas en el entorno de la balsa.

En los taludes interiores de la balsa, construidos con escollera, también se aplicarán técnicas de restauración vegetal. Para ello, los huecos creados entre las piedras deberán rellenarse con tierra vegetal, implantándose posteriormente estaquillas con especies adaptadas a estas condiciones de humedad.

Se recomienda modificar el contorno de la balsa, haciéndolo más sinuoso, con objeto de que pueda albergar a una mayor población de fauna acuática, así como de estar mejor integrada paisajísticamente.

3.m) Con el fin de evitar el riesgo de colisión de avutardas y aguiluchos cenizos, en un sector con densidades importantes de ambas especies, se contemplará el enterramiento de la línea eléctrica de media tensión. Si esta medida fuese técnica o económicamente inviable, se instalarán dispositivos salvapájaros.

3.ñ) Los acabados exteriores de las edificaciones necesarias (sobre todo la caseta de bombeo), presentarán totalidades cromáticas acordes con las características tradicionales del entorno, preferentemente rojizas para las cubiertas y ocres o terrosas para los paramentos.

5. La Consejería de Agricultura y Ganadería deberá redactar proyectos de restauración, preferiblemente independientes, correspondientes a la concentración parcelaria y transformación en regadío.

A1.2.2.3. Separata ambiental del Proyecto de transformación en regadío del sector IV de la zona regable del canal del trasvase Esla-Carrión. Obras de interés general. Fase I

Promotor: ITACYL. Consejería de Agricultura y Ganadería. Junta de Castilla y León

Autor: David Martínez Paniagua (ingeniero agrónomo), María González Corral (ingeniera de caminos, canales y puertos) y Javier Gregorio Arroyo (ingeniero de caminos, canales y puertos)

Fecha: enero 2009

Este documento se plantea como un capítulo dentro del Proyecto de ejecución de la transformación en regadío del sector IV, fase I. Incorpora las siguientes actuaciones:

1.- Reconocimiento arqueológico.

De encontrarse yacimientos en la zona afectada por las obras, se adoptarán las medidas propuestas por el órgano competente en materia de Cultura. 


\section{2.- Restauración vegetal.}

En primer lugar, se desaconseja la plantación de especies arbustivas y arbóreas en el talud exterior de la balsa, por su elevado desarrollo radicular, dado que pueden incrementar la permeabilidad de la balsa. Se propone la plantación en el exterior de los taludes, en rodales monoespecíficos de $100 \mathrm{~m}^{2}$, cubriendo un $50 \%$ de la superficie considerada. Para ello se seleccionan gayomba, escaramujo y endrino. El marco será de $1,5 \times 1,5 \mathrm{~m}$, se colocarán protectores y se realizarán labores de protección de la plantación.

En segundo lugar se plantea la restauración de un tramo de arroyo de $1000 \mathrm{~m}$ afectado por la balsa, introduciéndose árboles de ribera y arbustos: álamo, nogal, sauces, fresno, saúco, escaramujo y endrino.

En tercer lugar se proyecta la plantación de árboles en la franja perimetral a la balsa, con una anchura a forestar de 15 a 20 m (Figura A1.20). Se seleccionan álamo, sauce, almendro, pino piñonero, encina y quejigo, con una densidad de 625 pies/ha. Se colocarán protectores y se realizarán labores de mantenimiento. En todos los casos habrá una reposición de marras durante 2 años.

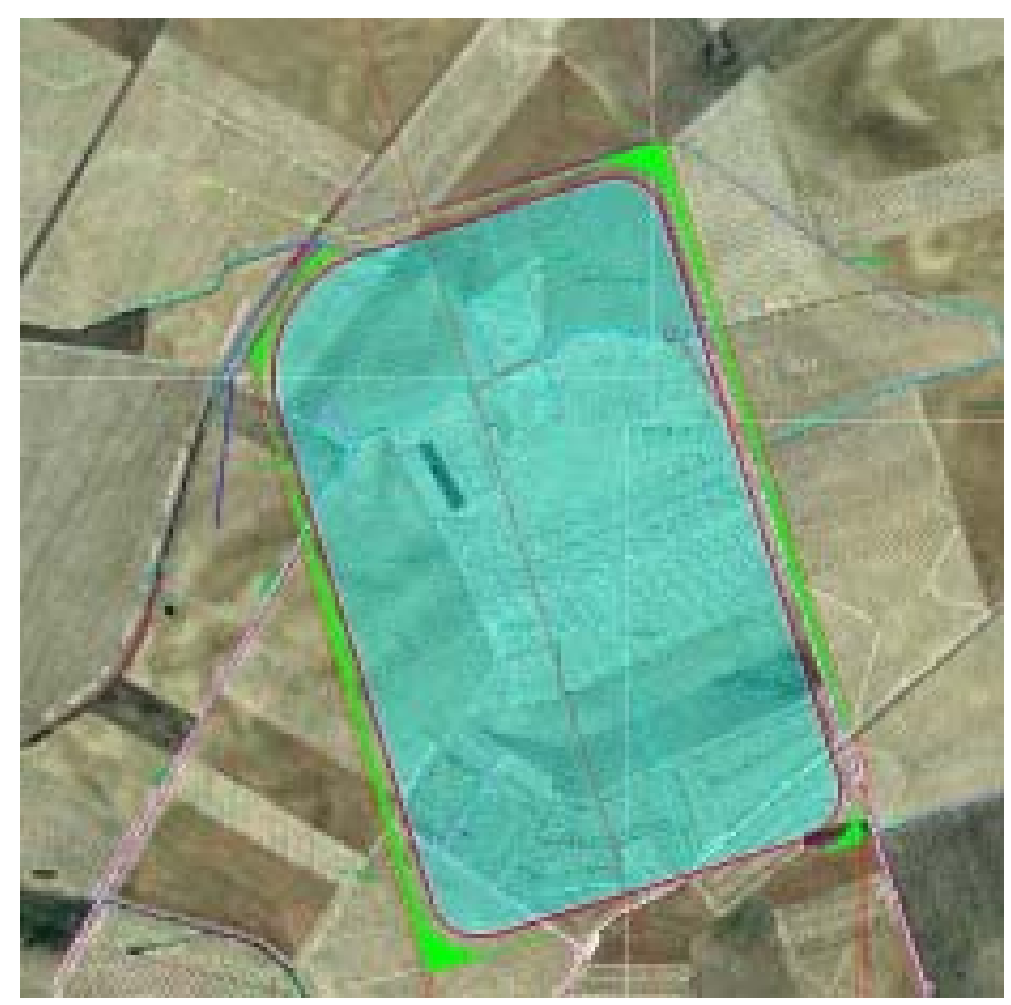

Figura A1.20. En color verde se reflejan las zonas susceptibles de plantaciones arbóreas y arbustivas.

En cuarto y último lugar, se incluye la restauración herbácea de los taludes de la balsa (Figura A1.21). Para ello, se separará la tierra vegetal afectada por la balsa durante la explanación, en cordones alineados en la parte exterior de la misma. Una vez construida la balsa y previo 
perfilado de taludes se aportará dicha tierra en los taludes exteriores de la misma. Inmediatamente después se realizará la hidrosiembra con semillas de la zona procedentes de los rechazos de las plantas de clasificación y limpieza de semillas de cereales.

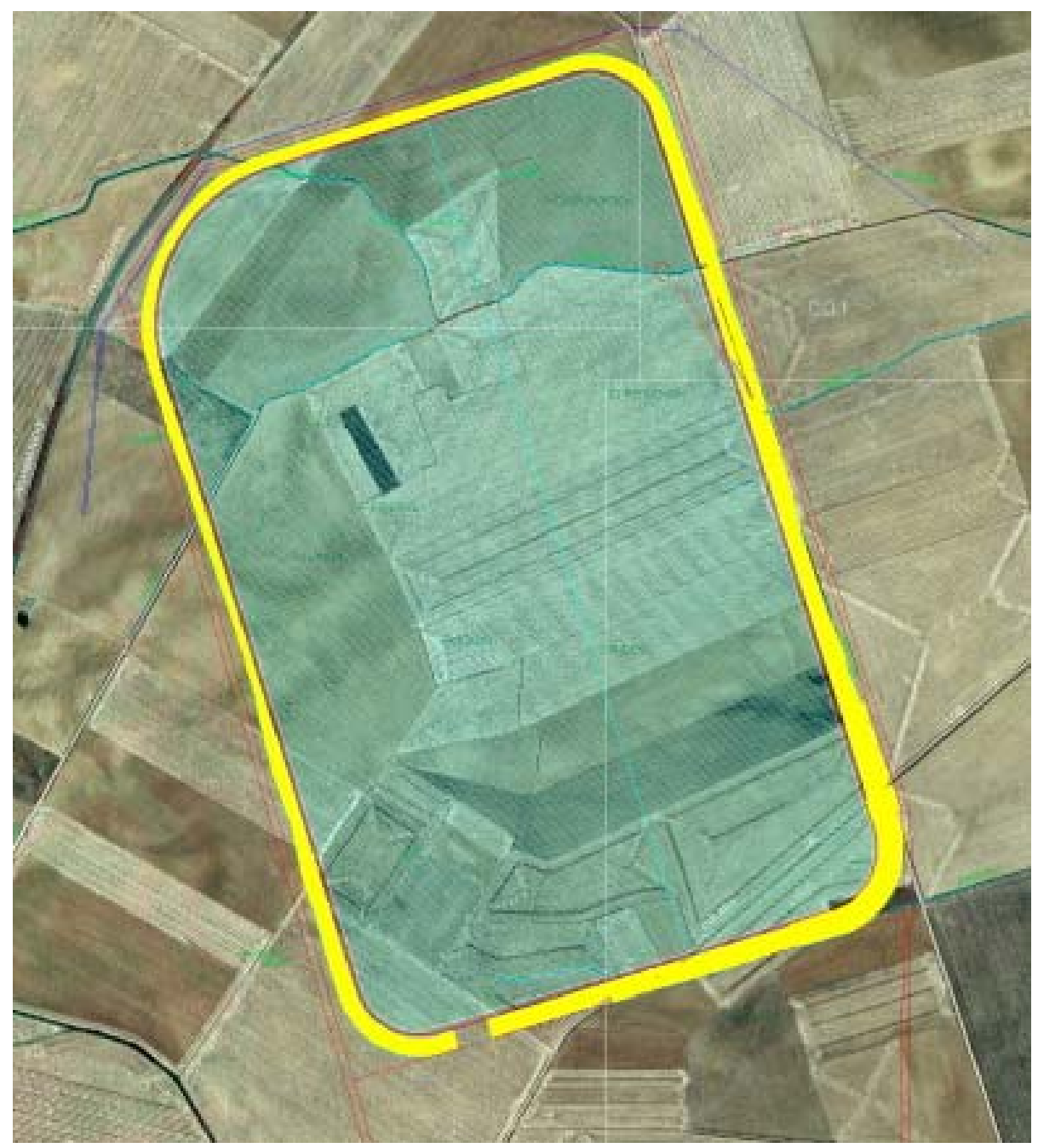

Figura A1.21. En color amarillo se observa la superficie de talud exterior de terraplén de la balsa, que será restaurada con la extensión de tierra vegetal, siembra de herbáceas y posterior plantación de matas arbustivas.

\section{3.- Señalización de sendero de pequeño recorrido.}

Para mejorar la función educativa y social del espacio natural afectado por la transformación, se señalizará una ruta desde la antigua vía del ferrocarril hasta la balsa, donde podrá observarse una vista panorámica de la zona húmeda. Hay que tener en cuenta que, previsiblemente, la en la balsa se asentará una importante población de anátidas y otras especies acuáticas. 


\section{4.- Instalación de bancos y carteles informativos.}

Se proyectan 4 carteles relacionados con los dos tipos de hábitat más característicos de la zona, el de zonas húmedas y el de zonas esteparias. Como complemento se colocarán 10 bancos que permitan el descanso de los transeúntes, ubicados en el entorno de la balsa.

5.- Colocación de balizas de visualización y elementos preventivos de electrocución de aves en líneas eléctricas.

Se establecerán las medidas reglamentarias para evitar la electrocución de aves, así como también se instalarán balizas de señalización (salvapájaros) para disminuir el riesgo de colisión.

6.- Eliminación de ruidos de las estaciones de bombeo e integración paisajística de las mismas.

Los locales de las estaciones de bombeo se aislarán con una capa de aislamiento acústico para minimizar las molestias sobre la fauna que pudiera merodear por zonas próximas. Además se han proyectado los cerramientos exteriores de las edificaciones en totalidades cromáticas acordes con el entorno, en ladrillo caravista de tonalidades ocres o terrosas. En una modificación posterior se plantea la utilización de planchas de hormigón prefabricado con acabado exterior en tipo "adobe", así como una cubierta metálica con acabado en tonos teja.

7.- Restauración de canteras y escombreras.

Se utilizarán los $800000 \mathrm{~m}^{3}$ de material sobrante de construcción de la balsa en el relleno y restauración de espacios degradados próximos, en un total de 40 ha. Se propone una antigua balsa de purines próxima a la zona y varios espacios degradados de los cuatro términos afectados.

8.- Observatorio de aves.

La magnitud superficial de la balsa (casi $100 \mathrm{ha}$ ) hace prever un importante asentamiento de aves acuáticas. Para su visualización, se incorporan en el proyecto dos observatorios de madera tratada, ubicadas en zonas próximas a la antigua vía del ferrocarril. Una posterior modificación del proyecto incorporó la construcción de un terraplén adyacente al talud exterior occidental de la balsa, donde se dispondrá un único observatorio y una pequeña área natural de esparcimiento (Figura A1.22). 


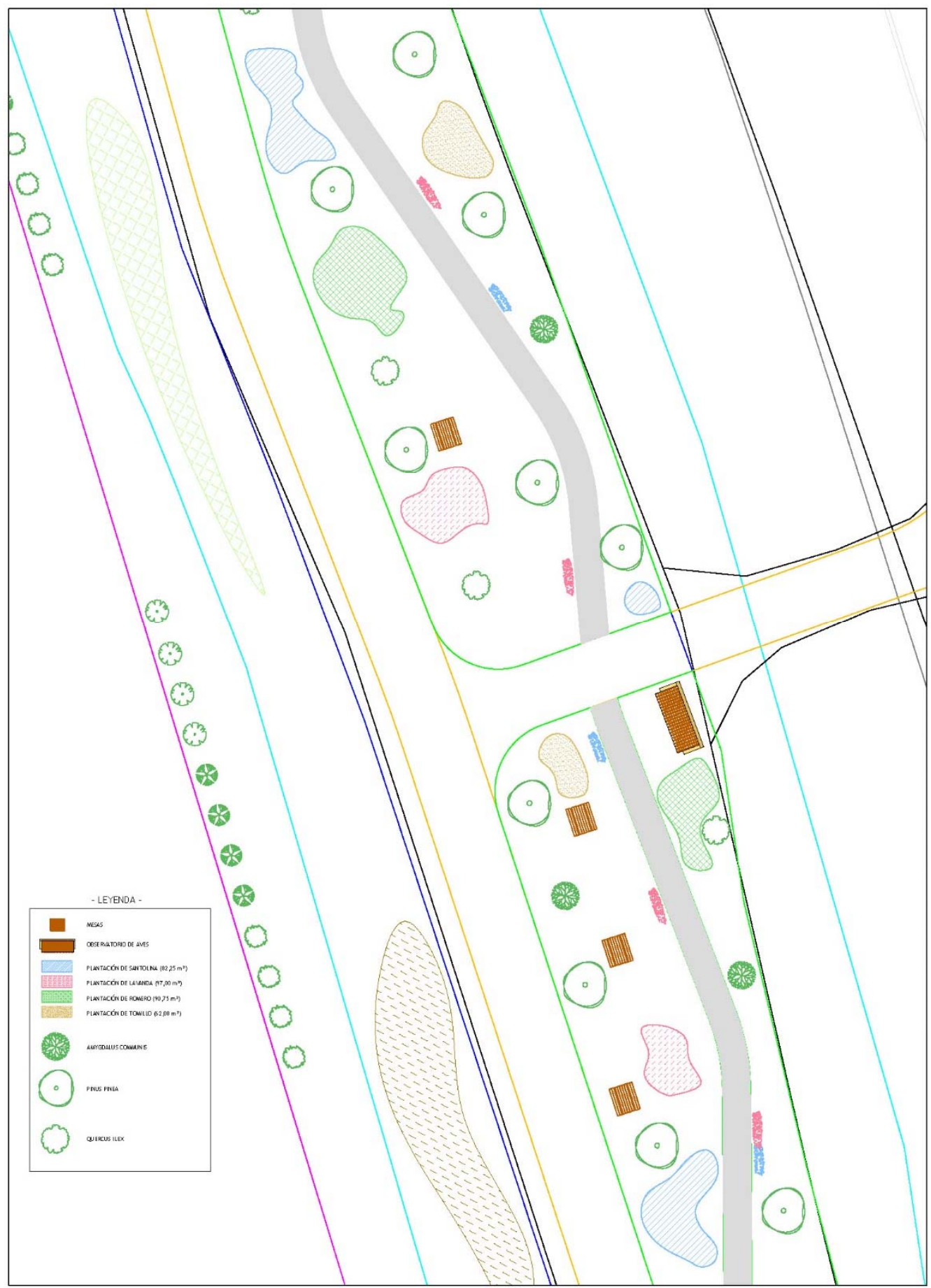

Figura A1.22. Plano con el diseño de la adecuación paisajística del entorno del observatorio de aves, que además incluye una senda peatonal y diversas plantaciones vegetales.

\section{9.- Plataforma en balsa y playa.}

Se proyecta una zona de talud más tendido a la del resto de la balsa, que permitirá la estancia, refugio y nidificación de especies acuáticas. También se plantea la colocación de estructuras flotantes que permitan el solaz y esparcimiento de las aves sin ser molestadas; estas imitarán 
islotes e irán ancladas al fondo de la balsa para evitar su arrastre. Se proyectan 10 unidades con dimensiones de $2 \times 2 \mathrm{~m}$.

10.- Valla.

Para evitar la libre circulación de personas ajenas al control del regadío y por motivos de seguridad, se proyecta la instalación de un vallado con malla cinegética, de modo que pueda permitir la libre circulación de la fauna silvestre. Se realizará con postes de madera tratada y alambres de acero galvanizado.

\begin{tabular}{|c|c|c|}
\hline Subcapítulo & Concepto & Importe (€) \\
\hline 1 & Reconocimiento arqueológico & 10800 \\
\hline 2 & Plantaciones y siembras & 301145 \\
\hline 3 & Señalización de sendero de pequeño recorrido & 1028 \\
\hline 4 & Instalación de bancos y carteles informativos & 2448 \\
\hline 5 & $\begin{array}{l}\text { Colocación de balizas y elementos seguridad en líneas } \\
\text { eléctricas }\end{array}$ & 21976 \\
\hline 6 & Eliminación de ruidos en estaciones de bombeo & 9988 \\
\hline \multirow[t]{2}{*}{7} & Restauración de escombreras & 268962 \\
\hline & TOTAL & 616347 \\
\hline
\end{tabular}

El presupuesto de ejecución material (Figura A1.10) de las medidas de integración ambiental contempladas en el proyecto asciende a $616347 €$. Esta cantidad supone un 3,31\% del presupuesto de ejecución material del Proyecto de transformación en regadío del sector IV de la zona regable del canal del trasvase Esla-Carrión.

\section{A1.2.3. Ejecución}

\section{A1.2.3.1. Seguimiento de la obra e informes de vigilancia ambiental.}

Para este apartado se han realizado numerosas visitas técnicas a la obra, de fechas $22 / 9 / 9$, $7 / 4 / 10,24 / 9 / 11,19 / 1 / 12,3 / 5 / 12,24 / 5 / 12,21 / 6 / 12,2 / 9 / 13,21 / 10 / 13,20 / 5 / 14,23 / 10 / 14$, $13 / 3 / 15$ y $12 / 4 / 15$. También sirven de referencia los informes de vigilancia ambiental no 3 (noviembre 2011), no 6 (septiembre 2013) y no 7 (enero 2015) elaborados por Alfonso Millán Ortega, ingeniero de montes del ITACYL. 
Las obras comenzaron en octubre de 2009. La primera fase consistió en el desbroce y retirada de la tierra vegetal, acordonándola en la parte exterior de la zona de ocupación en montones de altura no superior a $2 \mathrm{~m}$. Posteriormente se inició la excavación del terreno de ubicación de la balsa y la construcción del dique, mediante el terraplenado por sucesivas tongadas del material extraído en el hueco (Figura A1.23). El extendido y compactado de los taludes del dique de la balsa se realizó con camiones volquetes, traíllas, dúmper, motoniveladora, buldócer y rodillo autopropulsado vibrante. Se dispuso un dren chimenea inclinado en el interior del dique con un geotextil, realizado con material drenante calibrado capaz de garantizar la evacuación del agua y retener las partículas finas del dique.

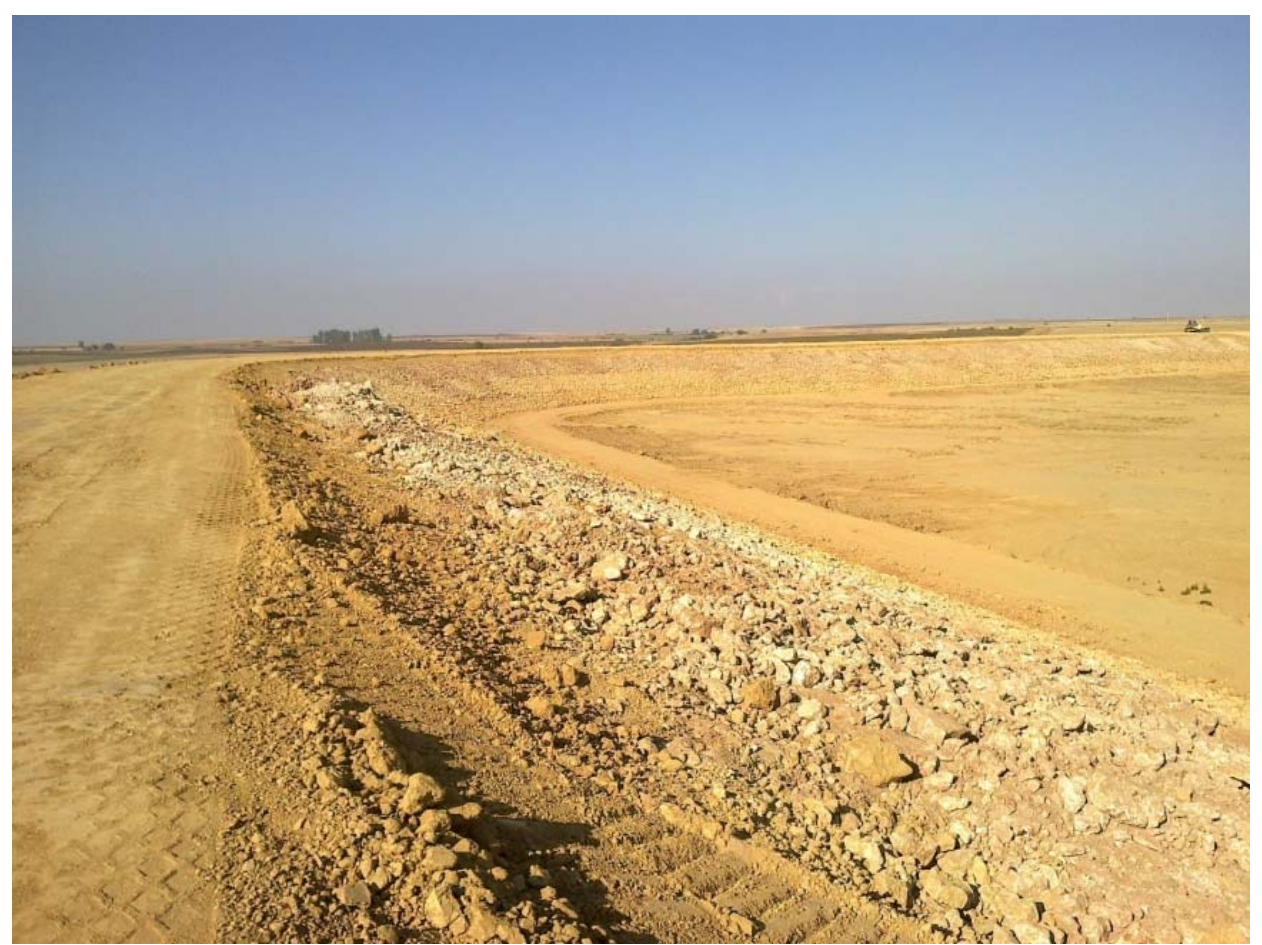

Figura A1.23. Imagen inicial de las obras en la balsa. El material extraído en el vaso se utiliza fundamentalmente para la creación del dique. A la par, se dispone la escollera de protección del talud interior.

Paralelamente se construía la galería visitable, la cámara de válvulas y el cuenco de amortiguación, en hormigón armado con juntas de PVC para garantizar su estanqueidad.

Los taludes exteriores se conformaron con una pendiente de $1 \mathrm{~V}: 2,3 \mathrm{H}$. Se recubrió de escollera la parte inferior de dichos taludes, para su protección. Posteriormente se extendió la tierra vegetal previamente acopiada, mediante buldócer con pala empujando el material de abajo a arriba. Finalmente, los taludes se sembraron a voleo con semillas de gramíneas procedentes del rechazo de plantas de selección (Figura A1.24). 

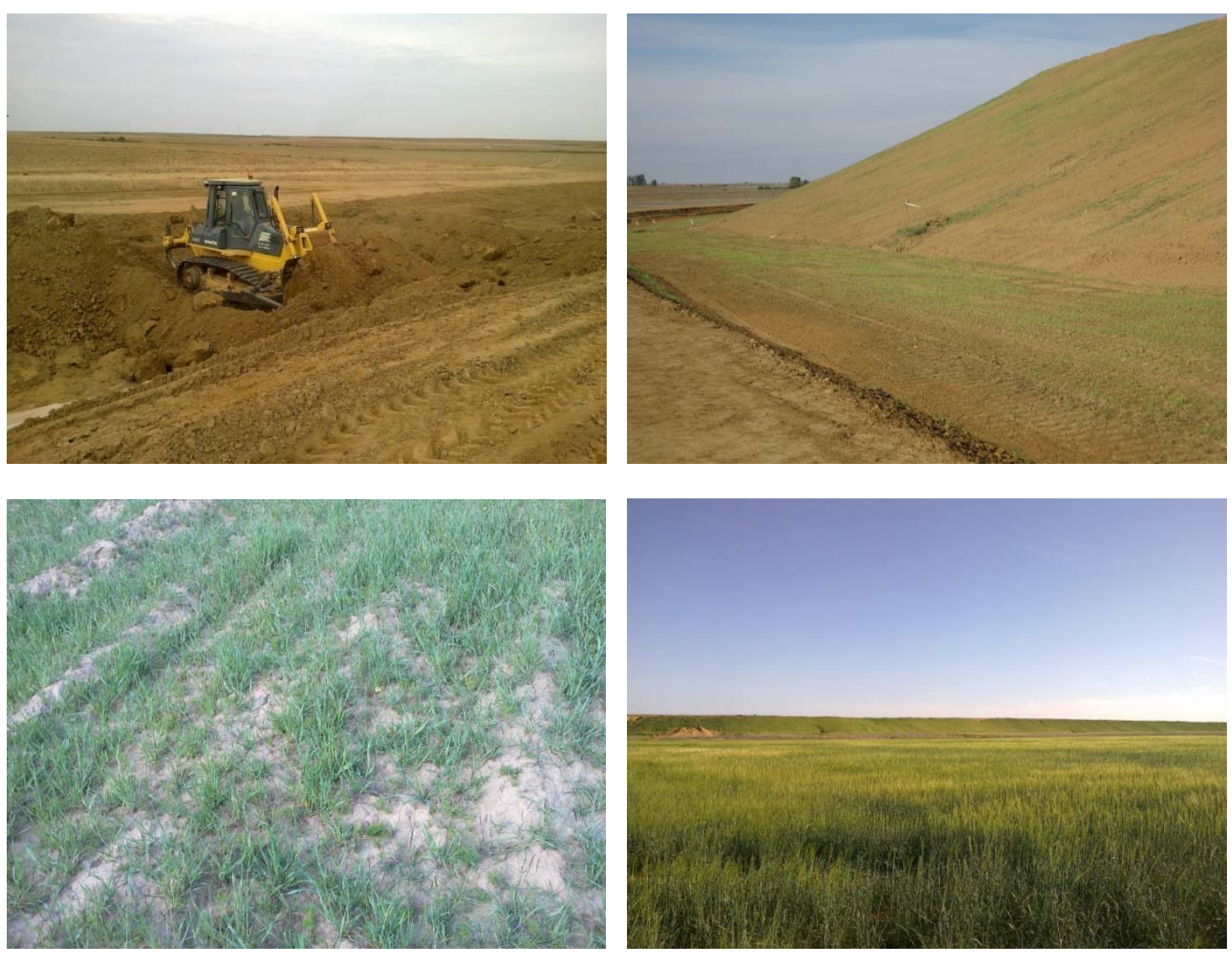

Figura A1.24. Distintas fases de la restauración vegetal del talud exterior de la balsa de regadío. Arriba izquierda, extensión de la tierra vegetal con buldócer. Arriba derecha, primera fase de la nascencia de herbáceas. Abajo izquierda, detalle del talud con una aceptable cobertura herbácea. Abajo derecha, vista al fondo del dique en primavera muy bien integrado en el paisaje.

La escollera se transportó desde una cantera de piedra caliza del páramo de Torozos, en La Mudarra. Los áridos, de graveras situadas en la vega del río Cea.

En esta primera fase también se realizó la restauración de varios espacios degradados con el volumen de desmonte sobrante de la excavación de la balsa, retirando determinados residuos, extendiendo la tierra y remodelando adecuadamente el terreno. En ese momento no se realizaron las plantaciones vegetales sobre estas zonas (lo hicieron en 2015). Tampoco se ultimó la restauración de la antigua balsa de purines, por desacuerdo con el propietario. 

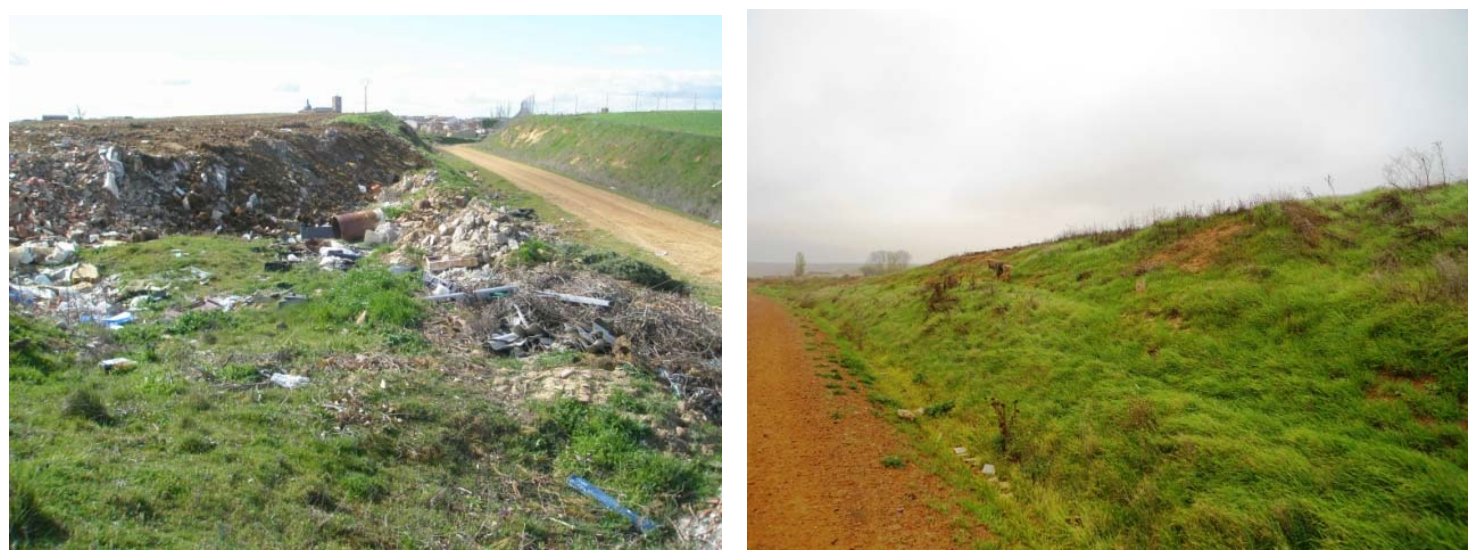

Figura A1.25. Antes y después de la restauración de una parcela en Villalón de Campos, realizada con sobrantes del desmonte de la balsa de riego.

A finales de octubre de 2011 se paralizaron los trabajos. Estos se iniciaron en verano de 2013 con, entre otras actuaciones, la construcción de una zona elevada unida a la balsa con la finalidad de servir de zona de recreo y donde está previsto instalar un observatorio de aves.

En otoño de 2014 el terraplén del dique llegó a coronación, se recubrió de escollera todo el talud interior, se acondicionó el camino perimetral y se colocó una bionda de protección de hormigón. El lecho de la balsa no se perfiló en un mismo plano; posee ligeras irregularidades topográficas que, en época de mínimo nivel de agua (final del periodo de riego) permitirán la presencia de charcas distribuidas por la superficie (Figura A1.27). En la primavera de 2015 las obras se centran en toda la infraestructura contemplada en el proyecto (Figura A1.26), que es complementaria a la balsa: obra de toma, estación de bombeo a la balsa y limpieza del repié de la escollera exterior a la misma.

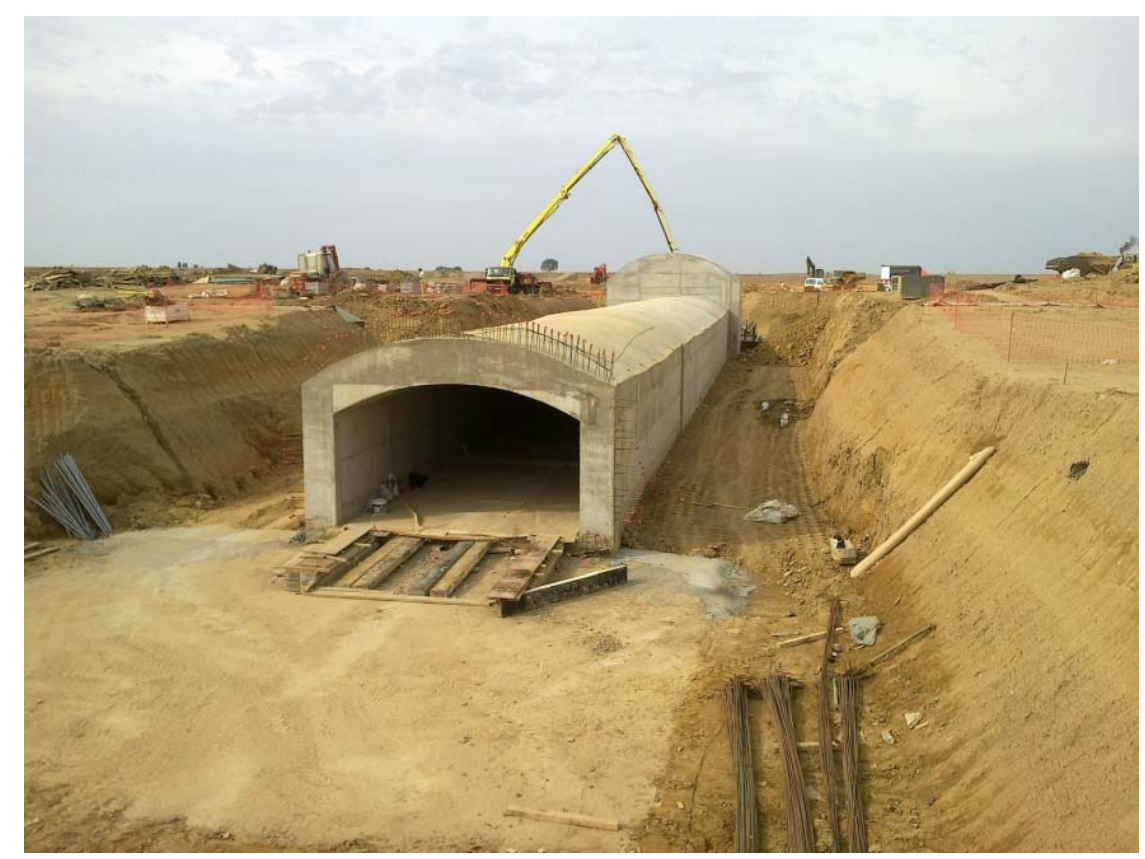

Figura A1.26. Imagen de una fase de la obra en la que se observa su magnitud. 


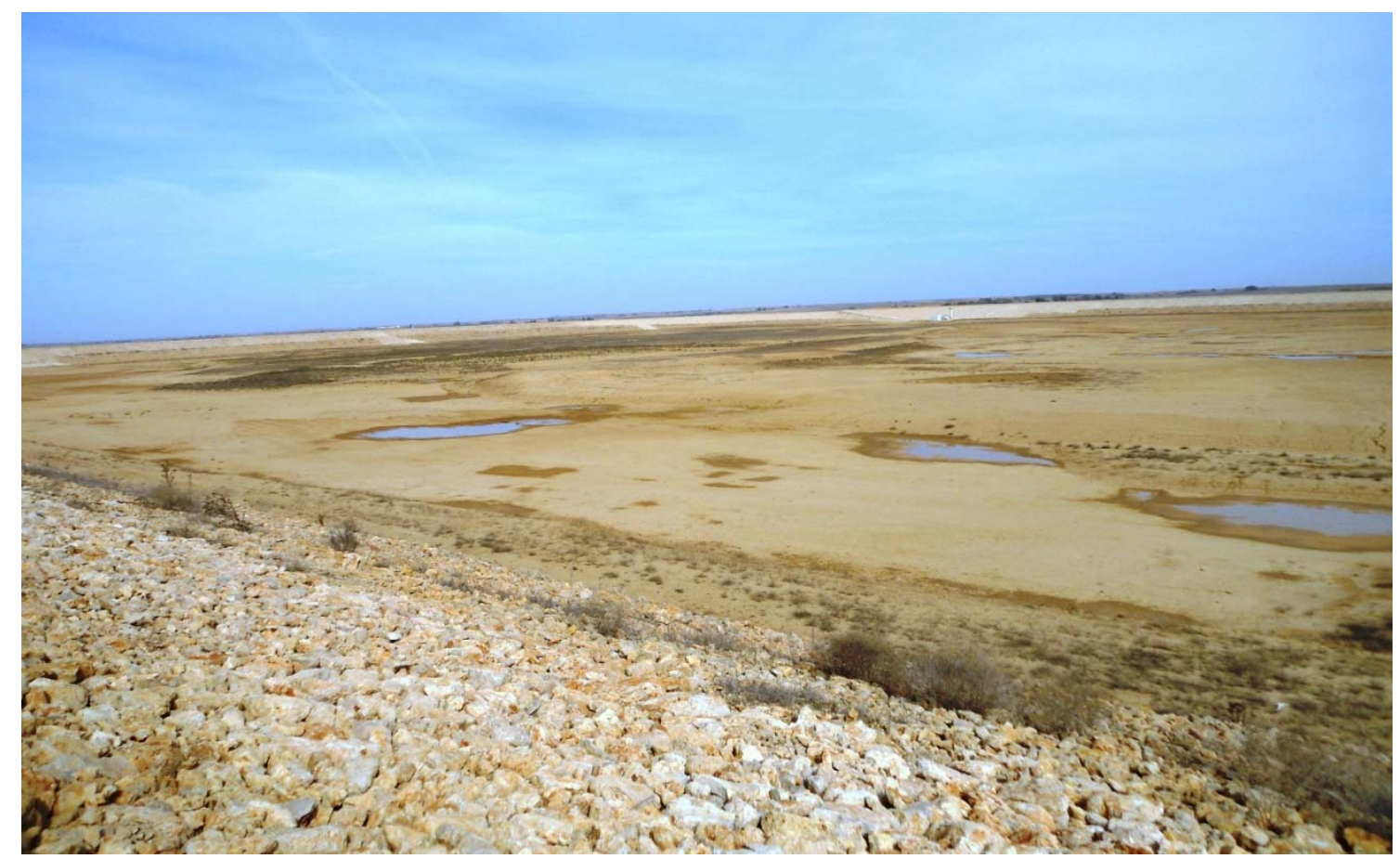

Figura A1.27. Imagen del interior de la balsa una vez alcanzada la coronación del dique. Se observa la integración de la piedra de escollera del talud interior, así como las irregularidades topográficas en el lecho.

Las plantaciones vegetales se comenzaron a realizar a finales de noviembre de 2014 , aunque las heladas invernales las postergaron en su mayoría a los meses de febrero y marzo de 2015 (Figura A1.28). La primera zona de actuación fue el talud exterior, donde se plantaron arbustos cuyo crecimiento radical no fuese excesivo, para no afectar a la estabilidad e impermeabilidad del terraplén. La preparación del terreno del perímetro de la balsa se realizó con un gradeo y posterior subsolado, mientras que en los taludes se realizaron hoyos de forma manual. La presencia de conejos exigió la colocación de protectores (malla de rejilla de plástico con tutor). En el perímetro de la superficie ocupada por la actuación se realizó un caballón, con objeto de proteger el terreno público de posibles intrusiones; esto se ayudó con una posterior plantación lineal de arbustos. Tanto el invierno como el inicio de la primavera de 2015 han sido muy secos, por lo que existe un riesgo considerable de que se produzcan marras en las plantaciones. 

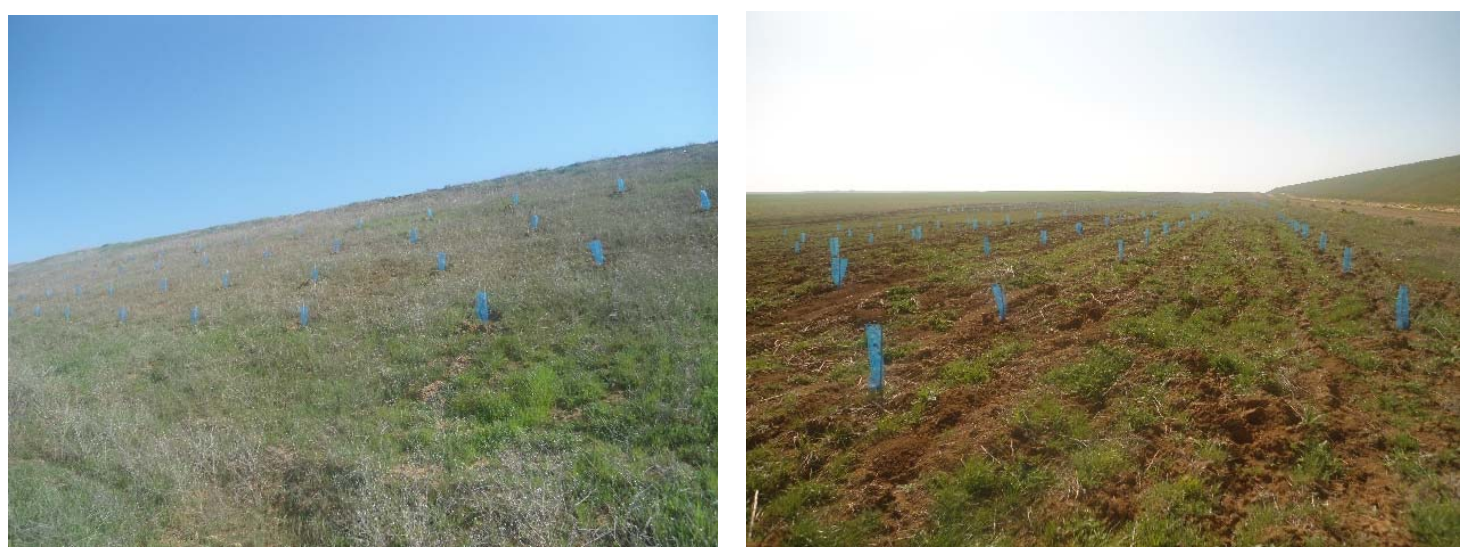

Figura A1.28. Imágenes de las plantaciones en abril de 2015: en el talud exterior (izquierda) y en la franja exterior a la balsa (derecha).

Está previsto que las obras del proyecto de construcción de la balsa y sus infraestructuras asociadas finalicen en agosto de 2015.

\section{A1.2.3.2. Conclusiones del seguimiento ambiental}

De acuerdo a todo lo aportado en el presente estudio, se considera que el proyecto de transformación en regadío es positivo para esta zona de Tierra de Campos desde muchos puntos de vista. En particular, constituye una mejora de su paisaje, ya que la introducción de nuevos cultivos proporcionará mayor variedad en el paisaje agrícola y el riego en verano supondrá la irrupción de importantes superficies verdes en un entorno eminentemente árido.

La construcción de una balsa de riego de notable extensión (aproximadamente 100 ha) supone otra mejora añadida para el paisaje (Figura A1.29). El agua es uno de los elementos consustanciales a los paisajes de calidad visual, por lo que su incorporación a la trama agraria reportará ineludiblemente una mejora de este atributo. Por otro lado, desde el punto de vista del paisaje ecológico también la mejora es sustancial; la creación de una gran lámina de agua acarreará un nuevo hábitat que, a buen seguro, será ocupado por un gran número de especies acuáticas. 


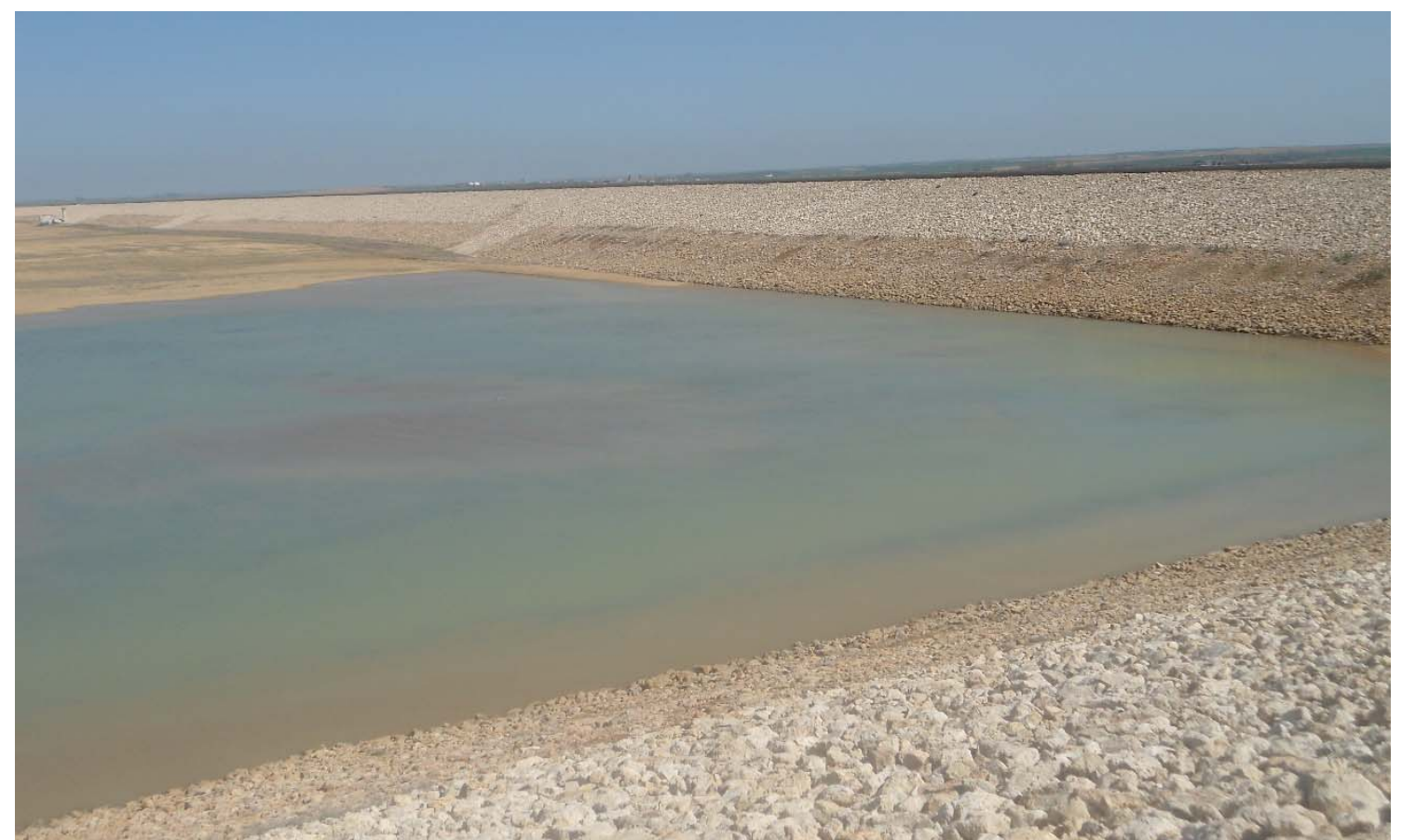

Figura A1.29. La irrupción de una importante superficie de agua en Tierra de Campos supondrá una notable mejora de su paisaje, tanto en su vertiente visual como ecológica.

La adecuación de la balsa para fines naturales y recreativos -compatibles evidentemente con el uso del regadío- puede generar una importante valorización del paisaje de Tierra de Campos. En este sentido, la rehabilitación de la antigua vía del ferrocarril como vía verde es un valor añadido, ya que conecta las poblaciones de Boadilla de Rioseco y Villalón de Campos (e indirectamente otras localidades) con la balsa a través de un recorrido naturalizado. La construcción de observatorios para la avifauna, la creación de senderos de pequeños recorridos, la adecuación de áreas recreativas $u$ otros proyectos que se planteen en el futuro pueden ser excelentes oportunidades para el desarrollo turístico de la comarca.

No se ha cumplido la recomendación de la DIA para diseñar el contorno de la balsa de forma sinuosa. La justificación esgrimida ha sido la inviabilidad técnica. No obstante, la elevada superficie del vaso a inundar y su configuración rectangular con aristas redondeadas, permite afirmar que la balsa posee unos altos índices de naturalidad.

La reducida pendiente de los taludes también es un factor que contribuye a naturalizar en buena medida esta obra, en concordancia con la geomorfología de la comarca de llanuras suavemente onduladas. En lo que respecta al talud exterior -que es el más visible- este hecho es garantía de que se producirá su restauración vegetal espontánea; de hecho, en general no se aprecian fenómenos erosivos, a pesar de su gran extensión.

Otro factor añadido que favorece la naturalización de la balsa es la utilización de piedra caliza del cercano páramo de Torozos para la protección con escollera del talud interior. Su color es muy próximo al de la tierra de la comarca, y además proporciona una textura característica al conjunto. 
Se ha realizado adecuadamente la retirada selectiva de la tierra vegetal-condición fundamental en una superficie de tal magnitud-, su mantenimiento en cordones perimetrales y su posterior utilización para la restauración de los taludes exteriores de la balsa. El hecho de que se hayan revegetado de forma natural con rapidez es una muestra de la efectividad de esta medida.

El proyecto contempló un correcto equilibrio entre los volúmenes de desmonte y terraplén, lo que es muy positivo en términos ambientales. El hecho de que existiese un cierto volumen sobrante, además de no precisar nuevos préstamos, supuso la posibilidad de restaurar una superficie considerable de espacios degradados del entorno. En este caso se trata de un impacto ambiental positivo inducido.

Las prescripciones incluidas en el proyecto de ejecución permiten asegurar la integración paisajística de las edificaciones asociadas a la balsa (Figura A1.30), por su tipología y sus acabados (terrosos en los paramentos y en tonos teja en las cubiertas).

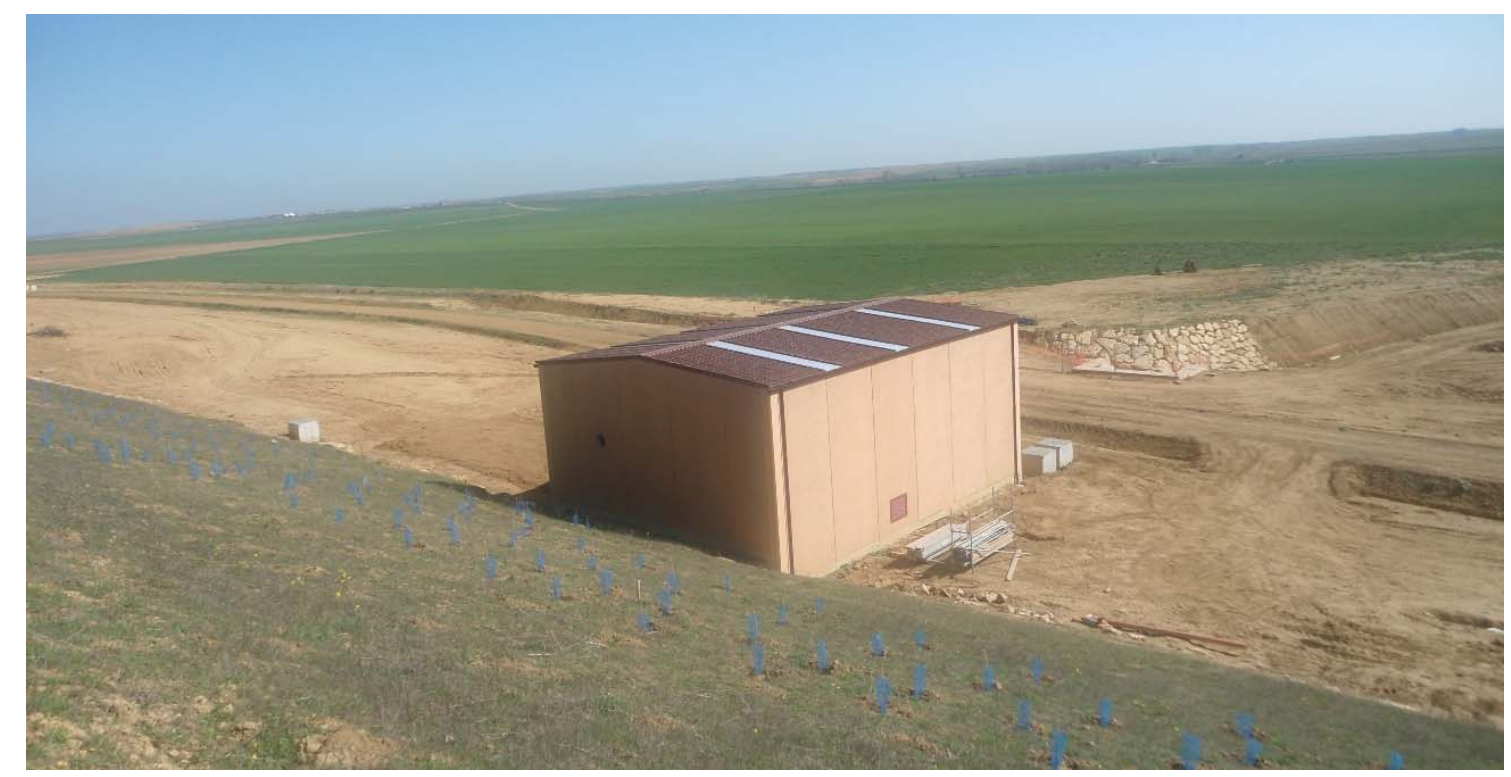

Figura A1.30. Vista de la caseta de bombeo perfectamente integrada en el paisaje, construida con paneles de hormigón con acabado de adobe y cubierta metálica en tonos teja.

Se ha realizado una correcta incorporación de las medidas de protección y recuperación ambiental en el proyecto de ejecución, que forman un capítulo independiente. El análisis y detalle de las actuaciones es apropiado para las características de Tierra de Campos, y su presupuesto es suficiente (un 3,3 \% del presupuesto de ejecución material del proyecto de regadío).

La restauración vegetal herbácea del talud exterior de la balsa es, en principio, suficiente para garantizar una adecuada cobertura del terreno y evitar fenómenos de erosión. En su mayoría proviene del banco de semillas de la tierra vegetal, así como de la incorporación espontánea de semillas del entorno agrícola. No obstante, teniendo en cuenta que la inmensa mayoría de las especies asentadas son gramíneas anuales, hubiese sido conveniente introducir en la mezcla especies leguminosas que tienen un mayor grado de permanencia. 
No se incluyó en el proyecto original la plantación de especies arbóreas y arbustivas en los taludes interior y exterior de la balsa. Asumiendo esta inviabilidad para el talud interior, por motivos técnicos y de seguridad, se estima que en el talud exterior sí que es factible la plantación de arbustos, pues sus raíces nunca podrían afectar a la impermeabilidad del dique. En el caso extremo, al menos se deberían incluir matas. Más que efectos negativos, los arbustos proporcionan estabilidad al talud, evitando fenómenos de erosión ante episodios de lluvia torrenciales. De hecho, el último modificado del proyecto de construcción recogió una partida para plantación de arbustos en un determinado porcentaje de la superficie del talud de terraplén, lo que se considera paisajísticamente muy positivo.

Ha resultado acertado que las plantaciones de árboles afecten a la mayoría de la superficie exterior afectada por la balsa, para asegurar la integración paisajística de la obra y crear una verdadera zona verde. También es correcto que se hayan diferenciado rodales de plantación en función de la humedad edáfica, con especies para zonas secas (pino piñonero, encina, almendro, etc.) y otras para zonas húmedas (chopo, álamo, sauce, etc.). Ante la duda se debería optar por estas últimas, cuyo crecimiento es mayor y son más propias de riberas y humedales.

En general, tanto el diseño de la restauración vegetal como su ejecución han sido muy acertadas. La elección de las especies (autóctonas o propias de la zona) es correcta, como también lo es el hecho de que sea planta pequeña forestal. La superficie ocupada por plantaciones es considerable y se reparte de un modo homogéneo alrededor de la balsa, lo que permite asegurar la integración paisajística de esta infraestructura de regadío.

Sin embargo, el hecho de que la plantación se haya realizado de forma tardía (finales de invierno y comienzo de la primavera) representa un inconveniente en años como el de 2015, que en sus inicios está teniendo unos muy bajos índices de precipitación. Además, teniendo en cuenta que las obras de la balsa finalizan el 15 de agosto de 2015, la retirada de los efectivos humanos y materiales de la obra principal supone otro riesgo añadido para el mantenimiento de la plantación, dado que precisamente en esta época del año es donde necesita más cuidados (riegos, alcorques, reposición de marras, etc.).

Los cauces de algunos de los arroyos rectificados, que ahora discurren por el perímetro exterior de la balsa, se conformaron inicialmente con unos taludes de pendientes excesivas (en torno a $1 \mathrm{~V}: 1 \mathrm{H})$. Sería necesaria su remodelación para que fuesen más estables y pudiesen albergar las especies con las que se pretende su restauración.

No se ha contemplado el soterramiento de la línea eléctrica de suministro a las estaciones de bombeo, de acuerdo a la recomendación de la DIA, pero sí que se ha reducido notablemente su longitud, disminuyendo de este modo el impacto visual y el riesgo de colisión para la avifauna. 


\section{A1.3. Explotación de ganado ovino en Ampudia.}

\section{A1.3.1. PROYECTO}

\section{A1.3.1.1. Proyecto de ejecución de alojamiento e instalaciones para ganado ovino de leche en Ampudia (Palencia).}

Promotor: Cooperativa Nuestra Señora de Alconada

Autor: Javier Pérez García (ingeniero técnico agrícola)

Fecha: febrero de 2010

La explotación ganadera se proyecta en la parcela catastral 2 del polígono 307 del término municipal de Ampudia, que tiene una superficie de 6,27 ha. El uso actual es agrícola de secano. La parcela está clasificada urbanísticamente como suelo rústico, aunque está muy próxima al casco urbano, a unos $200 \mathrm{~m}$.

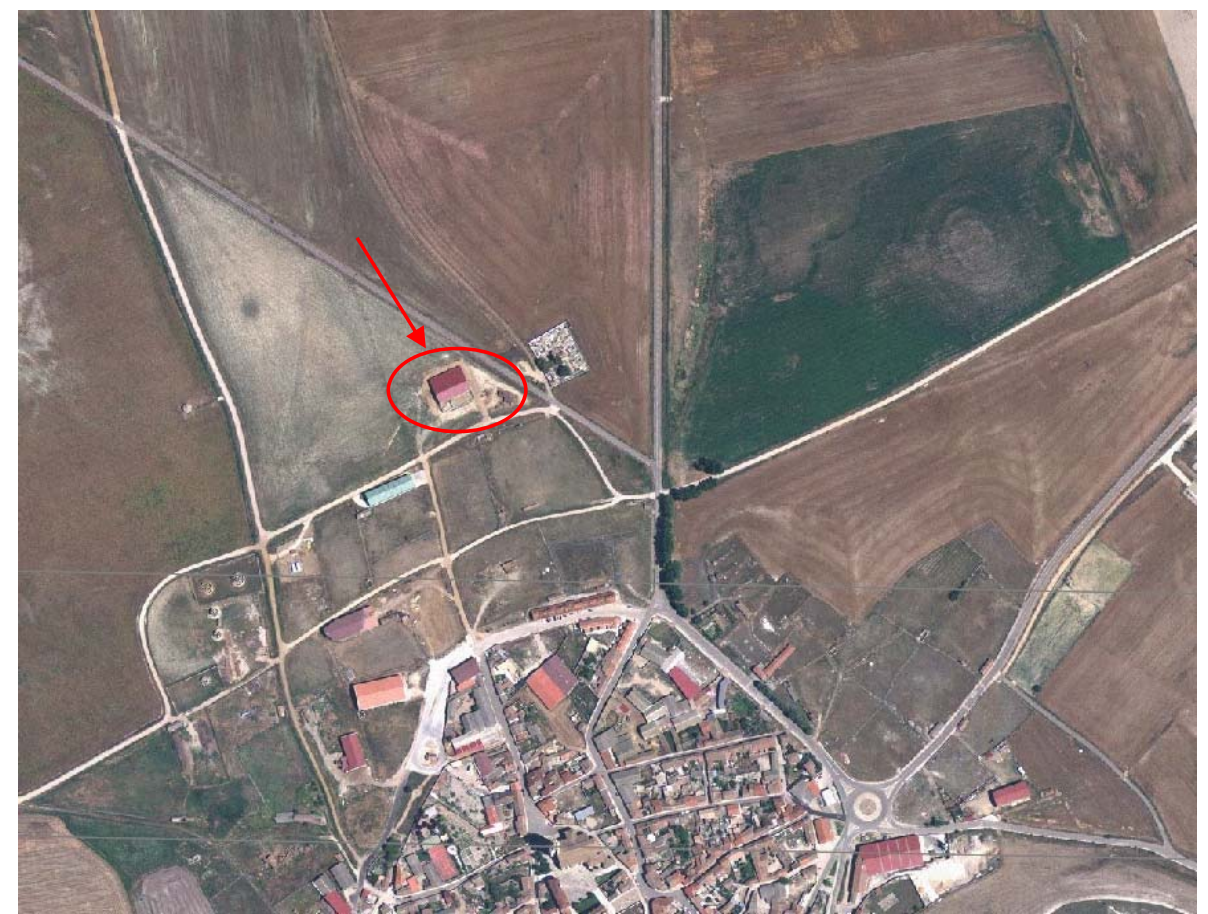

Figura A1.31. Ortofotografía con la ubicación de la nave ganadera al norte del casco urbano de Ampudia.

El proyecto se trata de la construcción de un edificio de $6 \mathrm{~m}$ de altura máxima a alero, con parte de la fachada sur abierta a la parcela de acceso, diseñándose una estructura de pórticos metálicos empotrados, con una altura a cumbrera de $8,50 \mathrm{~m}$ a dos aguas, pendiente de cubierta del $25 \%$ y una luz de 27,46 m. La construcción proyectada es de planta rectangular, con una superficie construida total de $967 \mathrm{~m}^{2}$ y con las siguientes dimensiones: 27,46 m x 35,22 m. 
El programa de necesidades se refiere a una edificación de planta baja para alojamiento del ganado ovino e instalaciones de ordeño mecánico. La explotación está orientada a la producción de leche y carne de ovino.

Las instalaciones cuentan con el propio alojamiento de ganado ovino (que ocupa la mayor parte de la superficie), sala de ordeño, lechería, zona de espera y oficina.

En cuanto al sistema estructural, la cimentación se realiza a base de zapatas y vigas de cimentación de hormigón armado. La estructura portante se compone de pórticos metálicos IPE, la de cubierta está formada por correas metálicas a una separación máxima de 1,50 m. Se utilizará acero laminado.

La cubierta será de chapa de acero prelacado de 0,6 $\mathrm{mm}$ de espesor. Los cerramientos estarán formados por un muro de hormigón de $1 \mathrm{~m}$ de altura y paneles verticales de acero prelacado de 0,6 mm sobre estructura auxiliar metálica formada por correas y fábrica de bloques de termoarcilla de baja densidad.

La edificación cumple con las condiciones de edificación de las Normas Urbanísticas Municipales de Ampudia para el suelo rústico, en particular en lo referente a retranqueos (más de $10 \mathrm{~m}$ ), altura máxima (6 $\mathrm{m}$ ) y a ocupación máxima de parcela (1,54 \%).

El presupuesto de ejecución material asciende a $112790 €$. Incluye un capítulo de gestión de residuos de $61 €$ y ninguno relativo a la adecuación del entorno.

\section{A1.3.2. Condicionantes ambientales}

\section{A1.3.2.1. Memoria ambiental del proyecto de ejecución.}

Promotor: Cooperativa Nuestra Señora de Alconada

Autor: Javier Pérez García (ingeniero técnico agrícola)

Fecha: febrero de 2010

La orientación de la explotación ganadera es de producción de leche y carne. La leche se almacena en la propia explotación, en dos tanques refrigerados (lechería). El sistema de producción utilizado es el de semi-estabulación; se corresponde con un sistema de estabulación tradicional estante, con estabulación al final de la gestación, durante la lactación y por las noches.

El Reglamento de Actividades Molestas, Insalubres, Nocivas y Peligrosas clasifica la actividad como molesta, insalubre y nociva, por los ruidos, malos olores, residuos y vertidos que se producen y potencialmente por el riesgo de enfermedades infectocontagiosas.

Se estima que el total de estiércol generado será de $989 \mathrm{~kg} /$ día. El sistema de evacuación de estiércol será discontinuo; se trata de realizar una limpieza periódica de las instalaciones, una o dos veces cada 60 días, que dependerá del tiempo de estancia de los animales en el aprisco y la época del año. 
El estiércol-deyecciones sólidas y líquidas- procedente de la explotación, se utilizará como fertilizante orgánico en tierras agrícolas, y se repartirá sobre áreas sin cultivo en ese momento (rastrojos o barbechos). El promotor cuenta para ello con una superficie agrícola total de 254 , 36 ha de secano.

El estiércol se transportará y depositará en la parcela 12 del polígono 308 de Ampudia, ubicada a unos $2500 \mathrm{~m}$ al norte de las instalaciones y del casco urbano. El estiércol se transportará y distribuirá mediante remolque esparcidor; para reducir o evitar los malos olores que originan las fermentaciones anaerobias, durante el transporte se cubrirán los remolques con lona plástica.

En cuanto al tratamiento de aguas residuales, el sistema propuesto consiste en una red de saneamiento formada por tubos de PVC procedente de la lechería, que se unen en un pozo o fosa de homogeneización (separador de grasas). La fosa se vaciará y limpiará de sedimentos periódicamente, una vez al mes o cada vez que se retire el estiércol del aprisco, y se depositará conjuntamente en la parcela destinada a estercolero.

La Memoria Ambiental contiene una serie de medidas de control complementarias: desinfección de las instalaciones, aislamiento del rebaño de determinados animales para evitar enfermedades, medidas sanitarias en el interior de la explotación, registro de tratamiento de medicamentos, registro de operaciones de gestión de deyecciones ganaderas, protección de animales, protección contra incendios, etc.

\section{A1.3.2.2. Informe de la Comisión Territorial de Prevención Ambiental, de $\mathbf{2 7}$ de mayo de 2010.}

En primer lugar, se considera que la actividad se encuentra sometida al régimen de licencia ambiental según lo establecido en el artículo 24 de la Ley 11/2003, de 8 de abril, de Prevención Ambiental de Castilla y León.

En segundo lugar, se informa favorablemente la actividad, aceptando las medidas correctoras contenidas en el Proyecto y en la Memoria Ambiental, debiéndose además cumplir otras adicionales. A continuación se detallan las relativas a la protección del paisaje:

2.C) Se prohíbe la acumulación de estiércol a menos de $500 \mathrm{~m}$ del núcleo de población y a menos de $100 \mathrm{~m}$ de cauce público.

2.D) Junto con la comunicación de inicio deberá presentar justificación documental del destino de los residuos generados en la fase de construcción ante el Ayuntamiento y ante el Servicio Territorial de Medio Ambiente de la Junta de Castilla y León en Palencia.

2.G) Con objeto de integrar la construcción en el paisaje, se recomienda que sus acabados exteriores presenten tonalidades cromáticas acordes con las características del entorno, preferentemente rojizas para las cubiertas y ocres o terrosas para los paramentos, sin perjuicio de lo previsto al efecto en la normativa urbanística vigente.

Las medidas correctoras fueron íntegramente transcritas en la licencia ambiental y urbanística expedida por el Ayuntamiento de Ampudia, resuelta con fecha 4 de junio de 2010. 


\section{A1.3.3. Ejecución}

\section{A1.3.3.1. Seguimiento de la obra.}

Las obras fueron realizadas en el segundo semestre de 2010 y principios de 2011, teniendo en cuenta que la licencia de apertura tiene fecha de 6 de abril de 2011.

El 7 de febrero de 2013 se realizó visita técnica a la explotación ganadera. Se comprueba que las obras se han adecuado en general al proyecto, encontrándose en normal uso pecuario (Figura A1.32).
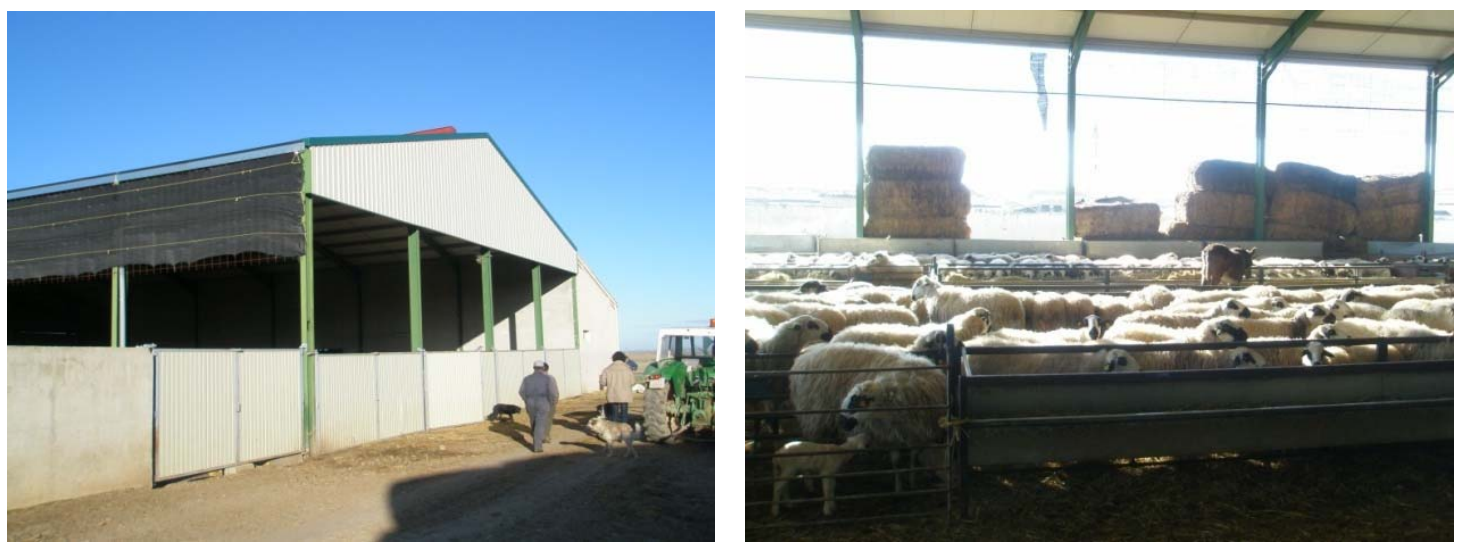

Figura A1.32. Imágenes de la nave ganadera y de su interior.

La explotación está limitada perimetralmente por una malla metálica (Figura A1.33). El terreno no está pavimentado, encontrándose ocupado parcialmente por pacas de paja y maquinaria diversa.
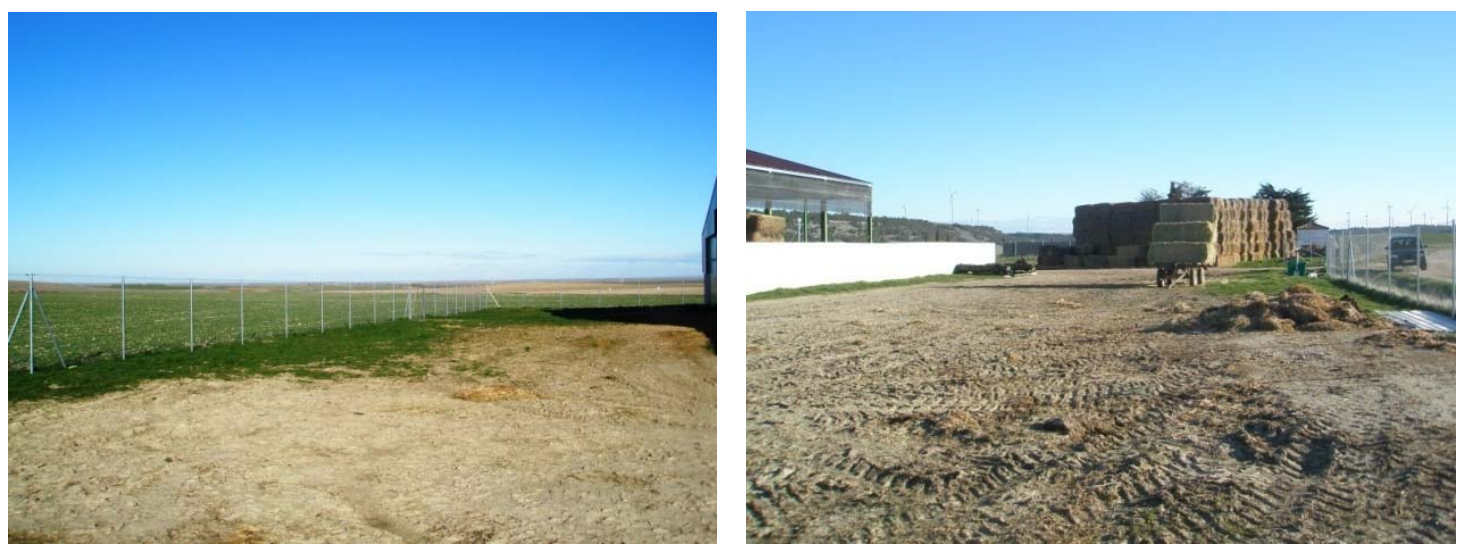

Figura A1.33. Imágenes del entorno vallado de la nave de ovino.

La nave está parcialmente abierta, siendo visibles los pilares metálicos de la estructura, que han sido pintados en color verde claro. La chapa metálica de los paramentos cubiertos es de color 
ocre claro; también se han pintado en este tono las paredes construidas con termoarcilla y hormigón (muro del aprisco, oficina, lechería). La cubierta está formada por paneles de chapa prelacada rojiza (Figura A1.34).
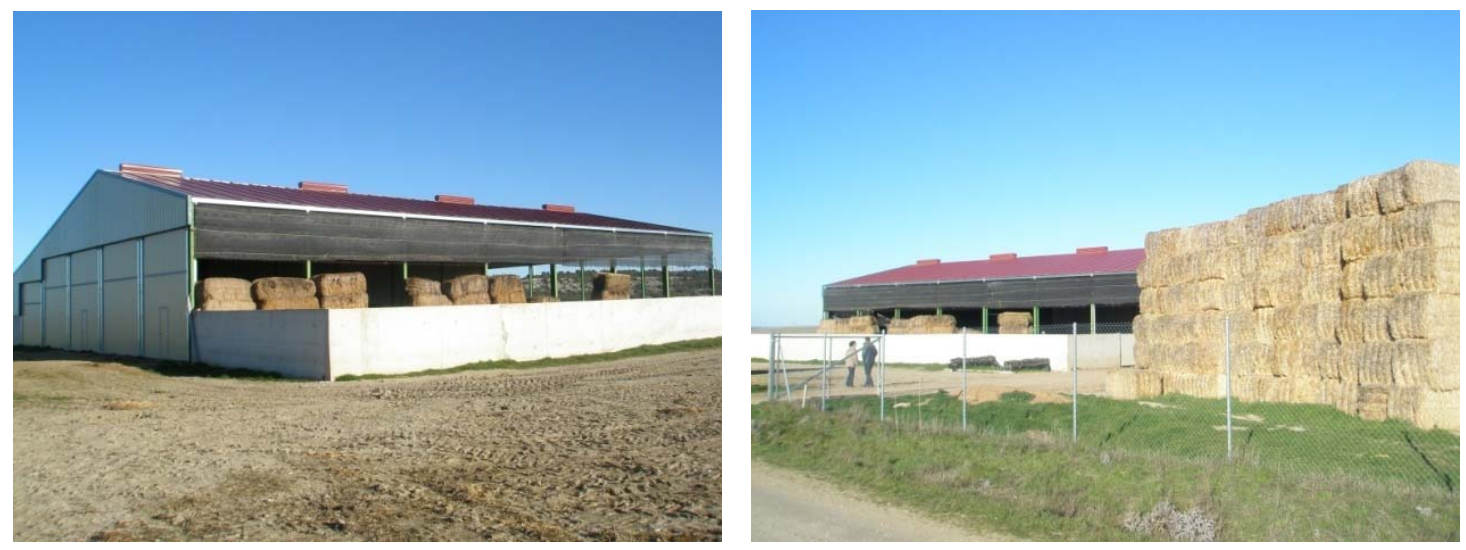

Figura A1.34. Sendas vistas de la construcción ganadera.

El promotor señala que la tierra vegetal y los escasos residuos de construcción y demolición de las obras fueron destinados a la mejora de tierras (los cerámicos) mientras que los plásticos fueron quemados. Las aguas de limpieza se dirigen a una fosa de aproximadamente $1 \mathrm{~m}^{3} \mathrm{de}$ capacidad, que es limpiada cada 3 meses de forma manual.

El estercolero no se ha ubicado en la posición indicada en el proyecto, modificándose a otro emplazamiento ubicado en las eras próximas al pueblo (Figura A1.35).

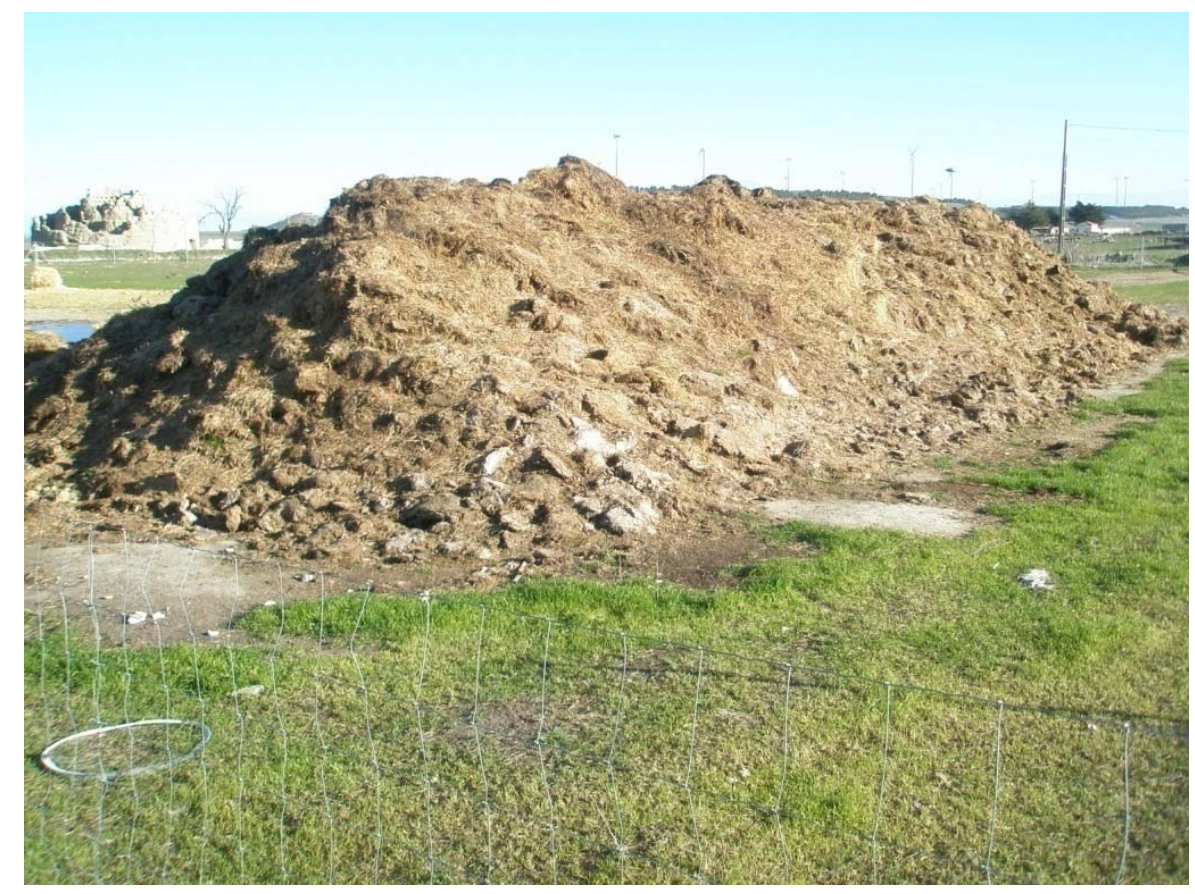

Figura A1.35. Imagen del estercolero, que también se encuentra vallado. 


\section{A1.3.3.2. Conclusiones del seguimiento ambiental.}

El impacto paisajístico de la nave ganadera es moderado: su recuperación no precisa de prácticas protectoras o correctoras intensivas. Se trata de un uso pecuario en suelo rústico común, donde es plenamente admisible.

La ubicación es acertada: se sitúa en las cercanías del pueblo y, por tanto, del resto de edificaciones, pero a la vez suficientemente alejada como para que los olores y molestias generadas sobre la población no sean significativas.

Se ha cumplido la recomendación de integración de la construcción en el paisaje, con paramentos ocres y cubiertas rojizas. Se considera que esta medida es muy adecuada para minimizar el impacto visual de estas grandes edificaciones, más en este caso teniendo en cuenta que Ampudia está declarado como conjunto histórico-artístico.

En el entorno de la nave no hay depósitos de escombros u otros residuos, y presenta un adecuado aspecto en cuanto al orden y disposición de los elementos auxiliares de la explotación.

Sería muy interesante la plantación de árboles y arbustos en el entorno de la nave, para mejorar su integración paisajística. Una adecuada distribución sería la plantación de arbustos autóctonos en la valla y de árboles (autóctonos o frutales) en alguna zona no transitable. Existe espacio suficiente para compatibilizar todos los usos.

La ubicación del estercolero en un terreno distinto al proyectado podría incumplir la condición de estar situado a más de $500 \mathrm{~m}$ del casco urbano. Aunque el olor generado por el estiércol de ovino no es muy fuerte, sí que existe un cierto riesgo de que en determinadas condiciones de viento y temperatura se produzcan olores indeseados a la población de Ampudia. 


\section{A1.4. Explotación de ganado ovino en Cisneros.}

\section{A1.4.1. Proyecto}

A1.4.1.1. Proyecto básico de ampliación de explotación ovina de cebo en Cisneros (Palencia).

Promotor: Cárnicas Andrés Antolín, S.L.

Redactor: José María Moreno García (ingeniero agrónomo)

Fecha: octubre de 2009

El proyecto plantea la ampliación de una explotación ganadera, que en la actualidad cuenta con una capacidad para lechazos de cebo de 500 cabezas, hasta alcanzar una capacidad total de cebo de 1450 cabezas en dos naves.

La explotación se sitúa en la parcela 13 del polígono 26 del término municipal de Cisneros (Palencia), cuya superficie es de $5200 \mathrm{~m}^{2}$ (Figuras A1.36 y A1.40). La distancia al casco urbano es de algo menos de $100 \mathrm{~m}$. Dado que el municipio no cuenta con planeamiento urbanístico propio, son de aplicación las Directrices de Ordenación de Ámbito Subregional de la provincia de Palencia, aprobadas por Decreto 6/2009, de 26 de enero. De acuerdo con esta norma, la parcela ocuparía suelo rústico común. 


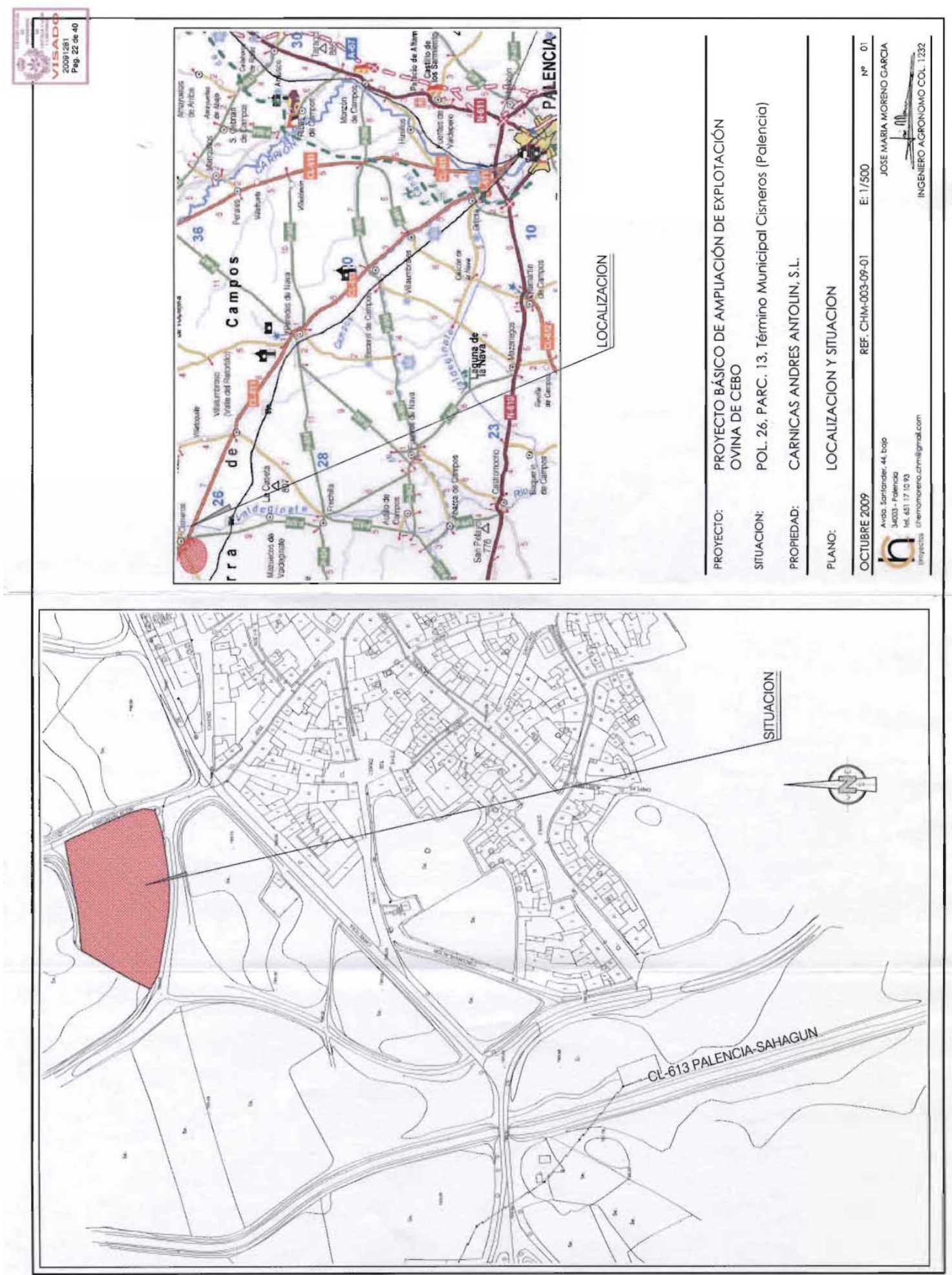

Figura A1.36. Plano de localización y situación del Proyecto básico. 


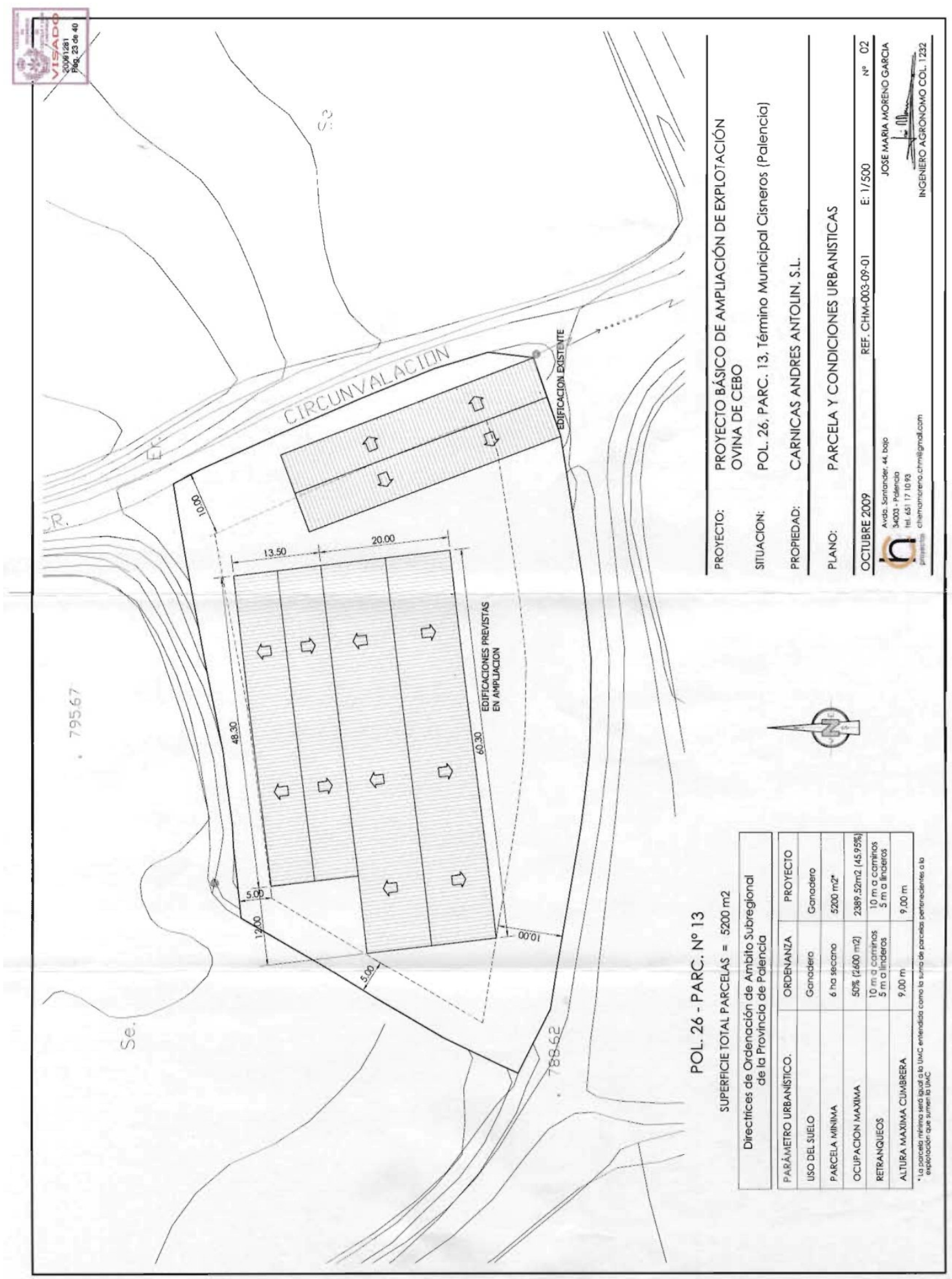

Figura A1.37. Plano de parcela y condiciones urbanísticas del Proyecto básico.

En el proyecto se contempla la construcción de una nueva edificación de $1828 \mathrm{~m}^{2}$ (Figura A1.37), diseñada mediante estructura metálica y cerramientos de hormigón. En ella se distribuye la zona de cebadero con distintos apriscos, la zona de pasillo, zona de almacén de maquinaria, silos de pienso y muelle de carga de animales. Esta nave de cebadero dispone de puertas de garaje en 
cada aprisco, con objeto de facilitar las labores de limpieza de estiércol y de aprovisionamiento de forraje a los animales por medio de tractores.

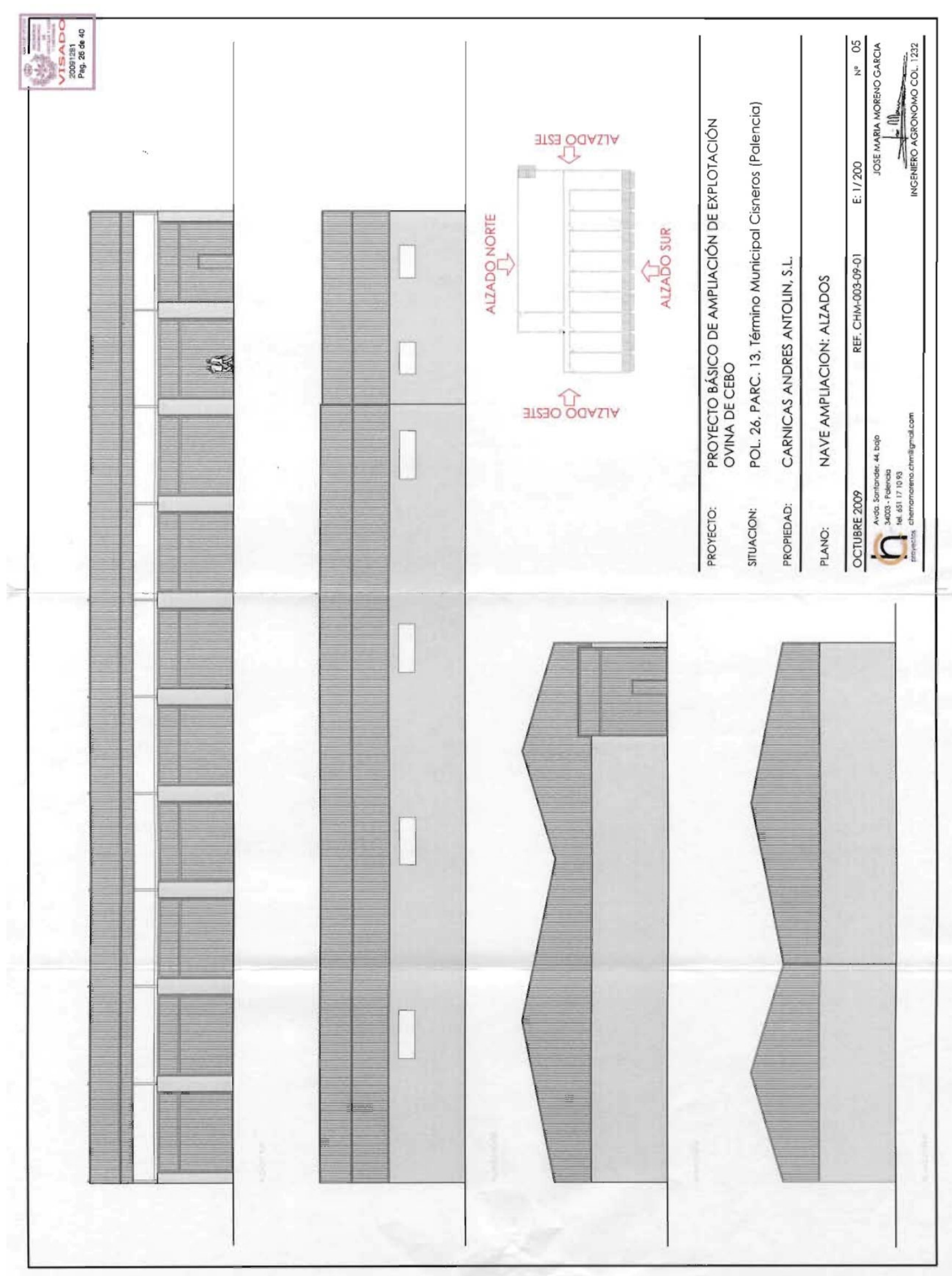

Figura A1.38. Plano de alzados de la nave ampliación del Proyecto básico. 
No se dispone de estercolero en la misma parcela, ya que la nave cuenta con solera de hormigón sobre la que se extiende la cama de paja. Esta con el tiempo constituye el estiércol y una vez al año se realiza una limpieza de todo el material de cama, cargándolo directamente a remolque para su distribución en parcelas agrícolas de cultivo como abono orgánico.

También se proyecta la instalación de un vallado perimetral en la parcela, para limitar el acceso a la misma por personas ajenas a la explotación. Se construirá mediante un cercado de $2 \mathrm{~m}$ de altura realizado con malla simple torsión galvanizada y postes de tubo de acero galvanizado.

La nueva edificación se resuelve mediante estructura metálica porticada a dos aguas, como dos naves adosadas. La nave de apriscos dispone de unas dimensiones exteriores de 60,30 $\mathrm{m}$ de longitud por $20 \mathrm{~m}$ de anchura, mientras que la nave de maquinaria dispone de $48,30 \mathrm{~m}$ de longitud por 13,50 m de anchura. La nave de apriscos dispondrá de portones de garaje, con ventilación en la zona superior a estas puertas y en cumbrera del edificio (Figura A1.38).

Los cerramientos proyectados combinan el hormigón armado con los cerramientos de chapa metálica prelacada por su lado exterior y panel sándwich. La cimentación de diseño se compondrá de zapatas aisladas de hormigón armado unidas mediante un cimiento corrido que servirá de arranque al muro de zócalo de hormigón perimetral.

El presupuesto de ejecución material asciende a $155200 €$. No incluye ningún capítulo relativo a gestión de residuos o acondicionamiento del entorno.

\section{A1.4.2. Condicionantes ambientales}

\section{A1.4.2.1. Memoria de actividad del Proyecto básico.}

Promotor: Cárnicas Andrés Antolín, S.L.

Redactor: José María Moreno García (ingeniero agrónomo)

Fecha: octubre de 2009

De acuerdo con el Reglamento de Actividades Molestas, Nocivas, Insalubres y Peligrosas, la explotación se clasificaría en molesta (por la posible producción de ruidos y olores procedentes del ganado) y nociva (por el estiércol generado y la posible contaminación del suelo).

El estiércol generado en la explotación se mantiene en los corrales hasta su limpieza periódica, que coincide con las épocas de aplicación de abono orgánico a las tierras de cultivo. Por ello, no se ve necesaria la disposición de un estercolero para almacenamiento del estiércol. Se incluye un plan de producción y gestión de estiércol, en el que se requiere un mínimo de 41 ha de secano para esparcir el estiércol generado en la explotación.

Además se contemplan una serie de medidas correctoras para la minimización de la incidencia de la actividad sobre el medio ambiente, destacando las siguientes: 
- La actividad de explotación de ovino no es productora de ruidos y olores excesivos; no obstante, su distancia a núcleo urbano y su ubicación en suelo rústico común evita las posibles molestias.

- Las aguas pluviales recogidas en cubierta se verterán directamente a la parcela por medio de canalones y bajantes, no existiendo la posibilidad de vertido sobre estercoleros.

\section{A1.4.2.2. Informe de la Comisión Territorial de Prevención Ambiental, de 21 de julio} de 2010.

En primer lugar, se considera que la actividad se encuentra sometida al régimen de licencia ambiental según lo establecido en el artículo 24 de la Ley 11/2003, de 8 de abril, de Prevención Ambiental de Castilla y León.

En segundo lugar, se informa favorablemente la actividad, aceptando las medidas correctoras contenidas en el Proyecto y en la Memoria Ambiental, debiéndose además cumplir otras adicionales. A continuación se detallan las relativas a la protección del paisaje:

2.C) Se prohíbe la acumulación de estiércol a menos de $500 \mathrm{~m}$ del núcleo de población y a menos de $100 \mathrm{~m}$ de cauce público.

2.F) El sistema de evacuación de las aguas pluviales será canalizado al terreno o a la red de saneamiento, evitando el arrastre de los residuos ganaderos.

2.G) Junto con la comunicación de inicio deberá presentar justificación documental del destino de los residuos generados en la fase de construcción ante el Ayuntamiento y ante el Servicio Territorial de Medio Ambiente de la Junta de Castilla y León en Palencia.

2.H) Con objeto de integrar la construcción en el paisaje, se recomienda que sus acabados exteriores presenten tonalidades cromáticas acordes con las características del entorno, preferentemente rojizas para las cubiertas y ocres o terrosas para los paramentos, sin perjuicio de lo previsto al efecto en la normativa urbanística vigente.

Las medidas correctoras fueron íntegramente transcritas en la licencia ambiental y urbanística expedida por el Ayuntamiento de Cisneros, resuelta con fecha 28 de julio de 2010.

\section{A1.4.3. Ejecución}

\section{A1.4.3.1. Seguimiento de la obra.}

En visita técnica realizada el 7 de febrero de 2013 se comprueba que la ampliación de la explotación de ganado ovino se encuentra construida y en uso normal (Figura A1.39). La nave preexistente fue construida a base de muros de ladrillo visto y cubierta de fibrocemento en su color. 

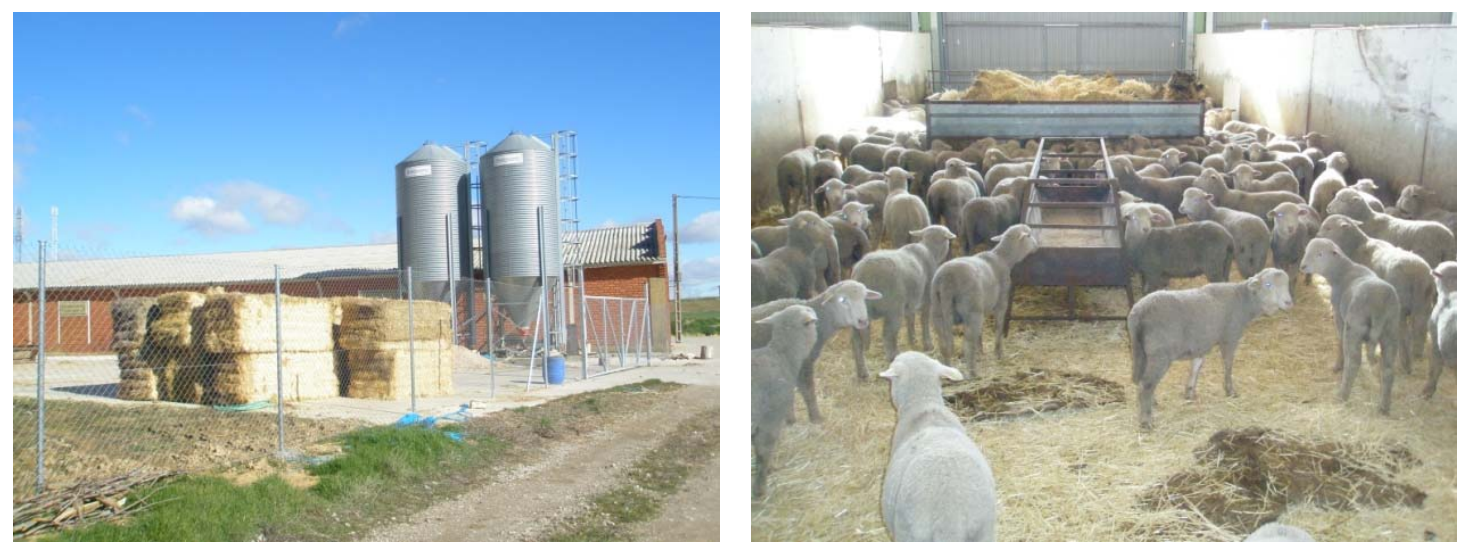

Figura A1.39. A la izquierda, vista de la explotación antigua. A la derecha, corderos en el interior de la nueva nave.

Las nuevas naves se han construido conforme a lo indicado en el Proyecto básico, transcurriendo las obras entre julio de 2010 y junio de 2011 (el 29 de junio de 2011 se concede la licencia de apertura).

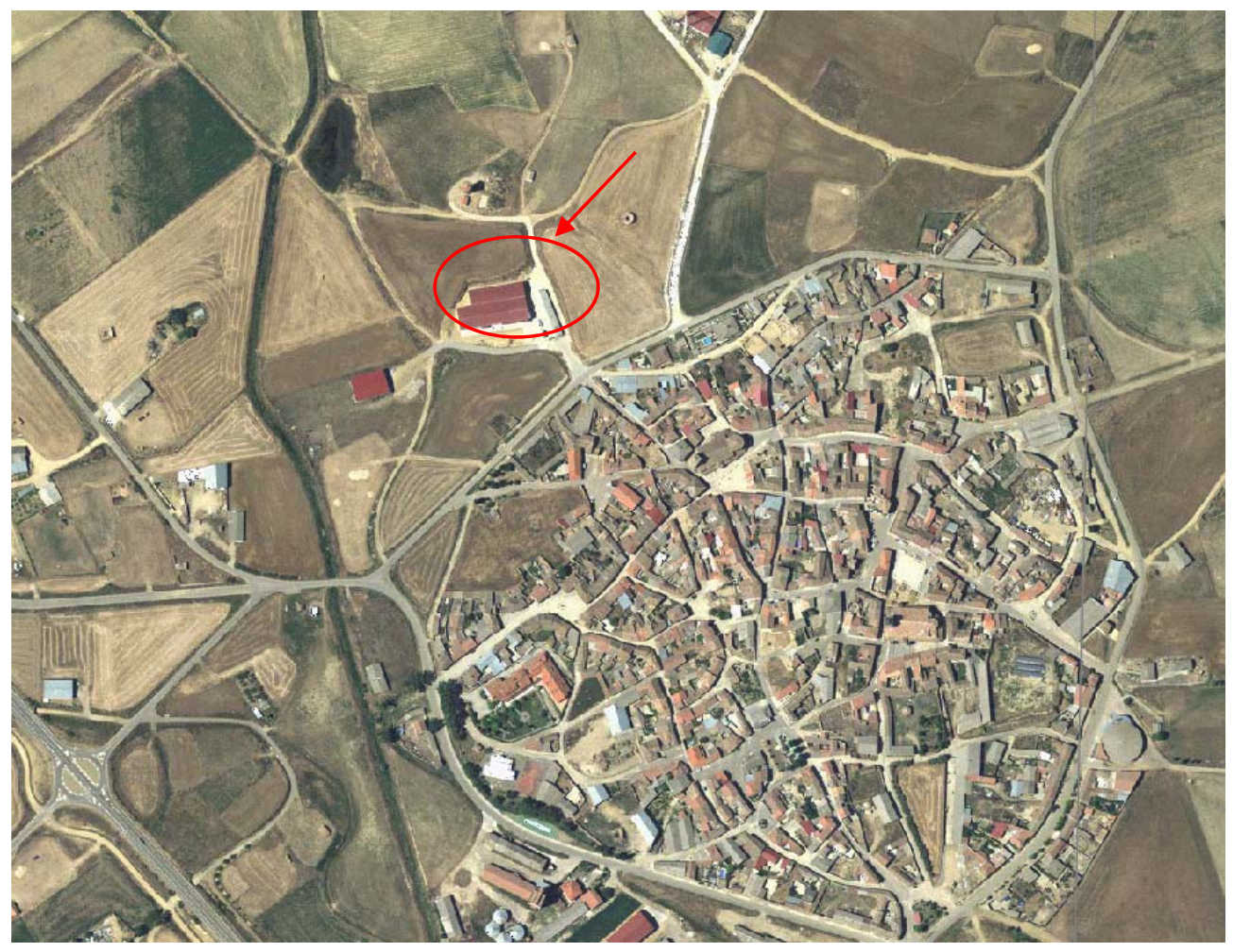

Figura A1.40. Ortofotografía de 2011 con la ubicación de la explotación ganadera.

Los paramentos de las naves están construidos como muros de hormigón pintados en color ocre y chapa metálica prelacada ocre. La cubierta está acabada en chapa metálica prelacada roja, que es también el color de las numerosas puertas colocadas (Figura A1.41). 


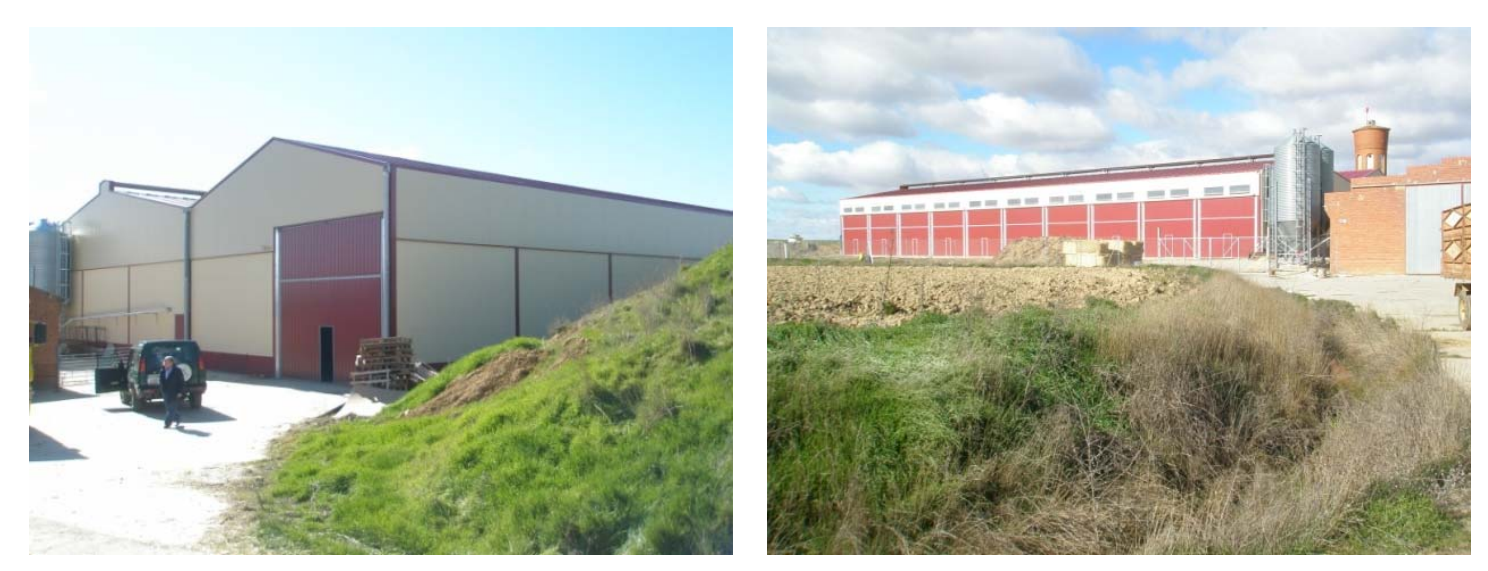

Figura A1.41. Vista de los paramentos exteriores y las cubiertas.

El recinto está limitado por una valla metálica. El interior no está pavimentado, salvo la entrada.

Se observa la presencia de un estercolero en el exterior de las naves, así como de distintos montones recientes de escombros, tanto en el interior de la explotación como en las cercanías (Figura A1.42). 

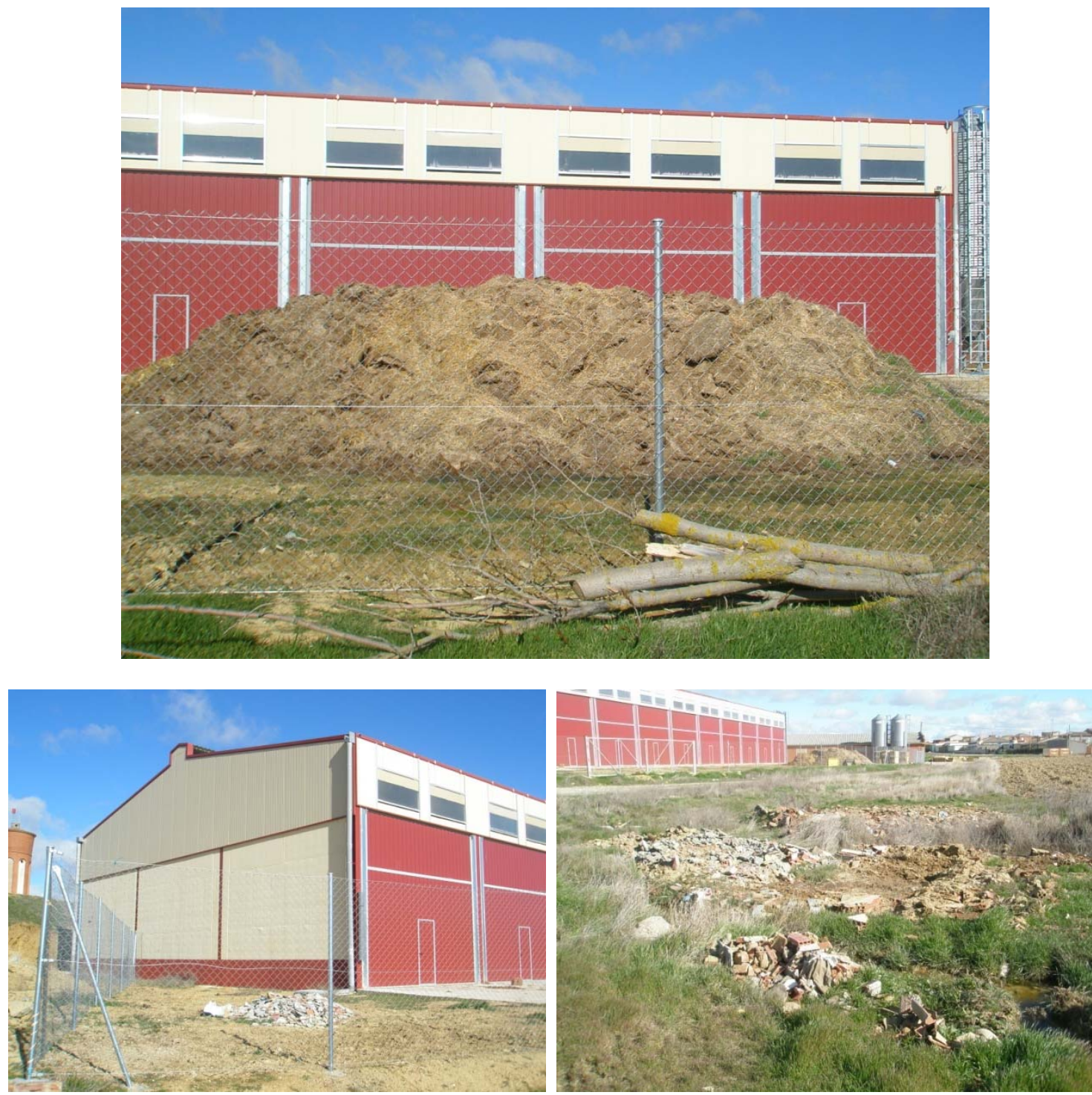

Figura A1.42. Fotografías del estercolero (arriba) y de los montones de escombros (abajo, izquierda y derecha).

\section{A1.4.3.2. Conclusiones del seguimiento ambiental.}

El impacto paisajístico de la nave ganadera y de su ampliación es moderado: su recuperación no precisa de prácticas protectoras o correctoras intensivas. Se trata de un uso pecuario en suelo rústico común, donde es plenamente admisible.

La ubicación no es muy acertada: se encuentra muy cerca del límite con el casco urbano (a escasos $100 \mathrm{~m}$ ), por lo que los olores y molestias generadas sobre la población pueden ser significativas.

Se ha cumplido la recomendación de integración de la construcción en el paisaje, con paramentos ocres y cubiertas rojizas. Se considera que esta medida es muy adecuada para minimizar el impacto visual de estas grandes edificaciones en una comarca como Tierra de 
Campos. Tal vez se debería haber cambiado el color de las numerosas puertas colocadas (ocre por rojo), ya que destacan excesivamente.

En el entorno de las naves hay depósitos de pallets, material diverso y algún montón de escombros, que provoca un deficiente aspecto estético. Su posterior retirada por el promotor a una planta de residuos de construcción y demolición (2,48t) mejoró notablemente el entorno.

Aunque el espacio libre de la parcela no es muy grande, sería muy interesante la plantación de árboles y arbustos en el entorno de la nave, para mejorar su integración paisajística. Una adecuada distribución sería la plantación de arbustos autóctonos en la valla y de árboles (autóctonos o frutales) en alguna zona no transitable, sobre todo en el frente sur que mira hacia el casco urbano de Cisneros.

La ubicación del estercolero en el exterior de las naves incumple la condición de estar situado a más de $500 \mathrm{~m}$ del casco urbano. Aunque el olor generado por el estiércol de ovino no es muy fuerte, sí que existe riesgo de que en determinadas condiciones de viento y temperatura se produzcan olores indeseados a la población de Cisneros. 


\section{A1.5. Variante de carretera de Villada}

\section{A1.5.1. Proyecto}

\section{A1.5.1.1. Estudio informativo - Variante de Villada.}

Promotor: Consejería de Fomento. Junta de Castilla y León.

Autor: José M. Santos Martín (ingeniero de caminos, canales y puertos)

Director: Luis Turrión Aznar (ingeniero de caminos, canales y puertos)

Fecha: noviembre de 1995

El Estudio Informativo es el documento técnico previo al proyecto que plantea distintas alternativas para la construcción de una variante en la carretera C-611, de Tordesillas a Cistierna, por Medina de Rioseco, Villalón de Campos y Sahagún, a su paso por Villada. Este tramo de vía recoge a su vez el tráfico de la carretera C-613 que procede de Palencia y confluye con la anterior en dicha localidad, haciendo de la misma una zona de gran intensidad de tráfico y problemas de seguridad.

El citado Estudio Informativo analiza dos alternativas de trazado (Figura A1.43): una por el Este, que inicia su recorrido en la C-611, al Sur de Villada, y finaliza al Norte de dicha población, y otra que se inicia en la C-613, que comunica con Palencia, desarrollando su recorrido hacia el Sur y el Oeste de Villada, finalizando al norte en la C-611, en el mismo punto que la anterior. 

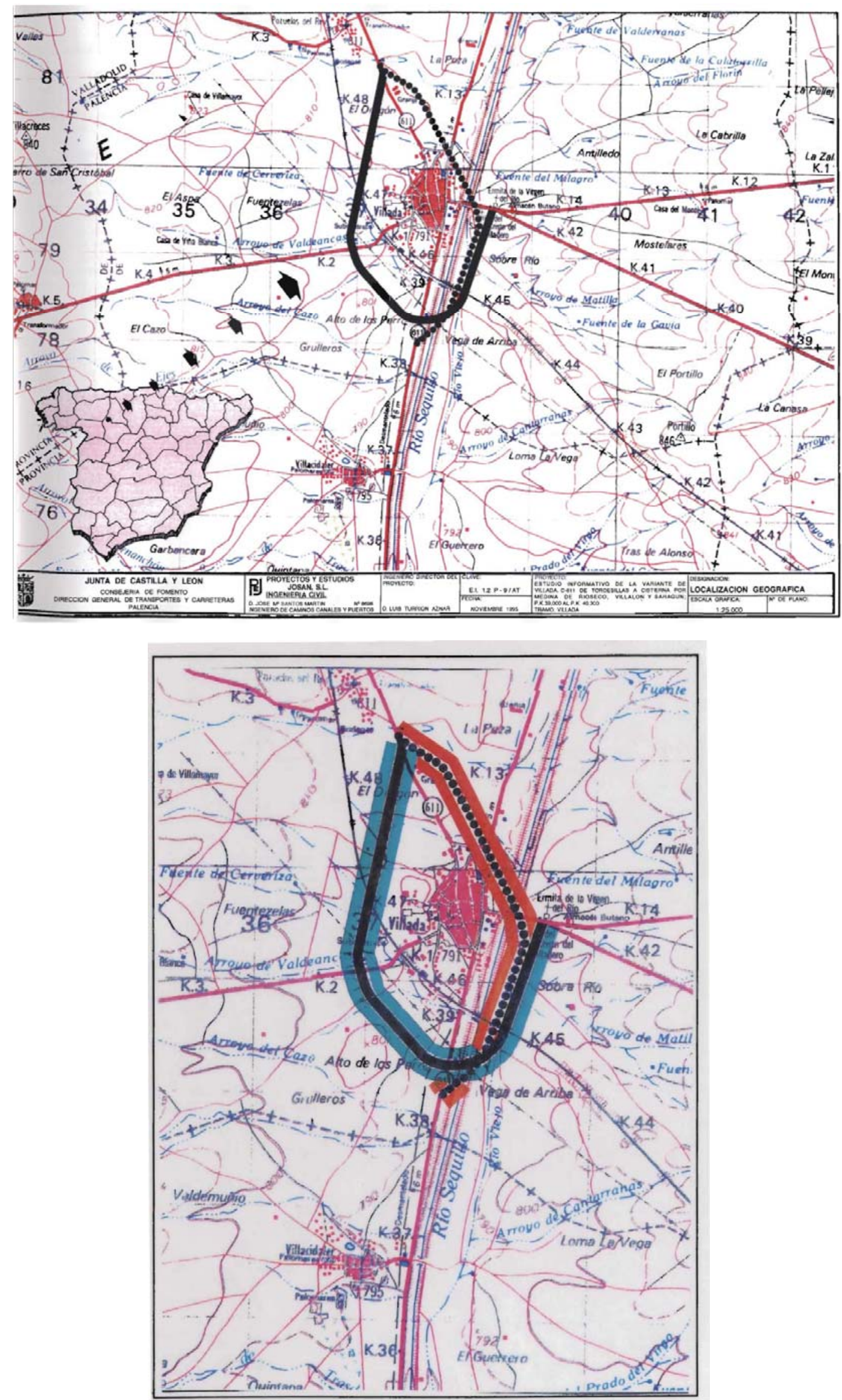

Figura A1.43. Planos de localización geográfica con las dos alternativas de variante planteadas en el Estudio Informativo. 
Las características de ambas alternativas son las siguientes:

- Variante Este: Su longitud es de $4100 \mathrm{~m}$, con radios de curvatura no inferior a $350 \mathrm{~m}$ y una anchura total de pista de $10 \mathrm{~m}$. Conlleva un paso inferior bajo la línea del ferrocarril y una estructura sobre el río Sequillo. Los terraplenes se diseñan con una pendiente media de $2 \mathrm{~V}: 3 \mathrm{H}$, previéndose un volumen total de $38681 \mathrm{~m}^{3}$. Existe un claro desequilibrio en el movimiento de tierras de esta alternativa, ya que se prevé un volumen de desmonte de $60876 \mathrm{~m}^{3}$. Ello requerirá que en fase de proyecto se localice un vertedero para albergar los materiales sobrantes.

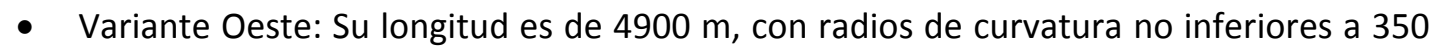
$\mathrm{m}$ y una anchura total de pista de $10 \mathrm{~m}$. Se localiza un paso inferior bajo la línea de ferrocarril. Los taludes de los terraplenes se plantean con una pendiente media de $2 \mathrm{~V}: 3 \mathrm{H}$, previéndose un volumen de $56251 \mathrm{~m}^{3}$, compensado con un volumen de desmonte de $57775 \mathrm{~m}^{3}$.

El Estudio Informativo, después de realizar un análisis multivariante, selecciona como alternativa más favorable la Variante Este.

\section{A1.5.1.2. Proyecto de Construcción. Variante de Villada.}

Promotor: Consejería de Fomento. Junta de Castilla y León.

Autor: José Antonio Gorjón Egido (ingeniero de caminos, canales y puertos). Ingeniería de Obras y Servicios, S.A. (INSERSA)

Director: Luis Turrión Aznar (ingeniero de caminos, canales y puertos)

Fecha: Febrero de 2000

Este proyecto desarrolla la alternativa Este de la variante de Villada seleccionada en el Estudio Informativo. Dicha variante difiere poco de la alternativa escogida como óptima en el Estudio Informativo, debido, en primer lugar, a la adaptación realizada de acuerdo con las exigencias de la Declaración de Impacto Ambiental, y en segundo lugar, para evitar que la carretera se asiente sobre áreas inundables del río Sequillo. De este modo, la traza se ha desplazado ligeramente hacia el Este, lo que conlleva un aumento de un $17 \%$ de su longitud.

La sección tipo o sección transversal de la carretera es como sigue:

- Calzada compuesta por dos carriles de 3,00 m cada uno.

- Arcén en ambas márgenes de 1,00 m de anchura, pavimentado de acuerdo con la misma sección que la calzada.

- Berma de 1,00 m de anchura de suelo seleccionado.

- Cuneta en tierra, con ancho de 0,90 $\mathrm{m}$ y profundidad de 0,30 $\mathrm{m}$ por debajo de la última capa del firme.

El Proyecto contempla la actuación en los siguientes tramos de carretera:

- Variante propiamente dicha, de $4784 \mathrm{~m}$ de longitud. 
- Intersección sur, conexión de la nueva variante con la carretera actual C-611 a Villalón de Campos en la zona sur (longitud: $86 \mathrm{~m}$ ).

- Glorieta de conexión con las carreteras C-613 (a Palencia) y con la carretera P-972 (a Cervatos de la Cueza).

- Modificación de la carretera de Cervatos de la Cueza para permitir su acceso a la glorieta indicada anteriormente (longitud: $90 \mathrm{~m}$ ).

- Glorieta partida de conexión con la carretera P-973.

- Enlace norte, conexión de la nueva variante con la carretera actual a Sahagún en la zona norte (longitud: $128 \mathrm{~m}$ ).

- Modificación del acceso al núcleo urbano de Pozuelos del Rey, mediante su conexión al tramo definido como "Intersección norte" (longitud: 90 m).

Para facilitar la permeabilidad de la zona atravesada por la nueva carretera, se proyectan siete tramos de caminos auxiliares, cada uno de ellos dotado de sus correspondientes obras de drenaje transversal y longitudinal.

Se disponen las siguientes estructuras a lo largo de la variante:

- Puente 1 sobre el río Sequillo, en el P.K. 0+469. Se trata de una estructura isostática de vigas que se apoyan sobre estribos prefabricados. La cimentación se realiza mediante pilotes fabricados "in situ" de $100 \mathrm{~cm}$ de diámetro. La anchura del tablero es de $12 \mathrm{~m}$.

- Paso inferior bajo la línea del ferrocarril. Se trata de un cajón de hormigón armado que se construirá fuera del terraplén sobre el que se apoya la línea férrea y que será colocado en su posición definitiva mediante su hinca. Las dimensiones interiores de dicho cajón serán de $10 \mathrm{~m}$ de anchura y 5,45 $\mathrm{m}$ de luz.

- Losa de paso del arroyo de Matilla, situado en el P.K. 1+420. Se apoya sobre muros de hormigón armado y tiene una luz de $6 \mathrm{~m}$. Las aletas serán prefabricadas.

- Puente 2 sobre el río Sequillo, en el P.K. 2+890. Se trata, al igual que el puente anteriormente descrito, de una estructura isostática de vigas que se apoyan sobre estribos prefabricados. La cimentación se realiza mediante pilotes fabricados "in situ" de $100 \mathrm{~cm}$ de diámetro y de las longitudes indicadas en los planos. La anchura del tablero será de $12 \mathrm{~m}$.

- Se han proyectado dos marcos prefabricados de hormigón armado para dar continuidad a la red de caminos, según lo exigido por la Declaración de Impacto Ambiental. Sus dimensiones interiores serán de $4 \mathrm{~m}$ de anchura y 3,5 $\mathrm{m}$ de altura. Los muros exteriores (aletas) también serán prefabricados.

Se ha previsto dar continuidad a la red de drenaje existente anteriormente mediante un conjunto de pequeñas obras de fábrica, principalmente caños de 120, 100 y $80 \mathrm{~cm}$ de diámetro, pero también un doble marco de sección transversal unitaria de $4 \mathrm{~m}^{2}$ y de dimensiones interiores $2,0 \times 2,0 \mathrm{~m}$ en el P.K. 0+809 y también un marco de $2 \mathrm{~m}$ de altura y $2,5 \mathrm{~m}$ de altura $\left(5 \mathrm{~m}^{2} \mathrm{de}\right.$ sección) en el P.K. $1+707,8$.

Para proteger los taludes de los terraplenes de la escorrentía producida por el agua de lluvia, se prevé la ejecución de bajantes formadas por piezas de hormigón prefabricado que recogerán el agua contenida por bordillos que se situarán en el borde de la calzada pavimentada. Dichos 
bordillos se abrirán en las zonas en las que se disponen dichas bajantes, que desaguarán al pie de los terraplenes.

El volumen de desmonte se cifra en $117108 \mathrm{~m}^{3}$, el de terraplén en $170810 \mathrm{~m}^{3}$ y el de pedraplén en $16591 \mathrm{~m}^{3}$. Existe una cierta descompensación entre estos volúmenes, lo que exige la generación de préstamos.

El resumen del presupuesto de ejecución material (en euros) del Proyecto de construcción es el siguiente (Tabla A1.11):

Tabla A1.11. Presupuesto de ejecución material del proyecto de construcción de la Variante de Villada.

\begin{tabular}{clc}
\hline № Capítulo & \multicolumn{1}{c}{ Descripción } & Importe \\
\hline 1 & MOVIMIENTO DE TIERRAS & 598709,64 \\
\hline 2 & AFIRMADO & 761899,10 \\
\hline 3 & OBRAS DE FABRICA Y DRENAJE & 908633,90 \\
\hline 4 & AFECCIONES & 1987,52 \\
\hline 5 & SEÑALIZACION Y ALUMBRADO & 218074,58 \\
\hline 6 & TRATAMIENTO IMPACTO AMBIENTAL & 29913,31 \\
\hline 7 & SEGURIDAD Y SALUD & 15848,26 \\
\hline 8 & VARIOS & $\mathbf{7 3 3 2 , 3 4}$ \\
\hline & & $\mathbf{2 5 4 2 3 9 8 , 6 5}$ \\
\hline
\end{tabular}

Tal como se puede apreciar en el presupuesto, el capítulo destinado a medidas de protección ambiental supone un $1,18 \%$ del montante total.

\section{A1.5.2. Condicionantes ambientales}

A1.5.2.1. Estudio de Impacto Ambiental de la variante de Villada.

Promotor: Consejería de Fomento. Junta de Castilla y León.

Autor: José M. Santos Martín (ingeniero de caminos, canales y puertos)

Fecha: noviembre de 1995

El área afectada por el proyecto se localiza en el norte de la comarca de Tierra de Campos. Su morfología está condicionada por la presencia de materiales detríticos que configuran una Ilanura sedimentaria. Hidrogeológicamente, la zona se ubica sobre el sistema acuífero no 8 del 
"Terciario detrítico central del Duero". Edafológicamente están representados en la zona suelos pardo calizos sobre material no consolidado y suelos aluviales, coluviales y transformados por el riego. Desde el punto de vista bioclimático, este conjunto pertenece al piso supramediterráneo. La variante Este atraviesa el río Sequillo. La vegetación actual del entorno del proyecto es agrícola de cereal de secano. Respecto de la vegetación potencial, la única serie climácica identificada es la de los quejigares de Cephalantero longifoliae-Querceto faginae. Las comunidades de fauna presenten están totalmente modificadas por la actividad humana, enriquecidas con las aves esteparias.

El paisaje rural es el característico de Tierra de Campos: dominio de las tierras cultivadas y el relieve llano o suavemente ondulado; homogeneidad con marcada horizontalidad y monotonía cromática y volumétrica, solo rota por alguna alineación de chopos, sobre todo en torno al río Sequillo. Respecto del paisaje urbano, se aprecia que la arquitectura tradicional está siendo sustituida por otra poco respetuosa con la historia y de dudosa estética.

Parte del término municipal de Villada (al sur de la localidad) está ubicada en la Zona de Especial Protección para las Aves (ZEPA) La Nava - Campos Norte, que forma parte de la Red Natura 2000.

Los impactos ambientales generados por las distintas actuaciones del proyecto y, en particular los referidos al paisaje, se califican como compatibles o moderados. No se aprecian diferencias significativas entre las dos alternativas. En lo referente a la capacidad de acogida del medio físico, sobre el medio perceptual se considera que es alta en las dos opciones.

Las principales medidas protectoras y correctoras consideradas en el Estudio de Impacto Ambiental relativas al paisaje y a su recuperación son las siguientes (Figura A1.44):

- El vertedero de tierras sobrantes deberá explanarse, cubrirse con tierra vegetal y ser revegetado.

- No se deberán afectar los cauces de agua.

- Se procurará no eliminar vegetación arbórea.

- Se retirarán todos los restos o infraestructuras provisionales necesarias para la ejecución de la obra.

- Para evitar los arrastres por escorrentía, se establecerán drenajes superficiales, siendo muy apropiadas las cunetas de guarda colocadas en las cabezas de los taludes. La pendiente de los taludes también será reducida.

- Se restituirá la tierra vegetal y se realizará un laboreo en las zonas compactadas.

- Respecto de la revegetación, en los taludes con pendiente entre el $25 \%$ y $45 \%$ se plantarán arbustos y tapizantes; entre el $45 \%$ y el $85 \%$ (el entorno de $2 \mathrm{~V}: 3 \mathrm{H}$ ) se realizará una hidrosiembra con especies herbáceas o leñosas autóctonas y en los superiores al 85 \% se dispondrá una manta orgánica previa la extensión de la tierra vegetal almacenada.

- Para evitar el efecto barrera sobre la fauna, se propone la instalación de un vallado y la adopción de pasos de cruce.

- Tratamiento de estructura sobre ríos, para minimizar su impacto visual, y restauración de sus márgenes. 
- Tratamiento de isletas, mejorando su calidad visual a la par de su funcionalidad (Figura A1.45).

- Creación de pantallas visuales vegetales, para mejorar el paisaje extrínseco.

- Para la recuperación vegetal, se han seleccionado las siguientes especies arbóreas y arbustivas:
o Fresno (Fraxinus excelsior)
- Chopo negro (Populus nigra)
o Chopo blanco (Populus alba)
o Retama (Spartium junceum)
o Lavanda (Lavandula latifolia)
o Tomillo (Thymus sp.)
o Romero (Rosmarinus officinalis)

- Acondicionamiento del área de estacionamiento de maquinaria y vías de acceso.

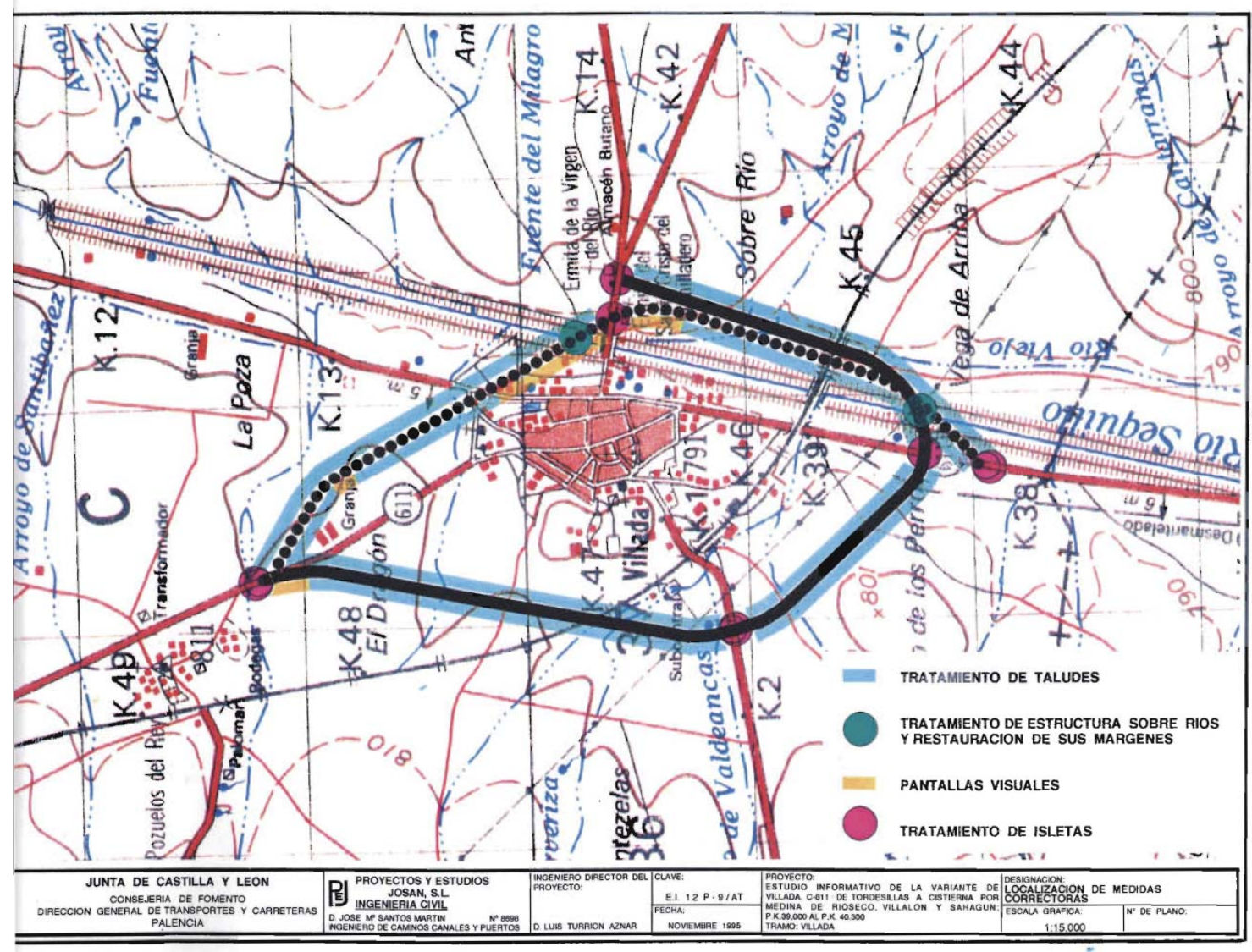

Figura A1.44. Plano de localización de medidas correctoras del Estudio de Impacto Ambiental. 


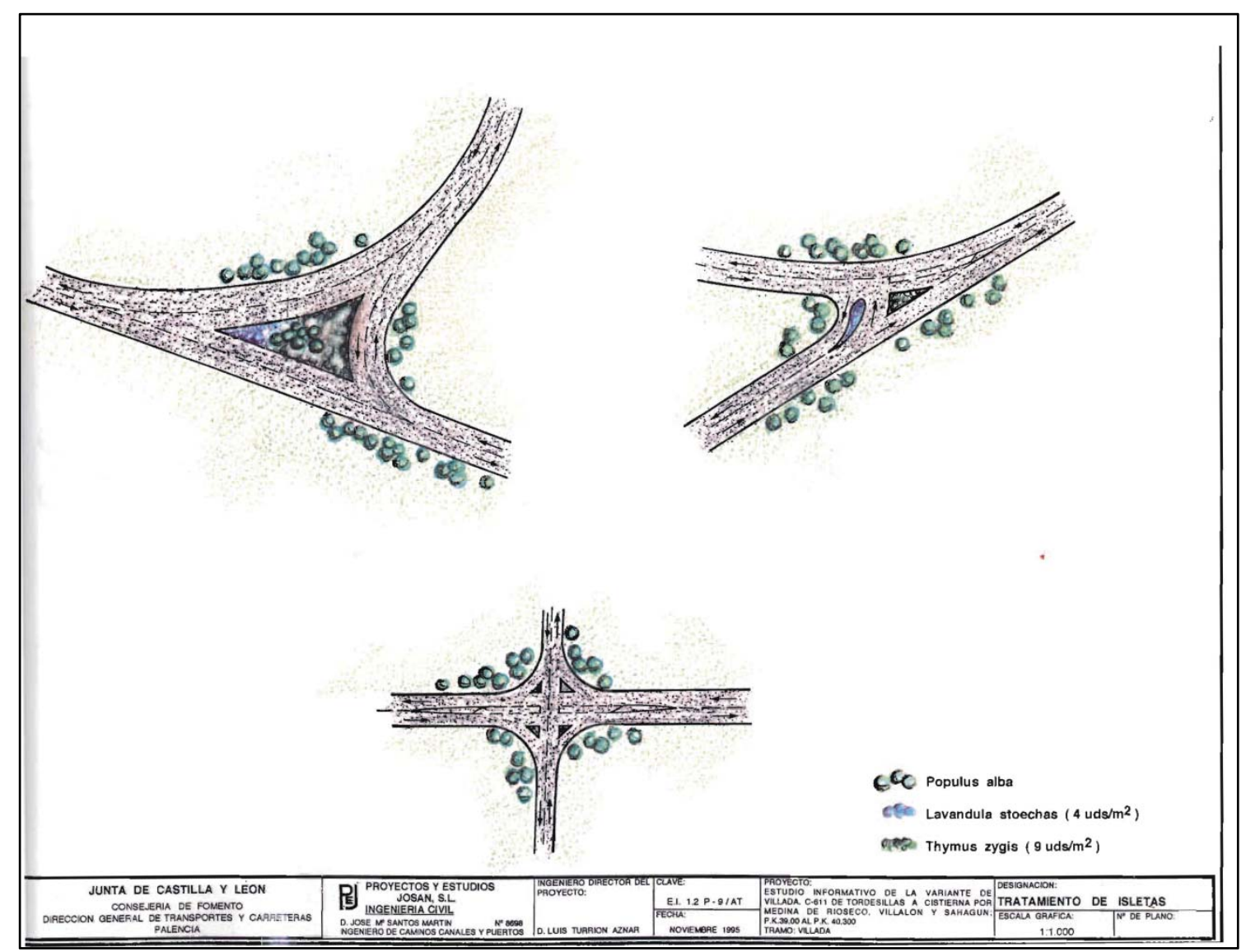

Figura A1.45. Plano de detalle del tratamiento de isletas incluido en el Estudio de Impacto Ambiental.

El presupuesto de ejecución material previsto para las medidas correctoras de la variante Este es el siguiente (Tabla A1.12):

Tabla A1.12. Presupuesto de ejecución material de medidas correctoras.

\begin{tabular}{clc} 
№ Capítulo & \multicolumn{1}{c}{ Descripción } & Importe \\
\hline C.I & Tratamiento de taludes & $8339 €$ \\
\hline C.II & $\begin{array}{l}\text { Tratamiento de estructura sobre río y } \\
\text { restauración de sus márgenes }\end{array}$ & $1673 €$ \\
\hline C.III & Tratamiento de isletas & $8025 €$ \\
\hline C.IV & Pantallas visuales & $7404 €$ \\
\hline C.V & $\begin{array}{l}\text { Acondicionamiento área maquinaria y } \\
\text { vías de acceso }\end{array}$ & $5499 €$ \\
\hline & & $30940 €$
\end{tabular}

En el Estudio de Impacto Ambiental se incluye un programa de vigilancia ambiental que, entre otras cuestiones, contempla el mantenimiento de las plantaciones vegetales. 
A1.5.2.2. Declaración de Impacto Ambiental, hecha pública por Resolución de 30 de julio de 1997, de la Consejería de Medio Ambiente y Ordenación del Territorio, sobre el estudio informativo E.I. 1.2.-P-9/AT de la variante de Villada (BOCyL 06/08/1997).

La Declaración de Impacto Ambiental informa favorablemente la alternativa Variante Este seleccionada en el Estudio Informativo, siempre y cuando se cumplan una serie de condiciones. Las medidas preventivas o correctoras referidas al paisaje o a su restauración, además de las contempladas en el Estudio de Impacto Ambiental, son las siguientes:

2.a) Los suelos ocupados por la traza de la nueva vía se retirarán de forma selectiva, reservando y tratando adecuadamente los que constituyen la tierra vegetal para su posterior utilización en la restauración de los márgenes del nuevo trazado y demás terrenos alterados. Los acopios se realizarán en cordones de reducida altura y se conservarán adecuadamente.

2.c) Se evitará afectar a la vegetación existente en terrenos que no sean los de la propia traza.

2.e) Se definirá la posible localización y características de las canteras y graveras, asegurándose su posterior restauración.

2.f) Se estudiará la viabilidad técnica y medioambiental de desviar la variante Este hacia esta misma orientación, de forma que se minimice la afección sobre las ermitas de la Virgen del Río y del Santo Cristo del Humilladero. Asimismo se desplazará ligeramente hacia el norte el segundo paso previsto sobre el río Sequillo, de forma que se respete la zona de paseo arbolada.

2j) En el supuesto de proceder a la anulación de algún tramo de la antigua carretera, se desmantelarán tanto la calzada como las infraestructuras auxiliares que carezcan de utilidad, restaurándose debidamente los terrenos afectados.

2.k) No se abandonarán con carácter definitivo materiales de obra en puntos en que ocasionen impactos visuales negativos.

2.I) Se proyectarán los pasos necesarios a través de la vía, preferentemente a distinto nivel, de manera que se garantice el mantenimiento de un grado de permeabilidad en el territorio acorde con las necesidades de accesibilidad y desplazamientos actuales.

2.ñ) Los enlaces e intersecciones se restaurarán mediante la plantación de las especies arbóreas previstas en el Estudio Informativo.

2.o) Se establecerá una pantalla visual en un tramo central de la margen izquierda de la variante. Asimismo se realizarán plantaciones en la margen izquierda, desde el paso inferior bajo el ferrocarril hasta el cruce con la carretera que se dirige a Frechilla.

2.p) Se elaborará un estudio detallado de acondicionamiento y adecuación paisajística, de forma que se preserven los valores tradicionales asociados a las ermitas y las zonas de paseo existentes en las proximidades de la variante.

2.s) Se especificarán las especies vegetales seleccionadas, preferentemente autóctonas, para la restauración de los márgenes y recuperación de los terrenos afectados, así como porte, calidad, 
presentación, densidad y método de siembra o plantación. Se impondrá en el Pliego de Condiciones un periodo de garantía para la implantación de la vegetación no inferior a dos años.

2.t) Las actuaciones de recuperación ambiental y restauración de las zonas afectadas deberán estar ejecutadas en su totalidad con anterioridad a la recepción de la obra.

\section{A1.5.2.3. Anejo 21 "Medidas correctoras de impacto ambiental", incluido en el Proyecto de Construcción.}

En este anejo se resumen las medidas recogidas en el Estudio de Impacto Ambiental y en la Declaración de Impacto Ambiental.

El capítulo del presupuesto de ejecución material del Proyecto destinado a estas medidas (Tabla A1.13) contempla las siguientes partidas (precios en $€$ ):

Tabla A1.13. Unidades y precio de medidas correctoras.

\begin{tabular}{|c|c|c|c|}
\hline Medición & Descripción & Precio & Importe \\
\hline $17720 \mathrm{~m}^{2}$ & $\begin{array}{l}\text { Formación de praderas mediante hidrosiembra efectuada } \\
\text { con mezcla y proporción estudiada de semillas de plantas } \\
\text { autóctonas (Agropirum cristatum, Agropirum desertorum, } \\
\text { Lolium rigidum, Lolium multiflorum, Festuca arundinacea, } \\
\text { Melilotus officinalis, Poa nemoralis, esparceta, } \\
\text { Brachypodium vulgare, Medicago rugosa, etc) en cantidad } \\
\text { de } 15 \mathrm{gr} / \mathrm{m}^{2} \text {, incluso tapado y primer riego. }\end{array}$ & 0,45 & 7987 \\
\hline 1000 ud & $\begin{array}{l}\text { Arbusto rastrero para protección de laderas y } \\
\text { ajardinamiento de medianas, tales como Spartium junceum } \\
80 / 100 \mathrm{~cm} \text {, Thymus s.p, Rosmarinus officinalis o Lavandula } \\
\text { latifolia de } 1 \text { año, incluyendo transporte, plantación, } \\
\text { apertura y tapado de hoyo, así como primer riego. }\end{array}$ & 4,60 & 4598 \\
\hline $63 \mathrm{~m}^{3}$ & $\begin{array}{l}\text { Tierra vegetal procedente de la traza, incluso manipulación y } \\
\text { extendido con medios mecánicos o manuales. }\end{array}$ & 2,22 & 140 \\
\hline $2 \mathrm{ud}$ & $\begin{array}{l}\text { Limpieza y restauración de los márgenes del río en la } \\
\text { superficie afectada por las obras en las zonas de los puentes } \\
\text { sobre el río sequillo, consistente en el laboreo y } \\
\text { descompactación del terreno por medios mecánicos hasta } \\
\text { una profundidad de } 30 \mathrm{~cm} \text {, completamente terminada. }\end{array}$ & 571 & 1142 \\
\hline 1545 ud & $\begin{array}{l}\text { Populus alba de } 8-10 \mathrm{~cm} \text { de circunferencia medidos a } 1 \\
\text { metro de la raíz, a raíz desnuda, incluyendo transporte, } \\
\text { plantación, apertura y tapado de hoyo, así como primer } \\
\text { riego. }\end{array}$ & 7,35 & 11356 \\
\hline $2080 \mathrm{~m}^{2}$ & $\begin{array}{l}\text { Demolición de firme de calzada existente, incluso base y } \\
\text { subbase, con carga y transporte de productos sobrantes a } \\
\text { vertedero o lugar de empleo, posterior explanación de la } \\
\text { superficie resultante con extendido una capa de } 10 \mathrm{~cm} \text { de } \\
\text { tierra vegetal de aportación y posterior formación de } \\
\text { pradera mediante hidrosiembra efectuada con mezcla y } \\
\text { proporción estudiada de semillas de plantas autóctonas en } \\
\text { cantidad de } 15 \mathrm{gr} / \mathrm{m}^{2} \text {, incluso tapado y primer riego. }\end{array}$ & 3,58 & 7451 \\
\hline
\end{tabular}


En el programa de vigilancia ambiental del anejo se establece que durante el periodo de garantía se realizarán las siguientes labores para conservar las especies vegetales de nueva plantación: riegos, siegas, resembrado, dos entrecavados anuales a árboles y arbustos, tratamientos fitosanitarios, enmiendas orgánicas, reposición de marras y limpieza.

\section{A1.5.3. Ejecución}

\section{A1.5.3.1. Seguimiento de la obra.}

Este proyecto se ejecutó entre los años 2002 y primera mitad del 2003. En visita técnica realizada el 21 de agosto de 2013, donde se recorre caminando todo el trazado de la variante por ambas márgenes, se comprueba que la carretera se encuentra en normal funcionamiento (Figuras A1.46 y A1.47).

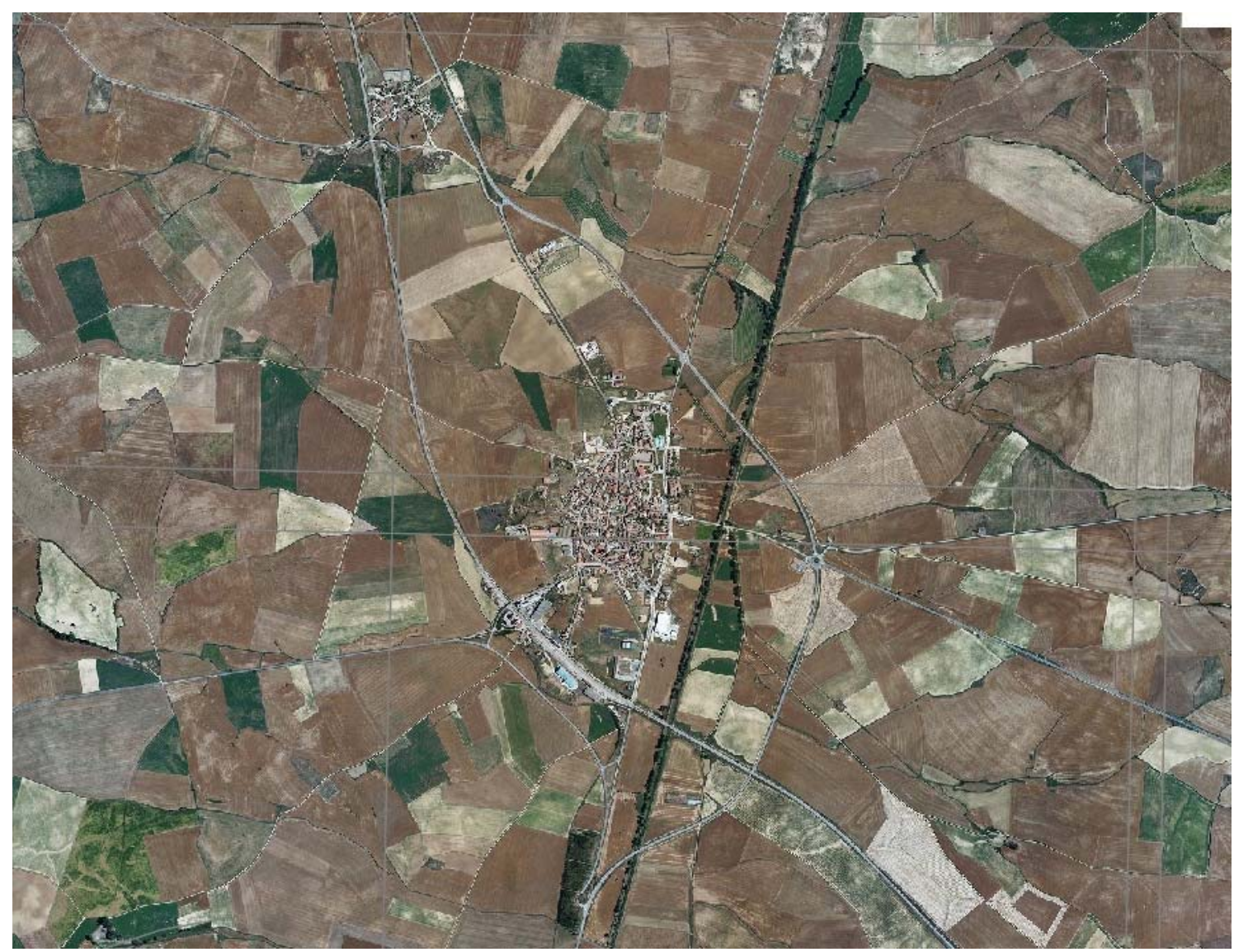

Figura A1.46. Ortofotografía de 2009, donde se puede apreciar la presencia y funcionalidad de la variante Este de Villada.

Las obras se han ejecutado de acuerdo a lo contemplado en el Proyecto de construcción, de febrero de 2000, que desvía aún más hacia el Este la alternativa seleccionada en el Estudio Informativo. La traza se aleja en mayor grado del núcleo de Villada -separándose de la ermita 
de la Virgen del Río- y queda adecuadamente conectada con las carreteras que confluyen en esta localidad. La sección transversal se mantiene tal como fue proyectada.
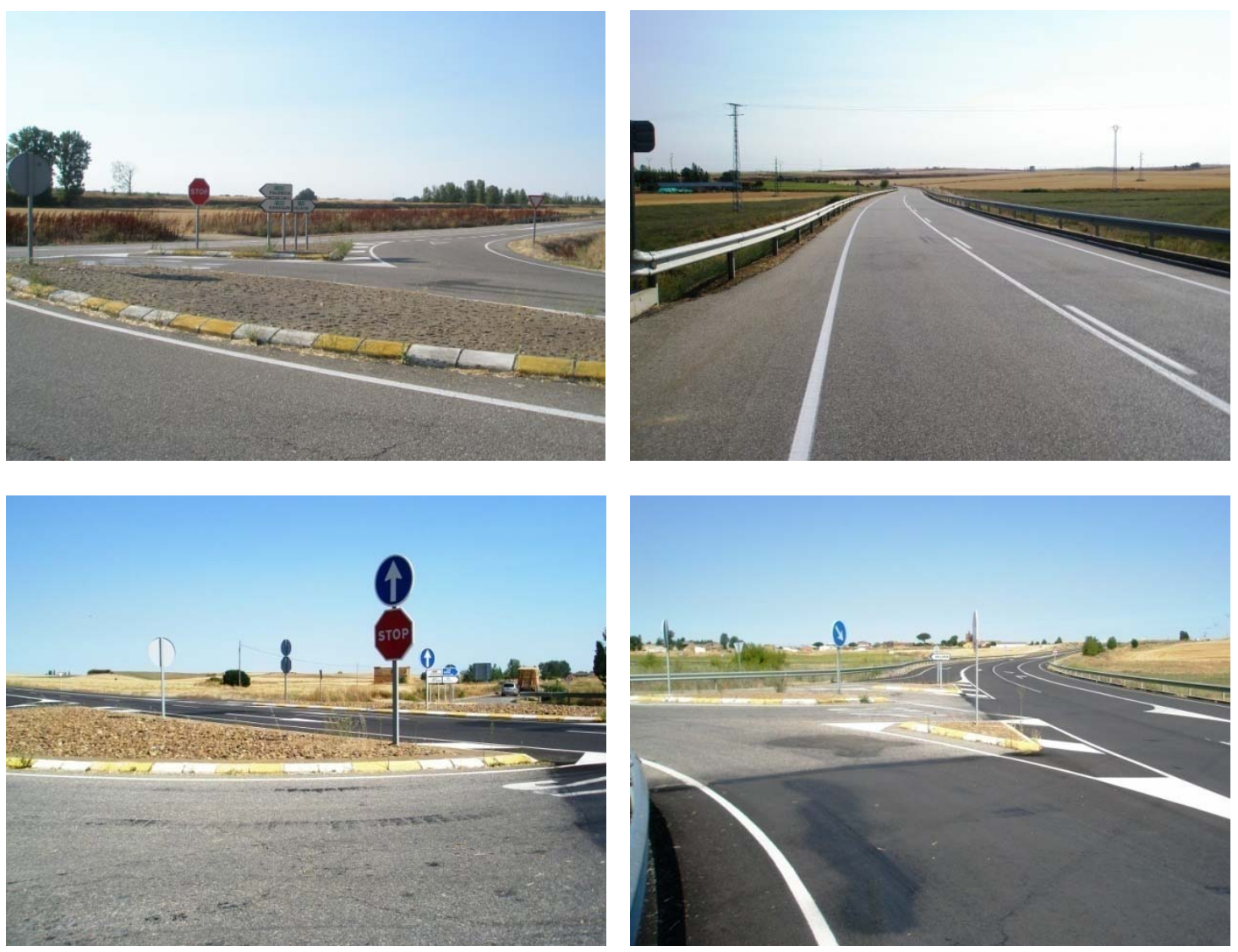

Figura A1.47. Diversas imágenes de los tramos principales: enlace Sur (arriba izquierda), vista de la carretera (arriba derecha), enlace con la carretera de Villelga y con Villada (abajo izquierda) y enlace Norte (abajo derecha).

Uno de los capítulos más importantes del presupuesto de la variante de carretera es el dedicado a las estructuras -en torno al $36 \%$ del total- (Figura A1.48), obras de fábrica y drenaje para soslayar el cruce con el ferrocarril, permitir la permeabilidad hidráulica y conectar los caminos rurales. Las obras se han llevado a cabo según lo proyectado. 

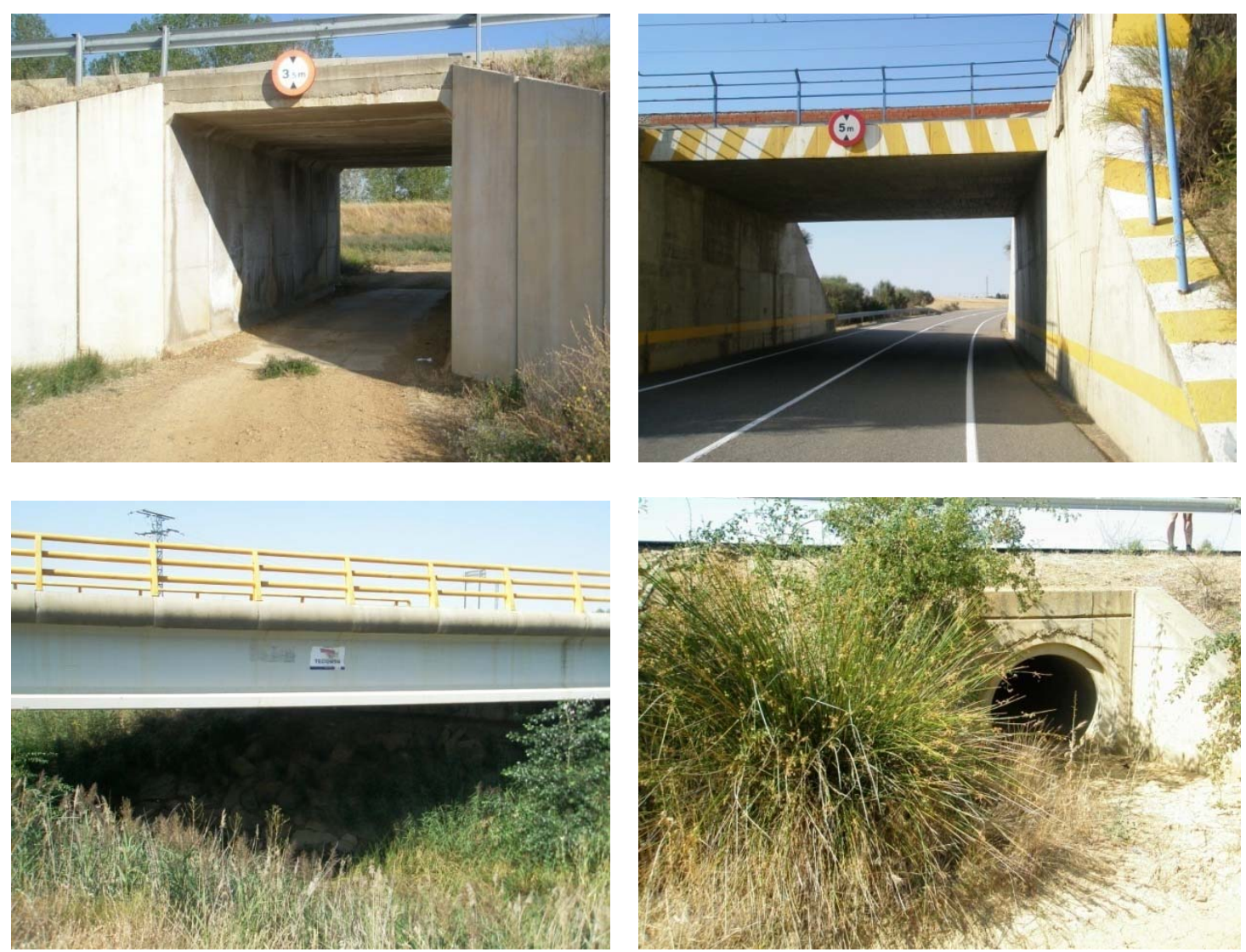

Figura A1.48. Varios ejemplos de estructuras: marco para el paso inferior de camino rural (arriba izquierda), paso inferior bajo el ferrocarril (arriba derecha), puente sobre el río Sequillo (abajo derecha) y obra de drenaje sobre arroyo (abajo derecha).

El volumen de material de préstamo necesario para la construcción de la variante fue adquirido en una parcela del Ayuntamiento de Villada situada en el margen de la carretera de Ledigos, más concretamente entre el río Sequillo y una antigua extracción. Esta superficie se restauró posteriormente, quedando como zona con encharcamiento periódico.

\section{A1.5.3.2. Conclusiones del seguimiento ambiental.}

El desvío de la traza de la variante hacia el Este ha ocasionado que esta se aleje suficientemente de las ermitas del Cristo del Humilladero y la Virgen del Río y, por ende, del casco urbano, lo cual es positivo. Además, la propia construcción de la variante supone la generación de nuevas vistas sobre el pueblo y la ribera arbolada del río Sequillo, lo que mejora la calidad del paisaje visual desde la carretera.

Aunque no se puede constatar si la gestión de la tierra vegetal fue la correcta en las obras de la carretera, sí que parece probable (debido al buen desarrollo de la vegetación) que esta fuese extendida adecuadamente en los terraplenes y las zonas auxiliares. 
No parece que las obras hayan causado afecciones a la vegetación arbórea existente en el entorno, tal como se puede comprobar por la permanencia de la orla de ribera existente en las márgenes del río Sequillo, que posee un gran valor.

Tampoco se ha afectado a los cauces hídricos. El paso superior sobre el arroyo Matilla se ha planteado mediante una losa de hormigón de amplia luz. Los cruces con el río Sequillo se han resuelto con dos puentes sobredimensionados, que mantienen franjas de terreno de continuidad de anchura suficiente (Figura A1.49). Tal vez podría haberse analizado la posibilidad de mantener un sendero bajo el puente con objeto de mantener la continuidad del paseo desde Villada hasta el pantano, que recientemente se ha recuperado ambientalmente.
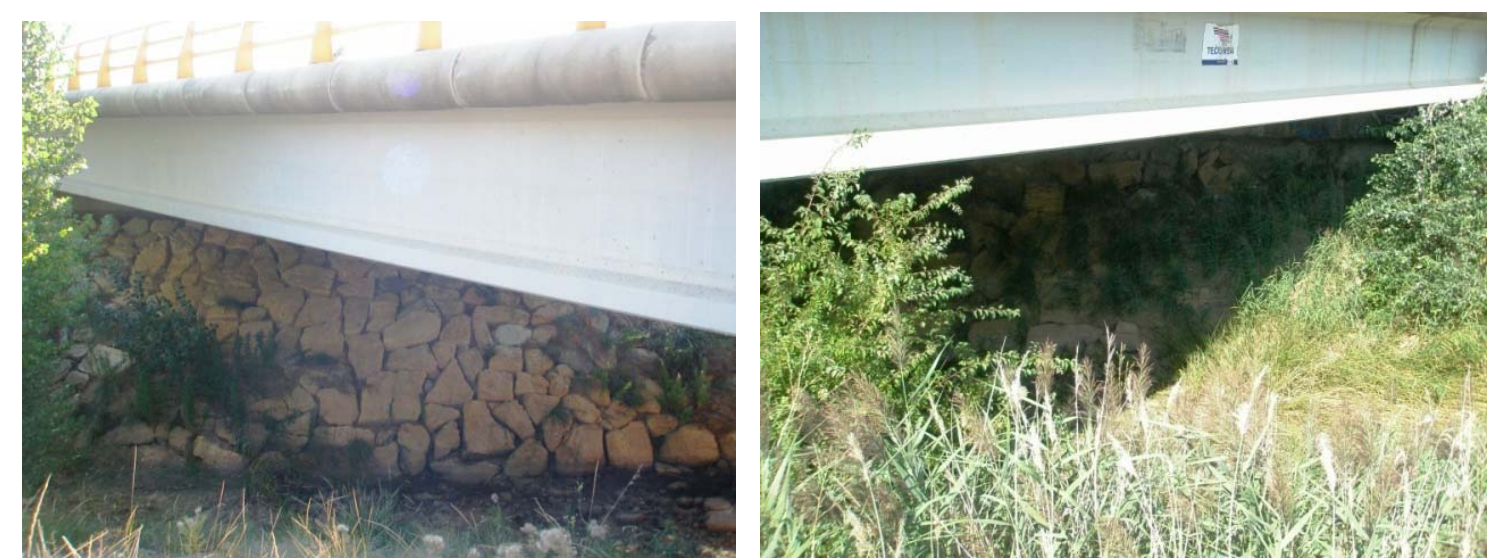

Figura A1.49. Imágenes de los dos puentes sobre el río Sequillo, donde se observa la franja de terreno de continuidad protegida mediante escollera, que permite su naturalización.

El drenaje de las aguas pluviales sobre las carreteras está correctamente diseñado; se observa la funcionalidad de los bordillos laterales, su entronque con las bajantes y la posterior evacuación hacia los márgenes (Figura A1.50). Ello permite que los taludes de terraplén no se vean afectados por procesos de erosión hídrica.
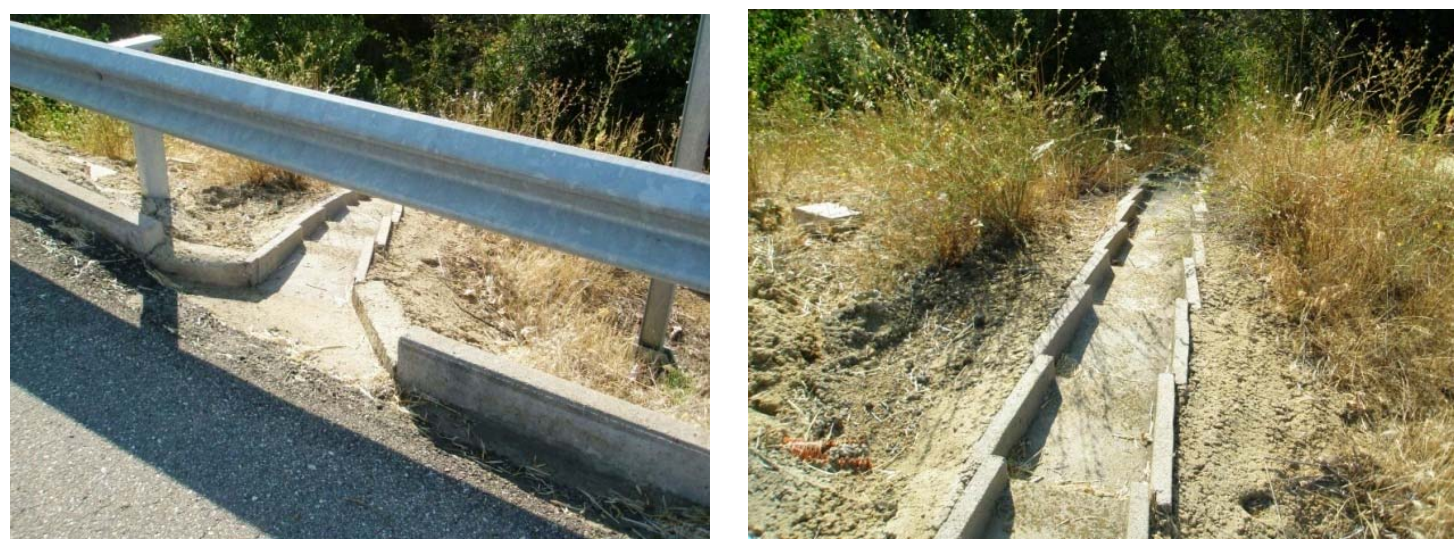

Figura A1.50. Vistas de bajantes a través de taludes de terraplén. 
No se ha realizado el vallado de la variante previsto, al objeto de conducir a la fauna silvestre a través de los pasos transversales. Sin embargo, se estima que los puentes, pasos superiores sobre caminos y arroyos y obras de drenaje son suficientes como para permitir un alto grado de permeabilidad faunística, más habida cuenta que su entorno se encuentra bastante naturalizado.

Los taludes tienen una pendiente adecuada. En el caso de los desmontes, esta es de $1 \mathrm{~V}: 2,7 \mathrm{H}$ $\left(20^{\circ}\right)$, debiendo tenerse en cuenta que en las declaraciones de impacto ambiental de infraestructuras de transporte, usualmente se indica una pendiente máxima de $2 \mathrm{~V}: 3 \mathrm{H}\left(34^{\circ}\right)$. Los terraplenes se han conformado con una pendiente de $1 \mathrm{~V}: 2 \mathrm{H}\left(25^{\circ}\right)$, bastante menor a la $2 \mathrm{~V}: 3 \mathrm{H}$ $\left(34^{\circ}\right)$ proyectada. Además, en algunos casos estos últimos se han reforzado en su base mediante escollera de piedra caliza (pedraplén), que resulta funcional al existir riesgo de inundación y tiene una alta integración paisajística (Figura A1.51).
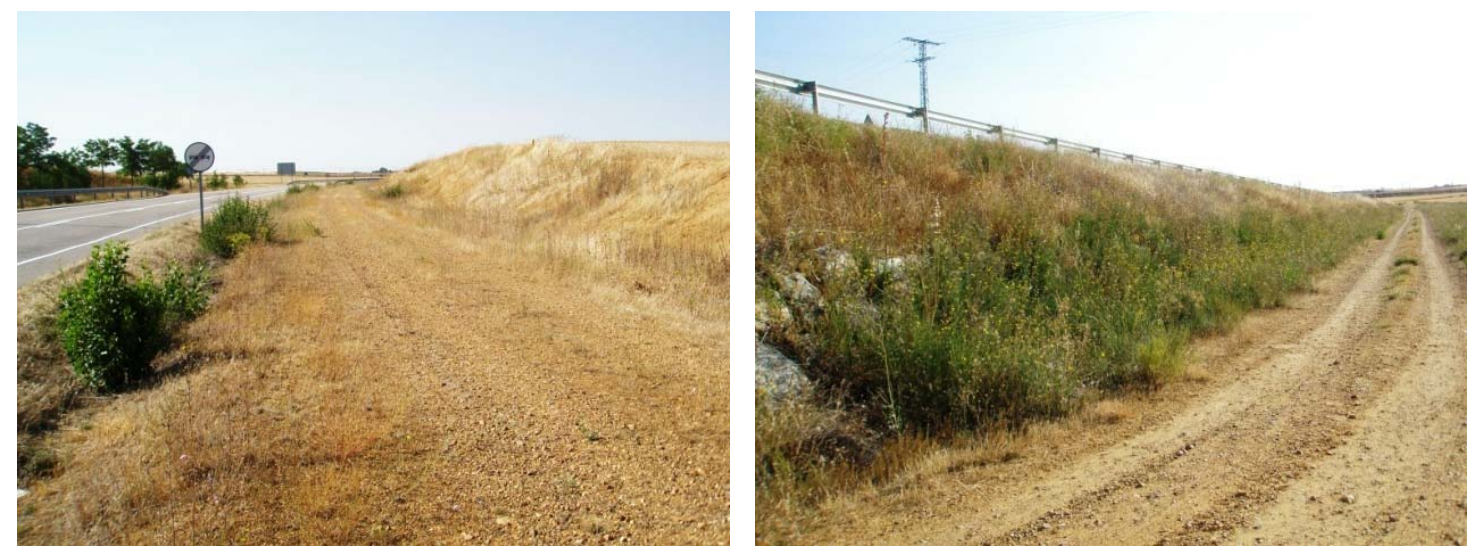

Figura A1.51. Vista de un talud de desmonte (izquierda) y de terraplén (derecha) protegido mediante escollera.

Sin embargo, su revegetación es diferente (Figura A1.52). Así como los taludes de terraplén están completamente cubiertos por vegetación herbácea (o incluso arbustiva), los de desmonte están parcialmente revegetados (se puede estimar en un $60 \%$ de media, que se reduce con su altura). Ello se debe a la mayor facilidad -a igualdad de condiciones- de revegetación natural de los taludes de terraplén, y a la falta de extensión de tierra vegetal en los taludes de desmonte. Tampoco se ha colocado manta orgánica alguna sobre estos últimos, como se indicaba en el Estudio de Impacto Ambiental. 

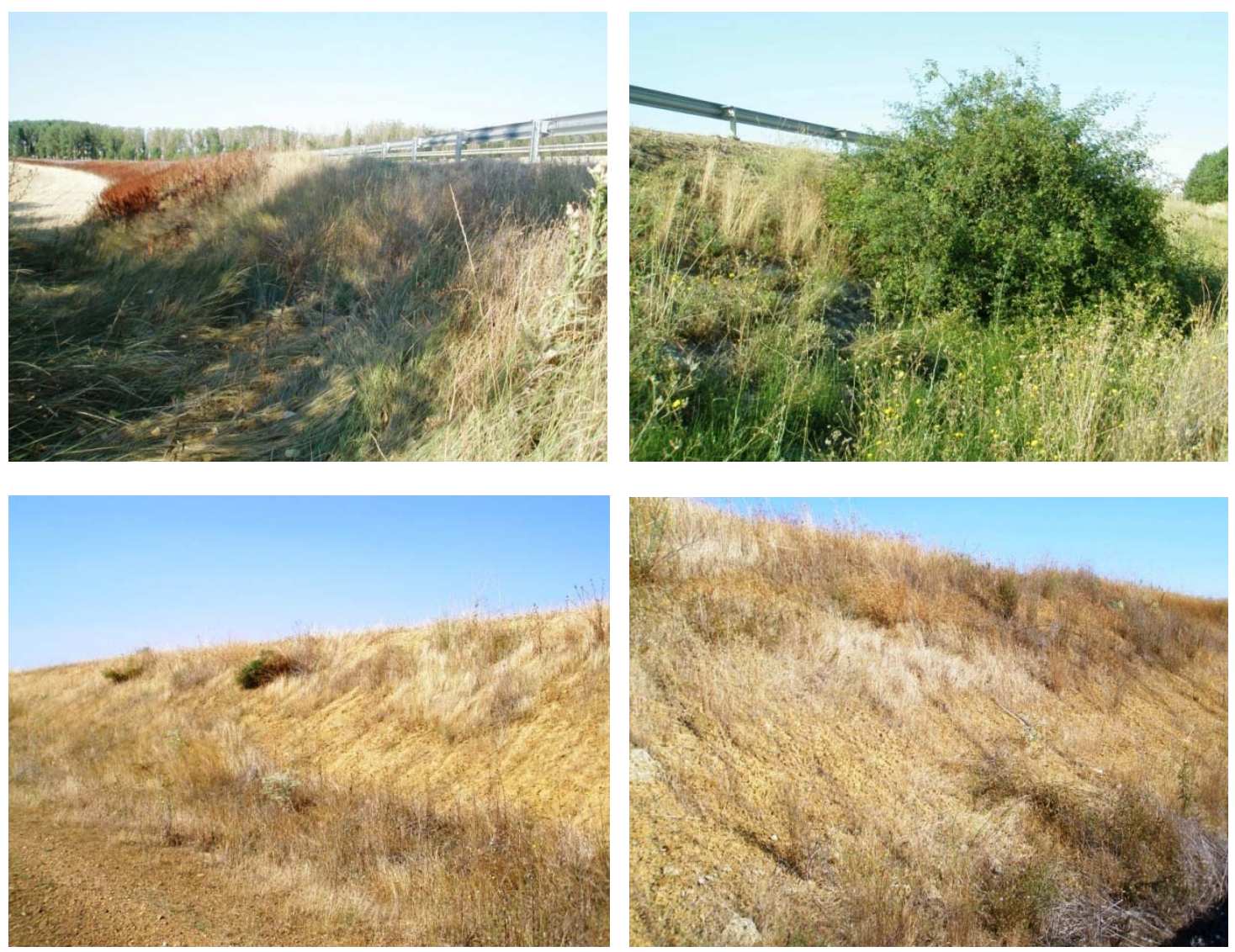

Figura A1.52. La diferencia entre la revegetación de los taludes de terraplén (arriba) y desmonte (abajo) es patente, tal como se observa en las fotografías.

Los márgenes, entorno de enlaces y zonas auxiliares están cubiertos por vegetación herbácea. Sin embargo, no se han realizado las plantaciones arbóreas tal como se indicaba en el Estudio de Impacto Ambiental y en el Proyecto de Construcción. Llama especialmente la atención que no se observe la presencia de ningún álamo (había 1545 presupuestados), que es una especie muy adecuada para su empleo en la zona. En el enlace Sur se han plantado chopos del país, que actualmente gozan de un buen estado vegetativo; en la zona central de la variante se han introducido ejemplares de acacia alineados (Figura A1.53), que perviven adecuadamente y, finalmente, en varias zonas auxiliares se han plantado pinos piñoneros que han sufrido un alto porcentaje de marras (se estima en un $80 \%$ ). 

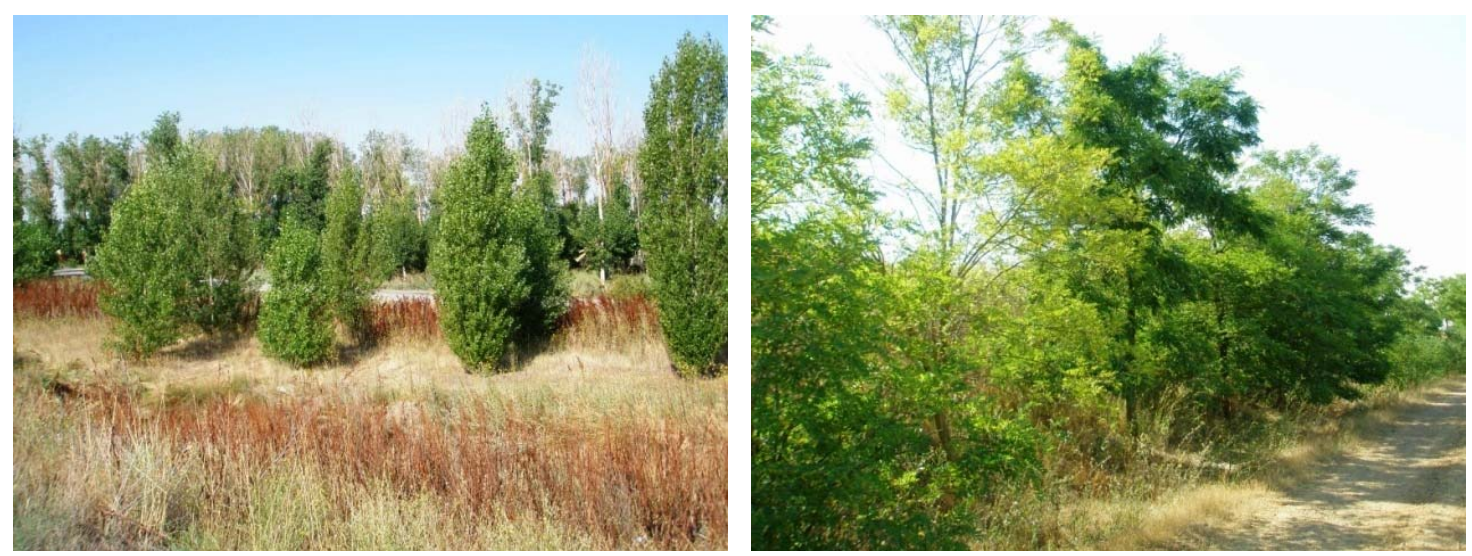

Figura A1.53. Chopos (Populus nigra) a la izquierda y acacias (Robinia pseudoacacia) a la derecha.

En relación a la introducción de los pinos se considera que no fue acertado el empleo de ejemplares de varios años. Su arraigo a falta de cuidados de mantenimiento (como así ha sido) es bastante complicado. Por otra parte, los ejemplares supervivientes tienen unos portes $y$ crecimientos defectuosos (Figura A1.54).
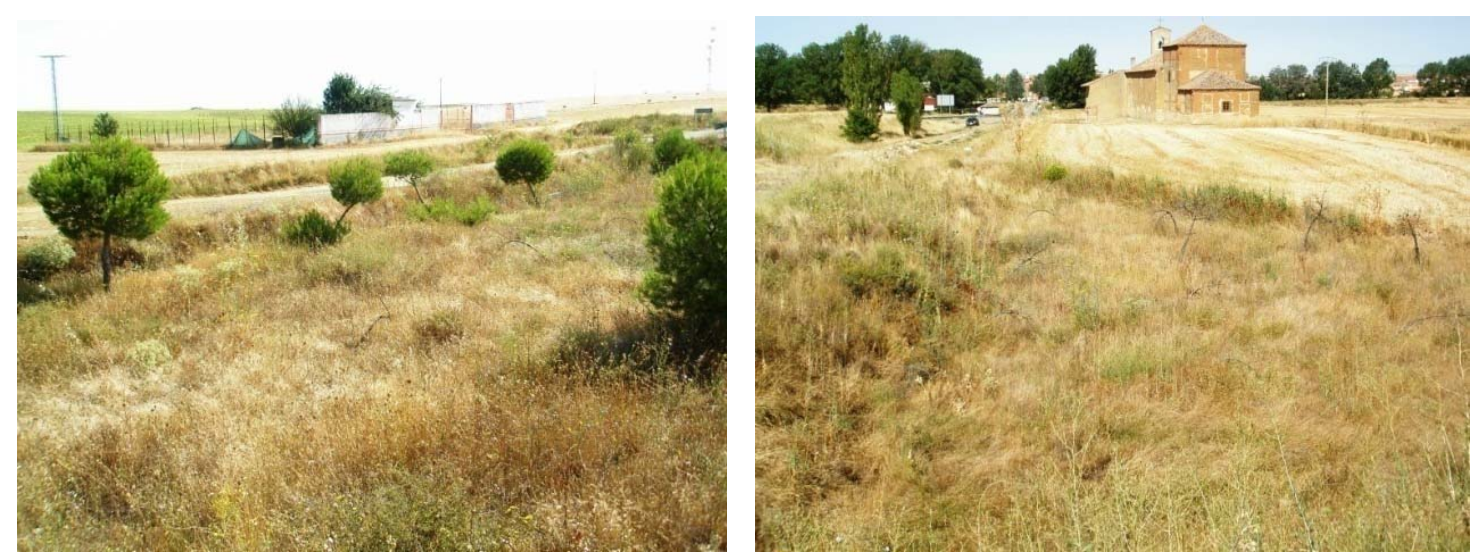

Figura A1.54. Vista de dos zonas de plantación de pinos, en las que se observa el alto porcentaje de marras y el deficiente estado vegetativo.

Las plantaciones de arbustos se han ceñido al uso de gayomba (Spartium junceum) en los taludes próximos al paso inferior bajo el ferrocarril, con un buen resultado, pero muy alejadas de las 1000 unidades presupuestadas (Figura A1.55). Tanto esta especie como otras autóctonas se podrían haber empleado para la revegetación de buena parte de la superficie ocupada por taludes. 

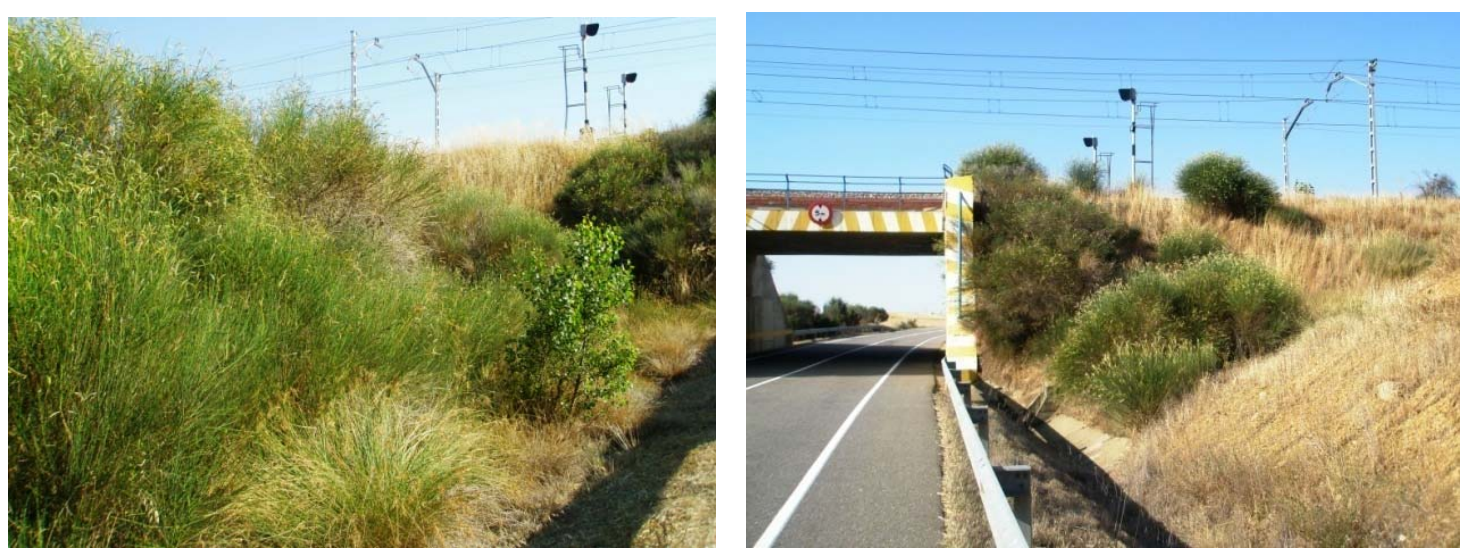

Figura A1.55. Imágenes del buen estado de las plantaciones de Spartium junceum.

Tal vez uno de los aspectos más positivos de la restauración del entorno afectado por la variante al cabo de unos ocho años desde su ejecución, ha sido la revegetación natural acaecida en varios tramos. En algún talud se observan ejemplares nacidos espontáneamente de Rosa canina, mientras que en márgenes y zonas con humedad se han reproducido naturalmente bastantes plantas de Salix sp. y Populus nigra, ambas especies presentes en las proximidades.
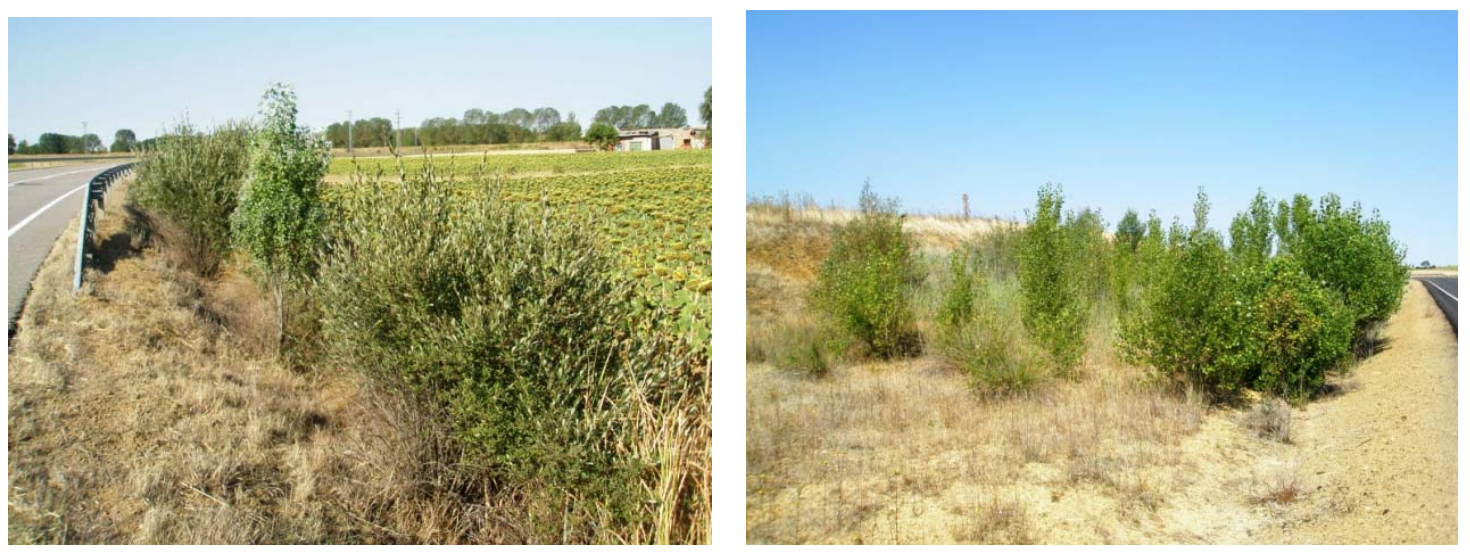

Figura A1.56. Márgenes regenerados naturalmente con sauces y chopos.

En cualquier caso, es esencialmente positivo -sobre todo en una comarca tan agraria como Tierra de Campos- que la construcción de este tipo de infraestructuras lineales de transporte lleve consigo la generación de zonas auxiliares (taludes, márgenes, enlaces, entronques, etc.) de titularidad pública. Estos terrenos suponen al final una superficie de cierta entidad cuya revegetación -ya sea artificial o natural- supone una mejora de la calidad paisajística tanto intrínseca de la carretera como extrínseca del entorno.

No se observan restos de residuos de las obras de construcción de la variante, por lo que se deduce que fueron adecuadamente gestionados y retirados en su día.

El tratamiento de las isletas (Figura A1.57) se ha realizado a base de hormigón con canto en superficie, lo que permite un fácil mantenimiento y una adecuada integración paisajística. En la 
glorieta y en alguna otra isleta se ha combinado la revegetación arbustiva y el mantenimiento de zonas con canto rodado. Esto último tiene el inconveniente de que permite el crecimiento de herbáceas si no se controlan periódicamente.
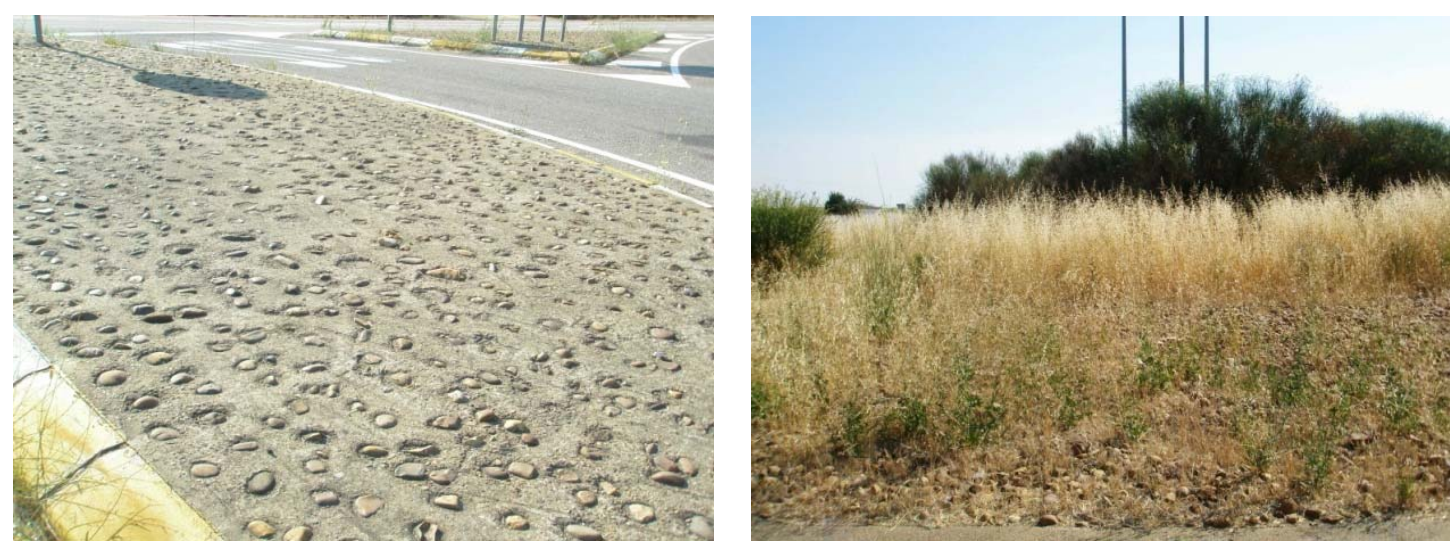

Figura A1.57. Vistas de las isletas del enlace Sur (izquierda) y de la glorieta (derecha), donde se observa una excesiva invasión de herbáceas en la zona de canto rodado.

En principio no se ha desmantelado ningún tramo de antigua carretera, ya que prácticamente todos son funcionales para mantener la continuidad, bien sea de otras carreteras o bien de caminos rurales. En el caso del tramo de vía que discurre por la ermita de la Virgen del Río tampoco se ha desmontado, ya que constituye el acceso desde Villada. No obstante, se podría haber realizado la adecuación paisajística del entorno mediante la integración de la antigua vía con los espacios circundantes a la ermita, la retirada de antiguos depósitos de escombros y la realización de alguna revegetación (Figura A1.58).
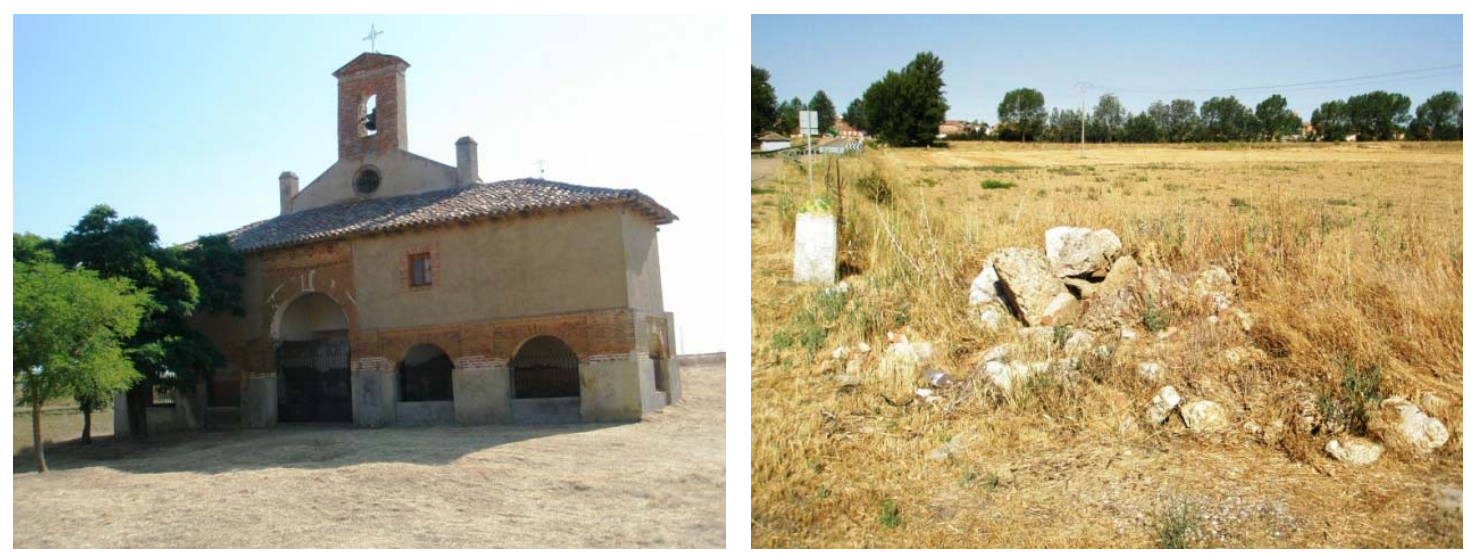

Figura A1.58. A la izquierda, vista de la fachada principal de la ermita de la Virgen de la Cruz; a la derecha, imagen del acceso desde Villada y de un depósito de escombros de antiguas obras de la carretera.

Se considera escaso el presupuesto destinado a medidas de integración ambiental en el Proyecto de Construcción (un 1,18 \%) del total. Aun así, se observa que una parte sustancial del mismo no se ha ejecutado de acuerdo con lo indicado en el anejo ambiental correspondiente. 


\section{A1.6. Explotación de la zona de préstamos PR-1 asociada al proyecto de construcción de la plataforma corredor norte- noroeste de alta velocidad tramo Palencia-León, subtramo Becerril de Campos - Valle del Retortillo. Términos municipales de Becerril de Campos y Paredes de Nava (Palencia).}

\section{A1.6.1. Proyecto}

A1.6.1.1. Proyecto de construcción de plataforma, corredor norte-noroeste de alta velocidad. Tramo: Palencia - León. Subtramo: Becerril de Campos - Valle del Retortillo. Provincia: Palencia. Recopilación de datos ambientales.

Promotor: Administrador de Infraestructuras Ferroviarias (ADIF). Ministerio de Fomento Autor: INECO - TIFSA

Fecha: Septiembre 2009

Este proyecto tiene como objeto definir las obras del subtramo Becerril de Campos - Valle del Retortillo, en la provincia de Palencia, cuya longitud es de $12.864 \mathrm{~m}$. El subtramo es una de las divisiones del tramo Palencia - León, que a su vez forma parte del corredor norte noroeste de alta velocidad.

Como antecedentes del mismo, cabe citar el Plan Estratégico de Infraestructuras del Transporte (PEIT) 2005-2020 del Ministerio de Fomento, en el que se enmarca el estudio informativo de este tramo de la red de alta velocidad española.

El 30 de enero de 2007, la Secretaría General para la Prevención de la Contaminación y el Cambio Climático del Ministerio de Medio Ambiente dicta resolución (SGPCCC, 2007) por la que se formula declaración de impacto ambiental sobre el proyecto de corredor norte - noroeste de alta velocidad, tramo Palencia - León. En el apartado 4.2 de dicha declaración se describen los principales impactos del proyecto, así como las medidas preventivas y correctoras propuestas una vez considerado el estudio de impacto ambiental.

Para corregir la afección sobre la geología y edafología -y en lo que a este proyecto respecta- se establecen zonas destinadas a préstamos y a vertederos, estableciendo como criterios de ubicación que se encuentren fuera de zonas de vegetación natural de interés, cauces fluviales, suelos de alta capacidad agrológica, espacios naturales protegidos o áreas de protección arqueológica. Los préstamos y vertederos contarán con un plan de restauración.

De acuerdo con estos condicionantes, el proyecto de construcción incorpora planos con una delimitación de zonas excluidas (ausencia total de afecciones), zonas restringidas (afección temporal admisible con restauración posterior) y zonas admisibles (afección permanente admisible con restauración posterior). Estas últimas son áreas de valor ambiental bajo, 
potencialmente receptoras de vertederos o préstamos. El préstamo PR-1 se ubica en una zona admisible (Figuras A1.59 y A1.61).

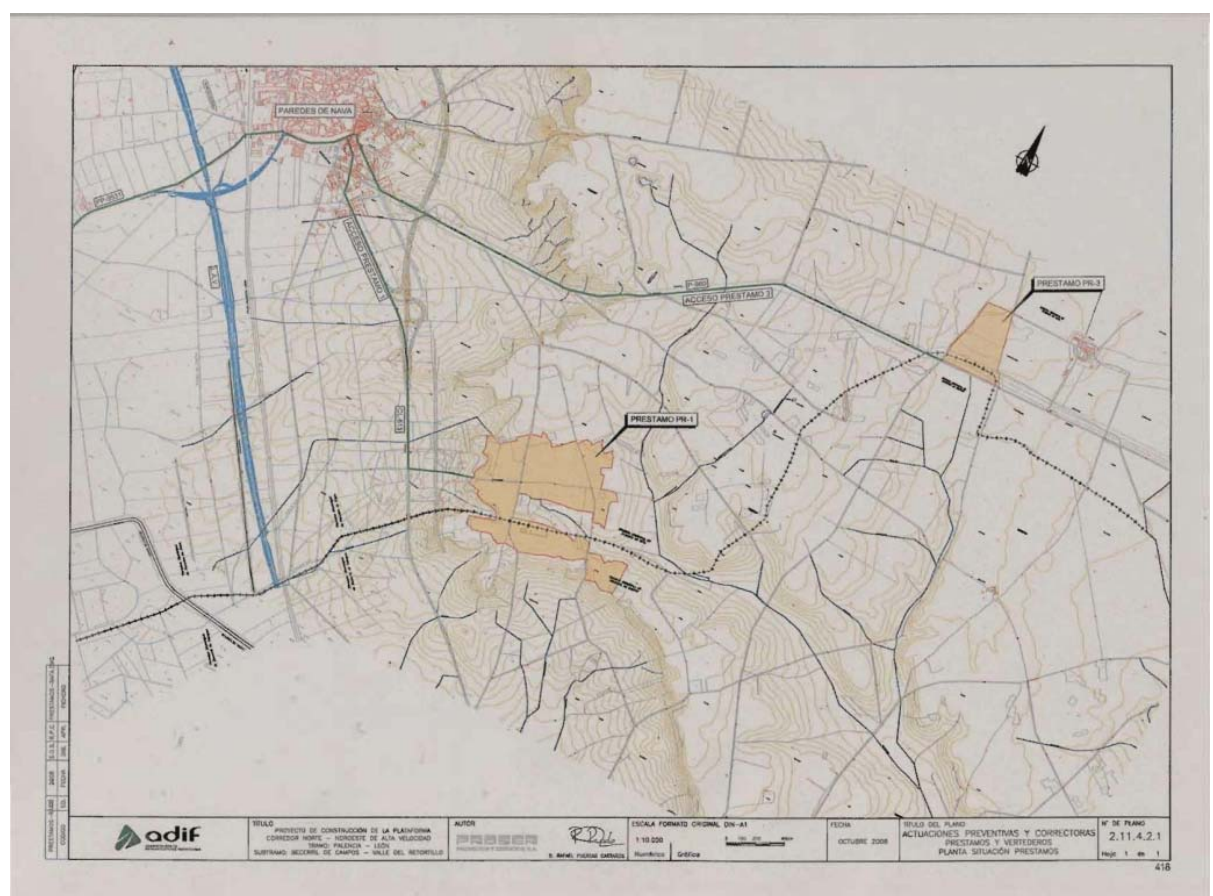

Figura A1.59. Plano de planta del proyecto de construcción, en el que se puede observar en la parte central la ubicación del préstamo PR-1 y, a la izquierda, la traza de la línea de alta velocidad.

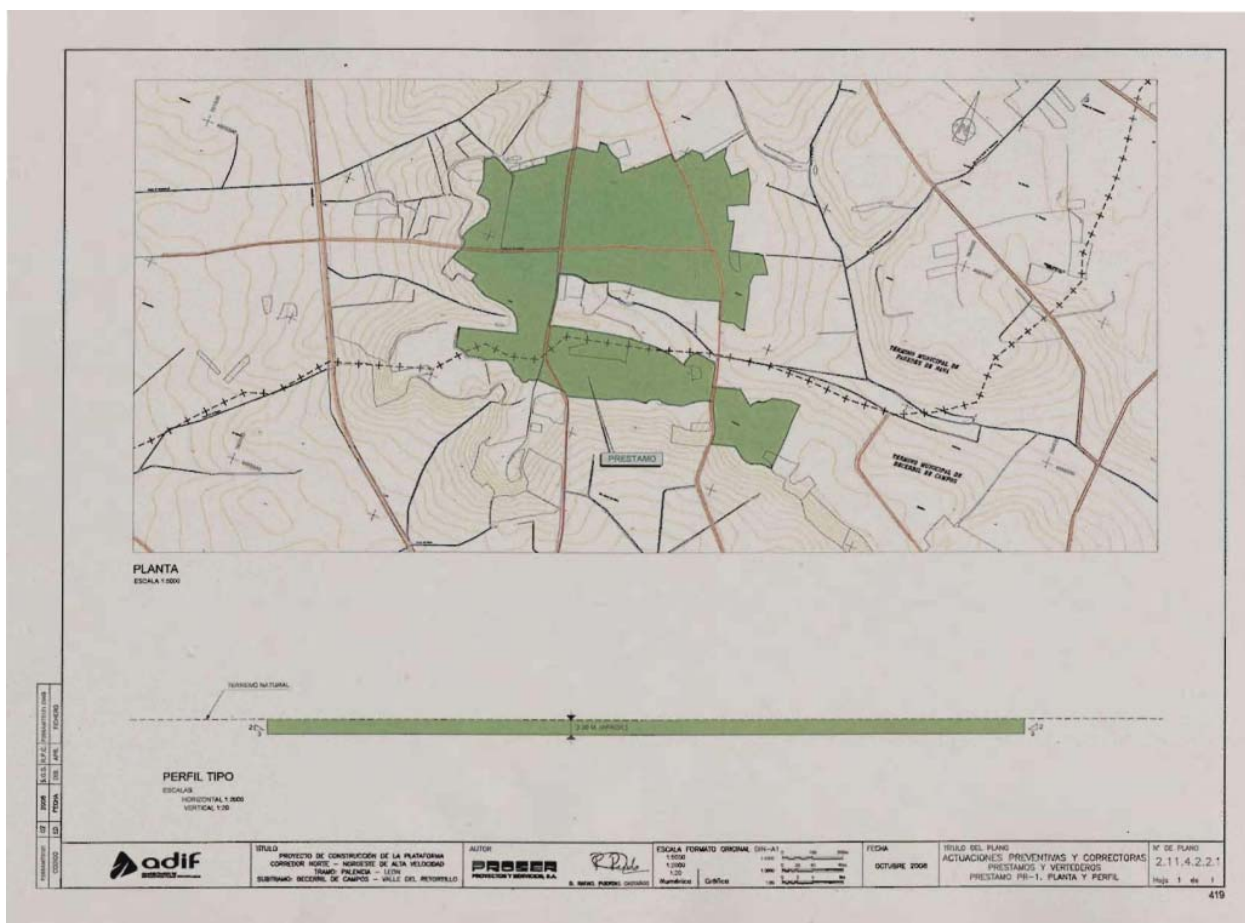

Figura A1.60. Plano de planta del proyecto de construcción, con un detalle del perfil tipo del préstamo $P R-1$. 


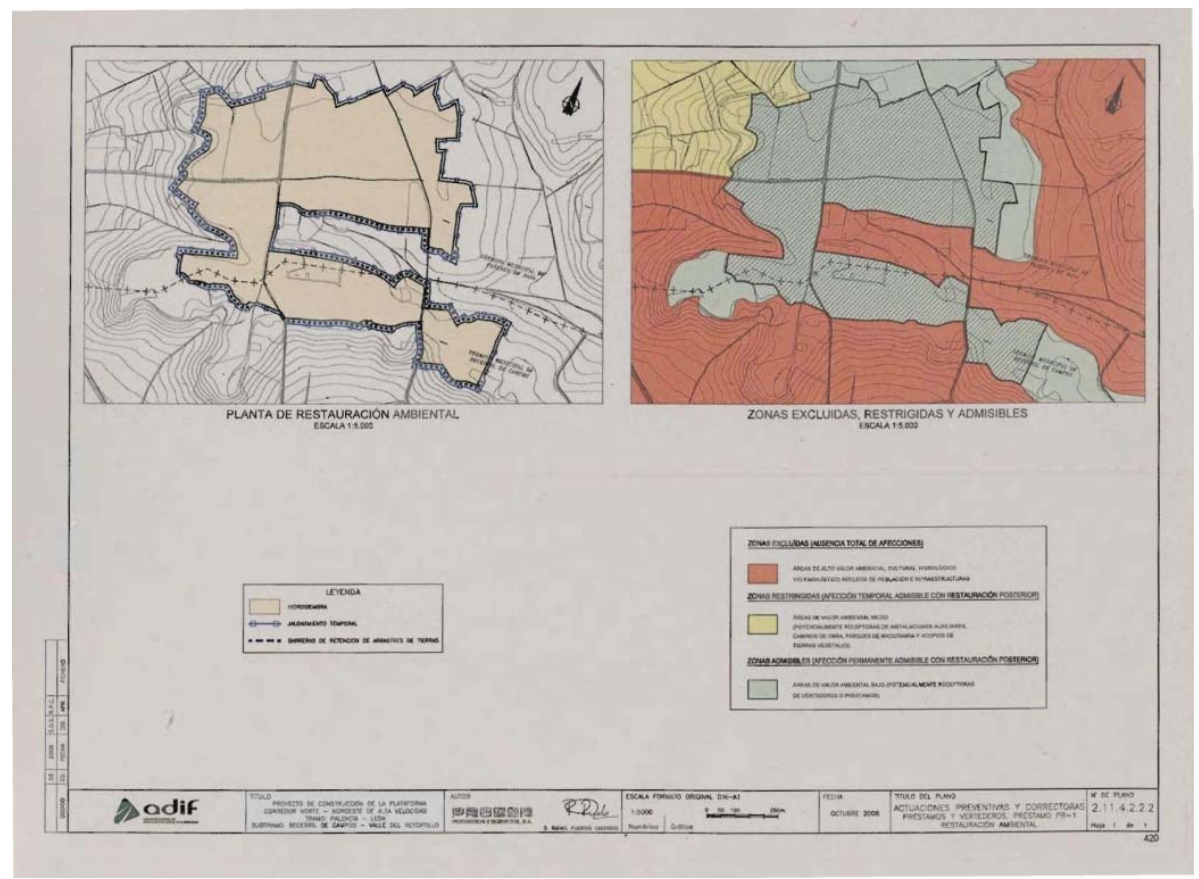

Figura A1.61. Plano de planta del proyecto de construcción en el que se grafía, por una parte, la restauración ambiental del préstamo $P R-1$ y, por otra, las zonas excluidas, restringidas y admisibles.

En el plano titulado "Actuaciones preventivas y correctoras préstamos y vertederos. Préstamo PR-1. Planta y perfil" (Figura A1.60), se puede observar que se plantea una profundidad de extracción de aproximadamente $2 \mathrm{~m}$, perfilándose los taludes con una pendiente $2 \mathrm{~V}: 3 \mathrm{H}$.

En el proyecto se citan una serie de técnicas generales para recuperar los préstamos:

- Previamente al comienzo de las actividades, se retirarán las tierras vegetales de todas las superficies afectadas por las obras.

- Se llevará a cabo una restauración fisiográfica de los nuevos préstamos, que consistirá en transformar los terrenos afectados hacia una morfología suave, de aspecto natural, que permita su integración en mayor medida en el paisaje circundante.

- Una vez concluida la fase de obra, se descompactarán los terrenos mediante un ripeado. Posteriormente se reextenderán de nuevo las tierras vegetales.

- A continuación se procederá a su hidrosiembra con especies herbáceas.

\section{A1.6.2. Condicionantes ambientales}

\section{A1.6.2.1. Plan de Restauración Ambiental del préstamo PR-1}

Promotor: UTE BECERRIL (UTE Gea 21 - Ogensa)

Autor: Alberto Lozano Moya (ingeniero técnico forestal) 
Fecha: junio de 2010

Este documento pretende dar cumplimiento al Real Decreto 975/2009, de 12 de junio, sobre gestión de los residuos de las industrias extractivas y de protección y rehabilitación del espacio afectado por actividades mineras. De acuerdo con esta norma, la entidad explotadora debe realizar con sus medios los trabajos de restauración del espacio natural afectado por las labores mineras, en este caso por la extracción de material para préstamo de las obras del corredor de alta velocidad.

Asimismo se justifica y desarrolla en virtud de lo dispuesto en la declaración de impacto ambiental sobre el proyecto de corredor norte - noroeste de alta velocidad, tramo Palencia León, que obliga a elaborar planes de restauración de los préstamos y vertederos.

La zona donde se ubica la extracción de áridos se localiza al sureste de la localidad de Paredes de Nava, a una distancia de 2,7 km aproximadamente. El préstamo se desarrolla en numerosas parcelas de los términos municipales de Becerril de Campos y Paredes de Nava, que ocupan una superficie de 102,74 ha (Figura A1.62). Esta extensión es sensiblemente superior a la inicialmente prevista en el proyecto de construcción, aunque toda ella está incluida en zonas admisibles.

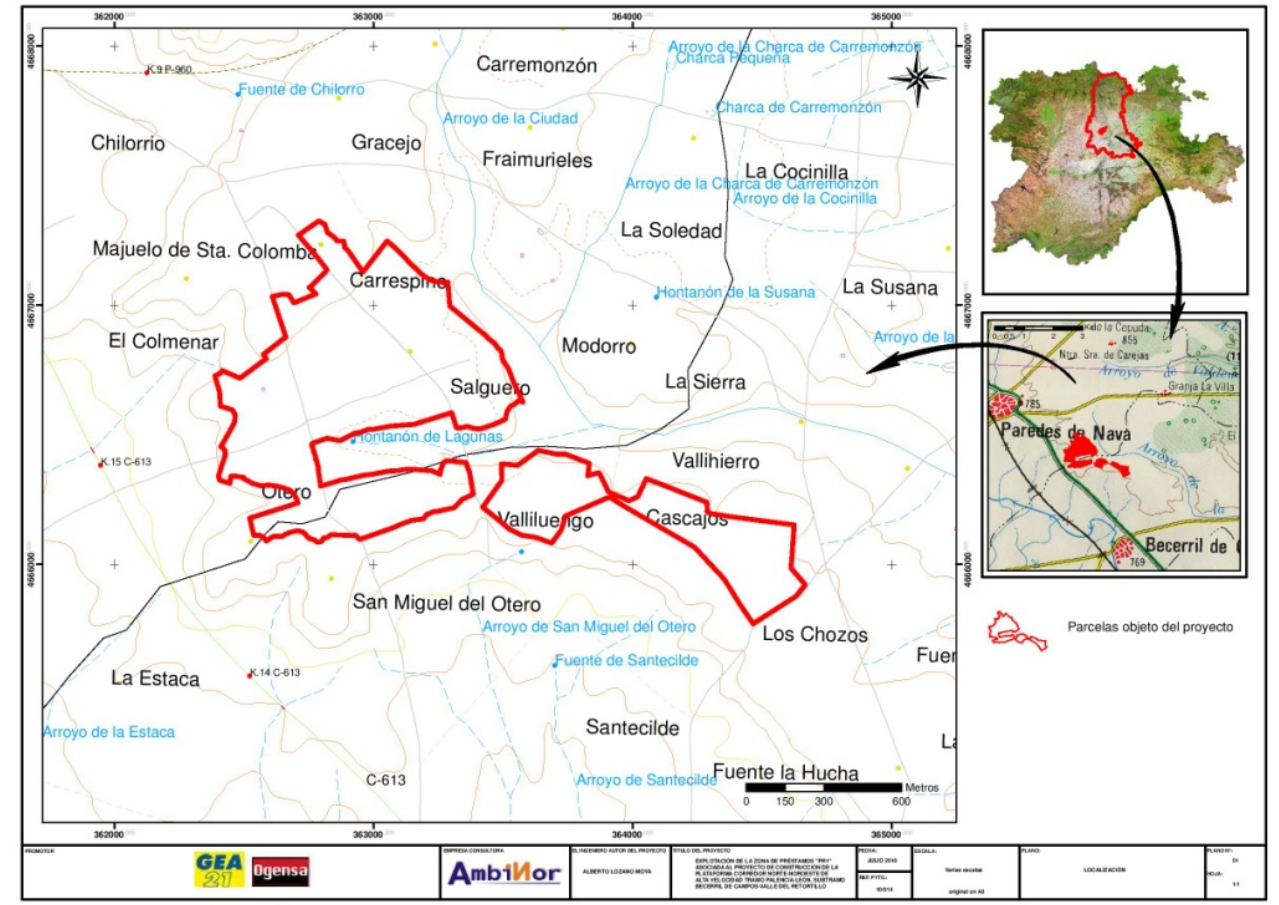

Figura A1.62. Plano de localización del préstamo PR-1, incluido en el plan de restauración.

El uso previo es agrícola y la zona presenta una topografía prácticamente llana. Los suelos son cambisoles cálcicos. La serie de vegetación potencial es la 22a : Serie supra mediterránea castellano-maestrazgo-manchega basófila de Quercus rotundifolia o encina (Junipero thuriferaeQuerceto rotundifoliae sigmetum). La fauna presente es la asociada a cultivos cerealistas, 
destacando la avifauna esteparia. El paisaje es el característico de cultivos de Tierra de Campos, con práctica ausencia de vegetación arbustiva o arbórea (Figura A1.63). Los terrenos se encuentran fuera de espacios naturales protegidos u otra figura de protección natural.

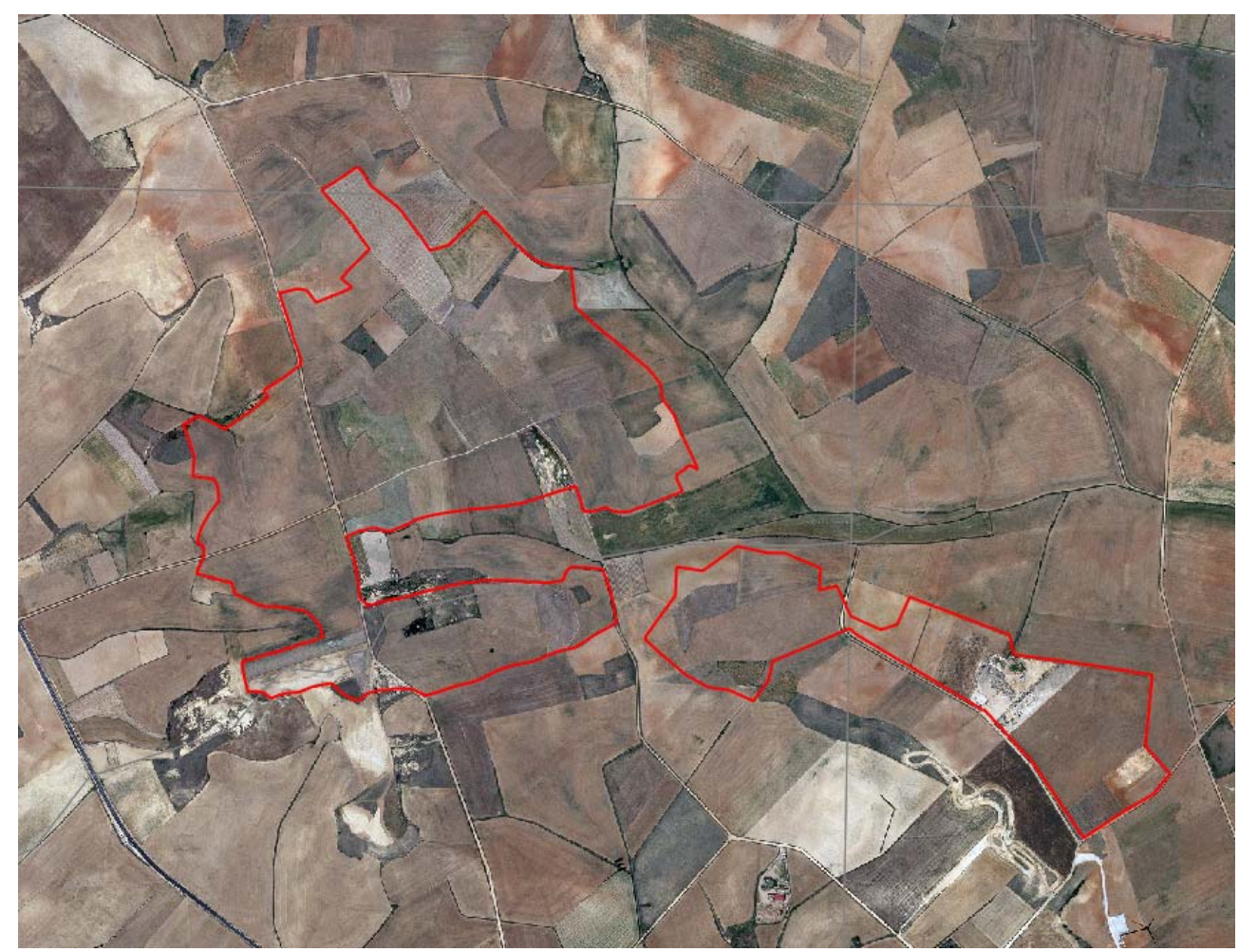

Figura A1.63. Ortofotografía de la zona afectada por el préstamo, realizada en 2009, en la que se observa la naturaleza agrícola de toda su superficie.

La superficie realmente explotable se cifra en 100,08 ha, el espesor de zahorras en 1,17 m, el espesor de estéril más suelo en $0,3 \mathrm{~m}$, el volumen de zahorras en $1202075 \mathrm{~m}^{3}$, el volumen de estéril más suelo en $300229 \mathrm{~m}^{3}$ y el volumen total en $1502304 \mathrm{~m}^{3}$.

El sistema de explotación elegido es el de calles-transferencia, consistente en la retirada del suelo vegetal, acopio del mismo en caballones, explotación de la zahorra, extendido del suelo y restauración final. El arranque se realiza con retro-excavadora, utilizándose camiones dúmper para el transporte de materiales.

El talud perimetral -con altura de $2 \mathrm{~m}$ - no será continuo, ya que se dejará abierto en la vaguada existente al norte del conjunto con salida de las aguas hacia el este y en el resto se suavizará a una pendiente de $1 \mathrm{~V}: 3 \mathrm{H}$.

Las principales medidas previstas para la rehabilitación del espacio afectado son las siguientes:

- Remodelado del terreno, mediante el relleno parcial del hueco de extracción y el perfilado de los taludes con una pendiente de $1 \mathrm{~V}: 3 \mathrm{H}$. 
- Restauración del suelo, a través de su descompactación (escarificado) y la reutilización de la tierra vegetal (que previamente ha de ser retirada, acopiada y mantenida adecuadamente).

- Drenaje, fundamentalmente para evitar encharcamientos.

- Revegetación, mediante la hidrosiembra sobre toda la superficie afectada. Esta se plantea en dos fases (con tapado), incluyéndose una mezcla de 12 especies herbáceas autóctonas gramíneas y leguminosas, con una dosis de $35 \mathrm{~g} / \mathrm{m}^{2}$.

- Mantenimiento de la vegetación durante dos años, con reposición de marras y riego de mantenimiento.

El presupuesto de ejecución material del Plan de restauración asciende a $1609427 €$, valor resultante de la suma de los capítulos de labores previas (678717 €) e hidrosiembras (930710 $€)$. Esta cantidad representa un valor unitario de $16081 € /$ ha.

El Plan de restauración ambiental del préstamo PR-1 fue informado favorablemente por el Servicio Territorial de Medio Ambiente de la Junta de Castilla y León en Palencia el 30 de noviembre de 2010. En dicho informe se establece alguna medida correctora adicional, entre las que destaca la siguiente:

i) Restauración vegetal: Una vez conformados, los taludes serán sembrados con una mezcla de gramíneas y leguminosas pratenses autóctonas. Tanto en los taludes como en las franjas de protección se plantarán especies arbustivas del tipo Rosa canina, Retama sphaerocarpa, Prunus spinosa y Spartium junceum, a razón de 2000 pies/ha.

Asímismo se recomienda la realización de una plantación de árboles autóctonos o propios de la zona (encina, pino piñonero, almendro, etc.) en diferentes rodales o alineaciones, para aumentar la diversidad ecológica y paisajística, de forma que ocupe una superficie de al menos el $25 \%$ del total explotado. Se deberán llevar a cabo todos los tratamientos necesarios para asegurar la pervivencia y el buen estado de la vegetación implantada: aporcados, desherbados, riegos, reposición de marras, siembras, etc. durante un plazo de al menos 2 años.

\section{A1.6.3. Ejecución}

\section{A1.6.3.1. Seguimiento de la obra e informe final de restauración del préstamo PR-1.}

Autor: GEA 21-Ogensa

Fecha: junio 2012

En este documento se afirma que el plan de restauración se ha ejecutado de manera coordinada con la explotación. Las actuaciones contempladas han ido orientadas a naturalizar lo máximo posible la orografía generada como consecuencia de la extracción de los préstamos, y a implantar una cubierta vegetal con la consiguiente mejora paisajística. 


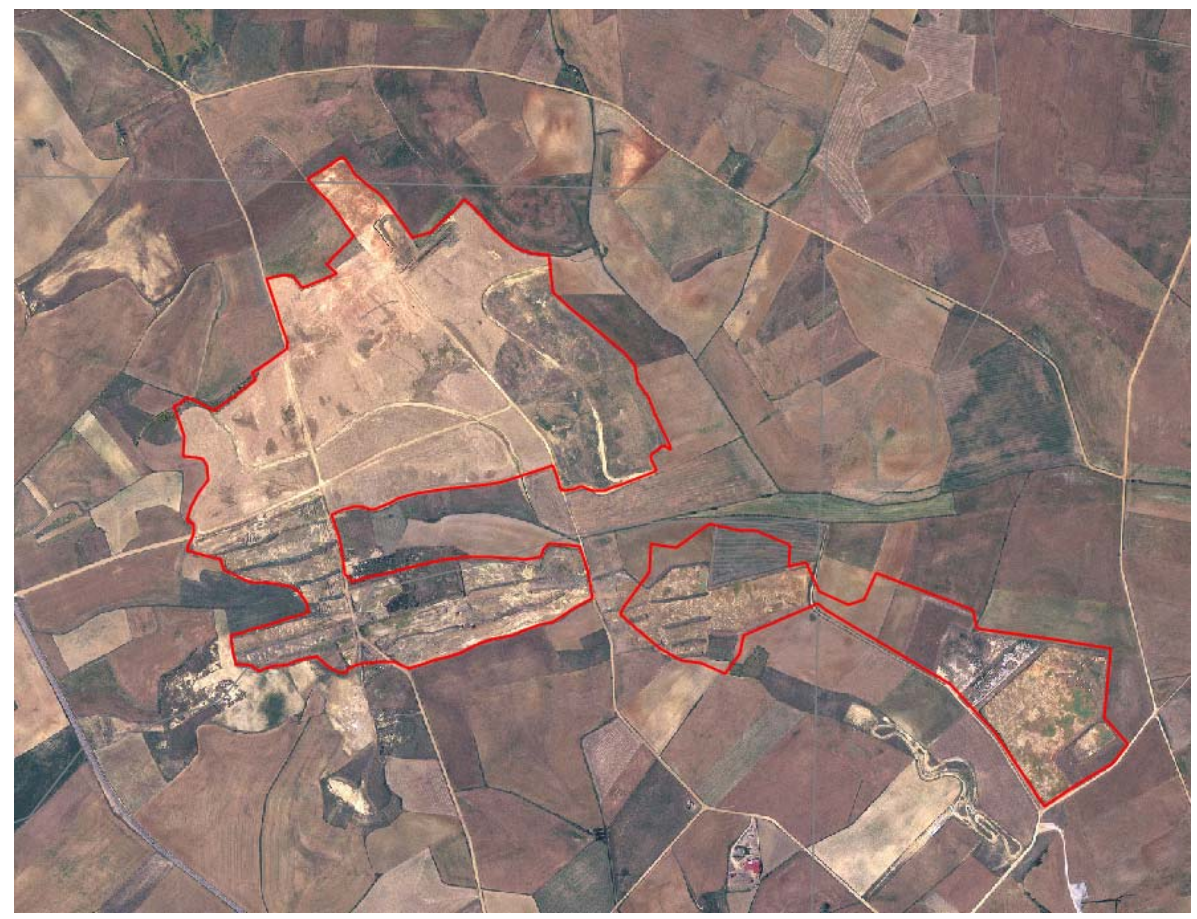

Figura A1.64. Ortofotografía de 2011 del préstamo PR-1, en la que se aprecia que el proyecto se encuentra en la fase de extracción; en algunas zonas se observan cordones lineales de los acopios previos de tierra vegetal.

Los trabajos de explotación se han llevado a cabo conforme a lo previsto en el Proyecto de construcción. Los trabajos tuvieron lugar fundamentalmente durante el primer semestre de 2011 (Figura A1.64).
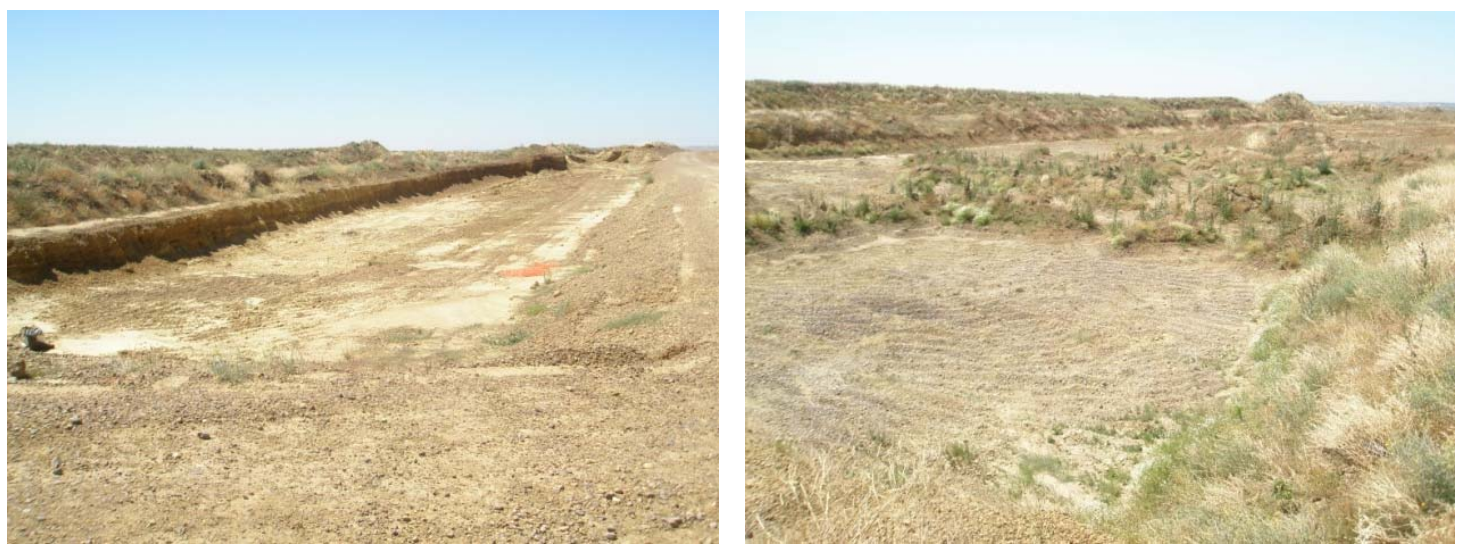

Figura A1.65. Vista de dos zonas de la extracción de áridos llevada a cabo en el préstamo PR-1, en julio de 2011.

En cuanto a la restauración, se señala que también se ha realizado en líneas generales según lo previsto en el Plan de restauración. Las labores se llevaron a cabo a continuación de la explotación, en verano y otoño de 2011 (Figura A1.65). Una vez finalizada la extracción en cada franja de trabajo, se realizaba en relleno parcial del hueco con los materiales sobrantes y la tierra vegetal. Posteriormente se llevó a cabo una remodelación topográfica de la superficie total 
afectada, reduciéndose la pendiente de los taludes finales (siempre inferior a $1 \mathrm{~V}: 3 \mathrm{H}$ ), allanando la plataforma, escarificando el horizonte edáfico superficial y recreando un pequeño cauce al objeto de servir de drenaje de las aguas pluviales (Figura A1.66).
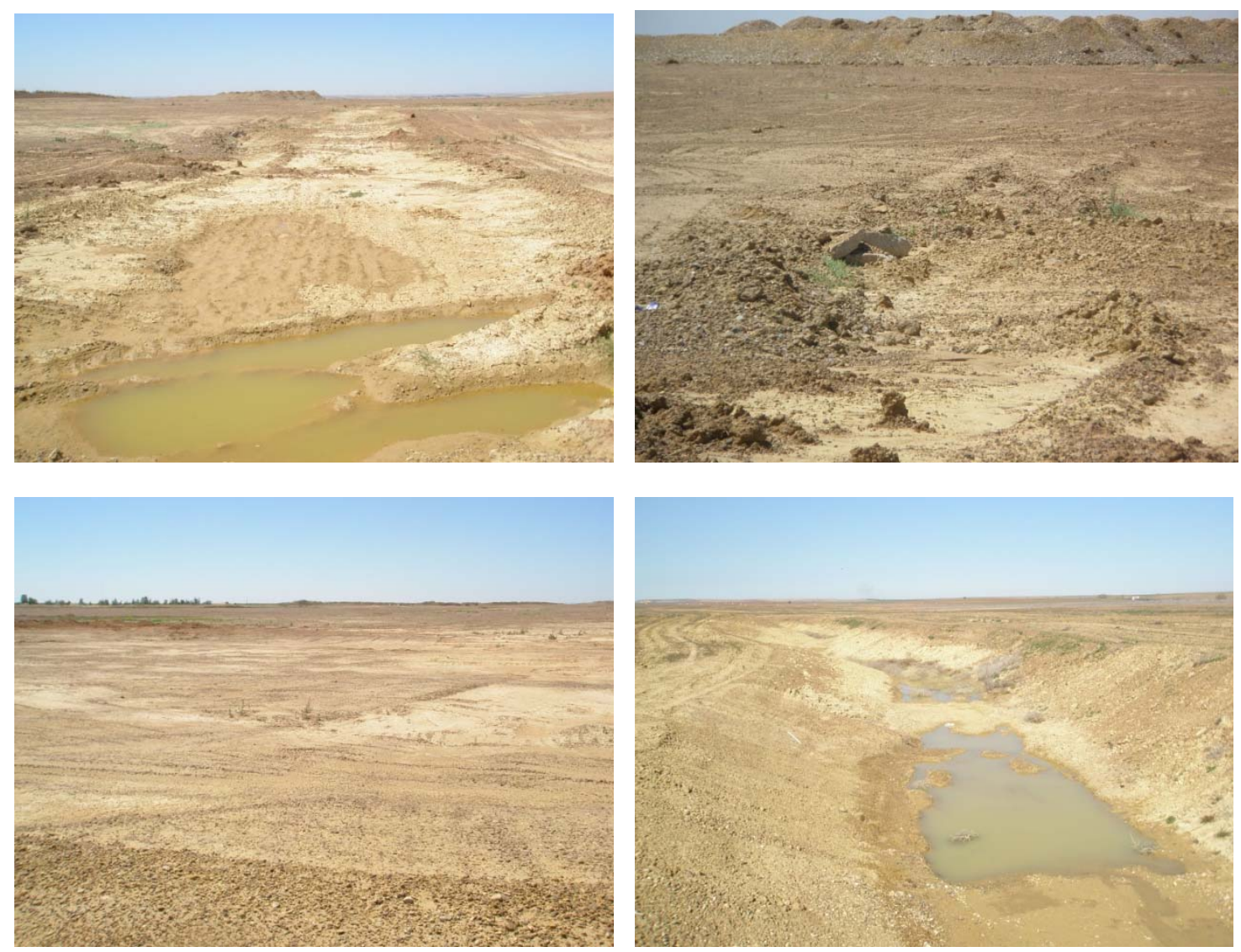

Figura A1.66. Diferentes imágenes de zonas en remodelación topográfica. En la fotografía de abajo a la derecha se observa el cauce de drenaje recreado en la parte oriental del préstamo.

Las actuaciones previstas en el Plan de restauración se han complementado con una plantación de árboles y arbustos en bosquetes que ocupan un $40 \%$ de la superficie total del préstamo, dispuestos de forma irregular por toda la superficie afectada. El préstamo se dividió en 63 zonas, en las que se hicieron 7 tipos diferentes de plantación (Figura A1.67). La densidad de arbustos ha sido de $2000 \mathrm{ud} / \mathrm{ha}$ y la de árboles, de $600 \mathrm{ud} / \mathrm{ha}$. Se han utilizado las siguientes especies:

Árboles: Populus alba, Populus nigra, Fraxinus angustifolia, Quercus faginea, Quercus ilex, Amygdalus communis, Pinus pinea.

Arbustos: Salix sp., Spartium junceum, Rosmarinus officinalis, Rosa canina, Rubus ulmifolius, Retama sphaerocarpa, Prunus spinosa. 


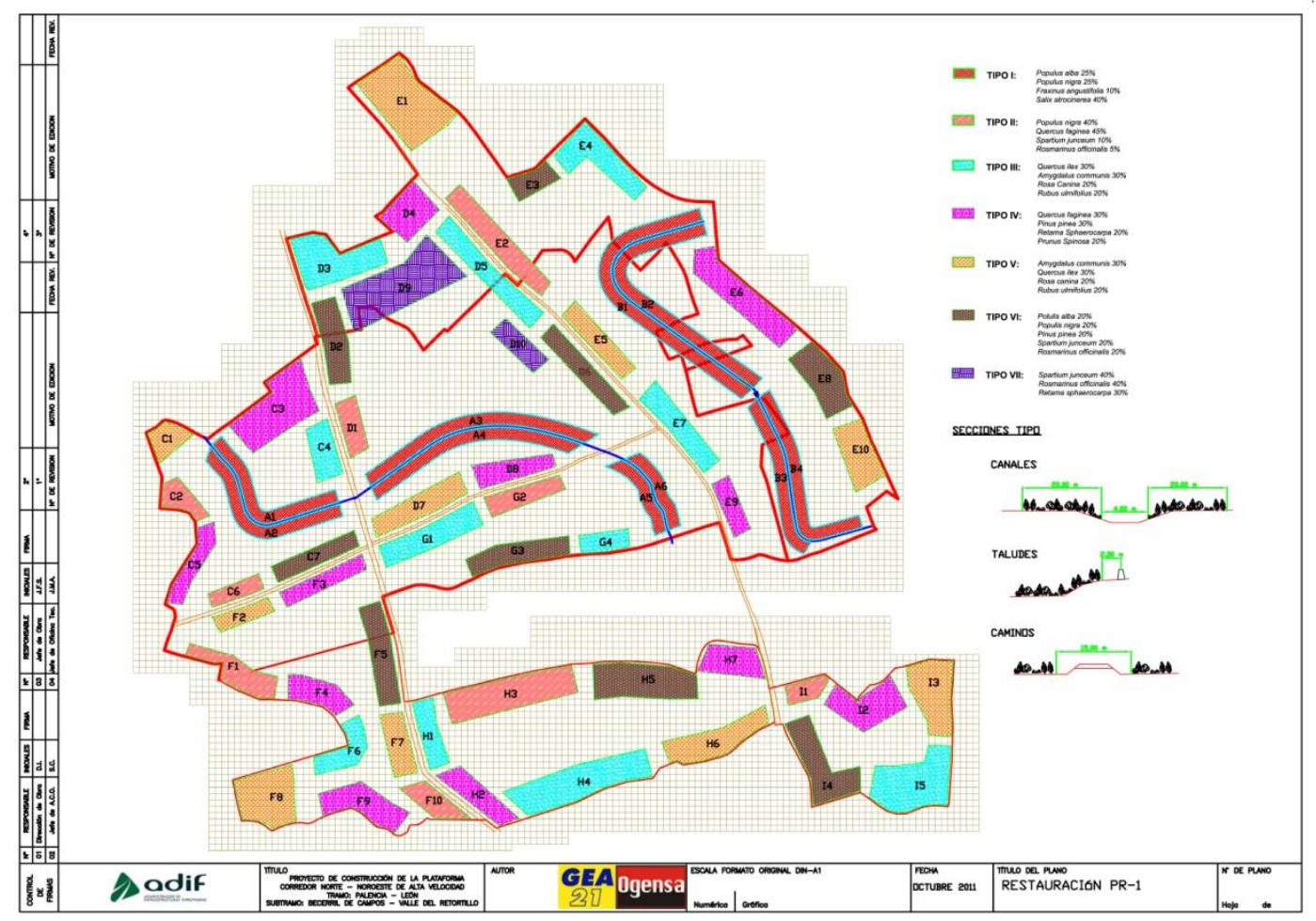

Figura A1.67. Plano de detalle con los distintos rodales de la restauración realizada en el préstamo PR-1, en la que se diseñan siete tipos diferentes de agrupación de especies.

La plantación se realizó mediante subsolado lineal en octubre de 2011 -con una profundidad de $40 \mathrm{~cm}$ - y posterior colocación de la planta con azada (Figura A1.68). Se utilizó planta autóctona, la mayoría de una savia, repicada, con región de procedencia conocida, en contenedor de 200$300 \mathrm{~cm}^{3}$ y un tamaño de entre 20 y $60 \mathrm{~cm}$ de altura. Las labores de plantación se realizaron durante el mes de noviembre de 2011.
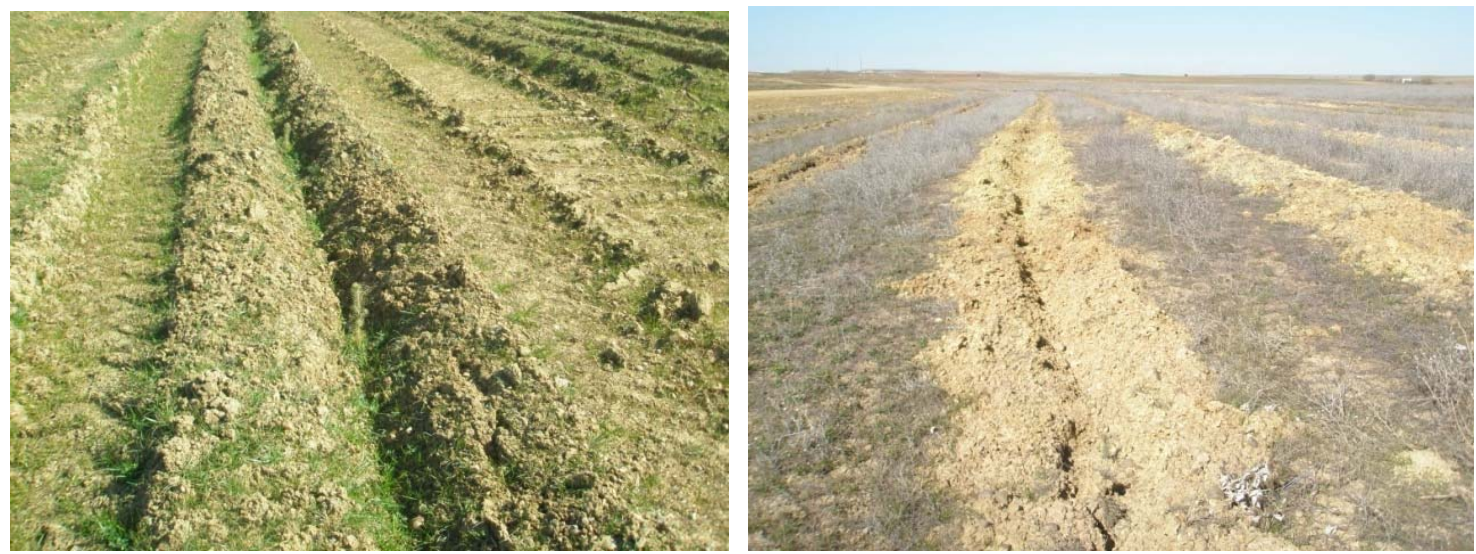

Figura A1.68. Detalle del subsolado lineal realizado para la plantación de árboles y arbustos. En estos surcos se aprecia algún pino piñonero. 
Se han realizado visitas técnicas a la zona los días 28 de julio de 2011, 28 de febrero de 2012, 20 de abril de 2012, 2 de mayo de 2013 y 7 de agosto de 2013.

Al final del invierno de 2012 tuvo lugar la emergencia de la siembra de herbáceas realizada (Figura A1.69), que poco a poco llegó a cubrir la casi totalidad de la superficie afectada, comenzando a competir con los árboles y arbustos plantados.
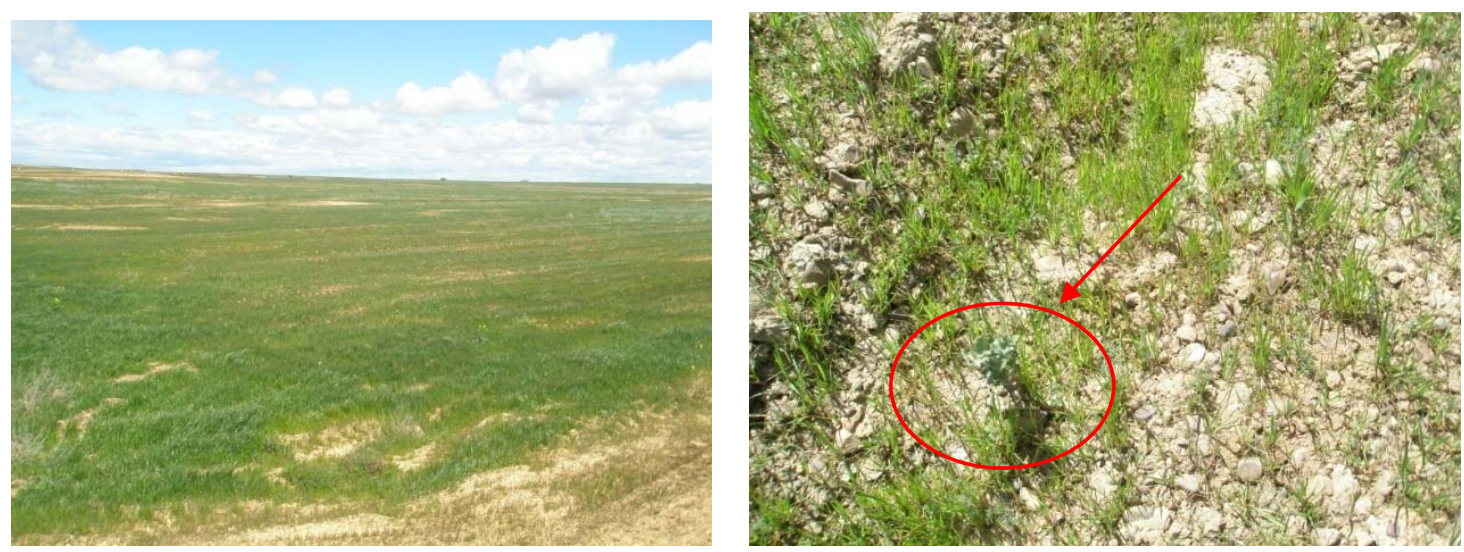

Figura A1.69. Vista general de la plataforma sembrada (izquierda) y detalle del entorno de una encina plantada, en el que crece la vegetación herbácea.

La primavera y verano de 2012 fueron estaciones muy secas, y no se realizaron riegos de mantenimiento, lo que dio lugar a numerosas marras en la plantación. La vegetación herbácea se desarrolló sin embargo con gran profusión, llegando a tapar a los pequeños árboles y arbustos. Se originan pequeñas zonas de encharcamiento de agua (Figura A1.70).
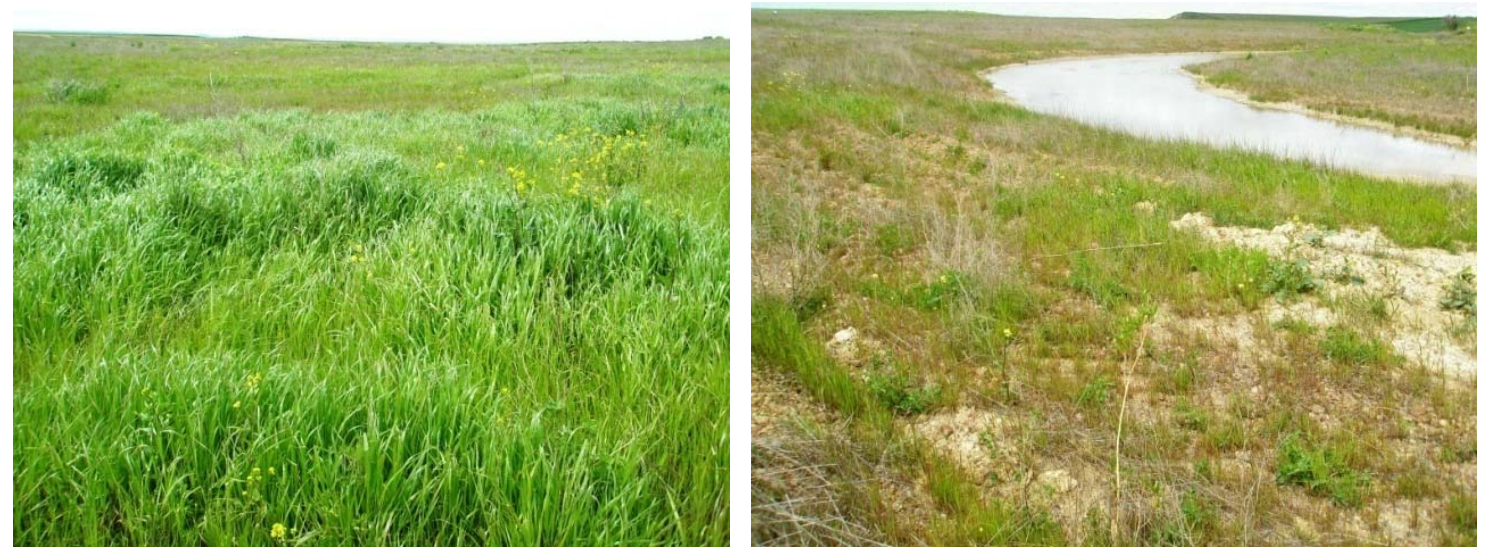

Figura A1.70. Imágenes del préstamo PR-1 en mayo de 2013. A la izquierda se puede apreciar la densidad y desarrollo de la vegetación herbácea; a la derecha, la funcionalidad del cauce hídrico recreado.

Al igual que se ha realizado en todos los terrenos expropiados afectados por las obras de la línea de alta velocidad, el área objeto del préstamo PR-1 ha sido delimitado físicamente con grandes mojones de hormigón pintados en blanco. 
En verano de 2013, tras varios recorridos por la zona afectada, se observa que el porcentaje de marras asciende aproximadamente al $70 \%$. Aunque el resultado no es homogéneo, se comprueba que, con carácter general, han muerto más las especies de ribera y han marrado menos los pinos, encinas y retamas.

En noviembre de 2013, la empresa constructora realiza una reposición de marras en el préstamo, que se justifica en un Anexo al informe final de restauración PR-1, con fecha de 26 de noviembre de 2013 y cuyo autor es GEA 21-Ogensa. Se ha actuado en todos los rodales donde se intervino en la restauración original, empleándose pino piñonero (Pinus pinea) al $60 \%$ y encina (Quercus ilex) al $40 \%$, por ser las especies arbóreas que menos marras tuvieron. Se aprovechó la preparación lineal del terreno previa, plantándose a un marco aproximado de $4 \times 4$ m (625 plantas/ha) y respetando las plantas aún vivas. Se han plantado 7245 pinos piñoneros y 4725 encinas, de 1 savia, tamaño $20 \mathrm{~cm}$, en contenedor de $300 \mathrm{~cm}^{3}$. Se justifica la utilización de plantas con pasaporte fitosanitario, número de lote, región de procedencia local y material autóctono.

\section{A1.6.3.2. Conclusiones del seguimiento ambiental}

Se puede estimar que la ejecución del proyecto del préstamo PR-1 ha ocasionado un impacto sobre el paisaje moderado, es decir, tal que su recuperación no ha precisado prácticas protectoras o correctoras intensivas, y en el que la consecución de las condiciones ambientales iniciales ha requerido un cierto tiempo. Aunque la superficie del préstamo es elevada, el tiempo de explotación (inferior a un año) ha sido bastante reducido, no se han realizado grandes movimientos de tierra por unidad de superficie, no se han generado taludes de gran altura ni se ha afectado a vegetación forestal de interés.

Se considera muy acertado el hecho de que la restauración de los terrenos haya ido pareja a su explotación. Esta ha sido una de las causas principales de que el impacto sobre el paisaje no haya sido elevado y ha facilitado sin duda que las labores de recuperación fuesen más eficaces, por economía de medios.

La recuperación ambiental de los terrenos afectados por el préstamo ha sido en general buena. A ello destaca el papel jugado por la remodelación de los terrenos, que se ha realizado con notable acierto. Se ha interpretado correctamente el paisaje de Tierra de Campos para diseñar la fisiografía final del terreno: pendientes suaves, formas redondeadas y recreación de cursos hídricos al objeto de propiciar la máxima integración paisajística de la zona alterada. De hecho, para un observador ajeno al proyecto es difícil apreciar que haya sido un área de extracción.

En principio, la gestión de la tierra vegetal ha sido adecuada. Se realizó una retirada selectiva de la misma a medida que avanzaba la explotación del préstamo, para después extenderse sobre toda la superficie afectada.

La delimitación del préstamo PR-1 mediante mojones blancos conlleva un cierto impacto visual, ya que estos son numerosos y contrastan con los tonos ocres, marrones o verdosos del paisaje terracampino. No obstante, este amojonamiento es positivo de cara a la conservación de esta importante propiedad pública; de hecho, en un futuro merecería la pena considerar la posible catalogación de estas aproximadamente 100 ha como monte de utilidad pública, ya que en estos 
terrenos se podrían concitar varias de las razones que recoge la legislación forestal para promover esta declaración.

Se considera desacertada la realización de una siembra de herbáceas en toda la superficie objeto de extracción. De no haberse efectuado se habrían ahorrado casi un millón de euros, de acuerdo con lo presupuestado en el Plan de restauración (el precio unitario era de casi $1 € / \mathrm{m}^{2}$ ). Por un lado, la adecuada remodelación de los terrenos efectuada ha eliminado los riesgos de erosión del suelo y por tanto la necesidad de una cubierta protectora. Además, el extendido de la tierra vegetal y el posterior escarificado del horizonte superficial podrían haber generado de forma natural la aparición de una cubierta herbácea autóctona; de una forma paulatina pero sin duda segura. Por último, la densidad de la cubierta herbácea sembrada ha ejercido una fuerte competencia sobre la vegetación arbustiva y arbórea implantada, que ha provocado la muerte de numerosos ejemplares.
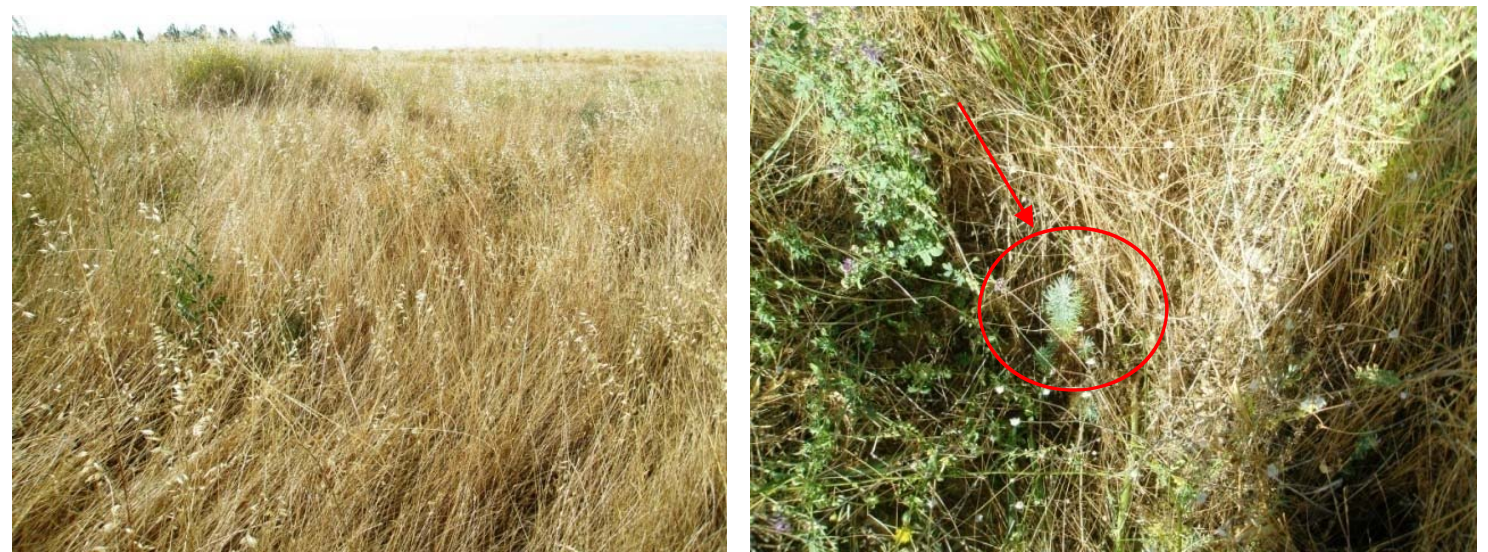

Figura A1.71. Detalle de la densidad y envergadura de la vegetación herbácea implantada. A la derecha se observa un pino que ha sobrevivido a pesar de la fuerte competencia de la cubierta adyacente.

Se observa la existencia de pequeñas zonas encharcables repartidas por toda la superficie, que constituyen un buen hábitat para especies de fauna acuática. En estas áreas ha fracasado la plantación (por el ahogamiento de la vegetación), pero se aprecia una regeneración natural (Figura A1.72) de especies frondosas propias de zonas húmedas (Populus nigra, Salix sp.). Por su importancia ecológica, se deben mantener estas zonas en el estado en el que actualmente se encuentran, sin necesidad de que se drenen o se planten nuevamente. 

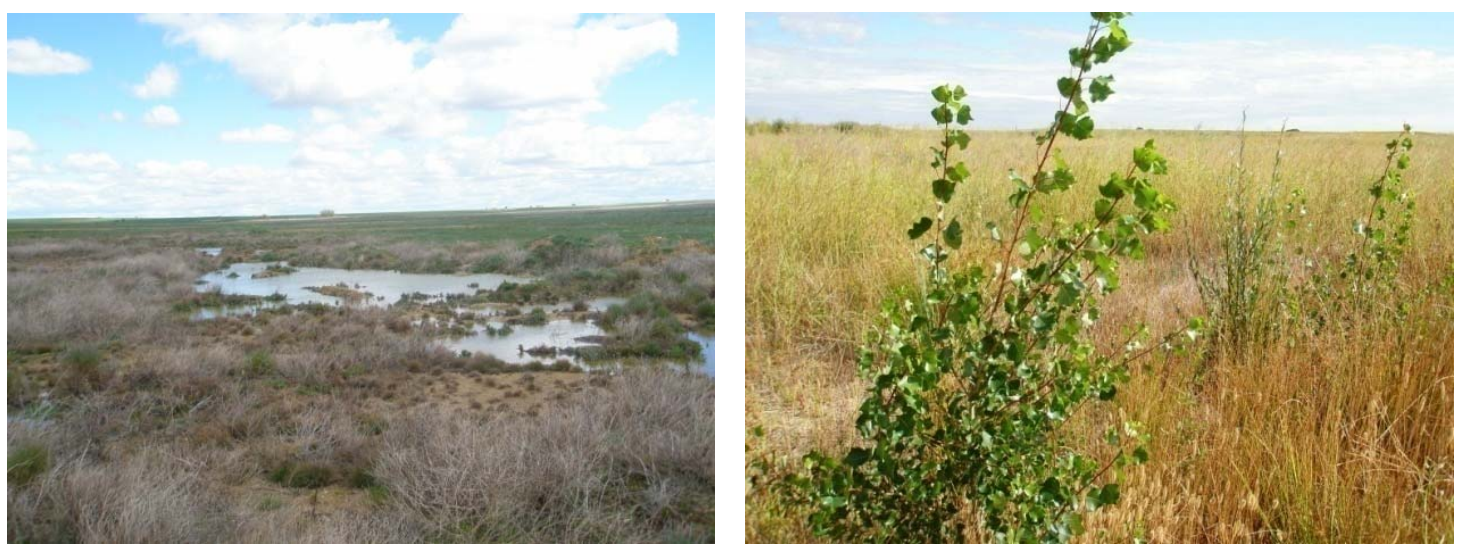

Figura A1.72. Zonas húmedas en el interior del préstamo restaurado, donde se aprecia la aparición espontánea de especies frondosas de ribera.

La realización de plantaciones arbóreas y arbustivas autóctonas en un $40 \%$ de la superficie del préstamo es una muy buena medida para recuperar ambientalmente el paisaje del entorno. Si la vegetación pervive, se generaría un ecosistema natural -un "bosque isla" o una "mancha" en lenguaje ecológico- en medio de un paisaje tremendamente dominado por la agricultura intensiva. Para ello es fundamental que se mantenga la propiedad pública (de momento ADIF, Ministerio de Fomento) y que su gestión futura conserve el carácter de recuperación con fines naturales o restauración ecológica.

El diseño irregular de la plantación -como un conjunto de rodales repartidos por toda la superficie, con una diferente mezcla de especies- es adecuado para conseguir que la recuperación ambiental tenga un objetivo natural. No obstante esto conlleva una mayor dificultad para su seguimiento. Tal vez se podrían conseguir unos fines similares con una cierta simplificación de los rodales; también sería interesante realizar alguna delimitación física (surcos, estaquillas de madera, etc.) para diferenciarlos.

Aunque la superficie del préstamo está amojonada, resulta necesario prevenir de un posible pastoreo por parte del ganado ovino, al menos durante los primeros años de desarrollo de la vegetación forestal. La instalación de pequeños carteles indicadores de la presencia de árboles, así como la comunicación a los ayuntamientos y juntas agropecuarias locales de los términos municipales afectados podrían ser herramientas eficaces para conseguir este objetivo.

En la reposición de marras se debe tener en cuenta la pervivencia de las especies implantadas en el primer momento. Teniendo en cuenta que la mayor parte de la zona afectada posee una escasa humedad edáfica, se deben seleccionar especies para zonas secas, considerándose más interesante los árboles frente a los arbustos. En este sentido, es correcta la elección de pino piñonero y encina en la reposición de marras realizada en noviembre de 2013. 


\section{A1.7. Línea eléctrica aérea de alta tensión entre las subestaciones de transformación de Ampudia y Grijota (Palencia)}

\section{A1.7.1. Proyecto}

A1.7.1.1. Proyecto de línea de alta tensión 220 kV subestación Grijota - subestación Ampudia

Promotor: Proyectos de Cogeneración, S.L. (PROYDECO)

Autor: Ramón Fernández de Bordons (ingeniero del ICAI)

Fecha: julio 2003

El objeto de este proyecto es la construcción de una línea eléctrica de alta tensión, de $220 \mathrm{kV}$, desde la subestación Ampudia hasta la subestación Grijota. Mediante esta línea se evacua la energía de varios parques eólicos situados en el entorno de Ampudia; aunque en un principio la previsión de los parques era otra, actualmente exporta la energía producida en los parques eólicos La Muñeca (27 aerogeneradores, 40,5 MW), Alconada (3 aerogeneradores, 4,5 MW), Cuesta Mañera (33 aerogeneradores, 49,5 MW), El Castre (16 aerogeneradores, 25,6 MW), Dehesilla I ( 25 aerogeneradores, 46,875 MW), Dehesilla II (25 aerogeneradores, 46,875 MW) y Esquileo I ( 25 aerogeneradores, 46,875 MW). Es decir, esta línea eléctrica evacua la energía que producen 154 aerogeneradores, con una potencia total de 260,73 MW.

La línea eléctrica tiene una longitud de $28737 \mathrm{~m}$ y atraviesa los términos municipales de Ampudia, Pedraza de Campos, Villamartín de Campos, Villaumbrales, Husillos y Grijota (Palencia), discurriendo íntegramente por la comarca de Tierra de Campos (Figura A1.73). Cuenta con un total de 80 apoyos metálicos de celosía tipo HAYA y DRAGO, cuya altura oscila de media entre 30 y $40 \mathrm{~m}$. 


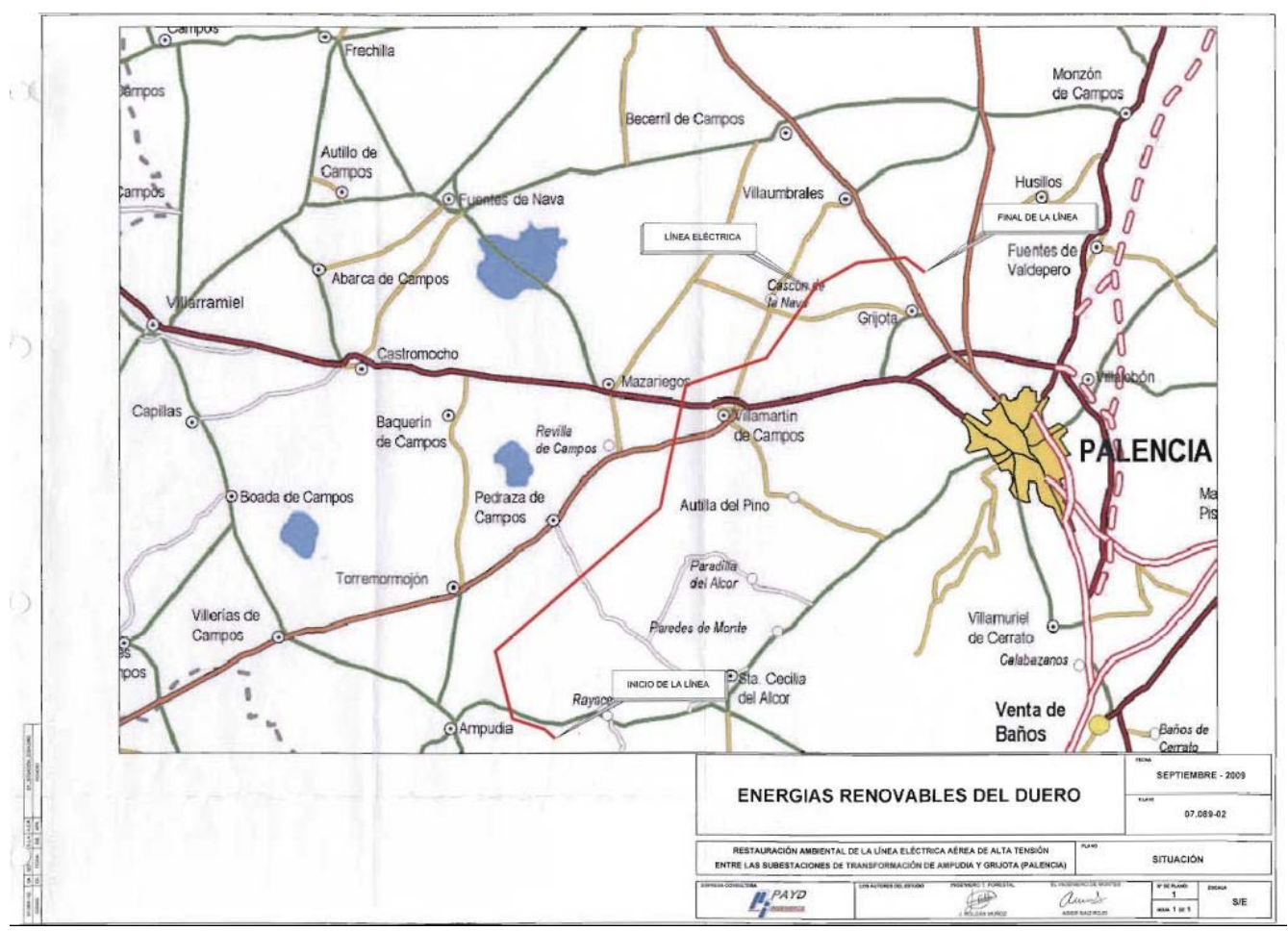

Figura A1.73. Trazado de la línea eléctrica (en rojo).

El presupuesto de ejecución material del montaje de los equipos eléctricos es de $590024 €$, mientras que el de la obra civil es de $209674 €$, por lo que el presupuesto total asciende a 799698 $€$.

\section{A1.7.2. Condicionantes ambientales}

A1.7.2.1. Estudio de Impacto Ambiental y Plan de Restauración de la línea de alta tensión 220 kV subestación Grijota -subestación Ampudia (Palencia)

Promotor: Proyectos de Cogeneración, S.L. (PROYDECO)

Autores: Pedro Ricardo Pérez Casado (ingeniero técnico de minas) y equipo multidisciplinar Ingenieros de Castilla y León, S.L.

Fecha: julio 2003

El Estudio contempla tres alternativas de trazado, que básicamente difieren en el tramo de transición del páramo a la campiña desde la subestación de Ampudia; en particular, en la forma de bordear las masas arboladas y las poblaciones. De las tres alternativas analizadas, el Estudio selecciona la número 3 por considerar que es la más adecuada desde el punto de vista ambiental, al presentar menor longitud de trazado y discurrir la mayor parte de su trayecto sobre terrenos de cultivo, con menor calidad paisajística. Existen también ventajas económicas, puesto que discurre por terreno bastante llano. 
En el apartado de identificación de los elementos medioambientales que se verán alterados, en lo relativo al paisaje señala que durante la fase de obras será constante el movimiento de la maquinaria y de las personas encargadas de realizar los trabajos de levantamiento de los apoyos y su respectiva aparamenta (crucetas, aisladores, etc.) donde se apoyarán los conductores; todo ello constituye un elemento alterante de la calidad visual de la zona. Durante la fase de funcionamiento, se indica que la existencia de la línea provoca impacto por la presencia física de un objeto no natural, formado por los conductores eléctricos y los apoyos, de perfil recto y coloraciones discordantes con el medio que le rodea (Figura A1.74). El impacto fundamental es ocasionado por el tendido rectilíneo, discordante con las líneas onduladas y sinuosas del relieve de fondo. La visibilidad es bastante elevada durante todo su trayecto. Teniendo en cuenta que los cultivos representan una unidad paisajística caracterizada por el escaso contraste de colores y que la zona es esencialmente llana, el impacto visual es elevado debido a su fácil percepción por parte de cualquier observador. El impacto sobre el paisaje se cuantifica como moderado a severo.
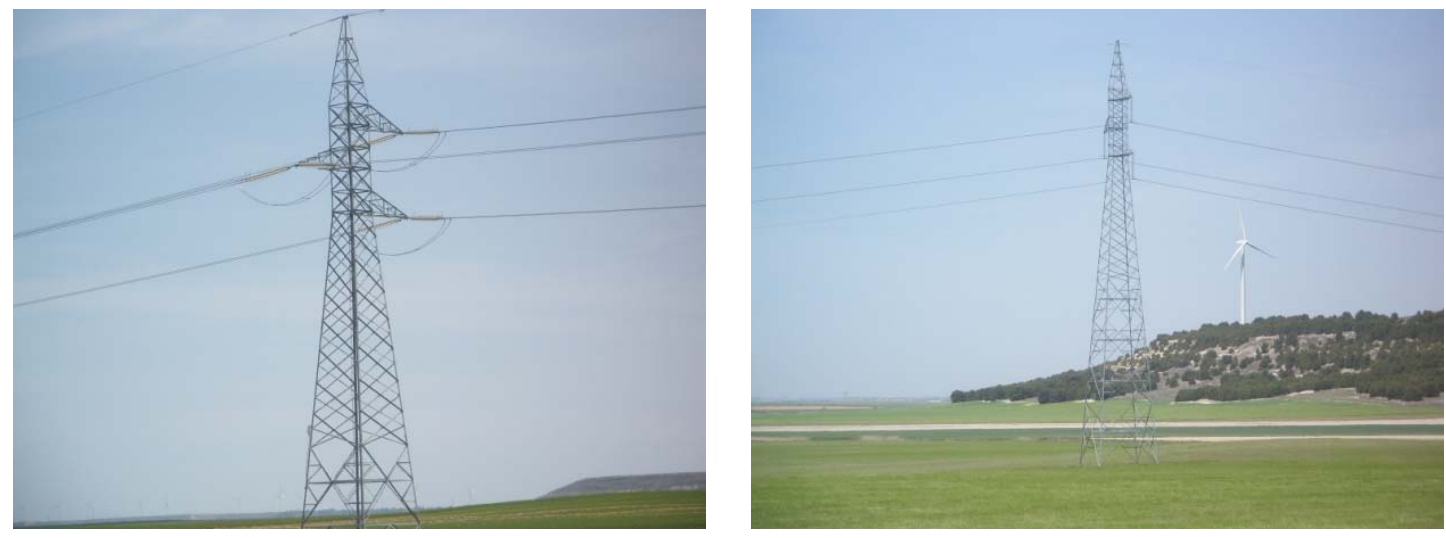

Figuras A1.74. Vista de dos apoyos de la línea eléctrica

En el apartado de medidas correctoras referentes al paisaje, tan solo se señala que la mejor medida preventiva es la elección de un buen trazado. Además existen en la zona algunas líneas de alta tensión y telefónicas, lo que hace que los impactos sean más bajos.

El Plan de Restauración contempla la siembra con herbáceas de las zonas alteradas donde la línea discurre por terrenos no agrícolas (laderas del tramo inicial, cruce con el Canal de Castilla y alguna otra zona puntual). Se estima una superficie de siembra de $13500 \mathrm{~m}^{2}$. El presupuesto de ejecución material asciende a $3780 €(0,47 \%$ del proyecto de la línea).

A1.7.2.2. Declaración de impacto ambiental, hecha pública por Resolución de 26 de noviembre de 2004, de la Consejería de Medio Ambiente (BOCyL 9/12/2004).

La Declaración informa favorablemente la alternativa 3 seleccionada en el Estudio de Impacto Ambiental y contiene una serie de medidas protectoras. En el apartado 2.f) Protección de la 
vegetación, indica que las cortas de arbolado se limitarán a los pies estrictamente necesarios para garantizar la seguridad de la línea. El apoyo no 71 deberá reubicarse para no afectar directamente a la isleta de vegetación natural en que se proyecta.

El apartado 2.g) Restauración vegetal señala que las áreas afectadas por las obras deberán ser restauradas empleando como cobertura especies herbáceas, de matorral o arbustivas adecuadas a los distintos entornos. Como base de esta implantación se utilizará, cuando así sea posible, la capa de terreno vegetal procedente de las extracciones para la cimentación. En todo caso, los restos de excavación se nivelarán evitando la formación de montones o caballones.

En el apartado 2.i) Integración paisajística, se recoge que se remodelarán convenientemente, devolviéndoles su carácter inicial, todas aquellas áreas alteradas por las obras en general y las zonas de instalación y montaje de los apoyos en particular.

\section{A1.7.2.3. Proyecto de restauración ambiental de la línea eléctrica aérea de alta tensión entre las subestaciones de transformación de Ampudia y Grijota (Palencia).}

Promotor: Energías Renovables del Duero

Autores: Jesús Roldán Muñoz (ingeniero técnico forestal) y Asier Saiz Rojo (ingeniero de montes)

Director de obra: Jesús Roldán Muñoz

Fecha redacción proyecto: septiembre 2009

Informe final de las obras: julio 2012

Memoria valorada de la reposición de marras: octubre 2014

El proyecto se localiza en los términos municipales de Grijota, Husillos, Villaumbrales, Villamartín de Campos, Pedraza de Campos y Ampudia, coincidiendo con la zona de transición de los páramos calizos y Tierra de Campos, aunque la mayor parte de la infraestructura se ubica en esta comarca.

El objetivo principal del proyecto es conseguir la restauración paisajística, natural y social del medio afectado por las obras de construcción de la línea eléctrica, además de integrar del mejor modo posible el conjunto de las instalaciones en el medio natural en que se enmarcan. Otros objetivos más específicos son la restauración del ecosistema natural del entorno de la línea eléctrica o el hecho de favorecer las especies faunísticas de la zona, aportándolas refugio y alimento. 


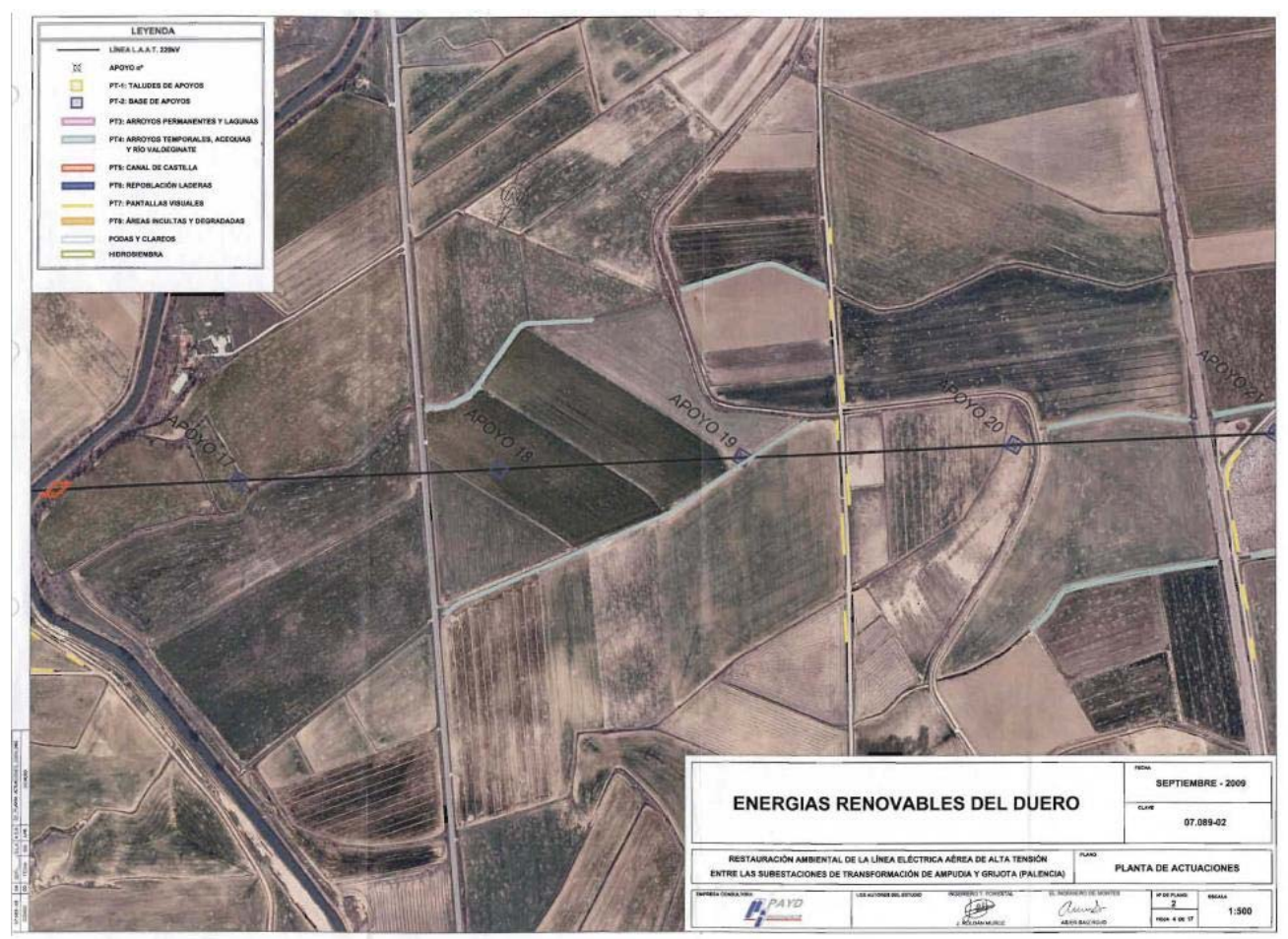

Figura A1.75. Ejemplo de plano de actuaciones, en este caso en arroyos y caminos

Los terrenos sobre los que discurre la infraestructura eléctrica son llanos o de ligeras pendientes (más acusadas en su tramo inicial de páramos), estando ocupados por cultivos herbáceos de secano, salvo una pequeña proporción de cultivos de regadío en las inmediaciones de Villamartín de Campos y Villaumbrales.

Las actuaciones de restauración se han ceñido a una franja de $200 \mathrm{~m}$ a cada lado del eje de la línea eléctrica, ámbito considerado como aquel donde el impacto ambiental -paisajístico en particular- es más elevado. A continuación se describen de forma sucinta:

\section{1.- Restauración de taludes.}

Esta actuación se refiere a la adecuación de los taludes generados como consecuencia de la instalación de alguno de los apoyos de la línea eléctrica, fundamentalmente donde atraviesa zonas de mayor pendiente. Sobre estos taludes se propone la implantación de una cubierta arbustiva con especies vegetales autóctonas.

Para esta zona alterada que ocupa 0,2210 ha se define la unidad de plantación PT-1, con apertura manual de hoyos de 60×60×60 cm, estructura areal, marco de $2 \times 2 \mathrm{~m}$, densidad 2500 pies/ha y composición de especies siguiente:

- Rosal silvestre (Rosa canina)

- Majuelo (Crataegus monogyna)

- Retama (Cytisus scoparius)

- Romero (Rosmarinus officinalis)

- Mejorana (Thymus mastichina) 
El tamaño medio de la planta es de $40 \mathrm{~cm}$, en alvéolo forestal o contenedor. El número total es de 553 plantas.

\section{2.- Restauración de la base de los apoyos}

Esta zona es la que queda bajo los apoyos de la línea eléctrica y su entorno más inmediato, que no son aprovechables para otro uso, en especial el agrícola. La actuación consiste en la plantación de especies arbustivas y subarbustivas, procurando distribuir la planta de forma que el crecimiento de la vegetación no dificulte las posibles labores de mantenimiento de la línea eléctrica (Figura A1.76). Con ello se pretende ocultar las cimentaciones de los apoyos, enmascarar la base de las estructuras metálicas y ofrecer un refugio a las especies silvestres existentes en la entorno.

En estas áreas que ocupan 5,2060 ha se define la unidad de plantación PT-2, con apertura manual de hoyo de 60×60×60 cm, estructura areal, marco $3 \times 3 \mathrm{~m}$, densidad 1100 pies/ha y siguiente composición:

- Rosal silvestre (Rosa canina)

- Romero (Rosmarinus officinalis)

- Mejorana (Thymus mastichina)

- Espliego (Lavandula latifolia)

- Abrótano (Santolina chamaecyparissus)

El tamaño medio de la planta es de $30 \mathrm{~cm}$, en contenedor o alvéolo forestal. El número total es de 5727 plantas. En general, esta actuación se ha llevado a cabo sin problemas.

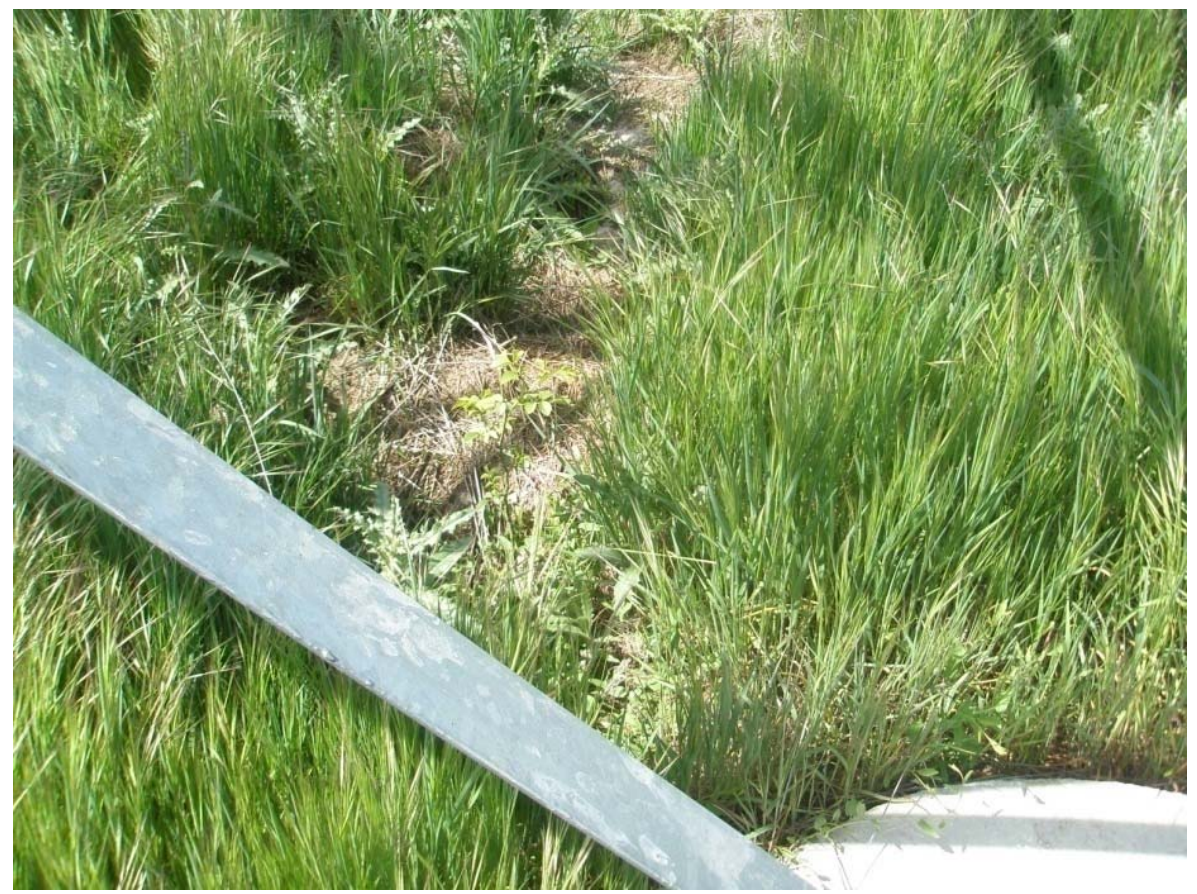

Figura A1.76. Pequeño rosal silvestre (centro de la imagen) en la base de un apoyo. 


\section{3.- Restauración de arroyos permanentes y lagunas}

En este caso se trata de zonas húmedas y arroyos interceptados o situados próximos a la línea eléctrica que, aunque no afectados de forma directa por las obras, se pueden considerar como medidas compensatorias por el impacto paisajístico y sobre la avifauna de esta infraestructura lineal (Figura A1.75). Se plantea una restauración vegetal con especies riparias, que fijen sus márgenes y reduzcan los fenómenos erosivos.

En estas zonas se define la unidad de plantación PT-3 en una superficie de 0,749 ha, con apertura mecanizada de un hoyo de 60×60×60 cm con retroexcavadora, estructura areal, marco $3 \times 3 \mathrm{~m}$, densidad 1100 pies/ha y siguiente composición específica:

- Chopo (Populus nigra)

- Endrino (Prunus spinosa)

- Sauce blanco (Salix alba)

- Cornejo (Cornus sanguínea)

- Madreselva (Lonicera periclymenum)

El tamaño de la planta varía de 40 a 300 cm y su forma de presentación puede ser en contenedor o raíz desnuda. El número total es de 824 plantas.

4.- Restauración de arroyos temporales, acequias y río Valdeginate

Las zonas y objetivos son similares a los de la actuación anterior. Se establecen plantaciones longitudinales con árboles y arbustos propios de ribera. En un tramo de $200 \mathrm{~m}$ del río Valdeginate -en la zona de cruce con la línea eléctrica- se plantean como medidas compensatorias por la afección presente o futura de la misma, la estabilización de taludes mediante hidrosiembra, plantaciones con especies leñosas y tratamientos selvícolas (podas y clareos) en las masas arbóreas que aparecen en los taludes (Figura A1.77).
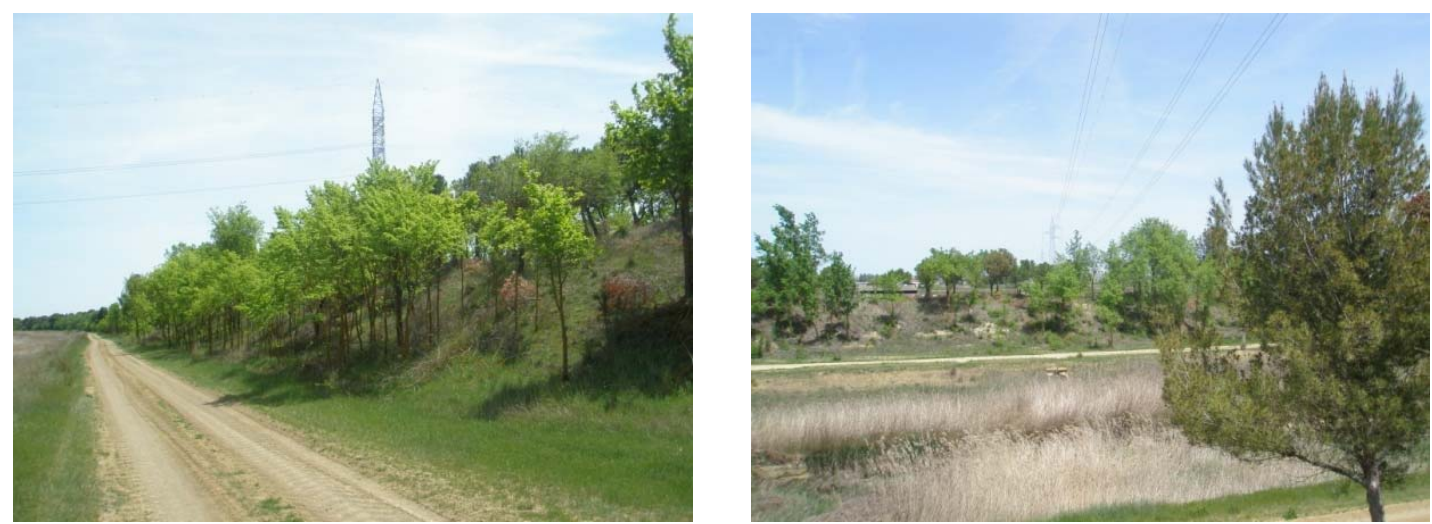

Figura A1.77. Actuaciones en la intersección con el río Valdeginate

Se define la unidad de plantación PT-4 en una superficie de 3,560 ha, con apertura mecanizada de hoyos de 60×60×60 cm con retroexcavadora, estructura areal, marco $3 \times 3 \mathrm{~m}$, densidad 1100 pies/ha y siguiente composición específica: 
- Cerezo (Prunus avium)

- Endrino (Prunus spinosa)

- Fresno (Fraxinus angustifolia)

- Olmo (Ulmus minor)

- Saúco (Sambucus nigra)

- Zarza (Rubus ulmifolius)

El tamaño medio de la planta es de 60-80 cm y la forma de presentación, contenedor o alvéolo forestal. El número total es de 3916 plantas.

En la práctica se han tratado de forma conjunta estas dos últimas actuaciones, que básicamente se han desarrollado en varios tramos de arroyos temporales (Figura A1.78). En la ejecución, se ha aumentado la longitud de plantación proyectada, con objeto de compensar la disminución de plantaciones de pantallas vegetales en bordes de caminos.

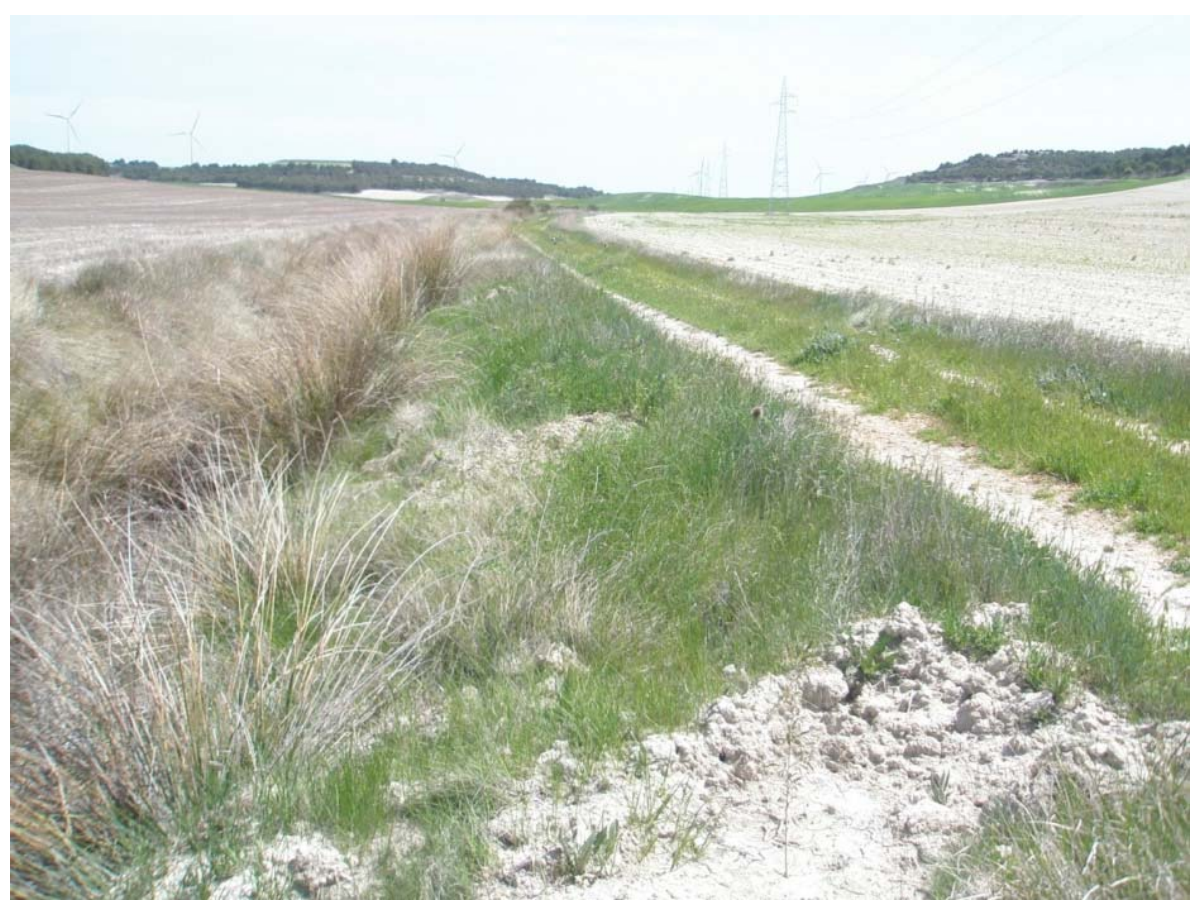

Figura A1.78. Plantación de árboles en margen del arroyo del Salón, que discurre paralelo a la línea en buena parte de su trazado

5.- Restauración de la intersección de la LAT con el canal de Castilla.

Con objeto de restaurar las márgenes del Canal de Castilla en los dos puntos de intersección con la línea eléctrica, donde se ha procedido a la corta de arbolado para su ejecución, se propone la plantación de especies arbustivas bajo el tendido eléctrico.

Se define la unidad de plantación PT-5 que abarca a una superficie de 0,0600 ha, con apertura mecanizada de hoyos de $60 \times 60 \times 60 \mathrm{~cm}$ con retroexcavadora, estructura areal, marco $3 \times 3 \mathrm{~m}$, densidad 1100 pies/ha y siguientes especies: 
- Endrino (Prunus spinosa)

- Saúco (Sambucus nigra)

- Zarza (Rubus ulmifolius)

- Retama (Cytisus scoparius)

El tamaño medio de la planta es de $60 \mathrm{~cm}$ y la forma de presentación, contenedor o alvéolo forestal. El número total es de 66 plantas.

Esta actuación no se ha realizado, dado que se constató una rápida regeneración de la vegetación arbustiva posteriormente a la tala de arbolado.

6.- Repoblación de laderas

En esta actuación se propone la repoblación de alguna de las laderas que se encuentran mayoritariamente al inicio del trazado de la línea eléctrica, en la zona de transición de Tierra de Campos con el páramo calizo (Figura A1.79). Estas laderas se encuentran sin vegetación y presentan fenómenos erosivos importantes en algunos casos, por lo que se conseguiría una mejora del ecosistema que, a su vez, contribuiría a integrar paisajísticamente la línea.

Estos lugares serán restaurados mediante la implantación de una cubierta vegetal con las especies que fueron utilizadas en la repoblación forestal de otras laderas próximas.

Se define la unidad de plantación PT-6 que abarca a una superficie de 3,6500 ha, con apertura mecanizada de hoyos de 60×60×60 cm con retroexcavadora, estructura areal, marco $3 \times 3 \mathrm{~m}$, densidad 1100 pies/ha y siguiente composición específica:

- Pino piñonero (Pinus pinea)

- Pino carrasco (Pinus halepensis)

- Ciprés de Arizona (Cupressus arizonica)

El tamaño medio de la planta es de $25 \mathrm{~cm}$, en alvéolo forestal. El número total es de 4015 plantas.

Esta actuación se ha llevado a cabo sin problemas, ya que se realizaba en propiedad municipal y se contaba con su disponibilidad; en realidad se trata de una repoblación forestal clásica, continuación de otras cercanas. La superficie proyectada se ha ampliado ligeramente para compensar la ausencia de plantaciones de otras unidades. 


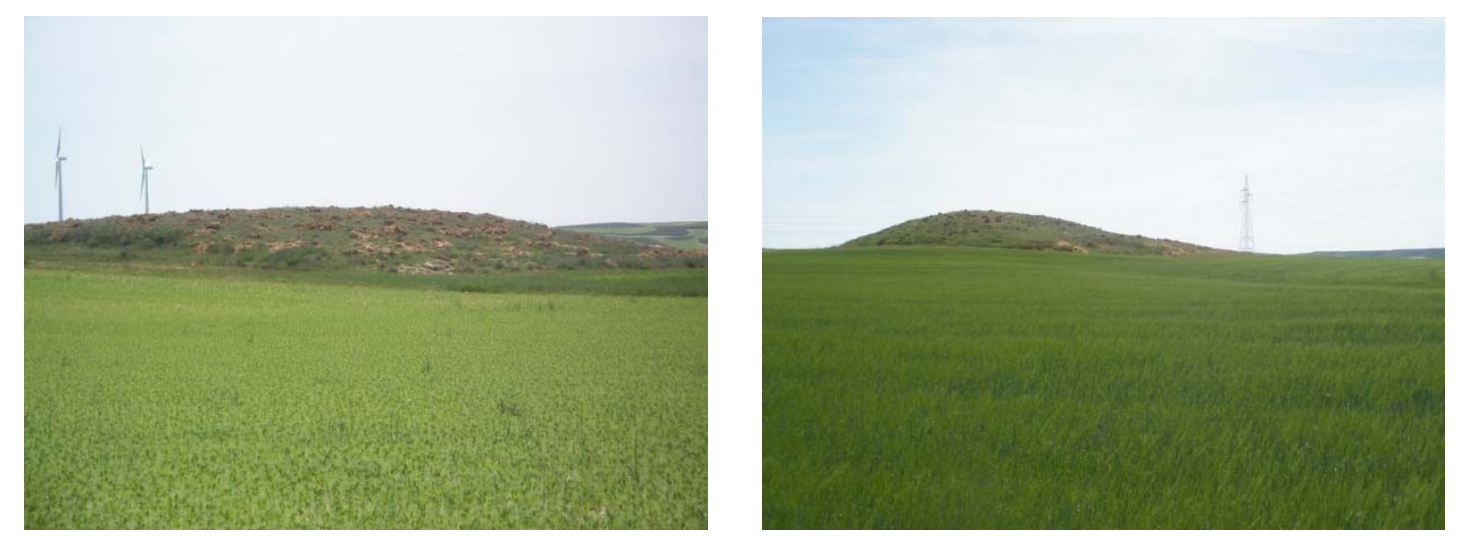

Figura A1.79. Pequeños montículos cercanos a la traza repoblados.

\section{7.- Plantación de pantallas visuales}

Con objeto de ocultar parcialmente y romper la linealidad de la línea eléctrica, se propone realizar plantaciones en los márgenes de caminos que discurren próximos a esta infraestructura, en aquellos que dispongan de espacio suficiente y donde no se impida el tráfico de la maquinaria agrícola (Figura A1.80).

Se define la unidad de plantación PT-7 en 11,970 km, con apertura mecanizada de hoyos de 60×60×60 cm con retroexcavadora, estructura lineal, marco $1 \mathrm{ud} / 10 \mathrm{~m}$ para árboles y $1 \mathrm{ud} / 5 \mathrm{~m}$ para arbustos; densidad de 100 pies/km para árboles y 200 pies/km para arbustos y siguiente composición:

- Cerezo silvestre (Prunus avium)

- Almendro (Prunus dulcis)

- Olmo (Ulmus minor)

- Rosal silvestre (Rosa canina)

- Romero (Rosmarinus officinalis)

- Espliego (Lavandula latifolia)

- Retama (Cytisus scoparius)

El total de plantas se estima en 1796 ejemplares.

Esta es una de las actuaciones que han sido más difíciles de llevar a cabo, por la negativa de varios Ayuntamientos y de agricultores de la zona, al considerar que perjudicaría el tránsito de los vehículos agrarios por los caminos. Durante la ejecución del proyecto se modificaron algunas ubicaciones (en ciertos casos, más alejadas de la línea) y se compensó la ausencia de estas plantaciones por otras en diferentes unidades. 

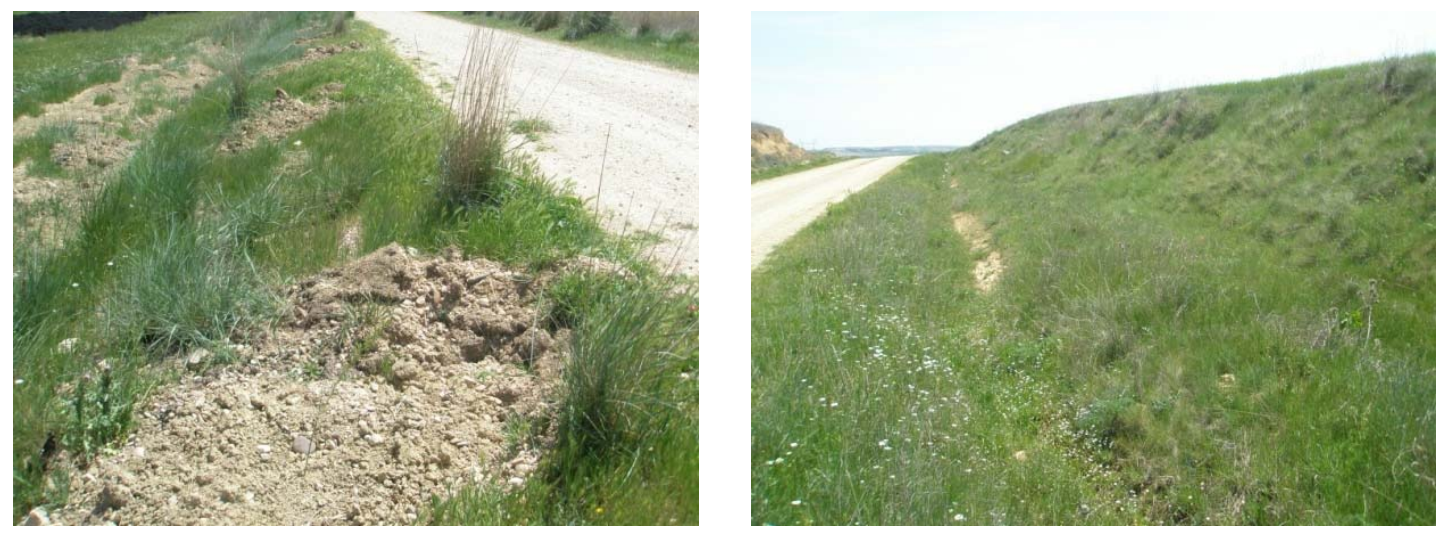

Figura A1.80. Plantaciones realizadas en margen (izquierda) y talud (derecha) de camino.

\section{8.- Plantación en áreas incultas y degradadas}

Se trata de espacios de dimensiones relativamente reducidas que se han visto afectados por la ejecución de las obras o bien áreas incultas próximas a la línea eléctrica. Sobre ellos se realizará una revegetación utilizando especies propias de la zona.

Se define la unidad de plantación PT-8 en una superficie de 0,1400 ha, con apertura mecanizada

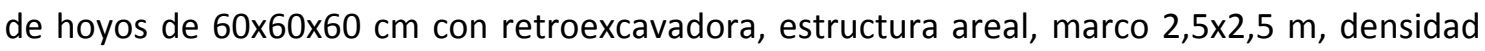
1600 pies/ha y siguiente composición específica:

- Rosal silvestre (Rosa canina)

- Romero (Rosmarinus officinalis)

- Retama (Cytisus scoparius)

- Cerezo (Prunus avium)

- Olmo (Ulmus minor)

- Almendro (Prunus dulcis)

El tamaño medio de las plantas será de $50 \mathrm{~cm}$ para los arbustos y $90 \mathrm{~cm}$ para los árboles, y la forma de presentación, en contenedor o alvéolo forestal. El número total es de 224 plantas.

En la ejecución de esta unidad también ha habido cierta flexibilidad, modificando las ubicaciones inicialmente proyectadas por otras más idóneas de igual naturaleza, aun cuando en algún caso se superó la distancia de $200 \mathrm{~m}$ a la traza de la línea eléctrica.

El presupuesto de ejecución material del Proyecto de restauración asciende a $38773 €$. Esta cantidad supone un 4,85\% del presupuesto del proyecto de la línea eléctrica. El número total de árboles y arbustos a plantar es de 17101 ejemplares. El resumen del presupuesto es el siguiente (Tabla A1.14): 
Tabla A1.14. Presupuesto ejecución material proyecto restauración

\begin{tabular}{lcc}
\multicolumn{1}{c}{ CAPÍTULO } & EUROS & $\%$ \\
\hline Plantaciones & 32258 & 90,23 \\
\hline Hidrosiembra & 1677 & 4,33 \\
\hline Tratamientos culturales & 398 & 1,03 \\
\hline Riegos & 840 & 2,17 \\
\hline Limpieza de obras e imprevistos & 600 & 1,55 \\
\hline Total ejecución material & 38773 & \\
\hline
\end{tabular}

\section{A1.7.3. Ejecución}

\section{A1.7.3.1. Seguimiento de la obra.}

El informe final de las obras justifica la correcta ejecución del Proyecto de restauración. Se trata de un proyecto complejo que ha debido llevarse a cabo con cierta flexibilidad -sobre todo en cuanto a zonas de actuación (Figura A1.81)- pero manteniendo los objetivos fundamentales, de recuperación ambiental de zonas alteradas por la línea eléctrica e integración paisajística de la misma. De hecho, en los albaranes de planta incluidos en el informe se detalla un listado con un total de 19824 ejemplares (2723 más que las proyectadas), de las que 13007 son árboles y 6817 son arbustos. Las especies empleadas son prácticamente las mismas a las proyectadas, aun cuando hay pequeñas diferencias en cuanto a su distribución espacial. 


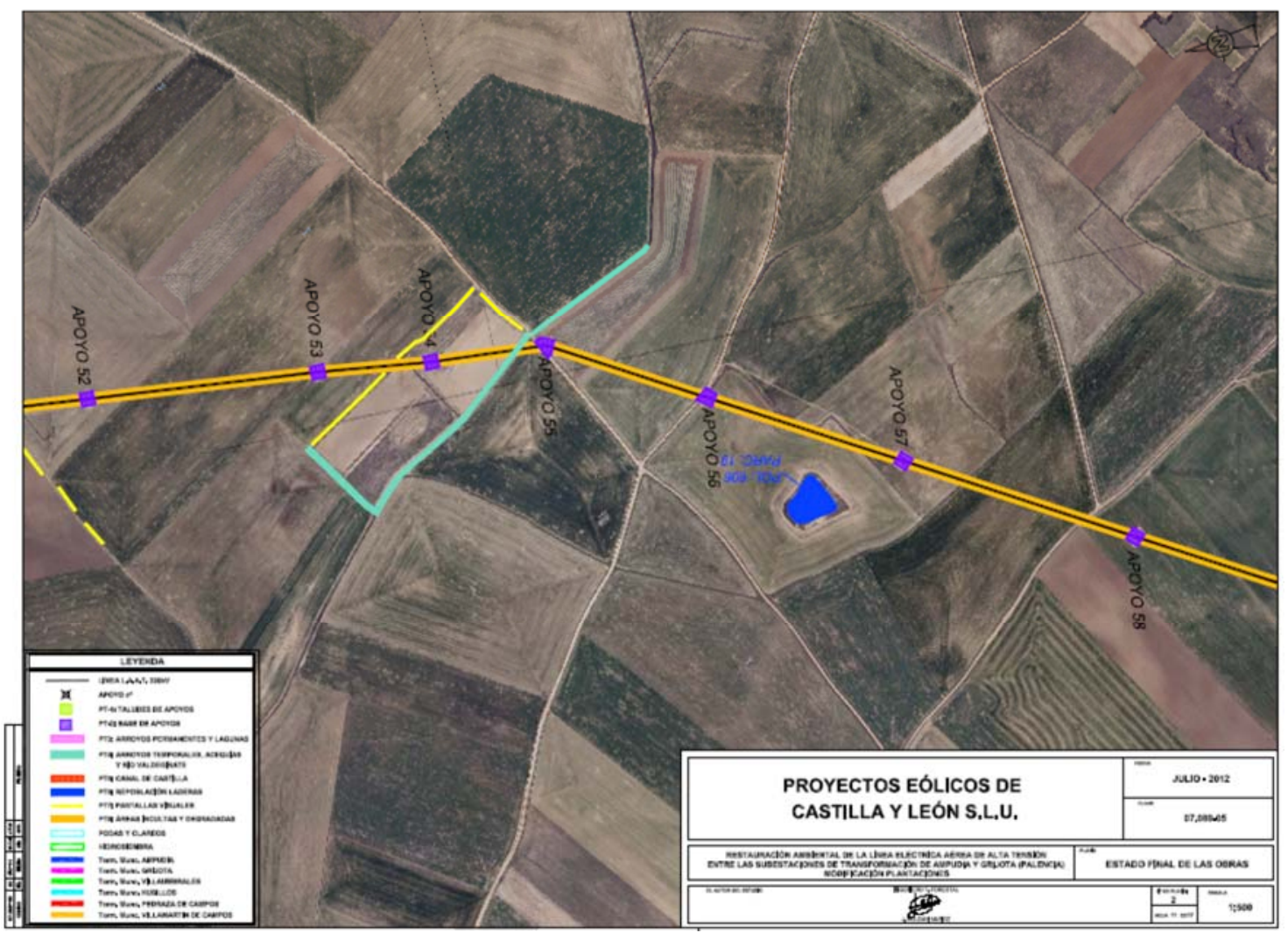

Figura A1.81. Ejemplo de un plano del informe final de las obras, que incluye actuaciones de restauración.

Tras un requerimiento del órgano ambiental, el promotor realizó un muestreo de las marras producidas tres años después de la plantación, que resultaron cuantiosas (Tabla A1.15).

\begin{tabular}{lc}
$\begin{array}{l}\text { Tabla A1.15. Porcentaje de marras en las plantaciones vegetales. } \\
\text { Zona de plantación }\end{array}$ & \% de marras \\
\hline Repoblaciones en laderas & 51 \\
\hline Arroyos temporales y acequias & 87 \\
\hline Pantallas visuales & 93 \\
\hline Áreas incultas y degradadas & 53 \\
\hline Arroyos permanentes y lagunas & $<10$ \\
\hline
\end{tabular}

Las causas que se estiman en estos resultados deficientes son el comportamiento de agricultores y propietarios de las parcelas colindantes, la quema de cunetas y arroyos, los daños por labores agrícolas, otros daños por ganado ovino y conejos y el efecto de la vegetación competidora.

En la Memoria valorada de la reposición de marras, de octubre de 2014, se justifica que esta se realice en aquellas zonas donde sea mayor la viabilidad de las plantaciones. En primer lugar se determinó la nueva plantación en 2,4 ha de una ladera deforestada próxima a la línea eléctrica, 
en el término municipal de Ampudia. Se proyecta la colocación de protectores y la realización de riegos. La especie elegida es el pino piñonero, que es la que ha contado con mayor éxito de arraigo en la plantación original. Se diseñó una densidad de 625 pies/ha (4 4 m), por lo que se plantaron 1500 árboles. En segundo lugar, la reposición de marras en laderas, con la plantación de 1465 pies de pino piñonero. En tercer lugar, se contempló la plantación de 100 retamas y 184 almendros en las zonas definidas como pantallas visuales. El presupuesto de ejecución material asciende a $10700 €$. La plantación se realizó en noviembre de 2014; la preparación del terreno se llevó a cabo mediante una retroaraña, que dejó la tierra movida en el hoyo, y posteriormente tuvo lugar la plantación propiamente dicha (Figura A1.82).

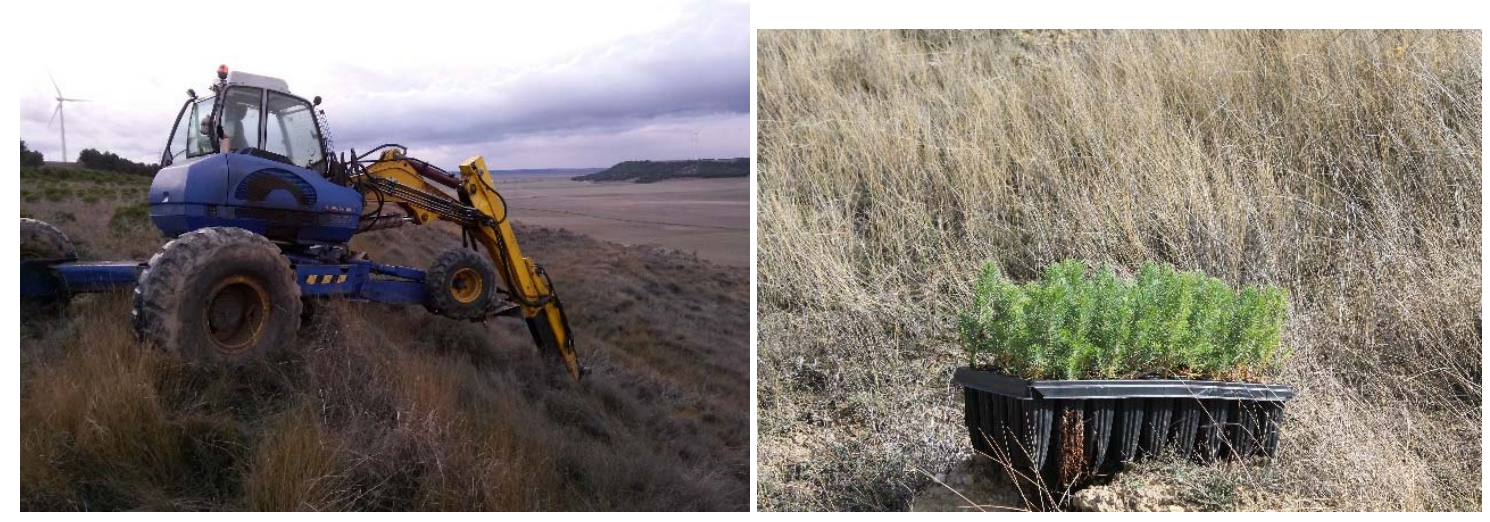

Figura A1.82. A la izquierda, vista de la retroaraña realizando hoyos. A la derecha, pinos piñoneros en envase forestal (Fotografías de Jesús Roldán).

\section{A1.7.3.2. Conclusiones relativas al seguimiento ambiental.}

Se pone de manifiesto que la presencia física de la línea eléctrica provoca un impacto paisajístico de elevada magnitud. La envergadura de los apoyos provoca que sean visibles desde una amplia cuenca territorial, sin existir elementos de ocultación (geomorfológicos, de vegetación, etc.).

En este caso, desde el punto de vista del paisaje, el análisis de varias alternativas no ha supuesto una mejora sustancial del proyecto, dado que el territorio atravesado posee unas características homogéneas. No obstante, se estima que es acertada la elección de la alternativa de menor longitud, que por otra parte, conlleva el mínimo impacto paisajístico; así como las pequeñas correcciones efectuadas para que los apoyos no afecten a la escasa vegetación forestal presente en la zona.

Se juzga acertado no emplear tonos o colores diferentes a los del acabado convencional de los apoyos eléctricos (galvanizado metálico claro). El resultado es homogéneo con otras infraestructuras eléctricas y existe escaso contraste con el fondo escénico.

El hecho de que la inmensa mayoría de los apoyos se sitúen en suelos agrícolas supone que sea rápida la restauración del entorno y, por consiguiente, mínima la superficie alterada. La integración de este elemento artificial es, por tanto, mayor. Al tratarse de terrenos llanos, tampoco se generan taludes. 
La gestión de la tierra vegetal ha sido, en general, correcta. Se ha distribuido en el entorno de los apoyos y ha contribuido a la rápida revegetación de su entorno.

Se observa que ha habido una correcta gestión de residuos y restos de obra en la zona afectada por el proyecto.

La elaboración y ejecución del Proyecto de restauración ambiental de la línea eléctrica es una medida muy acertada para poder llevar a la práctica actuaciones más detalladas de recuperación de las zonas alteradas, que no se habrían desarrollado en un proyecto de construcción convencional de una línea eléctrica. De hecho, en este caso ha resultado fundamental la gestión del órgano ambiental de la Administración, en el marco del cumplimiento del condicionado de la declaración de impacto ambiental. Recoge numerosas y variadas actuaciones (sobre todo de revegetación) en el entorno del trazado de la línea, que es el mejor modo de favorecer su integración paisajística. Se trata de un proyecto muy novedoso del que se pueden extraer interesantes conclusiones prácticas.

El presupuesto del Proyecto de restauración ambiental representa un 4,85\% respecto del correspondiente al proyecto de construcción de la línea eléctrica. Es una cantidad razonable, teniendo en cuenta los impactos generados por esta infraestructura lineal.

Se constata la dificultad de ejecutar el Proyecto de restauración ambiental con el grado de detalle en que ha sido redactado. Se trata de actuar sobre muchos terrenos de propiedad diversa, circundados por parcelas agrícolas cuyos titulares no ven, en general, con buenos ojos las plantaciones vegetales. En este sentido, la gestión municipal resulta de gran trascendencia, ya que buena parte de los terrenos susceptibles de restauración son municipales: en el caso de Ayuntamientos sensibles a los temas medioambientales, las facilidades son mayores (Ampudia, por ejemplo); el resto pusieron en general más énfasis en los problemas que en los beneficios. Aun tratándose de inversiones gratuitas en el municipio (el promotor es particular), las actuaciones se perciben con gran susceptibilidad, llegándose en algún caso al extremo de exigir contraprestaciones económicas.

Resulta de vital importancia la figura del director de obra, que en este caso coincide con el autor del proyecto. Es conocedor de las actuaciones propuestas y del objeto fundamental del proyecto: mejorar la integración ambiental de esta infraestructura lineal. Ha de tratar y consensuar con muchos propietarios de terrenos y debe explicar la naturaleza del proyecto para facilitar su ejecución. Es fundamental que exista flexibilidad en cuanto a la disponibilidad de los terrenos, siempre que las actuaciones se localicen en un entorno razonable de la traza; de hecho, así ha sucedido en este proyecto y es lo que ha permitido llevarlo a cabo en unas condiciones más que razonables (se ha mantenido el número total de ejemplares plantados).

La mayor dificultad del Proyecto de restauración ambiental se ha encontrado en la realización de pantallas visuales en los márgenes de caminos, debido a la posición contraria del sector agrícola al considerar que interferiría el tráfico agrícola. Es una lástima, teniendo en cuenta que la red de caminos del entorno de la traza de la línea tiene una densidad muy alta y podría permitir localizar zonas públicas para realizar plantaciones cercanas a los apoyos. Aunque puede ser comprensible que una plantación masiva de árboles en los márgenes de los arroyos ocasione dificultades en el tránsito agrario, la realidad es que siempre existen ubicaciones puntuales 
(pequeños desmontes, terraplenes, sobreanchos, enlaces, etc.) donde estas actuaciones se podrían llevar a cabo. Una posible solución habría podido ser plantear exclusivamente la plantación de arbustos en el margen del camino donde fuese más factible.

Las actuaciones planteadas en los márgenes de los arroyos han tenido mejores resultados, teniendo en cuenta que no ha habido grandes impedimentos por la Confederación Hidrográfica del Duero y los posibles problemas se han solucionado con flexibilidad. Estas actuaciones son muy positivas dada la importante longitud de la red de arroyos y desagües en la zona, además del alto grado de humedad de los terrenos, que permite facilitar el arraigo y desarrollo de la vegetación. En cambio, han existido problemas puntuales por las quemas realizadas por los agricultores para combatir la proliferación de topillos. 


\section{A1.8. Parque eólico El Castre, en los términos municipales de Torremormojón y Pedraza de Campos (Palencia).}

\section{A1.8.1. Proyecto}

A1.8.1.1. Anteproyecto del parque eólico El Castre, de $50 \mathrm{MW}$.

Promotor: ELECDEY

Autor: Ignacio Lapuente Bujía (ingeniero industrial del ICAI)

Fecha: mayo 2002

Este documento plantea la construcción de un parque eólico de 40 aerogeneradores de 1250 $\mathrm{kW}$ de potencia unitaria, por lo que su potencia total será de $50 \mathrm{MW}$. Se sitúa en los términos municipales de Torremormojón y Pedraza de Campos, entre las cotas 830 y 860 msnm (Figura A1.83).

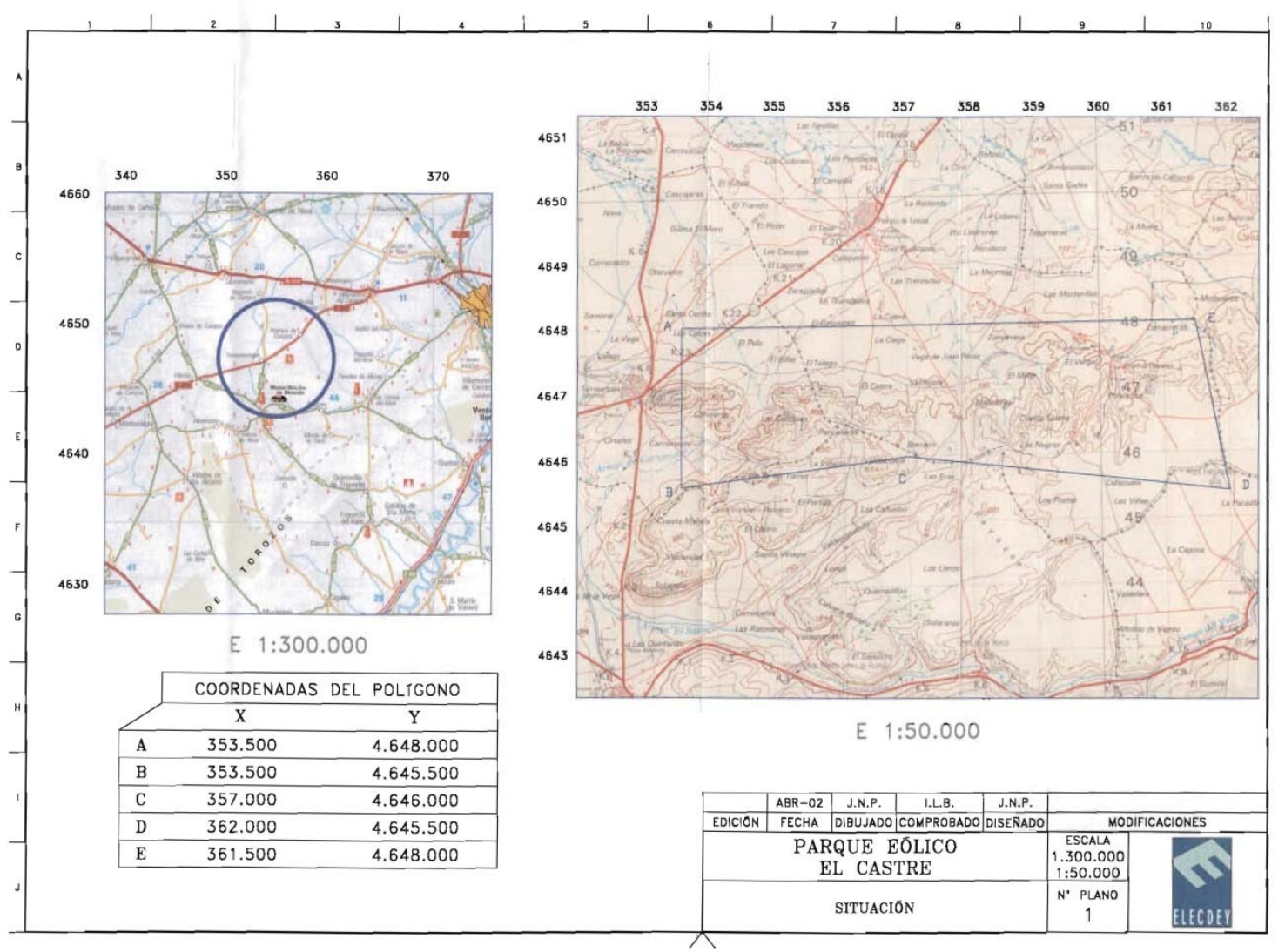

Figura A1.83. Plano de situación del anteproyecto.

Se contemplan dos alternativas denominadas A y B similares en características y ubicación. La alternativa A supone la instalación de 62 aerogeneradores Made $800 \mathrm{~kW}$, mientras que la alternativa B plantea la instalación de 40 aerogeneradores Dewind 1250 kW. Ambas son más o 
menos coincidentes en la construcción de un edificio de control, subestación eléctrica de 20/132 kV y la conexión entre aerogeneradores mediante líneas subterráneas.

Del análisis efectuado teniendo en cuenta el menor impacto visual, la menor ocupación de suelo, la conservación cultural por la presencia de restos arqueológicos y la optimización energética, se selecciona la alternativa $\mathrm{B}$.

El tipo de aerogenerador es tripala de rotor horizontal. El parque eólico se distribuye en cinco formaciones en los lugares conocidos como El Castre, Las Cárcavas, Pan Caliente, Majadero, Berraco, Las Largas, Las Negras, Cabezuela, Cuesta Solana y Villarramiro. Las alineaciones se asientan en las zonas más altas dispuestas para captar adecuadamente los vientos energéticamente dominantes, de direcciones WSW y NE. Para ello, se han mantenido separaciones no inferiores a los $120 \mathrm{~m}$ entre aerogeneradores.

La obra civil necesaria para la construcción, puesta en marcha y explotación del parque es la siguiente:

- Caminos de acceso y de servicio a cada uno de los aerogeneradores. En las vías de acceso, la anchura máxima es de $5 \mathrm{~m}$ y el radio mínimo de $30 \mathrm{~m}$; se colocará una capa de $20 \mathrm{~cm}$ de zahorra artificial compactada. En los caminos de servicio (interiores al parque), la anchura será de 4,5 m, la pendiente máxima del $11 \%$, el drenaje se efectuará mediante cunetas y obras de paso de hormigón de $40 \mathrm{~cm}$ de diámetro, los desmontes tendrán una inclinación $1 \mathrm{H} / 1 \mathrm{~V}$ y los terraplenes $3 \mathrm{H} / 2 \mathrm{~V}$. La longitud total de caminos de servicio será de $14,7 \mathrm{~km}$, de los que 4,6 km son existentes.

- Plataformas de montaje. Para cada aerogenerador se proyecta una pequeña explanación que permita un mejor acceso para realizar la excavación de la zapata, así como el estacionamiento de la grúa de montaje de la torre. Las plataformas tienen forma rectangular y unas dimensiones de $35 \times 20 \mathrm{~m}$.

- Cimentaciones. Se opta por una losa octogonal de 5,68 m de lado construida en hormigón armado y dispuesta 2,6 $\mathrm{m}$ bajo el nivel del suelo. En la losa queda embebida la virola de cimentación, terminada en su extremo superior con una brida dispuesta para ser atornillada a la primera sección de la torre. El acceso de los cables al interior de la torre se realiza por tubos de PVC enterrados en peana de hormigón.

- Torres de los aerogeneradores. Es una torre metálica troncocónica, de $60 \mathrm{~m}$ de altura total, formada por tres secciones terminadas en bridas de acero preparadas para ser unidas mediante tornillos. Contiene pernos de alta resistencia, puerta de acceso, tres plataformas de acero intermedias de seguridad y descanso, escalera de acceso a la puerta, escalera metálica para subida a las distintas plataformas y góndola, elementos metálicos necesarios, alumbrado de emergencia y cuadro de baja tensión situado en el interior de la góndola.

- Edificio de control. Se sitúa en la plataforma de Cuesta Solana. El edificio se proyecta para sobresalir lo menos posible en el paisaje, utilizando las tipologías arquitectónicas de la zona. Sus dimensiones exteriores en planta son de $24 \times 11 \mathrm{~m}$ y la altura máxima de 4,5 m (Figura A1.84). Se compone de cinco dependencias: sala de control y oficina, almacén, zona de servicios, aula de la naturaleza y sala de reuniones. La estructura del edificio será mayoritariamente de muros portantes de bloque de hormigón de $20 \mathrm{~cm}$ de 
espesor. Las cubiertas serán de teja árabe. El acabado exterior de los bloques de hormigón será del tipo "Split" rugoso en color blanco para dar el aspecto de encalado.

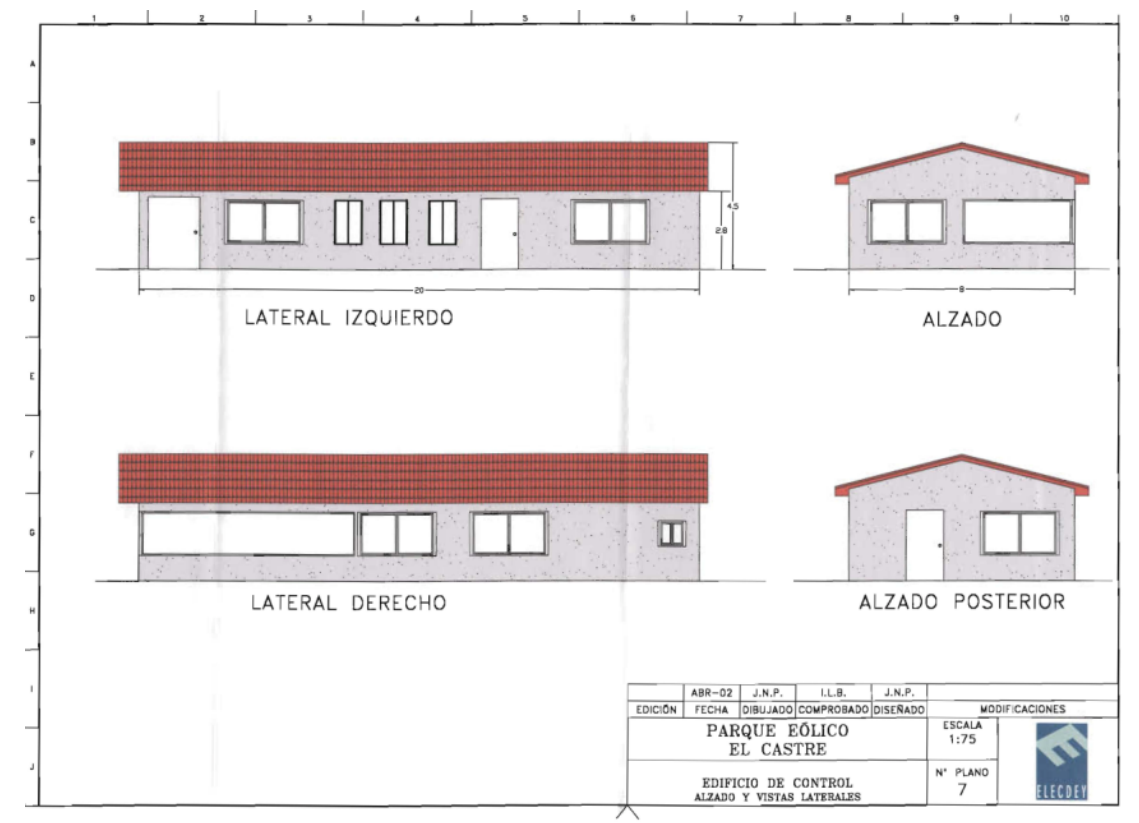

Figura A1.84. Plano del edificio de control incluido en el anteproyecto.

- Subestación eléctrica. Se localiza en la zona denominada como Cuesta Solana, próxima al edificio de control y ocupa una superficie rectangular de 29,5 m x $14 \mathrm{~m}$ a la intemperie. Todo el recinto estará protegido por un muro de una altura de $2 \mathrm{~m}$, con el fin de reducir en lo posible el impacto visual que ocasiona la aparamenta de la subestación (Figura A1.85). El muro se ejecutará en hormigón, enfoscado y pintado en blanco, coronado por una cubierta de tejas.

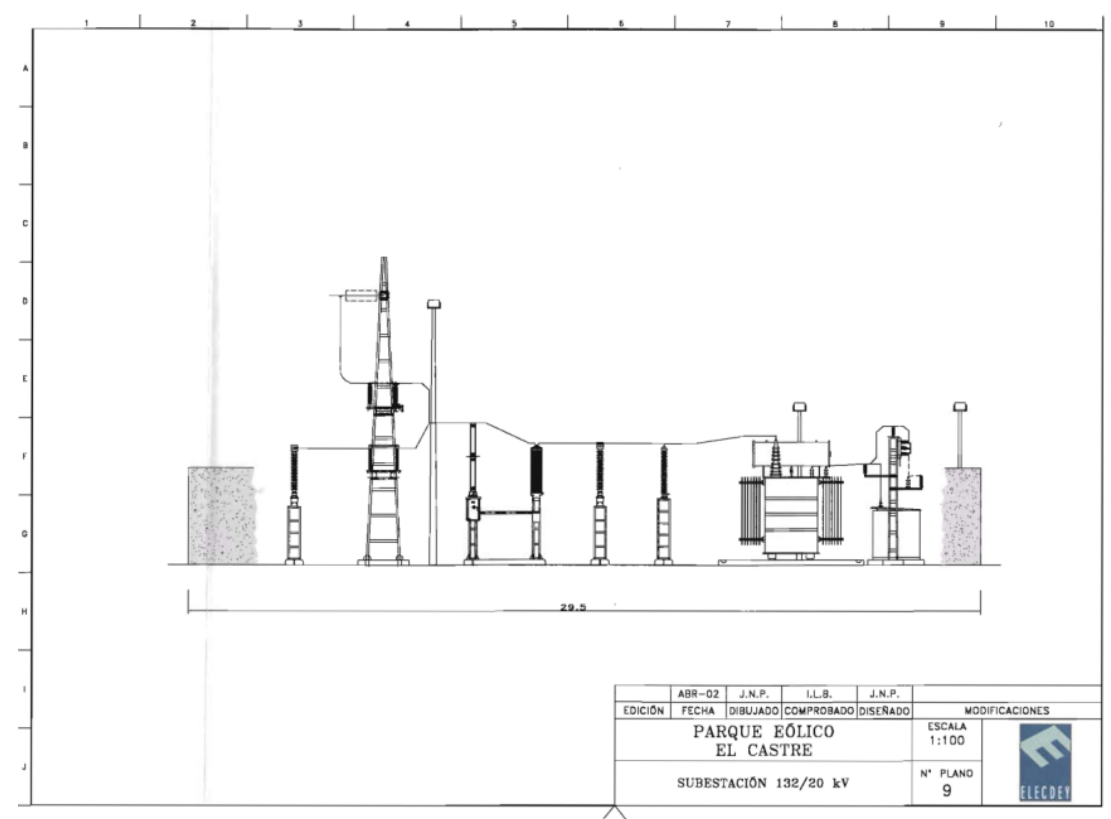

Figura A1.85. Plano de alzado de la subestación eléctrica. 
- Zanjas. Estas unen los centros de transformación ubicados en los aerogeneradores con la caseta de celdas situada en la subestación. El trazado será paralelo a los caminos de servicio. Las zanjas se ejecutarán verticales hasta una profundidad mínima de 1,2 $\mathrm{m}$ y entre 0,60 y $0,90 \mathrm{~m}$ de anchura. Los cables se protegerán con sendas capas de arena y otra de ladrillo. La longitud total de zanja es de $16,2 \mathrm{~km}$.

Las instalaciones electromecánicas son las siguientes:

- Aerogenerador. El diámetro del rotor es de $64 \mathrm{~m}$. Las palas se caracterizan por un perfil optimizado aerodinámica y acústicamente. Consta además de sistema de cambio de paso (que adapta su orientación a las condiciones del viento), multiplicador, generador (que puede producir energía a partir de $2,5 \mathrm{~m} / \mathrm{s}$ de velocidad mínima del viento), sistema de frenos, inversor, góndola, sistema de orientación, sistema hidráulico, protección contra descargas eléctricas y cuadros de control y protecciones eléctricas.

- Conexión generadores - centro de transformación.

- Centros de transformación 0,69/20 kV. Se instalan en su totalidad en el interior de la torre de cada aerogenerador.

- Conexión C.T. 0,69/20 kV con la subestación, mediante línea subterránea. Sobre la zanja totalmente cubierta se instalarán hitos que indiquen el trazado de la misma.

- Conexión edificio de control con subestación 20/132 kV.

- Subestación 20/132 kV. Se instala el siguiente aparallaje: trafo de potencia, transformadores, autoválvulas, seccionadores, embarrado, celdas, servicios auxiliares, armario de control y equipo de medida.

- Línea aérea de $132 \mathrm{kV}$. Tendrá una longitud de $19 \mathrm{~km}$, hasta enlazar con la subestación de Grijota, de Red Eléctrica de España. Será objeto de otro proyecto independiente.

- Red de tierras.

El presupuesto de ejecución material del anteproyecto es muestra en la tabla A1.16. 
Tabla A1.16. Presupuesto del anteproyecto de parque eólico El Castre

\begin{tabular}{llc}
\hline & \multicolumn{1}{c}{ OBRA CIVIL } & \\
\hline Capítulo I & Accesos & $339276,04 €$ \\
\hline Capítulo II & Aerogeneradores & $4405916,63 €$ \\
\hline Capítulo III & Conexión aerogeneradores a subestación & $444239,30 €$ \\
\hline Capítulo IV & Edificio de control & $42536,03 €$ \\
\hline Capítulo V & Subestación 132/20 Kv & $64450,44 €$ \\
\hline Capítulo VI & Reposición del terreno y de las infraestructuras afectadas & $90000,00 €$ \\
\hline & EJECUCIÓN MATERIAL OBRA CIVIL & $\mathbf{5 3 8 6 4 1 8 , 4 4 €}$ \\
\hline Capítulo I & Aerogeneradores & $20800788,40 €$ \\
\hline Capítulo II & Centros de transformación 20/0,69 Kv & $1033282,01 €$ \\
\hline Capítulo III & Conexión de C.T. a subestación & $\mathbf{1 4 0 2 0 6 3 , 1 3} €$ \\
\hline Capítulo IV & Subestación 132/20 Kv & $\mathbf{2 9 2 5 7 8 0 1 , 9 4} €$ \\
\hline Capítulo V & Seguridad e higiene & $9079,29 €$ \\
\hline & EJECUCIÓN MATERIAL OBRA ELECTROMECÁNICA & \\
\hline & TOTAL EJECUCIÓN MATERIAL & \\
\hline
\end{tabular}

El capítulo VI contempla la reposición de las infraestructuras afectadas, canteras y movimientos de tierra, vegetación y cualquier otro elemento afectado durante el desarrollo de las obras. Representa una partida alzada de $90000 €$, que supone el 1,67 \% del presupuesto de ejecución material de la obra civil y el 0,38 \% del total del parque eólico.

En abril de 2006 consta la tramitación de la primera modificación del proyecto de parque eólico El Castre. El número de aerogeneradores se reduce de 40 a 30; la potencia unitaria, de $1250 \mathrm{~kW}$ a $850 \mathrm{~kW}$ (potencia total, de 50 a 25,5 MW); la altura de la torre asciende de $60 \mathrm{~m}$ a 64,5 m, reduciéndose en cambio el diámetro del rotor de $64 \mathrm{~m}$ a $54 \mathrm{~m}$.

En septiembre de 2007 el promotor tramita una segunda modificación del proyecto referido que, en el mismo emplazamiento, pasa a componerse de 16 aerogeneradores de $1600 \mathrm{~kW}$, siendo la potencia total del parque eólico de 25,6 MW (Figura A1.86). La altura de la torre asciende a $78 \mathrm{~m}$ y el diámetro del rotor, a $80 \mathrm{~m}$. No se modifican las características de la subestación eléctrica ni de la línea aérea de evacuación de 220 kV. El presupuesto de ejecución material, englobándose la obra civil y la obra electromecánica, se reduce a $16239323 €$. 


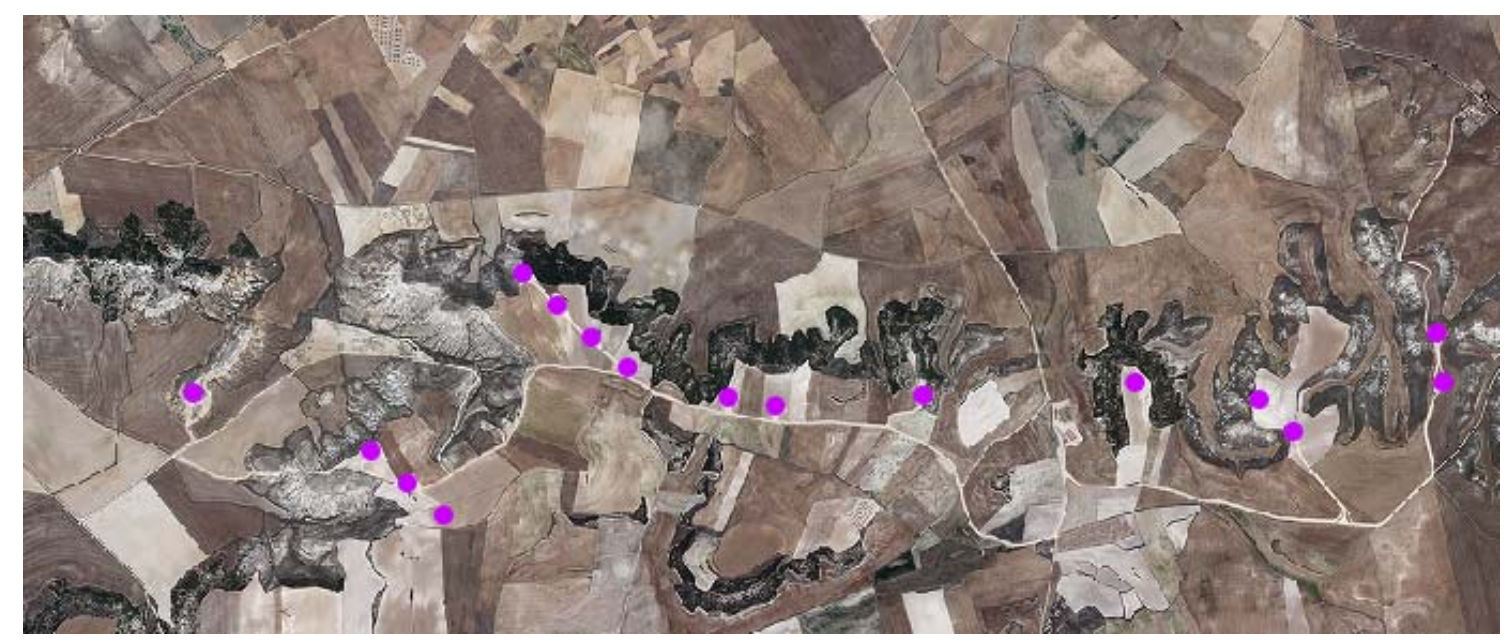

Figura A1.86. Ortofotografía con la ubicación definitiva de los 16 aerogeneradores.

\section{A1.8.2. Condicionantes ambientales}

\section{A1.8.2.1. Estudio de Impacto Ambiental del parque eólico El Castre.}

Autor: PAYD INGENIEROS. Germán Albarrán Sanz (ingeniero técnico industrial), Fco. Javier Manteca Beneitez (ingeniero técnico de obras públicas), Fernando Robles Albarrán (ingeniero técnico agrícola) y Jesús M. Roldán Muñoz (ingeniero técnico forestal).

Fecha: abril de 2002

Este documento señala que los aerogeneradores se implantarán en terrenos llanos o con baja pendiente, estando ocupados por cultivos agrícolas herbáceos de secano. El parque eólico se sitúa en el límite de las unidades naturales de Tierra de Campos y los páramos calcáreos (Montes Torozos). Las laderas están cubiertas por repoblaciones de pino carrasco.

En el análisis de alternativas, se cuantifica el valor de utilidad ambiental de la opción $B$ seleccionada $(6,07)$ (Figura $A 1.87)$, muy superior al de la alternativa $A(3,11)$, tras valorar como criterios la conservación de la vegetación, la menor superficie de suelo ocupada, el menor movimiento de tierras, la mejor conservación de la avifauna, la menor incidencia en el paisaje y la conservación del patrimonio cultural. 

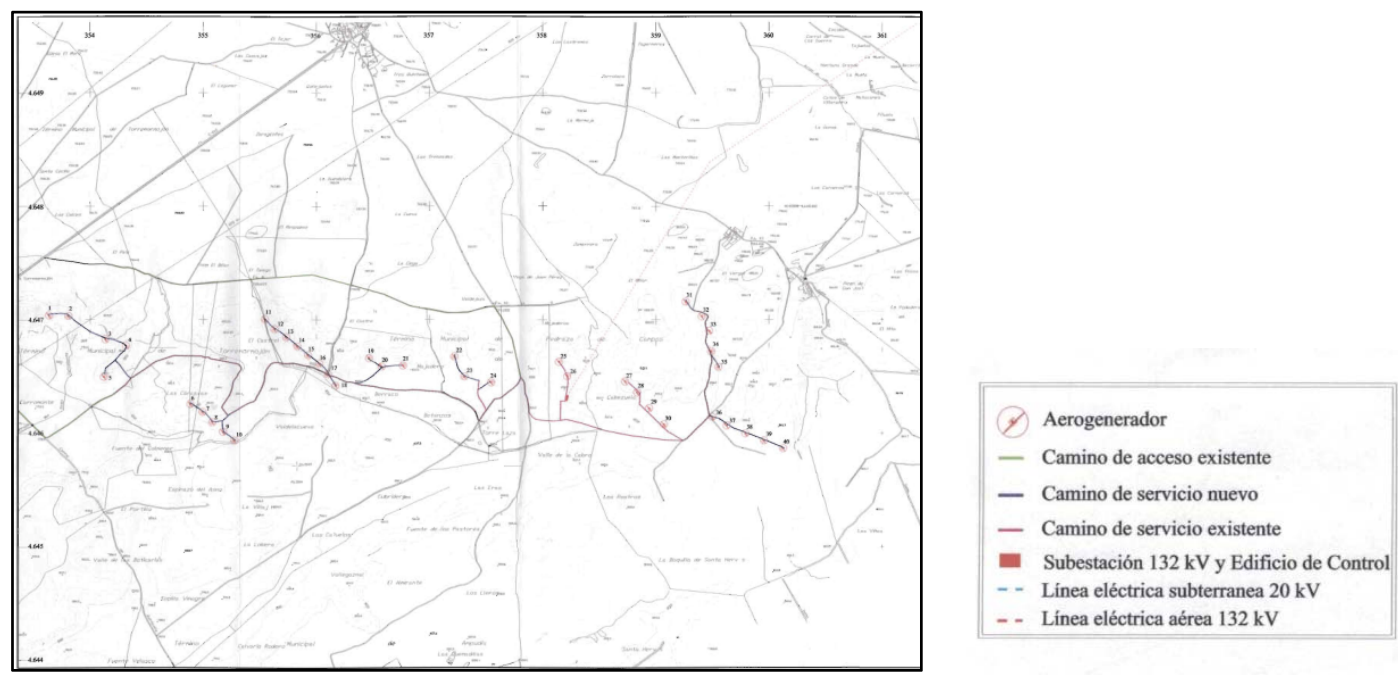

Figura A1.87. Plano de ubicación de los aerogeneradores en la alternativa seleccionada, incluido en el estudio de impacto ambiental.

El lugar donde se situará el proyecto es una zona calificada por el Plan Eólico de Castilla y León como zona de desarrollo libre, al tener las características de viabilidad técnica elevada y sensibilidad ambiental baja. El parque eólico se ubica a una distancia de $500 \mathrm{~m}$ de la ZEPA "La Nava-Campos Sur".

Urbanísticamente, las Normas de planeamiento municipal con ámbito provincial clasifican una zona de la superficie del suelo de la zona de páramos y cuestas, como suelo no urbanizable de especial protección con alto valor forestal, estando el resto del páramo calificado como suelo no urbanizable común.

En el inventario ambiental se realiza un análisis específico del paisaje, describiéndose las unidades de paisaje de Tierra de Campos y Montes Torozos, que están unidas por las Cuestas. La cuenca visual alcanzará a una superficie muy grande, siendo el parque visible desde numerosas poblaciones (Figura A1.88). Por su situación elevada, la fragilidad visual del parque eólico se califica como media-alta y, por tanto, la capacidad de acogida del territorio se estima como media-baja. La calidad visual intrínseca se califica como de grado medio, destacándose como valor visual positivo las laderas, por la variación de formas que introducen en un territorio homogéneo y por su vegetación. La calidad visual del entorno inmediato se califica como baja y en la calidad del fondo escénico se destaca la amplísima visibilidad. En resumen, el paisaje de la zona de estudio posee elementos de interés visual como son las cuestas y la gran amplitud de vistas que presenta la superficie de Tierra de Campos. Presenta además un alto grado de intervisibilidad y vistas escénicas amplísimas, sobre todo desde la línea de cerro. No obstante, carece de naturalidad y presencia disrupciones antrópicas, fundamentalmente debidas a los núcleos urbanos, líneas eléctricas e infraestructuras, además del tipo de uso fundamental al que está sometido el suelo, el cultivo agrícola. Por ello, se considera que la calidad paisajística de la zona afectada por el parque eólico es media-baja. 


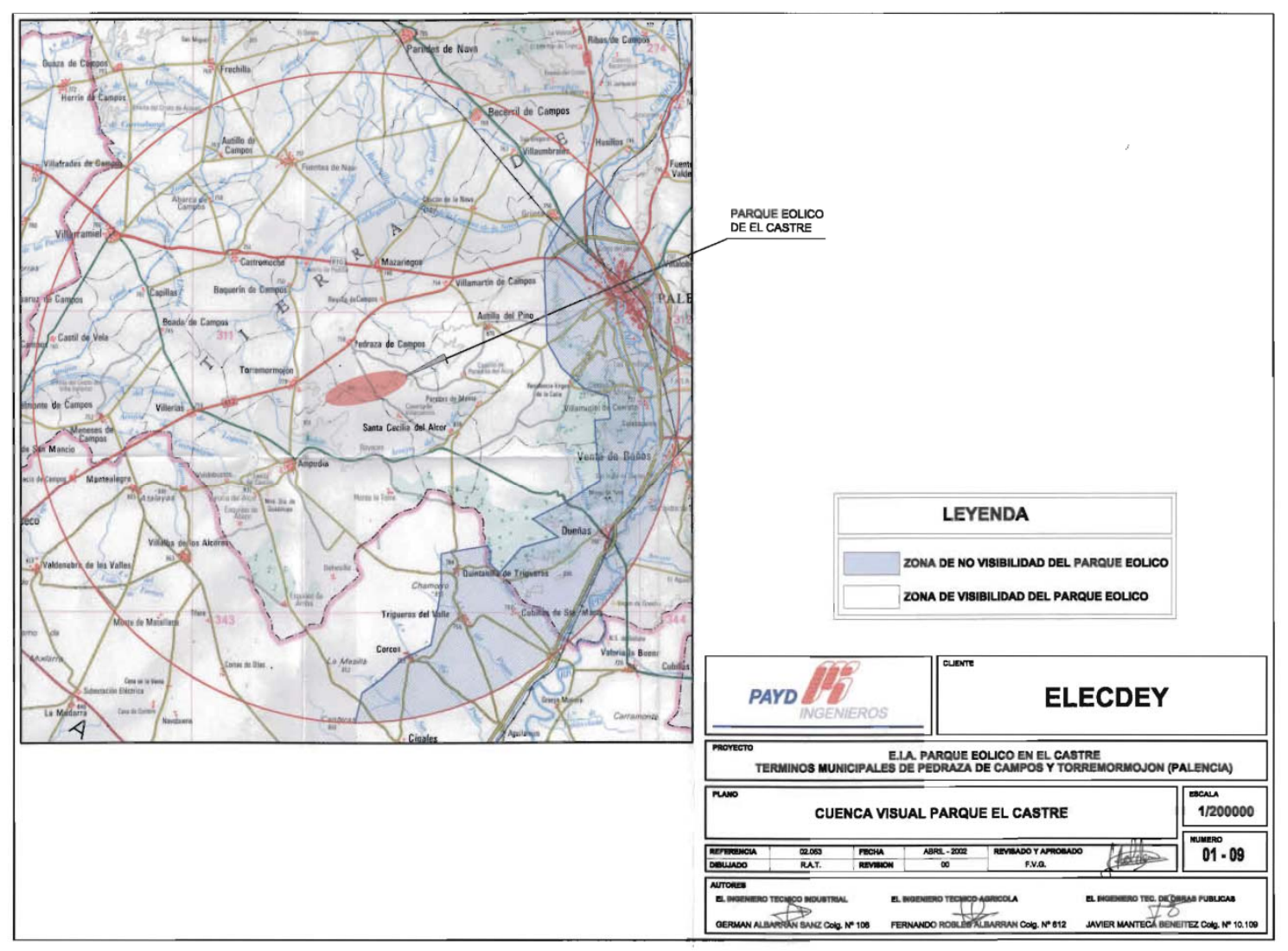

Figura A1.88. Cuenca visual del parque eólico, en la que se puede comprobar que la zona visible es mayoritaria.

En el entorno del proyecto existen dos bienes de interés cultural: el castillo de Torremormojón, declarado como monumento, aunque en estado de ruina, y la iglesia parroquial de Santa María del Castillo.

En cuanto a la valoración de los impactos ambientales, el impacto sobre la vegetación se califica como moderado, el ejercido sobre la fauna se valora como moderado, igual al producido sobre los procesos geofísicos. En cambio, el impacto sobre el paisaje se valora como severo, ya que la gran altura que tienen los aerogeneradores y la localización en una zona de páramo les harán visibles desde una superficie muy grande y provocarán una alteración importante en la estructura del paisaje de la zona. Cabe destacar la localización de dos aerogeneradores muy cercanos al castillo de Torremormojón, considerando el impacto como moderado sobre los bienes de interés cultural.

Las principales medidas protectoras, correctoras y compensatorias relativas al paisaje son las siguientes:

- Retirada selectiva de la tierra vegetal en las superficies afectadas por las obras, para su utilización en las labores de restauración de la zona degradada.

- Reutilización de los estériles procedentes de las obras para el relleno de viales y terraplenes, o en su defecto traslado a un vertedero controlado.

- Reducción de las pendientes del movimiento de tierras con el fin de reducir la capacidad erosiva de la lámina de agua. 
- Revegetación de las superficies alteradas por las obras con especies autóctonas de la zona y con la densidad adecuada, para prevenir los procesos de erosión.

- En caso de ser necesario el balizamiento de los aerogeneradores, se hará solo con luces rojas. La iluminación de la subestación evitará en lo posible la difusión de la luz.

- El diseño de los trazados de las líneas eléctricas, caminos y aerogeneradores buscará su menor visibilidad, procurando disminuir en lo posible su efecto visual sobre el paisaje.

- Los aerogeneradores e instalaciones deberán tener, como norma general, un color blanco-gris mate.

- Se deberá optimizar el trazado de las líneas eléctricas de evacuación de forma que provoque el mínimo impacto visual. Si fuera posible, también se deberán hacer converger en una sola las líneas de evacuación de parques eólicos próximos.

- Se usarán los caminos ya existentes como accesos y vías de servicio del parque eólico. Si no fuera posible, los nuevos caminos se diseñarán adaptando su trazado a la fisiografía natural, utilizando para el firme materiales del terreno o de su color y restaurando correctamente las zonas afectadas por su construcción.

- El área afectada por las obras de construcción del parque eólico deberá quedar perfectamente acondicionada una vez acabadas estas, de manera que se retiren las infraestructuras auxiliares y los residuos.

- El parque eólico no se ubicará en zonas que no permitan la visión de elementos que formen parte del patrimonio histórico, sobre todo en el caso de que sean bienes de interés cultural.

- Realización de una repoblación forestal con especies de la zona en el entorno del parque, ya que ayudará a mitigar el impacto negativo de sus instalaciones.

El Estudio de Impacto Ambiental también incluye un plan de restauración, que contempla tres actuaciones básicas. En primer lugar, en la zona de pinar de repoblación afectada por la instalación del parque, se realizarán plantaciones de árboles y arbustos: pino carrasco, ciprés de Arizona, rosal silvestre y majuelo. En los alrededores de los aerogeneradores e instalaciones del parque situadas en tierras de cultivo se plantará un seto de cipreses. Ambas actuaciones tienen por objeto mejorar la integración del parque eólico en el paisaje de la zona y crear zonas de refugio para la fauna. En tercer lugar, se realizarán siembras e hidrosiembras en los taludes que resultan de la construcción de los caminos de acceso, para evitar la erosión. Se incluyen una serie de cuidados posteriores a la implantación: fertilización, riego, reposición de marras, control de calidad del sustrato y eliminación de malas hierbas.

Finalmente, el Estudio recoge dos medidas compensatorias:

- Con objeto de compensar los impactos sobre el paisaje que se pueden producir desde determinados puntos de interés -bienes de interés cultural, carreteras o localidadesdesde donde la incidencia visual de los aerogeneradores sea destacable, se procederá a la implantación de setos o pantallas vegetales con especies de crecimiento rápido.

- Para compensar las afecciones sobre los cotos de caza se proponen varias medidas: repoblaciones arbustivas, creación de bebederos, creación de bardos para conejos, rehabilitación de palomares, repoblaciones con especies cinegéticas y control de predadores. 
A1.8.2.2. Declaración de Impacto Ambiental, hecha pública por Resolución de 17 de marzo de 2003, de la Delegación Territorial de la Junta de Castilla y León en Palencia (BOCyL 24/09/2003).

La Declaración de Impacto Ambiental informa favorablemente el desarrollo del Proyecto del parque eólico El Castre, promovido por Elecdey, S.L., en los términos municipales de Pedraza de Campos y Torremormojón (Palencia), sujeto a una serie de condiciones. Las medidas preventivas o correctoras referidas al paisaje o a su restauración, además de las contempladas en el Estudio de Impacto Ambiental, son las siguientes:

2.- Eliminación de la posición del aerogenerador $n$ ㅇ 1, por su afección paisajística crítica respecto al Bien de Interés Cultural El Castillo de Torremormojón, declarado monumento, y a la iglesia parroquial de Santa María del Castillo.

3.a) Retirada selectiva de la tierra vegetal procedente de las excavaciones, para ser utilizada en la restauración de las áreas degradadas.

3.b) Restauración de los accesos para acopio, excavación, hormigonado, plataformas de izado de los aerogeneradores y drenajes.

3.d) Cumplimiento de los niveles sonoros contemplados en el Decreto 3/1995, de 12 de enero, por el que se establecen las condiciones que deben cumplir las actividades clasificadas por sus niveles sonoros y de vibraciones.

3.e) Las torres de los aerogeneradores tendrán un acabado neutro.

3.g) Para el control de colisiones de avifauna (en cuanto paisaje ecológico), se establecerá un seguimiento periódico mensual de los aerogeneradores, con una afección de 100 m a cada lado.

Por Acuerdo de la Comisión Territorial de Prevención Ambiental de 29 de junio de 2004, se considera que la primera modificación del proyecto no es sustancial a efectos ambientales, no modificándose por consiguiente las condiciones de la declaración de impacto ambiental.

En cuanto a la segunda modificación del proyecto de parque eólico, el Acuerdo de la Comisión Territorial de Prevención Ambiental de 31 de octubre de 2007 señala que tampoco es sustancial. No obstante, considera que las características de los aerogeneradores -cuya altura total aumenta de $92 \mathrm{~m}$ a $118 \mathrm{~m}$ - provocan la generación de un significativo mayor impacto sobre el paisaje, que en el caso del entorno del castillo de Torremormojón (catalogado como bien de interés cultural) se hace crítico. Se estima, por consiguiente, que deberá ser reubicado el aerogenerador más próximo al castillo (que ya había sufrido un alejamiento en la DIA), hasta una distancia mínima de $900 \mathrm{~m}$. Se deberá presentar un proyecto de recuperación ambiental que recoja las medidas correctoras, entre las que se incluirá la recuperación y mejora paisajística del entorno del castillo de Torremormojón. 
A1.8.2.3. Proyecto de restauración ambiental del parque eólico "El Castre" en Torremormojón y Pedraza de Campos (Palencia) y su entorno próximo.

Promotor: ELECDEY

Autores: Jesús Roldán Muñoz (ingeniero técnico forestal) y Asier Saiz Rojo (ingeniero de Montes), PAYD ingenieros.

Fecha: marzo 2008

Este documento plantea las siguientes actuaciones:

- Retirada previa de tierras vegetales. Su espesor es de $30 \mathrm{~cm}$. Se llevará a cabo en los caminos, cimentaciones y plataformas de aerogeneradores y subestación eléctrica.

- Restitución de caminos y plataformas de montaje de aerogeneradores.

- Restauración de taludes, mediante la extensión de tierra vegetal e hidrosiembra. En los que tengan más de $2 \mathrm{~m}$ de altura, se colocará una manta orgánica.

- Restauración de terrenos aledaños a los aerogeneradores, con plantación de pinos y encinas.

- Restauración de las plataformas y plantas de cimentación de aerogeneradores, mediante el aporte de tierra vegetal, siembra y plantaciones en sus bordes.

- Restauración de vías de acceso y caminos de servicio del parque eólico.

- Restauración de las inmediaciones de la subestación de transformación, mediante la plantación de arizónicas, pinos piñoneros y almendros.

- Restauración en arroyos y manantiales.

- Repoblación forestal y construcción de diques en las laderas del castillo de Torremormojón.

- Acondicionamiento del camino de acceso al castillo de Torremormojón (extensión y compactación de capa de zahorra y construcción de obras de drenaje) y colocación de paneles informativos relativos al recurso cultural y natural.

- Acondicionamiento de la senda que bordea el castillo de Torremormojón (anchura de $1,5 \mathrm{~m}$, con pavimento de zahorras estabilizadas a base de cemento de vidrio reciclado) y colocación de barandilla de madera.

- Plantaciones en el entorno del castillo de Torremormojón (seto leñoso perimetral y cedros) y colocación de bancos de madera.

- Tratamientos selvícolas en las masas forestales próximas al castillo de Torremormojón (claras y podas).

El presupuesto de ejecución material del proyecto de restauración ambiental asciende a 236172 $€$. 


\section{A1.8.3. EJECUCIÓN}

A1.8.3.1. Informes de vigilancia ambiental del parque eólico El Castre.

Promotor: Elecdey Palencia, S.L.U.

Autor: A. Rubio, Asesoría e Ingeniería Ambiental, S.L.

Fechas: $2^{\circ}$ semestre 2010,10 semestre 2011,20 semestre 2011,19 semestre 2012,1 semestre 2013, 20 semestre 2013, 1ㅇs semestre 2014.

En el primero de los informes se señala que las obras de construcción del parque eólico se han realizado sin que se hayan producido incidentes ambientales de ningún tipo. Se justifica el cumplimiento de las medidas protectoras y correctoras de la DIA, entre las que se encuentran las relativas al paisaje y a su restauración. No obstante, se indica que falta de realizarse la adecuación del entorno del castillo de Torremormojón.

En los siguientes informes se continúa concluyendo el cumplimiento de las citadas medidas, haciendo más énfasis en la fase de funcionamiento del parque eólico (en especial, en la afección sobre la avifauna, detectándose escasas colisiones). El certificado acústico indica que no se superan los niveles de inmisión en las localidades más cercanas, de Torremormojón y Pedraza de Campos. También se alude al progresivo crecimiento de la vegetación implantada.

\section{A1.8.3.2. Informes de seguimiento del proyecto de restauración ambiental del parque eólico El Castre.}

Promotor: Elecdey Palencia, S.L.U.

Autor: José Luis Martín Lapresa, ingeniero agrónomo.

Fechas: febrero 2010, julio 2010 y mayo 2012.

En el primero de ellos se indica que la restauración se encuentra en ejecución, ilustrándose las labores de revegetación y las obras de adecuación paisajística. En particular, se constata el empleo de una barrena manual para el ahoyado, y la utilización de especies autóctonas o propias de la zona, mayoritariamente de una savia y con cepellón: almendros, encinas, pinos piñoneros, chopos, álamos, serbales, retamas negras, escaramujos, romeros, lavandas, endrinos, etc.

En el segundo, se informa que en general se ha realizado una correcta ejecución del resto de actuaciones planteadas: más plantaciones de árboles y arbustos, siembra de taludes con alfalfa y trigo, colocación de carteles interpretativos, instalación de 5 diques de tablas de madera para la retención de sedimentos en cárcavas, etc.

En el último de ellos se analiza el crecimiento de la vegetación implantada y se alude a alguna actuación realizada a posteriori, como la corrección de deficiencias en la adecuación de la plataforma del castillo o la plantación de acacias en esa zona. 


\section{A1.8.3.3. Conclusiones del seguimiento ambiental.}

Además de la información contenida en los documentos anteriormente mencionados, se han realizado 6 visitas técnicas a la zona afectada por el parque eólico, de fechas 10/10/2007, $31 / 03 / 2009,13 / 08 / 2009,20 / 10 / 2010,31 / 05 / 2014$ y 19/09/2014. Las conclusiones extraídas son las siguientes:

Se confirma la amplia visibilidad del parque eólico, derivada de la altura de los aerogeneradores y a su ubicación en la cumbre de cerros testigos próximos a los páramos de Torozos (Figura A1.89). En días despejados, los aerogeneradores se ven de forma nítida hasta desde una distancia de $20 \mathrm{~km}$. Asimismo, la fragilidad del paisaje de Tierra de Campos frente a este tipo de proyectos es muy elevada.

Sin embargo, se considera acertada la elección del color blanco neutro para el conjunto de los aerogeneradores, que por otra parte afortunadamente se ha asumido para todos los parques eólicos de nuestro entorno. A pesar de la gran envergadura de las máquinas y su carácter artificial, el diseño funcional de las máquinas también contribuye a su integración, por la gracilidad de sus formas y, tal vez, la asociación que el espectador realiza con una fuente de energía limpia y renovable (Figura A1.90).

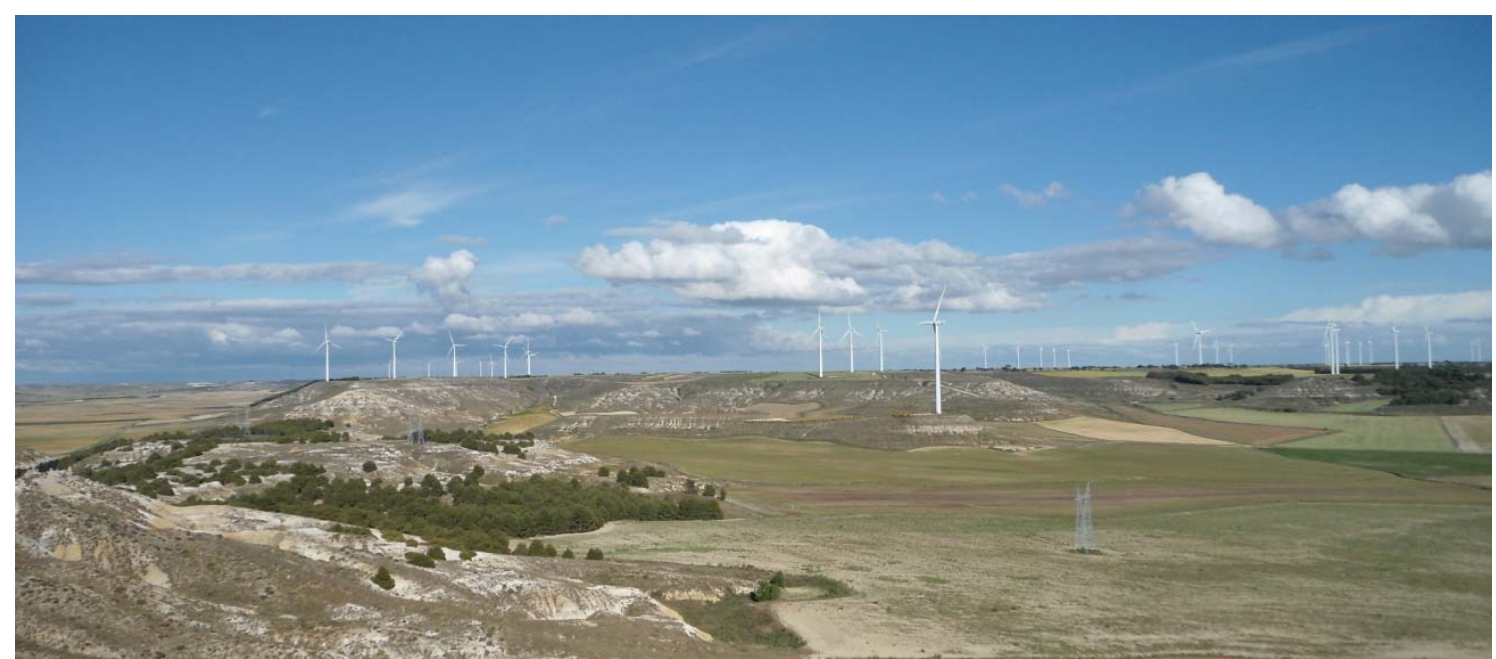

Figura A1.89. Vista del parque eólico El Castre desde el castillo de Torremormojón. Al fondo se divisan más aerogeneradores correspondientes a otros parques ubicados en Ampudia. 


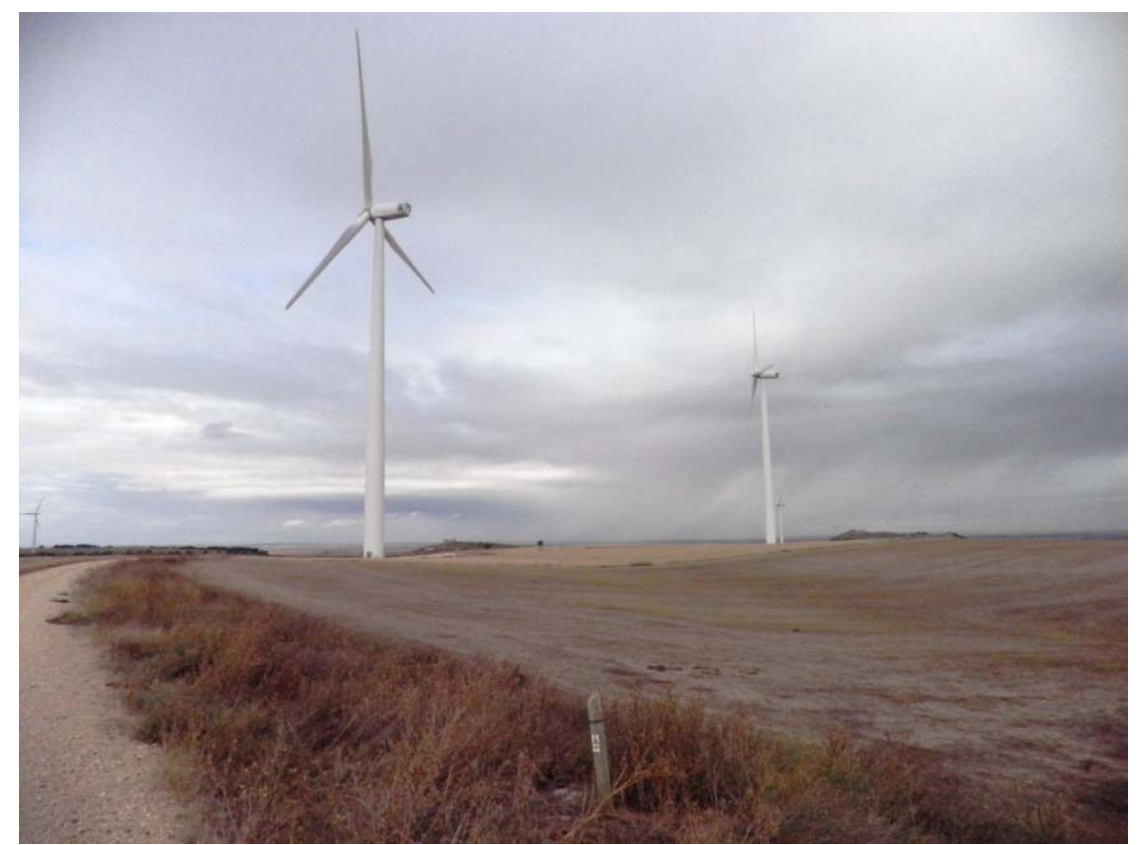

Figura A1.90. Imagen de dos aerogeneradores. En días nublados el contraste de las máquinas con el fondo escénico es muy reducido. Hay que tener en cuenta que, a lo largo del año, son escasos los días en que el cielo está totalmente despejado.

Es fundamental considerar el impacto acumulativo y sinérgico del conjunto de parques eólicos situados en una misma zona. Tal es el caso del parque eólico El Castre junto con los ya instalados en el vecino término municipal de Ampudia, que conforman realmente una gran instalación eólica. Especial incidencia cabe reseñar en cuanto al impacto sobre el paisaje visual y a la afección a la avifauna por colisiones. De igual modo, aunque en las evaluaciones no se suele prestar especial atención, es especialmente severo el impacto producido por la iluminación nocturna; en este caso se conjugan diferentes colores (blanco y rojo) y desajustes en los destellos, que son visualizados de forma molesta desde una amplia superficie de Tierra de Campos.

La evaluación de impacto ambiental se ha demostrado un procedimiento eficaz para minimizar el impacto sobre el patrimonio cultural, en este caso sobre el castillo de Torremormojón. Las sucesivas reubicaciones de los aerogeneradores más próximos a este bien de interés cultural han propiciado que quedase exento del parque eólico, a una distancia suficiente como para que la envergadura de las máquinas no supusiese un impacto crítico sobre el mismo.

Tanto la subestación eléctrica como el edificio de control poseen una buena integración paisajística. Se ha modificado el acabado blanco de los bloques de hormigón del muro perimetral (proyecto) por el ocre, que se adecua mejor a la tipología cromática de Tierra de Campos; también se emplea este color en el enfoscado del edificio de control. Por otra parte, alrededor de estas instalaciones se han realizado plantaciones de árboles y arbustos, lo que contribuye a mejorar su adecuación en el entorno (Figura A1.91). 


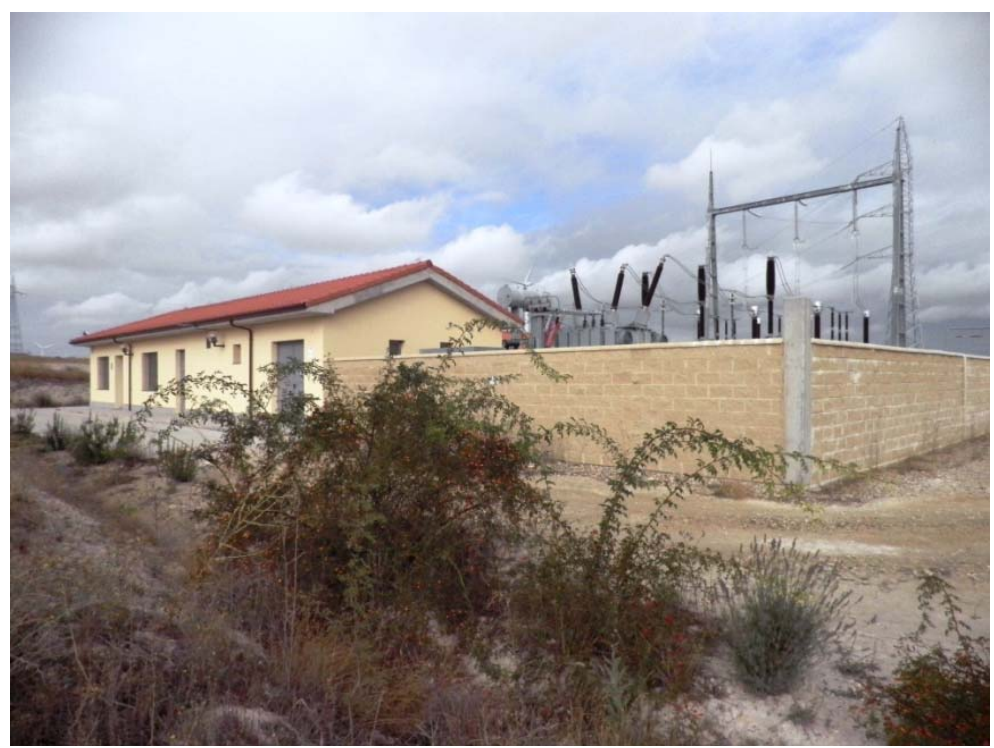

Figura A1.91. Imagen del edificio de control y la subestación eléctrica; en primer plano, plantaciones ya consolidadas de lavandas y escaramujos.

La obra civil del proyecto relativa a construcción de plataformas, zanjas de conexión de líneas eléctricas y caminos se ha ejecutado con una adecuada integración en el entorno (Figura A1.92). En cuanto a los viales, la zahorra caliza es la apropiada para la zona, la pendiente de los taludes de desmonte y terraplén es suficientemente reducida y las obras de drenaje longitudinal y transversal aseguran las oportunas correcciones hidrológicas. Además, las embocaduras de estas últimas se han chapado en piedra.
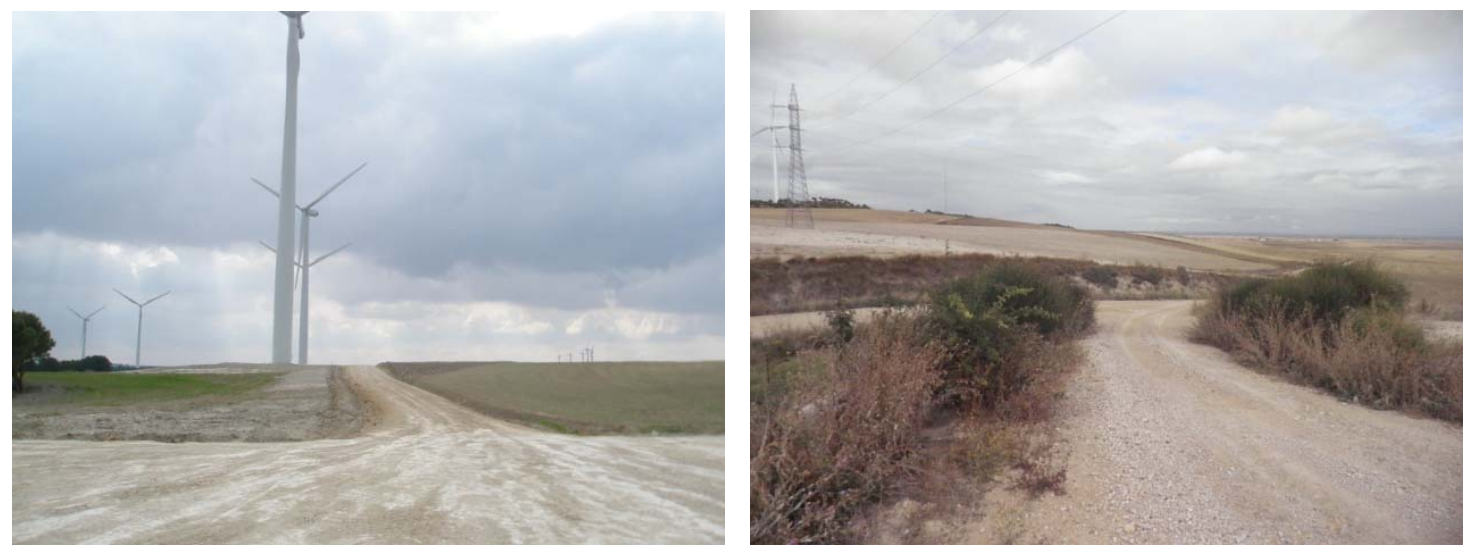

Figura A1.92. Izquierda, obras de plataformas, zanjas y caminos recientemente remodelados. Derecha, camino y zanjas revegetadas 5 años después.

La redacción del proyecto de restauración ambiental y su ejecución con dirección de obra asociada son herramientas fundamentales para asegurar el cumplimiento de las medidas correctoras y compensatorias de la declaración de impacto ambiental. Su importe ha representado tan solo un 1,45 \% del presupuesto de ejecución material del proyecto del parque eólico, aunque ha permitido que la integración ambiental del parque haya sido muy buena. 
En cuanto a la revegetación, en primer lugar cabe reseñar que los taludes generados están parcialmente restaurados; ello se debe en parte a la dificultad por la escasa tierra vegetal de estos suelos. Por otra parte, se han realizado un buen número de plantaciones en las zonas auxiliares del parque: entorno de las plataformas, taludes, márgenes de caminos, entorno de la subestación, etc. La elección de especies ha sido muy adecuada, al igual que la implantación. No obstante se detectan unas marras en el conjunto del parque de en torno a un $40 \%$, que deberían ser repuestas a lo largo de la vida útil de la instalación eólica. En este sentido, también cabe hacer hincapié en el inconveniente derivado de la aplicación de herbicidas y el laboreo excesivo de los terrenos agrícolas colindantes, que han provocado la muerte de numerosas plantas.

La decisión por parte del órgano ambiental de incluir como medida compensatoria la restauración del entorno del castillo de Torremormojón es muy acertada. Aunque se ha señalado anteriormente que se ha reducido el impacto visual por el alejamiento de algunos aerogeneradores, lo cierto es que este es innegable. Ahora bien, con esta medida se "da la vuelta" a la visión destructiva del medio ambiente que se tiene de los proyectos energéticos. Tal como se ha reflejado en los paneles interpretativos, con esta actuación se conjuga el aprovechamiento de un recurso renovable (el viento), la valoración de un bien de interés cultural olvidado y la recuperación paisajística de un mirador que puede ser emblemático en Tierra de Campos; no en vano tiene vistas impresionantes en sus $360^{\circ}$ de amplitud (Figura A1.93).
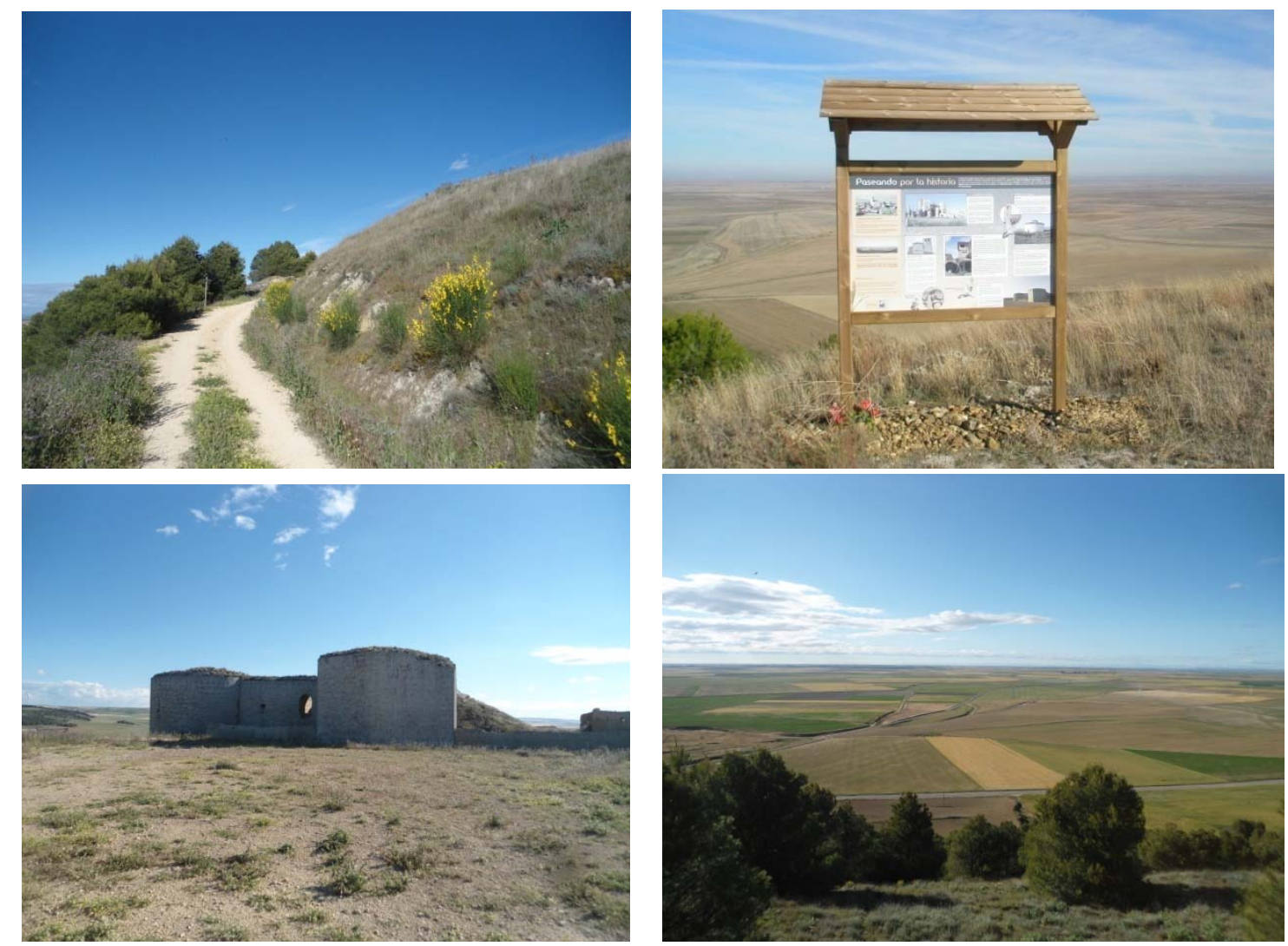

Figura A1.93. Arriba izquierda, adecuación del camino de acceso, con revegetación de sus márgenes. Arriba derecha, panel interpretativo del paisaje y el patrimonio cultural. Abajo izquierda, castillo de Torremormojón. Abajo derecha, vista del paisaje de Tierra de Campos en primavera. 
Resulta fundamental el mantenimiento de las actuaciones de recuperación. En las últimas visitas técnicas efectuadas se ha detectado la presencia de basuras, la falta de desbroce de la vegetación en el mirador o la ausencia de señalización para la realización de visitas de forma adecuada. Estas cuestiones deberían ser solventadas por el Ayuntamiento -tal vez junto con la Diputación provincial- que son las entidades que deberían involucrarse para que este recurso pudiese realmente ser productivo. 


\section{A1.9. Polígono industrial sector 1 en Paredes de Nava}

\section{A1.9.1.Proyecto}

\section{A1.9.1.1. Plan Parcial de ordenación sector Polígono industrial, en Paredes de Nava (Palencia).}

Promotor: Ayuntamiento de Paredes de Nava

Autor: Manuel Astorgano Feo (arquitecto)

Fecha: mayo de 2003

El Plan Parcial plantea el desarrollo del sector 1 de suelo urbanizable delimitado de la modificación puntual de las Normas Subsidiarias Municipales de Paredes de Nava, aprobada definitivamente por la Comisión Provincial de Urbanismo de Palencia el 18 de julio de 2002. Este instrumento de planeamiento ordena un sector industrial de $70717 \mathrm{~m}^{2}$ de superficie, ubicado en la parcela 25 del polígono 29 de dicho término municipal. Se sitúa al sureste del casco urbano de Paredes de Nava, lindando con la carretera autonómica CL-613, un camino rural y una finca rústica (Figura A1.94).

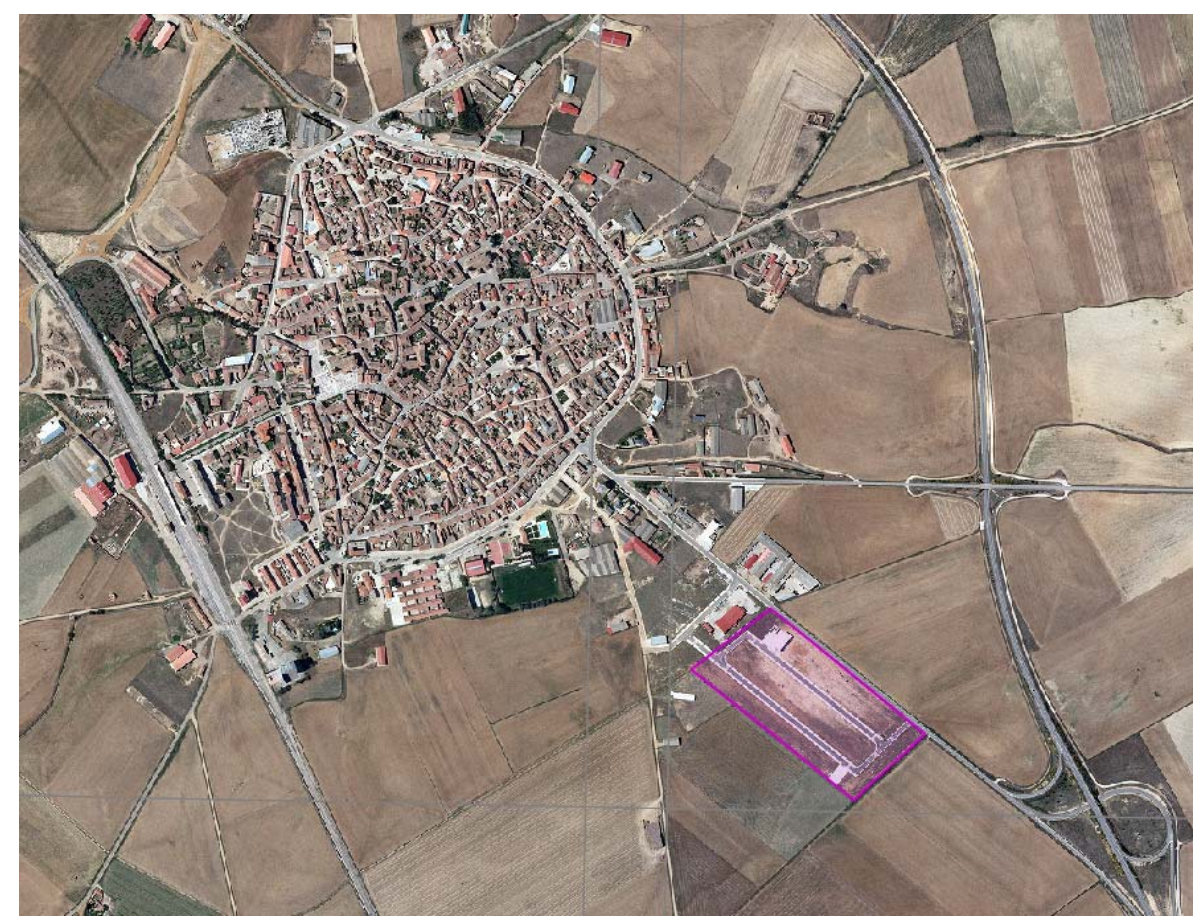

Figura A1.94. Ortofotografía con la ubicación del sector 1 de suelo industrial de Paredes de Nava.

Se definen las siguientes intensidades y usos para el sector (Tabla A1.16): 
Tabla A1.17. Intensidades y usos del sector 1 polígono industrial.

\begin{tabular}{|c|c|c|c|}
\hline \multicolumn{4}{|c|}{ SUELO } \\
\hline Usos & Superficies & $\%$ & \\
\hline Industrial & $40970,82 \mathrm{~m}^{2}$ & 57,94 & \\
\hline Espacios libres públicos & $8344,18 \mathrm{~m}^{2}$ & 11,80 & \\
\hline Equipamientos & $8502,14 \mathrm{~m}^{2}$ & 12,02 & \\
\hline Aparcamientos/Viales & $12899,86 \mathrm{~m}^{2}$ & 18,24 & \\
\hline TOTAL & $70717,00 \mathrm{~m}^{2}$ & 100,00 & \\
\hline \multicolumn{4}{|c|}{ APROVECHAMIENTO MÁXIMO } \\
\hline & S. bruta del Sector & S. Uso Característico Industrial & $\%$ \\
\hline Modificación Normas & 70717,00 & 41500,00 & 58,00 \\
\hline Plan Parcial & 70717,00 & 30690,23 & 43,39 \\
\hline \multicolumn{4}{|c|}{ OCUPACIÓN MÁXIMA } \\
\hline & Superficie & S. Uso Característico Indust & \\
\hline Normas & $80 \%$ & 56573,60 & \\
\hline Ley & 2/3 Sup. Sector & 47144,67 & \\
\hline Plan Parcial & Según alineaciones & 34893,27 & \\
\hline
\end{tabular}

Las ordenanzas reguladoras del Plan Parcial determinan para las diferentes tipologías de edificación y parcelación una serie de limitaciones (Tabla A1.18).

Tabla A1.18. Limitaciones del Plan Parcial.

\begin{tabular}{lc}
\hline \multicolumn{1}{c}{ Normativa } & Industrial \\
\hline Parcela mínima $\left(\mathrm{m}^{2}\right)$ & 500 \\
\hline Ocupación máxima & Según Alineaciones \\
\hline Altura máxima $(\mathrm{m})$ & 9,00 \\
\hline $\mathrm{N}^{\circ}$ de plantas & $\mathrm{PB}+1$ \\
\hline Aprovechamiento medio máximo $\left(\mathrm{m}^{2} / \mathrm{m}^{2}\right)$ & 0,50 \\
\hline Retranqueos de fachada a calle & $5,00 \mathrm{~m}$
\end{tabular}

Los objetivos principales de la actuación consisten en desarrollar el sector para la producción de suelo urbano, de uso industrial, en las inmediaciones y colindante con el núcleo de Paredes de Nava, y posibilitar el desarrollo de una zona con un elevado potencial con las debidas garantías de protección medioambiental. 
La ordenación propuesta (Figura A1.95) plantea una distribución de baja densidad, que deja las zonas verdes en las proximidades del casco urbano, como límite con la carretera comarcal y el arroyo. El suelo dotacional se ubica en el límite suroeste. En cuanto a los viales, se trata de una distribución en anillo, tomando como referencia el suelo urbano industrial de la localidad y conectándose, de manera concreta y eficaz, con el tejido existente a través de un eje de conexión. Así, se desarrollan dos viales de nueva apertura, paralelos a la carretera CL-613, como prolongación de las nuevas vías de servicio proyectadas para el suelo urbano industrial. Las vías se descomponen en una calzada de $8 \mathrm{~m}$, dos aceras de $1 \mathrm{~m}$ cada una y dos bandas de aparcamiento de $3 \mathrm{~m}$. Se reservan 307 plazas de aparcamientos. 


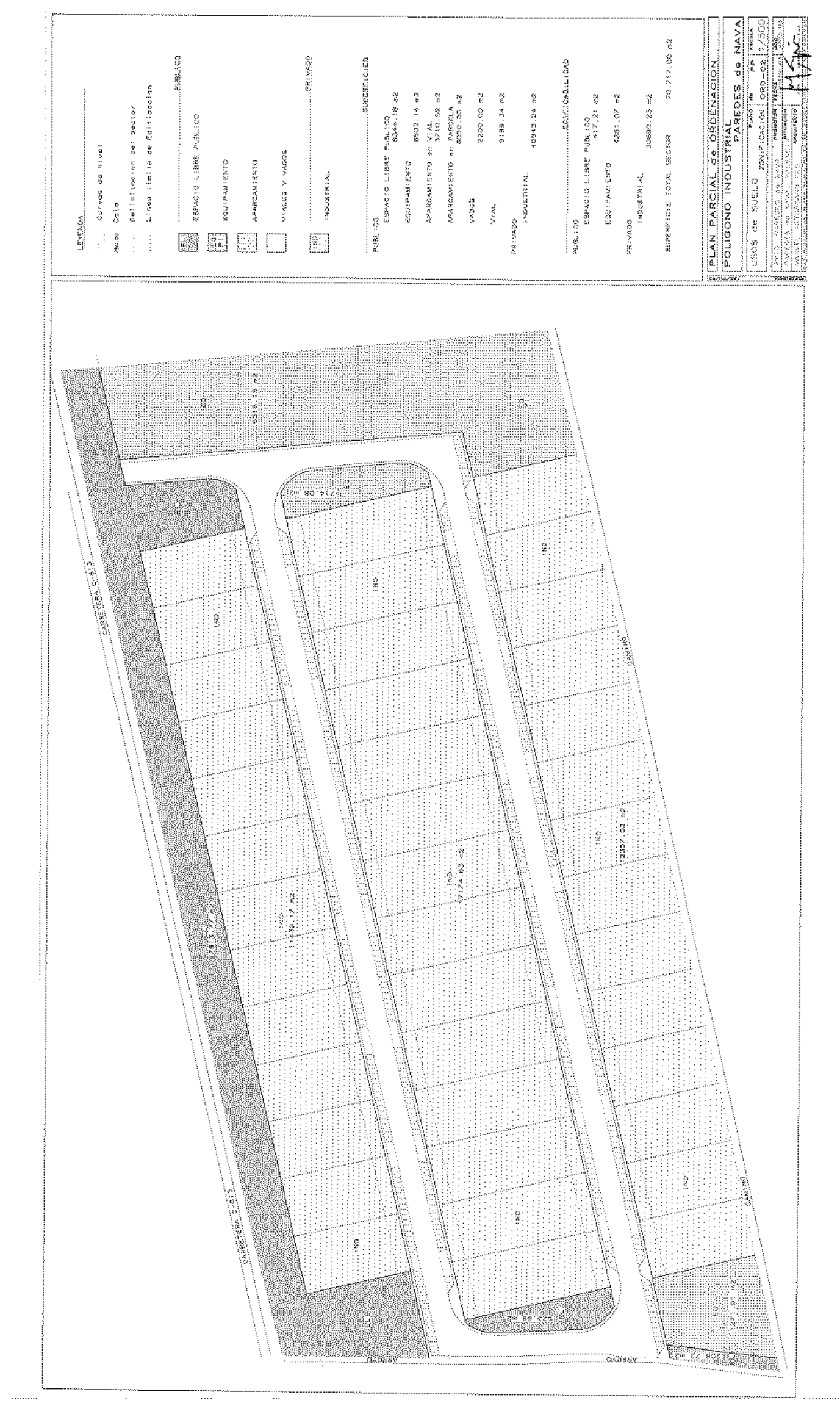

Figura A1.95. Plano de zonificación del Plan Parcial del polígono industrial de Paredes de Nava. 
En relación con los espacios libres públicos, se han reservado para este fin $8.344 \mathrm{~m}^{2}$, cifra superior al mínimo que prescribe la Ley 5/1999 de Urbanismo de Castilla y León ( $20 \%$ de la edificabilidad predominante, $30690 \mathrm{~m}^{2}=6138 \mathrm{~m}^{2}$ ). Se han dispuesto en tres zonas: la primera (destinada a jardines) limítrofe con la carretera comarcal CL-613, en el límite noreste de la actuación, como continuación de la distribución que se realiza en la zona urbana industrial; la segunda como remate de la franja central de uso industrial, y la tercera en el límite suroeste, discurriendo paralela al arroyo existente.

Se reservan dos parcelas para equipamientos, que ocupan $8502 \mathrm{~m}^{2}$.

El abastecimiento de agua al sector se conseguirá mediante su conexión a la red de abastecimiento de Paredes de Nava. La red prevé una tubería de polietileno, arquetas de registro, bocas de riego e hidrantes, válvulas, ventosas, etc.

La red de saneamiento propuesta es unitaria, canalizando por la misma red las aguas pluviales y las sucias y fecales procedentes del sector. La acometida a la red existente se prevé en la parte noreste de la parcela, por donde discurrirá el emisario que recogerá el saneamiento del sector. Se plantean una red de tuberías de PVC $315 \mathrm{~mm}$, sumideros sifónicos de calzada, pozos de registro, cámaras de descarga, etc.

Asimismo, el Plan Parcial plantea una red subterránea de suministro de energía eléctrica, una red de alumbrado público y una red de telecomunicaciones.

Como aspectos más relevantes de las Ordenanzas reguladoras del Plan Parcial, señalar que se incluyen una serie de condiciones estéticas para la zona industrial, siendo las más importantes:

- Las fachadas y medianeras tendrán idénticos materiales y acabados, siendo preferentemente los cerámicos en tonos naturales, rojos y tierras y enfoscados y revestimientos continuos con pinturas en tonos similares. No se permitirán los siguientes materiales: aplacados de piedras naturales pulidos, plaquetas cerámicas vitrificadas y azulejos.

- Las cubiertas, siguiendo la tipología tradicional, serán inclinadas de faldón continuo, con una pendiente máxima de $30^{\circ}$, no permitiéndose los siguientes materiales de cubrición: pizarra, placas onduladas de fibrocemento en su color y chapa metálica sin lacar (preferentemente serán colores tierra).

- El perímetro de cerramiento a espacio público podrá ser realizado mediante elementos ciegos de una altura máxima de $0,80 \mathrm{~m}$, autorizándose a rebasar ésta con setos vegetales o con protecciones diáfanas estéticamente admisibles con un máximo de $2 \mathrm{~m}$.

- La publicidad y decoración de establecimientos comerciales o industriales deberá respetar criterios de armonía general con el conjunto.

En los equipamientos y espacios libres públicos, las condiciones estéticas más importantes son las siguientes:

- Las normas para las fachadas y cubiertas son similares a las del uso industrial. 
- Condiciones genéricas de protección del paisaje (topografía, cauces naturales, arbolado, caminos, etc.).

- Se potenciará la vegetación natural, repoblando en su caso con especies autóctonas.

- Los espacios libres públicos serán mantenidos por el Ayuntamiento o por los particulares de la zona, según se llegue a un acuerdo entre ambos.

- El arbolado existente deberá conservarse adecuadamente.

- Se prestará especial atención a la adecuación en el entorno del mobiliario urbano: bancos, cabinas, puntos de venta, etc.

- Los tendidos y elementos de infraestructura y servicios no podrán ser exteriores.

En el estudio económico-financiero del Plan Parcial se incluye un resumen de la evaluación económica (Tabla A1.19).

Tabla A1.19. Resumen de la evaluación económica del Plan Parcial industrial.

\begin{tabular}{lrcc}
\multicolumn{1}{c}{ CAPÍTULO } & $\begin{array}{c}\text { COSTO E.M. } \\
\boldsymbol{\epsilon}\end{array}$ & $\begin{array}{c}\text { REPERC. } \\
\boldsymbol{\epsilon} / \mathbf{m}^{\mathbf{2}}\end{array}$ & $\begin{array}{c}\% \\
\text { sobre total }\end{array}$ \\
\hline VIALES Y PAVIMENTACIÓN & 306611,12 & 4,34 & 44,79 \\
\hline ABASTECIMIENTO DE AGUA & 62738,11 & 0,89 & 9,18 \\
\hline RED DE SANEAMIENTO & 53990,88 & 0,76 & 7,84 \\
\hline RED DE ENERGÍA ELÉCTRICA & 179792,51 & 2,54 & 26,21 \\
\hline RED DE TELECOMUNICACIONES & 31547,60 & 0,45 & 4,64 \\
\hline JARDINERÍA & 49903,31 & 0,71 & 7,34 \\
\hline \multicolumn{1}{c}{ TOTAL } & $\mathbf{6 8 4 5 8 3 , 5 3}$ & $\mathbf{9 , 6 9}$ & $\mathbf{1 0 0 , 0 0}$ \\
\hline
\end{tabular}

\section{A1.9.2. Condicionantes ambientales}

A1.9.2.1. Estudio de Impacto Ambiental del Plan Parcial de ordenación de polígono industrial en Paredes de Nava (Palencia).

Promotor: Ayuntamiento de Paredes de Nava

Autores: Luis Merino Caballero (ingeniero agrónomo) y Mónica Maestro López (geógrafa)

Fecha: abril de 2003

Respecto de la descripción del entorno (inventario ambiental), como aspectos más reseñables se señala que el suelo de la parcela tiene una textura franco-arcillo-arenosa, un $\mathrm{pH}$ de 8,5 y un porcentaje de materia orgánica de 0,9 . El uso previo del terreno es agrícola. La morfología de la zona es bastante plana. En el Inventario no consta la existencia de yacimientos arqueológicos en la parcela. El espacio natural protegido más próximo es la Laguna de la Nava, situado a $12 \mathrm{~km}$ del polígono industrial. La parcela constituye un paisaje de valor potencial reducido y la 
presencia del futuro polígono industrial repercutirá en la calidad del paisaje de manera poco intensa, al encontrarse en una parcela cercana al casco urbano.

En cuanto a la identificación y valoración de impactos, realiza una valoración cuantitativa y sendas matrices en las fases de construcción y explotación. Los impactos se califican como moderados, compatibles o positivos; no hay impactos severos o críticos. La alteración del paisaje es calificada como moderada, debido al efecto de la construcción de edificaciones y la pavimentación.

Las medidas preventivas y correctoras planteadas en relación con el paisaje son las siguientes:

- Instalar los contenedores necesarios para recoger los residuos que se generen durante las obras de forma adecuada. Finalizadas las obras, se retirarán todos los materiales sobrantes e instalaciones auxiliares, restos de encofrados y materiales inútiles.

- Para tratar de reducir el impacto visual causado por las construcciones, se usarán colores ocres o terrosos en los paramentos verticales, mientras que el tejado se realizará en fibrocemento imitando a la teja árabe.

- Creación de una pantalla vegetal, proponiéndose las siguientes especies: aligustre, laurel, chopo, encina y pino. Los pies de plantación se dispondrán al tresbolillo, en doble fila, con una distancia de $5 \mathrm{~m}$ entre pies de la misma fila y separación de $2 \mathrm{~m}$ entre filas. También se indica la plantación de árboles y arbustos fuera de la pantalla con otras especies: aliso, arce, sauce, tamarindo, madroño, majuelo, endrino, cornejo, aladierno, saúco, rosal silvestre y mostajo.

A1.9.2.1. Declaración de Impacto Ambiental, hecha pública por Resolución de 15 de octubre de 2003, de la Delegación Territorial de la Junta de Castilla y León en Palencia (BOCyL 27/10/2003).

La Declaración de Impacto Ambiental informa favorablemente el desarrollo del Plan Parcial del polígono industrial sector 1, promovido por el Ayuntamiento de Paredes de Nava, sujeto a una serie de condiciones. Las medidas preventivas o correctoras referidas al paisaje o a su restauración, además de las contempladas en el Estudio de Impacto Ambiental, son las siguientes:

2.a) Los materiales sobrantes en ningún momento se acumularán en las márgenes del arroyo. Estos, así como los escombros y otros residuos no tóxicos que se generen tanto en la ejecución de las obras como en el posterior desarrollo de las actividades que se efectúen, se depositarán únicamente en vertederos autorizados.

2.b) Los suelos ocupados se retirarán de forma selectiva, reservando y tratando adecuadamente los que constituyen la tierra vegetal para su posterior utilización en la restauración de los terrenos alterados.

2.i) Las parcelas perimetrales dotacionales, situadas al Este del área industrial, deberán ajardinarse con especies arbóreas o arbustivas de manera que formen una pantalla visual vegetal en sus bordes exteriores. 


\section{A1.9.3. Ejecución}

A1.9.3.1. Seguimiento de la obra e informe de vigilancia ambiental del polígono industrial Pedro Berruguete, de Paredes de Nava (Palencia).

Promotor: Ayuntamiento de Paredes de Nava

Autor: Francisco Javier Antolín Mateo (arquitecto)

Fecha: enero de 2010

En este informe se señala que la urbanización del polígono industrial finalizó en 2007 y fue realizada por la empresa GESTURCAL, S.A. Cuenta con todos los servicios necesarios: agua, alcantarillado, energía eléctrica, red de telefonía, alumbrado público, etc. Se han definido 64 parcelas industriales y 4 de equipamiento público, además de las zonas dedicadas a viales y aparcamientos y a espacios libres públicos.

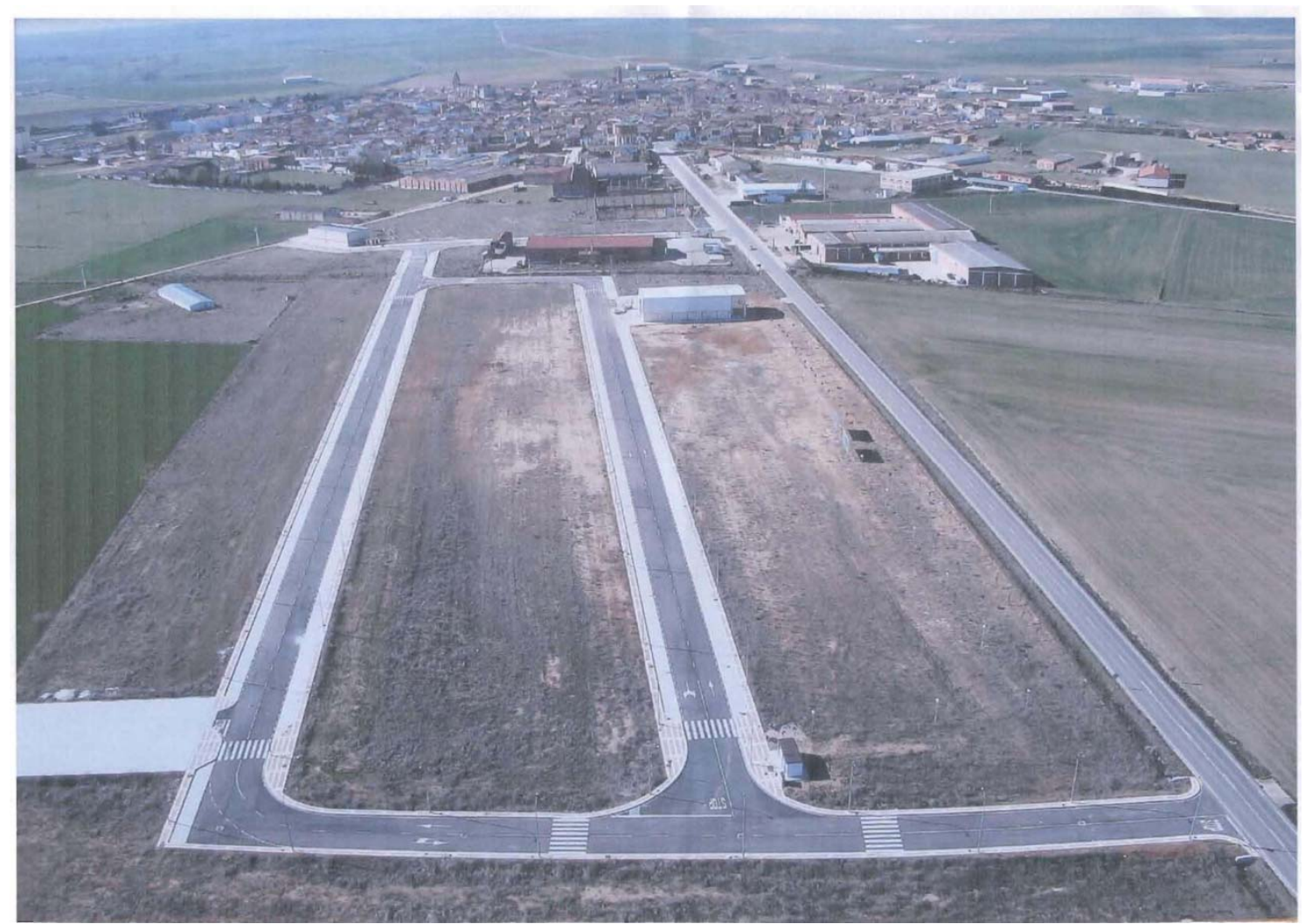

Figura A1.96. Imagen de una vista aérea del polígono industrial, contenida en el informe de vigilancia ambiental de enero de 2010.

Este documento justifica que se han cumplido las medidas correctoras planteadas en la declaración de impacto ambiental mencionada. Se destaca la restauración de las zonas afectadas con vegetación, así como la minimización del impacto visual, dada su ubicación en continuidad con una zona industrial del núcleo de Paredes de Nava (Figura A1.96). 
En visita realizada el 7 de agosto de 2013 se observa que se encuentran ocupadas dos parcelas del polígono (Figura A1.97).
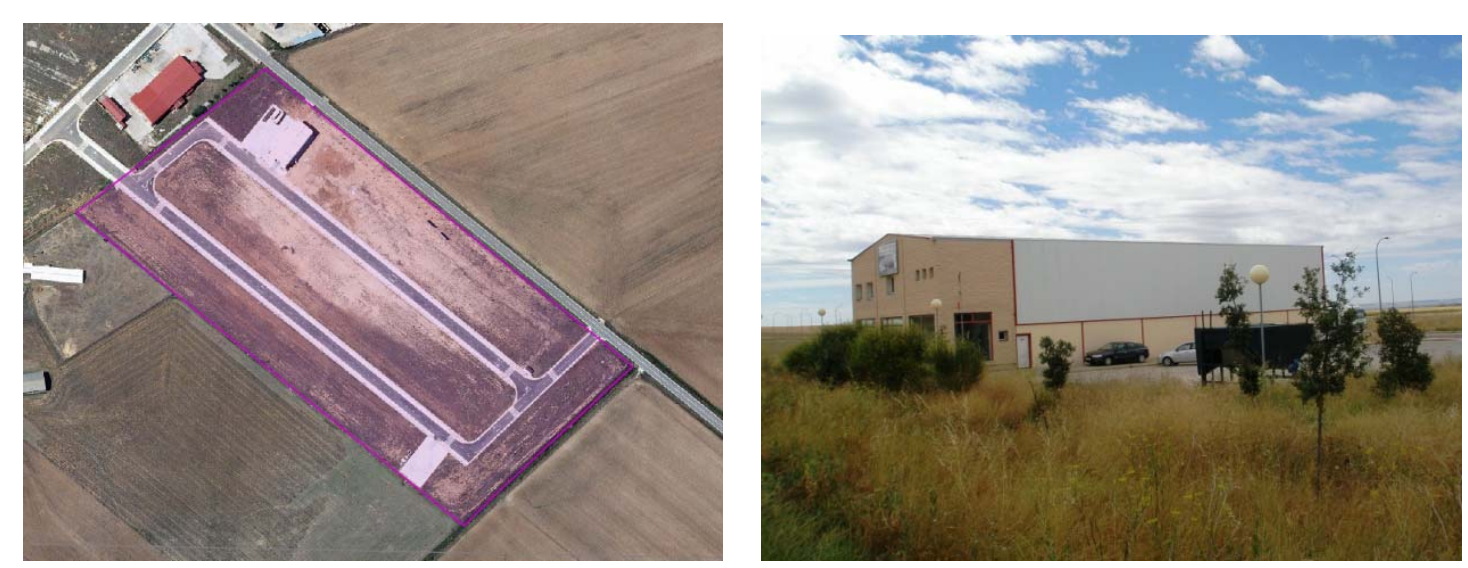

Figura A1.97. Izquierda, ortofotografía de 2011 del polígono industrial; derecha, una de las dos naves instaladas.

En todas las zonas dedicadas a espacio libre público (ELP) se han realizado plantaciones de árboles y arbustos (Figura A1.98). En la franja paralela a la carretera CL-613 se han dispuesto dos filas de encinas (que actualmente poseen una altura de $2,2 \mathrm{~m}$ ) a un marco aproximado de $5 \times 5$ $\mathrm{m}$, mientras que en el medio se ha plantado una fila de retama negra (Spartium junceum), a una distancia de $3 \mathrm{~m}$ (cuya altura actual es de 1,5 m). Puntualmente este arbusto se ha sustituido por jara pringosa (Cistus ladanifer). En el resto de las parcelas de espacio libre público se han plantado encinas a una separación de $5 \mathrm{~m}$.
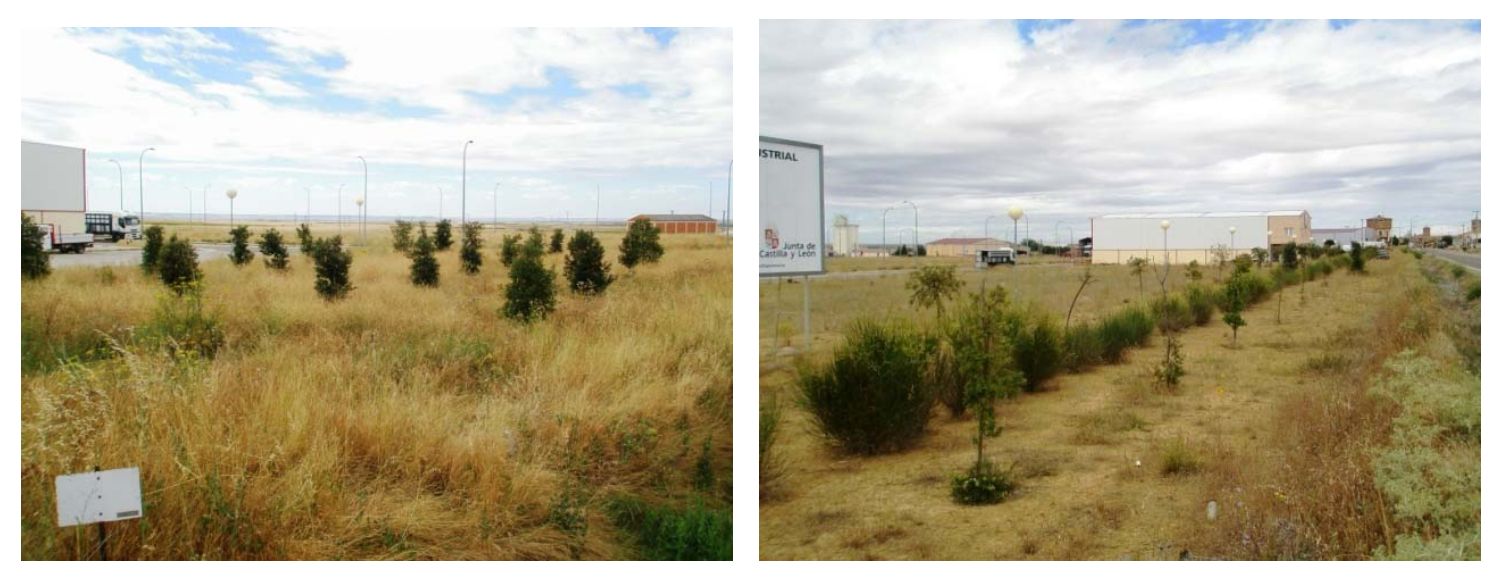

Figura A1.98. Izquierda, encinas en una parcela de ELP cercana al arroyo. Derecha, parcela de ELP paralela a la carretera CL-613.

\section{A1.9.3.2. Conclusiones del seguimiento ambiental.}

Desde el punto de vista de sostenibilidad ambiental e integración paisajística se considera que la alternativa seleccionada por el Plan Parcial para el polígono industrial es acertada. La parcela posee un tamaño proporcionado para esta finalidad, tiene un acceso fácil a través de una carretera autonómica y se encuentra colindante con suelo urbano industrial, por lo que el desarrollo urbanístico es coherente con la lógica de núcleos compactos. 
El Plan Parcial realiza un diseño adecuado de la zonificación interna de usos en el sector. Respeta el arroyo existente al norte del desarrollo urbanístico, como tal vez la preexistencia ambiental más notable de la zona. No contempla un aprovechamiento máximo del uso característico industrial $y$, a la vez, planifica una holgada superficie dedicada a equipamientos públicos y espacios libres públicos.

Los espacios libres públicos están bien trazados desde un punto de vista paisajístico. La superficie más amplia es la ocupada por una franja paralela a la carretera CL-613, con el fin de conformar una pantalla vegetal que amortigüe el impacto visual desde dicha vía. Otra zona está planteada en el entorno del arroyo, con lo que se asegura su protección. Incluso se ha clasificado como ELP alguna otra porción de superficie en el interior del polígono.

Podría haber sido interesante diseñar alcorques en las aceras de los viales y en los aparcamientos (Figura A1.99), con objeto de plantar árboles en forma de alineaciones, aunque su separación fuese elevada (8 o más metros) para ocasionar las menores molestias. La vegetación contribuiría a integrar estos elementos urbanos y mejoraría la calidad estética del conjunto industrial.
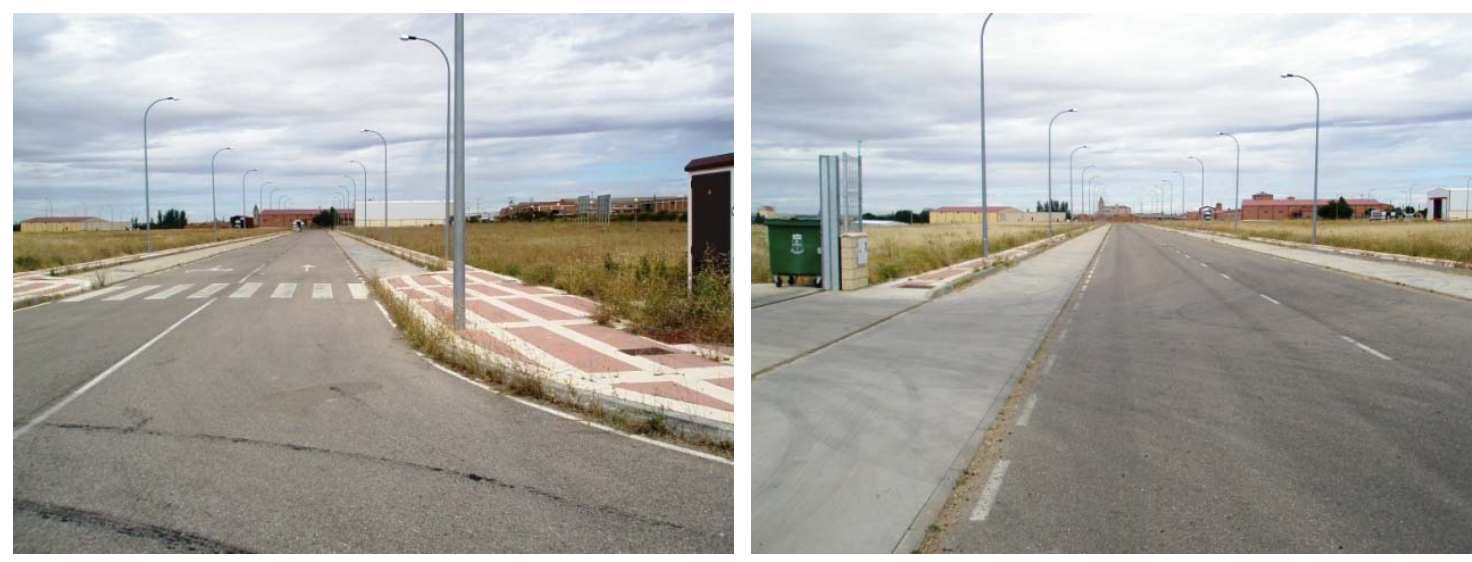

Figura A1.99. Viales que podrían contar con alineaciones de árboles en sus aceras.

No hay constancia de que la tierra vegetal de la parcela se haya separado selectivamente para, posteriormente, ser utilizada en los espacios libres públicos. La cubierta herbácea existente parece predecir que la tierra vegetal fue aportada fundamentalmente en el espacio próximo al arroyo.

No se observa la presencia en el polígono de residuos de construcción y demolición o de otra tipología.

El presupuesto contemplado para jardinería en el Plan Parcial es adecuado, un $7 \%$ del total de la obra. Esta se ha realizado con criterios de rusticidad y paisajismo: no se ha sembrado césped ni flores y, por el contrario, se han plantado árboles y arbustos autóctonos en todos los espacios libres públicos. Afortunadamente no se han elegido las especies propuestas en el Estudio de Impacto Ambiental, muchas de ellas con unos requerimientos ecológicos diferentes a los de esta zona. Habría sido interesante haber instalado un sencillo sistema de riego por goteo en los 
árboles, conectado a la red de abastecimiento del polígono: con un bajo consumo hídrico se aseguraría el arraigo y crecimiento de los vegetales.

No parece que se realice un mantenimiento periódico de las zonas ajardinadas (Figura A1.100). Su diseño no requiere que este sea intenso, pero se deberían llevar a cabo unas labores mínimas: reposición de marras (en torno a un 20 \%), riegos estivales, siega de la vegetación herbácea, etc.
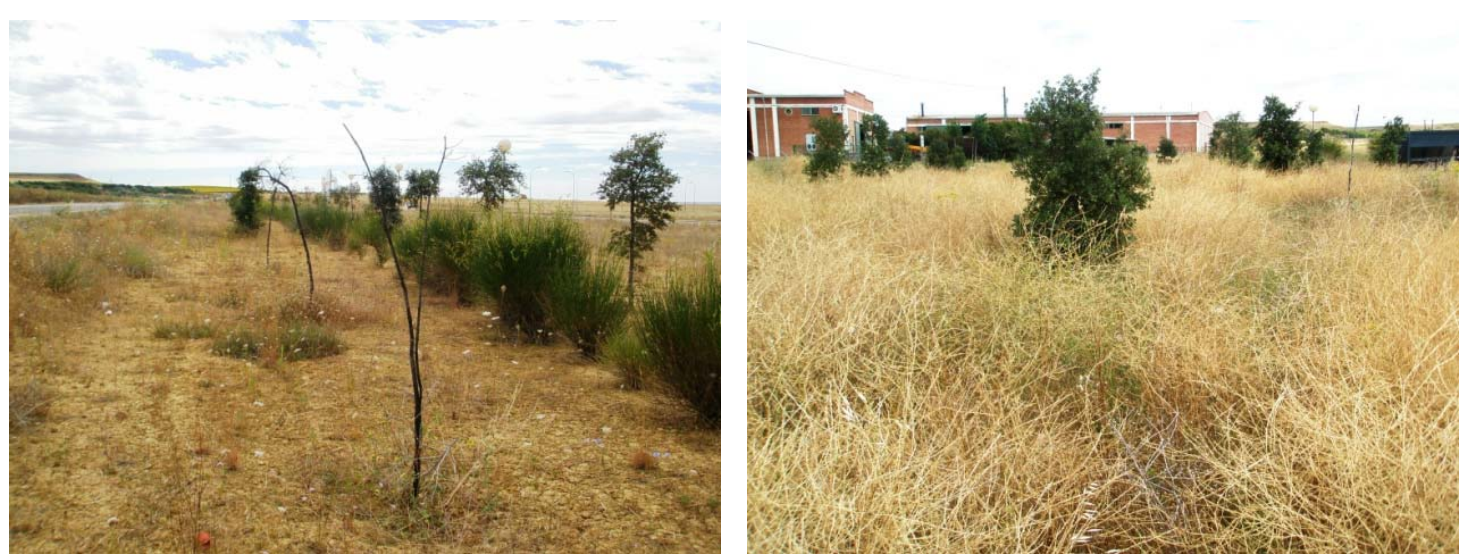

Figura A1.100. Izquierda, marras de encinas; derecha, vegetación herbácea sin segar.

Las únicas dos naves construidas hasta la fecha no generan unos impactos visuales significativos. En esencia cumplen las condiciones estéticas del Plan Parcial, salvo tal vez en la tonalidad de las cubiertas, que es excesivamente clara.

Los anuncios o carteles empleados en las construcciones existentes no son estridentes y su impacto es asumible. No así sucede precisamente con los dos grandes carteles institucionales instalados al lado de la carretera, cuyo impacto visual es notable.

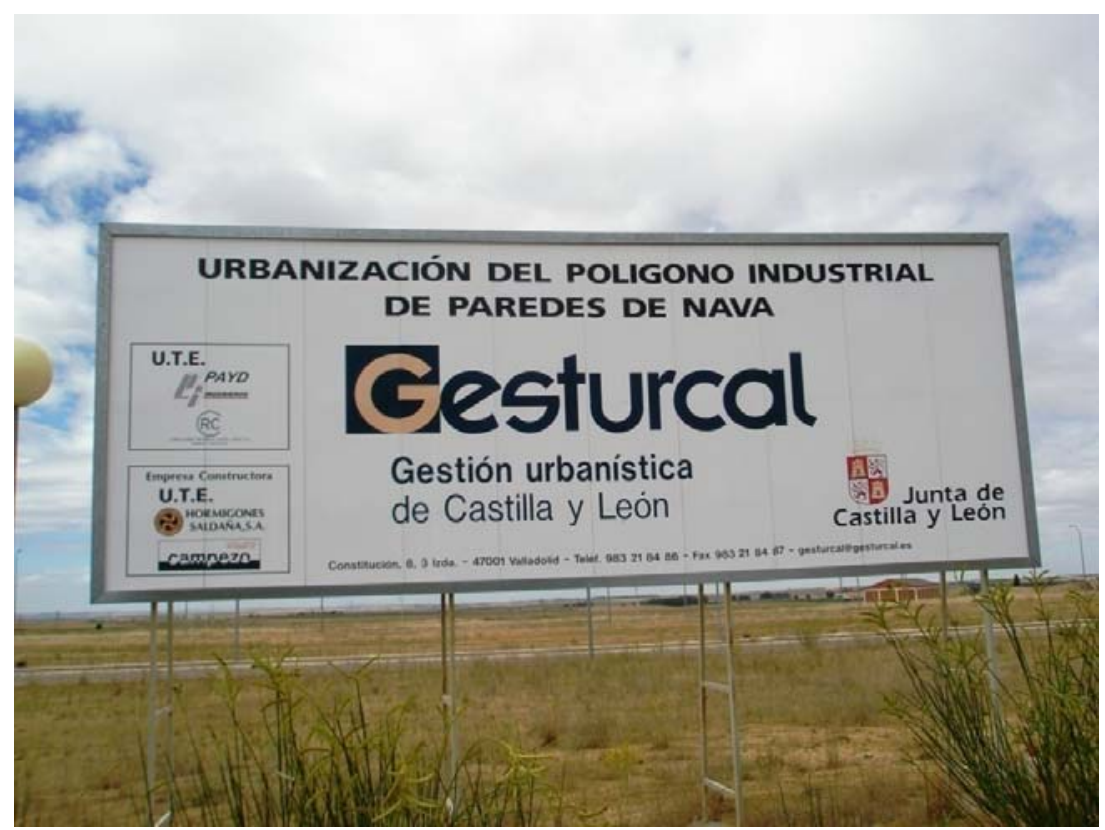

Figura A1.101. Uno de los carteles anunciadores del polígono industrial, situado en una parcela de espacios libres públicos. 


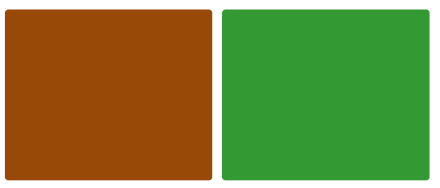

\section{ANEJO 2.}

Proyectos de recuperación ambiental singulares en Tierra de Campos 


\section{A2.1. Realización de plantaciones, construcción de área de descanso y tramo accesible en el Camino de Santiago en la provincia de Palencia}

\section{A2.1.1. Proyecto}

Promotor: Fundación Patrimonio Natural de Castilla y León y Obra Social “La Caixa”

Autores: Ernesto Gómez Carrascal (ingeniero técnico forestal) y Víctor González Báscones (ingeniero de montes)

Director de obra: Víctor González Báscones

Fecha: octubre 2009

El Camino de Santiago es una ruta de peregrinos hacia Santiago de Compostela, que comenzó en la época medieval y actualmente posee una gran importancia por el número de personas que lo transitan, fundamentalmente caminando y, en menor medida, en bicicleta. Ocasionalmente se utilizan caballos u otros medios.

En este proyecto se plantean diversas actuaciones en el tramo del Camino de Santiago francés que atraviesa la provincia de Palencia, con objeto de crear o mejorar las infraestructuras y realizar plantaciones de árboles que permitan a los peregrinos transitar las etapas de una forma más descansada y agradable (Figura A2.1). Hay que tener en cuenta que el Camino atraviesa la provincia por la zona norte de Tierra de Campos, a lo largo de un paisaje agrícola desarbolado, por lo que el calor en la época de verano es el mayor enemigo climatológico de los caminantes. Por consiguiente, tal como se justifica en el proyecto, una de las actuaciones más necesarias en algunos tramos es la plantación de árboles que ayuden a sombrear el Camino y a mejorar el paisaje en el recorrido con la plantación de especies autóctonas.

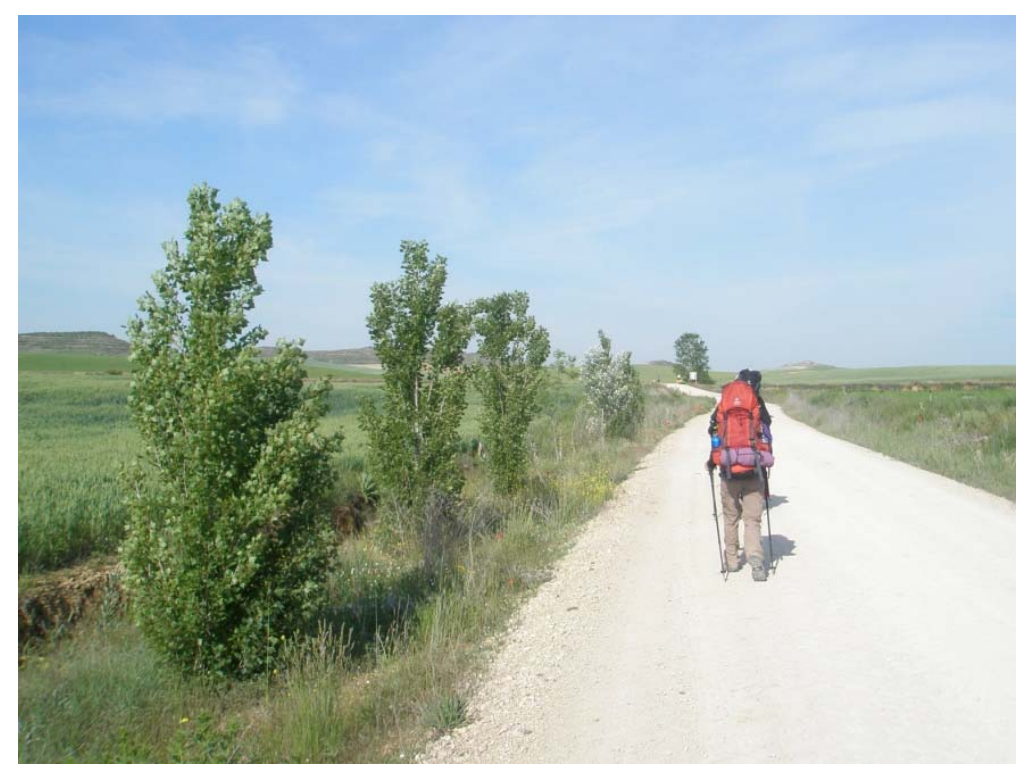

Figura A2.1. Imagen de un peregrino en un tramo de Camino recientemente plantado de árboles. 
Otros objetivos que persigue el proyecto son los siguientes:

- Poner en valor los recursos naturales de Castilla y León y facilitar su conocimiento, mediante su señalización.

- Permitir a personas con diferentes discapacidades poder realizar ciertos tramos del Camino.

- Construcción de un área de descanso nueva, que complemente a las existentes en la actualidad, teniendo en cuenta que las distancias entre pueblos son grandes.

- Incentivar y facilitar la realización del Camino de Santiago a caballo, mediante la instalación de una nave con boxes que complemente a las existentes en diversos pueblos.

La longitud del Camino de Santiago en la provincia de Palencia es de $67 \mathrm{~km}$, y en su recorrido atraviesa 15 términos municipales.

A continuación se describen las actuaciones del proyecto, cuyo presupuesto se resume en la Tabla A2.1:

Plantaciones

En diferentes tramos del recorrido se han planteado zonas donde es posible la plantación de árboles, teniendo en cuenta su dificultad debido a la falta de espacio en los márgenes del camino.

La preparación del terreno se realizará con retroexcavadora, que abrirá un hoyo de 1×1x1 m. La planta tendrá cepellón, excepto la del género Populus. El tamaño de la planta será de $12-14 \mathrm{~cm}$ de perímetro de tronco. En general, la distancia media entre planta será de $8 \mathrm{~m}$. En total se plantarán 2862 árboles. Las plantaciones serán lineales, colocando los árboles en general en el lateral sur del camino. En el momento de la plantación se realizará un alcorque a cada planta y se regará abundantemente. Se incluye un plan de mantenimiento durante dos años con varios riegos mediante un tractor con cuba, así como una bina y una escarda.

Las especies a plantar y el número son los siguientes:

- Álamo blanco (Populus alba): 138

- Álamo temblón (Populus tremula): 138

- Olmo siberiano (Ulmus pumila): 138

- Almez (Celtis australis): 138

- Almendro (Amygdalus communis): 138

- Cerezo (Prunus avium): 138

- Nogal (Juglans regia): 138

- Pino piñonero (Pinus pinea): 138

- Fresno (Fraxinus angustifolia): 138

Durante la ejecución del proyecto se modificó ligeramente la elección de especies, contemplando además encina, quejigo y varios arbustos propios de la zona. 


\section{Tratamientos selvícolas}

En varios puntos del recorrido se han marcado zonas para realizar tratamientos de masas arboladas existentes. Estos tratamientos consistirán en la selección de brotes existentes en los márgenes del camino, la poda del arbolado existente, la eliminación de arbolado muerto y la trituración de los restos. Se presupuestan un total de 1,82 ha.

\section{Mantenimiento}

En los dos años siguientes a la plantación se realizará un mantenimiento de la plantación realizada, consistente en 14 riegos mediante tractor con cuba y un peón que manejará una manguera, para aportar aproximadamente 50 I por planta en cada riego. Anualmente se procederá a realizar una bina y una escarda de $1 \mathrm{~m}^{2}$ alrededor de cada árbol plantado, remarcando el alcorque inicial.

\section{Área de descanso}

El área de descanso está situado en el límite de los términos municipales de Carrión de los Condes y Calzadilla de la Cueza. Se proyecta un pequeño cobertizo para resguardo de los peregrinos, de $28 \mathrm{~m}^{2}$ de superficie y $3,45 \mathrm{~m}$ de altura. La estructura se diseña mediante seis pilares verticales de acero situados dentro de un muro de piedra, prolongados en la parte superior con postes de madera laminada. Se colocarán vigas y viguetas en madera laminada. La cubierta, a dos aguas, se realiza con tablas de madera machihembrada cubierta con teja cerámica curva.

También se prevé la construcción de dos bancos-tumbonas, así como la plantación de 16 árboles de sombra.

\section{Tramo accesible}

Este tramo está ubicado entre las poblaciones de Frómista y Población de Campos. A la salida del primer núcleo se acondicionará un aparcamiento señalizado con plazas para discapacitados. Desde el aparcamiento se proyecta una senda accesible de $2,8 \mathrm{~km}$ de longitud para los discapacitados visuales, con un firme terrizo adecuado, bordillos delimitadores con rollizos de madera y bancos en diferentes puntos.

\section{Cartelería}

Se colocarán carteles interpretativos y señales en el aparcamiento y en el paso por la Red Natura 2000.

\section{Naves con boxes para caballos}

Se construirá una nave de $109 \mathrm{~m}^{2}$ de superficie, donde se ubicarán 12 boxes para caballos. La estructura se realizará a base de perfiles metálicos y la terminación exterior será con madera natural de pino tratada en autoclave. La cubierta se dispondrá con chapa sándwich rematada con teja cerámica curva. 
Tabla A2.1. Resumen del presupuesto de ejecución material del proyecto

\begin{tabular}{|c|c|c|}
\hline CAPÍTULO & EUROS & $\%$ \\
\hline PLANTACIONES ÁRBOLES & 93508 & 32,84 \\
\hline Plantaciones & 71138 & \\
\hline Tratamientos selvícolas & 7018 & \\
\hline Mantenimiento & 15353 & \\
\hline ÁREA DE DESCANSO & 22829 & 8,02 \\
\hline Demoliciones y acondicionamiento terreno & 1368 & \\
\hline Obra civil & 19420 & \\
\hline Plantaciones & 1651 & \\
\hline Árboles & 390 & \\
\hline TRAMO ACCESIBLE & 82467 & 28,97 \\
\hline Mejora de firme & 26999 & \\
\hline Límites pavimentos & 51268 & \\
\hline Mobiliario & 3693 & \\
\hline Aparcamiento & 507 & \\
\hline CARTELERÍA & 12309 & 4,32 \\
\hline Señalización & 9323 & \\
\hline Cartel de obra & 2986 & \\
\hline NAVE CON BOXES & 69099 & 24,27 \\
\hline Nave prefabricada de madera & 66702 & \\
\hline Instalaciones & 2397 & \\
\hline SEGURIDAD Y SALUD & 4484 & 1,57 \\
\hline Instalaciones & 1609 & \\
\hline Equipos protección colectivas & 1083 & \\
\hline Equipos protección individual & 1791 & \\
\hline PRESUPUESTO DE EJECUCIÓN MATERIAL & 284696 & \\
\hline
\end{tabular}




\section{A2.1.2. Seguimiento ambiental}

Tal como se señala en los antecedentes del proyecto, el tránsito del Camino de Santiago por la provincia de Palencia (coincidente con la comarca de Tierra de Campos) es extremadamente duro en verano, por la escasez de zonas arboladas que proporcionen sombra o frescor al caminante. Además, en la época estival los cultivos cerealistas se encuentran en fase de rastrojo, por lo que el paisaje se manifiesta netamente uniforme y árido. No en vano, como desafortunada curiosidad cabe citar que una guía turística del Camino editada en Estados Unidos aconseja realizar todo este tramo en autocar. Debido a la necesidad de arbolado en esta ruta histórica tan transitada surge este proyecto que, en sus inicios (incluso con otro nombre, "Árboles del Camino"), pretendía llevar a cabo este objetivo de manera prioritaria. Distintos aconteceres diversificaron esta finalidad por lo que, al final, el capítulo dedicado a plantaciones en el presupuesto de ejecución material apenas alcanza el $33 \%$. Sin pretender juzgar la bondad del resto de actuaciones, se considera desacertado el hecho de no tratar como prioritaria la restauración con árboles en los márgenes del Camino, teniendo además en cuenta que al final solo se ha plantado una pequeña proporción de la longitud desarbolada.

En la línea del argumento anterior cabe apuntar que, transcurridos varios años desde su ejecución, las naves para boxes de caballos -que representan el 24 \% del proyecto de ejecución material- aún no están en uso por desacuerdos en la titularidad de la gestión (A2.2).

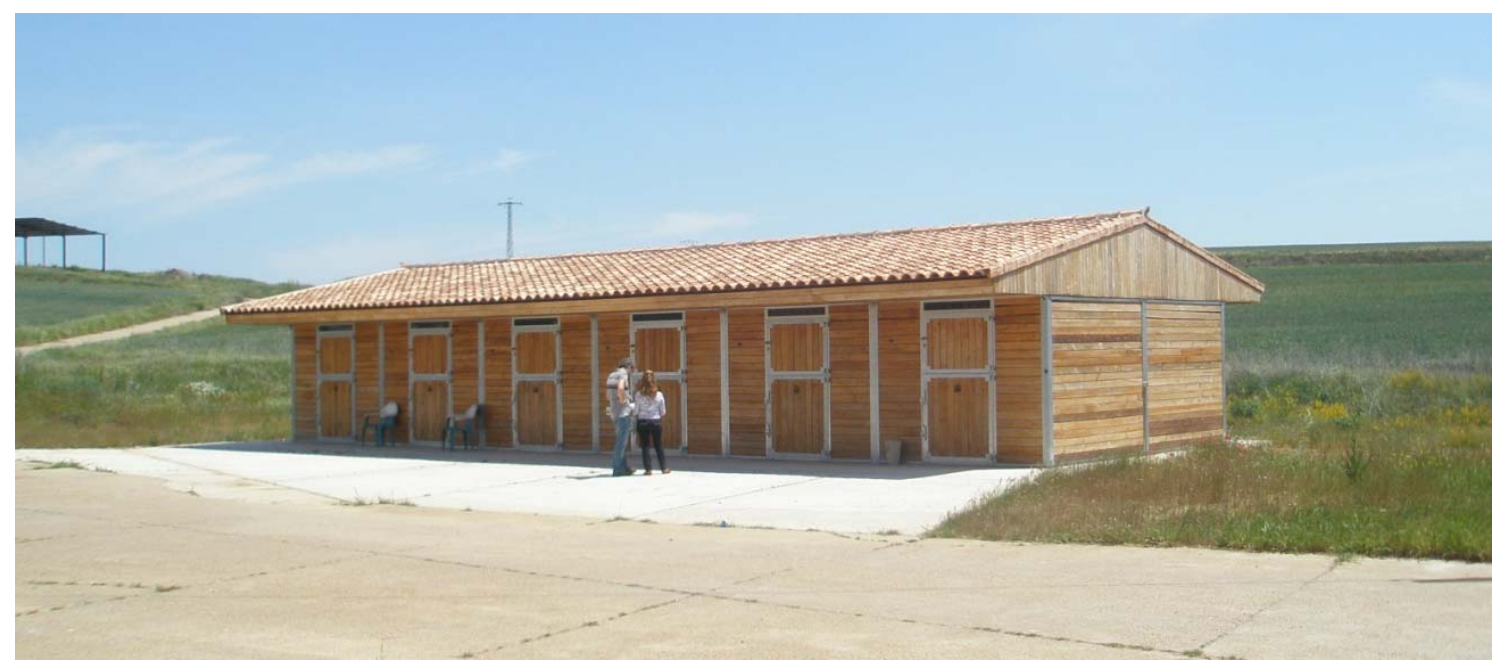

Figura A2.2. Nave para boxes de caballos cerrada. Al menos, se consiguió la integración paisajística de la construcción, de acuerdo a las prescripciones de la Comisión Territorial de Patrimonio.

El área de descanso ubicado entre Carrión de los Condes y Calzadilla de la Cueza (Figura A2.3) se ha construido con un diseño austero y con gran sensibilidad y respeto hacia la arquitectura tradicional de Tierra de Campos, empleando adobes para las paredes y teja árabe para la cubierta. 

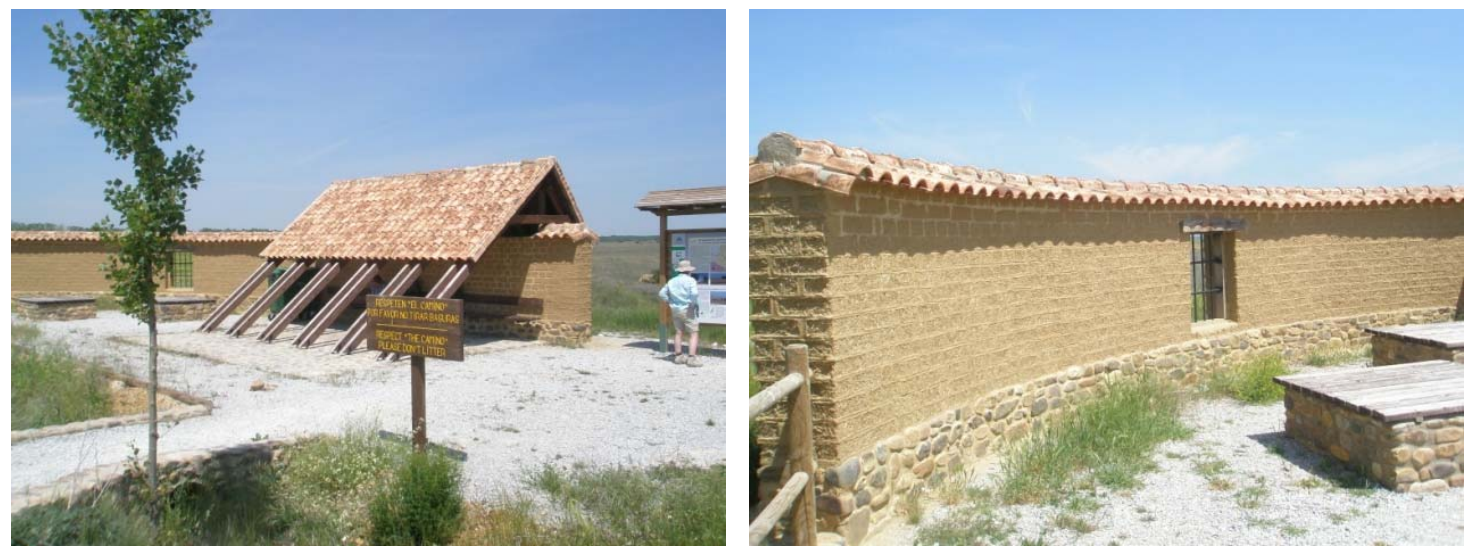

Figura A2.3. Dos imágenes del área de descanso poco después de su ejecución. Dentro de una concepción contemporánea del diseño, se han integrado en la construcción materiales típicos de la arquitectura tradicional de Tierra de Campo: bolos de grava para el zócalo, adobe en los paramentos, madera y teja árabe en la cubierta.

Sin embargo, para esta actuación, así como para otras similares a lo largo del Camino, se debe tener en cuenta siempre el mantenimiento futuro; en este caso la limpieza de basuras (Figura A2.4), el tratamiento de la madera y la protección de los adobes frente a la lluvia. Es algo que se debería asegurar en todos los proyectos de estas características.

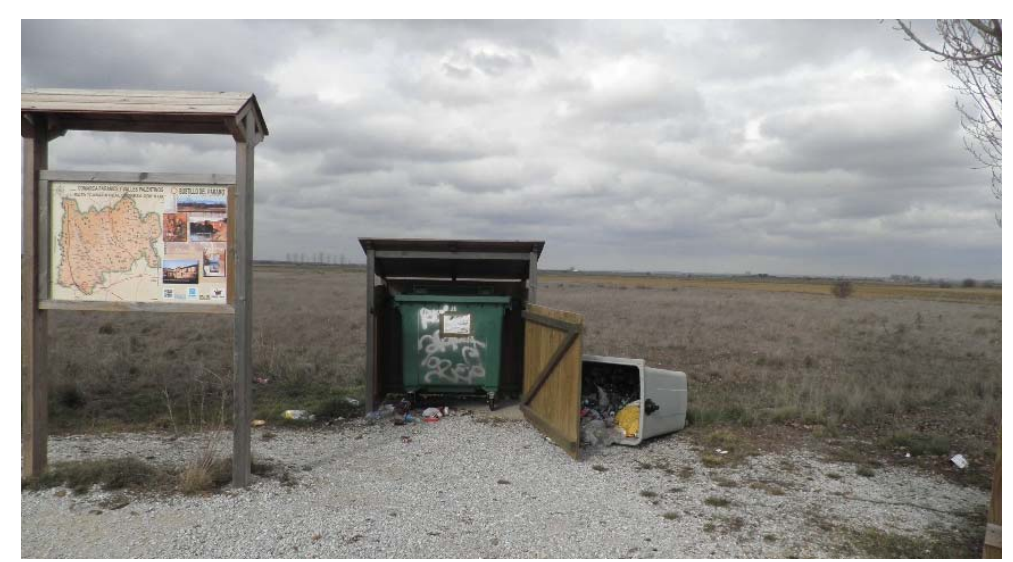

Figura A2.4. Por desgracia, la ausencia de mantenimiento provoca situaciones desagradables como la de la imagen, donde se aprecia la acumulación de residuos sin recoger de los contenedores.

La construcción del tramo accesible deriva del compromiso de la Obra Social "La Caixa" con los discapacitados, en este caso visuales, actuación que en sí ha de ser valorada positivamente. Ahora bien, su coste elevado (supone el $29 \%$ del proyecto) debería exigir un uso permanente mínimo, algo que se habrá de comprobar en el futuro. También en este caso se debe contemplar su mantenimiento y promoción, algo que se debiera prever ya en el proyecto. 


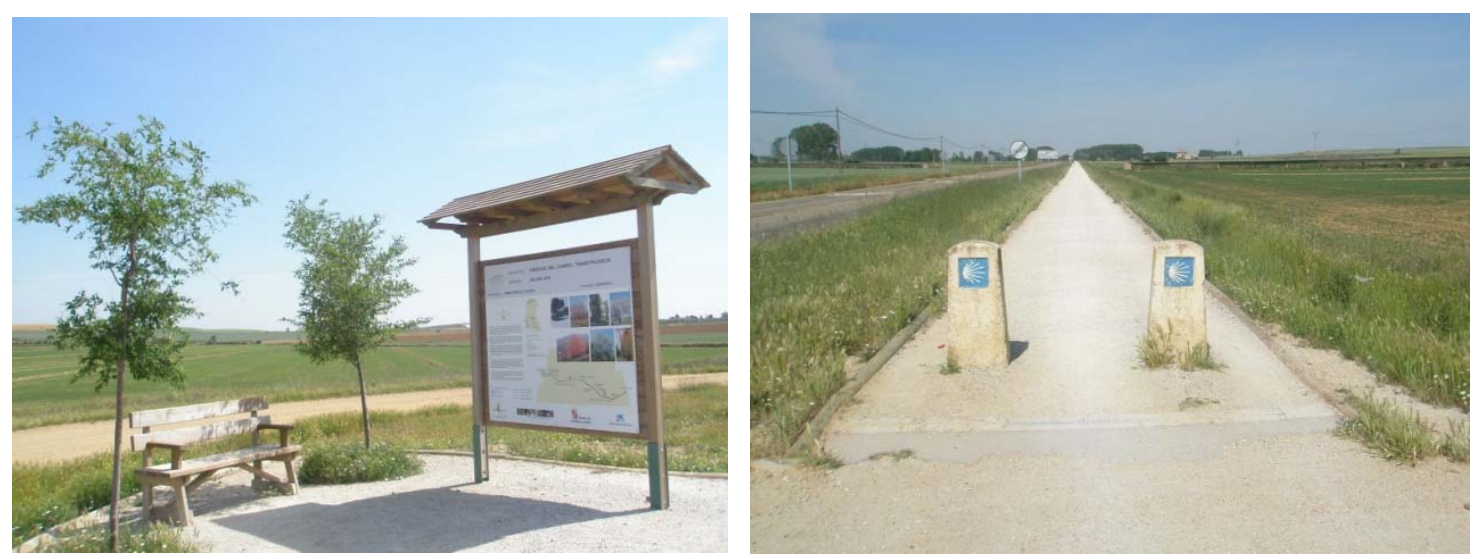

Figura A2.5. Dos imágenes del tramo accesible. A la izquierda, un detalle del acceso con un pequeño área estancial. A la derecha, tramo del Camino limitado con rollizos de madera.

En esta zona, el Camino de Santiago discurre en muchas ocasiones de forma paralela a carreteras de cierto tránsito. Ello hace que sea molesto para el viajero y genere un entorno paisajístico de baja calidad (Figura A2.6). Para reducir estos efectos la vegetación puede jugar un importante papel pero, lamentablemente, la Consejería de Fomento de la Junta de Castilla y León no permitió las plantaciones en la zona de afección de estas vías. Se estima que esta decisión es totalmente desacertada ya que -aunque se base en aspectos reglamentarios- siempre puede haber soluciones que compatibilicen la implantación vegetal con la seguridad viaria: arbolado de bajo porte, arbustos, ubicación alejada de la carretera, etc. Es algo que, a buen seguro, no entenderán los miles de caminantes extranjeros que visitan esta ruta histórica.

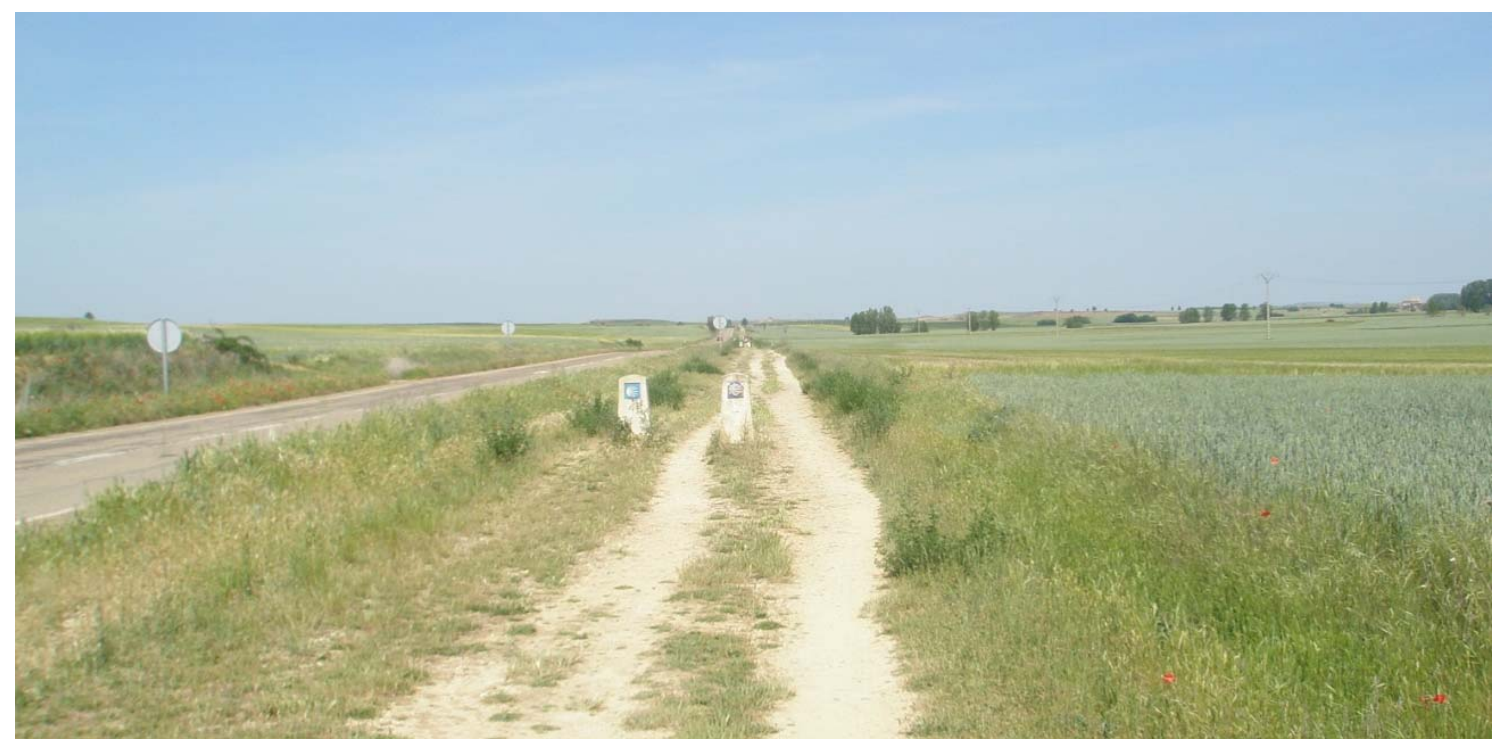

Figura A2.6. Vista de un tramo del Camino que discurre paralelo a una carretera autonómica. La sensación para el caminante es desoladora: sin un árbol en kilómetros y con la compañía del ruido de los coches. 
En cuanto a las plantaciones, en este proyecto se ha optado por tratar de asegurar su viabilidad, de modo que el coste unitario presupuestado ( $28 €$ /unidad) permite asegurar una buena calidad de planta, adecuada preparación del terreno (los hoyos llegaron incluso a los $2 \mathrm{~m}$ ) y realización de labores culturales. También se han contemplado importantes partidas para el mantenimiento durante dos años, lo cual es positivo y ha traído como consecuencia que el porcentaje de marras sea reducido (inferior al $20 \%$ ).

Las plantaciones se realizaron en marzo de 2010, un poco al límite del periodo posible. Se considera que en Tierra de Campos - debido a la larga sequía estival- es conveniente adelantar la revegetación a finales de otoño, evitando en cualquier caso los días de helada.

Para la preparación del terreno se utilizó máquina retroexcavadora con cazo, que abría un hoyo y rellenaba el anterior. Dos operarios se encargaban de la colocación del árbol y la realización del alcorque (Figura A2.7).
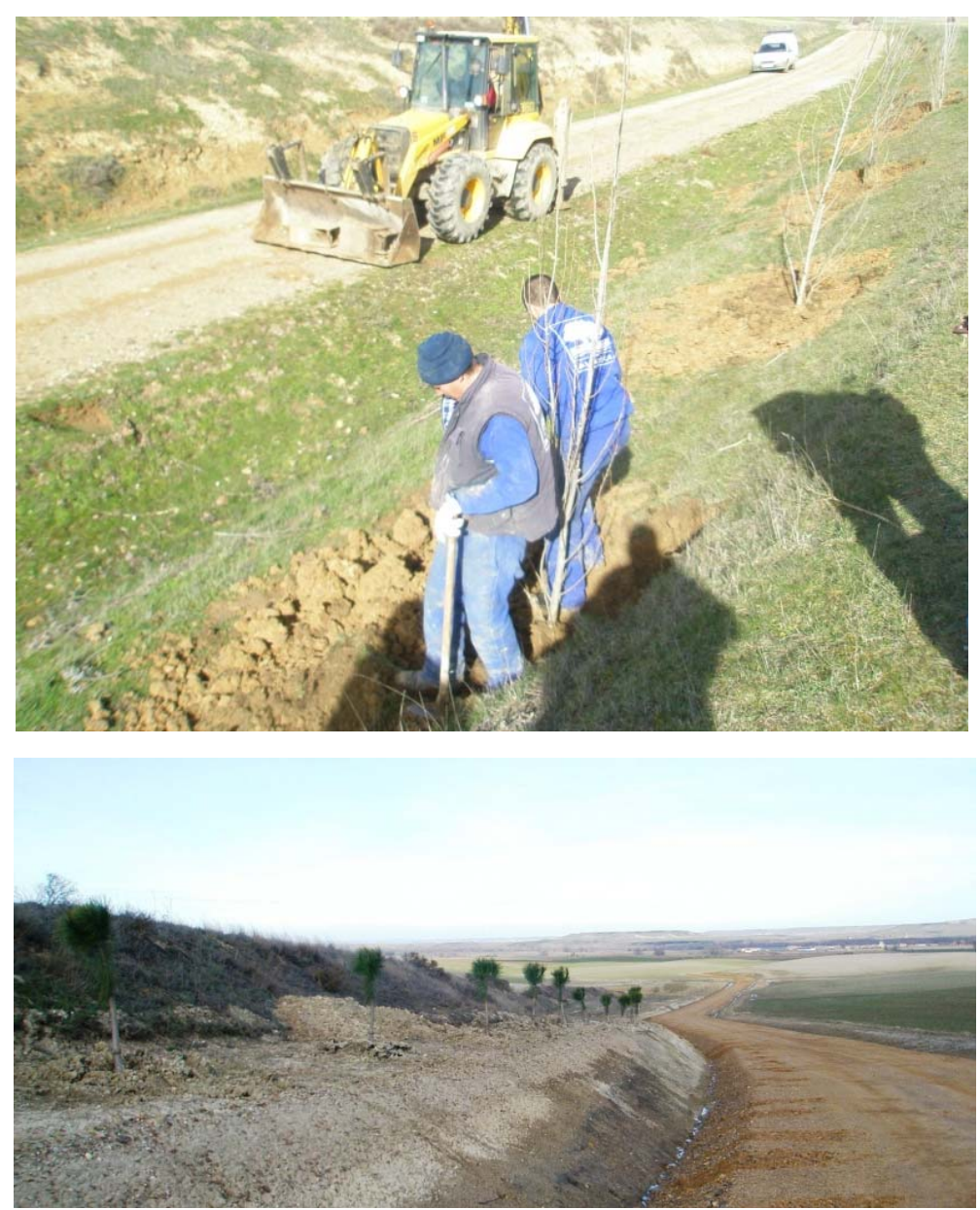

Figura A2.7. En la imagen superior se observa la máquina y operarios realizando la implantación. En la inferior se visualiza una fila de pinos piñoneros con el alcorque realizado. 
Dentro de las especies seleccionadas, durante la ejecución se diferenciaron las zonas secas (pino piñonero, almendro, encina, etc.) de las húmedas (chopo, álamo, fresno), lo cual es una garantía de éxito de la plantación.

En el capítulo de plantaciones vegetales también se incluyó una actuación de tratamientos selvícolas de rodales arbolados existentes descuidados. En estos casos se realizaron resalveos y poda de los mejores ejemplares, que han redundado en la mejora estética de estos enclaves y a buen seguro en su mayor crecimiento (Figura A2.8).

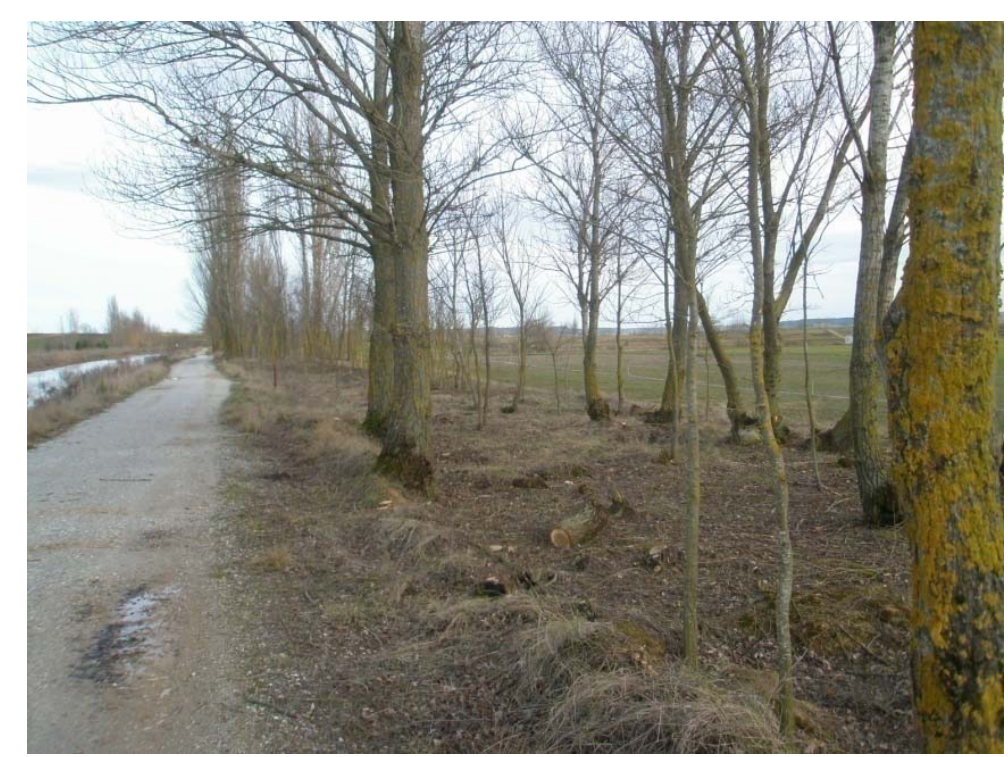

Figura A2.8. Rodal de olmos y chopos donde se han eliminado los pies defectuosos y se han podado los mejores ejemplares. En este tramo, el Camino discurre paralelo al Canal de Castilla, lo que proporciona un atractivo adicional.

Uno de los mayores problemas de este proyecto ha radicado en la dificultad para encontrar zonas susceptibles de plantación, ya que en muchos tramos las parcelas agrícolas llegan hasta el Camino y el cultivo se apura al máximo. Una buena solución sería planificar las concentraciones parcelarias de modo que se clasifiquen como públicas franjas paralelas al Camino. De no darse esta situación se deberían agotar todas las posibilidades para conseguir que se pueda implantar la mayor vegetación posible: llegando a acuerdos con los propietarios colindantes, plantando en todos los taludes existentes en los márgenes del Camino, introduciendo también arbustos, etc. No hay que olvidar que el Camino de Santiago es un proyecto turístico/cultural de primer orden para el territorio que atraviesa. Una comarca tan desfavorecida como Tierra de Campos no se puede permitir el lujo de dar una mala imagen al caminante (Figura A2.9). 

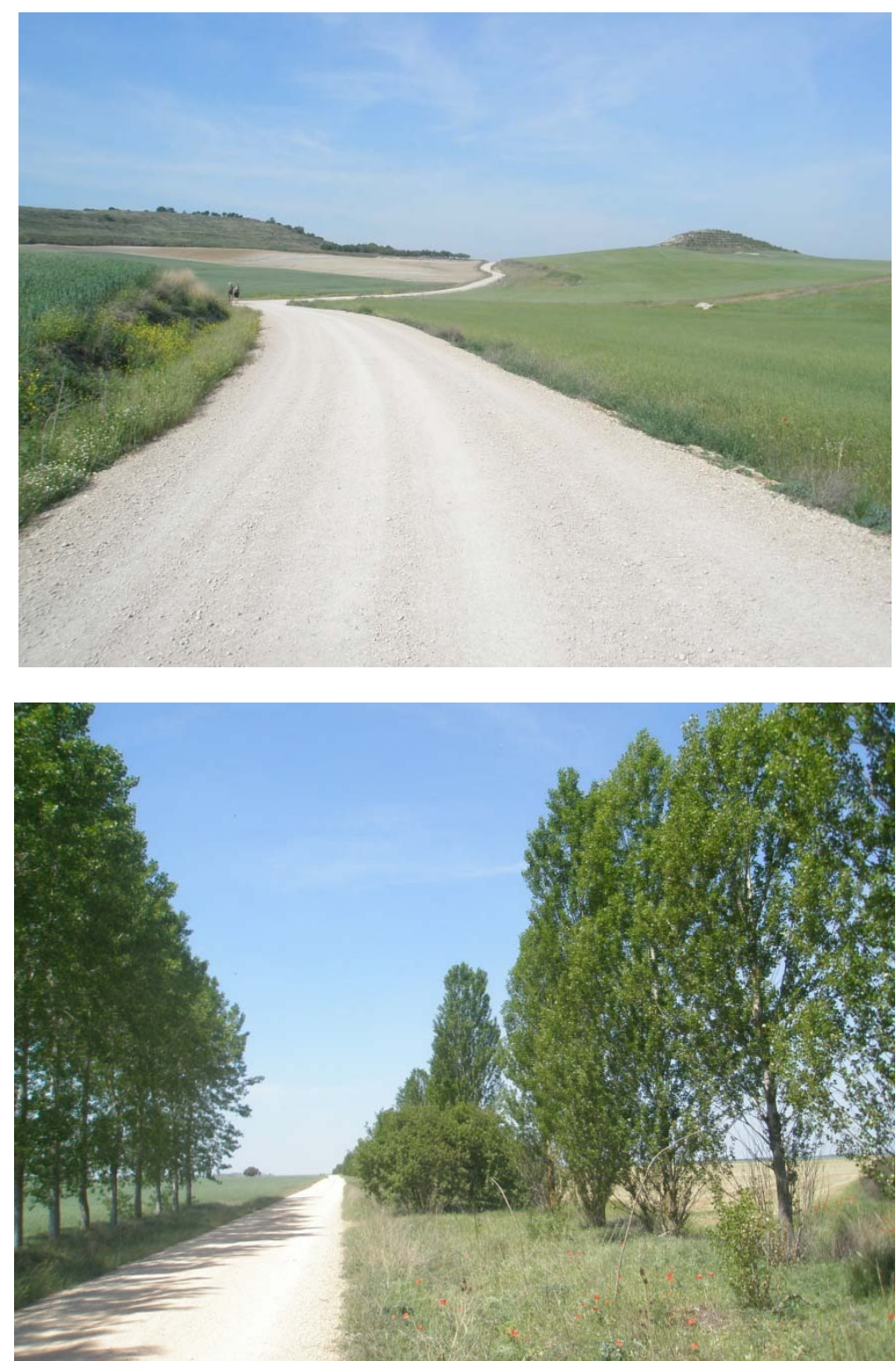

Figura A2.9. La diferencia entre las imágenes superior e inferior solo se encuentra en los árboles del Camino. El paisaje agrícola adyacente es el mismo, pero el valor añadido que aporta la vegetación a su calidad es indudable.

Aunque, tal como se ha reseñado, el proyecto puede ser mejorable en diferentes aspectos, lo cierto es que conlleva unos beneficios notables sobre el paisaje de Tierra de Campos. En primer lugar, es indudable la mejora del paisaje visual -tanto extrínseco al Camino como, sobre todo, intrínseco al mismo-, representa la creación de un corredor lineal ecológico (aunque esté muy humanizado) y, finalmente, contribuye a valorizar sin ninguna duda el paisaje de la comarca a través de esta ruta milenaria. 


\section{A2.2. Repoblación forestal en una parcela sobrante de vía pecuaria, en el término municipal de Herrín de Campos.}

\section{A2.2.1. Proyecto}

Promotor: Consejería de Medio Ambiente. Junta de Castilla y León

Fecha: 1994

El terreno objeto de la actuación fue el situado en la actual parcela 69 del polígono 202 del término municipal de Herrín de Campos, propiedad de la Consejería de Fomento y Medio Ambiente de la Junta de Castilla y León, sobre una superficie aproximada de 8 ha (Figura A2.10). Se trata de una parcela de reemplazo de las denominadas sobrantes de vías pecuarias, obtenida como consecuencia de la eliminación o reducción de la anchura de las vías pecuarias en muchos términos municipales. La reconcentración parcelaria que está afectando a este y otros tres términos más adyacentes, ha añadido una pequeña zona colindante, de modo que ahora cuenta con 8,81 ha. Está situada a una distancia de $1 \mathrm{~km}$ al Este del casco urbano, entre el camino y la carretera que se dirige a Guaza de Campos. En el terreno se pueden distinguir dos zonas: una central de menor extensión más elevada, en forma de teso poco pronunciado y de menor calidad edáfica, y otra hacia el norte y sur de la parcela, ligeramente en vaguada y cuyos suelos tienen mejor calidad. Una parte de esta última es más húmeda y ya contaba con varios ejemplares de chopos y álamos.

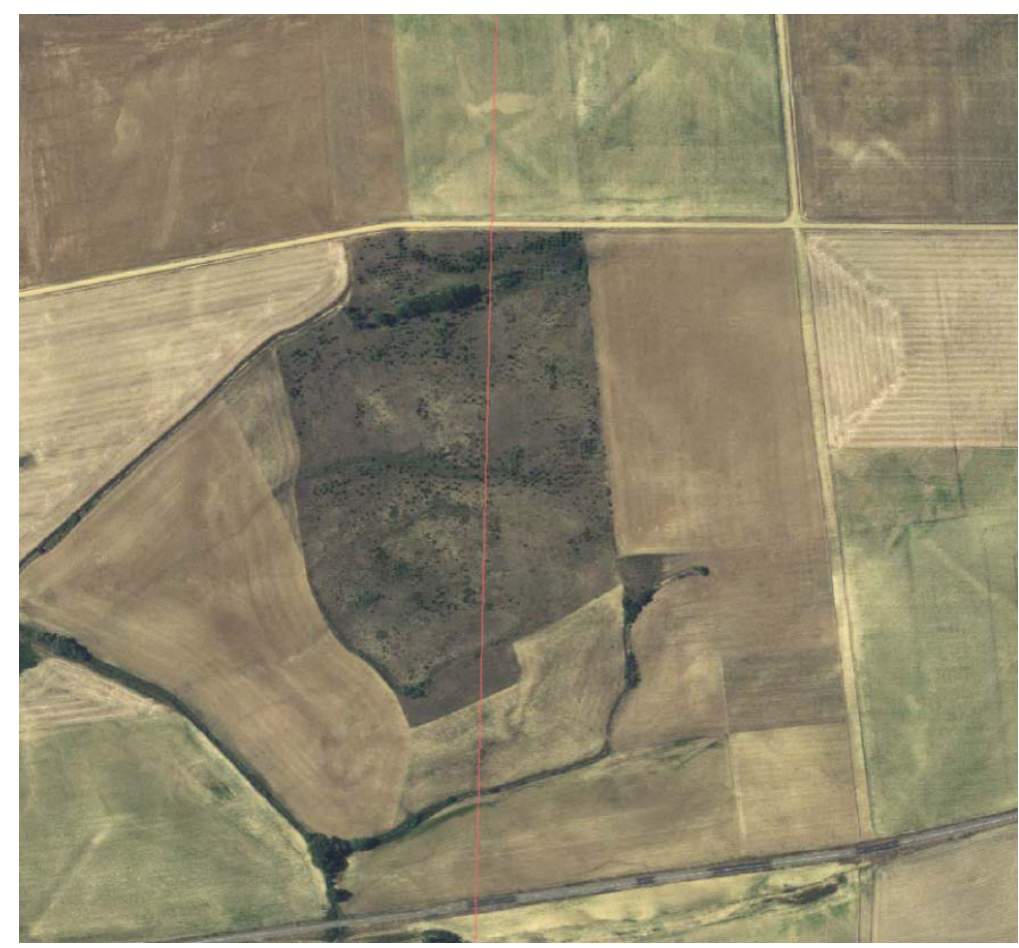

Figura A2.10. Ortofotografía de 2011 en la que se aprecia la parcela repoblada inmersa en terrenos agrícolas. 
Con cargo a presupuestos propios de la Consejería, hace 20 años se realizó una repoblación forestal en esta parcela (Figura A2.11), con una finalidad básicamente de protección de la naturaleza -ecológica y paisajística- teniendo en cuenta la escasez de zonas arboladas de Tierra de Campos. Como objetivo secundario se situaba la producción de piñón. El método de preparación del terreno fue el subsolado lineal, realizado mediante buldócer con rejones situados a una distancia de $3 \mathrm{~m}$, con una profundidad de $40 \mathrm{~cm}$. La distancia de plantación aproximada en cada calle era de 2,5, con lo que la densidad inicial fue de 1300 pies/ha.

Las especies utilizadas y los porcentajes estimados fueron pino piñonero (65\%), encina (20\%), almendro (5\%), gayomba (5\%) y romero (5\%). La planta era de una savia en envase forestal y su introducción en el suelo se realizó de forma manual, con azada. Las dos primeras especies se mezclaron en superficie y las tres restantes se plantaron en los bordes y por rodales. Las reposiciones de marras posteriores se centraron en la zona más elevada y trataron de seguir esta pauta.

No se han realizado cuidados culturales o de mantenimiento posteriores a la plantación.

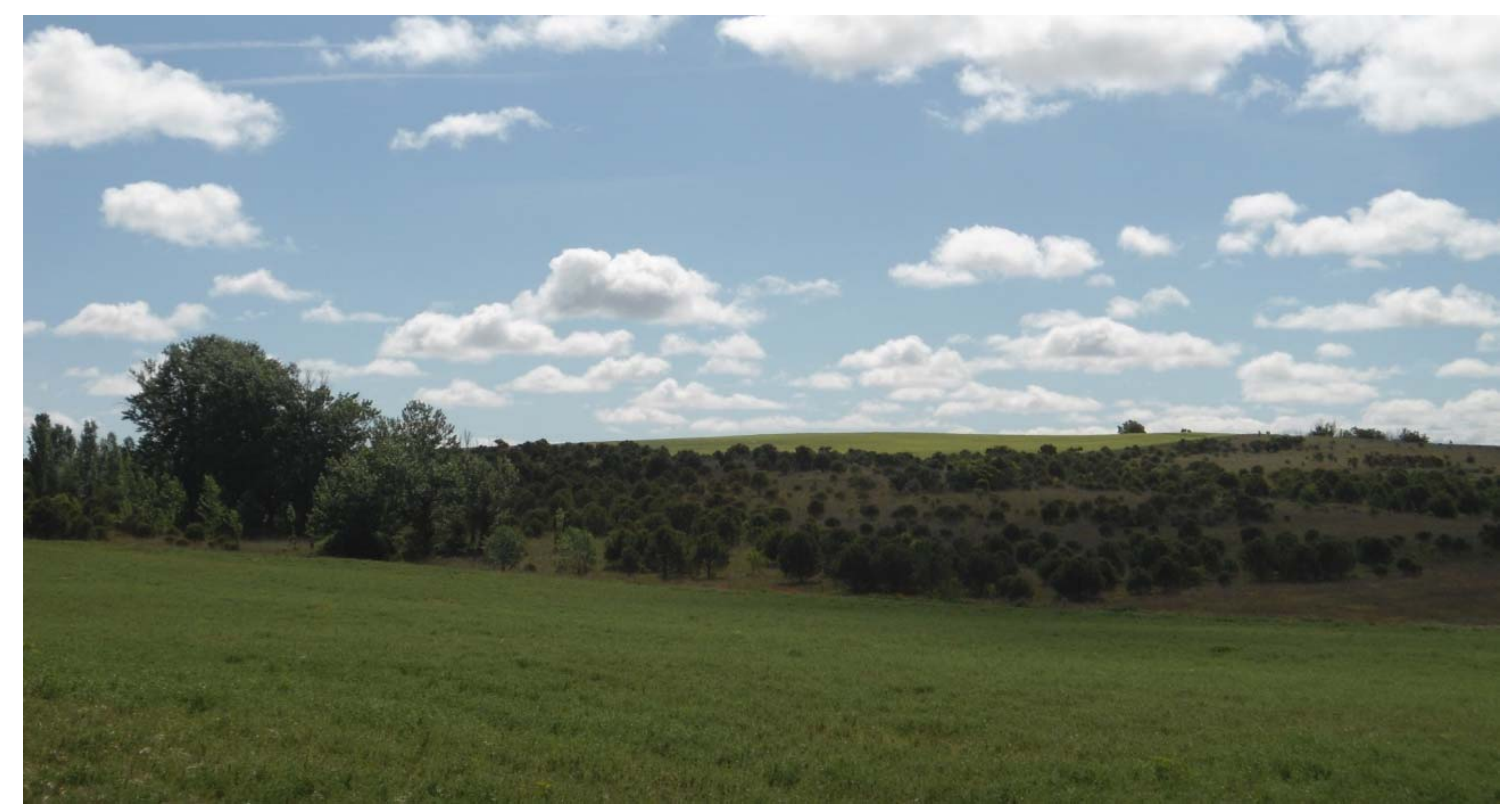

Figura A2.11. Vista general de la parcela desde el camino de acceso.

\section{A2.2.2. Seguimiento ambiental}

La repoblación forestal ha cumplido en general los objetivos previstos, encontrándose los terrenos cubiertos prácticamente en su totalidad de una cubierta vegetal arbórea y arbustiva. Se estima la densidad media de la parcela en 800 pies/ha. La parcela arbolada es visible desde la carretera de Herrín de Campos a Guaza de Campos y desde varios caminos rurales, contribuyendo a aumentar la diversidad del paisaje de la zona. Por otra parte, se ha creado un hábitat (mancha, en el lenguaje de ecología de paisaje) variado constituido por una serie de especies vegetales autóctonas o propias de la zona, que a su vez es refugio de numerosas especies de fauna. 
La elección de especies ha sido correcta, con una proporción adecuada a los resultados previsibles. En teoría, el pino piñonero es el árbol más rústico, propio de la zona y adaptado a condiciones desfavorables; el almendro es otra especie propia de la zona que sobre todo contribuye a proporcionar diversidad cromática; la encina es la especie autóctona, de menor crecimiento pero que a largo plazo debería ser la principal.

Se observa que la especie arbórea que tiene mejor desarrollo es el pino piñonero, después el almendro y posteriormente la encina. Gayomba y romero presentan similar comportamiento, aunque el porte de la primera y su crecimiento inicial es notablemente superior.

En la zona elevada (Figura A2.12) el porcentaje de marras ha sido más cuantioso y, en consecuencia, la densidad es menor, que se estima en 600 pies/ha. Asimismo también es inferior la altura del arbolado; la del pino piñonero es de 1,5 m, mientras que la de la encina es 0,5 m. La causa probablemente provenga de la menor calidad edáfica debida a los procesos de erosión sufridos después de siglos de cultivo agrícola.

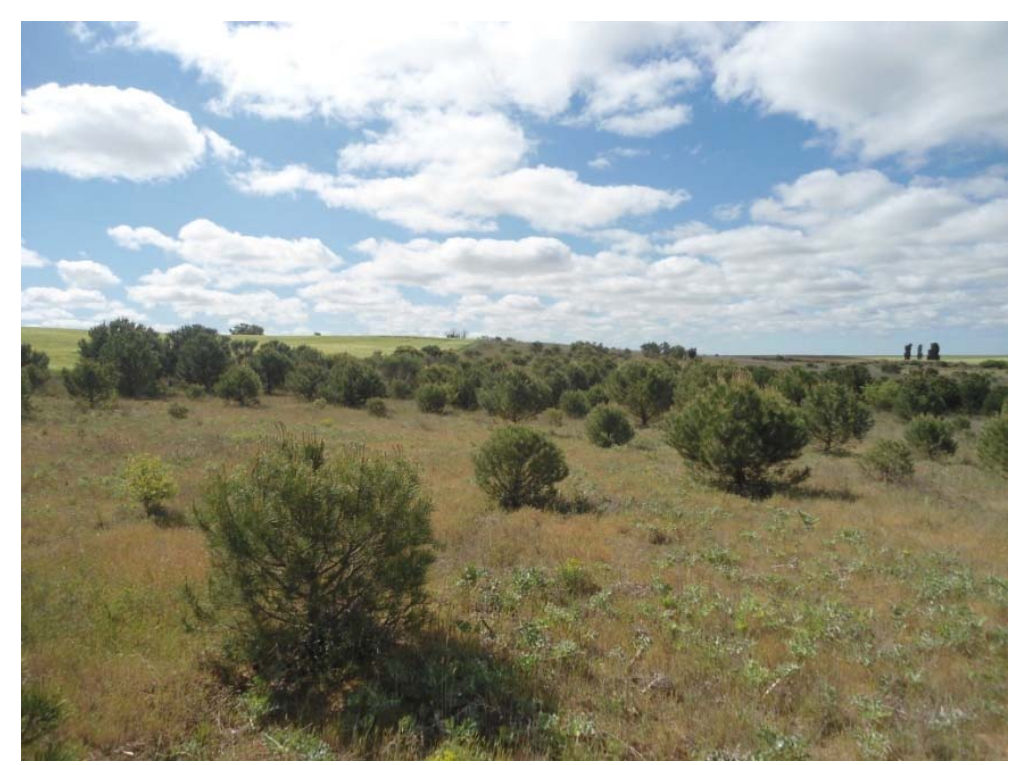

Figura A2.12. Imagen de la zona más elevada de la parcela, con arbolado de menor porte.

Las zonas inferiores (Figura A2.13) presentan una elevada cobertura; la densidad se puede estimar en 900 pies/ha. La altura media del pino piñonero es de 3,5 m, mientras que la de la encina es de 0,8 m. Al contrario de la zona elevada, esta se ha beneficiado de los procesos de erosión y sus suelos son mejores. 


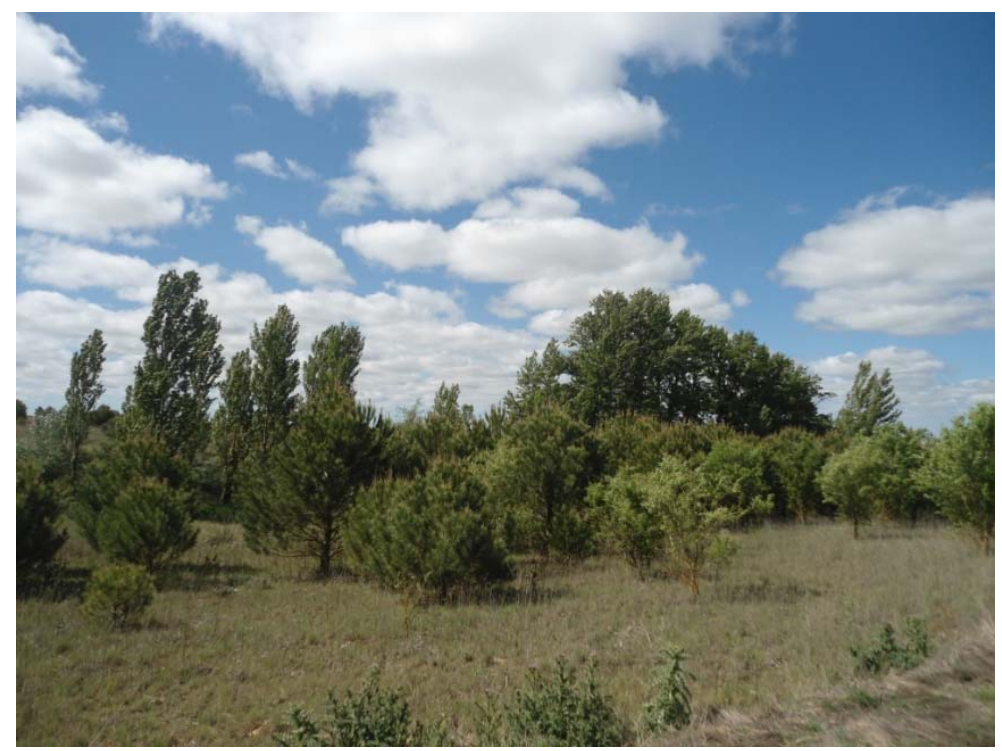

Figura A2.13. Vista de una parte de la zona baja. Al fondo se pueden apreciar ejemplares de chopos y álamos de los que se conservaron previamente.

Los terrenos están teniendo una muy buena regeneración de especies arbustivas autóctonas como endrino, escaramujo o espino albar, que mejoran la diversidad de la zona forestada. También se puede apreciar regeneración natural de chopos y álamos en la zona más fresca.

La densidad de plantación ha sido probablemente demasiado elevada. Es cierto que esta fue una de las primeras repoblaciones forestales de las campiñas de Campos y, por tanto, se pretendió asegurar la total cobertura vegetal. Ahora bien, con los resultados obtenidos tanto en esta como en otras actuaciones similares, la densidad podría reducirse a los 800 pies/ha.

Ya se podría realizar un primer tratamiento selvícola de la masa vegetal situada en las zonas bajas, incluyéndose la corta de los ejemplares de peor conformación hasta llegar a una densidad de 400-500 pies/ha, la poda de los que permanezcan en un $50 \%$ de su altura y la eliminación de los restos mediante su trituración. No deben tocarse las encinas ni los arbustos.

En el terreno añadido en la reconcentración parcelaria se debería realizar una plantación similar a la ya ejecutada en el resto de la parcela. En tanto en cuanto no se lleve a cabo, es conveniente delimitar la propiedad con una pequeña cuneta para evitar intrusiones.

Se deberían retirar los pequeños depósitos de residuos existentes en algún punto de la parcela, para evitar que den lugar a la futura creación de una escombrera ilegal. 


\section{A2.3. Repoblación forestal de laderas en el término municipal de Ampudia}

\section{A2.3.1. Proyecto}

Promotor: FORESA

Fecha: 2003

Esta repoblación forestal se realizó en el marco del Programa de Forestación de Tierras Agrarias subvencionado por la Unión Europea, el Ministerio de Agricultura, Pesca y Alimentación y la Junta de Castilla y León. La solicitud se promovió el 10 de febrero de 2003 por la empresa Forestación y Repoblación, S.A. (FORESA), en representación del Ayuntamiento de Ampudia (propietario mayoritario), la Cámara Agraria de Valoria del Alcor y Fernando Ovejero Santiago. Las parcelas afectadas se reflejan en la Tabla A2.2.

Tabla A2.2. Parcelas a forestar en Ampudia.

\begin{tabular}{lccc}
\hline \multicolumn{1}{c}{ Titular } & Polígono & Parcela & Superficie (ha) \\
\hline Ayuntamiento de Ampudia & 19 & 10 & 24,00 \\
\hline Ayuntamiento de Ampudia & 25 & 25 & 10,52 \\
\hline Fernando Ovejero Santiago & 25 & 26 & 1,90 \\
\hline Cámara Agraria de Valoria del Alcor & 25 & 35 & 1,68 \\
\hline Ayuntamiento de Ampudia & 3 & 28 & 5,08 \\
\hline TOTAL & & & 43,18 \\
\hline
\end{tabular}

La forestación afecta a dos laderas de transición del páramo calizo a la campiña (Figura A2.14), ubicadas al Este y al Oeste de la localidad de Ampudia. Son terrenos margosos e incluso yesosos, muy arcillosos, con un horizonte orgánico muy reducido o incluso eliminado por la erosión hídrica. 

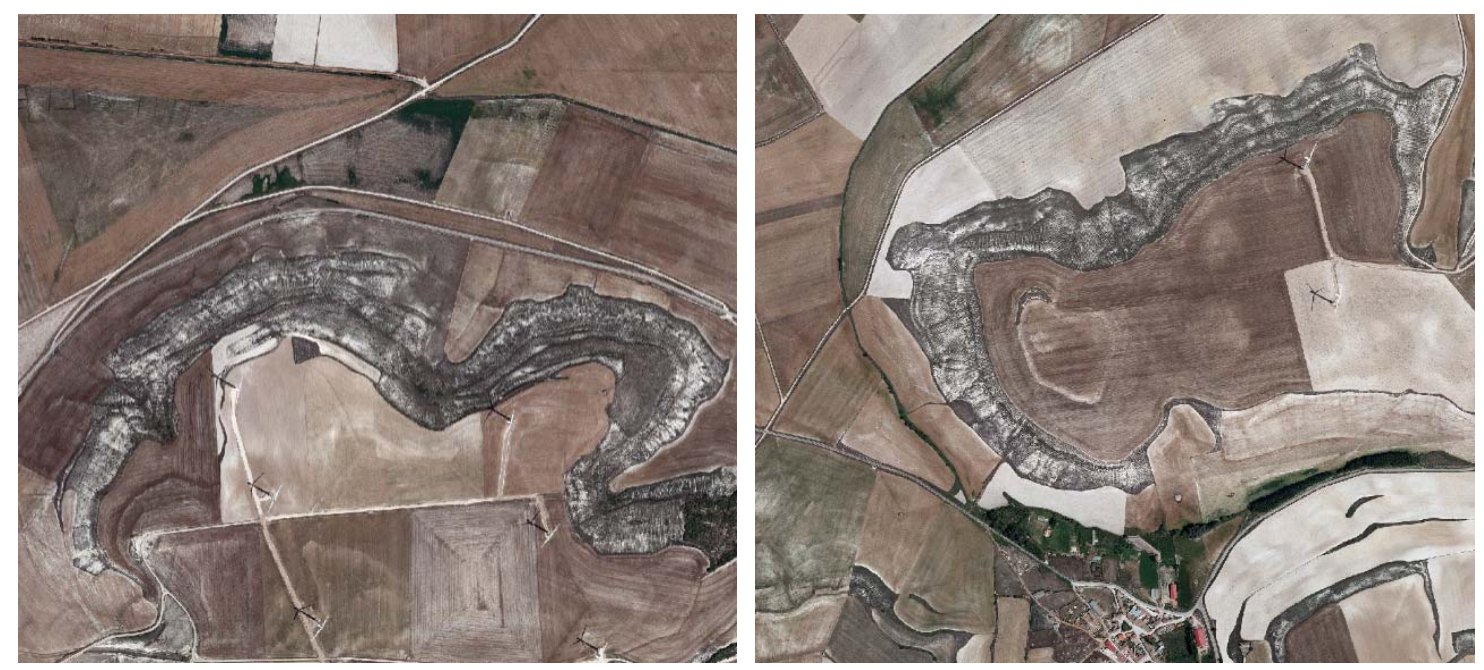

Figura A2.14. Ortofotografía de 2011 de las dos laderas; a la izquierda la ubicada al Este de Ampudia y, a la derecha, la situada entre esta localidad y Valoria del Alcor. Se distinguen por su contorno irregular y sus tonos grisáceoblanquecinos, debido a los intensos procesos erosivos sufridos.

La memoria valorada señala que se toma como referencia el cuaderno de zona no 11 del citado Programa en Castilla y León (Campos Centro). Dentro de esta zona, se selecciona la estación 5 (suelos arcillosos y pendientes de 30-60\%). Las especies elegidas fueron las siguientes (Tabla A2.3):

Tabla A2.3. Especies seleccionadas en la forestación de Ampudia.

\begin{tabular}{llc}
\hline Aconsejable: & Pinus pinea (pino piñonero) & $75 \%$ \\
\hline Posible: & Quercus ilex (encina) & $14 \%$ \\
\hline Accesorias: & Spartium junceum (sebe o gayomba) & $3 \%$ \\
\cline { 2 - 3 } & Rosmarinus officinalis (romero) & $2 \%$ \\
\cline { 2 - 3 } & Prunus spinosa (endrino) & $4 \%$ \\
\cline { 2 - 3 } & Crataegus monogyna (espino albar) & $1 \%$ \\
\cline { 2 - 3 } & Rosa canina (escaramujo) & $1 \%$ \\
\hline
\end{tabular}

La repoblación se llevó a cabo en invierno de 2003. La densidad de plantación fue de 1600 pies/ha. El método de preparación del terreno empleado fue el ahoyado mecanizado sin roza previa, realizado con buldócer provisto de dos rejones que se desplaza de arriba a abajo en la ladera. Los hoyos tienen una profundidad mínima de $50 \mathrm{~cm}$, quedando con una ligera contrapendiente al objeto de retener la mayor cantidad de agua posible. Las especies accesorias se colocaron por rodales en los linderos de las parcelas. Aunque se solicitaron en un principio, finalmente no se colocaron protectores. 
Se utilizó planta forestal de una savia en envase forestal de $200-300 \mathrm{~cm}^{3}$ de capacidad. Se trata de material de reproducción identificado. La región de procedencia del pino piñonero es la Meseta Norte. Los lotes de plantas cuentan con pasaporte fitosanitario. El vivero forestal de planta autóctona se ubica en Cabezón de Pisuerga (Valladolid).

Considerándose un precio unitario de $1.493 € /$ ha, para las 43,18 ha la subvención ascendió a $64468 €$, que cubrió el coste total de la obra.

Durante los años posteriores a la plantación se realizaron reposiciones de marras, que se estimaron en un $15 \%$ el primer año, $15 \%$ el segundo, $10 \%$ el tercero y $5 \%$ el último. En el caso de las parcelas de propiedad particular, el Programa atendió los costes de mantenimiento durante cuatro años; en las parcelas municipales el coste se sufragó por el Ayuntamiento solo durante los dos primeros años.

\section{A2.3.2. Seguimiento ambiental}

El Programa de Forestación de Tierras Agrarias ha sido un buen instrumento para repoblar estos espacios degradados, las laderas, que durante siglos han sido cultivados y pastoreados intensamente, lo que ha generado severos fenómenos erosivos.

El hecho de que buena parte del proyecto afectase a propiedad municipal facilitó la disponibilidad de los terrenos. Evidentemente, también ayudó que el Programa subvencionase la totalidad de la repoblación y que la tramitación y ejecución se llevase a cabo mediante una empresa forestal.

Resulta muy adecuado que el uso dado a la recuperación sea el forestal-natural. Numerosas investigaciones científicas han demostrado el importante papel de la vegetación -en todos sus estratos, arbóreo, arbustivo y herbáceo- en la disminución de las tasas de escorrentía y erosión, sobre todo en laderas como estas de fuertes pendientes (en torno a un $25 \%$ ).

El método de preparación del terreno (ahoyado mecanizado) ha sido eficaz para propiciar el éxito de la repoblación. En primer lugar, altera una superficie muy reducida de la ladera, tan solo el hoyo (menos de un $10 \%$ de la total), lo que genera un impacto visual compatible (los cinco primeros años) y una modificación puntual de la morfología natural. En segundo lugar, crea una microcuenca (Figura A2.15) alrededor de la planta que permite acumular el agua de precipitación y escorrentía durante los primeros años de la plantación, que son los más críticos. No se puede constatar si la realización de los hoyos por el buldócer se realizó en dos fases como es lo correcto, levantando el rejón y volviéndolo a hincar más arriba- de modo que quedase tierra movida alrededor de la planta. 


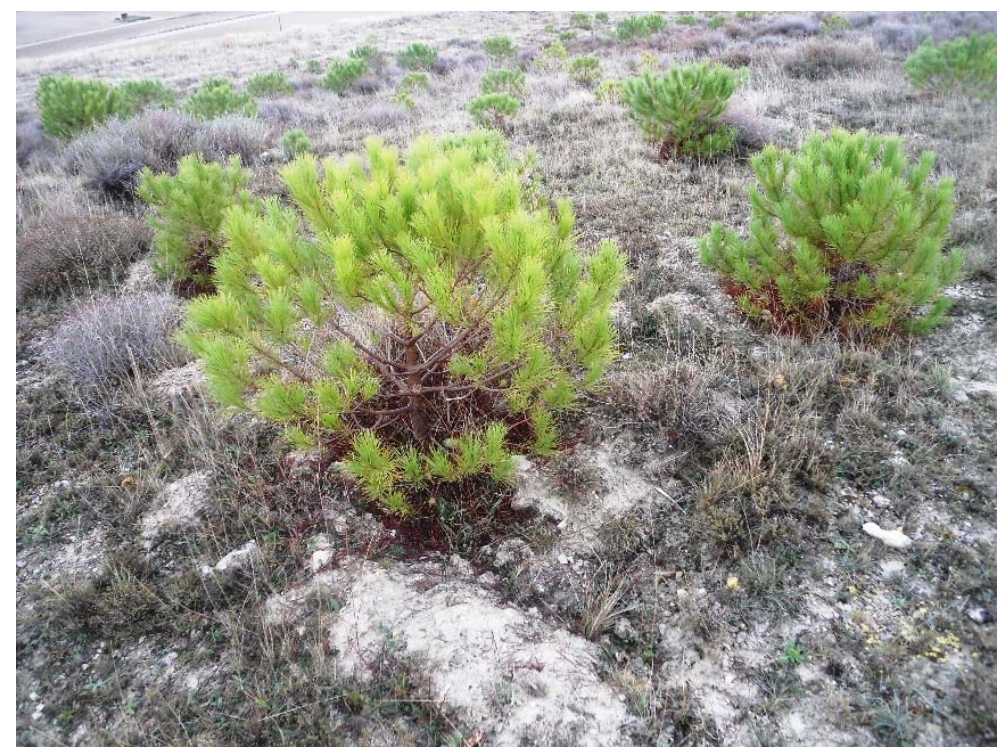

Figura A2.15. En primer término se observa la microcuenca generada por el ahoyado mecanizado, que aún se conserva. Tal como se aprecia, la alteración del perfil natural de la ladera es mínimo.

Una de las consecuencias indirectas más beneficiosas de las repoblaciones forestales es que los terrenos quedan acotados al aprovechamiento de pastos. En estas laderas, ello ocasionó la recuperación de la vegetación herbácea y matas subarbustivas en la mayor parte de la superficie afectada, lo que a buen seguro ha propiciado una disminución de la erosión laminar. No obstante, aún quedan pequeñas zonas más degradadas, donde no existe un horizonte edáfico orgánico capaz de albergar a la vegetación natural.

Tras once años de la repoblación forestal, el porcentaje de marras actual se estima en un $10 \%$, que es perfectamente asumible y confirma el éxito de la recuperación. Al igual que en la mayoría de las repoblaciones forestales, se observa que las marras se repiten en las mismas zonas, a buen seguro debidas a condiciones edáficas desfavorables. Por el contrario, las plantas que arraigan el primer año suelen pervivir en los siguientes.

Se observa que el grado de arraigo ha sido similar en todas las especies, lo que demuestra el acierto en su elección (Figura A2.16). La altura media de los pinos piñoneros es de $60 \mathrm{~cm}$, relativamente reducida pero válida teniendo en cuenta las críticas condiciones edáficas de las laderas. Las encinas tienen una altura media de $40 \mathrm{~cm}$; algunas incluso parecen marras porque casi no se han desarrollado (hay un ejemplar increíble que alcanza los $3 \mathrm{~m}$ ). La sebe o gayomba es la que ha tenido mayor desarrollo vegetativo $(\mathrm{h}=150 \mathrm{~cm})$; el resto de arbustos tienen una altura de $40-60 \mathrm{~cm}$. 

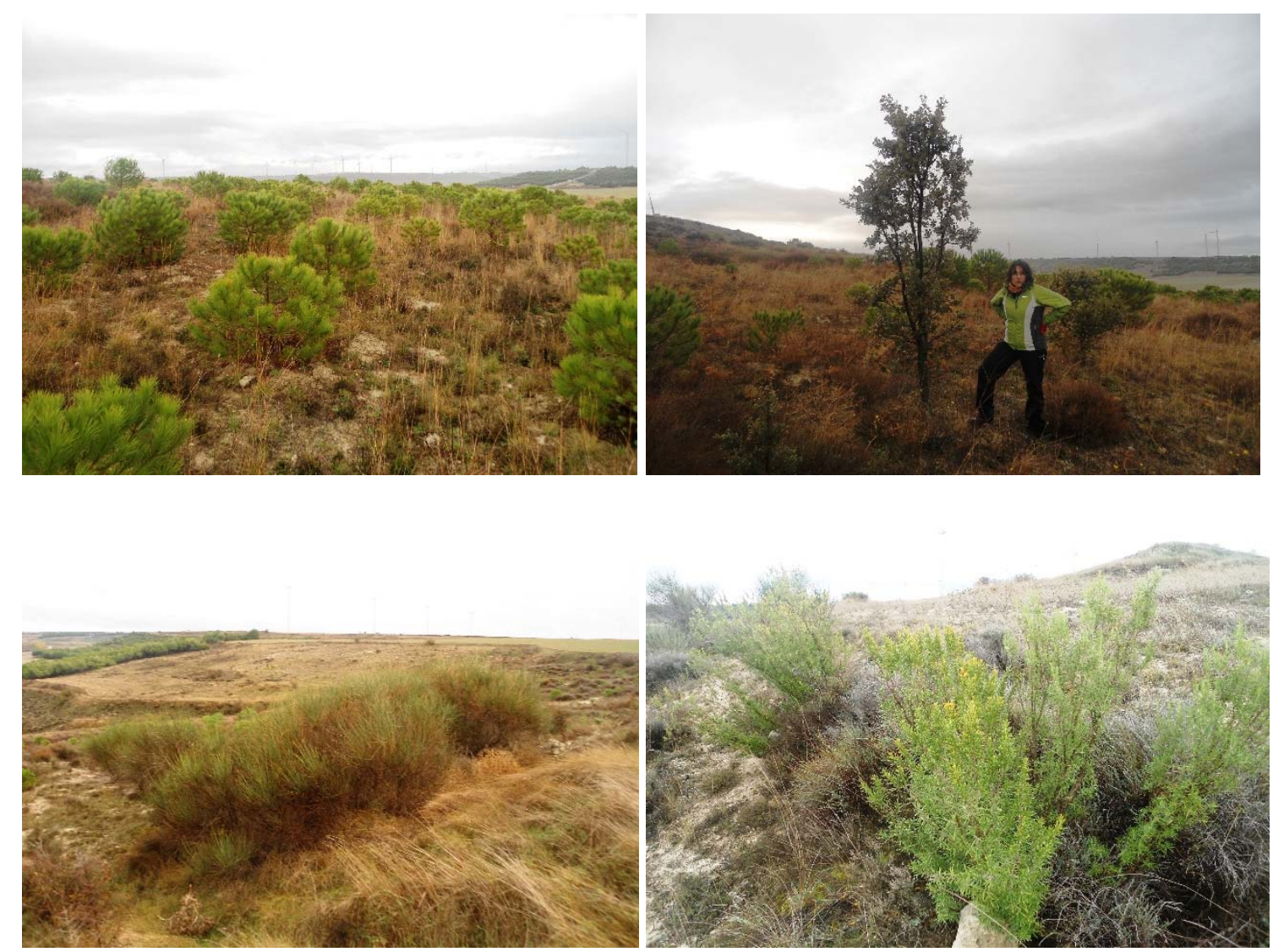

Figura A2.16. Arriba izquierda, imagen general de los pinos piñoneros. Arriba derecha, encina excepcional. Abajo izquierda, rodal de sebes. Abajo derecha, rodal de romeros.

Se está consiguiendo una adecuada cobertura vegetal; aunque en el estrato arbóreo ahora es incipiente, de no sufrir incendios la zona con casi total probabilidad se augura que los árboles cubran prácticamente toda la ladera. En este sentido, se considera acertada la densidad inicial de 1600 pies/ha cuando la finalidad es de protección de las laderas. El crecimiento de la vegetación implantada es lento pero su calidad es alta. En las zonas peores se observa la presencia de alguna plaga en pinos (evetria, que ataca las yemas) o enfermedades que dejan a estos achaparrados (Figura A2.17).
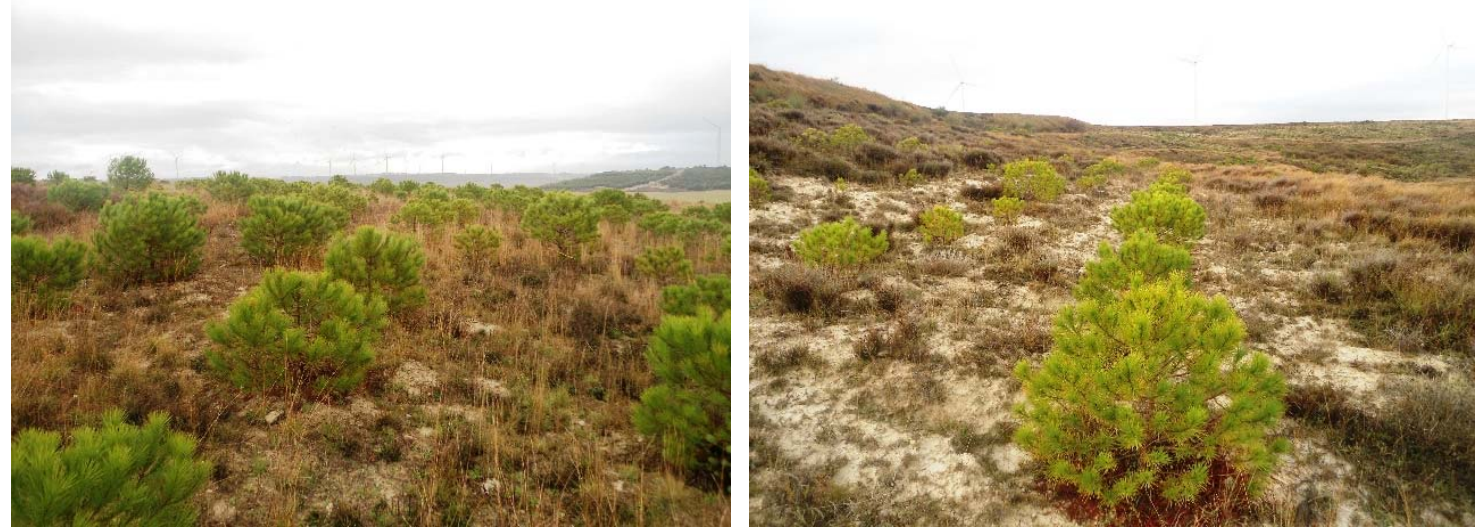

Figura A2.17. En la fotografía de la izquierda se observan pinos piñoneros en buen estado vegetativo. En la de la derecha su estado es más deficiente, debido a que las condiciones edáficas son peores. 
Probablemente hasta los 25-30 años de edad no sea necesaria la realización de tratamientos selvícolas. En función de la evolución de la masa, se podría realizar un clareo de los 1450 pies/ha actuales a 700-800 pies/ha y una poda ligera de los árboles que permanezcan. Es muy importante que los restos de este tratamiento se trituren en la ladera, para que mejoren las características físicas de los suelos.

La repoblación forestal mejora indudablemente el paisaje perceptivo de la franja de Tierra de Campos incluida en su cuenca visual (se puede estimar en $10 \mathrm{~km}$ de anchura). Las laderas, antes descarnadas, se aprecian con un mayor verdor, que contrasta sobre todo con la aridez de los cultivos en la época estival (Figura A2.18). En este caso, además, el futuro arbolado contribuirá a mejorar la capacidad de absorción visual frente a los aerogeneradores situados en la cumbre de parte de las laderas.

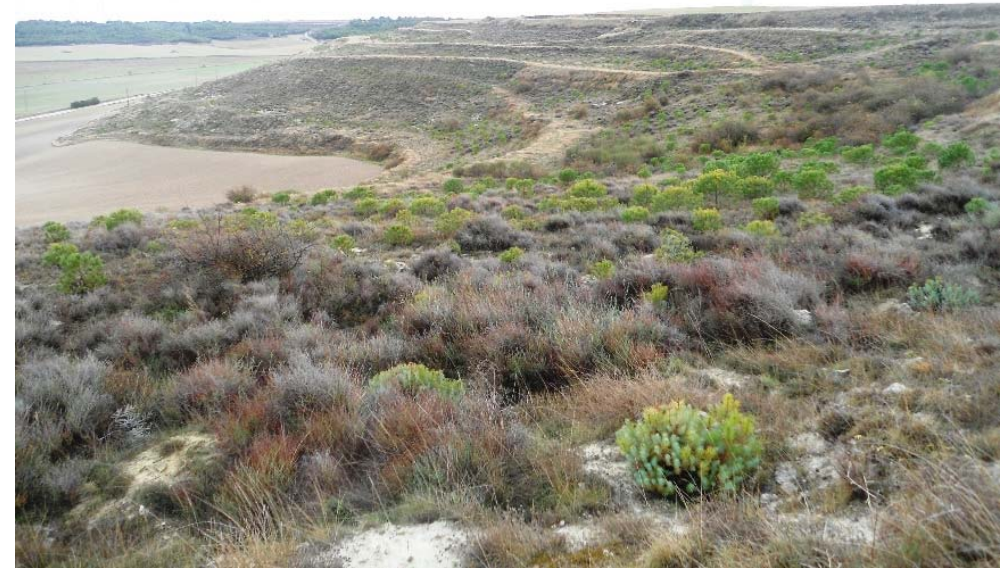

Figura A2.18. Vista general de las laderas, con una buena cobertura vegetal y donde los pinos comienzan a despuntar.

La repoblación forestal también mejora la calidad del paisaje ecológico. Las laderas no dejan de ser corredores ecológicos que constituyen el perímetro de la comarca, rodeadas en su inmensa mayoría por cultivos agrícolas tanto en la campiña como en el páramo.

Esta recuperación ambiental tiene un importante potencial de valorización del paisaje. En particular, hay laderas muy próximas a la población de Valoria del Alcor que pueden configurarse como zona verde de la misma. 


\section{A2.4. Repoblación forestal de una parcela de masa común en el término municipal de Frechilla}

\section{A2.4.1. Proyecto}

Promotor: FORESA

Fecha: 1994

Se trata de una repoblación incluida en el Programa de Forestación de Tierras Agrarias. La solicitud se realizó el 14 de abril de 1994 por la empresa Forestación y Repoblación, S.A. (FORESA), representando al Ayuntamiento de Frechilla, propietario de los terrenos.

La actuación tuvo lugar en la parcela 1 del polígono 13 de Frechilla, situada a unos $600 \mathrm{~m}$ al noreste de esta localidad, que ocupa una superficie de 10,93 ha (Figura A2.19). Es una parcela clasificada como masa común en la concentración parcelaria que, una vez finalizada esta, se adjudicó al Ayuntamiento. En la zona occidental el terreno es llano, mientras que en la oriental tiene una cierta pendiente (es un teso); en la parte sur aparece alguna cárcava.

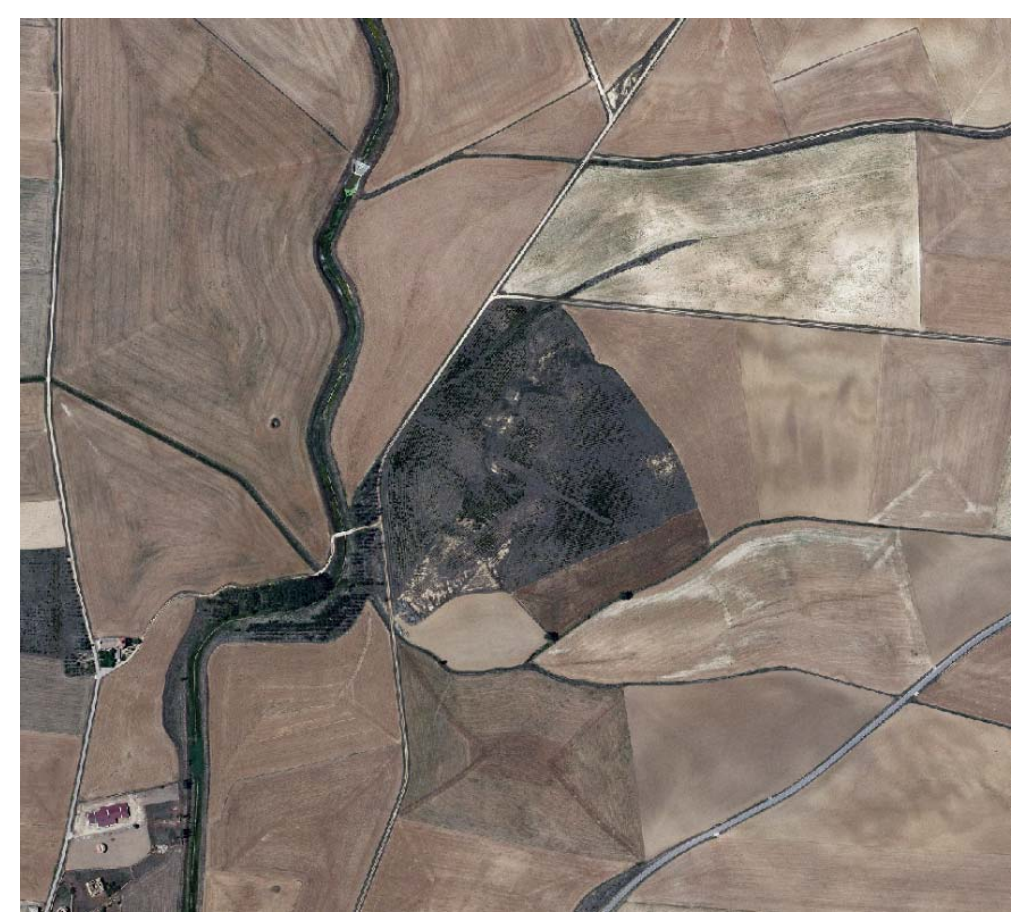

Figura A2.19. Parcela forestada, que linda con el río Valdeginate y parcelas agrícolas (ortofotografía de 2011).

En la memoria técnica se indica que se toma como referencia el cuaderno de zona no 11 del citado Programa en Castilla y León (Campos Centro). Dentro de esta zona, se selecciona la estación 11 (suelos arcillosos y pendiente menor de $10 \%$ ). Las especies elegidas fueron las siguientes (Tabla A2.4): 
Tabla A2.4. Especies seleccionadas en la forestación de Frechilla.

\begin{tabular}{llc}
\hline Aconsejable: & Pinus pinea (pino piñonero) & $90 \%$ \\
\hline Posible: & Quercus ilex (encina) & $10 \%$ \\
\hline
\end{tabular}

La repoblación se llevó a cabo en invierno de 1994. El método de preparación del terreno fue el arado con desfonde lineal, utilizándose un gran arado de vertedera que invierte los horizontes edáficos, afectando a una profundidad superior a $50 \mathrm{~cm}$. En las zonas de cárcavas se realizaron hoyos manuales. La densidad de plantación fue de 1600 pies/ha.

El presupuesto subvencionado de forestación fue de 120000 ptas/ha $(721,21 € /$ ha), siendo el importe total de 1313000 ptas $(7891,29 €)$.

\section{A2.4.2. Seguimiento ambiental}

Desde el punto de vista medioambiental ha resultado muy acertada la aplicación del Programa de Forestación de Tierras Agrarias para la repoblación forestal de una parcela de masa común. Estos terrenos se adjudican a los ayuntamientos después de finalizado el proceso de concentración parcelaria; en la mayoría de los casos, son arrendados a agricultores para su cultivo agrícola. La existencia de la subvención del gasto total de repoblación seguramente facilitó la realización de la obra.

Es muy adecuado el uso forestal/natural dado a la restauración de la parcela. Tal como se puede constatar sobre el terreno o analizando las ortofotografías actuales, se trata del único terreno arbolado del entorno. Incluso se aprecia cómo la ribera del río Valdeginate -que discurre por el perímetro de la parcela- se encuentra casi totalmente desprovista de vegetación.

A la vista del éxito de la repoblación, se puede inferir que el método de preparación del terreno (arado con desfonde) fue acertado. Si los caballones son muy pronunciados, es cierto que se produce una importante alteración morfológica de los terrenos donde se aplica esta técnica. No obstante, en la actualidad se observa en este caso que los caballones están bastante tendidos, siendo por tanto el impacto reducido.

Existe una zona de la parcela con presencia de residuos, que con probabilidad es consecuencia de su carácter público. Como sucede en otros casos similares, es conveniente que se retiren de forma periódica, pues de lo contrario se generaría un vertedero ilegal.

A pesar de la repoblación, aún se observan fenómenos de erosión laminar en algunas zonas con pendientes acusadas. En estos suelos esqueléticos, el arraigo de los árboles ha sido muy reducido (Figura A2.20); tal vez aquí fuese conveniente realizar plantaciones por hoyos con especies arbustivas (retama, escaramujo, romero, etc.). 


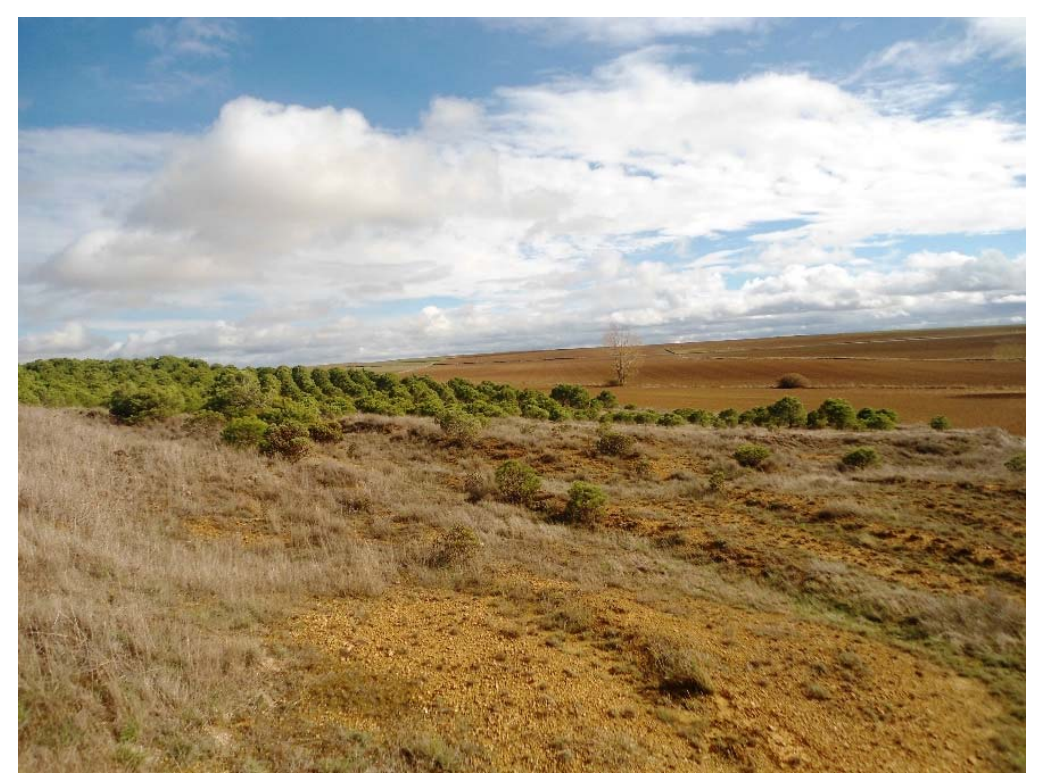

Figura A2.20. En la zona sur-tal como ya se indicó en la memoria previa a la repoblación- los suelos eran pobres, por lo que en ellos el arraigo de la vegetación fue considerablemente menor.

En los terrenos llanos situados en el pie del teso se ha alcanzado una muy buena cobertura vegetal (Figura A2.21). De hecho, de los 1600 pies/ha de la repoblación, se estiman las marras en un $10 \%$. Los pinos tienen una altura media de $2,5 \mathrm{~m}$ y un buen crecimiento, mientras que la altura media de las encinas es de $0,5 \mathrm{~m}$.

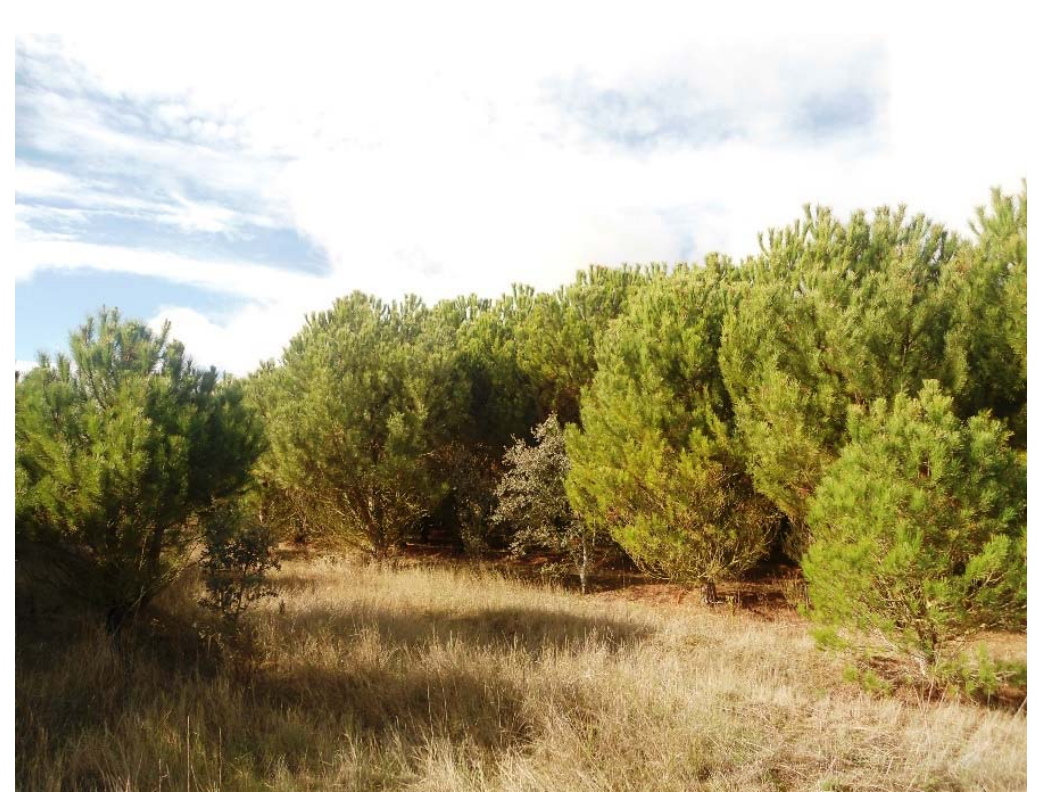

Figura A2.21. En esta imagen se constata el buen desarrollo vegetativo del pinar en los terrenos llanos, aunque la densidad sea excesiva. También se aprecia que las encinas tienen un crecimiento más discreto. 
Para estas zonas con alta densidad, la selvicultura productiva del pino piñonero aconseja realizar una clara de la masa y una poda de los ejemplares que permanecen. En la actualidad se opta por la realización de una corta sistemática de una fila y otra selectiva entre la que permanece, de modo que la densidad se reduce a los 400-500 pies/ha. La clara puede ser rentable o a coste cero si se utiliza el método del aprovechamiento del árbol completo para biomasa; los árboles se retiraran mediante un autocargador que transita por las calles, que los transporta al camino donde se trituran los restos vegetales. Este procedimiento tiene las desventajas de una excesiva regularidad, la eliminación de pies de pino piñonero con buen porte y el riesgo de daño a las encinas.

En las zonas altas del teso, el crecimiento de los pinos piñoneros ha sido inferior: su altura media es de $1,5 \mathrm{~m}$ y el porcentaje de marras se estima en un $30 \%$. En estas áreas sería conveniente realizar plantaciones complementarias con una preparación del terreno puntual, introduciendo fundamentalmente especies arbustivas que fomentasen la biodiversidad y la defensa frente a la erosión hídrica.

La repoblación forestal contribuye a mejorar el paisaje visual de la zona. La introducción de una masa vegetal arbórea favorece la generación de un contraste visual perceptible sobre todo en la época estival, modifica la textura fina de la campiña cerealista y aumenta la diversidad, lo que redunda en un aumento de la calidad del paisaje perceptivo (Figura A2.22).

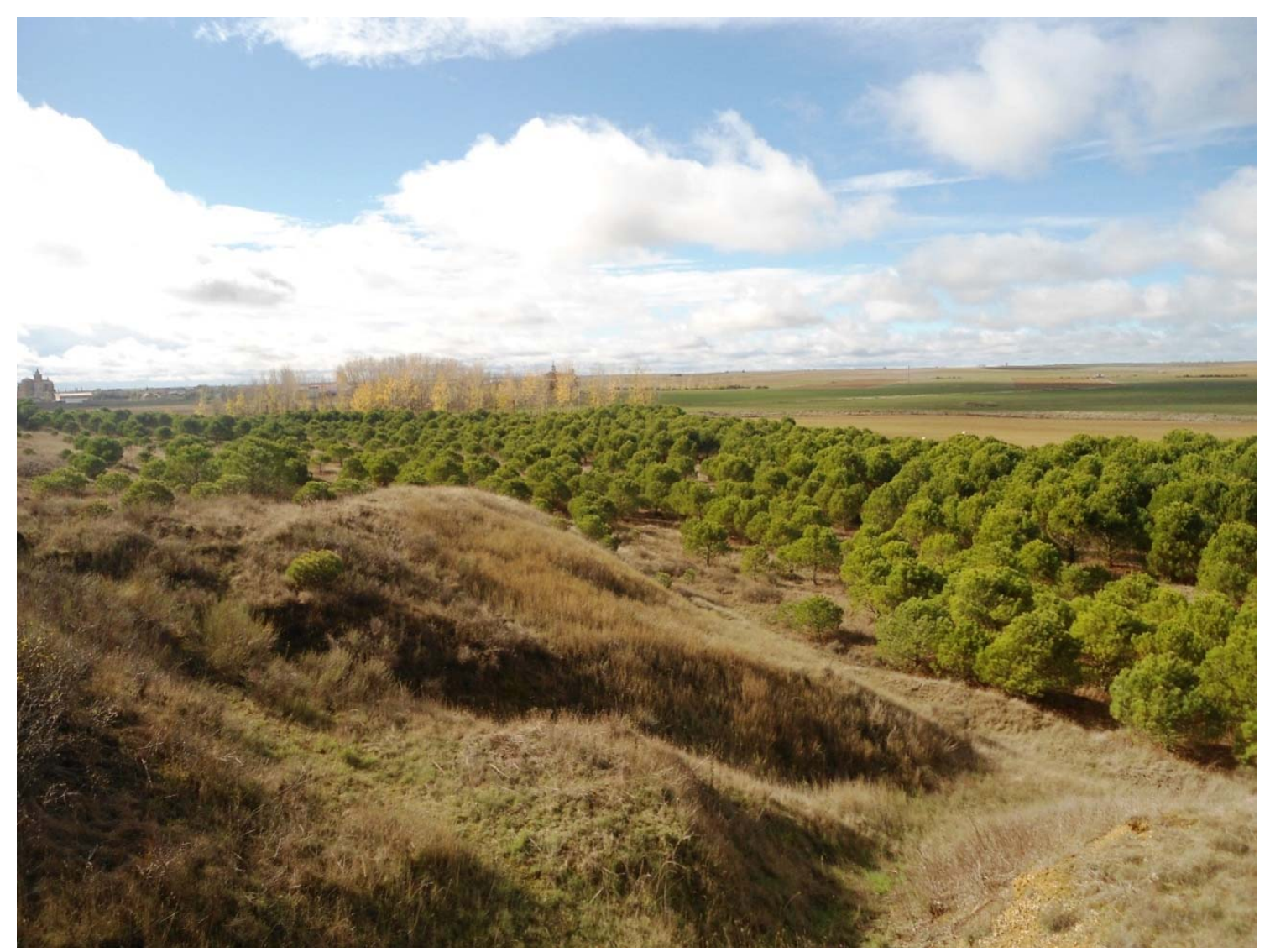

Figura A2.22. Vista del pinar desde el teso, donde se observa el éxito de la repoblación forestal. 
La repoblación forestal también mejora el paisaje ecológico de la zona. En esta parcela no existe un aprovechamiento intensivo del suelo, tal como se produce en el resto de la campiña: no hay laboreos periódicos, tratamientos con herbicidas, extensión de fertilizantes inorgánicos, etc. Estas zonas se convierten en pequeñas "manchas" naturales en un entorno apabullantemente agrícola; existen árboles y se genera un hábitat de matas y especies herbáceas autóctonas, donde se refugia una fauna variada. No obstante, esta biodiversidad puede aumentarse disminuyendo la densidad del pinar, conservando las encinas e incluso introduciendo otras especies fundamentalmente arbustivas: escaramujos, retamas, endrinos, etc.

Teniendo en cuenta la cercanía con el núcleo urbano de Frechilla, este pinar puede contribuir a valorizar el paisaje; una vez realizados los tratamientos selvícolas pertinentes $y$, a medida que crezca la vegetación, la parcela puede constituirse en una zona de esparcimiento para los vecinos. Resultaría muy agradable la adecuación de un sendero para caminar o ir en bicicleta desde el pueblo al pinar, que podría discurrir próximo a la ribera del río Valdeginate.

\section{A2.5. Restauración hidrológico-forestal y posterior tratamiento selvícola y plantación de diversificación en la cuesta de Coruñeses, término municipal de Medina de Rioseco.}

\section{A2.5.1. Proyecto}

Este proyecto, que se presenta de una forma global, en realidad está formado por dos actuaciones realizadas en el mismo espacio físico, pero distantes en el tiempo varias décadas. La cuesta de Coruñeses es un conjunto de laderas de transición de las campiñas de Tierra de Campos al páramo de Torozos, en el término municipal de Medina de Rioseco, que son atravesadas por la carretera nacional N-601 Valladolid-León. Se trata de una restauración paradigmática, ya que esta ubicación hace que su historia, evolución y situación actual sean conocidas por las numerosas personas que circulan por esta transitada vía de comunicación.

En primer lugar, la restauración hidrológico-forestal de las cuestas fue llevada a cabo por la administración forestal del Estado hacia el año 1960. En esa época, la situación general de las laderas era desoladora: superficies esquilmadas de todo rastro de vegetación como consecuencia de cortas de leña abusivas, pastoreo excesivo e incluso roturación de terrenos para su cultivo. La deficiente protección vegetal de los suelos y la elevada pendiente (superior al $30 \%$ ) ocasionaba elevadas tasas de erosión hídrica laminar e incluso la formación de numerosas cárcavas. Este es el caso crítico que aquí nos ocupa y las razones que dieron lugar al desarrollo del proyecto de restauración, que se enmarcaba dentro de un programa nacional de protección de suelos, de defensa de los cultivos, de regulación hidrológica y de repoblación forestal (Figura A2.23). 

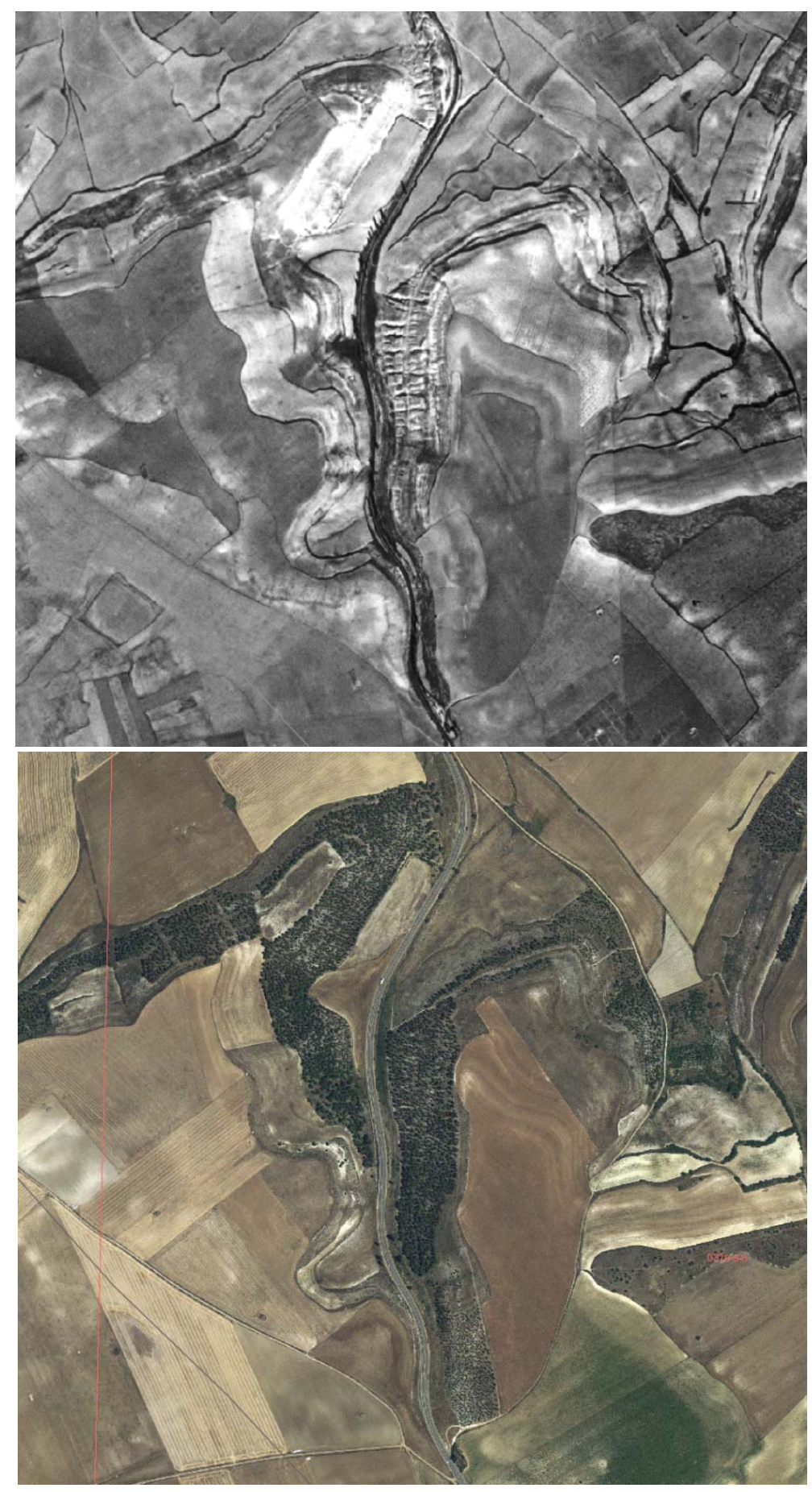

Figura A2.23. En la primera ortofotografía, procedente del vuelo americano de la década de los 50 del siglo pasado, se observa la deforestación e intensos procesos de erosión de las laderas de Coruñeses; como curiosidad, por el contrario, también se constata la existencia de arbolado en los márgenes de la carretera, así como de linderas de vegetación en las parcelas. En la segunda ortofotografía de 2011, se distingue la gran diferencia ocasionada por la repoblación forestal de las cuestas, cuya trama vegetal contrasta con los terrenos agrícolas. 
A su vez, la restauración hidrológico-forestal contó con dos subactuaciones complementarias. Los intensos procesos erosivos generadores de las cárcavas se trataron de contener con la construcción de una serie de pequeños diques de mampostería de piedra caliza suelta (Figura A2.24), de unos $4 \mathrm{~m}$ de anchura y $1 \mathrm{~m}$ de altura, diseñados de forma curva y con cierta contrapendiente transversal. A lo largo de cada torrente se construyeron varios diques, a una distancia aproximada de $10 \mathrm{~m}$.
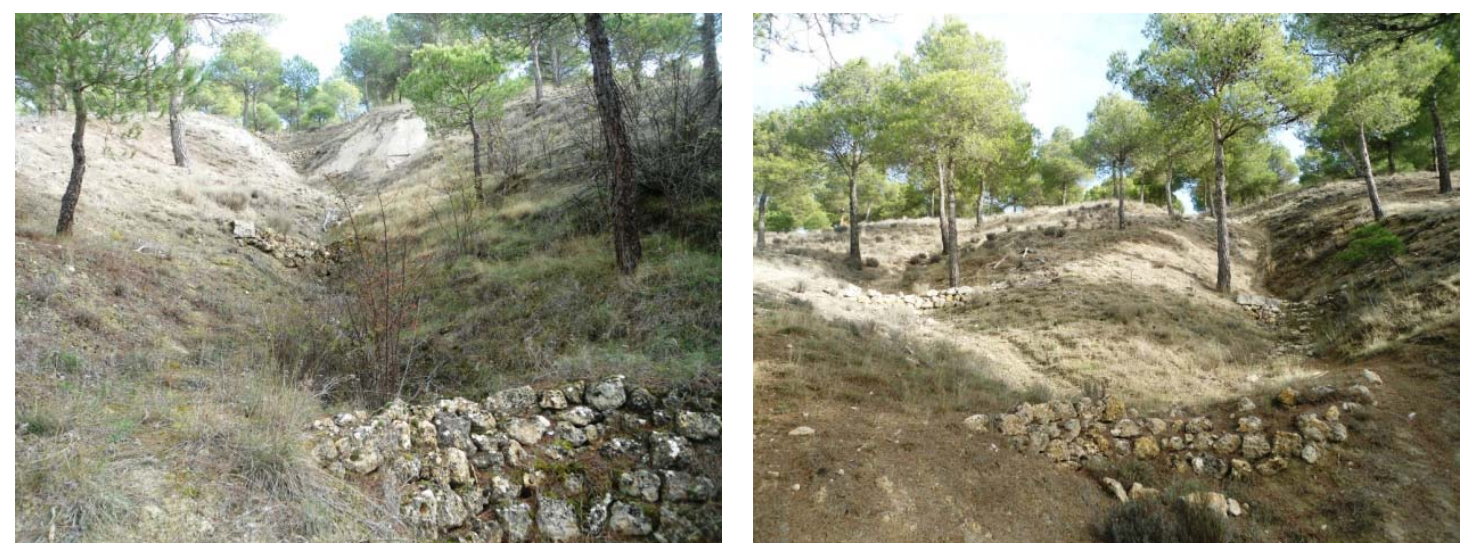

Figura A2.24. Imágenes de varios diques de piedra de mampostería que, tal como se observa, se encuentran totalmente aterrados y han conseguido la práctica eliminación de los fenómenos erosivos generados en las cárcavas.

La segunda subactuación consistió en la repoblación forestal de las laderas. El método de preparación del terreno empleado fueron las banquetas de tracción animal, que fue el más usual en las cuestas de Tierra de Campos. Este es un proceso de preparación lineal del terreno mediante la formación de superficies estrechas (de menos de $1 \mathrm{~m}$ de ancho) y largas, en rellano o contrapendiente, siguiendo curvas de nivel y utilizando aperos tirados por parejas de bueyes (ICONA, 1975). La separación entre ejes fue de $3 \mathrm{~m}$. El arado era de vertedera, monosurco, reversible, conocido en aquella época como "bravant", que conseguía una profundidad aproximada de $40 \mathrm{~cm}$.

La plantación se realizó con Pinus halepensis (pino carrasco), a raíz desnuda procedente de viveros locales, que se introducía en el terreno con plantamón. La densidad fijada fue en torno a 1600 pies/ha, considerándose que se trataba de una forestación protectora.

En determinadas zonas no forestadas en su momento, hacia el año 1994 se realizó una plantación complementaria de Pinus pinea (pino piñonero), mediante fajas subsoladas con buldócer y densidades de planta similares.

La segunda actuación contemplada en la cuesta de Coruñeses fue la realización de tratamientos selvícolas en 2004, promovidos por la Consejería de Medio Ambiente de la Junta de Castilla y León, siendo el autor y director del proyecto el ingeniero de Montes Luis Finat Gómez. El buen arraigo y desarrollo de la restauración hidrológico forestal, cuya plantación arbórea ya tenía una edad superior a los 40 años, había generado una masa vegetal con una elevada densidad, alta biomasa y acusada monoespecificidad, ya que la cobertura vegetal impedía la regeneración de otras especies autóctonas. 
Con objeto de disminuir el riesgo de incendios, mejorar la estabilidad de la masa y posibilitar la paulatina entrada de otras especies vegetales en el ecosistema, se planificó la realización de una drástica reducción de la densidad arbórea, que pasó de los aproximadamente 1500 pies/ha a los 200-300 pies/ha en mejor estado. El apeo, desramado, tronzado y traslado de las trozas al pie de la ladera se realizó de forma manual. La masa remanente fue podada hasta aproximadamente un tercio de su altura. Los restos vegetales fueron acordonados y posteriormente triturados por un tractor con desbrozadora de martillos. La madera fue finalmente enajenada.

Este tratamiento se complementó con una plantación de diversificación de frondosas (encina y quejigo) en las zonas claras, con una densidad aproximada de 100 pies/ha, realización de hoyos mecanizados y utilización de planta de una savia en envase forestal.

\section{A2.5.2. Seguimiento ambiental}

La restauración hidrológico-forestal es una técnica para la recuperación de cuencas hidrológicas degradadas, que ha resultado muy apropiada para el tratamiento de laderas muy erosionadas como la de Coruñeses. La combinación de hidrotecnias tales como la construcción de pequeños diques, con la realización de plantaciones vegetales, ha tenido efectos sinérgicos favorables para conseguir que las cuestas vuelvan a poseer el uso forestal-natural que verdaderamente les corresponde.

El diseño y construcción de los pequeños y numerosos diques de mampostería ha permitido disminuir de una forma escalonada la pendiente longitudinal de los cursos hídricos erosionados, estabilizando progresivamente las cárcavas que se habían formado. Actualmente estos diques se encuentran colmatados, la morfología se ha estabilizado y los cursos hídricos se hallan revegetados (Figura A2.25).

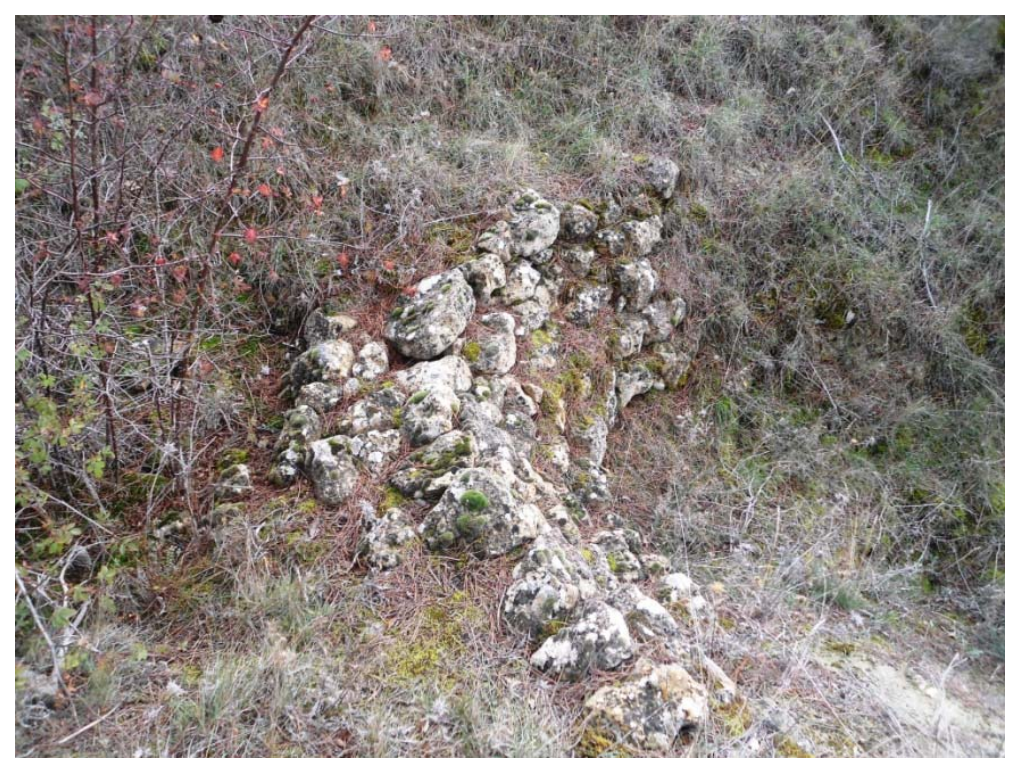

Figura A2.25. La imagen muestra la naturalización del entorno del pequeño dique, que además se encuentra perfectamente integrado paisajísticamente. 
La repoblación forestal de los años 60 del siglo pasado fue exitosa, generando una masa arbórea densa (en el entorno de los 1500 pies/ha) que ha proporcionado una cubierta vegetal muy eficaz para proteger la ladera de los procesos erosivos. La interceptación de las copas de los pinos, así como la creación de una capa de tamuja en el terreno degradado ha hecho que progresivamente las tasas de escorrentía y erosión fuesen disminuyendo hasta situarse en valores muy reducidos.

El pino carrasco no es una especie autóctona de la meseta norte castellana, pero su homologación ecológica con otros terrenos calizos y subáridos del Este peninsular provocó su selección para la reforestación de muchas laderas. Transcurridos más de 50 años desde la repoblación forestal -y a pesar de que es muy difícil valorar con ojos de 2014 lo realizado en 1960-, se puede considerar que esta elección fue acertada para los objetivos protectores previstos, considerándose que las coníferas constituían la primera fase de la evolución ecológica. No obstante, cabe citar que tal vez hubiese sido conveniente haber incluido más especies en la mezcla, como pino piñonero (lo que se hizo posteriormente), encina, quejigo o arbustos, con objeto de favorecer la diversidad biológica y avanzar en esa evolución en una fase más temprana.

Los pinos, a pesar de asentarse de suelos esqueléticos, tienen la virtud de ser especies muy frugales con un crecimiento que no es excesivamente lento. De hecho, actualmente los pinos carrascos poseen actualmente un diámetro normal medio de $25-30 \mathrm{~cm}$ y una altura de unos 8 $\mathrm{m}$, mientras que la altura media de los pinos piñoneros es de $4 \mathrm{~m}$ y su diámetro normal, de 12$15 \mathrm{~cm}$ (Figura A2.26).
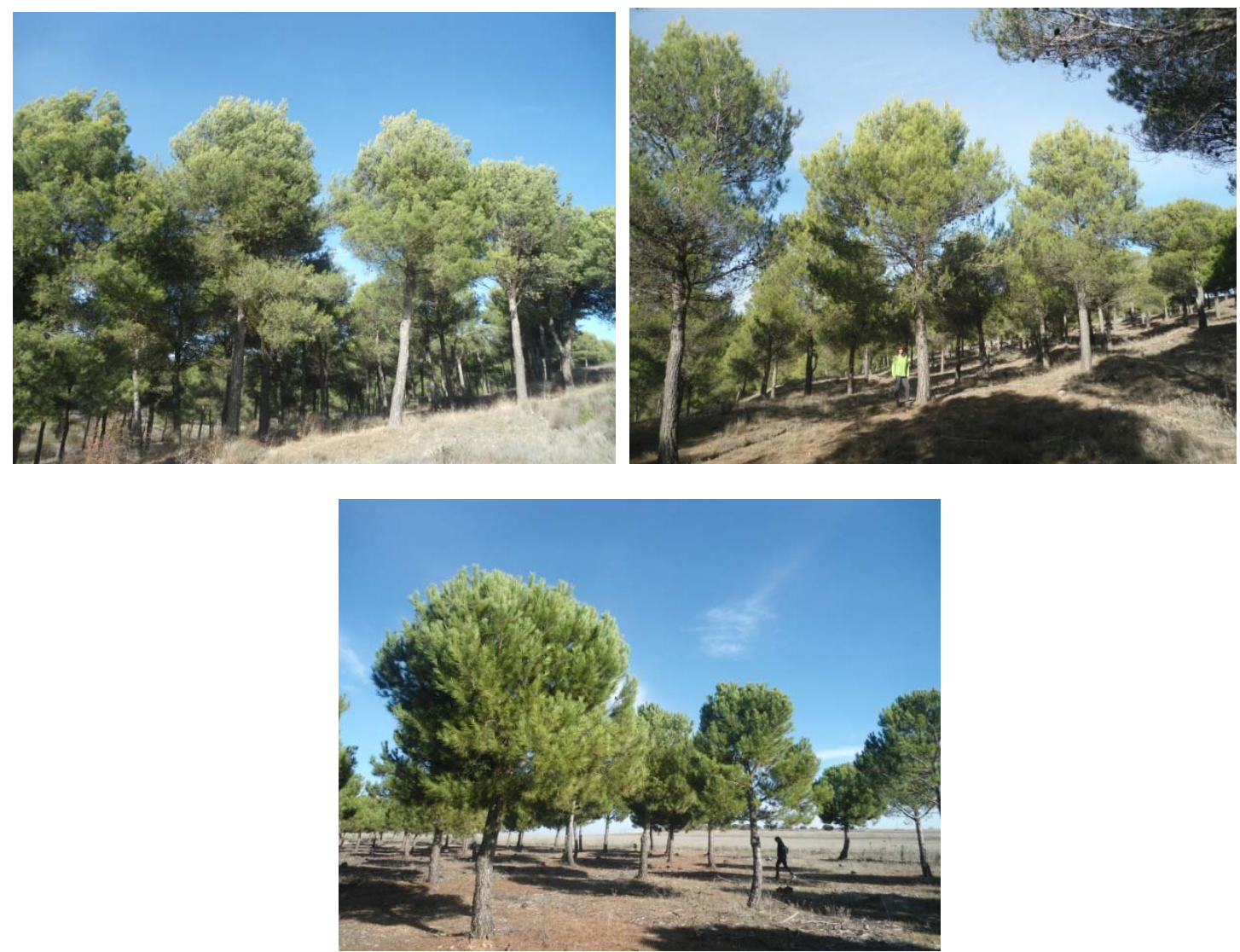

Figura A2.26. En las imágenes superiores se observa el buen porte que actualmente poseen los pinos carrascos de la repoblación primitiva. En la imagen inferior se constata el aceptable crecimiento (tal vez algo mayor en términos relativos) de los pinos piñoneros. 
Mediante el tratamiento selvícola realizado en 2004 se ha logrado crear una masa arbórea estable de pinar, cuyos ejemplares cuentan con un buen porte y una adecuada estabilidad, a pesar de haber vivido en densidad excesiva (de hecho, hay escasos derribos). Aunque el peso de la clara fue muy alto -ya que no se había realizado ninguna previamente-, transcurridos diez años se constatan los beneficios del tratamiento: mejora fenológica de la masa remanente, disminución del riesgo de incendios como consecuencia de la ruptura de la continuidad horizontal y vertical de la biomasa, regeneración natural de pinos, arbustos y matas que aumentan la biodiversidad, incorporación de restos vegetales al suelo orgánico tras su trituración, etc.

Con la plantación de encinas y quejigos en los claros del monte se persigue la aceleración de la sucesión vegetal natural, ya que en las proximidades no hay fuentes naturales de dispersión de las semillas. Con esta medida se cumplen las pretensiones de los ingenieros de montes que diseñaron y aplicaron el Plan nacional de forestación, que perseguía la introducción futura de especies autóctonas tras la mejora de los suelos proporcionada por las coníferas. Aunque el crecimiento de estas especies es en general lento (su altura media a los 10 años es de $60 \mathrm{~cm}$ ), vivir bajo cobertura aumenta sus posibilidades de arraigo, posibilita el afianzamiento de las raíces pivotantes $y$, a medio plazo, permitirá crear un cierto sotobosque de quercíneas autóctonas. De hecho, se han observado puntualmente algunos ejemplares con crecimientos espectaculares (altura de $2 \mathrm{~m}$, con un crecimiento de $80 \mathrm{~cm}$ el último año). Estas especies son las llamadas a sustituir en un futuro al pinar (Figura A2.27), o al menos a crear una masa mixta de coníferas y frondosas, más estable frente a las consecuencias del cambio climático o al riesgo de incendios (las quercíneas rebrotan de cepa).
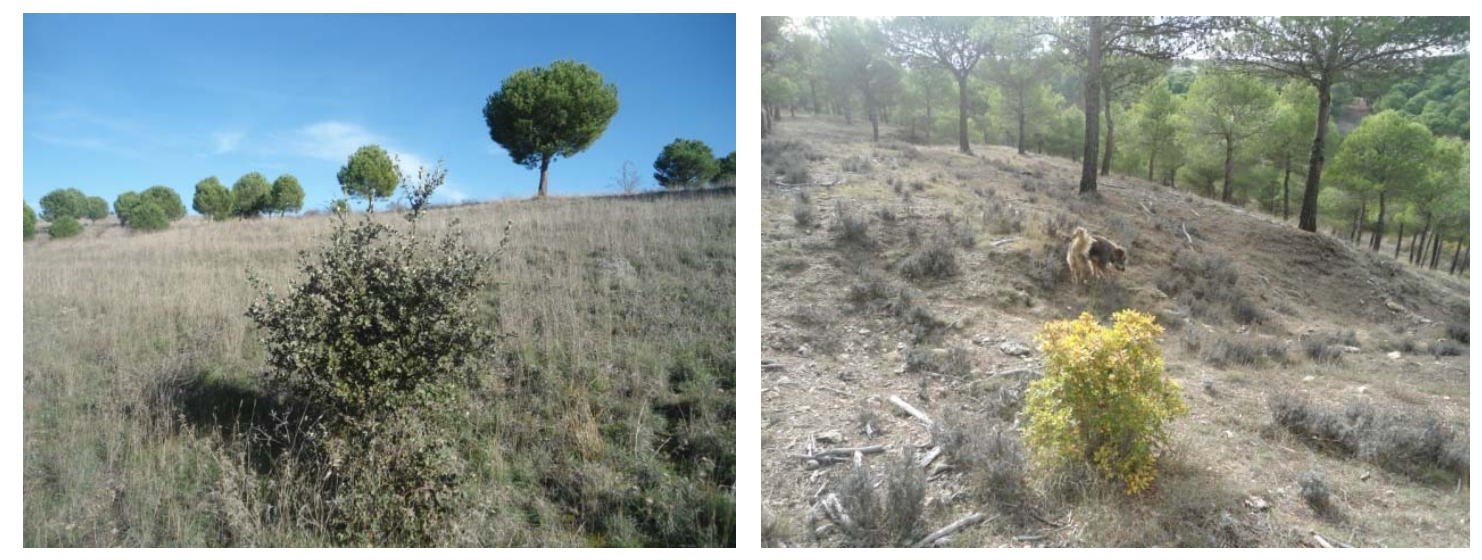

Figura A2.27. Imágenes de una encina (izquierda) y un quejigo (derecha). Aunque el crecimiento de estas especies es muy lento en sus inicios, una vez afianzadas sus raíces pivotantes este aumenta notablemente.

La restauración hidrológico-forestal y el tratamiento selvícola posterior han mejorado indudablemente el paisaje visual del entorno. De hecho este es uno de los puntos de la comarca donde probablemente más se constate el aumento de la calidad del paisaje, ya que el pinar es visible desde la transitada carretera nacional N-601, que cruza el monte (Figura A2.28). Actualmente se tiene la sensación de que la cuesta de Coruñeses constituye ya un bosque maduro que contrasta de un modo nítido con la campiña que se abre a sus pies. 


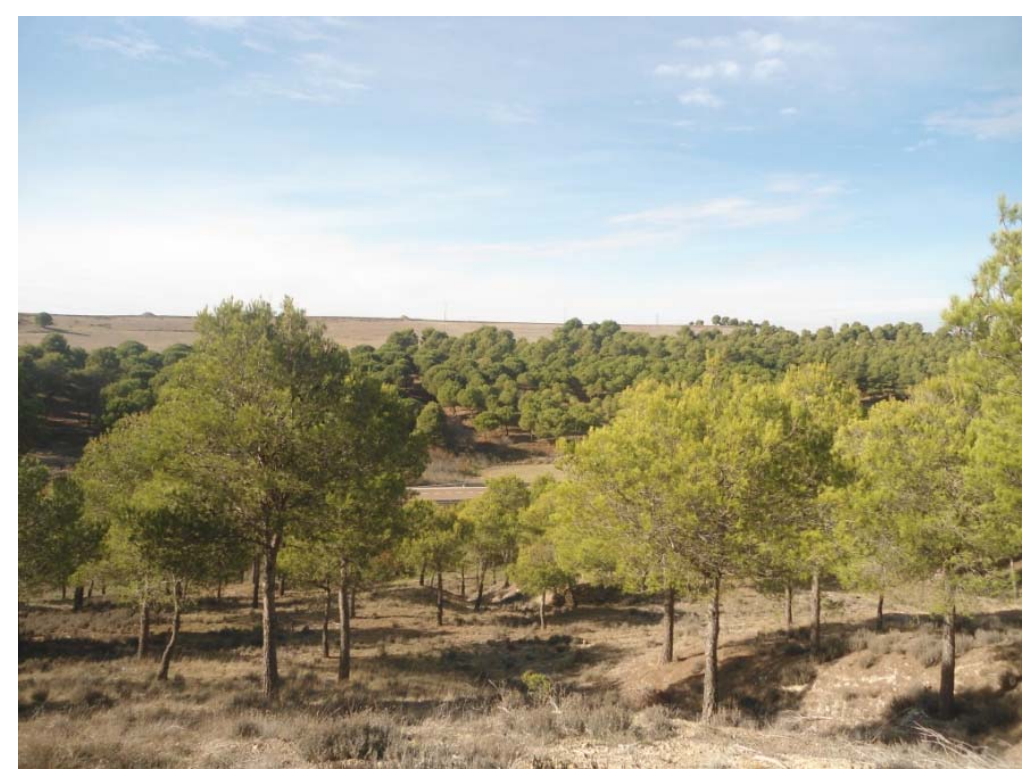

Figura A2.28. Imagen de las dos laderas cubiertas de pinar de la cuesta de Coruñeses, en la que se aprecia un pequeño tramo de la carretera nacional $\mathrm{N}$ 601 que discurre por el espacio central.

La restauración mejora asimismo el paisaje ecológico de Tierra de Campos, teniendo en cuenta la continuidad de las laderas en el borde de Tierra de Campos. Esta mejora aumenta a medida que el monte evolucione hacia una sucesión vegetal más avanzada, con mayor biodiversidad, donde las frondosas autóctonas (encina y quejigo) cobren mayor protagonismo.

Esta recuperación ambiental podría contribuir sin duda a valorizar el paisaje de Tierra de Campos. Como una primera idea, desde la carretera nacional se podría crear un acceso señalizado y una pequeña ruta a través del pinar que condujese a una zona de observatorio de la campiña y Medina de Rioseco al fondo. Curiosamente, esta parte de la campiña es de las pocas que aún conserva restos de linderas arbustivas y de almendros, lo que en determinadas épocas del año le dota de un especial atractivo. 


\title{
A2.6. Recuperación ambiental y adecuación de la "Ruta de los Parques" en Villalón de Campos
}

\section{A2.6.1. Proyecto}

\author{
Promotor: Ayuntamiento de Villalón de Campos \\ Autor: Asier Saiz Rojo (ingeniero de montes) \\ Fecha: marzo 2014
}

El proyecto pretende recuperar ambientalmente las zonas periurbanas de Villalón de Campos, adecuando los parques y las zonas verdes desde un punto de vista ambiental (mejora de la vegetación y de los hábitats para la fauna) y social (promoción de áreas recreativas, mejora paisajística, conservación de recursos culturales, etc.).

Villalón de Campos es un municipio donde, afortunadamente, en los últimos 30 años se han restaurado numerosas zonas degradadas como espacios ajardinados más o menos cuidados. Estos se reparten fundamentalmente en la periferia del casco urbano (Figura A2.29). En este proyecto se plantea la creación de un recorrido circular que atraviese buena parte de estas zonas verdes, de modo que el paseante pueda disfrutar de las mismas a través de una ruta agradable (Figura A2.30). Además, con ello se consigue la revalorización de los parques del municipio.

Las características de los parques atravesados por la Ruta no se describen en este apartado, ya que están extensamente documentadas en el Anejo 3 de este estudio, teniendo en cuenta que varios de los Recorridos paisajísticos analizan esta Ruta.

La idea persigue consolidar el hecho de que cada vez más vecinos realizan paseos por distintas partes del pueblo, como una actividad deportiva y saludable. Se plantea que una persona pueda comenzar la ruta por cualquier punto de la misma, pudiendo dirigirse a través de ella en ambos sentidos. Otra idea es recuperar nombres antiguos que se tenían para distintos espacios del pueblo, que de otra forma caerían en el olvido.

De este modo, los objetivos que se pretenden conseguir con el proyecto son los siguientes:

- Mejora medioambiental del entorno

- Potenciación del uso social para los ciudadanos

- Mejora de la movilidad en el municipio

- Recuperación de zonas abandonadas

- Mejora de las instalaciones existentes

- Fomento de la educación ambiental y del patrimonio histórico y cultural del entorno 

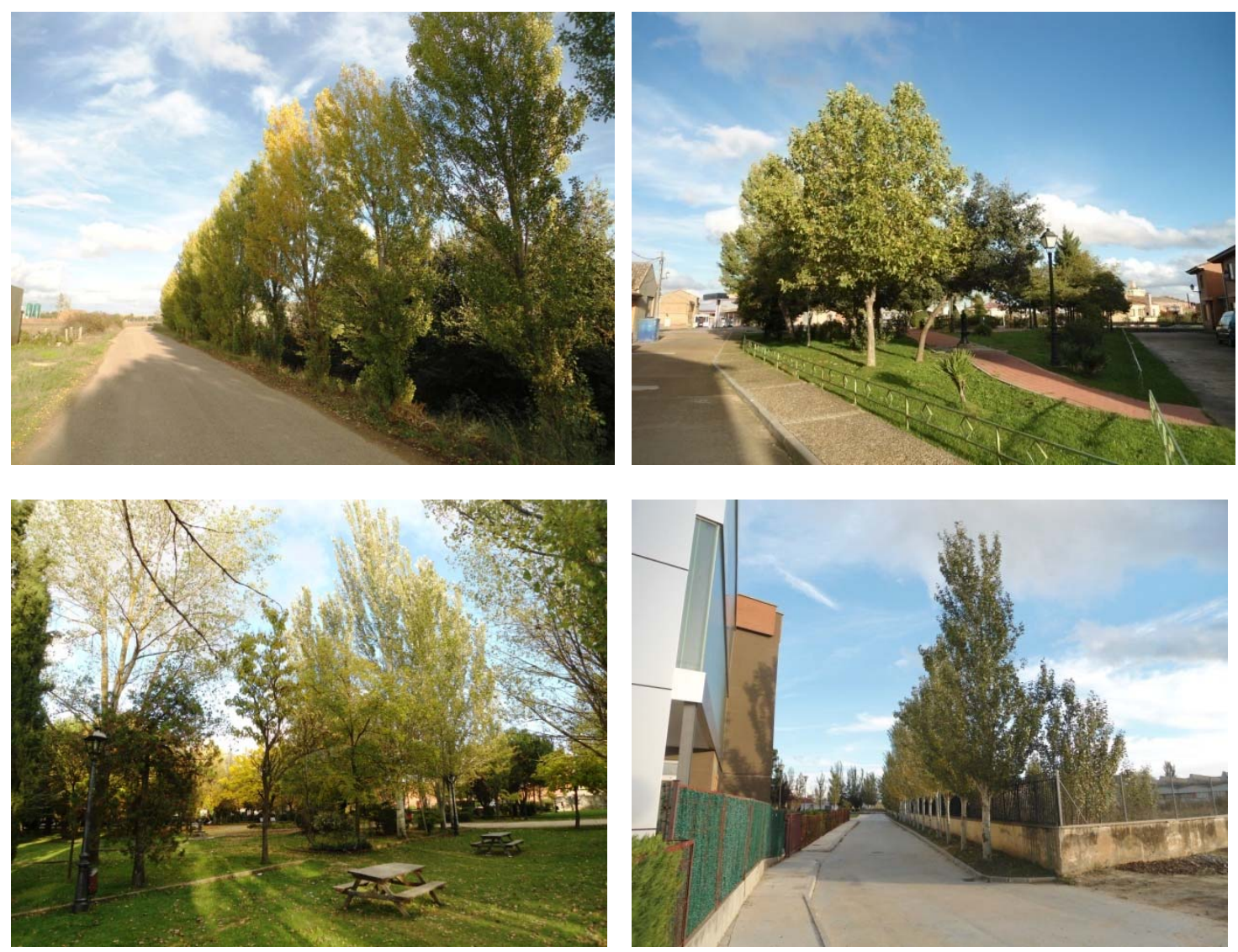

Figura A2.29. Imágenes de cuatro espacios verdes del municipio. Arriba izquierda, ribera del arroyo Pajarillas; arriba derecha, parque del Hospital de San Roque; abajo izquierda, parque del Paseo; abajo derecha, paseo de la Residencia.

La Ruta de los Parques tiene una longitud de 4,430 km y su recorrido caminando puede realizarse en una media de 50 minutos. Es asimismo totalmente ciclable.

Las actuaciones propuestas son las siguientes:

1.- Señalización y cartelería de la "Ruta de los Parques".

Se realizará mediante marcas de pintura de color verde oscuro en aceras, bordillos, postes, etc. Estarán configuradas por un rectángulo horizontal en dirección longitudinal a la ruta, ya que el recorrido podrá realizarse en los dos sentidos. Asimismo se establecerán marcas para informar de giros y cambios de dirección en la ruta.

Las marcas pintadas se complementarán con carteles indicadores de madera en los que se informará del nombre de cada zona verde. También se instalarán dos paneles informativos de $1,8 \times 1,2 \mathrm{~m}$ de dimensiones en los que se incluirá un plano de la ruta y otra información de interés. Finalmente, se instalarán 5 carteles indicadores de madera con forma de flecha, señalando otros recursos cercanos de interés.

Como aspecto común y elemento vertebrador de la ruta, se plantarán a lo largo de la misma dos especies arbustivas: romero y cantueso. 


\section{2.- Plantaciones en la Plaza Mayor.}

En esta ubicación, como punto de encuentro y salida a la ruta, se plantarán varios árboles grandes para completar los alcorques vacíos: 4 Chamaecyparys lawsoniana y 4 Cupressus sempervirens.

3.- Recuperación ambiental de las zonas verdes (con descripción sucinta) (Figura A2.31).

- Ribera del arroyo Pajarillas: Pintado de barandillas de puente y plantaciones.

- Paseo de la huerta del Moral: Plantaciones.

- Picón de las Acacias: Colocación de banco.

- Parque de la Reguera del Tinte: Plantaciones, siembra de césped rústico y delimitación.

- Plaza de la laguna del Tinte o laguna de San Juan: Colocación de banco.

- Rincón de San Francisco

- Plaza de San Juan: Arreglo de fuente.

- Parterres de la Pedrera (de Oriente): Plantaciones.

- Parterres de la Laguna: Plantaciones.

- Picón de los Cuartos de San Miguel: Plantaciones.

- Parque del hospital de San Roque: Arreglo de fuente y pintado de valla.

- Era del Depósito: Plantaciones.

- Travesía de la carretera N-610: Plantaciones.

- Parque del Paseo

- Parque temático del Pan y el Queso: Establecimiento de un sendero peatonal y plantaciones.

- Paseo de la Residencia: Plantaciones.

- Paseo del Instituto: Plantaciones.

- Jardines del Polideportivo: Establecimiento de una senda peatonal, encachado de piedra caliza y plantaciones.

- Paseo del campo de fútbol: Plantaciones.

- Paseo de la piscina: Plantaciones y colocación de señal de peligro.

- Aparcamiento de las piscinas municipales: Delimitación mediante traviesas de madera, siembras y plantaciones.

- Paseo de las eras de San Pedro: Colocación de señal de peligro y plantaciones.

- Parque de la laguna de San Pedro: Señalización de paso de peatones.

- El Majuelo de Pajarillas: Plantaciones y recreación de un viñedo.

- Paseo de Barrios o Pajarillas: Siembra de césped rústico, plantaciones y delimitación.

- Paseo de la antigua Estación: Rasanteo y perfilado de montones de escombros y recuperación de piedras calizas para la delimitación de otras zonas.

Las especies elegidas para las plantaciones de árboles y arbustos son autóctonas o adaptadas a los requerimientos ecológicos de la zona: chopo, álamo, fresno, pino piñonero, encina, almendro, ciprés, olmo, nogal, plátano, moral, endrino, tamarindo, gayomba, romero, cantueso, etc. 


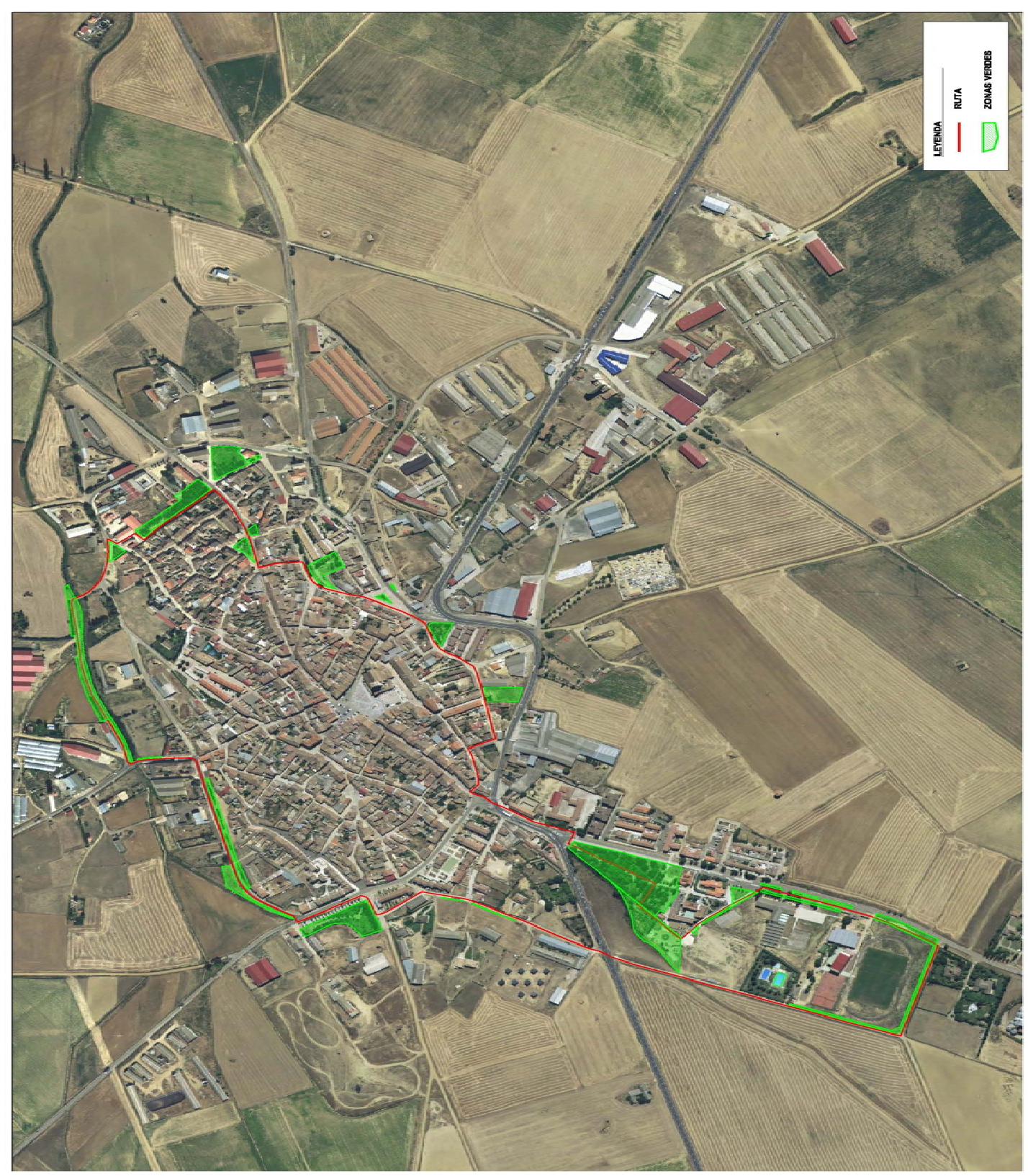

Figura A2.30. Ortofotografía con las zonas verdes y la Ruta de los Parques (en rojo). 


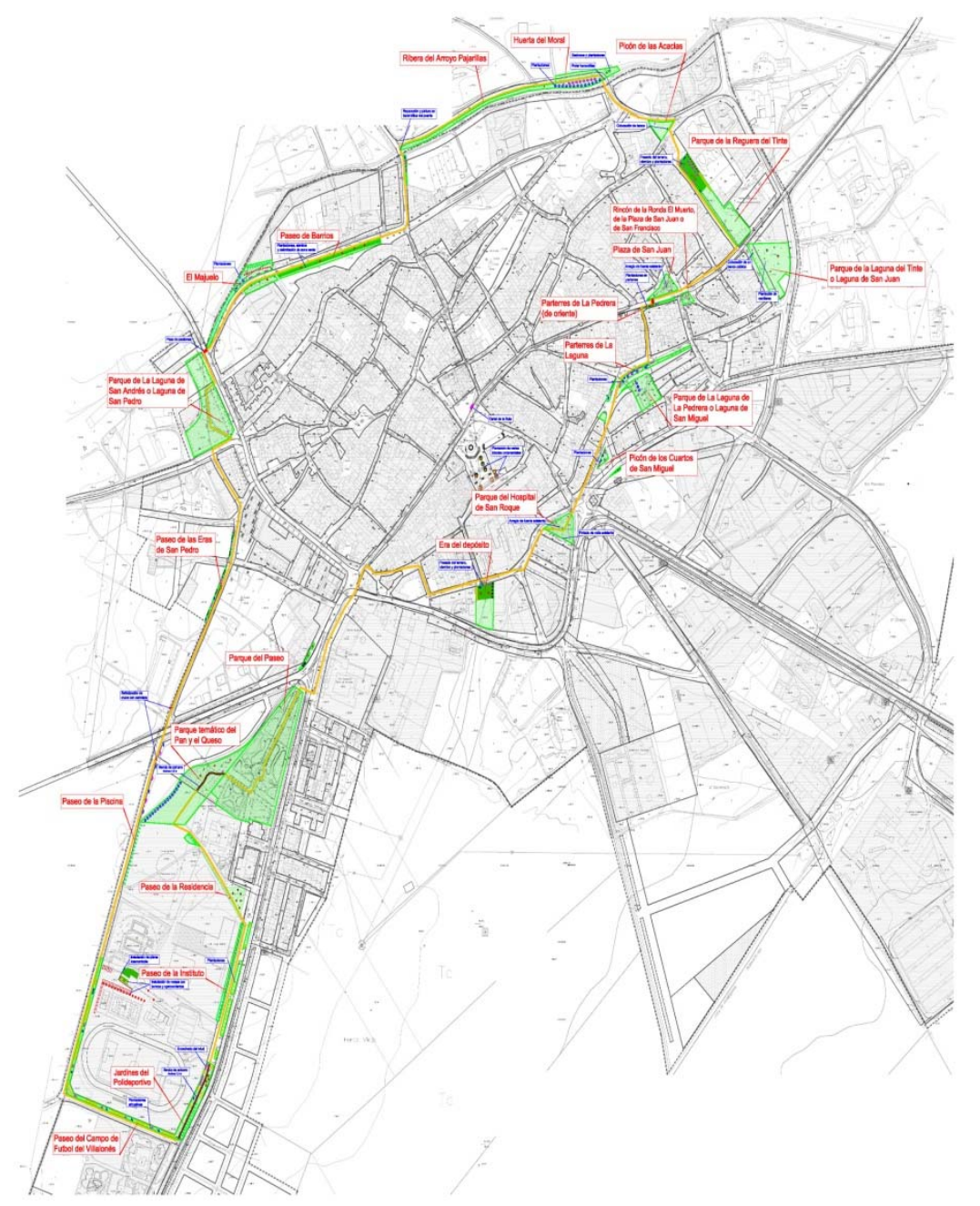

Figura A2.31. Plano de las zonas verdes y las actuaciones.

El presupuesto del proyecto es muy modesto (Tabla A2.5), pretendiéndose inicialmente que fuese ejecutado directamente con personal del Ayuntamiento.

Tabla A2.5. Resumen del presupuesto de ejecución material del proyecto.

\begin{tabular}{clcc}
\hline Capítulo & Resumen & Importe $(\boldsymbol{€})$ & $\%$ \\
\hline 1 & Operaciones previas & 676 & 3,15 \\
\hline 2 & Señalizaciones rutas & 3193 & 14,88 \\
\hline 3 & Pavimentos & 2763 & 12,88 \\
\hline 4 & Plantaciones & 3299 & 15,38 \\
\hline 5 & Siembras & 4292 & 20,01 \\
\hline 6 & Mobiliario urbano & 6904 & 32,18 \\
\hline 7 & Seguridad y salud & 180 & 0,84 \\
\hline 8 & Gestión de residuos & 149 & 0,69 \\
\hline TOTAL & & $\mathbf{2 1 4 5 6}$ & \\
\hline
\end{tabular}




\section{A2.6.2. Seguimiento ambiental}

La ejecución se realizó finalmente de un modo repartido. Las plantaciones, siembras, cartelería y pavimentos (fundamentalmente) fueron realizados por una empresa especializada, que llevó a cabo estas actuaciones en la segunda mitad del mes de marzo de 2015. El resto de actuaciones se han llevado a cabo desde el propio Ayuntamiento con posterioridad, finalizando la mayoría en mayo de 2015.

Se ha observado que en algunos espacios verdes periurbanos se ha eliminado la vegetación herbácea con herbicida total (glifosato), por parte de empleados municipales. No puede ser esta práctica más contraria al espíritu del proyecto. Lo que aquí se persigue es crear y valorizar zonas verdes, no eliminarlas con productos químicos tan contaminantes. El mejor tratamiento de estas zonas es el desbroce manual o la siega, de modo que queden como praderas naturales, aunque se agosten en verano.

Respecto de los pavimentos, se decidieron pequeñas modificaciones del proyecto inicial, en el sentido de dar más protagonismo a dos zonas: la continuación del paseo del Polideportivo y el paseo de Barrios, que han resultado ser positivas paisajísticamente por su situación colindante a carreteras (Figura A2.32).
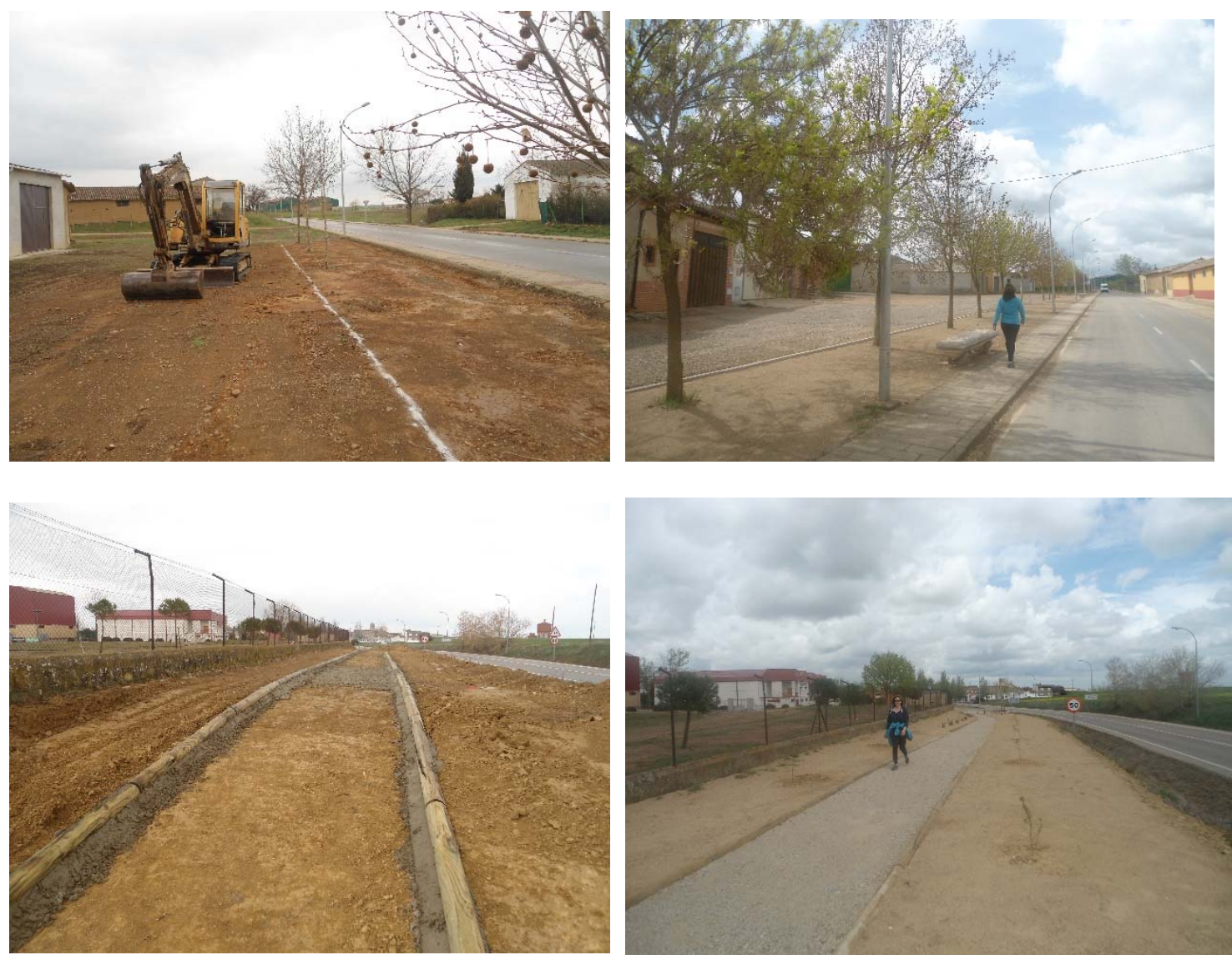

Figura A2.32. Arriba, recuperación del paseo de Barrios o Pajarillas (izquierda, antes; y derecha, después). Abajo, adecuación del paseo del Polideportivo. 
Las plantaciones se llevaron a cabo según el detalle previsto en el proyecto. La preparación del terreno se realizó mediante hoyos por retroexcavadora y, en algún caso, por ahoyadora manual de barrena. La planta era pequeña, semiforestal, de un tamaño proporcionado y con raíz en envase; características todas ellas favorables al arraigo. Se realizó un alcorque y riegos de implantación. La época fue un poco tardía, ya que algunas de las plantas estaban brotadas; no obstante, los riegos posteriores han propiciado que el porcentaje de marras sea mínimo.

En la Plaza Mayor no se han plantado los ejemplares de gran tamaño que se habían previsto. En su lugar se han colocado pequeños cipreses. Dado que es un espacio donde juegan mucho los niños, estas plantas tendrán serios riesgos de conservación si no se les protege adecuadamente. Se debería reconsiderar esta actuación, colocando los Chamaecyparys lawsoniana proyectados, con los elementos de protección necesarios.

Se apunta que el riego de las plantas, sobre todo en la época estival, será un factor crítico para asegurar el éxito del proyecto. Por el tamaño reducido de los árboles y arbustos, el riego ha de realizarse -con el esmero oportuno- de forma imperiosa durante el primer año posterior a la plantación. Durante el segundo sería conveniente, aunque más espaciado y, probablemente, ya no fuese necesario en años posteriores.

Una actuación interesante es la colocación de más bancos de los proyectados, en nuevos espacios acondicionados (Figura A2.32), aprovechando mobiliario urbano que el propio Ayuntamiento tenía almacenado. Los bancos crean zonas estanciales intermedias que resultan muy agradables para el conjunto de la Ruta.

A finales de abril de 2015 comenzó la señalización de la Ruta, con un premarcado de las señales verdes. Se comprueba que es esta una tarea laboriosa pero muy necesaria, dado que al paseante no le deben quedar dudas acerca de su exacto trazado. Asimismo se constata que es preciso realizar un premarcado en los dos sentidos de la Ruta, ya que las visiones en ambos son diferentes. El color verde oscuro mate empleado tal vez no sea excesivamente visible para los fines previstos.

En lo referente a la cartelería, se ha realizado un diseño sencillo y atractivo (Figura A2.33), que en el caso de los de mayor tamaño incluye el trazado (se ha incluido un pequeño tramo alternativo), un pequeño texto interpretativo, una descripción de las señales y un logotipo común que aparece en toda la Ruta. El conjunto formado por estos y los de tamaño menor indicadores de dirección y del nombre de cada parque-, contribuyen de manera significativa a aportar sentido unitario a la Ruta, realzando los paseos y zonas verdes que atraviesa. 


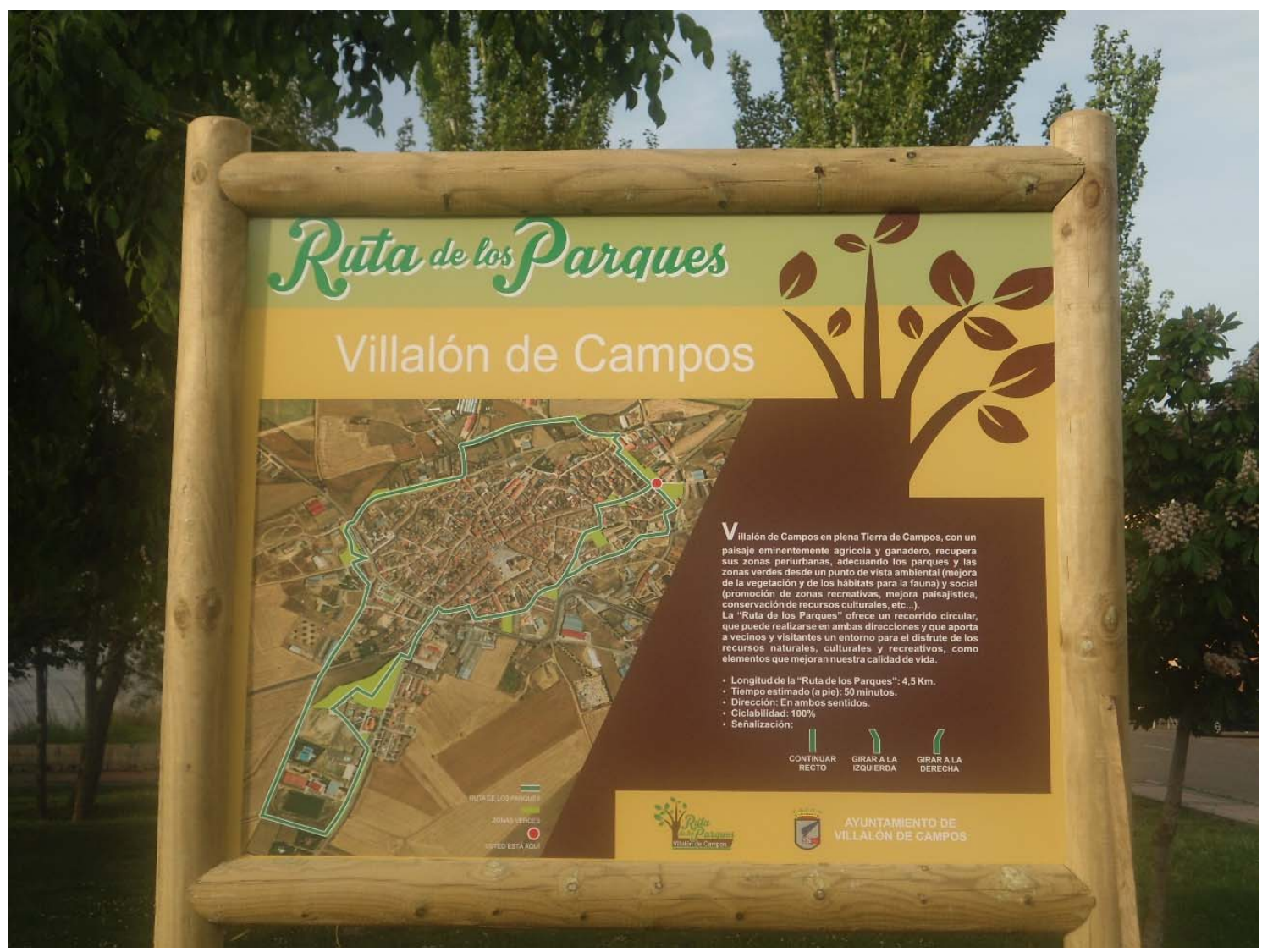

Figura A2.33. Imagen de uno de los dos grandes carteles interpretativos de la Ruta, ubicado en el parque de la reguera del Tinte.

Una de las actuaciones pendientes más importantes es la retirada de los abundantes residuos que aparecen en los márgenes y cunetas de la Ruta (papeles, plásticos, botes, etc.), que afean considerablemente el recorrido. Se constata que esta labor es fundamental, tanto en esta fase previa como en la posterior de mantenimiento.

Aunque el proyecto de la Ruta de los Parques se está finalizando en la fecha de culminación del presente estudio, ya se observa que es utilizada por un buen número de paseantes, bien sea en su totalidad o con recorridos parciales. Además de todos los beneficios ya mencionados que conllevará este proyecto sobre la calidad de vida y salud de los usuarios, se empieza a constatar otro no menos interesante: es el referente a la socialización. Los paseos en ambos sentidos y el hecho de atravesar zonas verdes estanciales provocan el continuo cruce entre vecinos, con todo lo que lleva consigo de convivencia.

Sería muy interesante la promoción futura de esta Ruta por parte del Ayuntamiento, mediante folletos o circulares explicativas que incentivasen el uso entre los vecinos. Este proyecto es una idea muy original, que representa una valorización efectiva de los parques y jardines de Villalón de Campos (y, por tanto, de su paisaje urbano), así como una fácil oportunidad para el disfrute y la actividad física de los vecinos en contacto con la naturaleza. 


\section{A2.7. Adecuación de camino turístico en el término municipal de Tamariz de Campos}

\section{A2.7.1. Proyecto}

Promotores: Diputación Provincial de Valladolid, Ayuntamiento de Tamariz de Campos y Consejería de Medio Ambiente de la Junta de Castilla y León

Fecha: 2006

El río Sequillo atraviesa la localidad de Tamariz de Campos en dirección aguas abajo a Medina de Rioseco. Este curso hídrico sufría frecuentemente desbordamientos, que anegaban las praderas situadas entre el pueblo y el Canal de Castilla, y daban lugar a charcas con abundante presencia de aves acuáticas (Figura A2.34). Como consecuencia del encauzamiento de este río, estas zonas húmedas desaparecieron. No obstante, fruto de otra mentalidad, a finales de los 90 del siglo pasado comenzó la restauración de la laguna de Tamariz de Campos por la Consejería de Medio Ambiente de la Junta de Castilla y León, recuperando el régimen natural de llenado que tuvo la laguna mediante aportaciones del Canal de Castilla.
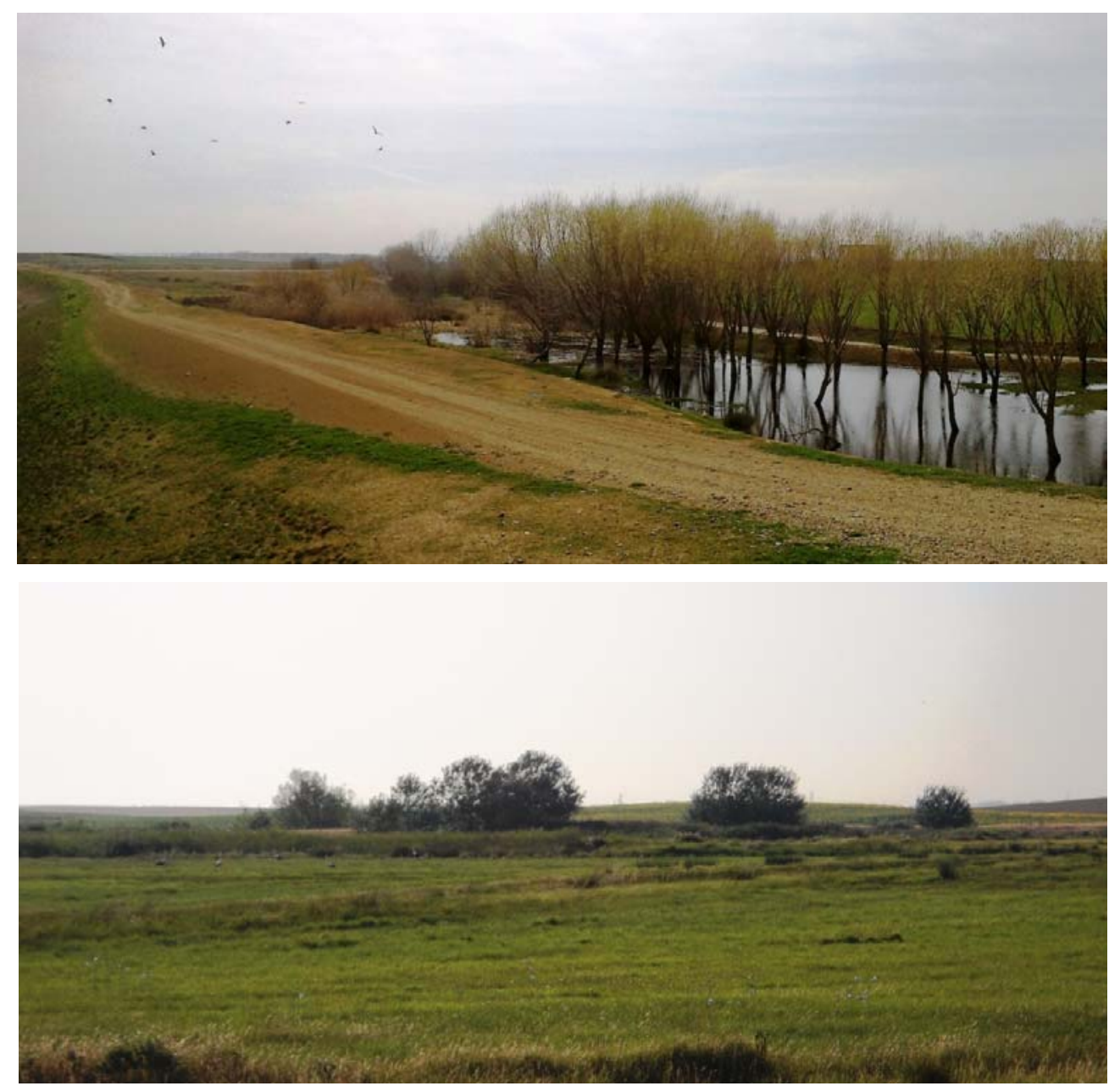

Figura A2.34. Imágenes del conjunto de zonas húmedas situadas entre el río Sequillo y el Canal de Castilla, que son visualizadas en todo momento desde el Camino turístico. En la fotografía superior se aprecia la presencia de una laguna junto al río, con tamarindos y aves acuáticas. En la inferior se observa una pradera húmeda con un nutrido grupo de cigüeñas. 
Además de la restauración de la laguna propiamente dicha, la Consejería de Medio Ambiente construyó un observatorio de avifauna en madera y realizó una repoblación forestal en distintos rodales de las praderas inundables, preferentemente en su perímetro, utilizando especies propias de riberas y zonas húmedas: sauces, chopos, álamos, etc. (Figura A2.35).
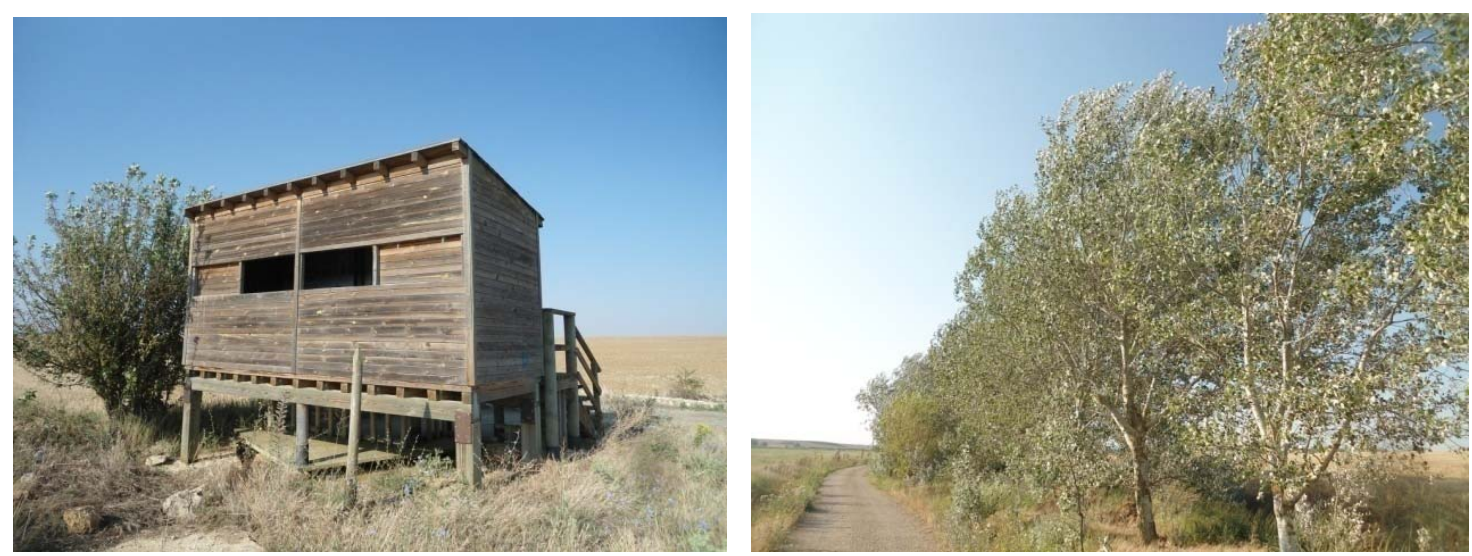

Figura A2.35. A la izquierda, observatorio de avifauna cercano a la laguna y colindante con el Camino turístico. En la imagen de la derecha se observa un grupo de álamos que ahora acompañan el tránsito por varios tramos de esta vía.

Con objeto de conectar la laguna con el pueblo de Tamariz de Campos, unos años más tarde (en 2006) surge este proyecto de Camino turístico promovido por la Diputación Provincial de Valladolid. La obra tenía dos finalidades añadidas: valorizar el conjunto formado por la laguna y la séptima esclusa del Canal de Castilla (Figura A2.37) y adecuar este camino como tramo del Camino de Santiago de Madrid (Figura A2.36).
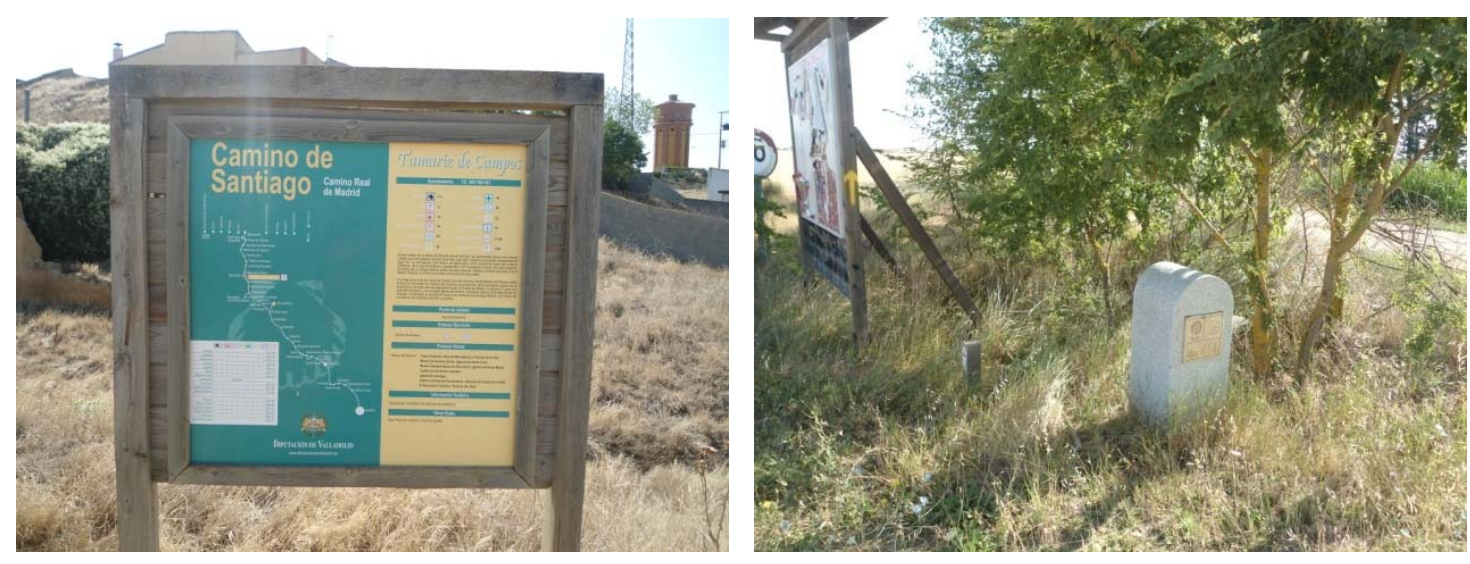

Figura A2.36. En la imagen de la izquierda se observa un panel informativo del Camino de Santiago Real de Madrid, colocado en Tamariz de Campos. En la de la derecha se distingue un hito de granito de este ramal, así como una de las tradicionales flechas amarillas que sirven como guía a los caminantes 


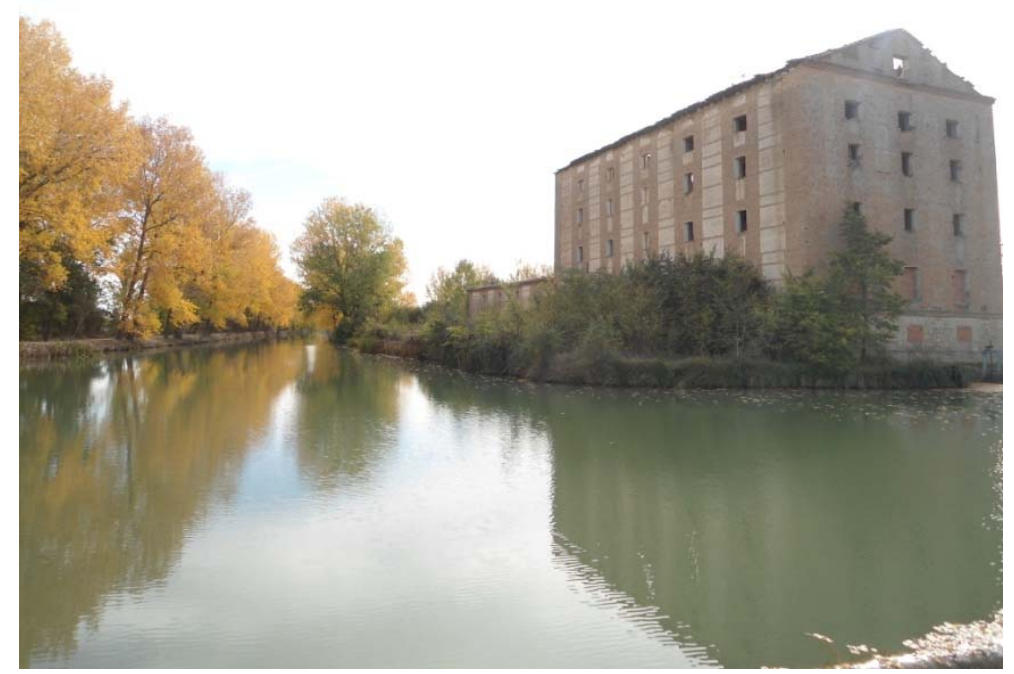

Figura A2.37. Séptima esclusa del Canal de Castilla, punto final del recorrido. Se trata de una zona realmente bella, en la que se conjuga la existencia de la propia esclusa (que realmente funciona para el barco turístico), una antigua fábrica de harinas, la chopera que acompaña los caminos de sirga y una gran lámina de agua en el quiebro que realiza la traza del Canal.

De forma paralela, la Fundación del Patrimonio Natural -dependiente de la Consejería de Medio Ambiente de la Junta de Castilla y León- creó sobre este camino un sendero de Pequeño Recorrido (PR, señalizado con franjas blancas y amarillas) que empalma con el sendero de Gran Recorrido (GR-98 "Canal de Castilla", señalizado con franjas blancas y rojas) precisamente en la séptima esclusa.
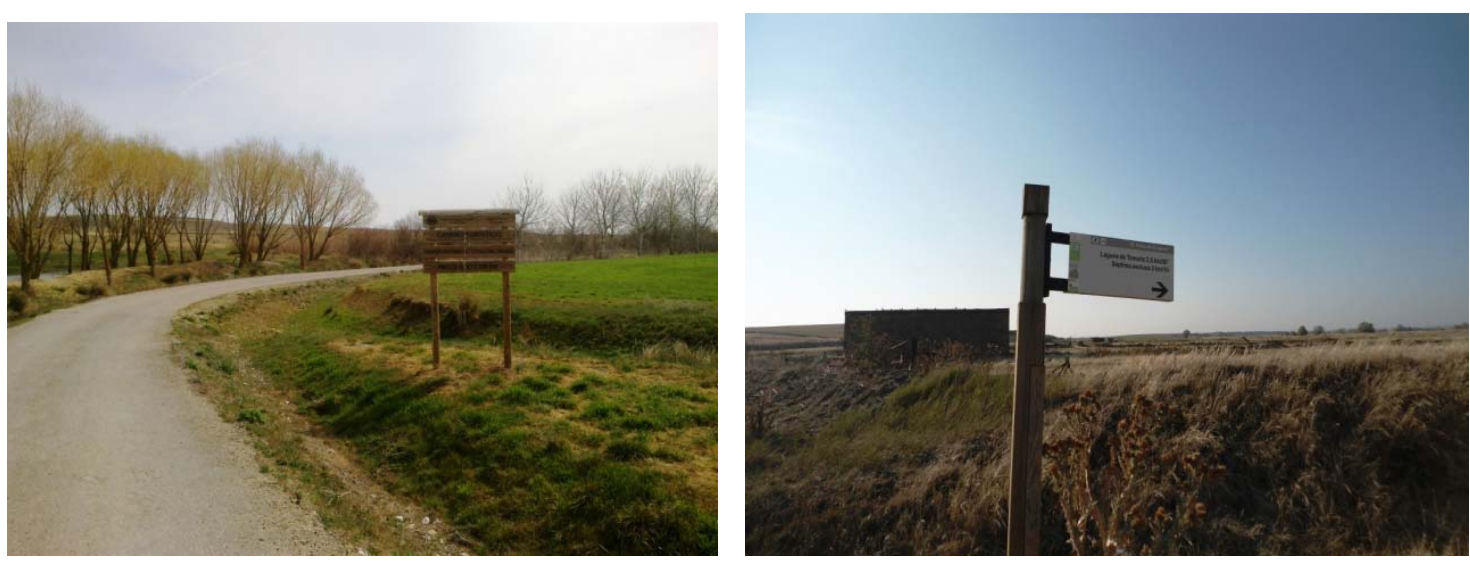

Figura A2.38. Los carteles de Camino turístico (izquierda) y sendero PR de Pequeño Recorrido (derecha) conviven a lo largo del trazado.

Por todo lo que antecede podemos afirmar que este proyecto singular realmente tiene una promoción múltiple, habiéndose involucrado distintas administraciones (local, provincial y regional) a lo largo de varias fases. 
La longitud total del recorrido es de $2950 \mathrm{~m}$, aprovechándose la traza irregular de un camino rural tradicional. La anchura de la plataforma es de $4 \mathrm{~m}$ (es una vía estrecha), con cunetas de aproximadamente $2 \mathrm{~m}$ a cada lado. En el proyecto se consolidó la base con una capa de zahorra y se extendió un firme con aglomerado asfáltico.

El camino comienza en el pueblo de Tamariz de Campos. Atraviesa el río Sequillo y discurre por un entorno arbolado, con presencia de varias charcas o lagunillas. A partir de ahí, la traza discurre de forma sensiblemente paralela al Sequillo, dejando parcelas de cultivo y las praderas asociadas al río (Figura A2.39). En varias parcelas agrícolas se han realizado pequeñas plantaciones de la medida de condicionalidad de la PAC del árbol/ha, que se encuentran en muy buen estado vegetativo y contribuyen a mejorar el paisaje. En el último tramo se localiza el observatorio de aves, desde donde se visualiza la laguna de Tamariz, finalizando en la séptima esclusa del Canal de Castilla.
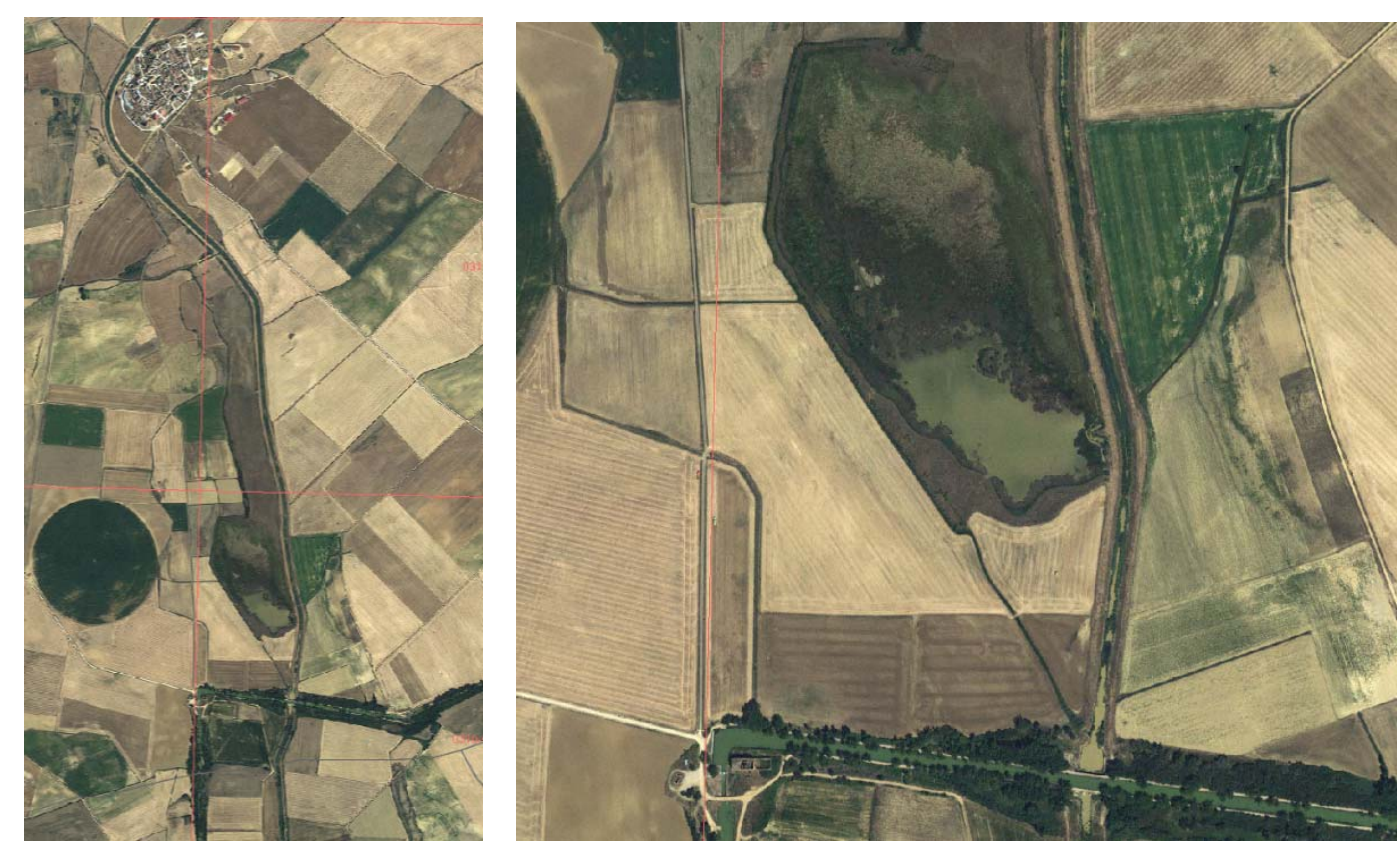

Figura A2.39. A la izquierda, ortofotografía en la que se enmarca el camino turístico desde Tamariz de Campos (al norte) y la séptima esclusa del Canal de Castilla (al sur). En la ortofoto de la derecha se observa con más detalle la laguna de Tamariz y el Canal de Castilla.

\section{A2.7.2. Seguimiento ambiental}

La idea del proyecto es francamente acertada. El objetivo básico es la revalorización de un entorno de gran variedad y belleza constituido por un pequeño pueblo típico de Campos, la ribera del río Sequillo y sus praderas naturales, la intercalación de cultivos de secano y regadío, la laguna de Tamariz y la séptima esclusa del Canal de Castilla. La simple adecuación del firme y señalización de un camino rural tradicional permite generar un uso turístico a través de la contemplación del entorno natural mediante el paseo o la circulación en bicicleta. Se puede considerar asimismo como un ejemplo de colaboración entre administraciones. 
Con esta actuación se consigue un objetivo añadido: la mejora ambiental de un tramo del Camino de Santiago Real de Madrid, que cada vez tiene mayor uso. Hay que reseñar que esta ruta posee un gran potencial turístico, ya que atraviesa Tierra de Campos de sur a norte hasta conectar con el Camino francés en Sahagún.

Afortunadamente, en la zona afectada por el proyecto no existen escombreras o depósitos puntuales de residuos, aunque la salida del pueblo tiene un cierto riesgo a su generación.

Se observa que en la adecuación del camino turístico no se han construido cunetas o estas son excesivamente reducidas. Este es un elemento hidrológico necesario para el mantenimiento del camino, que también puede derivar en una mayor disponibilidad de superficie (pequeños taludes) para realizar plantaciones de árboles o arbustos. Se debe tener en cuenta también la presión de los colindantes agrícolas, que apuran excesivamente las labores en el límite de las parcelas.

Se podría haber alcanzado una mayor cobertura de vegetación si se hubiesen realizado plantaciones de árboles en la segunda mitad del trazado del camino, cuando este se acerca a la laguna y a la séptima esclusa del Canal de Castilla. En este tramo el camino es demasiado rectilíneo y, por tanto, monótono; la vegetación -aunque sea en pequeños grupos- jugaría un importante papel para mejorar la naturalidad y diversidad del recorrido (Figura A2.40). Por el contrario, en la primera mitad del sendero la vegetación (álamos, sauces, almendros, tamarindos, etc.) alcanza actualmente unas considerables densidad y tamaño, que hacen muy agradable el trayecto.
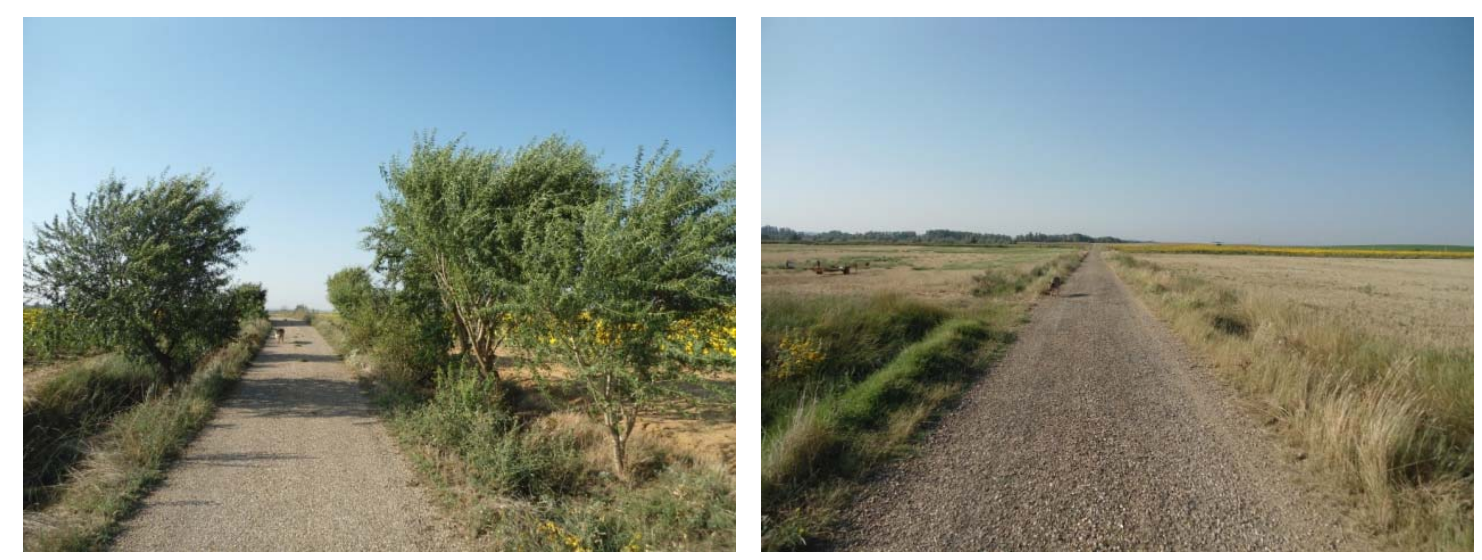

Figura A2.40. Se observan las notables diferencias que provoca la presencia o no de vegetación en los márgenes del camino. En los tramos que aparecen árboles o arbustos, el trayecto tiene mayor belleza y se hace más diverso.

En cuanto a las especies vegetales, se considera muy acertada su elección, apreciándose una selección basada en criterios de presencia o ausencia de humedad edáfica. Especial atinada ha sido la utilización de tamarices (Tamarix, sp.), que dieron lugar a la denominación de Tamariz al pueblo. Se ha realizado un diseño de pequeños bosquetes monoespecíficos, que tienden en mayor grado a la naturalidad. No se han realizado cuidados culturales especiales a las plantas, aunque se aprecia que su crecimiento es adecuado. 
En toda la ruta se pueden visualizar sin mayor dificultad numerosas especies de avifauna, fundamentalmente acuáticas, lo que hace que el trayecto sea realmente atractivo.

Sería conveniente mejorar la calidad paisajística del primer tramo del camino turístico, en la salida de Tamariz de Campos, con actuaciones tales como la mejora de la señalización, la sustitución de la valla de protección del puente sobre el río Sequillo u otras similares.

\title{
A2.8. Rehabilitación de antigua vía del ferrocarril como Vía Verde "Tierra de Campos", tramo Cuenca de Campos - Villalón de Campos.
}

\author{
A2.8.1. Proyecto \\ Promotor: Ministerio de Medio Ambiente. Aguas del Duero. \\ Fecha: 2006
}

Esta actuación se promovió en torno al año 2014 por el Ministerio de Medio Ambiente en el marco de las medidas de restauración de un proyecto complejo de abastecimiento de agua a las localidades de la comarca. Uno de los ramales de esta red atraviesa la antigua vía del ferrocarril de vía estrecha, conocido popularmente como el "tren burra". La construcción de una zanja por la vía generó una considerable afección a la misma, por lo que se contempló que su restauración fuese más allá de lo necesario y abarcase un proyecto de rehabilitación como Vía Verde en la línea de otros promovidos por el Ministerio.

Teniendo en cuenta los requerimientos técnicos de construcción de la antigua vía del ferrocarril, con un perfil longitudinal de escasa pendiente, fue necesario realizar importantes movimientos de tierra que hicieron que en la vía se alternasen desmontes y terraplenes. La adaptación a la topografía del terreno también provocó un trazado sinuoso, totalmente diferente a los eminentemente rectilíneos de las infraestructuras de transporte actuales.

El tren burra tuvo una gran importancia en el desarrollo socioeconómico de la comarca durante décadas, hasta que en 1967 fue clausurado definitivamente por falta de rentabilidad. La línea que nos ocupa unía Valladolid con Medina de Rioseco y Villalón de Campos. En esta localidad se bifurcaba en dos: un ramal hacia Palencia y otro hacia Villada.

El tramo rehabilitado tiene una longitud de $4,5 \mathrm{~km}$. Comienza en la localidad de Cuenca de Campos -donde desgraciadamente se perdió el antiguo trazado-, utiliza como acceso un agradable paseo arbolado que conduce a la ermita de San Bernardino y discurre por el trazado sinuoso de la antigua vía hasta la antigua estación del ferrocarril de Villalón de Campos. En los márgenes aún se conserva algún chopo de los que antaño poblaban toda la traza. Los edificios de la antigua estación también fueron lamentablemente demolidos, aunque la Vía Verde tiene continuidad por el vial de un micropolígono industrial. La Vía ha de cruzar la carretera nacional $\mathrm{N}-610$ y llega en el último tramo hasta el cruce con la carretera provincial que conduce a Herrín de Campos (Figura A2.41). 

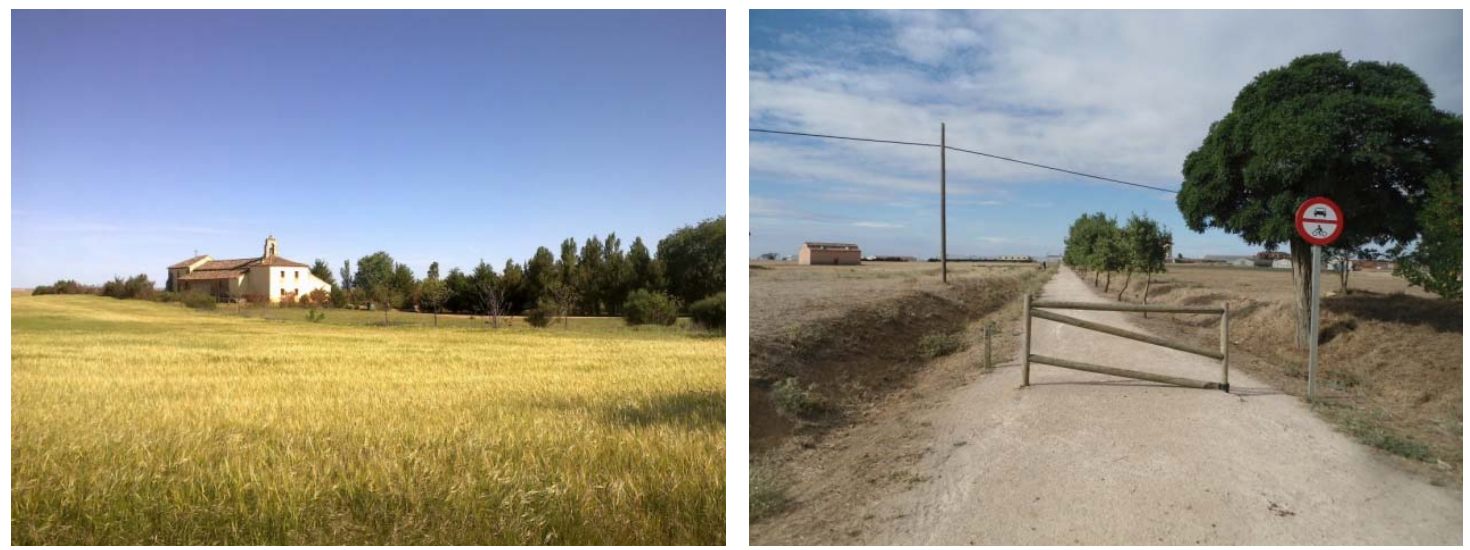

Figura A2.41. A la izquierda, vista de la ermita de San Bernardino y la zona arbolada en el inicio de la Vía Verde en Cuenca de Campos. A la derecha, final del tramo en el cruce con una carretera en Villalón de Campos; se puede apreciar la talanquera y un cartel con prohibición para vehículos a motor.

La Vía Verde planteada se conoce como "Tierra de Campos" y forma parte del programa de Caminos Naturales del Ministerio. Además, la inmensa mayoría del trazado coincide con el Camino de Santiago Real de Madrid, que viene de Medina de Rioseco, dirigiéndose desde Villalón de Campos hasta Sahagún.

En el proyecto se incluyeron las siguientes actuaciones:

- Restauración de los pequeños puentes con rollizos y tabla de madera tratada.

- Nivelación y refino de la plataforma (con una anchura de $4 \mathrm{~m}$ ), así como realización de cunetas en ambos márgenes ( $2 \mathrm{~m}$ en cada uno).

- Extensión y compactado de una capa de zahorra natural como subbase y de una capa de gravilla fina como material de firme.

- Colocación de talanqueras de rollizos de madera para prohibir el paso a los vehículos de motor en los puntos de cruce con caminos rurales.

- Creación de tres zonas estanciales, en las que fueron colocados un par de bancos de madera y un panel interpretativo del paisaje, dispuestos sobre una plancha de hormigón. En las cercanías se implantaron antiguos raíles de hierro del ferrocarril, recreando la antigua vía.

- Restauración vegetal, que consistió en la plantación lineal de árboles en el mismo margen de la plataforma, cambiando de lado por tramos con objeto de alcanzar mayor naturalidad. La distancia entre árboles planteada fue de $8 \mathrm{~m}$, salvo en un tramo más próximo a Villalón que fue de $5 \mathrm{~m}$. Las especies empleadas fueron almendro, pino piñonero, encina, quejigo, chopo castellano y álamo blanco. También se intercalaron arbustos en algunos taludes (escaramujo, endrino, gayomba, etc.) (Figura A2.42).

- Colocación de señales y de hitos con los puntos kilométricos. 


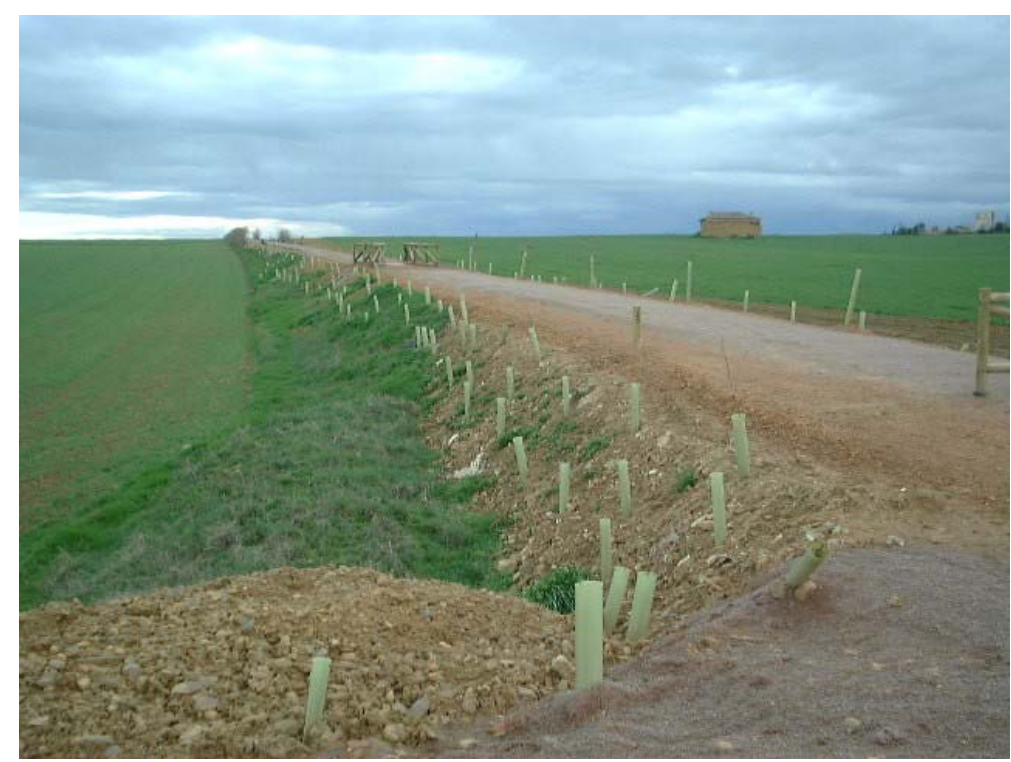

Figura A2.42. Imagen de la Vía Verde justo después de su construcción. La plataforma está totalmente afirmada, se han colocado las infraestructuras y se han realizado las plantaciones. En este tramo se observa además que, además de los árboles en línea, se han plantado arbustos en el talud de terraplén, todos con protectores.

\section{A2.8.2. Seguimiento ambiental}

La rehabilitación como Vía Verde del antiguo trazado del ferrocarril de vía estrecha es una magnífica idea con la que se cumplen dos objetivos esenciales: la recuperación de un espacio degradado por pérdida de su funcionalidad y la valorización del paisaje de Tierra de Campos. De hecho, 10 años después de su construcción puede contemplarse que esta Vía es frecuentemente utilizada por numerosos vecinos -bien sea a pie o en bicicleta- de Cuenca de Campos y Villalón de Campos (Figura A2.43), así como por peregrinos del Camino de Santiago Real de Madrid.

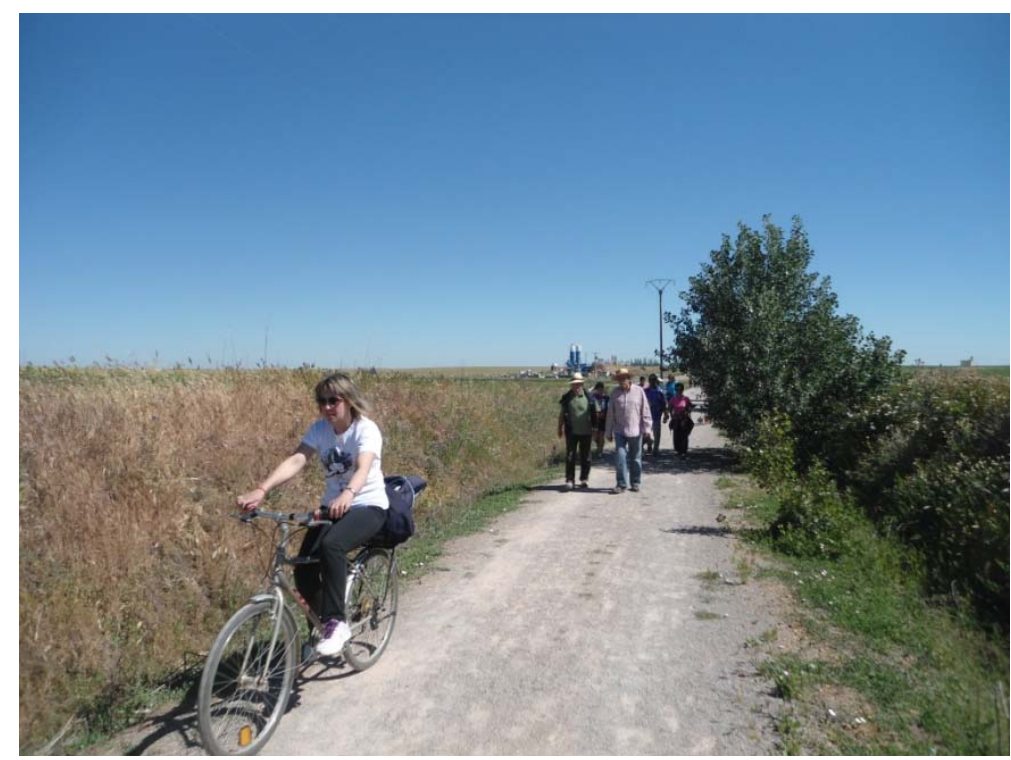

Figura A2.43. Grupo de personas caminando y en bicicleta en el Día nacional de las Vías Verdes, que se celebra anualmente. 
Se puede afirmar que la disponibilidad de los terrenos ha sido casi milagrosa. Después del cierre del ferrocarril en 1967, la vía entró en un paulatino estado de desmantelamiento. En muchos casos los terrenos pasaron a propiedad de los Ayuntamientos que, incluso, los vendieron a particulares. En este caso además existía el riesgo de que la concentración parcelaria que comenzaba a gestarse eliminase o modificase la traza, al considerarla sin uso. Por otro lado, el hecho de que la traza transcurra entre desmontes y terraplenes ha jugado a favor de su conservación, frente a la presión de colindantes. Afortunadamente aquí la rehabilitación pudo ser llevada a cabo, lo que sin duda será un motivo para la conservación del resto de las trazas para su futura recuperación. No en vano, se han redactado ya los proyectos para los tramos Villalón de Campos-Boadilla de Rioseco y Palencia-Castromocho (Canal de Castilla).

En este proyecto no ha sido necesaria la realización de remodelación topográfica alguna. Los taludes se hallaban totalmente naturalizados, con pendientes suaves $(2 \mathrm{~V}: 3 \mathrm{H}$ en los desmontes y menor en los terraplenes), y adecuada cobertura herbácea que eliminaba los riesgos de erosión.

La red de drenaje es funcional, ya que las cunetas realizadas permiten el flujo de las escorrentías y la adecuada conservación de la plataforma.

Aunque mejorable, se considera que se ha conseguido una adecuada cobertura de vegetación a lo largo del trazado rehabilitado. Se plantaron un total de 522 árboles, adaptados en general para zonas secas: almendro, pino piñonero y encina a partes iguales, más algunos ejemplares de quejigo; al pie de los desmontes (con más humedad) se plantaron chopos castellanos y álamos en menor cantidad. Los hoyos se realizaron con ahoyador manual de barrena helicoidal y se colocaron protectores. Se repusieron marras al año siguiente y, posteriormente, algún año por parte de los ayuntamientos.

Después de realizar un recuento en agosto de 2014, los resultados se reflejan en la Tabla A2.6.

Tabla A2.6. Especies plantadas y número de marras.

\begin{tabular}{lc}
\hline \multicolumn{1}{c}{ Especie } & Ejemplares \\
\hline Almendro & 71 \\
\hline Pino piñonero (grande) & 84 \\
\hline Pino piñonero (pequeño) & 24 \\
\hline Encina (grande) & 76 \\
\hline Encina (pequeña) & 36 \\
\hline Quejigo & 11 \\
\hline Álamo, chopo & 40 \\
\hline Arbustos & 34 \\
\hline MARRAS Árboles & 180 \\
\hline TOTAL Árboles & $\mathbf{5 2 2}$ \\
\hline
\end{tabular}


La diferenciación entre pinos y encinas grandes o pequeñas alude a que, estas últimas, proceden de recientes reposiciones de marras. No se conoce el número de arbustos plantados, pero sin duda las marras han sido numerosísimas.

El porcentaje de marras de los árboles ( $34 \%$ ) es elevado, teniendo en cuenta que se han repuesto en varias ocasiones. Se apuntan las siguientes causas de este fracaso:

- La preparación del terreno para los árboles fue de escasa profundidad. Menor lo fue incluso en el caso de los arbustos.

- Las primeras plantaciones se realizaron a finales de marzo, en un periodo ya tardío y expuesto a posteriores de sequía.

- No se realizaron alcorques ni riegos posteriores, al menos durante el primer año.

- Las reposiciones de marras repiten los errores apuntados.

La elección de las especies ha sido adecuada. De hecho se observa que el porcentaje de marras ha sido similar en las principales especies empleadas. No obstante, se observan diferencias sustanciales en su crecimiento: la altura media de los chopos y álamos es de 4,5 m, la de los almendros es de $3,5 \mathrm{~m}$, la de los pinos piñoneros de $2 \mathrm{~m}$ y la correspondiente a las encinas es de 1,5 m (Figura A2.44). Teniendo en cuenta que el objetivo de la restauración vegetal en las vías verdes es conseguir arbolado de cierta altura lo antes posible, se puede inferir que las prioridades podrían ir en el orden indicado: chopos y álamos en todos aquellas zonas que dispongan de mayor humedad, y preferencia para el almendro en las zonas secas. Esta última especie posee un valor paisajístico añadido por su explosiva floración.
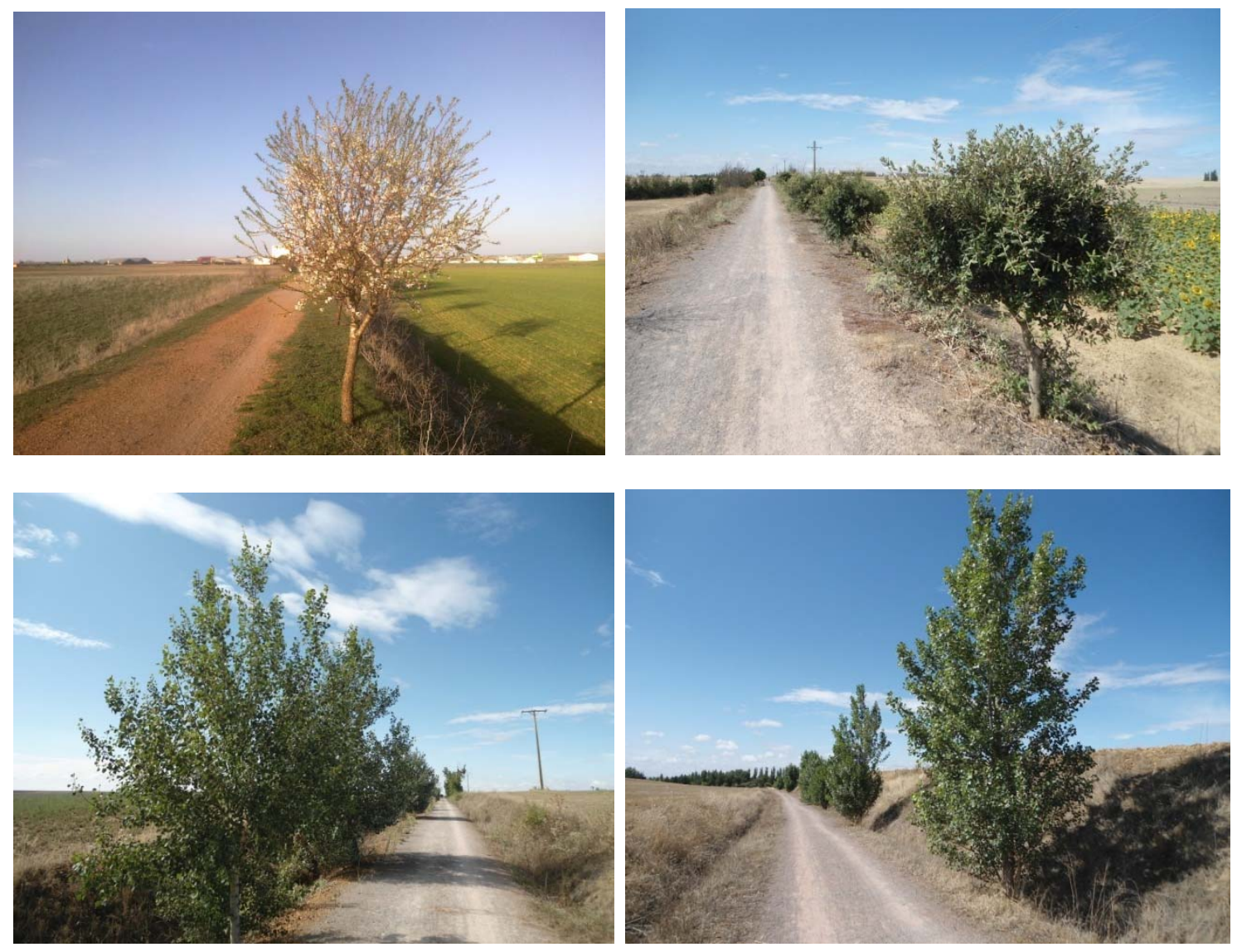

Figura A2.44. Arriba izquierda, almendros en flor. Arriba derecha, rodal de encinas. Abajo izquierda, grupo de álamos y abajo derecha, chopos castellanos ya con una altura considerable. 
En el caso de algunos pinos se emplearon ejemplares excesivamente grandes, con desproporción entre la parte aérea y la radical, por lo que han tenido a la postre mayores problemas (porte defectuoso, descompensado y torcido; Figura A2.45). En estos casos es fundamental la posterior colocación de vientos y tutores, lo que solo se ha realizado parcialmente.
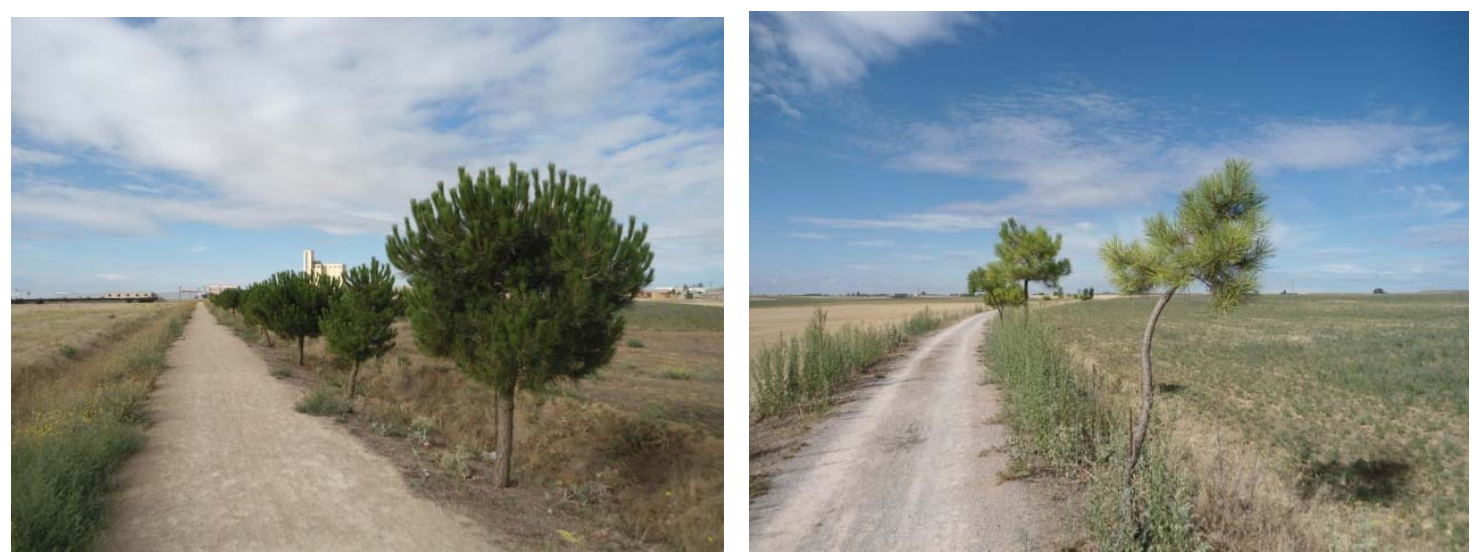

Figura A2.45. Diferencias en el crecimiento de los pinos piñoneros. Paradójicamente, los pinos de la imagen izquierda tenían un porte pequeño en su plantación, por lo que su crecimiento ha sido más proporcionado. Lo contrario sucedió en los ejemplares de la imagen derecha, que han crecido muy poco y no han logrado mejorar su porte y calidad vegetativa.

Obviamente, se respetaron los árboles existentes: grupos de chopos lombardos, brotes de olmo y algún almendro, que tienen buen porte y desarrollo. El valor actual que poseen es muy alto para el entorno de la vía.

Los pequeños puentes de madera construidos sobre los sillares de piedra de la antigua vía contribuyen a revalorizar estas estructuras, además de estar muy integrados en el paisaje (Figura A2.46).
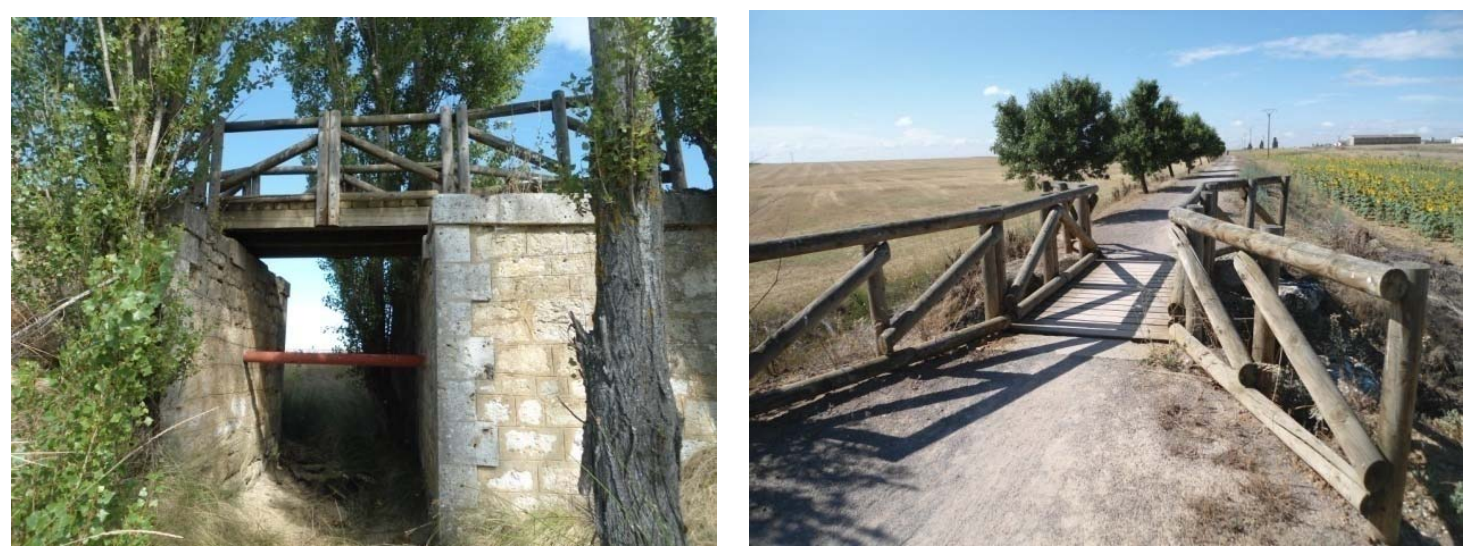

Figura A2.46. A la izquierda se refleja el nuevo puente de madera sobre los antiguos sillares de piedra; incluso se observa la tubería de abastecimiento de agua que, indirectamente, propició la restauración de la Vía Verde. A la derecha, detalle de otro puente construido con rollizos de madera tratada. 
La señalización de la Vía Verde y la instalación de paneles informativos (Figura A2.47) contribuyen a proporcionar carácter a este Camino Natural, que sin duda se acrecentará en el caso de futuras ampliaciones.
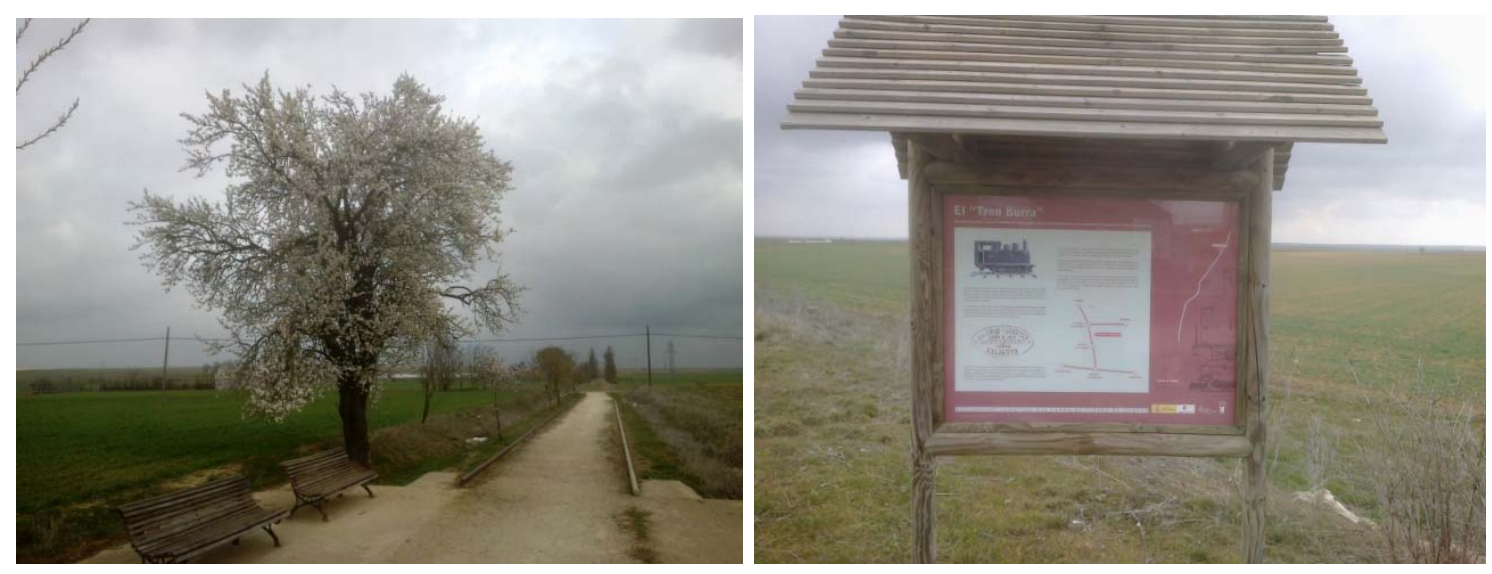

Figura A2.47. En la imagen de la derecha se muestra un área estancial diseñada junto a un antiguo almendro de gran belleza, que se encuentra florido en su totalidad. A la derecha se observa un panel informativo sobre el "tren burra", con una tipología homologada de acuerdo con el programa de Caminos Naturales.

El mantenimiento de la plataforma como vía es algo complejo, ya que requiere la eliminación de la vegetación herbácea que la invade. Los ayuntamientos utilizan herbicida total en la primavera, tanto para la vía con gravilla como para los márgenes, pero induce en estos un fuerte rebrote posterior de vegetación herbácea alta y cardos en verano, por otra parte la época de mayor uso. Sería aconsejable delimitar exclusivamente el uso del herbicida a los $3 \mathrm{~m}$ centrales de la plataforma, utilizando en el resto el desbroce manual con motodesbrozadoras.

En estas vías es fundamental asegurar su continuidad y la fácil lectura de su recorrido por el usuario. Esto último se echa en falta en el tramo que atraviesa el micropolígono industrial de Villalón de Campos y, sobre todo, en el cruce con la carretera nacional N-610. También es preciso señalizar adecuadamente la situación de la Vía desde los núcleos urbanos; en el caso de esta última localidad las indicaciones son deficientes, como también lo es el acceso hasta la antigua estación, que necesita de una recuperación paisajística.

Este proyecto de recuperación ambiental, además de conseguir la rehabilitación como Vía Verde de la antigua vía del ferrocarril, logra una mejora sustancial en el paisaje visual del entorno que atraviesa. La alineación arbolada y las infraestructuras creadas son especialmente visualizadas desde la cercana carretera Villalón de Campos-Valladolid, que mejora sustancialmente la calidad de su entorno. También el paisaje ecológico se ve beneficiado, en cuanto que se crea un corredor de vegetación que constituye un hábitat para numerosas especies de fauna; no en vano en los paseos por la Vía se constata la mayor presencia de aves en los tramos con árboles. 


\section{A2.9. Restauración del arroyo Berruez en el término municipal de Villalón de Campos.}

\section{A2.9.1. Proyecto}

Promotor: Confederación Hidrográfica del Duero. TRAGSA.

Fecha: 2010

Este proyecto se enmarca en las actuaciones de conservación y mejora de cauces de la Confederación Hidrográfica del Duero, que en los últimos años han derivado en conservación y mejora del estado ecológico (FRECHILLA et al., 2011). En particular, esta actuación persigue la naturalización del arroyo Berruez a lo largo del término municipal de Villalón de Campos cuyo cauce -como el de todos los de Tierra de Campos- fue rectificado y encauzado para evitar la inundación de los terrenos colindantes. Realmente se trata de una naturalización parcial, ya que no se pretende la recuperación de los antiguos trazados o de las zonas de inundación.

Actualmente el arroyo Berruez no cuenta con vegetación de ribera alguna; no existen árboles y tan solo se observa algún ejemplar aislado de escaramujo. Por el contrario, en su fondo hay una gran invasión de especies helófitas (Figura A2.48). La agricultura intensiva llevada a cabo hasta sus límites y las limpiezas periódicas del cauce han derivado en una ausencia prácticamente total de vegetación. Teniendo en cuenta, por consiguiente, que los ejemplares existentes no pueden dispersarse de forma natural, se pretende con esta actuación acelerar el proceso evolutivo de naturalización de la ribera.

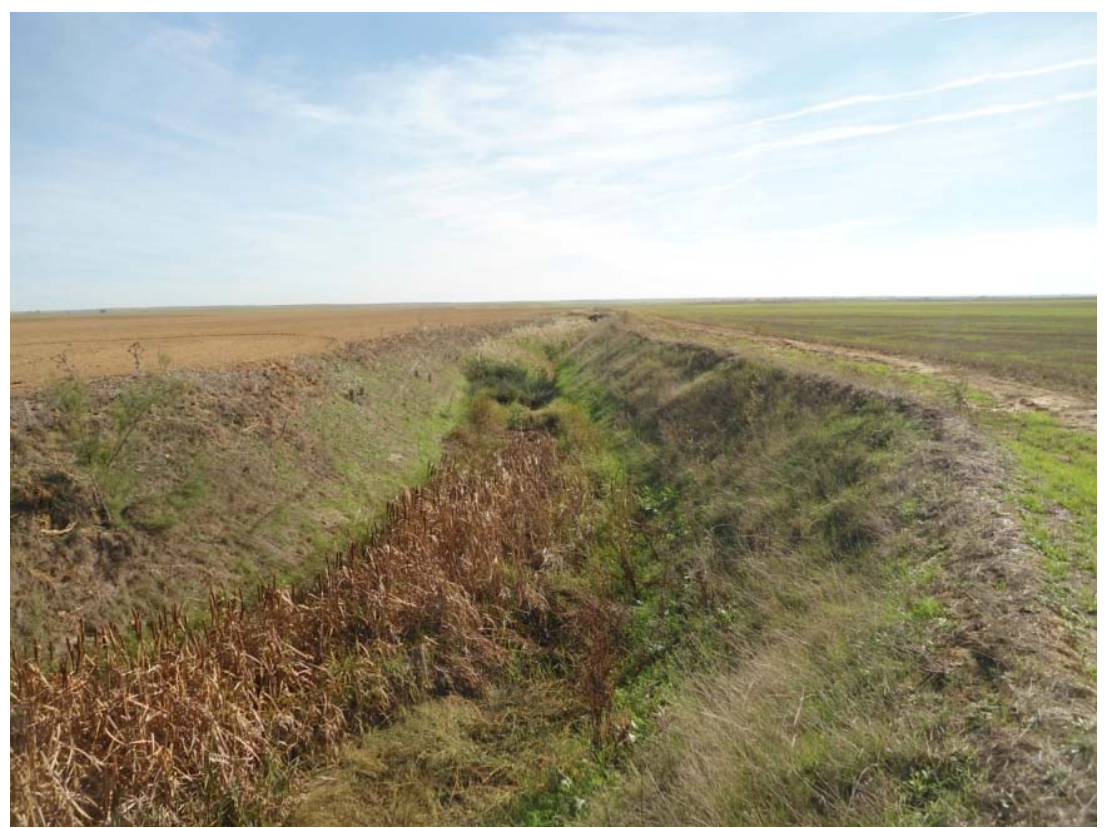

Figura A2.48. Imagen inicial del arroyo Berruez, característica de la mayor parte de cursos hídricos de Tierra de Campos. Se aprecia el cauce dragado, con invasión de especies helófitas y ausencia de vegetación de ribera; los cultivos llegan hasta el borde mismo del cauce. 
Este estado artificial es relativamente reciente. Consultando la toponimia del lugar se encuentran los pagos "El Prado", "El Pradillo", "Los Ríos", que indican la anterior presencia de un cauce trenzado y llanuras de inundación. Incluso hay otro denominado "La Alameda" -que da título a una canción muy popular en Villalón de Campos, "Árboles de la Alameda"- que alude a la presencia arbolada en las riberas del arroyo.

El arroyo Berruez atraviesa de Norte a Sur el término municipal de Villalón de Campos, hasta desembocar en el río Sequillo en la localidad de Villafrades de Campos, tras haber recorrido una longitud de 10,5 km. La anchura media del cauce es de $10 \mathrm{~m}$, su profundidad es de $3 \mathrm{~m}$ y la pendiente de sus taludes es de $1 \mathrm{~V}: 1,2 \mathrm{H}$. Ha estado sometido a dragados periódicos de su fondo, que lo han ido socavando; las tierras extraídas han sido extendidas por las parcelas agrícolas adyacentes, llegando el cultivo hasta el mismo límite del cauce.

De forma previa se realizó una actuación de dragado selectivo, que limpiaba el fondo con el cazo de una retroexcavadora, respetando los escasos ejemplares arbustivos existentes. Se pretendía también aumentar ligeramente la anchura del cauce -al menos en uno de sus márgenes- con objeto de disponer de mayor superficie para las plantaciones. Aunque en una primera instancia esta actuación fue considerablemente impactante, lo cierto es que rápido se produjo la revegetación herbácea de los taludes afectados.

Las características de las especies plantadas fueron los siguientes (Tabla A2.7):

Tabla A2.7. Especies seleccionadas, presentación y ejemplares plantados.

\begin{tabular}{llc}
\hline \multicolumn{1}{c}{ Especie } & Presentación & No ejemplares \\
\hline Populus alba & Raíz desnuda & 150 \\
\hline Populus nigra & Raíz desnuda & 100 \\
\hline Sambucus nigra & Envase forestal & 50 \\
\hline Sorbus domestica & Envase forestal & 100 \\
\hline Tamarix gallica & Envase forestal & 50 \\
\hline Amygdalus communis & Envase forestal & 100 \\
\hline Crataegus monogyna & Envase forestal & 150 \\
\hline Prunus spinosa & Envase forestal & 25 \\
\hline Rosa canina & Envase forestal & 100 \\
\hline Salix atrocinerea & Estaquilla & 250 \\
\hline Populus canescens & Estaquilla & 100 \\
\hline TOTAL & & 1175 \\
\hline
\end{tabular}


La preparación del terreno se ha realizado mediante hoyos, mayores en la planta a raíz desnuda, hasta encontrar la humedad freática, y menores (casillas de $40-50 \mathrm{~cm}$ ) para el matorral y resto de árboles. En esta actuación se ha empleado un ahoyador adosado a una máquina retrocargo, pues facilitaba las tareas con mayor seguridad. Los hoyos se realizaron en la parte media del talud. Posteriormente se realizaron alcorques.

Las plantaciones se han realizado por bosquetes de una misma especie, sin espaciamiento regular. En general, debido a la escasa superficie disponible, la distribución ha sido lineal (Figura A2.49).

La actuación de revegetación se realizó en marzo de 2011. Para la planta pequeña se colocaron protectores de malla de plástico oscura. Durante la época estival se realizaron varios riegos para asegurar el mantenimiento.
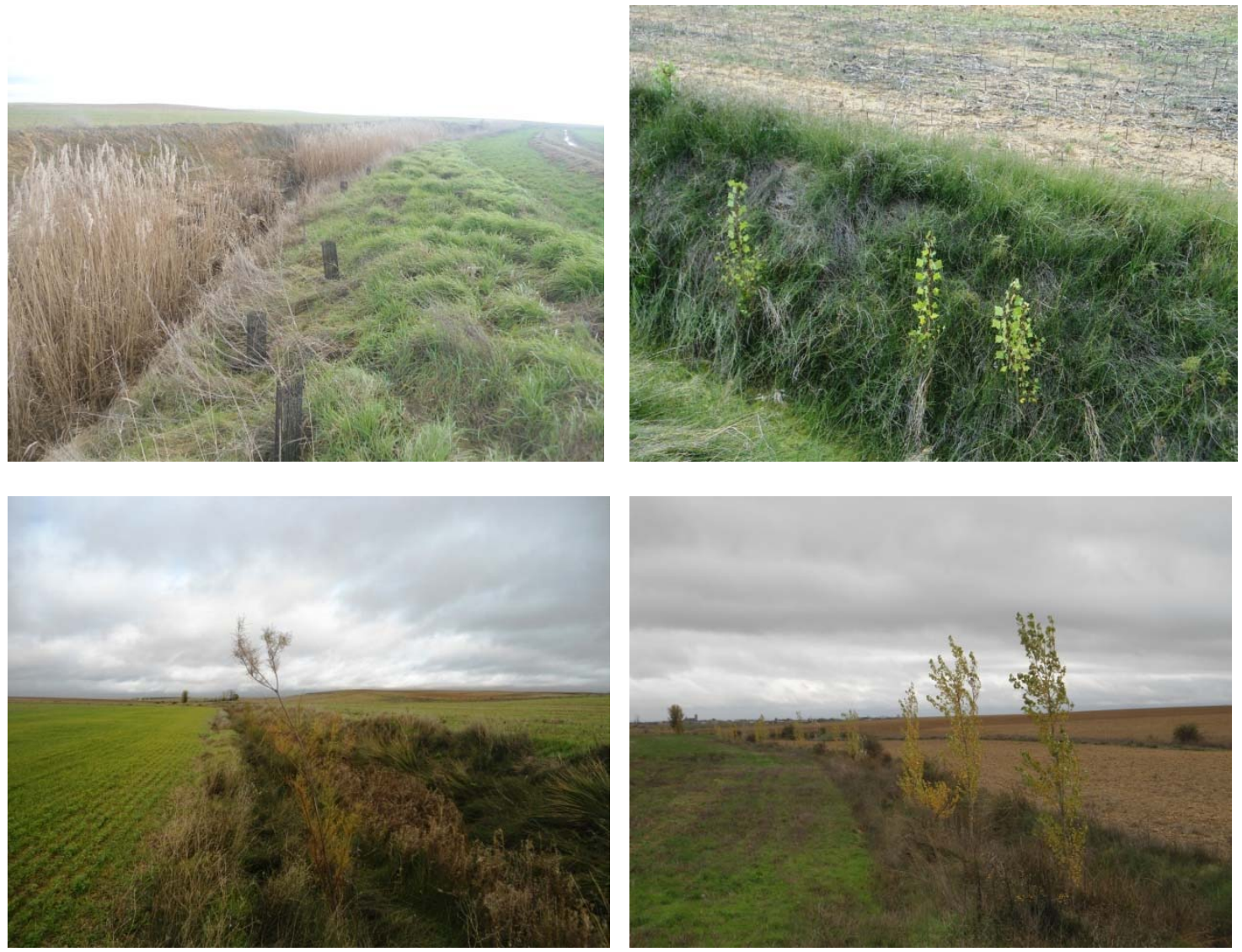

Figura A2.49. Varias imágenes en los primeros años tras la plantación. Arriba izquierda, planta pequeña con protectores. Arriba derecha, estaquillas de chopo brotadas. Abajo izquierda, tamariz en primer plano. Abajo derecha, alineación de chopos en otoño.

\section{A2.9.2. Seguimiento ambiental}

En este tipo de proyectos el mayor problema viene derivado de la falta de disponibilidad de terrenos. El dominio público hidráulico no está deslindado, por lo que los cultivos agrícolas llegan hasta el cauce. Al no existir riberas, las únicas superficies disponibles para la restauración vegetal 
son los taludes del cauce. Lo ideal sería ampliar la anchura de la superficie pública, bien sea mediante deslindes por la Confederación Hidrográfica del Duero o bien en el procedimiento de concentración parcelaria. En particular, en la concentración parcelaria de Herrín de Campos, Villafrades de Campos, Villalón de Campos y Boadilla de Rioseco se clasificaron parcelas de restauración del medio natural paralelas a los arroyos (en el Berruez hay algunas), aunque son totalmente insuficientes para este cometido.

En sentido estricto, este proyecto no plantea una restauración ecológica pura del arroyo; para ello se debería haber vuelto a la fase anterior a las rectificaciones y encauzamientos, persiguiendo un arroyo de trazado sinuoso, cauce difuso y poco profundo y riberas anchas por donde se inundaría el curso periódicamente. Actualmente este objetivo parece utópico, precisamente porque se mantiene la presión agraria para evitar la inundación de los cultivos e incluso la de las poblaciones. Nos encontraríamos, pues, en una restauración parcial ecológica y paisajística, nada desdeñable conociendo las dificultades y la situación previa, donde lo que existe antes de la actuación es realmente un canal de tierra.

Tal como se ha señalado anteriormente, la remodelación topográfica del terreno es poco ambiciosa; se remite tan solo a tratar de tender ligeramente unos taludes con una pendiente excesiva (próxima a $45^{\circ}$ ) y, por consiguiente, con unas formas muy poco naturales.

La funcionalidad hidrológica está sobredimensionada ya en el momento del encauzamiento, cuando precisamente se persigue evitar cualquier riesgo de inundación. Por el contrario, estos cauces provocan que la velocidad de la escorrentía superficial y subsuperficial sea muy elevada, con altos caudales punta, que provocan la erosión del fondo del cauce y su paulatino ahondamiento. Además, en los periodos secos se reduce sustancialmente la humedad de los terrenos colindantes, al actuar los arroyos como drenajes; esto supone una dificultad añadida para la implantación de vegetación en los taludes, pues el nivel de humedad edáfica disminuye considerablemente.

Partiendo de una realidad inicial crítica, de ausencia total de vegetación, podemos afirmar que con este proyecto se ha logrado una adecuada cobertura vegetal. Con los datos aportados, la densidad de la plantación ha sido de 0,11 plantas/m, o lo que es lo mismo, algo más de una planta cada diez metros de cauce. No es el ideal, pero supone una primera fase de restauración que puede conllevar una posterior colonización natural por la propia dinámica del arroyo o por el efecto de la fauna o el viento.

El porcentaje de marras ha sido muy reducido-se estima alrededor de un $10 \%$ - por lo que puede afirmarse que la plantación ha sido un éxito.

Las especies seleccionadas son idóneas como vegetación propia de ribera. En el seguimiento realizado pasados varios años se observa el especial arraigo y crecimiento del chopo castellano (cuatro años después alcanza los $5 \mathrm{~m}$ de altura, con crecimientos anuales de $80 \mathrm{~cm}$ ), seguido por el álamo (con una altura media de $4 \mathrm{~m}$ ) y los sauces (unos $3 \mathrm{~m}$ ). Dentro de las especies arbustivas, se destaca el rápido crecimiento del tamarindo. 

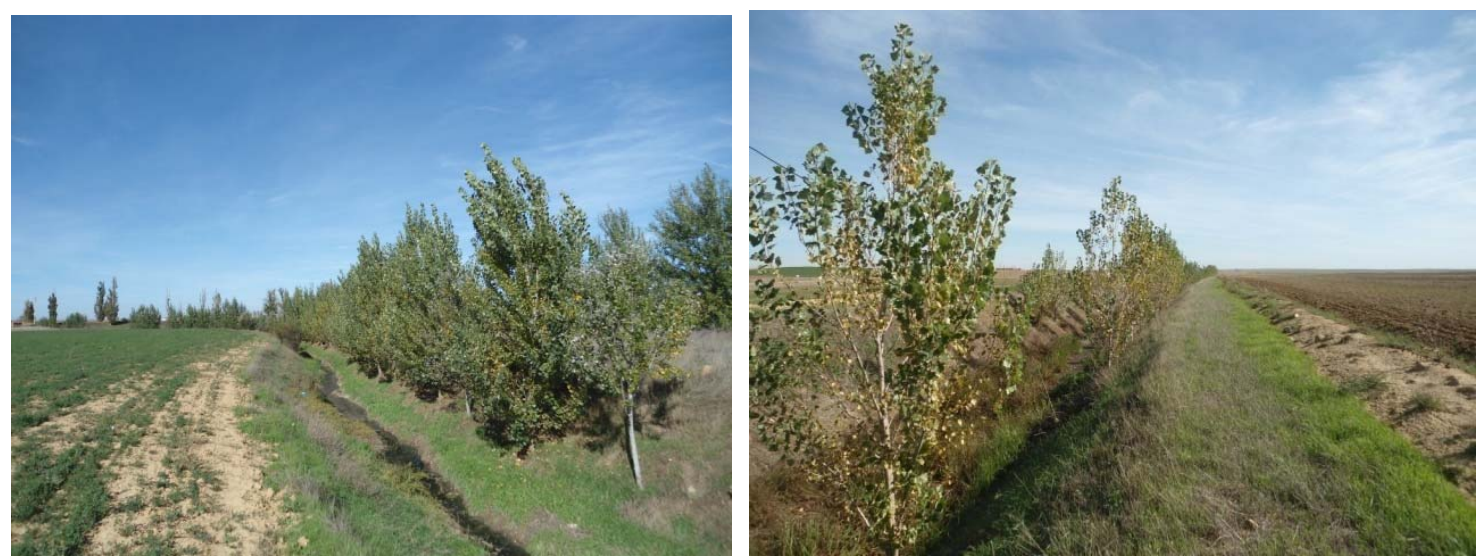

Figura A2.50. Imágenes en las que se aprecia el buen crecimiento de los chopos a los cuatro años tras su plantación. En la fotografía de la izquierda se observa cómo las labores agrícolas llegan hasta el borde del cauce, por lo que las plantas se han de colocar en su talud. En la de la derecha aparece una franja de $10 \mathrm{~m}$ sin cultivar a un lado del mismo, que se dejó posteriormente en la concentración parcelaria para restaurar; de extenderse este hecho abriría notablemente las posibilidades de restauración integral de los arroyos desnaturalizados.

El estaquillado ha tenido un peor resultado, seguramente debido a que en los taludes no está asegurada la humedad edáfica a lo largo de todo el año, algo imprescindible para este método de reproducción vegetativo.

La restauración del arroyo Berruez mejora notablemente el paisaje visual del entorno. La creación de una alineación -aunque sea discontinua- de arbolado supone un contraste visual con la monotonía de los cultivos agrícolas. Chopos, álamos y el resto de especies mantienen la hoja verde en verano, cuando en el resto del territorio dominan los ocres y marrones; se modifica la textura y se aumenta la diversidad, lo que redunda en un aumento de la calidad visual. Especial belleza poseen estas alineaciones en otoño, con la irrupción de las hojas ocres y amarillentas de los chopos.

Esta restauración entraña también una mejora del paisaje ecológico. Las plantaciones vegetales crean un hábitat y un corredor ecológico muy interesante a lo largo de todo el cauce del arroyo (Figura A2.51), que a su vez conecta con otros cauces menores y, finalmente, con el río Sequillo. Esta conectividad ecológica es mayor si cabe, teniendo en cuenta que el corredor presenta una aceptable naturalidad y grado de diversidad al estar constituido por especies autóctonas de ribera.

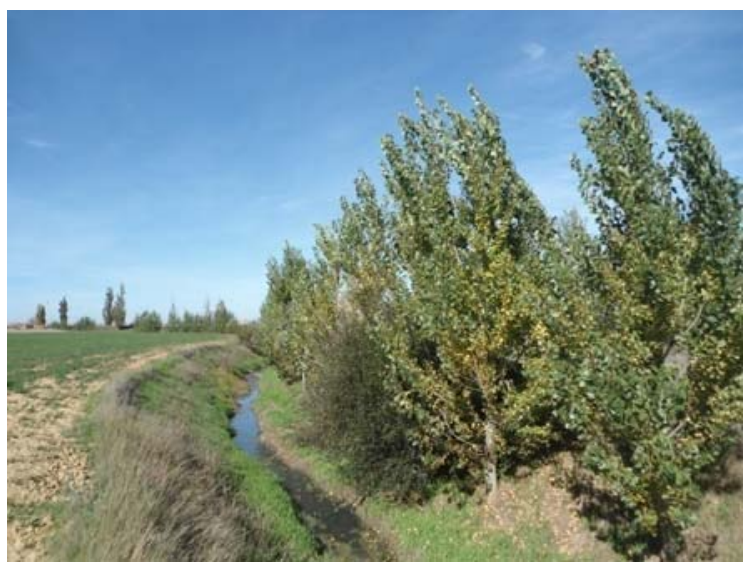

Figura A2.51. La restauración vegetal del arroyo Berruez está cambiado en gran medida el paisaje del entorno, creando un corredor ecológico natural y diverso. 


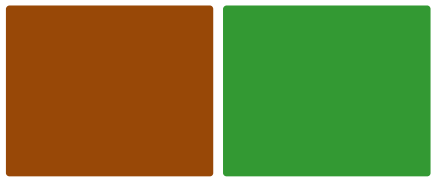

\section{ANEJO 3.}

Recorridos paisajísticos por Villalón de Campos 


\title{
A3.1. Fichas de los recorridos paisajísticos
}

\author{
- Fecha: 15 de junio de 2013, 11:15 h. \\ - Medio: En bicicleta. \\ - Itinerario: Desde ermita de Fuentes - camino exterior - \\ fuente la Florida - cruce carretera Boadilla - balsa de regadío \\ - camino paralelo a vía - cruce carretera de Herrín. \\ - Longitud: $14,2 \mathrm{~km}$ \\ - Condiciones meteorológicas: Despejado. \\ - Características de la vía: Camino de zahorra compactada, \\ plataforma de $6 \mathrm{~m}$. Franja de $1 \mathrm{~m}$ a cada lado y $0.3 \mathrm{~m}$ en el \\ centro con herbáceas y muchas flores.
}

RECORRIDO: Ruta exterior, fuente la Florida y antigua vía FICHA 1

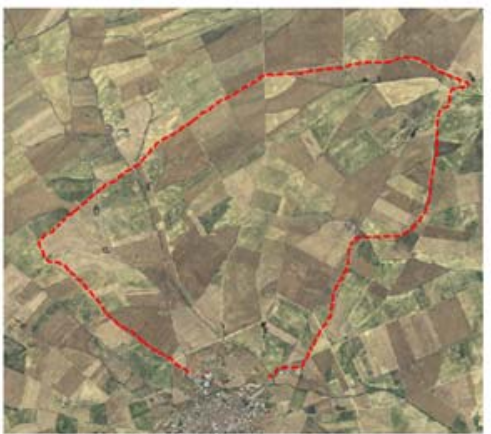

\section{CARACTERÍSTICAS DEL PAISAJE}

- Entorno inmediato de la vía: Cunetas revegetadas, con muchas flores muy vistosas, $2 \mathrm{~m}$ de anchura. Altura media de los taludes: $>2 \mathrm{~m}=5 \%, 1-2 \mathrm{~m}=40 \%,<1 \mathrm{~m}=55 \%$, siendo la mayoría de desmonte. Más revegetados los de umbría.

- $\quad$ Espacio agrícola: En la cebada el verde se va tornando ocre intenso (Figura A3.2). Cereal granado (Figura A3.3). Leguminosas de color verde intenso, muy crecidas. Tal vez sea uno de los momentos más bonitos del año.

- $\quad$ Agua: Por los arroyos y regueras no circula agua.

- Ruido: Inapreciable.

- Olores desagradables: Inexistentes.

- Vegetación: Es la zona del término municipal que tal vez posea más vegetación. En el arroyo Berruez se comienzan a percibir las plantaciones. Hay bastantes regueras con arbustos, sobre todo con escaramujos, que están en flor (Figuras A3.4 y A3.6). Soto paradigmático en la reguera el Monte, con sauces, olmos, espinos, escaramujos, etc. (es parcela de RMN). También tiene vegetación similar la fuente de la Florida. La antigua vía del ferrocarril es un auténtico corredor ecológico, con tramos de chopos altos (Figura A3.5), almendros, acacias y muchos matorrales (escaramujos, gayomba, espinos). Árboles y arbustos se encuentran en su máximo esplendor, con sus hojas de un color verde intenso.

- $\quad$ Fauna: Bastantes pajaritos, especialmente abundantes en los lindes y sotos mencionados.

- Actuaciones humanas:

o Balsa de regadío (ver anejo 1). En construcción. Taludes revegetados naturalmente con herbáceas.

- Elementos singulares:

o Fuente la Florida, con depósito de ladrillo antiguo.

o Chopo lombardo aislado de gran altura (cerca de $30 \mathrm{~m}$ ) en la antigua vía del ferrocarril.

\section{DEGRADACIONES DEL PAISAJE}

- Caminos excesivamente rectilíneos, sin naturalidad, impacto severo (Figura A3.1).

- $\quad$ Arroyos encauzados y rectificados, sin naturalidad, impacto severo.

- Depósitos de residuos muy puntuales en cunetas de caminos, impacto moderado. 


\section{RECUPERACIONES DEL PAISAJE}

- $\quad$ RES 1: Escollera para proteger los taludes de terraplén de caminos en entronque con arroyo Berruez, de piedra caliza muy integrados.

- RES 2: Restauración del arroyo Berruez (ver anejo 2).

- RES 3: Estaquillas de 2 años en reguera, $40 \mathrm{~cm}$ de altura, crecimiento $10 \mathrm{~cm} / \mathrm{año}, 30 \%$ de marras.

- AHA 1: Picón triangular de $1500 \mathrm{~m}^{2}$. Pino piñonero, protectores, cuidados, distancia $4 \mathrm{~m}, 0 \%$ de marras.

- FUE 1: Fuente la Florida: Parcela pública de aproximadamente 1 ha. Hace unos 30 años se plantaron olmos siberianos en una parte de la parcela, con mal resultado. Tiene una magnífica restauración natural de espinos y escaramujos. Hace 20 años se realizó una plantación de estaquillas de sauces sobre hoyo realizado con barrena helicoidal manual; ahora tienen una altura de unos $6 \mathrm{~m}$, crecimiento de $40 \mathrm{~cm} /$ año y un resultado de $50 \%$ de marras.

- $\quad$ AHA 2: Lindera de $20 \mathrm{~m}$ en medio de una tierra (antigua reguera). Pino piñonero, distancia $3 \mathrm{~m}$, protectores, sin cuidados, $70 \%$ de marras.

- $\quad$ AHA 3: Picón triangular de $1100 \mathrm{~m}^{2}$. Pino piñonero, distancia $3 \mathrm{~m}$, protectores, con cuidados, $0 \%$ de marras.

- AHA 4: Lindero en una tierra de $120 \mathrm{~m}$. Pino piñonero, distancia $3 \mathrm{~m}$, protectores, sin cuidados, $10 \%$ de marras.

- AHA 5: Lindero paralelo a la vía de $50 \mathrm{~m}$. Pino piñonero, distancia $3 \mathrm{~m}$, protectores, sin cuidados, $100 \%$ de marras.

\section{RECUPERACIONES POTENCIALES}

- Restauración vegetal de taludes de caminos.

- Restauración vegetal de regueras.

- Plantaciones de diversificación en el interior de las parcelas agrícolas.

- Rehabilitación de la antigua vía del ferrocarril como vía verde, con el especial atractivo de que conduce a la balsa de regadío, tanto desde Boadilla de Rioseco como desde Villalón de Campos. Se ha de incluir la reposición de pasos, la preparación del firme, la extensión y compactación de zahorra artificial (en una anchura de 3 m) y la plantación de árboles en los márgenes.

- Fuente la Florida: Adecuación del depósito y del entorno; plantación de especies de ribera en la parcela; delimitación de la misma. 


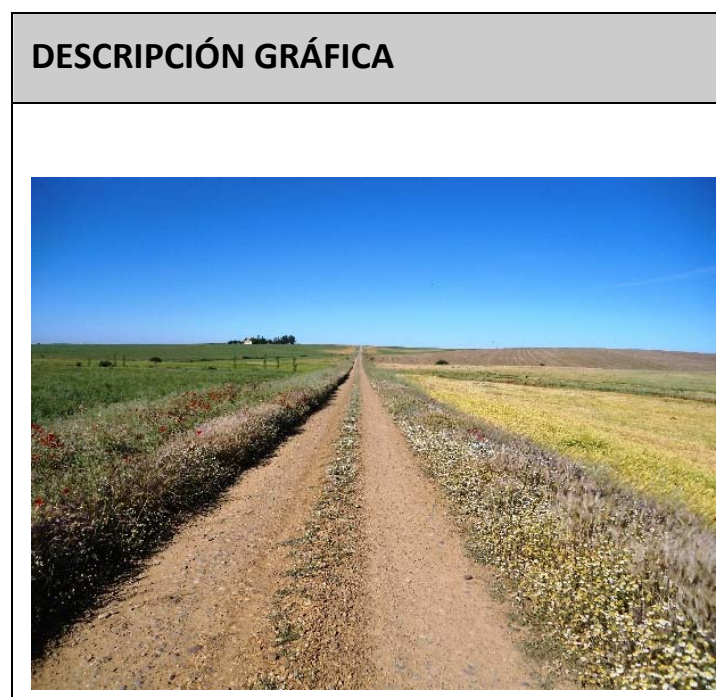

Figura A3.1. Vista general de camino

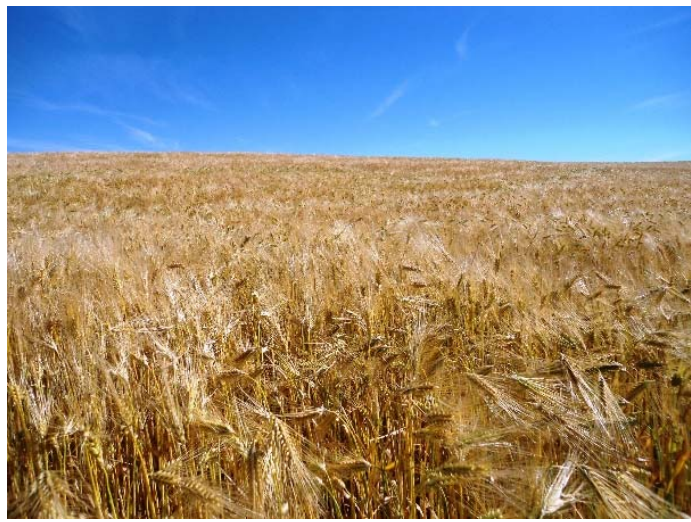

Figura A3.3. Detalle de espigas de cebada

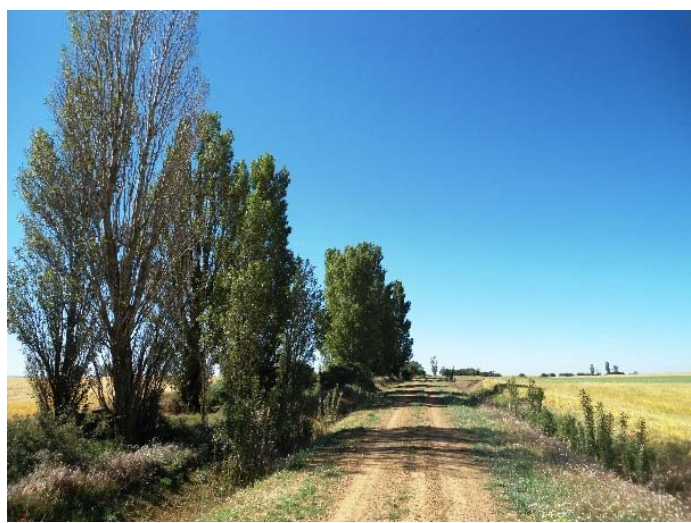

Figura A3.5. Chopos lombardos en antigua vía del ferrocarril

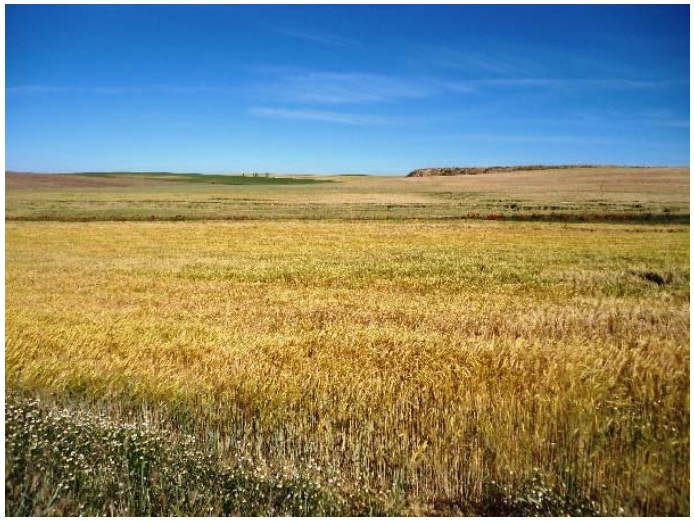

Figura A3.2. Paisaje de cereal madurando

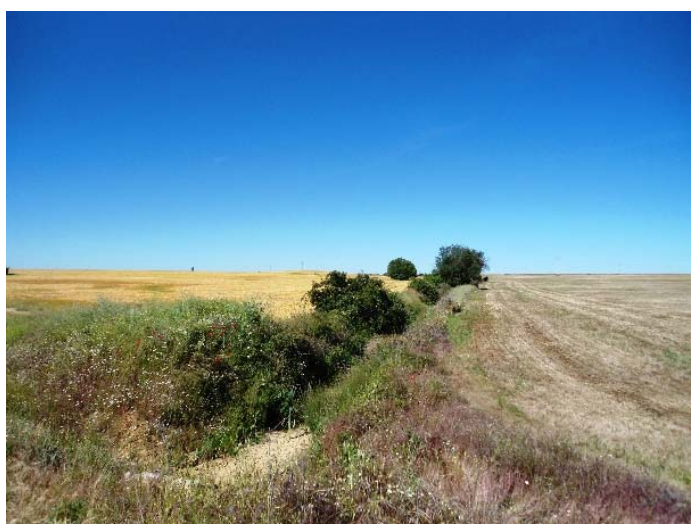

Figura A3.4. Reguera con arbustos

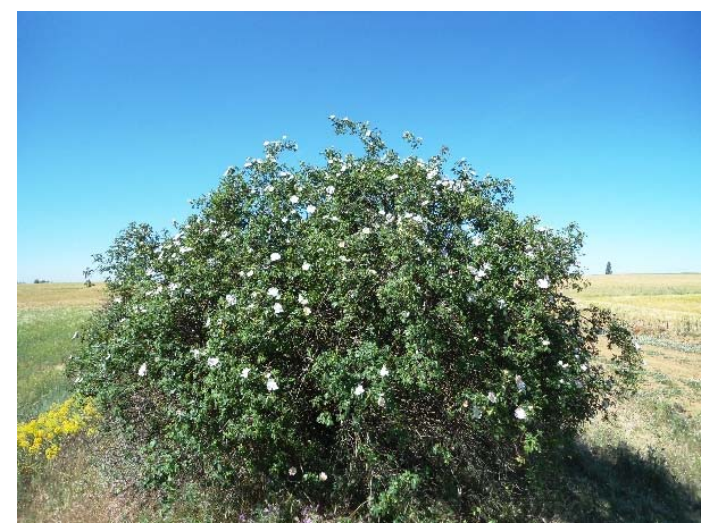

Figura A3.6. Escaramujo en flor 
- Fecha: 23 de junio de 2013, $11 \mathrm{~h}$.

- Medio: Caminando.

- Itinerario: Desde carretera a Fontihoyuelo - vereda Camino de León - camino circunvalación exterior - fuente la Gacha - ermita de Fuentes - vuelta al punto de inicio.

- Longitud: $6,4 \mathrm{~km}$

- Condiciones meteorológicas: Despejado.

- Características de la vía: Camino de zahorra; el primer tramo suelta (mal para caminar), después compactada. Plataforma de 6 $\mathrm{m}$ de anchura, en sus bordes y franja central revegetada con herbáceas en flor.

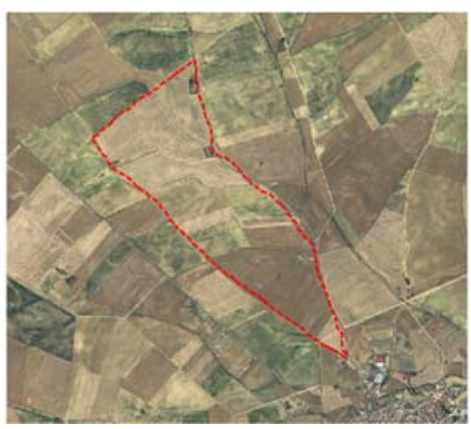

\section{CARACTERÍSTICAS DEL PAISAJE}

- Entorno inmediato de la vía: Cunetas revegetadas de $2 \mathrm{~m}$ de anchura, con muchas flores muy vistosas. Altura media de los taludes: $>2 \mathrm{~m}=5 \%, 1-2 \mathrm{~m}=60 \%,<1 \mathrm{~m}=35 \%$, siendo la mayoría de desmonte.

- Espacio agrícola: La cebada ya tiene un color ocre intenso (Figuras A3.10 y A3.11). El girasol va creciendo y contrasta con la tierra (Figuras A3.7 y A3.12). Alfalfa todavía verde.

- $\quad$ Agua: Por los arroyos y regueras no circula agua (Figura A3.8).

- Ruido: Inapreciable.

- Olores desagradables: Puntuales debido a la presencia de un estercolero de gallinaza.

- Vegetación

- Fauna: Bastantes pajaritos.

- Actuaciones humanas:

- En la fuente la Gacha hay un depósito con una placa solar, que lleva el agua a la ermita de Fuentes.

- Elementos singulares: Ermita de Fuentes (ver otros recorridos) (Figura A3.9).

\section{DEGRADACIONES DEL PAISAJE}

- Caminos excesivamente rectilíneos, sin naturalidad, impacto severo.

- Arroyos encauzados y rectificados, sin naturalidad, impacto severo.

- Existen taludes de caminos con desmoronamientos puntuales, impacto moderado

- Algún depósito de escombros y restos de antiguas obras de fábrica de los caminos, impacto moderado. 


\section{RECUPERACIONES DEL PAISAJE}

- $\quad$ RES 1: Durante las obras de adecuación de los caminos de la concentración parcelaria, en el movimiento de tierras se aprovechó para usar como base los abundantes escombros estériles que fueron depositados durante años en las cunetas próximas al pueblo.

- $\quad$ AHA 1: 200 m de lindero en medio de parcela. Pino piñonero, con protectores, sin cuidar, distancia $3 \mathrm{~m}, 90 \%$ de marras.

- $\quad$ RES 2: Estaquillado con chopos en $50 \mathrm{~m}$ de reguera, hace 3 años, con $5 \mathrm{~m}$ de separación. $80 \%$ marras. Altura $40 \mathrm{~cm}$. Crecimiento $20 \mathrm{~cm} /$ año.

- $\quad$ RES 3: Estaquillado con chopos en $50 \mathrm{~m}$ de reguera, hace 2 años, con $5 \mathrm{~m}$ de separación. $80 \%$ marras. Altura $40 \mathrm{~cm}$. Crecimiento $20 \mathrm{~cm} /$ año.

- $\quad$ AHA 2: Lindero paralelo a arroyo de $80 \mathrm{~m}$. Pino piñonero, sin protectores, con cuidados, $3 \mathrm{~m}$ distancia, $0 \%$ de marras.

- RES 4: Estaquillado con chopos en 50 m de reguera, hace 5 años, con 5 m de separación. 70 \% marras. Altura 110 $\mathrm{cm}$. Crecimiento $30 \mathrm{~cm} /$ año.

- RES 5: Estaquillado con chopos en 200 m de arroyo de la Gacha (entronque con camino, humedad), hace 2 años, cada $5 \mathrm{~m} .60 \%$ marras. Altura $120 \mathrm{~cm}$. Crecimiento $50 \mathrm{~cm} /$ año.

- $\quad$ RES 6: Protección de la base de los taludes con escollera, en los terraplenes del camino en entronque con arroyo. Piedra caliza del páramo, muy integrada, deja salir la vegetación por las juntas.

\section{RECUPERACIONES POTENCIALES}

- Restauración vegetal de taludes de caminos

- Restauración vegetal de regueras.

- Plantaciones de diversificación en el interior de las parcelas agrícolas.

- Retirada de escombros a planta de RCD o valorización in situ. 


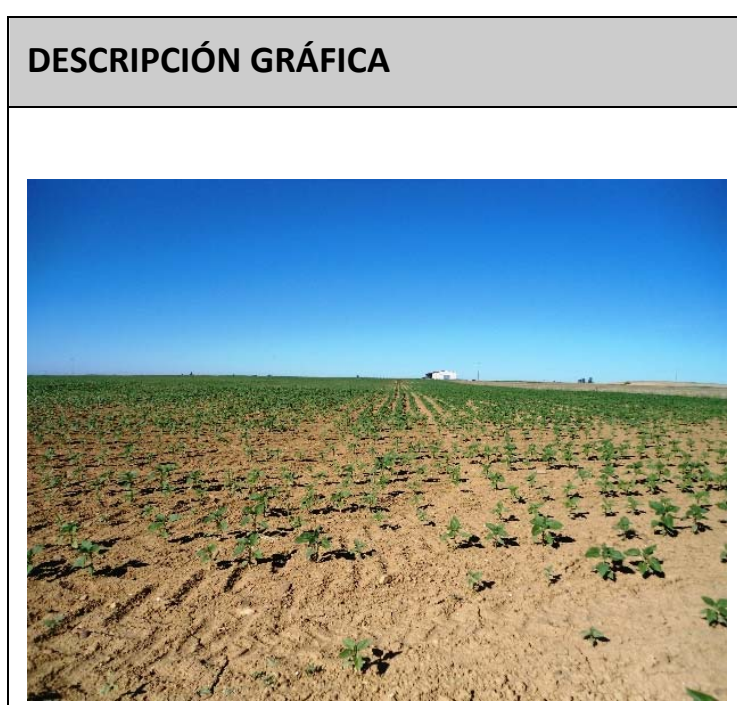

Figura A3.7. Girasol en crecimiento

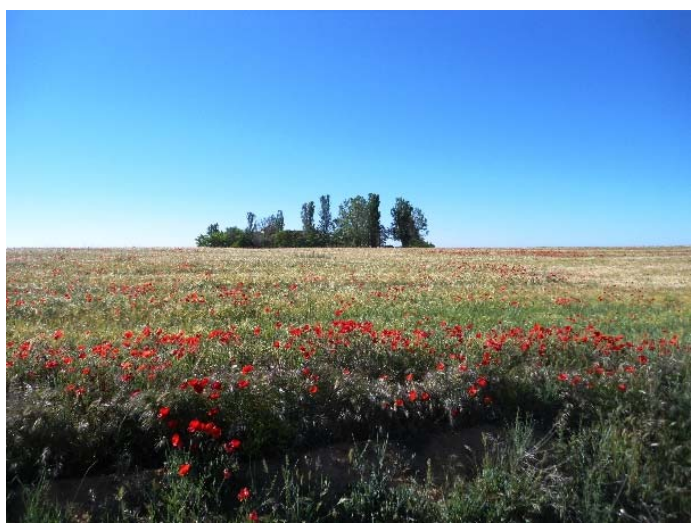

Figura A3.9. Vista de la arboleda de la ermita de Fuentes y abundantes amapolas.

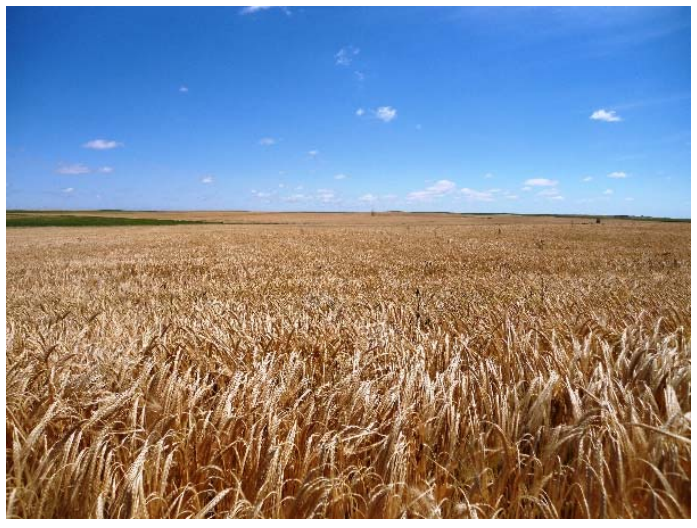

Figura A3.11. El ocre del cereal se hace dominante en el paisaje.

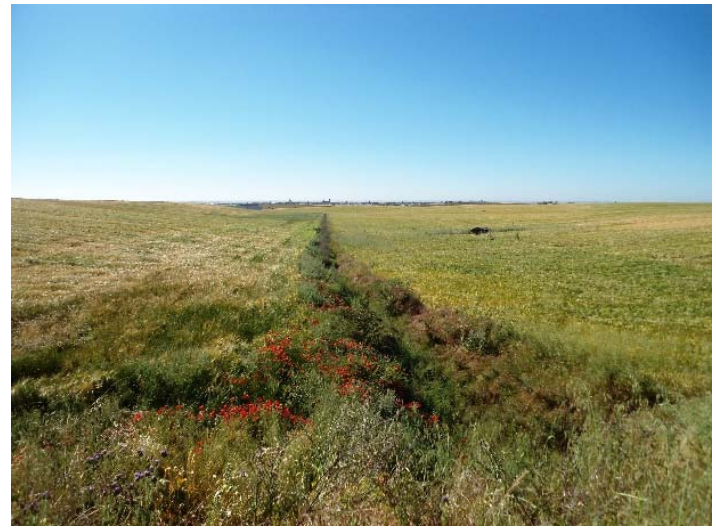

Figura A3.8. Arroyo de la Gacha, al fondo el pueblo

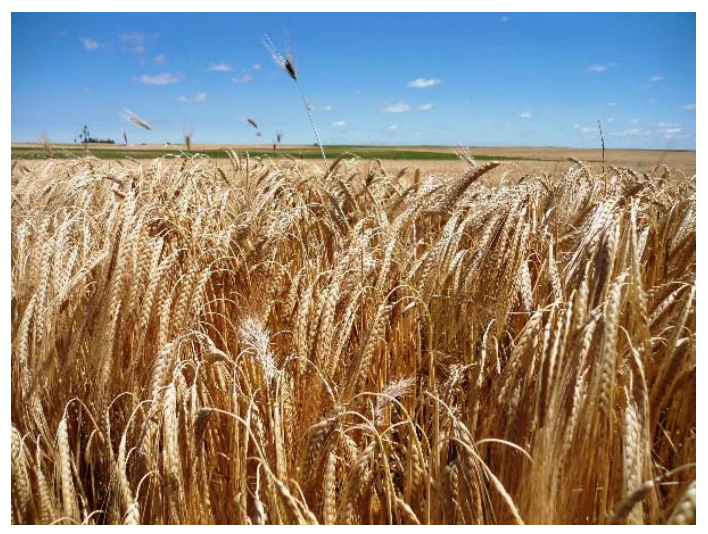

Figura A3.10. Detalle de espigas de cebada, ya muy maduras.

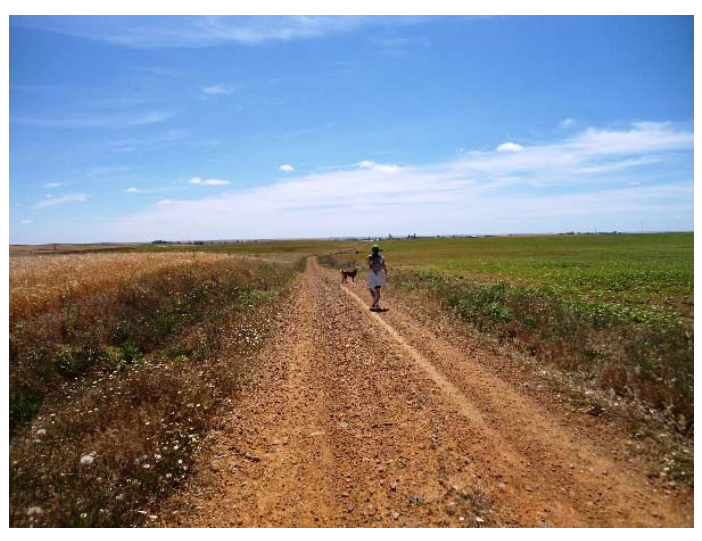

Figura A3.12. Vista del camino; a ambos lados, cereal y girasol. 


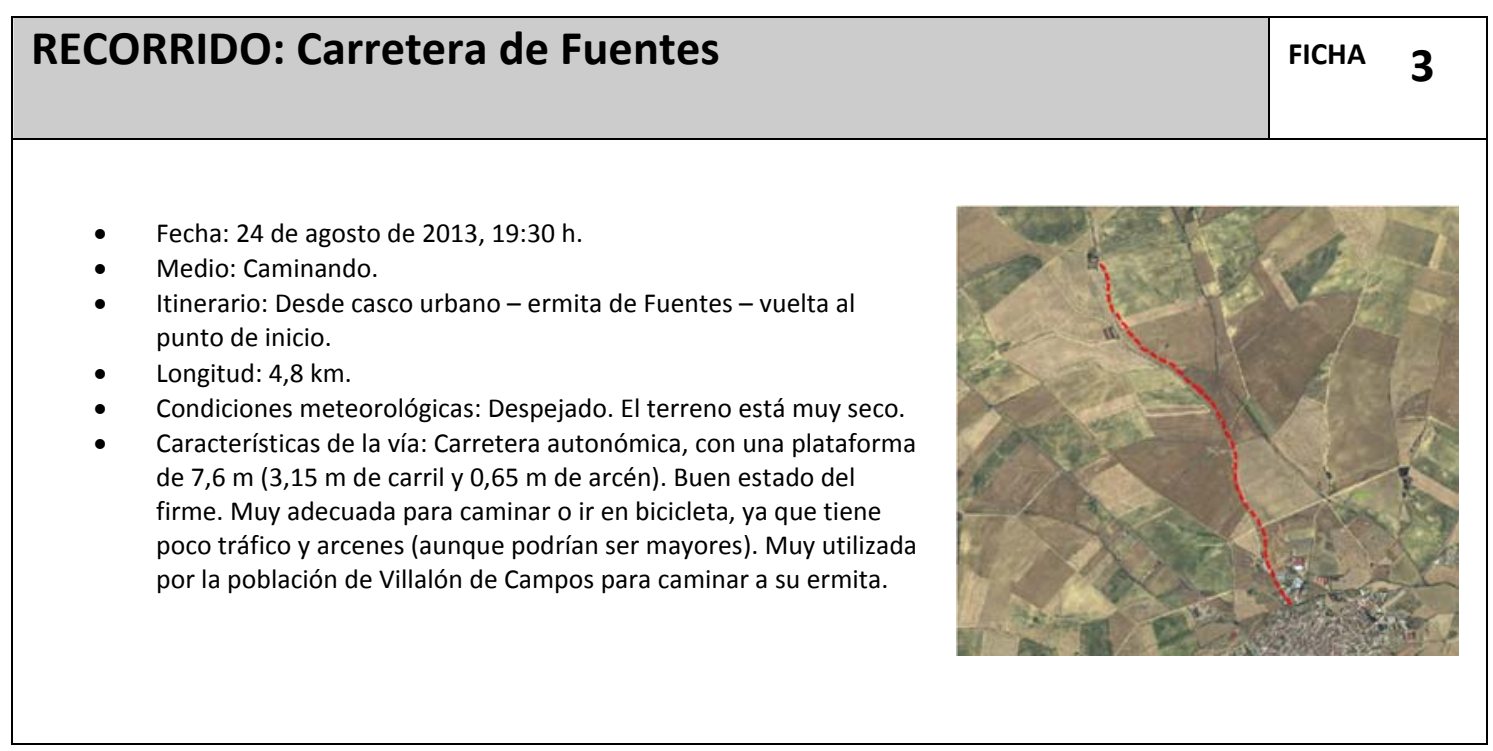

\section{CARACTERÍSTICAS DEL PAISAJE}

- Entorno inmediato de la vía: Cunetas de 3 - $4 \mathrm{~m}$ de anchura, revegetadas en su mayor parte. Altura media de los taludes: $>2 \mathrm{~m}=30 \%, 1-2 \mathrm{~m}=60 \%,<1 \mathrm{~m}=10 \%$, siendo prácticamente todo de desmonte.

- Espacio agrícola: Dominio del tono ocre del rastrojo (Figuras A3.13 y A3.15). Se intercalan las parcelas de girasol, con su colorido amarillo, y las de leguminosas de verde pálido.

- Agua: Ausencia.

- Ruido: Puntual debido al tráfico, aunque es escaso.

- Olores desagradables: Puntuales en un tramo determinado, por la presencia cercana de un estercolero de gallinaza.

- Vegetación: En los márgenes de la carretera hay algún tramo con almendros y diversas zarzas. Hay varias regueras con escaramujos, cuyo verdor contrasta en gran medida con los rastrojos (Figura A3.14).

- Fauna: Se ven pajaritos, sobre todo en las alfalfas, pero prácticamente no se percibe su sonido por la molestia del tráfico.

- $\quad$ Actuaciones humanas: Ver recorrido 8.

- Elementos singulares: Ver recorrido 8.

\section{DEGRADACIONES DEL PAISAJE}

- Desmoronamientos de un talud de considerable altura $(5-6 \mathrm{~m})$, impacto moderado.

- Presencia de residuos en las cunetas de la carretera, impacto moderado.

\section{RECUPERACIONES DEL PAISAJE}

- $\quad$ RES 1: Estaquillado con chopos en $100 \mathrm{~m}$ de reguera, hace 5 años, cada $5 \mathrm{~m} .80 \%$ marras. Altura $80 \mathrm{~cm}$. Crecimiento $10 \mathrm{~cm} /$ año.

- $\quad$ RES 2: Estaquillado con sauces en $50 \mathrm{~m}$ de reguera (escasa humedad), hace 5 años, cada $5 \mathrm{~m} .100 \% \mathrm{marras}$.

- RES 3: Estaquillado con chopos en $50 \mathrm{~m}$ de reguera, hace 5 años. $70 \%$ marras. Altura $90 \mathrm{~cm}$. Crecimiento 10 $\mathrm{cm} /$ año. 


\section{RECUPERACIONES POTENCIALES}

- Plantación de arbustos en todos los taludes de más de $1 \mathrm{~m}$ y de árboles (almendros) en los taludes de más de $2 \mathrm{~m}$ donde no exista riesgo de accidente.

- $\quad$ Adecuación de un carril bici, ensanchando uno de los arcenes. Es una ruta muy transitada durante todo el año. Incluso hay varias procesiones, que discurren desde el pueblo hasta la ermita de Fuentes.

- Limpieza periódica de los residuos de las cunetas.

- Restauración vegetal de regueras.

- Plantaciones de diversificación en el interior de las parcelas agrícolas. 


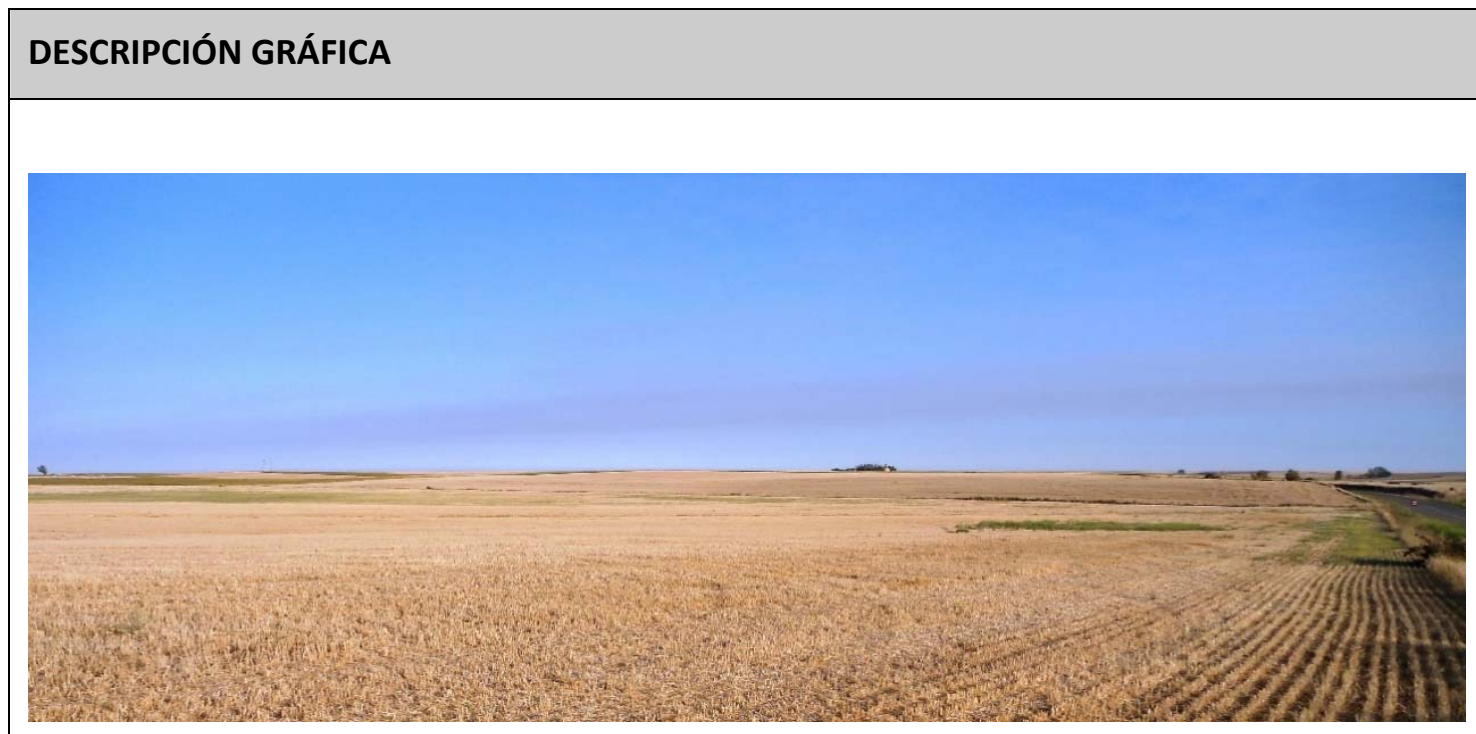

Figura A3.13. Panorámica de rastrojos con la ermita de Fuentes al fondo

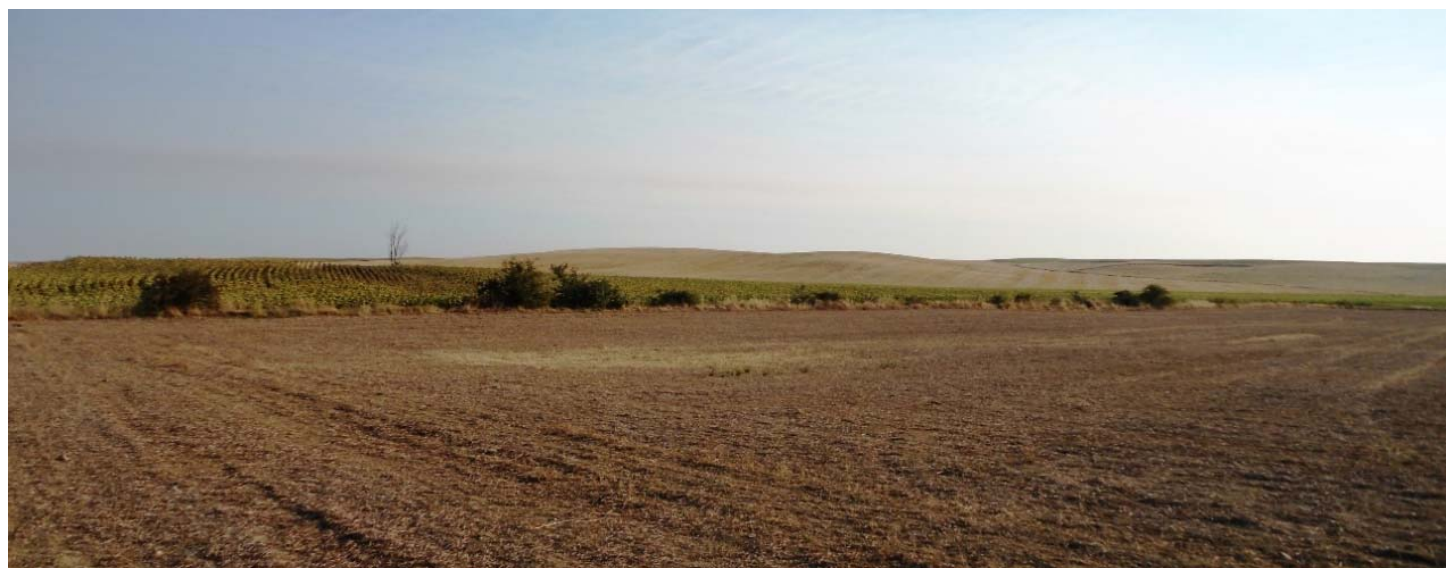

Figura A3.14. Rastrojos y girasol se dividen con una reguera poblada con escaramujos, que aumentan la diversidad paisajística

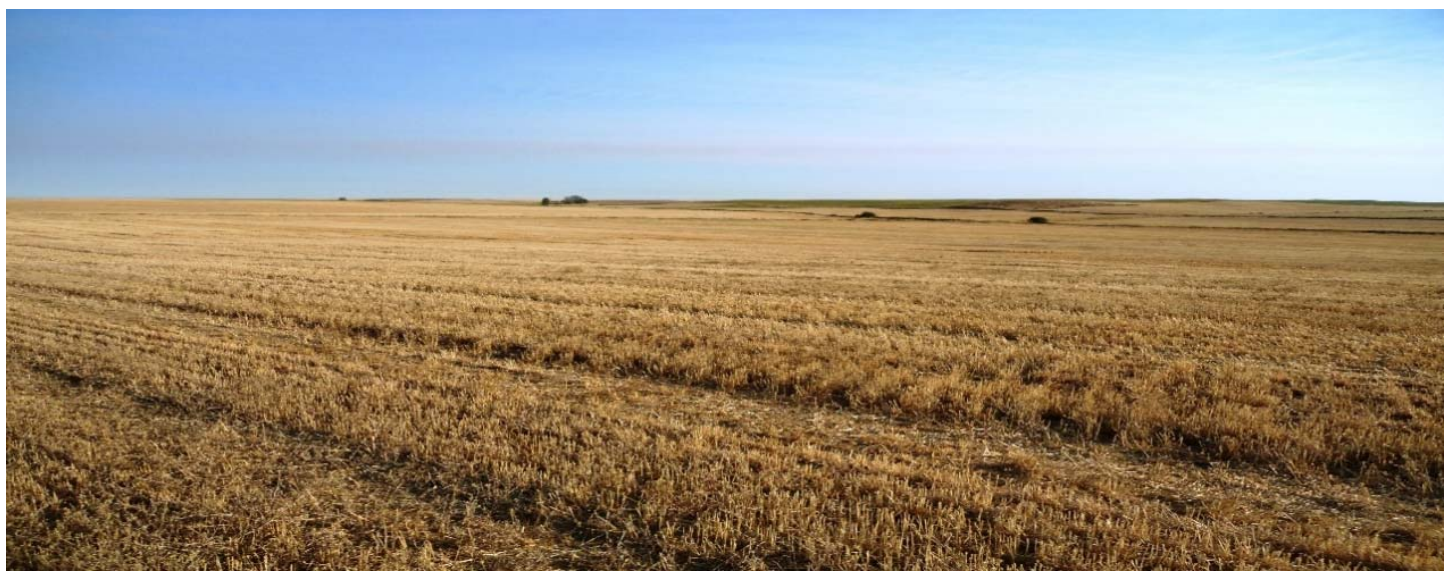

Figura A3.15. El color ocre del rastrojo es el dominante en esta época estival 
RECORRIDO: Ronda exterior

- Fecha: 18 de octubre de $2013,17: 45 \mathrm{~h}$.

- Medio: Bicicleta.

- Itinerario: Camino de Fuentes - camino circunvalación exterior - cruce carretera de Fonthoyuelo - camino circunvalación exterior - cruce carretera Boadilla - camino paralelo a antigua vía del ferrocarril - casco urbano.

- $\quad$ Longitud: $14,2 \mathrm{~km}$

- Condiciones meteorológicas: Parcialmente nuboso. El terreno está húmedo de lluvias recientes.

- Características de la vía: Caminos de zahorra. Salvo el primer tramo, que el árido está suelto, el resto está bien compactado y es adecuado para caminar o ir en bicicleta. Es un recorrido muy agradable, con vistas muy amplias (se divisan la Cordillera Cantábrica), que rodea el término y conecta con muchos caminos. Ver recorridos 1 y 2 .

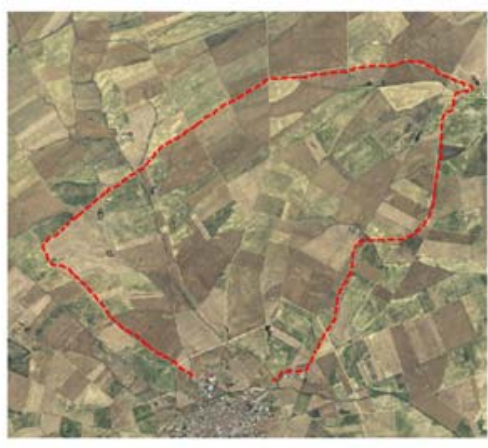

\section{CARACTERÍSTICAS DEL PAISAJE}

- Entorno inmediato de la vía: Cunetas revegetadas de $2 \mathrm{~m}$ de anchura, que ahora se encuentran secas. Altura media de los taludes: $>2 \mathrm{~m}=5 \%, 1-2 \mathrm{~m}=60 \%,<1 \mathrm{~m}=35 \%$, siendo la mayoría de desmonte.

- Espacio agrícola: En parte de los rastrojos se ha realizado siembra directa, otros se han comenzado a gradear y sembrar de forma tradicional. Aún quedan rastrojos sin tratar, en los que nace hierba. La alfalfa tiene un buen aspecto, que aporta tonos verdes al ocre todavía dominante. El girasol está todo cosechado.

- Agua: Ausencia.

- Ruido: Inapreciable.

- Olores desagradables: Inexistentes.

- Vegetación: En la línea de lo indicado en los recorridos 1 y 2, esta es una de las zonas de mayor vegetación del término municipal. Los árboles y arbustos están todavía verdes, lo que les confiere una gran importancia paisajística en esta época al contrastar con el ocre o tierra dominante. El escaramujo está en fruto muy rojo (tapaculos).

- Fauna: Bastantes pajaritos. 2 perdices. 2 bandos de avutardas, de 6-8 ejemplares.

- Actuaciones humanas: Ver recorridos 1 y 2.

- Elementos singulares: Ver recorridos 1 y 2.

\section{DEGRADACIONES DEL PAISAJE}

Ver recorridos 1 y 2 


\section{RECUPERACIONES DEL PAISAJE}

Ver recorridos 1 y 2

\section{RECUPERACIONES POTENCIALES}

Ver recorridos 1 y 2

DESCRIPCIÓN GRÁFICA

No hay fotografías. 


\section{RECORRIDO: Carretera de Fontihoyuelo}

- Fecha: 19 de octubre de 2013, 10:30 h.

- Medio: Caminando.

- Itinerario: Desde casco urbano - carretera de Fontihoyuelo hasta kilómetro 4 - vuelta al punto inicial.

- Longitud: $8 \mathrm{~km}$.

- Condiciones meteorológicas: Nublado. Ha llovido la noche anterior.

- Características de la vía: Carretera autonómica, con una plataforma de 7,6 m (3,15 m de carril y 0,65 m de arcén). Buen estado del firme. Muy adecuada para caminar o ir en bicicleta, ya que tiene poco tráfico y buenos arcenes. Muy utilizada por la población de Villalón de Campos para caminar a su ermita.

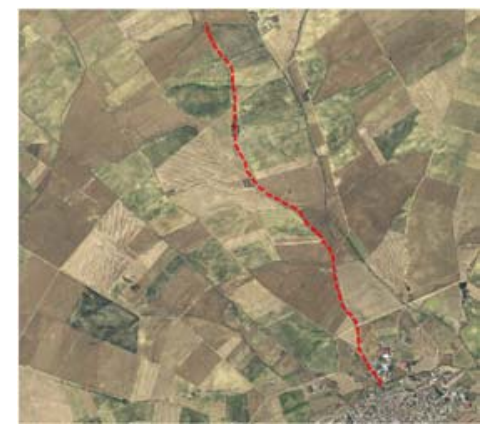

\section{CARACTERÍSTICAS DEL PAISAJE}

- Entorno inmediato de la vía: Cunetas de 3 - $4 \mathrm{~m}$ de anchura, revegetadas en su mayor parte. Altura media de los taludes: $>2 \mathrm{~m}=30 \%, 1-2 \mathrm{~m}=60 \%,<1 \mathrm{~m}=10 \%$, siendo prácticamente todo de desmonte. En algunos se aprecian regueros de erosión y algún desmoronamiento.

- Espacio agrícola: Tonalidades variadas, con dominio del marrón sobre el ocre y de este sobre el verde. La siembra directa ya está nacida. Se ve alguna parcela del girasol sin cosechar; la que lo está se encuentra en cañas. Rastrojos con hierba nacida. Alguna parcela labrada.

- $\quad$ Agua: Charcos en cunetas y regueras.

- Ruido: Puntual debido al tráfico, aunque es escaso.

- Olores desagradables: Puntuales en un tramo determinado del comienzo del recorrido, por la presencia cercana de un estercolero de gallinaza.

- Vegetación: En los márgenes de la carretera hay algún tramo con almendros, chopos y diversas zarzas. Hay varias regueras con escaramujos, que se encuentra en fruto. Pasada la ermita de Fuentes se ven varios grupos de chopos, ahora con las hojas amarillentas.

- Fauna: Se escucha el canto de bastantes pajaritos.

- $\quad$ Actuaciones humanas: Ver recorrido 8.

- Elementos singulares: Ver recorrido 8.

\section{DEGRADACIONES DEL PAISAJE}

- Depósitos puntuales de residuos en las cunetas de la carretera, impacto moderado.

- Impacto visual severo de la escombrera municipal, que está ubicada en terraplén y, por tanto, se ve mucho desde la carretera.

- Eliminación de una reguera con arbustos situada en el interior de una parcela agrícola, impacto severo. 


\section{RECUPERACIONES DEL PAISAJE}

Ver recorridos 3 y 8.

\section{RECUPERACIONES POTENCIALES}

- $\quad$ Retirada periódica de los residuos de las cunetas, por la empresa de mantenimiento de la carretera.

- $\quad$ Plantación de arbustos en los taludes de altura superior a $1 \mathrm{~m}$ y de árboles allí donde sea posible por seguridad vial.

- Restauración de la escombrera municipal. Deberá incluir la retirada de residuos peligrosos, la remodelación topográfica, la extensión de tierra vegetal (sobre todo en el terraplén) y la plantación de árboles y arbustos para zonas secas.

- Restauración vegetal de regueras.

- Plantaciones de diversificación en el interior de las parcelas agrícolas.

\section{DESCRIPCIÓN GRÁFICA}

No hay fotografías. 
RECORRIDO: Ruta de los parques (recuperaciones)

- Fecha: 23 de octubre de 2013, $18 \mathrm{~h}$.

- Medio: Caminando.

- Itinerario: Se trata de una ruta circular que puede iniciarse por cualquier punto e incluso recorrerse en ambos sentidos. Se incluye la plaza mayor, ya que desde aquí se puede acceder a varios puntos de la ruta. En este caso, consideraremos el siguiente inicio: plaza Mayor - C) Marceliano Serrano - restos de la antigua muralla $-\mathrm{C}$ ) Sahagún - arroyo Pajarillas - huerta del Moral - picón de las acacias - parque de

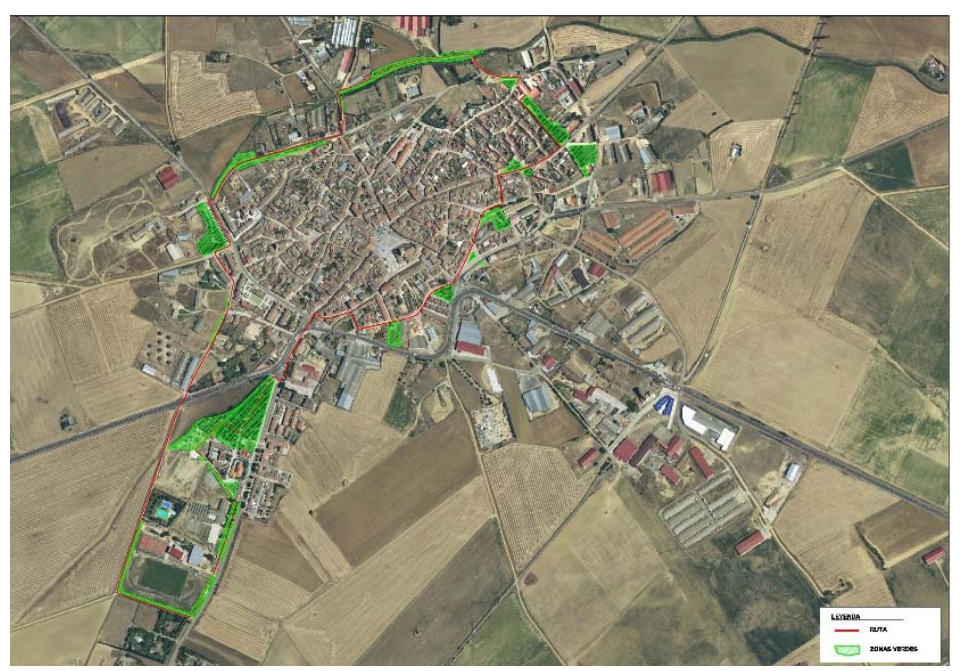
la reguera del Tinte - parque de la laguna del Tinte - C) Constitución - plaza de San Juan - casas de la Pedrera plaza de San Miguel - casas del convento - era del depósito - C) Gaspar Grajal - cruce con ctra. nacional - avda. del Parque - cruce con ctra. de Valladolid - parque del Paseo - parque temático - instituto - polideportivo - camino alrededor campo de fútbol - camino de la piscina - cruce con ctra. nacional - parque de San Pedro - paseo de Barrios - restos de la antigua muralla.

- $\quad$ Longitud: $4,5 \mathrm{~km}$

- Condiciones meteorológicas: Nublado. Ha llovido los últimos días.

- Características de la vía: El recorrido por las zonas más urbanas discurre por calles de hormigón, en regular estado de conservación, pero adecuadas para el tránsito de viandantes. Hay un porcentaje también alto de trayecto por caminos asfaltados, en general en buen estado. Hay algún tramo (avda. del parque y parque del Paseo), donde la vía está bien adoquinada. Puntualmente, existe un pequeño tramo con una senda en tierra, entre la entrada al polideportivo y el camino del campo de fútbol.

\section{CARACTERÍSTICAS DEL PAISAJE}

- Entorno inmediato de la vía: Los caminos asfaltados tienen, en general, cunetas que están revegetadas; no hay taludes altos salvo algún punto muy concreto. En algún tramo hay márgenes en hierba o en zahorra, que se suele tratar con herbicida.

- $\quad$ Espacio agrícola: En los tramos donde se divisan parcelas agrícolas, estas cumplen el patrón señalado en recorridos anteriores: tonalidades variadas, con dominio del marrón (barbecho) sobre el ocre (rastrojos) y de este sobre el verde (leguminosas y cereal nacido).

- $\quad$ Agua: Ausente, salvo algún charco. Destaca la presencia de la cascada del parque del Paseo.

- Ruido: Puntual, en las cercanías de la carretera nacional.

- $\quad$ Olores desagradables: Puntual, en las proximidades de las granjas ganaderas.

- Vegetación: Es un recorrido que atraviesa los parques municipales y, por tanto, tienen mucha vegetación. En este momento la hierba está verde, tanto el césped como las praderas naturales. Los árboles que son frondosas tienen todavía la hoja, aunque empiezan a marchitarse, como son los casos de los castaños de indias o los chopos; ello conlleva la irrupción de unos preciosos tonos ocre-amarillentos (especialmente estético en los fresnos). Se acaban de podar los plátanos, tal vez un poco temprano, porque de este modo se pierde la belleza otoñal de su copa.

- $\quad$ Fauna: Muchos pajaritos, sobre todo en las zonas verdes.

- Actuaciones humanas: Ver recorrido 16

- Elementos singulares: Ver recorrido 16. 
DEGRADACIONES DEL PAISAJE

Ver recorrido 16

\section{RECUPERACIONES DEL PAISAJE}

- VER 1: Parterres de la plaza Mayor. Históricamente ha habido más vegetación en esta plaza, aunque una de las últimas remodelaciones (hace 30 años) la restringió a 6 alcorques en la zona de la fachada lateral de la iglesia y varios parterres en la parte superior, entre los que no se superan los $25 \mathrm{~m}^{2}$. La última obra, además, eliminó casi todos estos parterres para construir una fuente, que suele estar sin funcionar. Originalmente se plantaron cedros en los alcorques, aunque solo ha sobrevivido uno, por las condiciones de extrema humedad de los huecos (no hay buen drenaje). También se mantiene un ciprés replantado. En los parterres hay alguna conífera baja.

- VER 2: Ribera del arroyo Pajarillas (Figura A3.16). Su cauce tiene una anchura de $10 \mathrm{~m}$, siendo la superficie total de esta zona verde de $1840 \mathrm{~m}^{2}$. Hace varias décadas poblaban esta ribera varios olmos de gran tamaño que, después de morir por la grafiosis, dieron lugar a vigorosos brotes que vegetan en el tramo inicial. En el otro talud de este arroyo se plantaron chopos lombardos con retroexcavadora hace unos 20 años, a una distancia de $5 \mathrm{~m}$, protegidos con malla contra las ovejas. Han sido podados varias veces en la parte inferior del tronco, pero vuelven a brotar, lo que demuestra su ineficacia (por otra parte, paisajísticamente es más estético el porte columnar). Actualmente presentan un magnífico aspecto, tienen una altura media de $9 \mathrm{~m}$ y conforman un precioso paseo.

- VER 3: Paseo de la huerta del Moral (Figura A3.17). Esta franja verde posee una superficie de $630 \mathrm{~m}^{2}$. En el margen izquierdo del mismo camino existe un lindero con brotes de los antiguos grandes olmos que rodeaban esta famosa huerta. Actualmente están resalveados y presentan un aspecto vegetativo relativamente bueno. Finaliza en un pequeño picón en el que tradicionalmente se han depositado residuos. Hace unos 10 años fue restaurado y hace 2 se plantaron 6 frondosas, al objeto sobre todo de alertar para evitar nuevos vertidos. Tiene hierba natural que no se cuida.

- VER 4: Picón de las acacias (Figura A3.18). Se trata de un pequeño espacio triangular de $305 \mathrm{~m}^{2}$ que, en el marco de una urbanización de viales, fue restaurado como zona verde en un curso de jardinería hace 4 años. Está delimitado con aceras, tiene césped, riego semiautomático por aspersión que manejan los vecinos y varias acacias con muy buen porte y crecimiento. Su altura es de unos $5 \mathrm{~m}$.

- VER 5: Parque de la reguera del Tinte. En un espacio periurbano y tradicionalmente degradado se halla esta franja rectangular de $2920 \mathrm{~m}^{2}$ que tiene dos partes definidas. La primera parte (no cuidada, Figura A3.19)) se asienta sobre escombros, no tiene tapiz herbáceo (se suele tratar con herbicida) y tiene algunos árboles (olmos, chopos, acacias) con una edad del entorno de 25 años; hay coches que incluso son aparcados en esta zona. La segunda parte está muy cuidada (Figura A3.20); se trata de una pradera con una fuente y arbolado variado y bien desarrollado, que asombra totalmente en verano. Hay algún banco. El marco de plantación fue regular, a 5 × 5 m. Es una especie de jardín botánico, ya que se pueden encontrar hasta 16 especies de árboles: olmo, álamo, álamo boleana, chopo, castaño de indias, abedul, encina, ciprés, acacia, haya, fresno, roble, sauce tortuoso, pruno, pino piñonero y laurel. Las primeras plantaciones se realizaron hace 26 años, siendo completadas en fechas posteriores hasta cubrir toda la zona. Se riega algo en verano con aspersores móviles por los vecinos, verdaderos artífices de esta ejemplar restauración.

- VER 6: Parque de la laguna del Tinte o laguna de San Juan (Figura A3.21). Es esta una antigua laguna que fue rellenada hace décadas con escombros y tierras. Tiene una superficie de $3.330 \mathrm{~m}^{2}$. Durante un periodo se mantuvo como pradera semidegradada con varias acacias aunque, en el marco de un programa municipal de restauración de espacios degradados, se creó un jardín rústico hace 8 años. Se mantiene una pradera más cuidada, que los vecinos riegan con aspersores móviles. Tiene también arbolado de portes diferentes, más o menos a un marco de $6 \times 6 \mathrm{~m}$ (álamos, acacias, pinos piñoneros etc.) y arbustos aislados (destacan los tamarindos, encontrándose también adelfas y parras). Tal vez faltarían coníferas para asegurar la permanencia del verde en invierno.

- VER 7: Rincón de San Francisco. Se trata de una pequeña plazuela de $280 \mathrm{~m}^{2}$ ajardinada a un lado de la iglesia de San Juan hace unos 30 años. Tiene varios árboles que dan buena sombra en verano (acacias fundamentalmente) y alguna conífera; algunos rosales y un seto perimetral de aligustre. Posee una fuente y bancos. Tiene riego semiautomático, que manejan los vecinos. Está muy bien cuidada.

- VER 8: Parque de la plaza de San Juan (Figura A3.22). Zona verde triangular que se halla enfrente de la iglesia de San Juan. En el centro tiene la conocida popularmente como "fuente del chicharro", que no funciona. Posee un paseo central y una acera perimetral embaldosada, asimismo tiene varios bancos. Tiene una pequeña pradera y árboles variados: sauces, prunos, pinos piñoneros, etc., plantados en diferentes años. Al otro lado de la carretera hay pequeñas zonas verdes; algunas tienen árboles (higueras sobre todo), el resto solo tienen una pradera. En total, la superficie de esta zona verde es de $750 \mathrm{~m}^{2}$. 
- VER 9: Parterres de la Pedrera (de Oriente). Son una serie de parterres que se prolongan desde las casas construidas en la antigua laguna (también fue mercado muy poco utilizado); están empradizados y poseen una alineación de árboles: acacias y álamos boleanas, fundamentalmente. También hay varios arbustos aislados. Tiene una superficie de $520 \mathrm{~m}^{2}$.

- VER 10: Parque de la laguna de la Pedrera o de San Miguel (Figura A3.23). En parte del espacio que ocupaba esta laguna se construyó un parque de $1300 \mathrm{~m}^{2}$. Tiene una zona de juegos infantiles, un paseo embaldosado central y una pradera natural con árboles (predominan acacias y álamos boleanas). Todo el arbolado tiene gran tamaño. En estas dos zonas verdes hay bancos, farolas y una fuente. Se realizaron hace unos 17 años, con mejoras posteriores.

- VER 11: Parterres de la laguna (Figura A3.24). Son unas pequeñas franjas dejadas en la urbanización de esta zona, algunas en pendiente, que ahora están mínimamente adecentadas con pradera natural y algunos árboles y arbustos (un ciprés, un pruno, etc.). Han sido restauradas hace unos 5 años por los vecinos. En total ocupan 115 m². $^{2}$

- VER 12: Picón de los cuartos de San Miguel (Figura A3.25). Se trata de un pequeño espacio triangular que sirve para ordenar una intersección de varias calles. Dispone de pradera, varios árboles (nogal, arce, fresno, encina), bancos y una fuente. Había unos álamos boleanas muy altos que fueron cortados por posibles afecciones a los viales y a las casas. Restaurado en varias fases, aunque la última fue hace unos 15 años. Existe un pequeño parterre al otro lado de la carretera, que está sin cuidar. La superficie asciende a $190 \mathrm{~m}^{2}$.

- VER 13: Parque del hospital de San Roque (Figura A3.26). Es una zona verde de $1170 \mathrm{~m}^{2}$ creada cuando se edificaron las viviendas ubicadas sobre el antiguo hospital, hace 21 años. Está ordenada con pequeñas sendas pavimentadas hacia un parterre central en alto, y una fuente y una escultura de un niño a los lados. Combinan de buen modo coníferas y frondosas; se pueden encontrar las siguientes especies: falso ciprés, chopo, acacia, árbol del paraíso, pino piñonero, plátano, quejigo (árboles), adelfa, rosal y durillo (arbustos). Está delimitada por aceras y una pequeña valla metálica. Tiene riego semiautomático, que manejan los vecinos.

- VER 14: Eras del Depósito. Se trata de una pradera alrededor de un gran depósito para el abastecimiento municipal de agua, edificio catalogado urbanísticamente. La superficie susceptible de zona verde se cifra en $500 \mathrm{~m}^{2}$.

- VER 15: Jardines del Colegio (Figura A3.27). Pequeño espacio ajardinado a la entrada de este centro de enseñanza, creado hace unos 30 años. Tiene un espacio de hierba, setos de aligustre, varios árboles (aligustre árbol, acacias, lilar, pruno y arce), otros arbustos aislados (tamarindo y laurocerasus) y una franja de álamos boleanas perimetral al patio, de gran altura. La superficie de este espacio asciende a $375 \mathrm{~m}^{2}$.

- VER 16: Parque del Paseo (Figura A3.28). Es el mayor y más representativo parque del pueblo, con una superficie de $12010 \mathrm{~m}^{2}$. Era prácticamente el único espacio verde que tenía el pueblo con anterioridad a la década de los 80 del siglo pasado, que es realmente el periodo a partir del cual se comienzan a restaurar espacios degradados y crear zonas verdes. De hecho este parque había vivido periodos de mayor esplendor a mediados del siglo pasado, para pasar posteriormente una época de descuido. Hace 30 años comenzó a rehabilitarse en diferentes fases. Se restauró la cascada, que es tal vez el elemento más singular del parque. Se creó un ancho vial como paseo central, pavimentado, y otros laterales en gravilla, que han sido posteriormente empradizados. Se construyó un muro perimetral con forja y revestido con piedra caliza, con una gran puerta de entrada en forja. Se eliminaron los olmos perimetrales, afectados por la grafiosis, manteniéndose solo algunos árboles notables, como un pino laricio, álamos y un corro de thuyas. Se plantaron numerosos árboles: castaños de indias -en las alineaciones centrales- y en los parterres una gran mezcla de especies: arce, secuoya, álamo boleana, acacia, picea, pino piñonero, fresno, plátano, árbol del amor, sauce tortuoso, pruno, magnolio, ciprés, cedro, chopo, etc. Hay también numerosos arbustos aislados (rosal, tamarindo, cotoneaster, durillo, romero, etc.). Inicialmente se contempló que el suelo de los parterres fuese colonizado por hiedra, aunque posteriormente muchos de ellos se fueron cambiando por césped. En algún pequeño parterre se plantan flores anuales. Hay bancos, papeleras y farolas. Tiene una zona de juegos infantiles, un itinerario para bicicletas y un espacio con aparatos de gimnasia de mantenimiento. Está instalado el riego automático. Actualmente se trata de un exuberante jardín, que se encuentra muy cuidado, con una arboleda densa que alcanza los $15 \mathrm{~m}$.

- VER 17: Parque temático del Pan y el Queso (Figura A3.29). Se trata de un espacio verde adyacente al parque del Paseo, creado hace 5 años como parque de aventuras con los motivos del pan y el queso, productos muy propios de la comarca de Tierra de Campos. Tiene una superficie de $5595 \mathrm{~m}^{2}$. Se encuentra delimitado por una valla metálica y puede cerrarse. Se construyó una caseta prefabricada de madera. Las sendas se realizaron a base de gravilla fina. Tiene una fuente y riego automático. Hay bancos, mesas de madera y papeleras. Se plantaron especies diversas, por grupos: acacias, arces, fresnos, prunos, plátanos, etc., a las que acompañan una pradera con chopos y álamos que ya poblaba ese espacio. Hay parterres con plantas aromáticas. Una parte de la valla tiene un seto de leylandi.

- VER 18: Paseo de la Residencia (Figura A3.30). Es este un pequeño paseo de hormigón que discurre a un lado del centro asistencial de San Roque, desde el parque temático hasta el instituto. Al principio hay un parterre sin acondicionar. Tiene una franja de álamos boleanas de unos 10 años y ya considerable altura (unos $7 \mathrm{~m}$ ), plantados cada $4 \mathrm{~m}$. Finaliza con un parterre triangular delimitada por las calles, empradizada y con varias frondosas que han tenido bastantes fallos. La superficie total de esta zona verde es de $620 \mathrm{~m}^{2}$.

- VER 19: Paseo del Instituto (Figura A3.31). Se trata asimismo de otro paseo entre la carretera de Valladolid y el instituto Jorge Guillén, que discurre entre dos filas de álamos boleanas. La interior al recinto del centro de enseñanza fue plantada hace algo más de 30 años; en el exterior hay abundantes brotes que, una vez podados recientemente, tienen un buen porte de árboles. Su superficie es de $470 \mathrm{~m}^{2}$.

- VER 20: Jardines del Polideportivo. Se trata de varias zonas verdes que rodean las instalaciones del polideportivo: edificio cubierto, frontones, piscinas, etc. En la entrada hay dos parterres con varios árboles; uno de ellos, un chopo de gran tamaño, al que acompañan algún pino piñonero y álamo. Suelo en tierra o pradera, terreno bastante descuidado. Una zona de taludes está plantada con arbustos (cotoneaster) y una franja paralela al vial principal fue plantada con chopos y plátanos, en no muy buen estado, debido a los requerimientos de humedad de estas especies. Hay parterres colindantes al frontón sembrados de hierba en buen estado. Este espacio dispone de una fuente. Actualmente hay una zona de aparcamientos con firme de zahorra, sin ordenar y de aspecto bastante degradado. La superficie susceptible de ajardinamiento se cifra en $3000 \mathrm{~m}^{2}$. 
- VER 21: Paseo del campo de fútbol. Rodeando el campo de fútbol nos encontramos con un agradable paseo asfaltado en el que se divisa el campo de césped y, sobre todo, una alineación de pinos piñoneros. Estos fueron plantados hace unos 12 años, cada $6 \mathrm{~m}$ y tienen un discreto crecimiento (altura media de $3 \mathrm{~m}$ ). Su superficie asciende a $1930 \mathrm{~m}^{2}$.

- VER 22: Jardines de las piscinas. Este recinto cerrado cuenta con tres piscinas y un gran entorno con césped, un seto de arizónica que cubre la valla metálica y bastantes árboles: chopos, álamos, arces, etc., con un marco irregular de unos $5 \mathrm{~m}$ de media. Se ha ido realizando en varias fases desde hace unos 30 años. Tiene riego automático. Actualmente es una zona muy fresca en verano, que permite disfrutar de espacios soleados y otros de sombra. La zona ajardinada asciende a $2200 \mathrm{~m}^{2}$.

- VER 23: Parque de la laguna de San Andrés o de San Pedro (Figura A3.32). Se trata de los terrenos que formaron parte de una laguna, desecada con el relleno de estériles y escombros. Su superficie asciende a $4085 \mathrm{~m}^{2}$. Durante bastantes años fue un espacio degradado. Hace unos 22 años se restauró como jardín xerófilo, con calles de gravilla y varios parterres delimitados con piedra caliza y plantados con árboles y muchos arbustos. Tiene un pequeño murete perimetral rematado con forja. Se plantaron álamos lateralmente, que actualmente tienen una gran altura. Con motivo de obras de saneamiento municipales hace 13 años, hubo que pasar una tubería de gran diámetro diagonalmente a lo largo del parque, por lo que se afectó a buena parte del espacio. Posteriormente se restauró con una configuración más sencilla: un vial de gravilla hacia una fuente central y el resto una gran pradera con arbolado. Fue depositada una importante capa de tierra vegetal. Se plantaron sobre todo leylandis paralelos al vial y pinos piñoneros, que tienen un magnífico crecimiento y unos $5 \mathrm{~m}$ de altura; también hay alguna especie complementaria (ciprés, sauce, árbol del paraíso). Hay una zona dedicada a juegos infantiles; también se cuenta con bancos, papeleras y farolas. Entre el parque y la carretera de Bustillo se diseñó un pequeño paseo con bancos y plátanos de sombra.

- VER 24: Picón de Pajarillas. Es una pradera lindante con el arroyo Pajarillas, que fue zona de depósito de escombros y posteriormente recuperada en un programa municipal de restauración de áreas degradadas. Se retiraron los depósitos y se adecuó el terreno; posteriormente se plantaron varias especies en varias fases, aunque ahora solo viven unos sauces, un grupo de tamarindos y un chopo. Su superficie asciende a $1100 \mathrm{~m}^{2}$.

- VER 25: Paseo de Barrios (Figura A3.33). Se trata de una zona antaño degradada, ubicada entre la alineación irregular del casco histórico (que seguramente hacía de muralla) y la carretera de circunvalación. Ha estado de tierra y zahorra mucho tiempo, siendo zona de depósito de escombros. Hace 14 años se plantó una fila de plátanos y fresnos paralela a la carretera, que ha cambiado radicalmente la imagen de esta zona. Tienen un relativamente buen crecimiento -para ser un terreno con deficiencias- con una altura media de $5 \mathrm{~m}$. Bajo sus pies crece vegetación herbácea, que se desbroza o se trata con herbicida. En el margen izquierdo hay varios parterres al lado de las casas, con varias especies sobre todo arbustivas (lilar, adelfa, rosal, etc.). La superficie de esta franja verde asciende a $975 \mathrm{~m}^{2}$.

\section{RECUPERACIONES POTENCIALES}

Ver recorrido 26 . 


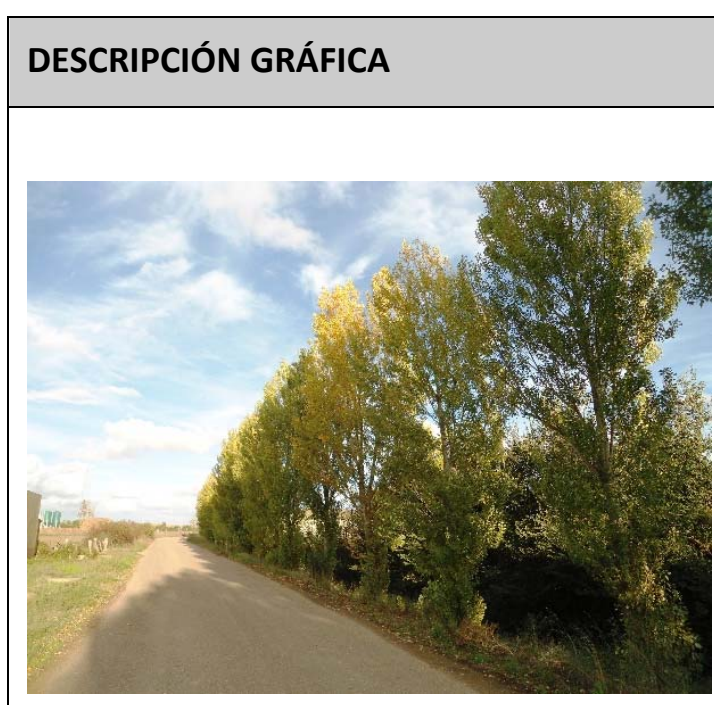

Figura A3.16. Ribera del arroyo Pajarillas

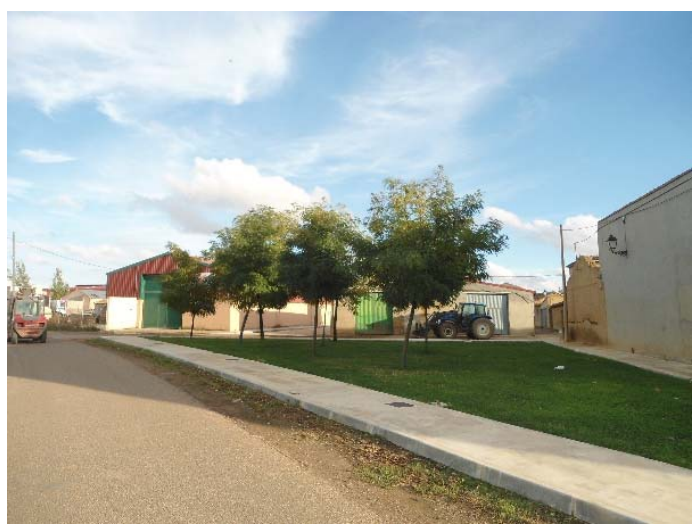

Figura A3.18. Picón de las acacias

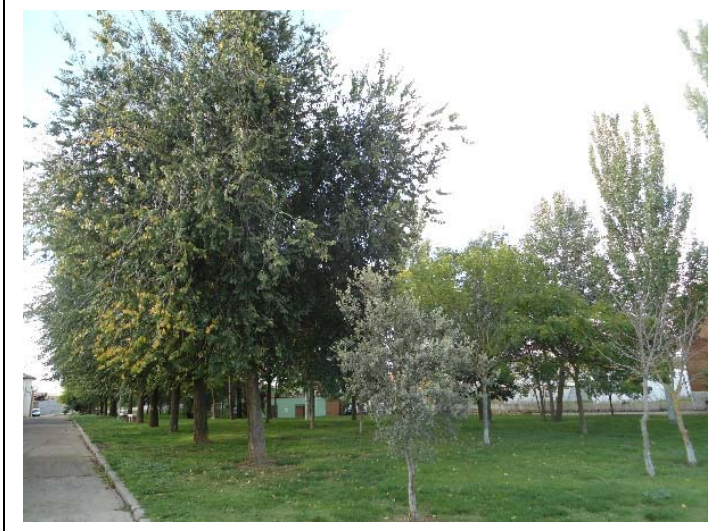

Figura A3.20. Parque de la reguera del Tinte (segundo tramo)

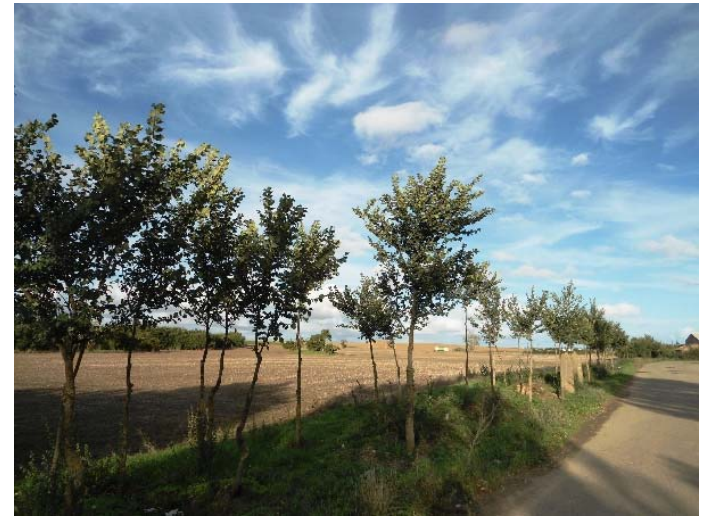

Figura A3.17. Paseo de la huerta del Moral

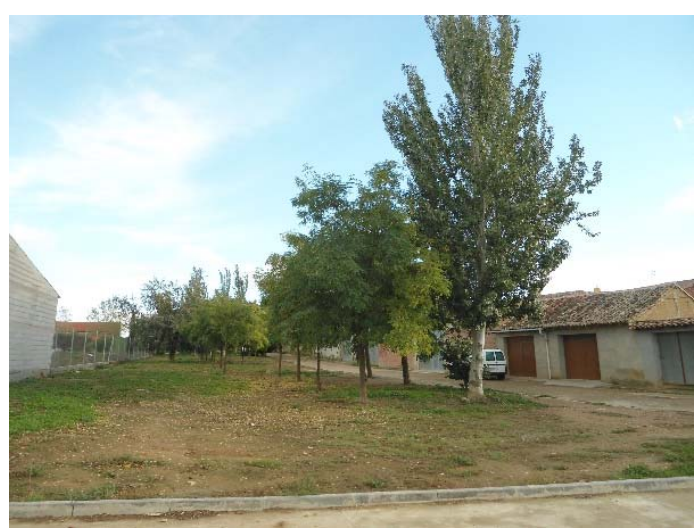

Figura A3.19. Parque de la reguera del Tinte (primer tramo)

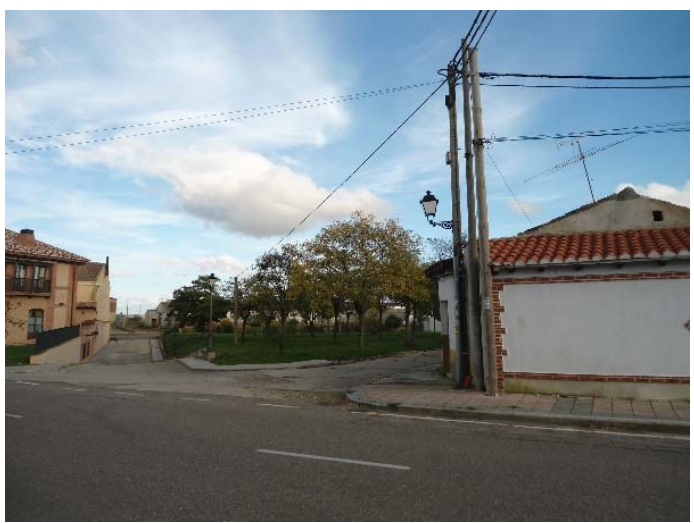

Figura A3.21. Parque de la laguna del Tinte o laguna de San Juan. 


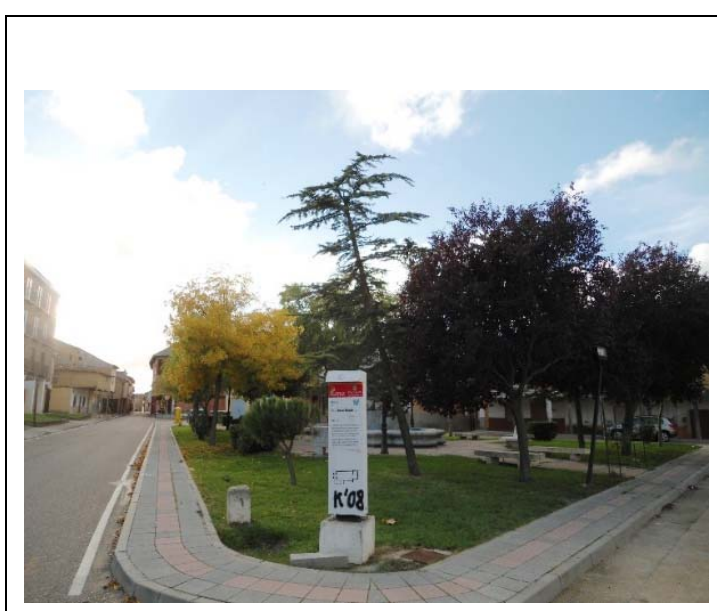

Figura A3.22. Parque de San Juan

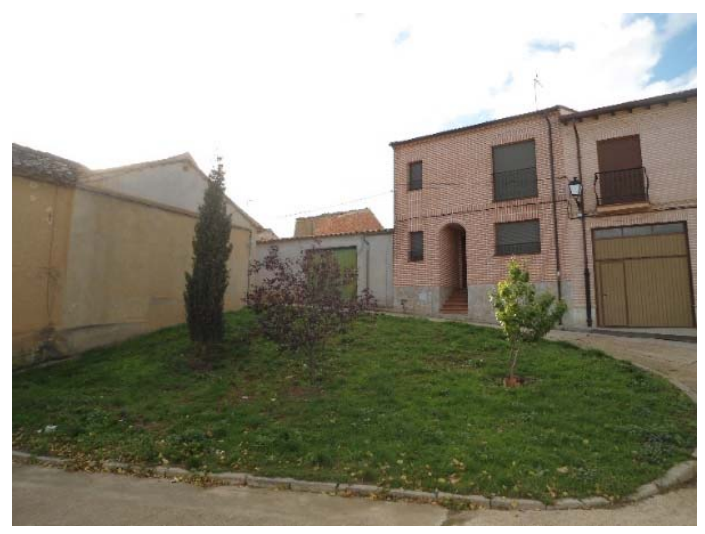

Figura A3.24. Parterres de la laguna

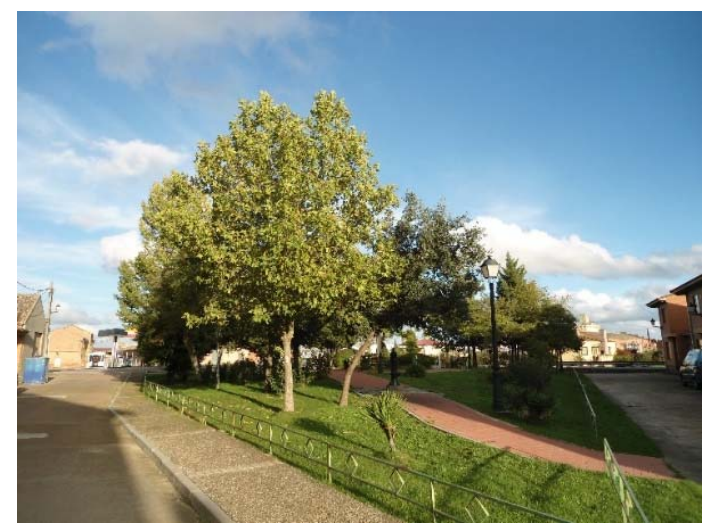

Figura A3.26. Parque del hospital de San Roque

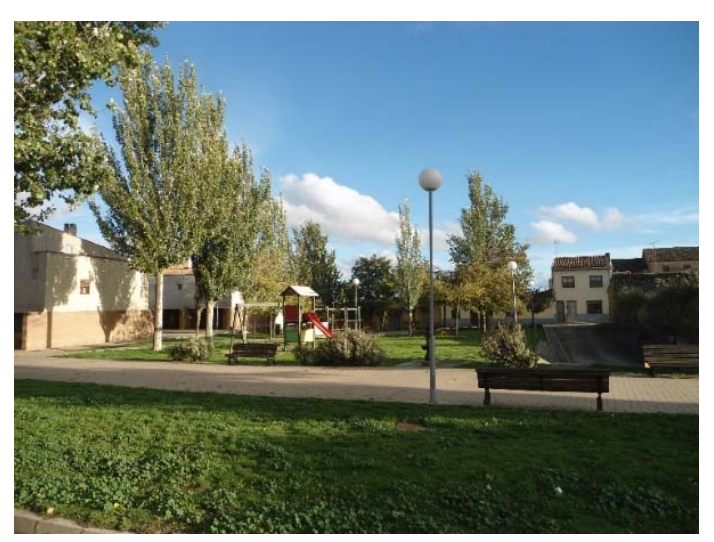

Figura A3.23. Parque de la laguna de la Pedrera

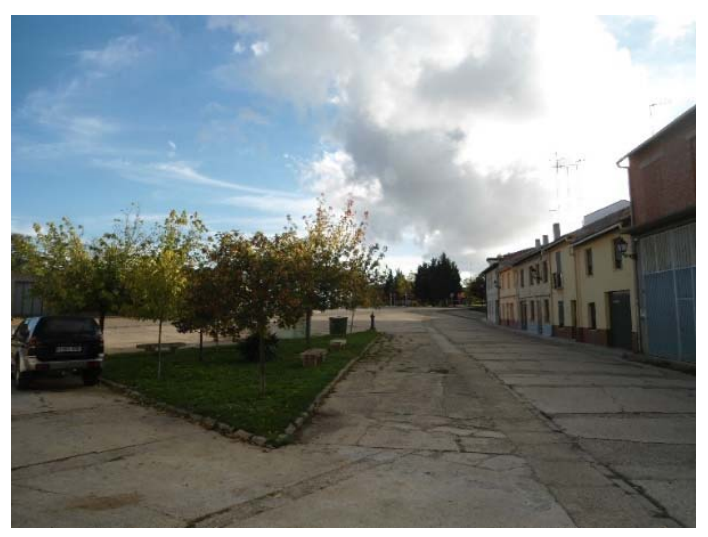

Figura A3.25. Parterres de los Cuartos de San Miguel

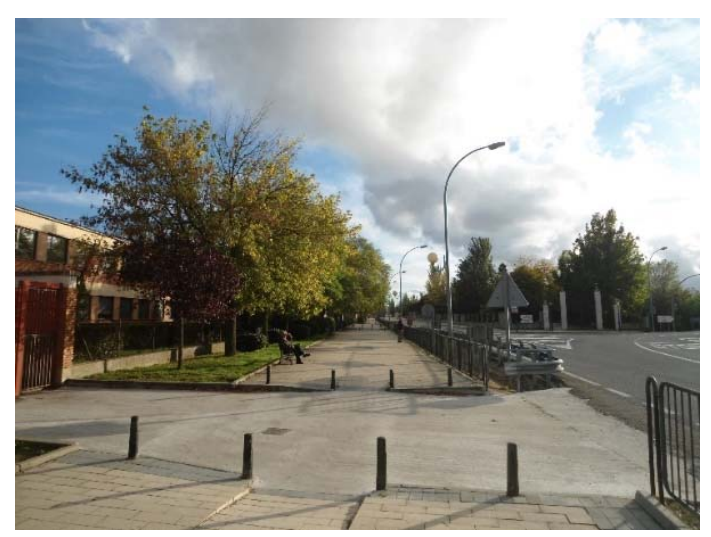

Figura A3.27. Avenida del Parque y jardines del Colegio 


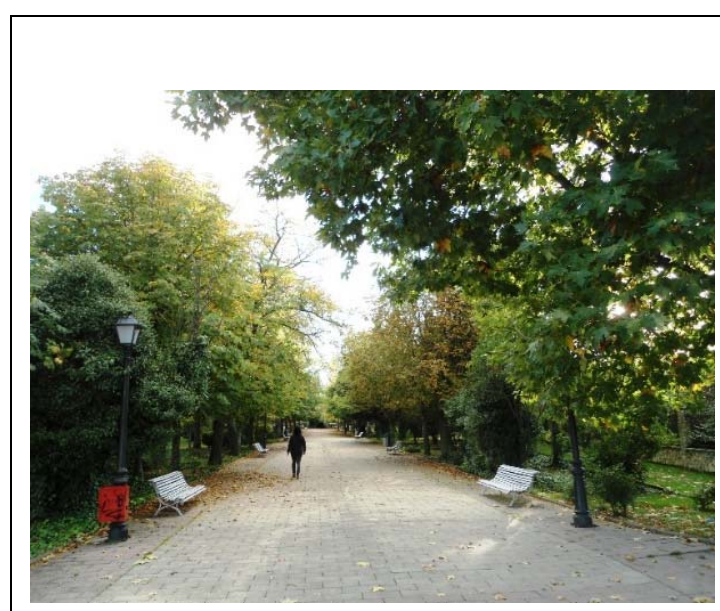

Figura A3.28. Parque del Paseo

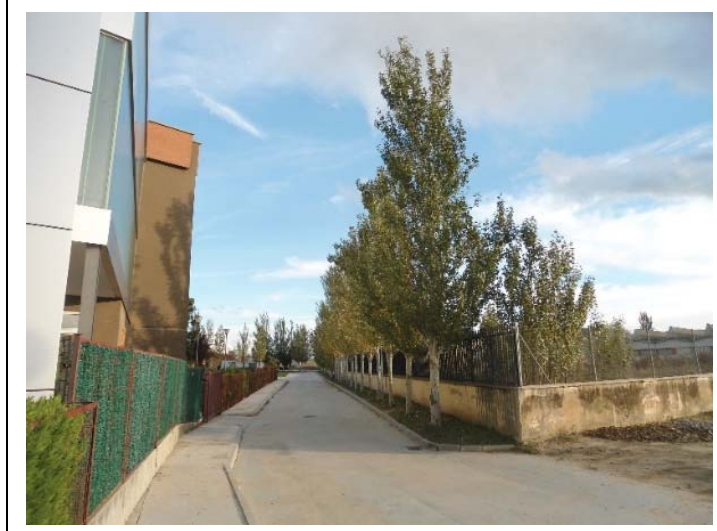

Figura A3.30. Paseo de la Residencia

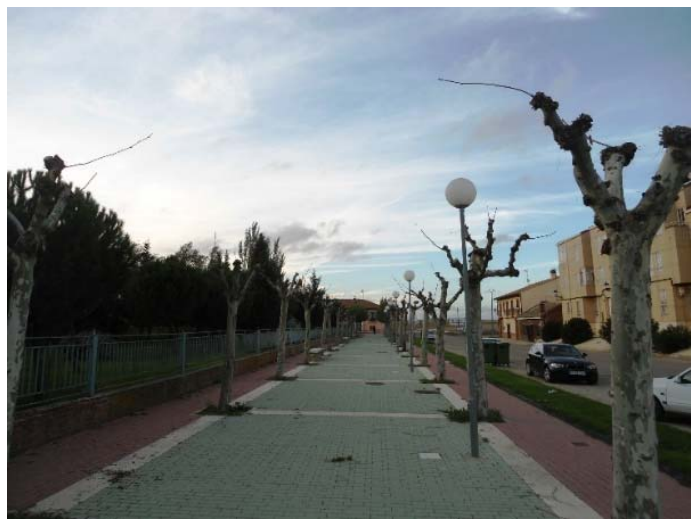

Figura A3.32. Parque de la laguna de San Pedro

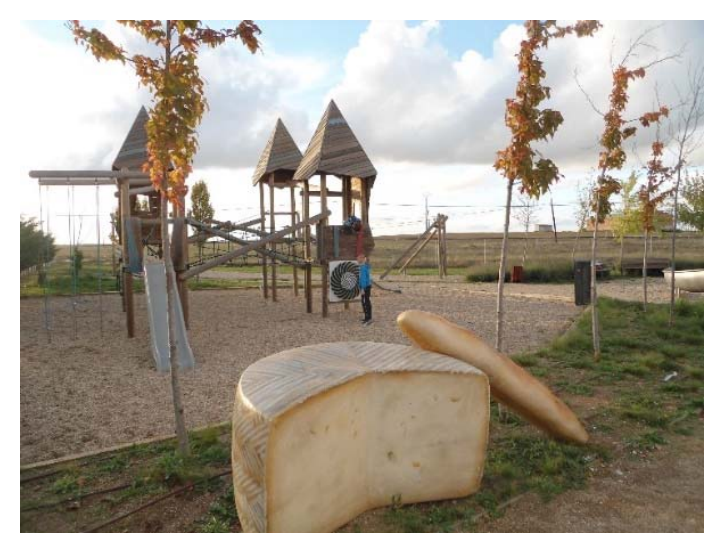

Figura A3.29. Parque temático del pan y el queso

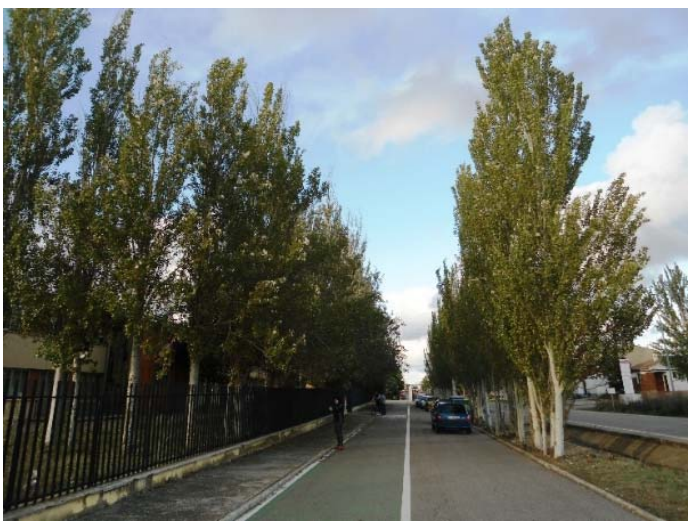

Figura A3.31. Paseo del Instituto

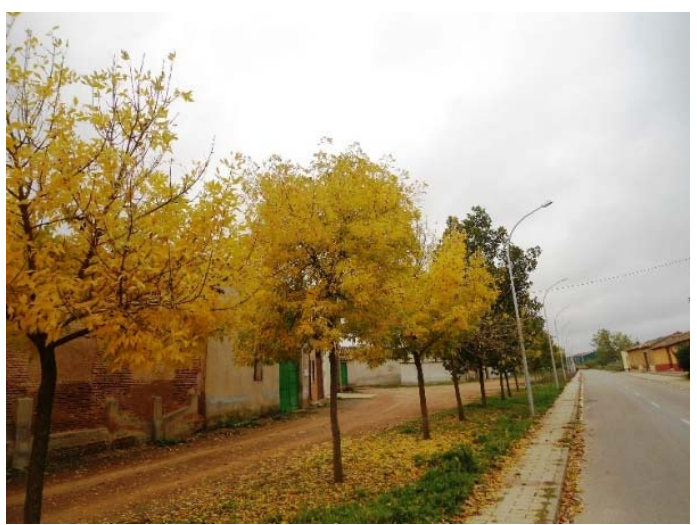

Figura A3.33. Paseo de Barrios 
- Fecha: 25 de octubre de 2013, 17:45 h.

- Medio: En bicicleta.

- Itinerario: Desde casco urbano - carretera de Boadilla hasta límite de término municipal - vuelta al punto de inicio (Figura A3.39).

- $\quad$ Longitud: $11,6 \mathrm{~km}$

- Condiciones meteorológicas: Muy nublado. Hay bastante humedad.

- Características de la vía: Carretera autonómica VA-905, con una plataforma de $8 \mathrm{~m}$ ( $3 \mathrm{~m}$ de carril y $1 \mathrm{~m}$ de arcén). Buen estado del firme. Muy adecuada para caminar o ir en bicicleta, ya que tiene relativamente poco tráfico y buenos arcenes, aunque es excesivamente rectilínea.

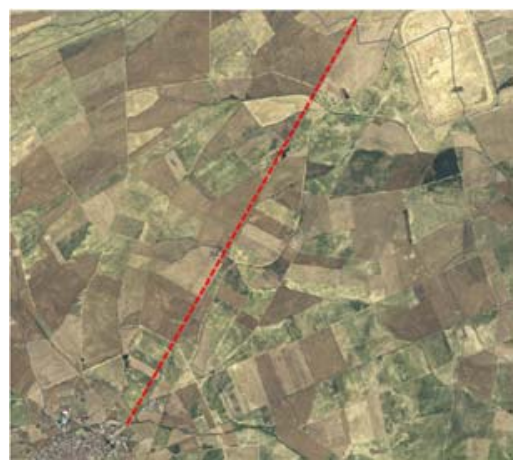

\section{CARACTERÍSTICAS DEL PAISAJE}

- Entorno inmediato de la vía: Cunetas de $3 \mathrm{~m}$ de anchura, revegetadas en su mayor parte. Se tratan con herbicida los márgenes. Altura media de los taludes: $>2 \mathrm{~m}=30 \%, 1-2 \mathrm{~m}=60 \%,<1 \mathrm{~m}=10 \%$, intercalándose desmontes y terraplenes.

- Espacio agrícola: Predominio del marrón de los barbechos y del girasol cosechado. Presencia todavía significativa del ocre de los rastrojos. El verde pálido se restringe a alguna parcela ya nacida de cereal y el verde intenso a las leguminosas.

- $\quad$ Agua: Charcos en cunetas y arroyos.

- Ruido: Puntual debido al tráfico, aunque es relativamente escaso.

- Olores desagradables: Puntuales en las proximidades de las granjas avícolas.

- Vegetación: Es una carretera con bastante vegetación en los márgenes; tiene tramos arbustivos (olmos, escaramujo y alguna gayomba) y, sobre todo, un tramo de una gran chopera hacia la mitad de las dos poblaciones (Figura A3.35). En esta se pueden apreciar las ventajas de la vegetación arbolada en los márgenes de las carreteras: sombra, buen olor, hábitat de aves, diversidad paisajística, etc. Se observa también alguna reguera con arbustos y algún chopo aislado (Figura A3.34).

- Fauna: Se observan pajaritos, sobre todo en los arbustos de los márgenes y en la chopera.

- Actuaciones humanas:

o Dos líneas de alta tensión, de 20 y 30 kV, a ambos lados de la carretera.

o Nave agrícola, con paramentos de chapa metálica ocre y cubierta de chapa en su color.

o Matadero de lechazos, con dos naves blancas y cubierta de fibrocemento.

- Granja avícola, con nave de dos plantas blanca y cubierta de teja roja.

o Granja avícola (ver recorrido 18).

- Nave agrícola metálica, de paredes blancas y cubierta roja.

- Granja avícola (ya alejada del casco urbano), con cinco naves blancas y cubierta de fibrocemento. Silos metálicos en su color, transformador e instalaciones auxiliares.

- Elementos singulares:

- Casa de huerta color tierra y teja árabe.

o Palomar blanco con varios tejadillos rojos (Figura A3.38). 


\section{DEGRADACIONES DEL PAISAJE}

- Carretera totalmente rectilínea sin vegetación en sus márgenes, impacto severo.

- Impacto moderado de las líneas eléctricas (Figura A3.36), por introducción de elementos extraños a la pauta general del paisaje.

- $\quad$ Acumulación considerable de residuos en las cunetas de la carretera, con impacto moderado.

- Eliminación de la vegetación herbácea de los márgenes de la carretera mediante herbicida, con impacto moderado sobre el hábitat.

\section{RECUPERACIONES DEL PAISAJE}

- $\quad$ PAR 1: Plantación de varias coníferas y otras especies alrededor de casa de huerta, con una altura media de unos 5 m.

- $\quad$ AHA 1: Franjas de $800 \mathrm{~m}^{2}$ alrededor de nave agrícola (Figura A3.37). Pino piñonero, marco de $2.5 \times 2.5 \mathrm{~m}$, con cuidados y $0 \%$ de marras.

- $\quad$ PAR 2: Plantación de álamos boleanas y varias especies más alrededor de granja avícola, con una altura aproximada de $3 \mathrm{~m}$.

\section{RECUPERACIONES POTENCIALES}

- $\quad$ Plantación de arbustos en los taludes de la carretera de altura mayor a $1 \mathrm{~m}$ y de árboles en los mayores de $2 \mathrm{~m}$ allí donde sea posible.

- Plantación de arbustos en las vallas metálicas de las granjas.

- Plantación de almendros y coníferas en el margen de la carretera a la entrada del pueblo, para minimizar el impacto de las naves existentes y enmarcar el pueblo.

- Limpieza periódica de los residuos de las cunetas de la carretera.

- Restauración vegetal de regueras.

- Plantaciones de diversificación en el interior de las parcelas agrícolas. 


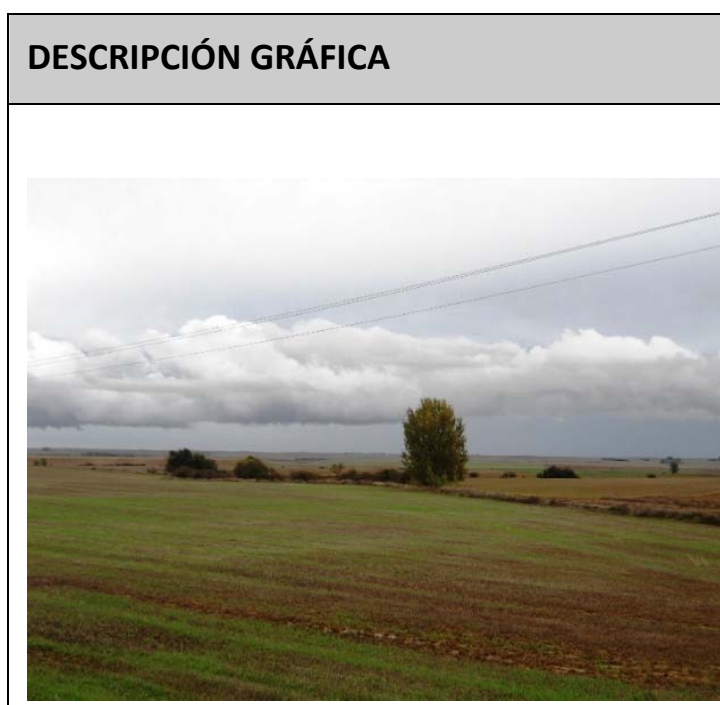

Figura A3.34. Paisaje agrícola con vegetación

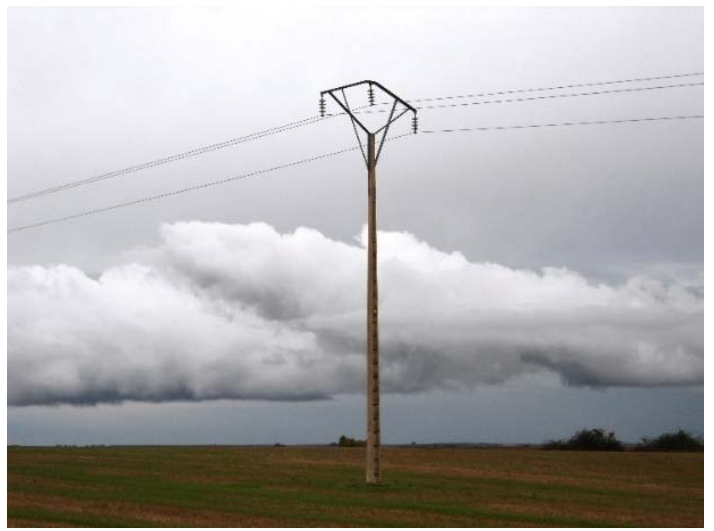

Figura A3.36. Detalle de apoyo de una línea eléctrica

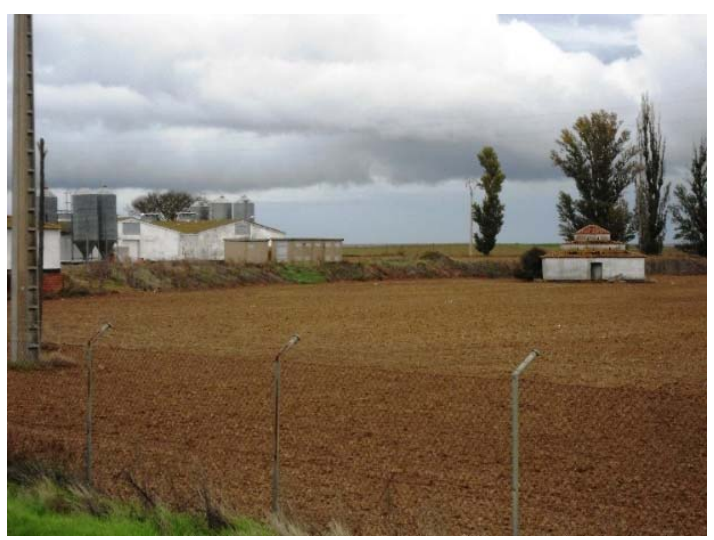

Figura A3.38. Palomar y granja avícola conviven en un mismo espacio

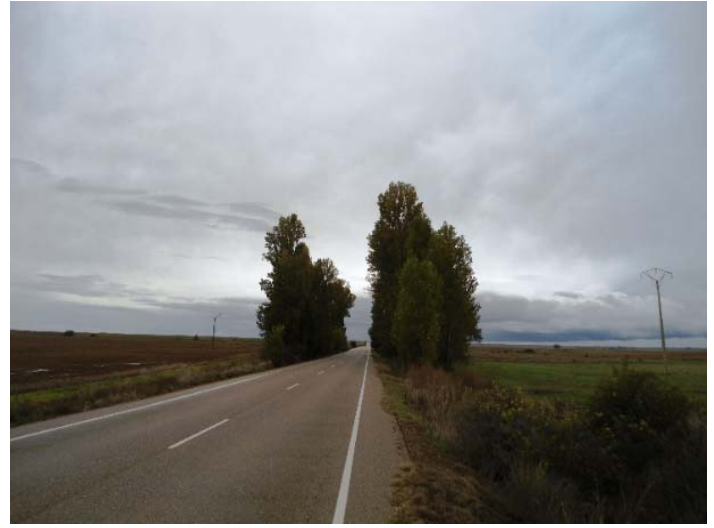

Figura A3.35. Chopos en los márgenes de la carretera

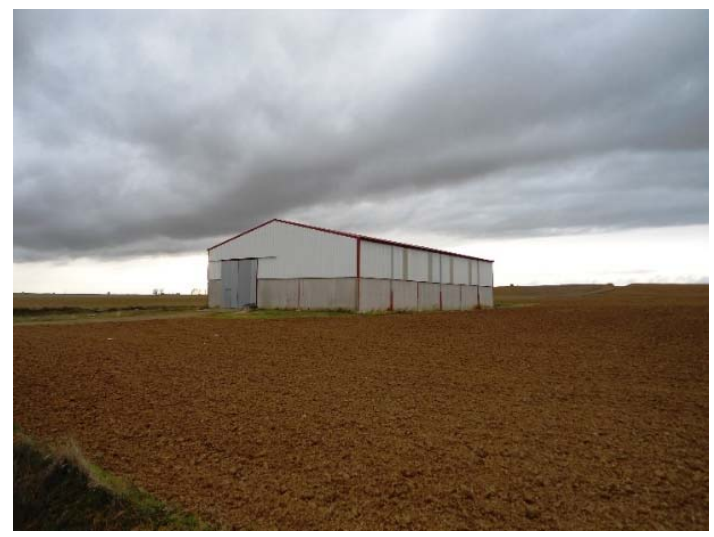

Figura A3.37. Nave agrícola, que tiene plantación del árbol/ha

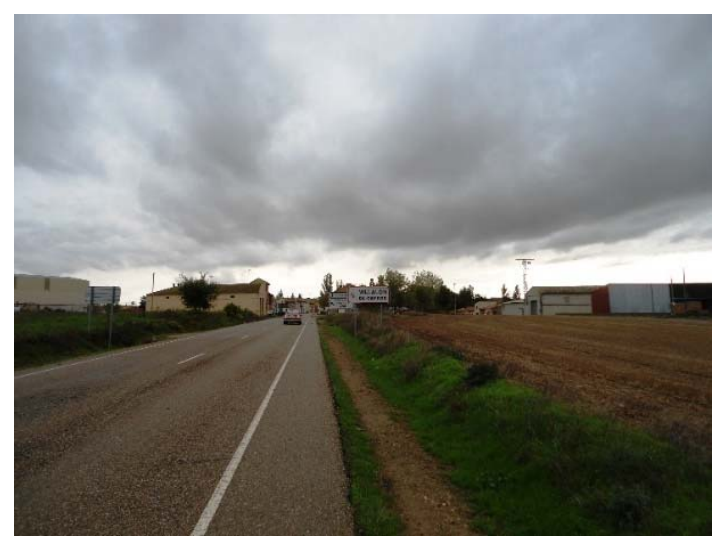

Figura A3.39. Entrada al pueblo. 


\section{RECORRIDO: Carretera y ermita de Fuentes}

- Fecha: 27 de octubre de 2013, 11:15 h.

- Medio: Caminando.

- Itinerario: Desde casco urbano - ermita de Fuentes - vuelta al punto de inicio.

- Longitud: $6 \mathrm{~km}$

- Condiciones meteorológicas: Nublado. El terreno está bastante húmedo.

- Características de la vía: Carretera autonómica, con una plataforma de 7,6 $\mathrm{m}$ (3,15 $\mathrm{m}$ de carril y 0,65 $\mathrm{m}$ de arcén). Buen estado del firme. Muy adecuada para caminar o ir en bicicleta, ya que tiene poco tráfico y buenos arcenes. Muy utilizada por la población de Villalón de Campos para caminar a su ermita, especialmente el día 8 de septiembre (día de la patrona) y otras celebraciones.

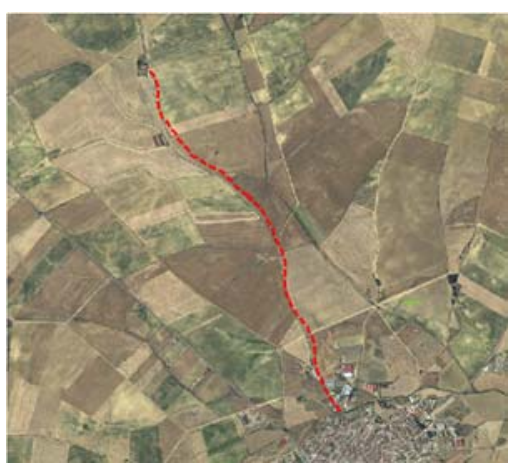

\section{CARACTERÍSTICAS DEL PAISAJE}

- Entorno inmediato de la vía: Cunetas de 3 - $4 \mathrm{~m}$ de anchura, revegetadas en su mayoría, salvo las de mayor altura. Altura media de los taludes: $>2 \mathrm{~m}=30 \%, 1-2 \mathrm{~m}=60 \%,<1 \mathrm{~m}=10 \%$, siendo prácticamente todos de desmonte.

- Espacio agrícola: Por tonalidades, dominio del marrón del barbecho sobre el ocre de los rastrojos y, finalmente, el verde de la alfalfa y el cereal nacido.

- Agua: Charcos puntuales.

- Ruido: Puntual debido al tráfico, aunque es escaso.

- Olores desagradables: Inexistentes.

- Vegetación: En los márgenes de la carretera hay algún tramo con almendros y diversas zarzas. Hay varias regueras con escaramujos, que van perdiendo la hoja.

- Fauna: Bastantes pajaritos, sobre todo en los arbustos. 5 avutardas. 2 rapaces. Hay cazadores en el campo.

- Actuaciones humanas (casi todas cerca del casco urbano, Figura A3.40):

o Numerosas vallas metálicas para cercar las parcelas.

o Línea de 20 kV y transformador y línea de teléfonos.

- Caseta de barro y pequeño invernadero en era agrícola.

o Caseta blanca y teja árabe, con era agrícola y huerta.

o Caseta de ladrillo viejo y era ajardinada.

o Antiguo molino de cemento pintado en blanco y tejado de fibrocemento.

- Caseta de barro y adosado de chapa roja.

o Casetas de era revestidas en cemento.

o Invernaderos de plástico.

o Caseta del Ayuntamiento de ladrillo rojo y teja árabe.

- Nave del Ayuntamiento con paredes de bloque ocre y cubierta de chapa roja, con parcela-almacén de materiales de obra y residuos.

o Nave agrícola -alejada del casco urbano- con paramentos en chapa metálica blanca y cubierta en chapa roja.

- Elementos singulares:

o Depósito de agua, acabado en forma de palomar, de ladrillo rojo, paños blancos y cubierta de teja. Es un edificio catalogado por el Plan General de Ordenación Urbana del municipio.

- Algunas casetas de era en barro (muy pocas para las que hubo).

o Ermita de Fuentes (Figura A3.47). Edificio barroco del siglo XVIII, que consta de tres naves y soportal edificado posteriormente. Las fachadas fueron construidas a base de ladrillo macizo de tejar y de paños de mortero a la cal (Figura A3.51). Tiene varios tejadillos en teja mixta curva similar a la antigua. En su interior se venera la patrona de Villalón de Campos: la Virgen de Fuentes, de talla gótica. 


\section{DEGRADACIONES DEL PAISAJE}

- Impacto moderado debido a la proliferación de vallados metálicos.

- Presencia de residuos en las cunetas de la carretera, que generan un impacto moderado.

- Impacto crítico debido a la pérdida o degradación de las numerosas casetas de era, construidas en adobe y barro, que existieron en esta zona del pueblo hasta hace relativamente poco (Figura A3.43).

- Impacto severo, por intrusión visual de elementos, provocado por la línea eléctrica y, sobre todo, por el transformador instalado al lado del depósito de agua (Figura A3.41).

- Impacto moderado provocado por la erosión en regueros o en desmoronamientos de un talud alto de desmonte de la carretera, a la salida del pueblo (Figura A3.45).

- Impacto severo por la existencia en suelo agrícola y cerca de la ermita de Fuentes de una nave agrícola (otra en construcción adyacente), de gran volumen y color relativamente llamativo (Figura A3.46).

\section{RECUPERACIONES DEL PAISAJE}

- $\quad$ PAR 1: Seto de hiedra en una de las vallas de parcela, con varios árboles en su interior.

- PAR 2: Seto de leylandi (Figura A3.42) en la valla metálica de la zona de invernaderos, de $4-5$ años, con un rápido crecimiento; tienen una altura de cerca de $2 \mathrm{~m}$.

- PAR 3: Colocación de una malla verde en la valla metálica que rodea la parcela donde el Ayuntamiento almacena residuos y materiales (Figura $A 3.44$ ).

- PAR 4: Plantación perimetral de almendros alrededor de la nave agrícola aislada, cada $3 \mathrm{~m}, 1,5 \mathrm{~m}$ de altura, con cuidados, $0 \%$ de marras.

- $\quad$ RES 1: Pradera de la ermita de Fuentes. Se trata de una pradera de aproximadamente 1 ha en la que se ubica la ermita, que no se riega aunque se siega periódicamente, manteniendo el verde todo el año salvo el periodo estival. Está delimitada por una valla de rollizos de madera tanalizada (Figura A3.48). El aparcamiento de vehículos se ha de hacer en su exterior. Tiene varios bancos de hormigón, piedras sueltas de sillería, pozo, pila y fuente (Figura A3.49), cuya agua proviene de la fuente la Gacha. La pradera anterior se encuentra libre salvo dos cedros que sustituyeron a los antiguos grandes olmos que murieron por la grafiosis, y varios árboles a la entrada; en su perímetro se han plantado acacias, pino piñonero y chopos a una distancia de $4 \mathrm{~m}$. La pradera posterior (Figura A3.50) está toda ella plantada de árboles de modo irregular, a un marco aproximado de $5 \times 5 \mathrm{~m}$, conteniendo pinos piñoneros, falsos cipreses, álamos boleanas, acacias, etc., además de un grupo de laurocerasus. Las plantaciones se han venido realizando en varias fases, desde hace unos 20 años. La altura media de los árboles se puede cifrar en $7 \mathrm{~m}$. Por los fallos habidos en estos años y el estado vegetativo de los ejemplares existentes, se puede constatar que no es una zona apta para especies de zonas húmedas, que requieren un esfuerzo suplementario y a la larga están condenadas al fracaso. Por el contrario, se confirma la idoneidad de la acacia por su rusticidad.

\section{RECUPERACIONES POTENCIALES}

- Plantación de arbustos en todos los taludes de más de $1 \mathrm{~m}$ y de árboles (almendros) en los taludes de más de $2 \mathrm{~m}$ donde no exista riesgo de accidente.

- Adecuación de un carril bici, ensanchando uno de los arcenes. Es una ruta muy transitada durante todo el año. Incluso hay varias procesiones, que discurren desde el pueblo hasta la ermita de Fuentes.

- Limpieza periódica de los residuos de las cunetas.

- Acondicionamiento de aparcamiento en parcela adyacente dejada en la concentración parcelaria para el ayuntamiento. Tanto en esta, como en la entrada asfaltada, también se podrían plantar árboles en su perímetro.

- Mejorar la zona recreativa y estancial de la pradera: sustituir los bancos y mesas degradadas por otros rústicos.

- Restauración vegetal de regueras.

- Plantaciones de diversificación en el interior de las parcelas agrícolas. 


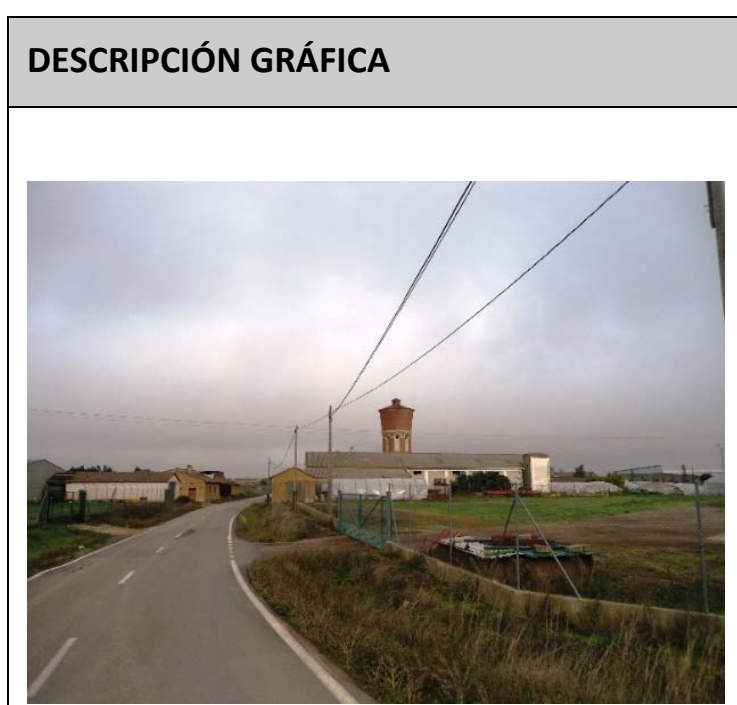

Figura A3.40. Varias construcciones agrícolas a la salida del pueblo.

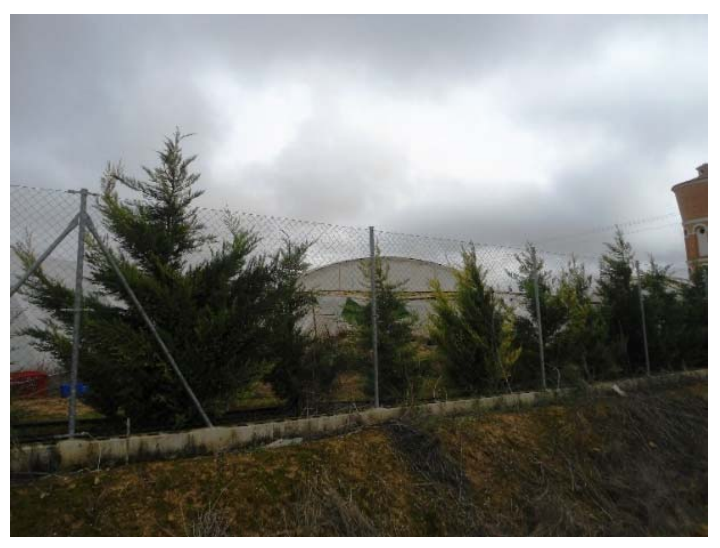

Figura A3.42. Seto de leylandi en parcela de invernaderos

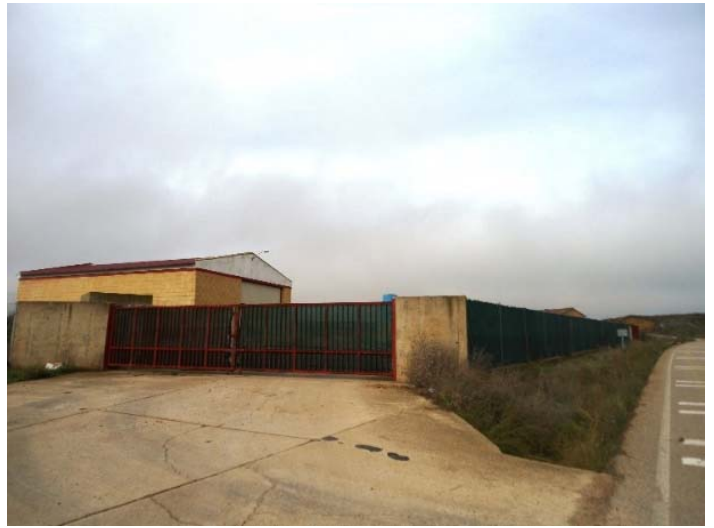

Figura A3.44. Parcela - almacén del Ayuntamiento, bastante Integrada.

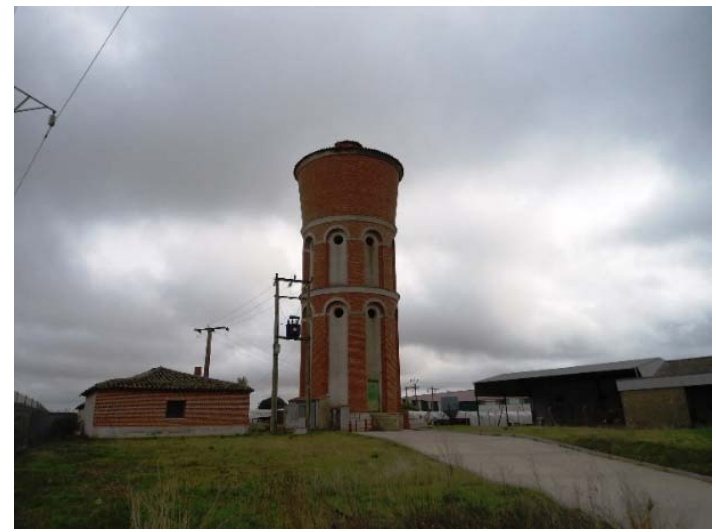

Figura A3.41. Línea eléctrica y transformador al lado de depósito.

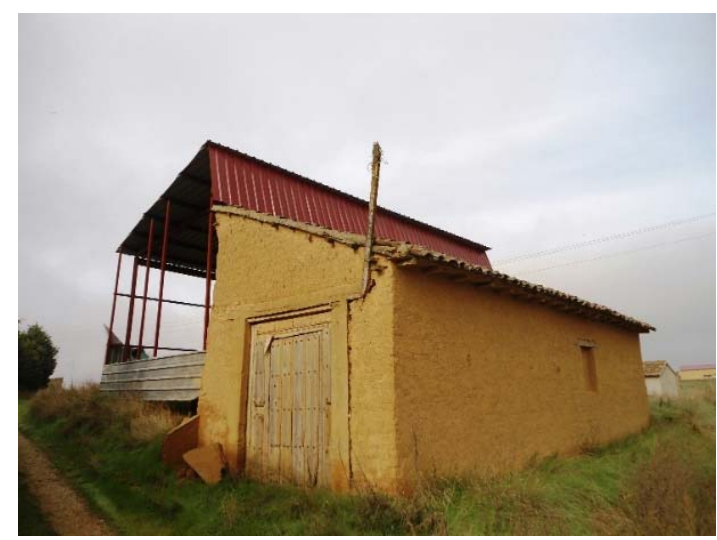

Figura A3.43. Antigua caseta de barro degradada por construcción metálica

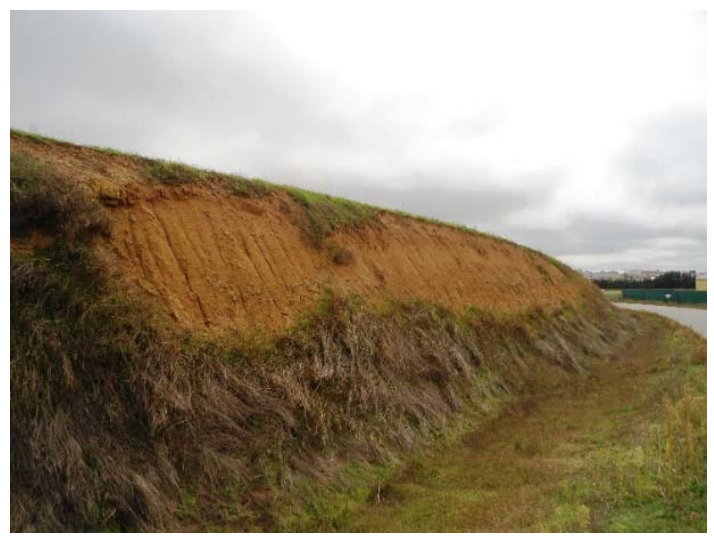

Figura A3.45. Taludes de desmonte de la carretera, erosionados 


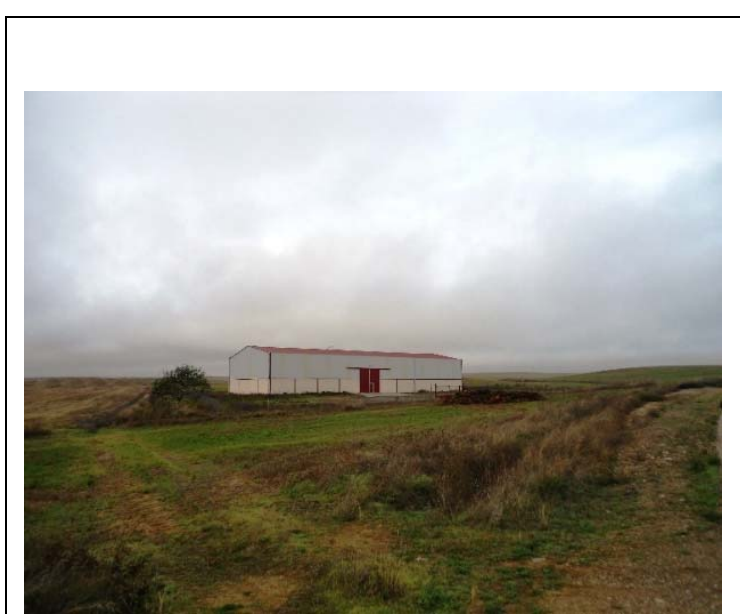

Figura A3.46. Nave agrícola aislada

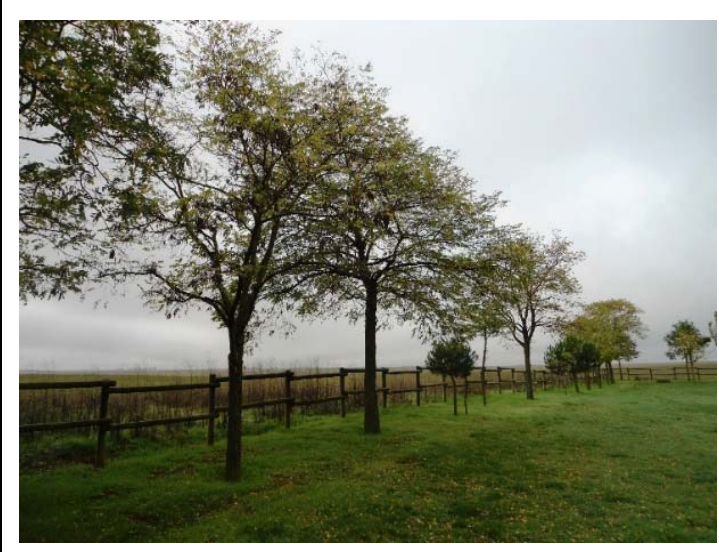

Figura A3.48. Valla de madera y acacias en perímetro de la pradera.

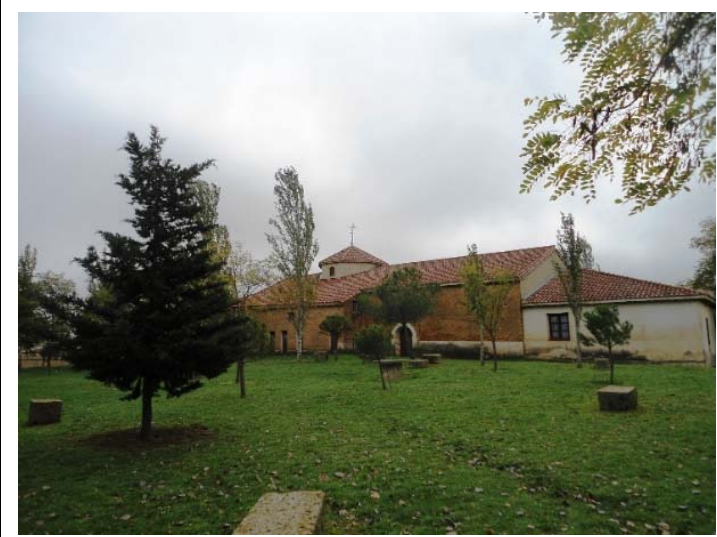

Figura A3.50. Pradera posterior

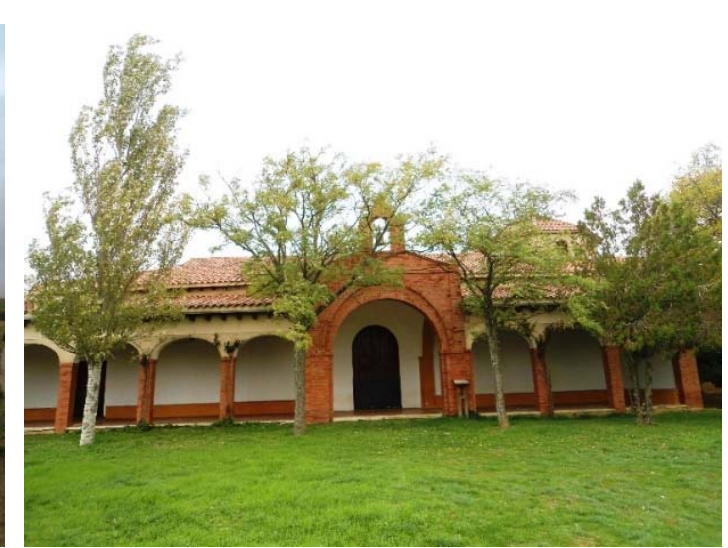

Figura A3.47. Fachada principal de la ermita de Fuentes

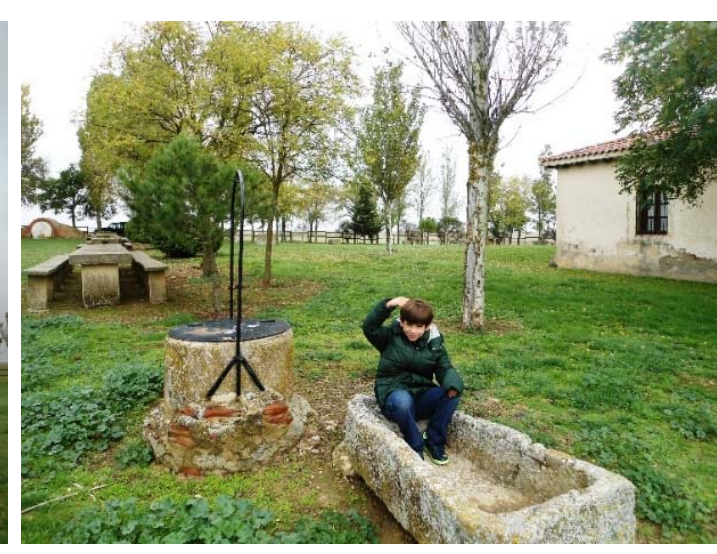

Figura A3.49. Zona de bancos, con pozo, pila y fuente

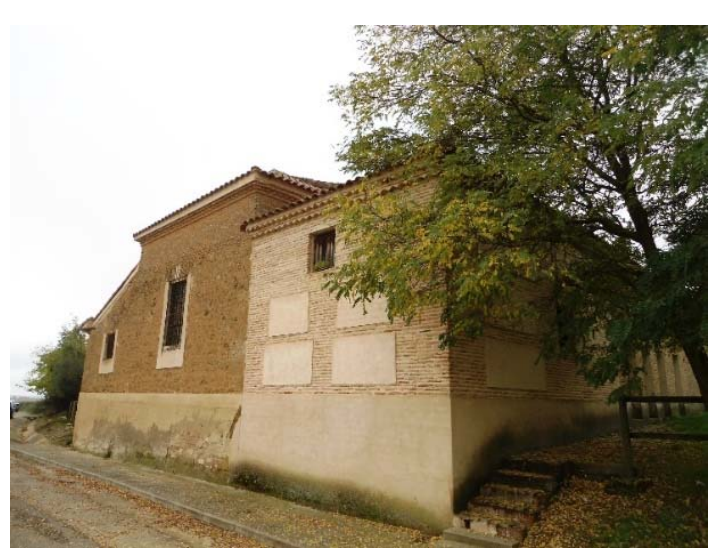

Figura A3.51. Fachada lateral de la ermita a la carretera 
- Fecha: 1 de noviembre de 2013, 11:15 h.

- Medio: Caminando.

- Itinerario: Plaza mayor - C) Ángel María Llamas - cruce carretera nacional (Figura A3.55) - vía de servicio - camino del cementerio - cementerio.

- Longitud: 0,5 km

- Condiciones meteorológicas: Nublado.

- Características de la vía: La plaza mayor está pavimentada con paños de granito pulido combinados con otros de adoquín de hormigón rústico térreo. La calle Ángel María Llamas tiene adoquines antiguos en mal estado, también tiene soportal con baldosas rojas. La vía de servicio de la carretera nacional es de hormigón. El camino del cementerio está asfaltado (Figura A3.56). En el cementerio las principales zonas de tránsito son de hormigón y algunas se encuentran en tierra. Se trata de un

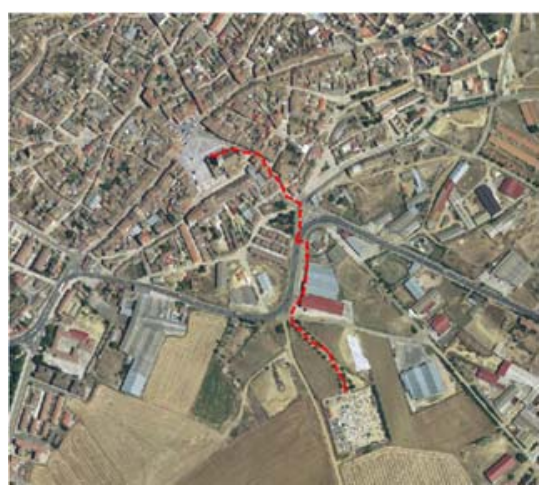
recorrido realizado con frecuencia por los vecinos de Villalón de Campos: en todos los funerales y en las fechas situadas en el entorno del día de Todos los Santos.

\section{CARACTERÍSTICAS DEL PAISAJE}

- Entorno inmediato de la vía: No procede, salvo en el caso del camino del cementerio, donde el vial es de $3 \mathrm{~m}$, no tiene cunetas y el margen es de $4 \mathrm{~m}$; se trata con herbicida.

- Espacio agrícola: No procede.

- Agua: Ausencia.

- Ruido: Considerable por el cruce por la carretera nacional.

- Olores desagradables: Inexistentes.

- Vegetación: Se atraviesa por el parque del Convento y por un camino arbolado que conduce al cementerio. Las frondosas han perdido prácticamente la hoja, pero hay bastantes coníferas en ambas zonas verdes.

- Fauna: Inapreciable.

- Actuaciones humanas:

o Espacio urbano desde la plaza mayor hasta la carretera nacional. Se corresponde con el casco histórico, de hecho al final se encontraba una de las puertas de la villa. Tipología de manzana compacta, con edificaciones antiguas de planta baja más una o planta baja más dos. Hay soportales (Figura A3.53), con los pilares de diferente conformación y baldosa roja. Dominan los enfoscados ocres sobre las fachadas de ladrillo de tejar (Figura A3.54). Abundante presencia de balcones de forja. Carpintería de madera o metálica en tonos oscuros. Domina la teja árabe sobre la mixta. Existen varias viviendas con riesgo de ruina.

- Espacio urbano de ensanche, con grupo de viviendas de $\mathrm{PB}+1$ con ladrillo rojo y teja de hormigón oscura.

- Vivienda aislada ocre y teja plana, con parcela vallada y ajardinada.

o Dos naves-taller blancas y teja rojiza.

o Dos naves agrícolas metálicas, con paramentos verdes y cubierta en su color.

o Edificio industrial de transformación alimentaria, con paramentos ocres, bien integrado.

- Cementerio, con tapias de cemento pintadas en color ocre bastante desgastado. Zona frontal con ladrillo rojo a hueso y puerta de forja. Varias construcciones auxiliares en su interior. Predominan los panteones sobre los nichos (Figura A3.57).

- Elementos singulares:

o Iglesia de San Miguel (Figura A3.52): magnífico monumento de estilo gótico-mudéjar. La fachada principal es un gran soportal neoclásico. El resto de fachadas tienen acabado de ladrillo de tejar con varios arcos y figuras propias de este estilo, recientemente restauradas. Solo una de las fachadas, que corresponde con edificaciones anexas, tiene revocos en cemento en su color. Posee amplias cubiertas con teja árabe. Es Bien de Interés Cultural. Es la única iglesia con uso religioso en el pueblo.

o Varios edificios, por su tipología tradicional, poseen catalogación integral o ambiental, de acuerdo con la normativa urbanística. 


\section{DEGRADACIONES DEL PAISAJE}

- Impacto moderado provocado por la presencia de una de las fachadas de la iglesia de San Miguel con cemento gris.

- $\quad$ Deficiente estado del pavimento de la calle Ángel María Llamas (Figura A3.54), construido a base de adoquines antiguos de granito, impacto moderado.

- Estado de ruina de algunas viviendas de la calle Ángel María Llamas, impacto severo.

- Impacto crítico provocado por la corta, hace ya varios años, de varios cipreses centenarios existentes en el interior del cementerio.

\section{RECUPERACIONES DEL PAISAJE}

- VER 1: Parque del Convento (ver ruta de los Parques).

- $\quad$ PAR 1: Varios árboles en parcela de vivienda aislada y arbustos en valla.

- VER 2: Paseo del camino del cementerio, en una longitud de unos 150 m, a base de acacias y cipreses intercalados. Esta plantación se realizó hace cerca de 30 años. Distancia entre árboles de $5 \mathrm{~m}$. Actualmente tienen una altura de 5 $-6 \mathrm{~m}$, se encuentran en buen estado vegetativo y cumplen una importante función de calidad ambiental de este recorrido.

\section{RECUPERACIONES POTENCIALES}

- Adecuación de la fachada de cemento de la iglesia de San Miguel, al menos pintándola de color ocre.

- Restauración del adoquinado de la calle Ángel María Llamas, eliminando los bacheados de asfalto.

- Uniformización, en lo posible, de los pilares de los soportales (por ejemplo, que todos los pilares metálicos tengan el mismo color).

- Adaptación de las nuevas construcciones o de las reformas exteriores a la tipología arquitectónica tradicional: diferenciación de fachadas originales, fachadas en ladrillo tipo antiguo o mortero bastardo, conformación armoniosa de huecos, balcones de forja, canecillos de madera, cubiertas de teja árabe o mixta curva similar, carpintería exterior de madera u oscura, etc. Cumplimiento en todo caso de la normativa urbanística y en materia de Patrimonio para la conservación de los edificios catalogados.

- Mejora y señalización del cruce con la carretera nacional.

- Sustituir el tratamiento con herbicida por el desbroce mecánico, para el control de la vegetación del margen del camino del cementerio.

- En el cementerio, adecuar los espacios de paso actualmente en tierra con gravilla ornamental.

- Restaurar tejadillos de varias zonas de antiguos nichos u otras zonas de interés patrimonial del cementerio.

- Plantar cipreses en algún parterre del interior del cementerio, así como en su perímetro exterior. 


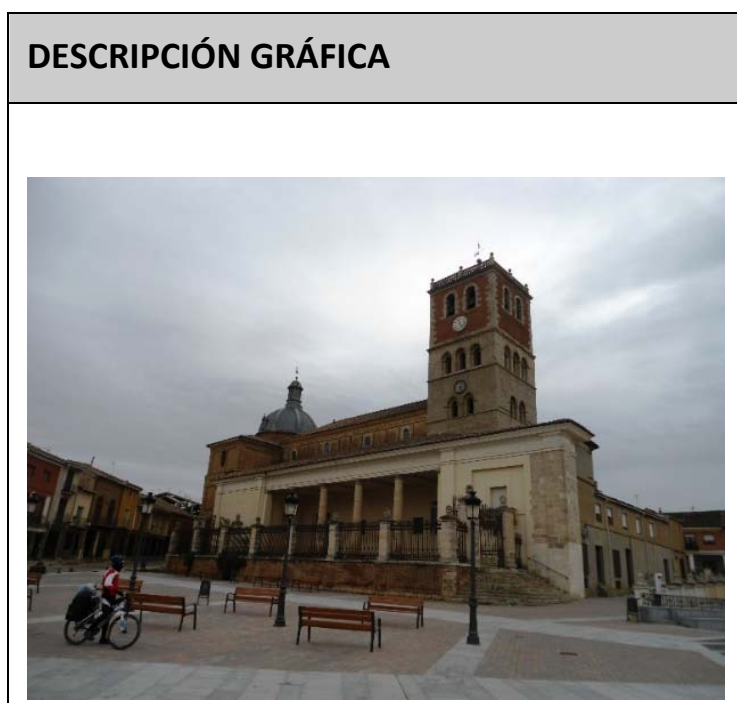

Figura A3.52. Plaza mayor e iglesia de San Miguel

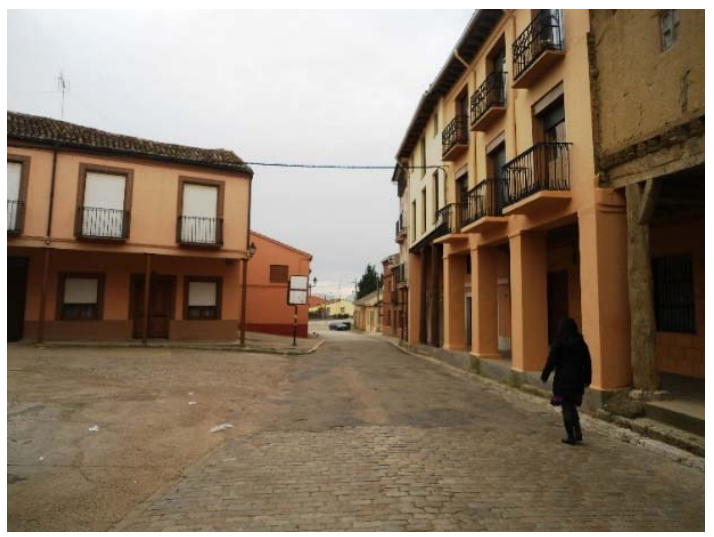

Figura A3.54. C) Ángel Mã Llamas, hacia arriba

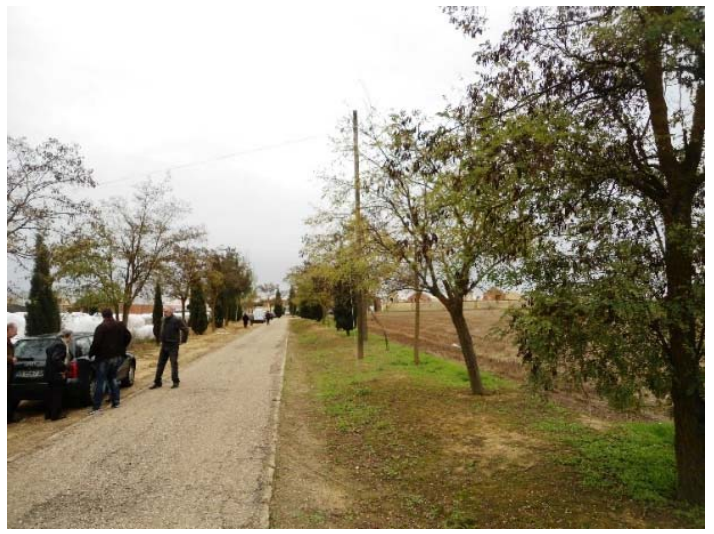

Figura A3.56. Camino del cementerio

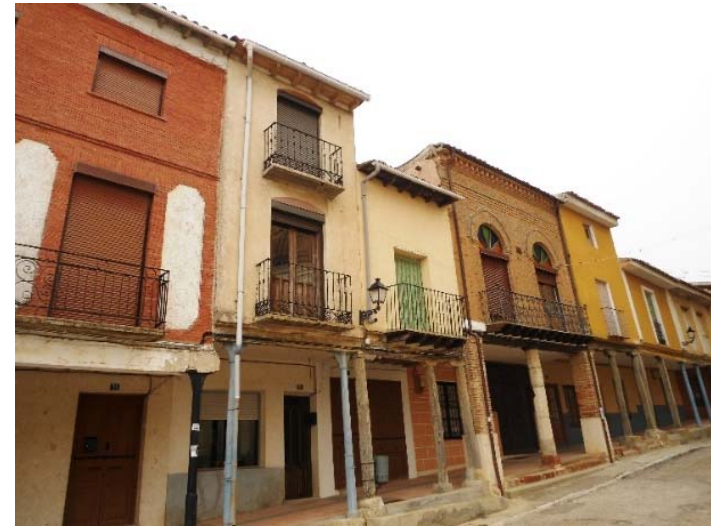

Figura A3.53. Soportales en C) Ángel Mạ Llamas / plaza Mayor

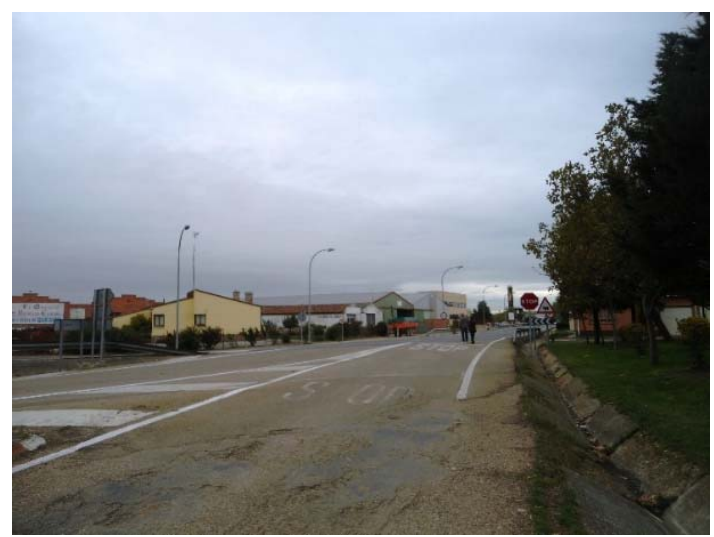

Figura A3.55. Cruce por la carretera nacional

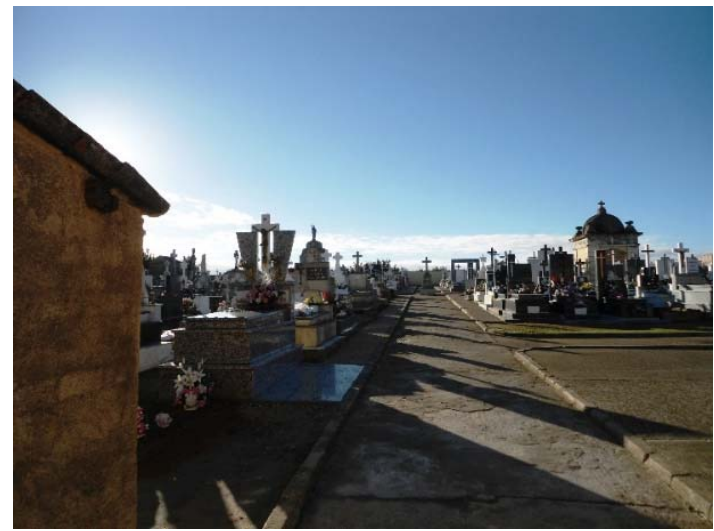

Figura A3.57. Interior del cementerio 
- Fecha: 2 de noviembre de 2013, 11:30 h.

- Medio: Caminando.

- Itinerario: Desde casco urbano (Figura A3.58) - colada de Sahagún fuente el Rosario - límite de término - cruce campo a través por reguera - arroyo Berruez - fuente el Arco - arroyo Berruez - camino del Rosario - punto de inicio.

- $\quad$ Longitud: $10,7 \mathrm{~km}$

- $\quad$ Condiciones meteorológicas: Nublado. Terreno con humedad.

- Características de la vía: Camino de zahorra natural silícea suelta, desagradable para caminar o ir en bicicleta. Plataforma de $6 \mathrm{~m}$.

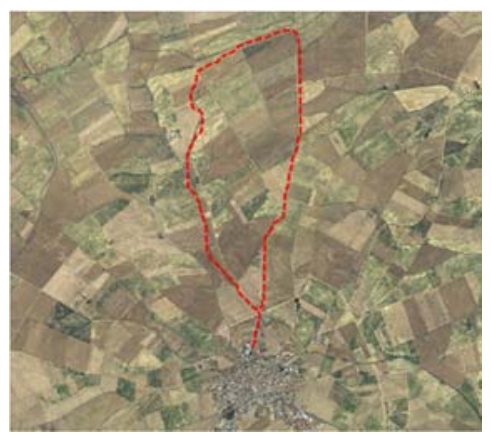

\section{CARACTERÍSTICAS DEL PAISAJE}

- $\quad$ Entorno inmediato de la vía: Cunetas de $2-3 \mathrm{~m}$ de anchura parcialmente revegetadas. Altura media de los taludes: $>2 \mathrm{~m}=15 \%, 1-2 \mathrm{~m}=50 \%,<1 \mathrm{~m}=35 \%$, con predominio del desmonte, sobre todo en el primer tramo.

- Espacio agrícola: Dominio del color marrón de los barbechos (Figura A3.69). También hay presencia de rastrojos (ocre) y siembras nacidas (verde pálido). Se ven tractores gradeando (Figura A3.66) y sembrando.

- Agua: Hay charcos en cunetas y regueras.

- $\quad$ Ruido: Inapreciable.

- $\quad$ Olores: Inexistentes.

- Vegetación: Prácticamente nula en los márgenes del camino. En las regueras hay bastantes escaramujos, que han perdido la hoja pero tienen un fruto rojo vivo. Franja arbolada (chopos) y con arbustos aguas abajo de la fuente el Rosario (Figura A3.61). Se comienza a divisar la plantación lineal de especies de ribera en el arroyo Berruez. Los olmos aún tienen hoja verde y la de los chopos va amarilleando.

- $\quad$ Fauna: Bastantes pajaritos, más en las franjas arbustivas. 2 milanos reales. Bando de 10 avutardas (Figura A3.67).

- Actuaciones humanas:

o Nave agrícola paramentos blancos con franjas verdes y cubierta metálica roja.

- Muro de ladrillo sin revestir.

o Invernaderos agrícolas.

o Era con huerta, jardín y dos casas (paredes ocres y cubierta de teja antigua).

o Línea eléctrica de $20 \mathrm{kV}$.

o Numerosos vallados metálicos.

o Naves industriales de tratamiento de lana de oveja; paredes de cemento u ocres y cubiertas metálicas rojas.

o Pequeña caseta vallada para el abastecimiento municipal de agua.

o Antiguo aprisco de ovejas, con naves de cemento y cubiertas de fibrocemento; casa blanca y teja antigua.

- $\quad$ Elementos singulares:

o Fuente el Rosario (Figura A3.62), con depósito de ladrillo antiguo y bebederos.

o Palomar de barro y teja antigua.

\section{DEGRADACIONES DEL PAISAJE}

- $\quad$ Caminos excesivamente rectilíneos, sin naturalidad, impacto severo (Figura A3.63)

- Arroyos encauzados y rectificados, sin naturalidad, impacto severo (Figura A3.64).

- Impacto visual moderado de nave agrícola con paramentos blancos y verdes, por cambio de las características visuales básicas.

- Presencia de residuos en las cunetas del primer tramo del camino (plásticos, ruedas, pequeños depósitos de escombros, etc.).

- Impacto visual moderado por la proliferación de vallados metálicos.

- Impacto visual moderado debido a la existencia de la línea eléctrica, por introducción de elementos extraños a la pauta general. 


\section{RECUPERACIONES DEL PAISAJE}

- $\quad$ PAR 1: Era con valla de madera y enredadera, álamos boleanas y dos grandes pinos piñoneros.

- $\quad$ PAR 2: Entorno de las naves industriales de lana (Figura A3.59), con grupos de árboles frutales, chopos y acacias; hacen de buena pantalla visual.

- RES 1: Restauración de antigua escombrera en una superficie de unos $800 \mathrm{~m}^{2}$, con remodelación del terreno, depósito de tierra vegetal y acondicionamiento de taludes con suave pendiente (Figura A3.60). Se encuentra revegetada con herbáceas.

- $\quad$ RES 2: Entorno de la fuente el Rosario. Grupo de chopos plantados hace unos 30 años, que ahora presentan un gran porte de unos $20 \mathrm{~m}$ de altura. Algunos olmos siberianos más jóvenes, de mediano porte; un pino piñonero y gayombas en la linde.

- $\quad$ AHA 1: Linde paralela a reguera, de unos $80 \mathrm{~m}$. Pinos piñoneros, distancia $3 \mathrm{~m}$, protectores, sin cuidados, $100 \%$ de marras.

- $\quad$ AHA 2: Linde paralela a reguera, de unos 100 m (Figura A3.65). Pinos piñoneros, distancia 3 m, sin protectores, con cuidados. $0 \%$ de marras.

- $\quad$ AHA 3: Linde en medio de una parcela, de unos $80 \mathrm{~m}$. Pinos piñoneros, distancia $3 \mathrm{~m}$, con protectores, sin cuidados. $100 \%$ de marras.

- RES 3: Plantación de un grupo de 4 chopos en arroyo Berruez, hace unos 20 años; buen estado, altura de unos 12 m.

- RES 4: Restauración del arroyo Berruez (Figura A3.68), ver anejo 2.

- $\quad$ AHA 4: Linde de unos $200 \mathrm{~m}$ en reguera interior a parcela. Pinos piñoneros, cada $3 \mathrm{~m}$, con protectores, cuidados, 0 $\%$ de marras.

\section{RECUPERACIONES POTENCIALES}

- Restauración vegetal de taludes de caminos.

- Restauración vegetal de regueras.

- Plantaciones de diversificación en el interior de las parcelas agrícolas.

- Plantación de arbustos en vallados metálicos.

- Limpieza periódica de residuos en cunetas de caminos.

- Plantación de almendros y arizónicas en los taludes del primer tramo de camino, de altura considerable, para minimizar el impacto visual de las construcciones en suelo rústico.

- Plantación de árboles en talud de la escombrera restaurada. 


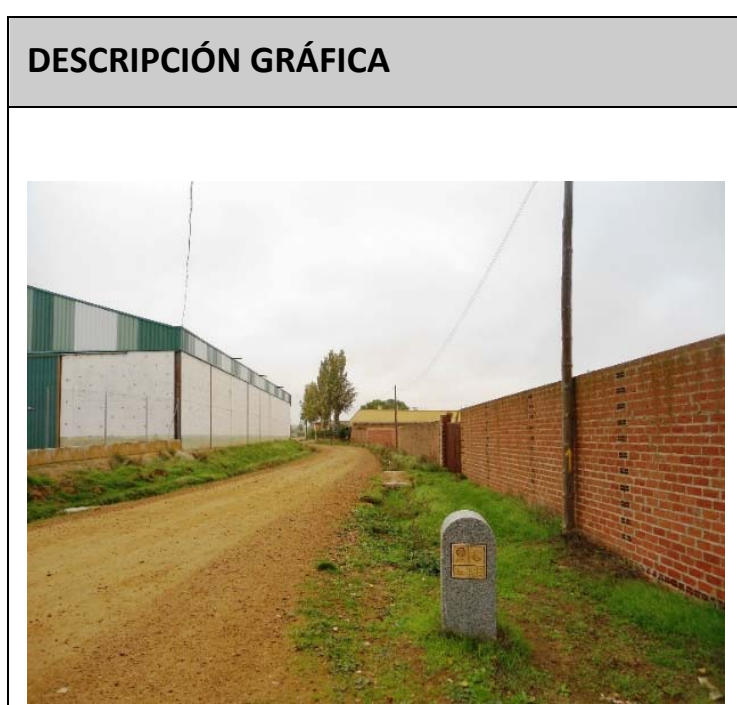

Figura A3.58. Camino de salida del pueblo

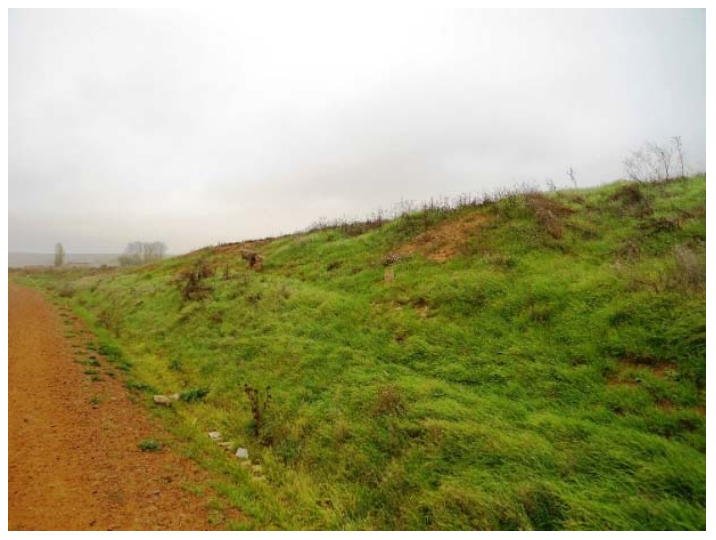

Figura A3.60. Restauración de antigua escombrera

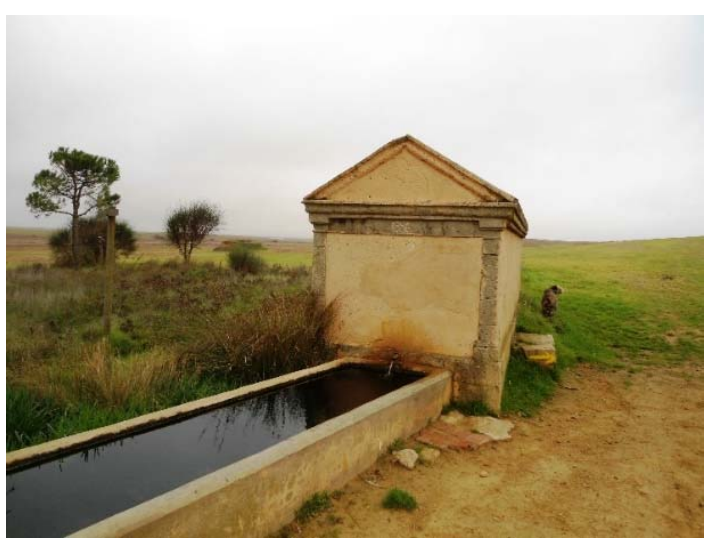

Figura A3.62. Fuente el Rosario

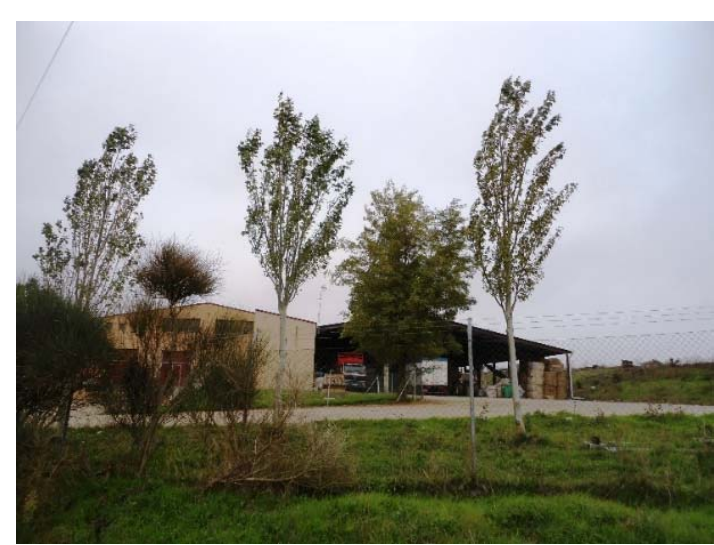

Figura A3.59. Arbolado en industria de tratamiento de lana

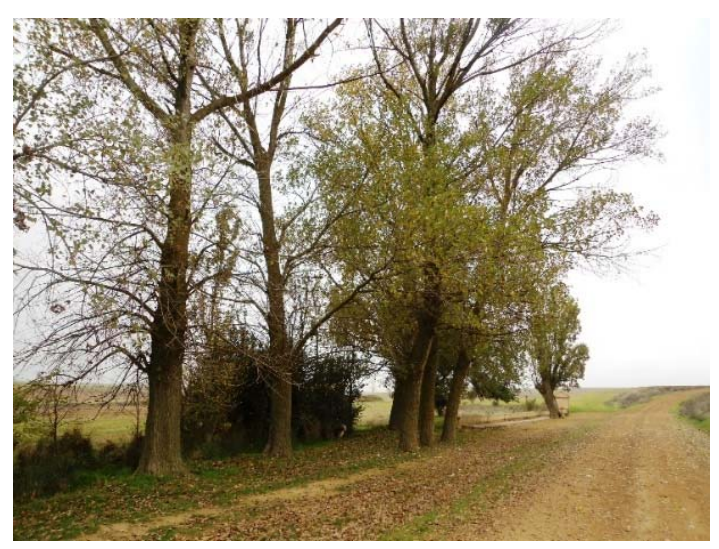

Figura A3.61. Chopos en fuente el Rosario

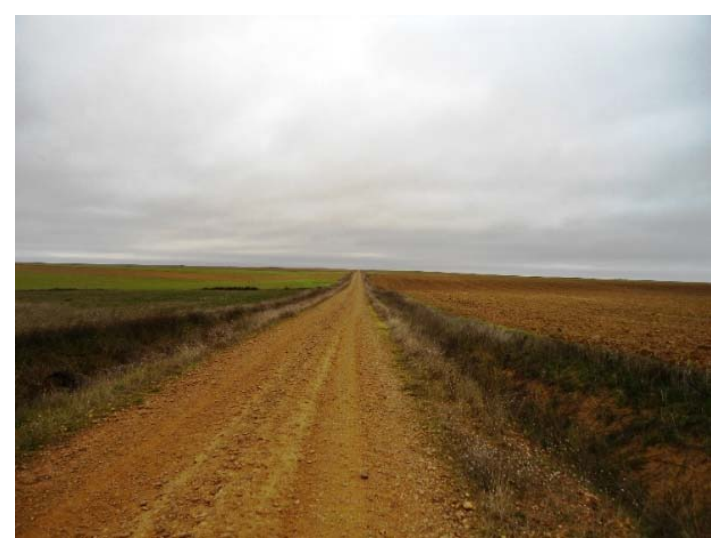

Figura A3.63. Vista general del camino 


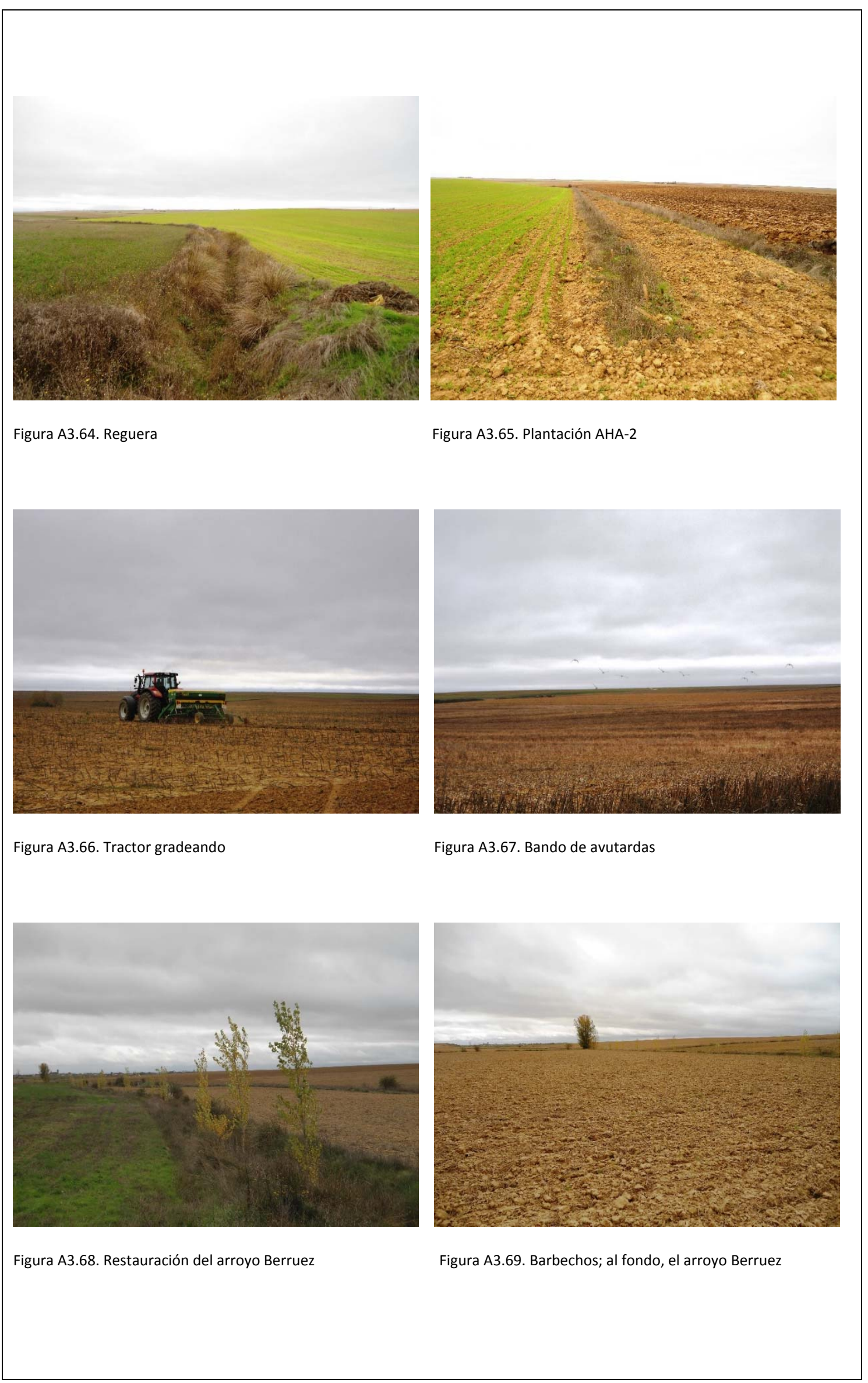




\section{RECORRIDO: Ruta de los parques}

- Fecha: 7 de noviembre de 2013, 17:30 h.

- Medio: Caminando.

- Itinerario: Se trata de una ruta circular que puede iniciarse por cualquier punto e incluso recorrerse en ambos sentidos. Se incluye la plaza mayor, ya que desde aquí se puede acceder a varios puntos de la ruta. En este caso, consideraremos el siguiente inicio: plaza Mayor -C) Marceliano Serrano restos de la antigua muralla -C) Sahagún - arroyo Pajarillas - huerta del Moral - picón de las acacias parque de la reguera del Tinte - parque de la laguna

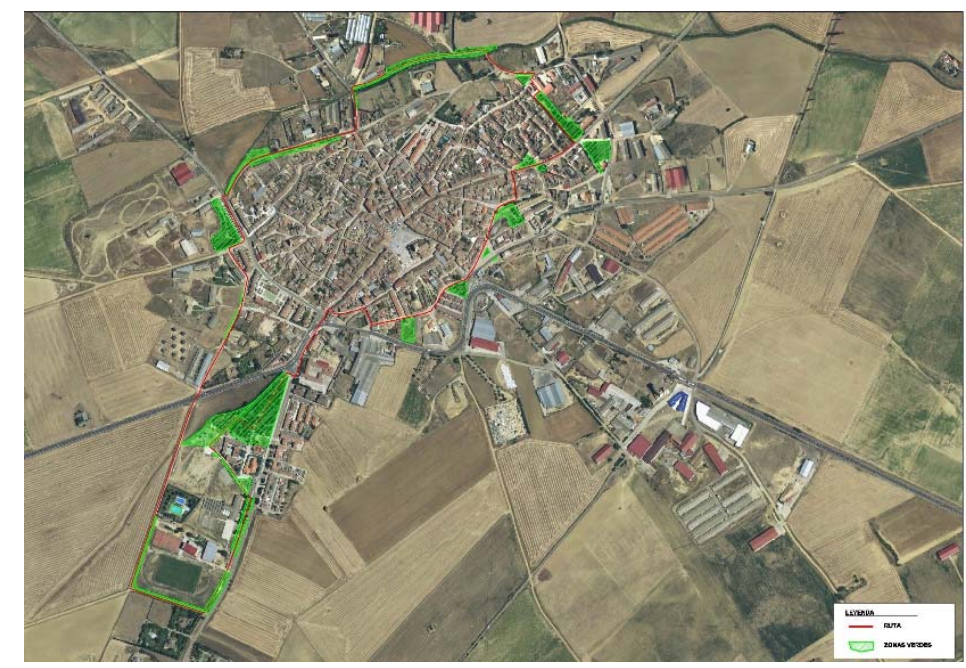
del Tinte - C) Constitución - plaza de San Juan - casas de la Pedrera - plaza de San Miguel - casas del convento era del depósito - C) Gaspar Grajal - cruce con ctra. nacional - avda. del Parque - cruce con ctra. de Valladolid parque del Paseo - parque temático - instituto - polideportivo - camino alrededor campo de fútbol - camino de la piscina - cruce con ctra. nacional - parque de San Pedro - paseo de Barrios - restos de la antigua muralla.

- $\quad$ Longitud: $4,5 \mathrm{~km}$

- $\quad$ Condiciones meteorológicas: Nublado. El terreno tiene mucha humedad. Hay un atardecer precioso.

- Características de la vía: El recorrido por las zonas más urbanas discurre por calles de hormigón, en regular estado de conservación, pero adecuadas para el tránsito de viandantes. Hay un porcentaje también alto de trayecto por caminos asfaltados, en general en buen estado. Hay algún tramo (avda. del parque y parque del Paseo), donde la vía está bien adoquinada. Puntualmente, existe un pequeño tramo con una senda en tierra, entre la entrada al polideportivo y el camino del campo de fútbol.

\section{CARACTERÍSTICAS DEL PAISAJE}

- Entorno inmediato de la vía: Los caminos asfaltados tienen, en general, cunetas que están revegetadas; no hay taludes altos salvo algún punto muy concreto. En algún tramo hay márgenes en hierba o en zahorra, que se suelen tratar con herbicida. Ahora la mayoría están verdes.

- Espacio agrícola: En los tramos donde se visualizan parcelas agrícolas, domina el marrón del barbecho sobre el ocre de los rastrojos y el verde pálido del cereal nacido y las leguminosas.

- Agua: Poca, algún charco en cunetas. Destaca la presencia de la cascada del parque del Paseo.

- Ruido: Puntual debido al tráfico de la carretera nacional.

- Olores desagradables: Inexistentes.

- Vegetación: Otoño intenso (Figuras A3.72 y A3.73). Los chopos tienen un color ocre muy llamativo (Figura A3.70), también los castaños de indias (Figura A3.74). Los olmos todavía están verdes. Los álamos han perdido casi toda la hoja (Figura A3.75). Se puede percibir el interesante contraste entre coníferas y frondosas. La hierba de los parterres y praderas está muy verde (Figura A3.71). Las hojas caídas en el suelo proporcionan una estética muy agradable al conjunto ajardinado.

- Fauna: Bastantes pajaritos, sobre todo en las zonas verdes.

- Actuaciones humanas: Ver recorrido 16.

- Elementos singulares: Ver recorrido 16. 
DEGRADACIONES DEL PAISAJE

Ver recorrido 16.

RECUPERACIONES DEL PAISAJE

Ver recorrido 6.

RECUPERACIONES POTENCIALES

Ver recorrido 26 . 


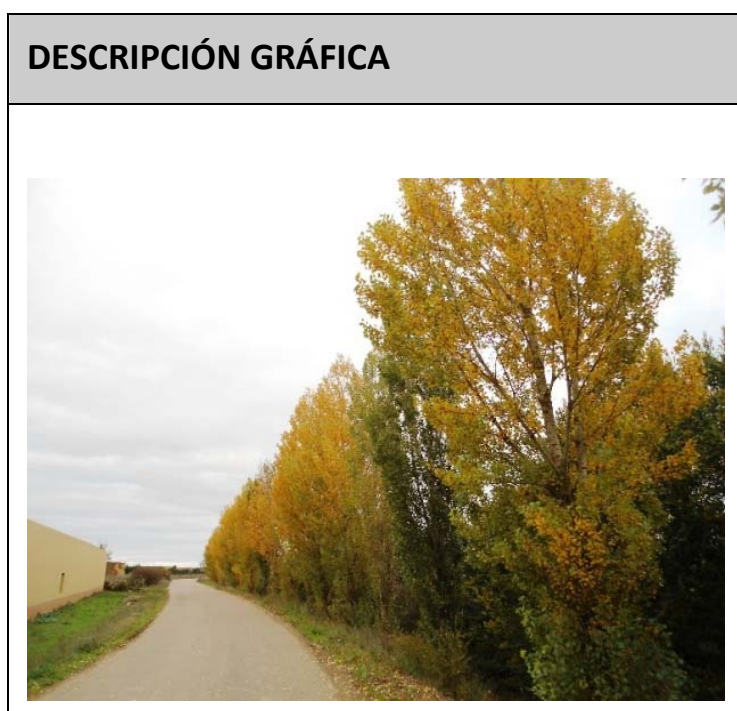

Figura A3.70. Chopera ocre del arroyo Pajarillas

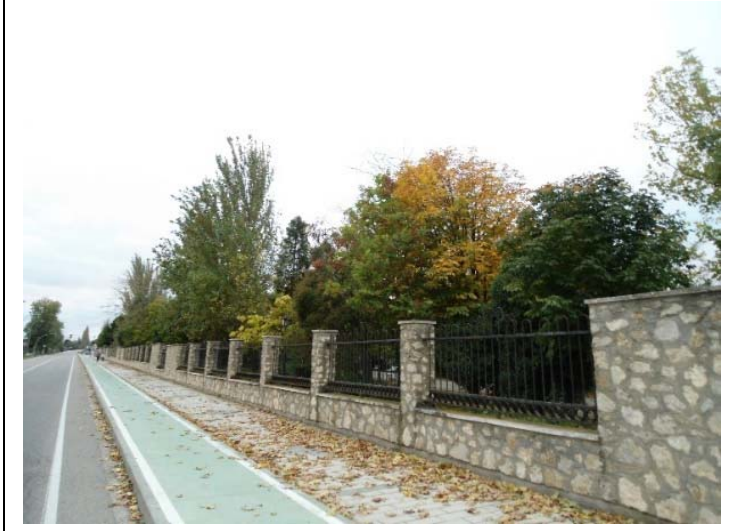

Figura A3.72. Contraste de colores en el parque del Paseo

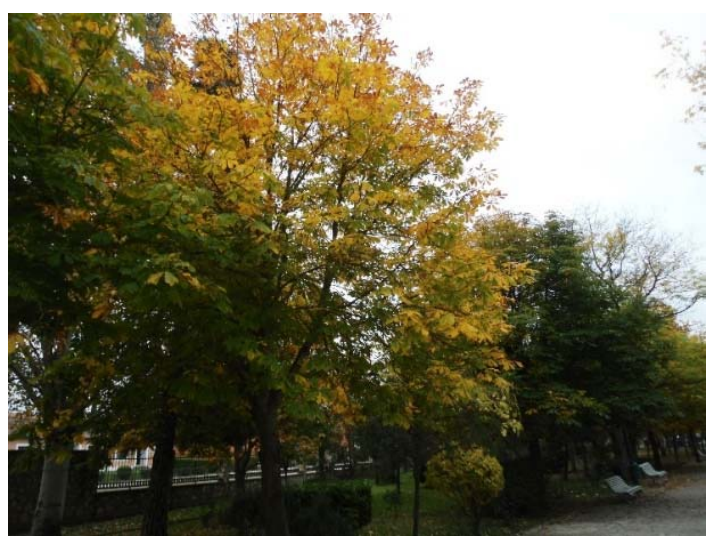

Figura A3.74. Los castaños de indias muestran el ocre de sus hojas marchitándose.

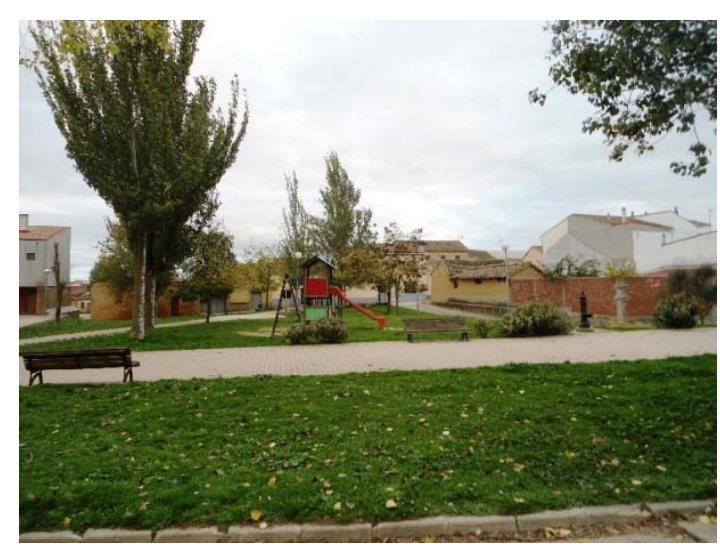

Figura A3.71. Las praderas están muy verdes

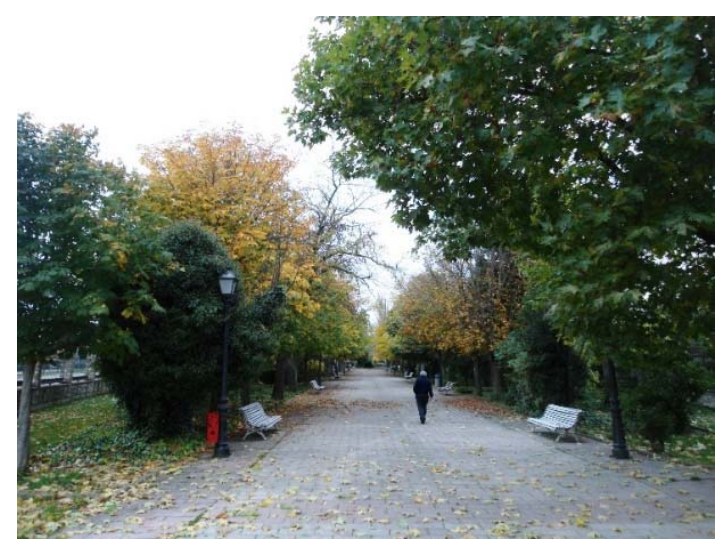

Figura A3.73. El otoño es intenso en los jardines

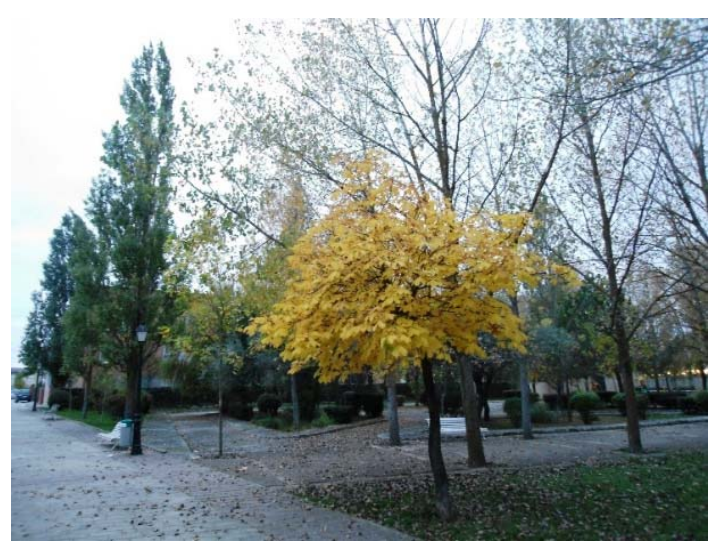

Figura A3.75. Muchos árboles ya han perdido sus hojas. 


\section{RECORRIDO: Colada de Villalón a Villada, San Salva y ruta larga por el Rosario}

- Fecha: 9 de noviembre de 2013, 9:45 h.

- Medio: Caminando.

- Itinerario: Desde últimas construcciones del pueblo (arroyo Pajarillas) (Figura A3.76) - colada de Villalón a Villada - fuente San Salva colada de Villalón a Villada - camino izquierda - colada de Sahagún fuente el Rosario - camino izquierda hasta punto de inicio.

- $\quad$ Longitud: 5,3 km

- $\quad$ Condiciones meteorológicas: Cielo despejado, mucho viento.

- Características de la vía: Estas vías pecuarias, como todas, están transformadas en caminos rurales por las concentraciones parcelarias. Plataforma de zahorra natural silícea rojiza de $6 \mathrm{~m}$ de anchura. Es un recorrido bastante curvilíneo porque se asienta precisamente sobre las vías pecuarias, que son caminos históricos.

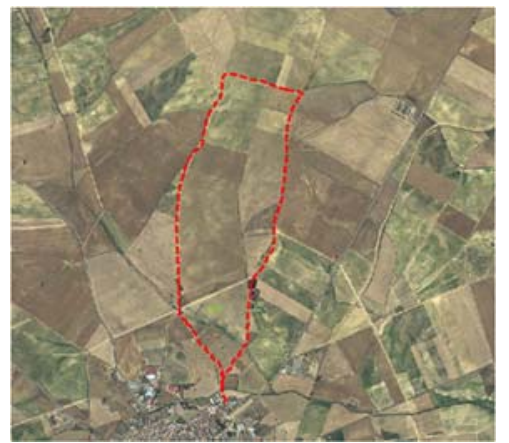

\section{CARACTERÍSTICAS DEL PAISAJE}

- Entorno inmediato de la vía: Cunetas de $2-3 \mathrm{~m}$ de anchura parcialmente revegetadas. Altura media de los taludes: $>2 \mathrm{~m}=20 \%, 1-2 \mathrm{~m}=50 \%,<1 \mathrm{~m}=30 \%$, con predominio del desmonte, sobre todo en el primer tramo.

- Espacio agrícola: Equilibrio entre barbechos (marrón), rastrojos (ocre) y cereal nacido y leguminosas (verde pálido).

- Agua: No hay, solo en las fuentes.

- Ruido: Inapreciable. Algún tractor sembrando.

- Olores: Inexistentes.

- Vegetación: Prácticamente nula en los márgenes del camino. Algunos árboles en zona de huertas al inicio y final del recorrido, en particular un pino piñonero (Figura A3.77) y un álamo esbeltos. En las regueras hay bastantes escaramujos, que han perdido la hoja. Franjas arboladas (chopos) y con arbustos en el entorno de las fuentes de San Salva y el Rosario. Se comienza a advertir la plantación lineal de especies de ribera en el arroyo Berruez. Los olmos aún tienen hoja verde y la de los chopos sigue amarilleando.

- Fauna: Bastantes pajaritos. Bando de palomas, 2 rapaces, un conejo. Un rebaño de ovejas (Figura A3.79).

- Actuaciones humanas:

o Casa-huerta de barro y teja árabe.

o Antigua casa-huerta, parte de barro y parte de bloques de hormigón blancos.

o Casa-merendero vallada, con huerta y zona arbolada.

o Antigua extracción de arcilla de unos $2.000 \mathrm{~m}^{2}$, con taludes finales verticales de gran altura (unos $6 \mathrm{~m}$ ).

o Antiguo aprisco de ovejas, con naves de cemento y cubierta de fibrocemento. Casa blanca con teja árabe.

o Huerta - chamizo vallada con muchos materiales reciclados (ver recorrido 10).

o Varias líneas de $20 \mathrm{kV}$ cruzan el recorrido.

o Caseta vallada para el abastecimiento municipal de agua.

- $\quad$ Elementos singulares:

o Fuente San Salva, con depósito de agua de ladrillo de tejar

o Fuente el Rosario, con depósito de ladrillo antiguo y bebederos (ver recorrido 10).

o Palomar de barro y teja antigua (Figura A3.81), ver recorrido 10. 


\section{DEGRADACIONES DEL PAISAJE}

- $\quad$ Caminos excesivamente rectilíneos, sin naturalidad, impacto severo.

- $\quad$ Arroyos encauzados y rectificados, sin naturalidad, impacto severo.

- Impacto moderado por la presencia de varias líneas eléctricas, elementos extraños a la pauta general del paisaje agrario.

- Impacto moderado debido a la existencia de una antigua extracción de arcilla sin restaurar los taludes. Su verticalidad contrasta con las formas naturales redondeadas del terreno de Tierra de Campos.

- Impacto moderado por la presencia de residuos estériles en un terraplén de una parcela agrícola (Figura A3.80), donde además se contempló su sujeción con un muro de contención de ladrillos. Al menos se plantaron gayombas.

\section{RECUPERACIONES DEL PAISAJE}

- $\quad$ AHA 1: Picón triangular de unos $300 \mathrm{~m}^{2}$. Pino piñonero y encina, marco de $3 \times 2.5 \mathrm{~m}$, con protectores, sin cuidados, $50 \%$ de marras.

- $\quad$ RES 1: Plantación en el arroyo Berruez (ver anejo 2). Precisamente en este tramo se detectan algunas marras por las ovejas.

- $\quad$ PAR 1: Plantaciones de árboles y arbustos en parcela con caseta situada al lado de San Salva. Tiene frutales, pinos piñoneros, gayomba, etc. en buen estado de conservación.

- $\quad$ RES 2: Fuente de San Salva. Se realizó una mejora del entorno natural por parte de la Consejería de Medio Ambiente hace unos 30 años, con varias actuaciones posteriores complementarias. Tiene un vallado metálico con pilares intercalados de piedra y seto interior de gayomba. Refugio de hormigón chapado en piedra caliza, con teja árabe. En el interior de la parcela se plantaron fundamentalmente álamos blancos boleanas, a un marco de $3 \times 3 \mathrm{~m}$; en la zona húmeda están muy altos (más de $20 \mathrm{~m}$ ), peor se mantienen en la zona seca. Da excesivos brotes. Se intercaló alguna conífera: arizónicas (bien), cedro y pino silvestre (regular), y thuyas (bien). Bancos y mesas de materiales variados: hormigón, piedra, madera; algunos rotos. Dos barbacoas rotas. El entorno de la fuente se encuentra bastante degradado. Es una fuente emblemática en el pueblo, ya que ha sido utilizada como espacio de esparcimiento en las temporadas en que ha sido cuidada (en los últimos años, esto ha ocurrido periódicamente).

- $\quad$ AHA 2: Lindero paralelo a camino de $100 \mathrm{~m}$. Pino piñonero, $3 \mathrm{~m}$ distancia, sin protectores, con cuidados, $20 \%$ de marras.

- $\quad$ AHA 3: Lindero paralelo a camino-reguera de $50 \mathrm{~m}$. Almendro, $3 \mathrm{~m}$ distancia, sin protectores, con cuidados, $0 \%$ de marras.

- $\quad$ RES 3: Fuente el Rosario (ver recorrido 10)

- PAR 2: Plantación de chopos y otros árboles en huerta-chamizo situada al final del recorrido, que ya tienen una considerable altura.

\section{RECUPERACIONES POTENCIALES}

- Restauración vegetal de taludes de caminos.

- Restauración vegetal de regueras.

- Plantaciones de diversificación en el interior de las parcelas agrícolas.

- Plantación de almendros y coníferas en los márgenes del camino hasta San Salva, de forma que se configure como una ruta de paseo desde el pueblo. Es una zona con taludes de desmonte altos, donde esta actuación puede llevarse a cabo.

- $\quad$ Fuente San Salva (Figura A3.78): Limpieza y adecuación del depósito de la fuente y su entorno, así como de su manantial. Desbroce periódico de los brotes de chopo y de las herbáceas; conveniente dos veces al año, durante la primavera y al comienzo del verano (ya no brotan más). Arreglo del mobiliario estropeado, utilizando materiales rústicos. Ampliación de la fuente con la parcela dejada en la concentración parcelaria.

- Restauración de la antigua extracción de arcilla, bien tendiendo los taludes, bien añadiendo tierra en su base, de forma que quede una pendiente estable (en torno a $2 \mathrm{~V}: 3 \mathrm{H}$ ). Extensión de tierra vegetal y siembra en su caso con herbáceas y arbustivas.

- $\quad$ Restauración del talud del camino en el que se vertieron escombros. Extensión de tierra vegetal, siembra (si no hay regeneración natural) y plantación de arbustivas.

- Plantación de frondosas de ribera en el tramo del arroyo Pajarillas que atraviesa varias explotaciones ganaderas, para minimizar el impacto de las naves. 

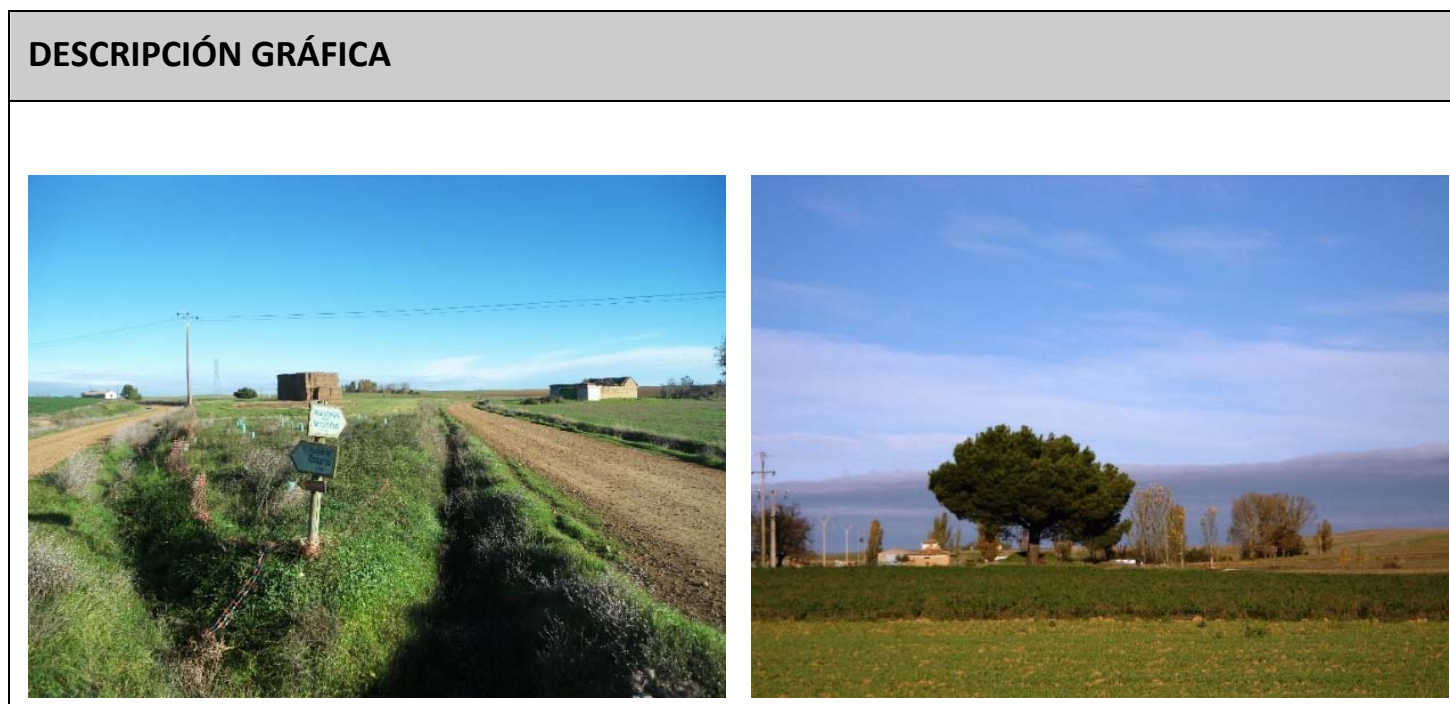

Figura A3.76. Inicio y final del recorrido

Figura A3.77. Pino piñonero en zona de antiguas huertas
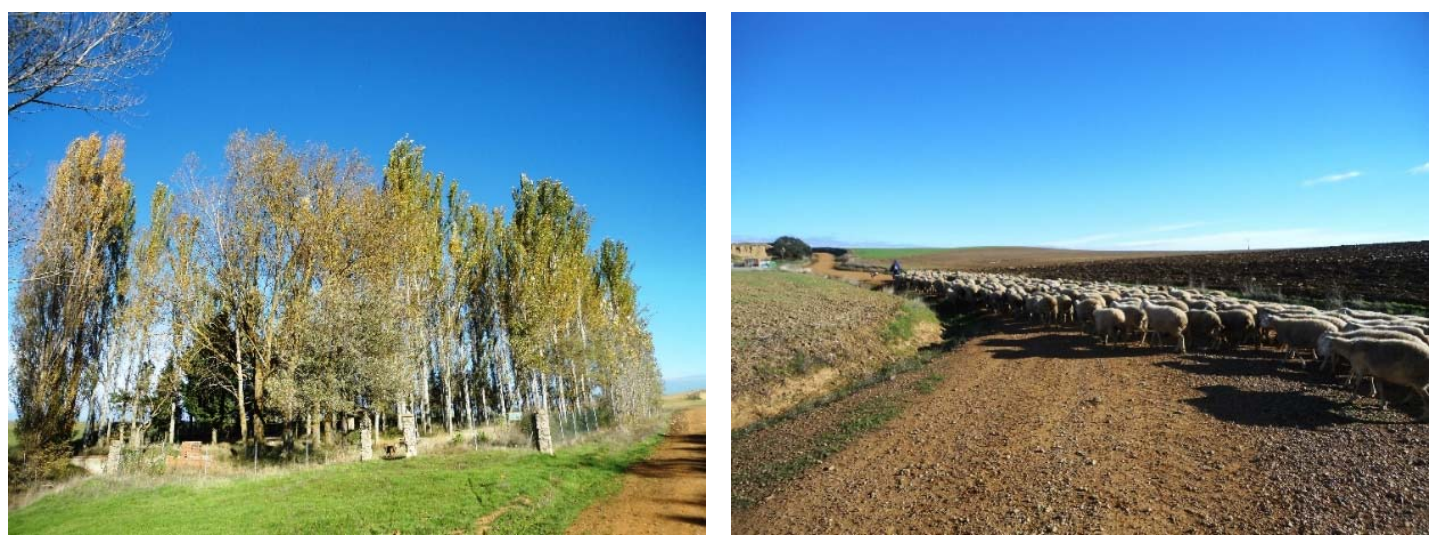

Figura A3.78. Fuente San Salva

Figura A3.79. Rebaño de ovejas
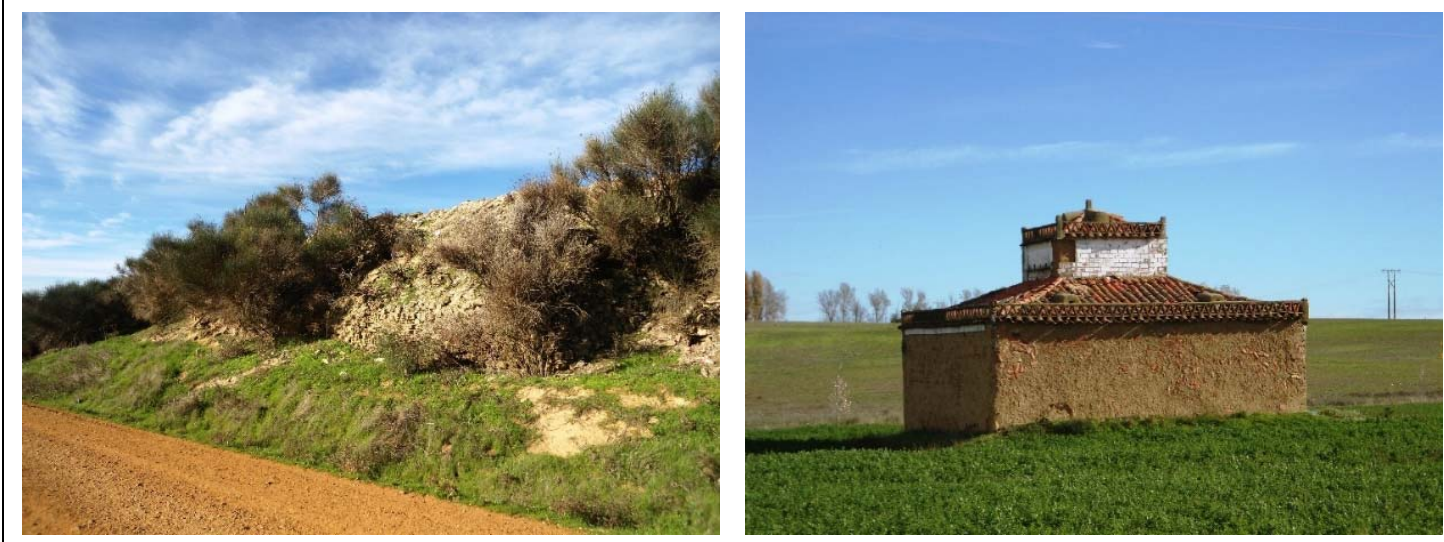

Figura A3.80. Escombros en talud

Figura A3.81. Palomar 
- Fecha: 12 noviembre 2013, 18:10 h.

- Medio: Bicicleta

- Itinerario: Desde la carretera a Fontihoyuelo - camino la Alameda fuente el Arco - límite término municipal - vuelta al punto de inicio.

- $\quad$ Longitud: $6 \mathrm{~km}$

- Condiciones meteorológicas: Soleado. El terreno se va secando, ya que no ha llovido en los últimos días.

- $\quad$ Características de la vía (Figura A3.82): Camino de zahorra, con 6 m de plataforma. Hierba en $80 \mathrm{~cm}$ a cada lado de la plataforma. Solo hay una curva, el resto del trayecto es rectilíneo.

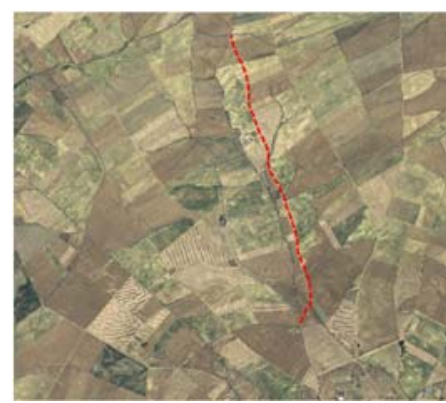

\section{CARACTERÍSTICAS DEL PAISAJE}

- $\quad$ Entorno inmediato de la vía: Presencia de taludes, sobre todo de terraplén, con pendiente aproximada 2V:3 $\mathrm{H}$. Cunetas de los caminos de anchura media de $2 \mathrm{~m}$, revegetadas. La altura media de los taludes es $>2 \mathrm{~m}=10 \%, 1-2 \mathrm{~m}$ $=60 \%,<1 \mathrm{~m}=30 \%$. Márgenes y taludes revegetados con herbáceas, sin presencia de árboles o arbustos.

- Espacio agrícola: Terreno bastante ondulado. Se está sembrando el rastrojo y el girasol, por lo que domina el suelo desnudo (marrón) sobre el verde de las leguminosas y el cereal ya nacido.

- $\quad$ Agua: Ausencia.

- Ruido: Inapreciable. Algún tractor sembrando o gradeando (Figura A3.83).

- Olores desagradables: Inexistentes.

- $\quad$ Fauna: Presencia de pajaritos. Una rapaz. Bando de 8 avutardas.

- Vegetación: El único árbol que había en el camino se ha secado (en la fuente La Alameda, Figura A3.84)). Se ve algún chopo en las proximidades, más abundantes hacia el Arco. Los arroyos y regueras que cruzan, sobre todo en la segunda mitad del tramo, tienen bastantes arbustos.

- $\quad$ Actuaciones humanas:

- Escombrera municipal: Ocupa una superficie de unas 2,3 ha. Residuos sólidos urbanos, fundamentalmente inertes. Depósitos en terraplén. Taludes altos, visibles desde la carretera a Fontihoyuelo, parcialmente revegetados de forma natural. No existen acopios de tierra vegetal. Actualmente se encuentra clausurada. Sin restaurar.

- Elementos singulares:

o Fuente La Alameda, con depósito de ladrillo de tejar antiguo.

o Fuente el Arco, con depósito de ladrillo de tejar antiguo.

\section{DEGRADACIONES DEL PAISAJE}

- Caminos excesivamente rectilíneos, sin naturalidad, impacto severo.

- $\quad$ Arroyos encauzados y rectificados, sin naturalidad, impacto severo.

- Impacto severo por la desecación de la fuente la Alameda, que ha provocado a su vez que también lo hayan hecho los dos grandes chopos castellanos que la acompañaban.

- Impacto severo debido a la existencia de la escombrera (Figuras A3.86 y A3.87), que genera un fuerte impacto visual y riesgo de contaminación por depósito de residuos peligrosos, más si cabe teniendo en cuenta la cercanía del arroyo Berruez. 


\section{RECUPERACIONES DEL PAISAJE}

- $\quad$ RES 1: Restauración del arroyo Berruez: (Ver anejo 2).

- RES 2: Estaquillado primera reguera izquierda $25 \mathrm{~m}$ longitud, el año pasado, cada $5 \mathrm{~m}$ aproximadamente. $80 \%$ de marras, altura $20 \mathrm{~cm}$, crecimiento $5 \mathrm{~cm} /$ año.

- RES 3: Estaquillado primera reguera derecha $50 \mathrm{~m}$ longitud, hace tres años, cada $5 \mathrm{~m}$ aproximadamente. $40 \%$ de marras, altura $80 \mathrm{~cm}$, crecimiento $10 \mathrm{~cm} /$ año.

- $\quad$ AHA 1: En teso Muerto (Figura A3.85). Superficie aproximada de $4000 \mathrm{~m}^{2}$. Previamente labrado superficialmente. Distancia entre plantas de $4 \mathrm{~m}$. Marco irregular. Mezcla de especies (pino piñonero, encina, quejigo, almendro, etc.). Porcentaje de marras del $25 \%$.

- RES 4: Estaquillado segunda reguera derecha $100 \mathrm{~m}$ longitud, el año pasado, cada $5 \mathrm{~m}$ aproximadamente. $10 \%$ de marras, altura $30 \mathrm{~cm}$, crecimiento $10 \mathrm{~cm} /$ año.

- RES 5: Estaquillado segunda reguera izquierda $50 \mathrm{~m}$ longitud, el año pasado, cada $5 \mathrm{~m}$ aproximadamente. $100 \%$ de marras.

- RES 6: Estaquillado tercera reguera izquierda $125 \mathrm{~m}$ longitud, el año pasado, cada $5 \mathrm{~m}$ aproximadamente. $100 \%$ de marras.

- $\quad$ Fuente El Arco: Plantación de Ulmus pumila en las zonas secas y chopo híbrido en las húmedas, con edad aproximada de 30 años. Los olmos tienen una altura de 5-6 m, mientras que los chopos, de 8-12 m. No se han realizado tratamientos. Posteriores plantaciones de Spartium junceum en el lindero, un ciprés y chopos del país en la reguera. Revegetación natural de rosales silvestres. Colocación de un banco de madera. Vegetación herbácea sin segar, en los últimos años no se usa por las ovejas. La fuente mana en invierno y primavera. Edificio-depósito de ladrillo de tejar. Bebedero de hormigón, sin uso.

\section{RECUPERACIONES POTENCIALES}

- Restauración vegetal de taludes de caminos.

- Restauración vegetal de regueras.

- Plantaciones de diversificación en el interior de las parcelas agrícolas.

- Fuente la Alameda: Recuperación del manantial. Plantación de álamos al menos en cuneta (la fuente no tiene parcela asociada).

- $\quad$ Fuente el Arco: Adecuación de la fuente y su entorno. Poda del arbolado. Plantación de la parcela adyacente dejada en la concentración parcelaria.

- Escombrera: Recuperación integral. Importante movimiento de tierras, explanación y taluzado, disminuyendo la pendiente de la escombrera. Extensión de tierra vegetal, sobre todo en los taludes. Posible hidrosiembra de taludes si no se revegeta naturalmente. Plantación de árboles y arbustos en toda la superficie, con especies para zonas secas. 


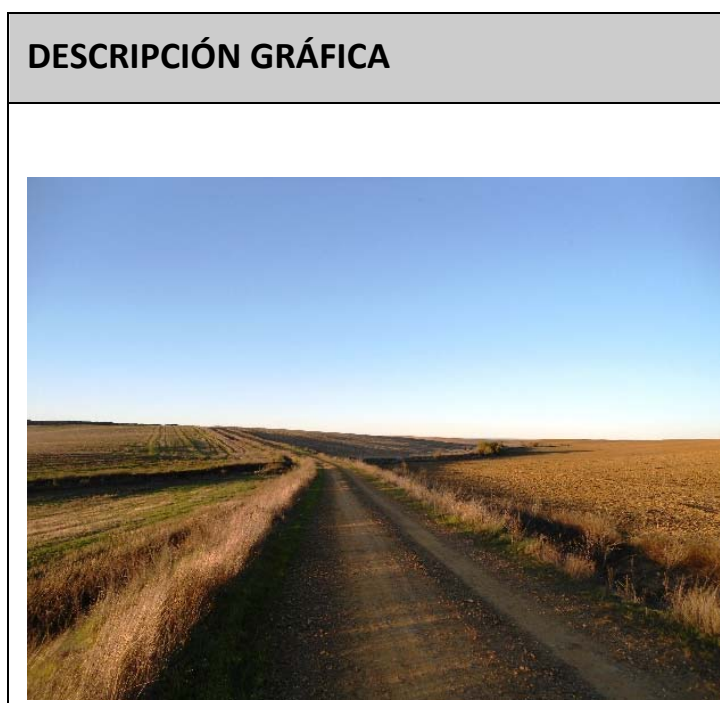

Figura A3.82. Vista del camino y el paisaje adyacente

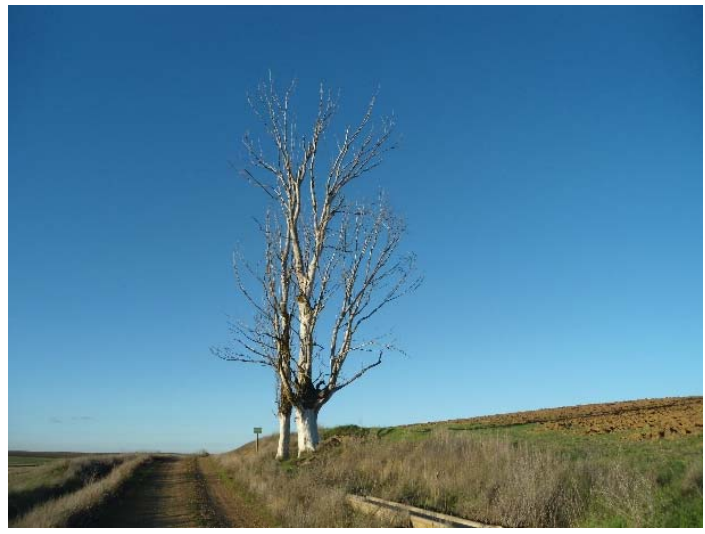

Figura A3.84. Fuente la Alameda, con chopos secos

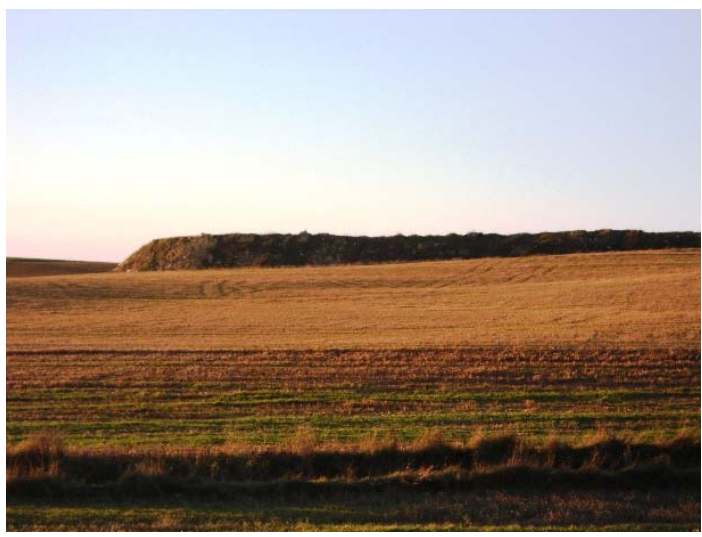

Figura A3.86. Escombrera municipal

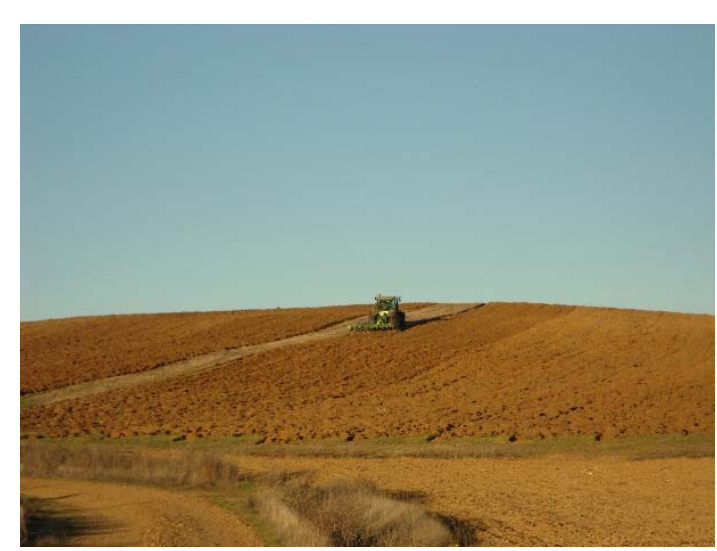

Figura A3.83. Tractor gradeando el rastrojo

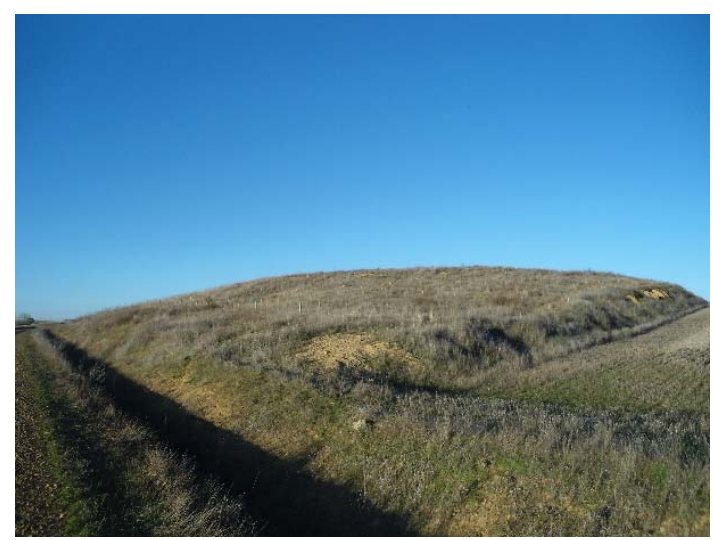

Figura A3.85. Plantación del árbol/ha en el teso muerto

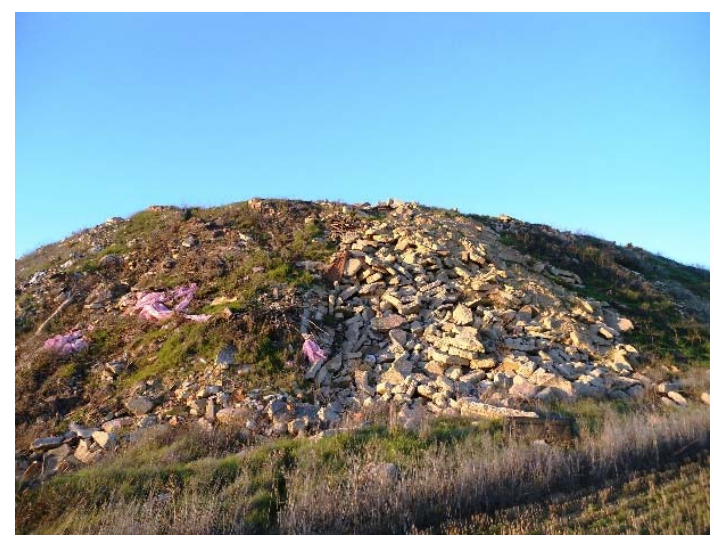

Figura A3.87. Detalle terraplén escombrera 
RECORRIDO: Huerta el Moral y San Andrés

- Fecha: 16 de noviembre de 2013, 11:50 h.

- Medio: Caminando.

- Itinerario: Restos muralla - C) Sahagún (Figura A3.88) - camino de la huerta del Moral - C) San Andrés - C) Marceliano Serrano (Figura A3.93).

- Longitud: $1 \mathrm{~km}$

- Condiciones meteorológicas: Nublado, hace mucho viento.

- Características de la vía: La mitad del recorrido es de hormigón, tal como están las calles urbanas, en algún tramo en estado deficiente. El camino de la huerta del Moral, antes de zahorra, se asfaltó porque se usa bastante como camino de circunvalación. Se cruza dos veces mediante un puente el arroyo Pajarillas, con vallas metálicas sin pintar en mal estado.

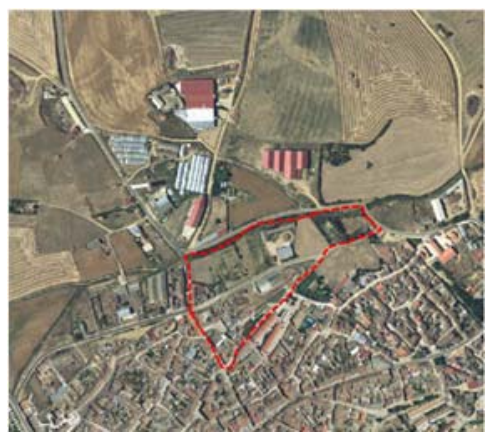

\section{CARACTERÍSTICAS DEL PAISAJE}

- Entorno inmediato de la vía: El camino de circunvalación tiene alguna cuneta y pequeños márgenes, parcialmente revegetados, en tierra o zahorra. Estas zonas se suelen tratar con herbicida.

- Espacio agrícola: Barbechos o siembra recién nacida de cereal.

- Agua: Ausencia.

- $\quad$ Ruido: Puntual por algún coche o tractor, aunque hay muy poco tráfico.

- Olores desagradables: Considerables, sobre todo en las cercanías de las explotaciones ganaderas.

- Vegetación: La restauración del arroyo Pajarillas con una chopera marca el recorrido, que lo hace muy agradable. Hay algún pequeño parque y varias zonas con árboles frutales y setos diversos. Los chopos aún mantienen las hojas amarillentas.

- $\quad$ Fauna: No se percibe la existencia de pajaritos, seguramente por el viento.

- Actuaciones humanas:

o Zona urbana de viviendas, con tipología de manzana compacta; planta baja, planta baja más una (mayoritaria) y planta baja más dos (puntual). Dominan los enfoscados ocres (antes de barro) sobre las fachadas revestidas con ladrillos rojizos, aunque hay algunas revocadas en cemento gris sin pintar. Zócalos en color diferente. Presencia de balcones de forja. Existencia de grandes puertas traseras -la mayoría de chapa metálica-, con diversos acabados (en su color, marrón, verde, rojo, pintado solo el bastidor, etc.). La carpintería suele ser metálica en tonos oscuros. Cubiertas en teja vieja árabe; las nuevas se van cambiando a teja mixta o teja plana, en colores rojizos u oscuros. Aceras de baldosas grises.

- Abundante cableado de teléfono, electricidad, etc.

o Huerta con vallado, casa de barro y teja árabe.

o Nave almacén ocre y cubierta metálica roja.

- Huerta con caseta ocre y teja árabe.

o Granja de porcino, con nave de cemento y cubierta de fibrocemento. Valla metálica (Figura A3.89).

- Granja de ovino con tres naves metálicas, paramentos blancos y cubierta roja, silos, estercolero e instalaciones auxiliares (Figura A3.90).

o $\quad$ Caseta de bloques blancos de hormigón y teja plana, con parcela vallada.

o Parcela grande vallada con casa-huerta ocre y teja árabe, en parte ajardinada.

o Pequeña parcela-huerto vallado.

o Granja de ovino, con nave de cemento y cubierta de fibrocemento. Valla metálica.

- $\quad$ Elementos singulares:

o Restos de piedra de sillería de la antigua puerta de Sahagún, que cerraba el pueblo.

o Alguna vivienda de barro, con riesgo de ruina. 


\section{DEGRADACIONES DEL PAISAJE}

- $\quad$ Pérdida general de patrimonio y de la tipología arquitectónica tradicional, con impacto crítico.

- Viviendas u otros edificios con fachada en cemento gris o acabados sencillos similares, por cambio de las características visuales básicas, con impacto moderado.

- Puertas traseras metálicas sin pintar o pintadas en colores estridentes, por cambio de las características visuales básicas, con impacto moderado.

- $\quad$ Presencia de grandes respaldos (medianeras) sin tratar adecuadamente, sobre todo cuando son colindantes edificios de notable diferencia en altura, generando un impacto moderado.

- Impacto severo provocado por la abundancia y desorden del cableado de las zonas urbanas, postes de teléfonos, etc.

- Presencia de explotaciones ganaderas en suelo urbano/periurbano que generan molestias y olores desagradables y, por consiguiente, un impacto severo.

- Impacto moderado debido a la presencia masiva de vallas metálicas para delimitar las parcelas (Figura A3.91).

- Presencia de residuos en los márgenes del camino de circunvalación y en el arroyo Pajarillas, con impacto moderado.

- Impacto moderado debido al tratamiento con herbicida de la vegetación de los márgenes de los caminos.

\section{RECUPERACIONES DEL PAISAJE}

o VER 1: Pequeño parterre de $70 \mathrm{~m}^{2}$ al lado de la puerta de Sahagún, con árboles y arbustos de diferentes especies. Generalmente cuidado.

o RES 1: Chopera del arroyo Pajarillas (ver ruta de los Parques).

o PAR 1: Plantación de chopos, pinos piñoneros y acacias en la granja de porcino. Tienen una edad aproximada de 15 años, están cuidados y actualmente su altura media es de $5 \mathrm{~m}$. Muy buena función de integración paisajística de la explotación ganadera.

- RES 2: Resalveo de las matas de olmos que rodean la parcela de la huerta del Moral.

- RES 3: Picón del arroyo Pajarillas (ver ruta de los Parques).

PAR 2: Seto de aligustre en valla de casa blanca.

PAR 3: Seto de vid en valla de huerto, que también tiene varios frutales.

PAR 4: Diversas plantaciones en casa-huerta: seto de arizónica (alto), frutales, olivos y diversos árboles más.

PAR 5: Seto de thuyas en vallado metálico de granja de ovino, que cubren bastante la explotación.

- VER 2: Parque de nuevas viviendas (Figura A3.92), pavimentado con baldosa, alcorques para boleanas y plátanos, bancos. Es una agradable zona estancial, tal vez excesivamente pavimentada.

o VER 3: Picón de $250 \mathrm{~m}^{2}$ hasta hace poco degradado. Se han retirado basuras, se siega periódicamente la hierba y se han plantado varios árboles, con un $60 \%$ de marras.

\section{RECUPERACIONES POTENCIALES}

- $\quad$ Pintar las fachadas (viviendas, naves o muros) de cemento gris en colores ocres o tierras.

- Pintar las puertas traseras de acuerdo a un abanico de colores armónicos para el conjunto del pueblo; se proponen los siguientes: marrón, verde oscuro y rojo oscuro.

- Sacar progresivamente las explotaciones ganaderas del casco urbano y delimitar una distancia mínima al mismo para futuras explotaciones.

- Adaptación de las nuevas construcciones o de las reformas exteriores a la tipología arquitectónica tradicional: fachadas en ladrillo tipo antiguo o mortero bastardo, canecillos de madera, cubiertas de teja árabe o mixta curva similar, carpintería exterior de madera u oscura, etc.

- Pavimentación de las calles con hormigón, diferenciando los paños con adoquines rojos. Aceras también diferenciadas, también se propone la utilización de baldosas rojas, como en otras zonas del pueblo.

- $\quad$ Ordenar e integrar en lo posible el cableado variado existente.

- Tratar los respaldos como fachadas, de forma que se minimice su impacto visual.

- Limpieza periódica de residuos en los márgenes de caminos y en el arroyo Pajarillas.

- Sustituir el tratamiento de hierbas de los márgenes de caminos por el desbroce en vez del herbicida (salvo donde sea necesario).

- Plantación de árboles o arbustos, allí donde sea posible, en los márgenes del camino de circunvalación, para minimizar el impacto de las naves agropecuarias.

- Plantación -donde no se haya hecho ya- de arbustos en las vallas metálicas que delimitan parcelas en suelo periurbano/rústico. 


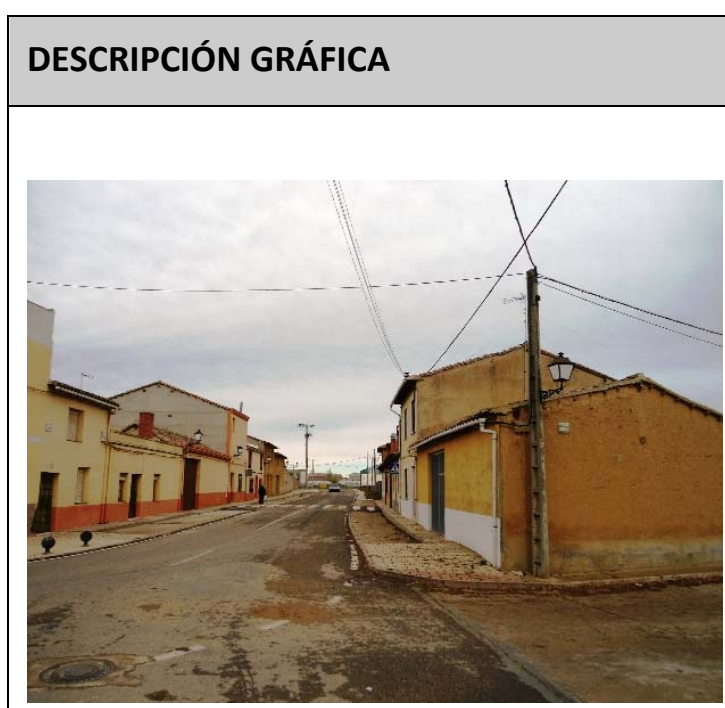

Figura A3.88. Calle Sahagún

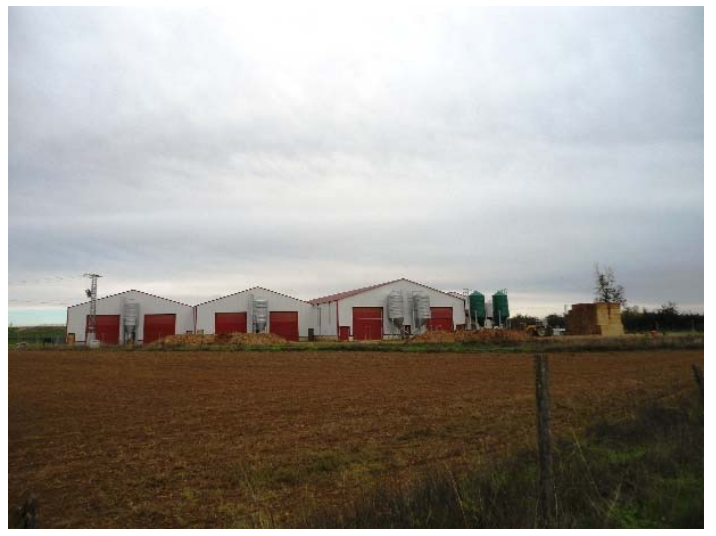

Figura A3.90. Granja de ovino

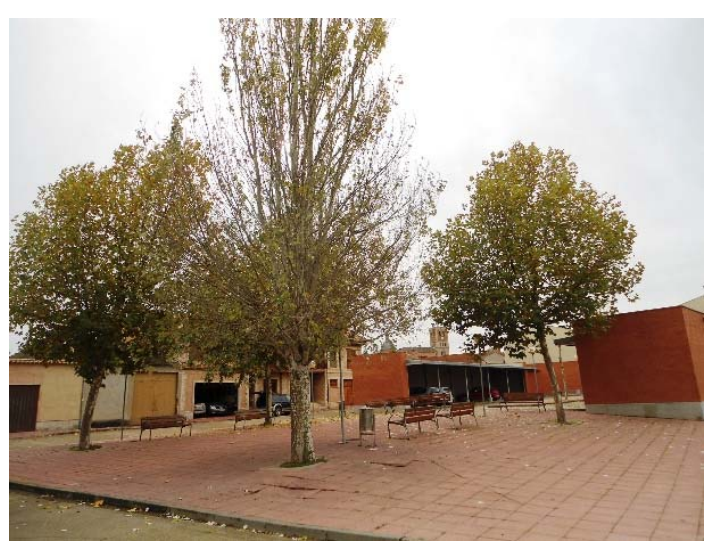

Figura A3.92. Parque en casas nuevas

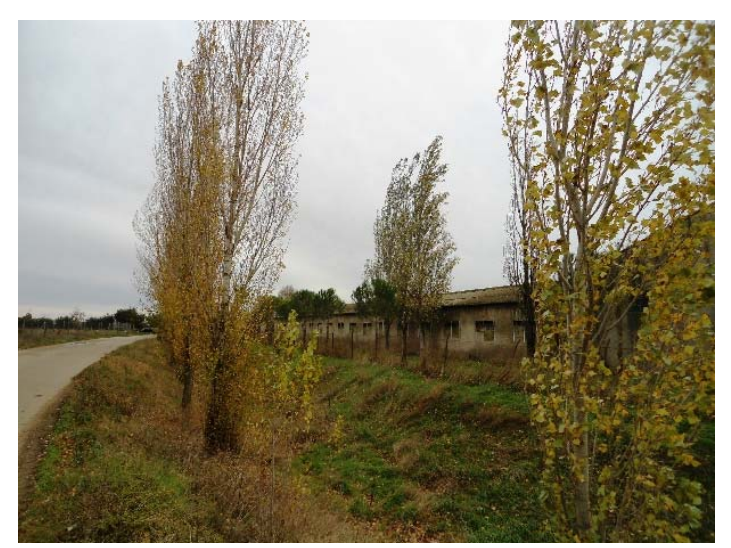

Figura A3.89. Arroyo Pajarillas y granja de porcino

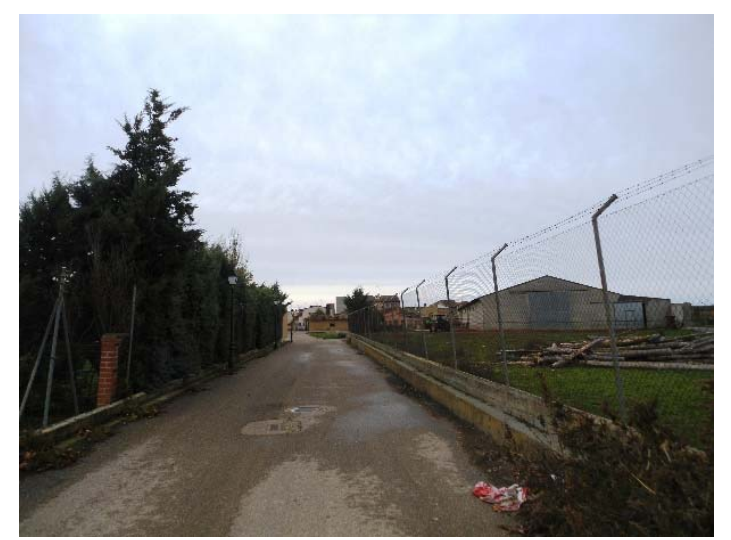

Figura A3.91. Camino entre vallas

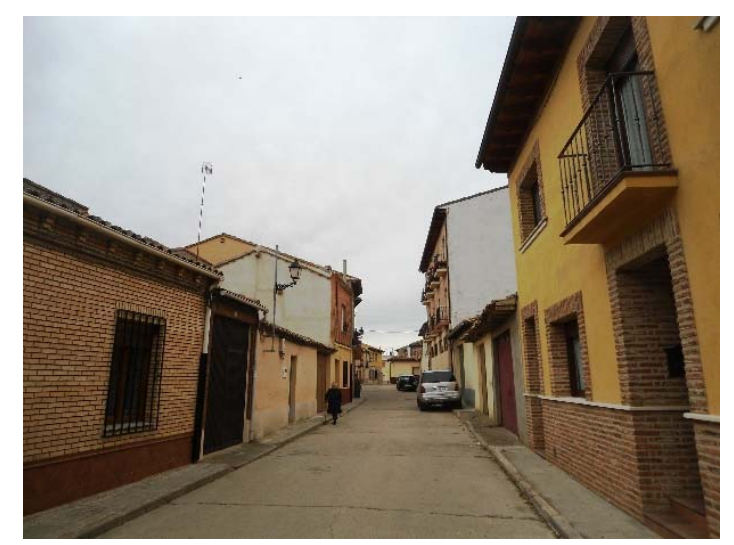

Figura A3.93. Calle Marceliano Serrano 


\section{RECORRIDO: Villarrobejo, camino de circunvalación y San Juan}

- Fecha: 19 de noviembre de 2013, $17 \mathrm{~h}$.

- Medio: Caminando.

- Itinerario: C) Villanovefo - C) Villarrobejo (Figura A3.96) - camino circunvalación (Figura A3.98) - cruce ctra. Boadilla - camino circunvalación - C) El Trinquete - C) San Francisco - plaza de San Juan - C) Hospital - C) Gabriel Castañeda - C) Villarrobejo.

- $\quad$ Longitud: $1,2 \mathrm{~km}$

- $\quad$ Condiciones meteorológicas: Despejado. No ha llovido últimamente.

- Características de la vía: La mayoría es de hormigón (zona urbana), muchos de sus paños en mal estado. El camino de circunvalación está asfaltado. Aceras con baldosas grises, solo rojas en algún punto.

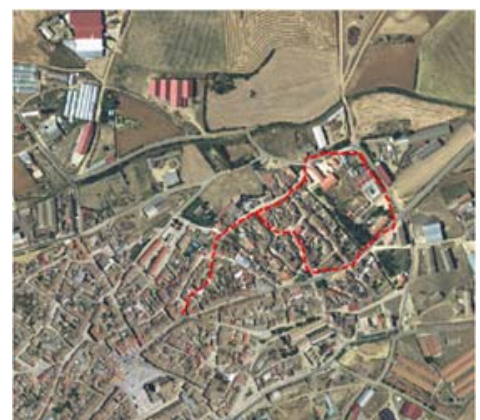

\section{CARACTERÍSTICAS DEL PAISAJE}

- Entorno inmediato de la vía: El camino de circunvalación tiene alguna cuneta y pequeños márgenes, parcialmente revegetados, en tierra o zahorra. Estas zonas se suelen tratar con herbicida.

- Espacio agrícola: No procede.

- Agua: Ausencia.

- Ruido: Puntual por algún coche o tractor, aunque hay muy poco tráfico.

- $\quad$ Olores desagradables: Considerables, sobre todo en las cercanías de las explotaciones ganaderas o del matadero.

- Vegetación: El recorrido discurre por varios parques periurbanos. Las frondosas han perdido casi toda la hoja, tan solo alguna acacia la mantiene; destaca el verde perenne de las coníferas.

- Fauna: Se perciben algunos pajaritos.

- Actuaciones humanas:

o Zona urbana de viviendas, con tipología de manzana compacta; planta baja, planta baja más una (mayoritaria) y planta baja más dos (puntual). Dominan los enfoscados ocres (antes de barro) sobre las fachadas revestidas con ladrillos rojizos, aunque hay bastantes revocadas en cemento gris sin pintar, bloques u otros acabados similares. Zócalos en color diferente. Presencia de balcones de forja. Abundante presencia de grandes puertas traseras -la mayoría de chapa metálica-, con diversos acabados (en su color, marrón, verde, azul, rojo, pintado solo el bastidor, etc.). La carpintería suele ser metálica en tonos oscuros. Cubiertas en teja vieja árabe; las nuevas se van cambiando a teja mixta o teja plana, en colores rojizos u oscuros. Presencia de solares, en algunos casos solo delimitados con una malla metálica. Abundante cableado por el exterior de las fachadas. En la plaza de San Juan hay soportales.

o Zona periurbana con uso predominante agropecuario. Dominan las construcciones tipo nave alineadas a fachada, aunque se encuentren a efectos urbanísticos en suelo urbano. Las fachadas suelen ser de cemento gris sin pintar. Tienen grandes puertas traseras, de diversos acabados. La cubierta es de fibrocemento o de chapa metálica roja. Su uso es de almacén agrícola, pero también hay explotaciones ganaderas (ovino).

o Parcela - almacén de materiales de construcción, delimitada por valla metálica.

o Explotación de ganado ovino. Naves de cemento y cubierta de fibrocemento. Vallado con malla metálica y muro de ladrillo hueco doble sin revestir.

o Explotación de ganado vacuno, con naves blancas con cubierta de fibrocemento y otras pequeñas metálicas, en su color y rojas (pared y cubiertas).

o Nave con fachada ocre y cubierta de fibrocemento.

o Nave de antigua explotación de ovino, con paredes blancas y cubierta de fibrocemento.

o Matadero municipal en tonos ocres y cubierta en teja árabe, delimitada por una verja metálica.

- Elementos singulares:

o Escuelas de San Juan, de ladrillo macizo a hueso y cubierta de teja plana, rehabilitado como centro de acción social.

o Iglesia de San Juan Bautista (Figura A3.102), de estilo gótico-mudéjar del siglo XV y espadaña posterior. Exterior con paños de ladrillo de tejar y tapial, espadaña de ladrillo y cubierta de teja árabe. Mal estado de conservación y en desuso.

o Antiguo hospital de la Vera Cruz (Figura A3.103), de influencias mudéjares, de ladrillo antiguo con molduras y teja árabe. Soportal con pies derechos de madera. Muy mal estado de conservación y deshabitada la vivienda.

o Soportales de la plaza de San Juan, con desigual estado de conservación.

o Alguna vivienda de barro, con riesgo de ruina (Figura A3.105) 


\section{DEGRADACIONES DEL PAISAJE}

- $\quad$ Pérdida general de patrimonio y de la tipología arquitectónica tradicional, con impacto crítico.

- Ruina de casas antiguas, con impacto severo.

- Viviendas u otros edificios con fachada en cemento gris, bloques grises o acabados similares, por cambio de las características visuales básicas, con impacto moderado.

- Puertas traseras metálicas sin pintar o pintadas en colores estridentes, por cambio de las características visuales básicas, con impacto moderado (Figuras A3.101 y A3.104).

- $\quad$ Presencia de naves en el espacio urbano (Figura A3.100), que son elementos extraños al paisaje urbano, generando un impacto severo.

- $\quad$ Presencia de explotaciones ganaderas en suelo urbano (Figura A3.97) que generan molestias y olores desagradables y, por consiguiente, un impacto severo.

- $\quad$ Existencia de naves o muros en ladrillo sin revestir, con impacto moderado.

- Impacto moderado provocado por la existencia de solares urbanos sin delimitar o delimitados con una simple malla metálica (Figura A3.95).

- $\quad$ Presencia de residuos en los márgenes del camino de circunvalación, con impacto moderado.

- Impacto moderado por la visión de los materiales de construcción en la parcela dedicada a este fin.

\section{RECUPERACIONES DEL PAISAJE}

- PAR 1: Plantación de árboles y arbustos variados (sobre todo chopos) en el entorno de una explotación de ovino.

- PAR 2: Plantación de un seto de leylandi y árboles diversos en el entorno de una explotación de vacuno.

- VER 1: Picón de las acacias (ver ruta de los parques).

- VER 2: Parque de las escuelas de San Juan (Figura A3.99). Se pavimentó todo con embaldosado, dejando alcorques que fueron plantados con plátanos. Sale hierba por las hiendas de las baldosas.

- VER 3: Parque de la laguna del Tinte (ver ruta de los parques)

- VER 4: Corro de San Francisco (ver ruta de los parques).

- VER 5: Parque de San Juan (ver ruta de los parques).

\section{RECUPERACIONES POTENCIALES}

- Pintar las fachadas (viviendas, naves o muros) de cemento gris o similar en colores ocres o tierras (Figura A3.94).

- Revestir las fachadas en ladrillo hueco con mortero bastardo (cemento blanco, arena roja y posible pigmento ocre).

- Pintar las puertas traseras de acuerdo a un abanico de colores armónicos para el conjunto del pueblo; se proponen los siguientes: marrón, verde oscuro y rojo oscuro.

- Sacar progresivamente las explotaciones ganaderas del casco urbano y delimitar una distancia mínima al mismo para futuras explotaciones.

- Delimitar los solares urbanos con muros de $3 \mathrm{~m}$ de altura, con acabados ocre o tierra y rematados con tejadillo.

- Adaptación de las nuevas construcciones o de las reformas exteriores a la tipología arquitectónica tradicional: fachadas en ladrillo tipo antiguo o mortero bastardo, canecillos de madera, cubiertas de teja árabe o mixta curva similar, carpintería exterior de madera u oscura, etc.

- Pavimentación de las calles con hormigón, diferenciando los paños con adoquines rojos. Aceras también diferenciadas, también se propone la utilización de baldosas rojas, como en otras zonas del pueblo.

- Limpieza periódica de residuos en los márgenes de caminos. 
- $\quad$ Sustituir el tratamiento de hierbas de los márgenes por el desbroce en vez del herbicida (salvo donde sea necesario).

- Plantación de árboles o arbustos, allí donde sea posible, en los márgenes del camino de circunvalación, para minimizar el impacto de las naves agropecuarias.

- Plantación de arbustos de crecimiento rápido (leylandi) o colocación de una malla verde u ocre opaca, para la ocultación de la parcela de materiales de construcción.

- $\quad$ Parque de las escuelas de San Juan: Tratamiento periódico con herbicida de las hierbas de las hiendas. Adecuación de la fuente-abrevadero. Plantación en los alcorques con marras de árboles adaptados a la humedad (chopo negro, por ejemplo).

- Plantación de árboles, arbustos y matas aromáticas en el entorno del matadero municipal, para minimizar en lo posible el impacto provocado por los olores desagradables del mismo.

- Rehabilitación de la iglesia de San Juan, dotándola de un uso (por ejemplo, museo de arte sacro). Al menos, afianzamiento de su estructura y su configuración exterior, de forma que se asegure su mantenimiento.

- Rehabilitación del antiguo hospital de la Vera Cruz, confiriéndolo también un uso. Al menos, afianzamiento de su estructura y su configuración exterior, de forma que se asegure su mantenimiento. 


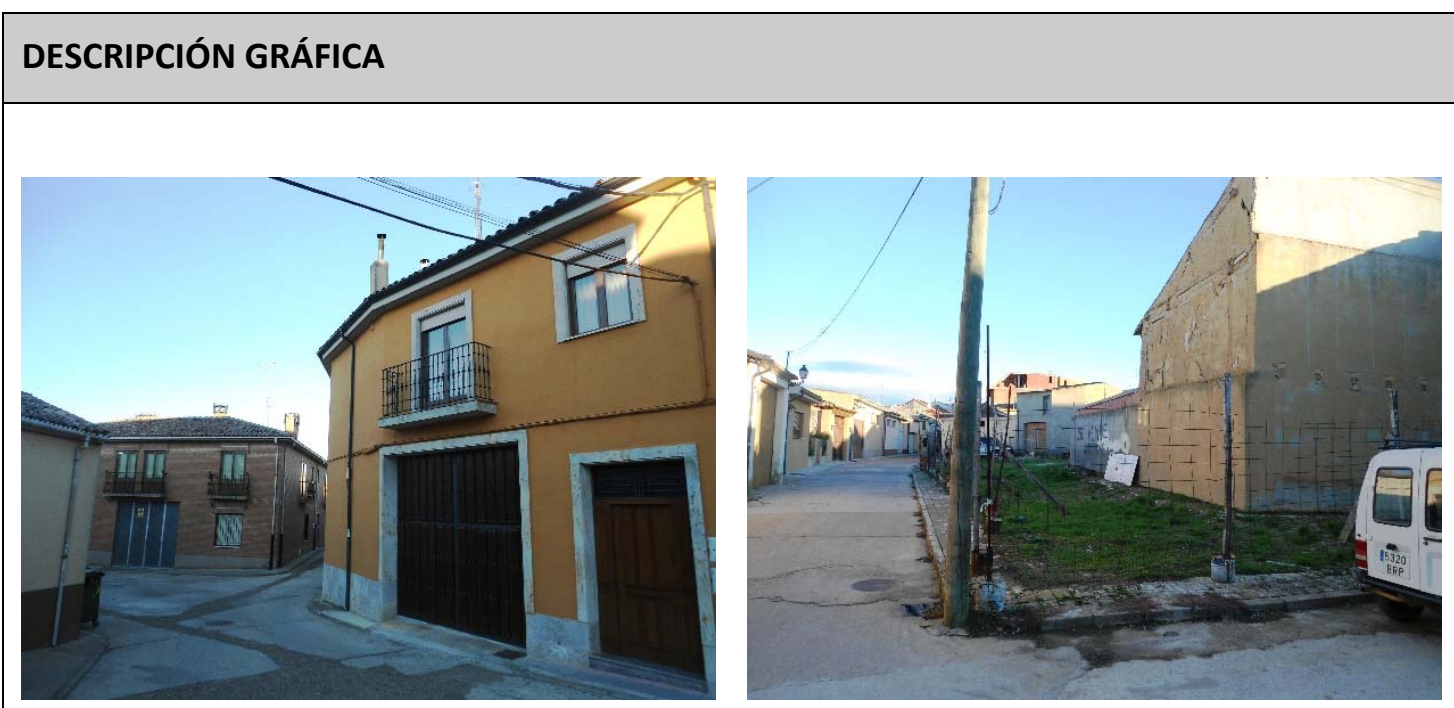

Figura A3.94. Buen ejemplo de integración en el paisaje urbano Figura A3.95. Solar urbano con vallado metálico

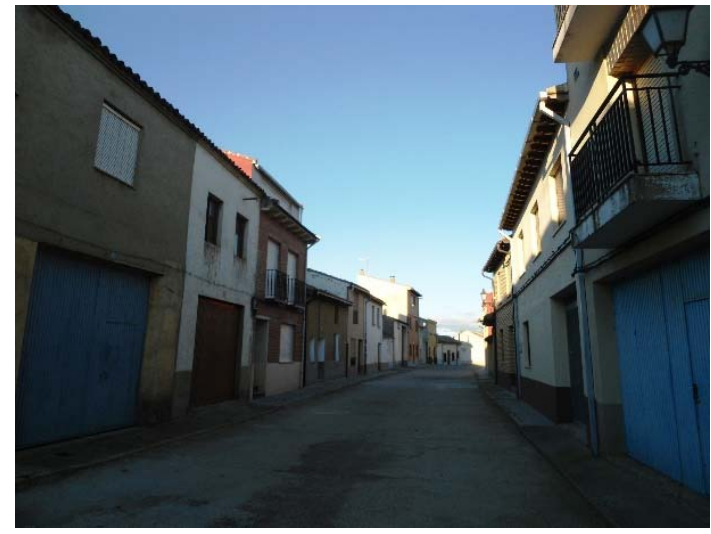

Figura A3.96. Imagen urbana de la calle Villarrobejo

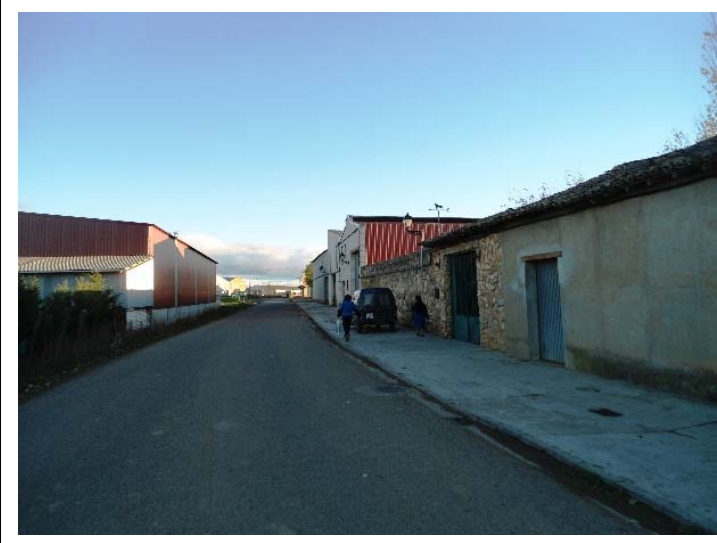

Figura A3.98. Camino de circunvalación, con varias explotaciones ganaderas

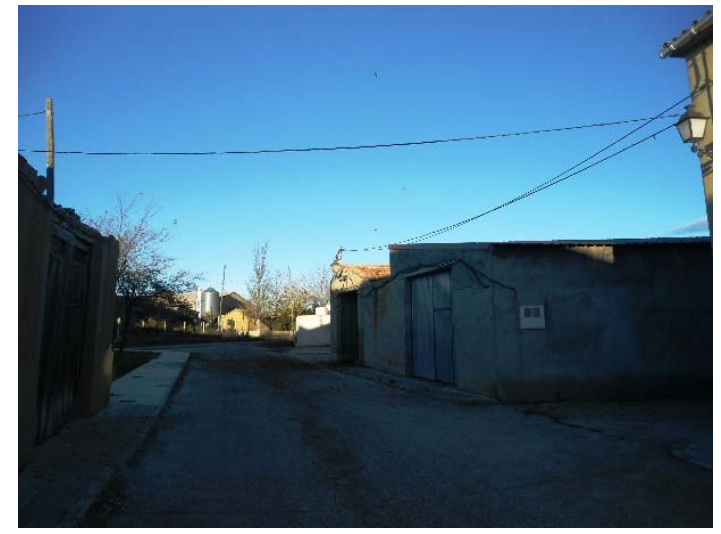

Figura A3.97. Apriscos de ovejas en el casco urbano

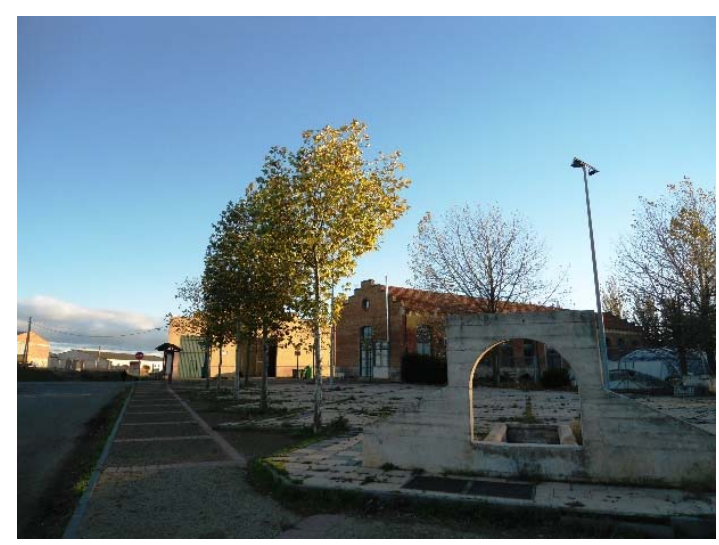

Figura A3.99. Parque de las escuelas de San Juan 


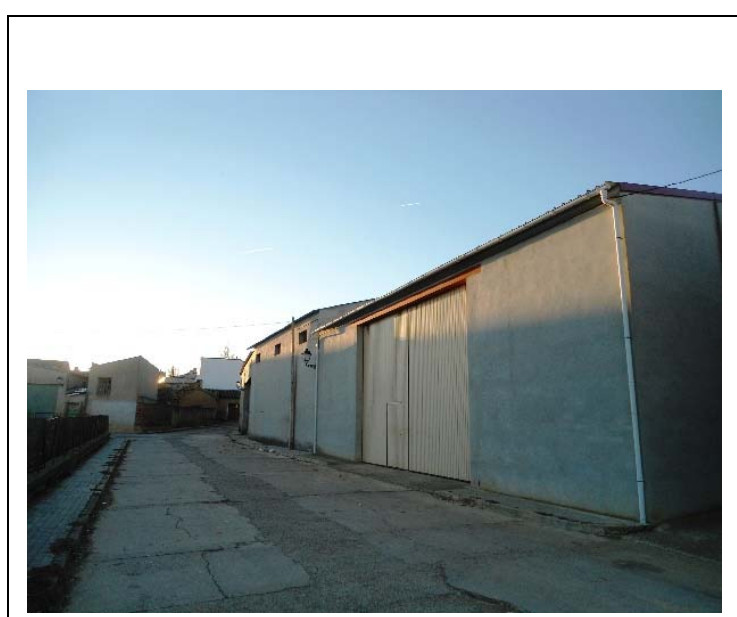

Figura A3.100. Naves agrícolas en el casco urbano

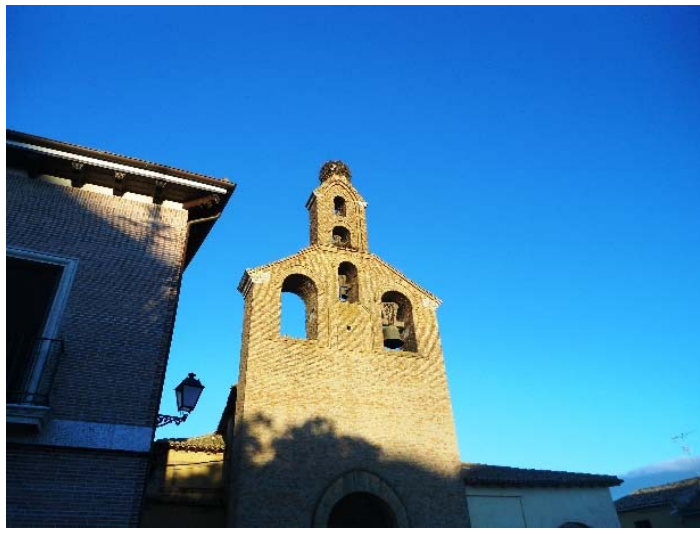

Figura A3.102. Espadaña de la iglesia de San Juan

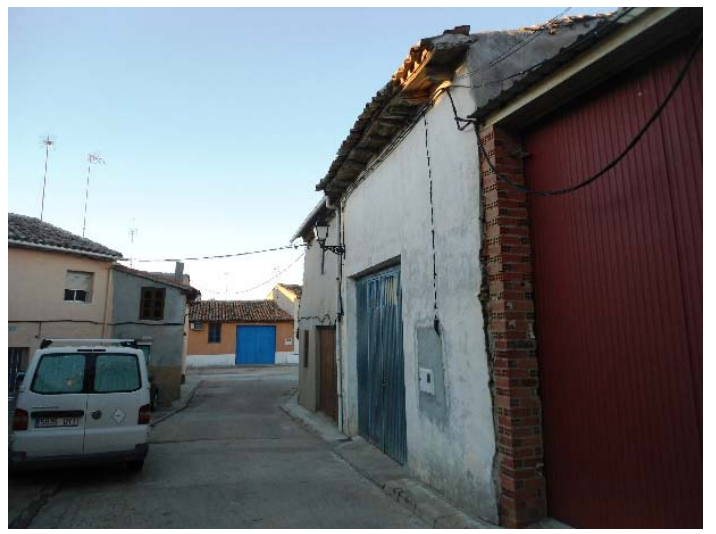

Figura A3.104. Las puertas traseras son un factor de degradación del paisaje urbano

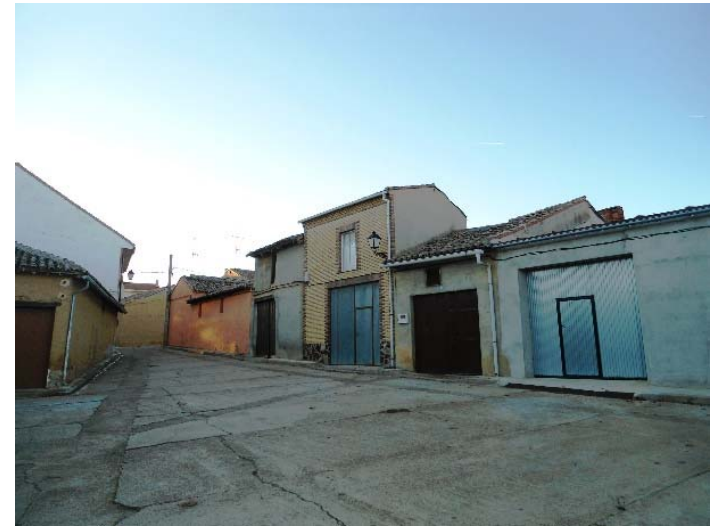

Figura A3.101. Puertas traseras diversas

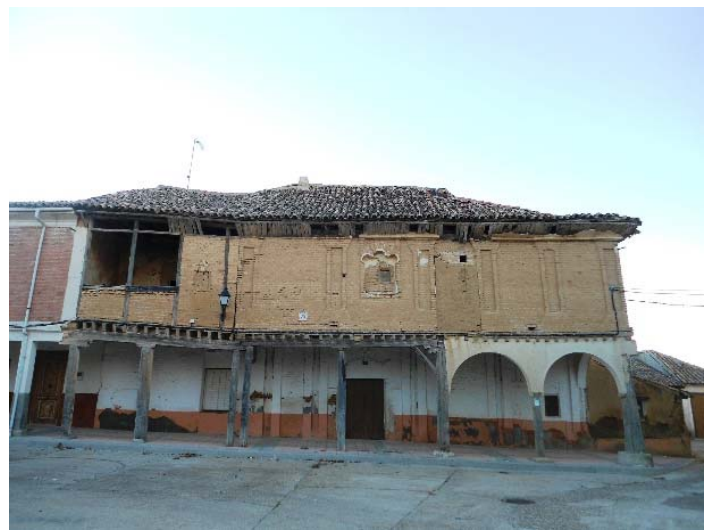

Figura A3.103. Antiguo hospital de la Vera Cruz

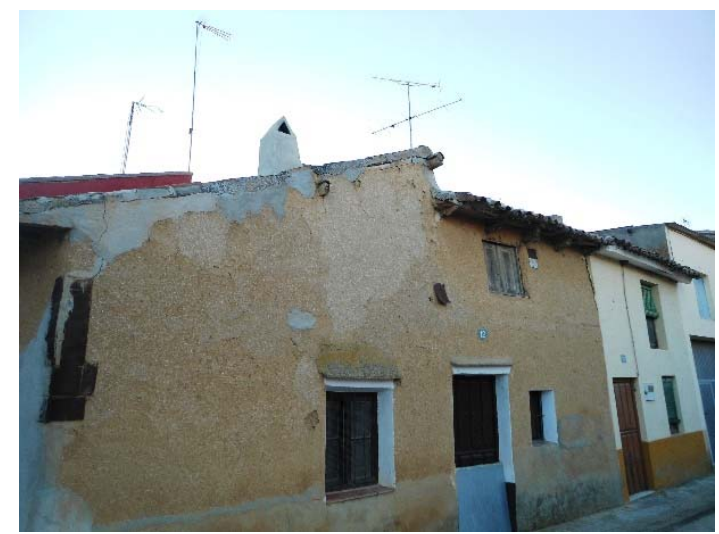

Figura A3.105. Un elemento singular en extinción: las casas de barro 


\section{RECORRIDO: Ruta de los parques (actuaciones/degradaciones)}

- Fecha: 21 de noviembre de 2013, $17 \mathrm{~h}$.

- Medio: Caminando.

- Itinerario: Se trata de una ruta circular que puede iniciarse por cualquier punto e incluso recorrerse en ambos sentidos. Se incluye la plaza Mayor, ya que desde aquí se puede acceder a varios puntos de la ruta. En este caso, consideraremos el siguiente inicio: plaza Mayor - C) Marceliano Serrano - restos de la antigua muralla $-\mathrm{C}$ ) Sahagún - arroyo Pajarillas - huerta del Moral - picón de las acacias - parque de la reguera del Tinte - parque de la laguna del Tinte $-C$ ) Constitución - plaza de San Juan - casas de la Pedrera - plaza de San Miguel - casas del convento - era del depósito - C) Gaspar Grajal - cruce con ctra. nacional - avda. del Parque - cruce con ctra.

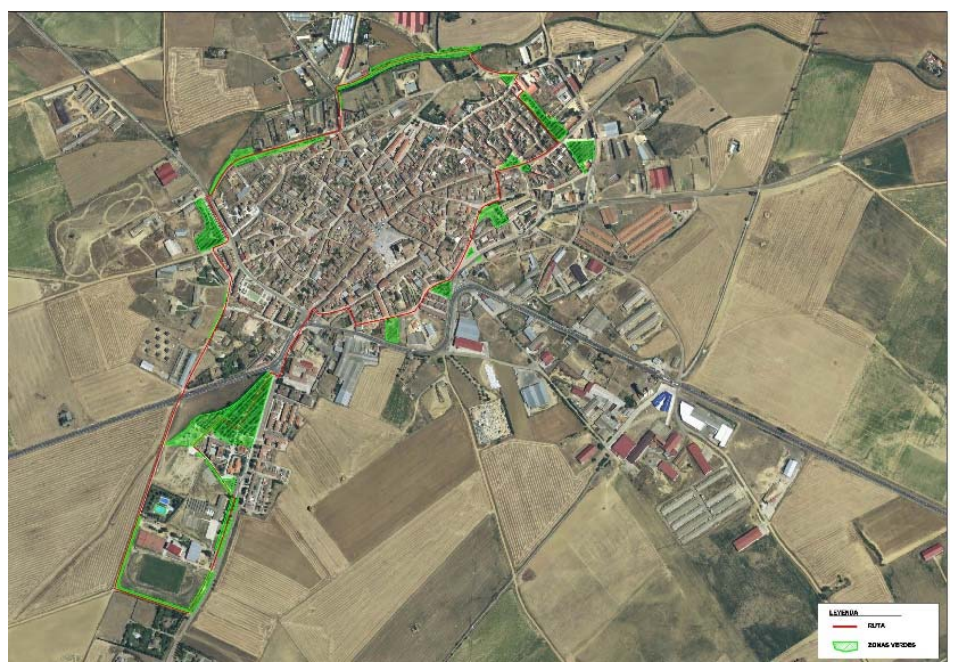
de Valladolid - parque del Paseo - parque temático - instituto - polideportivo - camino alrededor campo de fútbol - camino de la piscina cruce con ctra. nacional - parque de San Pedro - paseo de Barrios - restos de la antigua muralla.

- Longitud: $4,5 \mathrm{~km}$

- Condiciones meteorológicas: Cielo despejado. No ha llovido últimamente. Hay un atardecer muy bonito (Figura A3.111).

- Características de la vía: El recorrido por las zonas más urbanas discurre por calles de hormigón, en regular estado de conservación, pero adecuadas para el tránsito de viandantes. Hay un porcentaje también alto de trayecto por caminos asfaltados, en general en buen estado. Hay algún tramo (avda. del parque y parque del Paseo), donde la vía está bien adoquinada. Puntualmente, existe un pequeño tramo con una senda en tierra, entre la entrada al polideportivo y el camino del campo de fútbol.

\section{CARACTERÍSTICAS DEL PAISAJE}

- $\quad$ Entorno inmediato de la vía: Los caminos asfaltados tienen, en general, cunetas que están revegetadas; no hay taludes altos salvo algún punto muy concreto. En algún tramo hay márgenes en hierba o en zahorra, que se suelen tratar con herbicida. Ahora la mayoría están verdes.

- Espacio agrícola: Siguen dominando los terrenos en barbecho. Los sembrados de cereal, poco nacidos, también están bastante en tierra, por lo que domina claramente el color marrón.

- Agua: Ausencia. Destaca la presencia de la cascada del parque del Paseo.

- Ruido: Puntual debido al tráfico de la carretera nacional.

- Olores desagradables: Puntuales en las cercanías de las granjas ganaderas.

- Vegetación: La mayoría de las hojas de las frondosas han caído (Figura A3.110). Estas abundan en el suelo de los jardines, lo que provoca un estético contraste de su color amarillo con el verde de las praderas. Se nota la importancia de las coníferas por su carácter perennifolio.

- Fauna: Se perciben pajaritos, sobre todo en las zonas verdes.

- Actuaciones humanas:

- Espacios urbanos de viviendas, con tipología de manzana compacta; planta baja, planta baja más una (mayoritaria) y planta baja más dos (puntual). Dominan los enfoscados ocres (antes de barro) sobre las fachadas revestidas con ladrillos rojizos, aunque hay bastantes revocadas en cemento gris sin pintar, bloques u otros acabados similares. Zócalos en color diferente. Presencia de balcones de forja. Abundante presencia de grandes puertas traseras -la mayoría de chapa metálica-, con diversos acabados (en su color, marrón, verde, azul, rojo, pintado solo el bastidor, etc.). La carpintería suele ser metálica en tonos oscuros. Cubiertas en teja vieja árabe; las nuevas se van cambiando a teja mixta o teja plana, en colores rojizos u oscuros. Presencia de solares, en algunos casos solo delimitados con una malla metálica. 
Abundante cableado por el exterior de las fachadas. En la plaza de San Juan hay soportales, lo que también se observa en el cruce con la calle la Rúa.

- Espacios urbanos de ensanche. Se han construido varias urbanizaciones fuera del casco histórico, en tipología de manzana cerrada con planta baja más una. Alguna tiene patios exteriores. La mayoría tienen acabados en ladrillo rojizo y cubierta de hormigón curva.

- Zona periurbana con uso predominante agropecuario. Dominan las construcciones tipo nave alineada a fachada, aunque se encuentren a efectos urbanísticos en suelo urbano. Las fachadas suelen ser de cemento gris sin pintar. Tienen grandes puertas traseras, de diversos acabados. La cubierta es de fibrocemento o de chapa metálica roja. Su uso es de almacén agrícola, pero también hay explotaciones ganaderas (fundamentalmente de ovino).

- Viviendas aisladas construidas en espacios periurbanos/rústicos, más hacia el final del recorrido. La mayoría están edificadas sobre antiguas eras, siendo de una o dos plantas. Sus acabados son en enfoscado ocre o ladrillos pardo-rojizos y cubiertas con teja mixta curva rojiza.

- Naves agrícolas en suelo periurbano/rústico, que se multiplican a lo largo del recorrido. También suelen estar edificadas en antiguas eras. Su acabado mayoritario es de paramentos en cemento gris y cubierta de fibrocemento, aunque últimamente se han construido varias en chapa metálica.

o Numerosos cercados de parcelas con valla metálica.

o Varias líneas eléctricas de alta tensión $(20-30 \mathrm{kV})$ y línea de teléfonos, sobre todo en el camino de la piscina.

o Antena de telefonía móvil, en hormigón.

- Elementos singulares:

- Escuelas de San Juan (ver recorrido 15).

- Iglesia de San Juan Bautista (ver recorrido 15).

o Antiguo hospital de la Vera Cruz (ver recorrido 15).

- Soportales de la plaza de San Juan y de la calle la Rúa, con desigual estado de conservación.

- Alguna vivienda de barro, con riesgo de ruina.

- Depósito de almacenamiento de agua en la calle los Molinos, con ladrillo rojo y paños claros y rematado en su cúpula con la forma de un palomar.

o Escuelas de la avenida del Parque, construidas con ladrillo de tejar y cubierta de teja árabe, ahora rehabilitadas como museo del Queso y sala de exposiciones de arte.

o Edificio de usos múltiples, que fue una antigua cárcel, situado al final del parque del Paseo.

\section{DEGRADACIONES DEL PAISAJE}

- Pérdida general de patrimonio y de la tipología arquitectónica tradicional, con impacto crítico.

- Viviendas u otros edificios con fachada en cemento gris, bloques grises o acabados similares, por cambio de las características visuales básicas, con impacto moderado (Figura A3.109). En algunas de ellas se han realizado pintadas.

- Puertas traseras metálicas sin pintar o pintadas en colores estridentes, por cambio de las características visuales básicas, con impacto moderado (Figuras A3.107 y A3.108).

- Presencia de naves en el espacio urbano, que son elementos extraños al paisaje urbano, generando un impacto severo.

- Presencia de explotaciones ganaderas en suelo urbano que generan molestias y olores desagradables y, por consiguiente, un impacto severo.

- Existencia de naves o muros en ladrillo sin revestir, con impacto moderado (Figura A3.106).

- Impacto moderado provocado por la existencia de solares urbanos sin delimitar o delimitados con una simple malla metálica.

- Pavimentación en estado deficiente en varios tramos, sobre todo aquellos realizados con paños de hormigón, impacto moderado.

- Sobre todo en los espacios periurbanos, falta de rigor urbanístico en cuanto a la definición de usos, lo que provoca que se mezclen viviendas, naves agrícolas y explotaciones ganaderas, por ejemplo. Se trata de un impacto que se puede calificar como severo.

- Presencia de residuos en algunos márgenes de los caminos, así como en alguna zona verde que no ha sido totalmente recuperada, de impacto moderado.

- Impacto moderado provocado por la existencia de vallados metálicos que delimitan pequeñas parcelas periurbanas o equipamientos como el polideportivo.

- Impacto moderado por la presencia de líneas eléctricas o telefónicas.

- Impacto severo provocado por la presencia de la antena de telefonía móvil, un elemento extraño a la pauta general del paisaje, de considerable magnitud.

- Existencia de espacios públicos susceptibles de ser zonas verdes, pero que actualmente se encuentran en cierto grado de degradación, como la primera parte de la reguera del Tinte, la era del Depósito o determinadas zonas del polideportivo. 


\section{RECUPERACIONES DEL PAISAJE}

Ver recorrido 6

\section{RECUPERACIONES POTENCIALES}

Ver recorrido 26 


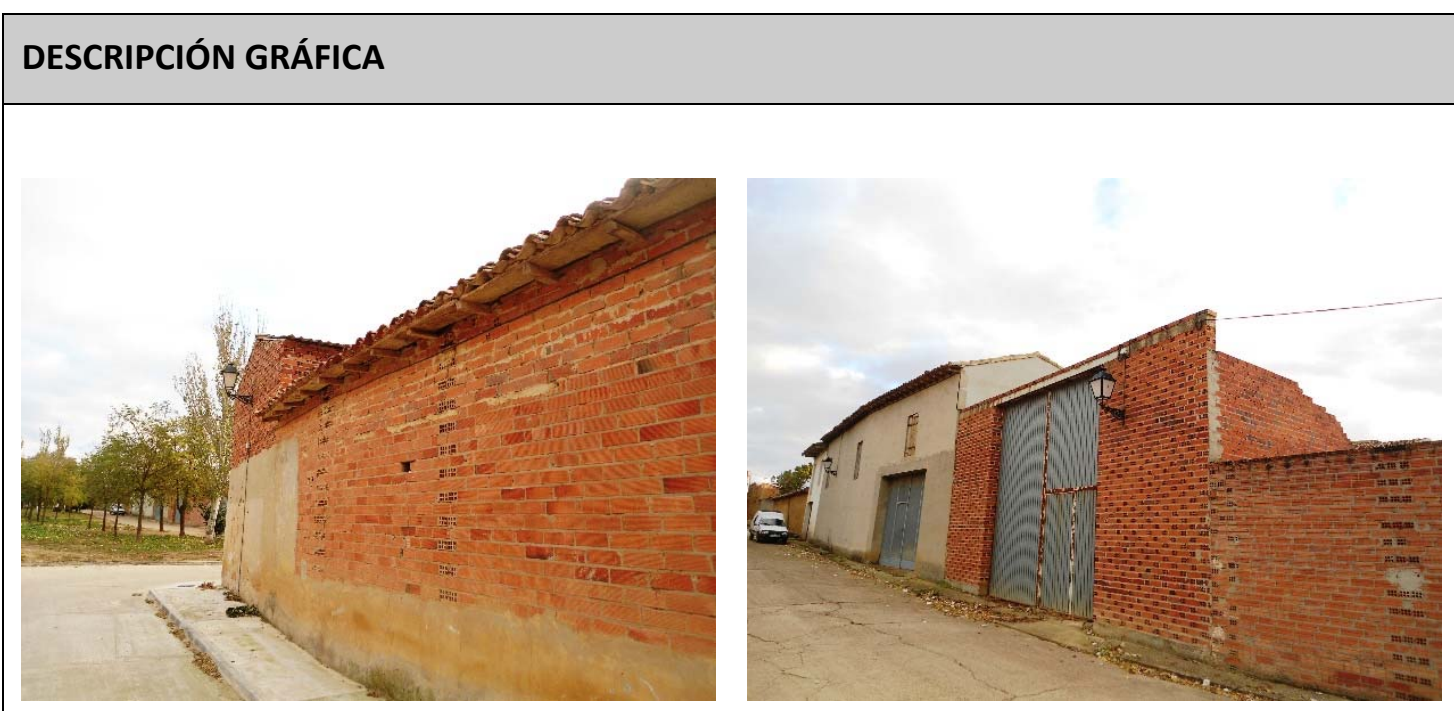

Figura A3.106. Aprisco de ovino en casco urbano, ladrillo visto Figura A3.107. Conjunto de traseras grandes, ladrillo visto, cemento, etc.

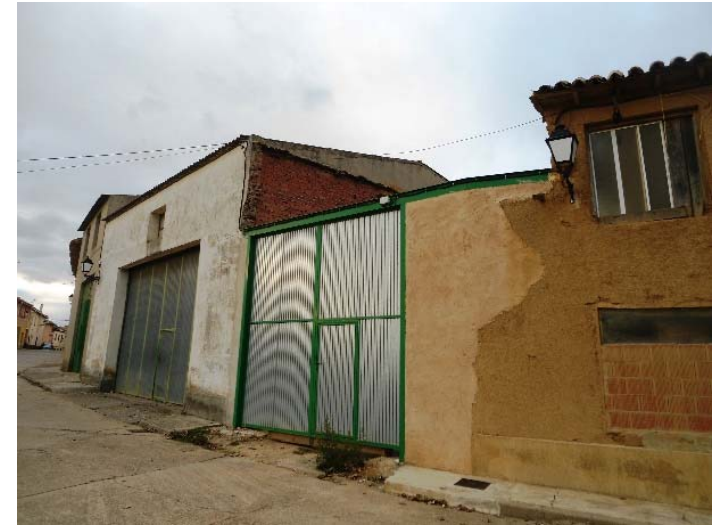

Figura A3.108. Las puertas metálicas brillan mucho al comienzo de su colocación

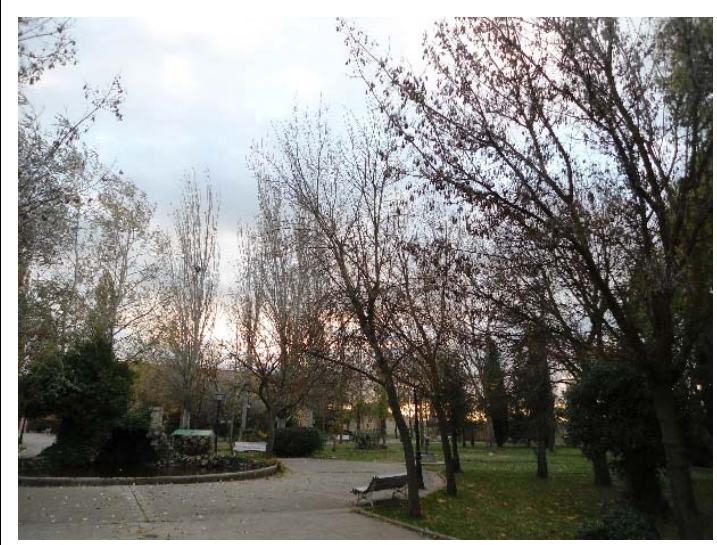

Figura A3.110. El parque del Paseo está ya sin hojas

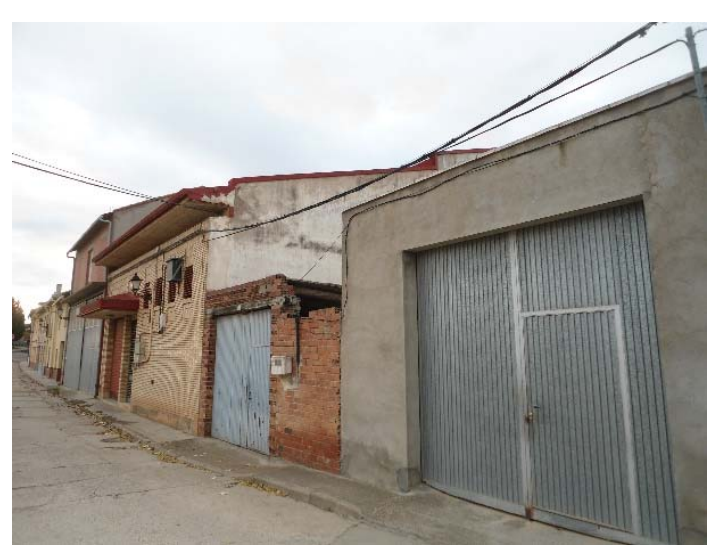

Figura A3.109. Plaza de San Miguel en clara degradación

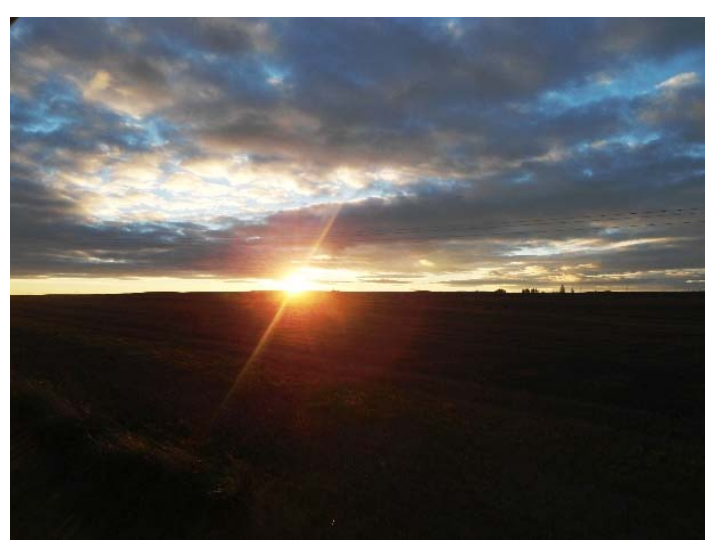

Figura A3.111. Atardecer en Tierra de Campos 


\section{RECORRIDO: Carretera de Fuentes}

- Fecha: 6 de diciembre de 2013, 13:30 h.

- Medio: Caminando.

- Itinerario: Desde casco urbano - ermita de Fuentes (Figuras A3.116 y A3.117) - vuelta a Villalón.

- Longitud: $6 \mathrm{~km}$.

- Condiciones meteorológicas: Cielo despejado. Hace tiempo que no llueve.

- Características de la vía (Figura A3.115): Carretera autonómica de plataforma de 7,6 m (3,15 m de carril y 0,85 $\mathrm{m}$ de arcén). Muy utilizada para pasear.

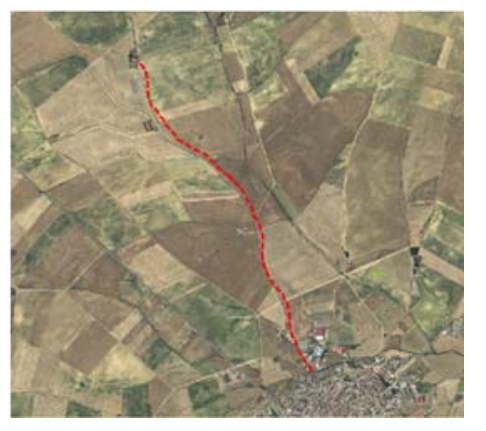

\section{CARACTERÍSTICAS DEL PAISAJE}

- $\quad$ Entorno inmediato de la vía: Cunetas de 3 - $4 \mathrm{~m}$ de anchura, revegetadas en su mayoría, salvo las de mayor altura. Altura media de los taludes: $>2 \mathrm{~m}=30 \%, 1-2 \mathrm{~m}=60 \%,<1 \mathrm{~m}=10 \%$, siendo prácticamente todos de desmonte.

- $\quad$ Espacio agrícola: Se han preparado los barbechos para su siembra (Figura A3.114). Hay bastante siembra directa. Dominan los colores marrones -barbecho (Figura A3.113), terreno recién sembrado- sobre los verdes (leguminosas, cereal nacido). No hay ocres.

- Agua: Ausencia.

- $\quad$ Ruido: Puntual debido al tráfico, aunque es escaso.

- Olores desagradables: Inexistentes.

- Vegetación: En los márgenes de la carretera hay algún tramo con almendros y diversas zarzas. Hay varias regueras con escaramujos. En la ermita solo están verdes las coníferas y los Prunus lauracerasus.

- Fauna: Algunos pajaritos. Un rebaño de ovejas pasta las eras (Figura A3.112).

- Actuaciones humanas: Ver recorrido 8.

- $\quad$ Elementos singulares: Ver recorrido 8

\section{DEGRADACIONES DEL PAISAJE}

Ver recorrido 8.

\section{RECUPERACIONES DEL PAISAJE}

Ver recorrido 8.

\section{RECUPERACIONES POTENCIALES}

Ver recorrido 8 . 


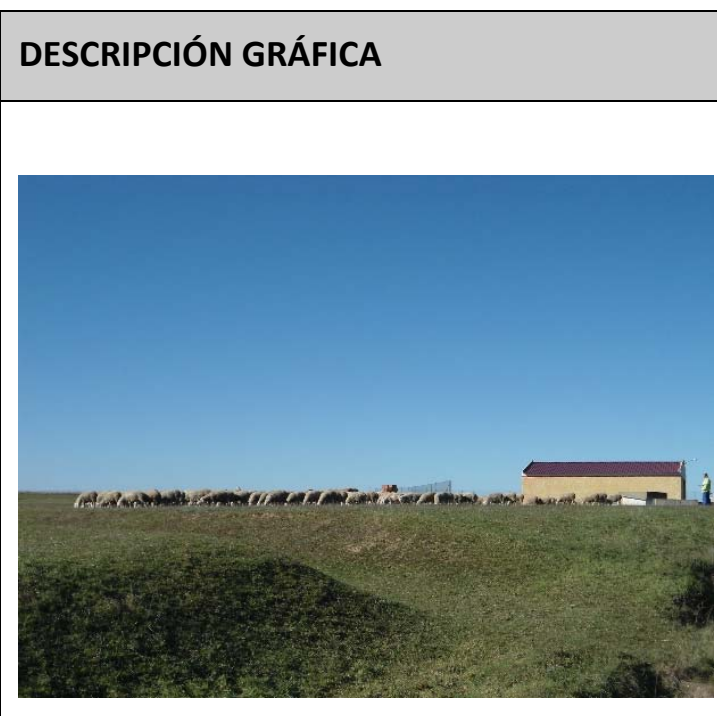

Figura A3.112. Rebaño de ovejas pastando las eras cercanas al pueblo

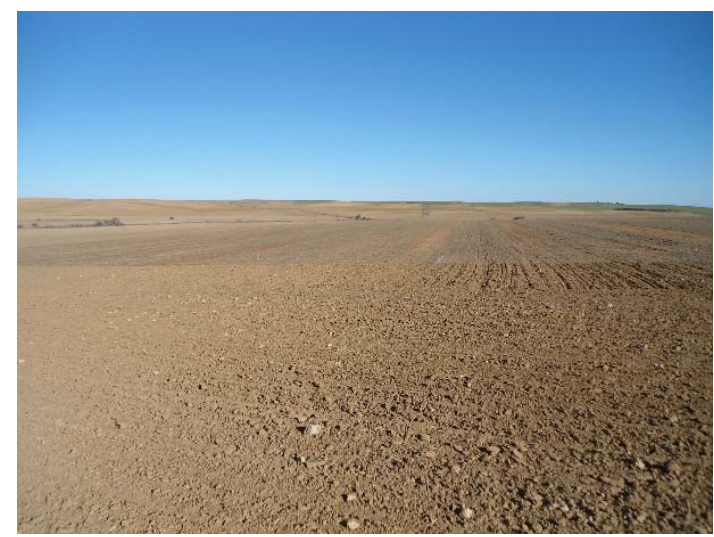

Figura A3.114. Terrenos recién sembrados. Monotonía cromática

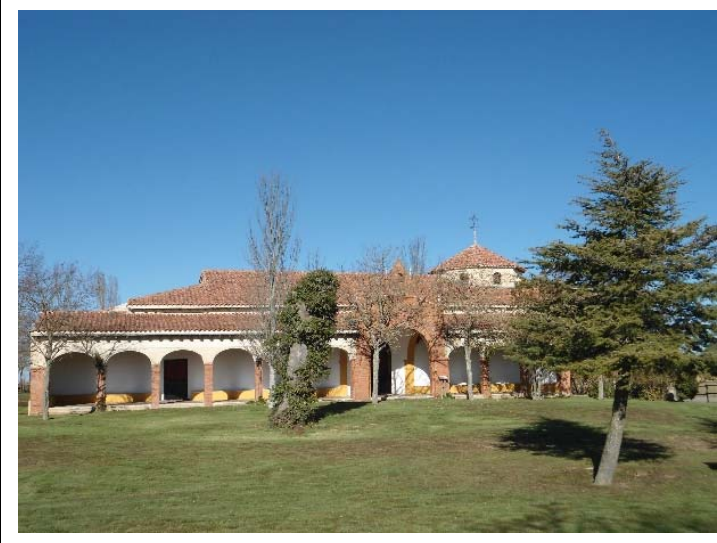

Figura A3.116. Fachada principal de la ermita de Fuentes

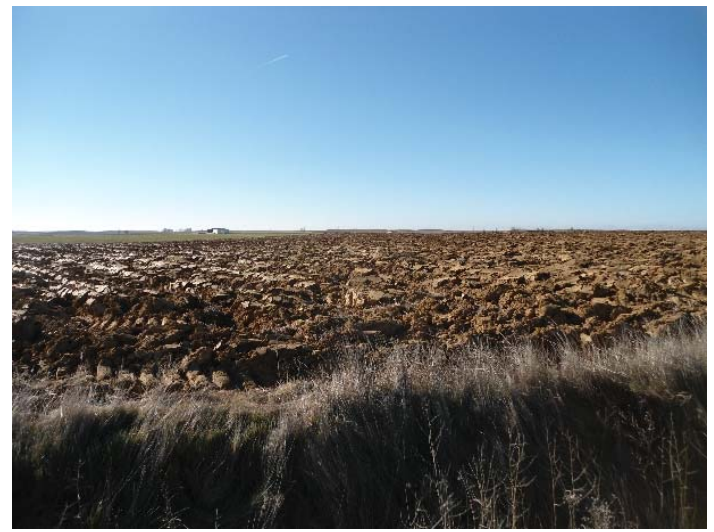

Figura A3.113. Los barbechos aportan textura al paisaje

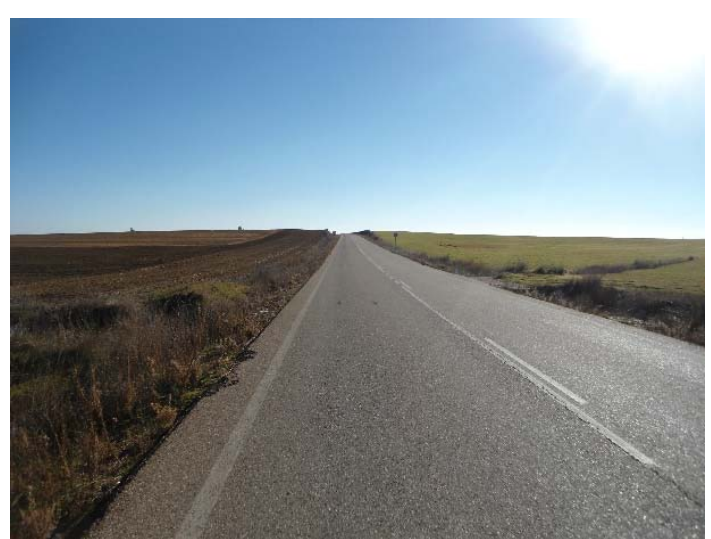

. Figura A3.115. Vista general de la carretera

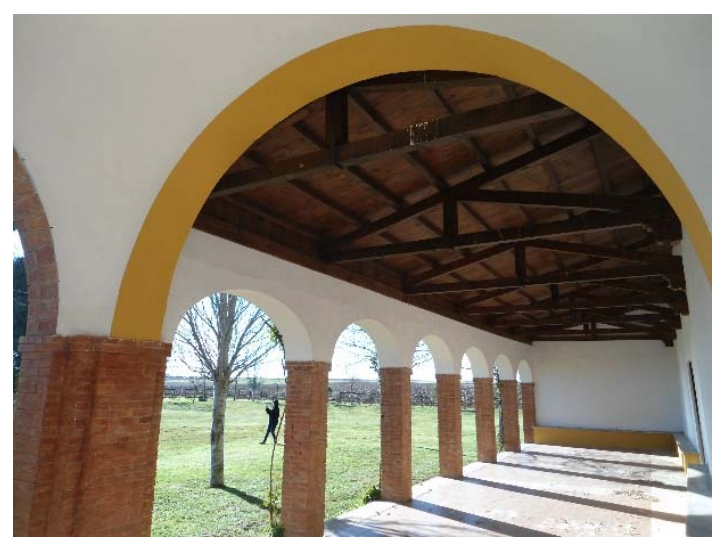

Figura A3.117. Interior del soportal 


\section{RECORRIDO: Vereda Camino de Cisneros y Valdelafuente}

- Fecha: 14 de diciembre de 2013, 13:30 h.

- Medio: Caminando.

- Itinerario: Desde carretera de Boadilla - vereda Camino de Cisneros - fuente Valdelafuente - arroyo del cuérnago del Pocillo (Figura A3.123) - camino hasta punto inicial.

- Longitud: 6,7 km

- Condiciones meteorológicas: Cielo despejado. Ha llovido el día anterior después de una larga temporada sin hacerlo.

- Características de la vía: Camino de zahorra natural silícea. Plataforma de $6 \mathrm{~m}$, encontrándose revegetados $0.8 \mathrm{~m}$ a cada lado. Muy rectilíneo salvo algún cambio de dirección. El camino de vuelta está en tierra, de mejor caminar.

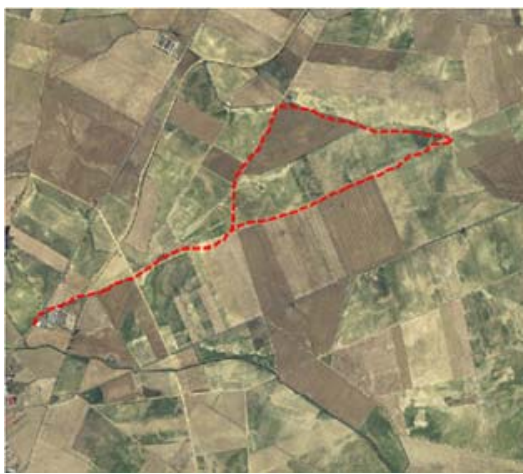

\section{CARACTERÍSTICAS DEL PAISAJE}

- Entorno inmediato de la vía: Cunetas de los caminos de anchura media de $2 \mathrm{~m}$, revegetadas. La altura media de los taludes es $>2 \mathrm{~m}=10 \%, 1-2 \mathrm{~m}=55 \%,<1 \mathrm{~m}=35 \%$, predominando los desmontes.

- Espacio agrícola: Dominio del color marrón del barbecho, con intercalaciones de verde pálido del cereal recién nacido y las leguminosas (Figura A3.119).

- Agua: Ausencia.

- Ruido: Inapreciable. Solo un tractor

- Olores desagradables: Puntuales en las cercanías de la granja avícola.

- Vegetación: Prácticamente inexistente; tan solo una acacia y varios chopos en arroyo en Valdelafuente (Figura A3.121) y un escaramujo en arroyo. Vegetación sin hojas.

- Fauna: Bastantes pajaritos. 2 milanos reales. 2 cernícalos.

- Actuaciones humanas:

o Granja avícola (Figura A3.118) formada por cuatro naves blancas y cubierta de fibrocemento, cercado con valla metálica e instalaciones auxiliares.

- Elementos singulares:

o Fuente Valdelafuente (Figura A3.122), con depósito de ladrillo de tejar revocado en cemento.

\section{DEGRADACIONES DEL PAISAJE}

- Caminos excesivamente rectilíneos, sin naturalidad, impacto severo.

- Arroyos encauzados y rectificados, sin naturalidad, impacto severo (Figura A3.120).

\section{RECUPERACIONES DEL PAISAJE}

- $\quad$ AHA 1: Lindera de $80 \mathrm{~m}$ paralela a camino. Chopos, cada $4 \mathrm{~m}$, sin protectores, con cuidados, $20 \%$ de marras.

- AHA 2: Pequeño picón de $30 \mathrm{~m}^{2}$. Árboles variados (chopos, pinos, acacias), cada 1,5 m, sin protectores, con cuidados, $0 \%$ de marras. 


\section{RECUPERACIONES POTENCIALES}

- Restauración vegetal de taludes de caminos.

- Restauración vegetal de regueras.

- Plantaciones de diversificación en el interior de las parcelas agrícolas.

- Fuente Valdelafuente: Arreglar fuente y entorno. Revocar en mortero bastardo el ladrillo visto del murete del abrevadero. Plantación de frondosas de ribera en reguera. Plantación de especies para zonas secas en el resto. Como en todas las recuperaciones, poner protectores para el ganado ovino. 


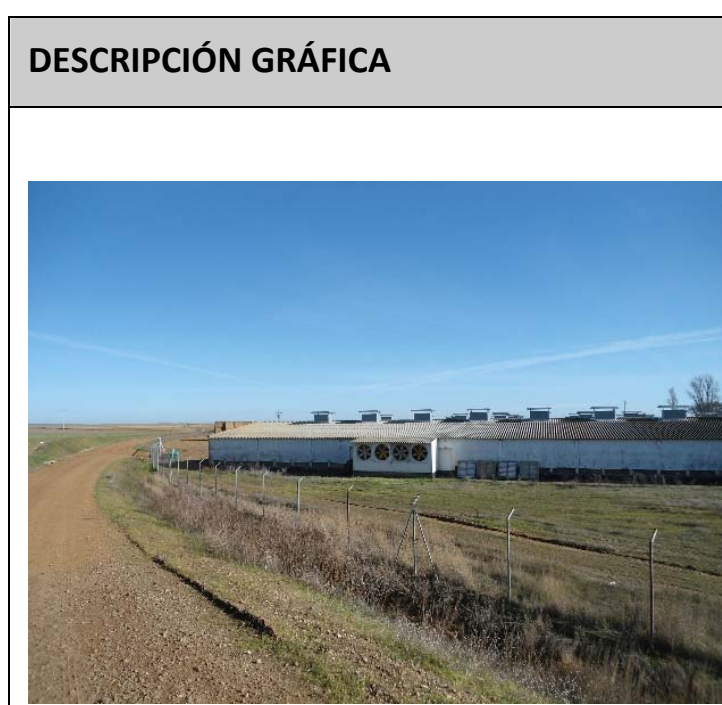

Figura A3.118. Granja avícola

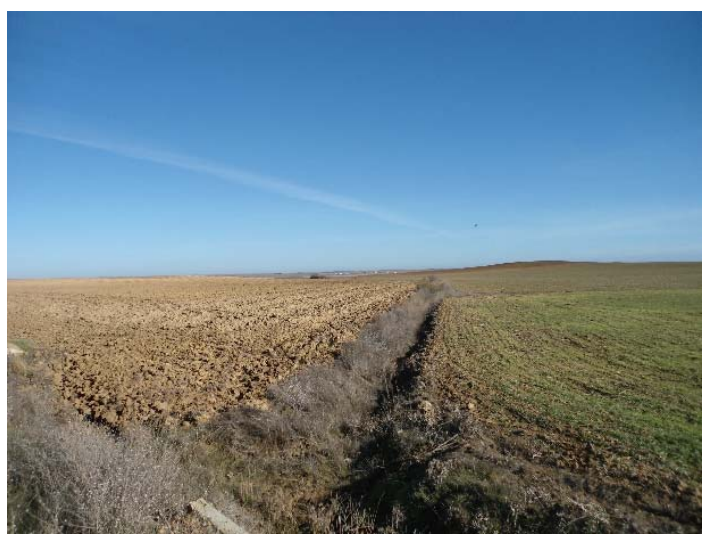

Figura A3.120 Reguera, barbecho (izquierda) y cereal nacido (derecha)

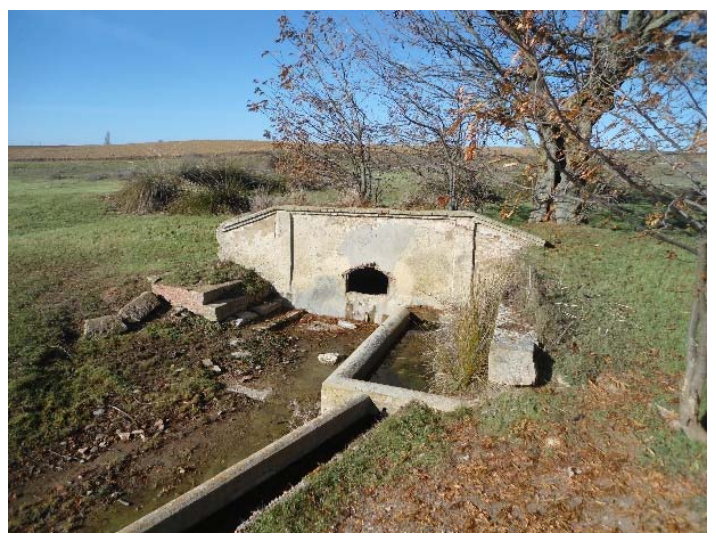

Figura A3.122. Detalle de la fuente de Valdelafuente

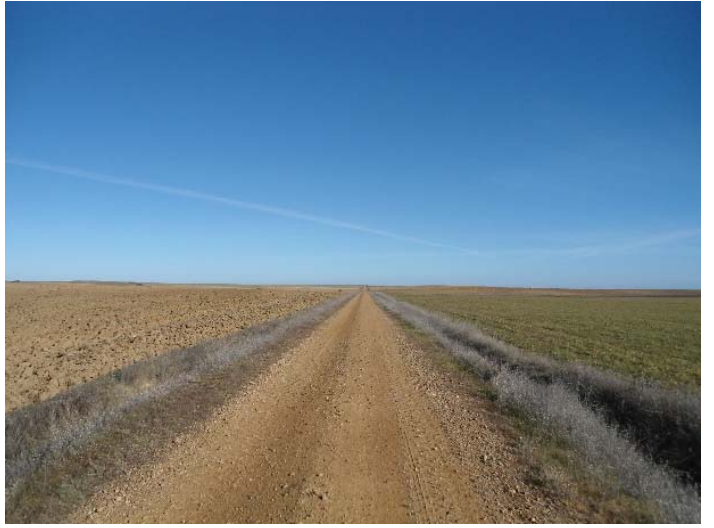

Figura A3.119. Camino- vereda, barbecho (izquierda) y leguminosas (derecha)

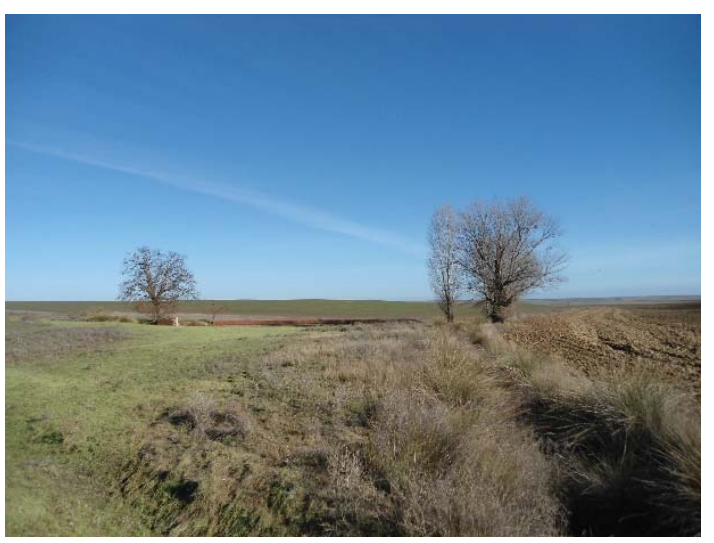

Figura A3.121.Valdelafuente, con los únicos árboles del recorrido

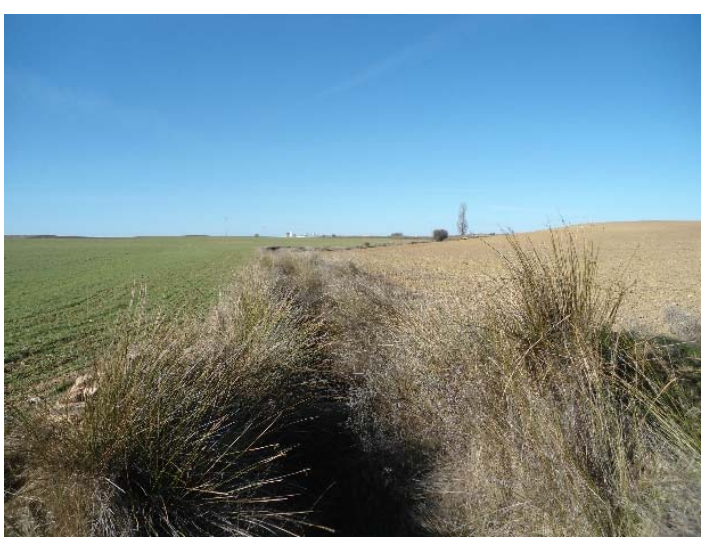

Figura A3.123. Arroyo del cuérnago del Pocillo 
RECORRIDO: Valdelafuente a Trinchas

- Fecha: 11 de enero de 2014, 13:15 h.

- Medio: Caminando.

- Itinerario: Desde fuente Valdelafuente hasta fuente Trinchas, ida y vuelta por el mismo camino.

- $\quad$ Longitud: 4,6 km

- Condiciones meteorológicas: Cielo despejado. Ha llovido bastante en las Navidades.

- Características de la vía: Camino de zahorra natural, totalmente rectilíneo (Figura A3.124). Anchura de $6 \mathrm{~m}$, de los que $1 \mathrm{~m}$ a cada lado están revegetados e incluso en algunos tramos $0.6 \mathrm{~m}$ en una franja central.

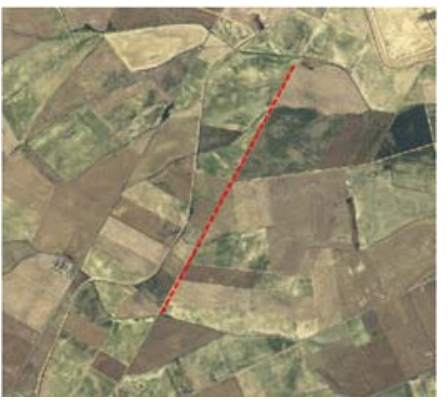

\section{CARACTERÍSTICAS DEL PAISAJE}

- $\quad$ Entorno inmediato de la vía: La anchura media de las cunetas de los caminos es de $2 \mathrm{~m}$, estando revegetadas; la altura media de los taludes es $>2 \mathrm{~m}=2 \%, 1-2 \mathrm{~m}=55 \%,<1 \mathrm{~m}=43 \%$, alternando desmonte y terraplén.

- Espacio agrícola: Dominio del color verde, todavía poco intenso (cereal y leguminosas) con intercalaciones marrones del barbecho. Terrenos ondulados como, en general, en todo el término municipal.

- $\quad$ Agua: Encharcamientos puntuales (Figura A3.126). El agua corre por las regueras (Figura A3.127).

- $\quad$ Ruido: Inapreciable. Silencio absoluto solo interrumpido por un coche.

- Olores desagradables: Inexistentes.

- Vegetación: Algún escaramujo en márgenes de caminos. Varias regueras con arbustos y algún chopo aislado (Figura A3.125). Vegetación sin hojas.

- $\quad$ Fauna: Bastantes pajaritos, más en las parcelas sembradas con leguminosas. 2 milanos reales.

- Actuaciones humanas:

- Pequeña parcela cercada con valla metálica, en la que se está construyendo una caseta-establo para caballos.

- Elementos singulares:

o Fuente Trinchas (Figura A3.129), con depósito de ladrillo de tejar.

\section{DEGRADACIONES DEL PAISAJE}

- Caminos excesivamente rectilíneos, sin naturalidad, impacto severo.

- $\quad$ Arroyos encauzados y rectificados, sin naturalidad, impacto severo. 


\section{RECUPERACIONES DEL PAISAJE}

- $\quad$ AHA 1: Franja rectangular de $650 \mathrm{~m}^{2}$. Pino piñonero, marco $4 \times 4 \mathrm{~m}$, con protectores, sin cuidados, $25 \%$ de marras.

- $\quad$ AHA 2 (Figura A3.127): Picón triangular de $1250 \mathrm{~m}^{2}$. Pino piñonero y alguna frondosa, con protectores (Figura A3.128), con cuidados, $0 \%$ de marras.

\section{RECUPERACIONES POTENCIALES}

- Restauración vegetal de taludes de caminos.

- Restauración vegetal de regueras.

- Plantaciones de diversificación en el interior de las parcelas agrícolas.

- $\quad$ Fuente Trinchas: Se trata de una pequeña fuente con depósito, que mana a una reguera y de ahí a un arroyo. Había dos grandes chopos que se secaron, ahora hay brotes de los mismos con mucha fuerza. Antes no tenía parcela asociada, pero ahora la concentración parcelaria le ha dejado una de 1 ha aproximadamente. Es preciso delimitarla físicamente en la colindancia con otra parcela agrícola. Se debería hacer una plantación para zonas húmedas en las regueras y otra para zonas secas en el resto de la parcela. 


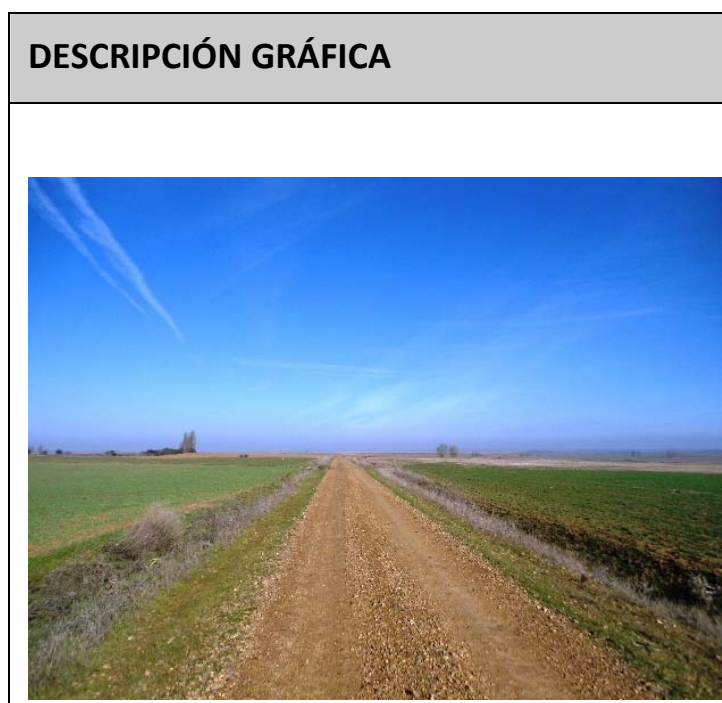

Figura A3.124. Estado del camino y paisaje adyacente

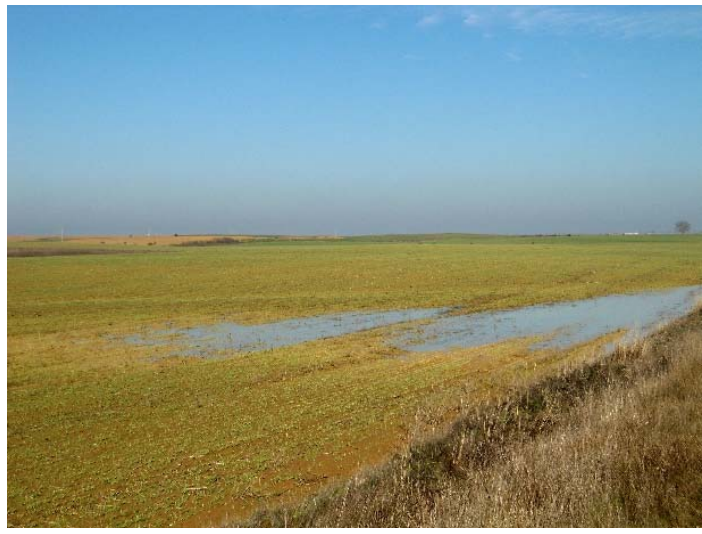

Figura A3.126. Encharcamientos en parcela sembrada

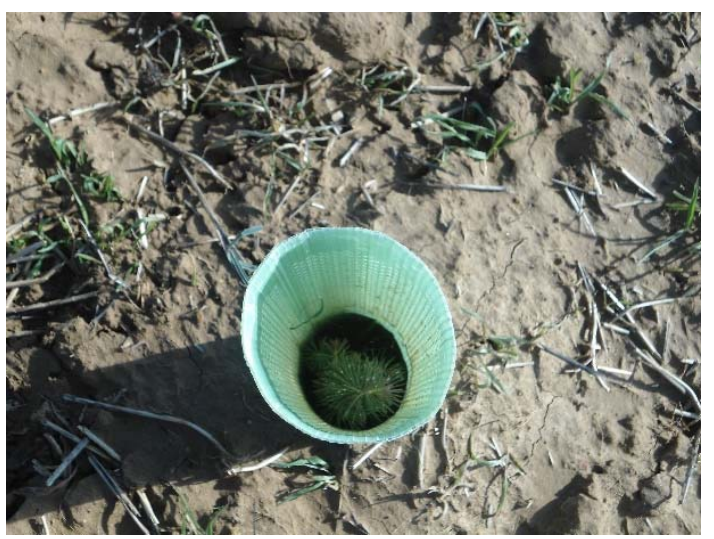

Figura A3.128. Detalle de pino con protector en AHA 2

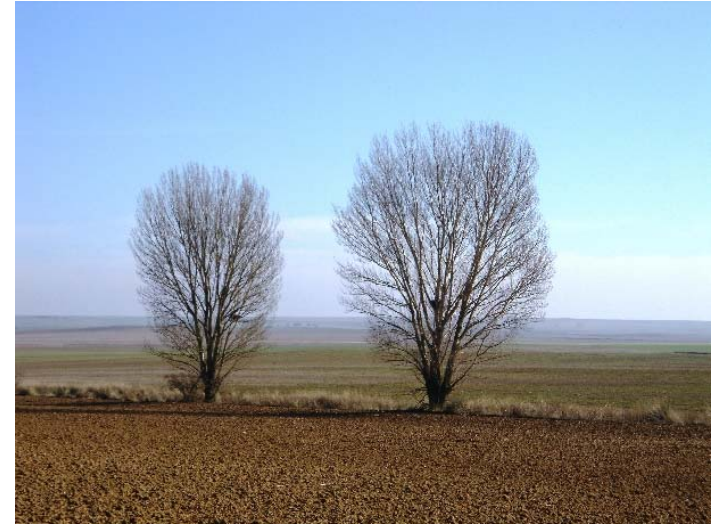

Figura A3.125. Chopos aislados en una reguera

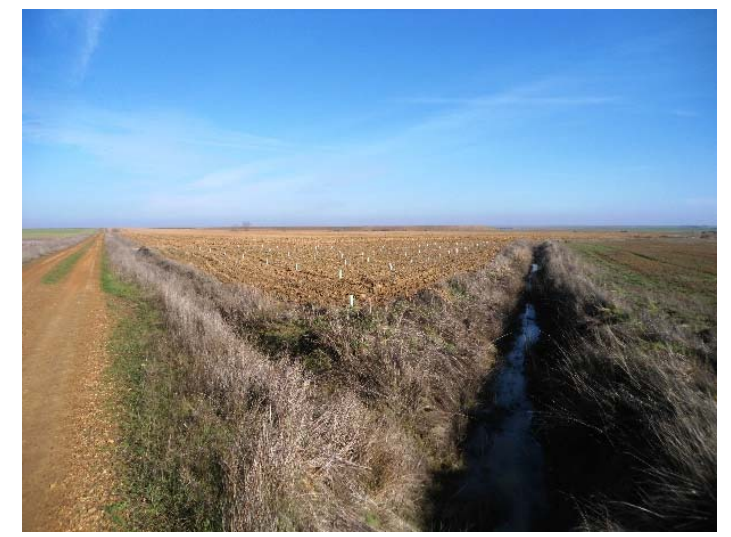

Figura A3.127. Camino, árbol por ha AHA 2 y reguera con agua

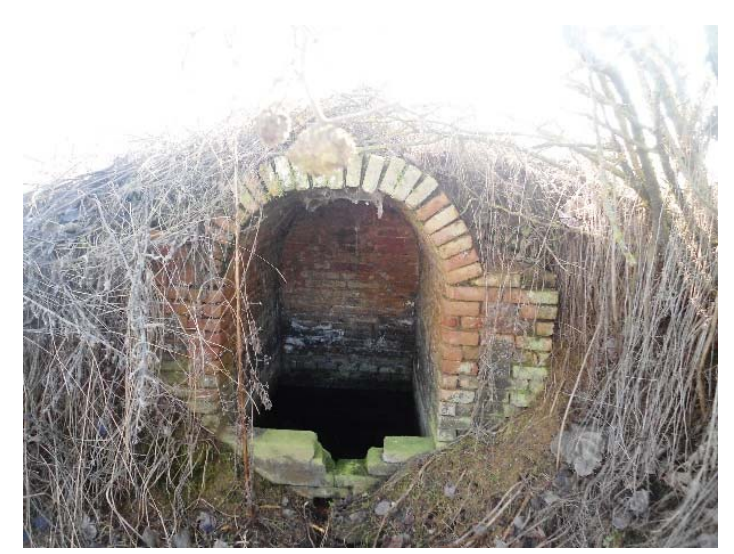

Figura A3.129. Fuente de Trinchas 


\section{RECORRIDO: Trinchas, balsa y Villacilda}

- Fecha: 12 de enero de 2014, 10:50 h.

- Medio: Caminando.

- Itinerario: Desde fuente Trinchas - balsa de regadío - futuro observatorio - contorno balsa en construcción - camino dirección Villalón - desvío derecha - fuente Villacilda - fuente Trinchas.

- $\quad$ Longitud: $4,8 \mathrm{~km}$

- $\quad$ Condiciones meteorológicas: Nublado. Terreno muy húmedo.

- Características de la vía: Camino de zahorra, prensado con las últimas Iluvias, de buen caminar. Plataforma de $6 \mathrm{~m}$ de anchura, con franjas laterales revegetadas con herbáceas de $80 \mathrm{~cm}$ y otra central de $60 \mathrm{~cm}$.

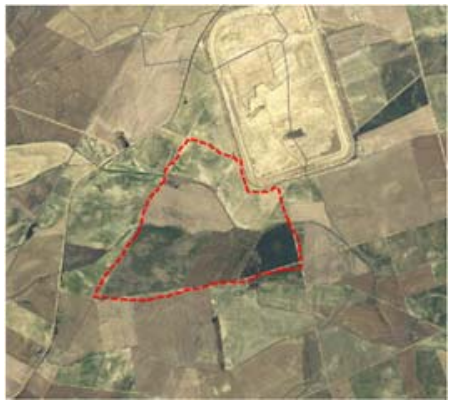

\section{CARACTERÍSTICAS DEL PAISAJE}

- Entorno inmediato de la vía: La anchura media de las cunetas de los caminos es de $2 \mathrm{~m}$, estando revegetadas; la altura media de los taludes es $>2 \mathrm{~m}=2 \%, 1-2 \mathrm{~m}=55 \%,<1 \mathrm{~m}=43 \%$, alternando desmonte y terraplén.

- Espacio agrícola: Dominio del color verde con tonos ocres (hay más leguminosas que, con el frío, adquieren esa tonalidad) sobre el marrón de los barbechos.

- $\quad$ Agua: Pequeñas charcas en el interior de parcelas. El agua corre por regueras y arroyos (Figura A3.134). La balsa acumula bastante agua (Figura A3.133).

- $\quad$ Ruido: Inapreciable.

- Olores desagradables: Inexistentes.

- Vegetación: Alguna reguera con arbustos. Chopos aislados que, aun sin hojas, proporcionan diversidad al paisaje.

- Fauna: Muchos pajaritos, se nota que hay bastantes parcelas sembradas de leguminosas. Se divisan patos en la balsa. 15 avutardas. En los chopos de Villacilda hay un grupo de 10 milanos reales.

- Actuaciones humanas:

o Balsa de regadío en construcción. Taludes exteriores con tierra vegetal, parcialmente revegetados (Figura A3.132). Taludes interiores revestidos con escollera de piedra caliza. La plataforma se ha remodelado a distintas cotas, de forma que queda bastante naturalizada.

- Elementos singulares: No hay.

\section{DEGRADACIONES DEL PAISAJE}

- Caminos excesivamente rectilíneos, sin naturalidad, impacto severo (Figura A3.130).

- Arroyos encauzados y rectificados, sin naturalidad, impacto severo.

- Intrusión en la fuente Villacilda, que es de propiedad pública, impacto moderado. 


\section{RECUPERACIONES DEL PAISAJE}

- $\quad$ AHA 1 (Figura A3.131): Picón triangular de $5.100 \mathrm{~m}^{2}$. Mezcla de pino piñonero (50 \%), encina (25\%) y quejigo (25\%). Marco de $3 \times 3 \mathrm{~m}$. Protectores. Cuidados culturales (gradeo, alcorques, riegos, primeras micropodas). $0 \%$ de marras. Es una plantación ejemplar.

- $\quad$ AHA 2: Franja rectangular de $1000 \mathrm{~m}^{2}$. Mezcla de pino piñonero (50\%), encina (25\%) y quejigo (25\%). Marco de $2,5 \times 2,5 \mathrm{~m}$. Protectores. Sin cuidados. $25 \%$ de marras.

- AHA 3: Franja rectangular de $750 \mathrm{~m}^{2}$. Mezcla de pino piñonero (50 \%), encina (25\%) y quejigo (25\%). Marco de $2,5 \times 2,5 \mathrm{~m}$. Protectores. Sin cuidados. $40 \%$ de marras.

- $\quad$ RES 1: Protección con escollera de taludes de terraplén de caminos en contacto con arroyos. Piedra caliza integrada.

\section{RECUPERACIONES POTENCIALES}

- Restauración vegetal de taludes de caminos.

- Restauración vegetal de regueras.

- Plantaciones de diversificación en el interior de las parcelas agrícolas.

- Fuente Villacilda (Figura A3.135): Realmente se trata de una fontana, de donde mana agua hacia una pequeña laguna y de ahí a un arroyo. Hay cuatro grandes chopos que parecen dos. Se debe retirar un montón de escombros con obras de fábrica antiguas de las obras de concentración parcelaria. En la zona húmeda, plantación de especies arbóreas de ribera; en la seca hacia el camino, plantación de especies para zonas secas. Se debe delimitar la parcela para defender la propiedad pública. 


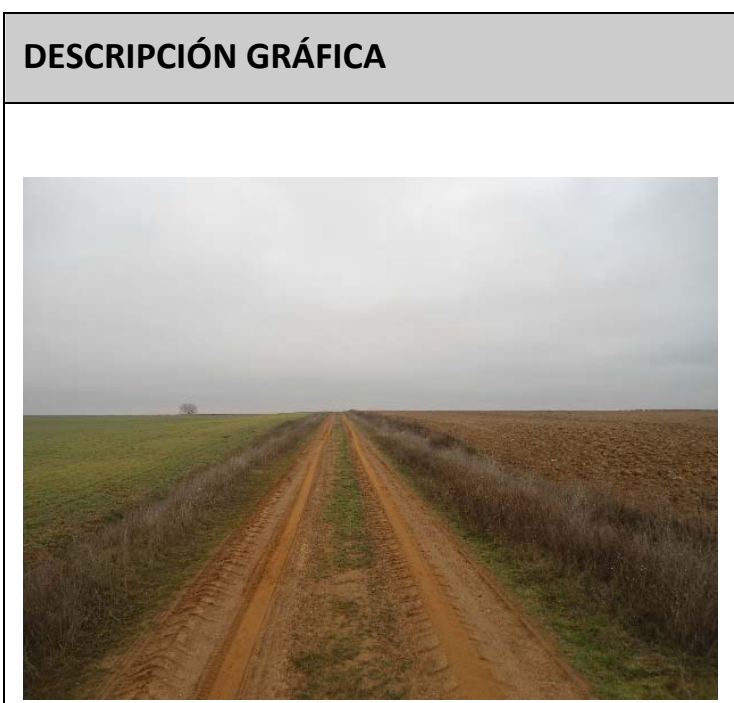

Figura A3.130. Camino y paisaje agrícola

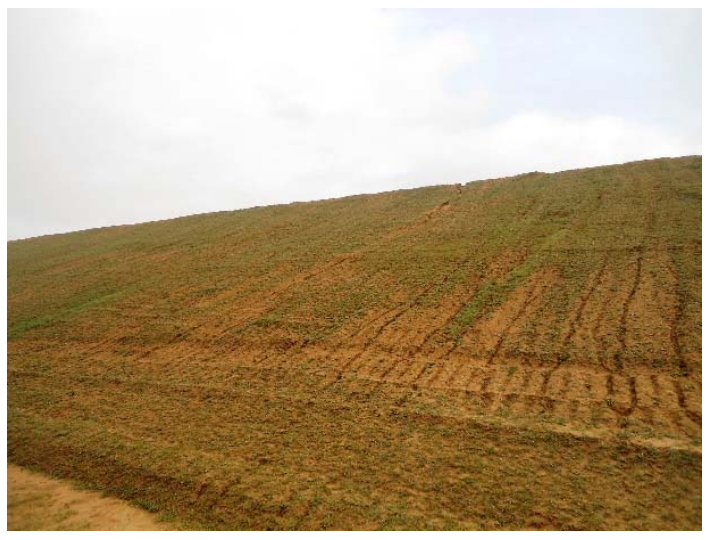

Figura A3.132. Talud de terraplén de la balsa, con regueros de erosión

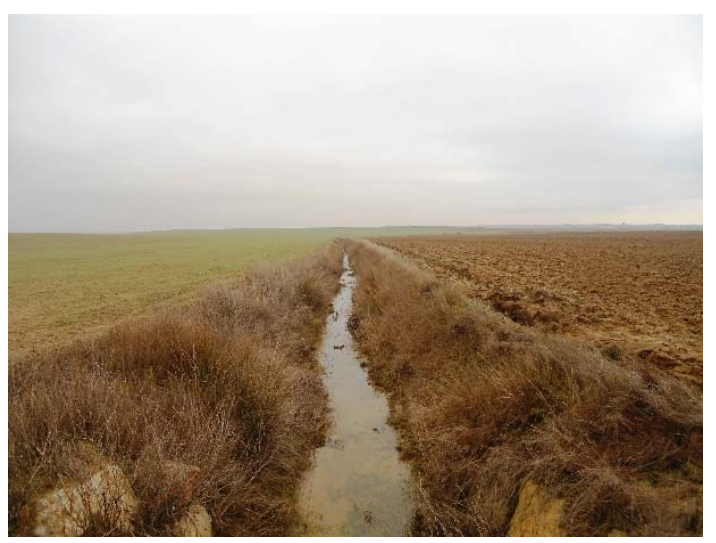

Figura A3.134. Reguera con agua en circulación

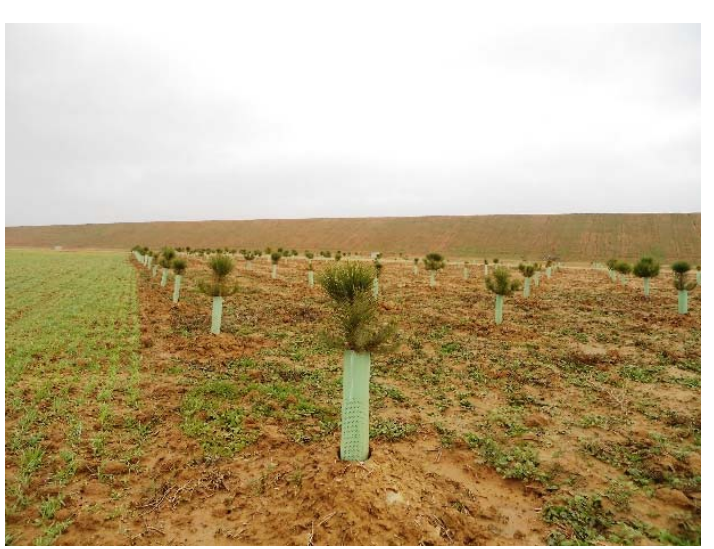

Figura A3.131. Plantación de árbol por hectárea ejemplar

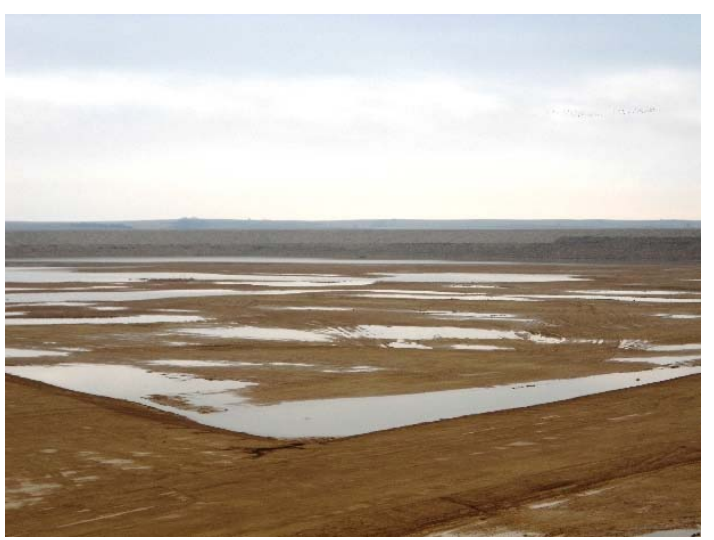

Figura A3.133. Plataforma de la balsa con agua abundante

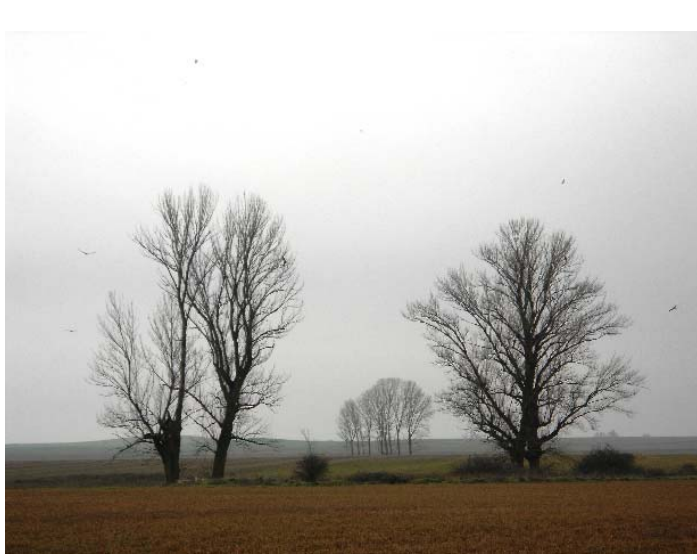

Figura A3.135. Fuente Villacilda, con cuatro chopos singulares 


\section{RECORRIDO: Colada de Villalón a Guaza y carretera de Herrín}

- Fecha: 25 de enero de 2014, 10:45 h.

- Medio: Caminando.

- Itinerario: Desde carretera de Boadilla - vereda Camino de Cisneros colada de Villalón a Guaza - camino derecha - carretera de Herrín fuente Herrín - punto de inicio (Figura A3.141).

- $\quad$ Longitud: $9,8 \mathrm{~km}$

- $\quad$ Condiciones meteorológicas: Despejado. Terreno muy húmedo por las lluvias recientes. Se ven las montañas nevadas de la Cordillera Cantábrica.

- Características de la vía: Caminos de zahorra de $6 \mathrm{~m}$ de plataforma, bien compactada, adecuada para caminar o ir en bicicleta. Revegetados $80 \mathrm{~cm}$ de ambos bordes y una franja de $30 \mathrm{~cm}$ central. Carretera provincial de $5,6 \mathrm{~m}$ de plataforma, con dos carriles de $2,8 \mathrm{~m}$ sin arcén. Bastante utilizada para caminar, a pesar de no tener arcenes.

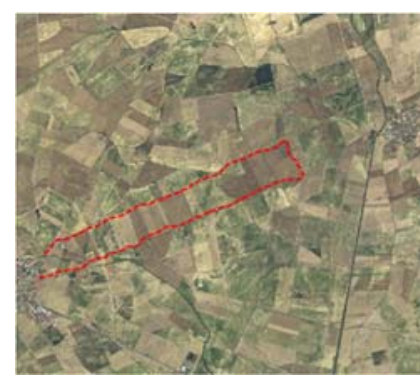

\section{CARACTERÍSTICAS DEL PAISAJE}

- Entorno inmediato de la vía: En el caso de los caminos, la anchura media de las cunetas es de $2 \mathrm{~m}$, encontrándose revegetadas; la altura media de los taludes es $>2 \mathrm{~m}=5 \%, 1-2 \mathrm{~m}=30 \%,<1 \mathrm{~m}=65 \%$, predominando los de desmonte. En la carretera la proporción estimada es la siguiente: $>2 \mathrm{~m}=30 \%, 1-2 \mathrm{~m}=40 \%,<1 \mathrm{~m}=30 \%$.

- $\quad$ Espacio agrícola (Figura A3.137): Domina el color verde, cuyo tono se intensifica a medida que va naciendo el cereal. Importante presencia del barbecho, que aumenta la diversidad cromática y textural del paisaje.

- $\quad$ Agua: Corre por regueras y arroyos. Bastantes charcas, más en los márgenes de la carretera por el efecto de presa que produce.

- $\quad$ Ruido: Inapreciable en caminos y puntual en la carretera, por el escaso tráfico que tiene.

- Olores desagradables: Puntual en las proximidades de la depuradora y el arroyo Berruez, así como en la entrada en el pueblo por el matadero y la granja avícola.

- Vegetación: Los márgenes de los caminos prácticamente no tienen arbusto alguno, tampoco se divisan árboles en las cercanías. Por la carretera solo hay dos localizaciones que poseen grupitos de árboles: chopos en el tramo medio y acacias a la entrada del pueblo. Inexistencia de hojas tanto en árboles como en arbustos.

- Fauna: Muchos pajaritos. 2 cigüeñas blancas. Bandada de 21 avutardas. 6 milanos reales en 3 grupos. 1 garza real en arroyo Berruez.

- Actuaciones humanas:

o Granja avícola delimitada con valla metálica, paramentos blancos y cubierta de fibrocemento.

o Depuradora, con edificios color tierra, instalaciones propias y ajardinamiento alrededor.

o Varias huertas a la entrada del pueblo.

o Naves metálicas abiertas para almacén de pacas de paja, con cubierta roja.

o Granja de vacuno, con paredes blancas y cubierta de fibrocemento.

o Varias naves en eras, de cemento y cubierta de fibrocemento.

- Nave almacén blanca y tejado rojo.

o Granja avícola con varias naves blancas y cubierta de teja plana roja e instalaciones auxiliares.

o Edificio de oficinas-vivienda, con ladrillo oscuro y teja árabe.

o Muchos vallados metálicos.

o Línea de teléfono aérea, con postes de madera.

- Elementos singulares:

o Fuente Herrín, con depósito de ladrillo antiguo macizo.

o Varios puentes de la carretera sobre arroyos, con bóvedas de ladrillo de tejar y piedra de sillería (Figura A3.139).

o Palomar color tierra con teja árabe.

o Palomar blanco con teja árabe. 


\section{DEGRADACIONES DEL PAISAJE}

- $\quad$ Caminos excesivamente rectilíneos, sin naturalidad, impacto severo.

- Arroyos encauzados y rectificados, sin naturalidad, impacto severo.

- Carretera totalmente rectilínea sin vegetación en sus márgenes, impacto severo.

- Depósitos de residuos puntuales en los márgenes de la carretera, con impacto moderado.

- Corta de un grupo de árboles en un margen de la carretera, que genera un impacto severo.

- Impacto igualmente moderado provocado por la proliferación de vallados metálicos a la entrada del pueblo.

\section{RECUPERACIONES DEL PAISAJE}

- $\quad$ AHA 1: Lindero paralelo a camino de $50 \mathrm{~m}$. Chopos por esquejes cada $3 \mathrm{~m}$, sin cuidados, $50 \%$ de marras.

- RES 1: Protección de taludes de caminos en entronque con arroyos con escollera de piedra caliza, muy integrada y que permite la revegetación de los intersticios (Figura A3.136).

- RES 2: Plantación de pinos piñoneros en arroyo del Cuérnago del Pocillo (por particular colindante) en un tramo de unos $200 \mathrm{~m}$ (Figura A3.138). En grupos, de unos 12 años de edad, a un marco irregular de $3-5 \mathrm{~m}$. Actualmente tienen una altura media de $1,5 \mathrm{~m}$ y un buen aspecto.

- RES 3: Fuente Herrín. Hace unos 12 años la Consejería de Medio Ambiente llevó a cabo una repoblación de la parcela asociada, de aproximadamente 1 ha. Preparación del terreno con subsolado lineal, con separación entre filas de 3,5 m y entre ejemplares de $3 \mathrm{~m}$ (en torno a 1000 pies/ha). Las especies empleadas fueron almendro (muy bien), encina, quejigo, pino piñonero (mal), gayomba y retama (bien). Las marras se pueden cifrar en un $60 \%$. Los ejemplares existentes tienen una altura media de $1,8 \mathrm{~m}$, marcada sobre todo por el buen crecimiento de los almendros.

- $\quad$ RES 4: Retirada de montón de basura. Hace 3 años, con motivo de las obras de concentración parcelaria, se retiró un montón de unos $400 \mathrm{~m}^{3}$ de basura y estiércol.

- RES 4: Restauración del arroyo Berruez (ver anejo 2).

- $\quad$ RES 5: Acondicionamiento paisajístico de la depuradora (Figura A3.140), realizado hace unos 9 años. Los paramentos de los edificios se han rematado en mortero bastardo con acabado en tierra y la cubierta es rojiza. Se han empleado thuyas como seto (unos $2 \mathrm{~m}$ ) y álamos perimetralmente (tienen $5-6 \mathrm{~m}$ y magnífico crecimiento). Es un ejemplo de integración en el paisaje de Tierra de Campos.

- $\quad$ PAR 1: Seto de arizónica en la valla que delimita una nave agrícola de almacén de paja, con cuidados. Tiene 5 años aproximadamente y una altura de $3 \mathrm{~m}$, magnífico crecimiento.

\section{RECUPERACIONES POTENCIALES}

- Restauración vegetal de taludes de caminos.

- Restauración vegetal de regueras.

- Plantaciones de diversificación en el interior de las parcelas agrícolas.

- Plantación de matorral en los taludes de la carretera de más de $1 \mathrm{~m}$ y de arbolado en aquellos superiores a $2 \mathrm{~m}$ que no afecten a la seguridad vial; ello sería posible sobre todo en el pie de los terraplenes.

- Restauración de la fuente Herrín, con adecuación de la propia fuente, plantación de las zonas de marras y poda de los ejemplares de mayor altura (sobre todo los almendros).

- Restauración y limpieza de los puentes de la carretera, que tienen un gran valor como patrimonio de la obra civil.

- Plantación de almendros y coníferas en los márgenes de la carretera a la entrada del pueblo, para minimizar el impacto visual de las naves. 


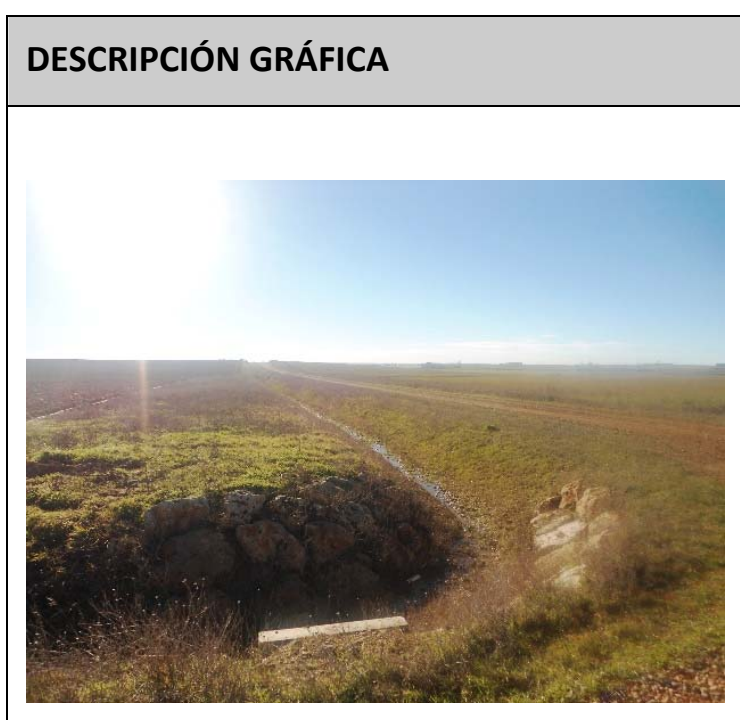

Figura A3.136. Restauración con escollera en caminos y arroyo

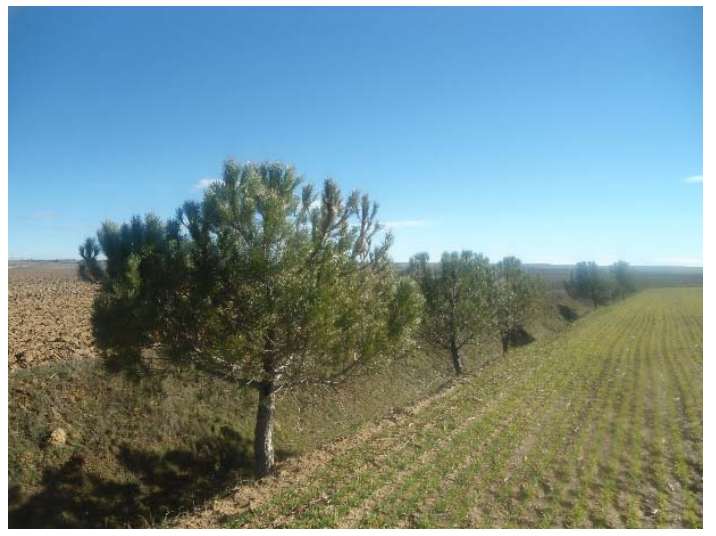

Figura A3.138. Restauración de pinos en arroyo del cuérnago del Pocillo

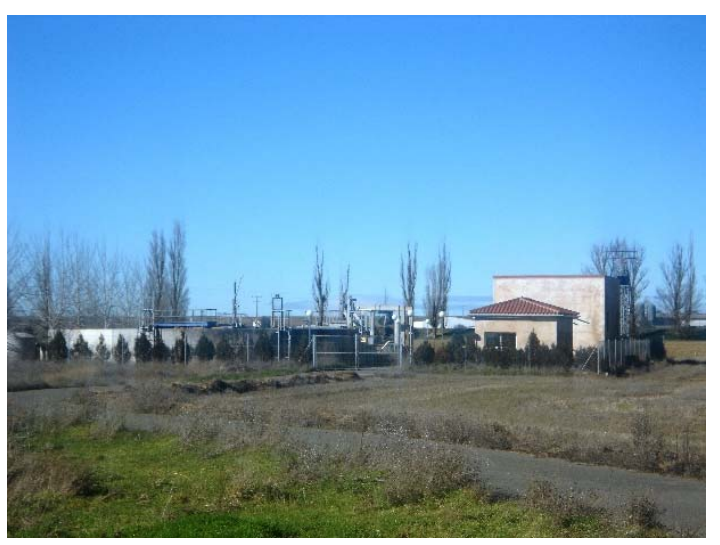

Figura A3.140. Depuradora integrada paisajísticamente

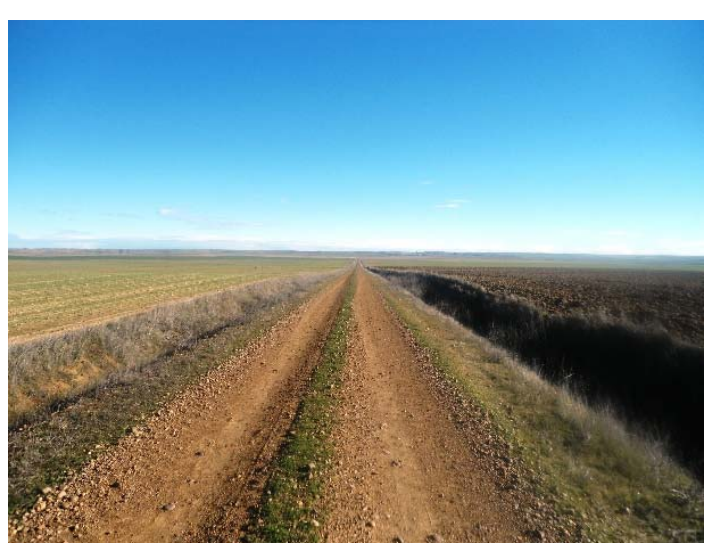

Figura A3.137. Vista general del camino y del paisaje agrícola

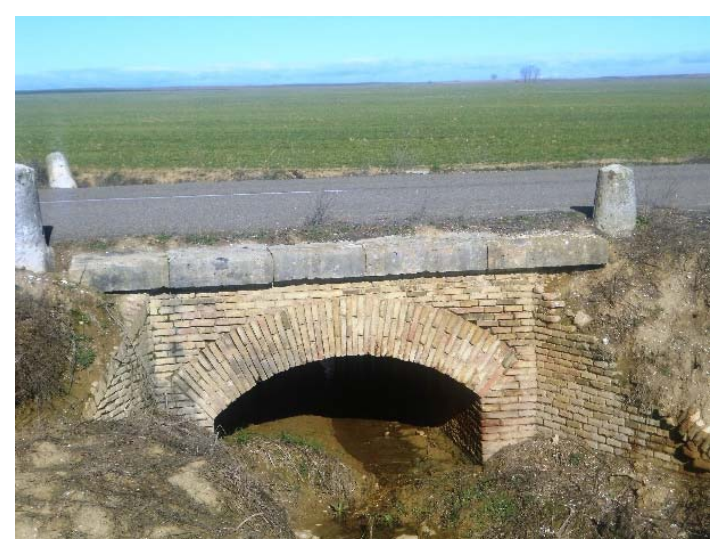

Figura A3.139. Puente singular en la carretera

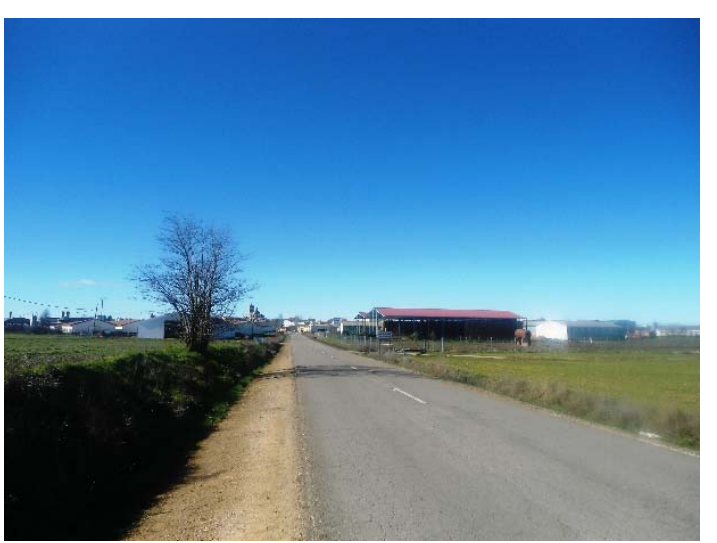

Figura A3.141. Entrada del pueblo con varias naves agropecuarias 


\section{RECORRIDO: Arroyo Berruez y camino de Villafrades}

- Fecha: 1 de febrero de 2014, 12:20 h.

- Medio: Caminando.

- Itinerario: Desde carretera de Herrín - camino derecha a Villafrades - camino dirección Herrín - parva del arroyo Berruez - camino de Villafrades a Villalón hasta punto de inicio.

- Longitud: 6,3 km

- Condiciones meteorológicas: Nublado con sol ocasional, mucho viento y algo de granizo. Cielo con nubes espectacular (Figura A3.146). Terreno muy húmedo.

- Características de la vía: El primer camino (Figura A3.143) con reciente depósito de zahorra, bien para caminar; plataforma de $6 \mathrm{~m}$. Parva del arroyo con parcela asociada de Restauración del Medio Natural de la concentración parcelaria, alargada (Figura A3.144), de

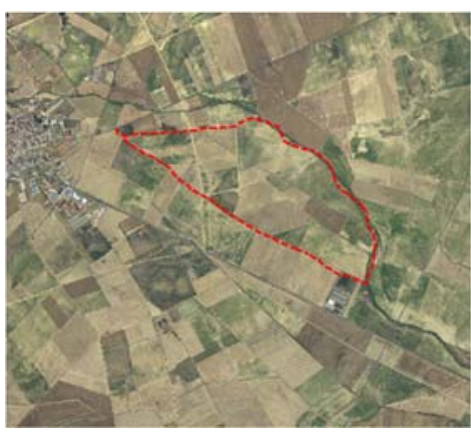
unos $8 \mathrm{~m}$ de anchura, en tierra, delimitada por una zanja. Camino de vuelta de $6 \mathrm{~m}$, con hierba en $1 \mathrm{~m}$ a cada lado (Figura A3.147).

\section{CARACTERÍSTICAS DEL PAISAJE}

- Entorno inmediato de la vía: En el caso de los dos caminos, la anchura media de las cunetas es de $2 \mathrm{~m}$, encontrándose revegetadas; la altura media de los taludes es $>2 \mathrm{~m}=5 \%, 1-2 \mathrm{~m}=55 \%,<1 \mathrm{~m}=40 \%$, siendo todos de desmonte.

- $\quad$ Espacio agrícola: Domina el verde, aunque con el frío del invierno el cereal se amarillea un poco.

- Agua: Abundante en el arroyo Berruez (Figura A3.145). Bastantes charcas; los caminos muchas veces hacen de barrera en su formación. Agua presente en cunetas y arroyos.

- $\quad$ Ruido: Inapreciable.

- $\quad$ Olores desagradables: Puntuales a la salida del pueblo procedente de las granjas avícolas y en un estercolero.

- Vegetación: Inexistente en los márgenes de los caminos. Algún arbusto aislado en las regueras. Ya se comienza a percibir el arbolado de la restauración del arroyo Berruez, con especies de ribera

- $\quad$ Fauna: Pajaritos imperceptibles. 2 milanos reales, 1 cigüeña blanca, 1 aguilucho.

- Actuaciones humanas:

o Granja de ovino (Figura A3.142), con nave metálica de paramentos blancos, zócalo color tierra y cubierta roja. Instalaciones y depósitos típicos de este tipo de explotación ganadera (estercoleros, pacas de paja, etc.).Valla metálica.

o Línea eléctrica de $40 \mathrm{kV}$ paralela al camino de Villafrades.

- $\quad$ Elementos singulares: No hay.

\section{DEGRADACIONES DEL PAISAJE}

- Caminos excesivamente rectilíneos, sin naturalidad, impacto severo.

- Impacto severo provocado por el dragado y rectificación del arroyo Berruez, que en su día modificó notablemente su naturalidad.

- Impacto moderado de una línea eléctrica de $40 \mathrm{kV}$ paralela al camino de Villafrades. 


\section{RECUPERACIONES DEL PAISAJE}

- $\quad$ RES 1: Plantación de chopos y alguna otra frondosa en el margen del camino en una franja de 200 m situada en la granja de ovino. Distancia de $5 \mathrm{~m}$. Edad aproximada de 5 años. Cuidada. Dificultades de prosperar por estar en una zona seca y ser especies exigentes en humedad.

- $\quad$ AHA 1: Picón de $50 \mathrm{~m}^{2}$, con pino piñonero, protectores, $3 \times 3 \mathrm{~m}$. Sin cuidados. $20 \%$ de marras.

- RES 2: Restauración del arroyo Berruez (ver anejo 2).

\section{RECUPERACIONES POTENCIALES}

- Restauración vegetal de taludes de caminos.

- Restauración vegetal de regueras.

- Plantaciones de diversificación en el interior de las parcelas agrícolas.

- $\quad$ Plantación de frondosas de ribera en toda la franja de las parcelas de RMN dejadas en la concentración parcelaria. Mejor a raíz profunda. Marco 4x4 irregular. Arbustos en el caballón perimetral de la zanja. Protecciones para las ovejas. 


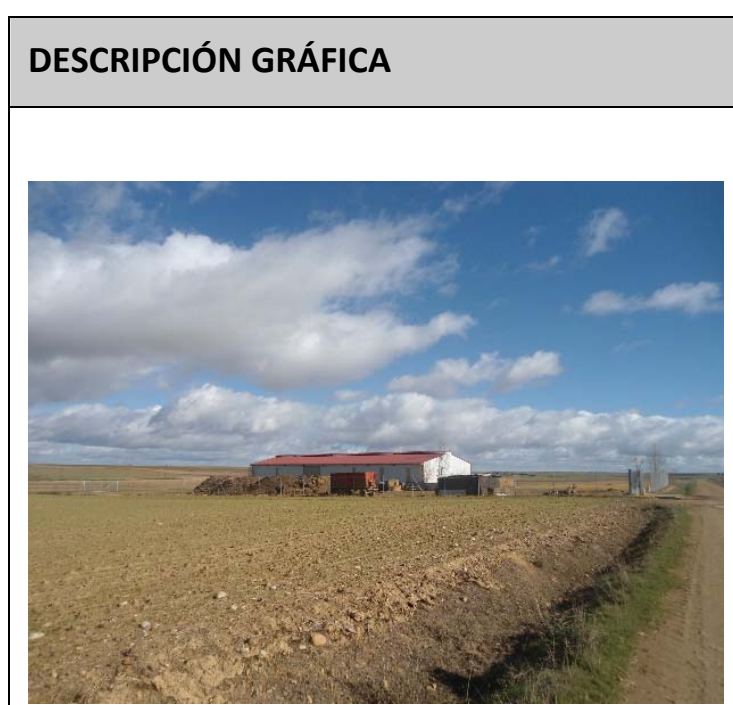

Figura A3.142. Granja de ovino

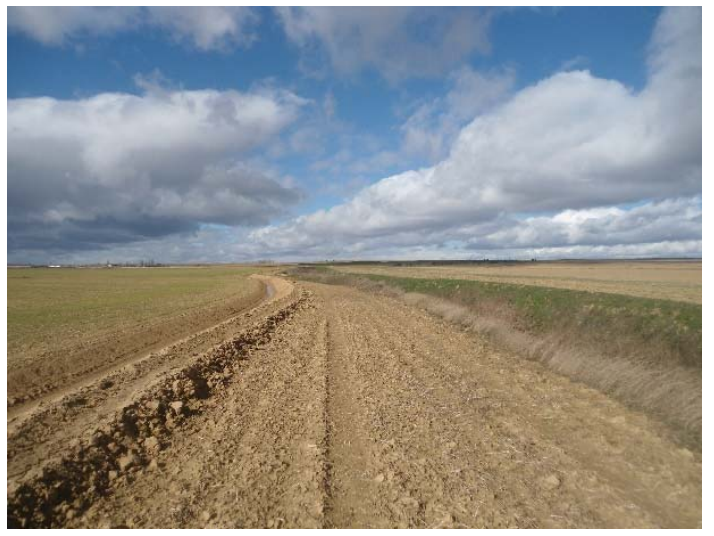

Figura A3.144. Parcela de RMN en el arroyo Berruez

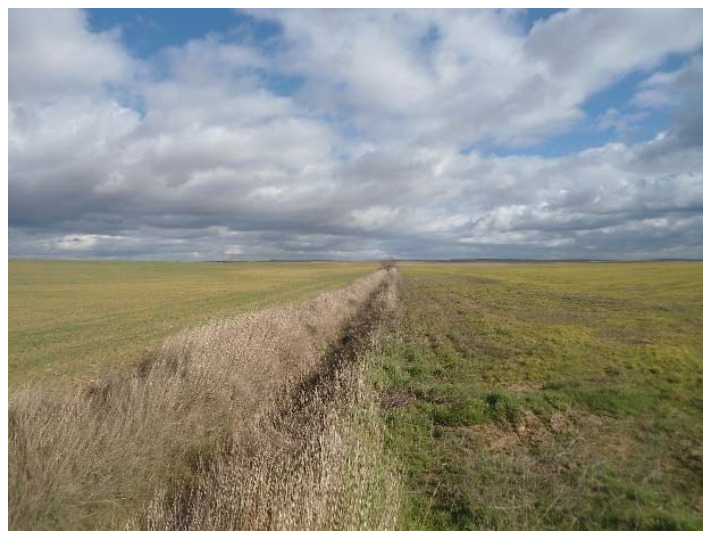

Figura A3.146. Reguera, sembrados y cielo espectacular

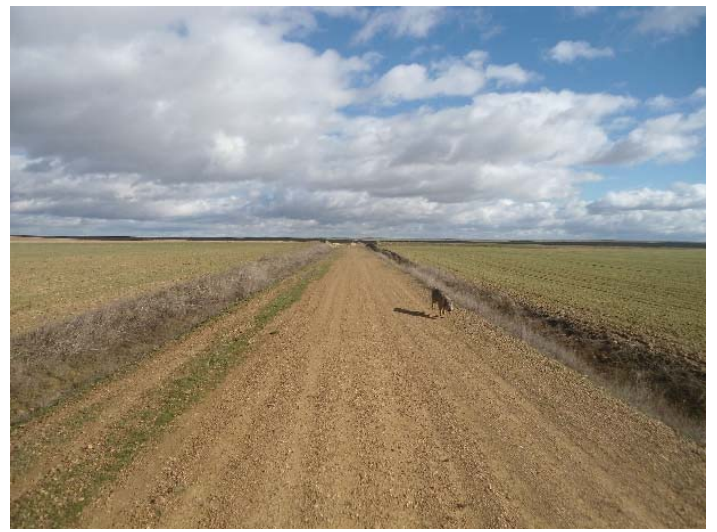

Figura A3.143. Vista primer camino

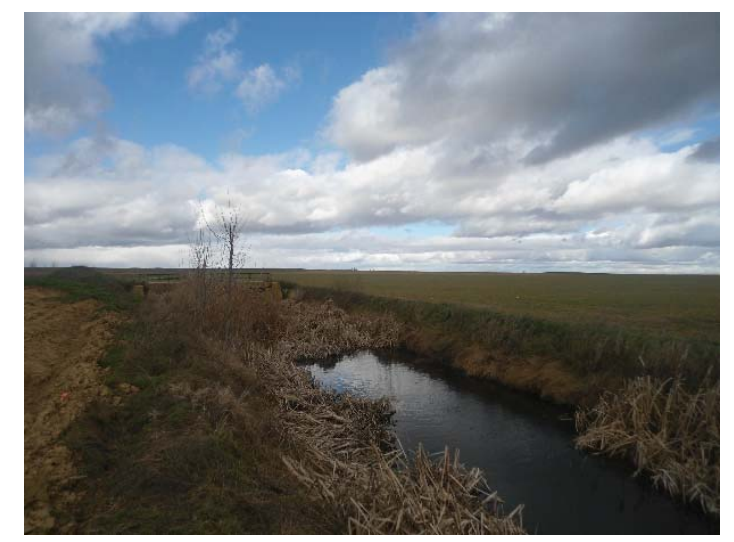

Figura A3.145. Arroyo Berruez con agua abundante

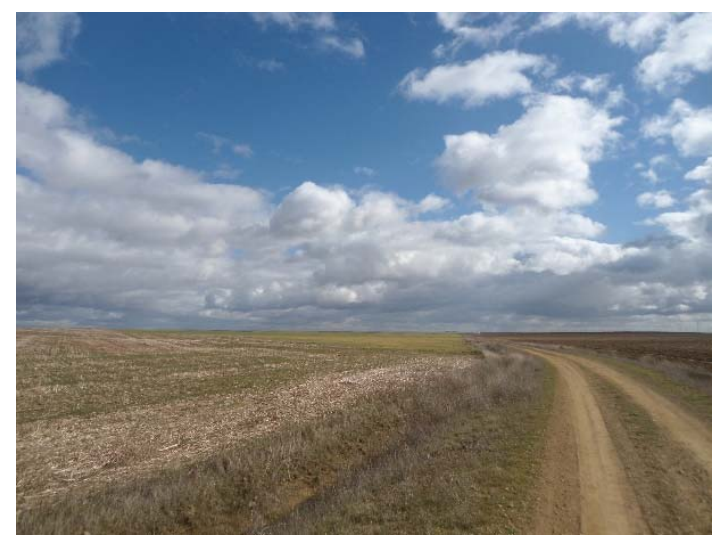

Figura A3.147. Rastrojo, camino de Villafrades y cielo 
- Fecha: 08/02/2014, 12:15 h.

- Medio: caminando.

- Itinerario: desde casco urbano, carretera nacional N-610 dirección Palencia hasta límite con término municipal de Villafrades de Campos, ida y vuelta (Figura A3.152).

- $\quad$ Longitud: $7,8 \mathrm{~km}$.

- Condiciones meteorológicas: la mayor parte del recorrido, despejado, con mucho viento. Ha llovido bastante últimamente, terreno muy húmedo.

- Características de la vía (Figura A3.155): asfalto, muy buen estado del firme. Plataforma de $9 \mathrm{~m}$ de anchura total $(1 \mathrm{~m}$ margen a cada lado y 2 carriles de 3,5 m cada uno). Mucho tráfico, con alto porcentaje de pesado.

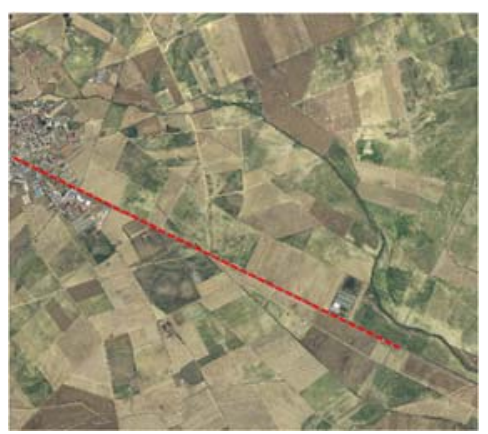

\section{CARACTERÍSTICAS DEL PAISAJE}

- Entorno inmediato de la vía: Prácticamente no se han conservado las cunetas, probablemente al arrimarse en exceso los agricultores a la plataforma. En algún tramo se ha depositado grava como drenaje y para evitar la irrupción de herbáceas. Taludes en terraplén (Figura A3.156) (>2 m: $35 \%, 1-2$ m: $60 \%,<1$ m: $5 \%$ ), pendiente media $1 \mathrm{~V}: 2,5 \mathrm{H}(22 \circ)$. Margen izquierdo en su mayoría con un tramo de $10 \mathrm{~m}$ sin labrar previsto por la concentración parcelaria para la construcción de un camino. En la margen derecha el margen es escaso. Taludes revegetados al 50 $\%$, la parte desnuda se debe a que el terraplén está construido con materiales inertes, sin posterior depósito de tierra vegetal; también posible tratamiento con herbicida.

- Espacio agrícola: dominio del color verde poco intenso del cereal nacido, con intercalaciones del marrón de los barbechos.

- $\quad$ Agua: Abundante (Figura A3.158). Al pie de los taludes se concentra bastante agua, por la inexistencia o ineficacia de las cunetas. En las obras de drenaje transversales se acumula el agua, que no corre por las longitudinales.

- $\quad$ Ruido: Molesto, como consecuencia del elevado tráfico.

- $\quad$ Olores desagradables: Puntuales; son más intensos a la salida del pueblo, por la presencia de granjas avícolas.

- Fauna: Poco perceptible. Alguna bandada de pajaritos. 2 cernícalos.

- Vegetación: Muy escasa. 2 chopos en el antiguo tramo de la vía del tren burra (Figura A3.157). Rodales de brotes de olmo, muchos secos, algún ailanto. Alguna acacia cerca del pueblo. Muy pocos arbustos (una mata de Rubus, algún Spartium junceum). Arbustos y árboles sin hojas.

- Actuaciones humanas:

o Gasolinera diseño estándar Repsol, muy llamativo (Figura A3.148).

o Almacén antiguo descuidado de cemento y teja árabe.

o Muro de ladrillo sin revestir.

o Estación de autobuses vallada, paramentos en bloques ocres y cubierta metálica rojiza.

o Dos naves de talleres mecánicos, paredes blancas y cubierta de fibrocemento.

- Era vallada ajardinada, con caseta-almacén agrícola.

o Caseta antigua de cemento y teja antigua.

- Nave agrícola de ladrillo hueco muro sin revestir, con cubierta metálica sin lacar.

o Dos depósitos altos verdes para almacén de sal para las carreteras, con valla de bloques ocres y seto de leylandi (Figura A3.149).

o Nave - taller mecánico, con paredes blancas y cubierta de fibrocemento.

o Gasolinera abandonada (Figura A3.151).

o Silo del antiguo SEMPA de $25 \mathrm{~m}$ de altura aproximadamente, muy voluminoso, pintado en color ocre. Actualmente se encuentra en desuso.

o Naves pareadas de micropolígono industrial; paredes blancas y azules y cubierta metálica azul.

o Nave almacén agrícola de cemento y cubierta de fibrocemento.

o Industria agroalimentaria; edificio de oficinas ocre y gran almacén en chapa metálica gris.

o Planta de hormigón y almacén de materiales y maquinaria (Figura A3.154).

- Granja avícola con 5 naves y otra nave clasificadora, paredes blancas y cubiertas de fibrocemento, con valla metálica (Figura A3.159).

- $\quad$ Elementos singulares:

o Edificio de influencias modernistas de principios de siglo (Figura A3.150). Paredes de ladrillo rojo a hueso, con molduras. Fue asilo de ancianos y se encuentra abandonado desde hace varias décadas. 
DEGRADACIONES DEL PAISAJE

- Impacto paisajístico severo consecuencia de un desorden urbanístico general. Mezcla descontrolada de usos. Falta de viales y otras infraestructuras básicas. Ausencia de criterios estéticos en las construcciones (especialmente importante al tratarse de la entrada del pueblo).

- Impacto visual severo de las líneas eléctricas. Hay varias, a las que hay que añadir las conexiones, transformadores, etc. Es sintomática la presencia de un apoyo en plena fachada del único edificio singular modernista de la zona.

- Impacto visual moderado de los carteles publicitarios (Figura A3.153), que al menos se concentran en un único punto.

- $\quad$ Presencia de montones de escombros (Figura A3.151), restos de la antigua carretera o residuos de diversa tipología, que ocasionan un impacto moderado.

- Impacto severo del silo de trigo, por su magnitud y altura. Además, su pérdida actual de función conlleva a convertirle en un elemento degradado permanente en el paisaje.

- Impacto visual severo del micropolígono industrial (blanco y azul llamativo), por cambio de las características visuales básicas. A pesar de tratarse de un edificio de promoción pública, se ha primado más el diseño corporativo que la integración en el paisaje de la comarca.

- Carretera totalmente rectilínea sin vegetación en sus márgenes, impacto severo.

\section{RECUPERACIONES DEL PAISAJE}

- RES 1: Pantalla visual vegetal alrededor de los depósitos de sal, formada por un seto de leylandi de unos 6 años, que ha crecido rápidamente. También se construyó un murete perimetral con bloques de hormigón ocre rústicos.

- $\quad$ PAR 1: Pequeños parterres con arbustos y flores en uno de los talleres mecánicos, situados en el margen de la carretera.

- $\quad$ PAR 2: Plantación de un seto de aligustre además de varios árboles en una era - almacén agrícola.

- PAR 3: Plantación de un olivo más otros árboles en el entorno de una nave agrícola.

- $\quad$ AHA 1: Linde de unos $30 \mathrm{~m}$, con pinos piñoneros a $3 \mathrm{~m}$ de distancia, protectores, sin cuidados. $100 \%$ de marras.

\section{RECUPERACIONES POTENCIALES}

- Urbanización de los caminos de servicio, al menos de zahorra, ya que ahora no hay continuidad.

- Limpieza periódica de los residuos; retirada de escombros a planta de reciclaje de residuos de construcción y demolición.

- $\quad$ Plantación de coníferas en los márgenes de la carretera -allí donde sea posible en las zonas públicas-, como arizónicas, cipreses, falsos cipreses, leylandi, etc., para minimizar el impacto visual de las construcciones y focalizar la imagen hacia la torre de la iglesia de San Miguel.

- Restauración del asilo y de su entorno, eliminando el apoyo de la línea eléctrica.

- Plantación de arbustos en los taludes de la carretera. En los taludes de terraplén de altura superior a $2 \mathrm{~m}$-que son numerosos- se deberían plantar árboles, pues tienen la protección de las biondas a efectos de seguridad vial. No hay que olvidar que los márgenes de esta carretera estuvieron arbolados.

- Plantación de árboles en la franja situada entre un futuro camino rural y la carretera (margen izquierda dirección Palencia).

- Retirada de los carteles que hayan caducado.

- Restauración vegetal de regueras.

- Plantaciones de diversificación en el interior de las parcelas agrícolas. 


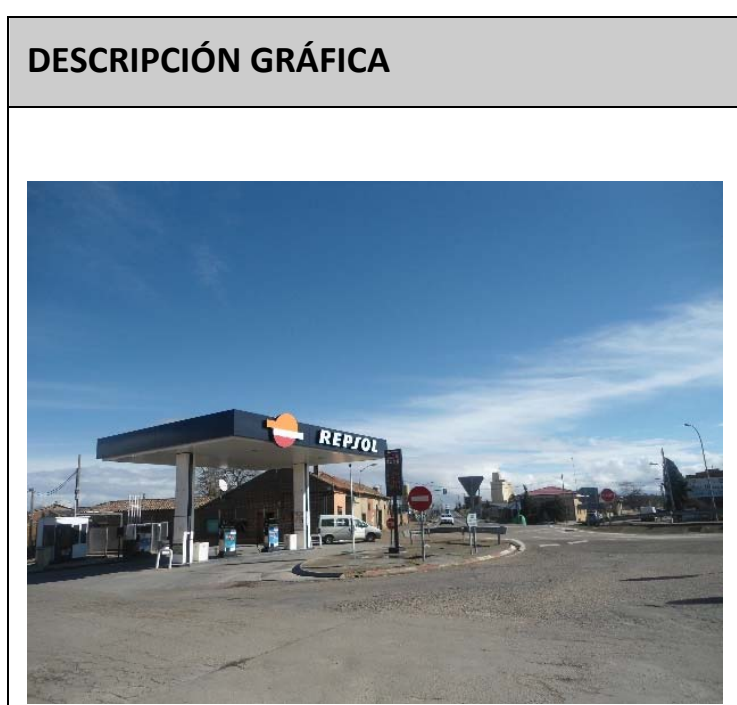

Figura A3.148. Gasolinera a la entrada del pueblo

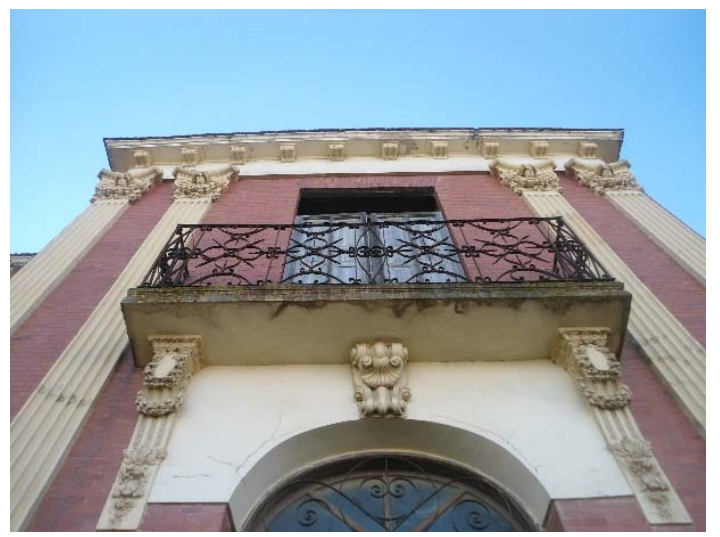

Figura A3.150. Fachada del antiguo asilo modernista

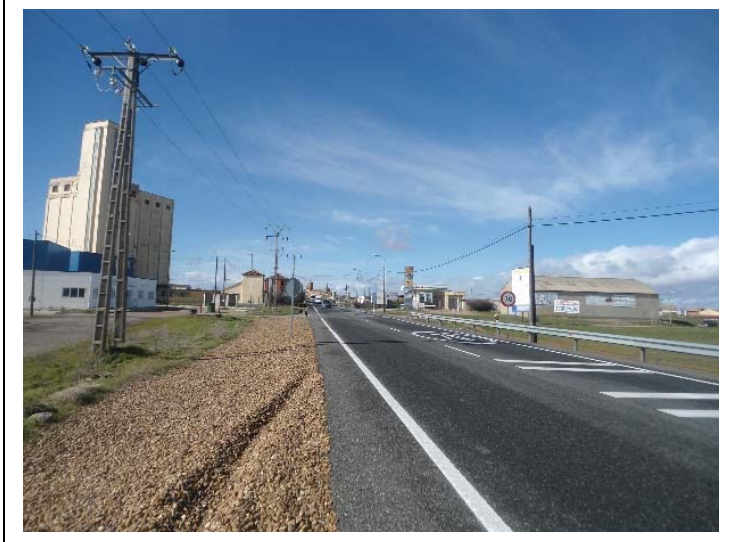

Figura A3.152. Vista general de la entrada del pueblo

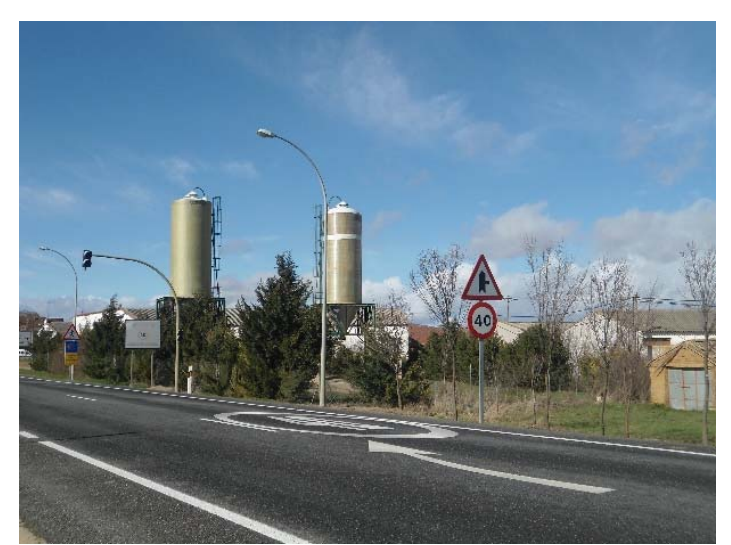

Figura A3.149. Depósitos de sal y seto de leylandi

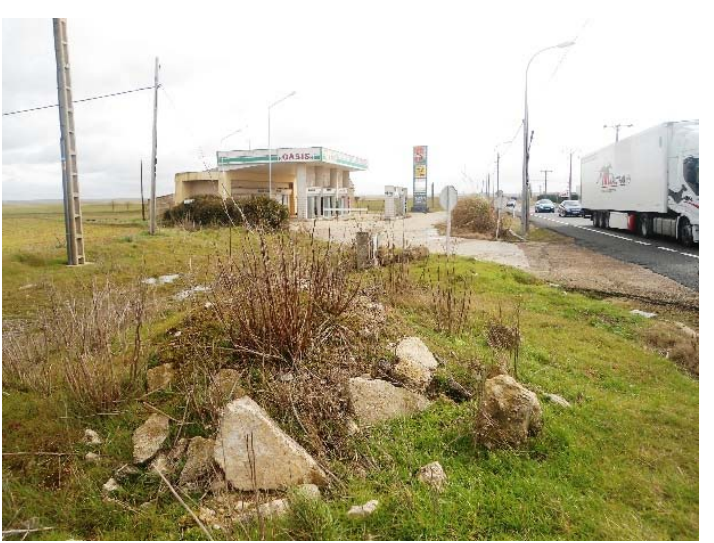

Figura A3.151. Escombros y antigua gasolinera

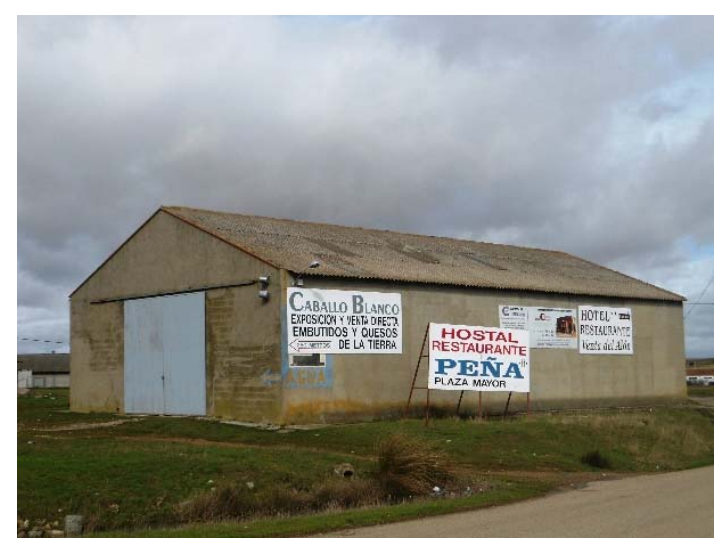

Figura A3.153. Carteles publicitarios 


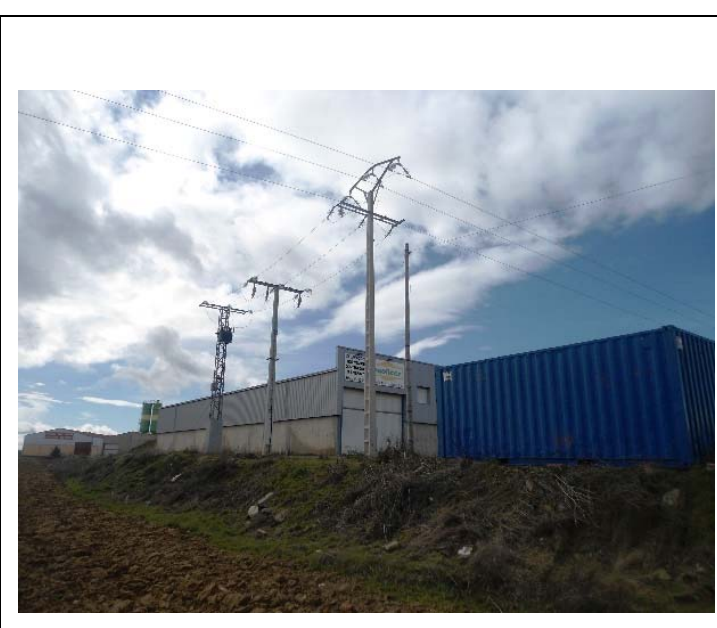

Figura A3.154. Planta de hormigón

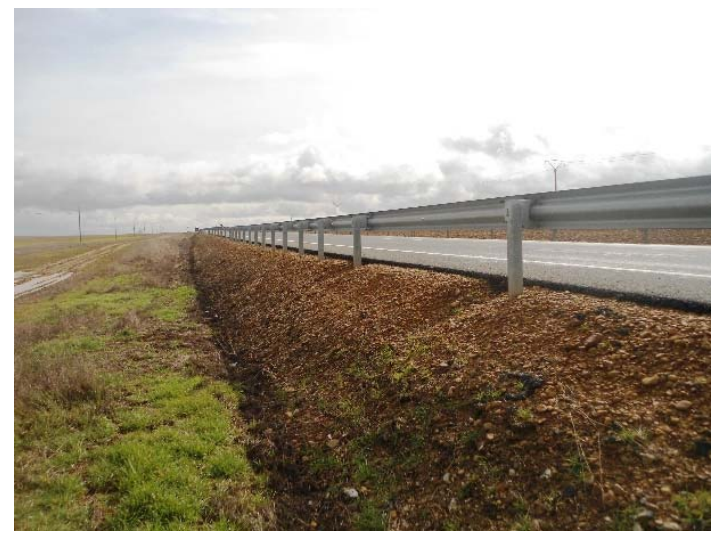

Figura A3.156. Terraplén y biondas

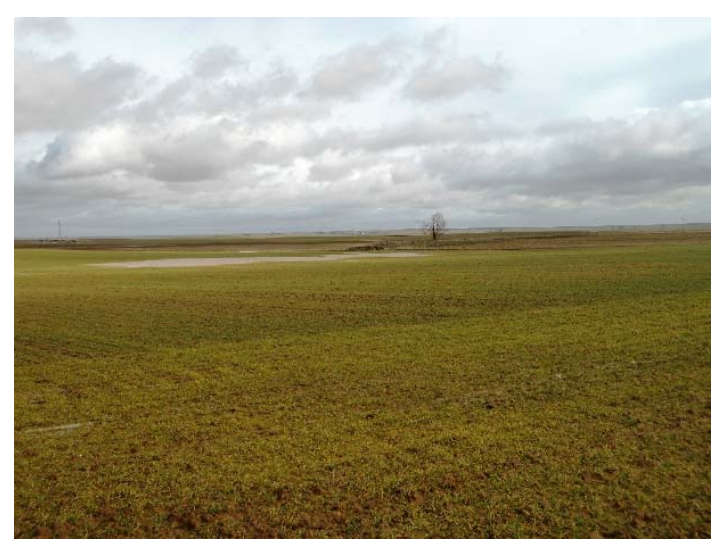

Figura A3.158. Cereal y encharcamientos

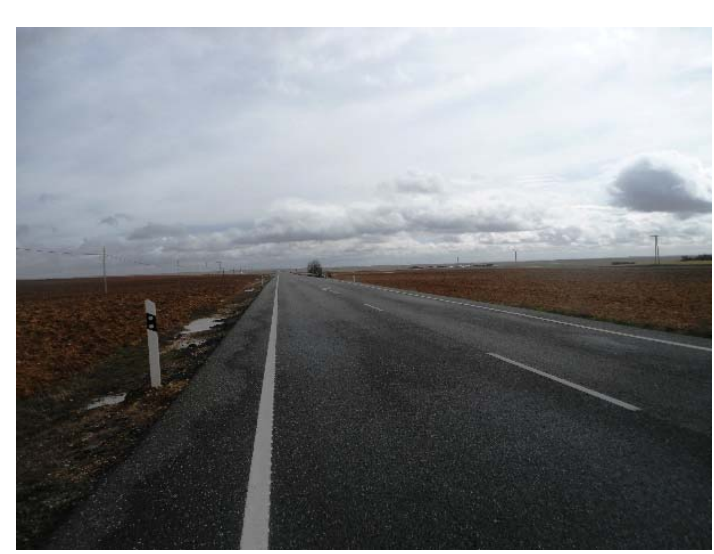

Figura A3.155. Vista de la carretera nacional

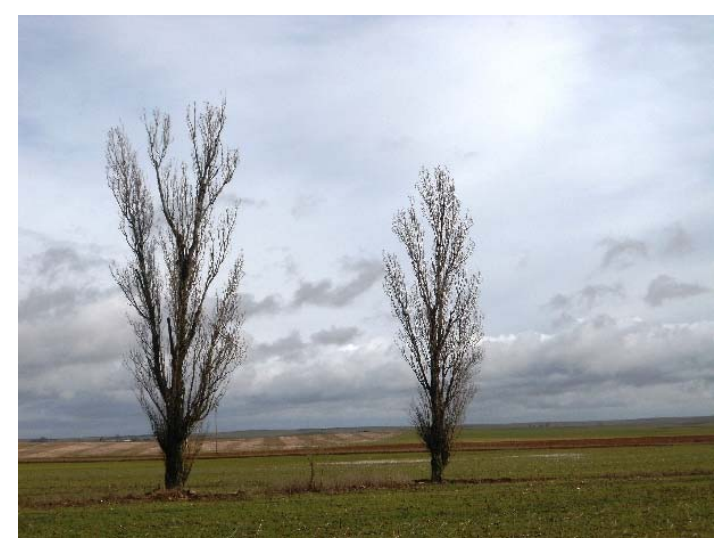

Figura A3.157. Chopos aislados en antigua vía del ferrocarril

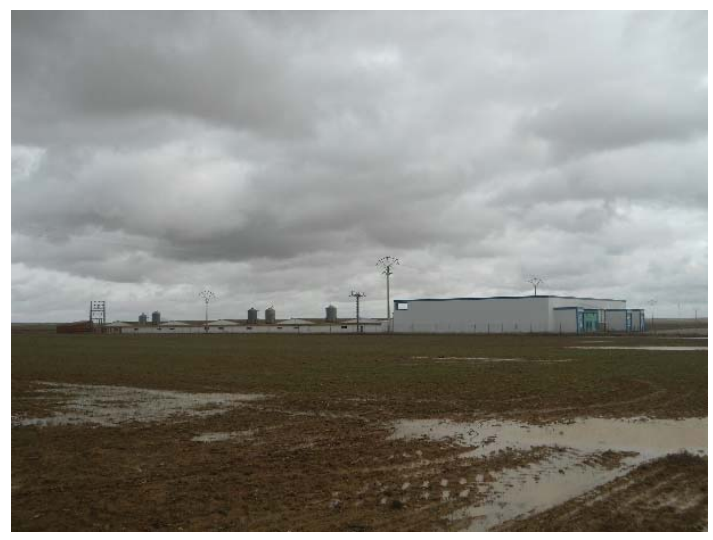

Figura A3.159. Planta clasificadora al final del término municipal 
- Fecha: 15/02/2014. 12:10 h.

- Medio: caminando.

- Itinerario: desde micropolígono industrial - camino de Gatón desvío izquierda dirección sureste - fuente Murcia - arroyo antigua vía tren burra dirección Villalón - en el punto de cruce con la carretera N-610, desvío hacia el oeste - camino de Gatón hasta punto de inicio.

- $\quad$ Longitud: 7,9 km

- Condiciones meteorológicas: Día nublado. Mucha humedad en el terreno.

- Características de la vía: En los caminos rurales, firme de zahorra en buen estado. Plataforma de $6 \mathrm{~m}$ de anchura, revegetada $1 \mathrm{~m}$ en cada margen. Antigua vía ferrocarril con bolos de zahorra o piedras calizas, con hierba cubriendo toda la plataforma (de 5-6 m de anchura).

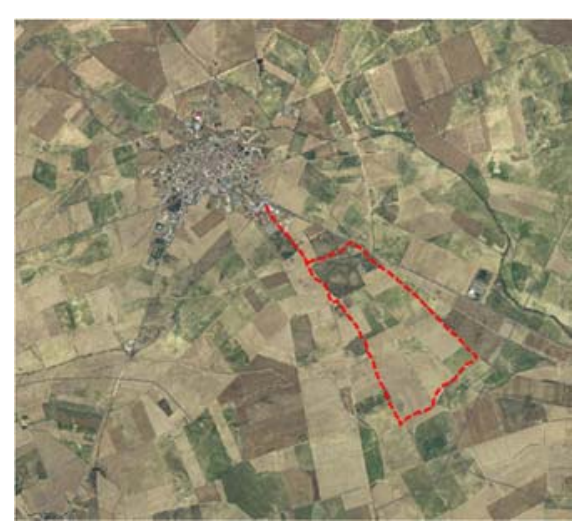

\section{CARACTERÍSTICAS DEL PAISAJE}

- Entorno inmediato de la vía: En los caminos rurales, los márgenes tienen una anchura aproximada de $2 \mathrm{~m}$ y están revegetados, salvo alguno puntual con cierta altura. Altura estimada de taludes: $>2 \mathrm{~m}=40 \%, 1-2 \mathrm{~m}=50 \%,<1 \mathrm{~m}=$ $10 \%$, con clara dominancia de los desmontes. En la antigua vía la anchura de los márgenes oscila entre $2-3 \mathrm{~m}$, están revegetados y predominan los taludes de terraplén, con alturas estimadas: $>2 \mathrm{~m}=80 \%, 1-2 \mathrm{~m}=10 \%,<1 \mathrm{~m}$ $=10 \%$.

- Espacio agrícola: Cereal nacido, leguminosas nacidas y barbecho. Domina el verde poco intenso con intercalaciones marrones.

- Agua: Presencia de agua abundante en arroyos, regueras (Figura A3.164) y pequeñas charcas en las tierras. Suelo saturado.

- $\quad$ Ruido: Inapreciable.

- Olores desagradables: Puntuales, solo en granja avícola con depósito de gallinaza.

- Vegetación: Muy escasa. Arbustos aislados (rosal silvestre, gayomba). Chopos híbridos en huerta y en antigua extracción. Toda la vegetación sin hoja.

- Fauna: Bastantes pajaritos. 2 bandadas de palomas, 5 milanos reales, 3 patos, avefrías.

- Actuaciones humanas:

o Naves industriales agroalimentarias, paredes grises y cubierta plana, todas metálicas.

- Nave cooperativa, con ladrillo de tejar antiguo y cubierta metálica roja a dos aguas.

o Líneas de alta tensión de 20 kV, con apoyos de hormigón.

- Granja avícola de 8 naves y varias instalaciones (Figura A3.161); paredes de cemento blancas y cubierta de fibrocemento a dos aguas; otra nave blanca de cemento con cubierta metálica roja; depósito de gallinaza.

o Planta de hormigón, con tolva verde y bandas amarillas, nave hormigón, caseta y parcela anexa con rellenos de residuos inertes.

o Nave agrícola, de paredes metálicas blancas, zócalo alto ocre y cubierta metálica rojiza a dos aguas.

- Vallados metálicos cercando las parcelas edificadas.

o Antigua extracción de arcilla de reducida extensión.

- Nave agrícola con paredes de cemento blancas y cubierta metálica sin lacar; huerta y diversas instalaciones (Figura A3.167).

- Granja avícola con 2 naves de paredes de cemento, blancas, y cubierta a dos aguas de fibrocemento.

- Huerta con caseta de paredes blancas de cemento y cubierta de fibrocemento.

o Huerto solar de 1,9 ha (Figura A3.166).

- Elementos singulares:

o Antigua fábrica de harinas (Figura A3.160); precioso edificio modernista de ladrillo rojo con molduras; restaurado para fábrica de queso; actualmente en desuso pero bien conservado.

o Fuente Murcia (Figura A3.165), con depósito de ladrillo macizo antiguo con arco; laguna alrededor; la concentración parcelaria ha dejado una parcela alargada de 1 ha para tener acceso desde el camino. 


\section{DEGRADACIONES DEL PAISAJE}

- Caminos excesivamente rectilíneos, sin naturalidad, impacto severo.

- Arroyos encauzados y rectificados, sin naturalidad, impacto severo.

- Desaparición de la armonía del entorno del casco urbano, como consecuencia de la construcción de numerosas edificaciones de usos dispares y formas y colores no integrados. A ello se añade la presencia asociada de tendidos eléctricos, vallados metálicos, etc. En gran medida se debe a una ausencia de urbanismo o a su falta de aplicación. Especialmente grave por tratarse de una entrada principal del pueblo. Impacto severo.

- Impacto visual por intrusión y cambio de las características visuales básicas de la gran tolva verde-amarilla de la planta de hormigón (Figura A3.162). Impacto severo.

- Presencia de depósitos puntuales de residuos y de un relleno de residuos en general inertes en el entorno de la planta citada, aunque bien remodelado topográficamente. Impacto moderado.

- Impacto visual de las cubiertas de chapa metálica sin lacar de alguna nave, moderado.

- Introducción de elementos extraños a la pauta general del paisaje, en el caso del huerto solar construido en suelo rústico, impacto severo.

\section{RECUPERACIONES DEL PAISAJE}

- $\quad$ PAR 1: Plantación antigua de frutales y de varios arizónica en una superficie aproximada de $500 \mathrm{~m}^{2}$, en situación de abandono.

- PAR 2: Plantación de chopos híbridos en antigua extracción de arcilla de unos $1.000 \mathrm{~m}^{2}$. Se conservan $10-12$ en deficiente estado. Algunos afectados por realización de cunetas.

- PAR 3: Plantación de chopos castellanos alineados en el entorno de granja avícola. Unos 25 años de edad, desmochados pero relativamente en buen estado.

- $\quad$ PAR 4 (Figura A3.163): Plantación de chopos híbridos en parcela de 1 ha aproximadamente; en torno a 20 años de edad; muy mal estado salvo los que se encuentran en la reguera. Frutales variados en $300 \mathrm{~m}^{2}$, en buen estado. Plantación de pino piñonero en $360 \mathrm{~m}^{2}$, marco de $3 \times 3 \mathrm{~m}$, con protectores de malla metálica, realizado alcorque, herbicida alrededor, $0 \%$ de marras .

- AHA 1: Alineación de pino piñonero en $50 \mathrm{~m}$ al lado de antigua vía, marco $3 \times 3 \mathrm{~m}$, protector de malla metálica, riego por goteo con pequeño depósito, $50 \%$ de marras.

- $\quad$ AHA 2: Pequeño cuadro de $10 \mathrm{~m}^{2}$ en una esquina de parcela, con 2 pinos piñoneros, malla, separados $4 \mathrm{~m}, 0 \%$ de marras.

- $\quad$ AHA 3 (Figura A3.167): Superficie rectangular de $360 \mathrm{~m}^{2}$, pino piñonero, marco 3x3 m, malla metálica protectora, situados al lado de una nave agraria, $0 \%$ de marras.

\section{RECUPERACIONES POTENCIALES}

- Restauración vegetal de taludes de caminos.

- Restauración vegetal de regueras.

- Plantaciones de diversificación en el interior de las parcelas agrícolas.

- Primer tramo del camino con naves y diversas construcciones: plantación de árboles a ambos lados en cuneta desmonte, que es alta. Preferiblemente coníferas para servir de pantalla, por ejemplo arizónicas.

- Parcela asociada a la fuente Murcia: plantación de arbustos en linde. Plantación de frondosas de ribera en zonas próximas a la reguera y alrededor de la pequeña laguna. Plantación de árboles para zonas secas aguas arriba de la fuente, hacia el camino.

- Antigua vía del ferrocarril: Mantenimiento de la continuidad con la realización de pequeños puentes, a base de madera o de tableros de hormigón en acabado terroso. Adecuación de plataforma con zahorra y gravilla fina. Plantación de árboles a ambos lados al pié de los taludes, con especies de zonas secas o húmedas según estado del terreno. 


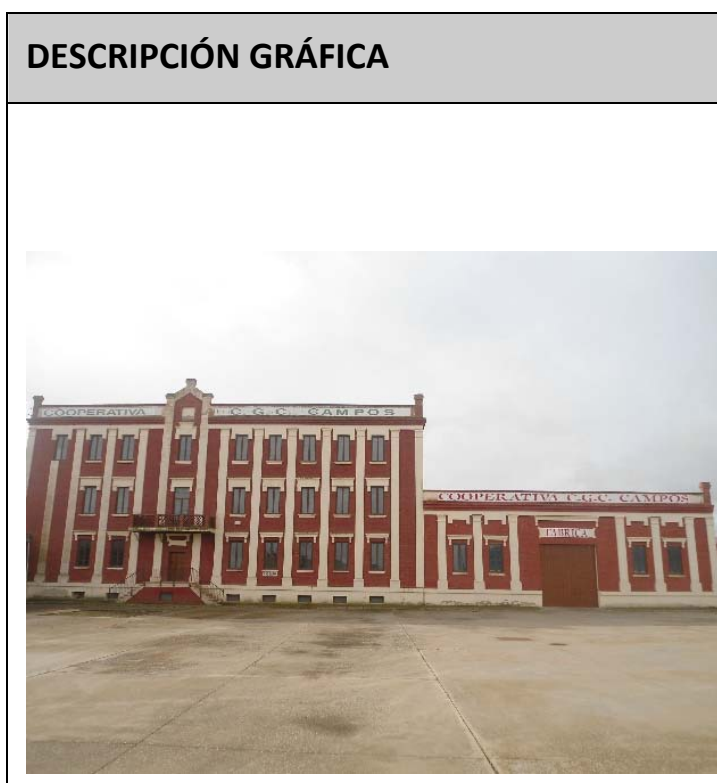

Figura A3.160. Antigua fábrica de harinas

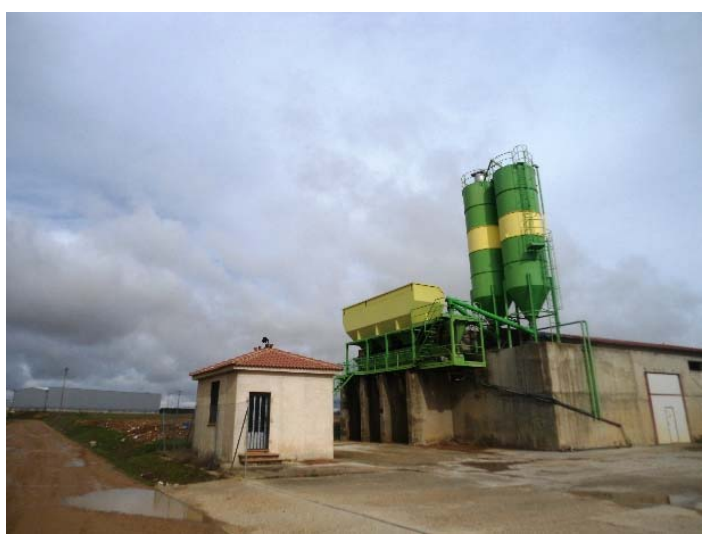

Figura A3.162. Tolvas de la planta de hormigón

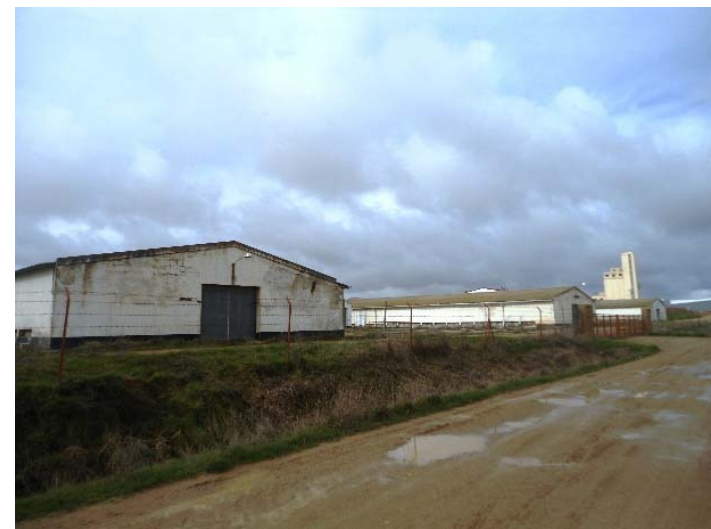

Figura A3.161. Construcciones ganaderas cerca del pueblo

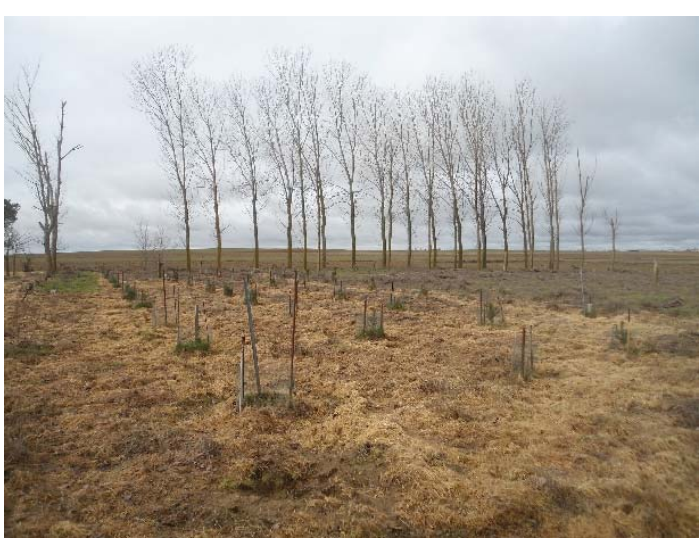

Figura A3.163. Plantaciones de PAR 4 


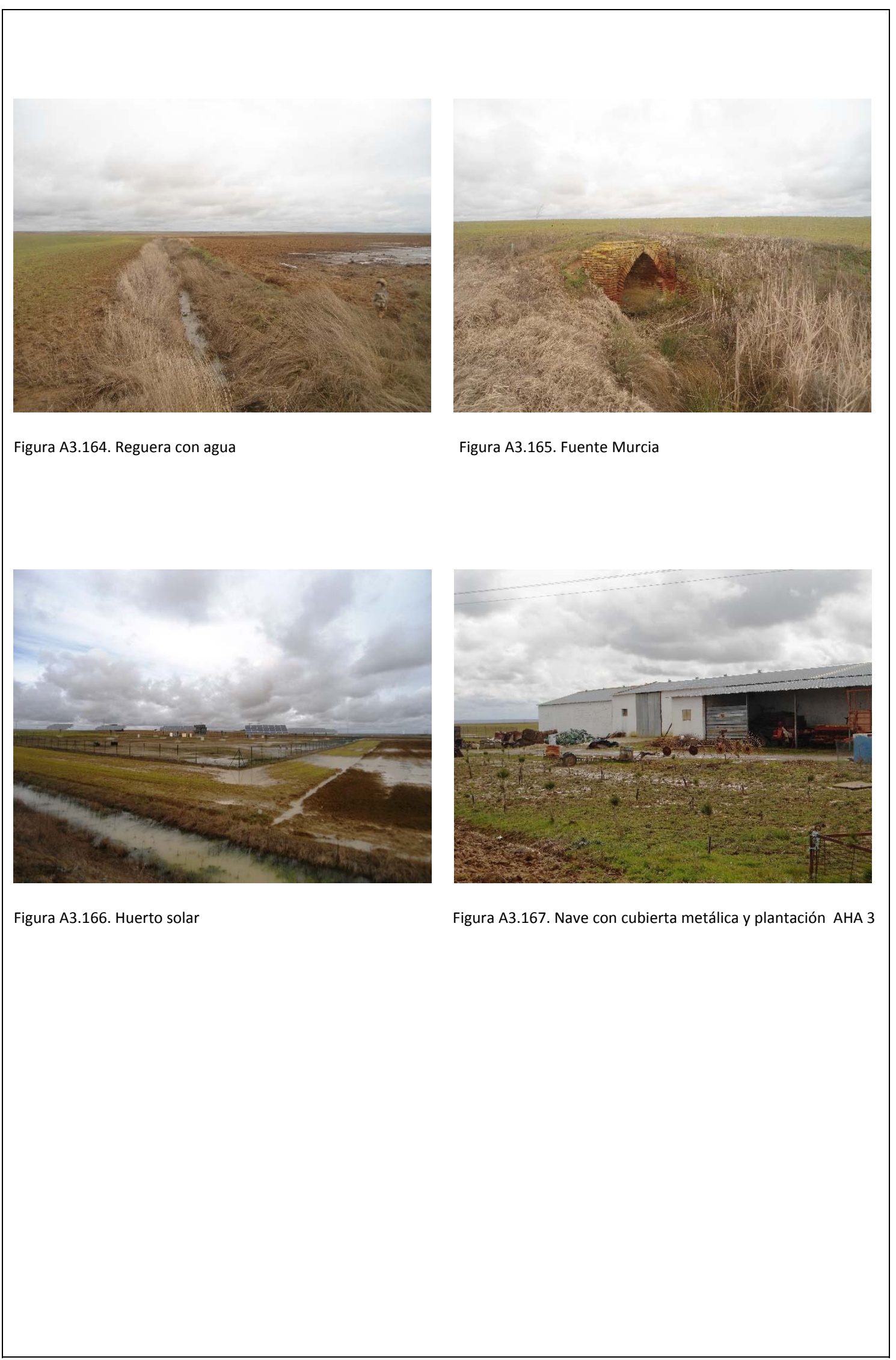




\section{RECORRIDO: Camino de Villabaruz y fuente el Toro}

- Fecha: 22 de febrero de 2014, 11:30 h.

- Medio: caminando.

- Itinerario: desde huerta de Hilario - camino Villabaruz - camino Cuenca - fuente el Toro - punto inicial.

- $\quad$ Longitud: $6,4 \mathrm{~km}$

- Condiciones meteorológicas: Cielo con nubes y claros espectacular (Figura A3.169).

- Características de la vía: Zahorra. Buen estado del firme. $6 \mathrm{~m}$ de plataforma. Está revegetado con herbáceas $1 \mathrm{~m}$ a cada lado y 0,3 $\mathrm{m}$ en el centro (Figura A3.172).

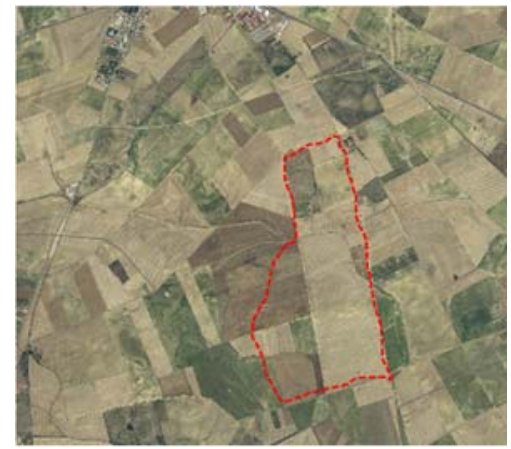

\section{CARACTERÍSTICAS DEL PAISAJE}

- Entorno inmediato de la vía: $2 \mathrm{~m}$ de cuneta a cada lado del camino. Revegetadas con herbáceas. Altura estimada taludes: $>2 \mathrm{~m}=0 \%, 1-2 \mathrm{~m}=80 \%,<1 \mathrm{~m}=20 \%$, predominando los de desmonte.

- Espacio agrícola: No hay cambios respecto a anteriores recorridos. En particular, se constata que la siembra directa, al mantener el rastrojo, favorece los tonos ocres durante más tiempo (Figura A3.171).

- Agua: Presencia de abundante agua en cunetas, charcas y circulando por los arroyos (Figura A3.168).

- Ruido: Inapreciable.

- Olores desagradables: Inexistentes.

- Vegetación: No hay presencia de árboles, ni prácticamente de arbustos. Una pequeña linde de gayomba.

- Fauna: 42 avutardas en tres grupos, 2 patos, 2 milanos reales, 1 aguilucho.

- Actuaciones humanas:

o Pequeño huerto vallado con todo tipo de materiales.

- Elementos singulares:

o Fuente el Toro, con depósito de ladrillo macizo (Figura A3.170). No tenía entrada desde camino, por lo que se ha dejado una parcela de 1 ha en la concentración parcelaria. No hay vegetación.

\section{DEGRADACIONES DEL PAISAJE}

- Caminos excesivamente rectilíneos, sin naturalidad, impacto severo.

- $\quad$ Arroyos encauzados y rectificados, sin naturalidad, impacto severo.

- Impacto visual, aunque moderado, por la presencia de elementos artificiales (uralitas, alambres, somieres, etc.) en pequeña huerta.

- Presencia puntual de residuos de antiguas obras de fábrica de hormigón. 


\section{RECUPERACIONES DEL PAISAJE}

- $\quad$ AHA 1: Superficie $1100 \mathrm{~m}^{2}$ rectangular. Pino piñonero. Marco 3x4 m. Protectores botellas de plástico. Sin cuidados culturales. $50 \%$ marras.

- $\quad$ AHA 2 (Figura A3.173): Superficie triangular de $25 \mathrm{~m}^{2}$. Pino piñonero. Marco $2.5 \times 2.5 \mathrm{~m}$. Protectores. Sin cuidados culturales. $50 \%$ marras.

\section{RECUPERACIONES POTENCIALES}

- Restauración vegetal de taludes de caminos.

- Restauración vegetal de regueras.

- $\quad$ Plantaciones de diversificación en el interior de las parcelas agrícolas.

- Retirada de materiales de vallado de la huerta y colocación de valla más uniforme e integrada en el paisaje.

- Fuente el Toro: Restaurar fuente. Plantación de especies para zonas secas en parcela.

- Retirada de residuos de construcción y demolición a planta de tratamiento.

- Plantación de dos parcelas de restauración del medio natural (concentración parcelaria) con especies para zonas húmedas. 


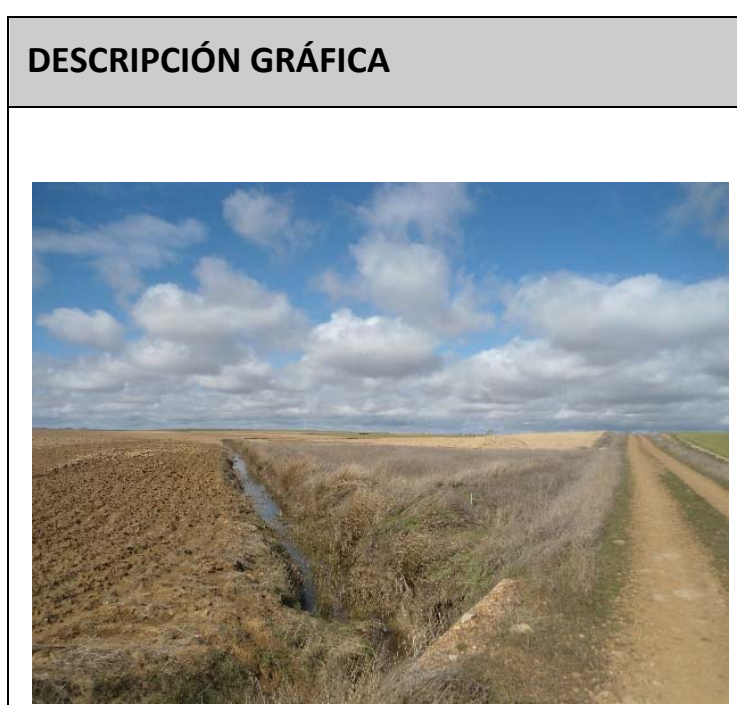

Figura A3.168. Reguera y parcela de restauración del medio natural.

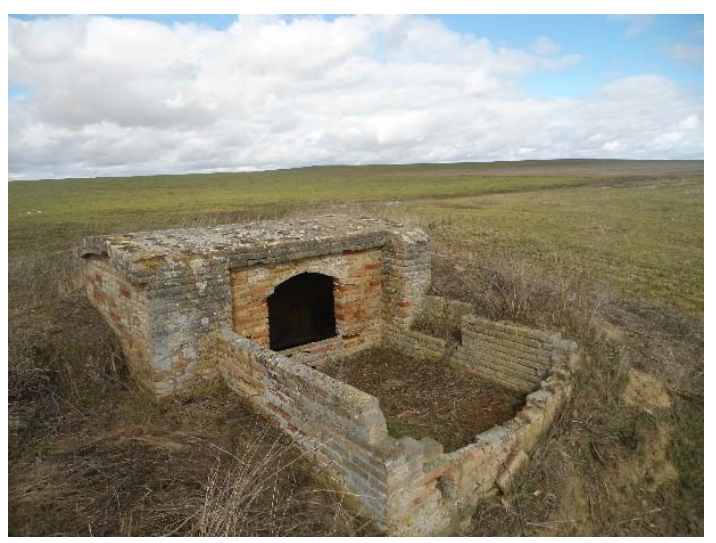

Figura A3.170. Fuente el Toro

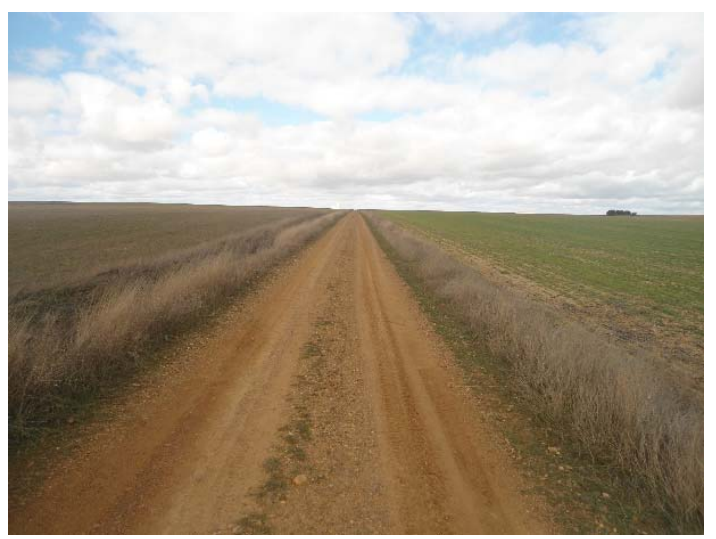

Figura A3.172. Vista de un camino

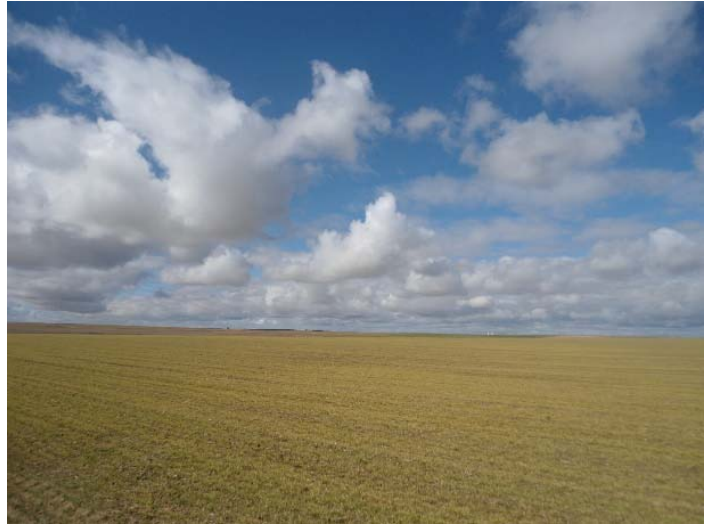

Figura A3.169. Paisaje general con nubes espectaculares

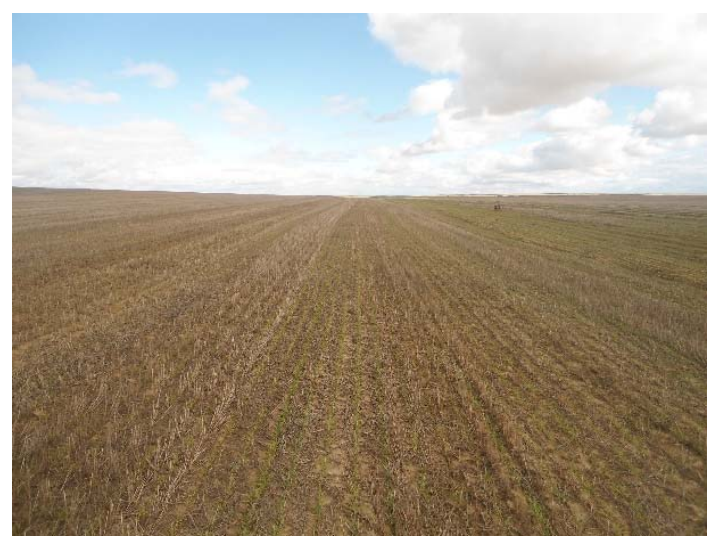

Figura A3.171. Siembra directa nacida

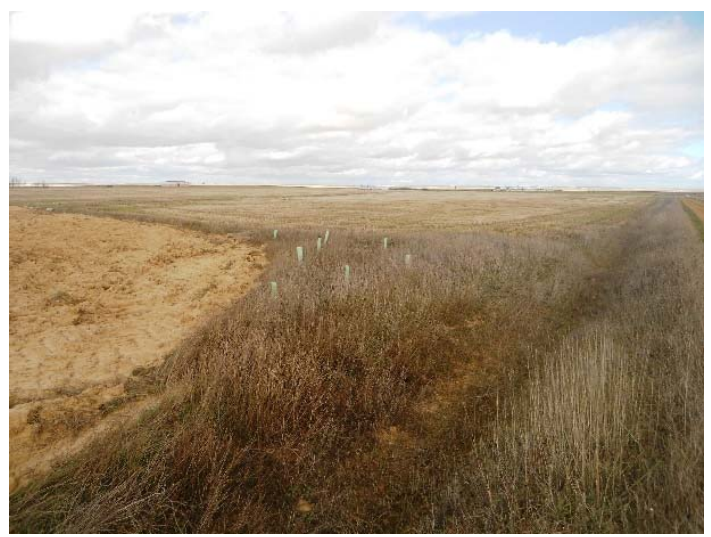

Figura A3.173. Árbol por ha AHA 2 
- Fecha: 8 de marzo de 2014. 12:10 h.

- Medio: Caminando.

- Itinerario: Se trata de una ruta circular que puede iniciarse por cualquier punto e incluso recorrerse en ambos sentidos. Se incluye la plaza mayor, ya que desde aquí se puede acceder a varios puntos de la ruta. En este caso, consideraremos el siguiente inicio: plaza Mayor - C) Marceliano Serrano - restos de la antigua muralla $-\mathrm{C}$ )

Sahagún - arroyo Pajarillas - huerta del Moral - picón de las acacias - parque de

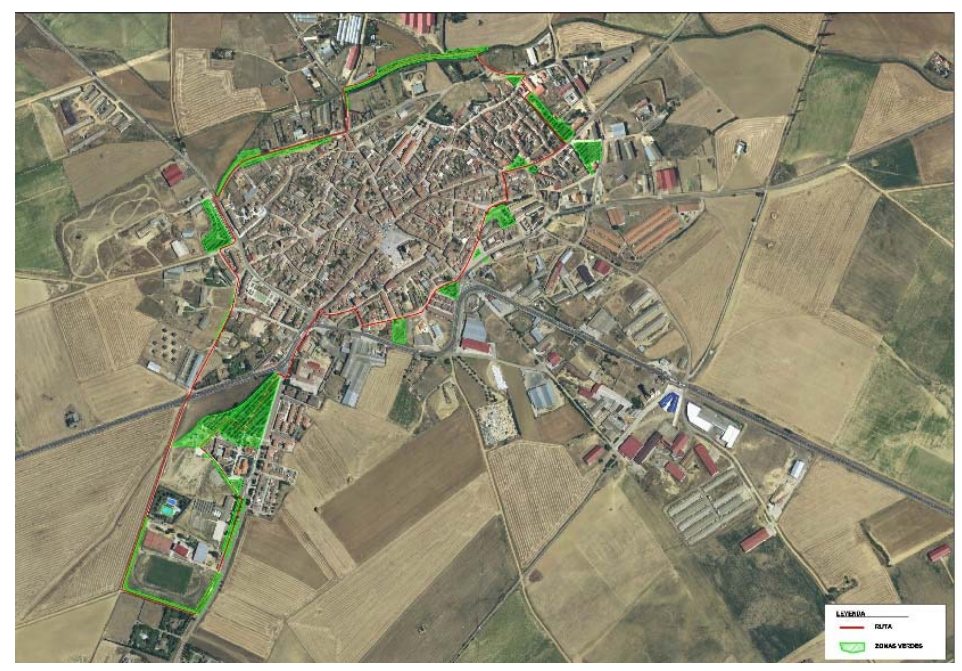
la reguera del Tinte - parque de la laguna del Tinte - C) Constitución - plaza de San Juan - casas de la Pedrera plaza de San Miguel - casas del convento - era del depósito - C) Gaspar Grajal - cruce con ctra. nacional - avda. del Parque - cruce con ctra. de Valladolid - parque del Paseo - parque temático - instituto - polideportivo - camino alrededor campo de fútbol - camino de la piscina - cruce con ctra. nacional - parque de San Pedro - paseo de Barrios - restos de la antigua muralla.

- $\quad$ Longitud: $4,5 \mathrm{~km}$

- Condiciones meteorológicas: Totalmente despejado.

- Características de la vía: El recorrido por las zonas más urbanas discurre por calles de hormigón, en regular estado de conservación, pero adecuadas para el tránsito de viandantes. Hay un porcentaje también alto de trayecto por caminos asfaltados, en general en buen estado. Hay algún tramo (avda. del parque y parque del Paseo), donde la vía está bien adoquinada. Puntualmente, existe un pequeño tramo con una senda en tierra, entre la entrada al polideportivo y el camino del campo de fútbol.

\section{CARACTERÍSTICAS DEL PAISAJE}

- Entorno inmediato de la vía: ver fichas anteriores.

- Espacio agrícola: No hay cambios respecto a anteriores recorridos.

- Agua: Presencia de agua en arroyo Pajarillas. Algunas zonas encharcadas.

- Ruido: Puntual en la carretera nacional.

- Olores desagradables: Inexistentes.

- Vegetación: Características invernales, pequeños cambios respecto a fichas anteriores. Las frondosas se mantienen con las hojas totalmente caídas; con ello se destaca el papel diversificador de las coníferas.

- $\quad$ Fauna: Muchos pajaritos a lo largo de todo el recorrido. Presencia abundante de palomas, así como de varias cigüeñas, con nidos en la iglesia de San Juan y en el Depósito.

- Actuaciones humanas: ver fichas anteriores.

- Elementos singulares: ver fichas anteriores. 
DEGRADACIONES DEL PAISAJE

$>\quad$ Ver fichas anteriores

\section{RECUPERACIONES DEL PAISAJE}

$>\quad$ Ver fichas anteriores

\section{RECUPERACIONES POTENCIALES}

- $\quad$ Parterres de la plaza Mayor

- Plantación de 4 Chamaecyparis lawsoniana en los huecos

o Plantación de coníferas y aromáticas en la zona alta

o Reparación de fuente

o Colocación de panel de la ruta de los parques

- Calles de la Rúa y Constitución

o Colocación de jardineras móviles con boj, para evitar aparcamientos y dar continuidad a la ruta de los parques

- Ribera del arroyo Pajarillas

o Arreglar puente El Cojo y pintar (ocre/verde oscuro/gris oscuro)

o Segar $2 \mathrm{~m}$ de anchura en ribera

o Reponer aproximadamente 10 chopos castellanos

- $\quad$ Paseo de la huerta del Moral

o Limpieza de residuos

o Plantación de aprox. 10 morales

- Picón de las acacias

o Colocación de panel de las fuentes

- $\quad$ Parque de la reguera del Tinte (primer tramo) (Figura A3.174)

o Gradeo del terreno

o Retirada de escombros de mayor tamaño

o Siembra de herbáceas rústicas

o Plantación de arizónicas en valla metálica, como pantalla visual

o Plantación de árboles a un marco de $5 \times 5 \mathrm{~m}$, con mezcla de coníferas y frondosas

o Delimitación con algún bordillo, para que no aparquen los coches (posibilidad de utilizar piedras de la estación). Posible complemento con algún cartelito de no aparcar.

o Colocación de algún banco

- $\quad$ Parque de la laguna del Tinte o laguna de San Juan

o Colocación de algún banco

o Plantación de 6 coníferas para diversificar

- Rincón de San Francisco

- Parque de la plaza de San Juan

o Reparar la fuente, eliminando la pintura

o Plantación de aprox. 5 cipreses en alineación (Figura A3.175)

o Plantación de aromáticas en pequeños rodales

- $\quad$ Parterres de la Pedrera (de Oriente)

- $\quad$ Parque de la laguna de la Pedrera o de San Miguel

o Reparar y pintar bancos

o Arreglar fuente

o Reponer 5 chopos boleanas en alineación cada 5-6 m 
- $\quad$ Parterres de la laguna

o Plantación de aromáticas

- $\quad$ Picón de los cuartos de San Miguel

o Plantación de 3 frondosas en parterre del otro lado de la carretera

- $\quad$ Parque del hospital de San Roque

o Pintar valla metálica (gris oscuro/verde oscuro)

- $\quad$ Era del Depósito (Figura A3.176)

o Gradear terreno alrededor del depósito

o Sembrar con herbáceas rústicas

- Plantación de arbustos/aromáticas en vallas y límite con edificaciones

- Jardines del Colegio

- Adecuar parterres de la carretera nacional

o Plantación de aromáticas

o Homogeneizar color vallas a gris oscuro

- $\quad$ Parque del Paseo

o Colocación de panel de la ruta de los parques

- Parque temático del Pan y el Queso

o Adecuar tramo de sendero con zahorra fina y bordillos

o Plantación de fila de arbustos y álamos en valla metálica (Figura A3.177)

o Reposición de marras con aprox. 6 coníferas

- $\quad$ Paseo de la Residencia

o Reponer 8 coníferas en parterre

- $\quad$ Paseo del Instituto

- Plantación de chopos castellanos a lo largo de toda la valla en el interior del recinto

- Jardines del Polideportivo

o Adecuar sendero y delimitarlo, desde la entrada por la derecha del edificio

o Reponer alguna conífera

- Plantar plátanos en los huecos que faltan y en el límite Sur, para dar sombra

o Colocación cartel prohibido vehículos hacia el frontón

o Delimitación rústica de aparcamientos piscina (Figura A3.178)

- Paseo del campo de fútbol

o Adecuación de tramo de camino, con extendido de gravilla y realización de cuneta

o Plantación de arbustos a lo largo de toda la valla metálica, por el exterior (Figura A3.179). Distribución de especies por rodales (p.e. de 10 en 10). Marco $3 \times 3 \mathrm{~m}$.

o Plantación de árboles en alineación paralela donde falten, con marco 5x5 m.

o Delimitación de aparcamientos.

- Jardines de las piscinas

- Camino de las piscinas

o Plantación de frondosas en alineación paralela al camino exterior (marco 5x5 m)

o Adecuación de camino desde parque temático hasta camino exterior, con trazado irregular Extensión de zahorra y gravilla, realización de cunetas y posible plantación de árboles en alineación

- Parque de la laguna de San Andrés o de San Pedro

o Plantación de alguna frondosa de diversificación

- Paseo de Barrios

o Plantación de chopos castellanos en las faltas del arroyo Pajarillas ( $5 \times 5 \mathrm{~m})$

o Plantación de álamos en picón entre arroyo y carretera $(5 \times 5 \mathrm{~m})$

o Reposición de alguna falta en alineación (plátanos o fresnos)

o Gradeo, limpieza de residuos y siembra de herbáceas rústicas en franja paralela a la carretera. Delimitación rústica, con piedras o similar

- Partidas generales

o Limpieza de residuos

o Colocación de carteles en cada parque $(1-2$, visible por cada cara)

- Colocación de papeleras

- Colocación de carteles de "Mantén limpia la ruta de los parques" o similar

o Señalización de toda la ruta: postes de madera bajos con indicación y marcas de pintura numerosas a lo largo de todo el recorrido (verdes)

o Señalización de otros itinerarios que surjan a partir de la Ruta de los parques (Ermita de Fuentes, fuente del Rosario, fuente de San Salva, Vía Verde, etc.) 


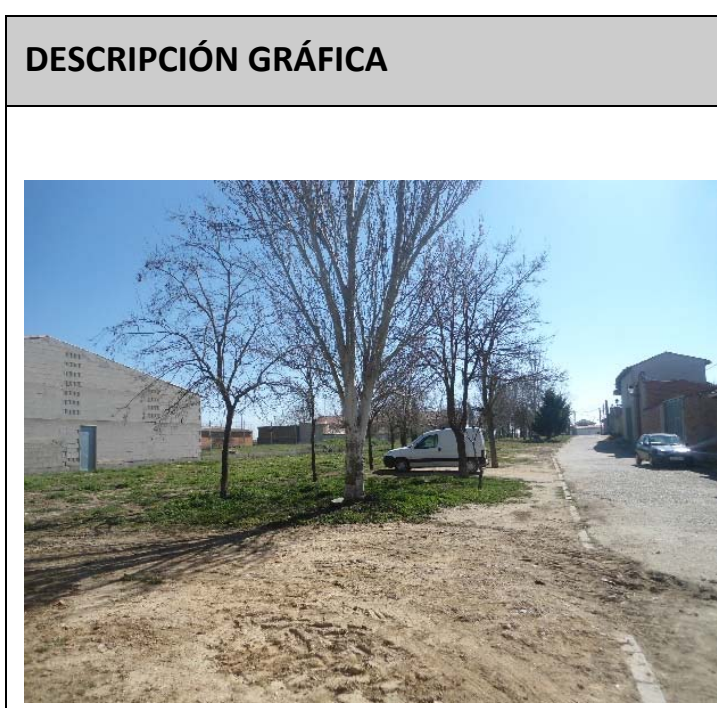

Figura A3.174. Parque reguera del Tinte, tramo a restaurar

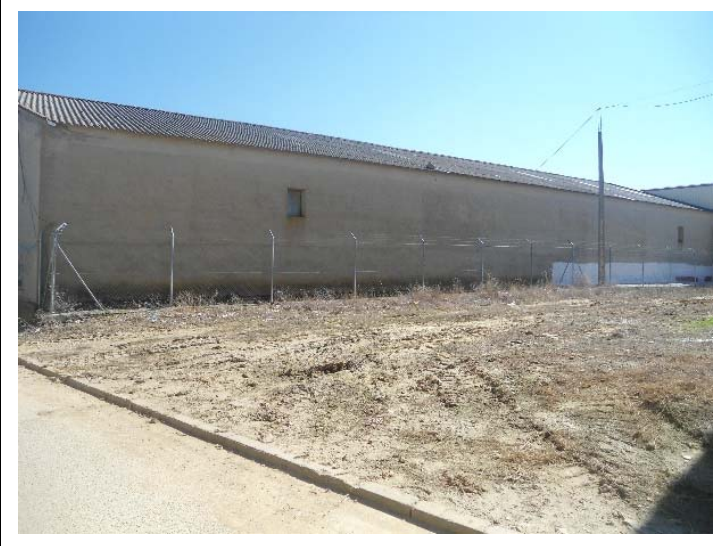

Figura A3.176. Lateral de la era del Depósito

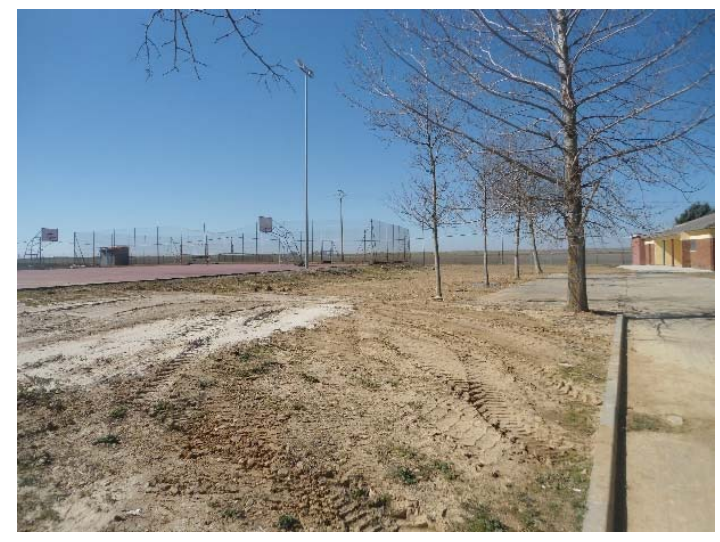

Figura A3.178. Zona aparcamientos piscina

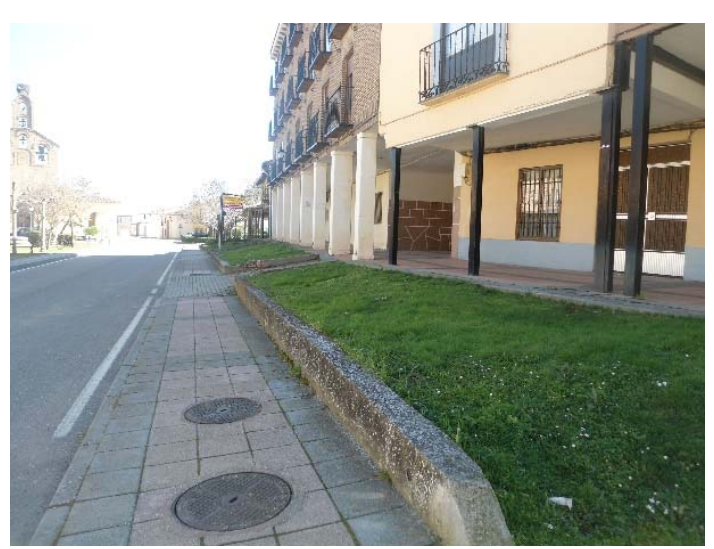

Figura A3.175. Parterres de la plaza de San Juan

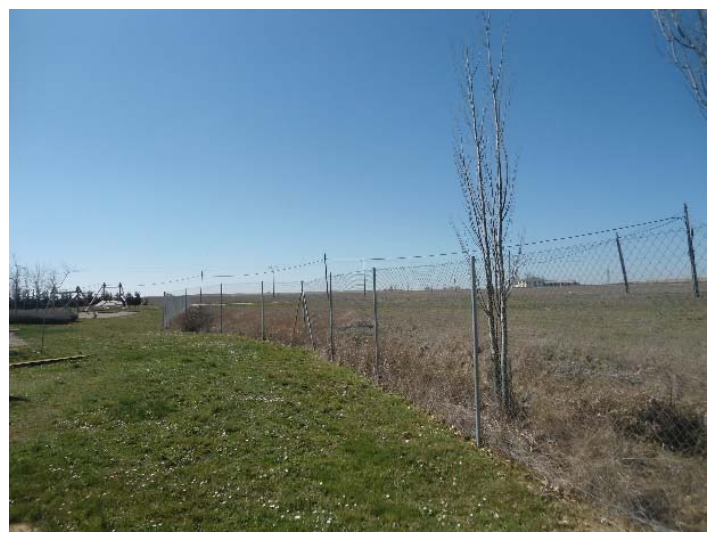

Figura A3.177. Valla metálica en Parque temático

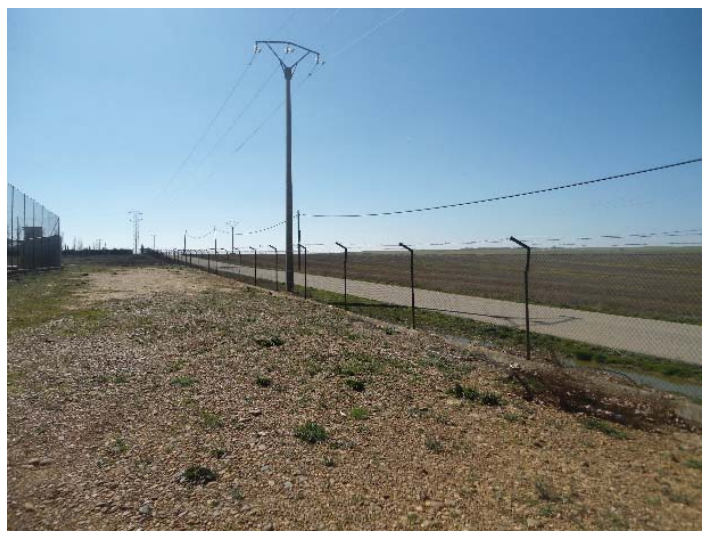

Figura A3.179. Valla metálica en Paseo del campo de fútbol 


\section{RECORRIDO: Camino de Villabaruz y Vía verde}

- Fecha: 15 de marzo de 2014, 12:30 h

- Medio: caminando.

- Itinerario: desde $\mathrm{CN}-610$, camino Villabaruz, cruce Vía verde, cruce nuevo camino circunvalación, desvío derecha camino dirección Cuenca hasta su final, cruce arroyo de los Molinillos, campo a través derecha, Vía verde, punto de inicio.

- Longitud: $6 \mathrm{~km}$.

- Condiciones meteorológicas: Totalmente despejado. El terreno ha oreado un poco después de varios días de sol y viento.

- Características de la vía: Camino de Villabaruz con zahorra de canto suelo, desagradable para caminar; $6 \mathrm{~m}$ de anchura de plataforma, con $1 \mathrm{~m}$ revegetado a cada lado. Camino dirección Cuenca en tierra, adecuado para pasear pero produce polvo; también de $6 \mathrm{~m}$ de anchura y

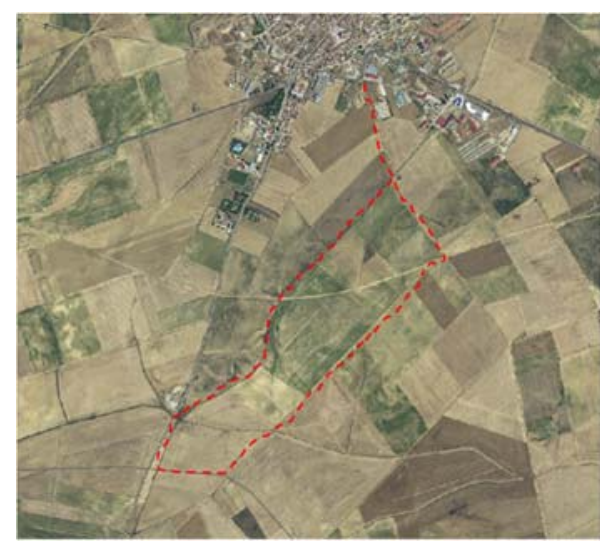
revegetados $1 \mathrm{~m}$ a cada lado. Vía verde de $4 \mathrm{~m}$ de plataforma, con zahorra y gravilla fina, firme muy adecuado para caminar (no admite vehículos a motor); $1 \mathrm{~m}$ revegetado a cada lado, se ha tratado recientemente con herbicida. Además de vía verde, su traza coincide con el Camino de Santiago de Madrid.

\section{CARACTERÍSTICAS DEL PAISAJE}

- Entorno inmediato de la vía: En el caso de los dos caminos, la anchura media de las cunetas es de $2 \mathrm{~m}$, encontrándose revegetadas; la altura media de los taludes es $>2 \mathrm{~m}=15 \%, 1-2 \mathrm{~m}=40 \%,<1 \mathrm{~m}=45 \%$, siendo todos de desmonte. En la vía verde, la anchura media de las cunetas es de $1 \mathrm{~m}$, estando revegetadas; la altura estimada de los taludes es $>2 \mathrm{~m}=50 \%, 1-2 \mathrm{~m}=30 \%,<1 \mathrm{~m}=20 \%$, estando repartidas al $50 \%$ desmonte y terraplén.

- Espacio agrícola: Tanto el cereal como, sobre todo, las leguminosas, tienen un mayor verdor, que es el color dominante. Se ven varios tractores esparciendo herbicida (Figura A3.182) y abono mineral. Los barbechos se van preparando para la siembra del girasol.

- Agua: No hay encharcamientos, pero el agua fluye todavía por los caminos.

- Ruido: Inapreciable.

- Olores desagradables: Puntuales a la salida del pueblo; dos estercoleros en el recorrido.

- Vegetación: Prácticamente no hay árboles ni arbustos (salvo en la vía verde); varios chopos y un sauce en el arroyo de los Molinillos.

- Fauna: Bastantes pajaritos, más en las leguminosas y en los árboles de la vía verde. 1 cigüeña y 4 milanos reales.

- Actuaciones humanas:

o Era con valla metálica, caseta ocre y teja árabe, frutales en el perímetro y pequeña huerta.

o Planta de hormigón con vertedero de estériles, depósitos de áridos, nave de cemento y tolvas oxidadas sin pintar de unos $10 \mathrm{~m}$ de altura.

o Tapia del cementerio (Figura A3.180) con pilares de ladrillo macizo y muros de cemento con restos de pintura ocre; teja árabe en remate.

o Varias líneas de alta tensión de $20 \mathrm{kV}$.

- Elementos singulares: No hay. 
DEGRADACIONES DEL PAISAJE

- $\quad$ Caminos excesivamente rectilíneos, sin naturalidad, impacto severo (Figura A3.181).

- $\quad$ Arroyos encauzados y rectificados, sin naturalidad, impacto severo.

- Impacto visual severo de la planta de hormigón, por introducción de elementos extraños e intrusión visual al encontrarse en la dirección hacia la torre de la iglesia de San Miguel. Ello con el agravante de que es la entrada al pueblo por el Camino de Santiago de Madrid.

- Impacto visual moderado de las líneas de alta tensión, por los mismos motivos pero de menor magnitud.

- Presencia puntual de residuos en la salida del pueblo

\section{RECUPERACIONES DEL PAISAJE}

- $\quad$ RES 1: Construcción de una vía verde sobre el antiguo trazado del Tren Secundario de Castilla, tramo Villalón de Campos - Cuenca de Campos. Esta actuación se promovió hace unos 10 años por el Ministerio de Medio Ambiente como medida de restauración de un proyecto complejo de abastecimiento a las localidades de la comarca. Uno de los ramales de esta red atraviesa la vía. Su longitud asciende a unos 4,5 km. Se incluyó la rehabilitación de los pequeños puentes con rollizos de madera tratada, la preparación de la plataforma con posterior extensión y compactado de zahorra natural y gravilla fina, realización de cunetas, prohibición mediante talanqueras de su uso por vehículos a motor, colocación de algún banco y paneles de interpretación del paisaje. La restauración vegetal consistió en la plantación de árboles en el mismo margen de la plataforma, cambiando de lado por tramos con objeto de alcanzar mayor naturalidad. La distancia entre árboles es de $8 \mathrm{~m}$, salvo en un tramo más próximo a Villalón que es de $5 \mathrm{~m}$. Las especies empleadas fueron almendro, pino piñonero, encina (Figura A3.184), quejigo, chopo castellano y álamo blanco. La preparación de los hoyos fue manual y de escasa profundidad. En el caso de los pinos se emplearon ejemplares grandes, que han tenido a la postre mayores problemas (porte defectuoso, descompensado y torcido, Figura A3.183). El porcentaje de marras de la primera plantación de árboles se puede estimar en un $50 \%$; la especie que mejor ha respondido ha sido claramente el almendro. Posteriormente el Ayuntamiento ha ido reponiendo marras durante varios años con hoyos manuales y similares especies, de modo que actualmente las plantaciones cubren aproximadamente el $80 \%$ de su longitud. El mayor defecto de las plantaciones es la falta de riego al menos el primer año. En la primera fase de la restauración también se plantaron arbustos (gayomba, endrino, retama) en los taludes, con fuertes marras ( $80 \%$ ), debido sobre todo a una preparación deficiente del terreno. Obviamente, se respetaron los árboles existentes: grupos de chopos lombardos, brotes de olmo y algún almendro, que tienen buen porte y desarrollo. El mantenimiento de la plataforma como vía es algo complejo, ya que requiere la eliminación de la vegetación herbácea que la invade. El Ayuntamiento utiliza herbicida en la primavera, tanto para la vía con gravilla como para los márgenes, pero induce en estos un fuerte rebrote posterior de vegetación herbácea alta y cardos en verano, por otra parte la época de mayor uso. Sería aconsejable delimitar exclusivamente el uso del herbicida a los $3 \mathrm{~m}$ centrales de la plataforma, utilizando en el resto el desbroce. Actualmente se puede afirmar sin lugar a dudas, que la restauración de la vía verde ha sido un éxito. Se emplea a diario por numerosas personas, bien sea para caminar, correr o ir en bicicleta. Es ruta para peregrinos del Camino de Santiago de Madrid, que incluso recorren una noche el tramo en un encuentro anual. En junio se celebra el Día nacional de las vías verdes, con gran concurrencia de vecinos.

- $\quad$ RES 2: Restauración de antiguo basurero (Figura A3.185). Hace unos 18 años se clausura el antiguo basurero del municipio ya que, a partir de esa fecha, los residuos se gestionan de manera mancomunada. Se transportan hasta la planta de transferencia de Ceinos de Campos y de allí al centro de tratamiento provincial de Valladolid. La superficie aproximada de la parcela es de 0,41 ha. La restauración corrió a cargo de la Consejería de Medio Ambiente de la Junta de Castilla y León, constando de remodelación de los residuos, apelmazamiento, construcción de chimeneas de evacuación de gases tóxicos con bolos de grava y extensión de una capa de tierra vegetal. Posteriormente, voluntarios de la asociación de Amigos de las Fuentes realizaron plantaciones perimetrales de gayomba, pinos y encinas, que actualmente cubren algunos lindes de la parcela. En la actualidad la plataforma se haya ligeramente hundida, revegetada con herbáceas en su totalidad y cuenta con la presencia de algún montón de escombros.

- $\quad$ AHA 1: Picón triangular de $35 \mathrm{~m}^{2}$. Plantación de pino piñonero, a $3 \mathrm{~m}$, con protector de plástico, sin cuidados culturales de mantenimiento. $100 \%$ de marras. 


\section{RECUPERACIONES POTENCIALES}

- Plantación de cipreses y arizónicas en taludes de desmonte situados a la entrada del pueblo, en el entorno del cementerio y de la planta de hormigón.

- Pintar de ocre las paredes de la tapia del cementerio.

- Restauración vegetal de taludes de caminos.

- Restauración vegetal de regueras.

- Plantaciones de diversificación en el interior de las parcelas agrícolas.

- Reposición de marras en la plataforma de la vía verde. Utilización preferente de almendros. Hoyos de suficiente profundidad y riego obligatorio el primer año.

- Plantación de arbustos en taludes de la vía verde, sobre todo en los de terraplén.

- Cuidados culturales en árboles existentes de la vía verde: enderezar pinos, podas ligeras, desbroces periódicos, acolchado y riego de las reposiciones recientes.

- $\quad$ Plantación de árboles y arbustos para zonas secas en la plataforma del antiguo basurero, con una preparación puntual del terreno para no poner la basura en superficie. 


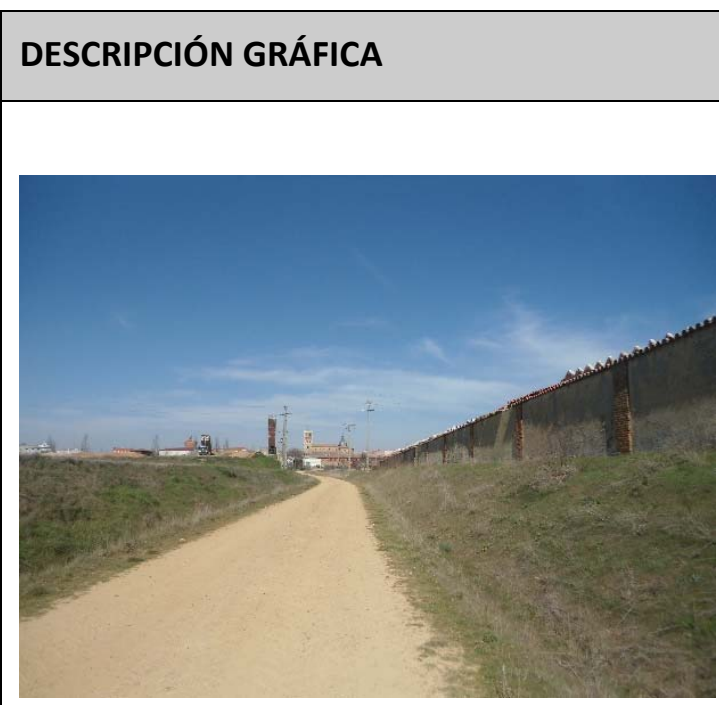

Figura A3.180. Tapia del cementerio y planta de hormigón al fondo.

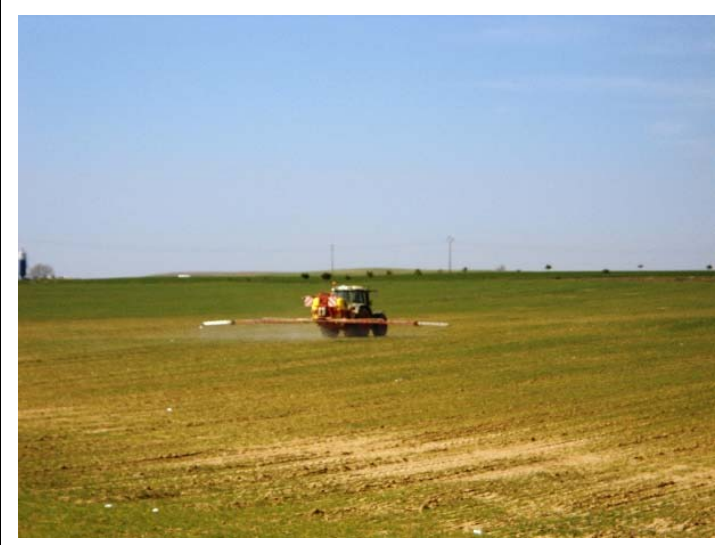

Figura A3.182. Tratamiento con herbicida

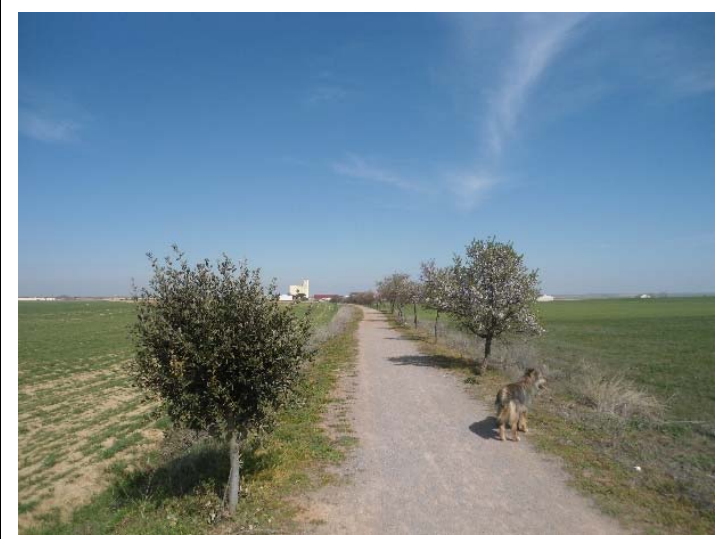

Figura A3.184. Vía verde con encinas y almendros

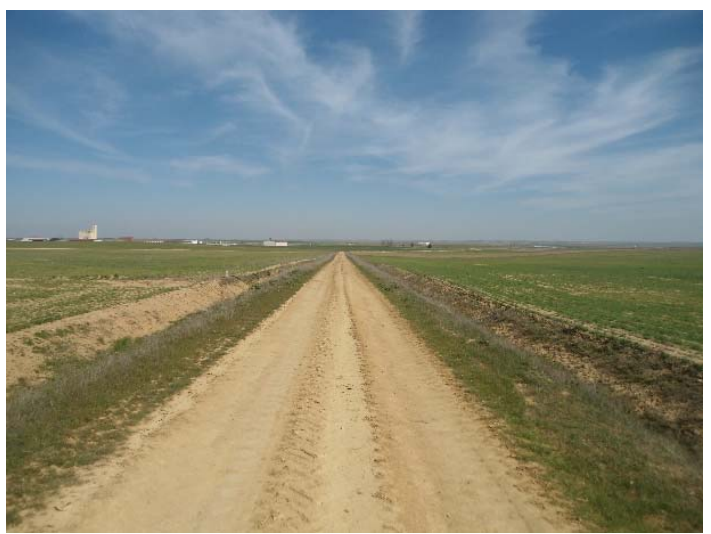

Figura A3.181. Camino en tierra rectilíneo

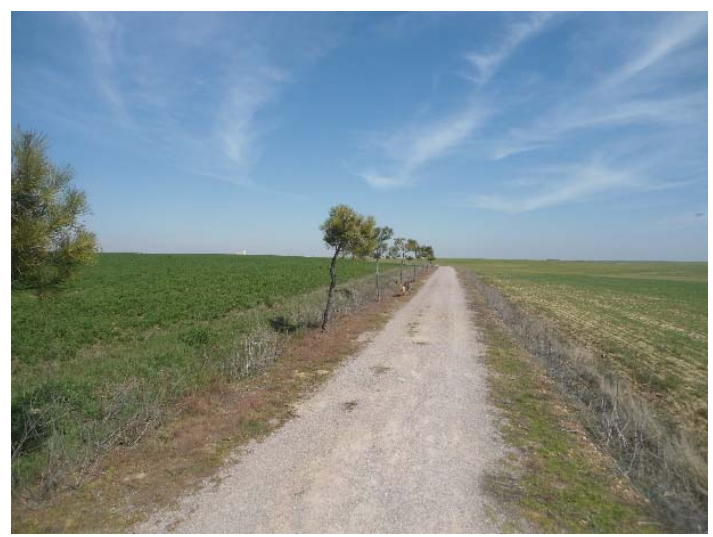

Figura A3.183. Vía verde con pìnos algo torcidos

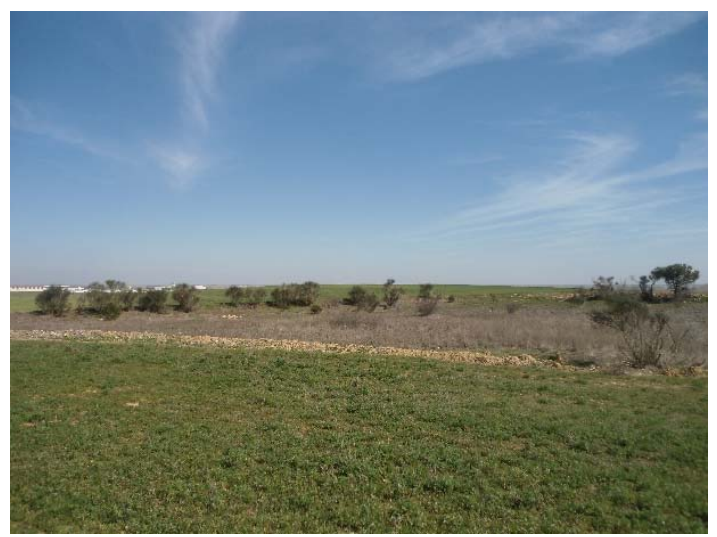

Figura A3.185. Antiguo basurero restaurado 


\section{RECORRIDO: Carretera de Valladolid}

- Fecha: 22 de marzo de 2014, 12:50 h.

- Medio: Caminando.

- Itinerario: Desde casco urbano (polideportivo), por carretera de Valladolid hasta el límite del término municipal y vuelta al punto inicial.

- Longitud: $3,2 \mathrm{~km}$

- Condiciones meteorológicas: Nublado parcialmente. Ha llovido un poco recientemente.

- $\quad$ Características de la vía: Carretera autonómica VA-905 (Figura A3.187), de $8 \mathrm{~m}$ de plataforma (3 $\mathrm{m}$ de carril y $1 \mathrm{~m}$ de arcén). Tiene biondas en terraplenes. Bastante tráfico, no es agradable para caminar o ir en bicicleta.

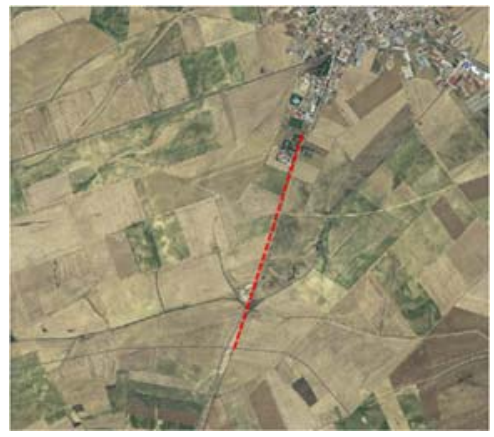

\section{CARACTERÍSTICAS DEL PAISAJE}

- Entorno inmediato de la vía: Cunetas de $2.5 \mathrm{~m}$ de anchura, revegetadas en su mayor parte. Altura media de los taludes: $>2 \mathrm{~m}=10 \%, 1-2 \mathrm{~m}=50 \%,<1 \mathrm{~m}=40 \%$, alternándose desmontes y terraplenes.

- Espacio agrícola: Las leguminosas han crecido y tienen un intenso verdor. El cereal tiene aún un verde pálido (Figura A3.189). Existen zonas en tierra que fueron ocupadas por agua, con el cereal sin nacer.

- Agua: Se cruza el arroyo Gorreras, con agua pero que no circula.

- $\quad$ Ruido: Considerable por el tráfico.

- Olores desagradables: Inexistentes.

- Vegetación: En los márgenes de la carretera, tan sólo algún ejemplar de escaramujo y de brotes de los chopos y álamos que antaño fueron plantados. Abundante vegetación en los chalets existentes a la salida del pueblo. Las frondosas aún no tienen hojas.

- Fauna: Se ven pajaritos, sobre todo en las alfalfas, pero prácticamente no se percibe su sonido por la molestia del tráfico.

- Actuaciones humanas:

o Dos viviendas en una gran parcela revegetada, de una planta, con acabados de ladrillo y teja árabe.

o Una vivienda en otra parcela grande, de una planta y similares características.

o Fábrica de piensos de grandes proporciones (Figura A3.190), con varios edificios (paredes blancas y teja plana roja), tolvas cilíndricas, almacenes de unos $15 \mathrm{~m}$ de altura, en tonos ocres. Relativamente integrada en el paisaje.

o Pequeña caseta de huerta, paredes ocres y cubierta de teja, con varios frutales alrededor.

o Planta de hormigón y almacén de prefabricados (Figura A3.188), con depósito de áridos, diversos materiales, vehículos y maquinaria. Tolvas de unos $10 \mathrm{~m}$ de altura, azules con franjas blancas. Valla metálica.

o L Línea eléctrica de $20 \mathrm{kV}$ paralela a carretera y otra de $30 \mathrm{kV}$ que la cruza.

- $\quad$ Elementos singulares: No hay.

\section{DEGRADACIONES DEL PAISAJE}

- $\quad$ Carretera totalmente rectilínea sin vegetación en sus márgenes, impacto severo.

- Impacto visual severo de la planta de hormigón, por introducción de elementos extraños, intrusión visual teniendo en cuenta que se trata de la principal entrada del pueblo y desaparición de la armonía (tonos azules estridentes).

- Acumulación de residuos importantes en los márgenes de la carretera (botellas de plástico, ruedas, sacos, etc., Figura A3.186). 


\section{RECUPERACIONES DEL PAISAJE}

- $\quad$ PAR 1: Abundante arbolado alrededor de las dos viviendas citadas (Figura A3.191): chopos boleanas y cipreses en perímetro, encinas, almendros, abetos (en mal estado), pinos piñoneros, seto de thuyas. Adecuada conjunción de frondosas y coníferas. Mejora la imagen de la entrada del pueblo.

- $\quad$ PAR 2: Similares características en la zona ajardinada del otro chalet, tal vez con menor diversidad de especies: boleanas, varias coníferas, etc.

- $\quad$ RES 1: Pantalla visual arbolada alrededor de la planta de hormigón, recorriendo todo el perímetro. Distancia entre ejemplares de 3-4 m. Varias especies, sobre todo frondosas. Abundantes marras. Sería muy importante que creciese rápidamente, porque actualmente no consigue su objetivo.

\section{RECUPERACIONES POTENCIALES}

- $\quad$ Plantación de arbustos en los taludes de la carretera cuya altura sea superior a $1 \mathrm{~m}$.

- Restauración vegetal de regueras.

- Plantaciones de diversificación en el interior de las parcelas agrícolas.

- Densificación de la pantalla visual de la planta de hormigón: utilización de arbustos y, sobre todo, coníferas (arizónicas y leylandi, en caso de que se pueda regar).

- Limpieza periódica de los residuos de los márgenes de la carretera por parte de la empresa concesionaria de su mantenimiento. 


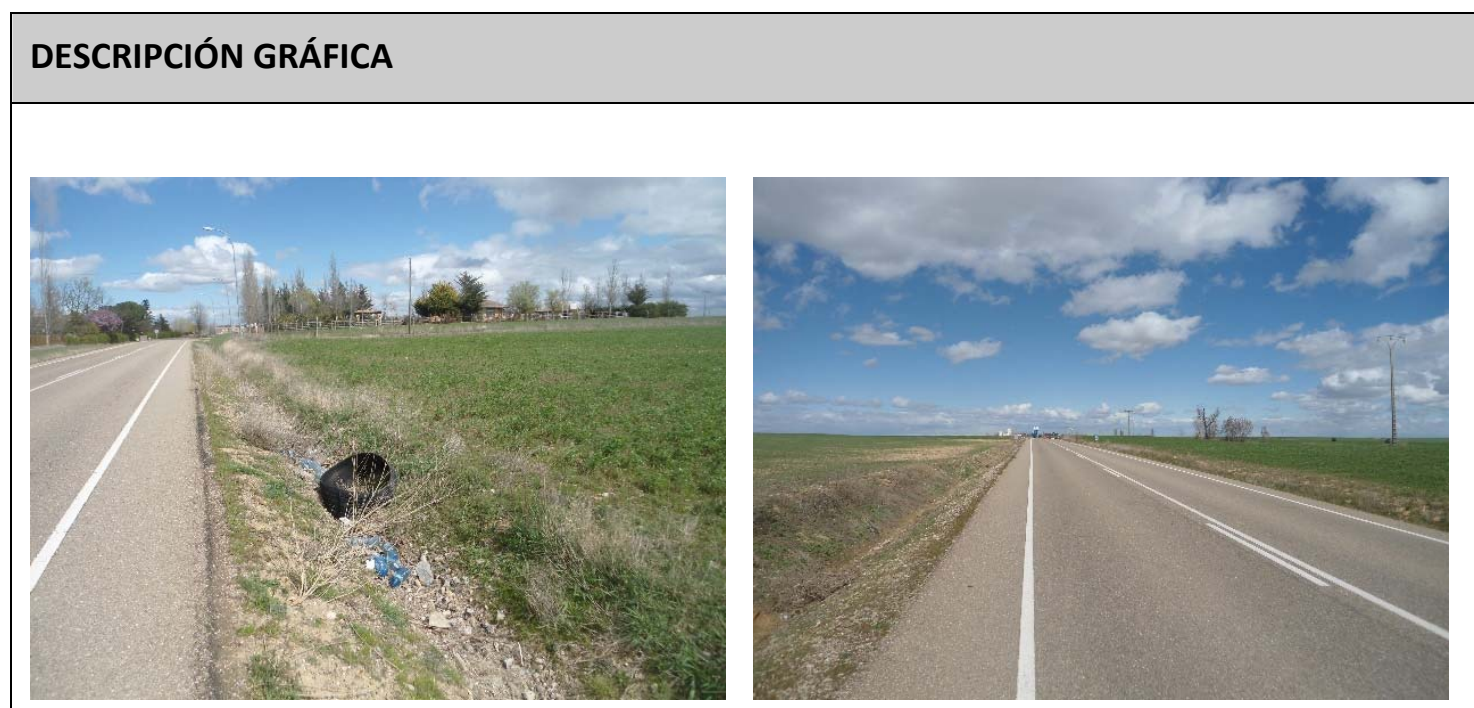

Figura A3.186. Detalle de basuras en la cuneta; al fondo, chalets Figura A3.187. Vista general de la carretera

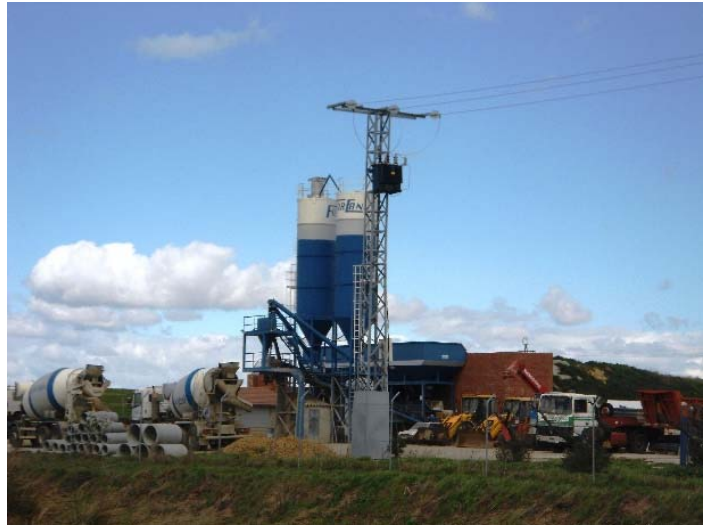

Figura A3.188. Planta de hormigón

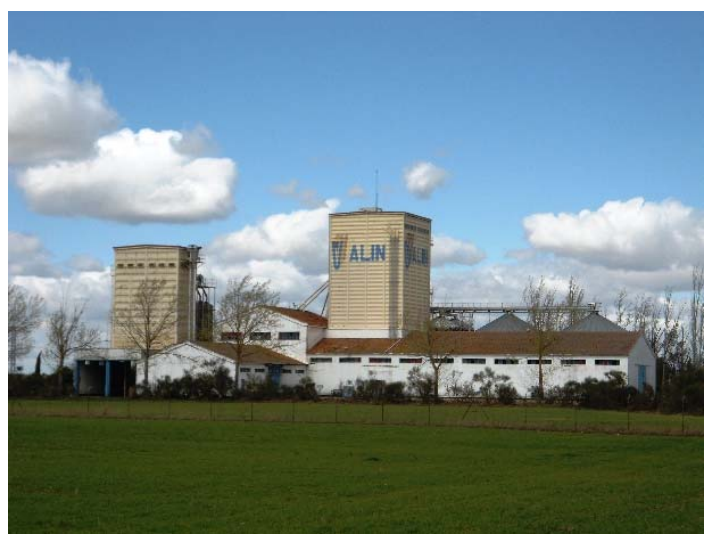

Figura A3.190. Fábrica de pienso

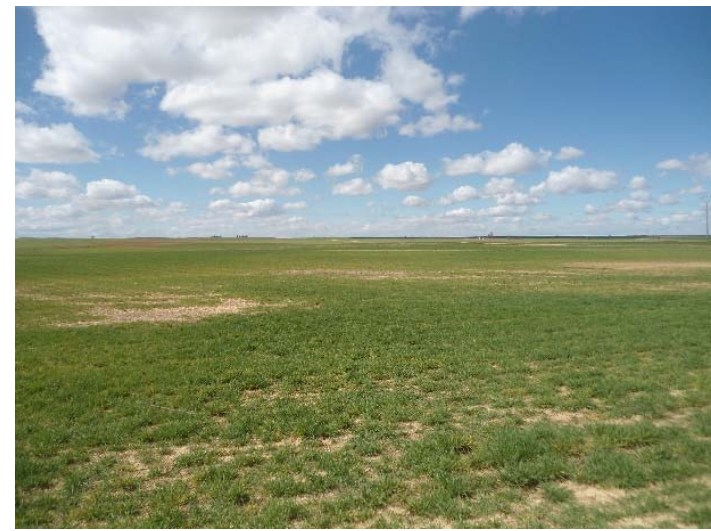

Figura A3.189. Parcela de cebada

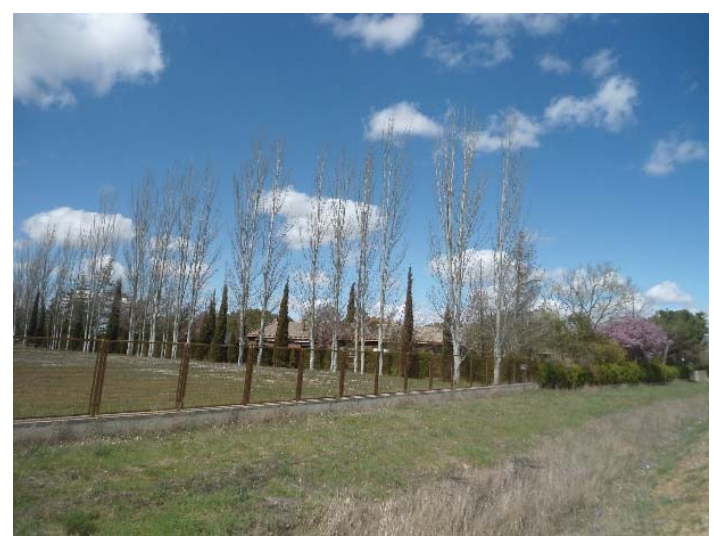

Figura A3.191. Ajardinamiento de chalets 
- Fecha: 12 de abril de 2014, 12:30 h

- Medio: Caminando.

- Itinerario: Desde campo de fútbol - colada de Carreceinos - continuación camino - arroyo Gorreras - fuente Cortaelaire - colada de Carreceinos - punto de inicio.

- Longitud: 8,7 km.

- Condiciones meteorológicas: Despejado. El terreno está seco en superficie, ya que se ha oreado bastante en los últimos días.

- Características de la vía: Primer camino totalmente rectilíneo, en zahorra, $6 \mathrm{~m}$ de plataforma con 0,6 $\mathrm{m}$ revegetados a cada lado. Resto de caminos en tierra, dado que están en la primera fase de explanación de las obras de la concentración

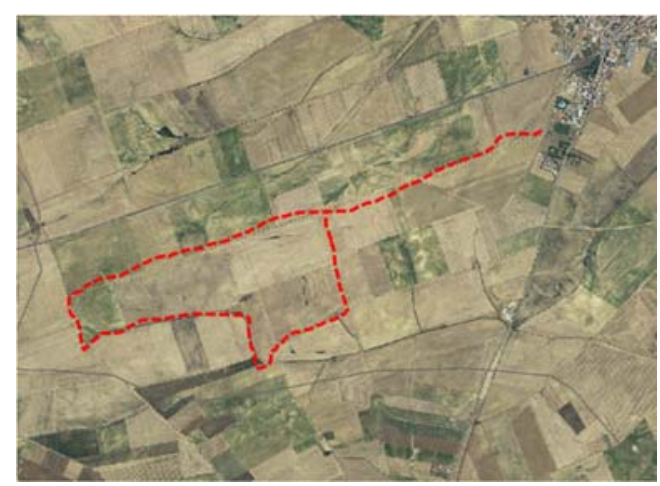
parcelaria.

\section{CARACTERÍSTICAS DEL PAISAJE}

- Entorno inmediato de la vía: Cunetas parcialmente revegetadas, más en umbría (explanación reciente), $2 \mathrm{~m}$ de anchura. Altura media de los taludes: $>2 \mathrm{~m}=5 \%, 1-2 \mathrm{~m}=40 \%,<1 \mathrm{~m}=55 \%$, siendo la mayoría de desmonte.

- Espacio agrícola: El cereal ha crecido bastante y tiene un color verde más intenso. En los barbechos se ha pasado ya el rastro y se están sembrando de girasol (Figura A3.193). Se ven varios tractores sembrando.

- Agua: Por los arroyos principales aún circula algo de agua. No hay encharcamientos en las parcelas.

- Ruido: Inapreciable. En el primer camino se percibe ligeramente el tráfico de la carretera nacional N-610.

- Olores desagradables: Inexistentes.

- Vegetación: En los caminos no hay rastro de vegetación; el taluzado de los caminos ha desbrozado algún arbusto. Hay una reguera interior / antigua lindera de unos $300 \mathrm{~m}$ con vegetación muy interesante (álamos, olmos, rosales silvestres, majuelos, gayombas, Figura A3.194). Un buen tramo del arroyo Gorreras tiene bastante vegetación (muchos rosales y varios sauces y chopos de buen porte, Figura A3.196). Muy buena arboleda en la fuente Cortaelaire. Comienzan a salir las hojas de las frondosas. El espino albar está en plena floración.

- $\quad$ Fauna: Bastantes pajaritos, 2 perdices (cantando), 2 palomas, 1 cernícalo.

- Actuaciones humanas: No hay.

- Elementos singulares:

o Fuente Cortaelaire, con un depósito antiguo de ladrillo de tejar y un imponente chopo centenario.

\section{DEGRADACIONES DEL PAISAJE}

- Caminos excesivamente rectilíneos, sin naturalidad, impacto severo (Figura A3.192).

- Arroyos encauzados y rectificados, sin naturalidad, impacto severo.

- Acumulación puntual de residuos de construcción y demolición de las antiguas obras de fábrica (caños, Figura A3.195). 


\section{RECUPERACIONES DEL PAISAJE}

- $\quad$ AHA 1: Lindera de $60 \mathrm{~m}$ paralela al camino, con pino piñonero plantado a una distancia de $3 \mathrm{~m}$, con protectores, $\sin$ cuidados culturales, $100 \%$ de marras.

- RES 1: Plantación de 5 chopos hace unos 20 años en el arroyo Gorreras. Actualmente tienen un magnífico porte, de unos $15 \mathrm{~m}$ de altura.

- $\quad$ FUE 1 (Fuente Cortaelaire, Figura A3.197): Es un buen ejemplo de restauración de fuente. Tiene una superficie de 1 ha propiedad de la Junta de Castilla y León, a la que se ha añadido una parcela de 0,4 ha en la concentración parcelaria. Hace unos 30 años se realizó una primera recuperación, con abrevadero circular de hormigón y plantación de Ulmus pumila con retroexcavadora, marco $5 \times 5 \mathrm{~m}$ y resultado irregular (bien en la parte húmeda de la parcela, alcanzando los $10 \mathrm{~m}$ de altura, y mal en la parte seca). Hace unos 20 años se llevó a cabo una repoblación por voluntarios, utilizándose pino piñonero, encina y gayomba; los pinos están en muy buen estado, con una altura de unos $4 \mathrm{~m}$, aunque les falta una poda.

\section{RECUPERACIONES POTENCIALES}

- Restauración vegetal de taludes de caminos.

- Restauración vegetal de regueras.

- $\quad$ Plantaciones de diversificación en el interior de las parcelas agrícolas.

- Recogida de residuos de construcción y demolición y retirada a planta de reciclaje.

- $\quad$ Fuente Cortaelaire: Poda de todos los árboles en $1 / 3-1 / 2$ de su altura, con trituración o retirada de los restos. Adecuación y limpieza de la fuente. Plantación de la parcela adyacente, fundamentalmente con especies de ribera. 


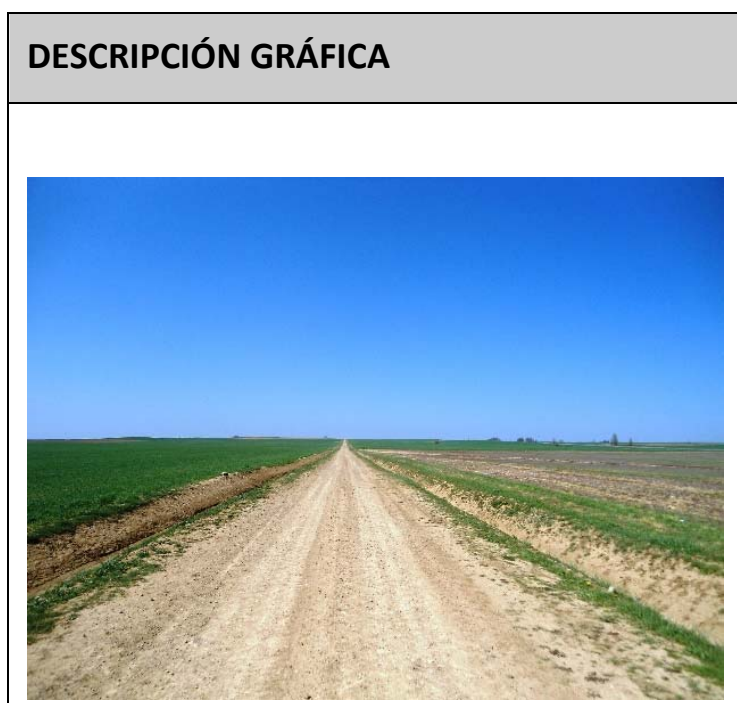

Figura A3.192. Camino excesivamente rectilíneo

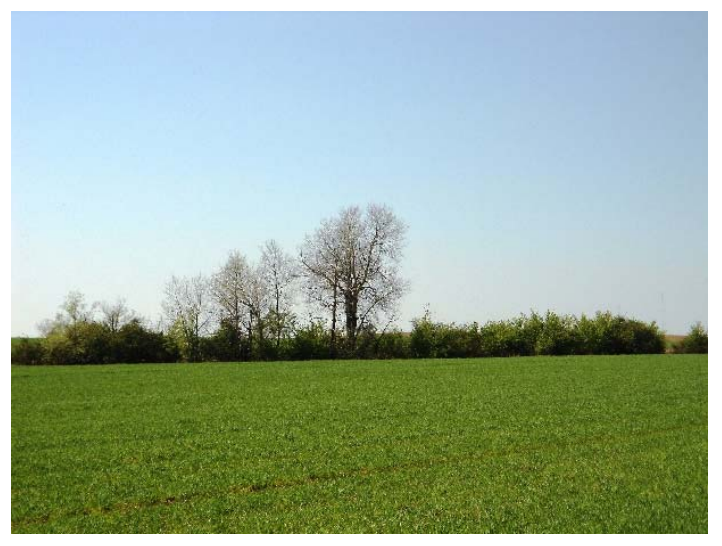

Figura A3.194. Lindera vegetal en reguera interior de una parcela Figura A3.195. Restos de caños antiguos

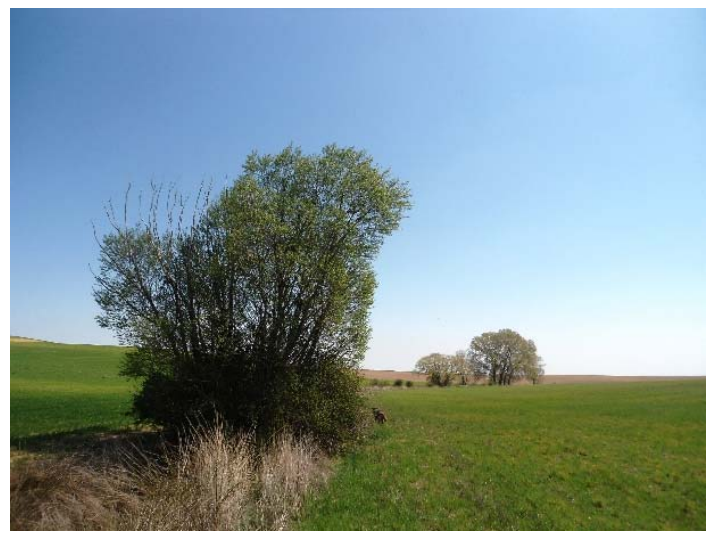

Figura A3.196. Arroyo Gorreras con sauces y chopos al fondo
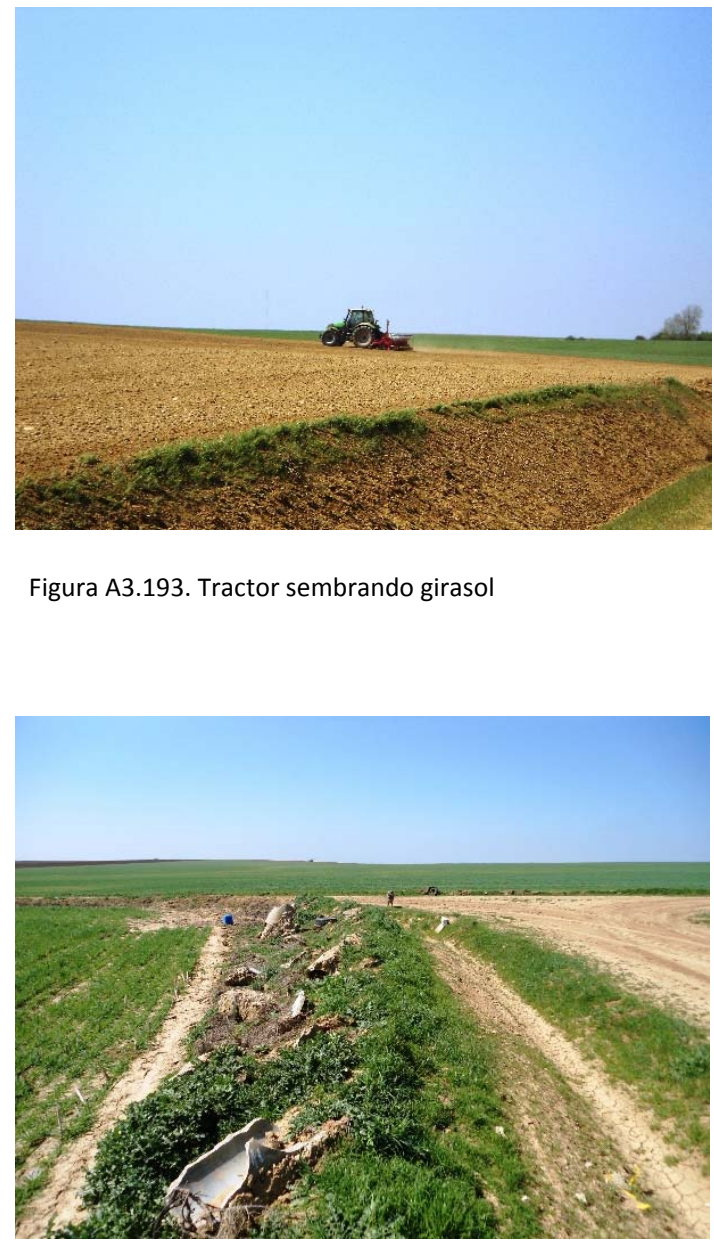

Figura A3.193. Tractor sembrando girasol

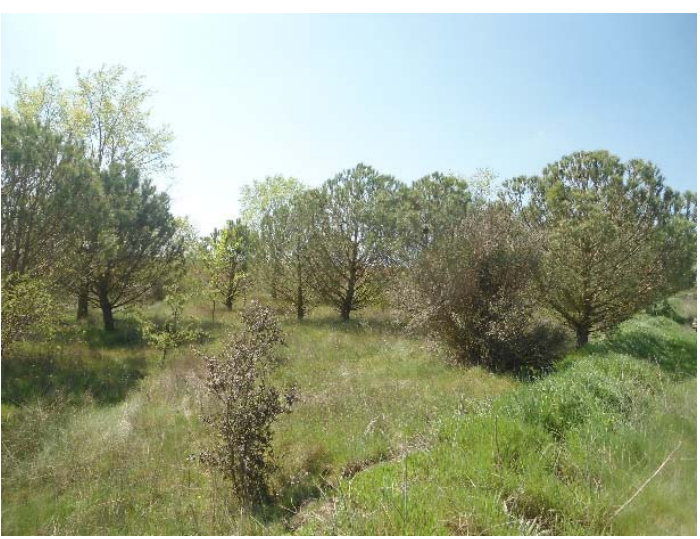

Figura A3.197. Restauración vegetal de la fuente Cortaelaire 


\section{RECORRIDO: Colada de Villacid y fuente el Cuquillo}

- Fecha: 18 de abril de 2014, 11:15 h.

- Medio: Caminando.

- Itinerario: Desde casco urbano - colada de Villacid (Figura A3.199) - fuente el Cuquillo - vuelta a punto de inicio.

- Longitud: $6,4 \mathrm{~km}$

- Condiciones meteorológicas: Despejado. Terreno seco en superficie.

- Características de la vía: $6 \mathrm{~m}$ de anchura de plataforma. Firme de piedra caliza machacada, de tamaño grueso; molesto para caminar o ir en bicicleta. El camino coincide con la ruta de senderismo de Gran Recorrido GR-26 "Tierra de Campos", de Valladolid a Mayorga.

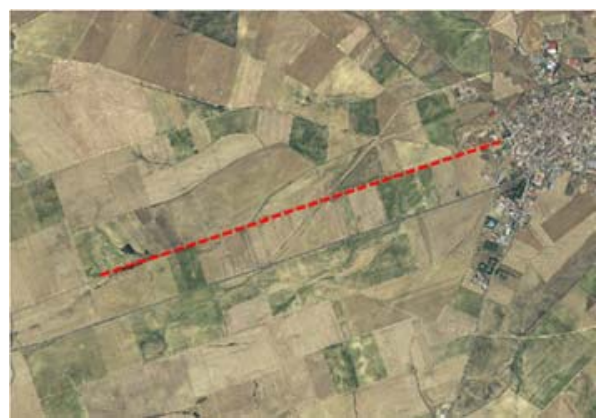

\section{CARACTERÍSTICAS DEL PAISAJE}

- Entorno inmediato de la vía: Cunetas de $2 \mathrm{~m}$ de anchura revegetadas. Altura media de los taludes: $>2 \mathrm{~m}=5 \%, 1-2$ $m=70 \%,<1 \mathrm{~m}=25 \%$, con predominio del terraplén.

- Espacio agrícola: Dominio del color verde, que es intenso en el caso de las leguminosas (veza, alfalfa). Se intercala el marrón (en un $25 \%$ aproximadamente de la superficie) de las parcelas donde aún no ha nacido el girasol.

- Agua: Todavía hay presencia de agua en las regueras importantes.

- Ruido: Inapreciable.

- Olores: Inexistentes.

- Vegetación: Presencia aislada de escaramujos en márgenes de caminos, tanto en los taludes de desmonte como en los de terraplén. También se ven en alguna reguera. El entorno de la fuente el Cuquillo es un oasis en el mar de campos, por la abundancia de grandes chopos y de matorral; tal vez es la zona del término municipal con más vegetación arbolada (Figura A3.200). Los chopos ya tienen hoja, de un color verde intenso.

- $\quad$ Fauna: Bastantes pajaritos, más en la zona arbolada. 2 perdices, 2 cigüeñas y 2 aguiluchos. Un rebaño de ovejas.

- Actuaciones humanas:

o Granja de ovino, con nave de paredes de cemento gris y cubierta de fibrocemento.

- Nave agrícola de paredes blancas y cubierta de fibrocemento.

o Subestación transformadora y dos líneas de 20 kV (Figura A3.198).

o Nave agrícola blanca, que contiene un palomar.

- Elementos singulares: No hay

\section{DEGRADACIONES DEL PAISAJE}

- Caminos excesivamente rectilíneos, sin naturalidad, impacto severo

- $\quad$ Arroyos encauzados y rectificados, sin naturalidad, impacto severo.

- Presencia de residuos en márgenes del camino en la salida del pueblo, con un impacto moderado.

- Impacto severo de la subestación y las líneas eléctricas que allí evacuan, por introducción de elementos extraños e intrusión visual. 


\section{RECUPERACIONES DEL PAISAJE}

- $\quad$ AHA 1: Lindero de $50 \mathrm{~m}$ paralelo a camino. Mezcla de pino piñonero, chopo y almendro. Distancia de $3 \mathrm{~m}$. Cuidados culturales. $20 \%$ de marras.

- AHA 2: Lindero de $200 \mathrm{~m}$ paralelo a camino. Pino piñonero, a una distancia de $4 \mathrm{~m}$, con protectores, sin cuidados. $100 \%$ de marras.

- AHA 3 (Figura A3.202): Lindero de $60 \mathrm{~m}$ paralelo a reguera. Pino piñonero, distancia de $3 \mathrm{~m}$, cuidados culturales. $0 \%$ de marras.

- $\quad$ AHA 4 (Figura A3.203): Doble lindero de $100 \mathrm{~m}$ en reguera. Pino piñonero, distancia de $3 \mathrm{~m}$, protectores, no cuidados. $10 \%$ de marras.

- RES 1: Chopos lombardos a ambos lados del camino desde la fuente el Cuquillo, a lo largo de $300 \mathrm{~m}$. Fueron plantados hace unos 25 años y tienen un magnífico estado, con unos $20 \mathrm{~m}$ de altura. Muchos arbustos (escaramujos, espinos, gayombas). Es un ejemplo de restauración, al aprovecharse una zona fresca.

- RES 2: Parcela particular plantada con chopos lombardos hace unos 30 años en aproximadamente $5.000 \mathrm{~m}^{2}$ de superficie (Figura A3.201). Muy buenos ejemplares, de unos $20 \mathrm{~m}$ de altura, con presencia abundante de zarzas.

\section{RECUPERACIONES POTENCIALES}

- Plantación de almendros y arizónicas en los taludes de desmonte (son elevados) del comienzo del camino, para minimizar el impacto de las naves, líneas eléctricas y subestación.

- Restauración vegetal de taludes de caminos.

- Restauración vegetal de regueras.

- Plantaciones de diversificación en el interior de las parcelas agrícolas.

- Recogida de residuos y retirada a planta de reciclaje de RCD.

- Plantación de dos pequeñas parcelas de Restauración del Medio Natural (de la concentración parcelaria) con especies para zonas secas. 


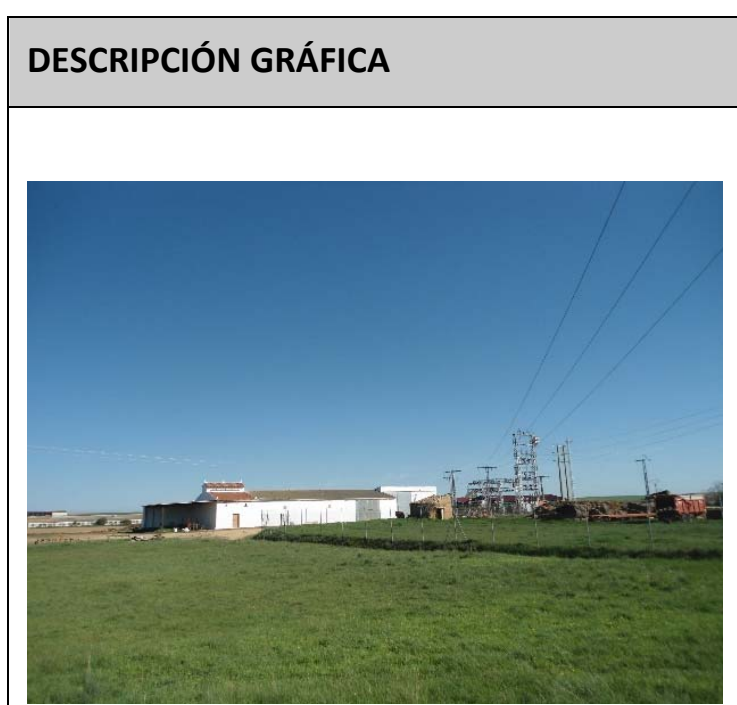

Figura A3.198. Subestación eléctrica y naves agrícolas

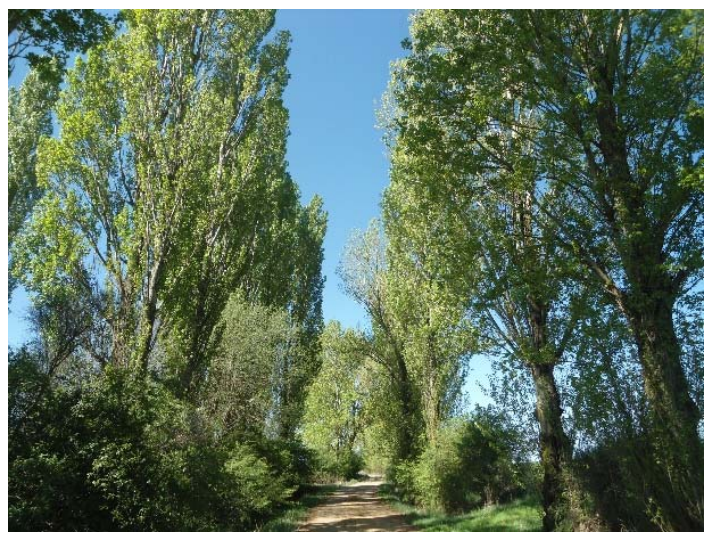

Figura A3.200. Chopos y matorral variado aguas abajo de la fuente el Cuquillo

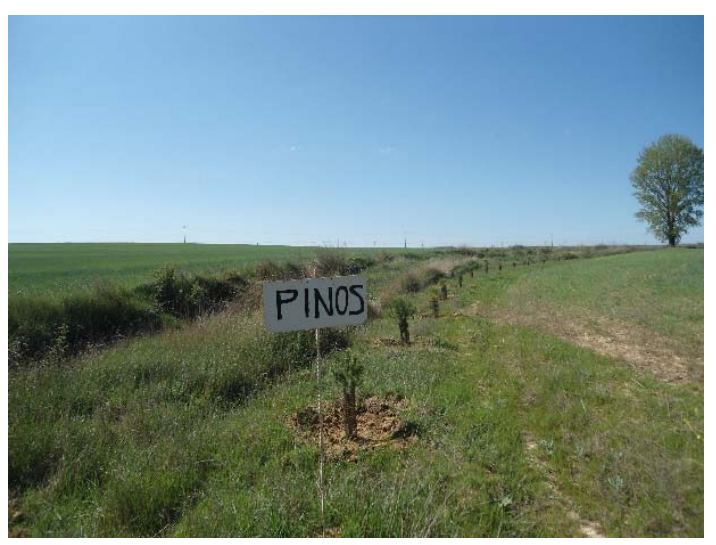

Figura A3.202. Plantación AHA 3

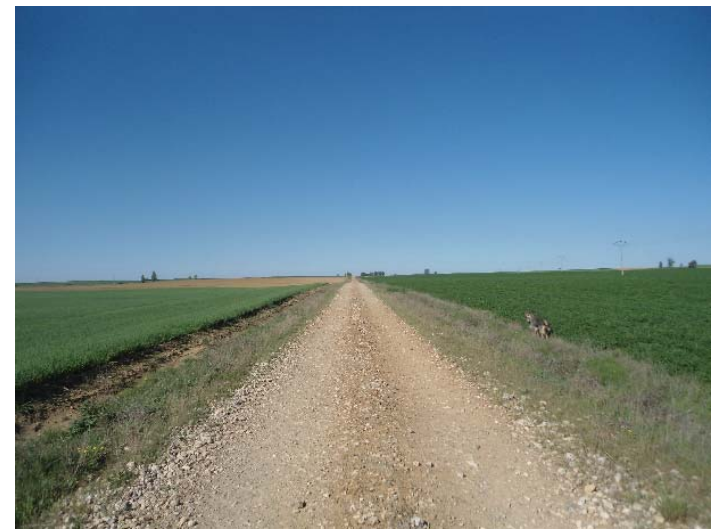

Figura A3.199. Colada de Villacid de Campos

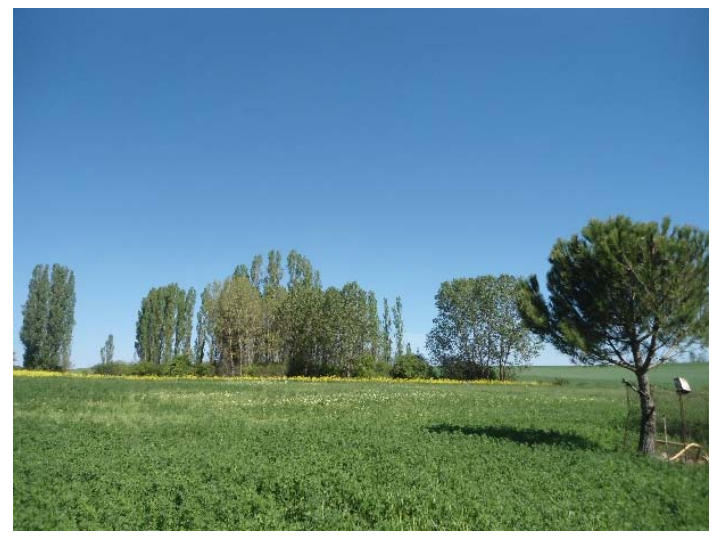

Figura A3.201. Chopera particular al fondo

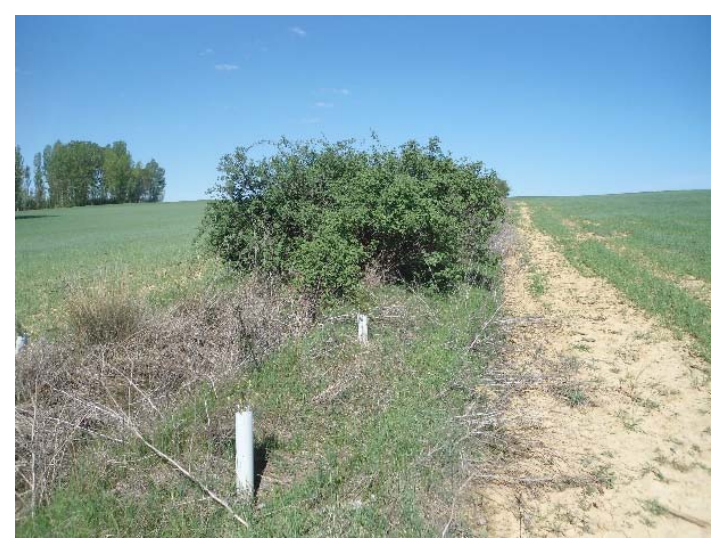

Figura A3.203. Plantación AHA 4 


\section{RECORRIDO: Ruta de los parques}

- Fecha: 2 de mayo de 2014, 11:20 h.

- Medio: En bicicleta.

- Itinerario: Se trata de una ruta circular que puede iniciarse por cualquier punto e incluso recorrerse en ambos sentidos. Se incluye la plaza mayor, ya que desde aquí se puede acceder a varios puntos de la ruta. En este caso, consideraremos el siguiente inicio: plaza Mayor - C) Marceliano Serrano - restos de la antigua muralla $-\mathrm{C}$ )

Sahagún - arroyo Pajarillas - huerta del Moral - picón de las acacias - parque de

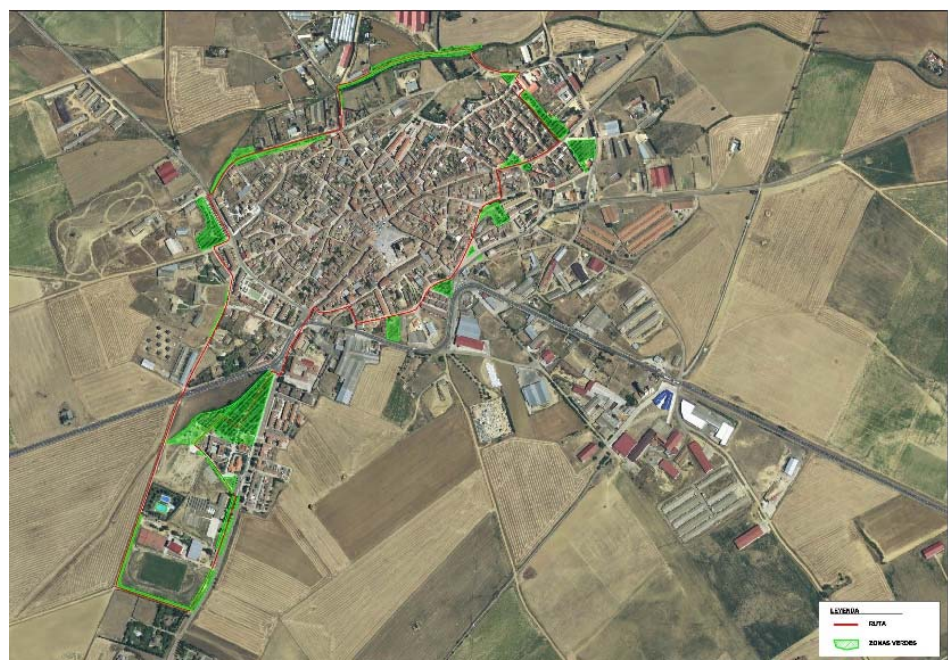
la reguera del Tinte - parque de la laguna del Tinte - C) Constitución - plaza de San Juan - casas de la Pedrera plaza de San Miguel - casas del convento - era del depósito - C) Gaspar Grajal - cruce con ctra. nacional - avda. del Parque - cruce con ctra. de Valladolid - parque del Paseo - parque temático - instituto - polideportivo - camino alrededor campo de fútbol - camino de la piscina - cruce con ctra. nacional - parque de San Pedro - paseo de Barrios - restos de la antigua muralla.

- Longitud: $4,5 \mathrm{~km}$

- Condiciones meteorológicas: Cielo despejado. El terreno tiene mucha humedad.

- Características de la vía: El recorrido por las zonas más urbanas discurre por calles de hormigón, en regular estado de conservación, pero adecuadas para el tránsito de viandantes. Hay un porcentaje también alto de trayecto por caminos asfaltados, en general en buen estado. Hay algún tramo (avda. del parque y parque del Paseo), donde la vía está bien adoquinada. Puntualmente, existe un pequeño tramo con una senda en tierra, entre la entrada al polideportivo y el camino del campo de fútbol.

\section{CARACTERÍSTICAS DEL PAISAJE}

- Entorno inmediato de la vía: Los caminos asfaltados tienen, en general, cunetas que están revegetadas; no hay taludes altos salvo algún punto muy concreto. En algún tramo hay márgenes en hierba o en zahorra, que se suelen tratar con herbicida.

- Espacio agrícola: En los tramos donde se divisan parcelas agrícolas, domina claramente el verde del cereal y las leguminosas, que es muy intenso.

- Agua: Ausencia. Destaca la presencia de la cascada del parque del Paseo.

- Ruido: Puntual debido al tráfico de la carretera nacional.

- Olores desagradables: Inexistentes.

- Vegetación: Es un recorrido que atraviesa los parques municipales y, por tanto, tienen mucha vegetación. En este momento está exuberante: han brotado con fuerza todos los árboles y arbustos después de un invierno muy Iluvioso, por lo que presentan hojas grandes y lustrosas (Figuras A3.204 y A3.206). Algunas especies están en plena floración, como la acacia (Figura A3.205), el castaño de indias (Figura A3.207), el lilar, el romero, el tamarindo o algún rosal, todas ellas con flores muy llamativas (Figuras A3.208 y A3.209). Por el contrario, los árboles que han sido podados con severidad (por ejemplo, los plátanos) están empezando a brotar, por lo que se pierde su frondosidad un periodo importante del año.

- Fauna: Muchísimos pajaritos, de gran variedad, sobre todo en las zonas verdes. Varias palomas.

- Actuaciones humanas: Ver recorrido 16.

- Elementos singulares: Ver recorrido 16. 


\section{DEGRADACIONES DEL PAISAJE}

Ver recorrido 16.

\section{RECUPERACIONES DEL PAISAJE}

Ver recorrido 6.

\section{RECUPERACIONES POTENCIALES}

Ver recorrido 26. 


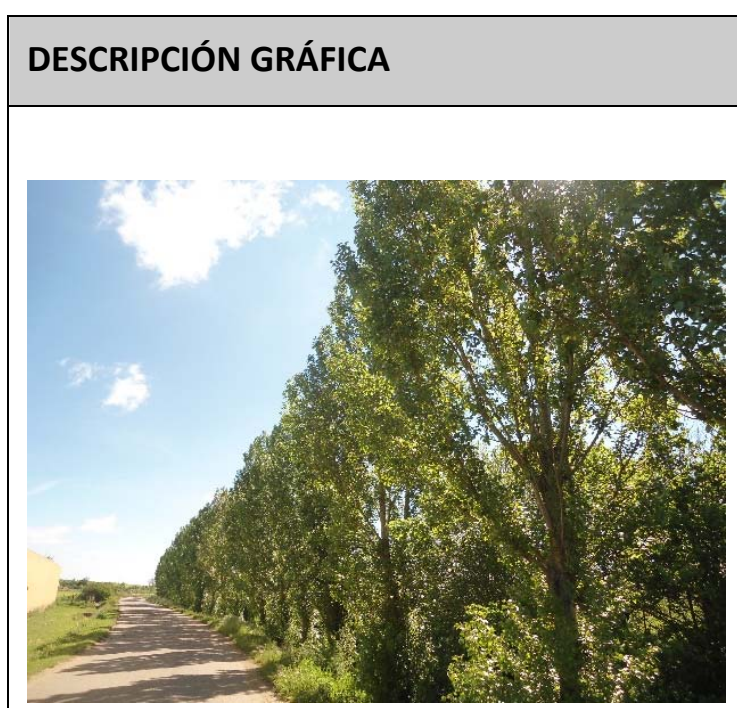

Figura A3.204. Chopera frondosa del arroyo Pajarillas

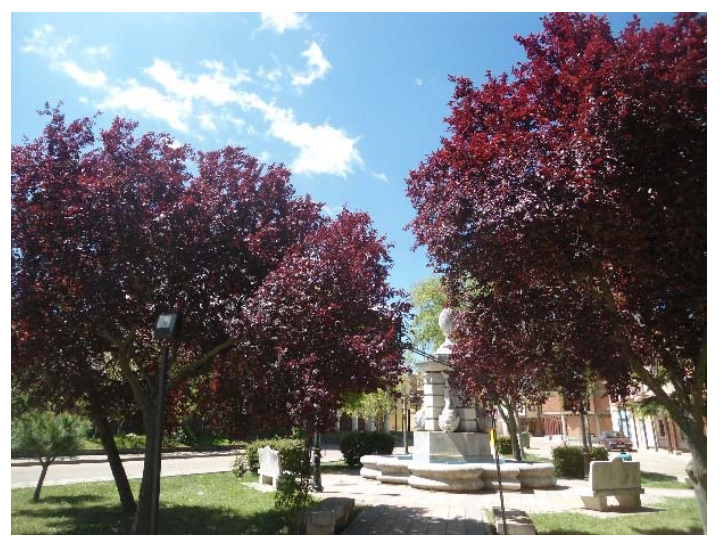

Figura A3.206. La hoja de los prunos aporta gran colorido

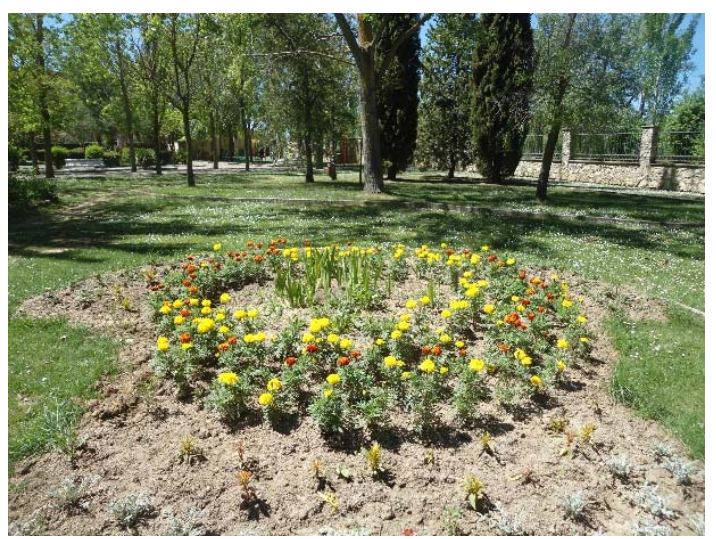

Figura A3.208. Parterre de flores anuales en el parque del Paseo

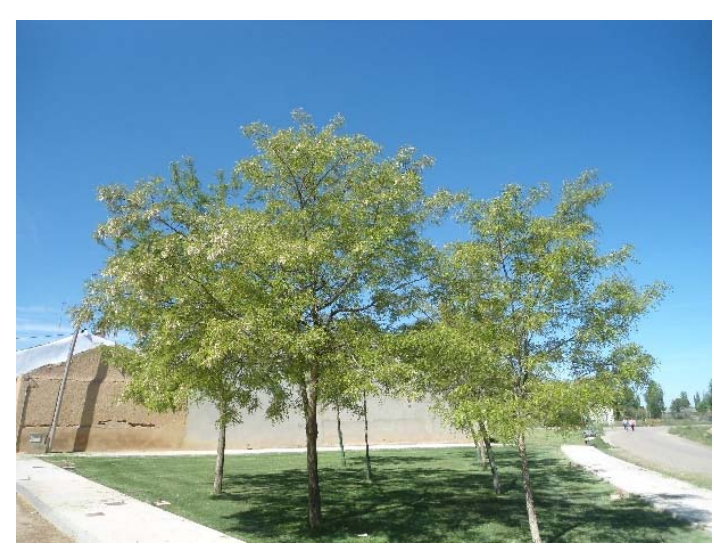

Figura A3.205. Acacias en flor

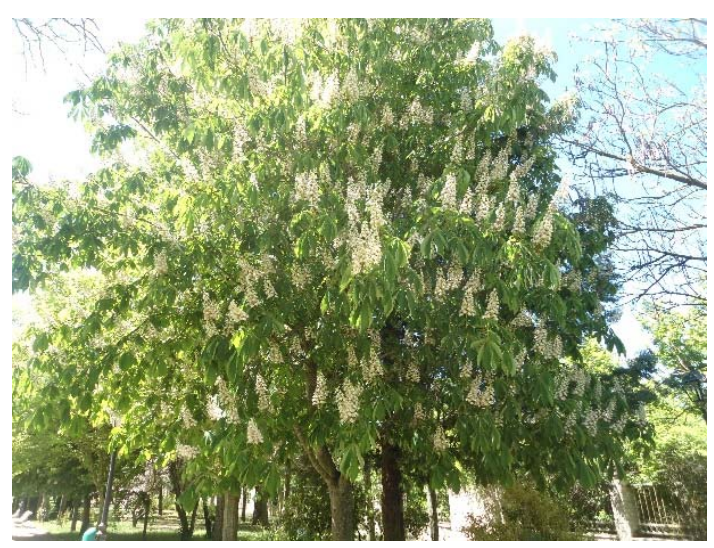

Figura A3.207. Grandes flores de los castaños de indias

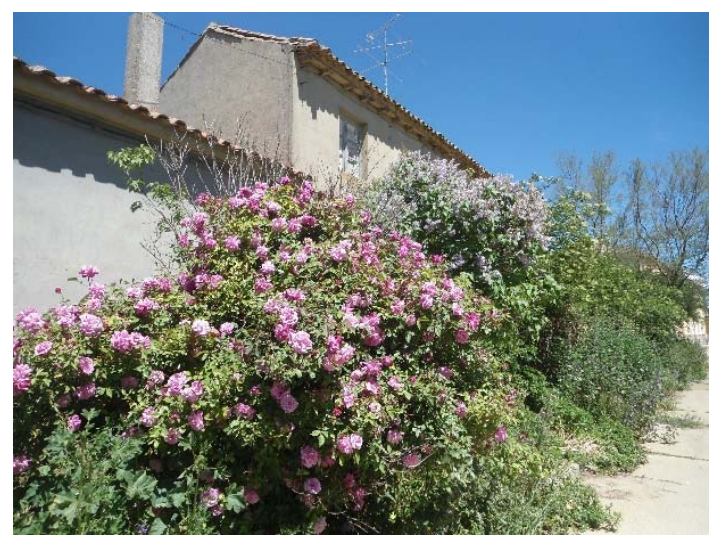

Figura A3.209. Rosas y lilas en un parterre del paseo de Barrios 


\section{RECORRIDO: Carretera de Benavente}

- Fecha: 4 de mayo de 2014, 11:45 h.

- Medio: En bicicleta.

- Itinerario: Desde casco urbano, carretera nacional N-610 sentido Benavente hasta límite con término municipal de Villacid de Campos, ida y vuelta (Figura A3.215).

- Longitud: $8 \mathrm{~km}$

- $\quad$ Condiciones meteorológicas: Cielo despejado. Terreno seco en superficie, ya que no ha llovido en los últimos días.

- Características de la vía (Figura A3.211): asfalto, muy buen estado del firme. Plataforma de $9 \mathrm{~m}$ de anchura total $(1 \mathrm{~m}$ margen a cada lado y 2 carriles de 3,5 m cada uno). Mucho tráfico, con alto porcentaje de pesado. No es adecuada

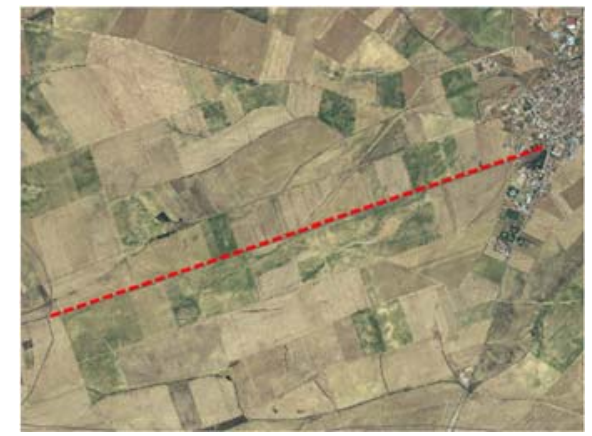
para caminar; en cuanto a la bicicleta, el firme es bueno y tiene arcenes, pero el tráfico es un riesgo.

\section{CARACTERÍSTICAS DEL PAISAJE}

- Entorno inmediato de la vía: Las cunetas está deficientemente conservadas. Los márgenes tienen una anchura de 3 $-4 \mathrm{~m}$. En algún tramo se ha depositado grava en los terraplenes como drenaje y para evitar la irrupción de herbáceas. Hay biondas en los terraplenes más altos. Taludes en desmonte y terraplén (>2 m: $20 \%, 1-2$ m: $60 \%,<1$ $\mathrm{m}: 20 \%)$. Taludes revegetados al $50 \%$, la parte desnuda se debe a que el terraplén está construido con materiales inertes, sin posterior depósito de tierra vegetal; también probable tratamiento con herbicida.

- $\quad$ Espacio agrícola: dominio del color verde de la cebada, que ya tiene la espiga formada (Figura A3.214). Las vezas se están segando (Figura A3.213). El resto son terrenos de girasol, que está ya naciendo, pero todavía son de color marrón.

- $\quad$ Agua: Ausencia.

- $\quad$ Ruido: Molesto, como consecuencia del elevado tráfico.

- Olores desagradables: Inexistentes.

- Fauna: Poco perceptible.

- Vegetación: Existen árboles aislados (chopos) en los márgenes de la carretera (Figura A3.212); también escaramujos. Se distingue algún espino albar en intensa flor blanca. En algunos tramos se ven choperas cercanas. La salida/entrada del pueblo tiene abundante vegetación, de varios parques y de jardines particulares. Los árboles tienen un color verde muy intenso.

- Actuaciones humanas (Figura A3.210):

o Varias viviendas y casetas aisladas a la salida del pueblo, de ladrillo rojo y cubierta de hormigón pardorojiza, con parcelas ajardinadas.

o Nave agrícola con ladrillo hueco muro visto y cubierta de fibrocemento.

o Huerto solar.

o Antigua granja avícola, con naves blancas y cubierta de fibrocemento.

o Antigua granja avícola pequeña, con naves blancas y cubierta de fibrocemento.

- Elementos singulares: No hay. 


\section{DEGRADACIONES DEL PAISAJE}

- $\quad$ Carretera totalmente rectilínea sin vegetación en sus márgenes, impacto severo.

- Impacto moderado provocado por la presencia del huerto solar, que es un elemento extraño a la pauta general del paisaje agrario.

\section{RECUPERACIONES DEL PAISAJE}

- $\quad$ PAR 1: Jardín en parcela de vivienda aislada. Tiene un seto de gayomba en el margen de la carretera y otro de thuyas en la valla de la parcela. Numerosos árboles en su interior, muy cuidados: pinos piñoneros, frutales, chopos, etc.

\section{RECUPERACIONES POTENCIALES}

- $\quad$ Plantación de arbustos en los taludes de la carretera. En los taludes de terraplén de altura superior a $2 \mathrm{~m}$ se deberían plantar árboles, pues tienen la protección de las biondas a efectos de seguridad vial. Se debe tener en cuenta que los márgenes de esta carretera estuvieron arbolados, lo que se constata en la ortofoto del vuelo áereo de mediados del siglo pasado.

- Restauración vegetal de regueras.

- Plantaciones de diversificación en el interior de las parcelas agrícolas. 


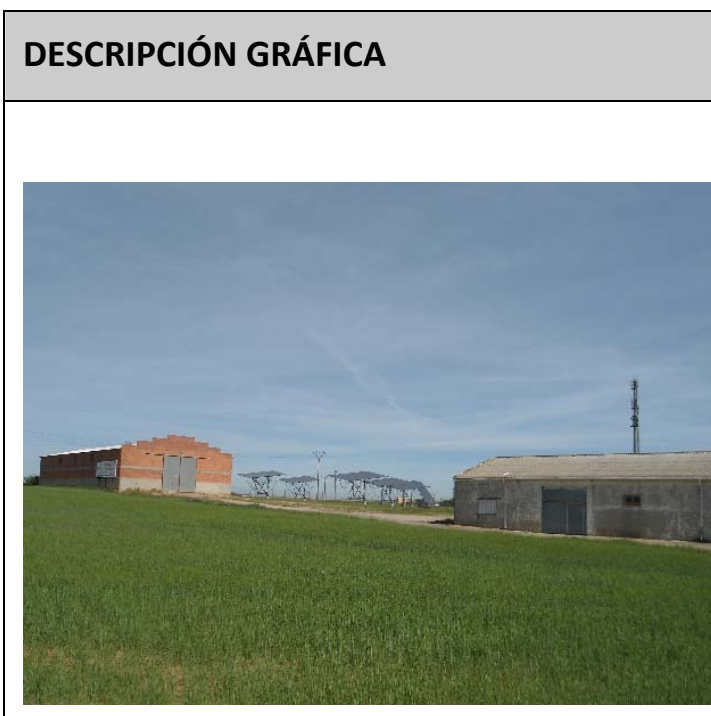

Figura A3.210. Varias construcciones a la salida del pueblo

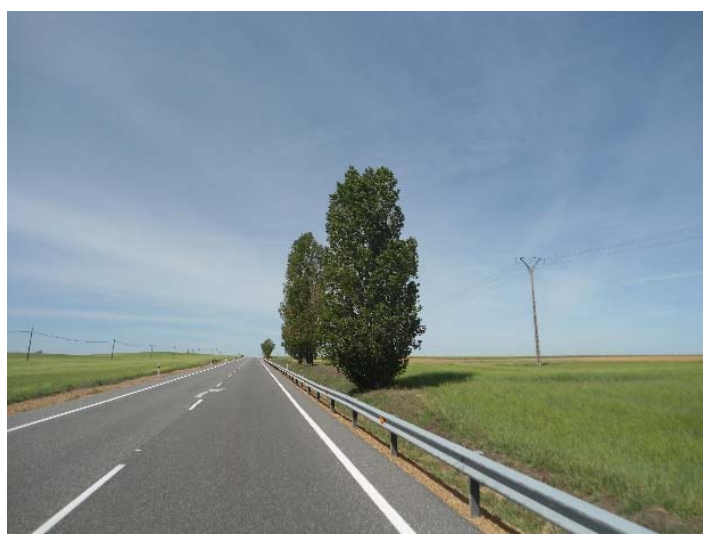

Figura A3.212. Chopos aislados en el margen de la carretera / línea eléctrica

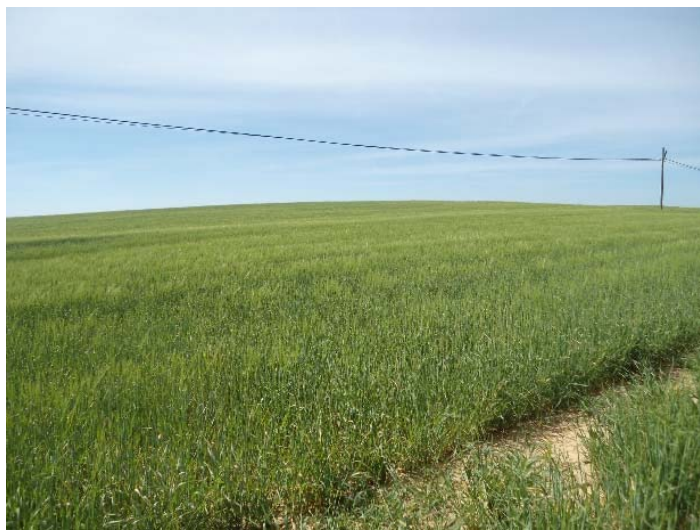

Figura A3.214. Cebada espigada / Poste telefónico paralelo a a la carretera

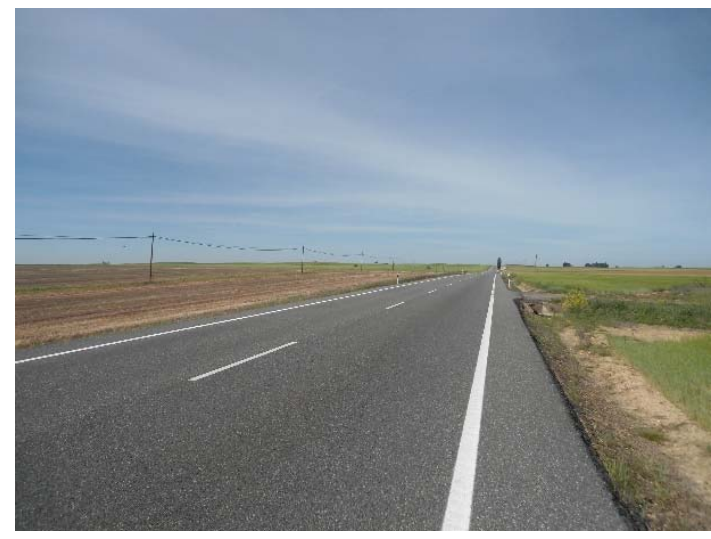

Figura A3.211. Vista de la carretera nacional

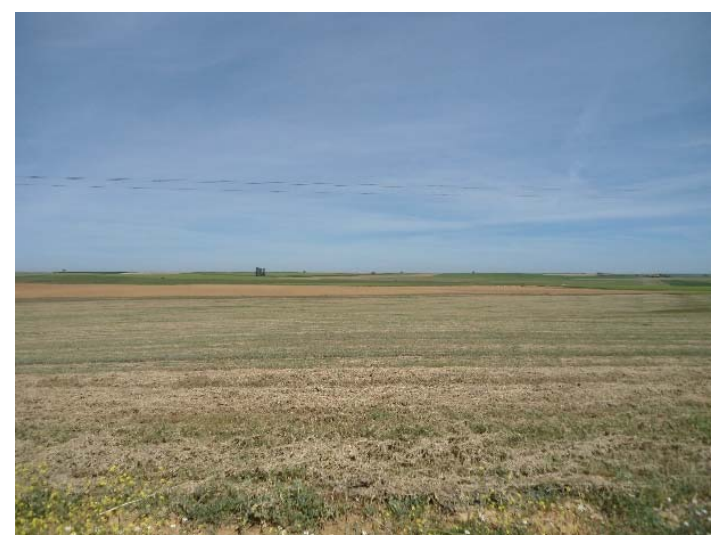

Figura A3.213. Vezas recién segadas

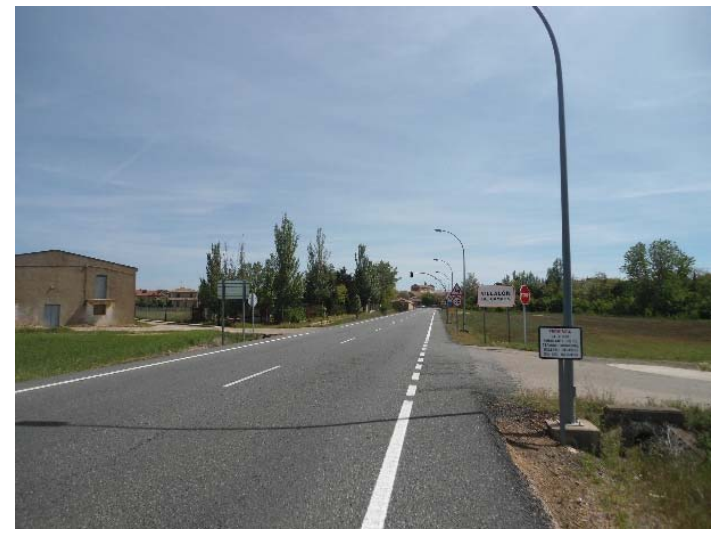

A3.215. Entrada a Villalón de Campos 


\section{RECORRIDO: Vereda de Mayorga a Herrín}

- Fecha: 12 de mayo de 2014, 12:40 h.

- Medio: En bicicleta.

- Itinerario: Desde casco urbano - vereda Mayorga a Herrín - límite de término municipal - vuelta a punto de inicio.

- Longitud: $12 \mathrm{~km}$

- Condiciones meteorológicas: Despejado. Terreno bastante seco en superficie.

- Características de la vía: En la mitad de la anchura de la vereda se trazó en la primera concentración parcelaria un camino rural, que hasta la fuente Juan Palacios discurre a la izquierda de la vía pecuaria y posteriormente a la derecha. Este camino tiene $6 \mathrm{~m}$

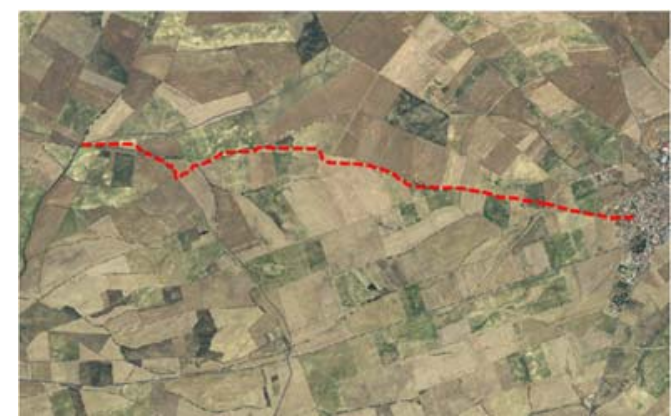
de anchura de plataforma. Firme de zahorra, suelta en el primer tramo por tránsito de ovejas, molesto para caminar o ir en bicicleta. En la clasificación de la vía pecuaria figura una anchura media de $20 \mathrm{~m}$, aunque sobre planos es algo irregular. De todas formas, actualmente hay numerosas intrusiones, teniendo en los casos más conservados una anchura media de $18 \mathrm{~m}$; los tramos mejor mantenidos son aquellos donde la vereda discurre en trinchera.

\section{CARACTERÍSTICAS DEL PAISAJE}

- Entorno inmediato de la vía: Cunetas del camino de $2 \mathrm{~m}$ de anchura revegetadas más la anchura variable de la vereda. El primer tramo está muy pastoreado. Altura media de los taludes: $>2 \mathrm{~m}=15 \%, 1-2 \mathrm{~m}=70 \%,<1 \mathrm{~m}=15 \%$, con predominio del desmonte; hay bastantes tramos en trinchera.

- Espacio agrícola: El cereal (cebada) continúa creciendo y madurando, en color verde intenso. Las leguminosas (alfalfa y veza) se han cortado y se están hilerando, con un color verde más pálido. Están naciendo las siembras de girasol y leguminosas de primavera, con color todavía marrón.

- $\quad$ Agua: Ausencia. Solo en las fuentes.

- Ruido: Inapreciable.

- Olores: Inexistentes.

- Vegetación: Presencia aislada de chopos en la propia vereda y en los arroyos cercanos, alguno muy esbelto. El paisaje vegetal cambia a partir de la fuente Juan Palacios, con bastante arbolado y zarzas en la vereda, regeneradas naturalmente debido al escaso pastoreo. Hojas de gran verdor. Comienzan a florecer algunos escaramujos. En esta zona hubo grandes arboledas, denominadas los árboles de Juan Palacios, que fueron taladas hace varias décadas.

- $\quad$ Fauna: Bastantes pajaritos. 4 perdices, varios conejos, 1 cigüeña.

- Actuaciones humanas: No hay.

- $\quad$ Elementos singulares:

o Fuente Juan Palacios (Figura A3.220). Se ha derivado el agua del manantial a un depósito de obra, con abrevadero puesto sobre solera de hormigón. Tiene un buen caudal y se utiliza mucho por el ganado ovino.

o Fuente la Teja (Figura A3.221). Realmente se trata de un manantial situado en un talud de la vereda de Mayorga a Herrín, rodeado de zarzas. Hay bastante humedad y un alto grado de naturalidad.

\section{DEGRADACIONES DEL PAISAJE}

- $\quad$ Arroyos encauzados y rectificados, sin naturalidad, impacto severo.

- Presencia puntual de escombros en alguna zona de la vereda, sobre todo en las cercanías del pueblo (Figura A3.216), impacto moderado.

- Numerosas intrusiones de la vía pecuaria (Figura A3.219), que es bien de dominio público, con impacto moderado.

- Presencia de ciertos desmoronamientos en taludes de desmonte de considerable altura, impacto moderado. 


\section{RECUPERACIONES DEL PAISAJE}

- $\quad$ RES 1: Recuperación de la vereda de Mayorga (Figura A3.217). Se llevó a cabo en 2007 a través de un taller de empleo de jardinería y restauración de áreas degradadas, actuándose en el primer tramo, hasta la fuente de Juan Palacios. Dado que había una gran cantidad de escombros incontrolados, se retiraron a la escombrera municipal con medios mecánicos. Posteriormente se realizó una plantación de 20 manzanos, 10 serbales, 104 almendros, 155 sauces y 30 tamarices; se regaron en verano y se colocó malla plástica protectora. Lamentablemente, las marras prácticamente alcanzan al $100 \%$ de la plantación; solo se salvan 5 sauces y 4 almendros; las causas probables son: deficiente elección de especies (sauce), ausencia de mantenimiento y daños por pastoreo intenso. Hay algún vertido puntual de escombros posterior.

- $\quad$ RES 2 (Figura A3.218): Plantación de chopos en un tramo de $30 \mathrm{~m}$ de reguera de la vereda de Mayorga, con humedad. Distancia entre ejemplares de $4 \mathrm{~m}$. Edad aproximada 30 años. Ahora tienen un magnífico porte y una altura de unos $25 \mathrm{~m}$. La linde también tiene numerosas zarzas.

- $\quad$ AHA 1: Lindera de $50 \mathrm{~m}$. Pinos piñoneros y algún frutal (son reposiciones), con protectores, sin cuidados, $3 \mathrm{~m}$ de distancia. $20 \%$ de marras.

- $\quad$ RES 2: Fuente de Juan Palacios. Se trata de una parcela de algo más de 1 ha propiedad de la Comunidad de Castilla y León. Durante muchos años estuvo totalmente desarbolada. En 2000 se realizó una plantación con escolares para celebrar el día del árbol. Para ello se dividió la parcela en tres zonas de superficie aproximada: la primera entre el camino y la fuente se dejó de pastizal; la segunda en terreno seco, donde se plantaron pinos piñoneros, encinas, sebes, zarzas, endrinos, espinos, etc. (marras $80 \%$ sobre todo en los árboles, en buena medida por el pastoreo) y posterior reposición con arce campestre (marras $50 \%$ ); la tercera en la zona más fresca, con álamos y chopos lombardos, en rodales (marras $20 \%$ ), que actualmente tienen una altura media de $5 \mathrm{~m}$ y magnífico estado. En ambos casos, marco irregular con una distancia aproximada entre plantas de $5 \mathrm{~m}$.

\section{RECUPERACIONES POTENCIALES}

- Vereda Mayorga a Herrín. En primer lugar, retirada de escombros y colocación de carteles de prohibición de vertidos. La delimitación física de su superficie es fundamental para evitar intrusiones; la mejor medida es la realización de una zanja con la pala de un bulldozer, plantándose posteriormente arbustos espinosos en el talud interior. En los taludes de desmonte también se propone la plantación de arbustos. En la plataforma de los tramos secos (la mayoría) se pueden plantar almendros en dos filas al tresbolillo; en los tramos húmedos, chopos y álamos. Fundamental protectores para evitar daños de las ovejas.

- Fuente Juan Palacios. Delimitación física en la colindancia con una parcela agrícola, que sufre una intrusión parcial. Colocación de carteles para delimitar también las zonas plantadas. Reposición de marras en la zona seca, con encinas y pinos piñoneros.

- Restauración vegetal de regueras.

- Plantaciones de diversificación en el interior de las parcelas agrícolas.

- Parcela/picón de $1500 \mathrm{~m}^{2}$ de la Consejería de Medio Ambiente, en la raya del término. Plantación para zonas secas (pino piñonero, encina, almendro y arbustos). Está bien delimitada. 


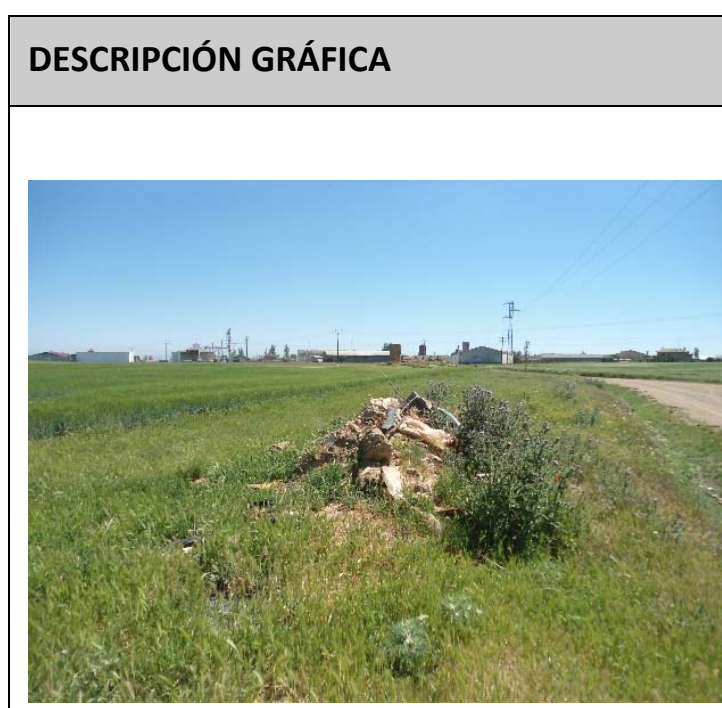

Figura A3.216. Tramos iniciales de la vereda con escombros

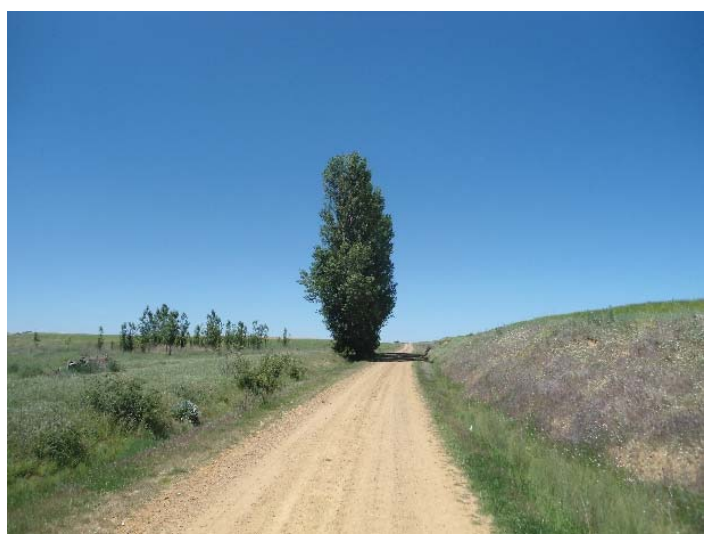

Figura A3.218. RES 2, con chopos en reguera paralela al camino

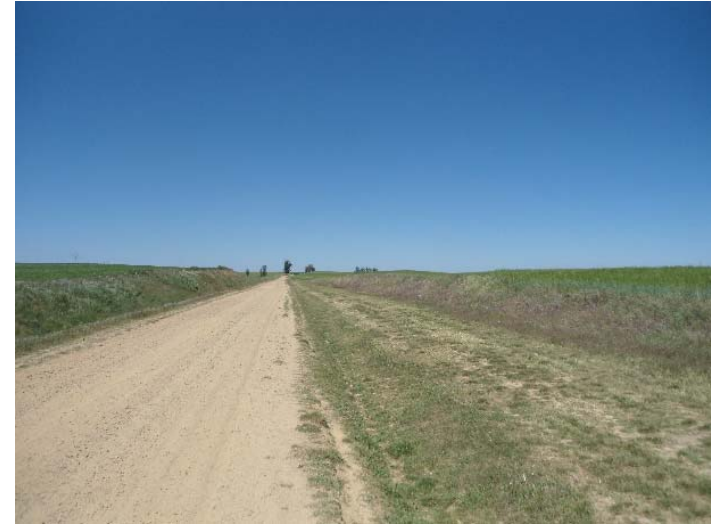

Figura A3.217. Vista general de una zona de la vereda conservada

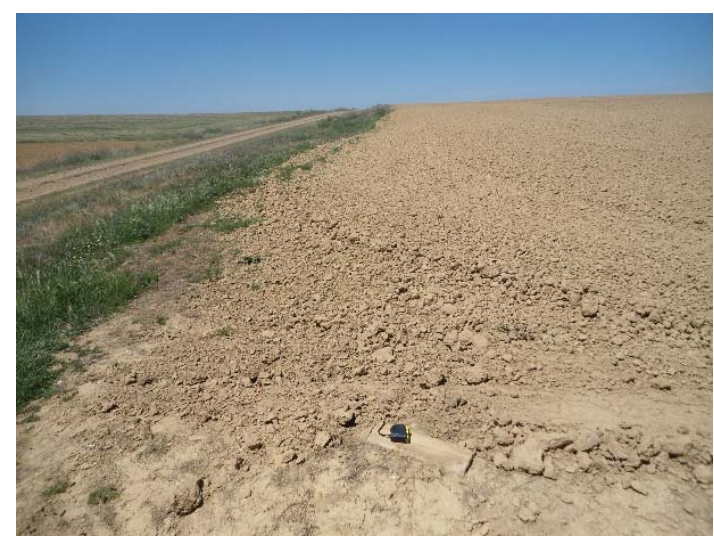

Figura A3.219. Mojón tirado (cinta métrica) e intrusión de toda la franja

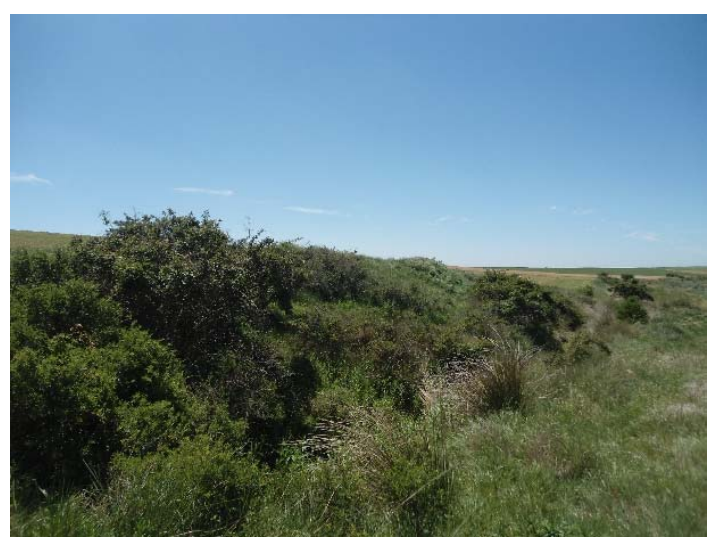

Figura A3.221. Fuente la Teja 
- Fecha: 24 de mayo de $2014,12: 10 \mathrm{~h}$.

- Medio: En bicicleta.

- Itinerario: Desde plaza mayor -C) La Rúa - urbanización Los Rosales - carretera de Bustillo - límite de término colada de Cabezón-Villalón (Figura A3.227) - casco urbano.

- $\quad$ Longitud: $9,9 \mathrm{~km}$

- $\quad$ Condiciones meteorológicas: Despejado. Terreno húmedo porque ha llovido en los últimos días.

- Características de la vía: La carretera de Bustillo es autonómica, recientemente acondicionada con buen

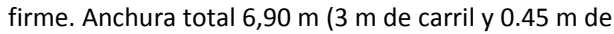
arcén). No es muy adecuada para caminar o ir en bicicleta porque, aunque no tiene mucho tráfico, los arcenes son pequeños y posee muchos cambios de rasante. La colada constituye un camino rural, de algo más de $6 \mathrm{~m}$ de anchura, con firme de zahorra. Adecuado para ir en bicicleta. $1 \mathrm{~m}$ a cada lado de la plataforma está revegetado con herbáceas.

\section{CARACTERÍSTICAS DEL PAISAJE}

- $\quad$ Entorno inmediato de la vía: La carretera tiene cunetas y márgenes de $3 \mathrm{~m}$ de anchura aproximadamente; las cunetas se tratan con herbicida. Altura media de los taludes: $>2 \mathrm{~m}=40 \%, 1-2 \mathrm{~m}=50 \%,<1 \mathrm{~m}=10 \%$, con predominio del desmonte. En los caminos, la altura media de los taludes es: $>2 \mathrm{~m}=10 \%, 1-2 \mathrm{~m}=60 \%,<1 \mathrm{~m}=30 \%$, con predominio también del desmonte.

- Espacio agrícola: El cereal (cebada) está totalmente espigado (Figura A3.226) y, con los últimos calores, ha madurado excesivamente, comenzándose a dorar. Las vezas se han cortado y se están pastando, por lo que tienen un color ocre-marrón. La alfalfa sigue verde. Le está costando nacer al girasol, por lo que todavía está en pleno marrón.

- Agua: Ausencia. Solo en la fuente Carrabustillo.

- Ruido: Puntual debido al escaso tráfico.

- Olores: Inexistentes.

- Vegetación: En el tramo de las urbanizaciones hay bastante vegetación en los jardines, así como en el parque de San Pedro. Ni la carretera ni el camino tiene vegetación en sus márgenes. No obstante, sí que se aprecia una relativamente presencia de la misma en las parcelas con casetas repartidas a lo largo del recorrido, así como en algún majuelo. Chopos aislados en regueras.

- Fauna: Bastantes pajaritos. 1 milano.

- Actuaciones humanas:

o Urbanización Los Rosales (Figura A3.223). Viviendas de PB+1 alineadas en calles con patio exterior, ladrillo rojo caravista y teja curva de hormigón. La línea de cornisa no es corrida, en desacuerdo con la tipología arquitectónica tradicional.

- Dos naves agrícolas, con paramentos metálicos verdes y cubierta roja. Vallada con malla metálica.

- Granja de porcino actualmente en desuso, con 8 naves blancas y cubierta de fibrocemento, balsa de purines e instalaciones auxiliares. Muy desvencijada. Vallada con malla metálica.

- Granja de vacuno (Figura A3.224) con una nave semiabierta, paramentos metálicos ocres y cubierta rojiza. Buena integración. Estercolero y almacén de paja. Vallada con malla metálica.

- Parcela vallada con pequeña nave para caballos (cemento gris y cubierta metálica roja) y caseta en construcción.

- Parcela vallada con nave y casa; ambas con paramentos ocres y cubierta con teja árabe. Mucha vegetación. Muy bien integrada.

o Antenas de telefonía móvil (Figura A3.225) en el punto más alto del término, en el margen izquierdo de la carretera.

o Línea eléctrica de $20 \mathrm{kV}$ paralela a la carretera por el margen derecho.

- Elementos singulares:

o Ayuntamiento (Figura A3.222), que es un edificio de estilo neobarroco construido a principios del siglo $\mathrm{XX}$.

o Conjunto soportalado de la calle La Rúa.

o Fuente Carrabustillo. Pequeña parcela de unos $500 \mathrm{~m}^{2}$ en un margen de la carretera, con un chopo y varios brotes. Cuenta con depósito, mana bastante agua. 


\section{DEGRADACIONES DEL PAISAJE}

- Impacto severo provocado por la ausencia de criterios estéticos en la cartelería, diferencias en los pilares de los soportales, deficiencia de control de aparcamientos y otros elementos disonantes en la calle La Rúa.

- Impacto moderado provocado porque no se ha respetado en exceso la tipología arquitectónica tradicional en la urbanización Los Rosales (patios exteriores, cornisas rotas, etc.). Ello se compensa con la presencia de vegetación en las fachadas.

- $\quad$ Carretera totalmente rectilínea sin vegetación en sus márgenes, impacto severo.

- Acumulación puntual de residuos (botellas, plásticos, ruedas, etc.) en las cunetas de la carretera.

- Eliminación de la vegetación de los márgenes de la carretera con herbicida, impacto moderado.

- Impacto severo provocado por las antenas de telefonía móvil, por introducción de elementos extraños en la escena. Un aspecto mitigador es el hecho de que están agrupadas.

- $\quad$ Presencia de la línea eléctrica, con impacto moderado.

- Caminos excesivamente rectilíneos, sin naturalidad, impacto severo.

- $\quad$ Arroyos encauzados y rectificados, sin naturalidad, impacto severo.

\section{RECUPERACIONES DEL PAISAJE}

- $\quad$ VER 1: Jardines de la urbanización los Rosales. Excesivo porcentaje de superficie pavimentada (se incluye pista para patinar). Parterres con coníferas.

- VER 2: Parque de San Pedro (ver Ruta de los Parques).

- PAR 1: Plantación de diversos árboles en el interior de la parcela ocupada por las naves verdes, así como una alineación de frutales en $40 \mathrm{~m}$, cada $3 \mathrm{~m}$. Acertada para la integración de las naves.

- PAR 2: Plantación de frutales en parcela con nave-caseta.

- PAR 3: Plantación de numeroso arbolado en parcela con nave y casa ocre: chopos, almendros, plátanos, así como de seto perimetral a lo largo de la valla (sebes, leylandis). Ejemplar.

- $\quad$ RES 1: Fuente Carrabustillo. En 1982 se adecuó el depósito de la fuente y el abrevadero, con ladrillo hueco muro y cemento. Actualmente se encuentra en deficiente estado: falta limpieza, excesiva vegetación herbácea, escombros, piedras de gran tamaño, etc.

- $\quad$ AHA 1: Lindero $50 \mathrm{~m}$. Frutales cada $4 \mathrm{~m}$. Sin protectores, con cuidados, $10 \%$ marras.

\section{RECUPERACIONES POTENCIALES}

- Armonización estética de la calle La Rúa, mediante el control de aparcamientos, la eliminación de grandes carteles llamativos, la definición de estilos básicos de pilares de soportales, etc.

- Restauración vegetal de taludes de la carretera.

- Limpieza de basuras de la carretera Bustillo.

- $\quad$ Adecuación de la fuente Carrabustillo.

- Restauración vegetal de taludes de caminos.

- Restauración vegetal de regueras.

- Plantaciones de diversificación en el interior de las parcelas agrícolas. 


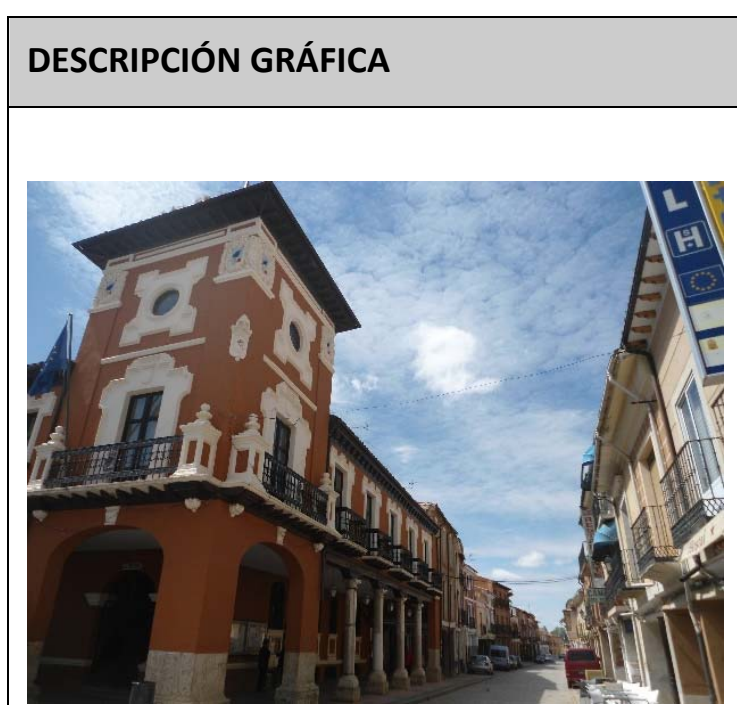

Figura A3.222. Ayuntamiento y calle la Rúa con soportales

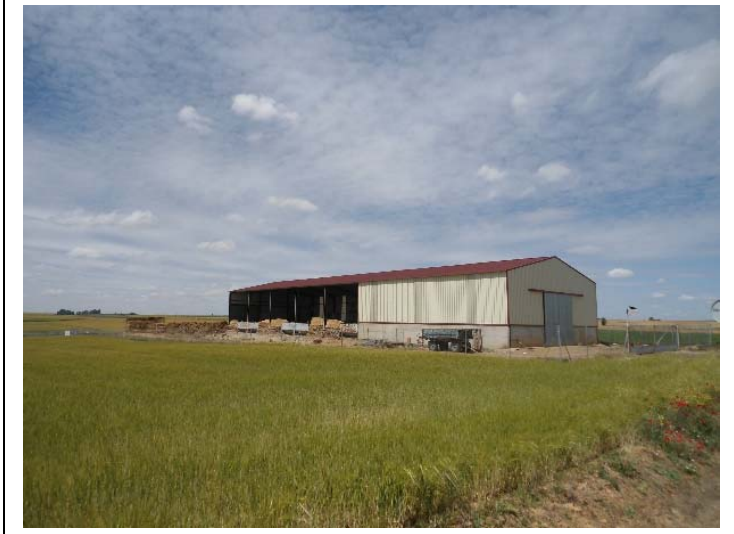

Figura A3.224. Granja de vacuno, con buena integración paisajística

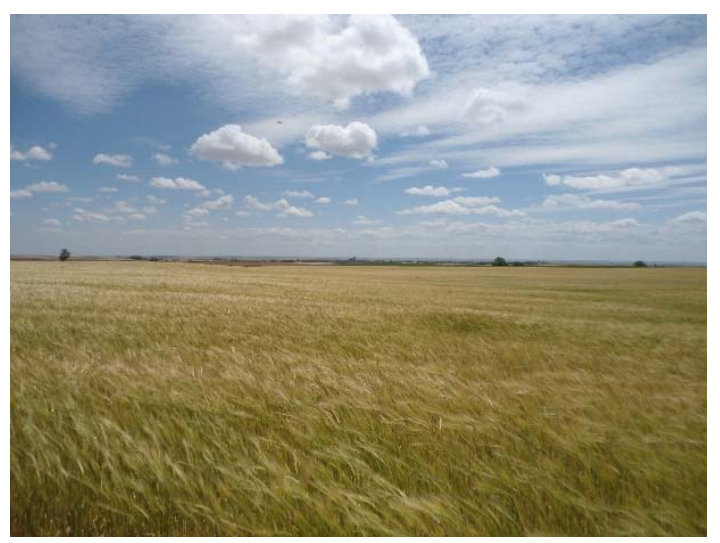

Figura A3.226. Estado de la cebada

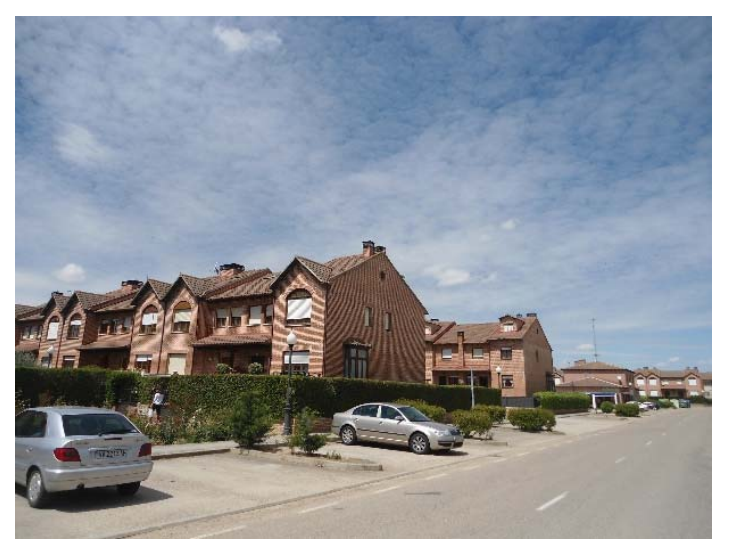

Figura A3.223. Urbanización los Rosales

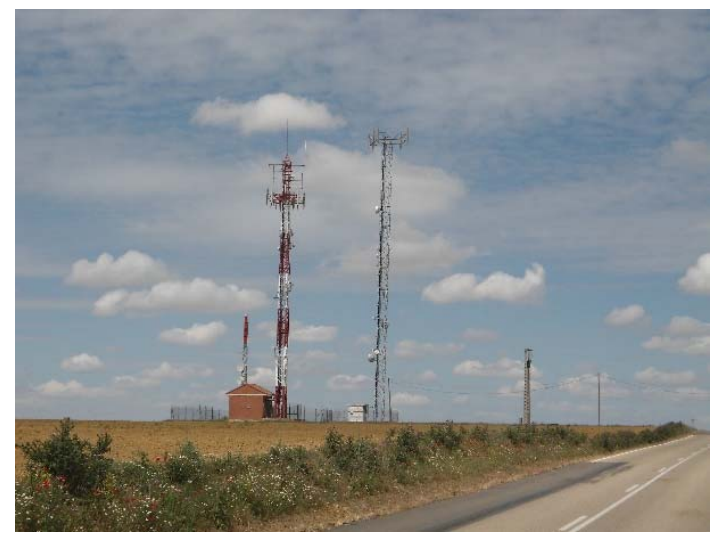

Figura A3.225. Antenas de telefonía móvil

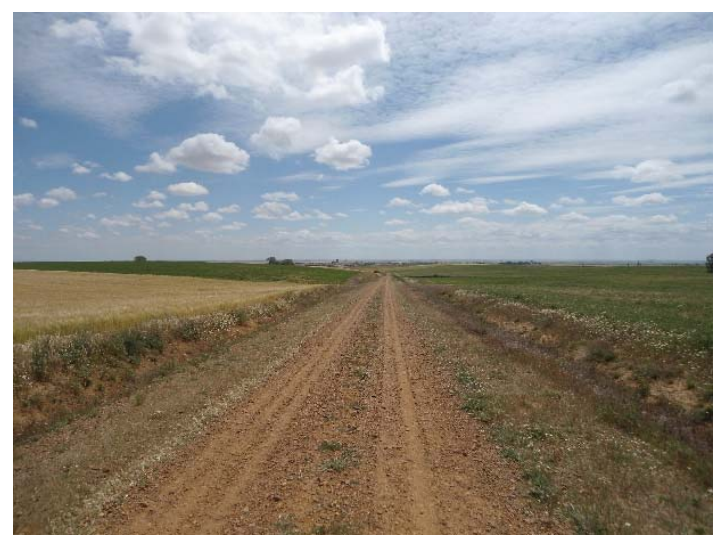

Figura A3.227. Vista de la colada de Cabezón-Villalón 


\section{A3.2. Seguimiento de las recuperaciones ambientales incluidas en el Anejo 3}

\section{A3.2.1. Plantación de 1 árbol/ha.}

En los Recorridos paisajísticos en Villalón de Campos incluidos en el anejo 3 se han muestreado un total de 28 localizaciones donde se han realizado plantaciones de 1 árbol/ha que, como se indicó en los antecedentes, es una de las medidas de condicionalidad de la Política Agraria Común (PAC). Los resultados obtenidos se muestran en la Tabla A3.1.

Tabla A3.1. Muestra de plantaciones de 1 árbol/ha en los Recorridos paisajísticos.

\begin{tabular}{|c|c|c|c|c|c|c|c|c|}
\hline Fecha & Código & Forma & Sup. $\left(m^{2}\right)$ & Especies & Protectores & Cuidados & Dist. (m) & Marras \\
\hline $15 / 06 / 2013$ & AHA 1 & picón triangular & 1500 & pino piñonero & si & si & 4 & 0 \\
\hline $15 / 06 / 2013$ & AHA 2 & alineación & 60 & pino piñonero & si & no & 3 & 70 \\
\hline $15 / 06 / 2013$ & AHA 3 & picón triangular & 1100 & pino piñonero & si & no & 3 & 0 \\
\hline $15 / 06 / 2013$ & $\mathrm{AHA} 4$ & alineación & 360 & pino piñonero & si & no & 3 & 10 \\
\hline $15 / 06 / 2013$ & AHA 5 & alineación & 150 & pino piñonero & si & no & 3 & 100 \\
\hline $23 / 06 / 2013$ & AHA 1 & alineación & 240 & pino piñonero & si & no & 3 & 90 \\
\hline $25 / 10 / 2013$ & AHA 1 & alrededor nave & 800 & pino piñonero & no & si & 2,5 & 0 \\
\hline $02 / 11 / 2013$ & AHA 1 & alineación & 240 & pino piñonero & no & si & 3 & 100 \\
\hline $02 / 11 / 2013$ & AHA 2 & alineación & 300 & pino piñonero & no & si & 3 & 0 \\
\hline $02 / 11 / 2013$ & AHA 3 & alineación & 240 & pino piñonero & si & no & 3 & 100 \\
\hline $02 / 11 / 2013$ & AHA 4 & alineación & 600 & pino piñonero & si & si & 3 & 0 \\
\hline $09 / 11 / 2013$ & AHA 1 & picón triangular & 300 & encina y pino & si & no & 3 & 50 \\
\hline $09 / 11 / 2013$ & AHA 2 & alineación & 300 & pino piñonero & no & no & 3 & 20 \\
\hline $09 / 11 / 2013$ & AHA 3 & alineación & 150 & almendro & no & si & 3 & 0 \\
\hline $12 / 11 / 2013$ & AHA 1 & franja rectangular & 4000 & mezcla & si & no & 4 & 25 \\
\hline $14 / 12 / 2013$ & AHA 1 & alineación & 240 & chopos & no & si & 4 & 20 \\
\hline $14 / 12 / 2013$ & AHA 2 & picón triangular & 30 & mezcla & no & si & 1,5 & 0 \\
\hline $11 / 01 / 2014$ & AHA 1 & franja rectangular & 650 & pino piñonero & si & no & 4 & 25 \\
\hline $11 / 01 / 2014$ & AHA 2 & picón triangular & 1250 & pino piñonero & si & si & 3 & 0 \\
\hline $12 / 01 / 2014$ & AHA 1 & picón triangular & 5100 & mezcla & si & si & 3 & 0 \\
\hline $12 / 01 / 2014$ & AHA 2 & franja rectangular & 1000 & mezcla & si & no & 2,5 & 25 \\
\hline $12 / 01 / 2014$ & AHA 3 & franja rectangular & 750 & mezcla & si & no & 2,5 & 40 \\
\hline $25 / 01 / 2014$ & AHA 1 & alineación & 150 & chopos & no & no & 3 & 50 \\
\hline $01 / 02 / 2014$ & AHA 1 & picón triangular & 150 & pino piñonero & si & no & 3 & 20 \\
\hline $08 / 02 / 2014$ & AHA 1 & alineación & 90 & pino piñonero & si & no & 3 & 100 \\
\hline $15 / 02 / 2014$ & AHA 1 & alineación & 150 & pino piñonero & si & si & 3 & 0 \\
\hline $15 / 02 / 2014$ & AHA 2 & franja rectangular & 10 & pino piñonero & si & si & 4 & 0 \\
\hline $15 / 02 / 2014$ & AHA 3 & alrededor nave & 360 & pino piñonero & si & si & 3 & 0 \\
\hline $22 / 02 / 2014$ & AHA 1 & franja rectangular & 1100 & pino piñonero & si & no & 4 & 50 \\
\hline
\end{tabular}




\begin{tabular}{|c|c|c|c|c|c|c|c|c|}
\hline Fecha & Código & Forma & Sup. $\left(m^{2}\right)$ & Especies & Protectores & Cuidados & Dist. (m) & Marras \\
\hline $22 / 02 / 2014$ & AHA 2 & picón triangular & 25 & pino piñonero & si & no & 2,5 & 50 \\
\hline $15 / 03 / 2014$ & AHA 1 & picón triangular & 35 & pino piñonero & si & no & 3 & 100 \\
\hline $12 / 04 / 2014$ & AHA 1 & alineación & 180 & pino piñonero & si & no & 3 & 100 \\
\hline $18 / 04 / 2014$ & AHA 1 & alineación & 150 & mezcla & no & si & 3 & 20 \\
\hline $18 / 04 / 2014$ & AHA 2 & alineación & 600 & pino piñonero & si & no & 4 & 100 \\
\hline $18 / 04 / 2014$ & AHA 3 & alineación & 180 & pino piñonero & no & si & 3 & 0 \\
\hline $18 / 04 / 2014$ & AHA 4 & alineación & 300 & pino piñonero & si & no & 3 & 10 \\
\hline $12 / 05 / 2014$ & AHA 1 & alineación & 150 & frutales y pino & si & no & 3 & 20 \\
\hline $24 / 05 / 2014$ & AHA 1 & alineación & 150 & frutales & no & si & 4 & 10 \\
\hline
\end{tabular}

La superficie total muestreada ocupada por esta plantación es de $23140 \mathrm{~m}^{2}$ (2,31 ha), que se estima suficientemente representativa.

De los datos contenidos en la tabla anterior y del análisis de los mismos se extraen las siguientes conclusiones:

- La distancia media entre árboles es de 3,12 m, que es mayor a la mínima exigida (2,25 $\mathrm{m}$ ) aunque todavía excesivamente baja. Teniendo en cuenta que la especie principal es el pino piñonero, que en su madurez necesita un gran espaciamiento para su adecuado desarrollo, las masas creadas tendrán en el futuro una elevada densidad. Este hecho será sobre todo acusado en los casos de picones triangulares y franjas rectangulares; el problema será menor en las alineaciones, ya que los árboles estarán más aislados.

- Si consideramos superficie total muestreada y distancia media entre árboles, el número de árboles muestreado es de 2378. Teniendo en cuenta que la superficie del término municipal de Villalón de Campos es de 7.000 ha aproximadamente - y que, por tanto, se deberían haber plantado 7000 árboles- la muestra teóricamente alcanza el 34 \%. Aparentemente se trata de una cifra baja, habida cuenta que los Recorridos cubren buena parte del término municipal, pudiéndose interpretar que esta medida no se ha cumplido en su integridad. No obstante, se debe reseñar que los Recorridos paisajísticos se realizan fundamentalmente por caminos y carreteras; dejan por tanto bastantes zonas muertas entre las infraestructuras lineales, así como en el interior de parcelas periurbanas no muestreables.

- De aceptarse la plantación de los 7000 árboles que corresponderían al término municipal de Villalón de Campos, la superficie afectada por esta medida de condicionalidad sería de 6,81 ha, algo inferior al uno por mil de la total, y muy alejada de la propuesta en la modificación de la PAC (greening) de reservar un $7 \%$ de la superficie cultivable como área de interés ecológico. Es decir, evidentemente se trata de una medida ambiental positiva, pero no llevará consigo una verdadera diversificación del paisaje agrícola intensivo. 
- La media del porcentaje de marras actual es del 34\%. En este sentido, conviene precisar que una parte de los árboles muestreados ya son reposiciones de marras, lo que indica un porcentaje inicial mayor. Se ha de tener en cuenta que los árboles se comenzaron a plantar en el otoño de 2010 y los Recorridos se han realizado entre 2013 y 2014. Dado que el compromiso es la conservación de 1 árbol/ha desde el 5 año de la plantación, en teoría en el otoño de 2015 se debería cumplir que el porcentaje de marras se aproximase a 0 , lo que todavía parece un poco lejano.

- En cuanto a la forma de las plantaciones, la mayoría son alineaciones (55\%) en márgenes de caminos, paralelas a arroyos o en el interior de las parcelas. Las superficiales ocupan un $40 \%$, del que un $24 \%$ son picones triangulares y un $16 \%$ franjas rectangulares; en cualquier caso, se trata siempre de zonas de cultivo más difícil. En todos estos casos sirven como elementos de diversificación del paisaje, bien sea como setos arbolados o como pequeños bosques isla. Finalmente, en un $5 \%$ de los casos estas plantaciones se realizan alrededor de naves agropecuarias ubicadas en suelo rústico, sirviendo como forma de integración paisajística de las mismas.

- La distribución por especies confirma la establecida en las entregas de planta realizadas por la Consejería de Medio Ambiente, aunque con ligero aumento del pino piñonero; es decir, en la reposición de marras se ha empleado algo más esta especie. El $68 \%$ de las plantaciones son de pino piñonero, el $18 \%$ mezcla de este árbol con encina, quejigo y almendro. El $8 \%$ corresponden a frutales incluido el almendro y el $5 \%$ restante, a chopos.

- El $71 \%$ de las plantaciones tienen tubos protectores; esta medida se recomendaba fundamentalmente para avisar y evitar daños por el ganado ovino, considerándose muy acertada. No obstante, no se observa que implique un menor porcentaje de marras.

- En el $42 \%$ de las plantaciones se ha detectado la realización de cuidados culturales (gradeo, tratamiento con herbicida, alcorques, riegos, incluso ya alguna poda). Puede que la cifra sea algo mayor, porque los riegos no se pueden constatar en su totalidad (se estiman los que tienen alcorques). En los casos de cuidados sí que se observa una consecuencia inmediata en el menor porcentaje de marras, que suele ser mínimo.

- En la mayoría de los casos, los hoyos se han realizado de forma manual después de un gradeo del terreno. Por el volumen de tierra movido alrededor de cada planta se infiere que la profundidad del hoyo no ha sido excesiva (inferior siempre a $40 \mathrm{~cm}$ ), lo que probablemente habrá sido una de las causas de las marras generadas.

- La percepción que, en general, tienen los agricultores es que se trata de una medida que ha de ser cumplida para recibir subvenciones de la PAC; en principio, no se interioriza como una práctica buena en sí mismo. Tal vez una de las causas de esta sensación puede 
radicar en la selección de especies que, aun siendo acertadas desde un punto de vista ecológico y forestal, no incluye o potencia otras semiproductivas como almendros, cerezos, guindales, etc. más "amigables" y que formaban parte del paisaje agrícola tradicional.

- La plantación de 1 árbol/ha supondrá una mejora indudable del paisaje visual de Tierra de Campos. Pese a que se trata de una medida de condicionalidad poco ambiciosa, lo cierto es que el hecho de que esta actuación esté repartida por todo el territorio agrícola mejorará el cromatismo, la textura, la diversidad y la calidad del paisaje de la comarca.

\section{A3.2.2. Restauración de fuentes}

Villalón de Campos es un municipio donde el peso de la actividad agrícola ha llevado a que la práctica totalidad de su superficie rústica esté ocupada por cultivos de secano. En medio de un paisaje eminentemente árido, surgen en su territorio 17 fuentes (Tabla A3.2) cuya importancia es tremenda, ya que son una especie de oasis en este medio tan inhóspito. Fue en el pasado cuando tuvieron más valor, en esa agricultura tradicional donde se pasaban tantas horas en el campo y el agua era tan necesaria para las personas y el ganado.

Tabla A3.2. Fuentes de Villalón de Campos, con los datos del Acuerdo de la reciente concentración parcelaria.

\begin{tabular}{lcccl}
\multicolumn{1}{c}{ Nombre } & Polígono & Parcela & Superficie & \multicolumn{1}{c}{ Propiedad } \\
\hline El Rosario & 407 & 76 & 0,1140 & Consejería de Medio Ambiente \\
\hline La Alameda & 407 & & 0,0000 & Camino rural \\
\hline El Arco & 407 & 58 & 0,5929 & Consejería de Medio Ambiente \\
\hline La Gacha & 406 & & 0,0000 & Arroyo \\
\hline Carrabustillo & 405 & 7 & 0,0608 & Consejería de Medio Ambiente \\
\hline Juan Palacios & 405 & 71 & 1,5945 & Consejería de Medio Ambiente \\
\hline La Teja & 405 & & 0,0000 & Vía pecuaria \\
\hline El Cuquillo & 404 & & 0,0000 & Camino \\
\hline Cortaelaire & 403 & 60 & 1,4798 & Consejería de Medio Ambiente \\
\hline El Toro & 402 & 106 & 1,0001 & Restauración del Medio Natural \\
\hline Murcia & 402 & 53 & 1,0005 & Restauración del Medio Natural \\
\hline Herrín & 401 & 114 & 1,2390 & Junta Agropecuaria Local \\
\hline Valdelafuente & 408 & 42 & 0.3167 & Consejería de Medio Ambiente \\
\hline Villacilda & 408 & 42 & 0.9498 & Consejería de Medio Ambiente \\
\hline Trinchas & 408 & 4 & 1.2072 & Junta Agropecuaria Local \\
\hline San Salva & 407 & 111 & 0.3707 & Consejería de Medio Ambiente \\
\hline La Florida & 409 & 29 & 0.5223 & Consejería de Medio Ambiente \\
\hline TOTAL & & & $\mathbf{1 0 , 4 4 8 3}$ & \\
\hline
\end{tabular}


Tal como se puede apreciar en la tabla anterior, las 17 fuentes se asientan sobre parcelas que ocupan 10,45 ha, es decir, una media de 0,61 ha por fuente. Con anterioridad a la segunda concentración parcelaria de la zona (analizada en el Anejo 1) las fuentes tenían menos superficie, estando incluso varias de ellas junto a caminos y regueras sin parcela asociada. Dentro de las medidas de la declaración de impacto ambiental de este proyecto se exigió que cada fuente contase con una superficie mínima de 1 ha, algo que se ha conseguido parcialmente después de numerosas dificultades. Tal como se observa, las fuentes tienen una propiedad pública o semipública (la JAL), algo que favorece su gestión.

En general, todas obedecen a un mismo patrón. En un manantial se deriva el agua hacia un depósito construido con ladrillo de tejar, de donde fluye a través de un caño hacia un abrevadero, que sirve para dar de beber a las ovejas. En la mayoría de las fuentes se han ido realizando plantaciones de árboles -sobre todo por voluntarios del pueblo- que ocupan una parte de la parcela; el resto es una pradera. En la fuente San Salva la Consejería de Medio Ambiente adecuó un área recreativa. De forma periódica también se han realizado arreglos de los depósitos o del entorno.

Del análisis de los datos aportados en el Anejo 3 en los que se analiza la situación y las recuperaciones realizadas en las fuentes de Villalón de Campos (código FUE), se extraen las siguientes conclusiones sobre su seguimiento ambiental:

- La superficie disponible para restaurar en cada fuente es muy escasa. Las 0,61 ha por fuente alcanzadas en la reconcentración parcelaria suponen un avance respecto de la situación anterior, pero aún están alejadas del mínimo óptimo de 1 ha para llevar a cabo una actuación adecuada. No obstante, desde luego que estas pequeñas superficies tienen un gran valor y se deben mantener en el mejor estado posible.

- Como en general ocurre con cualquier espacio público en Tierra de Campos, es muy fuerte la presión de los colindantes agrícolas, que puede derivar en intrusiones que se van perpetuando en el tiempo si no hay una adecuada protección o un uso definido. Por ello, además del mantenimiento de los mojones, una medida muy necesaria es la realización de una zanja con una motoniveladora en la lindera con otra parcela agrícola; sobre ella se deben plantar arbustos (escaramujos, retamas, etc.) que contribuyen a delimitar la propiedad.

- Otro de los problemas importantes que poseen las fuentes es su propio funcionamiento hidrológico. Cuando estas tenían verdadera función, los pastores se encargaban de mantenerlas para que el agua fluyese de forma permanente: limpiando los manantiales, desobstruyendo las conducciones, limpiando los depósitos y abrevaderos, etc. En la actualidad el pastoreo de ovino extensivo se está reduciendo considerablemente, con lo que estas actuaciones periódicas no se realizan. 
- Se aprecia que la mayoría de los depósitos tienen gran valor como patrimonio etnográfico; son pequeñas edificaciones antiguas, construidas de forma artesanal con ladrillo macizo o piedra, cuyo interés cultural y belleza hace precisa su conservación.

- Tal como se ha señalado anteriormente, en la mayoría de las fuentes se han realizado plantaciones de árboles en los últimos 30 años. Se partía de una situación prácticamente desarbolada, en la que alguna fuente poseía árboles aislados. Como se suele tratar de terrenos frescos, la mayoría acogen especies propias de zonas húmedas o riberas (chopos, álamos o sauces), que vegetan adecuadamente y poseen un buen crecimiento. En otras -o parte de ellas, con zonas secas- se han plantado pinos piñoneros, olmos, encinas, almendros, retamas, etc.; aun con menor crecimiento, el resultado también es muy positivo.

- Se ha constatado que uno de los principales problemas para la pervivencia de las plantaciones es la presión del ganado ovino, que va dañando las plantas hasta su muerte si atraviesa a menudo la zona. Por ello se debe contar con este inconveniente, bien sea delimitando espacios definidos de pastizal/árboles, bien con protectores, bien con señalización y, en cualquier caso, tratando de convencer al pastor de las bondades de los árboles y de sus nulos perjuicios.

- En varias parcelas el arbolado alcanza ya considerable altura. Las especies riparias no suelen necesitar cuidados culturales posteriores, pero sí las que se plantan en zonas secas; se observa la necesidad de realizar podas sobre todo en almendros y pinos piñoneros.

- La única fuente constituida como área recreativa (San Salva) suele estar muy descuidada por falta de un mínimo mantenimiento. Esta tarea correspondería fundamentalmente al Ayuntamiento, que debería realizar unas labores básicas un par de veces al año: desbroces de vegetación, limpieza, revisión de las infraestructuras, etc.

- En alguna fuente (Cortaelaire es el paradigma) se ha construido un abrevadero más amplio que, además de facilitar el abrevadero de agua al ganado, supone un punto de agua muy beneficioso para la fauna silvestre. Esta actuación debería ser extrapolable a la mayoría de las fuentes, bien sea con abrevaderos o con simples charcas.

- La recuperación de fuentes supone una mejora del paisaje visual de Villalón de Campos. 17 fuentes repartidas por todo el término municipal suponen otros tantos oasis en el medio cerealista. Sobre todo cuando están arboladas, introducen tonos verdes necesarios fundamentalmente en verano, crean nuevas texturas, dan lugar a la aparición de la variable vertical en contraste con una monótona horizontalidad, aumentan la capacidad de absorción visual y, sobre todo, mejoran la calidad visual del entorno. 
- La recuperación de fuentes también supone una mejora del paisaje ecológico de Villalón de Campos. Aunque su superficie sea reducida, se trata de pequeñas manchas naturales en una inmensa matriz agrícola, que aportan diversidad y que constituyen hábitat para las especies faunísticas silvestres. Especial interés tienen en el mantenimiento de la fauna cinegética, proporcionándola bebida y refugio.

- Finalmente, esta actuación contribuye a valorizar el paisaje de Villalón de Campos, aunque podría hacerlo en un grado mucho mayor. Las fuentes constituyen los puntos de una red natural de zonas verdes, que podrían ser frecuentemente visitadas por los vecinos mediante paseos a pié o en bicicleta a través de los caminos rurales. A pesar de que se han realizado labores en este sentido (trípticos, planos, carteles), lo cierto es que estos enclaves tienen un gran potencial para el bienestar de los vecinos, su calidad ambiental e, incluso, el desarrollo turístico.

\section{A3.2.3. Parques y zonas verdes}

El único Recorrido paisajístico que se ha repetido ha sido la denominada "Ruta de los parques". Se trata de un recorrido circular que discurre por espacios urbanos y periurbanos de Villalón de Campos (Tabla A3.3), de modo que atraviesa prácticamente todos sus espacios verdes (denominados con el código VER). Cada recorrido se centraba en analizar diferentes aspectos de estas zonas: las recuperaciones ya efectuadas, las degradaciones paisajísticas de la ruta y las recuperaciones potenciales. Estas últimas se han incorporado al Proyecto de recuperación ambiental y adecuación de la Ruta de los Parques, analizada en el Anejo 2. Por otro lado, la realización de esta ruta varias veces en un año ha permitido estudiar la evolución del paisaje ajardinado a lo largo de las estaciones.

Tabla A3.3. Parques y zonas verdes de Villalón de Campos

\begin{tabular}{lc}
\hline \multicolumn{1}{c}{ Parque } & Superficie $\left(\mathbf{m}^{\mathbf{2}} \mathbf{)}\right.$ \\
\hline Parterres de la plaza Mayor & 25 \\
\hline Ribera del arroyo Pajarillas & 1840 \\
\hline Paseo de la huerta del Moral & 630 \\
\hline Picón de las acacias & 305 \\
\hline Parque de la reguera del Tinte & 2920 \\
\hline Parque de la laguna del Tinte & 3330 \\
\hline Rincón de San Francisco & 280 \\
\hline Plaza de San Juan & 750 \\
\hline Parterres de la Pedrera o de Oriente & 520 \\
\hline Parque de la laguna de la Pedrera & 1300 \\
\hline Parterres de la laguna de la Pedrera & 115 \\
\hline Picón de los cuartos de San Miguel & 190 \\
\hline
\end{tabular}




\begin{tabular}{lc}
\hline \multicolumn{1}{c}{ Parque } & Superficie $\left(\mathbf{m}^{\mathbf{2}}\right)$ \\
\hline Parque del hospital de San Roque & 1170 \\
\hline Era del Depósito & 500 \\
\hline Jardines del Colegio & 375 \\
\hline Parque del Paseo & 12010 \\
\hline Parque temático del Pan y del Queso & 5595 \\
\hline Paseo de la Residencia & 620 \\
\hline Paseo del Instituto & 470 \\
\hline Jardines del Polideportivo & 3000 \\
\hline Paseo del campo de fútbol & 1930 \\
\hline Jardines de la piscina & 2200 \\
\hline Parque de la laguna de San Pedro & 4085 \\
\hline Picón de Pajarillas & 1100 \\
\hline Paseo de Barrios & 975 \\
\hline TOTAL & $\mathbf{4 6 2 3 5}$ \\
\hline
\end{tabular}

Las conclusiones generales del seguimiento ambiental de la recuperación y gestión de zonas verdes en Villalón de Campos son las siguientes:

- Teniendo en cuenta que la población actual de Villalón de Campos es de 1850 habitantes, la densidad de zonas verdes es de $25 \mathrm{~m}^{2}$ por habitante. Este valor es muy superior al rango mínimo aconsejado por la Organización Mundial de la Salud (OMS), de 10-15 $\mathrm{m}^{2} / \mathrm{hab}$ o a la recomendación de la Unión Europea de $15 \mathrm{~m}^{2} / \mathrm{hab}$. Como referencias de ciudades españolas, solo citar que Barcelona -como la gran mayoríasuspende con un valor de $6,6 \mathrm{~m}^{2} /$ hab y que Vitoria es la que posee el mayor índice (ostenta el título de capital verde europea), con 20,8 $\mathrm{m}^{2} / \mathrm{hab}$. Es decir, un pueblo de Tierra de Campos tiene más jardines que la ciudad española más verde. Este es un dato que debe ser valorizado de forma prioritaria cuando se compare la calidad de vida rural con la urbana; no olvidemos que uno de los índices más representativos de esta calidad es la densidad mencionada de zonas verdes.

- En Villalón de Campos se ha producido una transformación muy significativa de sus espacios verdes urbanos en los últimos 30 años. En la década de los 80 del siglo pasado solo existía el parque del Paseo; actualmente se contabilizan más de 25 zonas verdes, más o menos cuidadas. La recuperación ha sido paulatina y a ella han contribuido todas sus corporaciones municipales de los últimos años, lo que ha sido muy positivo.

- Aunque en los primeros años se concedía excesiva prioridad a la adecuación de los espacios verdes de la zona más nueva del casco urbano (salida dirección Valladolid), progresivamente se han ido restaurando espacios más dispares, con lo que su distribución territorial actual está más equilibrada. En este sentido, se considera 
fundamental aprovechar cualquier espacio degradado para su restauración: parterres, picones, márgenes de caminos o viales, riberas urbanas de arroyos, espacios marginales, paseos, etc. En particular, los paseos arbolados son muy interesantes porque contribuyen a conectar la trama verde $y$, en los espacios periurbanos, minimizan numerosos impactos paisajísticos.

- La línea anual conocida como "Zonas Verdes", promovida por la Consejería de Medio Ambiente de la Junta de Castilla y León (que desgraciadamente en los últimos años ha desaparecido), ha contribuido en gran medida a acometer las restauraciones efectuadas por el Ayuntamiento; mediante esta subvención, la Junta concedía la planta de su vivero central. También ha contribuido en igual medida la Diputación Provincial, que todavía mantiene esta línea de ayudas.

- El conjunto ajardinado formado por el parque temático y el parque del Paseo tiene tal calidad que podría revalorizarse siendo un reclamo para la visita turística de grupos familiares a Villalón de Campos. Ello exigiría una cierta promoción y una mayor atención al mantenimiento pero, desde luego, el recurso paisajístico existe y se debería aprovechar.

- El concepto arquitectónico más extendido de las plazas castellanas es que deben ser sobrias y abiertas, sin arbolado u otros elementos que oculten las vistas a los edificios con valor, sobre todo las iglesias. Este ha sido el criterio utilizado para las últimas adecuaciones efectuadas en la majestuosa plaza mayor de Villalón de Campos, que han dejado únicamente 6 alcorques para árboles (la mitad secos durante años). Aceptando este argumento con carácter general, se debe tener en cuenta que las plazas son lugares de encuentro, centros de socialización de los vecinos, espacios donde los niños juegan. Para ello las zonas verdes -aunque sean limitadas- son necesarias, ya que proporcionan sombra, delimitan espacios frescos con vida y, bien diseñadas, revalorizan el patrimonio arquitectónico. Esto se echa de menos en la plaza mayor; cabrían muchas opciones sin tapar las vistas más representativas. Una solución que mitiga en parte este problema es la colocación de jardineras móviles, que debería hacerse extensiva a otras plazas que no posean vegetación.

- Las piscinas municipales, que se encuentran en un entorno muy ajardinado, son muy importantes para un pueblo como Villalón de Campos. El entorno árido y caluroso estival en el que se encuentra hace muy necesaria la existencia de un espacio público ligado al agua y la vegetación; es además un atractivo para las personas que pasan sus vacaciones en el municipio.

- Se ha constatado que en los espacios verdes que no se encuentran muy atendidos resulta fundamental su delimitación, ya que en caso contrario son frecuentemente invadidos por vehículos. 
- Resulta necesario que, cuando se realicen obras de urbanización sobre todo en espacios periurbanos, se dejen sin hormigonar o asfaltar pequeños parterres o alcorques donde realizar plantaciones de árboles. Existen ejemplos en ambos sentidos y las diferencias son evidentes.

- Se ha demostrado que la jardinería y el paisajismo son disciplinas técnicas que requiere un alto rigor en las actuaciones. En este sentido, y de acuerdo con la experiencia adquirida, se considera fundamental la adecuada preparación del terreno para las plantaciones (hoyos de profundidad suficiente, por ejemplo), el cuidado de las plantas antes de su implantación (protección frente a heladas), el riego de implantación, la realización de alcorques, etc. Dentro de los cuidados culturales, se destaca la imperiosa necesidad de realizar varios riegos durante el verano posterior a la plantación; la falta de su realización ha provocado el fracaso de varias plantaciones, con la pérdida económica que ello supone.

- A pesar de algún fallo en los primeros años, en general se han utilizado especies adaptadas a los requerimientos ecológicos de la zona. Esto es fundamental y asegura la pervivencia de la vegetación en el futuro. Dentro de ellas, resulta muy necesaria la diferenciación entre especies para zonas secas (la mayoría) y especies para zonas húmedas. El ejemplo paradigmático es el del chopo: aquellos plantados en terrenos habituales pueden vivir, pero su calidad vegetativa es muy deficiente (malviven); cuando los chopos se han dispuesto en riberas, sus crecimientos han resultado espectaculares.

- Es importante que en todos los espacios verdes exista un equilibrio entre vegetación caduca y perenne. En las zonas donde no se produce, se constata que el invierno es un periodo poco atractivo en el aspecto visual. Este equilibrio también es importante que se produzca entre árboles y arbustos; estos últimos suelen ser más rústicos y poseen un gran valor ornamental.

- Debido a los problemas que se pueden plantear con posterioridad, es conveniente que no se planten árboles de amplio sistema radical -sobre todo superficial- en las proximidades de edificaciones. El ejemplo más paradigmático es el chopo boleana. A la inversa, tampoco se puede utilizar -como así ha sido- este argumento para eliminar árboles cuando se detecta cualquier desperfecto cercano.

- En situaciones como la actual, en la que no hay problemas de abastecimiento de agua en el municipio, es indudablemente mejor la creación de zonas verdes con instalación de riego, dado que existe mayor seguridad en la pervivencia de siembras o plantaciones y su crecimiento es superior. En cualquier caso, se aconseja su automatización y su regulación para que el aprovechamiento de agua sea máximo. No por el hecho de tener riego se ha de sembrar césped; de hecho, las praderas arboladas naturales (o con escaso riego) pueden convertirse en zonas verdes muy sostenibles y propias del territorio. 
- En algunos árboles como los plátanos se realizan unas podas excesivas. Con el objetivo de evitar barrer sus hojas, se adelanta su poda a octubre, por lo que se pierde la belleza de los cambios foliares otoñales y se reduce al mínimo la presencia de hojas en el año. Esto sin tener en cuenta de los daños que se provoca al propio árbol.

- En los espacios potencialmente verdes, pero que aún no han sido restaurados adecuadamente, se tiende a eliminar la vegetación herbácea mediante la aplicación de herbicidas totales (glifosato). Esta actuación se juzga francamente desacertada, por varios motivos: constituye un foco de contaminación en espacios urbanos, provoca un posterior repunte de la vegetación que se desea eliminar y genera zonas secas en la primavera, cuando las hierbas deberían estar verdes. Frente a esta operación, se considera más adecuada la realización de desbroces manuales con motodesbrozadora; con ellos se consigue tener praderas verdes durante la mayor parte del año (en torno a 9 meses).

- Se observa que existen muy pocos puntos con agua en movimiento en las zonas verdes de Villalón de Campos (una pequeña cascada en el parque del Paseo y una fuente de funcionamiento irregular en la plaza mayor). Este sería un aspecto a promocionar teniendo en cuenta el importante papel del agua en los espacios ajardinados y en el paisaje de calidad en general.

- Dentro de las labores periódicas de mantenimiento, que ineludiblemente han de ser realizadas, se considera prioritaria la limpieza de bolsas, plásticos y otros pequeños residuos. Se trata de un aspecto sutil pero que da idea de la calidad y el cuidado del conjunto ajardinado. En este sentido, siempre se debe asegurar la instalación suficiente de papeleras.

- El resto de acciones de mantenimiento son también muy necesarias: revisión de los sistemas de riego, desperfectos en las infraestructuras recreativas, pintado de bancos, etc.

- La gestión municipal dedicada a las zonas verdes en Villalón de Campos es irregular y, en general, escasa. El número medio de trabajadores en labores de jardinería es de 2, cifra que se considera insuficiente. Por otro lado, no siempre los operarios han estado permanentemente especializados en estas labores, aspecto este que es totalmente necesario, aunque en general han realizado las labores con diligencia y profesionalidad. 
- Teniendo en cuenta la amplia superficie de zonas verdes municipal y la escasez de recursos laborales, se considera fundamental que se realice una planificación anual de todas las actuaciones de jardinería, que permita establecer prioridades, no olvidar aspectos importantes, contemplar el mantenimiento periódico, etc., así como adaptar los recursos humanos a las necesidades de cada momento concreto.

Villalón de Campos, mayo de 2015

Raúl Blanco Esteban

Ingeniero de Montes 